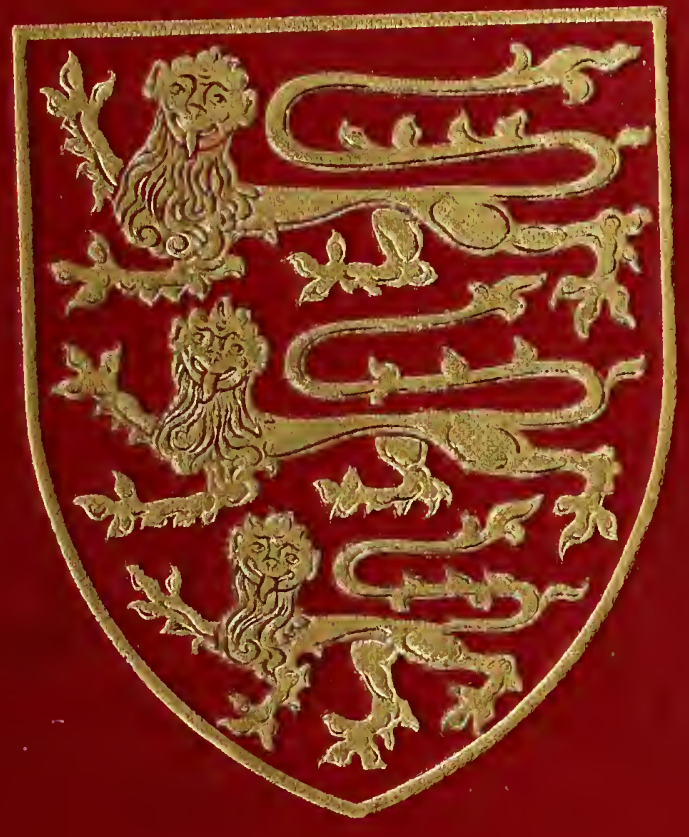


Digitized by the Internet Archive in 2014 



\title{
THE VICTORIA HISTORY OF THE
}

COUNTIES OF ENGLAND

\author{
A HISTORY OF \\ LEICESTERSHIRE
}

VOLUME IV 



\section{THE VICTORIA HISTORY OF THE}

\section{COUNTIES OF ENGLAND}

EDITED BY R. B. PUGH

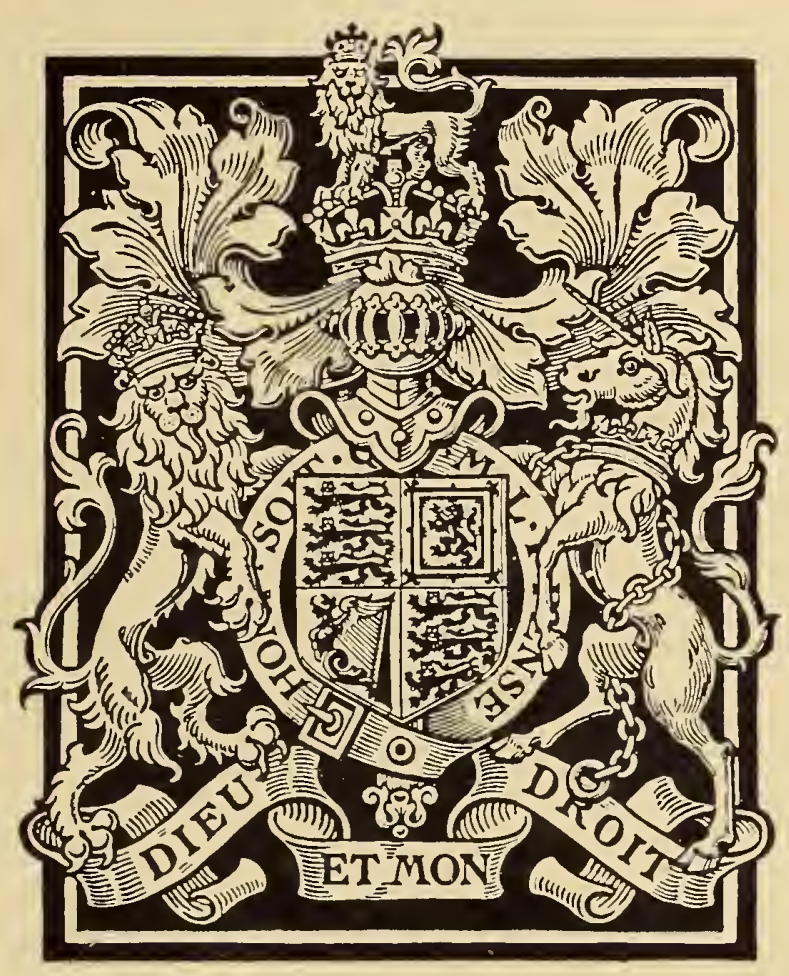

THE UNIVERSITY OF LONDON

INSTITUTE OF

HISTORICAL RESEARCH 
Oxford University Press, Amen House, London, E.C. 4 GLASGOW NEW YORK TORONTO MELBOURNE WELLINGTON BOMBAY CALCUTTA MADRAS KARACHI KUALA LUMPUR CAPE TOWN IBADAN NAIROBI ACCRA

(C) University of London 1958

PRINTED IN GREAT BRITAIN 
INSCRIBED TO THE

MEMORY OF HER LATE MAJESTY

QUEEN VICTORIA

WHO GRACIOUSLY GAVE THE TITLE TO

AND ACCEPTED THE DEDICATION

OF THIS HISTORY 




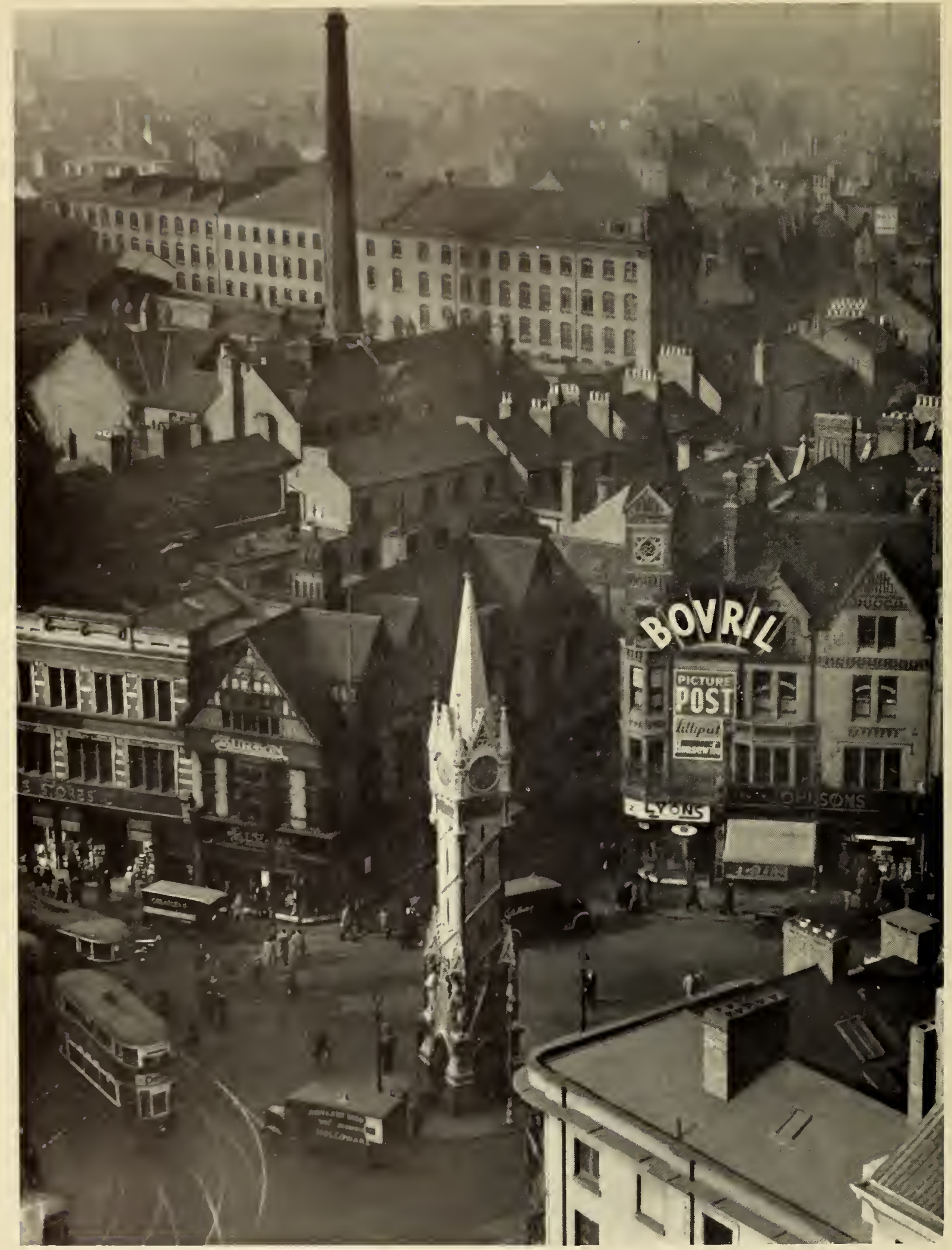

The Clock Tower, Leicester, $c$. $19+5$ 


\title{
A HISTORY OF THE COUNTY OF
}

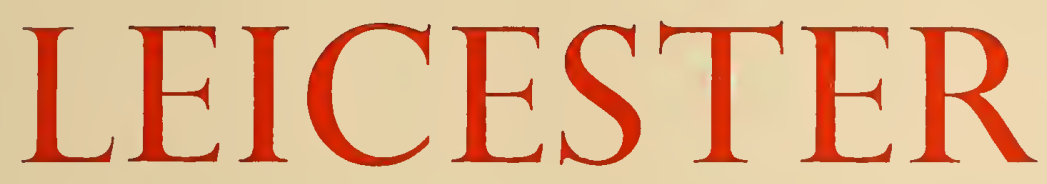

EDITED BY R. A. McKINLEY

\section{VOLUME IV}

\section{THE CITY OF LEICESTER}

\author{
PUBLISHED FOR
}

THE INSTITUTE OF HISTORICAL RESEARCH BY THE

\section{OXFORD UNIVERSITY PRESS}

AMEN HOUSE, LONDON

1958 



\section{CONTENTS OF VOLUME FOUR}

Dedication

PAGE

Contents

ix

List of Illustrations

$\mathrm{xi}$

List of Maps and Plans . $\quad . \quad$. . . . . . _ . . . xiii

Editorial Note . . . . . . . . . . . . .

Leicestershire Victoria County History Committee _ . . . . . xvii

Classes of Public Records used . . . . . . . . . . xix

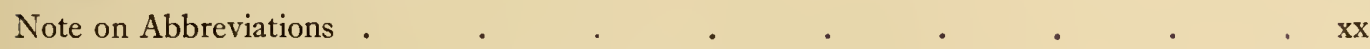

The City of Leicester

Political and Administrative History, I066-I 509

Social and Economic History, I066-I509 .

Political and Administrative History, I509-1660

Social and Economic History, I 509-1660 .

Parliamentary History, I660-I 835 .

Social and Administrative History, 1660-1835 .

Parliamentary History since 1835 . .

Social and Administrative History since 1835 .

By Audrey M. ERskine . . I

By Marian K. Dale . . 3 I

By Doreen Slatter • • 55

By E. W. J. KerRidge . $\quad 76$

By R. W. Greaves. • . I I

By W. A. Jenkins and C. T. Smith 153

By R. H. Evans . 201

By R. A. MCKINLEY and C. T. SMith 25I

Hosiery manufacture ․ . . By C. Ashworth . . . 303

Footwear manufacture . . . By V. W. HogG . . . 314

Elastic Web manufacture • • . B B JANET D. Martin . 326

Primary and Secondary Education ․ . By Janet D. MARTin • • 328

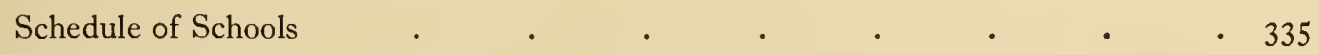

The Ancient Borough

Topography

By R. A. MCKinleY and JANET D. MARTIN; the section on Wyggeston's Hospital in 'Almshouses and Hospitals' by R. M. GARD • $\quad 338$

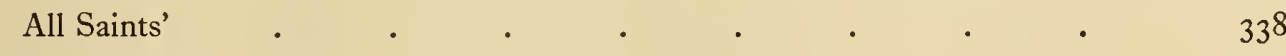

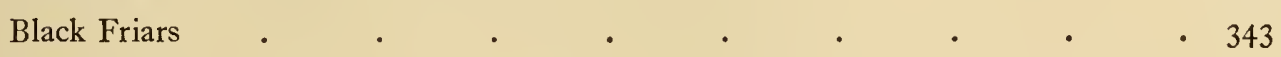

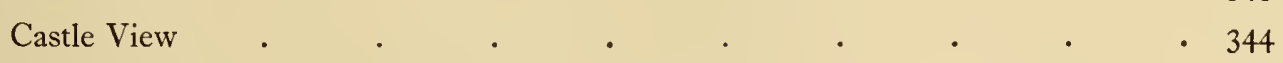

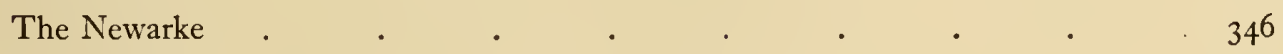

St. Leonard's . . . . . . . . . . . . . 348

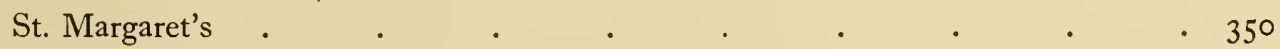

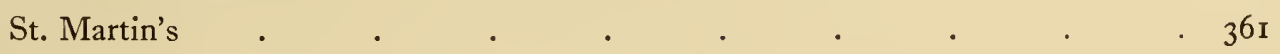

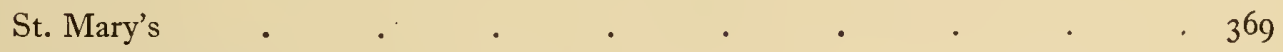

Bromkinsthorpe . . . . . . . $\quad 380$

St. Nicholas's . . . . . . . . . . . . . 383

White Friars $\quad . \quad$. $\quad . \quad$. $\quad . \quad$. $\quad . \quad 387$

Lost Churches . . . . . . . . . $\quad$. 388

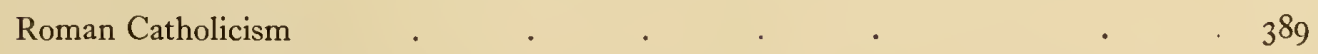

Protestant Nonconformity . . . . . . . . 390

Mills . . . . . . . . . . . . 395 


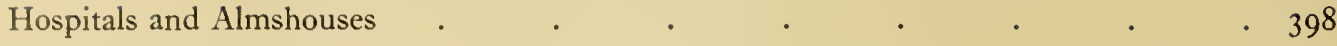

Municipal Charities . $\quad . \quad$. . . . . . 410

Parishes added to Leicester since 1892

Topography

Aylestone . . . . . . By Janet D. Martin and Pauline

Belgrave . . . B B. A. McKinley and Janet D.

MARTIN • • . 420

Braunstone. . . . . By R. A. McKinley and JANEt D.

MARTIN . . . . 428

Evington . . . . . B B Janet D. Martin and Dorothy

PIDGEON • . . . $\quad 434$

Humberstone . . . . By Janet D. Martin and Ruth BIRD • . . . . 439

Knighton . . . . . By Janet D. Martin and Ruth BIRD . . . . 443

North-West Leicester • • . By R. A. McKinley . 447

The Seals, Insignia, and Corporate Offices of Leicester

By R. A. McKinley • 457

Indexes to Volume IV . $\quad$ • _ . By Patricia M. Barnes . . 459

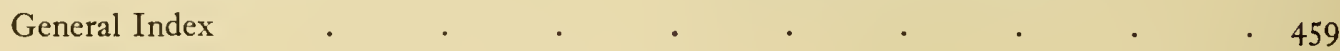

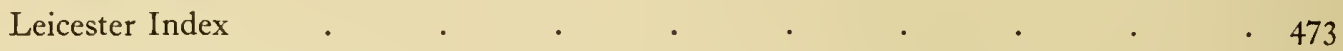

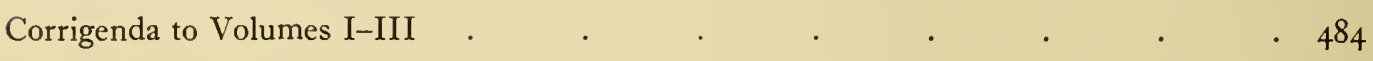




\section{LIST OF ILLUSTRATIONS}

Thanks are due to the City of Leicester Publicity Department, the Leicester Mercury, the Leicester Evening Mail, Mr. Edmund Wilford, Mr. R. A. Fathers, and Mr. F. L. Attenborough, who gave permission for the reproduction of photographs belonging to them, and especially to the Museum and Art Gallery Committee of the Leicester City Corporation and to the trustees of the late William Skillington, who gave permission to reproduce, respectively, paintings and photographs at Leicester Museum and the Newarke Houses Museum, Leicester, and watercolours from the Skillington collection now in the possession of Mrs. F. E. Skillington. Thanks are also due to the National Buildings Record for the loan of several prints (indicated below) and photographs.

The Clock Tower, Leicester, $c$. 1945. From a photograph in the possession of the Central Office of Information

The Chantry House, the Newarke. From a photograph by Margaret Tomlinson, 1957 - facing page 56

The Guildhall: the Great Hall, seen from the east end. From a photograph at Leicester Museum

Castle Green: the Tudor Gateway, with St. Mary's Church to the right, $c$. I 840 . Signed 'J. F.' From 35th Annual Report of the Leicester and Leicestershire Society of Architects.

Castle Green: the Castle and St. Mary's tower seen from Castle View, c. I879. From a watercolour by J. Fulleylove in the possession of Mrs. F. E. Skillington

Henry Hastings, 3 rd Earl of Huntingdon (c. $1536-1595)$. From a portrait by Christopher Carter at Leicester Museum .

John Biggs (I80I-7I). From a portrait by an unknown artist at Leicester Museum

Campbell Street Station in I840 (replaced by London Road Station, I 892). From a print at the National Buildings Record

The Leicestershire and Rutland Lunatic Asylum, c. I 849 (later University College, Leicester). From a drawing by T. Willson engraved by $\mathrm{H}$. Adland in Leicestershire and Rutland Lunatic Asylum (1849)

The Old Corn Exchange, or New Gainsborough: built I 748 , demolished 1851 . From a drawing of $c$. 1850 by William Millican at Leicester Museum.

The News Room, Granby Street: opened i 838 , demolished i 90 г. From a watercolour by J. Fulleylove in the possession of Mrs. F. E. Skillington

Spa Place, Humberstone Gate. From a photograph by Margaret Tomlinson, I957

Crescent Cottages in 1946. From a photograph by F. L. Attenborough, at Leicester Museum

General view of Leicester in 1804 ; showing the South Field and the London road in the foreground. From a print at the National Buildings Record .

The Interior of Leicester Castle in 1821. From J. Thompson, An Account of Leicester Castle (1 859)

The Market Place, with the New Corn Exchange, c. I879. From a watercolour by J. Fulleylove in the possession of Mrs. F. E. Skillington

The Castle and St. Mary's Church; seen from the river before the flood-prevention works of $c$. I89o. From a photograph at Leicester Museum .

Flood-prevention works in progress south of West Bridge. From a photograph at Leicester Museum

The last Leicester May Fair, I904: Humberstone Gate seen from the Clock Tower. From a photograph at Leicester Museum

High Street: with the Earl of Huntingdon's tower, the last surviving part of Lord's Place, finally demolished in I 902. From a photograph in the possession of the Leicester Mercury

Humberstone Gate from the east, c. 1938. From a photograph in the possession of the Central Office of Information

Central and south-east Leicester from the air, I953. From a photograph by Aerofilms Ltd.

St. Martin's Church: as seen from the junction of Loseby Lane with Silver Street and Guildhall Lane. From a watercolour by G. M. Henton, I922 . 


\section{LIST OF ILLUSTRATIONS}

High Cross Street and All Saints' Church, $c$. 1879. From a drawing by J. Fulleylove in the possession of Mrs. F. E. Skillington .

facing page 346

The Newarke, I890-2. From a watercolour by G. M. Henton, now in the Newarke Houses Museum, Leicester .

St. Mary's Church: the font. From a photograph by R. C. Stewart, I9I6

" 346

St. Margaret's Church: the 'Bossu' niche. From a photograph by R. A. Fathers, I $94^{2}$

St. Margaret's parish from the air, I953. From a photograph by Aerofilms Ltd. .

St. Nicholas's Church and the Jewry Wall, 1956. From a photograph in the possession of the City of Leicester Publicity Department

St. Margaret's Church from the south-east. From a photograph by Margaret Tomlinson, I957.

The County Rooms, built $1792-\mathrm{I} 8 \mathrm{n}$. From a drawing by C. E. Wilford in the possession of Mr. Edmund Wilford

I7 Friar Lane in 1946. From a photograph by F. L. Attenborough

The Town Hall, built I874-6. From a photograph by Margaret Tomlinson, I957

The New Corn Exchange, built $185^{1}$-6. From a photograph by F. Lumbers, I 900

The Great Meeting (Presbyterian), built I708. From a photograph at Leicester Museum

Belvoir Street Baptist Chapel ('The Pork Pie'). From a photograph by F. Lumbers, I950

Wyggeston's Hospital: the new buildings of I 867. From a photograph at Leicester Museum

The Free Grammar School, built c. I575. From a photograph at Leicester Museum

Braunstone Housing Estate from the air. From a photograph taken for the Leicester Evening Mail

Evington Chapel and Manse: originally belonging to the Countess of Huntingdon's Connexion and later to the Strict Baptists. From a photograph by Margaret Tomlinson, I957 


\section{LIST OF MAPS AND PLANS}

Thanks are due to the Archaeological fournal for the loan of the blocks of the two church plans, which first appeared in the Archaeological fournal for 1955. All the maps were drawn by C. T. Smith except those on pages 339 and 340 , which were drawn by J. H. Dexter.

The Expansion of Leicester, I718-1 844 PAGE

Borough and City Boundaries, I $835^{-1} 935$

New Building, I850-1860

The Expansion of Leicester, $1844^{-1} 95^{\circ}$

The Expansion of Building West of the River Soar 196

Parish and Borough Boundaries, I835-1935

- 252

Central Leicester

The South Fields

Ground Plan of St. Mary's Church, Leicester

. $26 \mathrm{I}$

Ground Plan of St. Nicholas's Church, Leicester

- 275

- 292

- 339

- 340

. 373

. 378

- 385 



\section{EDITORIAL NOTE}

THE system on which this volume has been compiled and edited is the same as that described in the editorial note to the second volume of the Victoria History of Leicestershire. The same group of Leicestershire patrons, under the distinguished chairmanship of Sir Robert Martin, have continued their generous grants for the support of a local editor, and the University of London has watched over the whole enterprise and published the results.

This is the first volume in the Victoria History series to be devoted exclusively to the history of a provincial town. Like its two predecessors, the second and third volumes of the Victoria History of Leicestershire, it was planned by Dr. W. G. Hoskins, while still Reader in English Local History at the University College, Leicester, now the University of Leicester. Dr. Hoskins also commissioned many of the articles that form the volume, but, owing to his departure for Oxford, he was unable to edit them. Designed to cover the history of Leicester since the Conquest, this volume falls into three main parts. The first part covers the political, social, economic and administrative history of the town as a whole. For this purpose the history of Leicester has been divided into four periods, and for each period there are two parallel chapters. In addition there are chapters on education and, for the period since I835, on three of Leicester's industries. There is no separate article, however, on engineering: it was deemed impossible to divide engineering in the city from engineering in the county, and the whole history of engineering in Leicester and in Leicestershire has been treated in a single chapter in Volume III. The second part of the present volume covers the topography of the area which constituted the borough until I89I. In this part it was found inconvenient, and in some respects impracticable, to deal with all the various subjects within the topographical framework familiar to readers of parish histories in this series. There are, therefore, in addition to chapters on the several parishes and liberties, separate chapters on mills, lost churches, Roman Catholic and Protestant nonconformity, the borough charities, and almshouses and hospitals. The third part of the volume covers the topography of the areas added to Leicester at various dates since I89I. It may be specially mentioned that the history of the population and physical growth of the city, which is the work of Mr. C. T. Smith, has been woven into the chapters on social and administrative history since 1660 , and not reserved, as in rural Leicestershire, for separate treatment.

For general help in the preparation of the volume, and especially for advice upon architectural descriptions, thanks are due to Professor Jack Simmons. Thanks are also due to Mr. C. D. B. Ellis for his advice, particularly on the history of charities. The services of Dr. L. A. Parker, the Leicestershire County Archivist, and Mr. G. A. Chinnery, the Leicester City Archivist, are recalled with like appreciation. Information provided by Mr. A. Wright, of Leicester City Library, and by Mr. J. Hill, of Leicester, about the history of the City in the nineteenth and twentieth centuries is gratefully acknowledged, as is also the permission given by parochial incumbents, clerks of charities, and others to consult records in their possession.

The articles in this volume were in preparation up to the summer of $195^{6}$, and do not take account of changes which have taken place since then, notably the transformation of University College, Leicester, into the University of Leicester. 



\section{LEICESTERSHIRE VICTORIA COUNTY HISTORY COMMITTEE}

as at 3 I December I957

Alderman Lt.-Col. Sir Robert E. Martin, C.m.G.,

T.D., D.L. (Chairman)

Councillor Mrs. M. E. Keay, B.E.M.

Councillor Lt.-Col. C. E. J. Freer, D.L.

The Revd. D. A. Adams

Alderman C. R. Keene, c.B.E.

Councillor Mrs. M. M. Trotter

$\int$ Representing Leicester County Council

C. D. B. Ellis, EsQ., C.B.E., M.c.

J. Milne, EsQ.

S. H. Russell, EsQ.

Representing the City of Leicester

Representing the Leicestershire Archaeological and Historical Society

Representing the Leicester Literary and Philosophical Society

Dr. A. K. B. Evans

Professor J. Simmons

Representing Leicester and County Chamber of Commerce

Representing the University of Leicester

The Rt. Revd. Dr. R. R. Williams, Bishop of Leicester

R. B. Pugh, EsQ.

Representing the Diocese of Leicester

Representing the Central Committee of the Victoria County History

Co-opted Members

Sir William Brockington, c.b.e. Dr. J. H. Plumb

L. H. Irvine, EsQ., M.B.E. $\quad$ Dr. H. P. R. Finberg

DR. W. G. Hoskins

Dr. L. A. PARKER

S. B. BORDOLI, EsQ.
Honorary Secretary

Honorary Treasurer 



\section{LIST OF THE CLASSES OF PUBLIC RECORDS USED IN THIS VOLUME WITH THEIR CLASS NUMBERS}

Chancery

C I Proceedings, Early

C 2 Proceedings, Series I

$\mathrm{C}_{3}$ Proceedings, Series II

C 5 Proceedings, Six Clerks' Series, Bridges

C I9 Miscellaneous Proceedings from Six Clerks' Office

C 33 Decrees and Orders, Entry Books of

C 47 Miscellanea

C 54 Close Rolls

C 66 Patent Rolls

C I3I Extents for Debts

C 219 Parliament, Writs and Returns of Members to

Court of Common Pleas

C.P. 25 (2) Feet of Fines, Series II

C.P. 40 Plea Rolls

Exchequer, King's Remembrancer

E IoI Accounts, Various

E 122 Customs Accounts

E 150 Inquisitions post mortem, Series II

E I78 Special Commissions of Enquiry

E I79 Subsidy Rolls, etc.

Exchequer, Augmentation Office

$E_{317}$ Parliamentary Surveys, Commonwealth

Exchequer, Lord Treasurer's Remembrancer E 368 Memoranda Rolls
Home Office

H.O. 40 Disturbances I812-I 855, Correspondence

Justices Itinerant

J.I. I Assize Rolls, Eyre Rolls, etc.

Duchy of Lancaster

D.L. I Bills, Answers, etc. (Pleadings)

D.L. 4 Depositions and Examinations, Series II

D.L. 5 Decrees and Orders, Entry Books of

D.L. I3 Patents, Drafts of and Particulars for

D.L. 29 Accounts, Ministers'

D.L. 30 Court Rolls

D.L. 37 Chancery Rolls

D.L. 38 Colleges and Chantries, Certificates of

D.L. 4I Miscellanea

D.L. 42 Miscellaneous Books

D.L. 44 Special Commissions and Returns

Privy Council Office

P.C. 2 Registers

Court of Queen's Bench

K.B. I Affidavits, General

Court of Requests

Req. 2 Proceedings

Special Collections

S.C. 8 Petitions, Ancient

S.C. I2 Rentals and Surveys 


\section{NOTE ON ABBREVIATIONS}

Among the abbreviations and short titles used the following may require elucidation:

Leic. Boro. Rec. IIO3-I327 Records of the Borough of Leicester, IIO3-I327, ed. Mary Bateson (London, 1899).

Leic. Boro. Rec. I327-I509 Records of the Borough of Leicester, I327-I509, ed. Mary Bateson (London, 1901).

Leic. Boro. Rec. I509-I603 Records of the Borough of Leicester, I509-I603, ed. Mary Bateson (London, 1905).

Leic. Boro. Rec. I603-I688 Records of the Borough of Leicester, I603-I688, ed. Helen Stocks (Cambridge, 1923).

Leic. Dioc. Cal.

Leicester Diocesan Calendar, Clergy List and Year Book, I928- ～(Leicester, $\left.1927^{-}\right)$.

Farnham, Leics. Notes

T.L.A.S.

Leicestershire Medieval Village Notes, collected by G. F. Farnham (6 vols., Leicester, 1929-33).

Transactions of the Leicestershire Archaeological .... Society (Leicester, I866- ).

Wyggeston Hosp. Rec.

A Calendar of Charters and Other Documents belonging to the Hospital of William Wyggeston at Leicester, ed. A. Hamilton Thompson (Leicester, 1933). 


\title{
THE CITY OF LEICESTER
}

\section{POLITICAL AND \\ ADMINISTR ATIVE HISTORY \\ 1066-1509}

Political History, p. I. The development of Borough Status, p. 8. The Jurisdictions and Franchises, p. 9. Relations with the Central Government, p. 17. Progress towards Incorporation, p. 19. Growth of the Town Council and Borough Government, p. 23.

\begin{abstract}
$\Lambda^{N}$ account of the political history of Leicester and the development of its borough government in the four and a half centuries between the Norman Conquest and the reign of Henry VIII must have a dual aspect. On the one hand, the town with its castle was parcel of the honour of Leicester and later of the Duchy of Lancaster. It was unusual among boroughs of comparable importance for the completeness of its mediatization from royal control into the hands of magnates, who at various times were in their own persons vital factors in English politics, and, from the i 3 th century onwards, in close family connexion with the royal house; moreover, even after the amalgamation of the Duchy of Lancaster with the Crown after I399, Leicester was primarily dealt with by the king in right of the duchy. On the other hand, there is through the period the development of borough institutions and the evolution of its corporate existence, which are organic growths of the town itself as a result of the activities of its burgesses. But this aspect cannot wholly be separated from the other, for the relationship of the earl and his stevvard with the burgesses was ever a considerable factor in borough government. Thus though the two aspects may be considered separately, such a division will always be an artificial one. However, a survey of the external history of Leicester may first be made, which is in effect an account of the earls of Leicester and Lancaster, and later the dukes of Lancaster, in relation to the town.
\end{abstract}

\section{POLITICAL HISTORY}

The effect of the Conquest on Leicester was immediate, for it was placed under a Norman lord. Hugh de Grentemesnil, one of the most trusted and powerful of William's followers, was rewarded for his part in the fighting by large grants of land in the Midlands. He was the greatest landholder in Leicestershire, with 37 manors in demesne, and was made sheriff of the county, with its third penny of all the profits of justice. He was also the most porverful though by no means the sole lord of the town, where he had by far the largest holding of houses. ${ }^{I}$ In $1086^{2}$ the king possessed 39 houses in Leicester, and 24 more which he held in common with Hugh; Hugh held independently a large estate of over 200 houses (or their burgesses), which was considerably greater than that of the other two main holders of land, Countess Judith who had 28 houses and some land,

V.C.H. Leics. i. $301-3$; ii. 79.

2 Ibid. i. 306; and see below, p. 3 I. 


\section{A HISTORY OF LEICESTERSHIRE}

and the Bishop of Lincoln who had 17 burgesses; the holdings of the Leicestershire tenants in chief were negligible by comparison. Hugh's unmistakable ascendancy is indicated by his possession of the third penny of the mint of the town. ${ }^{3}$

Leicester castle, which is not mentioned in Domesday or in contemporary chronicles, was probably constructed during the campaign of 1068 , when William I began to build the castles at Warwick, Nottingham, and Lincoln. ${ }^{4}$ Hugh seems to have been given the custody of the castle. At any rate Ordericus Vitalis calls him municipatus of Leicester, ${ }^{5}$ a title which seems to mean castellan, for Hugh was not absolute lord of the town. It was, indeed, upon this office, which became hereditary in his family, that the real power of Hugh was based. ${ }^{6}$ Hugh joined the baronial rebellion of Robert Courthose against William II in I088, and, according to the Anglo-Saxon Chronicle, waged private warfare in Leicestershire and Northamptonshire, during the suppression of which the town of Leicester suffered severely.

In spite of Hugh's misdemeanour, his son Ivo succeeded him in 1093 as keeper of Leicester castle and sheriff of the county. He shared the lordship of the town with the king, the Bishop of Lincoln, and Simon of St. Liz, ${ }^{7}$ Earl of Huntingdon and Northampton, but Ivo's position as farmer of the king's revenues gave him paramount influence. ${ }^{8} \mathrm{He}$, like his father, waged private war in Leicestershire on his own account, and had to be suppressed by the king. The town of Leicester suffered again from the ravages of the rising, ${ }^{9}$ and Ivo fell under a heavy fine. It was because of this that the Beaumont family was able to establish its lordship over Leicester, for Ivo was hard pressed to pay, and in consequence put himself under the protection of Robert de Beaumont, to whom he pledged his lands for fifteen years, partly to pay it and partly to finance his departure on a Crusade. When Ivo died on this journey, Robert kept Ivo's share of Leicester in his own hand, and gained all the rest of it, except the Bishop of Lincoln's Fee in the suburbs, by royal gift and by the judicious marriage of his daughter to the son of Simon of St. Liz. Thus 'by royal favour and his own astuteness' Robert became sole lord of the borough. ${ }^{\text {I }}$

This Robert de Beaumont was one of the most powerful vassals of the Crown in England, and his acquisition of the lordship of Leicester increased his influence. From his accumulation of lands may be traced the development of the large congeries of fees known by the end of the I 2 th century as the honour of Leicester. There is little record of his relations with the town of Leicester, but he may fairly be credited with a policy of building up the castle and churches of the town.

It is not certain whether Robert was made Earl of Leicester in his lifetime, but it is very probable, as his son Robert used the title when he was only fifteen years old, less than a year after his father's death in I I 8 , and it is unlikely that such a dignity would have been conferred on a minor. ${ }^{\text {II }}$ The younger Robert, called le Bossu or Hunchback, was, like his father, in a position of great power and influence in relation to the Crown. He was not very closely connected with Leicester except as the caput of his English

3 It must be emphasized that the third penny of the profits of justice of the shire is quite distinct from the third penny of the mint of the town. It is stated in Dom. Bk. that $£ 20$ yearly was to bè paid to the king and 'of these $f_{2} 20$, Hugh has the third penny'.

${ }_{4}$ F. M. Stenton, Development of the Castle (Hist. Assoc. Pamphlet) and L. Fox, 'Leic. Castle', T.L.A.S. xxii. I3I2. And see below, p. 344 .

5 Ordericus Vitalis, Historia Ecclesiastica, ed. le Prévost, ii. 222.

${ }^{6}$ F. M. Stenton, First Cent. of Eng. Feudalism, 234 and $\mathrm{n}$.

Leic. Boro. Rec. I103-1327, p. xiii.
8 Ordericus Vitalis, Hist. Eccl. iv. 169: 'municeps erat et vicecomes et firmarius regis'.

9 It has been demonstrated that the alleged destruction of Leic. in 1068 ('destructa erat civitate Leicestrie cum castello et ecclesia infra castellum') was in fact after the revolt of I IOI: J. H. Round, Feudal Eng. 456-8.

to The source of all this inf. is Orderic, who is a reliable historian of the events, for he was personally acquainted with the Grentemesnil family and knew of Leic. at close hand.

II For a full discussion of this point, see Complete Peerage, vii. 525-6. 
lands, but he maintained sufficient interest in the town to found there the Augustinian monastery of St. Mary de Pratis, and several grants of privileges to his burgesses are recorded.

Robert Blanchesmains, his successor, was to involve the town much more closely in the affairs of the kingdom. He joined the rebellion of Henry, the king's son, in I I 73, with disastrous results. The town of Leicester was dragged into the rebellion at his heels. It was taken and burnt by royal forces, the area of St. Michael's parish suffering most severely in this siege, though the castle held out for some weeks, which is some measure of the strength of its defences. ${ }^{12}$ The burgesses had to sue for peace, which they purchased for 300 marks, and many of them withdrew entirely from the town, which was garrisoned by royal forces. Robert was captured, and his castles surrendered, thus ending the episode which was known as the 'Leicester War'. ${ }^{13}$ Although he was soon released, the king was determined on the destruction of the defences of Leicester, and the pipe rolls bear witness to the thoroughness with which this was carried out, ${ }^{\mathrm{I}}{ }^{\mathrm{t}}$ the third destruction within a hundred years. Robert FitzParnell, the next earl, was invested with the earldom at Messina in II9I while crusading, and was not much in England, dying without an heir in 1204.

The death of Robert FitzParnell resulted in a reorganization of the honour of Leicester which decreased its size and brought it into de Montfort hands. ${ }^{15}$ The Beaumont inheritance was divided between his two sisters, Amice, Countess of Leicester, who was married to Simon de Montfort, and Margaret, the wife of Saer de Quency, whose moiety was absorbed into the honour of Winton. The partition was finally concluded in I 207, and by it Simon de Montfort (the son of Amice and the elder Simon) was to receive the third penny for the county, the chief messuage of Leicester, and the stewardship of the royal household. ${ }^{16}$ But before he could take seisin, de Montfort's lands were seized for payment of a large debt which he owed to the Crown and Leicester was later delivered over to the keepership of Ranulf, Earl of Chester. ${ }^{17}$ Until then, Leicester was relatively unaffected by the changes in the honour. The barons conspiring against King John had met there in $\mathrm{I} 20 \mathrm{I},{ }^{18}$ soon after the king's coronation, but no rising took place in the Midlands.

After the death of Simon de Montfort in $\mathrm{x} 2 \mathrm{I} 8$, his sons pressed their claims to the honour of Leicester, and after Amaury, the elder, had in 1229 quitclaimed his English patrimony to his brother Simon in return for their French inheritance, the claim to the honour devolved upon the younger Simon, who gained it in I23 I, and by 1239 he was invested as Earl of Leicester, ${ }^{19}$ by right of which he also claimed the Stewardship of England, which he apparently believed to give him power to supervise the government of the whole kingdom.

He was not much concerned with his town of Leicester, and was rarely in residence. However, in his relationship with the town can be seen the power of a magnate unfettered by royal control, for his acts towards the burgesses had almost the authority of royal power. The change of the custom of inheritance of the borough from ultimogeniture to primogeniture $^{20}$ is the outstanding example; ${ }^{2 I}$ it is true that the act received royal

I2 Gesta Regis Henrici II (Rolls Ser.), i. 48; Pipe R. I 74 (P.R.S. xxii), 47, 77, 106, I37; R. de Wendover, Chron. (Rolls Ser.), i. 94 .

${ }^{13}$ Red. Bk. Exch. (Rolls Ser.), p. ccxiv; V.C.H. Leics. ii. $8 \mathrm{i}-8 \mathrm{2}$.

${ }_{14}$ Pipe R. II75 (P.R.S. xxv), 179; ibid. II76 (P.R.S. xxvi), 29; R. de Hoveden, Chron. (Rolls Ser.), ii. I I8.

is For a full acct. of the descent of the honour of Leic. see L. Fox, 'Origin and Descent of the Honor of Leic.', E.H.R. liv. $3^{8} 5^{-99}$.
${ }^{16}$ Rymer, Foedera (Rec. Com.), i. 96.

17 He was also involved in a conspiracy against the king in I224: R. de Wendover, Chron. (Rolls Ser.), ii. 276; see also V.C.H. Leics, ii. $83,86$.

I8 R. de Hoveden, Chron. (Rolls Ser.), iv. I6r.

I9 Matt. Paris, Chron. Majora (Rolls Ser.), iii. 524.

20 Leic. Boro. Rec. IIO3-I327, 49-5I.

2I Ibid. Mary Bateson's edition of the rec. of the boro. of Leic. is still, nearly 50 years after its publication, the most important work on the hist. of the boro. and the basis 


\section{A HISTORY OF LEICESTERSHIRE}

confirmation from Henry III, but the act was the earl's, at the petition of his burgesses. Another action of a similar sort was the expulsion of the Jews from Leicester; in I23 I, or a little earlier, de Montfort granted liberty to the burgesses to banish the Jews from the town on the grounds of their usurious oppression of the inhabitants, thus anticipating by about sixty years their expulsion from England by Edward I.22 De Montfort's relations with the burgesses themselves are more difficult to discover, for evidence is scanty, though there is mention of a heavy fine of 500 marks which he laid upon Simon Curlevache, then the leading burgess of the town, a fine which Matthew Paris called 'extortionate'23 and which called forth criticism from the Bishop of Lincoln. ${ }^{24}$

In all the turmoil of the Barons' War, the town of Leicester was not closely involved. Henry III is said to have been entertained in Leicester in I264, after taking Northampton, ${ }^{25}$ but Leicester was not involved in any fighting, either then or later, when the war was at its height. Simon de Mlontfort's defeat and death at the battle of Evesham in I $26_{5}$ caused the town and honour to be forfeit into the king's hand.

The grant of the Earldom of Leicester, and with it the honour, town, and castle to Edmund Crouchback, the king's son, began a new phase in the history of the borough, for it was now brought into close relationship with the house of Lancaster and so with the Crown. By $1269^{26}$ Edmund had received the Stewardship of England, comital rank, and a grant of the privileges and liberties of the honours of Leicester, Derby, and Lancaster, so that his vast lands were composed of a considerable agglomeration of fees, and while Leicester was still the caput of one of his honours, the centre of the whole administration moved northwards and away from the Midlands. Leicester saw little of its earl, who, though occasionally resident in the castle, spent most of his time away from England.

The succession of Earl Edmund's son Thomas to the earldom and the rest of his father's lands and titles in I 296 brought Leicester once more into national affairs, for the town necessarily became involved in the political turmoil which he created. Thomas kept residence in Leicester in great state, and entertained lavishly, to such an extent that $f 7,000$ was spent in one year on hospitality alone. ${ }^{27}$ There are records that the castle was repaired and altered, King Edward I was entertained there in 1300 , Queen Isabel in I 309 , and Edward II in 1310 and 13 I I on his way to and from Scotland. ${ }^{28}$

By 1309 Thomas was in violent opposition to the king and court, and though he was pardoned in $\mathrm{I}_{3} \mathrm{I}_{3}$ for his activities as one of the Lords Ordainers against Gavesto1, he soon after formed another opposition party with the Despensers. Thomas came to Leicester in $\mathrm{r} 3 \mathrm{r} 8$, where the Bishop of Ely followed him to negotiate a peace. A large gathering took place in Leicester, ${ }^{29}$ at which cardinals sent by the Pope, and the king and queen, the Archbishop of Canterbury, and many magnates and bishops, were present, after which the king and the earl were reconciled at Zouch bridge, some.way outside the town. There is also an account in Knighton's chronicle of a long series of articles of agreement made at Leicester at the same time between the king and the bishops. ${ }^{30}$ But this peace was not to last long; Thomas was again roused to hostility by a royal coalition against the Despensers, and took up arms in the north, but, lacking support, was defeated at Boroughbridge in $\mathrm{I} 322$, and executed soon after as a traitor at Pontefract.

for all more recent research. Whenever a Latin text is quoted in translation in this article, the translation is hers.

${ }^{22}$ The charter expelling the Jews (Leic. Boro. Rec. I $509-1603,457$ ) is dated by C. Bémont (Simon de Montfort, 62) as c. 1253. However, as Simon does not use the title of earl, it is unlikely to be later than 1239. It seems most likely that the charter may be dated $c$. 1230: Roberti Grosseteste Epistolae (Rolls Ser.), 33.
23 Matt. Paris, Chron. Majora (Rolls Ser.), iv. 7.

${ }_{24}$ Roberti Grosseteste Epistolae (Rolls Ser.), I 4 I.

25 W. Kelly, Royal Progresses and Visits to Leic. II 2.

${ }^{26}$ Cal. Chart. R. 1257-1300, I1 8, 122.

${ }_{27}$ Chron. Edw. I and Edw. II (Rolls Ser.), ii. I8 I.

${ }^{28}$ Kelly, Royal Progresses and Visits to Leic. 133-5;

Leic. Boro. Rec. I IO 3-1 327, 236, 265; T.L.A.S. xxii. I 39.

${ }^{29}$ H. Knighton, Chron. (Rolls Ser.), i. 412-I 3 .

30 Ibid. i. 4I3-2I. 
Leicester suffered severely in the final stages of the earl's rebellion. Thomas raised a reluctant force from Leicester to aid him in the north, after his officers, having failed to raise a body of men from the town to go to Tutbury, had reported to the earl that 'the men of Leicester despised his commands'. ${ }^{31}$ But in spite of the town's favour to the king's cause, the town and its immediate neighbourhood suffered at the hands of the royal forces in their pursuit of the rebels northwards. At this time the keeper of the castle found himself unable to give a financial return for the demesne lands of the castle 'because there was no one who wanted to, or even could, farm the said pastures on account of the destruction wrought ... by the arrival of the king's army' nor would anyone undertake the reeveship 'because of the poverty of the tenants of the town and the devastation of the neighbourhood', for the same cause. ${ }^{32}$

Peace was not, however, yet restored. Queen Isabel returned to England from France with a rebel force led by Mortimer, and the new Earl of Lancaster, Thomas's brother Henry, joined her against the Despensers in I 326. In consequence, when the possessions of the elder Despenser were brought to Leicester Abbey, the followers of Earl Henry attacked the abbey and seized all the goods and treasure. ${ }^{33}$ After the usurpation by Mortimer Leicester was once more involved in rebellion. Mortimer did a great deal of damage in Leicester and the surrounding country, ${ }^{34}$ and Henry was forced to make his submission at Bedford. A council was held at Leicester, and a peace was patched up, but Henry was not restored to favour until after the fall of Mortimer in I 330 and the emergence of King Edward III from his mother's dominance.

Henry of Lancaster did not take any very active part in public life after his return to power, for his eyesight was failing, and he withdrew to Leicester, where he spent most of the rest of his life, standing high in royal favour until he died in I345. The main project of these last years was the building and endowment of the Newarke Hospital, which was to be the most magnificent and enduring monument to the Lancastrians in Leicester, for it was also enriched and enlarged by his descendants. Though Henry perambulated his estates to some extent, the amount of time he spent in Leicester is illustrated by the many payments of gifts to him recorded in the borough accounts. ${ }^{35}$ These entries also indicate a considerable number of royal visits. Edward III came first in 1327 , the king's marshal and his household in 1333 , and a year or two later the queen came on her way both to and from Scotland. On the visit of 1327 , a meeting of Convocation was held in connexion with the parliament at York.

Henry, who was buried with great pomp in the chapel of the Newarke, ${ }^{36}$ in the presence of the king and queen and a large gathering of bishops and magnates, was succeeded by his son Henry, Earl of Derby. This earl, dignus Henricus, nobilis dux, ${ }^{37}$ created Duke of Lancaster in I35I, enlarged his father's Newarke foundation, and increased its importance by obtaining a papal bull defining its status, and a holy relic of high reputation for it. ${ }^{38}$ The main local political event of this period was the holding of a session of parliament in the town in $1349 .{ }^{39}$ The duke died in $136 \mathrm{I}$, a victim of the Black Death, and was buried in Newarke College with a splendour equalling if not surpassing that of his father's funeral.

He left no male heir, and his inheritance passed to his daughters, one of whom died almost immediately, so that the whole estates passed to Blanche and her husband, John

is Leic. Boro. Rec. IIO3-I327, 329.

${ }^{2}$ D.L. $29 /$ I $146 / 9$, m. 3 d.; L. Fox, 'Ministers' Accounts of the Honor of Leic.', T.L.A.S. xix. 209.

33 H. Knighton, Chron. (Rolls Ser.), i. 435 ; Leic. Boro. Rec. $I 103-1327,380$.

34 Knighton, op. cit. i. 450 .

35 Leic. Bor Rec. I327-I509, pp. xix-xx. On the
Newarke Hospital, see V.C.H. Leics. ii. 48 .

${ }_{36}$ T. Walsingham, Hist. Angl. (Rolls Ser.), i. 266.

37 H. Knighton, Chron. (Rolls Ser.), ii. I I 4-16.

38 A. Hamilton Thompson, Hist. of Hosp. and Nerv Coll. of the Annunciation of St. Mary in the Nervarke, 27-30; V.C.H. Leics. ii. 48-49.

39 Rot. Parl. ii. 200. 


\section{A HISTORY OF LEICESTERSHIRE}

of Gaunt, Earl of Richmond. John of Gaunt became Earl of Lincoln, Derby, and Leicester, and soon after was created Duke of Lancaster. It was in his lifetime that Leicester reached the zenith of its magnificence as a ducal dwelling-place. He did not live continuously in Leicester, but it was one of his favourite residences, and both Edward III and Richard II were entertained there on various occasions. The royal visit of I 390 was marked by a particularly sumptuous entertainment, ${ }^{\circ}$ and an elaborate hunting party at which most of the chief magnates of the realm were present. This kind of lavish spending fell somewhat hardly upon the people of Leicester, who were frequently called on to make large gifts to keep in the good graces of their lord or of those who influenced him.4I There was another such magnificent occasion a few years later, when Constance, John of Gaunt's second wife, and his daughter-in-law Mary de Bohun, who had both died at the same time, were buried with great pomp in the collegiate church of the Newarke.

The duke was not unpopular with the people of Leicester, if their readiness to come to his support in $138 \mathrm{I}$ is any indication of their loyalty to him. The mob which burned the Savoy were reputed to be on their way to attack Leicester, and, in fear of this, John of Gaunt's treasure was brought for safe keeping to Leicester Abbey, though the abbot refused to receive it; 42 the mayor, greatly alarmed, proclaimed a muster on Gallowtree Hill to meet the threatened assault. After the accession to the throne as Henry IV of John of Gaunt's son, Leicester's immediate lord was the king, for the first time since the early I 2 th century. Henry provided that the Duchy and Palatinate of Lancaster should remain in the hands of himself and his heirs for ever, separate from the general administration of the realm, in the hopes that his heirs might retain this inheritance even if they lost the Crown. Moreover, from this time the dangerous office of High Steward, which had been attached to the Earldom of Leicester and Lancaster, was never again granted to a subject except for judicial or ceremonial purposes. Thus an alternative relationship between the king and the town of Leicester was set up, for he might address his town as its royal sovereign or as its feudal lord, and the records of the royal dealings with Leicester throughout the I 5 th century frequently show him acting under the duchy seal. 43 This duality did not persist throughout the entire period, for there were breaks in its continuity. The town and honour were settled on Queen Catherine in her widowhood, after the death of Henry $\mathrm{V}$, and later were included in the dowry of Margaret of Anjou. These ladies therefore were lords of the town in such matters as holding courts;44 but apart from these episodes, the town was held by the sovereign in right of the duchy.

In consequence of this new relationship, more royal grants were made to the borough than hitherto, in contrast to the sole confirmation of privilege about holding courts made by Richard II in return for the fitting out of a war vessel by the town, 45 which was the only royal grant to the town through the whole of the I 4 th century. Moreover, political events sometimes brought the king to the town, which was an opportunity to obtain a royal charter. Leicester was not, however, a royal residence, and although alterations and some repairs were made to the castle in the early I 5 th century, it declined considerably in importance, like other royal castles in the later I 5 th century. ${ }^{46}$

Henry Bolingbroke had passed through Leicester at the head of a large army in his

40 H. Knighton, Chron. (Rolls Ser.), ii. 313.

${ }^{41}$ e.g. Leic. Boro. Rec. I327-I 509, I 70, where various payments to 'minstrels of the Lord Duke of Lancaster' and others were made in $1377-8$.

${ }^{42}$ H. Knighton, Chron. (Rolls Ser.), ii. I $42 ;$ V.C.H. Leics. ii. 97.

43 Leases of the farm of the boro. were made under the duchy seal, but grants of pardon and release from debts, \&c. were made by letters patent, and the important charter setting up Justices of the Peace was made under the Great Seal. Edw. IV's grant of an annuity to the boro. was, however, made under the duchy seal. It is interesting to note that Hen. VII's interference in boro. elections was made also under the duchy seal: see below, nn. $47,48,54,55$.

44 Leic. Boro. Rec. I327-I509, 232, 256.

45 Ibid. 185 . 46 T.L.A.S. xxii. I $53-5$. 
campaign to seize the throne, and after his success, he came again in 1403,47 when he confirmed the freedom of the tenants of the honour of Leicester from toll, and among other visits may be mentioned one in 1406 when he pardoned the mayor and burgesses a debt of $f, 15 .{ }^{48}$ His son Henry $\mathrm{V}$ came less frequently, though he was present at the parliament held in Leicester in $\mathrm{I}_{4} \mathrm{I} 4$; on this occasion the mayor and burgesses profited by his presence to gain a pardon of the borough's fines and debts, and in I $4 \mathbf{I} 6$ obtained a confirmation of their freedom from toll. ${ }^{49}$ Henry came on few other occasions, but left a memorial to his own piety in Leicester, in the tomb which he erected for his mother, Mary de Bohun.

The holding of the Parliament of Bats in Leicester in 1426 was the occasion for the most solemn spectacle which the town was to see during the whole of the $5_{5}$ th century, for the young child Henry VI was at this time received into the order of knighthood while he was staying in Leicester castle for the parliament, and the imposing ceremony was performed in St. Mary's Church. ${ }^{50}$ Another parliament was held in Leicester in $145^{\circ},{ }^{51}$ after an adjournment from Westminster, but was dissolved before the threat of Cade's rebellion.

In spite of its long-standing Lancastrian connexions, the town of Leicester was more in favour of the Yorkist cause during the civil wars. There were disturbances in the Midlands in $145^{\circ}$, and although there was a lull in $145^{2}$, after the reconciliation of the king with the Duke of York, at which time Leicester was included in a general pardon, hostilities soon broke out again. In I455, Somerset summoned his supporters to Leicester, and the king failed to find much support in the Midlands in spite of a royal progress in 1456 ; the court stayed in this area for some time, and in 1459 , the king kept Christmas at Leicester. ${ }^{22}$ It appears that forces from Leicester supported Edward IV at Towton in $1461,{ }^{53}$ and certainly by 1462 , when Edward was in Leicester, the town was in high favour with him, and he granted an annuity of twenty marks for twenty years 'in consideration of the good and faithful and unpaid service which the mayor and burgesses ... have cheerfully rendered of late in our behalf against our enemies . . . as also of their no small losses incurred touching our business'. ${ }^{44}$ Although he subsequently revoked many similar grants, a special exemption was made for Leicester in various acts of resumption, and further favour was shown to the town in the grant of a fair ${ }^{55}$ and another annuity in 1473 .

Richard III came to Leicester in $\mathrm{I}_{4} 83$, the last time a king resided at the castle. He came again soon after, to raise a body of forces to subdue the Duke of Buckingham, but it was his third visit to the town which was to mark the end of his reign and the establishment of a new dynasty in England. In I $_{4} 85$ Richard and his supporters 'assembled to theyme atte Leicestre ... a grete hoste, traiterously intendinge, imagininge and conspireinge ... and with banners spred, mightyly armed and defenced with all manner Armes, as Gunnes, Bowes, Arrows, Axes and all manner Articles apt and needful to get and cause mightie Battaille', ${ }^{6}$ stayed the night in Leicester and went on to Bosworth Field.

Henry VII viewed the part which Leicester had played in these events with a favourable eye. His grant of an annuity to the borough in I 488 was made 'in consideration of the true and faithful service that the Maire and burges of our towne . . have done unto us and hereafter entend to doo and also the grete costes and charges that they

47 For his itin. see D.N.B.

48 Leic. Boro. Rec. I327-I 509, 223.

49 Ibid. $225-8$

50 Rot. Parl. iv. 299.

51 Ibid. v. 172.
52 C. L. Scofield, Life and Reign of Edw. IV, i. 40.

53 See Kelly, Royal Progresses and Visits to Leic. 223.

54 Leic. Boro. Rec. I327-I 509, 279.

55 Ibid. 296; and see below, p. 47.

56 Rot. Parl. vi. 276. 


\section{A HISTORY OF LEICESTERSHIRE}

have susteigned and borne by our commaundement in our journees, fieldes and batailles, and the costes that they dyde and made upon our servauntes wounded and maymed in our furst feld'. ${ }^{57}$ It is notable that he found it necessary to make a renewed recital of the liberties of the Duchy of Lancaster to re-establish his title after the troubles of the preceding years. ${ }^{58}$

During the $5^{\text {th }}$ century the relation of the borough with its lord ceased to be a personal one, now that its lord was the king. The lord was no longer in residence even for short periods, and contact with him in person was made only on the very short royal visits. As a result, another element in the political history of the borough began to emerge, a new concept of the idea of the 'lord' of the borough. The new personal influence was that of the steward of the town, who acted for the king, and began to take his place as the most influential personage in borough affairs. This stewardship became vested in one family, the Hastingses, ${ }^{59}$ which meant that there was continuity of influence, and these hereditary stewards became as important to the life of the town as the earl himself had been in the early medieval period. The first lord Hastings, William, was a friend and supporter of Edward IV, and from him may be traced the participation of the Hastings family in Leicester's politics. His son Edward lent his aid against Richard at Bosworth, and his father's estates were delivered to him after the accession of Henry VII. William, lord Hastings had been appointed steward of the honour of Leicester and keeper of the castle in $146 \mathrm{r}$, and this office was restored to his son. George, lord Hastings, who succeeded Edward in the title, was created Earl of Huntingdon in $1529,{ }^{60}$ and his family was to have paramount influence in Leicester for the next two centuries. The emphasis had changed, away from the influence of the earl or the king in person, towards that of a local family which was closely concerned with the affairs of the town, and it was with the Earls of Huntingdon that Leicester's political future was to lie.

\section{THE DEVELOPMENT OF BOROUGH STATUS}

The extent of the medieval borough, that is, of the area covered by the borough's jurisdiction, is not easily defined. Some of the suburbs were considered to be within the borough for some purposes but outside for others. ${ }^{61}$ By $\mathrm{I}_{4} 84$ at least the borough's jurisdiction extended beyond the walls to take in built-up areas to the north, south, and east, ${ }^{62}$ but large parts of St. Margaret's and St. Mary's were outside the borough's jurisdiction. ${ }^{63}$ The history of Leicester's evolution as a borough is more complex than that of many ancient towns. It appears, mainly from the evidence of the Domesday return, that Leicester immediately before the Norman Conquest had been a normal 'burh' of the Midlands type; it was one of the five burhs of the Danelaw, and as such was marked off from the rest of England by its peculiarly Danish organization, but, apart from this, it had the market, mint, court of justice, and its own special peace in a normal manner, and was maintained by the shire, while remaining apart from the shire organization, for it stood in no hundred. ${ }^{64}$ There is no definite statement in Domesday of its geld assessment to indicate its status, but the obligations of the burgesses to King Edward had been fairly considerable, of $\mathrm{I} 2$ burgesses for the army, 4 horses for transport, I 5 sestars of honey and $£ 30 .{ }^{65}$

\footnotetext{
57 Leic. Boro. Rec. $1327-1509,315 . \quad 58$ Ibid. 314.

59 See W. Scott, Story of Ashby de la Zouch, 5 sqq. for an acct. of the family.

${ }^{60} \mathrm{~J}$. 'Thompson, Hist. of Leic. i. 225 ; see also Complete Peerage, vi. 370 sqq.

or e.g. St. Leonard's and Bishop's Fee; see below,
}

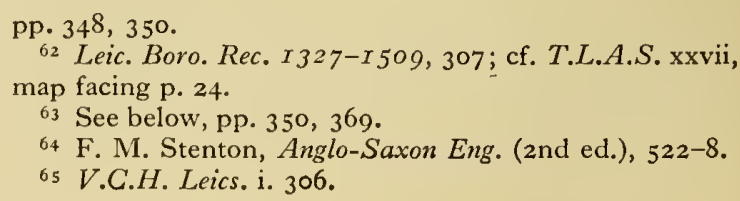


Domesday records a town of 322 houses and 56 burgesses, ${ }^{66}$ and though from their context it appears that these two terms are not interchangeable descriptions of a tenement, they may be taken to indicate that there were at least 378 houses in all. Though there is little direct mention of burgage tenure in Leicester until Henry II's reign, the Domesday phraseology tends to indicate that this form of free tenure was established in some form, at least, in Leicester. However, it is evident that not all tenure was wholly free from labour services during the 12 th century; it was not until about 1200 that the service of reaping the earl's cornlands ceased to be performed by the burgesses, ${ }^{67}$ and even then he retained the suit of mill and oven, from which they were never wholly freed throughout the period under review. Though Robert de Beaumont had abolished relief early in the $\mathrm{I}$ 2th century, there is a saving clause concerning wardship, relief, and escheats in many 13 th-century Leicester charters, though sale was apparently free by the mid-I 3 th century. ${ }^{68}$ Indeed, an inquisition of 1253 concerning the origin of gavelpence relates that a service of threepence was attached by Robert de Beaumont to all the houses which had a gable in the high street, in return for a burghal franchise to exclude the procedure of trial by battle in the settlement of disputes in the town, which indicates a special service attached to burgages in particular. ${ }^{69}$

The fact that full burgage tenure was only gradually reached is to be explained by the agrarian and to a large extent manorial nature of the community in the I2th century, which accounts for the survival of such predial services as reaping. The walled enclosure of the town and the fields lying outside formed a single economic unit. The town itself was an enclosed rectangle, protected on one side by the River Soar, and intersected by two principal roads at the extremities of which were the four gates; within this enclosure, on a rising motte by the river to the south-west, was the castle. Beyond the walls was an extensive stretch of three town fields, and to the north-west a considerable forest, where the townspeople had the right to gather wood. The eastern field was largely, though not wholly, taken up in the Bishop of Lincoln's manor, known as the Bishop's Fee; in the west field of Bromkinsthorpe were two manors, that of Westcotes, given to Leicester Abbey soon after its foundation by the earl, and that of Danet's Hall, held of the honour of Leicester in the $3^{3}$ th century by the Danet family; ${ }^{70}$ in the south field the earl made several attempts during the $\mathrm{r}$ th century to take part of the fields into his own demesne, thereby encroaching on the burgesses' rights in the Cowhay which they had by then established. ${ }^{71}$ It would thus be true to say that there was largely a farming community in Leicester in the 12 th century, though it was not a servile one; whatever variations in status there may have been between the burgesses themselves - and lack of evidence makes the precise status of burgesses hard to determine-they were free men. ${ }^{72}$ Nor were they subject to the unrestricted jurisdiction of any manor court; in 1277 it was acknowledged by the earl that neither the lord of the town nor any other had ever had right to make forcible entry on the fees of his tenants without the sanction of the court of the town. ${ }^{73}$

\section{THE JURISDICTIONS AND FRANCHISES}

This limitation of the earl's manorial jurisdiction by the town court was one of the foundations of the development of the borough government, but it was not a simple

66 Ibid. 306, 309, 328. See below, p. 31 .

67 Leic. Boro. Rec. IIO3-I327, 8; dated c. I I9I-I204.

68 See ibid. 4 for abolition of relief; ibid. 70 for free sale; and ibid. $381-400$ for various examples of this saving clause in charters.

69 Ibid. 40-43.

70 Ibid., p. xx; and see below, pp. $354,3^{8} \mathrm{I}-2$.

LEIC. IV

72 There are only 2 instances among the Leic. rec. of persons called 'vilein': one entering the merchant guild, and not therefore necessarily a burgess: Leic. Boro. Rec. $I I 03-I 327$, I 5 ; the other witnessing a charter: ibid. $38 \mathrm{I}$. 73 Leic. Boro. Rec. II03-I327, I 66. 


\section{A HISTORY OF LEICESTERSHIRE}

limitation, for the earl's officers exercised a measure of supervision over this court. To understand the later development of the constitution of the borough it is necessary first to survey the nexus of jurisdictions, franchises, and rights in the borough in the

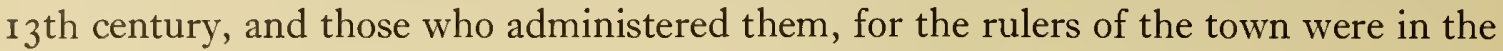
first place the officers of its courts. There was no simple conflict between the earl and the borough court, for other jurisdictions, those of the merchant guild, the Crown, and the liberties played their part; nor, indeed, was there always conflict, for relations between the earl and the town were usually amicable, and the frequent duality of function of individuals who served the earl in one office, and the town in another, together with the convergence of functions between the borough court and the court of the merchant guild, were also factors in the complexity of this relationship.

The most widespread and influential jurisdiction in Leicester was that of the earl. It was rare that ancient boroughs founded before the Conquest came under mesne lordship but Leicester is a notable exception. For the earl, the town was primarily of importance as the caput of his honour, which was administered entire as a private jurisdiction, so that Leicester was in this respect a unit in an extensive administrative and economic structure. It is incorrect to conceive of the earls as exercising a wholly independent and isolated authority, for in the last resort they enjoyed it of the Crown, and their liberties touched the royal interests and administration at all points, so that at times Crown grants of privilege, such as John's charter of I I99 concerning the borough court, 74 overrode the earl's power. None the less, in most eventualities the earl rather than the Crown must be regarded as the final authority in Leicester. All the men of the honour were quit of the shire and hundred courts, but the earl's private jurisdiction did the work of the shire and hundred, and the court of the castle, which met from three weeks to three weeks, represented the earl's justice in place of that of the sheriff, for by the end of the I 3 th century the private franchise was so complete that no officer of the Crown had any power to discharge any duty within the honour except by the earl's will and on receipt of a writ of non omittas from the king. 75 The earl had the right to execute royal writs and escheats throughout the honour, thus the normal work of the sheriff devolved on the earl's bailiffs. The earl's officers held the views of frankpledge and articles of the tourn several times a year. ${ }^{76}$ This was in effect the exercise of the police jurisdiction of the hundred court, which entailed the presentment of offenders by the responsible heads of tithings. There are no frankpledge records extant for Leicester in the I3th century, but it appears from the coroners' rolls that the town was divided into four quarters for this police organization, each quarter being one tithing.77

The grant of the honour of Leicester to Earl Robert by King John summarizes the full extent of the franchises of the honour, and this substantially held good through the

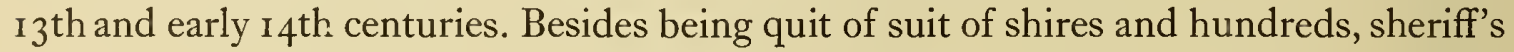
aid, murder fine, and frankpledge money, he was granted the usual manorial franchises of toll, team, infangtheof, soc and sac, and the chief exemptions in his demesnes were from pontage, passage, toll, pedage, pavage, stallage, tallage, geld, and danegeld, and works of castles, walls, bridges, and other buildings, with some specified free chase for hunting. ${ }^{78}$

The earl's court of the castle was the capital court of the honour, and dealt with all

74 Leic. Boro. Rec. IIO3-I327, 7.

75 F. Pollock and F. W. Maitland, Hist. of Eng. Law, i. 571 .

76 ilac. de Quo Warr. (Rec. Com.), 580-1, 658-9.

77 Leic. Boro. Rec. IIO3-1327, 359, 365: 'the townships came, that is, the East, West, South and North gates...'

The streets leading to the 4 gates probably made the division.

${ }_{78}$ Ibid. $35-36$, where John's grant to Earl Robert is inspected by Hen. III in favour of Simon de Montfort. 


\section{THE CITY OF LEICESTER}

manner of pleas touching infringements of these rights, and even claimed some pleas of the Crown, namely the pleas de namio vetito, that is, of hearing complaints against litigants who refused to deliver up a distress for security; ${ }^{79}$ the castle gaol in Leicester and the earl's gallows served the whole honour. ${ }^{80}$ The other courts in Leicester were chiefly a matter of financial interest to the earl's officers, for the profits of the borough court, the courts of the fair and market, and the views of frankpledge were paid over to the earl's receiver. Thus even though the burgesses or their officials might in some cases be responsible for the actual sessions, they were supervised, always in theory and usually in practice, by the earl's officers. The inquisition taken in $1327^{81}$ after the death of Thomas, Earl of Lancaster, on his possessions gives the value of the borough court of Leicester as $£_{2}$ (though this is presumably the net value, after all outgoings had been discharged, and so only a fraction of its whole value), and of the views of frankpledge, 'held yearly after Easter and Michaelmas', as $£^{6} \mathrm{I} 3 s .4 d$., but it does not mention the fair and market courts separately. These values were to increase considerably during the I 4 th century.

The chief officer of the earl, responsible for the pleas of the honour, was the steward, upon whom the administration of the whole honour depended. Although his was so important a position that much of his work was delegated, yet he played a chief part in the administration of the town, for it was only through him that the burgesses were able to reach the earl's ear; they made sustained efforts to keep in his favour, as the records of numerous presents and dinners given to him, and sometimes also to his wife, ${ }^{82}$ from time to time bear witness. It was the porter (janitor) of Leicester Castle who was most closely connected with the day-to-day administration of the town; he kept the gate, and the prison, and performed the execution of sentences of the castle court within the town, and the making of attachments, including the custody of those prisoners taken for felony and trespass. ${ }^{83}$ It is open to doubt whether there was a special officer called the earl's bailiff, for the references made to a bailiff usually mean either the steward or the town bailiff.

The earl's powers of taxation were an example of quasi-royal authority, which he was unable to exercise without specific permission from the Crown. The earl could tallage the borough when the king tallaged the royal demesne, but the town was also liable to contribute to subsidies paid by all boroughs. Thus Edmund Crouchback tallaged the town for 80 marks when his father was tallaging the ancient demesne, ${ }^{84}$ but at the same time a twentieth on movable property, 'granted to the king throughout the realm', 85 not only from ancient demesne, was levied from the town by Henry III for a Crusade. On the other hand, it appears that no royal permission was required for the levying of prises or gifts for the earl, or, his most frequent tax, a 'caption' in kind, or exhennia, and there is frequent evidence of quite heavy levies for these purposes. 86

The franchises exercised by the earl in the town were, however, by authority of the honorial privilege granted by King John, and these were of great importance to the town, for the chief one, of taking market tolls, was closely related to the trading economy

79 Rot. Hund. (Rec. Com.), i. 237.

80 Cal. Chart. R. 1300-26, 82. See also L. Fox, Administration of the Honor of Leic. in the I 4th Cent. 64-65: the gallows were the sign of infangtheof, the right to hang thieves within the earl's sphere of jurisdiction. On the castle gaol, see below, p. 345 .

${ }_{81}$ Leic. Boro. Rec. $1327-1509,3$.

82 Most of the mayors' accounts have note of some gift to the steward, e.g. Leic. Boro. Rec. IIO3-I327, 326: 'Salmon sent to the Steward's wife ... 7d.'
83 D.L. 29/1 I 47/20, m. 2.

84 Cal. Pat. 1266-72, 226; Leic. Boro. Rec. I IO3-I327, 128. See also S. K. Mitchell, Taxation in Medieval Eng. $35 \mathrm{I}-2$, where it is suggested that the heading of the tallage roll is a confusion by the scribe of 2 separate levies, one for the king and one for the earl.

85 Leic. Boro. Rec. IIO3-I327, p. lvi.

86 e.g. ibid. 126, 254, 274; Leic. City Mun. Room, boro. rec. box $12 \mathrm{~A} / 9$, a list of persons seeking payments for goods taken as a prise for the earl. 
of the townsfolk. The earl took the toll of Leicester fair, and a variety of market tolls; through-toll, on the transit of goods through the town, tronage on the weighing of goods, tolls on buying and selling, pickage on the setting up of stalls, and stallage on the stalls themselves. ${ }^{87}$ These were in all a considerable burden, but they were prevented from becoming unlawfully heavy by royal authority, for King John had granted in I I99 to the burgesses the right to come and go freely to trade through the land with their merchandise, 'saving . . . the just and due customs' ${ }^{88}$ Moreover, members of the merchant guild were exempt from a large part of these tolls, which thus were not too great an imposition. The earl's tax 'cannemol' was assessed and collected by town officers. ${ }^{89}$ With regard to murage and pavage, the townspeople apparently repaired their own walls and gates. ${ }^{90}$ Pontage was also the town's concern, for the negotiation of 1253 to get rid of bridge silver, a toll by the earl on wood from Leicester forest to be used for bridge building, had resulted in the transference of this burden to the town. ${ }^{91}$

When the earl's jurisdictions and franchises were fairly administered, relations with the burgesses appear to have remained amicable. But there was scope for great oppression and extortion, as is shown by an inquisition taken in $1322^{92}$ after the town had been in the hands of dishonest farmers acting for Earl Thomas. The complaints about toll were numerous; great fines had been imposed for the sale of cloth; fullers were not allowed to enter the town; butchers were forced to pay a levy; heavy ransoms were imposed on goods liable to toll, in excess of their value; the porters of the castle forcibly made attachments, laying aside the intervention of the town bailiff; the burgesses were compelled to be impleaded in the castle court, in suits which they should have had in their own court; there was interference in the carriage of wool and wood; 'cannemol' imposed was extortionate; and fish sellers were forced to trade only with agents of the farmers. The evocation in this inquisition of the palmy days of Earl Edmund, or indeed of the iniquities of the farmers, may have been exaggerated, but the statement serves as an illustration of how the earl's control could be misused.

Besides the earl's court there was, however, a jurisdiction in the town which was distinct from his and also to some extent a check upon it, because it was in the hands of the burgesses themselves. It was exercised through the portmanmoot, which was an ancient institution, undoubtedly dating from pre-Conquest times, in which suitors did not appear in their capacity of tenants of the earl, but as members of the borough community. The origins of such courts are usually to be found partly in manorial courts, partly in the pre-Conquest hundred courts, and the convergence of three rural hundreds upon the boundaries of the borough indicates that that of Leicester was probably in the second category. The antiquity of the urban hundredal jurisdiction is not known, and its hundredal nature became modified by borough custom and the earl's rights over it. But it may be conjectured from Domesday evidence that in other towns where Danish influence had been strong there had existed a class of hereditary lawmen, ${ }^{93}$ that the Leicester jurati of this court, first mentioned in a 13 th-century reference to I 2 th-century conditions, may possibly have had a pre-Conquest origin.

The portmanmoot was not, indeed, exempt from the lord's control. Its profits were included in the perquisites of the honour, and the earl's steward could, and frequently did, attend its meetings. The court existed by the earl's express grant, but this grant itself reveals its customary nature and antiquity. In the early 12 th century, Earl Robert

\footnotetext{
87 Leic. Boro. Rec. IIO3-I327, p. xxii.

89 Ibid. 212 ; and see below, p. 2 I.

90 Leic. Boro. Rec. IIO3-I327, 98.

91 Ibid. 43-44.
}

88 Ibid. 7.

${ }_{92}$ Cal. Inq. Misc. ii, p. 138 sqq.

93 D. M. Stenton, Eng. Society in the Early Middle Ages, 172. Such lawmen are mentioned in Dom. Bk. at Linc. and Stamford. 
granted 94 to the Leicester burgesses 'and those who desire to be of their community' that they should not have to go outside the town to answer pleas, or on account of any custom, except for one purpose, the nature of which is not clear. At the same time he freed them from suit of hundred and heriot. This raises the question of the definition of burgesses, which appears from this grant to be those who had a share in the franchise, who were 'in scot and lot', as the phrase went, to take their part of the responsibility of the borough, which might mean those who had a burgage tenement, though the qualifying phrase seems to indicate an element of choice in burgesshood.

The court had cognizance of various kinds of action. In the earliest portmanmoot roll in existence, dated $c$. 1260,95 there are pleas of debt, trespass, unjust distraint, assault, and unjust possession. By King John's grant of $1199,{ }^{96}$ the portmanmoot was a court of record for conveyances, an important adjunct to its powers. In consequence, surviving charters 97 conveying property in Leicester are of particular interest concerning personnel of the courts, because the attesting clauses usually include the names of the chief officers present, which supplement the lists which can be compiled from the borough records; the frequency of the appearance of the names of the stewards may well indicate that they were often present in the court. The frequency of the meetings of the court in the I 3 th and I 4 th centuries is uncertain, because of the lack of records, but during the 15 th century it met 36 times a year. ${ }^{98}$ There was a town gaol for offenders, separate from the earl's gaol. 99

Mention must be made of an abatement of the jurisdiction of the portmanmoot. If a tenant holding directly of the earl was impleaded in the portmanmoot either he or the earl could, to avoid judicial delays, have the suit transferred to the earl's court; there remained, however, an apparent right of appeal back to the portmanmoot. ${ }^{\text {. Conversely, }}$ if any burgess was impleaded in the court of the castle it was customary for the mayor and bailiffs to claim the transfer of the suit to the portmanmoot and for the suit to be heard there. ${ }^{2}$

The chief officer of the portmanmoot, who presided over its sessions, was the mayor, who is first mentioned by this title in $125 \mathrm{I}$; in 1257 the burgesses had some negotiation with the earl about the choice of a mayor, and in the following year Henry of Ruddington received the mayoralty from the earl, but apart from these instances there is no indication whether the office was elective or not in the $13^{\text {th }}$ century, although the mayor was sworn in before the earl in the castle court. ${ }^{3}$ There was also a body of jurati in the portmanmoot who gave judgements, for whose origin we must turn to the evidence in the inquisition about gavelpence in $\mathrm{I} 253$, which states a tradition that in the 12 th century the burgesses agreed to give the earl $3 d$. a year from certain tenements 'on condition that he would grant that all pleas touching them should henceforth be treated and determined by twenty-four jurats who were appointed in Leicester of old time'. 4 'This is not wholly reliable evidence, but none the less suggests a strong tradition for the existence

94 Leic. Boro. Rec. IIO3-I327, 4. The burgesses were not to be obliged to go outside the borough 'tantummodo ad coumecherchiam'. On the meaning of this phrase, see below, p. $3^{8} 5$.

95 Ibid. I I6-24.

96 Ibid. $7-8$.

97 Ibid. $38 \mathrm{I}-400 ; 1327-I 509,380-446 ;$ Wyggeston Hosp. Rec. 296 sqq.; B.M. Add. Chart. 24203, 21356 , 2 I 358,8 I25, 2 I359, 2 I 360 ; B.M. Harl. Chart. $52 / \mathrm{A} / 2$, $83 / \mathrm{G} / 45$; B.M. Cott. MS. Nero C. XII (Cartulary of Burton Lazars), ff. I Ioa-1 I $3 a$; Leic. City Mun. Room, Rothley Temple MSS. 44'28/8-16. All these charters have witness lists containing the names of various Leic. officials, and although it has been demonstrated that witnesses were not necessarily present when charters were made or confirmed, it is a reasonable inference from various such lists headed by the names of mayors and bailiffs that the lists were, largely at least, of persons present in the boro. court.

98 D.L. $29 / 198 / 3120,3122,3124$.

99 Leic. Boro. Rec. IIO3-I 327, 342, 360, 374-5, 378. And see below, p. 345 .

I Ibid. I 55 .

2 Cal. Inq. Misc, ii, p. I38. There was a complaint in 1332 that this was not permitted by Earl Thomas's farmers of the borough.

3 Leic. Boro. Rec. IIO3-I327, 75, 40I-3.

4 Ibid. $4 \mathrm{I}-42$; cf. above, p. I 2. 


\section{A HISTORY OF LEICESTERSHIRE}

of such a body, even though it is highly unlikely that its members went by the title of 'jurats' in the $\mathrm{i}$ th century. The executive officers of the court were the bailiffs, originally called prepositi, two of whom held office together, and first mentioned between 1234 and 1242.5 They were responsible for the execution of the sentences of the court, made attachments with the porter of the castle, and collected borough loans and the earl's dues on behalf of the town, ${ }^{6}$ but, like the mayor, they were to some extent also considered the earl's officers. ${ }^{7}$ The only other officer of the court who is mentioned with any regularity was a clerk. 8

The procedure of the portmanmoot court before the mid-I 3 th century is obscure, but the remarkably full and explicit charter reforming its conduct in $1277^{9}$ gives an exceptionally clear picture of the court at this time, and is worthy of special consideration, as being Leicester's nearest approach to a written corpus of borough customs. It was granted by Edmund Crouchback 'by his council and by the assent of the mayor, jurats, and community', which shows the close relationship of the earl to this court, and states that it was occasioned by the delays and injuries arising out of the previous procedure, upon which it throws light retrospectively, and which is noticeably Danish in origin and character. This is most clearly illustrated by the pleading procedure; a reasonable excuse for the non-attendance at court by a defendant was known as 'forfal'; the defendant denied the charge as soon as made by crying 'thwerthutnay'; if he failed to do so, he was called 'swarless', that is a non-defendant. This procedure was made more equitable by reforming the system of oath-helpers, who now had to be lawful men chosen by the court, and not, as heretofore, chosen by the plaintiff. A hindering action called 'holsake' was reformed by the abolition of false counter-accusations. The main reforms included a better method of levying distress - the bailiff could now enter, by a view of neighbours, to distrain for non-appearance; attornies could be appointed by both parties to a suit, and those absent at fairs could appoint attornies to act for them. No one was to be distrained unless he was a pledge or a debtor, and the earl's bailiff could only make distress by the assent of the borough court. The conduct of the mayor and jurats was regulated, 'to be present at the pleas, to do right, and to give judgement', and amercements were to be assessed by the jurats, not the bailiff. A tally was to be kept of anything borrowed for the use of the town, and the debt was to be paid within 40 days, or else appeal could be made to the castle bailiff. Tallage collectors were to be appointed by the mayor. An annual account for tallages was to be rendered by the mayor 'and those whom he should command' to auditors selected by the community, not to the castle court, and the remainder was to be placed in a sealed common purse. Thus the conduct of the portmanmoot was carefully regulated, not only in its jurisdiction, but also to a considerable extent in its executive functions.

A jurisdiction in the borough to be distinguished from that of the burgesses in the portmanmoot, and even freer from the earl's control, was that of the merchant guild, whose strength lay in its election of its own officers, and in the fact that it was the only court in Leicester whose perquisites did not go to the earl. This guild was an important factor in Leicester's development, for it was in a relatively advanced stage of organization even in the $\mathrm{x} z$ th century, when the portmanmoot had yet only a weak and dependent

5 B.M. Add. Chart. 24203 has an attesting clause, which includes the names of Walter Broneman and Ric. de Blaby, prepositi (temp. Simon Curlevach' and Wm. de St. Lo, aldermen, i.e. c. 1234-42). B.M. Cott. MS. Nero C. XII, f. xI Iv. has Robert de Scottum, prepositus (Peter, son of Roger, aldernan, i.e. $c .1249-50)$. Ibid. f. I 12 has the same alderman and Ric. de Champeden, prepositus, who must be at about the same date. Leic. City Mun. Room, 44'28/9 and 15 have Wylard and Walter Brunman with the same alderman. All these are prior in date to the first bailiff mentioned in Leic. Boro. Rec. IIO3-1327, $40 \mathrm{r}$.

6 Leic. Boro. Rec. IIO3-I327, 207, 212, 225, 228, \&c.

7 Abbrev. Plac. (Rec. Com.), 134.

8 Leic. Boro. Rec. IIO3-I 327, 403-4.

9 Ibid. $150-67$. 
status, and the merchant element in the life of the borough militated strongly against the manorial and agrarian tendencies of the time towards a more truly urban development.

The guild was confirmed ${ }^{10}$ to the merchants of Leicester by Earl Robert of Leicester early in the I2th century. " Its meetings were called Morningspeeches and were held about four times a year. ${ }^{12}$ These were presided over by the elected head of the guild, the alderman, and had a guild council to perform business and to pass judgement, sometimes sitting for several days at a time to complete the accumulated business. The meetings were primarily to admit members, and make trading regulations, but they also had judicial functions, foi here suits were heard relating to the infringement of such trading regulations. In practice this jurisdiction spread over a wider cognisance of cases, and matters relating to minor charges of a more general character which involved the good of the whole town were dealt with, so that sometimes the meeting is found to have been speaking for the town as a whole. Moreover, the justice of the guild court was not severe, and fewer oath-helpers were needed than in the portmanmoot, so there was an inevitable tendency to take cases there if it were possible.

As the guild was in existence by virtue of the earl's permission, it was not, of course, free from his control. The earl's steward was often present in the Morningspeech, ${ }^{13}$ the earl might make regulations for the guild, ${ }^{14}$ and, in the $\mathrm{I} 2$ th century at least, the guild was subject to payments to him as their lord. ${ }^{15}$ However, its exemption from his financial control put it in a prominent position in relation to the administration of the town, for the exaction of entrance fees laid the foundation of a substantial revenue for communal objects; the guild had a common purse, from which it made loans 'for the convenience of the town', ${ }^{16}$ and payments for amercements, gifts, and tallages are all found entered upon the guild rolls. The revenue of the guild was increased by the fact that the penalties imposed by its court were usually fines, and only rarely did the court go so far as to banish traders from the town-thus the money available in the purse mounted considerably.

The alderman of the guild (or aldermen, for there were sometimes two) was chosen by the whole guild as its chief. ${ }^{17}$ The earliest mention of such an official is William son of Leveric in $1209,{ }^{18}$ which is nearly 50 years earlier than the first mention of a mayor of the town; it seems clear that before the office of mayor was created, the aldermen were the chief men of the town. It is likely that the change to mayor, in or a little before I25I, was one of name only, for except for the styling of Henry of Ruddington, who was mayor in 1258 , as alderman of the guild at about the same time, ${ }^{19}$ the title of alderman disappears after $125 \mathrm{I}$, and it is to be presumed that the chief guild officer was thereafter, if not before, identical with the chief town officer.

The alderman summoned a council of the guild, to perform its business and to give advice, and these men, like those of the portmanmoot, were called jurati, and were often 24 in number, though sometimes as many as $35 .{ }^{20}$ This council was elective, and if members did not attend when summoned they were fined $6 d$. Besides the chief officer and council, the guild had its own agent for performing its ordinances and putting its judgements into effect, its sergeant; ${ }^{21}$ it also had chamberlains to attend to its finances as early as $122 \mathrm{I} .{ }^{22}$ Its development as an organization is indicated by the fact that it

I0 Ibid. I; cf. C. Grosse, Gild Merchant, i. 22.

II On the guilds' character, see below, p. 33 .

I2 Reg. of Freemen of Leic. I I 96-I770, ed. H. Hartopp, pp. xii sqq. 13 Leic. Boro. Rec. IIO3-I327, I86-7.

14 Ibid. 123.

15 F. M. Stenton, Doc. Illustrative of the Soc, and Econ. Hist. of the Danelaw, 259, 292-3.
16 Leic. Boro. Rec. IIO3-I327, 6 I.

17 Ibid. $26-28,60$.

18 Reg. Freemen of Leic. II96-I770, 5 .

I9 Called alderman (Leic. Boro. Rec. IIO3-I327, 76) and mentioned as receiving mayoralty (ibid. $77-78$ ).

20 Ibid. $34,76$.

21 Ibid., p. xliv. 


\section{A HISTORY OF LEICESTERSHIRE}

had a seal before 1258,23 and a guildhall of its own for its meetings; first a house was hired for this purpose, then, about $\mathrm{I} 274$, a special hall was built, at a cost of $£_{6}^{6} 9^{s} .3 d .{ }^{24}$ which was also used by the portmanmoot for its sessions at regular intervals.

There were some areas both within the walls of the town and in the suburbs which were included within the borough area but for one reason or another were to a greater or lesser degree exempt from the normal borough jurisdictions. These liberties, which included the Bishop's Fee and Knighton, the castle area and Newarke College, St. Leonard's parish, and Bromkinsthorpe, provided a disruptive element in the town jurisdiction in the same way as the town was an interruption to the normal functioning of the shire jurisdiction, and were a fruitful source of dissension and litigation. The most prominent and ancient of these was the Bishop's Fee, which had existed at least since I086. In Domesday, Remigius Bishop of Lincoln had so carucates in Leicester (an area to be identified with St. Margaret's field in the east suburb), two churches, one of which was probably St. Margaret's, the manor of Knighton, two-thirds of a hide in the southeast suburb, and $\mathrm{I} 7$ burgesses in the town. ${ }^{25}$ The number of burgesses increased, for at some time before I I39, Earl Robert le Bossu gave the bishop ro burgesses in satisfaction for damages; in I I 39 he had 32 burgesses. ${ }^{26}$ There followed then some rather complex arrangements between the earl and the bishop to give Knighton to Leicester Abbey, but this was greatly to the disadvantage of the church of Lincoln, and Knighton was restored to the bishop in or before $12 \mathrm{I} 8 .{ }^{27}$ The bishop had a manorial court for his tenants, and his court and demesne grange were in the east suburb. ${ }^{28}$

The relations between the burgesses and the men of the Bishop's Fee were frequently in question, though the burgesses of the bishop within the town were not involved, for although they owed manorial suit of court to the bishop and not the earl, they attended the portmanmoot and their relation with the guild merchant was not in question. With the tenants in the east suburb, on the other hand, there were disputes both about the guild and about liability to taxation. In 1270 the men of the fee refused to allow their goods to be rated by collectors appointed by the mayor, ${ }^{29}$ and the matter was frequently raised again in the next ten years. One aspect of it was a guild rule that a dweller in the fee might not enter the guild unless he was 'in scot and lot' with the burgesses. Richard of Bromley entered the guild in I 273 on condition that he should never dwell in the Bishop's Fee without losing the community of the guild. ${ }^{30}$ But in I 28I, a different agreement was made, occasioned by 'divers disputes' about tallage, which confirmed the previous ruling, that the bishop's tenants might enter the Guild Merchant to be in scot and lot in all things pertaining to the guild with the burgesses, and that they would pay their due proportion of tallages to the king of $£ 20$ or less, or to the earl of 20 marks or less, for the maintenance of the franchises of the guild, but not larger sums. ${ }^{31}$ Thereafter we find separate lists of 'bishop's tenants' in the tallage rolls on various occasions. Even this arrangement did not obviate all difficulties, for in $\mathbf{1} 322$ the men of Humberstone Gate (that is to say, in the Bishop's Fee) paid the royal subsidy with the hundred of Gartree, and not with the borough, and the men of Belgrave Gate were eager to do the same. ${ }^{32}$ This was to cause trouble in later periods, as was also the general understanding that no dweller in the Bishop's Fee, not being a burgess, could hold borough office. ${ }^{33}$

\footnotetext{
23 Leic. Boro. Rec. IIO3-I327, 82.

24 Ibid. 82,115 ; ibid. $1327-1509,383$.

${ }_{25}$ V.C.II. Leics. i. 309.

26 Registrum Antiquissimum, ed. C. W. Foster, i. 190-I.

27 Ibid. iii. $213^{-25}$; V.C.H. Leics. ii. I3; and see below, p. 443 .

2. Leic. Boro. Rec. IIO3-I327, 146 .
}

${ }^{30}$ Ibid. 112 ; ibid. $1327-1509,320$.

31 Ibid. $1103-1327,191-5$.

32 Ibid. 331 .

33 This raised various problems in-the early i 7 th cent. when medieval precedents were much discussed in the disputes about the liberties which arose from Queen Eliz. I's charter to the borough in 1599 ; see below, p. 58 . 
Another liberty of similar manorial origin was that of Bromkinsthorpe, in the west fields. In the I I th century it was considered to be a hamlet lying with all its customs in Leicester, but it was later divided into the two manors of Westcotes and Danet's Hall, which their lords, the Abbot of Leicester and the Danet family, considered to be entirely within their manorial jurisdiction. ${ }^{34}$ Its liberty was questioned; in I3I4 there was a dispute whether it lay in the liberty of the guild, and it was judged to be so by the mayor and jurats, ${ }^{35}$ but on the other hand a man had been murdered on his way home to Bromkinsthorpe in $\mathbf{1} 3 \mathbf{1 2}$, and the criminals had escaped because they were not in tithing, being outside the liberty of the town. ${ }^{36}$ However, Bromkinsthorpe seems to have been included in the subsidy assessments of the borough in the 15 th century, so that in some respects at least it was subject to the officers of the town.

An ecclesiastical liberty of somewhat later date was that of the Newarke. After the founding of Newarke College in I330, the canons claimed freedom from the jurisdiction of the town. This was confirmed to them by the king in 1360,37 in response to a petition from the dean and canons 'fearing that because the hospital at its foundation, the church at its erection, and the ... lands acquired ... are pretended to be in the town of Leicester whereas in truth they are in the suburb ... grave prejudice may easily arise hereafter..., and there is no later record that this liberty was disputed.

Two other liberties must be mentioned. That later known as the Castle View, next to the Newarke, apparently resulted from the fact that it was the seat of the town's overlords. The borough officers were consequently excluded from its precincts, where the earl's jurisdiction was special and paramount. ${ }^{38}$ The liberty of St. Leonard's parish is difficult to define; the parish lay outside the borough walls, and Leicester Abbey was patron of the church, so that as the land on either side of the parish, to the Soar on the south, to St. Mary's parish on the west, and to St. Margaret's on the east, also belonged to the abbey, ${ }^{39}$ it is likely that the parish was claimed by the abbey as an exempt ecclesiastical jurisdiction, but there is no evidence of the basis of any such claim.

\section{RELATIONS WITH THE CENTRAL GOVERNMENT}

This account of the local jurisdictions in the borough in the $13^{\text {th }}$ and early 14 th centuries may tend to give the impression that the earl's was ubiquitous and overriding. But the earl's judicial authority within the borough was in competition with the king's and subordinate to it; in the latter part of the I2th century justices in eyre began to visit Leicester; in II 80 the burgesses are found paying them a beaupleader fine of 80 marks. ${ }^{40}$ While business arising in the borough naturally continued to come before the justices throughout the next century, no special session for Leicester alone ever seems to have been held as was done in some other towns $;^{41}$ however, the justices were often entertained to dinner by the burgesses. ${ }^{42}$ Amercements for breaking the assize of beer were sometimes taken by royal officials, ${ }^{43}$ even though they were customarily the earl's concern, and special tallages had occasionally to be levied when justices came for

${ }^{34}$ Leic. Boro. Rec. II03-1327, p. xx; and see below, pp. $38 \mathrm{r}-2$, for the descent of the 2 manors.

35 Ibid. 29 r.

36 Ibid. 375 .

${ }^{37}$ Cal. Pat. 1358-6r, 486. The liberty of jurisdiction was confirmed to them very fully in $1406:$ Cal. Chart. $R$. I 34I-14I 7, 433. For the Newarke, see below, p. 346.

${ }_{38}$ There is little early evidence about the Castle View, but in the confirmation to the Newarke Coll. (cited above, n. 37) the Newarke liberty is said to contain the Castle View, 'a parcel of the said site is within the king's view of

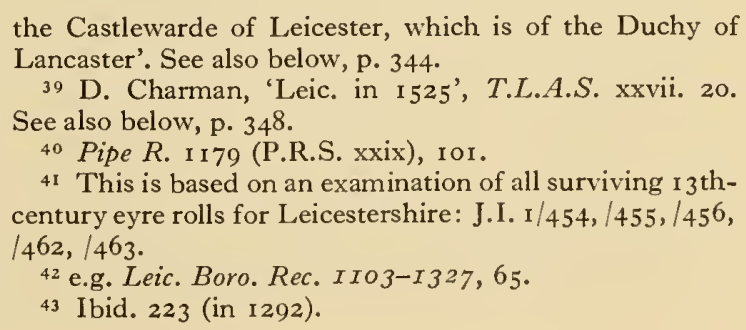

4I This is based on an examination of all surviving 13 thcentury eyre rolls for Leicestershire: J.I. I/454, /455, /456, $1462, / 463$.

42 e.g. Leic. Boro. Rec. IIO3-I327, 65 .

43 Ibid. 223 (in 1292).

LEIC. IV 
a specific purpose. ${ }^{44}$ Tallages were levied also for the greenwax. ${ }^{45}$ In times of disorder, justices of Trailbaston were sent out to deal with rioters; they are known to have come to Leicester in 1306 and 1317.46

Royal authority was also imposed by the issue of proclamations to be published in the town, of which the frequent prohibitions of tournaments because of danger from armed affrays are an example. In spite of the borough's freedom from interference by the sheriff, he was occasionally ordered to make such proclamations. ${ }^{47}$ There is an example of the sending of messengers by the king to explain what was required of the borough; in I $30 \mathrm{I}$ there was an order to the community to give credence to Peter of Leicester and Hugh of Nottingham 'to what they shall cause to be expounded to them on the king's behalf and to study to do it . . . 48 'The sheriff again entered the liberty of the borough in $\mathbf{1} 322$, this time to raise a military force to go north with the king. ${ }^{49}$ The raising of armed forces was in general a Crown privilege, which overrode the earl's authority, though the earl upon occasion raised forces of his own at the town's expense. ${ }^{50}$

Royal justice was also represented within the borough itself by the pleas of the Crown held by the borough coroners, who were themselves burgesses but were appointed as Crown officials, taking their oath before the justices in eyre.5I The borough coroners are mentioned in 1247.52 Though two leading burgesses (one of whom was later mayor) are named as coroners in Leicester in 1297,53 it is not known how they were chosen. The earliest royal order to elect a coroner for Leicester occurs in 1393,54 but it may perhaps be presumed that they were normally elected by the burgesses, for the order to elect was made in a special circumstance of an absentee coroner in the office. The two surviving rolls among the Leicester records of pleas of the Crown ${ }^{55}$ for the late $\mathrm{I} 3$ th and early I 4 th centuries show the coroners dealing with a wide variety of criminal cases, the usual duties of the county coroner.

Another aspect of the relations of the borough with the central government is to be found in the attendance of its representatives at parliaments. Leicester sent no representatives to the Parliament of $\mathrm{I}_{2} 65$, or to the assembly called in April I 268 . The Parliament of $\mathrm{I} 275$ included representatives of the towns, and this was the first to which Leicester sent burgesses. They were summoned by a writ of venire facias addressed to the sheriff, ${ }^{56}$ and the same procedure was followed to call Leicester representatives to the Parliaments of 1295 and $\mathrm{I} 298$.

The regular summons of burgesses to Parliament was by this time established, and the evidence available about the attendance of Leicester burgesses throughout the I 4 th and $15^{\text {th }}$ centuries throws some light on the general problem of the personnel of Parliaments during this period. From I300 to I 509, Leicester burgesses attended at least $\mathrm{I} 20$ gatherings, judging by the evidence of the sheriffs' writs de expensis for payment of their wages in conjunction with the evidence of payments of wages to Members of Parliament entered in the borough accounts. ${ }^{57}$ The payments made to the parliamentary burgesses were not regularly the same amounts; they varied from is. $3 d$. to $4 s$. a day, and horse hire and a groom were provided in addition. In I 340 John de Stafford

44 Leic. Boro. Rec. I IO3-I327,23I, 'Tallage assessed for the coming of justices" to enquire concerning articles contained in the writs' (of prohibition of purchase of wool).

45 Ibid. 3 I 3 .

46 Ibid. 246, 313. On the judges of Trailbaston, see Political Songs, ed. T. Wright (Camden Soc. vi), 320-I.

47 Cal. Close, $1307-13,334$.

48 Ibid. I $302-7,58-59$.

50 Leic. Boro. Rec. II03-I327, 277.

${ }^{5}$ S Select Cases from the Coroners' Rolls (Selden Soc. ix), ed. C. Gross, intro. passim.
52 J.I. $1 / 455$, m. 13.

53 Leic. Boro. Rec. IIO3-I327, 357-8.

54 Cal. Close, I 392-6, 56.

55 Leic. Boro. Rec. IIO3-I327, 357-80; I327-I509, $1-3$.

${ }^{6}$ C. H. Jenkinson, 'First Parl. of Edw. I', E.H.R. xxv. $231-4$.

57 J. G. Edwards, 'Personnel of the Commons in Parl. under Edw. I and Edw. II', Essays Presented to T. F. Tout, 209; M. McKisack, 'Borough Representation in Ric. II's Reign', E.H.R. xxxix. 5 I I -25 . 
was allowed 40 s. by the mayor and community for his stay of 40 days at Westminster, ${ }^{58}$ which gives a clear indication of the rate of pay at that date, but the lack of borough accounts in the $5_{5}$ th century prevents a general estimate of the rate of pay to be made for the later period.

Little is known of the individual activity of these burgesses at Parliaments on the town's behalf, for few petitions have been preserved which concern Leicester at all, and only one which expresses any grievances of the borough. ${ }^{59}$ It appears from a consideration of the names of the parliamentary burgesses that the same man was sometimes sent several times as representative. There are several examples of persons being re-elected, and William of Rodington was returned four times between I 3 I 6 and I 326.60 Most of those who were returned were among the leading burgesses in public office, and sometimes the mayor himself was returned.

\section{PROGRESS TOWARDS INCORPORATION}

A survey of the jurisdictions and franchises shows that various privileges had been accumulated and that the organization of the borough had begun to assume a coherent form by the early i 4 th century. The borough customs had been stated and confirmed, there was a chief officer in the mayor, the borough court had its sphere of jurisdiction and the town enjoyed privileged trade and a merchant guild; these are all attributes of autonomous burghal existence. It had, however, some way yet to go before its legal personality was fully developed. Since the town was a mesne borough a succession of important royal charters granting the privileges which in royal boroughs constituted. corporate independence were not to be expected. ${ }^{6 I} \mathrm{It}$ is true that there were important seigniorial grants ${ }^{62}$ but they were connected rather with legal reforms than with burghal immunities.

The beginnings of the concept of separate legal personality must be traced from the use of the term communitas in relation to the members of the borough, not necessarily including all inhabitants, and in Leicester there was a dual use of the term, sometimes for burgesses, sometimes for guild members. It is first used in grants of property to the borough. The idea of a community is first used rather widely and loosely, in Earl Robert's grant of freedom of pleading to the burgesses 'and those who are held to be of their company'.63 By I256, the term was used specifically by Henry III, confirming the right of primogeniture to communitatem burgensium de Leicestria. ${ }^{64}$ The earliest grant of property, ${ }^{65}$ in $\mathrm{I}_{25} 5^{\mathrm{I}}-5$, was made to the mayor, burgesses, and commune Leycestrie. A slightly later grant of rent ${ }^{66}$ was made to the mayor and burgesses de communitate Leycestrie, and this rent was secured maiori et burgensibus et eorum heredibus et successoribus de communitate Leycestrie, and payment of it was to be made de communitate. Thus the community is acting as an entity; a quitclaim by the mayor and burgesses in 1273 states that the action is taken communi assensu, ${ }^{67}$ and it is worthy of note that Crouchback's reforming charter of 1277 was made 'with the assent of the mayor, jurats, and community'-another and more important instance of the same concept.

58 Leic. Boro. Rec. I327-I 509, 48; other notes of payments, Leic. Boro. Rec. IIO3-1 327, 235, 248.

59 S.C. 8/10147, a petition relating to evil customs prevailing in the town in 1322 .

60 Leic. Boro. Rec. IIO3-I327, 404.

${ }_{61}$ The only royal charters before the I 4 th century were two of John and one of Henry III: Leic. Boro. Rec. IIO3I $327,7-8,56$; cf. Brit. Boro. Charters, I $216-1307$, ed. A. Ballard and J. Tait, p. xviii.

${ }_{62}$ The most important were Earl Simon's grant intro- ducing primogeniture and Earl Edmund's reform of the portmanmoot: Leic. Boro. Rec. IIO3-I327, 49-50, I50.

63 Ibid. 4.

${ }^{64}$ Ibid. 50.

65 Ibid. 5 I. J. Tait, Medieval Eng. Borough, 242, makes a note on the accompanying quitclaim, but it appears to be a misreading of Miss Bateson's summary, as 'mayor and burgesses' are mentioned in both documents.

${ }_{66}^{6}$ Leic. Boro. Rec. $1103^{-1327,57 .}$

67 Ibid. $5^{8-60 .}$ 


\section{A HISTORY OF LEICESTERSHIRE}

By the side of this use of the term, communitas was also frequently applied to the body of guildsmen in the Morningspeech. There is no mention of the community of burgesses, but it refers in most instances to the separate and distinct association of guild members. However, when the guild was dealing with matters relevant to the whole town, there was reference to the 'community of the town' or the 'community of Leicester', 68 and in I 272 the phrase seemed to be applied to the totality of the inhabitants except those of the Bishop's Fee, when the king's judges made a trading rule 'for any of the community and liberty of Leicester'. ${ }^{69}$ 'Thus by the end of the I 3 th century, the idea was well established but not yet very well defined, and far from being equated with the idea of 'corporation'.70

Though the right of possessing property in common was thus being exercised by the mid-I 3 th century, no large town estate was acquired. The messuage bought from William Ordriz in $125^{\mathrm{I}-5^{7 \mathrm{I}}}$ and some other very small acquisitions remained the sole urban possessions of the borough for some time, and consequently its finances were of a very simple nature; for a long period the borough owned only its guildhall and the cowhay pasture, and its only rent was $4 s$. from the shops under the hall. Even by 1452 , when several bequests had increased property in the borough, and a good deal of land at Whetstone, ${ }^{72}$ where the mayor and burgesses held a manorial court, had been acquired, the total rental ${ }^{73}$ came to little more than $£ \mathrm{I} 6$, in spite of a licence granted in $14 \mathrm{I}^{74}$ to acquire land in mortmain to the value of 40 marks a year. Thus the possessions of the borough were even in the 15 th century smaller than those of the powerful social guild of Corpus Christi, which was founded in $\mathrm{I} 343$ and soon acquired a formidable rent-roll in the town. This slowness in acquiring property is matched by a slowness in establishing a corporate claim to the town waste: it was by Earl Henry's grant that the mayor, burgesses, and commonalty obtained a piece of waste by the Soar for a privy in $1344 .^{75}$ Moreover, in spite of the burgesses' powers of acquiring and disposing of land, it must also be remarked that as late as $1343^{76}$ the lord's leave was first obtained before the burgesses leased a chamber over the East Gate. Seignorial surveillance was still a very real matter.

The use of the term communitas is also of significance with relation to the borough seal, though there is no proof that it was distinct from the seal of the merchant guild. The acquisition of a borough seal was an important step in the development of the burgess community, for although it is wrong to see it as embodying a very advanced idea of corporate entity, it brought boroughs into line with the recognized corporations of the period, the religious houses, and served in some measure as a symbol for the borough's unity - an action can be taken which, when authenticated by a seal, is more than a sum of the actions of the men involved, because it gives them responsibility as a body. The seal of Leicester had for its legend one of the rare uses of the phrase 'seal of the community' of the town ;77 and although the earliest extant impression is attached to a document dated $1343,{ }^{78}$ the spelling 'Leyrcestria' is an early 13 th century one, which went early into disuse, so that it gives some indication of the date of the matrix. Moreover, the Crouchback charter of 1277 states that it was authenticated with the 'seel de la commune de la vile' which is close enough in phraseology to permit the supposition that this same seal was used on that occasion, and used as the seal of the burgess and not the guild community.

68 Leic. Boro. Rec. IIO3-I327, 2 I 7, and pp. xli-xlvii.

69 Ibid. I 14.

70 Pollock and Maitland, Hist. of Eng. Law, i. 669: "the community is there; it may want privileges, but it exists'.

$7 \mathrm{I}$ Leic. Boro. Rec. IIO3-1327, $5 \mathrm{I}$.

72 Ibid. $1327-1509,147-8,204-5$.

73 Ibid. 258.

75 Ibid. 61 .

77 'Sigillum communitatis Leyrcestrie.'

78 Ibid. 57; cf. Tait, Medieval Eng. Boro. 239 nn. 
Some other of the liberties and privileges of the burgesses in the I $3^{\text {th }}$ century were pointing the way to the development of corporate action, but it had not yet quite been achieved. The burgesses had no real power of self taxation, but had on occasion acquired the necessary royal licence for short periods to levy murage and pavage for repairs to the town walls. ${ }^{79}$ There is no record of the town's being involved in litigation, but as early as I I 80 the burgesses banded together to quit themselves of the justices in eyre, 80 and it was only a few years later that they raised a sum of money to purchase the Cowhay pasture from the earl. ${ }^{81}$ The community as a whole was held to be responsible for debts incurred in the matter of payment of tallages. A large number of by-laws had been made, but they were framed by the guild community for the regulation of trading practices, ${ }^{82}$ and so cannot be viewed as the laws of the full burghal community, for they were enforceable in the court of the guild not that of the borough, and not until $1335^{83}$ is there an ordinance which can rightly be viewed as a borough law. Some progress towards united action had thus been made, but we must turn to the mid-I 4 th century to see any action on a large scale by the community of burgesses.

The first of the negotiations in which vigorous concerted municipal activity can be perceived is the attempt to gain freedom from tolls of fair, market, and borough from the Duke of Lancaster between I35 I and I36r. The guild had bought some kind of tolls charter for $£ 10$ in $1313,{ }^{84}$ which has not survived, and in 1353 the payment of 'huckstermol' by retail traders was released by the duke, ${ }^{85}$ though the payment of 'cannemol' was not. No records of the arrangements survive to show the extent to which the community was involved. However, the subsequent negotiations were by the burgess body. The first of them was successful, and in $1360^{86}$ the fair was shortened to a week, the duke gave up his tolls, and gave over the organization of the fair into the hands of the mayor and a small burgess committee to be chosen, deputed, and sworn each year by the burgesses themselves; in return for this privilege he continued to take the profits of the fair court.

The arrangements about the fair were a valuable addition to the independence of the borough community, but a more important effort was its attempt to obtain freedom from the various market tolls. ${ }^{87}$ The negotiation was never finished, for the Duke of Lancaster died before the final indenture was sealed, but the arrangements were all but complete. Because the duke was only tenant-in-tail of the lordship of Leicester, with the king as reversioner, he could not grant the tolls so as to bind either his heirs or the king to uphold the agreement. Therefore he conveyed his manor of Wrangle (Lincs.) to the community, and the burgesses gave him a bond for I0,000 marks to fulfil their covenant, on condition that Wrangle be reconveyed to the duke, subject to a condition of re-entry in case the release of tolls was ever in dispute with his heirs or with the king. Then the duke died, and nothing further is heard of the arrangement. Though it failed by this mischance, the negotiation is significant for the part played by the borough community. The party to the arrangement was 'the mayor and community and their successors the burgesses of Leicester', and the bond they made is a responsibility of the borough as such - 'we bind' they say 'ourselves and our successors to make that payment' of 10,000 marks, which is more than an agglomeration of personal responsibilities for they took seisin of Wrangle as security as a corporate body, their first large-scale action as a legal entity.

79 Cal. Pat. $128 \mathrm{I}-92,221$, a grant for 5 years in 1286 ; and ibid. 424 , a grant for 2 years in 1291 .

80 See above, p. 17.

81 Leic. Boro. Rec. IIO3-I327, 5.

82 See guild rolls passim, printed in Leic. Boro. Rec. $I I 03^{-I} 3^{27}$ and $I 3^{27-I 5 O 9 .}$

83 Leic, Boro. Rec. I327-I509, 20.

84 Ibid. $I I O 3-I 327,281$. 85 Ibid. I327-I509, 89.

86 Ibid. I I I. And see below, p. 47.

87 Ibid. I 1 3-24. The summary of these complicated negotiations is taken directly from Miss Bateson's account, ibid. xxii-xxiii. 


\section{A HISTORY OF LEICESTERSHIRE}

Soon after the failure of these negotiations, the community opened other negotiations of equal importance though of different form, to have the lease of the bailiwick from John of Gaunt, which they obtained in $1375 .{ }^{88}$ This was a short-term lease of ten years, whereby the town paid a yearly rent of $f 80$ instead of the total profits of the courts and probably also instead of the tolls of the borough, which hitherto had been collected through the duke's officers. The mayor and burgesses might elect two bailiffs, although they were to wear the duke's livery, and they had return of royal writs; but the duke did not include in the lease the rent of his mills and ovens, the rents levied by the porter of the castle, or the escheats of his free tenants.

The obtaining of this lease was a step forward in the constitutional development of the borough, for although it was for a very limited period it gave the burgesses a period of experience in the management of their own affairs. The lease was in some measure equivalent to the firma burgi, the right to farm the borough, which so many boroughs had already striven to obtain as a measure of independence from the Crown or their lords. Leicester was late in gaining even this partial grant of this privilege: both London and Lincoln had gained it by as early as I I3O, and it was a common borough privilege in the I $3^{\text {th }}$ century. ${ }^{89}$ The belatedness of the Leicester grant can in part be accounted for by the close relationship in which the town stood to its lord, with no middleman in the person of the sheriff. However, the borough had been let to farm on various occasions before, to agents of the earl. The earliest instance appears to have been in the late I2th century, of 'a certain clerk, Simon Maudit' who had the reeveship in farm. ${ }^{\circ 0}$ Burgesses sometimes had the farm for the earl, but they ivere not always honest, for Henry of Ruddington, who had the farm while he was mayor, in 1269 , was accused of taking gifts to conceal felonies. ${ }^{11}$ Complaints were made in the early I 4 th century that Earl Henry's farmers were dishonest and extortionate; 92 and there was a period, in 1322 , when no one could be found to take on the farm of the reeveship, because of the poverty and devastation of the town. ${ }^{93}$ It has been suggested by Tait that the election of reeves by the burgesses in 1276 was because the burgesses had a temporary lease of the farm at the time, 94 but there is no other evidence to support the conjecture that the burgesses had had the lease for the community before 1375 .

Though collective responsibility was a constitutional advance, and indeed a decision is recorded which regarded a fee-farm charter as proof of incorporation, 95 it was not viewved in this light by the burgesses at the time. The interests of the burgesses lay in finding the most economical and convenient way of dealing with their finances. If they were to be plundered by the farmers appointed by their lord, it was preferable to farm themselves, but if the rent asked by the lord was greater than the profits of the courts and other rights, then it was disadvantageous, and in any case the duke had the profits of fairs. They themselves had no great revenue to negotiate with, and, while it was preferable not to have the lord's bailiff present in the portmanmoot, their relations with that officer were generally good, so that little hardship was suffered by his presence.

These considerations, taken together with the fact that the lease of the bailiwick was a restricted one and far from being as lavish as the royal grants of firma burgi, go far to explain the subsequent history of the lease, which was not consistently, or even frequently, renewed. After the Duchy of Lancaster had come to Henry IV, he leased the bailiwick to the town for twenty years at a rent of $£ 90$; 96 then, when the town had been

88 Leic. Boro. Rec. I327-1509, 149-52.

89 'Tait, Medieval Eng. Boro. 157, 186.

90 Leic. Boro. Rec. IIO3-I327, 40.

91 Rot. Hund. (Rec. Com.), i. 240.

92 Leic. Boro. Rec. I327-I509, 89: this states that 'huckstermol' had been taken by the greed of the farmers. 93 T.L.A.S. xix. 209.

94 Tait, Medieval Eng. Boro. 186.

95 In 1467: M. Weinbaum, Incorporation of Boroughs, 125.
${ }_{96}$ Leic. Boro. Rec. 1327-1 509, 219-22. 
included in Queen Catherine's dower, it was renewed in 1423 for ten years at a rent of $£ 80.97$ No other such leases survive, and there is definite evidence in the intervening and subsequent periods that the bailiwick was not at lease. Thus, even though new sources of profit came to the town, such as forfeitures incurred under the growing body of borough by-laws which the mayor was authorized to enforce during the 15 th century, Leicester burgesses were never entirely successful in having the farm of the borough, and such as they did obtain was limited both in period and scope.

One effect, however, of the fee-farm grant was a reorganization of the town's financial system by the regular appointment of two borough chamberlains, to be responsible under the mayor for the accounting system. They included also in their duties the keeping in repair of the town's property and the bridges, walls, and ditches for which the town was responsible, though special expenses had to be authorized by the community, and, by the 15 th century, auditors were appointed yearly. ${ }^{98}$ The accounts were more complex than the old form of accounts rendered by the mayor, which they replaced from I 379 onwards, for not only were the financial activities of the borough extended by the fee-farm lease and the increased borough rental, but taxation during the French wars had become very heavy ${ }^{99}$ and large sums of money were involved. The first mention of a borough, as apart from a guild, chamberlain was in $1344,{ }^{\mathrm{I}}$ though, as no further mention of chamberlains is to be found until the series of annually elected officers begins in $1376,{ }^{2}$ he was presumably appointed only for a special term to help the mayor.

The office of bailiff was also affected by the grant of the fee-farm lease. While the town had this lease, pairs of bailiffs held office for one year only, elected officers of the borough, though in the duke's livery and so in some measure his servants. In the intervals of these leases, a man would hold office for long stretches of time as the earl's bailiff, or sometimes two would share the office, and, after the end of the term of Queen Catherine's lease, these bailiffs reverted to being the servants of the duke, or of the Crown in right of the duchy. These bailiffs were sometimes elected to the mayoralty, or acted in the borough court on the town's behalf as jurats; relations between the town and its lord were in this respect excellent, except for the single instance of the conflict with the bailiff Hotoft, ${ }^{3}$ for in most cases the bailiff represented the interest, in one or other of his capacities, of both town and lord.

\section{GROWTH OF THE TOWN COUNCIL AND BOROUGH GOVERNMENT}

An important corporate activity of the burgesses, that of making and issuing their own borough regulations, is bound up with the growth of a truly governmental body, a town council; the exercise of legislative functions in an organized manner by a special group of the burgesses is found as an established procedure in the early i 4 th century. The earliest ordinances were in $1335,{ }^{4}$ when the 'meyr, bayllyffes et les bons gens de Leicestre', besides making trading regulations, forbade men to go armed, an echo of a royal statute framed to check the disturbances of the time, which empowered mayors of boroughs to deal with offenders. The next ordinances, issued in $135^{2}, 5$ were made 'par le conseil du seygnour d'un part et le meir et le bone genz de la ville de l'autre part', concerning malefactors, tallages, trade regulations, distraints, and attendance at the

97 Ibid. 232.

98 Ibid., pp. xxvii-xxviii.

99 The borough incurred a charge of $£ 8 \mathrm{I}$ in $135 \mathrm{I}$ : ibid., p. xxix.
I Leic. Boro. Rec. I327-I509, 62.

2 Ibid. 449-50.

3 Ibid. 263-5.

4 Ibid. 20-2I.
5 Ibid. $85-88$. 
portmanmoot, all matters of borough concern. In $1379,{ }^{6}$ ordinances 'for the government of the town', which were chiefly devoted to the regulation of the salaries of borough officials and the duties of the chamberlains, were made by 'the mayor and jurats, with the unanimous consent and assent of all the community of the town', a fully corporate action.

The problem of the origin of the town council turns on the question of the origin of the jurats mentioned here, and their earlier function in the borough. In their function in $\mathbf{I} 379$, they approximate to the small council of prudhommes, 7 usually $\mathbf{I} 2$ or 24 in number, which grew up in many boroughs in England, sworn to fulfil the duties assigned to them to aid their mayor, and to uphold the liberties and customs of their towns. But the development of this body in Leicester was not a simple evolution, for there is a dual origin to be considered, as both the merchant guild and the borough court had a small group of judges or counsellors which can be equated to some extent with the jurati.

The jurats of the portmanmoot were reputed to have been in the $\mathrm{I} 2$ th century a body of 24 'appointed in olden time', exercising the function of hearing pleas in the court, and this tradition is confirmed by Crouchback's charter of 1277 , in which they were ordered to be present with the mayor in the portmanmoot, 'to do right and to give judgement', ${ }^{8}$ a judicial function. There is no hint of their exercise of a consultative function in the borough court; the first mention of a consultative body is of the summons of a guild council of 24 in $1225^{\circ}$ 'to come at every summons of the alderman of the guild to give counsel to the town and assist the alderman in the business of the town'. At this date the merchant guild was a more highly developed association than the burgess body as such, and there was no chief officer in the town besides the guild alderman, so that it is likely that it was the guild council which exercised governmental functions at this period, especially as it also controlled the town finances. This council was summoned regularly, but not until $\mathrm{I} 264^{\mathrm{I0}}$ are the jurats mentioned by that name, as giving judgement in the guild court about a guild matter. Jurats were considered necessary to the proper conduct of these Morningspeeches, as a session was pronounced invalid at which they did not attend. II On the other hand, a regulation of $\mathrm{I} 274^{\mathrm{I2}}$ laid down that no jurat might dwell in the Bishop's Fee, so that although the guild's franchise was a wider one, it was considered that the jurats must be burgesses. By this time the office of alderman of the guild had been merged and converted into the wider and more properly burghal office of mayor, who was head in one capacity of the borough portmanmoot, and in another of the guild Morningspeech. It is not therefore unlikely that a similar process had merged the functions of the portmanmoot justices and the Morningspeech council, and had transformed them into a new sworn council of the town. A sworn council undoubtedly did develop in the I $3^{\text {th }}$ century, for there exists a jurat's oath of the early $\mathrm{I} 4$ th century, whereas there is no evidence that either of the two previous bodies was sworn before the first mention of the term 'jurat' in $\mathbf{I} 253$. 'The existence of two lists dated $1273,{ }^{13}$ each of approximately 24 names, which are not identical, one said to have been chosen for the performance of guild business, the other 'by the community of Leicester', has been adduced as evidence of two separate bodies functioning side by side to perform different functions; but 'by the community' might well mean the community of the guild, and

\footnotetext{
6 Leic. Boro. Rec. I327-1509, 102.

7 For a discussion of these bodies see Tait, Medieval Eng. Boro. chap. x.

8 Leic. Boro. Rec. IIO3-I327, 163.

9 Ibid. 34 .

II Ibid. $x 68$.

Io Ibid. 104

12 Ibid. I 15

13 Ibid. $I x-12$ and $n$. A comparison of Mary Bateson's translation of these lists with the originals (Leic. City
}

Mun. Room, boro. rec. box $x / 2$ and box 3 , roll 72) shows her lists to be not absolutely accurate. Ric. de Blaby is included in the first list, Wm. le Waleys and John de Sharnfold are also additional names in the second list. This makes a total of 16 names on both lists which are identical, 8 names peculiar to the first list and 7 peculiar to the second. 
all the names are of guild members, so there is no sound evidence of a differing electoral body or of differing functions. This is the last mention to be found of the guild council, which possibly means that the mergence took place at about this time, though the absence of portmanmoot evidence makes conclusions only conjectural. It may also be remarked that there is no later mention of any election, so whatever the body of jurats might be, it was very probably by the I 4 th century a closed body, co-opting new members when necessary, and consisting chiefly of ex-mayors.

The earliest recorded oath of the jurats, of about $1335,{ }^{14}$ stresses the borough court element of origin of the office: '. . I I will render loyal judgements and loyally affeer both the poor and the rich. ... I will continually come to the court of portmoot and to the summons of my mayor ... and I will loyally maintain the assize of bread, wine, and beer with my mayor, and I will maintain and keep the franchises and good customs of the town. . '; but it is significant that the oath was taken before the brethren of the guild and the mayor in the Morningspeech. During the 14 th century, the duties and activities of the jurats grew in scope. They accompanied the mayor on town business; ${ }^{15}$ they received the accounts from the tallage collectors; ${ }^{16}$ court decisions are stated to be made with their consent; ${ }^{17}$ they dined with the mayor ${ }^{18}$ when he was presented in the lord's court to take up his office; their consent was necessary to payments made by the mayor ; ${ }^{19}$ throughout the 14 th century, examples multiply. Their numbers seem to have varied from time to time; though ustally 24 , there are instances in which 15 are named.

The Morningspeech had become the organ of the governmental activities of the community in the I 4 th century, the guild meeting had altered its nature and developed into a gathering for performing town business. It was in the Morningspeech that the borough ordinances were promulgated, and a great variety of pleas was heard, which to a great extent had the result that it superseded the portmanmoot by providing a mayor's sessions, a term which was first applied to it in $\mathrm{I} 335 .{ }^{20}$ The portmanmoot became limited to minor judicial business and the registering of conveyances, although it still performed a few other functions; for instance, regulations about market stalls were made there, ${ }^{2 \mathrm{I}}$ and the chaplain of St. John's Hospital-was ordered to be presented to the mayor and community and take his oath in the full court of the portmanmoot. ${ }^{22}$ Even though this change meant that more profits of justice came to the borough instead of to the lord of the town, the mayor and guild were still jealous to preserve the portmanmoot's jurisdiction, as in the case of a guildsman who attempted to take a suit which was of the portmanmoot's cognizance to the ecclesiastical court of the bishop. ${ }^{23}$ This tendency was maintained in the ${ }^{5} 5^{\text {th }}$ century; the taking of suits before the county justices of the peace was forbidden; 24 and in $1467^{25}$ it was ordered under pain of imprisonment that where the mayor's court could provide actions must be heard in it, and that a stranger could not sue in any town court except the portmanmoot.

The rise of the mayor's sessions is chiefly to be attributed to the necessity of enforcing the ever increasing number of royal statutes. The system of upholding the authority of the Crown in the country at large by means of the circuits of justices in eyre was declining in the early $\mathrm{I} 4$ th century, and in its place there was a great increase of statute law to be enforced in the localities by local royal officers, the justices of the peace.

14 Leic. Boro. Rec. I327-I509, 33.

15 Ibid. ro (1332).

I6 Ibid. 40 (1 337 ).

17 Ibid. 43 (1338)

18 Mayors' accts. of 14 th cent. passim, e.g. ibid. 45 .

I9 Leic. Boro. Rec. I327-I509, 47 (1340).

LEIC. IV
20 Ibid. 19.

21 Ibid. I7I sqq.

22 Ibid. IOI.

23 Ibid. 49.

24 Ibid. 225

25 Ibid. 290, 294. 


\section{A HISTORY OF LEICESTERSHIRE}

During the I $4^{\text {th }}$ century, there was no borough justice of the peace in Leicester to fulfil this function, and though the exercise of the duties proper to him was often delegated on particular occasions by the Crown to mayors of boroughs (who on other occasions carried out such duties without any legal sanction), the system was a makeshift one, and interference by the county justices of the peace was sometimes unavoidable; there is mention, for instance, of a dinner provided in 1332 for these officers who were present in the town to array men for the war in Scotland. ${ }^{26}$

All this Crown intervention meant a loss to the lord of the town of the business and therefore of the profits of the castle court as well as of the profits of the portmanmoot. After 1399, however, when Leicester went to the Crown as part of the Duchy of Lancaster, what the king lost as Duke of Lancaster he gained for the Crown, so the process was accelerated. By the mid-I 5 th century, the mayor's sessions had become entirely unequal to the effective enforcement of the laws, and in $1464^{27}$ the situation was remedied by Edward IV's appointment of the mayor, four burgesses, and a recorder 'learned in the law' to be justices of the peace with full powers within the limits of the borough of Leicester, to the exclusion of the county justices. The burgesses were to be elected yearly by and from the council of $\mathbf{2 4}$, as were two coroners for the borough. In addition, the mayor and burgesses were freed from any obligation to be empanelled on any assize or inquisition outside the borough.

Thus the sessions became the chief court of the borough, and from this time onwards they were a royal court, so that any powers remaining to any other court in Leicester were overridden. It became the custom for each mayor with the four burgesses who had preceded him in the mayoralty to fill the offices, the last burgess on the list retiring every year. The office of recorder was new; it was an office almost universally introduced in boroughs in the I 5 th century, to provide another foothold of the Crown among the ranks of municipal officials, for it was not filled by a burgess but by a professional lawyer. 28

A new sanction to borough legislation was provided by the appointment of the justices, for by-laws from this time on had royal authority behind them. This is reflected in the new tone of borough ordinances. The ordinances of 1467,29 besides setting out more detailed legislation for the trades and for the general administration and policing of the town than ever before, impose detailed limitations on the carrying of arms to 'keep the king's peese', order all men to come to affrays of arms when summoned 'in supportacion of the kynges pees', prohibit unlawful assemblies and livery and maintenance in terms resembling those of the statutes of the realm, and lay fines on all those who might fail to obey a summons to the council meeting to attend on the mayor 'or eny other thing that shalbe to the plesure of the Maire', a reflection of the increase of his authority.

The appointment of the mayor as justice of the peace was the culmination of the growth of the importance of that office which had been developing during the I 4 th and I 5 th centuries. From the end of the 13 th century, the mayor's predominance in borough affairs had become more noticeable, as is illustrated by the terms by which reference is made to him in the guild records. It was the mayor's mercy into which offenders fell; he, in the name of the community, regulated craft practices, and the phraseology of the suits suggests that it was the mayor's law which was broken. ${ }^{30}$ The rise of the sessions increased his judicial powers, and after 1464 , when he was a justice of the peace, his discretionary powers were very extensive; he had powers of imprisonment without

\footnotetext{
${ }^{26}$ Leic. Boro. Rec. I327-I509, 11 .

27 Cal. Pat. I461-7, 330; Leic. Boro. Rec. I327-I509, 280-2.
}

28 M. Weinbaum, Brit. Boro. Charters, I $307-1660$,

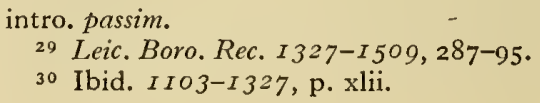


bail, and might in some cases inflict the death penalty; in more minor offences, his powers of summary jurisdiction were very wide indeed. The increase in the dignity of the mayor is seen in the use of a special seal of the mayoralty, which is first mentioned in I $434 .{ }^{3 \mathrm{I}} \mathrm{He}$ was paid a salary of $£ \mathrm{IO},{ }^{32}$ of which $f_{2}$ was to be spent at his dinner of taking up office, and some of the rest on the salaries of his clerk and sergeant. In spite of the dignity of the office, it was sometimes necessary to use coercion to ensure that it was filled, and in I $490^{33}$ the penalty for refusing it was $f_{20}$. In I 505,34 Henry VII's confirmation of the charter of $\mathrm{I}_{4} 64$ increased still further the powers of the borough justices of the peace, who thereby had fuller powers concerning felonies, murder, and counterfeit coinage. Moreover, the borough gained at the same time the important privilege of being taxed separately from the county, with the mayor and four burgesses as assessors, who also appointed the collectors, a further increase in the mayor's control of affairs.

The mayors themselves were, as the $\mathrm{I} 5$ th century progressed, increasingly persons of substance, and of some national importance. An outstanding example is Peter Curtis. ${ }^{35}$ In Leicester he pursued a relatively untroubled career as bailiff, member of Parliament, and mayor. Besides this, however, he was a prominent Yorkist. He was at one time member of Parliament for Appleby (Westmld.), a member of the royal household of Edward IV, and clerk of the Great Wardrobe. He went to France with the king in I475, was deprived by Richard III, was made a gentleman usher and life bailiff of Leicester by Henry VII, and ended his days with a royal corrody at Bury St. Edmunds. No other Mayor of Leicester of the time had had such a chequered career, but among prominent burgesses the Wigston family may be mentioned, for the filling of the mayoralty of Leicester became among them something of a family tradition. William, his sons Roger and John, and another William, son of John, were all mayors in their turn, and all were prominent in the wool trade and staplers of Calais. The Wigstons were the richest family in Leicester. ${ }^{36}$

At the same time a higher degree of organization of borough government can be seen in the multiplication of borough offices as the needs of the administration increased. The origin of the chamberlains has been mentioned; this was by no means a popular office, and the records are full of 'redemptions of service' by fines; $£ 5$ was the usual fine by $1490 .{ }^{37}$ The chamberlains were chosen by the council of 24 ; it was stated in $1477^{38}$ that one was elected for the community and one for the mayor. They took an oath to the mayor which reflects the last remnants of a distinction between town and guild: 'we shall charge ourself of all such mony as shall growe due unto this town . . . of eny lands, tenements, Chapman gild or otherwise', ${ }^{39}$ a reminder that the chamberlainship was originally a guild office.

In the $5_{5}$ th century can also be found the origin of the office of town clerk, which emerged from that of the mayor's clerk who wrote his accounts. In I 462 Richard Reynold is described in a conveyance as 'toune clerk', 40 and at about the same time there is record of a royal patent of appointment to the office. ${ }^{4 \mathrm{I}}$

The borough oaths of about $1489^{42}$ show that a large number of sworn officers assisted in the administration of the town. Constables and frankpledges were sworn, and fish-, flesh-, and leather-sayers and aletasters all made oaths to perform their duties

${ }^{31}$ Cal. Close, 1429-35, 295. There is a seal extant, attached to a deed of 1513 ; Leic. City Mun. Room, $\mathrm{IOD}_{34} / 785$.

${ }^{32}$ Leic. Boro. Rec. $1327-1509$, p. xxxii.

33 Ibid. 328.

34 Ibid. 365 .

35 See the summary of his career in Hist. of Parl.: Biog. of Members of the Commons Ho. I439-I509, ed. J. C. Wedgwood, 244-5.
${ }^{36}$ On this family see Wyggeston Hosp. Rec. introduction, passim and below, pp. 40-4I.

37 Leic. Boro. Rec. I327-I509, 328-9.

${ }^{38}$ Ibid. 449.

39 Ibid. $32 \mathrm{I}$.

40 Ibid. 272,278

${ }_{41}$ Thompson, Hist. of Leic. i. 332.

42 Leic. Boro. Rec. I327-I509, 319-23. 


\section{A HISTORY OF LEICESTERSHIRE}

of testing and inspecting goods in the market. These, with the auditors of accounts, were chosen by the council of 24 . The three stewards of the fair were usually chosen annually, "on for the newe maire and the secunde . . . be the old maire and the thurde for the commons'. ${ }^{43}$ Regular lists of these offices are only to be found after 1476 .

The better organization of the town is shown by the appointment of twelve aldermen, and the division of the town into twelve wards for police purposes under them, which took place in 1484,44 superseding the old division into four quarters for this purpose. One constable in each ward was the alderman's executive officer. The aldermen had summary powers of punishment over breakers of the peace and over householders who neglected the repair of pavements, and they could present persistent offenders to the mayor, without recourse to the old method of jury presentment by frankpledges. These aldermen were chosen from the council of 24 , and not from outside their number, so that the title of 'alderman' was restricted to half the members of that body.

There was a form of ladder of advancement through the lesser offices to the highest power in the borough. Many are the sayers and auditors who rose to important offices, and it is particularly noticeable that the position of steward of the fair was closely connected with the mayoralty. Moreover, burgesses for Parliament almost invariably held at some time in their careers the office of mayor of the borough, which is not surprising when the method of choosing these parliamentary representatives is considered, for it was not a power for very long exercised by the community. Leicester is included in the large group of boroughs which were not shires but which elected their representatives at the shire court held in the town. ${ }^{45}$ For instance, the sheriff's indenture returning names in $1478^{46}$ indicates that the election took place in the full county court of Leicester by the electors who chose both the knights of the shire and the burgesses. But other evidence shows that this was only a formal presentation of the borough's burgesses, for the borough Hall Book of that date shows that Peter Curtis was chosen at a Common Hall, and at the same time the mayor and his council chose John Wigston. ${ }^{47}$ These elections were apparently popular at first; in I338-9 Richard Leverich and Richard of Walcote are said to be 'chosen by consent of the community'. ${ }^{48}$ But by the I $5^{\text {th }}$ century, it became the custom for one at least of the burgesses to have been chosen by the town council, and often both of them, as the example already mentioned shows; for although Peter Curtis was said to be the choice of the commons, in this case they gave an assent to the choice already made by the council. The same thing seems to have happened in $1483,{ }^{49}$ when John Roberdes, the mayor, was chosen by the council, and Curtis by the commons. But even if the choice was restricted, it may be said with truth that those who did fill the borough and parliamentary offices had extensive experience in the work of government in one capacity or another.

The appointment of borough officers as justices of the peace is an example of the reorganization of the borough government, not through direct royal interference but by the Crown's use of existing machinery to convert it into an instrument of royal authority. A radical change was also made in the borough constitution in $\mathbf{I} 489$, but this time by direct intervention in borough affairs, although events inside the borough in the few years prior to this date led up to and provided the occasion for such intervention.

There is a gap in the borough records from about I 400 to 1470 , but the machinery of government had developed steadily in the interim, and when the series of records

43 Leic. Boro. Rec. $1327-1509,453$. The exact method of choice is not clear.

44 Leic. Boro. Rec. I327-I509, 305-8. In 1499 the number of wards was still 12: ibid. $356-7$. By I 557 the number had been reduced to Io; Leic. Boro. Rec. S509- $^{-}$

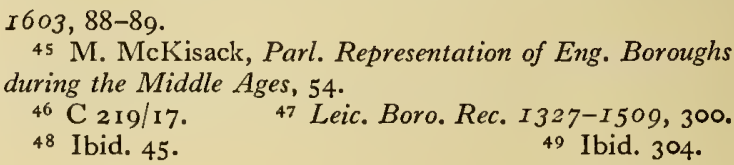

45 M. McKisack, Parl. Representation of Eng. Boroughs during the Middle Ages, 54.

$46 \mathrm{C} 219 / 17 . \quad 47$ Leic. Boro. Rec. I327-I509, 300.

48 Ibid. 45 .

49 Ibid. 304 . 
begins again, a body much more clearly defined than that of the 24 jurats emerges as a town council, consisting of the mayor and his 'twenty-four brethren of the bench'. The mayor on his own authority co-opted new members to this body, until I 477, when the brethren themselves took over this responsibility. ${ }^{50}$ From 1477 dates the first of the minute books of these meetings, called the 'Book of the Maioraltie', ${ }^{\text {I I }}$ and their business was soon entered up regularly. The guildhall where they met had come to be called the Common Hall, and the meetings themselves came to be called by that name.

At about this time, a significant change was made in the attendance at Common Hall meetings. In 1466,52 'only those and such as be franchised, that is to say, men entred into the Merchant Gild' (otherwise called the Chapman Guild) were to attend. In the next year, the order was amplified and made more explicit;53 because of 'ungodly rules and demeanings' of the commons, the same 'unenfranchised' were prohibited from attending, and from acclaiming anyone as mayor before he had been duly nominated by the bench. This indicates that the borough community at large had been in the habit of attending the meetings, but now the 'community', a term used loosely and without definition in the I $4_{\text {th }}$ century, had been limited to guild members, and the last distinction between the guild community and the governing commons removed.

These orders did, however, leave a considerable burgess body with the right of attending the meetings of the Common Hall, and it could still be said, as for example in the ordinances of 1467 , that orders were passed 'with the consent and by the assent of the commons'. But they paved the way for more restrictive changes, and these were soon to follow. In $1489,{ }^{54}$ an Act of Parliament stated that, because great discords had arisen in the towns of Leicester and Northampton 'and other corporate boroughs' among the inhabitants at the election of mayors and officers, 'by reason of the multitude of the inhabitants being of little substance and of no discretion, who exceed in the assemblies the other approved, discreet, and well disposed persons, and by their confederacies, exclamations and headiness have caused great troubles in the elections and in the assessing of lawful charges', elections were in future to be made differently. The mayor and the brethren of the bench should choose 48 of the 'wiser and sadder' inhabitants of the borough, and have discretion to change the whole 48 or any of them as seemed necessary. With this body, the mayor and the bench of 24 should elect the mayor every year. The justices of the peace and the burgesses for Parliament, and all other officers in the town were to be elected by the 24 only. The mayor was to have a casting vote if the voting was equally divided. No other method of voting was to be legal, and the fine for infringement of the Act was $£_{\mathrm{I}} \mathrm{O}$, half to the king, half to the mayor for the charges of the town, the mayor having power to commit to prison without bail those who would not pay the fine.

Thus the whole governing power of the town was to be vested in a total of 72 burgesses and the mayor, consisting of the 24 of the bench, who were the controlling factor, and the 48 new 'comburgesses'. No check at all was left on the activities of the 24 ; however, it had been necessary previously, in 1477,55 to make some provision for the likelihood of disagreement between these 24 brethren, and there is no indication that this arrangement did not still stand, as it was purely an unofficial scheme to meet the exigencies of a situation which might arise. In this case, the mayor and two wardens of the religious and social guild of Corpus Christi were to arbitrate between them, with power by this arbitrating body to impose a fine on the offending member, if he resisted, to be im-

50 Ibid. $298-300$.

51 Leic. City Mun. Room, Hall Bk. $1467-1553$.

52 Leic. Boro. Rec. I327-I 509, 285.

53 Ibid. 286.
${ }^{54}$ Ibid. 319, a summary of the Act of Parl.; and ibid. $324-5$, a letter from the king enforcing it.

55 Ibid. 298-300. 


\section{A HISTORY OF LEICESTERSHIRE}

prisoned, or to be deposed from the bench. The Corpus Christi Guild, the most important of the social and craft guilds in Leicester, had nothing whatsoever to do with the borough government, but it included among its members all the influential burgesses of the town, so therefore, as Mary Bateson expresses it, ${ }^{56}$ 'disagreements were to be submitted to the two officers of a club . . . to which the mayor and brethren all belonged as a matter of course, for it was the most fashionable club in Leicester'. It certainly provided no very sound check on the powers of the 24 brethren, for the two guild officers were usually brethren themselves.

The constitutional change did not take place without opposition. At the next election of the mayor, the commons elected independently one of the 24 in opposition to the candidate elected by the 24 and 48.57 The strength of the position of the brethren of the bench is demonstrated by their retaliation, for they removed the offending member from their number, withdrew their own candidate, and re-elected the mayor then in office. This was the last attempt at resistance, for in the next year the candidate originally put forward by the bench and the 48 comburgesses was elected without opposition.

This stringent curtailment of the franchise in the borough, eliminating completely the constitutional influence of the commons, may be viewed as the termination and culmination of the history of its development in the medieval period. This was no revolution, certainly; the development of the borough's own institutions and corporate identity and its emergence from the control of its overlord had been, as in other comparable boroughs, a movement towards control by the Crown and by an oligarchical council, for the oligarchical tendency had been apparent from the $\mathrm{I} 3$ th century onwards, and popular elections were less and less the means of choosing the body of counsellors, the borough officers, or the burgesses for Parliament, during the intervening period. However, it was a royal action from outside the borough itself which finally transformed the governing body, so the change cannot wholly be viewed as organic. The borough's development under this new ruling body belongs to a new period, leading up to the final official charter of incorporation of 1589 , which named the mayor, 24 , and 48 as 'the mayor and burgesses of the town of Leicester', reducing the rest of the population to the status of 'inhabitants'.

${ }^{56}$ Leic. Boro. Rec. 1327-1509, p. 1x.

57 Ibid. 326-30. 


\section{SOCIAL AND ECONOMIC HISTOR Y 1066-1509}

\section{LEICESTER IN 1086}

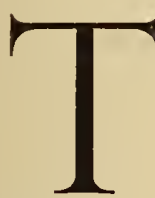

HE Domesday survey for Leicester describes an urban community comprising a small walled town and a much more extensive extramural area. Mary Bateson estimated the area of the walled town at about I30 acres, and the whole area of the borough, calculated on a fiscal assessment, at about 3,600 acres. ${ }^{\text {I }}$ C. J. Billson, however, after examining the district which was once within the walls, estimated its area at rather less than 160 acres; he also in the light of modern evidence about variations in the number of real acres in the fiscal hide estimated the total area at approximately 3,000 acres. ${ }^{2}$ This would put Leicester between Bedford $(c$. 2, I64 acres) and Cambridge (c. 3,200 acres). It had also a similarity in layout to the latter in that it was surrounded by open fields on all sides except to the north where, at Leicester, the woodland began outside the town gate.

Within the walls and divided by the two main streets leading to gates at the four points of the compass were 322 houses and 6 churches. ${ }^{3}$ The interconnexion between town and country is revealed in the Domesday list which shows that many of the houses were attached to rural manors. ${ }^{4}$ This connexion may have had a much earlier origin in the need to house men-at-arms from the outlying properties for the defence of the town, but as Mary Bateson ${ }^{5}$ and Sir Frank Stenton ${ }^{6}$ have shown, an equally important factor must have been the commercial advantage of possessing burgess rights to facilitate trade in commodities which could not be acquired or disposed of in the villages.

The course of the Soar had determined the arrangement of the three great fields, each with its portion of meadow and arable. Of these, the West Field and East Field, sometimes called 'the Great Field', were already manorialized. The West Field was held by Hugh de Grentemesnil, and may possibly have survived as a separate agricultural unit from the estate of a Roman villa which once stood on the Fosse Way outside the West Gate. It was assessed in I086 as 6 carucates belonging to Leicester with all customary dues, but Hugh also had at Bromkinsthorpe 2 carucates of the soc of Ratby. Hugh owned here a small demesne with 6 villeins, 3 serfs, and 3 bordars; the area was worked by 3 ploughs. ${ }^{7}$ During the century after the Conquest this holding became divided into two manors, Walsh's Hall, and Westcotes given by Robert Fitzparnell, Earl of Leicester, to the Abbey of St. Mary de Pratis. ${ }^{8}$ The greater part of the East Field comprised the ro carucates of land described as the Bishop of Lincoln's fee. In addition to his I 7 burgesses rendering $22 s$, the bishop owned land outside the

I Leic. Boro. Rec. IIO3-I327, pp. xi-xii.

2 C. J. Billson, 'Open Fields of Leic.' T.L.A.S. xiv. 3 .

3 V.C.H. Leics. i. 306, 309, not counting 39 burgesses, and 17 burgesses of the bp. of Linc. who may represent additional houses; sce above, p. 9.

4 A. Ballard, Domesday Boroughs, 28-29, and map facing p. 46 .

5 E.H.R. xx. 149.

6 V.C.H. Leics. i. 303 ; and see J. Tait, Medieval Eng. Borough, 26-27.

7 V.C.H. Leics. i. $3^{14-15}$; and see below, p. $3^{81}$.

8 Farnham, Leics. Notes, vi. 239. 


\section{A HISTORY OF LEICESTERSHIRE}

town walls rendering $5 s .4 d$. to him. The demesne, with its 5 ploughs, the priest, 3 villeins, and 12 bordars with another 4 ploughs, indicate the manorial character of this episcopal holding outside the walls. With it went 20 acres of meadow. ${ }^{9}$ Other meadow in this field adjacent to the river, later known as Lammas Ground or the Abbey Meadows, appears always to have belonged to the town. The south field is entered in the Domesday survey as 6 carucates held by the Countess Judith outside the walls. No manor was created on this field, but within the next century the earls acquired a demesne outside the South Gate and enclosed adjoining pieces of meadow known as Cowhay and Oxhay, and possibly also that called 'Taskholm'. By I204, however, the free burgesses 'dwelling within certain limits' had secured, or perhaps recovered, grazing rights in the Cowhay for the annual payment of $3 d$. a beast. ${ }^{10}$

Of the forest westwards, the Domesday survey specifically mentions a region called 'Hereswode', extending 4 leagues by i league, outside the town. The name may derive from pre-Conquest rights enjoyed by the inhabitants, which were redefined by charters of the first earls allowing the collection of wood and the right of way for the burgesses, their carts, and packhorses. ${ }^{\text {II }}$

\section{RELATIONS WITH THE EARL}

In 1086 the whole area was divided between four chief lords and a number of ecclesiastics and laymen who each held a few houses only. A description by Ordericus Vitalis, written in I IOI, shows that the four large holdings still existed at that date; but within a short period Robert de Beaumont, Count of Meulan, had acquired lordship of the whole with the exception of the fee at the East Gate held by the Bishop of Lincoln. ${ }^{12}$ The town was retained by Robert's successors as a borough in demesne; John's charter of I I99, granting to Robert's great grandson, the Earl of Leicester, the privileges of the honor and town, was confirmed by Henry III to Simon de Montfort and Roger de Quincy in 1236.13 Thus, like Chester, Winchester, and Warwick, Leicester held the unusual status of a mediatized borough not directly under royal control, and this brought its inhabitants into close relationship with the earl whose castle and chief dwelling-place until the end of the I 4 th century was within its walls. The earls drew income from rents, perquisites of courts, and tolls. The free tenants paid their rents of assize to the castle porter and owed suit at the earl's three-weekly court ${ }^{14}$ and at two views in St. Leonard's parish and two views 'in le Castelward'. ${ }^{15}$ The only reference to agricultural services on the demesne comes from a charter of about I200, later ${ }^{\circ}$ confirmed by Simon de Montfort, releasing the payments hitherto made for the reaping of the earl's crops. ${ }^{16}$ 'The earl's demesne land farmed in 1296 amounted to 320 acres of arable, 44 acres of meadow, and I hide of pasture. ${ }^{17} \mathrm{~A}$ few rents in kind are mentioned in the bailiffs' accounts. Special rents called Gavelpence (i.e. $3 d$. from every house with a gable on the high street) and Bridgesilver were redeemed by the burgesses in 1253 for a fixed annual rent. ${ }^{18}$ Rents of shops and booths or shambles, in the late i 4th century at least, came second only to the rents of assize. Other income accrued from 2. windmills, 2 watermills, and 6 common ovens, usually let to farm,

\footnotetext{
9 V.C.H. Leics. i. 309; and see below, p. 353 .

10 Ibid. i. 306 ; Leic, Boro. Rec. II03-I 327 , pp. xxi, 4 ; and see below, p. 371 .

II Ibid. II $3-1327,3,6$; L. Fox and P. Russell, Leic. Forest, 20-21, 24.

12 Leic. Boro. Rec. IIO3-I 327 , pp. xiii-xiv.

13 Cal. Chart. R. I227-57, 2 I6.
}

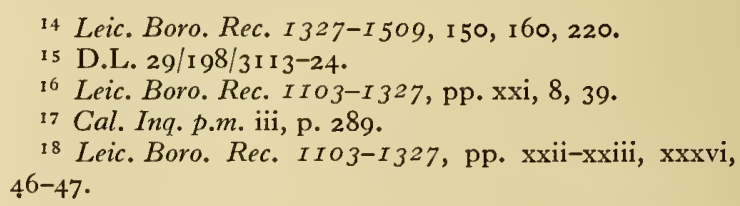


which the townsfolk were obliged to use. Although the portmanmoot was a borough court of probable pre-Conquest origin in which burgesses and all-comers might bring actions, its fines were received by the earl. Other courts from which he took the profits, even when in time they came to be conducted by the town officials, were those for the views of frankpledge at Easter and Michaelmas, the assizes of beer at Whitsun and of bread, and the piepowder courts and courts of fairs. ${ }^{19}$ In addition to the more usual exhennia and customary payments due to a feudal overlord, were certain special taxes or yearly licences; 'cannemol' from brewers, ${ }^{20}$ huckstermoll from regraters, ${ }^{2 I}$ and walkermoll from fullers. ${ }^{22}$ Tolls of the market are mentioned in the inquisitions post mortem of I 296 and I 327.23 The latter also listed the toll of the fair in May, worth $£_{\mathrm{I}}$ yearly, and the tronage of wool at Whitsun worth $\oint_{\mathrm{I}} 7$ yearly. An important attempt to free the borough from these tolls, or possibly to transfer their profits to the town purse, was made in $136 r .{ }^{24}$ The earl, Henry, Duke of Lancaster, was about to surrender all market tolls, stallage, pickage, and tronage in Leicester and within certain bounds called toll-marks, when his sudden death frustrated the negotiations at the final stage. Fourteen years later came a further attempt to obtain greater control of the revenues when the town leased the bailiwick from John of Gaunt for ten years at a rent of $£ 80 .{ }^{25}$ It is noteworthy that the rents of mills and ovens and also of the free tenants were not included in this grant. This lease was renewed upon slightly different terms for twenty years from I 403 and for ten years from I 423 , but evidence suggests that there was never a permanent contract between the borough and its lord even when the Duchy of Lancaster became Crown property. ${ }^{26}$ That it had not acquired from its earls the more complete firma burgi, usually secured by boroughs directly under the king, points to an exceptional relationship and this is borne out by a study of other aspects of the government of the borough. ${ }^{27}$

\section{THE GUILD MERCHANT}

The trade of the town was regulated by the Guild of Merchants which from the end of the I 4th century was also called the Chapman's Guild. A charter of Count Robert of Meulan, dated not later than I I $8,{ }^{28}$ granting their guild to 'his merchants' of Leicester, acknowledged its body of customs and appears to have greater precision than the charters of other towns. Its retrospective reference to all the customs held in the time of William I and William II suggests a different development from that of such towns as Ipswich where the commonalty formally met together to create the machinery of the Merchant Guild. ${ }^{29}$ A wealth of material exists for the study of the Leicester Guild in its series of rolls dating from I 196 to 1380.

Free membership of the Guild in Leicester was granted to a guildsman's heir, the youngest son until I 255 when the law of primogeniture was introduced. ${ }^{30}$ Varied payments were required from others; usually $3 s$. from natives and $6 s .8 d$. from strangers, together with bull money, the purpose of which can only be guessed since the records are silent on this point. The variations matched the circumstances: in I $_{2} 65$ Walter Brown the younger took his father's seat in place of his elder brother, but had to pay Is. $6 \mathrm{~d}$.; in I 289 Luke Shearman pledged 40 s. and swore that wherever he should be he

I9 Ibid. I 327-I 509, I 54, 272.

20 Ibid. 273 .

22 Ibid. I 56 ; and see below, p. 38 .

23 Cal. Inq. p.m. iii, p. 289 ; ibid. vii, p. 66.

24 Leic. Boro. Rec. I327-I 509, p. xxii.

25 Ibid. 149.

LEIC. IV
26 Ibid., pp. xxiv, 2 I $9,232$.

27 Ibid. II03-I327, p. xxxviii; ibid. I327-I509, p. xxvii.

28 Ibid. $I I 03-1327$, p. i.

29 C. Gross, Gild Merchant, i. 23-25.

30 Leic. Boro. Rec. I IO3-I327, 49. 
would answer with the guild. ${ }^{31} \mathrm{~A}$ similar oath and payment were made by Thomas of

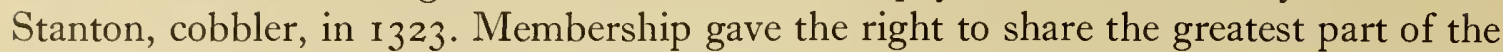
wholesale and retail trade of the borough and freedom from certain tolls exacted from non-members. A bargain must be shared with a fellow guildsman if he was present and claimed it at the time of making, not only in Leicester but also at fairs elsewhere in the kingdom. The mayor alone was privileged to ignore this obligation. There was, however, no joint-stock purchasing as, for example, at Chester. ${ }^{32}$ The general benefit which membership of the trading community would naturally bring found here specific expression in the use of guides for finding the best wool in the county, and of the services of an official broker in charge of the wool scales. ${ }^{33}$ A number of references in the town records at the end of the 13 th century and in the early i 4 th century show attempts to protect the guildsmen not only by forbidding trade with strangers even to the extent of disallowing it with a son not in the guild, ${ }^{34}$ but also by prohibiting trade financed by strangers. In 1260 these two rules were rescinded, but were reimposed within a fortnight when 'it was . . agreed in common that none of the guild shall sell in Leicester the wool or merchandise of those who are outside the guild for part-profits, to the detriment of the liberties of the guild'. Twelve men were appointed to different parts of the town and suburbs to see that this rule was kept. The guild's monopoly of retail trade is illustrated by numerous fines such as that of Henry of Staunton for selling meat and herring 'against the guild'. In these ways the guild was able to enforce to a certain degree its own and the royal ordinances regulating quality, weight, and price of goods. Thus in 1259 the mayor himself and a number of leading townsmen were fined for dyeing wool in woad and madder 'in likeness of perse colour, against the custom of the guild and in deceit'; in $\mathrm{I}_{3} \mathrm{O}_{4}$ Ralph Norman lost his membership for weighing wax with a stone said to equal 4 pound whereas it was a half-pound less. ${ }^{35}$

As in other towns, membership of the Guild Merchant was theoretically open to all manner of traders and craftsmen, with the exception of women. ${ }^{36}$ The list of admissions on the first extant roll, I I $96-$ I 225 , gives more than fifty different callings including the unexpected ones of 'medicus' and 'spitelman'. It is probable that as specialization developed only master craftsmen were admitted, but there is insufficient evidence on this point. ${ }^{37}$ Residence in Leicester was not a usual condition of membership so long as all financial responsibilities, including the payment of tallage with the guildsmen, were undertaken. One section of the trading community, however, remained outside the guild's control; namely, the licensed stall-holders on the earl's market. With the exception of one list from the period when the bailiwick was leased to the town, ${ }^{38}$ the names of these traders do not appear among the records, because their fees were payable to the earl. Their description stallatus is a more precise term than the intrantes, censers (censarii), or tensers of other towns:39 that they were actually stall-holders seems clear from a rule made in 1274 to prevent those impleaded for debt or trespass from later recovering a stall which they had temporarily given up by subterfuge to avoid the penalty of justice. ${ }^{40}$ The yearly total rents from these market booths are

${ }^{31}$ Leic. Boro. Rec. I103-1327, 203,343; ibid. $1327-1509$, 32,320 .

33 Ibid., pp. xxxi-xxxii.

34 e.g., ibid. 299.

35 Ibid. 84, 91, 93-94, 292, 243-4.

${ }^{36}$ Gross, Gild Merchant, i. I07, n. 2; E. Lipson, Econ. Hist. Eng. (1937), i. 370 ; Leic. Boro. Rec. IIO3-1327, pp. xxvii-xxx.

${ }^{37}$ Cf. E. Carus Wilson, 'Eng. Cloth Industry in the late 12th and early 13th cent.', Econ. Hist. Rev. xiv. 41. It should be noted that references to the giving up of manual work cannot be taken as proof that craftsmen were not admitted: the Guild Merchant sometimes, as a penalty, prohibited those outside the guild from doing their usual manual work; see, e.g., Leic. Boro. Rec. $1103-1327$, I70, I $80-1,185$.

${ }^{38}$ Leic. Boro. Rec. $1327-1509,163$.

39 J. Meadows Cowper, Intrantes: A List of Persons admitted to live and trade within the City of Cant. $1392-1592$; F. Aidan Herbert, "Tensers: an historical investigation into the status and privileges of non-gildated tradesmen in Eng. towns', Salop Arch. and Nat. Hist. Trans. (2nd ser.), iii. 253-64.

40 Leic. Boro. Rec. II03-1327, II6. 
given in inquisitions post mortem and valuations of the possessions of the dukes of Lancaster. ${ }^{41}$ It became necessary to keep a check on those who were of sufficient substance to enter the guild, and this grew increasingly important as the interests of guild and borough became merged, more especially from the end of the I 3 th century when the number of cases of illegal trading point to a growing amount of trade conducted outside the authority of the guild. ${ }^{42}$ As early as 1336 the guild oath required the guildsman to warn the mayor and community of any who remained non-members. This duty was also included in the chamberlains' oath, recorded in 1489 . Before this date it had been ordered that if any person 'of what craft or scians so[ever] he be off . . . open or sett up eny shope for hym self withinne this town or withinne the subberbys of the same or he be entrid into the Chappman Gylde, every siche person so openyng eny shope yerly shall pay iiis. iiiid., unto the tyme that he be entred in to the seid Chapman Gylde'. In I 502-3 the tailors' craft acknowledged an ordinance that none should set up as master before their wardens had paid Ios. entrance fee to the Chapmans Guild on his behalf. 43

All pleas of the guild were held before the council of senior members, presided over by the mayor. Punishment for offences was usually by fine, sometimes by loss of membership, entirely, or for a year and a day. ${ }^{44}$ The Morningspeeches were held whenever necessary, but the full Morningspeeches of which there is record after the middle of the $3^{\text {th }}$ century are all dated in February or March. The first known guildhall was situated in the parish of St. Nicholas and the second, purchased from the Ordriz family in I25I, stood at a corner opposite the churchyard of St. Nicholas in what is now called Blue Boar Lane. Repair and other considerations seem to have prevented the use of this house until after extensive work on it was undertaken in I $274 .{ }^{45}$ To this year also has been assigned the detailed building account which sets out the work done season by season. ${ }^{46}$ The hall had a gabled roof and 'consisted of a porch, a hall on the ground floor, and a large solar ... which hung over the street, and sheltered four shops or market booths', ${ }^{47}$ That this hall, though of moderate size, was put to other than guild uses is shown by an item for repair of its benches in I334-5, 'when they were broken and thrown down in the presence of the king's justices then sitting to hold the assise'. ${ }^{8}$ 'The alternative description, 'the Mayor's Hall' or the 'Common Hall' confirms that it was the usual meeting-place for the conduct of all business of the borough, but before the end of the ${ }_{5}{ }^{\text {th }}$ century it was found necessary to hold some meetings in the larger hall of the Corpus Christi Guild. ${ }^{49}$

There is little evidence of conflict between the Guild Merchant and the craft guilds, which with two exceptions do not appear to have been strongly organized before the I 5 th century. In 1260 certain rules for the weavers and fullers were agreed in the Guild of Merchants, and on a few other occasions there was need for interference. The fullers in 1260 swore not to hold any Morningspeeches except in the presence of two merchants specially chosen for this purpose; but fifteen years later they had to be fined for doing so. ${ }^{50}$ The only other sign of independence came from the watermen called 'lochelmen', who in the late I 4 th century were forbidden to form an association amongst themselves. ${ }^{\text {II }}$ Seventeen 'occupations' are known from the later records to have existed in Leicester, yet knowledge of their internal organization and development is scanty,

\footnotetext{
41 Ibid. I327-I 509, I 25, 272-6.

42 e.g. a charge, in 1319 , of trading outside the guild for 3 years after the mayor's prohibition: ibid. I I $03^{-1327}$, 3 I 9.

43 Leic. Boro. Rec. I327-I 509, 294, 363.

44 Ibid. IIO3-I327, 68-69, 2 I 4, 243, 254.

45 C. J. Billson, Medieval Leic. 50-5I.
}

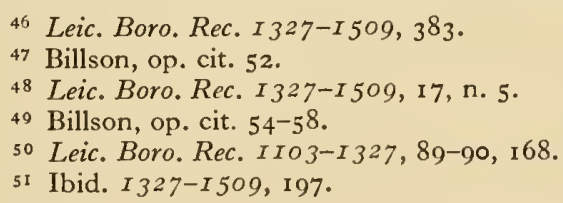




\section{A HISTORY OF LEICESTERSHIRE}

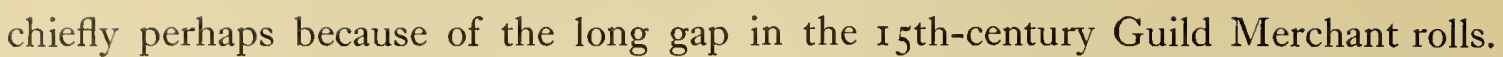
Chance has preserved the ordinances of the tallowchandlers, dated 1469 , endorsed with the names of nineteen men who had been masters of the craft. ${ }^{52}$ These ordinances show that they met four times a year and were governed by two masters who were yearly sworn before the mayor. Their regulations concerned the quality, weight, and price of candles, and delivery to the hucksters for sale. It is significant that members who were found guilty in the mayor's court of trade offences paid a fine to both the craft and the Guild Merchant.

The relationship between the community of the guild and the community of the town has been fully discussed elsewhere. ${ }^{53}$ But certain facts may be added concerning membership of the guild and the influence of its community on the development of the borough. It may be significant that the earliest extant charter, that referrring solely to the Guild Merchant, is addressed to the earl's 'merchants of Leicester'. ${ }^{44}$ All subsequent charters, including inter alia the rights of the guild, are granted to the burgesses. It is not evident until the late ${ }_{5}{ }^{\text {th }}$ century that membership of the guild conveyed burgess rights or that to be a burgess would automatically make one a guildsman. ${ }^{55}$ Awareness of the distinction is seen in a case brought in the fair court of St. Ives in I 275 when four burgesses and merchants of Leicester were attached for the debt for wool of Thomas Coventry of Leicester. The attached men denied that Thomas had ever 'been at scot and lot or a member of the commonalty'. ${ }^{6}$ In a dispute on the question of tallage settled by the justices in $\mathrm{I} 28 \mathrm{I}$ it was decreed that the tenants of the Bishop of Lincoln without the East Gate of the town should share in the responsibilities as well as the privileges of the guild but were excused from financial payments concerning the commune of the town, unless they were also burgesses owning property in the town. But Mary Bateson suggests that this was a redefinition to protect a particular section of the community, when the distinction was no longer sharply defined for others. ${ }^{57}$ With the growth of the importance of what may be called the town council, conducting its business through the meetings of the Common Hall, and in conformity with national policy, came the need to exclude irresponsible persons. Hence the order of 1466 which in its wording suggests the identity of burgess-ship with guildship: "that . . . no man presume to entre into the Gilde hall otherwise cald the Maires hall at eny comen hall . . but oonly thoes and sich as ben fraunchest, that is to say men entred into the Marchaundes Gild'. ${ }^{8}$ A bill amongst the Chancery Proceedings affords an illustration of the insistence on the civic responsibility of the guildsman in the early I6th century. After about ten years' membership of the Chapman's Guild, Robert Paner, mercer of Lutterworth, was elected one of the chamberlains of the town. He considered this contrary to usage since he did not reside there, 'nor never was sworn to the maire as oon of the fremen of the same', and therefore he openly renounced his brotherhood of the guild. Nevertheless, on a subsequent market day his linen cloth and other wares were distrained to the value of $£_{20}$ because he had refused to pay the fine of $£ 5$ for redemption of the office. ${ }^{59}$

Although evidence is not decisive that during the formative years there was one set

${ }^{2}$ S. H. Skillington, 'The Leic. Gild of Tallowchandlers', T.L.A.S. xv. $127-38$.

${ }_{53}$ Leic. Boro. Rec. I IO 3-1327, pp. xl-xlix; Gross, Gild Merchant, i. 62-63; C. Stephenson, Boro. and Town, I356; J. 'Tait, 'Boro. Community in Eng.', E.H.R. xlv. 537-9; and see above, p. I4.

54 Leic. Boro. Rec. IIO3-1327, I.

55 Mary Bateson (ibid,, p. xxviii) states 'By 1400 to enter the Merchant Gild of Leicester, that is to pay "scot and lot" with the men of the borough, was to enter the freedom of the borough'; but her references to Nichols (rectius Leics. i, App. 375, 377, 379) make it clear that the date should have been 1500 .

56 F. W. Maitland, Select Pleas in Manorial and other Seignorial Cts. Hen. III and Edw. I (Selden Soc. ii), ii. I 45-7.

57 Leic. Boro. Rec. II03-1327, pp. xl, xlviii.

58 Ibid. $1327-1509,285$.

$59 \mathrm{C}$ I/665/39. Cf. the payment of 5 marks by John Reed in 1504 : Leic. Boro. Rec. $1327-1509,445$. 
of officials for all offices, in two important aspects there was union. The 24 jurats for portmanmoot and for guild were identical; thereby forming one governing body; and, unlike Lynn, Exeter, and other towns, Leicester had one common purse. The first official named for town or guild, in I 209, was styled 'alderman of the guild' and when his title was changed to that of mayor in the mid-I 3 th century he continued to preside over the Morningspeeches of the guild. It was 'by common counsel of the guild' that the first 24 men were chosen in 1225 , 'to come to all the summonses of the alderman to advise the town and serve him in town business'.60 'The Guild Merchant might be described as the chief finance department which left jurisdiction (apart from trade offences) and police matters to the portmanmoot. The townsmen met sometimes as one court, sometimes as another, just as the suitors to a seignorial court might at one stage deal with leet business and at another with manorial affairs. Whether or not there was any distinction between burgess and guildsman during the medieval period, and despite the fact that the loss of practically all the portmanmoot rolls may tend to overemphasize the activities of the Guild Merchant, the trading community is seen playing its full and acknowledged part in creating and developing the government of the borough.

\section{WORKING LIFE}

It is difficult to make more than a very general analysis of the occupations of those who lived, or traded, in the town, since their callings are not always disclosed in the lists of the Guild Merchant entries and of the tallages. ${ }^{61}$ Within these limits it would appear that the numbers connected with the food-supply predominated over the rest. Leather-workers including shoemakers came second, though at some periods this place was shared by the group engaged in the woollen industry and trade. Next to these came the mercers, builders, and metal-workers. No appreciable change is noticed throughout the Middle Ages. Roughly 50 per cent. of the mayoral occupations are known. These in the $3^{\text {th }}$ and $\mathrm{I} 4^{\text {th }}$ centuries show a predominance of merchants, including mercers and wool merchants, with a few innkeepers and vintners; other callings are represented by one name only. From I 400 to I 500, among the merchants the description mercer gives place to draper, and several members of the leather trade are included. If the relative importance of the occupations in their contribution to the wealth of the town rather than the numbers pursuing them be considered, precedence should be given to the woollen industry and trade.

\section{WOOLLEN INDUSTRY AND TRADE}

There is evidence that the cloth industry flourished in Leicester in the early 13 th century. The Pipe Roll of $\mathrm{I} 2 \mathrm{O} 2$ records the payment of Io marks by the burgesses for licence to import $18 \frac{1}{2}$ baskets of woad from overseas: in the same year Gerard de Maisnil imported $\mathrm{I} \frac{1}{2}$ baskets of woad from Flanders. ${ }^{62}$ In I 202 , also, Leicester was one of the towns paying for freedom from Richard I's assize of cloth. ${ }^{63}$ Purchases of Leicester cloth were made for the royal household in several years, notably in I 244 when Peter de Calfof and his fellows, merchants of Leicester, received $£, 5^{\circ}$ for cloth

60 Leic. Boro. Rec. IIO3-I327, 34.

6I There is one list of shop rents, 1376 , giving the following numbers : drapers, 23 ; ironmongers, 18 ; mercers, 16; cordwainers, 13 ; butchers, 13 ; but these rents, payable to the earl, may represent only a nucleus, possibly those in the neighbourhood of the Saturday market: Leic. Boro. Rec. I327-I509, I56; H. Hartopp, Roll of Mayors of Leic. passim.

62 Pipe R. 1202 (P.R.S. N.S. xv), pp. xxi, 40.

63 Ibid., pp. $\mathrm{xx}, 39$. 
delivered to the king's tailor, and in 1254 when 2 cloths of blue and 2 of russet were ordered. ${ }^{64}$

'The weavers' customs together with those of the fullers were agreed to in the Guild of Merchants in 1260 . They swore not to conceal any flaw in their work, to maintain its quality by using three shuttles, and not to weave at night. Five years later the night rule was relaxed provided that standards were upheld. Prices were fixed at $\frac{3}{4} d$. a yard for russets and $\frac{1}{2} d$. for all other cloths. Work for country villages (a sign of the times) was forbidden so long as there was enough in the town; any scarcity of work to be reported to two specially appointed men of the Guild Merchant who might then allow weaving for strangers to be undertaken. ${ }^{65}$ The weavers appear, therefore, at this date not to have had their own wardens to represent their interests or to keep up standards. But sometime in the I4th century action was taken after two men had been pilloried for cutting thrums to the length of $\mathrm{I}_{2} \frac{1}{2}$ yards; and because of notorious falsity, "which people talk and speak of', two weavers were chosen by all the town as searchers and to rule the craft. ${ }^{66}$

The fullers were sufficiently organized by 1208 to pay ios. yearly as a guild to the earl. ${ }^{67}$ From them was derived the name of the vicum fullonum (mentioned in deeds c. I225), which extended outside the town wall from the North Gate westwards towards the Soar. ${ }^{68}$ This was known as Walkers Lane until the I 5 th century, but soon after I 4 I 7 there was a change to its present name of Soar Lane. ${ }^{69}$ Property in this lane was held by Roger of Ketton, who in 1257 was convicted of fulling coloured cloths contrary to the provisions agreed two years previously on oath by himself and by 'all the other master fullers' of Leicester. Their regulations were given in detail when agreed in the Guild Merchant in I260: namely, that they would not full coloured cloths in argol and lye, nor use beetles on dry cloth, and that they would not fix their own charges by agreement among themselves. Any defective fulling was to be shown to four specially appointed merchants from the Guild Merchant. These regulations include the first reference to a fulling-mill (outside the town) which was not to be used unless by consent of the parties concerned. This rule was still in force in I323-4. In I343 the use of iron instruments, 'to wit, any beetles, or teasels or combs', was forbidden as before. The fact that two fullers had to be appointed as wardens to present any shortcomings would suggest that they, like the weavers, had no official wardens of the craft. Reference has already been made to the control of their Morningspeeches by the Merchant Guild.

The fortunes of the fullers give an indication of the condition of the cloth industry generally, and Leicester by the early i 4 th century showed signs of that migration of the industry from the towns which is noticeable elsewhere in England. The inquisition of I 322 on the oppressions under Thomas of Lancaster the late earl stated that there remained only one fuller in the town and he a poor man. ${ }^{70}$ This figure can only be checked by a detailed study of all the tallage rolls; but the implication appears to be supported. Guild Merchant entries include no person named or described as fuller or walker from I 250 to $\mathrm{I} 300$, and only five persons from I 300 to $\mathrm{I} 35^{\circ}$. Three of these five entered during the years I 334 to I 336 . The tallage lists of I 336 and I 354 each give payments from two walkers. ${ }^{71}$ Evidence of later fluctuation in their numbers comes from the payments to the earl of the fullers' custom known as walkermoll; is. a head

\footnotetext{
64 Cal. Lib. 1240-5, 232; Close R. 1253-4, 46; cf. Close

R. $1234-7,301,375$.

65 Leic. Boro. Rec. IIO3-I327, 105.

66 Ibid. $1327-1509$, 195.

67 Pipe R. 1209 (P.R.S. N.S. xxiv), 24-25.
}

68 B.M. Add. Chart. 24202; Leic. Boro. Rec. IIO31327,381 .

69 Billson, op. cit. $13,17$.

70 Cal. Inq. Misc. ii, p. ${ }_{3} 8$.

71 Leic. Boro. Rec. $1327-1509,36,98$. 
was paid by 5 persons in 1377 , and by 15 in years preceding $14 \mathrm{II}{ }^{72}$ In this year their numbers dropped to 7 , and for the rest of the century varied from 6 to 12.73

The Leicester records refer less to dyeing than to the other chief processes in the cloth industry. Yet the dyers were well represented in the town. For example, among the Merchant Guild entrants from I 300 to 1350 whose occupation was given, Io were dyers compared with I weaver, 5 fullers, and 6 shearmen; the entrants from $\mathrm{I} 35^{\circ}$ to I3 80 included 7 dyers, 6 weavers, 3 fullers, and 5 shearmen. Whereas some dyers confined themselves to their craft, others, like Henry Houhil and Richard of Shilton in the mid-I 3 th century, became entrepreneurs employing the fullers and weavers and controlling the whole production of the cloth. ${ }^{74}$ As in other towns, such men belonged to the ruling classes in Leicester, and thus they did not need a guild of their own. It is significant that the only ordinance recorded for them, in 1263 , about making perse-coloured cloth 'without any admixture of black wool or grey wool, or madder or alum', was 'provided and agreed in common by the community of the guild of merchants'.

Cloth was often sold by merchants described as mercers in the Leicester records of the $\mathrm{I} 2$ th and $\mathrm{I} 3$ th centuries. This is seen in the references to the family of Beeby, whose fortunes have been traced from I I 99 to $1384 .{ }^{75}$ William of Beeby and at least two other mercers were among the nineteen men fined in 1292 for using false yard-measures. ${ }^{76}$ Other Beebys who were mercers or drapers rose to importance in the town affairs of the $14^{\text {th }}$ century. The mercers sometimes acted as a group, as for example when six of them, all members of the Merchant Guild, charged another mercer with standing "continually from day to day with his mercery in the Apple Lane under the solar of John of Sherford to the injury of his brethren of the guild'.77 The list of shop rents of I 376 names only I 6 men paying under 'Mercerie', compared with 23 paying rent under 'Draperie', an illustration of the increasing specialization of the drapers. The business troubles of one Leicester mercer in 1394 have resulted in the survival of a very long and comprehensive inventory completely filling a parchment 36 inches by 12 inches in size. In addition to British and imported cloth of twenty different kinds, his stock-intrade included bowstrings, whipcord, honey, onion seed, 'portsed' and 'colesed', pewter, purses of gold cloth and of hide, silk coifs and ribbons, skeins of Paris silk and silk of Lucca, gold and silver rings, pearls, pins, brushes, shoes, and straw hats, some white, some black. ${ }^{78}$

The different aspects of the wool trade in Leicester can be well illustrated. Guildsmen claimed shares in purchases made in the surrounding villages or at the more distant fairs. ${ }^{79}$ Others were fined for forestalling. ${ }^{80}$ 'The mayor's account for I $3{ }^{\mathrm{I}} 4^{-\mathrm{I}} 5$ included $4 d$. for four grooms, 'finding out whether anyone buys wool-fells outside the gates'. But this method did not prove effective, for two years later when Alan of Gissing was accused of standing on Berehill outside the East Gate on Saturdays with two servants waylaying wool-fells coming by road, his defence was that the men of other burgesses did the same. ${ }^{81}$ A watch was also kept on the activities of foreign merchants, notable among whom were Geoffrey of Louvain and Jakemin of Liége. ${ }^{82}$ In the mid-I $3^{\text {th }}$ century, because the foreign merchants were so heavily amerced in

72 Ibid. $156,273,274-6$.

${ }^{73}$ e.g. D.L. 29/198/3114-24; D.L. 29/199/3125-35; D.L. $29 / 200 / 3136-45$ (for the years $1439-40,1441-4$, 1446-7, 1453-4, I 460-1, 1469-70, $1480-7$ ).

74 Econ. Hist. Rev. xiv. 44.

75 Billson, op. cit. I $55-6$.

${ }^{76}$ Leic. Boro. Rec. IIO3-I327, 223. For another Wm., a mercer, see C.P. $40 / 270$ m. 64 d; C.P. $40 / 274 / 133$.

77 Leic. Boro. Rec. I327-I 509, 49-50. An example of a

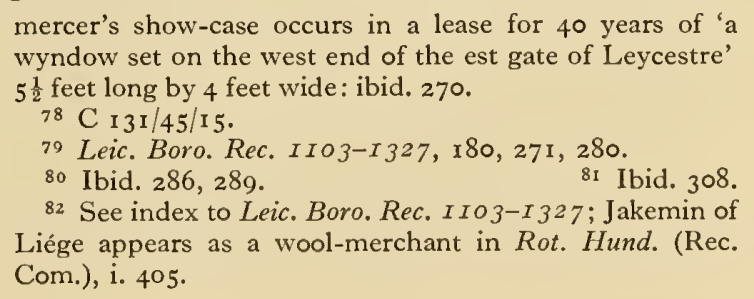


Leicester for wool bought wholesale in the county, the portmanmoot, at their request, agreed that they might buy freely in Lutterworth and seven other places named.83 In I 28 I seven women were warned against dressing the wool of strangers outside the town. In this year also the wages of the women wool-wrappers were fixed at $\mathrm{I} d$. a day with food in summer and winter. Complaints about wool washing, packing, and wrapping all show the attempt to keep these processes under supervision and within the town where just dues might be collected. ${ }^{84}$ Wool not used locally was marketed at the English fairs or exported from the eastern ports. Hugh de Leicester, who exported from Lynn in a ship of Calais, $\mathbf{1 2 8 8 , 8 5}$ was probably the Hugh le Mercer who on occasions bought from Leicester Abbey its surplus wool. ${ }^{86}$

Among the merchants exporting wool in the early I4th century was Roger Devet of Leicester. ${ }^{87}$ The gap in the Guild Merchant rolls from I3 30 would appear to have lost us the record of a man of note. In I 402 he shipped I,600 wool-fells from Kingston-uponHull in the 'Marishipp' of Rotterdam;88 in I $4 \mathrm{I} 3$ he was excused the subsidy on a similar consignment shipped from Lynn for Calais because it was captured by pirates. ${ }^{89}$ The first definite, though rather late, mention of Leicester men as merchants of the Staple comes from the patent roll of I 470 ; out of 28 merchants of London and a few other places pardoned for offences, four, namely, John Leamington, John Reynold, Thomas and Roger Wigston, were of Leicester.90 The first of these probably had family connexions with another stapler, Ralph Leamington of Loughborough, who kept ready money to the amount of 800 marks in a chest in the treasure house of the parish church of Loughborough; ; $^{1}$ the second, later to become mayor like his father and grandfather before him, dealt in cloth also. ${ }^{22}$ From this date to the turn of the century at least sixteen staplers lived in, or conducted business from, Leicester, and outstanding among these were the Wigstons who have left their mark on the town to the present day. ${ }^{93}$ Five staplers came from two generations of this family: others were connected with it by marriage. Roger Wigston was chosen Lieutenant of the Staple at Calais in $1483,{ }^{94}$ and William Wigston the younger, mayor there at a later date. ${ }^{95}$ Roger owned a considerable tenement in the Swinesmarket ${ }^{96}$ and held manors in five places in the county which passed to his son William Wigston senior. ${ }^{97}$ But the family fortunes reached a spectacular level through the activities of John Wigston (died I $\left._{5}{ }^{\mathrm{I}} 3\right)^{98}$ and his son William Wigston the younger (died $\mathrm{I}_{53}$ 6). ${ }^{99}$ The former conducted the business in Coventry, leaving to his son the control in Leicester. Scrutiny of the 1524 subsidy roll proves that William owned 22 per cent. of the taxable property in the town and was pre-eminently its wealthiest burgess. ${ }^{I}$ This is borne out by the inventory attached to his will, in which his plate was valued at $£ 298$ and his wool and fells in Calais at $£ 594$. Of the total amount of $£ 3,5$ I 7 due from debtors, about two-thirds was owed by foreign merchants. Not only must he have employed considerable labour in the town, but, having no

\footnotetext{
${ }^{83}$ Leic. Boro. Rec. IIO3-I $327, \mathrm{I} 23$.

84 Ibid. $185,189,190,216$.

85 E $122 / 93 / 14$.

86 S.C. $6 / 1257 / \mathrm{I}$. Two items in $\mathrm{I} 286$ amounted to I 3 sacks, 3 stone of wool; R. H. Hilton, Econ. Development of some Leics. Estates, 27 and $n$.

87 Spelt also Dovet and Duyet. This family perhaps came from Fleckneỹ: Leic. Boro. Rec. I327-I509, 94, 402. Roger held land in the Swinesmarket in $1408: W y g-$ geston Hosp. Rec. 325, 331.

${ }_{88} \mathrm{E}$ I 22/60/5.

89 Cal. Pat. 1413-16, 150. For shipments of his in 1399 and $\mathrm{I} 400$ see $\mathrm{E} 95 / 3 \mathrm{~mm} .3,4,8,9$. These accts. include exports of other men of Leic. and of the co., outstanding among whom was Wm. Dalby: see ibid. $7 / 3,8 / 3,4$, for shipments from Boston, 1378 .
}

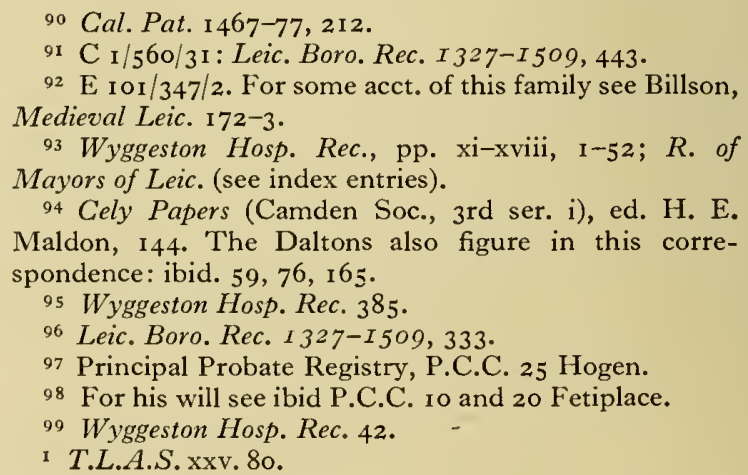


children, he was free to leave his wealth for charitable and pious purposes, most notable of which was the foundation of the Wyggeston hospital. ${ }^{2}$

\section{LEATHER INDUSTRY AND TRADE}

Although hides ranked with cloth as a leading article of trade in medieval England, leather does not figure in the Leicester records to the same extent as wool and cloth. It is mentioned occasionally: the share of a cow-hide refused to Richard of Lubbenham in Hinckley market, I3 I 2 ; the share of three ox-hides refused to Hugh of Braunstone, I 32I. At St. Ives fair in 1275 three dickers of ox-hides were attached for a Leicester debt. ${ }^{3}$ Borough regulations of the mid-I 5 th century included the order for butchers to bring into the town for sale the skins and tallow, as well as the flesh, of their animals. ${ }^{4}$ Leather testers must have been appointed for a considerable period before the first extant lists which date from 1477 (the beginning of the first Hall Book), when four men were named

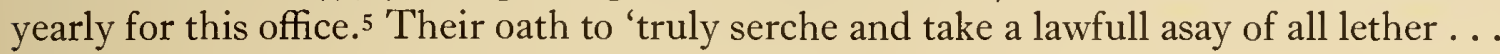
that it be well and sufficiently barked and able' was recorded with the oaths of other borough officials some years later. M. P. Dare has estimated from tallage rolls and guild entries that in 1300 there existed eight or nine tanning, and five footwear, establishments. ${ }^{6}$ From the indexes to Mary Bateson's volumes it appears that the town was adequately served in the usual branches of the leather industry, but the term 'tawyer' or 'white tawyer' was very rare. The number of skinners increased after the 13 th century and it is noticeable that after this century the name or description barker as an alternative to tanner was also much more frequent. From the tallage rolls individual shoemakers and tanners can be located in different parts of the town. The chief centre of the former, Cordwainers Row, is mentioned in a deed of 1300.7 It was situated on the west side of the High Street between the High Cross and the West Gate. In the list of shop rents, I 376 , the names of thirteen shoemakers are given. Their moderate status may perhaps be inferred from the fact that Guild Merchant entries for only three of them have been traced. The earliest tanners doubtless lived at the North Gate of the town, especially after the Assize of the Forest of I 84 which forbade the practice of this trade within the bounds of any forest except in a borough or market-town. The Leicester tanners enjoyed favourable conditions from the nearness of woods for their oak bark and of good water-supply for their vats. Their use of the Soar was the subject of an order from the chief steward of the Duke of Lancaster in I399, confirming that 'the burgesses and tenants of the town of Leicester were wont to have easement from old time to put their hides and wool-fells in the water of the Soar at the bridge which is called West Bridge up to the North Bridge'. ${ }^{8}$

Evidence as to the trade in leather is still insufficient to assess its importance compared with that of wool and cloth. An outstanding personality, Simon Curlevache, alderman, and one prominent in guild and town affairs for many years in the early I 3 th century, had licence in I 209 to export 720 hides. By I 239 he was rich enough to survive the payment of 500 marks for incurring the displeasure of Simon de Montfort. ${ }^{9}$ It is likely that other leading burgesses, styled simply 'merchants', many of whom became mayors, traded in hides as well as other commodities; but during the medieval period so far as is known only two saddlers (Laurence le Seler in I29I and Thomas Seburgh in

\footnotetext{
${ }^{2}$ Wyggeston Hosp. Rec., pp. xx-xxi; G. Cowie, Hist. of Wyggeston's Hosp. 8; see also below, p. 398.

3 Maitland, Select Pleas in Manorial and other Seignorial

Cts. ii. I $45-7$.

${ }_{4}$ Leic. Boro. Rec. I327-I509, 288-9.

5 Ibid. 457 .
}

6 Assoc. Archit. Soc. Rep. $\odot$ Papers, xxxix. 143.

7 Leic. Boro. Rec. IIO3-I327, 228.

8 Ibid. I327-I509, 2 I0-I X.

9 Billson, Medieval Leic. I 49-50; Leic. Boro. Rec. I I03I 327,6 , n. 3 .

LEIC. IV 


\section{A HISTORY OF LEICESTERSHIRE}

I 4 I 5), three glovers (Adam Racy in I 435 and I 440, John Penny in I 48I , and Roger Trigg in 1490 ), and one skinner (William Asty in 1427 and 1437 ) rose to mayoral office. Peter of Grendon, a wealthy saddler, leased the site of the East Gate and land in the town ditch outside, ${ }^{10}$ and at his death in $\mathrm{I} 354$ left considerable property, partly for the support of a chaplain in the Hospital of St. John outside the East Gate. ${ }^{11}$ Perhaps the growing importance of the local leather industry at the end of the 15 th century may be reflected in the career of John Norris, barker. In I 492 he owned a tenement on the town ditch, in extent $105 \mathrm{ft}$. by $40 \mathrm{ft}$., and in the same year paid the modest tallage of $\mathrm{I} s .6 \mathrm{~d}$. Several years later his lands were assessed to pay the comparatively high subsidy of $40{ }^{\mathrm{I}}{ }^{\mathrm{I}} \mathrm{He}$ became a leather tester in $\mathrm{I}_{494}-5$, chamberlain in $\mathrm{I} 495^{-6}$, steward of the fair in $\mathrm{I}_{502-3}$, and mayor in $1503-4$. In the next year he was one of the eight leading citizens who paid the highest rate of 20s. towards a benevolence for town expenses. By his will, proved in $\mathrm{I}_{5} \mathrm{IO}$, he left to his sons all his tenements in Soar Lane, a close lately purchased, and two tenements in North Gate. Another close, in All Saints parish, was bequeathed for an obit. ${ }^{13}$

\section{BUILDERS}

Although the fortunes of individual builders are difficult to trace, the borough records include a number of detailed building accounts which give costs of materials and rates of pay for the masons, artisans, and labourers. ${ }^{14}$ Sand, lime, and stone were always carried in carts hired for each job from a number of townsfolk. ${ }^{15}$ Stones came from Waverton (Ches.) for the High Cross in $1314^{16}$ and for the North Bridge from Swannington in $1327^{-8}{ }^{17}$ and Ibstock in $135^{1-2 .} .^{18}$ For the considerable alteration and additions to the castle in the 14 th century large quantities of slate were brought from Swithland, ${ }^{19}$ and stone on one occasion from Basford (Notts.). ${ }^{20}$ Expenses for the North, South, and West Gates in $135 \mathrm{I}-2$ list the payments to carpenters, sawyers, a tiler and his youth, a mason at $2 s .6 d$. a week, his youth at $\mathrm{I} s .4 \frac{1}{2} d$. a week, men carrying gravel and collecting stones at $3 \frac{1}{2} d$. a day. The payments to masons and their assistants at different dates throughout the I4th century show that their wages ranged from I $s .8 d$. to $2 s .6 d$. a week, presumably according to individual skill. These rates are similar to those paid elsewhere in the country. In $1327-8$ and $1365^{-6}$ special payments were made of $3 s .4 d$. weekly, by agreement ad tascam. ${ }^{21}$ While repairing the West Bridge in $\mathrm{I}_{3} \mathrm{I} 4$ Master John the mason received $2 s .6 d$. a week, his fellow mason, Is. $8 d$., and the two youths serving them, rod. each. ${ }^{22}$ Master John was a visiting craftsman who later in the same year was fetched from Banbury to repair the High Cross by contract for $f_{3} 6 \mathrm{~s} .8 d .{ }^{23}$ Another visiting mason, Master Peter of Bagworth, supervised further work on the West Bridge for nineteen weeks in $1325^{24} \mathrm{He}$ was assisted by other masons, sometimes as many as eight in one week; a house was hired for $5 s$. for a year and eight weeks 'for lime, and for masons and their implements and for wheelbarrows, riddles, trestles, centres and other things bought for the aforesaid work'; and $\mathrm{Is} .3 \frac{1}{2} \mathrm{~d}$. was expended in their beer and 'for the ale which is called closinghale'. ${ }^{25}$
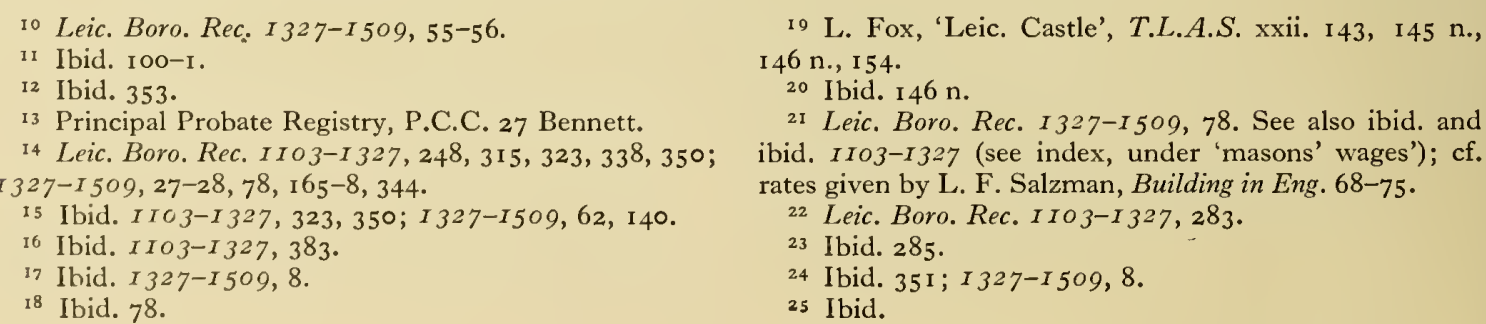


\section{FOOD SUPPLIERS}

More persons were employed in supplying the food of the town than in any other occupation. For example, out of some 50 different callings mentioned in the earliest Guild Merchant roll of I I 96 , there were I 5 bakers, 6 cooks, 2 butchers, and 2 fishers. ${ }^{26}$ This predominance was maintained throughout the medieval period, and if none, apart from several vintners and innkeepers, rose to pre-eminence in local affairs, many belonged to the middle range of tallage payers like Ingram le Bocher who entered the Guild Merchant and in I27I contributed I $3 s .4 d$. among many smaller payments from other persons ranging from $3 d$. upwards. ${ }^{27}$

Some aspects of the bakery trade have been described elsewhere. ${ }^{28}$ In 1086 corn could be ground at 3 mills whose toll was taken by separate lords. ${ }^{29}$ By I 296 the earl owned and farmed out 2 watermills and 2 windmills. ${ }^{30}$ These were probably the castle mill, ${ }^{31}$ the North Mill ${ }^{32}$ (I3OI), and windmills in the south field ${ }^{33}$ (I3 I6). The needs of the eastern suburb were perhaps supplied by Belgrave mill on the Soar to the northeast, doubtless farmed from the Bishop of Lincoln. ${ }^{34}$ A horsemill (I3I4) stood on the south side of the Swinesmarket. ${ }^{35}$ Another important mill existing from an early date was St. Mary's Mill. ${ }^{36}$

In the mid-I 4 th century complaint was made for the lord that debtors having no goods except their flour in the mill or their bread could not be distrained by these because they were taken by night from the mill to the oven. ${ }^{37}$ The use of the specially built communal ovens, which were a source of revenue to the earl, continued throughout the medieval period. A grant $c$. I 200 by the Countess of Leicester allowing bakehouse rights to a tenant outside the South Gate expressly excluded 'my customary tenants who are bound to my ovens within the town'. ${ }^{38}$ In $1327^{39}$ these ovens or bakehouses numbered 6 , of which 4 were situated in the centre and west of the town towards the castle, and the other 2 stood outside the east ${ }^{40}$ and north gates. ${ }^{4 I}$ The 4 central ones were in Holyrood Lane (later called Town Hall Lane), Applegate Street, and two places appropriately named 'Kepeoven Lane' and 'le Hotegate'. ${ }^{2}$ By I 399 the last-named oven had fallen into disuse, ${ }^{43}$ but in $\mathrm{I} 46 \mathrm{I}$, in addition to the farmers of the remaining 5 bakehouses, two other bakers were paying a small annual sum for licence to bake.44 These men presumably owned private ovens built in their own tenements, a practice which grew to an abuse towards the end of the I 5 th century: in 1488 Henry VII ordered the mayor and bailiffs to have removed the 'divers and many ovens' which were 'drawing away our own tenants that ought to bake at our common oven'. ${ }^{45}$ 'This practice, however, remained as a constant source of complaint. ${ }^{46}$ That the bread was

26 Ibid. $I 103-1327$, I 2-I 5 .

27 Ibid. 66, I 29, 1 45, 147, 208.

28 Billson, Medieval Leic. I28-37.

29 V.C.H. Leic. i. $306,309,315$.

30 Cal. Inq. p.m. iii, p. 289 . In I 3 I $4-15$ these were farmed to John Caleys together with the horsemill and the common ovens: D.L. $29 / \mathrm{I} / 3$. The site of the horsemill is described in D.L. 29/199/3126. For mills generally see below, p. 395 .

31 Leic. Boro. Rec. II03-I327, 37 I.

32 See below, p. 396.

33 Ibid. 398.

34 Let with a messuage and land to Laurence of Belgrave in $1398-9: C_{47} / 66 / 2$, no. 26. A fishery in the Soar from the North mill to Belgrave mill is mentioned in $1406-7$ : D.L. 29/1 $98 / 3$ I I 3 ; see also below, p. 424 .

35 D.L. 29/I/3; Leic. Boro. Rec. I 327-I 509, 206, 296.

36 See below, p. 397 .

37 Leic. Boro. Rec. I327-I 509, 87-88.

38 Ibid. $I I 03^{-I 327, ~ I O . ~ T h e ~ e a r l ' s ~ o v e n ~ a t ~ L e i c . ~ i s ~}$ mentioned in a doc. of late Hen. II : F. M. Stenton, Doc. Illustrative of Soc. and Econ. Hist. of Danelaw, 248.

39 Leic. Boro. Rec. I327-I509, 3.

40 Ibid. IIO3-I327, 288; D.L. 29/199/3126.

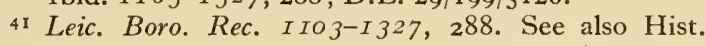
MSS. Com. Var. Coll. vii. 385 . For an example of a 30 years' lease of this oven with house, boards, and all instruments, see Leic. Boro. Rec. I327-I 509, 23 I-2.

42 D.L. 29/I99/3126; Leic. Boro. Rec. IIO3-I327, 358; I327-I509, 267, 307, 399; Cat. Anct. D. iii. D. 60I; Wyggeston Hosp. Rec. 306, 307. There appears to have been only one, not several, bakehouses in Hotgate. Cf. the description, Le Hotegate quondam venella cuiusdam furni. . . : D.L. 29/198/3 I 16 .

43 D.L. $29 / 212 / 3248$.

44 Ibid.

45 Materials for Hist. of Reign of Hen. VII (Rolls Ser.), ed. W. Campbell, ii. 369 ; D.L. $37 / 62$ m. 7 .

46 D.L. $37 / 62$ mm. 3od, 4Id; D.L. 5/3, f. 67 ; D.L. $42 / 95$, f. 36 . 


\section{A HISTORY OF LEICESTERSHIRE}

retailed by regrators and regratresses is evident from the complaint of the bakers in I 323-4 that these traders kept back the bakers' bread, 'for a week, fortnight, three weeks and more', thereby causing them great harm. ${ }^{47}$ In 1372 when all the bakers were fined because they had no wastell, i.e. best-quality bread, nine names were listed.48

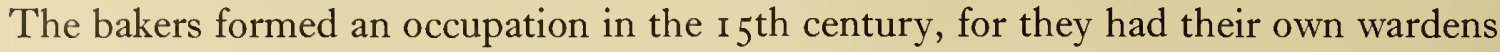
by 1488 , the date of an entry among the town ordinances: 'That no baker within this town take uppon hym to carrye any maner of bred into the cuntrey but that fyrst they and every of them shall bring ther seid bred on horsebake to the Mayer . . . or to the wardyns of that occupacion and ther to be weyyd and to se whether it be able bred and holsome.' 49 A bread-market is mentioned in the 15 th-century accounts, but its site is not indicated.50 The assize of bread authorized by a statute ascribed to I 266 appears to have been taken over more directly by the town officers in I 335 when an order for its enforcement was enrolled, although the revenue from fines still went to the lord. From this date the weighing of bread was conducted by the mayor and bailiffs, sometimes with the assistance of two jurors and two bakers. The number of these 'assizes' which have survived for the I 4 th century show the fluctuations in the size of the loaf according to the price of grain, and of the many kinds of bread supplied, such as 'ringebred', 'cokett', 'tratellus', 'Marchaunbred', and bread made of pease and beans. ${ }^{5}$

The earliest butchers' shops or shambles were in the parish of St. Nicholas in the south quarter of the town, along the street now called Applegate Street.52 Thirteen butchers rented these shambles in $1376: 53$ there is a record from the same date of payments made on successive Saturdays for tables in the Saturday market. ${ }^{54}$ With the development of this market in the ${ }_{1} 5_{\text {th }}$ century the St. Nicholas shambles became less convenient and sometime in the I6th century the company of butchers of the borough asked that the use of the Saturday market should be extended because 'the weekeday shambles, comonly cald the common shambles' were 'out of the way of tradeing and remote from the innes and shopkeepers who are the greatest support of the markett'. ${ }^{55}$ Ordinances for the butchers are included among those for other suppliers of food and drink. In I 279 it was ordered that no meat be sold in their houses before noon, nor be put up for sale beyond three days: ${ }^{56}$ in the ${ }_{5}$ th century the selling of flesh was prohibited from houses or shops and confined to the St. Nicholas shambles or the common market place. ${ }^{57}$ By this time the rules specifically included butchers of the country as well as those of the town. The purchases of food for the town's gifts or hospitality for visiting nobility, the earl's officials, justices, messengers, or other persons of note show a preponderance of beef, some mutton and venison with an occasional boar or kid. Live calves, porkers, and sheep might be bought by regrators for resale, but must be sold cooked and not as raw meat. ${ }^{58}$ Poultry sold by cooks included hens in bread and hens in paste, sometimes called bakers' hens. In 1467 the cooks were forbidden to engross 'wodecoke, cone, partrik, plover ne non other denteythes (dainties)' before the town was served. 59

Among the frequent gifts made by the town, fish was as often presented as other foods, and the mayors' accounts show a variety of kinds as great as that of today. To select from the many examples: herring, cod and dried fish, eels and fresh fish were bought for the earl's steward and his assistants in Lent, $\mathrm{I} 32 \mathrm{I} ; 60$ for a dinner on Lady

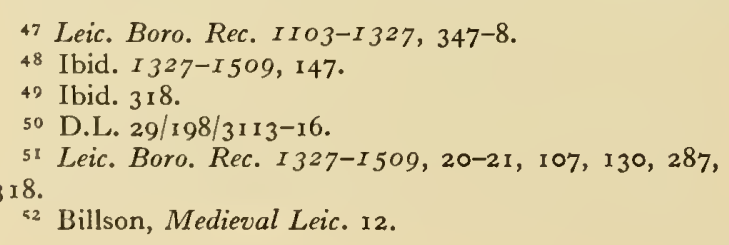

53 Leic. Boro. Rec. I327-I 509, 156.

54 Ibid. 163 . 55 Ibid. $x 509-x 603,452$.

56 Ibid. $1103-1327,181$.

57 Ibid. $1327-1509,288,292$.

58 Ibid. $I I O 3-I 327,180$.

59 Ibid. $I 327-I 509,289$.

60 Ibid. $I I 03-I 327,326$. 
Day, I 378 , the purchases included salmon, turbot, salt fish, hard fish, red and white herring, eels, mussels, and oysters. ${ }^{61}$ Supplies came chiefly from the east-coast ports; cod and stockfish from Scarborough and Grimsby, herring from Lynn and Yarmouth. ${ }^{62}$ The carters of Leicestershire were named as interested parties in the suit between Lowestoft and Yarmouth for unrestricted herring trade, heard before the king's council in $1378 .{ }^{63}$ Wholesale purchases were made at the great fairs. The question of tolls for all merchandise paid by Leicester men at Torksey (Lincs.) came to a head in I 43 I when 3 barrels of herring, 2 cades of red herring, and 4 stockfish belonging to William and Thomas Clerk were confiscated. ${ }^{64}$ Herrings, a staple diet for all, were sometimes illegally retailed in the market by persons not in the guild. ${ }^{65}$ Salmon appears less a delicacy than it has become today: in 1305 two men were found to have allowed strange merchants to retail salmon in the market;"66 John Hawys of 'Neuwerk', forestaller of salmon and corn, bought io salmon outside the market at night in the house of his host; for their entertaining in the 14 th century the mayors were allowed a salmon fee of $13 s .4 d$. each year (an average fish costing about $4 s$. ) ${ }^{67}$ Lampreys from the Severn were a rarity, on one occasion especially fetched from Gloucester and kept fresh with eels in two fishlocks put into the river. ${ }^{68}$ Two stews on the banks of the Soar for keeping fresh fish were leased from the castle porter in the I $4^{\text {th }}$ century. ${ }^{69}$ Fresh fish might come from inland rivers. John Sturdy senior bought a load of fish from Frisby on the Wreake and was convicted for arranging that the carter should bring other fish for sale of which they would share the profits, contrary to guild regulations. ${ }^{70}$ Local fisheries perhaps supplied more than private needs. Certain fishing rights in the Soar were leased with the castle mills by I440, possibly much earlier.7I Another fishery stretching from North Mill to Belgrave Mill was rented by Leicester Abbey, ${ }^{72}$ and another from Fieldingford to Blackpool was one of the subjects of the long arbitration between Richard Danet and the Dean and Chapter of the Newarke in 1428.73 Regulations in the $14^{\text {th }}$ century prohibited all fishers from having tables in any part of the high streets by day or night, and fishers of freshwater fish from standing in the market on any day after tierce had sounded. 'Farloupers' might not 'stand on the carts of fish or herrings' to undercut their price. ${ }^{74}$

The vintners did not make their mark in Leicester as a group during the medieval period, probably because wine was frequently sold by men trading in other goods or by the taverners. The sixteen persons fined by the King's Marshal in 1292-3 for defaults after the eyre of 1286 , that is, for selling wine at $6 d$. and $5 d$. against the assize, included several men engaged in the cloth industry, a saddler, a spicer, a goldsmith, and only one brewer (William de Bracina). ${ }^{75}$ Many of these were leading townsmen. In the middle of the 14 th century, orders prohibiting the sale of wine at a price dearer than that fixed by the mayor were directed to 'anyone whether he be a taverner or a jurat or . . . any other stranger carrying wine to Leicester to be sold' ${ }^{76}$

The list of fines in 1292-3 includes also more than 45 men and women who had brewed against the assize of ale. The Leicester brewers were subject to a yearly tax

61 Ibid. $1327-1509,169$.

${ }^{62}$ L. F. Salzman, Medieval Eng. Industries, 26 I, $275-7$. Two thousand stockfish for Leic. castle in 1380 came from Boston (Lincs.): Fohn of Gaunt's Reg. (Camden Soc., 3rd ser. lvi), ed. E. C. Lodge and R. Somerville, i. I 32.

${ }^{63}$ Select Cases before the King's Council, $1243^{-1} 482$ (Selden Soc. xxxv), ed. I. S. Leadam and J. F. Baldwin, 6I, 64; Rot. Parl. ii. 334.

${ }^{64}$ Leic. Boro. Rec. I 327-I 509, 244-5.

65 Ibid. $I I O 3-I 327,286,291,292$.

${ }^{66}$ Ibid. 250.

67 Ibid. $1327-1509$, I 7, 154 .
68 Ibid. 68.

69 D.L. 29/198/3 I I 3; D.L. 29/1 99/3126.

70 Leic. Boro. Rec. II03-I 327,167 . He was also charged with refusing to share a load of sea-fish. Several generations of his family were engaged in the fish trade: ibid. $78-79$, $25 \mathrm{I}, 357$.

71 D.L. $29 / 198 / 3$ I 6 .

72 Ibid.

73 Leic. Boro. Rec. I 327-I 509, 234-44.

74 Ibid. 22; 'farloupers' were apparently interlopers.

75 Leic. Boro. Rec. IIO3-I327, 222.

76 Ibid. I 327-I $509,84,93$. 
called 'cannemol' for right to sell, or possibly to brew, ale. Jakemin de Liége, a foreign merchant dealing principally in wool, denied trading illegally in various other commodities by stating that he was a 'stalled' man and that he paid 'cannemol' yearly 'at the rate assessed by the jurors'. 77 'This tax from the brewers of Leicester 'within the borough and without' was collected in $1288-9$ from 202 persons in all the quarters with the exception of the north quarter and the bishop's tenants without the East Gate. ${ }^{78}$ During the first half of the I 4 th century the numbers dropped: the total was 170 for the whole town in 1339.79 Some trouble about the tax arose with the bailiff of Thomas, Earl of Lancaster in 1306,80 and after the execution of 'Thomas in 1322 , among the long list of his exactions upon the town it was stated that whereas under Earl Edmund Crouchback the brewers had been amerced once yearly according to their offence and by assessment at $6 d$. or $12 d$. at the most, under Thomas his farmers had extorted a half mark or Ios. 'which they called farms of the cannemol'. ${ }^{81}$ In 1352 the mayor and three others with two grooms spent 12 days in London 'in the business of the jurats against the lord Duke for releasing cannemol'. ${ }^{82}$ It is not known whether they succeeded in getting rid of the tax as distinct from the payment of fines for breaking the assize. Accounts in the ${ }_{5}$ th century refer to fines for breaking the assize of ale called 'cannemol'83 and under Henry VII 'cannemol' courts were held, which perhaps corresponded to the meetings of the licensing justices elsewhere. ${ }^{84}$

\section{FAIRS AND MARKETS}

In the $5_{5}$ th century Leicester had three regular markets, on Wednesday, Friday, and Saturday. ${ }^{85}$ Their earlier history is obscured by the fact that they were held by grant not from the king but from the earl. The Wednesday market, possibly the oldest, since it was held by the High Cross in the centre of the town, was used for the sale of butter and eggs in the early I 4 th century. ${ }^{86}$ On Fridays in the early I 6 th century bread was sold here in addition to the other foodstuffs. ${ }^{87}$ The more important Saturday market is mentioned in a deed of 1298.88 Its site was that of the present Market Place, but it was more extensive, occupying all the south-eastern corner of the town. In this market and in the neighbouring streets, probably by the I 4 th century, most of the special markets were centred. In $\mathrm{I} 3 \mathrm{I}_{4}{ }^{-\mathrm{I}} 5$ the corn and bean markets were cleaned for $9 d$., and $6 d$. was spent on six posts for the boundaries of the grain market. ${ }^{89}$ It was ordered in 1467 that no corn be sold in this market 'til $x$ of the belle be streken'. ${ }^{0}$ 'The market bell was doubtless the 'Saturday bell' for which the ringer received a yearly wage of $4^{s .91}$ North of this market on the site of the present Silver Street stood the sheep market, which was moved into the Saturday market place in 1506,92 and its profits were subsequently leased to private persons, the first lease of I 508 including II 2 hurdles for the pens. ${ }^{93}$ A paved cattle market, in the neighbourhood of Swinesmarket, is mentioned in 1341.94 Later it must have been held in the Saturday market place since it was moved from there into the lane called Cow Lane, Cank Street, and Loseby Lane in 1597.95 Reference has already been made to the Saturday market shambles.

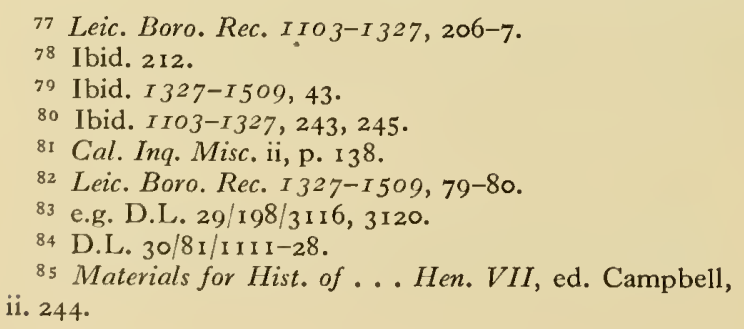

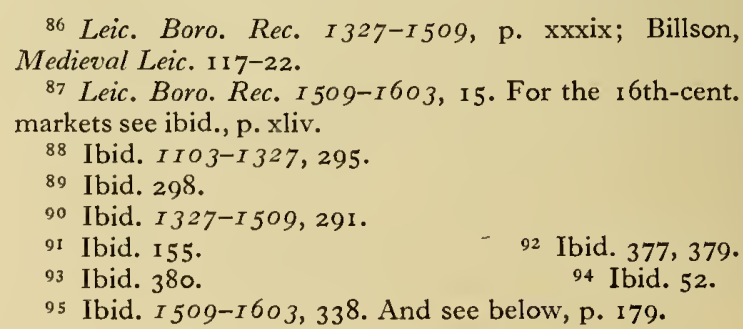


These were situated in a new house in the market built sometime before I 4I I, in which certain butchers rented shambles by the year, while others paid $\mathrm{I} \frac{1}{2} d$. a day to stand there. ${ }^{96}$ In this market house also were the clothiers' tables known as 'le draperie'.97 Within the market area shops and booths were let at yearly rentals to traders whose interests are shown by the names 'iremongerowe', 'gloversrowe', and 'shepsterrowe'. Here also were shops let to cobblers and shoemakers. ${ }^{98}$ The rents and profits of the market were taken by the earl who was therefore responsible for the repair of its buildings. Thus John of Gaunt's receiver in 1375 was allowed the costs for making 'novelles sondes des shoppes... en un place appelle Satirday marketh', 99 and the lease of the farm of the borough to the burgesses in the same year included the right to large timber from the duke's wood for 'improvements and repairs of the shops and shambles which are now rented in the market'. I

The earliest fair of which there is record was held from 3 I July (the vigil of St. Peter ad Vincula) for fifteen days. In I 229 Henry III granted to his 'good men of Leicester' the right to change the date of this fair to the morrow of the Purification ( 3 February), ${ }^{2}$ and by a further grant in 1235 its date was changed again to the fourth day after the Invention of the Holy Cross ( 7 May). ${ }^{3}$ The Earl of Leicester's own fair originated in a royal grant in 1307 to Thomas, Earl of Lancaster, in which it was described as 'a yearly fair at his manor of Leicester to be held on the morrow of the Holy Trinity and for the fourteen following days' (i.e. at the end of May or in June). ${ }^{4}$ An inquisition of 1326 on behalf of Roger of Belgrave, late steward, stated that in 1324 the issues of the fairs of the town and of the earl amounted to $60 s$. and $30 s$. respectively: ${ }^{5}$ but only the town's fair, whose toll was worth $20 s$. yearly, was mentioned in the inquisition post mortem dated 1327 of Thomas, who died in $1322 .{ }^{6}$ It would seem that under the next earl these two fairs were combined as one fair held at the beginning of May. The fair pleas extant for 1347 are described as 'of the fair of the town of Leicester', 7 and in 1382 , during the period when the town held the lease of the bailiwick, John of Gaunt, in order to safeguard his future rights, took care by proclamation to prevent a proposal to hold 'the fair' on the Bishop of Lincoln's fee. 'The date of this May fair had been changed in 1360 to Michaelmas. During the last years of Henry, Duke of Lancaster, the town negotiated for concessions regarding the fair tolls as well as the market and borough tolls. As a result, by royal charter the fair was shortened to one week at Michaelmas, and the duke, as Earl of Leicester, surrendered his dues so that both native and stranger might be free of toll, stallage, and pickage. ${ }^{9}$ At the same time, the earl by his own charter gave the entire ordering of the fair to the mayor and burgesses with the right to appoint yearly stewards, but he reserved the profits of the fair court. ${ }^{10} \mathrm{~A}$ grant of a new fair to the mayor and burgesses, which does not mention any previous fair held by them, was made by Edward IV in I473. Its conditions were similar to those in the I 360 grants and it was to be of seven days' duration, beginning on I May. ${ }^{\text {II }}$ These

96 D.L. $29 / 198 / 3114$.

97 Leic. Boro. Rec. I327-I 509, 275.

98 Ibid. These artificers are mentioned but not described by name in the earlier bailiffs' accts. The abuttals in a lease to Ric. of Linc, glover, show the position of Sutorsrowe and Ironmongerowe: D.L. 29/198/3120.

99 John of Gaunt's Reg. (Camden Soc., 3rd ser. xxi), ed.

S. Armitage-Smith, ii. 3 I 5 .

I Leic. Boro. Rec. I327-I 509, I 52 ; and see ibid. I 56 .

2 Close R. $1227-3 \mathrm{I}, \mathrm{r} 50$, where 'xiij days' is erroneously given for 'xiiij days': C $54 / 39 \mathrm{~m}$. 16 .

3 Ibid. $1234-7,64$.

4 Cal. Chart. R. 1300-26, ro8.

5 E $368 / 99 \mathrm{~m} .28$ : an inq. giving the values of the issues of the town for stated periods, $\mathrm{r}_{323-4}$, on behalf of Roger de Belgrave to whom the king had granted custody after the forfeiture of Thomas, Earl of Lanc.

6 Leic. Boro. Rec. I327-I 509, 3.

7 Ibid. 72. They refer to an event of 6 May.

8 Fohn of Gaunt's Reg. (Camden Soc., 3rd ser. 1vii), ii. $23^{8}$.

9 Cal. Chart. R. I341-1417, I67; Leic. Boro. Rec. I327I509, p. xxi.

so Leic. Boro. Rec. I327-I509, I I 1 . The lists of stewards exist from 1446 , with a gap, $1455-76$ : ibid. $453^{-4}$.

II Leic. Boro. Rec. I327-I509, 296; Cal. Chart. R. $1427-1516,241$. It should be noticed that the charters of these 2 farms only are listed among the boro. muniments, 1492: Leic. Boro. Rec. I327-I509, 341. 
two fairs developed into the great pleasure fairs which were held in Humberstone Gate until the end of the Igth century. ${ }^{\mathrm{I}}$

The importance to the trading life of the community of other great fairs in the kingdom can be well illustrated. At the portmanmoot of 1220 , absence at the fairs of St. Ives (Hunts.), Boston, Lynn, or Winchester was allowed as an essoin, ${ }^{13}$ and this privilege was restated in Edmund Crouchback's charter of $1277 .{ }^{14}$ Guild Merchant entry payments in the early $13^{\text {th }}$ century were sometimes collected at Stamford, Northampton, St. Ives, and Boston. ${ }^{15}$ The men of Leicester at Stowe fair in 1236 provided two good russets of Leicester for the king. ${ }^{16}$ At the Boston and Stamford fairs of the I $3^{\text {th }}$ century the Leicester merchandise was taken to special rows, but from I 257 there was difficulty in collecting the seldage payable for the shops or booths there. It was necessary to agree at a Morningspeech that the merchants should keep to these rows, and fines were exacted from those who disobeyed. Each merchant was ordered to pay towards seldage $3 d$. for each cloth if kept in the row and $6 d$. if kept outside; the rest to be paid from the guild purse. ${ }^{17}$ In 1258,28 s. was taken from the common fund for seldage at Stamford and an attempt by the Leicester Guild Merchant to resign the shops there was apparently unsuccessful. ${ }^{18}$ The same tendency to avoid seldage developed in Boston fair at the same time. The drapers were ordered to keep to the shops on the south side of the row and the wool- and fell-mongers to those on the north side. ${ }^{19}$ The next year the merchants were ordered to be responsible for seldage on these respective sides, whether they used them or not;20 and finally in $\mathrm{I} 26 \mathrm{I}$ it was agreed that while sale outside the row was forbidden the cloth might be taken to the merchants' lodgings at night for safe keeping or to fold and dress it. ${ }^{21}$ A general rule for seldage at St. Ives was also made at this time. ${ }^{22}$ The records of the St. Ives fair court give an occasional glimpse of trading by Leicester folk. Henry Coke left his daughter Amice a tally for a debt for wool sold in his house in Leicester to Thomas Coventry. Three years later, at the fair of St. Ives in I275. Amice and her husband attached Robert Howell, William Mountsorrel, and two other Leicester burgesses and merchants for this debt by taking from them 3 dickers of ox-hides, 300 dickers of fleeces of sheep, 200 fleeces of sheep, and 6 sacks of wool. ${ }^{23}$ Another case of debt disclosed how payments were to be made when Henry Curteis of Leicester and William English his partner sold wool-fells in Boston to three foreign merchants on I I August I 287. Half the price was payable on 24 August at Northampton and the residue on 8 September at the next fair of Winchester held on St. Giles's hill. ${ }^{24}$

The trade of Leicester, except for the export of hides, wool, and possibly cloth, consisted chiefly in the supply of local demand for the necessities of food, clothing, and building, and its general trend appears to have been similar to that of other English towns, one of prosperity until the mid-I 4th century, followed by decline during the I 5 th century. It is not possible to assess the effect of the attempted monopoly of control by the Guild Merchant, but it is certain that not all traders who were eligible could be made to join its ranks, especially from the end of the I 3 th century. ${ }^{25}$ The contribution of the craft guilds is unknown and the history of their developing strength and independence may be hidden in the lost Guild Merchant rolls of the period from I 380

\footnotetext{
12 Billson, Medieval Leic. I 4 . And see below, pp. 56, 179.

4 Ibid. I63.

13 Leic. Boro. Rec. IIO3-I327, 33 .

16 Close R. 1 $234-7,301$.

I5 Ibid. I 4, 29, 30-3I.

17 Leic. Boro. Rec. IIO3-I327, 74, 77.

18 Ibid. 78. Ric. of Beverley received Is. for his expenses to Stamford 'with letters petitory to resign the sheds which the burgesses of Leic. were wont to hold there': ibid. 82 .
}

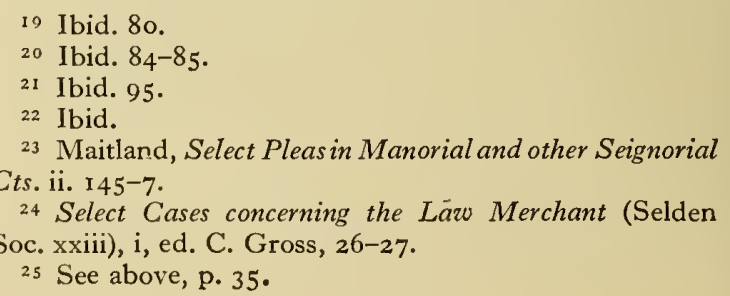


to 1465 . The importance of Leicester castle has been fully described by Mr. Levi Fox. ${ }^{26}$ As the result of the use of the castle as the headquarters of the midland section of the Duchy of Lancaster and as the chief residence of the earls of Leicester until the death of John of Gaunt in $\mathbf{r} 399$, the inhabitants incurred many expenses for hospitality and gifts, but trade was stimulated by the presence of numerous household and administrative officers and guests including many royal visitors. ${ }^{27}$ The earl's household expenses for the year $1_{3}{ }^{1} 4-15$ amounted to almost $£ 8,000$; and chance has preserved with this account a list of debts for food owing to some roo traders within and without the town. ${ }^{28}$ The lack of evidence of friction between the earl and his borough suggests that their relationship was profitable to both. The only exception occurs in the long and vivid inquisition of $\mathrm{r} 322$ upon the oppressions allowed by Earl Thomas, whose officials, inter alia, extorted fines from the sellers of oatmeal, salt, herrings, and fish, who had hitherto paid only toll; controlled the hire of carts by the wool-buyers and forced them to pay also $\mathrm{r} d$. a sack; and heavily fined 'the regrators of cloth selling in their windows' who were accustomed to being amerced only once yearly at $12 d$. by juries of the town. ${ }^{29}$ It is noticeable that whereas lesser boroughs obtained a continuous grant of the firma burgi, there is no trace that Leicester attempted to do so, except for the leases obtained for $1375-85,1404-24$, and $1423-33 \cdot 30$

In the absence of satisfactory statistics it is only possible to give a few indications of the position of Leicester in relation to other medieval English towns. The early importance of its cloth trade is shown in the list of towns paying for exemption from Richard I's assize of 1202 . By contributing £ro Leicester held fourth place with Northampton and Winchester after Lincoln $\left(£^{26}\right)$, York $\left(£^{20}\right)$, and Beverley $\left(£_{1}\right){ }^{31}$ The total collected in tax for the subsidy of 1269 ranked Leicester among the richer boroughs, next below London, the Cinque Ports, York, Lincoln, Yarmouth, Worcester, and Winchester. ${ }^{32}$ Evidence of prosperity in the early I 4 th century is seen in the town's building activities during a period when it had to bear the weight of severe national taxation. ${ }^{33}$ Leicester was not among the ten towns sending representatives to elect the mayor of the staple in 1326,34 but was included in petitions about the location of the staple in England ${ }^{35}$ and sent wool merchants in response to summonses for attendance at the York Parliament of $\mathrm{I}_{32} 8^{36}$ and before the Council at Westminster in 1357.37 Whether through its own decrease in population or the greater advance in trade made by other towns, towards the end of this century Leicester's status had dropped and it ranked $\mathrm{r} 7$ th and $\mathrm{r} 9$ th respectively in the $\mathrm{I} 377$ poll tax and the loan of $1398 .{ }^{38}$

\section{RELIGIOUS LIFE}

Domesday records six churches inside Leicester, and apparently a further one on the bishop's manor outside. ${ }^{39}$ By $\mathrm{r} 220$ there were nine churches and one chapel.40 In the middle of the 14 th century the town was served by the nine parish churches of

${ }^{26}$ L. Fox, 'Leic. Castle', T.L.A.S. xxii. I $38-52$.

27 Leic. Boro. Rec. IIO3-1327 and $1327-1509$, passim.

${ }_{28}$ D.L. $29 / 1 / 3$; Nichols, Leic. i. 223 ; T.L.A.S. xxii. 150.

${ }^{29}$ Cal. Inq. Misc. ii, pp. $13^{8-9}$.

30 Leic. Boro. Rec. I327-1509, 149, $219,232$.

${ }_{11}$ Pipe R. 1202 (P.R.S. N.S. xv), pp. xx, 39.

32 Leic. Boro. Rec. IIO3-I327, p. lvi.

33 Ibid. $1327-1509$, pp. xxviii-lx.

34 Cal. Close, 1323-7, 564 .

35 Rot. Parl. iii. 318-19.

${ }^{36}$ Cal. Close, $1327-30,237$. These may have been Ric. Cagg and Thomas Martin, whose expenses had been paid for a similar journey in 1322 : Leic. Boro. Rec. I IO3-I327, 334. This payment dispels doubt as to whether this assembly of 1322 was ever held: cf. J. C. Davies, 'An Assembly of Wool Merchants in 1322', E.H.R. xxxi. 596 sqq.

${ }^{37}$ Rot. Parl. ii. 457.

${ }_{38}$ Billson, Medieval Leic. 145.

39 V.C.H. Leics. i. $306,309,356$. A priest is mentioned on the bp.'s lands outside the town walls in 1086 , but there is no definite ref. to a ch.

40 Ibid. 361 ; Rot. Hugonis de Welles, ed. W. P. W. Phillimore, i. 238. 
All Saints, St. Clement, St. Leonard, St. Margaret, St. Martin, St. Mary de Castro, St. Nicholas, St. Michael, and St. Peter.4I The church of St. Mary de Castro also maintained the church of St. Sepulchre beyond the South Gate, in existence before ${ }^{1204},{ }^{42}$ and a chapel of St. Mary built over the eastern arch of the West Bridge sometime between 1344 and I365.43 There were also churches or chapels in the Abbey of St. Mary de Pratis, ${ }^{44}$ the College of St. Mary in the Newarke, ${ }^{45}$ the convents of Franciscan, Dominican, and Augustinian Friars, ${ }^{46}$ the Hospital of St. Mary Magdalene and St. Margaret, ${ }^{47}$ and the Hospital of St. John. ${ }^{48}$ St. John's Hospital maintained in addition the chapel of St. John in Belgrave Gate. 49 Thus to the humbler, unobtrusive work of the parish priests among the townsfolk can be added the activities of the numbers of clerics attached to these religious houses. ${ }^{50}$ For example, the chantry College of the Newarke included a dean, I2 secular canons, I 3 vicars, 6 choristers, and 3 clerks:51 the chantries founded in this college between $\mathrm{I}_{3} 8 \mathrm{I}$ and $\mathrm{I}_{5} \mathrm{I} 3$ were possibly served by additional chaplains. ${ }^{2}$ Its church, described by Leland as 'not very great but exceeding fair', possessed as a relic a thorn from Christ's crown which attracted many pilgrims. ${ }^{53}$ Wide influence was exercised by the wealthy Augustinian Abbey of St. Mary with its community of canons, who possessed a large library, ${ }^{54}$ taught grammar in their choir school and in the town, dispensed hospitality on a large scale, and tended the sick in their infirmary. From the mid-I 3 th century their authority in religious matters was supplemented by the arrival of the friars. ${ }^{55}$ Although these religious influences later declined and at the Dissolution the friaries counted a total of only 2 I inmates and St. Mary's Abbey a total of only 20, it has been estimated that at the beginning of the I6th century there were still no fewer than $9 \mathrm{I}$ priests of various kinds in and about the town. 56

Certain religious and social activities were centred in the guilds formed in at least six of the Leicester churches during the I 4 th century. Whereas the dukes of Lancaster and other rich individuals could found private chantries, persons of more modest means joined together primarily to support a priest to say masses for their own souls and also to provide funeral rites and to help their poorer members in sickness or other misfortune, including that of fire. The desire to make better provision for church services was sometimes expressly stated. ${ }^{57}$ By far the most important guild in Leicester was that of Corpus Christi which had its altar at the east end of the south aisle of St. Martin's, the town church..$^{8}$ Although this guild did not enjoy an official status comparable to that of the guilds of St. George at Norwich or Holy Trinity at Wisbech, it became closely associated with the government of Leicester from the fact that its

4 V.C.H. Leics. i. 363 . For an acct. of events in the parishes of All Saints, St. Clement, St. Leonard, St. Michael, and St. Peter, see P. Hepworth, 'All Saints, Leic.', T.L.A.S. xxvi. 93-104; and see below, pp. 342, $348,388-9$.

${ }_{42}$ Cal. Doc. France, ed. Round, 229; and see below, p. 376 .

${ }_{43}$ Billson, Medieval Leic. 90-91, 93-95; Leic. Boro. Rec. $1327-1509,140$. For the relationship of the parishes to the civic community, see Leic. Boro. Rec. I327-I509, pp. lxiv-v. For other parochial activities, e.g. plays in churches, and the Whitsuntide processions, when the diocesan offerings were taken to the bp.'s ch. of St. Margaret, see W. Kelly, Notices of the Drama, 7-36; and see $V$.C.H. Leics. iii. 86 for the chap. on the bridge.

${ }^{44}$ A. Hamilton Thompson, Leic. Abbey, passim; Nichols, Leics. i. 251-94, App. 53-108; Billson, Medieval Leic. 95-97; V.C.H. Leics. ii. I $3-19$.

45 A. Hamilton Thompson, Hist. of Hosp. and New Coll. of the Annunciation of St. Mary in the Newarke, passim; Nichols, Leics. i. 329-52; Billson, Medieval Leic.

\footnotetext{
79-83; V.C.H. Leics. ii. 48-51.

46 Nichols, Leics. i. 297-9; Billson, op. cit. 78-79; V.C.H. Leics. ii. $33-35 . \quad 47$ V.C.H. Leics. ii. 44 . $4^{8}$ Billson, op. cit. $83-85$; Nichols, Leics. i. 324-5. Other hosps. in Leic. may have had chapels: V.C.H. Leics. ii. 45 .

49 Nichols, Leics. i. 323 ; Billson, op. cit. 9 1-93. And see below, p. 359 .

so For the influence of the religious houses generally, see D. Charman, 'Leic. in 1525 ', T.L.A.S. xxvii. 26-27.

ss Hamilton Thompson, Hist. of Hosp. of Annunciation in the Newarke, $13,17$.

${ }_{52}$ Ibid. 84-98; Billson, op. cit. 81-82; V.C.H. Leics. ii. $49-50$.

${ }_{53}$ Leland, Itin., ed. Toulmin Smith, i. I 5.

${ }_{54}$ T.L.A.S. xix. I I I-61, 377-440; xxi, I-88; Nichols, Leics. i, App. ror-8. 55 V.C.H. Leics. ii. 33-35. 56 T.L.A.S. xxvii. 28 ; V.C.H. Leics. ii. $16,33,35$.

s7 S. H. Skillington, 'Extant Certificates of Leic. Gilds', T.L.A.S. xiv. $167-8$; and see below, p. 388 .

${ }^{88}$ See below, pp. 366-7.
} 
members were among the leading townsmen. Their influence is seen in its elaborate rules of membership. An unusual town ordinance of 1477 gave the two guild wardens power of arbitration with the mayor in complaints between the members of the town bench of jurats; the mayor himself being liable to fine by the two wardens should he fail to execute the judgement.59 The lack of reference to any social activities of the Guild Merchant, apart from special entertainment of visiting notables by a few persons, suggests that these found expression in the Corpus Christi guild: but however semiofficial its character it came to an end with the suppression of all the religious guilds.

Other guilds that existed at Leicester during the Middle Ages were that of St. Margaret and St. Katherine, attached to St. Margaret's church, ${ }^{60}$ that of the Assumption of the Virgin, in the north of the town, ${ }^{61}$ that of St. John the Evangelist and St. John the Baptist, attached to St. John's Hospital, ${ }^{62}$ that of Holy Trinity, attached to St. Mary's, ${ }^{63}$ that of St. George, attached to St. Martin's, ${ }^{64}$ and that of St. Michael, attached to the church of the same name. ${ }^{65}$ Two other guilds, those of St. Cross and St. Thomas, are mentioned in a will proved in $1419,{ }^{66}$ but nothing further is known of them. It is possible that the reference to the guild of St. Cross is really a mention of the Corpus Christi guild, since St. Martin's church, to which the Corpus Christi guild was attached, was sometimes known as St. Cross.

\section{PUBLIC SERVICES}

The upkeep of ways and bridges was financed at periods in the $\mathrm{I} 3$ th and $\mathrm{I} 4 \mathrm{th}$ centuries by royal grants of murage, pavage, and pontage obtained sometimes by the earl, more often by the burgesses. ${ }^{67}$ But the responsibility for this work fell chiefly upon the town, at whose expense the walls and gates were repaired in 1262 and the gate-keepers' fees paid in 1278.68 Private individuals might be expected to repair the pavement outside their own tenements; wages for paving and for the carting of materials for mending more important ways occur in the mayor's account for $134 \mathrm{I}-2 .{ }^{69} \mathrm{~A}$ Morningspeech of I 352 recorded a levy on cattle of $8 d$. a beast for the mending of bridges, ways, and gates. ${ }^{70}$ Before the end of the 14 th century this work had become a regular duty of the two chamberlains, as set out in the borough ordinances of $1379 .{ }^{71}$ The toll called 'bridge-silver' collected by the earl until redeemed by the town in 1253 was presumably used for the upkeep of the bridges.72 Yet before this date, $c$. I225, some Guild Merchant payments were put towards bridge work. ${ }^{73}$ By 1300 special tallages were collected for this purpose $;^{74}$ in the middle of the 14 th century the mayor's accounts show that such expenses were met from three sources: separate tallages from each quarter of the town, collections in the parish churches, and alms from individuals. ${ }^{75}$ The accounts also include detailed statements of the building expenditure. ${ }^{76}$

Sanitation, usually considered the responsibility of the householders, is hardly mentioned in the borough records until the $5_{5}$ th century. Then it became a matter for by-laws, perhaps influenced by general ordinances not now extant, governing the

59 Ibid. 298-9.

60 See below, p. 358 .

61 See below, p. 342 .

62 See below, pp. 342,408 .

${ }_{63}$ Thompson, Hist. Leic. i. 215.

64 See below, p. 367 .

65 See below, p. 389 .

66 A. Gibbons, Early Linc. Wills, 152.

67 Leic. Boro. Rec. IIO3-I327, p. Xxxvii; I327-I509, p. xxxix; Cal. Chanc. Wts. 1244-1326, 29. 68 Leic. Boro. Rec. IIO3-1327, 98, 179.
69 Ibid. $1327-1509,252$.

70 Ibid. 82.

71 Ibid. I93.

72 Ibid. IIO3-I 327 , pp. Xxxvii, 43-44.

73 Ibid., pp. xxxi, 34 .

74 Ibid. 229.

75 Ibid. I327-I509, 140 ; see also ibid., p. xl.

76 See also ibid. I4I; ibid. $I I 03-1327,349$. For inf. about the 6 bridges see Billson, Medieval Leic. 98-I I I, and V.C.H. Leics. iii. $69,86,88$. 


\section{A HISTORY OF LEICESTERSHIRE}

whole country. ${ }^{77}$ Muck, stones, timber, and clay must be removed from doorways within three days; sweepings should not be thrown out in wet weather; no man or woman should cast out 'hors, swyn, dogge ne catte, nor non other corypcion' but must 'voyde hit forthe in to the fylde from the course of the peple', or the penalty would be imprisonment at the mayor's pleasure. ${ }^{78}$ In fact it was expressly stated that the inhabitants must clean the king's streets before their own houses, hiring carts to take away the rubbish within three days.79 In ${ }^{7} 508$ three dumps, later called 'common muckle places,' 80 were assigned to the south and east of the town in 'the netherende of Belgrave gate and in the feld withowt Galtre gate end and beyond the hors feer' ${ }^{81}$ Exceptions to this individual responsibility occurred when the mayor found it necessary to pay for the cleaning of certain streets on a special occasion, ${ }^{82}$ and in the appointment in $\mathbf{I} 500$ of an officer at $\mathrm{I}_{3} s .4 d$. yearly to clean the Saturday market place by each Tuesday at the latest, as weather permitted.83

The town's water-supply, if not taken from the Soar for special purposes, was drawn chiefly from the common wells. Private wells are only disclosed by property deeds when they were to be shared. ${ }^{84}$ An order of 1467 forbade women to wash clothes at the common wells or in the High Street. 85 One of these was situated in the parish of St. Michael and another by St. Sepulchre's chapel outside the South Gate. ${ }^{86}$ In the next century the wells at the High Cross, at St. Martin's church, and in St. Margaret's churchgate were repaired at the town's expense. ${ }^{87}$ In 1584 they were made the responsibility of the ward or quarter in which they lay and well-reeves were appointed. ${ }^{88}$ The brewers drew their water from the Soar and used the services of the watermen. ${ }^{89}$ The water-carriers figure in the records from the $\mathbf{3}^{\text {th }}$ century, several of them being members of the early Guild Merchant. ${ }^{90}$ Payments to them occur in the mayors' accounts, especially for carrying water for the builders. ${ }^{91}$ 'They were of sufficient standing in the I 4th century to attempt to organize themselves into a guild, but were firmly stopped by the Guild Merchant by proclamation that "Henceforth the "lochelmen" called watermen shall be separated and shall serve the commune well and loyally according to the custom before used', and that should any association be found among them they should be fined by increasing amounts for each offence until they submitted. ${ }^{92}$.

\section{LEICESTER ABOUT $15 \mathrm{O} 9$}

By the end of the 15 th century the inhabited area of the town had not increased to any considerable extent beyond its earlier boundaries, except in the east suburb, though there is evidence in many deeds from the late $13^{\text {th }}$ to the end of the $5_{5}$ th centuries of the transfer of holdings in the north and east suburbs. ${ }^{93}$ Streets of some importance had grown up parallel to and beyond the walls and ditches, and along them went the traffic which was too ungainly to pass through the narrow gates or which could avoid the tolls levied in the town by using the streets outside the gates. The focal point of Leicester in medieval times was the High Cross. The main roads from all directions met there. It was the site of the Wednesday market, the most important

77 Leic. Boro. Rec. I 327-I 509, pp. xxxvi-xxxvii.

78 Ibid. 209.

79 Ibid. 291 . In the 16 th cent. once weekly was considered sufficient: ibid. I509-1603, I 91 .

80 Ibid. 329.

8I Ibid. $1327-1509,380$.

82 Ibid. $148-54$.

84 Ibid. 418.

86 Ibid. I9, I 54, 266.

87 Ibid. I509-1603, 93. For the site of St. Martin's well in Cank St. see Billson, Medieval Leic. Io, and below, p. 362 .

88 Leic. Boro. Rec. I509-I603, 212.

89 Ibid. I $327-I 509,295 ; I 509-I 603,86$.

90 Ibid. $I 103-1327,13,25,27,83 ; 1327-1509$, I09, I 37.

91 Ibid. I327-I 509, I 42, 344-5.

92 Ibid. 197.

93 Ibid. I I $03-1327,38$ I-400; ibid. I 327-I 509, 388445 ; Hist. MSS. Com. Var. Coll. vii. 382 . 
of the two weekly markets, and near it lay the old Town Hall, the Guildhall, the castle, and St. Martin's, the most prosperous of the medieval churches. The extent of building on each side of all the main streets leading from the gates to the High Cross and the cluster of inns which lay near it stressed its importance in the town as a whole. ${ }^{94}$

The expansion of the town to the west was limited by the course of the river and the existence of the manors of Westcotes and Danet's Hall, and to the south by meadow and grazing land. The great south and east fields still lay open and were cultivated under the three-field system. 95 Very often, especially in the east field and suburb, individual holdings were made up of scattered strips. ${ }^{96} \mathrm{~A}$ tenement in Belgrave Gate which changed hands in I 453 included eight pieces of land 'lying dispersedly' in this suburb, two of them being $900 \mathrm{ft}$. in length. ${ }^{97}$ Emphasis in this chapter has been placed upon the town's trading activities, but it still possessed a very rural aspect with its many gardens and an occasional orchard or dovecote. ${ }^{98}$ For example, a garden in St. Michael's parish, I 495, had 88 ash trees and 2 aspens growing in its hedges. ${ }^{99}$

Leicester had suffered great devastation from its sack by Robert Blanchesmains in I I $73^{\mathrm{I}}$ and after the passage of Edward II's army in I 322 there is evidence of tenements wholly ruinous and in decay and of the duke's demesne lands left tenantless and uncultivated. ${ }^{2}$ The Black Death carried off a large number of people. ${ }^{3}$ But all these effects appear to have been counteracted by the trading and other advantages afforded by town life in the $13^{\text {th }}$ and 14 th centuries. From his study of the first Guild Merchant roll, I I $9^{6-1225}$, and the tallage rolls of 1318,1336 , and 1354 , Billson considers that new tenants very soon entered the town to occupy the empty houses. ${ }^{4}$ The north-western part of the walled town, however, remained comparatively thinly populated. According to an analysis of the late-13th-century tallage rolls of the borough, the northern and western quarters of the town together contained at the time only two-sevenths of the total number of tax-payers in the town and east suburb.5 The population shifted gradually towards the suburbs to the north and east of the town walls. ${ }^{6}$ The churches of St. Peter and St. Michael were left to fall into decay and were entirely ruined in the I6th century if not earlier, their parishes being joined to that of All Saints nearer the North Gate. ${ }^{7}$ The town wall and ditch were still in existence and became the subject of an inquiry on the king's behalf in $149^{2-}-3$. The commissioners found the wall broken and stones removed; they drew up a detailed schedule of 79 encroachments, of which most of the frontages had a uniform measurement of $40 \mathrm{ft} .{ }^{8}$

The sad state of the town in the 16 th century described in a petition of 1540 , though doubtless exaggerated for its own purposes, seemed already in evidence in the first half of the 15 th century. ${ }^{9}$ 'The bailiffs' yearly valuations of the king's perquisites in Leicester in giving the receipts from farms of the shops and shambles include the constantly recurring phrase 'formerly at higher sums', taking the figures for comparison from I 424 and earlier. ${ }^{10}$ The movement of the centre of business away from the old quarters can be noted in the repeated orders about restoring the bakehouses and shambles addressed

94 T.L.A.S. xxvii. I sqq.; for the inns, see Billson, Medieval Leic. 23-40.

95 C. J. Billson, 'Open Fields of Leic.', T.L.A.S. xiv. 3-29; Leic. Boro. Rec. IIO3-I327, p. xii; and see below, pp. $354,37 \mathrm{o}$.

${ }_{96}$ Leic. Boro. Rec. IIO3-I 327, 397-8; I327-I 509, 390, 395-6, 400 .

97 Cal. Close, 1447-54, 422.

98 Billson, Medieval Leic. 76; Leic. Boro. Rec. I327I 509, 395, 402, 410, 4I 7, 427, 432.

99 Leic. Boro. Rec. I $327-1509,442$.

I Billson, op. cit. I I I.

2 D.L. 29/II47/20; L. Fox, 'Min. Accts. of Honor of

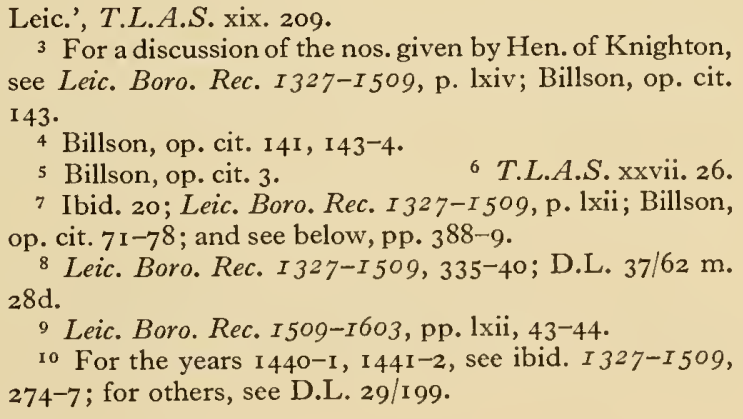

3 For a discussion of the nos. given by Hen. of Knighton, see Leic. Boro. Rec. I327-I509, p. lxiv; Billson, op. cit. 143.

4 Billson, op. cit. I4I, I43-4.

5 Billson, op. cit. 3 .

6 T.L.A.S. xxvii. 26.

7 Ibid. 20; Leic. Boro. Rec. I327-I 509, p. lxii; Billson, op. cit. 7I-78; and see below, pp. 388-9. $28 \mathrm{~d}$.

9 Leic. Boro. Rec. I509-I603, pp. 1xii, 43-44.

ro For the years $1440-1$, I 44I-2, see ibid. I327-I509, 274-7; for others, see D.L. 29/199. 


\section{A HISTORY OF LEICESTERSHIRE}

to duchy officials under Henry VII and Henry VIII. Many inhabitants in Bishop's Fee had built their own ovens, and butchers had deserted the king's shambles for stands also in Bishop's Fee. II The probable extent of borough jurisdiction at the end of the I 5 th century can be traced in the boundaries of the twelve wards drawn up in ${ }^{4} 485$ and I 499. The parishes of St. Margaret and St. Mary lay largely outside the borough, and St. Leonard's parish was entirely outside. ${ }^{12}$ A study of the 1524 tax returns discloses that the suburban wards were the most populated, especially the one including Belgrave Gate and Churchgate. ${ }^{13}$ That the richest wards were still within the town, namely, the two small ones of the Swinesmarket and High Street, is due to the concentration of wealth in the hands of a few families, most of them merchants of the Staple. ${ }^{\mathrm{I}}$ It would appear that, apart from this group, Leicester during the I 5 th century suffered a decline in prosperity and a depletion of its population. Yet the developing leather industry and other local trades were taking the place of the interests in the wool trade; ${ }^{15}$ any generalization, therefore, about the movement of population during this century needs support from a detailed study of private deeds related to the names on the Guild Merchant and tallage rolls of the town.

is D.L. $5 / 3$ f. 67 b; D.L. $38 / 62$ mm. 7, 3od; D.L. $42 / 95$ f. 36 .

${ }_{12}$ Leic. Boro. Rec. I327-I509, 306-8, 357; T.L.A.S. xxvii. I9-26.
13 T.L.A.S. xxvii. $26 ;$ xxv. $75-85$.

14 Ibid. xxv, 87-90.

15 Ibid. 90, 93. 


\section{POLITICAL AND \\ ADMINISTRATIVE HISTORY $15 \mathrm{O} 9-166 \mathrm{O}$}

Relations with the Central Government, p. 55. Taxation, p. 59. Parliamentary Representation, p. 60. Relations with the Duchy of Lancaster, p. 6I. Relations with the Clergy, Nobility, and Gentry, p. 65. Relations with the County Authorities, p. 66. The Borough Administration, p. 68.

\section{RELATIONS WITH THE CENTRAL GOVERNMENT}

HE town chamberlains' accounts record that Mary Tudor was duly proclaimed in Leicester, ${ }^{1}$ and it seems likely that the alleged treasonable assemb-

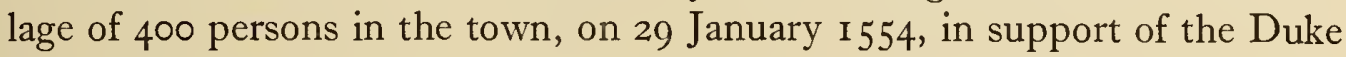
of Suffolk, owed more to local respect for the Greys of Bradgate than to any
other sentiment. Although it was considered necessary for certain offenders to be indicted before justices of oyer and terminer, ${ }^{2}$ it is evident from Holinshed ${ }^{3}$ that the Mayor of Leicester did not wish to be implicated in the affair. It is not clear what part was played by a certain Kettell of Leicester, who was tried and executed in Leicester in I554, but the names of other Leicester citizens involved appear on the Pardon Roll for that year. ${ }^{4}$ Seditious words against the Crown at other times are occasionally reported in the town records. In particular, the town council examined certain persons in 1586 in connexion with the Babington Plot, 5 shortly after Mary, Queen of Scots, had passed through the town on her way to Fotheringhay castle. Similarly, prompt measures were taken to inquire into possible seditious outbreaks in connexion with the Gunpowder Plot, ${ }^{6}$ which originated in the neighbouring county of Northampton.

The town records regularly mention that the beginning of a new reign was marked by an official proclamation, playing by the town waits, the ringing of bells, and other public celebrations.7 The town showed particular alacrity in recognizing the succession of James I. After examining premature rumours of the death of the queen on 2I March I $60 \mathrm{I}$, the corporation proclaimed James I as king on $26 \mathrm{March}, 8$ only two days after the actual date of her death and before instructions to that effect had been received from the Privy Council. Events of personal importance to the sovereign, such as the birth of Prince Edward in 1537, or of national importance, such as the defeat of the Spanish Armada in 1588 , were also duly celebrated. ${ }^{9}$ Special care was taken over the entertainment of the king and members of the royal house on the occasion of their visits to Leicester. Queen Elizabeth's unfulfilled intention of visiting Leicester involved the town in much unnecessary expense and trouble. ${ }^{10}$ On several occasions the town entertained James I and his family, for it lay on their route between London and Scotland. James also visited it in the course of his royal progresses. Distinguished visitors were

Leic. Boro. Rec. 1509-1603, 72.

2 Cal. Pat. I 553-4, 400, 499, 500.

3 R. Holinshed, Chron. ( 1587 ), iii. 1095, 1100.

4 W. Kelly, Royal Progresses and Visits to Leic. 281-3;

Cal. Pat. 1553-4, 430, 456; ibid., 1 554-5, 290.

5 Leic. Boro. Rec. I509-I603, 231.
6 Ibid. $x 603-88,37-41$.

7 Ibid. $218-19,227$.

to The queen was expected to visit Leic. in 1562,1575 , 1576, and 1585 : Leic. Boro. Rec. I509-I603, 101, I58, I60, $165,166,213$. 


\section{A HISTORY OF LEICESTERSHIRE}

frequently entertained at the Angel Inn in Leicester, or at Lord's Place, a mansion at one time belonging to the Earl of Huntingdon, but later purchased by the corporation. Leicester castle, formerly occupied by the earls and dukes of Lancaster, no longer fulfilled any social function, though it continued in use for administrative purposes connected with the county and the honor of Leicester. ${ }^{11}$

The Civil War made an issue of the question of allegiance and left a legacy of conflicting opinions in Leicester which remained long after the Restoration. The events of the summer of 1642 and the siege and capture of Leicester by the royalists under the king in person and of the subsequent recapture of the town are described below. ${ }^{12}$ While many of the inhabitants appear to have favoured the Parliament, it seems that the king also had a body of supporters in the town, including some who held office in the corporation. It was noticed that, in June $\mathrm{I}_{642}$, when leaders of both parties were attempting to levy soldiers, the mayor, Thomas Rudiard, 'in the whole progresse of this businesse, seemed backward to doe any thing for the Parliament'. ${ }^{13} \mathrm{He}$ was, in fact, subjected to a term of imprisonment by the parliamentary authorities, though thanked by the king. ${ }^{14}$ Edward Palmer, the town clerk, and Thomas Weldon, a macebearer, were deprived of their offices in 1645 for royalist activities. ${ }^{15}$

The corporation, having expelled the royalist element, accepted the Protectorate and persisted in its allegiance until the last. But it may be noted that Sir Arthur Hazlerigg, whose extreme republican views led him to oppose its establishment, was M.P. for Leicester in 1654,1656 , and 1659 . The town presented an address ${ }^{16}$ to Richard Cromwell on the death of his father, and the Earl of Stamford, who declared for the king at the time of Sir George Booth's rising in I 659, was taken into custody at Leicester. ${ }^{17}$ The corporation refused to join in the county's declaration of support for General Monck, at the same time unavailingly protesting ${ }^{18}$ that it was unable to accommodate any of his soldiers in the town. It is therefore not surprising that, when the Restoration took place, the mayor sought to impress the town's M.P. with the reality of the demonstrations of joy at the king's return 'for the provencion of any Calumnyes that may be cast on this Burrough'. ${ }^{19}$ The town also decided to present the king with a purse of $£_{3} 00$ and to surrender a fee-farm rent of $£_{1} 17^{20}$ The mayor wrote to Henry Hastings, Lord Loughborough, begging him to be present at the making of the gift and to continue the favour shown to the town by his ancestors. ${ }^{21}$

Leicester sought confirmation of its economic and administrative organization from each succeeding ruler, finally achieving a charter of incorporation in Elizabeth's reign. In 1540 the town obtained a grant of two fairs to be held for five days each in June and December, ${ }^{22}$ in addition to the medieval fairs in May and September. ${ }^{23}$ Confirmations by inspeximus of the town's charters since the reign of John were obtained from Edward VI, Mary, and Elizabeth I, ${ }^{24}$ soon after her accession. But, later in the reign of Elizabeth, the want of a full charter of incorporation became evident. This was particularly felt in connexion with the town's desire to participate in the secularization of church lands. Having passively accepted the dissolution of its various religious houses and endowments, Leicester embarked in ${ }_{1} 585$ upon a series of complicated transactions with a view to the purchase of the Newarke Grange estate, ${ }^{25}$ part of the possessions of the

iI See below, p. 345

12 See below, p. 67.

3 B.M. Pamphs. E. 154 (4).

14 Hollings, Hist. of Leic. in the Great Civil War, 18; Cal. S.P. Dom. 1641-3, 342 .

15 Leic. City Mun. Room, Hall Bk. I587-1707, pp. 588-90.

16 Leic. Boro. Rec. I603-88, 448.

17 Cal. S.P. Dom. 1659-60, 120.
18 Leic. Boro. Rec. I603-88, 458, 459.

${ }_{21}$ Ibid. $464,465$.
Ibid. 473 ; Bodl. MS. Carte 78, f. 84.

22 Ibid. 473 ; Bodl. MS. Carte 78,
Leic. Boro. Rec. I509-I603, 46.

23 See above, p. 46.

24 Leic. Boro. Rec. I 509-I603, 55, 77, 94. A list of the Leic. charters is in M. Weinbaum,-Brit. Boro. Charters, $I 307-1660,69$.

25 See below, p. 37 I. 


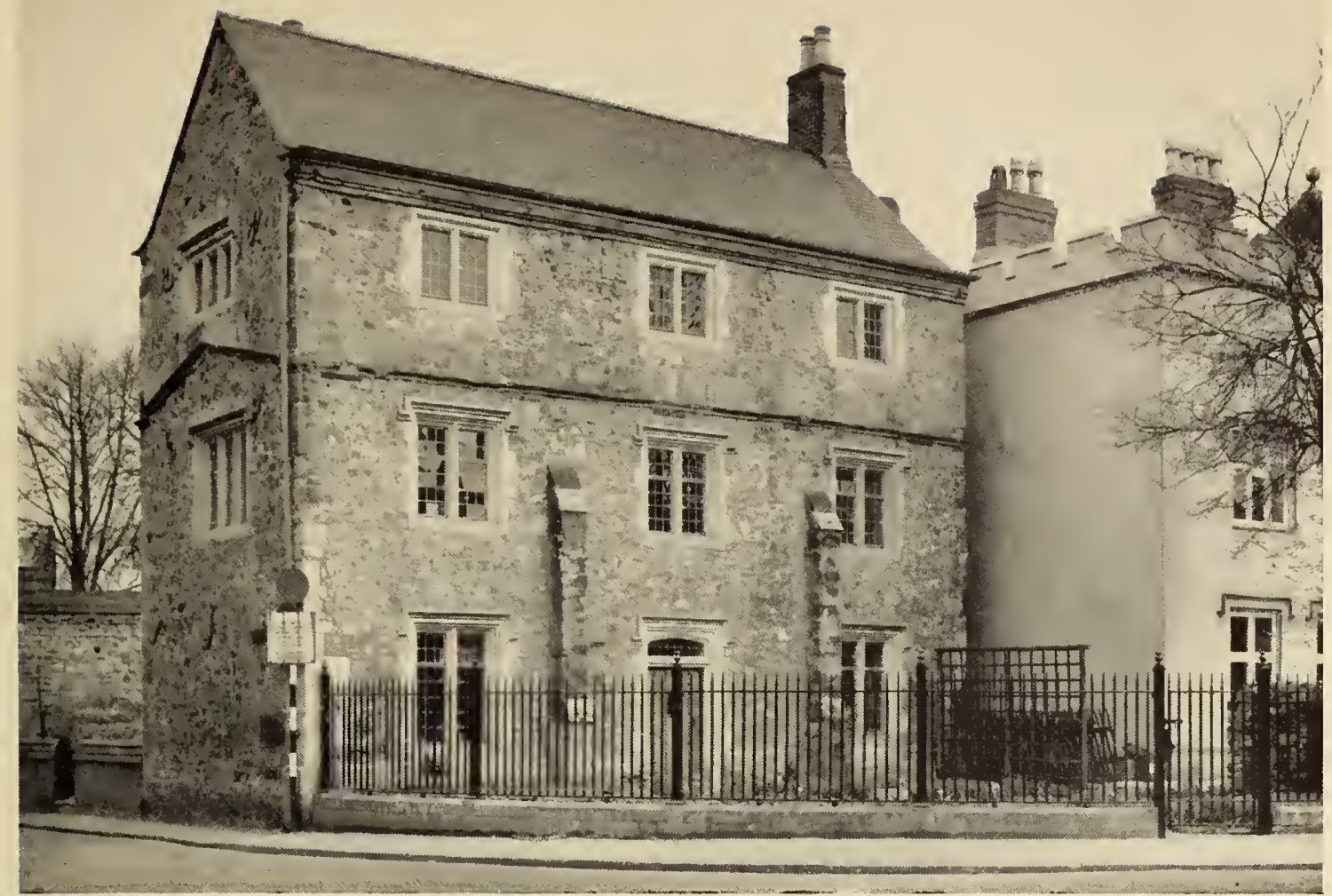

The Chantry House, the Newarke

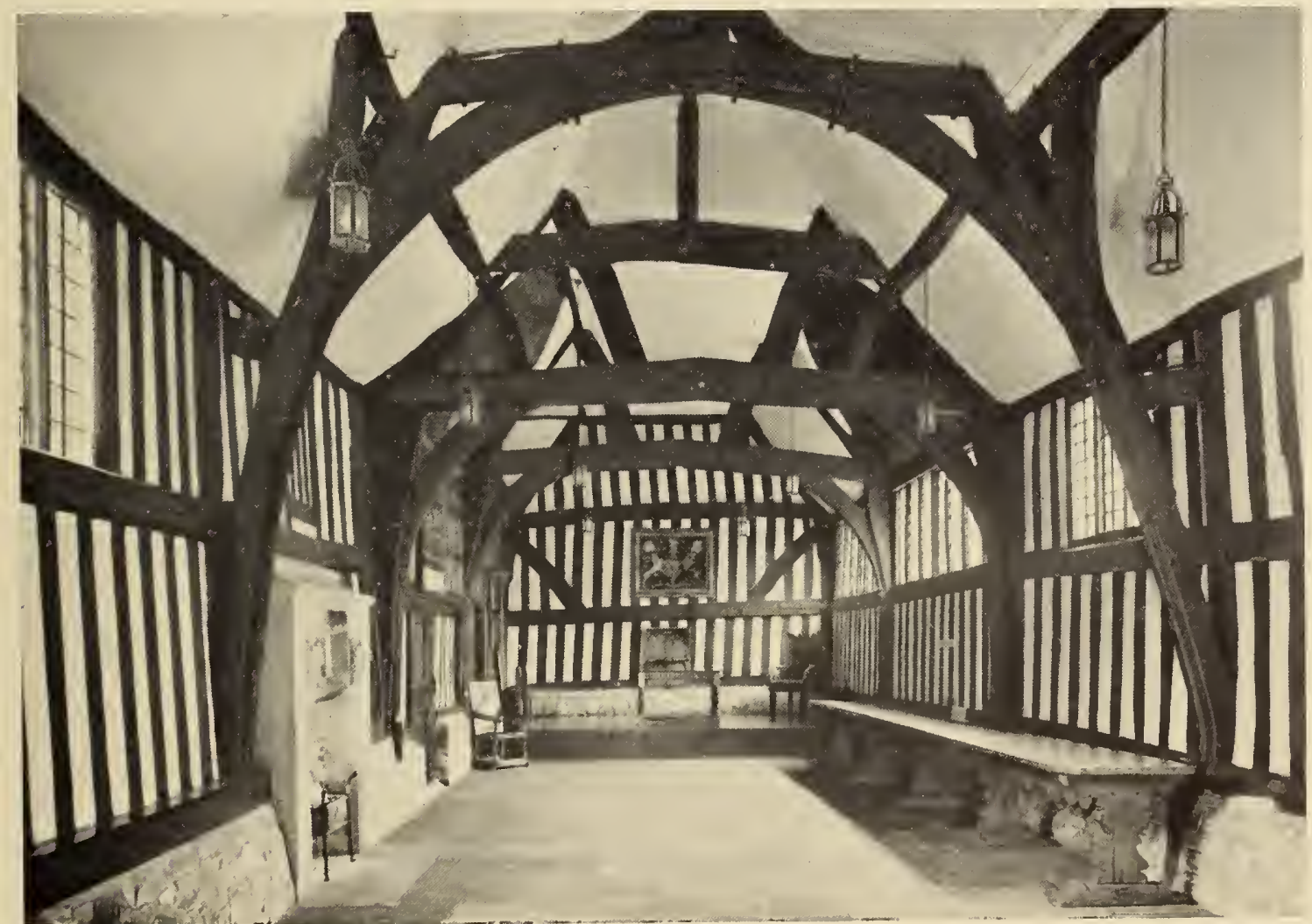

The Guildhall

The Great Hall, seen from the east end 


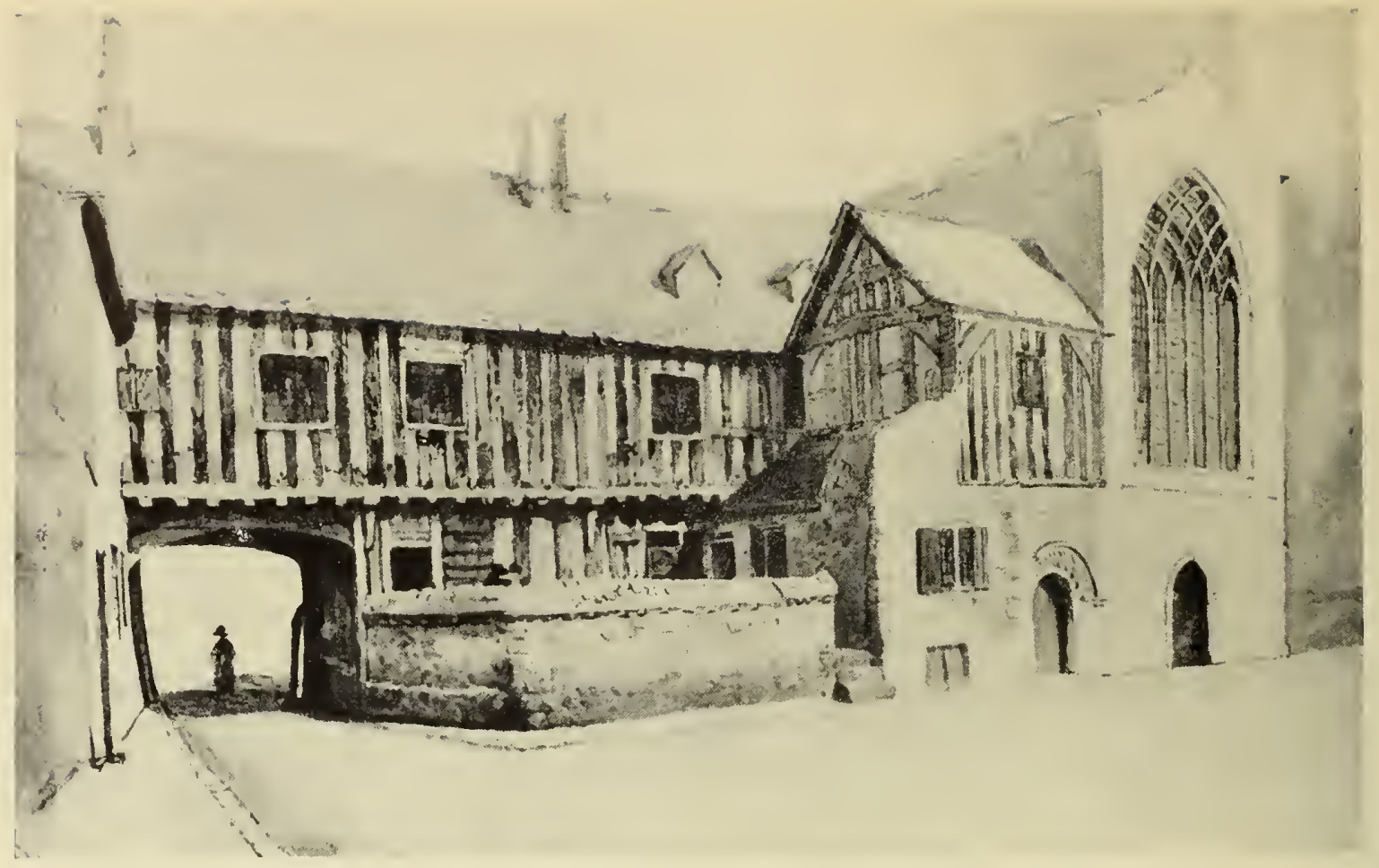

The Tudor Gateway, with St. Mary's Church to the right, $c$. I 840

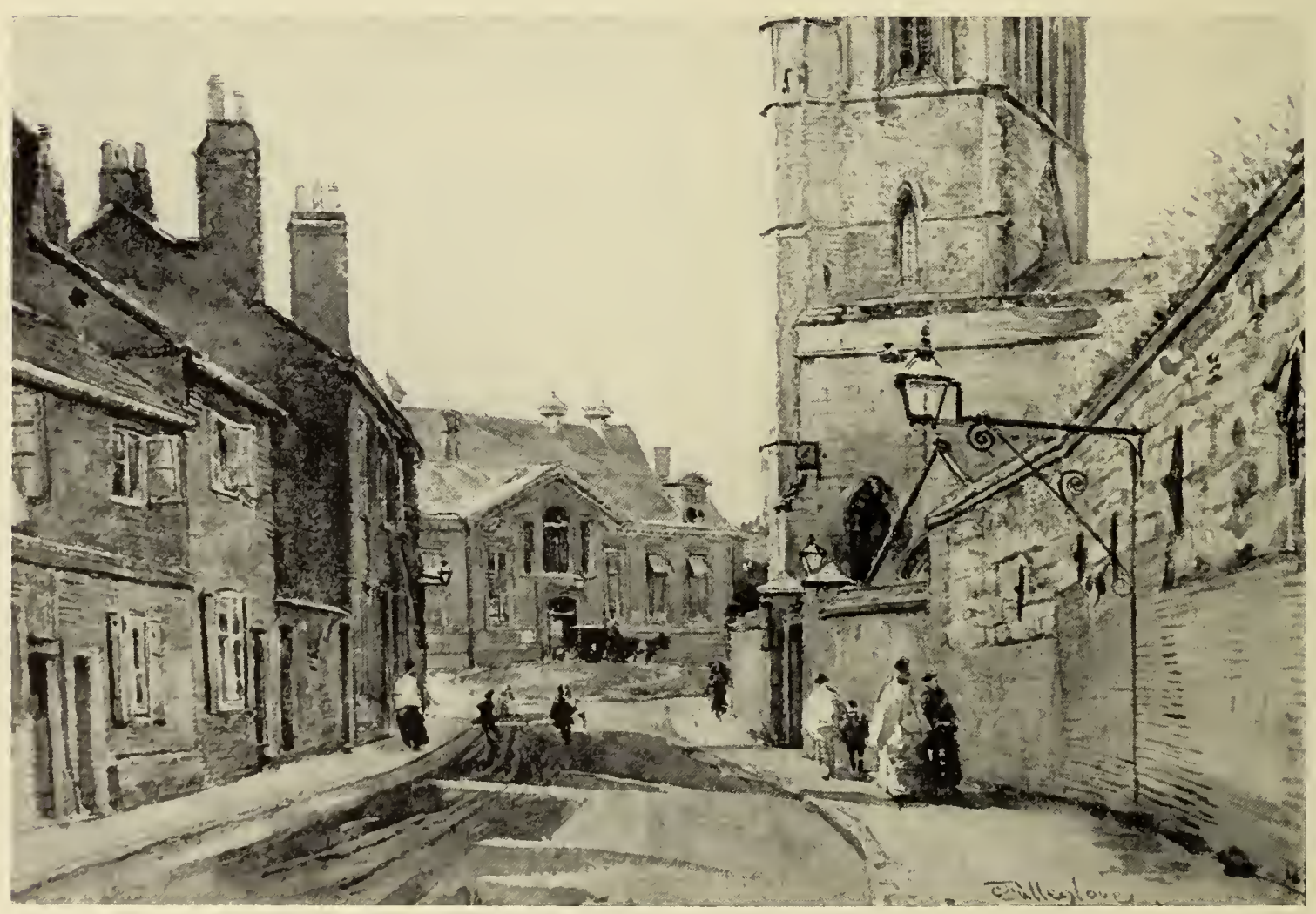

The Castle and St. Mary's tower seen from Castle View, c. I 879

Castle Green 
dissolved Newarke College. The fear that such transactions might be invalidated without a formal charter of incorporation, which would define the right of the municipal body to possess land, led directly to negotiations for a new charter, which was granted on 17 February $1589 .{ }^{26}$ The charter provided that the corporation of Leicester was to consist of a mayor, 24 aldermen, 48 burgesses. Provision was made for the election of the mayor and for the keeping of the court of portmoot or portmanmoot. As Mary Bateson has said, 'Leicester, which failed throughout the medieval period to obtain the firma burgi, succeeded in getting something like it in 1589 '. ${ }^{27}$

Later developments encouraged dissatisfaction with this charter, which was replaced by another in I 599, containing a more ample statement of town government. In I 597 Sir Edward Hastings had given up his office of Steward of Leicester, ${ }^{28}$ and it therefore became desirable that the position of the steward, and of his executive officer, the bailiff, should be defined in the charter. The town was now incorporated under the name of 'the Mayor, Bailiffs, and Burgesses of Leicester'.29 'The 24 aldermen were given the right to elect a recorder, a steward, two bailiffs, a town or mayor's clerk, and five sergeants-at-mace. The members of the corporation and the first holders of these offices were named in the charter. It was also provided that the Bishop's Fee, the Newarke, and the parts of St. Mary's and St. Leonard's parishes outside the borough ${ }^{30}$ were to be under the jurisdiction of the mayor and corporation, saving the rights of the queen and others interested. The town thus failed to obtain the definite exclusion of the county justices from these liberties and failed also in its further ambition to secure county jurisdiction within its boundaries. The charter also contained provisions of economic importance concerning the building of malt kilns and the establishment of a wool market.

It seems that even before the end of Elizabeth's reign it was found difficult to work the new charter. ${ }^{31}$ In 1604 the corporation, therefore, resolved that the charter should be renewed and amended. But their proposal to seek full jurisdiction in the liberties ${ }^{32}$ and their claim to nominate the steward met with powerful opposition. The first was opposed by Sir Henry Harrington, the owner of the manor of the Bishop's Fee, with the claim that it would result in interference with his court baron. The Earl of Huntingdon objected to the second point on the ground that it would diminish the liberties of the honor of Leicester. The corporation was also opposed by Christopher Tamworth, who had obtained a patent of the office of steward of the town from the king, and attempted to enforce his title by legal sanction. ${ }^{33} \mathrm{~A}$ charter was obtained on I 3 April I 605 by which the corporation appeared to have obtained its object, but a second charter of I 7 April I 609 restored the situation of I 599. Thus the question of the liberties was shelved, and the corporation and the Earl of Huntingdon came to a separate agreement over the stewardship. ${ }^{34}$ James I also granted a charter in I6I9, establishing a staple of wool at Leicester, the mayor being given the power to take and receive recognizances according to the Statute of Merchants and the Statute of Acton Burnell. ${ }^{35}$

On the accession of Charles I the borough authorities again attempted to improve their position, protesting that their powers were inadequate to prevent abuses in the Bishop's Fee and the Newarke, which it was alleged harboured unlicensed alehouses

26 Leic. Boro. Rec. I 509-I603, 247-52.

27 Ibid., p. xix.

28 Ibid. 339; see also below, p. 6 I.

29 Ibid. $359-64$.

30 For the origins of the liberties, see above, p. I6, and for later difficulties over jurisdiction, see below, p. I 29. On this point, compare the English translation in Leic. Boro. Rec. with the Latin text given by Nichols. The charter confuses the identity of the relevant areas by referring to 'the parish of St. Margaret called in English

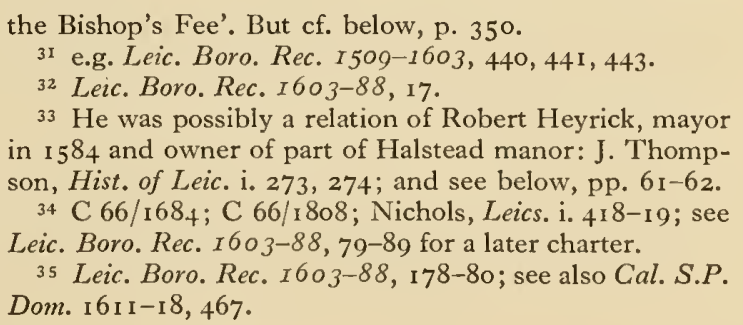
in 1584 and owner of part of Halstead manor: J. Thompson, Hist. of Leic. i. 273,274 ; and see below, pp. 6I-62.

${ }_{34}$ C 66/1684; C 66/1808; Nichols, Leics. i. 418-19; see Leic. Boro. Rec. $1603-88,79-89$ for a later charter.

35 Leic. Boro. Rec. $1603-88,178-80$; see also Cal. S.P. Dom. I 6 I I-I $8,467$.

LEIC. IV 


\section{A HISTORY OF LEICESTERSHIRE}

and nonconformists who 'account themselves in noe parish nor would be under anie government'. ${ }^{36}$ After receiving a report from the Attorney General upon the privileges desired, the king instructed him in 1629 to prepare a new charter. ${ }^{37}$ The provision that the corporation was to have the same authority in the Bishop's Fee, the Newarke, and the parishes of St. Mary and St. Leonard as in the borough was not among those questioned by the Attorney General. But the opposition which again came from the owner of the manor of the Bishop's Fee, the Countess of Devon, prevailed at the last moment. ${ }^{38}$ 'The borough's ambitions were finally quashed by a resolution of the Privy Council on 4 May I $632 .{ }^{39}$ In I 635 the corporation seems to have had some idea of taking the matter before the common law courts. A second petition was presented to the Privy Council in I64I after the Countess of Devon had withdrawn her opposition, whereupon the Council revoked its earlier order. ${ }^{40}$ Nothing further was attempted in the reign of Charles I, but Richard Cromwell's favourable reception of the town's congratulations encouraged the recorder to suggest taking the matter up again in ${ }^{6} 6_{5} 8$. The corporation accordingly resolved to seek to procure a new charter, but its plans again came to nothing owing to the fall of the government. A confirmation of existing privileges only was obtained from the new régime in 1665.41

The Crown's regulation of trade, public order and defence, and ecclesiastical affairs through the issue of proclamations and by the action of the Council can be illustrated in the history of Leicester. ${ }^{42}$ The mayor had a commission to receive royal proclamations and their receipt is regularly mentioned in the Leicester borough records, from which it appears that the messenger who brought them was usually paid a fee of a few shillings. ${ }^{43}$ Instructions were also transmitted to the town through the Privy Council, which exercised considerable power to ensure the enforcement of statute law and royal orders. Thus a number of letters from the Council on subjects of general interest ${ }^{44}$ or particular concern to Leicester also survive among the records. They are addressed at times to the sheriff of the county, at times to the mayor and corporation. A copy of the town's letter in reply detailing the action taken may sometimes be found. 45 In 1627 the Council ordered that watches should be kept for soldiers who had deserted from the force sent to the Isle of Rhé. ${ }^{46}$ In 1605 one James Johnson was arrested in Leicester on instructions from the Council despite the fact that the mayors of Leicester and Coventry could find nothing to say against him.47 It was also recognized that the Council possessed special equitable jurisdiction and the question of the borough of Leicester's authority in the liberties, as has been said, was referred to it in $\mathbf{6}_{3} 2$. But cases-usually those involving an element of disorder-were sometimes sent to the more public and formal Court of Star Chamber. Thus the Council disregarded the petition from Leicester and other places against the disafforestation of Leicester Forest in 1627 , and decided that the persons who had destroyed the new inclosures should be prosecuted in Star Chamber. ${ }^{48}$ According to the Earl of Huntingdon, the efforts of the corporation of Leicester in the reign of James I to maintain the exclusive right of freemen to trade in the borough also led to 'tumult' and to suits in the Star Chamber. ${ }^{49}$

36 Leic. Boro. Rec. I603-88, 259.

37 S.P. 16/146/20. An unexecuted charter survives among the corporation records: Hist. MSS. Comm. $8 \mathrm{th}$ Rep. App. I, section 2, 4 I $8 \mathrm{~b}$.

38 Leic. Boro. Rec. $1603-88,264,265$.

39 Ibid. $265-6$.

40 Ibid. 267, 305, 306; Leic. City Mun. Room, Hall Papers, I640-5, no. 23 ; P.C. $2 / 53$, p. 109.

${ }_{41}$ Leic. Boro. Rec. I603-88, 449-5 I, 499-503.

42 See R. Steele, Bibliog. of Royal Proclamations, ${ }_{4} 8_{5-}$ I7 14 .

\footnotetext{
43 e.g. Leic. Boro. Rec. I 509-I603, 3, x8o, I90.

44 e.g. musters, suppression of alehouses, planting mulberry trees.

45 e.g. Cal. S.P. Dom. I 547-80, 565: 7 Nov. I 577, certificate of no. of inns in the town.

46 Leic. Boro. Rec. I603-88, 237.

47 Ibid. 40, $4 \mathrm{I}$.

${ }_{48}$ Bodl. MS. Carte 78 , ff. I I I, $112 ;$ V.C.H. Leics. :i. 267.

49 Leic. Boro. Rec. I 509-I603, 419 ; ibid. I603-88, 1 3-14.
} 
The restoration of Catholicism and the revival of the heresy laws by Mary led to the burning of one person, perhaps two, for heresy in Leicester. ${ }^{50}$ In Elizabeth's reign local authorities were given new responsibilities in maintaining the Church of England as established by law, and legislation was reinforced by numerous royal proclamations, and by the issue of commissions for ecclesiastical causes, which became the Court of High Commission. Local authorities were expected to assist the messengers of the court in making arrests. Thus, a constable was sent, under a warrant from the Court of High Commission, to aid in the arrest of James Herrick of Thornton in $\mathrm{I}_{34}$, for holding a conventicle. ${ }^{5}$

During the Interregnum the town was similarly in touch with the new central and local authorities, though the insecurity of the times sometimes occasioned administrative difficulties. ${ }^{22}$ Committees set up for particular purposes, such as defence or ecclesiastical affairs, are mentioned in the borough records. ${ }^{33}$ The government's decision occasionally evoked protests, as in the case of Price and Angel, ministers who refused to take the Engagement and were therefore ordered to leave the town, despite a petition on their behalf.54 More serious was the riot at Leicester in 1649 which caused the Council of State to instruct the mayor and justices of the peace to make an inquiry and to report their findings at the assizes. ${ }^{55}$

\section{TAXATION}

Leicester had secured the separate assessment and collection of subsidies by the charter of 1464 and was anxious to obtain from the Lord Chancellor the nomination of sympathetic subsidy commissioners. Thus, the corporation protested in I 599 at the nomination of Sir John Grey, with whom it had quarrelled.56 Efforts were also made to have the town described to include the liberties named in the charter of I599, and an order was obtained in I6 I for the Newarke to be assessed for the subsidy with the town. ${ }^{57}$ The subsidy was collected according to an agreed rate from persons whose names appeared in the subsidy books, ${ }^{58}$ but complaints were received that the returns were unsatisfactory. ${ }^{59}$ The subsidy appears to have been becoming an increasingly rigid form of levy, like the tenths and fifteenths. These had become recognized as set sums and were granted several at a time. They were collected by persons named by the members of Parliament or elected in the town. ${ }^{60}$

In 1630 compositions were called for from those in Leicestershire who had failed to take up the honour of knighthood, nine citizens of Leicester being among them. ${ }^{61}$ In I63 I payment of a composition for failing to attend the king's coronation was refused in Leicester. ${ }^{62}$ No serious opposition to ship money was made at first in Leicester, perhaps because one of the aldermen made up the required sum out of his own pocket, and in I636 Sir Henry Skipwith, Sheriff of Leicestershire, was hoping to be the first sheriff to pay in his full contribution. ${ }^{63}$ Active opposition developed and the second levy of ship money had to be taken by distress in some cases in 1638.64

During the Interregnum new taxes were invented. From I 643 the mayor and one or

50 J. Strype, Hist. Memorials (172I), iii. 293, 294. A certain Thomas More was burnt in 1556 , but in a table (ibid., App. 85) Strype says 2 persons were burnt.

51 Leic. Boro. Rec. I603-88, $271,272$.

52 Cal. Cttee for Compounding, i. 189: 26 Mar. 1650.

53 Leic. Boro. Rec. $1603-88,383,402$.

54 Cal. S.P. Dom. 1651, 56.

55 Ibid. I649-50, 180.

${ }^{56}$ Leic. Boro. Rec. I 509-I603, 369, 370, 4I 3, 4I 4.

57 Ibid. $1603-88$, 109 .

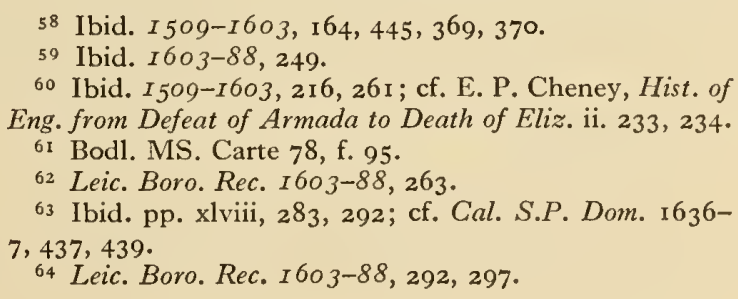




\section{A HISTORY OF LEICESTERSHIRE}

two others were nominated to serve on county committees appointed by Parliament for the levy of monthly or weekly sums assessed on the county of Leicester. ${ }^{65}$ The money was not, however, always forthcoming without reminders from the authorities in London. The tax on commodities begun in 1643 and known as excise was collected by local commissioners who were given special powers of jurisdiction. ${ }^{66}$ It was unpopular in Leicester, and when it was put out to farm in I $_{5} \mathrm{I}$ it aroused strong opposition. ${ }^{67}$

\section{PARLIAMENTARY REPRESENTATION}

The influence of the Crown upon the choice of members for the borough of Leicester was frequently exercised through the person of the Chancellor of the Duchy of Lancaster, though sometimes the wishes of the government were directly stated by the Privy Council. The chancellor was important enough for it to be said in I6I 4 that it was 'the prescription of the chancellor to have the nomination of one of the burgesses in every of the duchy boroughs'. ${ }^{68}$ In Leicester, however, he had to share his authority with the earls of Huntingdon, who at various times held office not only in the county but also in the honor of Leicester and in the central government. The corporation of Leicester was not incapable of independence, but found it not only politic but profitable to attempt to meet the wishes of the great lords, its patrons. One of the town's chief anxieties was to obtain members who would pay their own expenses, ${ }^{69}$ and the borough members, if not chosen from among the local gentry, were often prosperous merchants. The members for Leicester during the Interregnum include the famous names of Peter Temple, Sir Arthur Hazlerigg, and Thomas, Lord Grey. Temple was chosen in place of 'Thomas Coke, son of Sir John Coke, Charles I's secretary, who joined the king at Oxford and was expelled from the House of Commons in $1645 .^{70}$

The claims of conflicting interests in appointing members were often amicably settled, as in 1624, when Sir Humphrey May, Chancellor of the Duchy of Lancaster, obtained the Earl of Huntingdon's support for his candidature. ${ }^{71}$ Occasionally, however, the town refused to agree to the proposals of the local magnates. It refused to give the nomination of both its members to the Chancellor of the Duchy of Lancaster in I 593 and would not elect the Earl of Huntingdon's candidate in 1597.72 The election of George Belgrave as one of the burgesses in I 60I demonstrates not only the importance of influence on the borough elections but also the fact that the offence of a powerful patron might be attended with serious consequences. The earl accepted an apologetic statement that the town had been tricked into the election because Belgrave had appeared before the common council in the earl's livery, ${ }^{73}$ but took vengeance on Belgrave himself by bringing an action against him in Star Chamber. ${ }^{74}$ By doing so during the sitting of Parliament he raised a question of privilege, but the Commons resolved that Belgrave was free from offering the House any abuse. ${ }^{75}$ The corporation agreed in $\mathrm{I} 602$ to send a report on the election to the Privy Council, ${ }^{76}$ but nothing further is heard of the affair. It is noticeable that the other candidate at the election had personally sought the earl's approval, which the mayor wished to be confirmed by a letter of recommendation, and that Belgrave was asked whether he had any such letter.

65 Acts Eڤ Ords. of Interr., ed. Firth and Rait, i. 546.

66 Ibid. 202-I 4.

67 Leic. Boro. Rec. I603-88, 396, 454-5.

68 Quoted by J. E. Neale, Elizabethan Ho. of Commons, 232 ; cf. R. Somerville, Duchy of Lanc. i. 326-8.

69 e.g. Leic. Boro. Rec. I 509-1603, 336.

70 Cal. Cttee for Compounding, iii. 1844 .

71 Hist. MSS. Com. Hastings, ii. 63.

72 Neale, Elizabethan Ho. of Commons, I 73, I74.

73 Leic. Boro. Rec. I509-1603, 436.

74 St. Ch. 5/A $54 / 2$.

${ }_{75}$ 'Thompson, Hist. of Leic. i. 322; Neale, Elizabethan Ho. of Commons, I75-6.

76 Leic. Boro. Rec. I509-1603, 448. 


\section{RELATIONS WITH THE DUCHY OF LANCASTER}

The influence of the Chancellor of the Duchy of Lancaster, of which mention has been made, in fact affected not only the political but also the social and economic life of Leicester. Inhabitants of the Duchy of Lancaster were able to obtain relief in equity in their own court, 77 known as the Court of Chancery of the duchy or the Court of Duchy Chamber. The court was presided over by the chancellor and came to deal with many different subjects. It was extensively used, both by private citizens of Leicester and by the corporation. The court had the power of making orders and those affecting the town of Leicester were frequently engrossed, confirmed by the duchy seal, and preserved with the town's charters and other privileges. ${ }^{78}$

A matter frequently brought before the court, as it concerned the relations between Leicester and other towns, was the claim to exemption from toll outside the Duchy of Lancaster. In ${ }_{574}$ Leicester claimed that its exemption had been established by Act of Parliament and by several letters patent, 79 but after private negotiation between the mayors of Leicester and Nottingham and a lawsuit in the Duchy Chamber, the town of Nottingham continued to levy toll on cattle passing through it on the way to Leicester. ${ }^{80}$ A similar suit, concerning the levy of toll in the torvn of Derby, was heard in the Duchy Chamber in I 575. This privilege continued to be contested during the reign of James I, and the town also attempted to maintain the related claim to exemption from toll within the Duchy of Lancaster. ${ }^{8 I}$ In 1598 the corporation was involved in a suit in the Duchy Chamber with William Okes and Thomas Rogers, who claimed to have been assigned a lease of the tolls made by the queen to Randall Manning. After much expense, an order of the court was eventually obtained declaring all inhabitants of the borough, freemen as well as foreigners, exempt from all tolls and through tolls..$^{82}$ Nevertheless, the corporation was soon after made a party to a new suit by John Okes and in this the decision went in favour of Okes. ${ }^{83}$

It was thought necessary to reaffirm the rights of the Duchy of Lancaster in the I609 charter, which contained the provision that the mayor should take his oath at Leicester castle before the steward of the honor of Leicester. ${ }^{84}$ The position of the steward in relation to the town had been for some years before this the subject of dispute, the corporation of Leicester being anxious to secure independence of the lord's officers. The aspirations of the corporation had been encouraged by the sale to them by Sir Edward Hastings in I 594 of the profits of the borough courts for a yearly rent of $f_{1} \mathrm{O}$, and the surrender of his patent of the stewardship of the town in 1597.85 In 1605 the Earl of Huntingdon sought to prove that the town steward or town clerk was an officer dependent on the steward of the honor, while the corporation maintained that the town stewardship was a separate and independent office. ${ }^{86}$ The town stewardship had been acquired by Thomas Clarke when Mayor of Leicester in I 598,87 but the town failed to maintain control over the office, which was granted to a certain Christopher Tamworth in July I $603 .{ }^{88}$ The town vigorously opposed his claims, but in November he obtained a Duchy of Lancaster privy seal letter instructing the corporation to permit him to exercise the office on penalty of $f_{0} 100 .{ }^{89}$ Tamworth brought an action in the Court of Duchy Chamber against the corporation and, although a series of orders were

77 3oth Dep. Kpr's. Rep., pp. vii, viii; see also R. Somerville, 'The Duchy of Lanc. and Ct. of Duchy Chamber', Trans. R.H.S. $4^{\text {th }}$ ser., xxiii. I 59-77.

${ }_{78}$ Leic. Boro. Rec. I 509-1603, 399, 400.

79 D.L. I/92, f. 7 I.

80 W. H. Stevenson, Rec. of Boro. of Nott. iv. I44; Leic. Boro. Rec. I509-1603, 160-1.

${ }^{8 I}$ Hist. MSS. Com. 8th Rep. App. I, section 2, 4I 7 .
82 Leic. Boro. Rec. I509-1693, 399-400. (IV).

83 Hist. MSS. Com. 8th Rep. App. I, section 2, $435 a$

84 See below, p. 70

85 Leic. Boro. Rec. I 509-I603, 299, 300, 339.

86 Thompson, Hist. of Leic. i. 330-2.

87 Leic. Boro. Rec. I 509-1603, 339.

88 Ibid. I603-88, 83 .

89 Leic. City Mun. Room, box 3A/8. 


\section{A HISTORY OF LEICESTERSHIRE}

made in his favour, the action appears to have been still in progress in $\mathbf{I} 606.90 \mathrm{By}$ this time Henry, fifth Earl of Huntingdon (d. I643), had received a grant of the offices of steward and receiver of the honor of Leicester ${ }^{91}$ and the dispute was overshadowed by the negotiations for a new charter. The corporation finally came to an agreement with the earl that they should nominate the holder of the office alternately, and Tamworth's grant was revoked by the king. ${ }^{92}$

At the same time agreement was also reached concerning the appointment of the lord's other executive officer, the bailiff. During the second half of the 16 th century, the bailiwick, by royal grant, was in the possession of the Danet family and the town purchased leases of the office from them, nominating two bailiffs annually. ${ }^{93}$ But, as early as $155^{2}$, a project had been formed for obtaining the bailiwick in fee farm, and the matter was raised again when the 1589 charter was obtained. 94 The charter of 1599 gave the town the right to nominate two bailiffs, but in I600 it was found necessary to recognize John Wilne as bailiff for life. He had been holding the office since I 594, and nothing further is heard of the two bailiffs named by the town. In I 609 the Earl of Huntingdon tried to obtain control over the bailiwick as well as over the stewardship, and it was finally decided to accept the principle of alternate nomination by the earl and the corporation in this case as well. ${ }^{55}$ Wilne, who had been confirmed in his position by the charter of 1609 , was admitted to the office of bailiff by the mayor and burgesses in 1611.96 Robert Wright was nominated by the Earl of Huntingdon in 1622 , presumably on Wilne's death. The office included the keepership of the town gaol. The bailiff who held office for life was known as the king's bailiff. In addition, a second bailiff was appointed annually. 97

Several franchisal courts were held in Leicester and appear under varying names in the court rolls. ${ }^{98}$ One was the court leet with view of frankpledge, kept twice a year at Easter and Michaelmas. ${ }^{99}$ It dealt mostly with petty nuisances and assaults but its jurisdiction was giving way before that of the justices of the peace in quarter sessions. Infringements of the assizes of bread and beer and brewers' dues, known as 'cannemol', 1' were dealt with at the same time but a separate record of them was kept. The court leet was held for each of the four quarters of the town and proceedings in each quarter were recorded separately. Courts were also held before the mayor in connexion with the four annual fairs. ${ }^{2}$ The jurisdiction of the borough court of portmanmoot, which met every Monday, was defined and confirmed in successive charters. ${ }^{3}$ According to the charter of I 599, it was to be held by the mayor, recorder, bailiffs, steward, or one of them, and might entertain pleas of trespass, actions on the case, actions of debt, account, covenant, fraud, detinue, and contract arising within the borough. As a court of record, fines recording transfers of property were also made in it. ${ }^{4}$ Christopher

90 Leic. City Mun. Room, ID3 I/79/4: 6 orders occurring during the period 13 Feb. I604-12 Feb. I606.

91 Cal. S.P. Dom. I603-10, 194: I I Feb. I605.

92 Leic. City Mun. Room, box 3A/6: 20 Dec. I609; see also Leic. Boro. Rec. I603-88, 90-92, and Thompson, Hist. of Leic. i. 333, where deeds of I5 Feb. 1609 and 17 Apr. I609 are mentioned.

93 Leic. Boro. Rec. I 509-I603, 54, I79. R. Somerville equates the office of bailiff and town steward: see his list of bailiffs in Duchy of Lanc. i. 571-2.

94 Leic. Boro. Rec. I509-1603, 69, 235.

95 Ibid. 299, 316, 389, 459; ibid. $1603-88,77,90,93$.

96 Ibid. $1603-88,83$, 106.

97 Ibid. I06, 597-8; Leic. City Mun. Room, box 3A/6.

98 These include: court with view of frankpledge, canmole, canmote, court of market, court of piepowder, portmoot, portimote, halmote. Cf. Rec. of the Corporation of Leic., 5 $1-52$.
99 For list of Ct. R. see P.R.O. List VI, List and Index of Ct. R. (I), 74-77. On the earlier list of the courts, see above, pp. 9 sqq.

I e.g. D.L. 30/1 1 26/82 m. I (1 592).

2 Select Cases Concerning the Law Merchant (Selden Soc. xxiii), i. 132, I33; cf. Leic. Boro. Rec. I509-I603, 275 .

3 For cases held in the portmanmoot in $1619-20$, see Leic. City Mun. Room 9 D45/7; see also Leic. Boro. Rec. I 509-I603, I43-5.

4 Copies of deeds and fines are entered in the Old Lockt Book, I505-1693 (Leic. City Mun. Room); see also Leic. Boro. Rec. I509-1603, 359-64. It may be noted that in the Lockt Book the court is called at different times the Court of Portmoot of the Queen, the Court of Record of the Queen, and the Court of Record of the Lord Protector. 
Tamworth, as steward of the town, had attempted to maintain the steward's right that the court should be held in his presence and its proceedings be attested by him. According to the charter of 1609 , the court was to be held before the mayor, recorder, and aldermen, or any three of them, the mayor being one. The public importance of the court is shown by the act of submission before it of William Proudlove in $5^{\text {I } 7}$ for abusing the authority of the mayor. ${ }^{5}$

At the opening of this period the town had not succeeded in freeing itself from the lord's milling and oven rights. Inhabitants of Leicester were frequently taken to law over the right of suit to the mills held from the Crown, which at various times they tried to evade by using mills outside the town. ${ }^{6}$ The lawsuit with Dr. John Chippingdale at the end of the I 6 th century is a particularly important example. The town, however, eventually succeeded in purchasing the North Mill, the windmill in the South Field, the Newarke mill, and finally the castle mills by r638.7 The town was also involved in frequent disputes concerning the lord's right to have bread which was for sale baked in the lord's ovens. In I 533 there were said to be five ovens belonging to the king in Leicester, and a few years before it had been ordered that new ovens should be pulled down. ${ }^{8}$ The baking and sale of bread was the subject of frequent orders by the Duchy Court. ${ }^{9}$

The Duchy of Lancaster had its own financial machinery for the collection of dues and rents. A duchy auditor and receiver made an annual visit to the town in October to receive and audit the duchy revenues, including the quit rent of a broad arrow for the Butt Close. The audit was usually held at Leicester castle, though sometimes at the 'Angel' or other inn in Leicester, and was attended by the borough chamberlains. The chamberrlains presented their account, each item being entered in detail, and paid over their rents. ${ }^{10}$ They received a receipt and quittance, ${ }^{\mathrm{II}}$ and afterwards might entertain the auditor and receiver to dinner or regale them with wine and sugar. ${ }^{12}$

In the r6th century the Crown was drawing rents from many houses and lands in and around Leicester which were duchy property. All colleges and chantries within the duchy belonged to it rather than to the Crown and were administered by the Duchy Court according to a statute of $\mathrm{r} 547$. Separate officers were appointed in $\mathrm{r} 549$ to receive the revenues of the Newarke and duchy chantries. About i 587 the town decided to attempt to secure not only the reconstitution of the borough but to acquire the property paying fee-farm rents to the duchy. A commission of 1587 to examine the state of duchy property reported that there were 235 houses in the town in decay, the cost of repairing which would amount to $£ 5, \mathrm{r} 236 \mathrm{~s} .8 \mathrm{~d} .{ }^{13}$ This assessment presumably helped to induce the queen to include a grant of property in Leicester in her charter of I 589 , for the annual payment to the queen, in right of the Duchy of Lancaster, of f. 37 I 3 s. $7 \frac{3}{4} d$., which was the total of the fee-farm rents. 'The town thus gained control over the Shambles, the Drapery, and the Sheep pens, though the market stalls were omitted. ${ }^{14}$ Lands of the Hospitals of St. John and St. Leonard, of the guilds of St. Margaret and Corpus Christi, and of the colleges of St. Mary de Castro and St. Mary in the Newarke were enumerated. The town also secured a lease in reversion ${ }^{15}$ of the Newarke Grange lands ${ }^{16}$ for the annual rent of $£ .32$ rs. $4 d$., having previously purchased

5 Thompson, Hist. of Leic. i. 217 ; Leic. Boro. Rec. I 603-88, 49, 91, I09, 79-89.

6 e.g. D.L. $42 / 95$, f. I 06 (I529).

7 See below, pp. 396-7.

8 D.L. $42 / 95$, ff. $135^{\mathrm{v}}, 136$.

9 Leic. Boro. Rec. I $509-1603,394-5$; ibid. $1603-88$, $125^{-8}$.

Io Leic. City Mun. Room, press I 3, box I2, nos. I4, I 8.
II Ibid. nos. 30, 36, 40, 52-57.

12 Leic. City Mun. Room, Chamberlains' Accts. I6I0I I, I6I I-I2. Cf. lists of auditors and receivers in Somerville, Duchy of Lanc. i. 436-9, 567.

13 Ibid. I 509-I603, 239.

14 Whence arose the claims for concealed toll : see ibid., pp. xlii, xliii, 249-5I.

15 Ibid. $218,276,277$. I6 See below, p. 37 I. 


\section{A HISTORY OF LEICESTERSHIRE}

the leases held by Francis Hastings for $£ 7136 s .8 d$. by borrowing money on the security of the town estate. Leases of their new property were granted by the corporation as soon as possible, with the result that the town rental was considerably increased. Some difficulty was experienced at first over the collection of the rents and a court order had to be obtained that the tenants should pay the mayor and corporation, who would then pay the total in one lump sum to the queen's receiver. ${ }^{17}$ The Privy Council also found it necessary to instruct the mayor that the rents had been granted for the benefit of the town and were not to be put to private use. ${ }^{18}$

It was not until James I's reign that the corporation was able to purchase the fee farm of the Newarke Grange estate. A petition to the king indicating the corporation's desire to purchase was drawn up in $1604,{ }^{19}$ but the existing sub-tenant of one half of the Grange, Dr. Chippingdale, opposed the proposal and enlisted powerful support, so that the corporation's intentions were frustrated for the time being. ${ }^{20}$ The matter was raised again in 16 I 3 when both the Earl of Huntingdon and Sir William Heyrick gave the town their encouragement. Although quibbling at first over the price, the corporation eventually agreed to purchase the Grange, the Newarke Mill, and other lands for $f_{\mathrm{I}}, \infty 00$. Some town property had to be sold to raise the money and the transaction does not seem to have been completed until i623. ${ }^{21}$ About the same time, the mayor was also encouraged to attempt to define and establish the position of the old hospital in the Newarke and the corporation eventually obtained a grant of incorporation for the hospital in 16 i 5. The Crown continued to make grants for the maintenance of the poor from the revenues of the Duchy of Lancaster. ${ }^{22}$

A matter also affecting duchy rights was the disafforestation of Leicester Forest in the reign of Charles I. By commissions of 1627 , Sir Miles Fleetwood was authorized to survey the forest and to make allotments of land to those claiming rights in it. ${ }^{23}$ His task proved most unpopular. It was claimed that the allotments were unfair and that the inclosures would hinder trade by stopping up the highways. The hedges of the inclosures were thrown down by a band of rioters and some of the king's deer were killed. ${ }^{24}$ Meanwhile a complaint against the disafforestation was sent from Leicester and other places in the area to the king and the Duke of Buckingham. Their petition was referred to a committee of the Privy Council and the rioters were prosecuted in the Star Chamber. ${ }^{25}$ The inhabitants of Leicester presented a petition to the House of Lords, which upheld the allotments made by Fleetwood, though recommending that the Attorney General should approach the king for permission to stop the action in the Star Chamber. ${ }^{26}$ As compensation for the loss of its ancient right to take wood from the forest, Charles I gave the town of Leicester 40 acres of land in the forest, which were leased for $£_{\mathrm{I}} 6$ per annum, to provide 60 poor householders with loads of wood at midsummer. ${ }^{27}$ Twenty acres were also allotted in lieu of the rights of common belonging to the Grange lands. However, opposition to the inclosures remained very strong in Leicester. In I64I the town hoped there would be a chance of reopening the forest, and

17 Leic. Boro. Rec. 1509-1603, 300, 301.

18 Acts of P.C. 1592-3, $131,132$.

I 9 Leic. Boro. Rec. $1603-88$, 19.

20 Ibid. 69, 104-5; Cal. S.P. Dom. I603-10, I78; see also Hist. MSS. Com. Salisbury, xvi. 359, 409. The cause of Chippingdale's opposition was apparently that he feared that the corporation, if able to buy the fee-farm, would not renew his lease of the portion of the grange when it expired.

21 J. Throsby, Hist. of Leic. IoI ; Leic. Boro. Rec. I603$88,135,136,149,151,157,211$.

22 S. H. Skillington, Trinity Hosp. 30-32. The charter is in Lejc. City Mun. Room, I D3I/I; for the hosp. see below, p. 406.

23 Bodl. MS. Carte 78 , ff. I I I, I I $2 ;$ V.C.H. Leics. ii. 267.

24 Cal. S.P. Dom. 1 627-8, 255, 262.

25 Bodl. MS. Carte 78, ff. I I I, I 12 ; Hist. MSS. Com. 8th Rep. App. I, section 2, $436 a$ (V); Thompson, Hist. of Leic. i. 353 .

${ }^{26}$ L.F. iii. 872; see also Hist. MSS. Com. 4th Rep. App. XIX, and Leic. Boro. Rec. I603-88, 241.

27 Leic. Boro. Rec. IIO3-1327, 43; 32 nd Rep. Com. Char. Pt. 5 [163], p. 23, H.C. (1839), xv. 
a petition was sent to the House of Lords for a new commission to examine the proceedings of 1627.28

The organization of the Duchy of Lancaster was disrupted by the Civil War with serious consequences to the town. In I643, Parliament ordered the king's revenue in the duchy to be siezed ${ }^{29}$ and, in $\mathbf{1} 649$, the first Act for the sale of the royal estates was passed. ${ }^{30}$ In $165^{\circ}$ it was ordered that the fee-farm rents not granted away before $\mathrm{I} 64 \mathrm{I}$ should be sold. ${ }^{3 \mathrm{I}}$ This seriously affected the position of the corporation of Leicester and especially endangered the maintenance of the Trinity Hospital. It was hoped that the mayor and corporation would be allowed, as immediate tenants, to arrange a purchase. However, their claim was not admitted and 'the whole Honor of Leicester . . . pitcht upon by a Regiment'.32 The honor of Leicester with the castle was, in fact, purchased by John Sanderson of Hedleyhope (co. Dur.) in I650. The perquisites of the borough courts were held by the town from him, but difficulties arose over the payment of rent to his successor. ${ }^{33}$ At the Restoration, the town reverted to a lease of the courts made by Charles I. ${ }^{34}$

\section{RELATIONS WITH THE CLERGY, NOBILITY, AND GENTR Y}

The personal influence of ecclesiastics in the town at this period was slight. High ecclesiastics $^{35}$ rarely came to Leicester and the resident ecclesiastical bodies established there in the Middle Ages were destroyed at the Reformation. The authority of the Bishop of Lincoln over his court officials might occasionally conflict with their duty to the corporation, as in the case of Henry Palmer, clerk to the bishop's registrar, who was also a member of the town's common council. ${ }^{36}$ 'The fact that Bishop Williams of Lincoln for a time held the office of Lord Keeper of the Great Seal meant that the town had correspondence 37 with him that was no part of its normal relationship with its bishop. His commendation of the founding of the town library was made, however, as bishop, for the new arrangement involved the removal of books from the chancel of St. Martin's church. ${ }^{38}$ But the most well-known instance of the town's connexion with an ecclesiastical politician resulted from the fact that Cardinal Wolsey, on his journey to London in disgrace, took shelter in Leicester Abbey and died there. The mayor and principal citizens of Leicester were said to have been among those called to view the body before its burial in the abbey church. 39

The town of Leicester was prepared to offer deference to local lay patrons, who would assist it in its relations with the central government and take an interest in the material and spiritual well being of its inhabitants. Most influence in the affairs of the town was therefore accorded to those who combined political power with an interest in the locality derived from the possession of estates and the holding of official dignities in the county. But the town had political, and frequently social, relations with the members of several noble families living at various distances from Leicester, such as the Greys at Bradgate, the Cavendishes at Leicester Abbey, the Heyricks at Beaumanor, and the Hastingses at Donington Park, Ashby de la Zouch, and elsewhere. The

${ }^{28}$ Leic. Boro. Rec. 1603-88, 302, 307; Hist. MSS.

Com. 4th Rep. App. 79.

${ }_{29}$ Acts छळ Ords. of Interr. ed. Firth and Rait, i. 299-303.

30 Ibid. ii. 168-91.

3 Ibid. ii. $35^{8-62 .}$

32 Leic. Boro. Rec. $1603-88,379$.

33 Ibid. 458.

34 Ibid. 520.

35 See, however, Leic. Boro. Rec. I 509-I603, 30.

LEIC. IV
36 Ibid, $1603-88,4,5$.

37 Ibid. 225.

${ }_{38}$ Ibid. 270, 27 r. See below, p. 365 .

39 Cavendish, Life and Death of Thomas Wolsey (1667), 155. Kelly noted the entry of a gift to Sir Wm. Kingston in the Leic. Chamberlains' Accts. I530-I, which he thought confirmed the statement by Cavendish: Kelly, Royal Progresses and Visits to Leic. 267. 


\section{A HISTORY OF LEICESTERSHIRE}

lord lieutenants, the sheriffs, the county justices of the peace, and the officials of the duchy were all of consequence in the town by virtue of their office. Other factors were also taken into account, especially during and after the Civil War. For instance, Sir Arthur Hazlerigg owed his influence largely to his political success, ${ }^{40}$ while Lord Grey of Groby gained additional reputation from a military command. ${ }^{4 I}$ It may be noted that Hastings and Grey were names which had long been associated with the county, but the Heyricks of Beaumanor owed their rise to the wealth of Sir William Heyrick, jeweller to James I and Charles I.42 'Towards the end of the period, the Manners family, who were later to play so large a part in the affairs of the county, began to assume a growing importance. This was due to the prudence and good fortune of John Manners, eighth Earl of Rutland (d. I679), who contrived to remain in favour with the government both during and after the Interregnum.43

By far the most important influence on the town at this time was that of successive earls of Huntingdon. It reached its height under Henry Hastings, the third earl, whose power has been described as both 'amicable, eleemosynary, and authoritative' ${ }^{44} \mathrm{He}$ held several great offices of state and was lord lieutenant of a group of counties. He was Lord Lieutenant of Leicestershire from I 559 to ${ }^{5} 55$ and steward of the honor of Leicester. ${ }^{45}$ His advice was constantly sought and his aid invoked in matters involving relations between the borough and the central government, such as the occasion in I 597 when the mayor was accused of falsifying the coin of the realm. ${ }^{46} \mathrm{He}$ also played a leading part in various domestic concerns of the town. In addition to giving financial assistance, the Earl of Huntingdon drew up regulations for the government of the free school ${ }^{47}$ and Wyggeston's Hospital.48 The earl was also concerned with the provision and endowment of a town preacher. ${ }^{49}$ 'The earl's pronounced Puritan sympathies endeared him to the people of Leicester, and the same deference was not accorded to his descendant, the royalist, Henry, Lord Loughborough, at the outbreak of the Civil War. The traditional influence of the Hastings family was, however, recovered at the Restoration.

\section{RELATIONS WITH THE COUNTY AUTHORITIES}

The town was brought into close relations with the county authorities over various questions affecting both town and county. One of them, taxation, has been dealt with above. Another, defence, was the responsibility of the sheriff and the justices, and later of the lord lieutenant, a new official who during this period was taking an important place in county administration. In the business of mustering and training men, the rights and responsibilities of towns were stated in Acts of Parliament passed under Mary. When instructions were issued for general musters the town obtained special directions for musters in Leicester and the nomination of the mayor as a commissioner. ${ }^{50}$ The town was also anxious to maintain a right to be consulted about demands for men and equipment and to attempt to reduce the borough's commitments on all occasions. ${ }^{5}$ Instructions were not only given for men to be mustered and trained at home, but on a number of occasions demands were made for men and equipment for foreign service.

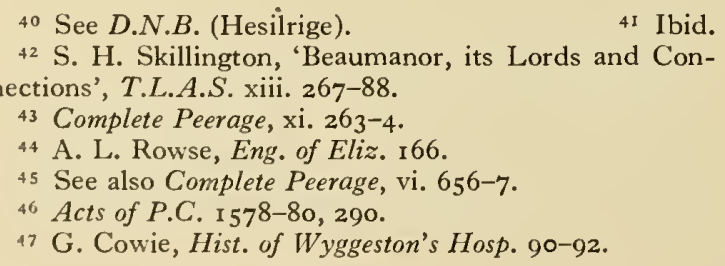

48 C. J. Billson, Leic. Memoirs, 43.

49 Ibid. 43-44; and see below, p. 74 .

50 An Act for the Having of Horse, Armour, and Weapon, $4 \& 5$ Phil. and Mary, c. 2 ; An Act for the Taking of Musters, $4 \& 5$ Phil. and Mary, c. 3 ; Leic. Boro. Rec. I 509-1603, 3, 1 40, 182-3: see also Acts of P.C. I 578-80, 422.

51 e.g. Leic. Boro. Rec. I 509-I603, 400-2. 


\section{(6)}
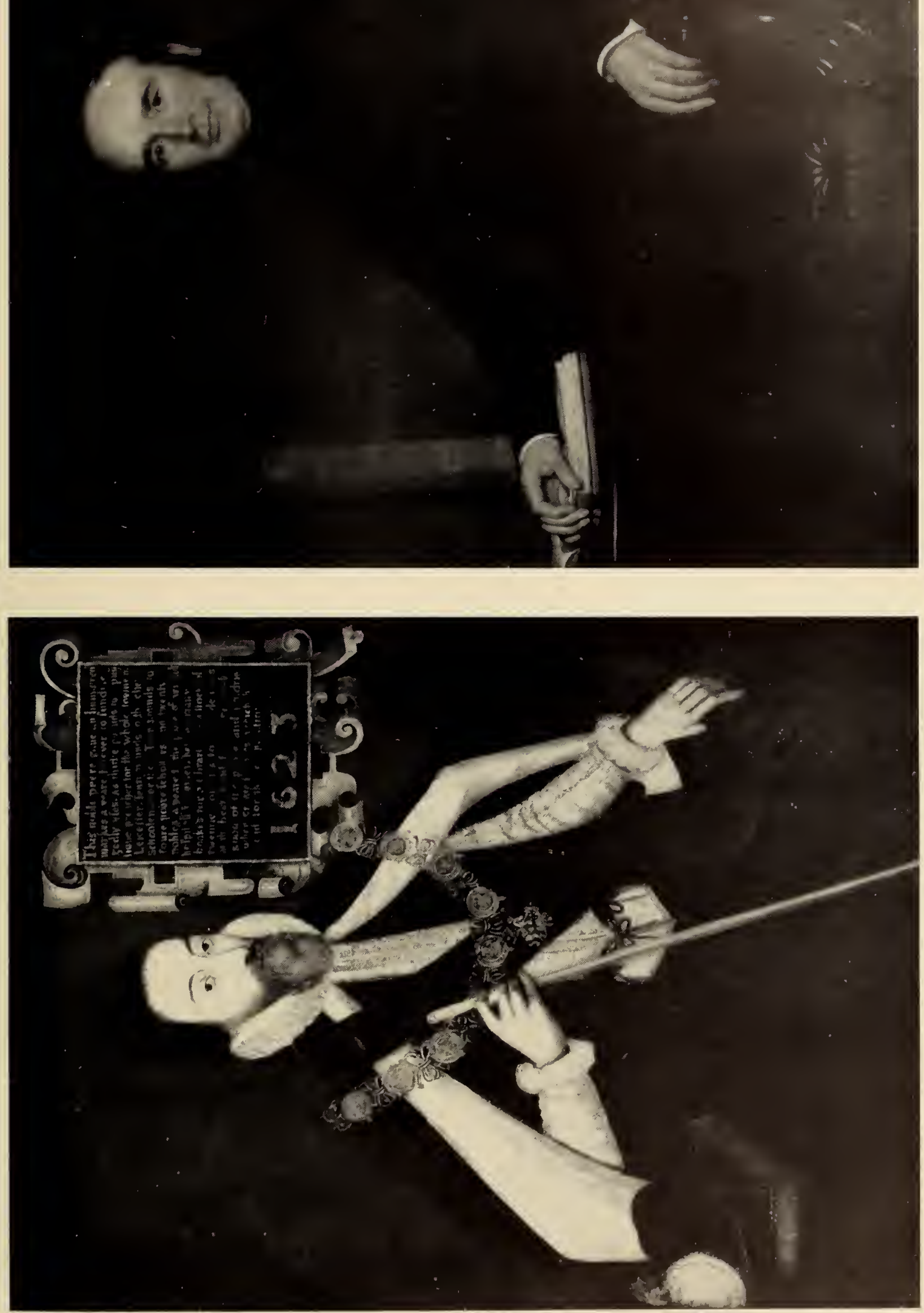

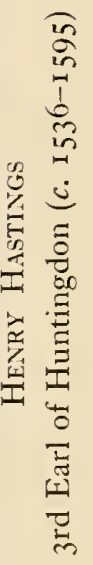



A contingent was sent to Tilbury from Leicester at the time of the Armada. ${ }^{2}$ The town also kept a stock of armour, ammunition, and weapons for the different types of service. Armour was acquired by gift and by purchase, ${ }^{53}$ and in 1607 a town armourer was employed to keep the stock clean and in good order. ${ }^{54}$ Expenses incurred in training and equipping soldiers were met by a levy from the corporation and the inhabitants at large in proportion, and the sums spent were recorded in the Chamberlains' Accounts. ${ }^{55}$

In the case of an emergency special instructions were issued. Shortly before the rebellion in the north in 1569 , the corporation ordered a levy to be raised for the purchase of ten large pikes and ten new corslets 'to serve the Quenes majestie ... if occasion shall happen'. ${ }^{56}$ 'The corporation was put to further expense and trouble by the precautions of the government. Mary, Queen of Scots, was moved from Ashby castle to Leicester and thence to Coventry in November I 569 . She was escorted by a considerable body of soldiers who were kept in the town a day and a night. 57 The army under the Earl of Warwick must have passed through Leicester a short time afterwards. ${ }^{8}$ A considerable amount of warlike stores was sent to him at Leicester and certain troops were ordered to assemble there. ${ }^{59}$ It was decided in 1570 to raise a special levy from the corporation and the inhabitants to defray the expenses incurred. ${ }^{60}$

The office of lord lieutenant was increasingly used after the rebellion. Besides the authority to hold musters in towns under the terms of his commission, he acquired a more general influence in other than strictly military matters. Especially was he prepared to take action in times of disorder, such as the anti-inclosure riots in which Leicester townsmen were involved in $1607 .{ }^{61}$ On this occasion he extorted the most humble submission from the Mayor of Leicester. He was also prepared to take the lead in the apprehension of seminary priests and expected to be consulted 'consideringe that in such cases, I houlde my aucthoritye somwhat more than any common justice amongste you'. The more ancient office of sheriff retained various duties, one of which was the execution of writs for the election of members of Parliament. As it affected Leicester, the process may be illustrated by the election of 1584 . The sheriff sent a precept dated 6 November to the mayor for the election of burgesses for the Parliament to meet on 23 November. The election took place on I 2 November and by 15 November the return had been sent to London. ${ }^{62}$

In the summer of 1642 a struggle took place in Leicestershire between the supporters of King and Parliament for the control of men and supplies. The great county families took opposing sides, Henry Hastings supporting the king, Lord Grey of Groby and Sir Arthur Hazlerigg the Parliament. Each side sought to gain possession of the county magazine at the Newarke. The corporation met a temporary ascendancy of the royalists with caution and showed no enthusiasm when the king visited the town in July. ${ }^{63}$ In August a royal letter directed the mayor to send arms and ammunition to Warwickshire, but the corporation protested that their store was too small to be worth transporting. ${ }^{64}$ In September Prince Rupert's demand of $£ 2,000$ under threat of besieging the town was met by the payment of $£, 500$, but the king disavowed his nephew's letter and the corporation was profuse in its thanks. ${ }^{65}$ Notwithstanding protestations to the contrary, Leicester seems to have admitted a parliamentary garrison some time in $1643 .{ }^{66}$ The

\footnotetext{
52 Thompson, Hist of Leic. i. 285-6.

53 Leic, Boro. Rec, I603-88, 7 I, 107.

54 Ibid. 73.

55 Ibid. I 52 ; Thompson, Hist. of Leic. i. 230.

${ }^{56}$ Leic. Boro. Rec. I509-I603, $126-7$.

57 Kelly, Royal Progresses and Visits to Leic. 290-4.

58 Ibid. 294.

59 Cal. S.P. Dom., I 547-8o, 347, 349, 354.

60 Leic. Boro. Rec. I509-I603, I $28,129$.
}

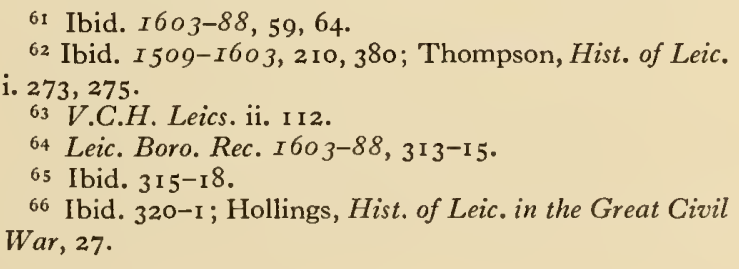




\section{A HISTORY OF LEICESTERSHIRE}

committee appointed in 1644 to defend the county included three townsmen. ${ }^{67} \mathrm{~A}$ certain amount was done to fortify the town and more vigorous preparations were undertaken when it became clear, early in I645, that Leicester was likely to be besieged. ${ }^{6}$ The town was ill provided with the means of making a prolonged defence and suffered much destruction. The town authorities were themselves plundered of the corporation insignia, as is recorded in the Town Hall Book, ${ }^{69}$ and had at once to face the problem of assisting those rendered homeless. More defensive work was undertaken after the recapture of the town from the royalists by Sir Thomas Fairfax, but in 1646 the garrison was disbanded and the defences gradually taken down. ${ }^{70}$ Colonel Edward Whalley, the major-general acting in Leicestershire, negotiated in 1656 between the town and county authorities over the licensing of a victualler in the Bishop's Fee. ${ }^{71}$

The administration of justice similarly brought the town and county authorities together. By the charters of Edward IV and Henry VII, the town had obtained the exemption of its inhabitants from appearance before the county justices and the right to appoint a recorder and its own justices of the peace and coroners. Separate sessions were thus held for the town and care was taken that the sheriff should not empanel any inhabitant to serve on his juries. Serious cases were referred by the justices of the peace to the assizes, which were held in Leicester, usually in the Newarke, but on occasion in the Town Hall. ${ }^{72}$ It is clear that the assizes were a source of profit to the townsmen, so that there was considerable disappointment when it was decided to hold them in Hinckley in I6I I because of the plague. ${ }^{73}$ This outbreak was so severe that the county justices undertook to levy rates in the county to assist the corporation of Leicester. ${ }^{74}$ The relations between the town and the county justices in the early 17 th century had not been very happy owing to differences over the I 599 charter. The town wished to secure exclusive jurisdiction in the liberties, but several county justices living in the Newarke sent a protest on the subject to Sir Robert Cecil in 1600.75 About the same time the Mayor of Leicester complained 76 to the judges that the county justices were taking advantage of the statutes 77 for the relief of poor prisoners and maimed soldiers and sailors to place unfair rating burdens on the town. As has been said, the corporation failed to obtain an extension of its jurisdiction and the problem of the liberties was left unsettled.

\section{THE BOROUGH ADMINISTRATION}

Although legal form was not given to the incorporation of Leicester until 1589 , the governing body of the town made use of the term 'corporation' before that date. Thus in $\mathbf{I} 573$ it was agreed 'by the Mayor and Comburgesses in the name of the holl Corporacion' that a new lease should be made of certain town land. ${ }^{78}$ 'The charter of $\mathrm{I} 599$ altered the style of the corporation from that of 'the Mayor and Burgesses of Leicester' to that of 'the Mayor, Bailiffs, and Burgesses' of Leicester. The corporation was declared to be a perpetual community, able to hold, receive, and grant and assign lands. It might plead and be impleaded in all courts and use a common seal.79 The government of the town was to be conducted by 24 aldermen and 48 councillors. Until I 599

\footnotetext{
67 Acts and Ords. of Interr. ed. Firth and Rait, i. 470-2.

${ }_{68}$ Leic. Boro. Rec. $1603-88,325,336$.

69 Leic. City Mun. Room, Hall Bk. 1587-1707, p. 578 .

70 Thompson, Hist. of Leic. i. 398, 400, 402. Many details are given in extracts from the Chamberlains' Accts. $1641-5 \mathrm{I}$, in ibid. App. L, 466-75.

${ }_{71}$ Leic. Boro. Rec. $1603-88,439$.

72 They were held in the Town Hall in $1611-12$ (ibid. I34) but usually in the Newarke (Hist. MSS. Com.
}

I th Rep., App. II, Cowper, ii. 339.

73 Leic. Boro. Rec. I603-88, 120.

74 Ibid. I Io, III.

75 Hist. MSS. Com. Salisbury, x. 88-89.

76 Leic. Boro. Rec. I 509-I 603, 397.

77 Acts for the relief of the poor, 43 Eliz. I, c. 2, 3.

${ }_{78}$ Leic. City Mun. Room, Hall Bk, 1553-86, p. 219.

79 See Visit. Leic. I6I9 (Harl. Soc. ii), 108-9. 
the chief officers of the ten wards had been known as aldermen, and the Twenty-four were referred to variously as the mayor's brethren, the masters of the bench, or the 'worshipful company of the Four-and-twenty'. ${ }^{80}$ The councillors were known as the company of the Forty-eight, the commonalty, or the comburgesses ${ }^{81}$ A variety of styles continued in use during the period.

The aldermen were elected from the 48 common council members and the councillors from the freemen of the town. The freedom might be acquired by birth, service as apprentice, or by gift of the corporation on payment of a money fine or a bottle of wine. ${ }^{82}$ During this period the freedom ceased to have practical meaning as admission to the Guild Merchant or Chapman Guild, and these terms and the description Brethren of the Guild gradually went out of use. ${ }^{83}$ The freemen and all corporation members and officers were required to take appropriate oaths. ${ }^{84}$ Fines were paid for refusal to serve either as alderman or councillor, resignation was allowed, and cases of dismissal are recorded for poverty and neglect of duty. ${ }^{85}$ Aldermen and councillors were subject, in some cases, to heavier penalties than the ordinary inhabitants for the infringement of the borough regulations but did not have to undergo the severer forms of imprisonment. ${ }^{86}$

It is not clear on what occasions both aldermen and councillors were summoned to the meetings of the governing body of the town known as 'common halls'. There seems to have been no by-law on the subject. Fines were payable for neglect of a summons to appear at a hall or to attend the mayor, ${ }^{87}$ and it was recorded, on occasion, that not enough persons were present for the proceedings of the hall to continue. ${ }^{88}$ From the later I 6th century it became usual to keep a note of the names of those present at the common halls from which it can be seen that decisions were regularly taken by a small number of persons. The aldermen are sometimes found acting by themselves ${ }^{89}$ and, towards the end of the period, there are references to 'courts' of aldermen. 90 In I609, the mayor, aldermen, and twenty-four seniors of the Forty-eight were authorized to make bargains with regard to the town lands. ${ }^{91}$ This recognized an earlier practice, but though commissioners for the town lands continued to be appointed, they did not become part of the regular machinery of town government. However, the 'ancients' of the two companies were often mentioned in general as persons of superior importance, as if their seniority enhanced the value of their votes..$^{92}$

There seems to be no clear record of voting at meetings of the companies until I 59I. In I 59I it was stated that a vote was taken on the proposed union of the parishes of St. Peter and All Saints by the dissentients leaving the council chamber. The majority of those present, including the mayor, remained behind. ${ }^{3}$ The importance of the mayor's vote on this occasion was made clear and it was sometimes mentioned that an issue was decided by the mayor's casting vote. ${ }^{94}$ In the 17 th century a favourite method of voting seems to have been by marking a document on which various proposed courses of action were set out.95 In $6_{59}$ it was recorded that the mayor was elected 'by tickets' which suggests some kind of ballot. ${ }^{96}$ Some lists have been preserved recording the voting in parliamentary elections. ${ }^{97}$

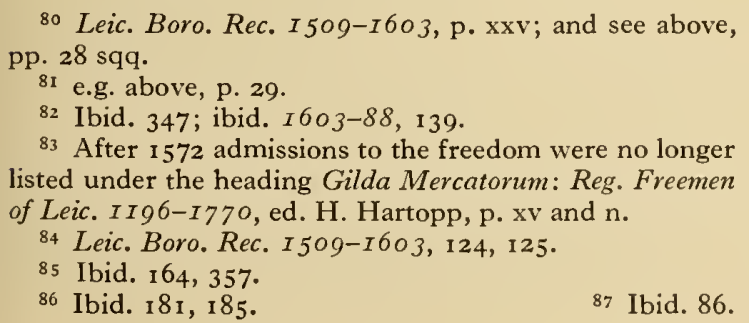

86 Ibid. 181,185 .

88 Ibid. 327.

89 Ibid. $1603-88,287$

90 Ibid. 454 .

91 Ibid. I 509-1603, I17, 324.

92 Ibid. $1603-88,452$.

93 Ibid. I 509-1603, 271 .

94 Leic. City Mun. Room, Hall Papers, I655-7, no. 319.

95 Many of these documents are preserved in the vols. of Hall Papers.

96 Leic. Boro. Rec. I603-88, 453.

97 Ibid. 419-21. 


\section{A HISTORY OF LEICESTERSHIRE}

During the later $\mathrm{I} 6$ th century regulations were made concerning the dress of the two companies. Both aldermen and councillors came to be required to wear caps and gowns at common halls, and at assizes, sessions, and fairs. ${ }^{98}$ During the same period better provision was made for the meetings of the two companies. The town authorities had used the hall of the Corpus Christi Guild both before and after its suppression by Edward VI. 99 Their right to the building was eventually secured when Robert Braham, the recorder, negotiated a purchase of the hall on behalf of the town in $1563 .{ }^{1}$ The town had already spent money on the upkeep of the hall and many charges for alterations and additions to the building may be found entered thereafter in the chamberlains' accounts. ${ }^{2}$ The hall passed into regular use as the Town Hall, while the old Town Hall seems to have been used as a store. ${ }^{3}$ Nichols suggested that the latter was the building in Blue Boar Lane known as the Old Shop, ${ }^{4}$ which was destroyed in $\mathbf{1} 645$.

The position of the chief officer of the corporation, the mayor, increased in dignity, importance, and responsibility at this time. The 1589 charter provided for his election by the two companies on St. Matthew's day. 5 'Two or more persons were nominated but there seems to have been no recognized system of rotation among the aldermen who were candidates for the office. According to James I's charter, the mayor had to take his oath at Leicester castle before the steward of the honor on the Monday following Martinmas. ${ }^{6}$ The reason for this provision was the Earl of Huntingdon's allegation that the mayor had grown slack in the performance of this obligation and that the oath had been taken in the Town Hall. ${ }^{7}$ The mayor, however, went in procession to the castle in 1609 to do as was required. ${ }^{8}$ It was possible to avoid acting as mayor by payment of a fine until 1644 when it was decided that no fine would be accepted. ${ }^{9}$ In

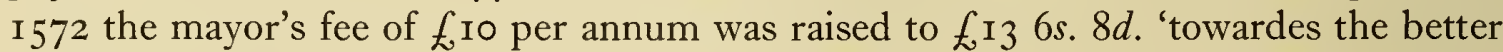
mayntenaunce of his howsse kepinge'. ${ }^{\circ} \mathrm{A}$ deputy mayor was appointed when occasion required. II

The mayor was expected to maintain a certain ceremonial dignity. In I 555 the Lord Chancellor and the Chancellor of the Duchy of Lancaster instructed him and his brethren to maintain ancient custom in dress, and in that year an 'Acte for the wearing of skarlet' was passed. ${ }^{22}$ 'The mayor was expected to wear scarlet at Christmas, New Year, Twelfth Day, Easter, Whitsun, and fair days, and to meet the judges at the assizes. Special regulations for the dress of the whole corporation were made on the occasion of royal visits to the town. ${ }^{13}$ When Samuel Wanley died in his year of office as mayor, his funeral was arranged with suitable pomp. ${ }^{14}$ It was incumbent upon the mayor to feast the corporation and to take a leading part in entertaining important visitors. ${ }^{15} \mathrm{He}$ attended church in state in the parish in which he resided. ${ }^{16}$

Two chamberlains were chosen annually, one from the Twenty-four, the other, who had precedence and was known as the town chamberlain, from the Forty-eight. They were paid $f_{\mathrm{I}}$ each, and were responsible for the whole finance of the town, including both permanent and ad hoc expenditure. ${ }^{17}$ The responsibility of the chamberlains for collecting rents was much increased during this period by the growth of the town rental produced by the acquisition of property and the falling in of expired leases. ${ }^{18}$

${ }_{98}$ Leic. Boro. Rec. I 509-I603, 382.

99 Ibid., p. xlv.

T. H. Fosbrooke and S. H. Skillington, Old Town Hall

Leic. 47, 48; see also Leic. Boro. Rec. I 509-1603, ro7-8.

2 e.g. Leic. Boro. Rec. I603-88, 293.

3 Ibid. 2 implies that it was a coal-house in 1603.

4 Nichols, Biblio. Topog. Brit. (1790), vii. 607.

5 Leic. Boro. Rec. I509-I603, 248, 249.

${ }^{6}$ Ibid. $1603-88,85$.

8 Ibid. $95,96$.

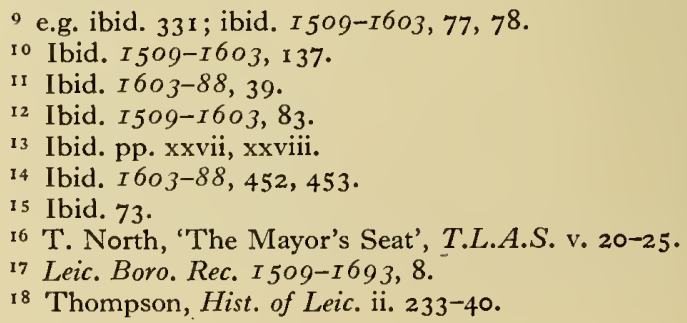


The chamberlainship was not a popular office, and in I $52 \mathrm{I}$ it was decided that no one should be able to redeem it for less than $f 5 .^{\mathrm{Ig}}$ But fines appear to have been varied by the corporation, presumably according to individual capacity to pay. ${ }^{20}$ The chamberlains were responsible for the production of an account of the borough finances, which was subject to audit and to production before a common hall on the first Friday in Lent. $^{21}$ In I 58 I it was agreed that the chamberlains should hold an annual dinner. The chamberlains carried staves. ${ }^{22}$

The official originally known as the mayor's clerk also increased rapidly in importance during this period. His position was recognized by the charter of I 599 which laid down that there should be a common clerk. ${ }^{23}$ His name was included thereafter in the annual list of corporation officers given in the Hall Book. He was also clerk of the peace and after 1572 received an annual fee of $26 s$. $8 d$. as mayor's clerk and $6 s$. $8 s$. as clerk of the peace. ${ }^{24} \mathrm{He}$ also received fees for recording admissions to the freedom, to the companies of Twenty-four and Forty-eight, and to the trade companies, and had the making of indentures of apprenticeship. The title of town clerk, originally given to the town steward, was transferred to the common clerk, who soon eclipsed him in importance, aided by the rise of quarter sessions and the decline of the leet. It can be seen that while the clerk carried out a great deal of secretarial work, such as writing out the chamberlains' accounts and the Hall Books, ${ }^{25}$ he was also employed in matters involving greater responsibility. He assisted especially with the legal business of the town and was particularly useful to the recorder. ${ }^{26}$ Matters involving the town records were referred to him. ${ }^{27}$ By the time of James I the town clerk employed a servant, ${ }^{28}$ and in ${ }^{6} 634$ it was decided that the town should provide the clerk with a gown but that this gift was to be no precedent. ${ }^{29}$

The position of the recorder was somewhat different from that of the other corporation officers. The corporation was primarily anxious to secure the services of a person whose legal qualifications and ability would be of value. The great patrons of the town frequently offered advice on the choice of a recorder. ${ }^{30}$ It was accepted that the recorder had his own interests in London and elsewhere, and his presence was only expected in Leicester on important occasions such as the election of the mayor, and at sessions and assizes. ${ }^{3 \mathrm{I}} \mathrm{He}$ was paid a fee which rose during the period from $26 s$. $8 d$. to £ $\mathrm{io}$ and frequently also his travelling expenses. ${ }^{32} \mathrm{~A}$ bedroom was provided for him in the town hall and in 579 it was decided that he should be given a scarlet gown. 33 'The recorders of Leicester have included some judges, such as Sir Augustine Nicolls, recorder from I603 to I6I2, and John Beaumont, recorder in I550, who became Master of the Rolls. It may also be noticed that the names of the recorders occur among the borough M.P.s during the I6th century. At the end of the period it appears that John Maior was employed as town solicitor from about ${ }^{6} 655$. He assisted in legal business such as the difficulty over the revenue of the Trinity Hospital ${ }^{34}$ and the suit brought against the corporation by Edward Palmer for being dispossessed from the office of town clerk. ${ }^{35}$

19 Leic. Boro. Rec. $1509-1603,18$.

20 e.g. ibid. $1603-88,272$.

21 Ibid. 355 ; ibid. $1509-1603,16$.

22 Ibid. $1509-1603,186$.

23 Ibid. 362,363 .

25 e. 1606-7.

${ }^{26}$ e.g. Leic. Boro Rec. $1509-1603,186$.

27 The records were kept in a room built for the purpose at the Town Hall. They were thrown into disorder by the king's soldiers after the capture of Leicester: ibid. 276; ibid. $1603-88,132,343,363$.
28 Leic. City Mun. Room, Chamberlains' Accts. I6067 (Roger Halfit).

29 Leic. Boro. Rec. $1603-88,277$.

30 e.g. Leic. City Mun. Room, loose Hall Papers: letter from the Earl of Huntingdon, 30 Nov. 1612.

${ }^{31}$ e.g. Leic. Boro. Rec. I509-I603, 386, 419.

32 Ibid. 8 ; cf. Chamberlains' Accts. 1605-6 (printed ibid. $1603-88,54-58)$.

33 Ibid. $1509-1603$, 195 , 180.

34 Ibid. $1603-88,434$. See p. 407.

35 Leic. City Mun. Room, Hall Papers, I 655-7, no. 395 (2 June 1657 ). 


\section{A HISTORY OF LEICESTERSHIRE}

The other corporation officers mentioned in the 1599 charter were the five sergeantsat-mace whose business was to make proclamations and arrests and to execute processes and keep the boundaries. ${ }^{36}$ The sergeants assisted the bailiff in the court of record and in 1655 it was decided, on account of the bailiff's neglect of his office, that the processes of the court should be directed to the chief sergeant-at-mace. ${ }^{37}$ The I 599 charter stated that the sergeants should be chosen by the mayor and aldermen though in ${ }_{1595}$ it had been agreed that the mayor should nominate two sergeants and the bailiff two sergeants. ${ }^{38}$ The sergeants were provided with gowns and had a fee for every prisoner committed. ${ }^{39}$ They also received a fee from the members of the Forty-eight and from those entering the freedom and the trade companies. ${ }^{40}$ Kelly has drawn attention to the fact that the position of mace-bearer was originally of some dignity, ${ }^{4}$ but about $6_{34}$ a resolution of the common hall was passed to restrain the sergeants from begging. ${ }^{2}$ The sergeants were required to attend the mayor and to carry silver-gilt maces. The town also possessed a great mace which was lost at the capture of the town by the king's army. ${ }^{43}$ There is also mention of a night mace which may have been capable of use against the disorderly. ${ }^{44}$

The position of the bailiffs has already been mentioned.45 Other annual officers not named in the charter were the coroners, stewards of the fair, auditors of accounts, and fish, meat, and leather testers. Two coroners, chosen from the aldermen who had not been mayors, held office each year, one retiring and one being appointed each year. Three stewards of the fair were usually appointed annually and three auditors of accounts for each of the four quarters of the town. Three persons were usually appointed annually as fish and meat testers and five as leather testers. The aldermen of the ten wards acted as ale testers unless they were themselves brewers. ${ }^{46}$ Special officers were occasionally appointed as ale testers. A company of waits was also maintained by the town and provided with badges and liveries. ${ }^{47}$ The waits were required to play in the town every morning and evening and to attend the mayor on special occasions. After I $58 \mathrm{I}$ they received a regular wage.$^{48}$ Other town officials were the librarian (after I633) ${ }^{49}$ and the beadle. ${ }^{50}$

According to the 599 charter, the mayor, the recorder, and the four aldermen who had last been mayor were to act as justices of the peace for the borough. Their jurisdiction had been defined by the charters of Edward IV and Henry VII'5 ${ }^{\text {I }}$ but the scope of their activities was considerably widened during this period. Particular mention may be made of the poor law regulations and of the parliamentary ordinance establishing civil marriage in $1653 .{ }^{52} \mathrm{~A}$ great deal of business was done by the mayor and one or more justices outside quarter sessions, which tended to become elaborate affairs. In 1599 it was agreed that the sessions should be held quarterly but that the mayor should give no dinner for the recorder. ${ }^{53}$ But at a later period the idea of quarterly sessions was given up, for in 1648 it was decided that at least three sessions should be held, the mayor to have $f_{\mathrm{I}} 6 s$. $8 d$. for each sessions dinner on this condition. ${ }^{44}$ From the surviving 17 th-century rolls ${ }^{55}$ two sessions appear to have been held a year, in April and September.
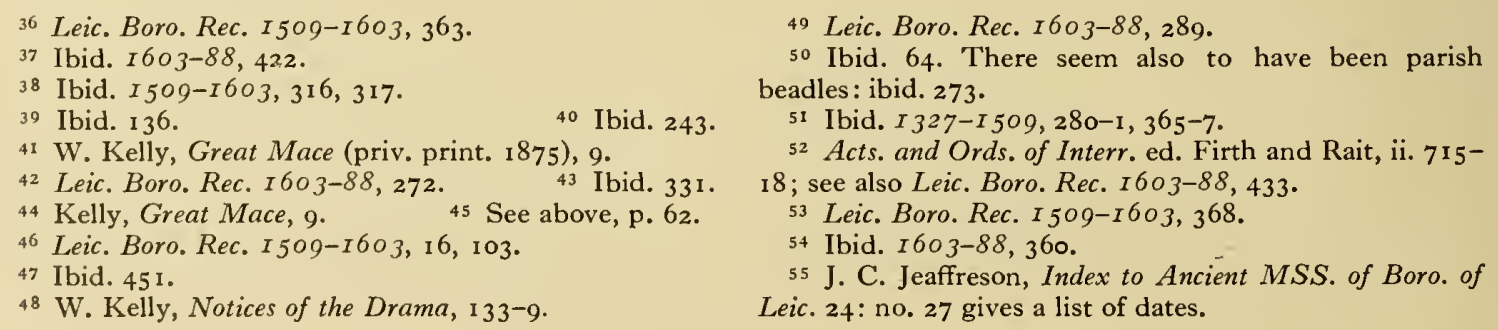
The town was divided into ten wards each placed under the supervision of an alderman. ${ }^{56} \mathrm{With}$ the assistance of their respective constables and thirdboroughs, they were responsible for carrying out various statutory and borough regulations for such purposes as taxation, defence, the preservation of public order, and the management of trade and commerce.57 Some matters depended on the co-operation of the parish officers. The constables and the overseers of the highways both had duties in connexion with the repair of the streets ${ }^{58}$ and the constables and overseers of the poor joined in the administration of the poor law. 59 The corporation had a particularly close interest in the church and parish of St. Martin ${ }^{60}$ and agreed to augment the stipend of the Vicar of St. Mary de Castro. ${ }^{6 r}$

The right of the corporation to make by-laws for the town was confirmed by the I 599 charter. An important and frequent subject of its concern was the 'policing' and maintenance of good order in the town. Regulations were made for the town to be watched at night from Ascension Day until Michaelmas, according to the Statute of Winchester, all freemen to contribute to the cost. ${ }^{62}$ The mace-bearer usually summoned the constables and thirdboroughs to receive their charge about the watch from the mayor on Ascension Eve. ${ }^{63}$ In ${ }_{1} 636$ it was ordered that one constable should perambulate the town at night to see that the watchmen were on duty.64 Penalties for being out of doors after 9 p.m. were fixed by an 'Acte for Nyght Walkers' which was passed in $\mathrm{I} 553$ and later renewed. ${ }^{65}$ Care was also taken to look out for places likely to be disorderly and in I 593 it was ordered that two of the Twenty-four and two of the Forty-eight should keep a watch on alehouses by night and day. ${ }^{66}$ Special regulations were made at times of particular disturbance or danger, as in July I642.67 A vigorous attempt was made to stem the spread of infection by preventing the movement of persons suffering from the plague. ${ }^{68} \mathrm{~A}$ watch was kept in general on lodgers and on strangers taking up residence in the town. ${ }^{69}$

Other matters with which the corporation was concerned were the upkeep of the streets, sanitation, and the prevention of fire. Regulations were made to enforce the obligation of every householder to clean and maintain the street before his house. ${ }^{70}$ Some work was done by hired labour, ${ }^{71}$ however, and building at times by contract. ${ }^{72}$ Special efforts were made on the occasion of a royal visit to the town. ${ }^{73}$ The inhabitants were liable to be presented at the court leet for leaving wood in the streets or in any way impeding the passage through them. ${ }^{74}$ In 1619 carts with iron-bound wheels were forbidden. ${ }^{75}$ Regulations were made for the disposal of dung ${ }^{76}$ and in 1588 it was decided to employ a scavenger. ${ }^{77}$ In ${ }_{5} 54$ the common wells were ordered to be kept in repair by the inhabitants of the ward or quarter in which they were placed. The aldermen were required to appoint well reeves. ${ }^{78} \mathrm{~A}$ conduit was erected in 1612,79 and in I 655 the corporation was discussing the further improvement of the water-supply. ${ }^{80}$ It was important to have a ready supply of water in case of outbreaks of fire. In I60 I it

${ }_{56}$ Leic. Boro. Rec. I509-I603, 88, 89. And see above, p. 28.

57. e.g. Leic. Boro. Rec. I 509-I603, 265; I603-88, 47 .

${ }_{58}$ Ibid. $I 603-88,274$.

59 Ibid. 246.

60 Ibid. I 509-I603, p. lxii.

${ }^{61}$ Nichols, Leics. i. 308.

62 Leic. Boro. Rec. I509-I603, 293.

${ }^{63}$ e.g. ibid. 319.

64 Ibid. $1603-88,288$

65 Ibid. $1509-1603,73,74$.

${ }^{66}$ Ibid. 293.

67 Ibid. $1603-88,313$

68 Ibid. I509-1603, I10; cf. ibid. I603-88, 224.

69 Leic. Boro. Rec. I509-I603, 102, 275, 288, 438; ibid. I603-88, 101, 206.

70 Ibid. I509-I603, I30, 163 ; ibid. $160.3-88,367$, $38 \mathrm{I}-2$.

71 Ibid. $1603-88,132-3$

72 Ibid. 294, 295.

73 e.g. ibid. $1509-1603,158$.

74 Ibid. 162.

75 Ibid. $I 603-88,186$.

76 Ibid. $1509-1603,133$.

77 Ibid. 246, 247.

${ }^{78}$ Ibid. 212

79 Throsby, Hist. of Leic. 376.

80 Leic. City Mun. Room, Hall Papers, $1655-7$, no. 40, letter to Mr. Bewdley of Coventry.

LEIC. IV 


\section{A HISTORY OF LEICESTERSHIRE}

was ordered that the aldermen should keep two leather buckets in their houses and the members of the Forty-eight should keep one, while it was agreed that a leather bucket and a hook should be kept at each of the town gates. ${ }^{81}$

The corporation exercised a general superintendence in matters of trade and commerce. An attempt was not only made to regulate the quality and prices of the goods offered for sale, but also to secure a monopoly of trade for the freemen of the town. At the end of the r6th century the corporation thus came to be involved in a protracted dispute with the glovers and fellmongers of neighbouring towns. ${ }^{82}$ Leicester was also to a great extent an agricultural community. The corporation therefore took up the defence of the freemen's right to pasture horses and cattle in the Frith, an arrangement which had been made with the Dean of the Newarke College and which had been disturbed by the inclosure of the Frith under Henry VIII. ${ }^{83}$ Disputes continued into the reign of James I despite the corporation's purchase of leases of the grange. ${ }^{84}$

The government frequently took a hand in the regulation of economic affairs. ${ }^{85}$ The question of the control of brewing and the licensing of alehouses was one of great concern to both town and state. The town sought to control wholesale brewing ${ }^{86}$ but the licensing of alehouse-keepers was dealt with by the justices and quarter sessions. ${ }^{87}$ The corporation and the government were both concerned with the number of alehouses in the town and the suppression of disorderly or unlicensed houses. ${ }^{88}$ Among the grants of monopoly made in the reign of James I, a patent for taking recognizances from innkeepers was issued to Robert Dixon and William Almond. ${ }^{89}$ This gave rise to peculation and discontent, moving the corporation of Leicester to protest against it to Sir Henry Hobart, Chief Justice of Common Pleas, in r6r8.90 The government also wished to enforce the eating of fish on fast days, and the Acts for this purpose affected the mayor's authority to license butchers to kill animals in Lent.91 Another object of the government was the enforcement of a uniform standard of weights and measures. A set of weights and measures was kept in the Town Hall and viewed periodically by the justices as the law required. ${ }^{92}$ In ${ }_{1} 578$ it was found that several were faulty. In ${ }_{5} 588$ new weights were received from the Exchequer but the town was said to be still using false ones in 1600.93

The corporation was also the guardian of the religion, education, and morals of the inhabitants. With the active and generous assistance of the Earl of Huntingdon, permanent provision was made for a town preacher, ${ }^{94}$ and in 1597 it was ordered that at least one from every house should attend the weekday sermons on Wednesdays and Fridays. 95 The alehouses were ordered to be closed in service time and butchers were forbidden to sell meat after 7 a.m. on Sundays. ${ }^{96}$ The building and endowment of the free school, to which the queen contributed, ${ }^{97}$ were no doubt intended to contribute to the instruction of the inhabitants in knowledge and orthodoxy. The execution of the poor law and the restriction of vagrancy, ill living, and contention was primarily the responsibility of the justices of the peace, ${ }^{98}$ while the town provided a cart, cuck-stool, and stocks for the punishment of those offending. ${ }^{99}$ There was also a Bridewell or house
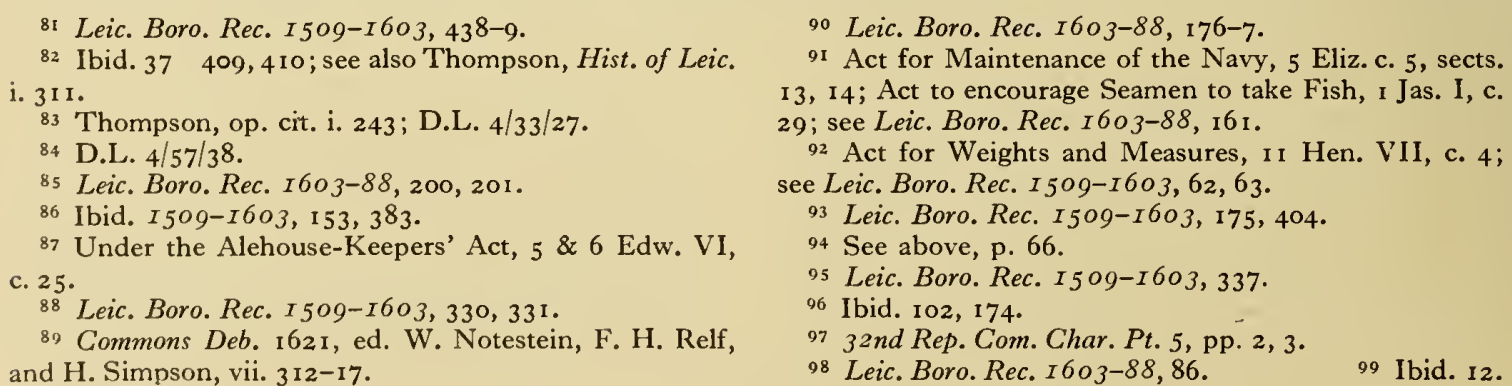
of correction, established sometime after 1604 , the inmates of which were employed in various tasks. ${ }^{\text {I }}$ Breakers of Cromwellian Sunday observance regulations were fined for the benefit of the poor. ${ }^{2}$

At the same time, much was done to relieve the material wants of the unfortunate. Various public schemes were set on foot for the distribution of doles or the provision of work for the poor. ${ }^{3}$ The corporation also became the agent for the philanthropic ambitions of many private individuals and was invested with land and money to lend or distribute in provisions. ${ }^{4}$ A notable endowment was that of Sir Thomas White, first given to Coventry in 1542 , in which Leicester came to participate. Loans from this benefaction were first distributed in Leicester in 1610.5 Institutions such as the Trinity Hospital became a favourite object of the benevolence of Leicester citizens. The mayor also had authority to take bonds from executors for the payment of legacies to orphans. This power, at first confined to the children of freemen, was extended to include the unfranchised in $1572 .{ }^{6}$ The Crown also stimulated generosity by the issue of briefs; one was issued in 1640 for the rebuilding of St. Leonard's Church, Leicester, ${ }^{7}$ and the practice was continued by Parliament, which issued an ordinance for the relief of distress in Leicester after the siege. ${ }^{8}$

The corporation of Leicester was brought into commercial and other relations with various neighbouring townships in the county. In the village of Whetstone, to the south of Leicester, it had important rights through the ownership of property. Courts were held for the corporation's tenants in Whetstone, which the mayor was allowed in 1569 to hold at his discretion. He either attended himself or sent one of the chamberlains. 9 It was possible to call upon the Whetstone tenants for assistance in times of difficulty, ${ }^{10}$ but they were also a source of trouble. The corporation might be called on to intervene in disputes between its tenants and the freeholders of Whetstone, ${ }^{\text {II }}$ while in ${ }^{6} 655$ the town solicitor was instructed to begin legal proceedings in the name of the corporation against persons who had set up a market there. ${ }^{\mathrm{I} 2}$

The period that witnessed the formal incorporation of the town of Leicester was one of great changes. The number of borough officers increased and national policy conferred many new duties upon them, while the duties of the justices of the peace and of quarter sessions grew at the expense of the other local courts. The town's estate increased by purchase and gift, and its control of charitable funds gave it influence in social activity, while at the same time increasing the complexities of government. In spite of the growth in the dignity and responsibilities of the corporation, the overlordship of the king as Duke of Lancaster remained a reality, and in political and other matters the town was, to a great extent, dependent on the good offices of local patrons who did not, on the whole, encourage the corporation's ambition to extend its authority.

A strong leaning towards Puritanism in the town was apparent from the reign of Elizabeth, the Puritan party finally gaining control after the Civil War and persisting in a firm attachment to the Protectorate. But a cleavage had been made in the ranks of the corporation, which found itself in an uneasy political position when Charles II was proclaimed in Leicester on 12 May 1660.

\footnotetext{
I Ibid. 21,267 .

2 Ibid. 408.

3 e.g. Leic. Boro. Rec. I 509-1603, 172, I 73: coals for the poor (I578). There was a scheme to lend money to a clothier to set the poor at work ( 1572 ): ibid. I 34 .

4 See below, e.g. pp. 4I I-I 2.

5 See below, p. 413.
}

\footnotetext{
6 Ibid. I 509-I603, I 04-6, I 35-6.

7 W. A. Bewes, Church Briefs, 33.

8 Ibid. 143.

9 Leic. Boro. Rec. 2509-1603, 126.

10 Ibid. 128, I 29: 4 Jan. I 570.

11 Ibid. I 86; cf. ibid. $I 603-88,254,255$.

12 Ibid. $1603-88,427$.
} 


\section{SOCIAL AND ECONOMIC HISTORY}

\section{$15 \mathrm{O} 9-166 \mathrm{O}$}

TEICESTER in the 16 th and 17 th centuries was a country town with a population of about 3,000 in $1509,3,500$ in 1600 , and probably not much less than 5,000 in I660. Its area was rather over 100 acres, and it was surrounded by open fields, 1 pastures, and the oaks and ashes of the forest. ${ }^{\mathrm{I}}$

The occupations of the people, as stated on the admission of freemen, are set out in Table I. While not without interest, they do not constitute a census of real occupations. First, the occupation entered by the freeman is not always given. Sometimes social

\section{TABLE I}

Admissions of Freemen, $1520-1660^{2}$

\begin{tabular}{|c|c|c|c|c|c|c|c|c|c|c|c|c|c|c|c|}
\hline \multirow{2}{*}{\multicolumn{2}{|c|}{$\begin{array}{l}\text { Occupations according to } \\
\text { the admission register }\end{array}$}} & \multicolumn{7}{|c|}{ Numbers } & \multicolumn{7}{|c|}{ Percentages } \\
\hline & & $\begin{array}{l}0 \\
\text { 1े } \\
0 \\
\text { on } \\
\text { ñ }\end{array}$ & $\begin{array}{l}0 \\
\text { in } \\
0 \\
\text { in } \\
\text { nd }\end{array}$ & $\begin{array}{l}9 \\
1 \\
0 \\
0 \\
0 \\
i \\
-1\end{array}$ & $\begin{array}{l}y \\
0 \\
0 \\
-1 \\
1 \\
0 \\
0 \\
\text { in } \\
-1\end{array}$ & $\begin{array}{l}n \\
0 \\
1 \\
1 \\
0 \\
0 \\
0\end{array}$ & $\begin{array}{l}7 \\
7 \\
1 \\
-1 \\
y \\
0 \\
0 \\
-1\end{array}$ & $\begin{array}{l}1 \\
6 \\
1 \\
7 \\
7 \\
0 \\
-1\end{array}$ & $\begin{array}{l}9 \\
\text { i } \\
1 \\
0 \\
\text { in } \\
\text { in }\end{array}$ & $\begin{array}{l}0 \\
\text { nे } \\
1 \\
0 \\
7 \\
\text { in } \\
n-1\end{array}$ & $\begin{array}{l}0 \\
1 \\
0 \\
0 \\
\text { in } \\
1\end{array}$ & $\begin{array}{l}4 \\
0 \\
0 \\
1 \\
1 \\
0 \\
0 \\
i n \\
-1\end{array}$ & $\begin{array}{l}n \\
0 \\
1 \\
1 \\
0 \\
0 \\
0 \\
-1\end{array}$ & $\begin{array}{l}7 \\
7 \\
1 \\
n \\
0 \\
0 \\
-1\end{array}$ & $\begin{array}{l}-1 \\
0 \\
1 \\
7 \\
7 \\
0 \\
-1\end{array}$ \\
\hline Wholesale trade (Merchant & & 2 & 2 & 0 & 3 & 4 & 5 & I9 & $I \cdot 3$ & $I \cdot 9$ & 0.0 & 0.8 & 0.9 & $I \cdot 4$ & 4.7 \\
\hline Retail trade & . & 14 & 19 & 46 & 53 & 69 & 56 & $5 I$ & $9 \cdot 3$ & I $8 \cdot 4$ & I 6.4 & $13 \cdot 4$ & $16 \cdot 0$ & $16 \cdot 0$ & $12 \cdot 6$ \\
\hline Leather Crafts . & . & $3 I$ & 33 & $68 \frac{1}{2} *$ & 100 & 75 & $6_{3}$ & $5+$ & 20.5 & $32 \cdot 0$ & $24 \cdot 5$ & $25 \cdot 3$ & I $7 \cdot 3$ & I $8 \cdot 0$ & I $3 \cdot 4$ \\
\hline Textile Crafts, \&c. & & 35 & 4 & $6 I$ & 60 & 80 & 57 & 56 & $23 \cdot 2$ & $3 \cdot 9$ & $2 I \cdot 7$ & $15 \cdot 3$ & $18 \cdot 5$ & $16 \cdot 2$ & 13.9 \\
\hline Victualling Crafts & . & $3^{8}$ & 25 & 45 & 74 & 78 & 64 & 82 & $25 \cdot 2$ & $24 \cdot 3$ & I $6 \cdot I$ & I $8 \cdot 7$ & $\mathrm{I} 8 \cdot \mathrm{I}$ & $18 \cdot 2$ & $20 \cdot 3$ \\
\hline Woodworking, \&c. & - & 5 & 6 & I 7 & 23 & 37 & 28 & 32 & $3 \cdot 3$ & $5 \cdot 8$ & $6 \cdot 1$ & $5 \cdot 7$ & $8 \cdot 6$ & $8 \cdot 0$ & $7 \cdot 9$ \\
\hline Metalworking . & . & IO & I & I $6 \frac{1}{2} *$ & $3 I$ & 27 & 22 & 27 & $6 \cdot 6$ & I.O & $5 \cdot 9$ & $7 \cdot 8$ & $6 \cdot 3$ & $6 \cdot 3$ & $6 \cdot 7$ \\
\hline Housing, furnishing, \&c. & $\bullet$ & 7 & 7 & 17 & 32 & 48 & 27 & 64 & $4 \cdot 6$ & $6 \cdot 8$ & $6 \cdot 1$ & $8 \cdot 1$ & I I $\mathbf{I}$ & $7 \cdot 7$ & $15^{\cdot 8}$ \\
\hline Arms Crafts & . & 5 & 0 & I & I & 0 & $\circ$ & 2 & $3 \cdot 3$ & 0.0 & 0.3 & 0.3 & 0.0 & 0.0 & 0.5 \\
\hline Husbandry, \&c. . & & $\circ$ & 2 & 3 & 2 & o & 4 & 2 & 0.0 & $2 \cdot 0$ & $I \cdot I$ & 0.5 & 0.0 & $I \cdot I$ & 0.5 \\
\hline Services, Professions, \&c. & . & 4 & 4 & 5 & I6 & I 4 & 25 & I 5 & $2 \cdot 7$ & $3 \cdot 9$ & $\mathrm{I} \cdot 8$ & $4 \cdot I$ & $3 \cdot 2$ & $7 \cdot 1$ & $3 \cdot 7$ \\
\hline Total & - & I 5 I & 103 & 280 & 395 & 432 & $35^{\mathrm{I}}$ & 404 & 100 & 100 & 100 & 100 & 100 & 100 & 100 \\
\hline
\end{tabular}

* One man had two occupations ascribed to him.

status is given, but this is no indication of occupation. Edward Glossop, yeoman, was not engaged in farming. ${ }^{3}$ Henry Mosley was described indifferently as yeoman or weaver. ${ }^{4}$ Thomas Swan, yeoman, was a miller as well as a farmer. ${ }^{5}$ Henry Slater, yeoman, was a maltster. ${ }^{6}$ Thomas Thompson, labourer, was a maltster. 7 Thomas Biggs, labourer, was a hosier. ${ }^{8}$ Mrs. Alice Gilbert, widow, was a substantial business woman. ${ }^{9}$ Gilbert Fawsitt the elder, gentleman, was a working saddler. ${ }^{10}$ Bartholomew Gracedue,

I D. Charman, 'Wealth and trade in Leic. in the early I6th cent.', T.L.A.S. xxv. 72-74; J. Throsby, Hist. of Leic. 22, 409; Leic. Boro. Rec. I509-I603, pp. xvi-xvii; I $603-88$, 19, 232; C. J. Billson, 'Open Fields of Leic.', T.L.A.S. xiv. 2 sqq.; C. D. B. Ellis, Hist. in Leic. 82; Assoc. Archit. Soc., Rep. and Papers, xxiii. 240-I ; S.C. I2/10/I I ; D.L. 44/7I I.

${ }^{2}$ Reg. of Freemen of Leic. II96-I770, ed. H. Hartopp,
65 sqq., 369 sqq., 535 sqq.

3 L.R.O. Probate Rec. Inv. of Edw. Glossop, I 558.

4 Ibid. Will and Inv. I 580 ; Reg. Freemen of Leic. I I96I770, 68 .

5 L.R.O. Probate Rec. Inv. I630/122.

6 Ibid. Inv, I 632/I I 6; Wills, I 632/124.

7 Ibid. Inv. I638/1 I2. 8 Ibid. Inv. I 633/69.

9 Ibid. Inv. I6 $45 / 7$. 10 Ibid. Inv. $1646 / 8$ (box 46 ). 
yeoman, was a glover. ${ }^{\mathrm{II}}$ William Chamberlin was a gentleman-woollen draper. ${ }^{\mathrm{I2}}$ Thomas Blount, gentleman, was a cultivating grazier with most of his money in good bonds and desperate debts. ${ }^{13}$ William Sherman, gentleman, left nothing at his death to indicate his occupation. ${ }^{14}$ Widow Anne Launder ran a pewterer's business, ${ }^{15}$ and Elizabeth Trickton, widow, an upholsterer's. ${ }^{16}$ Style was no guide to occupation and no sure guide to class. Secondly, it cannot be assumed that sons necessarily followed in their fathers' footsteps. Thomas Johnson was a cooper, but his third son was admitted as a chapman. ${ }^{17}$ Roger Warner was admitted as a labourer, but was the third son of a blacksmith. ${ }^{18}$ The eldest son of one currier became a maltster, ${ }^{19}$ as did that of a grazier. ${ }^{20}$ The figures of Table I, however, assume that sons followed their fathers' trade in some few cases, so that tolerance must be allowed for error. Thirdly, the guilds that men entered did not always indicate their real business activity. Richard Barnes, vintner, bought and sold wool as well as wine. ${ }^{21}$ Thomas Keckwick, fishmonger, was a farmer. ${ }^{22}$ Richard Byllyng was a member of the haberdashers' company, but an ironmonger. ${ }^{23}$ John Freake, butcher, was a grazing butcher and a cultivator. ${ }^{24}$ Richard Swan, who belonged to the fishmongers' occupation, was a grazier and part-time gaoler. ${ }^{25}$ John Launder was a pewterer who had most of his capital invested in malting. ${ }^{26}$ John Palmer, baker, was mainly interested in brewing and dairying. ${ }^{27}$ John Blackshawe was indeed a tanner, but most of his stock was in linen yarn. ${ }^{28}$ William Ludlam the butcher had no slaughterhouse or shop and was probably a grazing butcher. ${ }^{29}$ John Boxall, admitted as a beer brewer, was occupied in distilling. ${ }^{30}$ Richard Springthorpe, whittawer, was chiefly concerned with grazing. ${ }^{31}$ Henry Peale the elder, blacksmith, had twice as much invested in farming as in his craft. ${ }^{32}$ Sampson Pougher, made free as a jersey comber, was a well-to-do hosier six years later. ${ }^{33}$ Charles Robinson made his entry as a fellmonger and parchment maker in 1653 , and was described as a fellmonger by the appraisers of his inventory, from which, however, it is plain that he was a fletcher. ${ }^{34}$ John Ludlam was described in his inventory as a tallow chandler and had gained his freedom as such, but most of his capital was invested in hosiery. ${ }^{35}$ Richard Johnson, who was engaged in malting for the most part, was still described as a fellmonger at his death. ${ }^{36}$ Lastly, only some of the adult male population were freemen of the borough. Of 4 ig male testators, 253 were free and I 66 unfree. Hence attention must be paid to the businesses and occupations revealed by testamentary inventories, ${ }^{37}$ less comprehensive but more accurate than the admission register in this regard. These occupations are set out in Table II.

Nine merchants of the Staple were admitted to the freedom of the borough between

II Ibid. Inv. 1646/30 (box 698); Reg. Freemen of Leic. II96-I770, III.

${ }_{12}$ L.R.O. Probate Rec. Inv. I649/5r; Wills, I 649/49.

13 Ibid. Inv. 1663/129 (box I127).

14 Ibid. Inv. I663/129; Wills, $1664 / 39$ (the will is dated I66r).

15 Ibid. Inv. I669/206.

16 Ibid. Inv. $1675 / 111$.

17 Ibid. Inv. 1627/75; Reg. Freemen of Leic. II $196-1770$, I I I.

${ }_{18}$ L.R.O. Probate Rec. Inv. 1638/233; Reg. Freemen of

Leic. II96-x770, II6.

19 L.R.O. Probate Rec. Inv. 1666/26; Reg. Freemen of

Leic. II96-I770, 102.

${ }_{20}$ L.R.O. Probate Rec. Inv. 1675/88; Reg. Freemen of

Leic. II96-I770, 145 .

${ }_{21}$ C. $3 / 464 / 77$.

22 L.R.O. Probate Rec. Inv. 1558.

23 Ibid. Inv. $156 \mathrm{I}$.

24 W. G. Hoskins, Essays in Leics. Hist. I I 7-22.

25 L.R.O. Probate Rec. Inv. I 595.

26 Ibid. Inv. $1625 / 57$.

27 Ibid. Inv. $1627 / 83$.

28 Ibid. Inv, I627/107.

29 Ibid. Inv. $1628 / 24 \mathrm{I}$

30 Ibid. Inv. $1632 / 16 \mathrm{r}$; Reg. Freemen of Leic. I196I770, II2.

${ }_{31}$ L.R.O. Probate Rec. Inv, $1638 / 129$.

32 Ibid. Inv. 1639/101.

${ }_{33}$ Ibid. Inv. I661/52; Reg. Freemen of Leic. I I 96-I 770 , I 39 .

${ }_{34}$ L.R.O. Probate Rec. Inv. 1663/7; Reg. Freemen of Leic. $I 196-1770,136$.

${ }_{35}$ L.R.O. Probate Rec. Inv. 1669/37; Reg. Freemen of Leic. II96-I770, 9I, 100, I4I.

${ }^{36}$ L.R.O. Probate Rec. Inv. I671/4; Reg. Freemen of Leic. II96-1770, 134, I48.

37 The inventories examined for this article are those in L.R.O.; i.e. those concerning probates in the Archdeacon of Leicester's court or in Leicestershire peculiar courts. 


\section{TABLE II}

Occupations According to Inventories ${ }^{38}$

\begin{tabular}{|c|c|c|c|c|c|c|c|c|c|c|c|}
\hline \multirow[b]{2}{*}{ Occupations } & & & & \multicolumn{4}{|c|}{ Numbers } & \multicolumn{4}{|c|}{ Percentages } \\
\hline & & & & 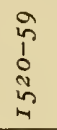 & $\begin{array}{l}\text { a } \\
i \\
0 \\
i \\
i \\
-1\end{array}$ & $\begin{array}{l}9 \\
1 \\
8 \\
\dot{1} \\
i\end{array}$ & 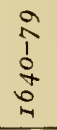 & 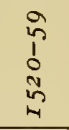 & $\begin{array}{l}9 \\
i \\
1 \\
0 \\
i \\
i n\end{array}$ & $\begin{array}{l}\stackrel{0}{0} \\
! \\
\vdots \\
\stackrel{\circ}{-1}\end{array}$ & 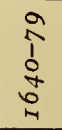 \\
\hline Wholesale trade (Merchants) & & . & . & 2 & $\circ$ & 0 & 2 & 4.4 & 0.0 & 0.0 & I.5 \\
\hline Retail trade . & . & . & . & 4 & 4 & 10 & 13 & $8 \cdot 7$ & $6 \cdot 2$ & $1 I_{4}$ & 10.1 \\
\hline Leather Crafts & . & . & . & I0 & 12 & 22 & 9 & $21 \cdot 7$ & I 8.8 & $25 \cdot 0$ & $7 \cdot 0$ \\
\hline Textiles, \&c. & . & . & - & 2 & 12 & II & 24 & 4.4 & 18.7 & $12 \cdot 5$ & $18 \cdot 6$ \\
\hline Victualling Crafts & . & . & . & $\circ$ & 9 & 12 & 24 & 0.0 & $14 \cdot 1$ & $13 \cdot 6$ & $18 \cdot 6$ \\
\hline Woodworking . & . & . & . & 3 & 2 & 3 & 7 & $6 \cdot 5$ & $3 \cdot 1$ & $3 \cdot 4$ & $5 \cdot 4$ \\
\hline Metalworking . . & . & . & . & I & 3 & 5 & 13 & $2 \cdot 2$ & $4 \cdot 7$ & $5 \cdot 7$ & IO. I \\
\hline Housing, furnishing, \&c. & . & . & . & 3 & 6 & 3 & 9 & $6 \cdot 5$ & $9 \cdot 4$ & $3 \cdot 4$ & $7 \cdot 0$ \\
\hline Arms Crafts & . & . & . & I & I & $\circ$ & I & $2 \cdot 2$ & $I \cdot 6$ & 0.0 & 0.8 \\
\hline Husbandry, \&c. & . & . & . & I4 & 12 & 14 & 21 & 30.4 & $18 \cdot 7$ & $15 \cdot 9$ & $16 \cdot 3$ \\
\hline Services, Professions, \&c. & $\cdot$ & - & . & 6 & 3 & 8 & 6 & 13.0 & 4.7 & $9 \cdot \mathrm{I}$ & $4 \cdot 6$ \\
\hline Total . & . & . & . & 46 & 64 & 88 & 129 & 100 & 100 & 100 & 100 \\
\hline
\end{tabular}

I 475 and I 535.39 The most famous merchant of the Staple of the early I 6 th century was William Wigston the younger. Others of his family had been members of the guild merchant and woolmongers, collecting wool for sale to the staplers. ${ }^{40}$ When Wigston died in 1536 his goods and chattels, including sperate debts, were valued at $f_{\mathrm{I}} \mathrm{I}, 024$. In the wool chambers at his house in the Newarke he had 50 stone of middle wool and 3 I stone of good, together with I, I00 ells of packing canvas. At Calais were 16 sarplers

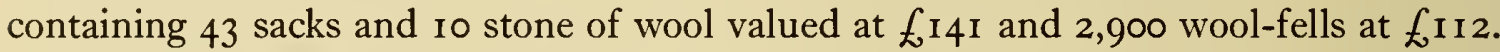
Among his sperate debts was one of $£ 40$ owed by the Earl of Huntingdon. In all they amounted to over $£^{234}$. Even greater were Wigston's desperate debts (mostly owed by men of Antwerp, Mechlin, Leyden, Bruges, and Delft) which totalled over $f_{2}, 2,33$. Moreover Wigston owed over $£_{14} 6$, including $£_{20}$ for images bought in Flanders. His real assets were less than $£_{\mathrm{I}, 000}$ and his export business was in disorder. His manors and lands were granted to the hospital of his foundation.4I It would seem that none of the staplers following Wigston attained great wealth, not even Thomas Davenport, who succeeded to his business, ${ }^{42}$ and the Boithes, at least, appear to have been financially embarrassed.43 A stapler named Vyllers took up the freedom in 1583 and was elected to the Forty-eight and the Twenty-four, ${ }^{44}$ but the day of great wool exporters was over.

In the early $17^{\text {th }}$ century Leicester was appointed one of the home wool staples, a hall was erected near Causeway Lane for the sale of wool, flax, and forage, and the borough made efforts to induce wool-growers to use these facilities and help meet the demand of local and northern clothiers. 45 Wool grown locally supplied Leicester as well as more distant markets, on the basis of direct sales by farmers to clothiers. In the neighbourhood many farmers and graziers produced wool and the needs of craftsmen could be met largely by Leicester and its environs, often by direct sale. ${ }^{46}$ There were, however, woolmongers. Richard Ynge was dealing in pelt, fleece, and refuse wool in I 557. He left only just under $£_{21}$ worth of goods and chattels of which slightly more than $f_{12} 2$ was in wool.47 In the later 17 th century this small-scale trade was frequently

\footnotetext{
38 See all inventories cited in footnotes and Reg. Freemen of Leic. I $Y 96-r 770$ (see entries in index).

39 T.L.A.S. xxv, 96.

$40 \mathrm{~J}$. Thompson, Hist. of Leic. i. 204-5, 220-I.

41 Wyggeston Hosp. Rec. 39 sqq.

42 T.L.A.S. vi. 2 I 6, 219; H. Hartopp, Roll of Mayors of Leic. 64 .
}

43 Req. $2 / 176 / 45 ;$ Req. $2 / 179 / 46$.

44 Leic. Boro. Rec. I 509-1603, 193.

45 Thompson, Hist. of Leic. ì. 309-10, 345-6; Leic. Boro. Rec. $1603-88$, pp. xli, 86, 170-2.

46 See below, pp. 99 sqq.

47 L.R.O. Probate Rec. Inv. 1557. 
conducted by the fellmongers, some of whom dealt also in leather and corn. Two such traders who died in 1647 left goods and chattels valued respectively at $£ 209 s .4 d$. and

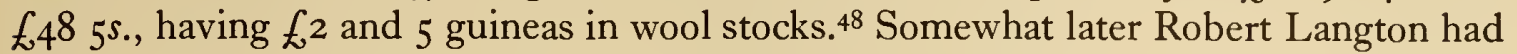
$£ 6$ invested in wool and leather out of $£ 30$ I 3 s. rod. and Richard Johnson $£$ ro in wool as a sideline to cornmongering. ${ }^{49}$ Richard Barnes the vintner employed William Dowell, a Lutterworth woolman, as his factor in wool-gathering. ${ }^{0}$ Those who purchased woolfells were able to sell fell wool, and glovers and fellmongers were, indeed, subject to the same ordinal. Richard Leydebeater, a glover, left 5 stone of best wool valued at $£_{1}$ 2s. 8d., 3 stone of middle cast at Ios., and 4 stone of the worst at 8s.51 Another glover, Richard Bristowe, had $\mathrm{I}_{3}$ stone of wool worth $\mathrm{f}^{2.5^{2}}$ John Hull, nominally a glover, could dispose of 8 tod of short wool worth $£_{5}$ I $2 s$. and 3 of long worth $£_{2} \mathrm{I}_{3}$ s. $4 d .53$ Richard Springthorpe, a whittawer, had wool and locks from fells that might have been purchased or might have come from some of his own sheep. ${ }^{44}$ Thus the wool trade continued without giving rise to wealthy merchants like those who had previously engaged in wool exports.

Cornmongers are named in neither the inventories nor the register of freemen, but in I 586 Richard Markbie was described as a badger who bought corn at Melton and Uppingham for sale in Leicester market. John Hunt, a cheesemonger, bought malt at Stamford and elsewhere. He made weekly purchases of corn in Leicester and district and sold it where he bought cheese. John Davie conducted a similar trade. Among other licensed badgers were Gregory Kinge and Edward Browne the cobbler. ${ }^{55}$ In I6 22 a great maltster was presented for buying wheat at the Corn Wall at the rate of a cartload a day and for carrying malt from Melton to Hinkley and Bosworth, so passing it from Leicester market. A mercer, a widow, and a gentleman were presented for similar unlicensed activities. ${ }^{5}$ Some years later others were charged with buying barley in the country and forestalling the market. ${ }^{57}$ Richard Johnson the fellmonger had $f 40$ worth of malt and $£ 35$ in a crop upon the ground that he could hardly have grown himself since he had no farm stock or implements. ${ }^{58}$ Larger stocks were employed in the corn than in the wool trade, but no great merchants emerged.

Perhaps typical of the early I 6th-century draper was Richard Beeston who left goods and chattels in I53 I to the value of $f_{140}$ I $6 s$. $8 d$., about half this being in cash and debts and only $\AA^{6}$ in shopware. 59 Such businesses were concerned with linens and woollens, sometimes combined with the sale of hosiery. ${ }^{60}$ From about the third quarter of the century, however, the term draper was dropped in favour of 'linen draper' and 'woollen draper', presumably because the occupation divided.6I William Gillot, a woollen draper who died in ${ }_{5} 80$, was a man of substance, leaving goods and chattels valued at $£ 467$ ios. In I 57 I -2 he had been mayor and was styled 'master'. He owned two houses, the one in which he lived having 15 rooms. In his shop and the chamber above it he had woollen cloth to the value of $f_{\mathrm{I}} \mathrm{g} 8$ Ios., and the shop fittings alone were worth several pounds. He brewed his own beer and stored it in his own beer cellar. In his garret he had 20 slippings of yarn worth $£ 3$. Besides wood and hogs in the yard, he

48 Ibid. Inv. I647/14, I8, 60 of Robert Wingfield and Robert Langton.

49 Ibid. Inv. I670/238; Inv. $167 \mathrm{r} / 4$.

50 C. $3 / 464 / 77$.

51 L.R.O. Probate Rec. Inv. I535; Leic. Boro. Rec. $1509-1603$, p. xxxix.

${ }_{52}$ L.R.O. Probate Rec. Inv. 1538.

53 Ibid. Inv. 1584 .

54 Ibid. Inv. $1638 / 129$.

55 Leic. City Mun. Room, press 22, box 17, no. I.

${ }_{56}$ Ibid. Quarter Sessions R. 21 April ro Jas. I, 1612 (on
R. for I 609).

57 Ibid. Quarter Sessions R. 26 Sept. 2 Chas. I, I626.

58 L.R.O. Probate Rec. Inv. I67 I/4.

59 Ibid. Inv. 1531.

60 Ibid. Will of Ralph Garrett, I 535 ; Leic. Boro. Rec. I 509-I603, 242-3.

6I Leic. Boro. Rec. I 509-I603, 306, 309, 328 ; L.R.O. Probate Rec. Will of John Parr, c. I562; Will and Inv. of William Gillot, 1580 ; Inv, of Thomas Bennett, I $648 / 28$, William Chamberlin, I649/51 ; Will of William Chamberlin, I 649/49 and see above, p. 76, n. 2. 
kept at St. Peter's Vicarage, which he leased, 2 geldings, a mare, a foal and a filly, I 5 sheep and 5 beasts, from which he supplied his milk-house and cheese-chamber. Over and above this he had debts to the value of $£_{1} 40 .{ }^{62}$ Another woollen draper, however, Thomas Bennett, left only $£ 39 s$. $6 d$. in 1648.63 Next year William Chamberlin, gentleman, a retired woollen draper, left goods worth almost $£_{\mathrm{I}} 48 .{ }^{64}$

Mercers were numerous in the I 7 th century when the town's usual complement was about nine. ${ }^{65}$ 'They did not confine themselves to mercery. About I620 the mercers' occupation swallowed up the linen drapers' and grocers'. As both sugarers and pepperers had previously merged with the grocers, the mercers' occupation emerged as a powerful amalgamated company, overshadowing those of the woollen drapers and haberdashers of hats. ${ }^{66}$ This amalgamation was the logical consequence of combined trade in mercery, grocery, and linens. The later mercers dealt in linens, silks, mercery, haberdashery, grocery, hosiery, tobacco, paper, strong waters, and other goods. ${ }^{67}$ From the side of the old grocers, this transition may be traced through the inventories. When William Ward the grocer died in I 558 his goods and chattels were worth $£_{1} 67$ I 2s. $4 d$., of which £ 106 I6s. Iod. was stock-in-trade. Of this sugar and grocery amounted to $f_{5} 7 \mathrm{~s} .4 d$., three pieces of broad russet to $£ 3$ I 8 s., a piece of English worsted to $£ 2$, and 2 cwt. of madder to $48 s$. He also sold hops, honey, sackcloth, narrow russets, holland, starch, spectacles, and straw hats. ${ }^{68}$ Mercers and grocers had originally dealt in their own wares separately and for this reason the inventories distinguish between grocery, mercery, drapery, and haberdashery wares, even when these were all handled by one following the mercers' occupation. ${ }^{69}$ Richard Hilton, who died in 1574 with an inventory of only $£ 37$ odd, deált in canvas, herefords, minsters, ghentish, carrel, mockado, russets, sackcloth, points, silks, cards, gloves, lace, thread, girdles, paper, brushes, leather laces, pins, cotton wool, pepper, saffron, cloves, nutmeg, almonds, rice, aniseed, brimstone, starch, sugar, prunes, treacle, currants, liquorice, and other commodities. ${ }^{70}$ William Manbie, a grocer, dealt in hats, mercery, haberdashery, grocery, linens, hemp, soap, packthread, honey, and other goods. He had in addition considerable stocks of malt, rye, and barley, and leased a close at Abbey Gate for his dairy and stables, leaving goods and chattels valued at $£ 359 .{ }^{71}$ Thus grocers developed into mercers. The name grocer, however, survived as late as 1632 , when James Fox was styled grocer, although he had been admitted to the mercers' company in 1629. Similarly William Stanley, who became free as a grocer in I 583-4, was called a mercer from I $595^{-6}$ onwards. ${ }^{72}$ Robert

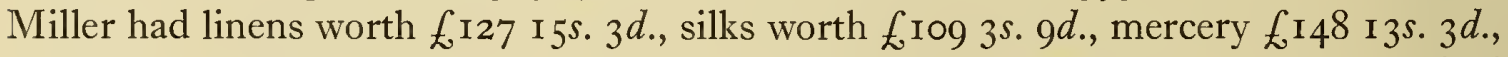
haberdashery $f_{8}$ I I os. $3 d$., grocery $f_{64}$ ios. $6 d$., and hosiery $f_{20} 4 s .9 d$. Also he had shops in Lutterworth and Melton with stocks valued at $f_{8} 863^{s} .7 d$. and $£_{20} 9^{s}$. I d. respectively; and a stock of hose at London worth $£_{\mathrm{I}} \mathrm{I}$. In spite of the fact that $£ 327 \mathrm{I} 4 \mathrm{~s} .9 \mathrm{~d}$. of his debts were doubtful or desperate, Miller could afford to live in style. The comfortable circumstances of James Andrew are shown by the contents of his study. Stocks continued to be heterogeneous. Nathaniel Brokesby sold, among other things, silks, silver lace, silk and cotton ribbons, buttons, taffety, tabby, calico, canvas, dimity, buckram, tobacco, flax, soap, oil, leather, and coloured skins. In I666 Robert Herrick was buying cotton goods wholesale from Manchester, where he had $£ 55$ in ready money.

62 Ibid. Will and Inv. of William Gillot, $1580 ;$ Reg. Freemen of Leic. I I96-1770, 79.

${ }_{63}$ L.R.O. Probate Rec. Inv. $1648 / 28$.

64 Ibid. Inv. $1649 / 51$.

${ }_{5}$ Leic. Boro. Rec. I603-88, 17, 97, 390-1.

${ }^{66}$ See above, p. 76, n. 2.

67 L.R.O. Probate Rec. Inv, of Robert Miller, $1632 / 149$, Nathaniel Brokesby, I663/54, Jas. Fox, 1667/89, Thomas

\footnotetext{
Sturges, I669/5; Leic. Boro. Rec. 1603-88, 268.

68 L.R.O. Probate Rec. Inv. of Wm. Ward, 1558.

69 See e.g. ibid. Inv, of Wm. Manbie, 1586.

70 Ibid. Inv. of Ric. Hilton, 1574.

71 Ibid. Inv, of Wm. Manbie, 1586.

72 Leic. Boro. Rec. I603-88, 268; Reg. Freemen of Leic. $1196-1770,93, \times 17$.
} 
Samuel Marshall, like many other mercers, ${ }^{73}$ had a stall in the Market Place in addition to his shop. The mercers, an analysis of whose inventories will be found in Table III,

TABLE III

Leicester Mercers' Inventories ${ }^{74}$

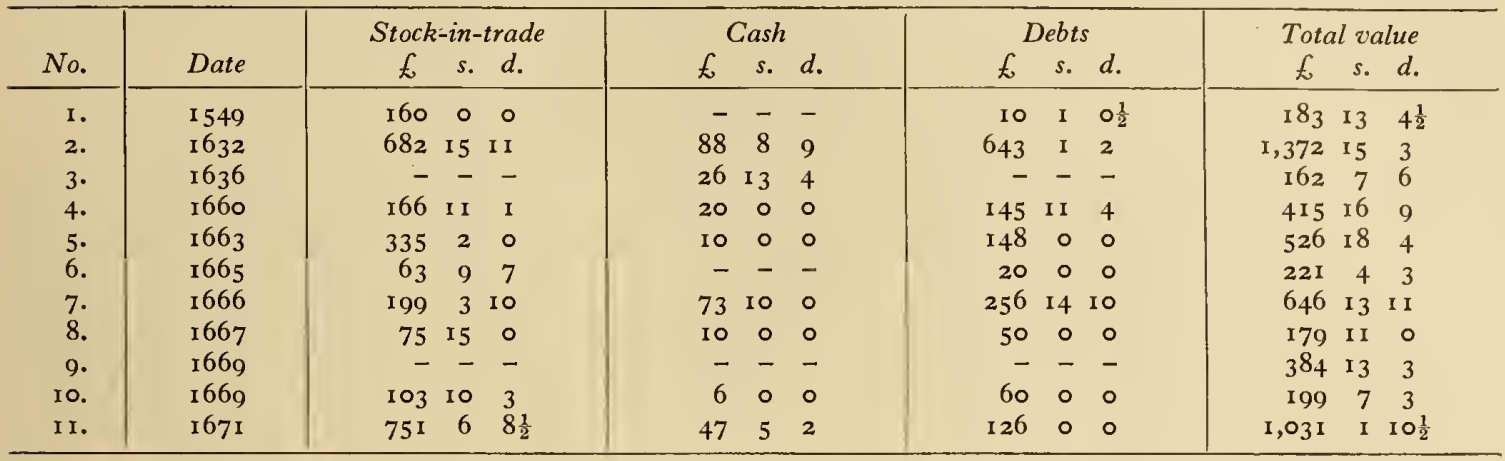

were wealthy general retailers with shops, market stalls, and country branches in some instances, buying wholesale from Manchester, London, and elsewhere, and selling to the people of Leicester and the countryside. ${ }^{75}$

The haberdashers of hats were small fry compared with the mercers. Edward Billers, alderman, left goods and chattels worth only $£_{1} 24$ in $1664 \cdot{ }^{76}$ Apart from $£_{5}$ of desperate debts John Stringer left only $f 86$ Ios. in I670. Among his shop goods were i 8 castors, I 5 beaver shags, 20 dozen odd of felt hats, I I dozen coarse Malton hats, i 6 satin, 4 taffety, and 20 leather caps, over two gross of hatbands, and calico and buckram hat linings. He possibly made some hats himself, but hatters bought most of their stocks from London, Malton, and elsewhere through the common carriers. ${ }^{77}$

There was originally an occupation of haberdashers who handled haberdashery before it was taken over by members of the mercers' company. 'The only 'haberdasher' of whom we find mention in the I6th century, however, was an ironmonger. Richard

TABLE IV

Leicester Ironmongers' Inventories ${ }^{78}$

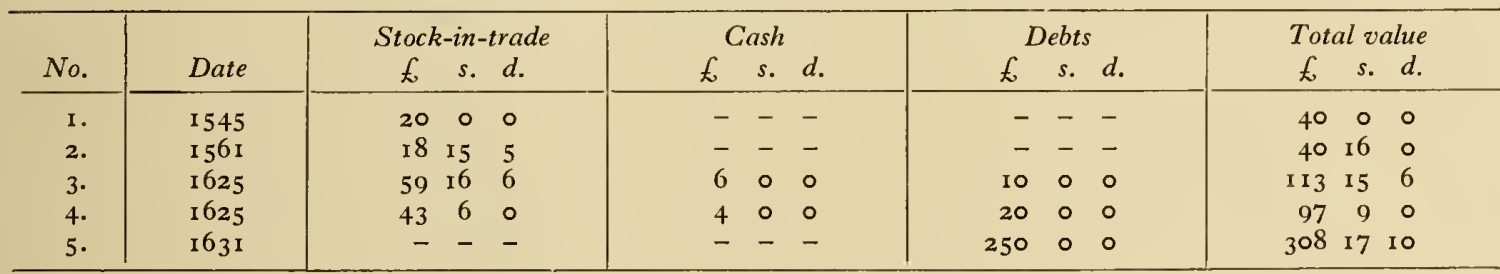

Byllyng, 'haberdasher', had three shops in Leicester, Lutterworth, and Melton, in which he sold, among other things, iron and lead nails of various sizes, mullen bits, steel, gads, hobnails, bellows, locks, straw-lath-nails, court clout-nails, wire, glue, cowbells, arrow heads, shoe buckles, awl blades, pack needles, latten plates, chisels, compasses with marking stones, aniseed, frying- and dripping-pans, shoe horns, lanterns,

${ }_{73}$ Leic. Boro. Rec. I603-88, 43, 390.

74 L.R.O. Probate Rec. Inv. of (I) Thos. Cotton, 1549 , (2) Robert Miller, I632/r49, (3) Jas. Andrew, I636/123, (4) Alexander Cotes, 1660/90, (5) Nathaniel Brokesby, I663/54, (6) Wm. Stanley, I665/96, (7) Robert Erieck, I666/6, (8) Jas. Fox, I667/89, (9) Thos. Sturges, 1669/5, (Io) Jonathan Wanley, I669/8o, (I I) Samuel Marshall, I671/184. For (3) see also Reg. Freemen of Leic. II961770,84 .

75 See above, n. 73 .

76 L.R.O. Probate Rec. Inv. of Edw. Billers, I664/66.

77 Ibid. Inv, of John Stringer, r670; Thompson, Hist. of Leic. i. 352.

${ }_{78}$ L.R.O. Probate Rec. Inv. of (1) Robert Burton, 1545 , (2) Ric. Byllyng, 1561, (3) Thos. Heyrick, I625/18, (4) John Brookes, 1625/166, (5) Phillip Cooper, I631/124.

LEIC. IV 
whipcords, bowstrings, packthread, scuttles, grafting saws, soap, raddle, pitch, tar, grindstones, basins, ropes, brown paper, points, cart saddles, skittles, spindles for wheels, horse-bells, pitchforks, pliers, pincers, planes, snaffles, hammers, collarmakers' rings, and tacks. Other commodities uttered by ironmongers, whose inventories are analysed in Table IV, included in 1625 parchment, charcoal, ladders, barrows, quicklime, glass, alder bark, ochre, crests, paving tiles, scales, millstones, pick-helves, slates, tobacco pipes, alum, wine bottles, pots, glasses, baskets, cradles, panniers, drums, tabors, trenchers, pens and ink-horns, scythe-stones, chalk, wicker chairs, forks, shovels, sheep-bells, tantivy bells, jersey and woollen stockings, bricks, jugs, rosin, purses, gloves, books of gold leaf, red lead, indigo, spurs, looking glasses, starch, painters' colours, warming pans, and shot.79 'Thus new industries and developments were reflected in the scene of the ironmongers' shop and it is hardly surprising that some ironmongers sold tobacco also. ${ }^{80}$ The ironmongery business required considerable capital stocks, but the possibility of intervening between the smith and the market was profitable.

The first stationer whom we find was John Langford, admitted to the freedom in I 59I-2. He left goods and chattels worth only $£ 205^{5}$. in 1633 , the shop wares being valued at $£_{1}{ }_{3} 6 s .8 d .{ }^{81}$ John Allen died in 1638 , much wealthier than Langford, largely through bookselling. With his debts still unappraised, the value of his inventory amounted to almost $£_{2} 200$. Of this bound books accounted for $£_{12}$ odd; paper, ink, ink-horns, and parchment for just over $£_{9} 9$; books in quires, pasteboard, and turkey leather for over $£_{3} 33$, and leather bindings for over $£_{\mathrm{I}} \mathrm{I}$. Among his customers was the borough, which bought other books direct from London, probably the usual practice before booksellers became established locally in the I580's. Thomas Green, the London carrier, used to fetch down books that he delivered to Godfrey Cowper the bookbinder. Presumably Cowper sold some books ready bound, but Allen specialized in this business. ${ }^{82}$

In $1605^{-6}$ Leicester boasted three vintners. ${ }^{83}$ Their trade is illustrated by the inventory of William Newton who was made free in 1648 and continued to trade until his death in 1674 . In his wine-cellar were French and decayed wines, vinegar and canary, worth in all just under $£ \mathrm{ioO}$. He had also a well-equipped brewhouse. Including $£_{44}$ of good and $£ 30$ of desperate debts, his inventory amounted to $£ 357$ odd. ${ }^{84}$ William Ives, vintner, became one of the most opulent burgesses in the early 17 th century. 85 Judging from the practice of Richard Barnes, Leicester vintners bought their wines from London. 86

Less wealthy generally than most shop retailers were the petty chapmen and pedlars who were numerous throughout the period. ${ }^{87}$ Such chapmen went their way on foot. ${ }^{88}$ William Clarke in 1613 left goods and chattels worth $f_{8} 8^{89}$ and in I62 I Daniel Wright slightly over $£ \mathrm{I} 8$. The latter peddled loom-work, drawn-work, Manchester and other coifs, garters, girdles, lawns, bonelace, thread and linen and woollen yarn. ${ }^{90}$ Robert Johnson, however, left over $£_{1} 100$ worth of goods in 1627 . His stock, worth over $£_{50}$, included such things as holland, cambric, scots cloth, sleezy holland, sleezy cloth, cobweb lawn, naples silk, cotton, needles, spectacles, and barber balls. ${ }^{91}$

79 See above, n. 78 .

so Leic. Boro. Rec. I603-88, 268.

81 Reg. Freemen of Leic. II96-I770, 90; L.R.O. Pro-

bate Rec. Inv. of John Langford, $1633 / 72$.

82 Leic. Boro. Rec. 1603-88, 252, 291; Thompson, Hist. of Leic. i. 269-7o; L.R.O. Probate Rec. Inv. of John Langford, I 633/72, John Allen, I 638/29o.

${ }^{83}$ Leic. Boro. Rec. I603-88, 55.
84 L.R.O. Probate Rec. Inv. of Wm. Newton, I 673/1 79.

85 Roll of Mayors of Leic. $86 . \quad 86$ C. $3 / 464 / 77$.

87 Leic. Boro. Rec. $1603-88$, 17.

88 None of the inventories cited in the three following notes mentions horses or panniers.

89 L.R.O. Probate Rec. Inv. of Wm. Clarke, I6r2.

90 Ibid. Inv. of Daniel Wright, I $6 \overrightarrow{2} \mathrm{I} / 86$.

91 Ibid. Inv. of Robert Johnson, $1627 / 75$. 
Generally it may be said that the decline of the great export merchants was only partially offset by the development of smaller trading businesses and commercial capital seems to have lost much of its formerly commanding position. Since the independent existence of commercial capital is in inverse ratio to the independent existence of industrial capital, we might suppose a corresponding growth and development of the latter. 92

TABLE V

Leicester Shoemakers' Inventories ${ }^{93}$

\begin{tabular}{|c|c|c|c|c|c|c|c|c|c|c|c|c|}
\hline No. & Date & \multicolumn{2}{|c|}{$\begin{array}{l}\text { Stock-in-trade } \\
f \text { s. } d .\end{array}$} & & ash & $d$. & $E^{1}$ & s. & $d$. & $\begin{array}{c}\text { Tot } \\
£\end{array}$ & $\begin{array}{l}a l v \\
s .\end{array}$ & $\begin{array}{l}\text { alue } \\
\text { d. }\end{array}$ \\
\hline I. & I 533 & 315 & 4 & - & - & - & - & - & - & 17 & 3 & 4 \\
\hline 2. & I $53^{8}$ & - & - & - & - & - & - & - & - & 2 & IO & 0 \\
\hline 3. & I $55^{8}$ & - & - & - & - & - & ○ & 6 & 8 & 5 & I 3 & 0 \\
\hline 4. & I $55^{8}$ & 5 & 0 & - & - & - & - & - & - & 7 & I & 6 \\
\hline 5. & I 570 & 518 & 4 & - & - & - & - & - & - & I I & 0 & 0 \\
\hline 6. & I 584 & - & - & - & - & - & - & - & - & 5 & 0 & o \\
\hline 7. & I 586 & $25 \quad 14$ & 0 & - & - & - & 40 & 0 & 0 & 145 & 5 & 6 \\
\hline 8. & I 595 & O IT & 0 & - & - & - & - & - & - & 39 & 9 & 9 \\
\hline 9. & I 6 I 4 & - & - & - & - & - & - & - & - & 60 & 9 & 0 \\
\hline Io. & I 62I & 05 & 0 & - & - & - & - & - & - & 9 & I 8 & 8 \\
\hline I I. & I 621 & 0 & 8 & - & - & - & - & - & - & 46 & 3 & Io \\
\hline 12. & 1626 & - & - & - & - & - & - & - & - & 37 & 5 & 2 \\
\hline 13. & $163 I$ & - & - & 0 & I & 0 & - & - & - & 4 & 6 & I0 \\
\hline I 4. & $16_{3} I$ & 8 IC & 0 & I & 0 & 0 & I & IO & 0 & 12 & 16 & 8 \\
\hline I 5. & I633 & 2 & 0 & - & - & - & - & - & - & I 5 & I 5 & IO \\
\hline I 6. & I 637 & - & - & I 5 & 0 & 0 & - & - & - & 29 & I0 & 6 \\
\hline 17. & I 637 & - & - & 6 & 0 & 0 & 30 & 0 & 0 & 97 & 17 & 2 \\
\hline I 8. & I 637 & 712 & $\circ$ & I & Io & o & 0 & IO & 0 & 17 & 3 & 0 \\
\hline I 9. & 1663 & - & - & 0 & IO & 0 & 56 & 0 & 0 & 56 & IO & 0 \\
\hline 20. & I 665 & - & - & 2 & I & 6 & 17 & 8 & $\circ$ & 26 & 13 & 6 \\
\hline 21. & I 665 & - & - & 19 & 0 & 0 & 13 & IO & 0 & 36 & I 6 & 6 \\
\hline 22. & I $67 \mathrm{I}$ & 8 & o & I & 0 & o & 7 & 0 & 0 & 24 & I 4 & 6 \\
\hline 23. & 1675 & 1010 & 0 & 3 & 0 & 0 & 5 & 0 & 0 & 42 & I 8 & 6 \\
\hline 24. & I 675 & I I 5 & 4 & I & 6 & 8 & - & - & - & 5 & 5 & Io \\
\hline
\end{tabular}

While some shoemakers attained modest wealth, most were poor, as may be seen from the inventories in Table V. Of those with no stock-in-trade, some were retired, but the poorer sort could have worked on materials owned by others. What is clear is that there were numerous journeymen shoemakers. In addition to the shoemakers' company' ${ }^{94}$ there was the 'compenie of the jornemen of schomakers', 95 a yeomanry organization of journeymen employed by members of the shoemakers' company. 96 The trading masters among the shoemakers probably controlled the yeomanry by means of the shoemakers' company, the borough government, and the residual powers of the guild merchant, as well as by the justices of peace and the Statute of Artificers. Thus in I 584 the journeymen shoemakers were called before the justices and registered as servants, ${ }^{97}$ the word 'servant' signifying a wage-worker under contract. ${ }^{98}$ In 1645 it was ordered that no man could claim the freedom of the borough by virtue of apprenticeship unless

$92 \mathrm{G}$. Unwin, Industrial Organization in the 16 th and I 7 th Cents. I I-I 4,70 sqq. and passim.

93 L.R.O. Probate Rec. Inv. of (I) Robert Fyllyppe, I 533, (2) Robert Johnson, I 538, (3) Harry Suffolk, I 538, (4) John Darker, I 558, (5) Ralph Johnson, I 570, (6) Ralph Fawkner, I 584, (7) Robert Roads, I 586, (8) John Duce, I 595, (9) Ric. Mole, I614/86, ( Io) John Ball, I 62 I/22, ( I I) John Stanforde, I62 I/94, (12) Wm. Jeffery, I626/ I 86, ( I 3 ) Noye Facken, I631/174, (14) Wm. Bowyer, I631/10o, (15) Thomas Webster, I633/68, (I6) Wm. Hopkins, I637/89, (1 7) Francis Churchman, I637/201, (18) Luke Jones, I637/ I 82, (I9) Anthony Webster, I 663/83, (20) Jas. Cooper, 1665/127, (21) Robert Browne, I665/145, (22) Robert
Freeman, I 671/37, (23) Ric. Moore, 1675/89, (24) Wm. Stacy, 1675/49; see also entries in index of Reg. Freemen of Leic. II96-I770.

94 Leic. City Mun. Room, Hall Papers I 593-8, no. 28 I ; C. J. Billson, Medieval Leic. 125-6; Thompson, Hist. of Leic. i. 227; Throsby, Hist. of Leic. 87.

95 Leic. Boro. Rec. I509-I603, 31 .

96 Cf. Unwin, Industrial Organization, I I ; G. Unwin, Gilds and Companies of London, $83-85$.

97 Leic. Boro. Rec. I 509-1603, I96; R. H. Tawney and Eileen Power, Tudor Econ. Docs. i. 338 sqq.

98 Leic. Boro. Rec. I 509-I603, 364 . 


\section{A HISTORY OF LEICESTERSHIRE}

this had been served in some trade that 'normally and legally' took apprentices. This order was directed against cobblers opening shops and taking apprentices. The shoemakers complained that divers cobblers, not being freemen, kept open shop, made wares, took apprentices, and covenanted to teach the craft of shoemaker, while others were working in backhouses contrary to statute. They petitioned against the admission of Robert Carr on the plea that there were already too many shoemakers. The complaint against working in backhouses suggests that some journeymen had set up as small masters working for merchant employers. That journeymen should set up as cobblers and shoemakers was inimical to the interests of the trading masters because the newcomers were master craftsmen who evaded journey-work. From these comes the petition of John Hall, reciting that he was apprenticed for seven years to a shoemaker, then for nineteen years 'wrought journey worke in this town to a shoemaker', afterwards working as a 'translator' (cobbler) for four years. Robert Carr asked for freedom to support his wife and seven children. He too had been apprenticed, had worked as a journeyman for twelve years and as a 'translator' for seven. Some cobblers had been made free in the later I 6th century, but those who now sought admission or kept open shop evidently intended to make shoes to measure or in stock sizes. While the shoemakers threatened to shut down the new-comers' shop windows, the latter accused company members of breaking their own ordinal by importing shoes, alluding perhaps to industry in the countryside. The company, however, refers to the ordinal, approved by the justices of assize under the Statute of Artificers, adding that the 22 interlopers pay little or nothing by way of taxes. The issue was settled by the borough licensing the 'translators' to keep open shop in 1646 , thus abrogating the monopoly of the shoemakers' company. 99

What made the victory of Carr and his associates relatively easy was not only the Great Rebellion but also the loss of control of the leather trade by the cordwainers' company, by virtue of which these trading masters had controlled the activities of the tanners also. Apparently in order to strengthen their hold on the leather trade, the shoemakers in 1648 opened a Leather Hall to which all tanned leather was to be brought for sale under the supervision of the cordwainers' company. The tanners refused either to use the new hall or to pay their contribution to its rent, which should have been shared by both town and country tanners but fell mainly on the former. Then the town tanners brought an action against those of the country, forcing them to pay their full share. In the midst of these disputes the system of control broke down and there ensued a period of free trade in leather to the advantage of the tanners and of the unfree 'translators' and shoemakers. Concurrently there was a clash between the cordwainers' company and the curriers. Some members of the shoemakers' company certified that the four curriers free of the borough were sufficient, and opposed the entry of others, especially of James Foxon, citizen and currier of London. Foxon's admission had presumably been approved by the curriers, however, and in the end the shoemakers' company also consented. ${ }^{1}$

The tanner's most essential investment was in hides, lime, and bark. His implements were not expensive and tan-house and tan-pit could be leased along with a dwelling, as also could a bark-mill. Alternatively bark could be bought ready crushed, or taken to a miller. It was not, therefore, difficult to set up as a tanner, but it was not every tanner who had his own mill, even a horse-mill being expensive. Hence a tendency for tanners

\footnotetext{
99 Leic. Boro. Rec. I603-88, pp. xliii, 350-1, 388-9; Unwin, Industrial Organization, 204 sqq.; Leic. City Mun. Room, Papers, $1645-7$, nos. 523, 529-30; ibid.
}

I $649-50$, no. 556 .

1 Leic. Boro. Rec. 1603-88, pp. xliii, 359, 391, 416, 461 ; cf. Unwin, Industrial Organization, 19, 22 n. 
THE CITY OF LEICESTER

to divide into those who undertook all processes and those who were forced to rely on others for their supplies of bark and other materials. William Halsope, for example, bought his bark from John Norris. No doubt leather was bought and sold similarly. Thus some tanners, as may be seen from Table VI, were able to develop into comparatively wealthy trading masters, leaving manual work to journeymen, or even into merchant employers.

\section{TABLE VI}

\section{Leicester Tanners' Inventories ${ }^{2}$}

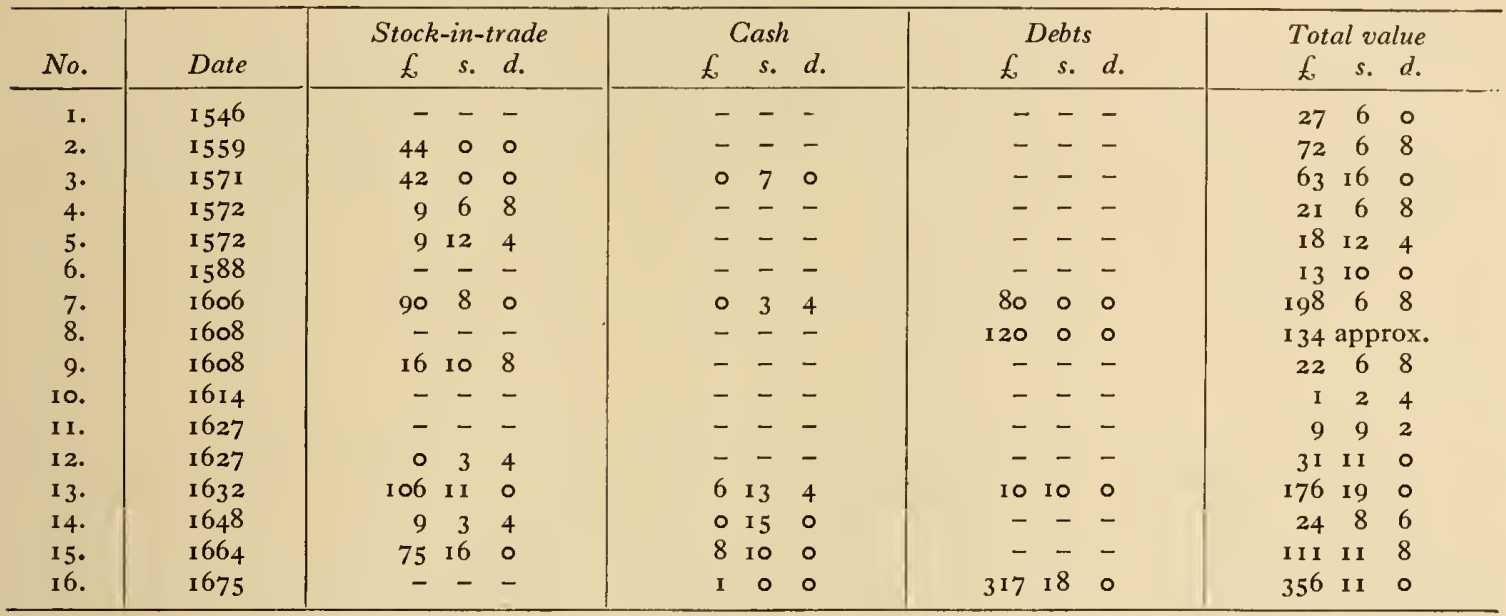

A set of currier's tools would cost only about i 5 s. in 1632 and skins 'with hair upon them' only about $5^{s}$. each in 1580 , so that great capital was not needed to set up in business. The only two curriers whose inventories have been seen had stocks of less than $£_{1}$ and total goods and chattels of $£_{28}$ and $£_{22}$ respectively in I 580 and I 632 and most curriers probably worked as small masters, dependent upon merchants among the shoemakers or tanners. ${ }^{3}$

The saddlers worked as master craftsmen. In 1636 Anthony Spence left goods and chattels valued at $£^{8}$ I $8 s$. $8 d$., of which his working gear was worth $4 s$, and the 8 saddles, 2 bridles, and one pillion that he had made were valued at $£ 2 .{ }^{4}$ In I 646 Gilbert liawsitt left $£ 30$ in goods and chattels, of which saddles, bridles, girths, stirrup leathers, and wooden ware were worth $£ 5$ i $s$. Fawsitt also owned two houses besides his own dwelling, which was comfortably furnished. 5

If the whittawers worked as master craftsmen - and this is not certain-it would seem that differentiation between members of the craft was great and trading masters were making their appearance. In I560 Richard Burton left goods and chattels valued at $£ 4$ I 7 s. $8 d$., of which just over $\AA_{\mathrm{I}}$ was stock-in-trade. ${ }^{6}$ In I 590 William Shuter left an estate of just $£_{\mathrm{I}} \mathrm{O}$, of which his implements were valued at $3^{s} .4 d$. and nine horse-hides at 2 I $s^{7}$ In 1638 , however, Richard Springthorpe had an inventory of $£_{1} 5^{6}$ I $4 s .2 d$. Of this, two fleeces of wool and locks were worth Ios., Ioo hides $£_{20}$, collars, basses, and other implements $\mathrm{I}_{3} s .4 d$., and an alum tub and a drench vat $\mathrm{I}_{5}$ s., so that his stock-intrade was about $£^{22}$. In fatting and dairying his investment amounted to over $£ 5^{\circ}$, and

2 L.R.O. Probate Rec. Inv. of (I) Wm. Halsope, I 546, (2) Hen. Stanforde, 1559, (3) John Morris, 1571, (4) Edw. Massey, 1572, (5) Wm. Watson, I 572, (6) John Tatam, I 588, (7) Margery Crosby, 1606/107, (8) Wm. Grene, I608, (9) Edw. Garnate, 1608, (10) Robert Robertes, 1614/I II, (II) Robert Roberts, 1627/156, (12) John Blackshawe, 1627/107, (13) Hamiel Hawford, I632/194, (14) John Haslocke, $1648 / 12$, (15) Nic. Simpson, $1664 / 133,(16)$ Thos.
Pippin, 1675/140.

3 Ibid. Inv. of John Coke, 1580 , Thos. Davye, $1632 / 199$;

Leic. Boro. Rec. I 509-I603, 359.

4 L.R.O. Probate Rec. Inv. I6 $66 / 34$.

5 Ibid. Inv. 1646/8 (box 46); Wills, 1646/71 (box I231); Roll of Mayors of Leic. 90.

6 L.R.O. Probate Rec. Inv. of Ric. Burton, 1560.

7 Ibid. Inv. of Wm. Shuter, 1589 . 


\section{A HISTORY OF LEICESTERSHIRE}

he had also $£ 26$ I $3 s .4 d$. in desperate debts. ${ }^{8}$ Self-styled glovers also tawed sometimes. Thus John Hall had no gloves, but wool and dressed and undressed whitleather to the value of $£ 46 s$. $8 d$, and $16 s$. worth of alum out of an inventory of $£ 32$ Ios. $6 d .9$

Most glovers, however, bought their whitleather from the whittawers, and sometimes leather from tanners. The glovers, a sample of whose inventories will be found in Table VII, were small masters dependent on traders, mostly mercers. Richard Leydebeater in I 535 and Richard Brisbone in I 538 both employed servants and were comfortably

\section{TABLE VII}

\section{Leicester Glovers' Inventories ${ }^{10}$}

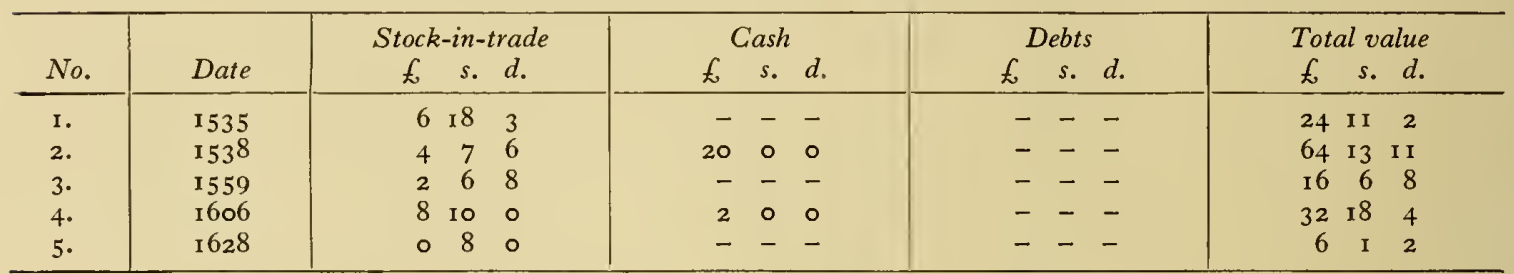

placed, but the same cannot be said for the later glovers. Even Richard Brisbone helped to make ends meet by the four spinning-wheels in his house. The glovers made gloves, purses, and bags from buckskins, doeskins, sheepskins, lambskins, and also cattle hides. II That the town glovers were increasingly faced with the competition of country glovers is evident from the clash between the two. In I 59I Robert Herrick, a Leicester glover who had removed to Mountsorrel, requested to be allowed to continue in liberty of the borough. He was not allowed to keep up his shop in Leicester, but was permitted to trade as a stranger. Herrick was not the only one concerned, for in I 594 the glovers of Mountsorrel petitioned their landlord, the Earl of Huntingdon, to help them reverse this decision. The borough remained adamant, for the objection to foreign glovers was not merely that they sold in the town but that they bought woolfells needed by Leicester. Herrick of Mountsorrel led the glovers of his town and of Ashby de la Zouch and Loughborough, with the support of the Earl of Huntingdon, in a struggle against Leicester corporation. The borough debarred the glovers of all the country save Loughborough from trading in the Saturday market, for which prohibition the Leicester glovers had placed $£_{5}$ at the borough's disposal. A compromise was arrived at, by which ten Mountsorrel and six Loughborough glovers were to have a monopoly of the 'outside' trade in return for taking up residence in the town. The Mountsorrel men, however, refused to abide by this and told the corporation their charter was 'only fit to stop mustard-pots'. Then the attorney-general of the duchy entered a bill in Star Chamber and sued a quo warranto against the glovers' market at Mountsorrel. Settlement was eventually reached. The country glovers were to pay ros. each for a licence to trade, and of this 5 s. was to go to the town glovers. In addition the country were to pay to the town glovers Is. apiece for brotherhood money. At the time of the Civil War the town glovers attempted to reverse the position and the corporation was induced to shut up the shops of the country glovers, who were nevertheless readmitted to the market on payment of appropriate fees. ${ }^{12}$

Woollen and worsted spinning was undertaken by many of the wives and daughters

${ }^{8}$ L.R.O. Probate Rec. Inv. I638/129.

9 Ibid. Inv. of John Hall, 1584; Reg. Freemen of Leic. $1196-r 770,79$.

${ }^{10}$ L.R.O. Probate Rec. Inv. of (I) Ric. Leydebeater, 1535, (2) Ric. Brisbone, I538, (3) Christopher Moore,

I559, (4) Thos. Walker, I606, (5) Roger Tompkinson, 1628/38. II See Inventories cited above, n. Io. 12 Leic. Boro. Rec. I509-1603, pp. xxxviii-xxxix, 276, 301, 368, 377, 409-10; I603-88, 373, 377; Thompson, Hist. of Leic. i. 310-12. 
of wage-labourers and craftsmen as well as by maids employed by shopkeepers, craftsmen, and farmers. Among the owners of spinning-wheels were people of all classes and occupations. ${ }^{13}$ Some men had as many as four wheels. ${ }^{14} \mathrm{~A}$ bellfounder had a spinninghouse for his two wheels. ${ }^{\mathrm{I5}}$ Carding was similarly a domestic occupation. Richard Brisbone the glover had two pairs of wool-cards as well as four spinning-wheels. The wheels were in the brewery for use by the womenfolk but the cards were in the servants' sleeping quarters. ${ }^{16}$ Similarly, John Norris had four wheels, two stools, and a pair of cards in his maids' chamber. ${ }^{17}$

As far as can be seen most weavers, whose inventories form the substance of Table VIII, worked under conditions of some economic independence. They invested in looms, one weaver not infrequently owning as many as six. The owner of six looms needed to employ two or three journeymen as well as apprentices and family labour. The damask loom employed by Richard Ayshehill was an expensive instrument worth $£ 5$ with the gears. ${ }^{18}$ Not all weavers were freemen, and the poorer supplemented their living from other sources. ${ }^{19}$ The weavers appear to have been dependent for sales upon the woollen drapers and mercers, but some of them were large masters.

\section{TABLE VIII}

\section{Leicester Weavers' Inventories ${ }^{20}$}

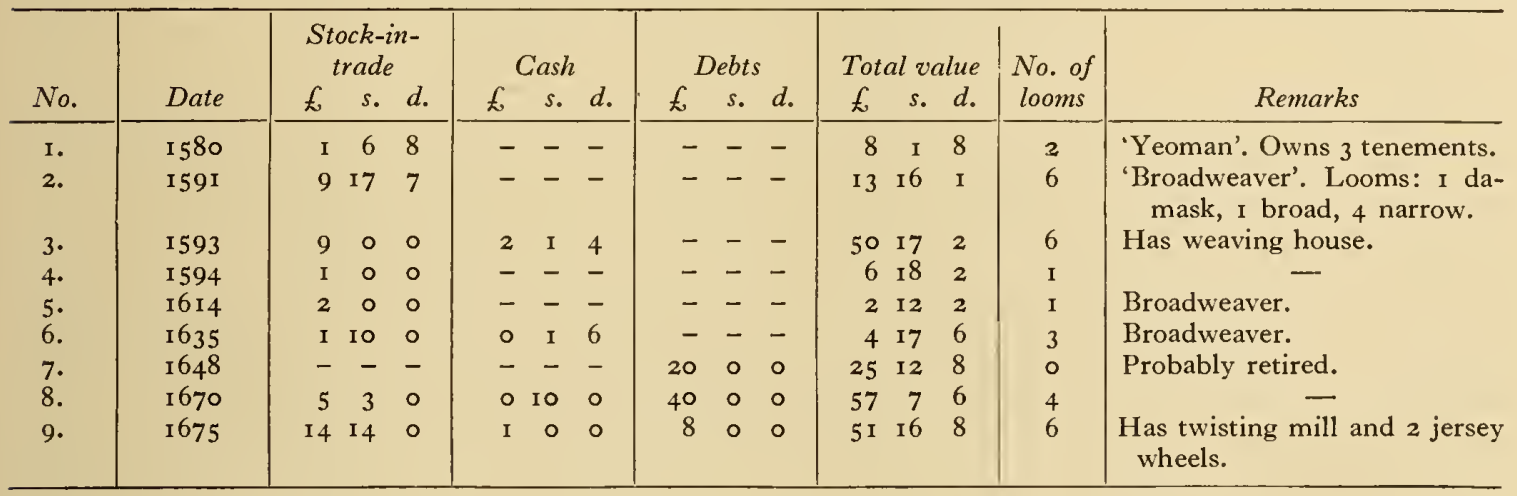

Fullers do not figure as such in either Register or inventories, probably being concealed among the millers. There were, however, at least two water fulling-mills, tenanted in the early $\mathrm{I} 7$ th century by two partners, neither of whom was a freeman. Apart from the mill lease, the fuller's capital expenditure was not great, and Leicester tuckers probably worked as independent masters. ${ }^{2 \mathrm{I}}$

The occupations of shearmen, clothworkers, and dyers were small. The clothworkers appear to have been small masters in modest circumstances. In 579 Ralph Randall left tenters, shears, and other tools to the value of $£ .5$ among goods and chattels valued at just over $\oint_{\mathrm{I}} 6 .^{22}$ Dyeing demanded more capital. When Mr. William Johnson died in I 670 he left an inventory of $\mathcal{I}_{\mathrm{I}} 45$ Ios. His dye-house equipment, including three coppers

13 e.g. L.R.O. Probate Rec. Inv. of Samuel Marshall, 1671/84, John Langford, I633/72, John Hall, 1584 , Eliz. Bennett, I558, Thos. Browne, I 558, John Oldham, I560, John Sherman, I627/166, John Bonnett, I632/75.

14 e.g. ibid. Inv. of Ric. Brisbone, I 538, John Norris, $1670 / 92$.

is Ibid. Inv, of Thos. Newcombe, i58I.

${ }_{16}$ Ibid. Inv. of Ric. Brisbone, 1538.

17 Ibid. Inv. of John Norris, 1670/92.

18 Ibid. Inv. of (1) Hen. Mosley, I580, (2) Ric. Ayshehill, I59I, (3) Thos. and Ellen Ramsdale, I 593, (4) Robert Molde, I594, (5) John Powell, 1614/163, (6) John Raven,
I635/77, (7) Ric. Coultman, I648/22, (8) Thos. Palmer, I670/104, (9) Hen. Mug, I675/18I; ibid. Wills, Hen. Mosley, 1580, Hen. Mug, 1675/147; Reg. Freemen of Leic. $1196-1770$ (see entries in index).

19 See references cited above, n. I8; Leic. Boro. Rec. I 509-1603, 376, 394-5 ; L.R.O. Probate Rec. Wills, John Whitehead, I 570 .

20 See references cited above, n. I8.

${ }_{21}$ Leic. City Mun. Room, press 24 , box 1, no. I8; J. U. Nef, 'Industrial Europe at the Time of the Reformation', Fnl. of Political Econ. xlix. 30.

22 L.R.O. Probate Rec. Inv. of Ralph Randall, I 579. 


\section{A HISTORY OF LEICESTERSHIRE}

and dyeing vessels, was worth $£^{20}$ and his dye-stuffs were valued at the same again. Furthermore, a large part of the wood and coals in his coalhouse must have been for his vats, so his industrial investment was about $£ 50$. He had two apprentices or journeymen who lived in the dye-house chamber. Johnson's position, then, was probably that of a trading master. ${ }^{23}$

Although some woollen drapers and others may have bought and sold yarn there is no indication of putting-out in these industries and as far as can be seen no middlemen intervened between craftsman and craftsman. ${ }^{24}$

Linen clothing was more widespread than woollen or worsted. Those who spun woollen also often spun linen yarn and many of the weavers must have woven linens. ${ }^{25}$ Most of the linen spinners owned their own flax and yarn in considerable quantities when more than one wheel was employed. ${ }^{26}$ No doubt some of this ownership of material concealed the activities of merchant-employers, ${ }^{27}$ and there were in addition some linen clothiers who put out yarn to be woven. John Blackshawe in I627 had ten yards of new flaxen cloth and fifteen yards of 'harden' worth i $8 s$. and also 'yarn and "hards" in the house and abroad' worth $9 s .2 d .^{28}$

In the I6th century, as part of a general programme of relief, poor were set to work making jerseys to be stitched into hose. In ${ }_{5} 84$ the corporation sent away for teachers of spinning, baize-making, fulling, and weaving, and in ${ }^{5} 89$ they tried to start capmaking and knitting. Children were taught jersey spinning, knitting, and bonelace weaving. ${ }^{29}$

Bonelacemakers appeared as freemen at the end of the i6th century and they continued as a small craft thereafter. In I6 Io Daniel Wright borrowed fio from the town to set pauper children to work. George Inninges left goods and chattels valued at $f_{4} \mathrm{I}$ Ios. in $\mathrm{I}_{5} 8$, by which time he had retired, $f_{4} 4 \mathrm{O}$ being in debts. ${ }^{30}$

Leicester could hardly support a hemp-dresser, ${ }^{3 \mathrm{I}}$ but there were a few ropers in the town. In I 570 William Moore left $£ 8$ I $6 s .6 d$., of which hempen ware made and unmade constituted $5^{s .}$ Iod. ${ }^{32}$ In I 663 John Shepie had in his garret 40 dozen whips, 50 yards of sackcloth, 3 yards of haircloth, 2 sacks, 2 bags, 9 bunches of cord and 8 of small cord, and other items, worth in all $£ 47$ s. In his shop he had hemp and hair, haircloth and sackcloth, hooks, mails, and weights worth $£ 37 s$., and Io stone of hemp worth $\AA_{\mathrm{I}} 6 \mathrm{~s} .8 \mathrm{~d}$. In his warehouse were materials worth $\AA^{2}$ more, more whips, and a "coat-ofmail' used for dressing the cloth, these being valued at 25 s. With the assistance of spinning he was able to live as a master craftsman. ${ }^{33}$

Tailoring was a craft that demanded little working capital. If the tailor could not afford a stock of cloth, then this could be supplied by the customer and all the tailor needed was his skill and his tools. The only times when a tailor's stock-in-trade was considerable was when it was mainly in cloth. Tailors, as may be seen from Table IX, ranged from paupers to well-to-do gentlemen, including some who were not working

\footnotetext{
23 L.R.O. Probate Rec. Inv. of Wm. Johnson, $1670 / 237$.

24 Ibid. Inv. of Wm. Gillot, 1580. Goods abroad in workers' hands are shown in ibid. Inv. of John Blackshawe, $1627 / 107$. For the ownership of materials by spinsters and various craftsmen see e.g. ibid. Inv. of Jas. Nutt, I668, Ric. Stretton, 1656/329, Ric. Brace, 1641/146.

${ }_{25}$ See e.g. ibid. Inv, of John Tatam, 1588 , Wm. Ball, 1584, John Oldham, 1560, Thos. Wodland, 1591, Robert Croston, 1 572, Dominic Redwey, 1581/121, Wm. Jerman, 1584. Alice Aboll or Johnson, 1588 , Thos. Joseph, 16 1 $3 / 66$, Wm. Cotes, $1628 / 75$, Samuel Huxley, $1656 / 53$, Chas. Robinson, I663/7, John Bell, I621/22.

${ }^{26}$ See e.g. ibid. Inv. of Jas. Nutt, I663, Ric. Alton, 1638/205, Ric. Springthorpe, I638/129, Dorothy Andrewe, I633/138, Edw. Taylor, 1594, Thos. Markby, c. 1520,
}

\footnotetext{
Robert Rypley, I544, Thos. Swan, I630/122, Geo. Mounteney, 1676/3, Robert Erieck, 1666/6, Mary Kellam, 1636/254, Thos. Walker, I648/21, John Fowker, 1649/75, Thos. Webster, I633/68.

27 See e.g. ibid. Inv. of Alexander Cotes, I66o/9o.

28 Ibid. Inv. of John Blackshawe, 1627/107.

29 Thompson, Hist. of Leic. i. 252; Leic. Boro. Rec. I 509-1603, pp. xlviii-xlix, 327, 346; I603-88, 101.

30 Ibid. $1603-88$, 10 1 L.R.O. Probate Rec. Inv. 1658.

31 Leic. Boro. Rec. $1603-88,257$.

${ }^{32}$ L.R.O. Probate Rec. Inv. of Wm. Moore, $1570 ;$ Reg. Freemen of Leic. I I96-I770, 75.

${ }_{33}$ L.R.O. Probate Rec. Inv. of John Shepie, I663. (box I127).
} 


\section{TABLE IX}

Leicester Tailors' Inventories ${ }^{34}$

\begin{tabular}{|c|c|c|c|c|c|c|c|c|c|c|c|c|c|c|}
\hline No. & Date & $\delta^{S t c}$ & $\begin{array}{c}c k-1 \\
\text { rade }\end{array}$ & & & $\begin{array}{l}\text { Cash } \\
\text { s. }\end{array}$ & $d$ & $f^{L}$ & Pebts & $d$ & Totc & $\begin{array}{c}\text { al } v c \\
s .\end{array}$ & $\begin{array}{l}\text { alue } \\
\text { d. }\end{array}$ & Remarks \\
\hline I. & I 538 & 3 & I9 & 2 & - & - & - & - & - & - & 19 & I & 3 & - \\
\hline 2. & I 546 & IO & 0 & o & - & - & - & - & - & - & 20 & I3 & 0 & 一 \\
\hline 3. & I 578 & - & - & - & - & - & - & - & - & - & 95 & 3 & 8 & No shop. \\
\hline 4. & I 578 & - & - & - & - & - & - & - & - & - & 7 & 12 & $\circ$ & - \\
\hline 5. & I $59 \mathrm{I}$ & $\circ$ & 4 & 6 & 23 & $\circ$ & 0 & 35 & $\circ$ & $\circ$ & 86 & $\circ$ & $\circ$ & - \\
\hline 6. & I 59 I & - & - & - & - & - & - & - & - & - & $5^{8}$ & I 8 & 6 & $\begin{array}{l}\text { Shop and fittings, value un- } \\
\text { known. }\end{array}$ \\
\hline 7. & I 594 & 2 & 3 & 4 & - & - & - & - & - & - & 6 & 9 & 8 & - \\
\hline 8. & I 596 & - & - & - & - & - & - & - & - & - & $\mathbf{I}$ & I 5 & 4 & - \\
\hline 9. & 1612 & - & - & - & - & - & - & 28 & 10 & $\circ$ & 45 & 8 & 6 & No shop. \\
\hline Io. & 1612 & - & - & - & - & - & - & - & - & - & 28 & 9 & 2 & No shop. \\
\hline I I. & 1628 & ○ & 5 & $\circ$ & - & - & - & - & - & - & 13 & 14 & 8 & Shop and tools. \\
\hline I2. & $163 I$ & - & - & - & - & - & - & - & - & - & 2 & I & 6 & - \\
\hline I3. & I633 & - & - & - & I & Io & ० & 4 & I 5 & ○ & 20 & I I & 4 & No shop. \\
\hline 14. & I636 & o & I & 4 & - & - & - & - & - & - & 2 & I 4 & 2 & 一 \\
\hline I 5. & 1637 & - & - & - & - & - & - & 6 & 7 & $\circ$ & 86 & 17 & $\circ$ & No shop. \\
\hline 16. & I 638 & - & - & - & I I & IO & ० & 32 & 0 & o & 82 & 17 & 0 & - \\
\hline 17. & I 648 & $\circ$ & 5 & 6 & - & - & - & - & - & - & 17 & I 6 & 7 & - \\
\hline 18. & I 660 & - & - & - & 20 & 0 & ० & 450 & $\circ$ & 0 & 602 & I 5 & 8 & No shop. \\
\hline 19. & I 66 I & - & - & - & - & - & - & - & - & - & 4 & I I & I I & - \\
\hline 20. & 1670 & $\circ$ & I 4 & ० & - & - & - & 6 & 10 & o & 24 & 6 & 4 & 一 \\
\hline $2 \mathrm{I}$. & I 674 & - & - & - & & & I IO & o & & & 12 & I 2 & $\circ$ & - \\
\hline 22. & I675 & $\circ$ & 3 & $\circ$ & I & 0 & $\circ$ & - & - & - & 19 & I 6 & 2 & - \\
\hline 23. & I 677 & - & - & - & - & - & - & I 2 & $\circ$ & o & 39 & 9 & IO & - \\
\hline 24. & I 678 & ० & I 5 & o & 0 & 5 & $\circ$ & - & - & - & 6 & 0 & $\circ$ & - \\
\hline
\end{tabular}

tailors, though they belonged to the company. Daniel Murfyn, whose goods and chattels were worth over $£ 600$ in 1660 , was also the owner of three houses and three tenements, not counting the one in which he lived, and although he was discharged from the office of chamberlain in $\mathbf{r} 626$ on grounds of illiteracy, he clearly lived as a gentleman. ${ }^{35}$ Many tailors, furthermore, derived part of their income or livelihood from dairies, brewhouses, pigs, spinning, and usury; and these often absorbed more capital than tailoring itself. ${ }^{36}$ Those tailors who possessed stocks of cloth had a considerable advantage over their competitors, especially as ready-to-wear tailoring was already making its appearance. In the early I 7 th century the tailors' company complains that one Shilcock 'not being content with the trade wherein he was brought up ... nowe byes great quantities of cloth of forrein clothiers, makes them up into garments, and sells and exposes them ready made to sale to the great impoverishinge of the drapers, mercers, taylers and other tradesmen.' Other tailors also took up specialized lines involving the stocking of cloth and other raw materials. Edward Lee, for example, set up as a 'body maker' and built up a flourishing business, selling bodices to shopkeepers and gentlewomen. ${ }^{37}$ 'The great complaint of the tailors' company was the activity of the poor tailors, who were not normally free of the company. Freedom was usually denied to these poor tailors, but some were authorized to work as 'botchers'. Complaint is thus made of those 'whoe like drone bees to the hyve, paying neither scot nor lot, lye lurking in the suburbs and other secret places, in and

34 Ibid. Inv. of (1) Randall Hyll, 1538 , (2) Nic. Wastell, 1546, (3) John Wathowe, I 578, (4) Geo. Furnys, I 578, (5) Wm. Winterscall, I591, (6) Wm. Staples, I591, (7) Wm. Browen, I 594, (8) see end of note, (9) Geo. Hunt, I612, (г) Roger Brookesbie, I6I2, (I I) John Slatters, I628/14, (12) Thos. Heyrick, I631/106, (13) Thos. Carr, I633/312, (14) Thos. Lutenham, I636/221, (15) Thos. Newton, I637, (16) Gabriel Cater, $1638 / 222$, (17) John Willson, I648/36, (18) Daniel Morfine or Murfyn, 166o/22, (19) Wm. Smith,
I66I/260, (20) Wm. Randall, I670/90, (2I) Wm. Ward, I674/102, (22) John Stafford, I675/146, (23) Thos. Simpson, I677/I19, (24) Ric. Harbert, I678/133. For (8) see Leic. Boro. Rec. I 509-I603, 323. See also entries in index of Reg. Freemen of Leic. II $96-1770$.

35 L.R.O. Probate Rec. Inv. I660/22; Wills, I660/33; Roll of Mayors of Leic. 94-95.

${ }^{36}$ See references cited above, n. 34 .

37 Leic. Boro. Rec. I509-1603, p. xlii. 


\section{A HISTORY OF LEICESTERSHIRE}

aboute this towne, and robbe your suppliants of the worke'. The mayor and the Fortyeight are petitioned 'not to make any more free of our company unless it be with our consent', according to the ancient custom. Botchers continued to be authorized from time to time provided they merely mended old clothes, did no cutting-out or turning, and took no apprentices or journeymen; but it became the practice to oppose the admission of strangers. Thus the tailors lived as small masters or journeymen, some of them exceedingly poor, or as merchant-employers or trading masters. ${ }^{38}$

There were hosiers in early 16 th-century Leicester who dealt in woollen cloth stockings. ${ }^{39}$ Later jersey spinning and knitting were taught as part of poor relief. ${ }^{40}$ Some of

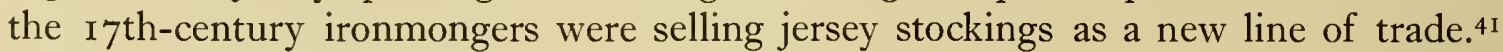
Mercers also took to trading in knitted hose. ${ }^{42}$ At the same time jersey-wheels begin to appear in the inventories. ${ }^{43}$ Concurrently there appear also jersey-mills, operated in by-employment, often by the jersey-spinners themselves and sometimes being kept in mill houses. ${ }^{44}$ Jersey stockings were worn by a number of testators. ${ }^{45}$

Knitting with needles was already common in the 15 th century, but hose was generally made of woven cloth, cut and stitched, and it was not until about 1570 that the practice of knitting jersey or worsted hose became general. ${ }^{46}$ In the mid- $\mathrm{I} 7$ th century hand-knitting was well established as a putting-out industry. 47 Already in $\mathrm{I}_{6} 2$ and $\mathrm{x} 633$ were made the inventories of early Leicester knit-wear hosiers. When William Hitchcock the gardener died in 1632 , he left, among other things, a pair of jersey-combs and a comb-pot, valued at $f_{\mathrm{I}} \mathrm{I}$, and books, hose, and yarn valued at $6 s$. He probably combed the jersey wool himself and then sold it to spinners, buying the yarn back again, either to be knitted by his family or for sale to other knitters and then repurchased. His whole production, however, was very small. ${ }^{48}$ Thomas Biggs, labourer, who died in 1633 , operated on a larger scale. In his parlour were a jersey-mill, 'pattens' for stockings, a pair of jersey-combs, and four jersey-wheels, all valued at $f_{\mathrm{I}}$. In his entry he had $\mathrm{I} 3 s .4 d$. worth of woollen yarn, £i worth of wool, and $\mathrm{i} 2$ pairs of jersey stockings valued at $36 \mathrm{~s}$. He had also 40 skeins of jersey yarn abroad and eight in the house. Possibly some of his $£ \mathrm{I} 6$ of debts were derived from the hosiery trade. Biggs was in a small way of business but he clearly combed jersey wool, had it spun, and then knitted. This occupation he combined with dairying and cheese-making. ${ }^{49}$

In $1657-8$ there were at least ten stocking makers in the town: Isabel Wells, Elizabeth Pougher, Elizabeth Beckit, Anne Browne, Elizabeth Browne, Mary Smith, Katherine Ayre, Elizabeth Tod, and the widows Sharp and Rennell. They petitioned for the admission of a turner whose services they required, presumably for the making of needles, wheels, or mills. He had already been doing work for them for some time. ${ }^{50}$ All the stocking makers were not spinsters or widows, Thomas Noone being admitted as stocking maker in 1634 and his son in $1663-4 \cdot{ }^{51}$ Although the other signatories of the petition cannot be traced, Elizabeth Pougher may serve as an example of their activity.

${ }^{38}$ Leic. Boro. Rec. 1509-1603, pp. xlii, 236, 238-9, 358; Leic. City Mun. Room, Hall Papers, I628-30, no. 306; ibid. $1630-2$, no. 238 ; ibid. $1647-9$, no. 53.

${ }^{39}$ L.R.O. Probate Rec. Wills, Ralph Garrett, I 535.

40 See above, n. 29.

${ }_{41}$ See above, p. $81, n .7 \dot{8}$.

${ }^{42}$ L.R.O. Probate Rec. Inv. of Robert Miller, ${ }^{6} 6_{32} / 149$.

43 e.g. ibid. Inv. of John Burch, r66r/78, John Shepie, 1663 (box I 127), Eliz. Knight, I664/9, Samuel Marshall, $1671 / 184$.

44 e.g. ibid. Inv. of Thos. Clarkson, I669/139, Edw. Pollard, innholder, $1674 / 143$

t5 e.g. ibid. Inv, of Margaret Lindsey, $1678 / 136$.

${ }^{46}$ W. Felkin, Hist. of Machine-Wrought Hosiery and
Lace Manufactures, 16-18; G. Henson, Hist. of the Framework Knitters, i. I I-I 3 .

47 F. A. Wells, Brit. Hosiery Trade, 55.

48 L.R.O. Probate Rec. Inv. 1632/51; Reg. Freemen of Leic. $1196-1770,93,123$.

${ }^{49}$ L.R.O. Probate Rec. Inv. $1633 / 69$.

50 Leic. Boro. Rec. I603-88, 455; Leic. City Mun. Room, Hall Papers, I 657-60, nos. 590-3; Reg. Freemen of Leic. $1196-1770,136$.

${ }^{51}$ Reg. Freemen of Leic. II96-I770, 121, 148: the second, not the first, entry appears to be mistaken; cf. L.R.O. Probate Rec. Inv. of Ric. Dand, I 69o/4o, for which Thos. Noone was an appraiser with Nic. Alsop and Thos. Aires. 
In I668 she left goods and chattels valued at $£ 754$ is. I I $d$. Of this $£ 200$ was in purse and apparel, $f_{\mathrm{I}} 66 \mathrm{I} 5 \mathrm{~s} .3^{\mathrm{d}}$. in debts, $f^{26}$ in barley, and $f_{66} 6 \mathrm{~s} .8 \mathrm{~d}$. in malt. In her wool chamber she had $£ 240$ worth of wool stockings, yarn, oil, and soap, and in her shop $f_{4}$ 'for the milne, combs and pattons and other materials for trade'. In other words, she was a maltster or cornmonger and a hosier. In the latter capacity she was a merchant employer, putting out the yarn to be knitted and perhaps the wool to be spun, while having the combing and milling done in her own shop. ${ }^{52}$ It cannot be proved that none of these stockings was made upon knitting-frames by knitters in Leicester or the countryside, and we know that there were such framework-knitters in the countryside by this time. Moreover, turners were needed in the making of stocking-frames, and it might have been for this that the stocking makers required the services of one. Nevertheless, it appears that the introduction of frames into the town of Leicester took place only at a somewhat later date and in the teeth of the opposition of the hand-knitters. ${ }^{53}$ William Bayley the chandler had a considerable stock of jersey wool and yarn in $\mathrm{I}_{66 \mathrm{I}}{ }^{54}$ Sampson Pougher was admitted as a jersey comber in 1655 and left goods and chattels worth f.3 I 5 I Is. $6 d$. in I66I; of this io guineas was in jersey yarn at home and abroad, $f 8_{\mathrm{I}}$ in 27 score stockings, $f_{\mathrm{I}} \mathrm{I}$ Ios. in wool combed and uncombed, $£ 4$ Is . in a low board bed, a jersey mill, bobbins, and 'pattins' in his garret, $\mathrm{I} 2 s$. in two pairs of combs and pots in his shop, and $f_{10} \circ$ in wares and debts in London. ${ }^{55}$ Another jersey comber, Geoffrey Wharton, left $£ .33$ Is. I I $d$. in I664, including jersey stockings and patiens to the value of $£_{\mathrm{IO}} \mathrm{I} 3^{s .} 4 d$. in his parlour, two pots of oil worth $8 s .4 d$., 2 I skeins of jersey yarn, some coarse wool and other things in his chamber worth $f_{\mathrm{I}} \mathrm{2} 2 \mathrm{~s} .8 \mathrm{~d}$., and in his barn 'one jersey mill with bobbins and washing rings and one kinnell' worth I6s. $2 d .{ }^{56}$ In 1667 Faustin Gilbert left $f 40$ worth of wool and $£_{20}$ worth of yarn out of a total of $£_{1} 50.57$ In I669 John Ludlam the tallow chandler left 'in the stockinge chamber, imprimis one presse, stockings, wool, pattings', \&c., worth $£ 442 s$.; of 'stockings, wooll and yarn in severell persons hands in the country' $\oint_{1} 53^{s}$.; 'in the combe shopp, one pair of combs, kenges, pads, combpott', \&c., worth $6 s$.; 'in the wooll chamber, wooll, weeke yarn', \&c., worth $£_{2} 5^{s}$.; and 'in the mill chamber, one jersey mill, one ditto tubb, three coffers, weeke yarne', \&c., worth $£ 3$. All told his inventory was valued at almost $£_{\mathrm{I}} 28 . .^{8} \mathrm{~A}$ jersey comber in $\mathrm{I} 67 \mathrm{I}$ left an inventory valued at $£_{\mathrm{I}} 93 \mathrm{I} 2 s$. $4 d$., of which $\AA_{36}$ Ios. was in wool and yarn, $f_{1} 207 s$. in stockings, and $f_{\mathrm{I}}$ I os. in working gear. ${ }^{59}$ William Loleby, a shearman who died in the same year, left $£ 230$, of which 'in the house chamber, stockings, tickeings, bookes, and stuffe' were worth $£ 35$; 'in the gallery, wooll, a mill, for jarsey wheeles, cheese', \&c., $£ 20$; 'in the shopp and chamber over it', two beds, two tables, and other furniture worth $£^{6.60}$ Next year John Humphries left in the closet in his hall 'I stocking press, I hangin press, stockings and other materialls' worth $\mathrm{f}_{\mathrm{I}} \mathrm{.}$. The contents of his wool chamber were valued at $f_{20} 6 s .8 d$., of his mill chamber at $£ 3$, and of his wool shop at Ios., the whole inventory being appraised at $£ 97$ I $2 s .8 d$. $^{61}$ Henry Mug, admitted as a weaver in ${ }_{1} 657$, had one twisting-wheel and two jersey-wheels beside his six looms. ${ }^{62}$ In

52 Ibid. Inv. 1668/1 33.

53 Ibid. Inv. of Geo. Hogsonn of Dixley Mill, r66o/265, Jonathan Huton of Market Bosworth, I668/62; Wells, Brit. Hosiery Trade, 55; A. Wolf, Hist. of Science, Techno$\log y$ and Philosophy in the $I 6$ th and $x 7$ th Cents. 465; Felkin, Hosiery and Lace Mftures. 31, 52, 62; J. D. Chambers, Notts. in the I8th Cent. 331 ; A. P. Usher, Hist. of Mechanical Invention, 240 sqq.; M. Dobb, Studies in the Development of Capitalism, I 46; J. D. Chambers, "The Worshipful Company of Framework Knitters', Economica, ix. 297-8. The first frame seems to have been set up in Leic. by Nic. Alsop, c. 1656-70; Wells, op. cit. 55 and n. 2; Reg. Freemen of Leic. I I 96-I770, I 39, I47, I 71, I 75, I 80; L.R.O. Probate Rec. Inv. of Nic. Alsop, I707, Ric. Dand, I690/40.

54 Ibid. Inv. I66 I (box I127).

55 Ibid. Inv. I66I/52 (box I 049).

56 Ibid. Inv. I664/74.

57 Ibid. Inv. I667/10r.

58 Ibid. Inv. $1669 / 37$.

59 Ibid. Inv. of Wm. Wykes, I671/86; Wills, I671/57 (box I 246).

60 Ibid. Inv. $1671 / 197 . \quad 61$ Ibid. Inv. $1672 / 129$.

62 Ibid. Inv. I675/18I; Wills, I675/147 (box 250); Reg. Freemen of Leic. II96-I770, I 41 . 


\section{A HISTORY OF LEICESTERSHIRE}

I678 Robert Cousens the fellmonger, who left goods and chattels worth only fir $99 s .5 d$., had in his wool chamber a parcel of hose and a hanger worth $f_{10}$ I $_{5} s .8 d$. and a coffer, a comb pot, a pair of combs, a parcel of wool, ten 'patens', \&c., worth $\oint_{\mathrm{I}}$ I Is. $6 d .63$ John Burbage, silkweaver, had goods and chattels worth $£_{96} 62 s$. $5 d$. in 1678 . Of this his debts sperate and desperate amounted to over $f 539,9$ looms and their gear to $f^{2} \mathrm{I} 6 s$., and silk and thread to $\AA_{6} 6 \mathrm{I}^{3}$ s.; I 4 pairs of stockings were valued at $2 s .4 d$. the pair, 2 pairs of silk stockings at $6 s$. the pair, 13 worsted girdles at $\mathrm{I} s$. the pair, and 48

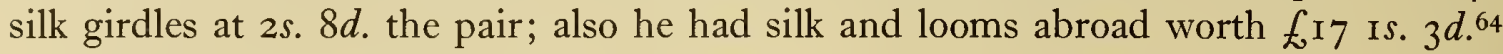
Richard Dan, 'hosier', left $£ 37$ I 4 s. in I679, of which a twisting mill, 2 wheels, 2 pairs of combs, and charcoal in his combshop were worth $f_{\mathrm{I}}$ Ios. ${ }^{65}$

Thus the hosiers were recruited from labourers, gardeners, chandlers, fellmongers, jersey combers, shearmen, weavers, and others. Some worked as master craftsmen, some as small masters, some were trading masters, and some merchant employers. Others were in transition from one stage of organization to another. Already the hosiers were beginning to sell their wares to London and already there was developing the class of merchant employers that was only superseded in the I 9 th century. ${ }^{66}$

Among the victualling occupations, butchers were the most numerous of the freemen in the 16 th and 17 th centuries generally. In addition, from I6 34 onwards, the country butchers were admitted to the freedom for markets only and by the mid-I 7 th century country butchers outnumbered town butchers. This appearance, however, is somewhat misleading. Many people were made free as butchers although butchering was not their main occupation and all butchers whatsoever were either grazing butchers, who bought stock in autumn and sold it in winter after feeding on preserved pastures; carcass butchers, who scoured the countryside for fat stock; or cutting butchers, equivalent to both modern slaughterman and meat purveyors. Philip Freake, for example, was a comburgess as a butcher, yet the major part of his capital was invested in cultivating grazing, for which he maintained two plough-teams ; and he was in fact a grazing butcher. ${ }^{67}$ So-called butchers and graziers will therefore be considered according to their main occupation as shown by the items of their inventories, and not according to their styles. None of the cutting butchers seems to have achieved great fortune, as may be seen from Table X. Cutting butchers' stocks were mostly in sheep, kine, calves, pigs, horses, and

TABLE X

Leicester Cutting Butchers' Inventories ${ }^{68}$

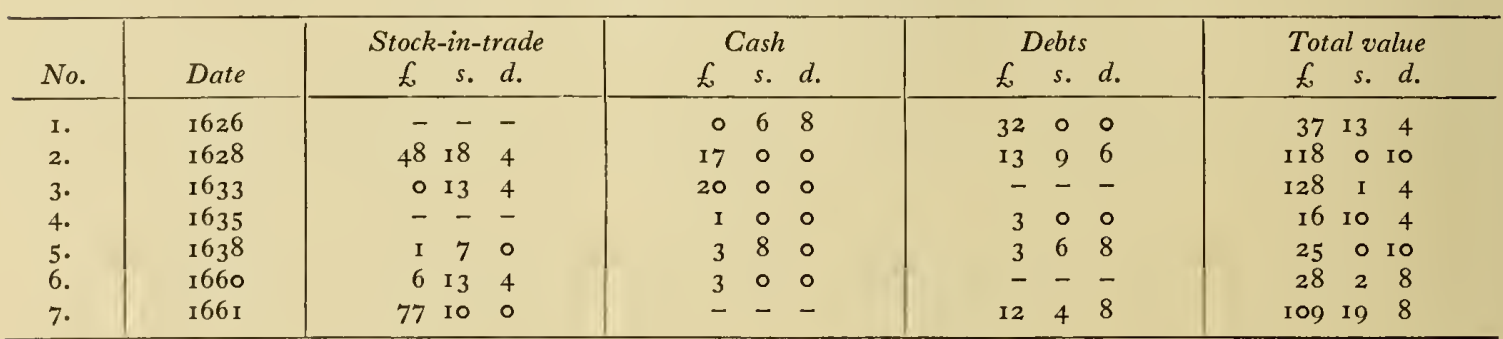

other livestock, in the modest equipment of slaughterhouses, in small quantities of tallow and other by-products, and in fodder and leases. William Cotes, who died in I628, was a substantial butcher. He had 72 sheep valued at $£ 20$ and 2 beasts valued at

63 L.R.O. Probate Rec. Inv. 1678/123.

64 Ibid. Inv. 1678/150; Wills, I678/123 (box 1254).

65 Ibid. Inv. 1679/130; Wills, 1679/107.

${ }^{66}$ E. Halévy, Hist. of Eng. People in 1815 (1924), 263-5; T. S. Ashton, Industrial Revolution, 32, 55 .
${ }^{67}$ Hoskins, Essays in Leics. Hist. $117-22$.

68 L.R.O. Probate Rec. Inv. of (I) Hugh Brewin, I626/ 194, (2) Wm. Cotes, 1628/75, (3) Johñ Heyrick, I633/82, (4) John Wood, 1635/215, (5) Ric. Atton, 1638/205, (6) Wm. Kirk, $1660 / 248,(7)$ Roger Atton, $166 \mathrm{r} / \mathrm{x}$. 
$£ 36$ s. $8 d$. These were for slaughter, as were also his 6 pigs. He had also 2 horses used for draught and worth $f_{3} \mathrm{I} 3 s$. $4 d$. and 2 cows and a calf for his dairy worth $f_{4}$. The lease of a close for sheep and beasts was valued at $f_{\mathrm{I}} \mathrm{a}$ and slaughterhouse equipment at $5^{s}$. Four stone of tallow were worth $\mathrm{I}_{3} s .4 d$. and cock and hens $3 s .4 d$. He had also $50 s$. worth of hay. With the aid of linen and woollen wheels, Cotes was able to make a comfortable living, but butchering neither demanded a great capital stock nor gave remarkable profits and the Cotes family lived modestly in their small house with its hall, nether parlour, kitchen, and cellar. William Kirk in I660 had only a mare, four sheep, and two swine, and lived in a house consisting of a hall, a little buttery, a kitchen, and two chambers. The labour of two or three persons sufficed to most butchers for slaughterhouse and pastures, and the butchers worked as self-employed persons, buying beasts from grazing butchers and farmers, and keeping and slaughtering them mainly by the labour of their families. ${ }^{69}$

Most Leicester people made their own household bread, taking it to be baked at the duchy common ovens to which they owed suit. In the I 7 th century there were six common ovens, and the bakers' company appointed Wednesday and Friday as the normal baking days, 'callers' going the round of the houses to fetch in the bread. There were also private bakehouses, licensed by the bakers' company, where white bread made of wheat for the gentry and horsebread made of beans and other horse-meat were baked. The household bread was made of rye or maslin. In addition country bakers brought in bread to sell at market and the common bakers also had bread for sale. ${ }^{70}$ The bakers operated as master craftsmen, sometimes employing a journeyman servant

TABLE XI

\section{Leicester Bakers' Inventories ${ }^{71}$}

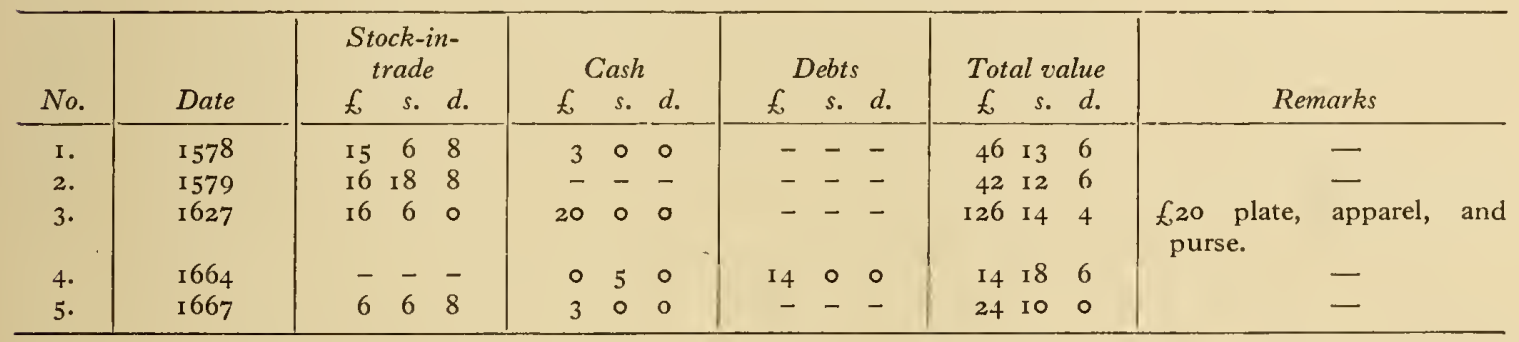

or so, although some trading masters may have appeared. ${ }^{72}$ In ${ }_{1} 578$ William Hilton left $£_{\mathrm{I}}$ in wheat and peas and $£_{\mathrm{I}}$ in malt, a horse, packsaddle, and pair of hampers valued at $\mathrm{I} 3 s$. $4 d$., and bakehouse equipment worth about $£_{\mathrm{I}}$. James Hilton left much the same in the next year, together with more corn and money. They both lived in the same house with its hall, parlour, chamber, kitchen, bakehouse, and yard. John Palmer, who died in $\mathbf{1 6 2 7}$, was a dairyman as well as a baker, leaving butter, cheese, bacon, and an old bed for a servant, worth in all $£ 3,6$ kine and 4 hogs worth $£ 20$, and milkhouse equipment to the value of $6 s .8 d$. He had also brewhouse equipment worth $f_{6} 6$ I $3 s .4 d$., and probably tippled. His flour, wheat, meal, and tubs were worth 5 os., his weights and other implements $£_{2}$, and his bread-house equipment $f_{\mathrm{I}}$ I $6 s$. Wood and coal fuel for these three lines of business, together with his hog troughs, were worth $£_{1} \mathrm{i} . \mathrm{73}^{73}$

Regulated baking in manorial ovens was opposed by a growing free trade movement.

69 See references cited above, n. 68.

70 D.L. $4 / 77 / 18, \mathrm{~mm} .3$ sqq.; D.L. 4/77/17, mm. I-2; Leic. City Mun. Room, press 22 , box 17 , no. 1 ; Thompson, Hist. of Leic. i. 223; Leic. Boro. Rec. I603-88, i 7 ; L.R.O. Probate Rec. Will of Edw. Carter, i 562.
$7 x$ Ibid. Inv. of (I) Wm. Hylton, I 578 , (2) Jas. Hilton, I 579, (3) John Palmer, I627/8 3 , (4) Thos. Ward, I664, (5) Ric. Bruce, I667/10.

72 Leic. Boro. Rec. $1509-1603,359$.

${ }^{73}$ See references cited above, n, $7 \mathrm{I}$. 
In 599 five town bakers brought an action against William Becket the weaver and victualler for default of suit of oven. Becket acknowledged his suit but refused to render it and complained to the Earl of Huntingdon, who secured a compromise whereby Becket was allowed to bake spiced bread for sale to his guests only.74 In I6 Io-I2 similar trouble recurred. The bakers of the company brought an action in the duchy court against the bakers of 'unlawful' bread. Among these was William Becket, but it was Thomas Wright who led the rebels. He himself was accused of baking sixpenny rye loaves in contravention of the assize of bread. In i6 i the duchy court ordered the five rebels to do suit of oven, forbade the baking of 'unlawful' bread except for burials and other festivals, and gave costs against the defendants, who, however, refused to pay. The defendants refused the judgement of the duchy court and referred themselves to the common law. Wright 'gave fourth braveing speeches', set up his own common oven, and continued to bake his household loaves. Several townsfolk testified that Wright's bread was more profitable to the buyer than company bread. He baked sixpenny rye loaves and sold them to such as were 'not of habilitye to buy their corne in the market'. The bakers asked Wright to be a brother of their company but he answered 'that he woulde neyther submitt himselfe to there orders nor be restrayned from bakinge his sixe penye howsholde loves but abide the order and censure of the lawe in that case made and provided'. Shortly afterwards Wright and Thomas Pestrell were imprisoned. Meanwhile, however, the duchy court had bowed to the storm and referred the matter to the borough court, which allowed Wright and others to bake loaves as they wished, only keeping the assize of weight, 'as being more necessarie and profittabler for the buyers' than bread of I $d$. or $2 d$. the loaf. Still further trouble ensued in 1628 when the bakers' company took action against bakers of pies and cakes in private ovens for sale without paying the company any rent or dues, and baking of pies at least was stopped, thanks no doubt to the changed political situation. In I649, however, there were renewed protests against the company. William Holmes the baker borrowed the company ordinal and cut out 'certain branches forth of the said ordinall' because 'he was trobled for bakinge of pies more than any of the other bakers'. After he had given satisfaction to the company, the court discharged him. ${ }^{75}$

The borough also owed suit of milli6 to the Castle Mills of the duchy. In the mid-I 6 th century suit of mill seems to have decayed, but in $\mathrm{I}_{60}$ Sir Edward Hastings, the owner of Abbey Mills and the tenant of Castle Mills and the windmill, brought a successful action in the duchy court for the enforcement of suit, though other mills could operate under licence. ${ }^{77}$

There was no company of millers and not all millers were exclusively engaged in this occupation. One miller was also a carpenter, ${ }^{78}$ and Thomas Swan ran the Newarke water-mill and windmill together with his farm. In the water-mill lived one of his servants whose bedding was worth ios. The lease of the mills was worth $£, 5$ and he had also two mill horses valued at $£_{2} 6 s$. $8 d$. But his farming interests were much greater than his milling. As for those who were mere millers, they worked as master craftsmen and lived modestly enough. In I 594 Edward Taylor left goods and chattels worth about $£ 49$; John Parsons in I6 12 of less than $£_{4}$; George Parr of less than $£_{5}$ in 1637 ; next year Richard Millington just over $£ 26$ and Robert Jordan just over $£_{30}$ in $\mathrm{I}_{66}$, his millhouse equipment being worth only $£ \mathrm{I}$ I $3 s .4 d .79$

\footnotetext{
74 Leic. Boro. Rec. I 509-1603, pp. liii-liv, 354-5, 376, 394-5, 405; C. J. Billson, Medieval Leic. 134-6.

${ }_{75}$ Leic. Boro. Rec. $1603-88$, pp. xl, 106, I25-8, 383 ; D.L. $4 / 77 / 18$.

76 For the mills in Leicester, see below, pp. 395-8.

77 Leic. Boro. Rec. I509-1603, p. liii; $1603-88,37$;
Thompson, Hist. of Leic. i. 337 ; D.L. 4/50/26.
${ }_{78}$ Leic. Boro. Rec. $1603-88,68$.
79 Ibid. 231 ; L.R.O. Probate Rec. Inv. of Thos. Swan, I630/122, Edw. Taylor, I594, John Parsons, I612, Geo. Parr, $1637 / 208$, Ric. Millington, $1638 / 176$, Robert Jordan, I665/22.




\section{THE CITY OF LEICESTER}

In the early 17 th century malting increased in importance and the occupation was the subject of considerable regulation. In I6 5 maltsters were henceforth forbidden to buy barley for malting and it was ordered that malt was to be sold either in open market or directly to common brewers and victuallers. For a time the maltsters were reduced to making their purchases of barley through wives and servants. The objection to the maltsters was that they had stores of barley that they did not bring to market but sold to tranters at their houses. They were therefore ordered to bring some barley to market weekly. At this time home brewing was practised by those who could afford a brewhouse. In addition there were reported to be about I 60 alehouses in the town. The market activities of maltsters evidently inconvenienced home brewers and alehouse-keepers and in 16 I 8 there were riots against maltsters who refused to sell corn on the market. The immediate cause of these riots was the prevalent dearth and a similar campaign was stirred up during the next serious dearth in I629-30. Extra pressure was brought upon maltsters by presenting their kilns as nuisances. Dannet Abney, for example, was presented for having an unlicensed kiln and he had to promise to remove it to where there would be no danger from fire. Other men were obliged to slate their malting rooms to avoid risk of fire, or to give bonds to their neighbours against such risk. At the same time those who were not freemen were debarred from malting. Malting had always been subject to regulation, but what now made the situation more difficult was the expansion of malting and brewery as home malting and brewing became more narrowly confined, being out of the reach of wage-earners, and also the series of harvest crises that marked the end of the old régime. ${ }^{80}$

TABLE XII

\section{Leicester Maltsters' Inventories ${ }^{81}$}

\begin{tabular}{|c|c|c|c|c|c|c|c|c|c|c|c|c|}
\hline \multirow[b]{2}{*}{ No. } & \multirow[b]{2}{*}{ Date } & \multicolumn{2}{|c|}{ Stock-in-trade } & \multicolumn{3}{|c|}{ Cash } & \multicolumn{3}{|c|}{ Debts } & \multicolumn{3}{|c|}{ Total value } \\
\hline & & $£ s$. & $d$. & & $s$. & $d$. & & s. & $d$ & $£$ & $s$. & \\
\hline I. & 1632 & $7 \mathrm{I}$ & 4 & 42 & $\circ$ & $\circ$ & I67 & 4 & $\circ$ & 415 & I 3 & 6 \\
\hline 2. & 1638 & 80 & 0 & 6 & 13 & 9 & 15 & 8 & $\circ$ & I 19 & 13 & 4 \\
\hline 3. & 1662 & I 3 & 8 & 2 & 0 & o & - & - & - & 48 & IO & 4 \\
\hline 4. & I 666 & 400 & $\circ$ & 5 & $\circ$ & ० & - & - & - & 77 & 18 & 6 \\
\hline 5. & 1670 & $50 \quad 10$ & $\circ$ & I 5 & $\circ$ & $\circ$ & - & - & - & 92 & I 2 & $\circ$ \\
\hline 6. & 1670 & I $48 \quad$ I 7 & 8 & . 5 & $\circ$ & o & 180 & $\circ$ & o & 384 & 4 & 2 \\
\hline 7. & 1670 & - & - & 2 & 10 & o & - & - & - & I3 & o & o \\
\hline 8. & I 675 & 100 & ० & 5 & 0 & o & - & - & - & 207 & $\circ$ & $\circ$ \\
\hline
\end{tabular}

Malting required considerable capital, especially for the purchase of barley and fuel. Maltsters, whose inventories are digested in Table XII, usually had stocks of wood and coals worth several pounds and sometimes as much as $f_{2} 20$. The maltsters also undertook the curing of tobacco. Henry Slater in 1632 had $\AA_{5} 5$ worth of tobacco and John Horne in I670 ios. worth. Some maltsters also brewed: Slater's brewery equipment was worth $f_{7} 6 \mathrm{~s}$. $8 d$., for example. A typical malting-house may have been the one in High (Southgate) Street with two floors each $60 \mathrm{ft}$. by $\mathrm{I} 4 \mathrm{ft}$. The business depended on having a working capital sufficient to maintain a constant flow through kilns and floors, the process lasting about two months. Thus John Swanne, who took to malting in I622, had only a few malting floors and depended on speedy sales and quick turnover. $\mathrm{He}$ sold about 20 quarters of malt weekly, like other maltsters, to divers brewers and chapmen who were his regular customers. ${ }^{82}$ Malting was also undertaken as a sideline by hosiers and others who commanded sufficient capital. Of the hosiers, for example,

\footnotetext{
${ }_{80}$ Leic. Boro. Rec. $1509-1603,246,314 ; 1603-88$, pp. xliv, I 7, I 52, I96, 250-I.

${ }_{81}^{8}$ L.R.O. Probate Rec. Inv. of (1) Hen. Slater, I632/ I 6 , (2) Thos. Thompson, I638/1 22, (3) Wm. Gutteridge,
}

I662/ I 3, (4) John Birkhead, $1666 / 26$, (5) John Horne, $1670 /$ 22 I, (6) Ric. Legitt, I670/83, (7) Edw. Walker, I670/3I, (8) Wm. Gutteridge, I675/88. The will of (I) is $1632 / 124$.

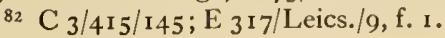




\section{A HISTORY OF LEICESTERSHIRE}

Sampson Pougher had $£_{40}$, Faustin Gilbert $£_{20}$, and Elizabeth Pougher nearly $£_{1}$ io invested in the business. ${ }^{83}$ In all probability the 17 th-century maltsters were large masters employing considerable wage-labour. ${ }^{84}$

Ale-brewing was old-established, but beer-brewing was not introduced until the 16 th century, a company being formed in 1574 and incorporating the old ale-brewers' company. Brewing was undertaken by three main groups of persons. First, many people brewed for their own consumption. Secondly, there were common brewers who served the public through tipplers or innholders. Many of these brewers, in the I6th century especially, combined brewing with some other occupation. Thirdly, the innholders were often full-blown brewers, although they were allowed to brew only for travellers and not for the townsfolk except by special licence. The common brewers also worked under licence. 85 Some of those who brewed beer had relatively expensive equipment and employed some wage-labour. They also engaged burnmen to cart water for them, but these probably worked as self-employed persons. William Lush had brewhouse equipment worth $£ 20$ in 1667 and a large supply of fuel, some of which was for brewing and some for heating and cooking in his inn. The scale of brewery establishments was growing and there are signs of the development of large-scale brewing involving the employment of large numbers of workpeople. ${ }^{86}$

There were also distillers in the town. John Boxall, the strong-waterman who died in I632, was a freeman of the brewers' company, but others were admitted as strongwatermen. Boxall left goods and chattels worth over $£^{216}$, of which $f_{107}$ was in debts and $f_{40}$ in purse and apparel. In his shop he had strong waters, a copper, and an alembric, worth in all $£_{22}$, and he had wood and coals in his yard to the value of $£_{1} 136 s .8 d .87$

Tippling was a common by-occupation of the craftsmen. Ale and beer were in such demand that anyone with a brewhouse had no farther to seek for a source of supplementary income. ${ }^{88}$ Innkeeping could be very profitable, especially if one had a brewery. A skittle alley was also an advantage; and the inn servants could be employed at spinning in slack periods. ${ }^{89}$ Victualling could be a whole- or part-time employment, and the occupation or company was heterogeneous in character: some members brewed and sold beer and ale, some were hay merchants, some wood- and coal-mongers. Bartholomew Gracedue, for example, who died in 1646 , sold wood and timber, charcoals and pit coals, as well as hay. ${ }^{90}$ Some cooks were able to earn good livings, ${ }^{91}$ but the salters were poor in the extreme..$^{22}$

This was the age of wood, and skilled woodworkers were of great importance to the economy. The carpenters worked as master craftsmen, employing small capital and attaining to only modest wealth. The wealthiest whose inventory has been examined left just over $£_{84}$ in goods and chattels in 1678 . Most were considerably poorer. ${ }^{93}$ The joiners were similarly placed, the most successful leaving goods and chattels worth

${ }^{83}$ L.R.O. Probate Rec. Inv. I661/52, I667/101, I668/ 133 respectively.

${ }_{34} \mathrm{C}_{3 / 415 / 145 .}$

85 Thompson, Hist. of Leic. i. 205; Leic. Boro. Rec. I 509-1603, 353-4; Billson, Medieval Leic. 126; Leic. City Mun. Room, press 22, box I 7, no. I.

${ }^{86}$ L.R.O. Probate Rec. Inv. of Wm. Lush, $1667 / 136$, John Bolivant, I646/50; Leic. Boro. Rec. I 509-1603, 300; I603-88, 96, 21 5, 221, 383; J. H. Thomas, Town Government in the 16 th Cent. $80-8 \mathrm{I}$.

87 L.R.O. Probate Rec. Inv. of Alice Dampard, I572, John Boxall, 1632/161; Leic. Boro. Rec. I603-88, 221.

88 Leic. City Mun. Room, press 22, box I7, no. I.

${ }^{89}$ L.R.O. Probate Rec. Inv. of Ric. Woodward, I 563, Wm. Davy, 1567, John Jefferey, I636/ I 10, Bartholomew Hunt, I66I/21 1, John Travel, 1666/125, Wm. Lush, 1667/
I36, Edw. Pollard, 1674/143, Edw. Biddolph, I676/167.

90 Ibid. Inv. of Ric. Bryan, I 58I, Bartholomew Gracedue, r 646/30, Ric. Stretton, I656/329, Bartholomew Fruett, I 66 I/287, Wm. Chapman, I665/154; Reg. Freemen of Leic. $1196-1770,76$, and see entries in index; Leic. Boro. Rec. I603-88, 439; Leic. City Mun. Room, press 22, box I 7 , no. $\mathbf{I}$.

91 L.R.O. Probate Rec. Inv. of Thos. Walton, I648/21, Thos. Hill, I673/14I.

92 Ibid. Inv. of Thos. Ricard, 1581 , Thos. Bailey, I602, John Burch, I66I/78, Wills, John Burch, I66I/C 75; Reg. Freemen of Leic. I I $96-1770,96$.

93 Leic. Boro. Rec. I603-88, 6I ; L.R.O. Probate Rec. Inv. of John Ossiter, 1612/110, Robert Mease, 1660/32, Ric. Jarvis, $1670 / 89$, Ric. Jerves, $1675 / 24$, John Inge, $1678 / 77$. 
$£ 72 \mathrm{I} 3 s .4 d$. in $1642 .{ }^{94}$ Cart and wagon wheels were almost universally iron-bound and the wheel-wright's craft was exceptionally skilled. Wheel-wrights operated with more capital than did carpenters or joiners. In $5_{54} 6$ William Hawkes was employing at least one maid and one manservant. William Hobby in 597 was also a farmer, but he had well over $f_{6} 60$ invested in his craft. He made some carts as well as wheels. ${ }^{95}$ Ploughwrights were no less skilled than wheel-wrights and probably worked under similar conditions. ${ }^{66}$ Turners were united in a single company with joiners, and their position was probably akin to those of the joiners and wheel-wrights, one of whom at least was also a turner. ${ }^{97}$ Other woodworkers fashioned spoons and trenchers for the table. ${ }^{8}$ Of three coopers, one left an inventory worth $£$, IO I $3 s$. $4 d$. in I $53^{8}$, a second nearly $£^{22}$ in I633, and another over $£_{1} 0_{5}$ in I649, having stocks-in-trade of $£_{6}^{6} 3_{3} .4 d$.,$£_{7}$, and $£_{3}$ I respectively. ${ }^{99}$

Blacksmiths could not hope for wealth from their smithies alone, especially when ironmongers intervened between them and the public. Many of them, indeed, were forced to supplement their livelihoods by spinning. The forge was often combined with a farm and a farmer-blacksmith might, like Henry Peale the elder in I639, leave goods and chattels worth nearly $£ 700$, with about $£_{2} 70$ invested in husbandry and about $£_{1} 100$ in his craft. Most blacksmiths worked much like modern ones, though they fashioned some objects, such as arrow-heads, that are now obsolete. ${ }^{\text {I }}$ Some specialist locksmiths were to be found, and some blacksmiths specialized in more intricate work such as locks, compasses, knitting pins, hand-saws and awl-blades, nippers, pincers, woolcards, sheep-bells, pack-needles, and the like, as did Thomas Armeson, who in I 672 maintained branch retail establishments at the Gainsborough, Loughborough, and Hinkley. He was, indeed, more of a metal-worker than a blacksmith and left over $£ 276$ in his inventory. ${ }^{2}$ There were also a few coppersmiths and goldsmiths working as rather needy master craftsmen. ${ }^{3}$ Smiths made some edge-tools, but these were usually produced by cutlers working as master craftsmen. One cutler, who died in $\mathrm{I} 663$, was also a gunsmith and his shop an armoury. ${ }_{4}$ Of the pewterers, John Launder left goods and chattels worth over $£_{104}$ in $\mathrm{I}_{625}$, but of this only $£_{4}$ IOs. was invested in pewtering and $£_{54}$ in malt. In these two trades he employed, in addition to family labour, two menservants who slept in a chamber apart. Anne Launder in 1669 had a casting chamber with moulds and other implements worth over $f_{14}$, and tools and fuel in her shop and yard worth $£ 5$ Ios., but most of her personal estate was made up by the $£ 4$ Io she had in purse, apparel, bonds, and debts. ${ }^{5}$ Braziers sometimes employed considerable capital; one who died in 1662 had $£ 93$ invested in craft goods ranging from coppers to candlesticks. He also had a brewhouse that exceeded his household requirements, and his inventory was appraised at over $£ 207.6$ Bellfounders also employed large capital. Robert Newcombe in ${ }^{5} 56$ was combining bellfounding with tanning, but had more invested in the former occupation. He left a personal estate of over $£ 250$ and employed two maids and five

${ }^{94}$ Ibid. Inv. of Ric. Morris, I 577, Thos. Brooksbye, 1638/113, Robert Cauldwell, 1642, Thos. Ichind, I667/ 191 .

95 Leic. Boro. Rec. I509-I603, 332-5.

96 Ibid. $1603-88,17$.

97 Ibid. I 509-1603, 309; I603-88, 361, 455, 469; Reg. Freemen of Leic. II I96-I770, I31 ; Leic. City Mun. Room, Hall Papers, I657-6o, nos. 590-3.

98 L.R.O. Probate Rec. Inv. of Robert Heryson, I 539.

99 Ibid. Inv. of Wm. Claver, I 538, Thos. Whipps, I633/ 150, John Fowlzer, 1649/75; Reg. Freemen of Leic. I I96$I 77^{\circ}$, see under index.

I L.R.O. Probate Rec. Inv. of Wm. Tayler, I557, Alborne Budworth, 1567, Thos. Chettleton, 1633/109,
Katherine Chettleton, I637, Hen. Peale, I639/101, Thos. More, I 657/380, Jas. Kinge, I660, Thos. Devonshire, I662/50, Jas. Nutt, I663, Hen. Peale, I664, Anthony Courtis, I664/100, Francis Mottley, 1678-9/162.

${ }^{2}$ Ibid. Inv. of Christopher Needham, 1603 , Thos. Armeson, I672/130.

3 Ibid. Inv. of John Turville, $1678 / 144$; Leic. Boro. Rec. I 509-I603, 205; I603-88, 98.

4 L.R.O. Probate Rec. Inv. of Wm. Ball, 1584 , Samuel Yates, I646/65, 92, John Yeatts, I663.

5 Ibid. Inv. of John Launder, I625/57, Anne Launder, I669/206.

6 Ibid. Inv. of Wm. Auger, r662/146. 


\section{A HISTORY OF LEICESTERSHIRE}

menservants. Thomas Newcombe combined bellfounding with a spinning house. $\mathrm{He}$ apparently traded with London and employed at least two indwelling menservants who lived in an outhouse and slept on rough boarded bedsteads. ${ }^{7}$ Some of the metal-workers employed wage-labour in considerable quantities, though usually only when they ran two occupations side by side.

Another group of craftsmen was concerned with building and the production of those household goods that were not made by carpenters and joiners. The register of freemen is not a good directory of trades in the I6th century and later, and it is not known, therefore, whether there were any glaziers admitted in the early I6th century. There was, however, at least one, Richard Ingulward, working in the town at that time, who was not a freeman, and there may well have been others. The later cheapening of glass production may have resulted in the recruitment of further glaziers, some of them from among the rough masons possibly, but those who were nominally rough masons might have been glaziers in fact. Possibly the two occupations were merged for a time. As the glaziers were expert in the use of lead, it is not surprising that some of them were also plumbers, and the two names may, indeed, have been used as alternatives. What is clear is that the glaziers were poor craftsmen with personal estates frequently of less than fio. ${ }^{8}$

The tallow-chandlers', slaters', plasterers', and pargeters' trades all overlapped one another and they all appear to have belonged to the same company. At the same time some members of the occupation branched out into other trades as well. In the midI 7 th century, for example, some chandlers were entering the hosiery business. ${ }^{9}$ Their inventories are summarized in Table XIII. It is plain that chandlers, slaters, and plasterers lived as poor craftsmen unless they were able to gain a footing in some fourth

\section{TABLE XIII}

\section{Inventories of Chandlers, Plasterers, and Slaters ${ }^{\mathrm{IO}}$}

\begin{tabular}{|c|c|c|c|c|c|c|c|c|c|c|c|c|c|c|}
\hline \multirow[b]{2}{*}{ No. } & \multirow[b]{2}{*}{ Date } & \multicolumn{3}{|c|}{$\begin{array}{l}\text { Stock-in- } \\
\text { trade }\end{array}$} & \multicolumn{3}{|c|}{ Cash } & \multicolumn{3}{|c|}{ Debts } & \multicolumn{3}{|c|}{ Total value } & \multirow[b]{2}{*}{ Remarks } \\
\hline & & & $s$. & $d$. & $£$ & s. & $d$. & & $s$. & $d$. & $£$ & $s$. & & \\
\hline I. & 1556 & $\circ$ & 6 & 8 & - & - & - & - & - & - & $4 \mathrm{I}$ & 9 & 5 & Plasterer-slater. \\
\hline 2. & 1557 & & - & - & - & - & - & - & - & - & I8 & 2 & 8 & Slater. \\
\hline 3 . & 1575 & $\circ$ & 13 & 4 & I & 2 & o & - & - & - & $3 \mathrm{I}$ & I 3 & 6 & Pargeter. \\
\hline 4. & 1577 & - & - & - & - & - & - & - & - & - & 6 & 12 & $\circ$ & Slater. \\
\hline 5 . & $159 \mathrm{I}$ & 2 & $\circ$ & $\circ$ & - & - & - & - & - & - & 12 & $\circ$ & 4 & Chandler. \\
\hline 6. & 1599 & 5 & 13 & 4 & 6 & $\circ$ & $\circ$ & - & - & - & $\mathrm{I} 48$ & 3 & 2 & Chandler-slater and grazier. \\
\hline 7 . & 1601 & 35 & 3 & 4 & - & - & - & - & - & - & 54 & 5 & 8 & Chandler-slater. \\
\hline 8. & 1614 & 3 & $\circ$ & $\circ$ & I & $\circ$ & o & I & 6 & 8 & 44 & II & 4 & Chandler-slater. \\
\hline 9. & 1646 & 19 & $4 \mathrm{I}$ & Io & I & o & o & - & - & - & 23 & 3 & 10 & Chandler. \\
\hline IO. & 1647 & 8 & 8 & $\circ$ & 3 & 6 & 8 & - & - & - & 27 & I 8 & 8 & Chandler. \\
\hline II. & 1671 & I 5 & $2 \mathrm{I}$ & I0 & $0 \mathrm{I}$ & 13 & 4 & - & - & - & 40 & 7 & 8 & Chandler-slater-plasterer. \\
\hline I2. & 1675 & 14 & 9 & o & 4 & o & o & 3 & o & o & 52 & I 8 & $\circ$ & Chandler-slater-plasterer. \\
\hline
\end{tabular}

occupation. As houses were made of timber, plaster, and slates, building needs could be met by members of the plasterers'- slaters'-chandlers' company and by the carpenters and joiners. There were also some masons and layers, and rough masons and rough layers, working as craftsmen and supplying their own materials. ${ }^{I}$ Some of these masons

7 L.R.O. Probate Rec. Inv. of Thos. Newcombe, i 58 r, Francis Watts, $1636 / 149$; Wills, Francis Watts, $1636 / 87$; Leic. Boro. Rec. I 509-I603, 96-98; Hoskins, Essays in Leics. Hist. I 16 ; V.C.H. Leics. iii. 47-48.

${ }^{8}$ L.R.O. Probate Rec. Inv. of Ric. Ingulward, I53 1 , Thos. Burstall, 1626/74; Reg. Freemen of Leic. I I 96-I770, 79,98 ; see also above, pp. 76-78; cf. Hoskins, op. cit. I ro-г I . 9 L.R.O. Probate Rec. Inv, of Wm. Bayley, I66I, John Ludham, $1669 / 37$.
10 Reg. Freemen of Leic. II $96-I 770,75-76$; L.R.O. Probate Rec. Inv. of (1) Wm. Berowe, 1556, (2) Edw. Carter, I 557, (3) Wm. Taylor, I 575, (4) Nic. Robinson, I 577, (5) Thos. Wodland, I 59 I, (6) Hen. Halpennye, I 599, (7) John Ludlam, 1602, (8) Wm. Gregory, 1614, (9) Wm. Coulson, $1646 / 73$, (ro) John Henshaw, I647/33, (I I) Thos. Wodland, 1671/201, (12) Rọbert Ogden, 1675/66.

II Leic. Boro. Rec. I 509-I603, 239-40; Thompson, Hist. of Leic. i. 283-4; D.L. 44/273. 
and layers were freemen of the town and some were not. William Jerman (d. I 584 ), an unfree mason, left just over $£_{50}$, and he and his family eked out their living by linen and woollen spinning and dairying. His working tools were valued at $2 s$. only. A rough layer left $£ 5^{2}$ odd in I664; of this $£ \mathrm{I} 8$ Ios. was in draught cattle and two old carts, presumably for the haulage of stones, and $£_{1} 5$ in dairy cattle. ${ }^{12}$ Painter-stainers were poor craftsmen with working capitals of about $f_{\mathrm{I}}$ in the mid-I 7 th century. ${ }^{13}$ One furnishing trade remains, upholstery. Upholsterers made or sold such things as cushions, blankets, manchester beds, scotch beds, rugs, coverlets, bolsters, and curtains. It was a profitable business, for one left goods and chattels worth $£_{\mathrm{I}} \mathrm{I}, 35^{8}$ in $\mathrm{I} 635$ and another of over $£_{4} 45^{\circ}$ in 1675 . The upholsterers seem to have developed from the mercers and linen drapers and must have exercised mainly trading functions, employing small masters in making up furnishings. ${ }^{14}$

Two crafts were concerned with armoury in addition to cutlers and gunsmiths, namely, the furbishers and fletchers. Furbishing can hardly have been very renumerative and the fletchers were virtually paupers, in spite of the fact that bows and arrows were still in wide use, if only for hunting and poaching. ${ }^{15}$ Transport and communications were served by the common carriers, some of whom maintained services to and from London, and by the postmaster. ${ }^{\mathrm{I} 6}$ Medical services were provided by apothecaries, barbers, surgeons, and physicians. Barbers and physicians seldom commanded any considerable means, but some of the later barber-surgeons had personal estates running into hundreds of pounds, usually consisting largely of debts and leases. ${ }^{17}$ Lawyers and scriveners were prosperous enough. ${ }^{18}$ There were gardeners, but these were concerned with tending flower gardens and orchards, and there is no sign of market-gardening. ${ }^{19}$ The rest of the occupations of the town-sergeants, gaolers, priests, criers, apparitors, schoolmasters, and musicians, provided essential services. The impression given is that social life in Leicester was no less cultivated in the early 17 th than in the early 20 th century. In many respects, indeed, cultural standards were higher then than now.20

The base of all this world of crafts, trades, and professions was agriculture. Leicester existed to serve the needs of the countryside and was itself part of the countryside. Husbandry in one form or another was the most general by-occupation of townsfolk of all classes, and the town had a profoundly rural aspect. Pigs and cows went their ways about the town, though ringed or herded, and as late as 16 Io it was necessary to forbid winnowing in the streets. ${ }^{21}$

The lands of Leicester were made up approximately as follows. In the walled town, I 32 acres; in the extra-mural town, 35 acres; East Field, I,I 80 acres; South Field, 6I 4 acres; West Field, 686 acres; and water, 60 acres. The West Field consisted of I40

12 Leic. Boro. Rec. I603/88, 294-5; L.R.O. Probate Rec. Inv. of Wm. Jerman, I584, Wm. Hastewell, 1664

${ }_{13}$ Ibid. Inv. of Wm. Pelton, I64I/I, Robert Bradshawe, x660/1 3 .

14 Ibid. Inv. of Hugh Low, I564, Wm. Trickten, I635, Eliz. Trickton, I675/III; Reg. Freemen of Leic. II96I770, I09, II 8 .

15 L.R.O. Probate Rec. Inv. of Randall Knight, I57I, Chas. Robinson, I663/7; Wills, Thos. Holme, 1546; Leic. Boro. Rec. I 509-I603, 222.

${ }_{16}$ Leic. Boro. Rec. I 509-I603, 3 I 5 ; I603-88, 39, 222; Thompson, Hist. of Leic. i. 269-70, 352.

17 Leic. Boro. Rec. I 509-I603, 219, 306; I603-88, I7, 7 I ; L.R.O. Probate Rec. Inv. of Thos. Langham, 1558, John Wryghte, I557, Peter Mayes, I571, Thos. Walter, 162 1/85, Robert Heyward, 1633/130, Hen. Eaton, 1664/ 108, Wm. Simpson, I666/ i 14, Hen. Heward, I673/167.
18 Ibid. Inv. of John Chippingdale, $1627 / 258$, Peter Whiteheade, I663/146; Leic. Boro. Rec. I603-88, I7; C $3 / 301 / 53$.

19 E 178/5409; L.R.O. Probate Rec. Inv. of Wm. Hitchcocke, 1632/51, Wm. Robinson, I664/129, Thos. Norris, 1670/193, Wm. Hitchcock, 1671/230.

${ }_{20}$ Ibid. Inv. of Ric. Huddylston, I 545, Ric. Swan, I 595, John Underwood, I599, John Worthington, I640/I I5, John Chambers, I 588, Wm. Reyd, I539, Robert Cowper, I 544, Thos. Jessons, I6 I $4 / 78$, Wm. Ruddyarde, I626/87, John Bonnett, I6 $32 / 75$, Wm. Blisse, I637/245, John Bell, I63 I/ 1 35; Leic. Boro. Rec. I509-1603, I, I 84, 358-9, 369, 450 et passim; I603-88, 53, I 91, 357, 399-400 et passim; Throsby, Hist. of Leic. 375; Thompson, Hist. of Leic. i. 354-6; Thomas, Town Government, I24.

${ }_{21}$ Leic. Boro. Rec. I603-88, 104. 


\section{A HISTORY OF LEICESTERSHIRE}

acres of Braunstone meadows (holmes) on the west bank of the Soar, and, after the addition of forest lands in 1627 , of $c .650$ acres of arable and $I_{52}$ of pasture. The arable was probably cultivated in the Midland three-field course of tilth, breach, and fallow successively. East (St. Margaret's or Great) Field contained c. 680 acres of arable and 500 of pasture, subdivided into Nether, Middle, and Conduit fields. South (St. Mary's or Town) Field contained $c .445$ acres of arable and I 69 of pasture, divided into Rawdykes, Gallowtree, and St. Mary's Fields, and the Cowhay near the river. These fields remained largely open in the $I 7$ th century. To the north of the town were the demesne lands of the abbey, which consisted in $155^{1}$ of 56 acres of arable in Hermitage and Peas Fields, I03 of meadow, I 80 of up-and-down arable in the park, and ten closes ranging in size from $2 \frac{1}{2}$ to 24 acres and amounting in all to $157 \frac{1}{2}$ acres. In addition, some Leicester people farmed the lands of other townships, or pastured beasts in the forest, just as foreigners were also to be found farming some land in Leicester. ${ }^{22}$ The open fields were subject to common rights and management. The town swineherd blew his horn about the town for the tack of swine, common of pasture was rated by the yardland, yardlands were laid down and altered from time to time, grass grounds were reapportioned, the course of cultivation regulated, the Cowhay fenced, the stint arranged, and agistment supervised in the manner of all common field townships. ${ }^{23}$

Many townspeople maintained a dairy for their own provision and there were numerous dairies working for the market. ${ }^{24}$ Such dairies included pigs to consume the whey, sheep to close-crop the grass, and half a dozen or more kine, besides weanling calves, heifers, and an occasional bull. Their produce was mainly butter and cheese, butter at least being sold to London through the carriers. The dairies were run as family businesses, little or no outside labour being employed. ${ }^{25}$

Non-cultivating graziers and grazing butchers were numerous. Their inventories are summarized in Table XIV. Sheep and beasts were kept or fattened on grass, hay, and oats. The non-cultivating grazier might make some of his own hay, or even all of it, but other fodder he would purchase from farmers or obtain from impropriated tithes or from sowing to thirds and halves, that is, share-cropping. In many cases, however, such graziers also ran dairies either for their households or for the market. Some also bred horses, as did 'Thomas Fleming, a member of the butchers' company who died in I 564 . Cheese, bacon, beef, and wool all figure in the inventories. Some graziers were also craftsmen, as Richard Springthorpe the whittawer (d. I638). Thomas Pippin was a member of the tanners' company and may merely have retired from tanning when he died in 1675 . Such grazing, even if combined with dairying, was economical of labour. Most of the businesses could have been run by family labour or by the use of a small number of maids and men. By avoiding plough work, the non-cultivating grazier spared himself the great expenditure and forewent the high profits of the farmer. ${ }^{26}$

The cultivating graziers grew mainly meat and animal products, often supported by a dairy, but they grew their own fodder crops: hay, barley, peas, oats, tares, beans, and rye, and food and drink crops often. Hence they had the working expenses of general farmers. First, they had implements such as iron-bound wagons, ploughs, harrows,

22 C. J. Billson, 'Open -Fields of Leic.', T.L.A.S. xiv. 2 sqq.; Assoc. Archit. Soc. Rep. and Papers, xxiii. 240-1; Hoskins, Essays in Leics. Hist. 121-2; Leic. Boro. Rec. I603-88, I05; L.R.O. Probate Rec. Inv. of John Tompson of Belgrave, $1645 / 41$.

${ }_{23}$ Throsby, Hist. of Leic. 87-88; Thompson, Hist. of Leic. i. 244 ; Leic. Boro. Rec. I603-88, 42, 66-67, 78-79, 214 ; S.C. $12 / 10 / 11$.

${ }^{24}$ L.R.O. Probate Rec. Inv, of Thos. Markby, c. 1520 ,
John Howgham, c. 1550, Edw. Wawarke, 1558, Robert Crofton, I 572, Eliz. Hubbarde, 1580 , Vasper Bruarns, 1614 , Thos. Chettleton, 1633/109, Robert Bennett, 1637/ 75, Mary Stretton, 1648/9, Ric. Birstall, I660/149.

${ }_{25}$ Ibid. Inv. of John Whitby, 1551 , Wm. Smith, 1557 , Thos. Browne, 1558 , Alice Aboll or Johnson, 1588 , Wm. Kyrkeham, I 535; Leic. Boro. Rec. 1603-88, 222.

${ }_{26}$ See below, n. 27, citing inv. upon which these statements are based. 
THE CITY OF LEICESTER

coulters, shares, plough-timber, yokes and harness, and so on. Secondly, they employed wage-labour in some quantity. Philip Freake, a grazing butcher, who died in 1588 ,

TABLE XIV

Non-cultivating Graziers' Inventories ${ }^{27}$

\begin{tabular}{|c|c|c|c|c|c|c|c|c|c|c|c|c|}
\hline No. & Date & $\begin{array}{c}\text { Stock- } \\
\text { trad } \\
£\end{array}$ & $\begin{array}{l}\text { in- } \\
\text { de }\end{array}$ & $\begin{array}{c}\text { Number of } \\
\text { sheep }\end{array}$ & $\begin{array}{c}\text { Number of } \\
\text { cattle }\end{array}$ & $\begin{array}{c}\text { Number of } \\
\text { horses }\end{array}$ & $\begin{array}{l}\text { Cas } \\
£\end{array}$ & s. & $\stackrel{£}{D}^{D e b t}$ & & $\begin{array}{l}\text { To } \\
\text { val } \\
\text { f. }\end{array}$ & $\begin{array}{l}\text { tal } \\
\text { lue } \\
\text { s. }\end{array}$ \\
\hline x. & $\times 55^{6}$ & & 7 & 400 & & $\cdots$ & - & - & - & - & & 10 \\
\hline 2. & $155^{8}$ & & $x_{3}$ & $4^{8}$ & 3 kine & . & $x$ & $\circ$ & - & - & 43 & I 8 \\
\hline 3. & 1560 & $12 I$ & 16 & 80 & $\begin{array}{l}2 \text { kine } \\
2 \text { heifers } \\
2 \text { calves }\end{array}$ & .. & - & - & - & - & 45 & 4 \\
\hline 4. & I 564 & $x^{x} x$ & ro & $\begin{array}{l}\text { 127 sheep } \\
40 \text { couples }\end{array}$ & $\begin{array}{l}\text { x } 6 \text { kine } \\
7 \text { calves } \\
4 \text { beasts }\end{array}$ & $\begin{array}{l}3 \text { mares } \\
2 \text { foals } \\
2 \text { colts }\end{array}$ & - & - & - & - & I 52 & 2 \\
\hline 5. & $x_{5} 64$ & 20 & 8 & $\begin{array}{l}\text { I } 6 \text { sheep } \\
\text { 20 lambs }\end{array}$ & . & . & - & - & - & - & 43 & 7 \\
\hline 6. & I 628 & $5^{\mathrm{I}}$ & 7 & 83 & 2 beasts & .. & - & - & 13 & o & 84 & I 5 \\
\hline 7. & $16_{3} I$ & 53 & 9 & 53 & $\begin{array}{l}6 \text { kine } \\
3 \text { calves }\end{array}$ & $\cdots$ & - & - & - & - & 65 & 18 \\
\hline 8. & 1638 & 60 & $\circ$ & 49 & $\begin{array}{l}5 \text { kine } \\
5 \text { beasts }\end{array}$ & $\begin{array}{c}3 \\
2 \text { mares }\end{array}$ & ro & o & $26 \mathrm{I}$ & 13 & I 56 & 14 \\
\hline 9. & 1670 & I 57 & 7 & $\begin{array}{c}167 \\
23 \text { lambs }\end{array}$ & I 6 kine & I & 20 & $\circ$ & $35 \mathrm{I}$ & 12 & 287 & I 6 \\
\hline ro. & $x 675$ & $3 x$ & 0 & 35 & 2 kine & . & I & o & $317 \mathrm{I}$ & 18 & 356 & I I \\
\hline XI. & 1676 & $213 I$ & ro & I 65 & 25 beasts & $x$ mare & 5 & o & - & - & 222 & 3 \\
\hline I2. & I 678 & 55 & 2 & 93 & $\begin{array}{l}4 \text { kine } \\
\text { ro heifers }\end{array}$ & . & I & o & - & - & 65 & ro \\
\hline
\end{tabular}

TABLE XV

Cultivating Graziers' Inventories ${ }^{28}$

\begin{tabular}{|c|c|c|c|c|c|c|c|c|c|c|c|}
\hline No. & Date & $\begin{array}{l}\text { Stock-in- } \\
\text { trade } \\
\& \quad s .\end{array}$ & $\begin{array}{c}\text { Number of } \\
\text { sheep }\end{array}$ & $\begin{array}{c}\text { Number of } \\
\text { cattle }\end{array}$ & $\begin{array}{c}\text { Number of } \\
\text { horses }\end{array}$ & $\begin{array}{l}\text { Crops } \\
\text { f } \quad s .\end{array}$ & $\begin{array}{l}\text { Cash } \\
£\end{array}$ & $h$ & $\begin{array}{l}\text { Debts } \\
£ \quad s .\end{array}$ & $\begin{array}{l}\text { Total } \\
\text { value } \\
\text { \& s. }\end{array}$ & \\
\hline I. & I 571 & $44 \circ$ & I I & $\begin{array}{l}\text { I } 7 \text { kine } \\
x \text { bull }\end{array}$ & I mare & 70 & 8 & $\circ$ & -- & 84 & 3 \\
\hline 2. & ${ }^{1} 588$ & $383 \times 5$ & 489 & 42 & $\begin{array}{l}2 \text { mares } \\
2 \text { foals } \\
2 \text { colts }\end{array}$ & 224 & 107 & ० & -- & 627 & 13 \\
\hline 3. & I 595 & 340 & $5^{6}$ & 5 beasts & 6 geldings & 70 & $4 \mathrm{I}$ & 10 & 30 & 103 & 5 \\
\hline 4. & 1625 & $39 \times 6$ & & Malt, corn, s & aw, and mon & $y-£ 34$ & & & 200 & $x^{2}$ & $x_{7}$ \\
\hline 5. & 1660 & 1510 & 7 & $\begin{array}{l}3 \text { beasts } \\
2 \text { heifers } \\
x \text { calf }\end{array}$ & .. & $3 \quad 17$ & $\mathrm{I}$ & 2 & - & 27 & I7 \\
\hline 6. & $x 663$ & 35 10 & 2 rams & $\begin{array}{l}\text { ro steers } \\
\text { I cow }\end{array}$ & 3 & 9 & 12 & $\circ$ & 204 10 & 299 & 7 \\
\hline 7. & 1675 & $203 \quad 3$ & $\begin{array}{l}67 \text { ewes } \\
2 \text { rams } \\
20 \text { ewe hogs } \\
2 \text { hogs } \\
29 \text { sheep }\end{array}$ & $\begin{array}{l}\text { 16 kine } \\
2 \text { bulls } \\
6 \text { heifers } \\
\text { I I calves }\end{array}$ & $\begin{array}{l}5 \text { mares } \\
\text { I horse }\end{array}$ & $\begin{array}{c}\mathbf{1} 2 \quad 0 \\
\text { (all hay) }\end{array}$ & 20 & o & $\begin{array}{c}\mathrm{I}, 787 \circ \circ \\
\text { mainly } \\
\text { mortgages }\end{array}$ & $2, \operatorname{II} 8$ & $\circ$ \\
\hline
\end{tabular}

must have employed men in plough and field work, and maids about the house and yard, and it is difficult to see how he could have run his farm with fewer than two or three servants in husbandry. Even John Shirman (d. 1675) maintained a plough, though he left only hay crops. It must be remembered, however, that much of the hay of these

27 L.R.O. Probate Rec. Inv. of (1) John Abbatt, I 556, (2) Isabel Carter, I 558 , (3) John Oldham, I 560 , (4) Thos. Flemyng, 1564 , (5) John Parker, I 564, (6) Hugh Hassell, I628/199, (7) John Pollard, I631/180, (8) Ric. Springthorpe, I638/129, (9) John Norris, I670/92, (10) Thos. Pippin, $1675 / 140$, (I I) Robert Baxton, I676/2, (I2) Roger Hewin, $1678 / 116$. Pence have been ignored in the cash columns.

28 Ibid. Inv. of (1) John Thompson, 1571 , (2) Ric. Swane, I 588, (3) John Freake, I 595/1 I 4, (4) Jas. Kinge, 1625 , (5) Thos. Blunt, I66o, (6) John Shirman, I663/107; Hoskins, Essays in Leics. Hist. I I 3-14, I 20-2. Pence have been ignored in the cash columns. 


\section{A HISTORY OF LEICESTERSHIRE}

graziers was cultivated, whether grass or tare hay. John Thompson (d. I 57 I), 'butcher', had a dairy, but was probably a grazing or carcass butcher also. The bigger of the cultivating graziers employed far more labour than did the non-cultivating, and, as may be seen from Table XV, they resembled in many ways the farmers of the time. ${ }^{29}$

The Leicester farmers, as may be seen from Table XVI, relied largely upon grazing, but this did not lead them to neglect the plough. On the contrary, they grew great quantities of corn. Wheat and rye were sown in considerable quantities, but the acreage under spring corn seems to have been much larger. Barley was an important crop, largely for malting samples, many farmers also being maltsters, but much barley was used for fodder and bread. Beans, peas, and oats were mainly for fodder: beans were the main constituent of horse-bread, and peas were fed to cattle, sheep, and swine. ${ }^{30}$ Grass-hay was the most common, though tare- and oat-hay may have been used also. Grass-hay came mainly from meadows and grasslands mown in rotation. Grass was an important crop and much of the common field was in leys of permanent grass, as for example in the South and West fields. ${ }^{31}$ Thus it was ordered in 1624 that 'all such leys and other greensward ground which hath beene plowed upp within the South Feilds at any tyme within $\mathrm{I} 8$ yeares last past shall be layd to grasse again'. Many leys were broken at about that time by farmers such as Mabbes, Abney, Swane, and Palmer. ${ }^{32}$ Outside the town fields convertible husbandry, provincially 'up-and-down' husbandry, was chiefly practised, and while domestic dairies and part-time farming were mostly confined to the common fields, most of the land cultivated by the large farmers lay outside them in inclosures. Horses were the more usual plough-beasts, though draught-oxen were also used widely and both oxen and horses were used in harrowing, different implements existing for the different teams. ${ }^{33}$

Husbandry was widespread as a part-time occupation, for the townsfolk needed not only domestic dairies but also supplies of grain for themselves. In 1586 , for example, Thomas Clark, innholder, planned to sow 3 acres of corn, as did one Morton, mercer. Robert Roberts, tanner and victualler, had 4 acres to sow. ${ }^{34}$ Most families could supply the labour for I plough but for every other plough maintained wage-labour would have been needed, at the rate of about 2 or 3 persons per plough. Thus Nicholas Bailey probably worked a single ox-team by family labour and William Colinson was in much the same position, though using horses. Robert Simpson, however, maintained at least 2 and perhaps 3 plough-teams. This would mean the employment of about 4 wage-labourers. And we find in fact that he had 4 beds in the chamber occupied by his menservants. William Hobby must have employed menservants, if only because he was also a wheelwright. Ralph Freeman had 6 iron-bound carts, 6 ploughs and a wagon, and kept I 5 draught horses. He had 2 beds in the stables, presumably for the carters, but he would have needed about 2 servants or labourers, if, as is assumed, he confined his activity to management. Henry Palmer, too, had half a dozen ploughs and probably twice as many menservants. Thomas Swan had 4 ploughs at work and beds for 3 carters in the stables. Of the 2 I farms inventoried possibly 5 had I plough, 6 had 2, 2 had 3,2 had 4 or 5 , and 6 had 6 ploughs. ${ }^{35}$ That is to say, there were 5 family farmers, 6 farmers employing about 2 men each, 2 employing about 4, 2 employing about 7, and 6 employing about I2. Thus the total composition of these farms would have been 5 family farmers, Io capitalist working farmers, 6 capitalist gentlemen-farmers, and to6 servants or labourers. For every score of farmers there must have been about roo wage-workers, while about

\footnotetext{
29 See references cited above, n, 28 .

30 Leic. Boro. Rec. I509-I603, 321 .

II Ibid. 453-4; I603-88, I 81-3; Leic. City Mun. Room, press 22 , box 14 , no. 6 .
}

\footnotetext{
32 Leic. Boro. Rec. I509-I603, pp. xxxvii, 201-2, 214.

33 See references cited below, n. 36 .

34 Leic. City Mun. Room, press 22 , box I7, no. I.

35 See references cited below, n. 36 .
} 
THE CITY OF LEICESTER

\section{TABLE XVI}

Leicester Farmers' Inventories ${ }^{36}$

\begin{tabular}{|c|c|c|c|c|c|c|c|c|c|c|c|c|c|}
\hline No. & Date & $\begin{array}{c}\text { Stock-in } \\
\text { trade } \\
£ \quad s . \\
\end{array}$ & & $\begin{array}{c}\text { Number of } \\
\text { sheep }\end{array}$ & $\begin{array}{c}\text { Number of } \\
\text { cattle }\end{array}$ & $\begin{array}{c}\text { Number of } \\
\text { horses }\end{array}$ & $\begin{array}{l}\text { Crops } \\
\text { f s. }\end{array}$ & $\begin{array}{l}\text { Cas } \\
£\end{array}$ & & $\begin{array}{l}\text { Debt } \\
£ \quad s\end{array}$ & & $\begin{array}{l}\text { Toto } \\
\text { valu } \\
\text { f }\end{array}$ & $\begin{array}{l}\text { tal } \\
\text { lue } \\
\text { s. }\end{array}$ \\
\hline I. & I 535 & I I & $\circ$ & . & $£ 2$ & $£, 2$ & 70 & - & - & - & - & 43 & $\circ$ \\
\hline 2. & I 535 & I 2 & 4 & . & 4 oxen & $\begin{array}{l}2 \text { geldings } \\
\text { I horse } \\
2 \text { mares }\end{array}$ & $\begin{array}{rr}8 & 0 \\
(44 & \text { ac. })\end{array}$ & - & - & - & - & I 3 & 3 \\
\hline 3. & I 544 & 18 & 2 & . & 7 beasts & 5 horses & 9 & - & - & - & - & $3^{6}$ & 9 \\
\hline 4. & I $55^{8}$ & 55 I & I9 & 20 sheep & $\begin{array}{l}\text { Io kine } \\
4 \text { heifers } \\
6 \text { calves }\end{array}$ & $\begin{array}{l}3 \text { horses } \\
4 \text { mares }\end{array}$ & 360 & - & - & - & - & c. 100 & \\
\hline 5. & ${ }_{15} 6 \mathrm{I}$ & 62 & $\circ$ & 5 sheep & $\begin{array}{l}6 \text { draught } \\
\text { oxen } \\
5 \text { kine } \\
6 \text { beasts }\end{array}$ & $\begin{array}{l}9 \text { horses \& } \\
\text { mares } \\
2 \text { fillies }\end{array}$ & $25 \quad 17$ & - & - & - & - & 88 & 9 \\
\hline 6. & I 570 & $7 \mathrm{I} I$ & I 3 & 34 sheep & 8 kine & 6 horses & 400 & 2 & $\circ$ & - & - & 88 & 17 \\
\hline 7. & I597 & $4 \mathrm{II}$ & I 3 & . & 2 kine & 4 horses & $\begin{array}{ll}3 \mathrm{I} & 3\end{array}$ & - & - & - & - & 120 & 6 \\
\hline 8. & I 598 & $33^{8}$ & 6 & . & $\begin{array}{l}3 \text { I kine } \\
2 \text { bulls } \\
2 \text { beasts } \\
\text { I } 8 \text { calves }\end{array}$ & $\begin{array}{l}\text { I } 5 \text { draught } \\
\text { horses } \\
4 \text { colts } \\
\text { I gelding } \\
\text { I mare } \\
\text { I foal }\end{array}$ & I 57 I0 & - & - & - & - & 478 & 6 \\
\hline 9. & 1626 & 77 & 3 & - & 3 kine & $\begin{array}{l}6 \text { draught } \\
\text { horses }\end{array}$ & 220 & 3 & 7 & - & - & 93 & I4 \\
\hline Io. & 1626 & 532 & 2 & I 58 sheep & $\begin{array}{l}2 \text { kine } \\
\text { I bull } \\
4 \text { heifers }\end{array}$ & $\begin{array}{l}4 \text { horses } \\
8 \text { geldings }\end{array}$ & $150 \quad 16$ & - & - & - & - & 599 & ro \\
\hline II. & I 628 & 403 & 0 & $\begin{array}{c}200 \text { sheep } \\
\text { I } 8 \text { lamb } \\
\text { hogs }\end{array}$ & $\begin{array}{l}5 \text { oxen } \\
3 \text { kine } \\
\text { I } 4 \text { beasts } \\
4 \text { bull } \\
\text { 'saggs' } \\
7 \text { heifers } \\
\text { I } 7 \text { calves }\end{array}$ & $\begin{array}{l}\text { I mare } \\
4 \text { colts } \\
\text { I foal }\end{array}$ & 1480 & 26 & I 3 & IO & $\circ$ & c. 604 & \\
\hline I 2. & $16_{30}$ & $64 \mathrm{I}$ & 6 & $\begin{array}{c}264 \text { sheep } \\
96 \text { ewes }\end{array}$ & $\begin{array}{l}\text { I } 2 \text { kine } \\
2 \text { bulls } \\
2 \text { heifers } \\
5 \text { beasts }\end{array}$ & $\begin{array}{l}£ 5^{\circ}+2 \\
\text { mill horses }\end{array}$ & c. 2 I 5 & 5 & I 3 & 71 & IO & $75^{8}$ & 3 \\
\hline 13. & 1632 & 75 & 0 & (a) 1 & $\begin{array}{l}2 \text { cows } \\
2 \text { calves }\end{array}$ & . & 28 & - & - & - & - & 95 & 7 \\
\hline 14. & 1639 & 269 & $\circ$ & Sheep, beasts & horses, and fo & dder-£, 37 & $\begin{array}{ll}115 & 0\end{array}$ & 30 & $\circ$ & 100 & $\circ$ & 694 & 3 \\
\hline 15. & 1642 & 403 IC & Io & $\begin{array}{l}149 \text { ewes } \\
90 \text { hogs } \\
3 \text { rams } \\
4 \text { I wethers }\end{array}$ & $\begin{array}{l}7 \text { kine } \\
2 \text { heifers } \\
\text { I bull }\end{array}$ & $\begin{array}{l}9 \text { horses \& } \\
\text { mares } \\
\text { I filly } \\
2 \text { foals }\end{array}$ & I 22 I 3 & I 5 & $\circ$ & - & - & $5^{6}{ }_{5}$ & 4 \\
\hline I6. & I 645 & 232 & $\circ$ & f6o & $\begin{array}{l}20 \text { beasts } \\
(£, 40)\end{array}$ & fro & 1080 & - & - & - & - & 274 & I 3 \\
\hline 17. & $166_{3}$ & 40 & $\circ$ & 2 lambs & 3 cows & I mare & $\begin{array}{c}c .20 \\
(12 \text { ac. })\end{array}$ & I & IO & - & - & II 8 & 6 \\
\hline 18. & $166_{3}$ & 805 & I & $\begin{array}{l}88 \text { ewes } \\
2 \text { rams } \\
28 \text { wethers } \\
6 \text { I hogs } \& \\
\text { other sheep } \\
\& \text { lambs }\end{array}$ & $\begin{array}{l}\text { I } 6 \text { beasts } \\
\text { I calf }\end{array}$ & $\begin{array}{l}6 \text { horses } \\
\text { I I mares } \\
2 \text { foals }\end{array}$ & c. 500 & $4 \mathrm{I}$ & I 8 & 142 & 3 & I, 044 & 7 \\
\hline 19. & 1669 & 1,465 & $\circ$ & $\begin{array}{l}360 \text { ewes } \\
360 \text { lambs } \\
280 \text { sheep }\end{array}$ & 48 beasts & $£ 45$ & 4150 & I I I & I & - & - & 1,655 & 6 \\
\hline 20. & 1676 & 56 & 4 & I4 sheep & $\begin{array}{l}4 \text { cows } \\
5 \text { heifers } \\
3 \text { beasts }\end{array}$ & . & $31 \quad 2$ & IO & ० & I 40 & $\circ$ & 253 & I6 \\
\hline $2 \mathrm{I}$. & 1678 & $40 \mathrm{I}$ & 17 & . & . & .. & 40 & 4 & 0 & IO & $\circ$ & 66 & 4 \\
\hline
\end{tabular}

${ }^{36}$ L.R.O. Probate Rec. Inv. of (I) Ric. Shipton, I 535, (2) Nic. Bailey, I535, (3) Wm. Colinson, I 544, (4) Thos. Keckwick, I 558, (5) Robert Tympson, I56I, (6) Thos. Taylor, 1570, (7) see end of note, (8) Ralph Freeman, I 598, (9) John Burgaland, I626/I5 I, (10) Hen. Palmer, I626/85, (II) Wm. Ludlam, I628/24, (12) Thos. Swan, 1630/122, (I 3 ) Hen. Biddle, I632/280, (14) Hen. Peale,
I639/IoI, ( I5) Wm. Billers, I642/7, (I6) John Tompson of Belgrave, I645/4I, (I 7 ) Jas. Nutt, I663, (I8) Ric. Ludlam, I663/52, (19) Dannet Abney, I669/I 5 I, (20) Geo. Mounteney, I676/3, (21) Thos. Mabbs, I678/40; for (7) see Leic. Boro. Rec. 1509-1603, 332 sqq. Pence have been ignored in the cash columns. 


\section{A HISTORY OF LEICESTERSHIRE}

two-thirds of the labour force were employed by about a quarter of the farmers. This takes no account of dairymaids, shepherds, and the like. ${ }^{37}$ It is clear that capitalist farmers were the largest employers of labour in Leicester and that most wage-labour must have been agricultural, since the farmers constituted about one-tenth of those at the head of enterprises. The rise of a class of wealthy gentlemen-farmers was thus one of the outstanding features of Leicester's history in this period. As far as can be judged the proportion of the population engaged in farming, grazing, and dairying did not decline, but the number of family farmers probably declined considerably. In wealth and social influence the gentlemen-farmers greatly excelled the mass of craftsmen and the majority of shopkeepers. Farmers' capital was by far the most important form of industrial capital, and industrial capital was already of great social and economic significance by virtue of its growth in agriculture alone.

Most of the industrial production of Leicester was in the hands of master craftsmen, trading masters, and small masters. The importance of the master craftsmen was declining. Trading masters dominated the shoemaking industry, although it appears that merchant employers and small masters were developing from the ranks of trading masters and journeymen. The hosiery industry was organized on a fully developed putting-out system by about I660. In spite of the decline of the wool merchants, commercial capital continued to be of great importance in the economy and exercised a more direct control over industry than it had done in the past. Nevertheless large masters and wage-workers were developing in the malting, brewing, metallurgical, and agricultural industries. Even if only to per cent. of the entrepreneurs were large masters employing an average of half a dozen wage-workers each, then for every Ioo entrepreneurs there would have been 60 wage-workers. And there can be little doubt that the proportion of wage-workers was increasing during this period, as was also the number of small masters. About Io per cent. of the entrepreneurs were merchants, shopkeepers, or merchant employers, possibly about 25 per cent. were small masters, and 55 per cent. were master craftsmen on the average over the whole period. It might be guessed that about a quarter of the male adults were wage-workers in the early I6th century and possibly about half in the mid-I 7 th century. As Table XVII shows, about 20 per cent. of the adult population of St. Mary's parish were in I 587 in-dwelling men and maidservants. ${ }^{38}$ One would not be surprised to find that in-dwelling wage-workers were equalled in numbers by whole and part-time day labourers. It must be said, how-

\section{Table XVII}

Adult Parishioners of St. Mary's, I58739

\begin{tabular}{|c|c|c|c|c|c|c|c|c|}
\hline \multirow{2}{*}{\multicolumn{2}{|c|}{ Households }} & \multirow[b]{2}{*}{ - } & \multirow[b]{2}{*}{ - } & \multirow[b]{2}{*}{ - } & \multirow[b]{2}{*}{ - } & \multicolumn{2}{|c|}{ Nos. } & \multirow{2}{*}{$\frac{\text { Percentages }}{\ldots}$} \\
\hline & & & & & & 172 & .. & \\
\hline Husbands & . & - & - & - & . & I 57 & I 57 & $76 \cdot 59$ \\
\hline Wives & . & . & . & . & . & 140 & . & . \\
\hline Daughters & . & . & . & . & . & I6 & $\cdots$ & $\cdots$ \\
\hline Sons & . & . & . & . & . & I I & .. & $\cdots$ \\
\hline Brothers & & $\cdot$ & - & . & - & $\mathbf{I}$ & . & . \\
\hline \multicolumn{4}{|c|}{ Widows and spinsters } & - & . & 15 & . & . \\
\hline \multirow{4}{*}{\multicolumn{2}{|c|}{$\begin{array}{l}\text { Menservants } \\
\text { Maidservants } \\
\text { Apprentices } \\
\text { Other relatives }\end{array}$}} & . & . & - & . & 22 & 22) 8 & \\
\hline & & . & - & - & . & 26 & $26 \int^{48}$ & $23^{\circ} 41$ \\
\hline & & . & . & . & . & IO & . & $\cdots$ \\
\hline & & and & imates & . & . & 17 & . & $\cdots$ \\
\hline Totals & - & - & . & - & . & 415 & 205 & 100.0 \\
\hline
\end{tabular}

37 For shepherds, see e.g. L.R.O. Probate Rec. Inv. of Thomas Good, 1632/18, Ric. Walker, 1558; Wills, Thos. Good, $1632 / 79$.
${ }^{38}$ Leic. City Mun. Room, press 22, box 17, no. I.

39 Ibid. The figures concern the whole of St. Mary's par. 
ever, that any reconstruction of Leicester society is hazardous and that only wide approximations are possible.

Many wage-labourers, journeymen, and servants are disclosed by the inventories of deceased persons. Of these inventories 52 were of such small value that those whose property they describe seem to have been servants or day-labourers. A number of persons in I 542, I 548, I 59 I, and I6 I 5, for example, left less than $£ 3$ worth of goods and chattels. In I 556 William Fallows, serving man, left $£$ i 8 i $7 s$. I I $d$. In I 572 John Meade, a servant of the Earl of Huntingdon, left $£ 4$ I $6 s$. $4 d$., but he had a half-year's wages owing to him. John Trowell, who left $£^{2} \mathrm{I} 9 s .2 d$. in I 59I, bequeathed 2s. to Margaret, his master's maid, and $4 s$. to his fellow 'Thomas 'Tillys. In I666 John Jarvis, John Johnston's servant at the White Lion, left $£_{27} 6 s$. Iod., suggesting fairly high wages. It seems that there were many day-labourers who eked out an existence by spinning and by the possession of a cow or a few pigs or poultry. 40

Owing to the virtual absence of guild records it is not easy to trace the history of industrial organization. Most crafts were organized into occupations or companies and some of these companies were amalgamations as, for example, the chandlers', slaters', and plasterers'.4I The occupations were supervised by the borough government-with which had been merged the Chapman Guild, a guild merchant-and to this the crafts had to take their ordinals to be approved or rejected. No new matter was to be put into any ordinal unless first agreed by the mayor and two justices of the peace. ${ }^{42}$ Apprenticeship was regulated and freedom of the borough was needed before one could set up shop. Many of those who were apprenticed went on to spend most of their lives as journeymen. Thomas Claxton, weaver, worked for 24 years as a journeyman to support his wife and three children. Finally, as he complained, the places where he had worked were supplied with apprentices and as he grew older and less able to take pains he had difficulty in finding employment. He therefore petitioned for his freedom, so that he might set up shop.43 It was the borough government that took action against unapprenticed masters, such as William Deane, the woollen draper. ${ }^{44}$ The occupations, however, claimed that freedom of the borough could be granted to one of their trade only with their consent. ${ }^{45}$ The authority of the borough government was reinforced by the Statutes of Labourers and of Artificers and by the office of justice of the peace. Journeymen were registered as servants, could only depart from a master under licence, and needed an endorsed passport. The leisure hours of men and maidservants were regulated and supervised. ${ }^{46}$ Thus the borough government ruled the working population with the assistance of royal authority, and in order to understand who wielded power in the town it is necessary to examine the composition of borough government. While much remains uncertain, it

40 L.R.O. Probate Rec. Inv. of Wm. Scott, r 535, John Lambert, I 542, Thos. Burgess, I 542, Robert Rypley, I 544 , John Wiggington, 1548 , Robert Clark, 1551 , Ric. Waterworth, I 552, Wm. Fallows, I 556, Edw. Glossop, 1558 , John Whiteman, 1559, Wm. Layton, i 560, John Shawell, 1572, John Meade, 1572, Dominic Redwey, 158I, Thos. Pighte, 1582, John Byrd, I584, John Trowell, i 591, Wm. Burstall, I 594, Wm. Baylie, I602, Wm. Wootton, I606, Thos. Joseph, 1613, Thos. Russell, 1614/161, Wm. Berridge, 1615, Arthur Crompton, 1627/121, Thos. Laicy, I63o/r 56, John Bell, I631/r 35, Wm. Keene, I633/45, Thos. Ingham, I635/165, Wm. Miller, 1637/315, Thos. Norton, 1637 , Roger Warner, r638/233, Thos. How, I64o/67, Wm. Avery, I641/1 16, Thos. Wrighte, 1646/53, John Davye, I 642/23, John Stretton, I649/61, Francis Burton, I649/4I, Samuel Huxley, $1656 / 53$, Wm. Whatton, $1660 / 244$, Thos. Hartshorne, 166r/209, Wm. Coxe, I664/31, Robert Hutton, I663/15i, Geo. Taplife, I663/69, Frances Purss, I666/55, John Jarvis, I666/1 28, Thos. Clarkson, I669/139,
Wm. Wood, I672/2, Wm. Olive, I674/26, Edw. Cetteling, I674/131, Valentine Abell, ı675/r28, Zachary Stretton, 1677/32, Wm. Measures, 1678/1 I 7; Wills, John Trowell, 1591/107. Inv. exist in large nos. for poor widows and spinsters.

4r C. J. Billson, 'The Leic. Gild of Tallow Chandlers', T.L.A.S. xv. 126 sqq.; Billson, Medieval Leic. 125-6; Thompson, Hist. of Leic. i. 227, 349, 464-6.

42 Leic. Boro. Rec. I 509-I603, pp. xl, 19, 100; Leic. City Mun. Room, Hall Papers, I 593-8, no. 281 ; ibid., press 22, box 14 , no. 4 .

43 Leic. Boro. Rec. I509-1603, pp. li-liii; Leic. City Mun. Room, Hall Papers I 647-9, no. 531; cf. ibid., no. 53 .

44 Leic. Boro. Rec. $1603-88,425$.

45 See above, p. 90, n. ${ }_{38 .}$.

46 Leic. Boro. Rec. I 509-I603, I96, 359, 364; I603-88, 21-22; Leic. City Mun. Room, Quarter Sessions R. I609, I626, 1639 . 


\section{A HISTORY OF LEICESTERSHIRE}

can at least be said that the major voice in town affairs in the early $\mathbf{r} 6$ th century belonged to the merchants. In the latter part of the century government was shared to a greater extent by craftsmen and producers, although the shopkeepers held preponderant influence. In the $\mathbf{I} 7$ th century the influence of the producing element was reinforced by maltsters, brewers, and gentlemen-farmers, and the commercial element by merchant employers. At all times the small masters were subject to those in control of the borough, but later in the period industrial capital counterbalanced the power of commercial capital. ${ }^{47}$ The borough government having passed into the hands of an oligarchy of traders, this position was legalized and reinforced by the Crown by letters patent and statute in 1488 and 1489 . In defiance of the craft or popular party, commoners were excluded from government. 48

The hegemony of the merchants arising from the function of commercial capital was strengthened by the operations of financial capital. Needy craftsmen and husbandmen were forced to borrow from wealthy traders, nearly all of whom had tens, scores, or hundreds of pounds owing to them by bond, bill, or other specialty. Of all the varied objects of these obligations the lending of money at interest must have been the most important. ${ }^{49}$ Usury was not a trade in itself but was the sideline of the business man and the stand-by of retired traders and moneyed widows. If rates of interest were high, the large amount of desperate debts recorded in the inventories testifies to the risks of such operations. ${ }^{50}$

The hegemony of the merchants was further strengthened by their activities as landlords. Though lending money was often subject to some risk, investment in rents was secure and a lower rate of interest could be generally demanded without any great diminution of the return for the capital employed in this way. Leicester traders and gentlemen had lands as far afield as Great Dalby, Whetstone, Grub Street, and Tottenhall Manor, and many of the mayors and aldermen of the borough owned lands and houses inside and outside the town, but the most general form of investment was in town houses and tenements which were let to poor craftsmen by gentle and armigerous merchants, mercers, vintners, ironmongers, and the like. Nor was it unknown for such merchant-landowners to be lords of manors. Just as commercial and financial capital were linked, so were financial and landlord's capital, and there was no cleavage or sharp division between traders, usurers, and landlords; but both usury and landlordism deepened the cleavages between small master and merchant. The industrial capitalistslarge masters, and capitalist farmers-did not, however, invest any considerable capital in rents or usury, and although some of them were owner-occupiers to a greater or lesser extent, they had much more capital invested in leases of land than in rents. ${ }^{51}$ The borough itself was a landowner and lord of Whetstone manor. In I 589 the Crown and duchy lands within the precincts were granted to the borough in fee-farm, and the borough later bought Newarke Grange, which it leased out to gentlemen-farmers who

47 Roll of Mayors of Leic. passim; Reg. Freemen of Leic. xr96-r770, passim.

${ }_{48}$ Unwin, Industrial Organisation, I7, 70, 74; C. Gross, Gild Merchant, ii. 144; S. Kramer, Craft Gilds and the Government, 24; Kramer, Eng. Craft Gilds: Studies in their Progress and Decline, 198; Roll of Mayors of Leic. pp. xiii-xvi; Leic. Boro. Rec. I509-I603, pp. xvii-xviii; Throsby, Hist. of Leic. 72-74; Thompson, Hist. of Leic. i. I 99-202, 206; see also above, p. 29.

49 Leic. Boro. Rec. I509-I603, p. xxv; C 3/399/95; C 3/403/I I ; Req. 3/30/9.

50 See e.g. L.R.O. Probate Rec. Inv. of John Rodes, I603, Mary Bonett, I624/101, John Pilkington, I625/165, Katherine Wildboare, I628/98, Thomas Sacheverill, I628/ 205, Ambrose Rawlyns, $163 \mathrm{I} / 107$, Dorcas Collin, I63I/
62, John Pulteney, 1637/220, Hen. Thorpe, I644/2, Robert Cooper, I645/16, Alice Gilbert, I 645/7, Eliz. Bambrigge, I664/24, Mary Chapman, I664/8, John Angell, I665/130, Francis Moreton, I666/147, David Thomas, I667/102, Mary Mabbs, r640/198.

${ }_{51}$ Ibid. Inv. of Wm. Stanforde, I 637/142, Wm. Cooke, I671/23; Wills, Thos. Cotton, I 549, Wm. Gillot, $5_{580 / 17}$, Wm. Morton, I620/54, Wm. Ludlam, I603/29, Ralph Chettell, I 598/1 or, Thos. Parker, I633/74, Thos. Herrick, $1625 / 13$, Nic. Gillot, 1634/7, John Heyrick, 1633/1 37 , Wm. Ludlam, 1628, Gilbert Fawsitt, 1646/71, Francis Churchman, I637/52, Daniel Murfin, I660/33, Wm. Stanley, I665/76, Edmund Cradock, I667/125, John Clay, 1680/3; Roll of Mayors of Leic. 46, 53-55, 71-75, 77, 79, 83 sqq., 98-99, 102, 104-5. 
resided in the town and were often leading men in the corporation..$^{2}$ As for security of tenure it cannot be said that it was better or worse in Leicester than in the countryside at large. Many examples of eviction may be found without in any way showing an abnormal degree of insecurity. ${ }^{53}$

The whole period was one of great building activity. Out-kitchens, second stories, garrets, and cellars were added to houses to conserve ground-space, while coal-houses and coal-fired grates were provided for the burning of pit-coal which was used increasingly for homes and industry, and special buildings were erected for such industries as malting, brewing, and hosiery. The increasing prosperity of a section of the townsfolk showed in improvement in housing, while the increasing numbers of wage-workers led to the division of houses between families and the taking of inmates. At the same time there were notable improvements in the water-supply, public wells being supplemented by conduits, waterworks, and common pumps. ${ }^{54}$

The borough was parcel of the Duchy of Lancaster, but all the town was not within the precincts of the borough. The liberty of the Newarke and the manors of Knighton, Bishop's Fee, and Danet's Hall and Westcotes in Bromkinsthorpe all impinged to a greater or lesser extent upon the authority of the borough.55 The position of Bishop's Fee, which has been discussed above, ${ }^{56}$ remained ambiguous during this period. In r 596, for example, Christopher Sutton was put out of the Forty-eight and disfranchised because he resided in the Bishop's Fee. ${ }^{57}$ Such anomalies spurred the burgesses to seek new charters giving them jurisdiction over the fee and the Newarke, but these attempts failed against opposition from the lords of the fee on the grounds that their manorial franchises would suffer and that the trading privileges of the borough were 'offensive and hurteful to the countie'. The borough was unable to rebut the tacit allegation that craftsmen in the fee would be subjected to the rule of Leicester traders. It appears, indeed, that precisely this subjection was one of the main objects of the proposed charters. Since the privileges of the burgess oligarchy were being slowly undermined by the spread of craft industries in the suburbs and liberties, the perpetuation of these privileges depended upon the extension of their scope to bring the liberties under borough regulations. To this, however, was opposed the free-trade movement of the craftsmen of town, suburbs, and countryside. This movement obtained the support of the country gentry concerned, in the interests of the prosperity of their tenantry and so of their own rent rolls. Defeated in its main object the borough could only conduct a long and losing war of attrition in defence of its privileges. ${ }^{8}$ At the same time the borough had to defend itself against tolls imposed by others, particularly by the lord of Gainsborough manor. 59

While the secular trend in Leicester economy in this period may be described as the simultaneous growth both of industrial capital and of the control of commercial capital over small masters, the course of development was not smooth but was distorted by short-term movements and in particular by harvest crises. Such crises occurred, for

52 Leic. Boro. Rec. I509-I603, pp. xix, 6, 286-7; I603-88, pp. xxxiv-xxxvi; T.L.A.S. xiv. $8,12,23,25^{-}$ 27; Throsby, Hist. of Leic. 98-99; see also above, p. 64 .

${ }_{53} \mathrm{C}_{\mathrm{I}} / \mathrm{I} 44 / 30 ; \mathrm{C}_{2} / \mathrm{R}_{\text {.II }} / 26 ; \mathrm{C}_{3} / \mathrm{I}_{30} / 52 ; \mathrm{C}_{3} / 208 / 38$;

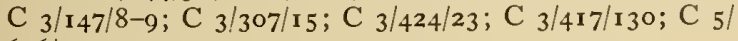
$616 / 73$.

54 Leic. Boro. Rec. I509-I603, I76; I603-88, I68, 240-I, 269-70, 430, 434, 457, 462; Throsby, Hist. of Ieic. 376; Thompson, Hist. of Leic. i. 281, 413; Thomas, Town Government, 6I-62, I I I-I 3; Leic. City Mun. Room, Quarter Sessions R. 1609, 1626, I639.

55 T.L.A.S. xiv. 6, 8, 12; Leic. Boro. Rec. I509-I603,
369; I603-88, pp. xxix, xxxi, xxxiv, I09, I I I. On the liberties at an earlier period, see above, pp. 16, 57. See also below, pp. 164-5.

${ }^{56}$ See above, p. 57.

57 Gross, Gild Merchant, ii. 56, 68; Leic. Boro. Rec. I $509-I 603,319,325$.

${ }_{58}$ Ibid., pp. xxxvii-xxxviii, I56; I603-88, pp. xxvii, I 3 sqq. , 44-45, 76, 199, 258-9, 264-6,427, 443; Thompson, Hist. of Leic. i. 304,307 .

59 Leic. Boro. Rec. I 509-I603, pp. xlii, xliii, 48; I603$88,142-4,183,427$; Thompson, op. cit. i. 304 . 


\section{A HISTORY OF LEICESTERSHIRE}

example, in $1558,1587,1595,1608,1622$, and $1629-3 \mathrm{I}$. In the 16 th century the danger of famine was met by the further regulation of the market, but while regulation and control continued to be the royal remedy for famine, by I 608 the burgesses were overriding the Book of Orders on the plea that 'the allowinge of some to buye the overplus will incurrage the husbandmen and others that bringe corne out of other counties where it is cheaper to our markitts, for if all should bee restrayned from buyinge, the fewver woulde come to the marketts to sell and soe make the marketts lesse and cause them to make theire markitts at home as wee have knowne by former experience'. ${ }^{60}$ Thus royal regulation was countered by argument for free internal trade.

Dearths were often accompanied or followed by pestilence, of which there were

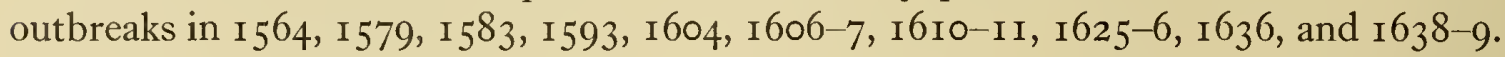
These plagues are indicative of famine, near-famine, and post-famine conditions and constituted the main impediment to population increase in early I 7 th-century Leicester. The periodic harvest crises and pestilences merged in the general crisis between 1625 and 1640 , with plague in $1625^{-6}$, dearth from 1629 to 1631 , and plague again in 1636 and $1638-9 .{ }^{61}$

It was particularly during the 'permanent' depression of 1625 to 1640 that the longterm changes in the economic and social structure of Leicester found political expression in opposition to the royal government. This opposition was not merely economic, social, and political, but also religious - puritanism ${ }^{62}$ having taken root among the socially discontented townsfolk. Here, however, we may only consider the social and economic aspects of this conflict.

The financial and military exactions of the Crown aroused opposition from most of the townspeople, although there was some division of opinion amongst them. ${ }^{63}$ Inclosures also focused discontent. During the anti-inclosure outbreaks of 1607 the mayor led soldiers from the town to Cotesbach to aid in suppression and a party of trained men was sent to Welham also. At the same time, however, at least 32 Leicester men went to Cotesbach to help the levellers cast down ditches, the four principal offenders being John Russell, John Browne, William Gracedieu, and Thomas Seawell the painter. Assisted by the gaoler, the townsfolk took down the gibbet set up on the orders of the Earl of Huntingdon. The earl subjected the mayor to house imprisonment, appointed a deputy in his stead, and finally arraigned the mayor before him, taking his hat from his head and requiring him to speak on oath. Next year the chief Leicester levellers were pressed into the army for Ireland wherever possible. This was the fate of Russell and Browne and would have been that of Seawell if he had not fled. It seems that the craftsmen and poorer sort of the town were of a levelling opinion, that the leading burgesses were opposed to levelling but feared the populace and that Huntingdon welcomed the opportunity to lord it over the burgesses. ${ }^{64}$ To the inclosure of Leicester Forest by Charles I the townspeople presented a united resistance. The corporation petitioned against inclosure and offered Charles $£, 500$ if he would desist, and the town artisans took the matter into their own hands and in 1628 were already casting down the ditches of royal inclosures. Eventually the king was forced to compromise and allotted 40 acres to the townsfolk and 20 to the corporation for rights of common enjoyed by the Grange farm, in addition to 76 to the freeholders of Bromkinsthorpe and 30 to

60 Throsby, IIist. of Leic. 92; Leic. Boro. Rec. 15091603, 231, 32I; 1603-88, 75; Thompson, op. cit. i. 348; E. M. Leonard, Early Hist. of Eng. Poor Relief, i 88; Leic. City Mun. Room, press 22, box I7, no. I.

6I Thompson, op. cit. i. 296, 298, 325, 340-2, 352; Throsby, Hist. of Leic. I08, I I0; Leic. Boro. Rec. 1509- r603, pp. xlv, 7I, I00, 232, 288; Thomas, Town Government, I 36-7, 140-1, I 5 I.

62 Thompson, op. cit. i. 351 ; Leic. Boro. Rec. I 603-88, p. xlix.

63 See above, p. 59

${ }^{64}$ Throsby, Hist. of Leic. 107; Leic. Boro. Rec. $1603^{-}$ 88 , pp. xxxviii, 59-64, 71, 75 . 
John Danet of Danet's Hall. The corporation nevertheless continued to support the commoners in a further petition against disafforesting. ${ }^{65}$

There can be little doubt that economic and social progress was retarded by the sack of Leicester in 1645 and until the Parliamentary armies were able to protect the town. ${ }^{66}$ The general crisis of the last years of royal government was thus prolonged in Leicester until the middle of the century.

The borough government opposed inclosure in principle and only grudgingly consented to it at Bushby in I647. The forest inclosures continued to provoke hostility and in 1649 four men were arrested for spreading a rumour that Parliament had given leave for the levelling of the king's inclosures. It is significant that these men were respited after having promised not to take any action without the consent of the mayor. ${ }^{67}$ In and after. I $_{53}$ the corporation opposed the inclosure of Belgrave and organized intercommunal petitions against it. A petition against depopulation was drawn up by the town clerk and Anthony Gilbert, James Fox, Jonathan Cooke, and Samuel Marshall collected signatures about the town. The borough also met the expenses incurred by Moore and Yaxley in presenting the petitions in London. These petitions, however, were not merely against inclosure. They proposed the institution of a special local tribunal to regulate all disorders arising either from common field husbandry or from inequitable and depopulating inclosure. ${ }^{68}$ Evidently the democratic breeze that blew through Leicester at this time had a powerful effect upon borough government, and the interests of industrial and agricultural producers received more attention than previously. Leicester favoured the Commonwealth and refused to join in addresses to General Monck. The opinion of the town artisans was probably summed up by William Dawes, who, on the king's arms being set up again, remarked 'it would doe the Devill good to see them' ${ }^{69}$

Greatly strengthened in the course of the preceding hundred years, industrial capital in Leicester emerged as a social force contributing its share to the overthrow of royal government; but this was by grace of the numerical force placed at its disposal by the small masters and it was again relegated to a position subordinate to commercial, landed, and financial capital until the Igth century. The craftsmen and husbandmen were strong enough to play a decisive part in the Great Rebellion, but much more accumulation and refinement of industrial capital was needed before landowners and merchants could be displaced from the head of Leicester society.

65 C. D. B. Ellis, Hist. in Leic. 82; Thompson, Hist. of Leic. i. 353 ; Leic. Boro. Rec. 1603-88, pp. xxxviii-xxxix, 239-4r, 243, 248; T.L.A.S. xiv. 9; D.L. 44/473, 679-8o, 7 Ir; V.C.H. Leics. ii. 267 ; see also above, p. 64.

${ }_{66}$ Throsby, Hist. of Leic. 106, 123 ; Thompson, Hist. of Leic. i. 393-4, 397-8; Leic. Boro. Rec. 1603-88, 317-19,

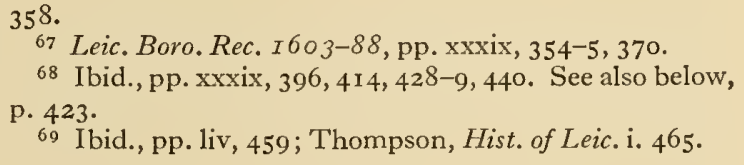




\section{PARLIAMENTARY HISTOR Y $166 \mathrm{O}-1835$}

1660-89, p. I10. $1689-1765$, p. I19. $1765^{-1818, ~ p . ~ 128 . ~ 1818-35, ~ p . ~} 140$.

\section{$166 \mathrm{O}-89$}

O the 12 th of May r660 King Charles II was duly proclaimed in Leicester, at the High Cross, the Barrell Cross, and the Gainsborough. ${ }^{I}$ Civic dignitaries who had taken up office under the regicides appeared to welcome the Stuart restoration. Yet the mayor does not seem to have been altogether easy. For many years the town had been represented in Parliament by Hazlerigg, a republican and a regicide. ${ }^{2}$ The corporation had received the approaches of General Monck equivocally. ${ }^{3}$ Hence no doubt the note of anxiety in the mayor's report to John Grey, member for the town in I660, of the zeal at Leicester for King Charles's return. ${ }^{4}$ Like many others, the corporation of Leicester hastened to efface any bad impressions by a present to the king of $£ 300$ in gold, in a rich purse of silk brocade, carried to London by three of the aldermen and the two chamberlains, attended by three sergeants at mace. ${ }^{5}$

Five times in the following 29 years the corporation of Leicester was remodelled. Three times a new charter was drawn up. There were obvious reasons why in uncertain times the government should attend to municipal corporations in this way. The corporations had often the greatest influence in the election of the parliamentary burgesses for the towns, who constituted the majority of the Commons. On the other hand, these burgesses were overwhelmingly recruited from the country gentlemen, who had in times past been so largely responsible for the multiplication of these seats, ${ }^{6}$ The parliamentary representation of Leicester was to all intents and purposes part of that of the county. Until 1832 , its members were almost invariably Leicestershire gentlemen, with houses at Rothley, Rotherby, Wanlip, Stoughton, Scraptoft, Brooksby, Enderby, Narborough.

The interest of Crown, Church, and gentry in the borough representation was increased by the Civil War and Interregnum. Since 1642 the several forms of puritanism had grown stronger. They were most influential in the towns, not least in Leicester. Puritan meetings might well be a cover for republican conspiracy. Very soon therefore the government set about the regulating of the corporations. The Corporation Act of r66r imposed upon all mayors, aldermen, common councillors, recorders, and other corporation officers the obligation to take the oaths of allegiance and supremacy, to repudiate by a formal declaration the rightfulness of resistance to the monarch by force of arms, and to receive the Communion at the hands of a minister and according to the rites (not yet settled) of the Church of England. Even more important was the machinery devised to enforce the Act. Commissioners were appointed for each county under the Great Seal, and given power until March 1663 'by order and warrant to

I Leic. Boro. Rec. I603-88, 463-4.

2 Ibid. 433-4.

3 Ibid. 458-60; J. Thompson, Hist. of Leic. i. 4 I8.
4 Leic. Boro. Rec. I603-88, 464-5.

5 Ibid. $472-3$; Nichols, Leics. i. 432.

6 J. E. Neale, Eliz. House of Commons (1949), 140-52. 
displace or remove' any members or officers they should think fit, even though they might have taken or be willing to take the oaths and fulfil the other requirements stated in the Act. ${ }^{7}$ In fact, for fifteen months the rights and powers of the corporations were virtually suspended. On the other hand, the Crown could go only so far as the gentry, who were strong in the Commons, would let it. Suggestions were rejected in the House that the Crown should have a practical veto on nominations of mayors, clerks, and recorders; that the towns should be forced to a surrender and renewal of their charters; and that the county justices should be made $e x$ officio magistrates within the corporate towns. ${ }^{8}$ Moreover, the men who were appointed as commissioners came naturally enough from the local gentry. Leicester was investigated by John Bale, Thomas Merry, George Faunt, William Whalley, and Richard Orton.9 Faunt and Orton were deputy-lieutenants, and Faunt was one of the knights of the shire elected in $166 \mathrm{I}^{10}$ and counted as one of the court party in that Parliament. ${ }^{I I}$

By October 1662 the Leicester corporation had been purged of 40 members, 15 being aldermen, and 25 common councilmen. ${ }^{12}$ No trace seems to have survived of the detailed grounds of rejection and choice. Local feuds and personal dislikes no doubt had their place, as well as the greater issues of Church and State, and the purpose of the commissioners to purge out the old leaven of commonwealth principles. A little later the commissioners forbade the corporation to 'intermeddle' in the choice of a new recorder: they had 'received informations of several things done by Mr. James Winstanley, which may render him incapable of continuing recorder'. ${ }^{13}$ 'The interests of the Crown were watched in Leicester by Henry, Lord Loughborough, no doubt acting in the stead of his nephew the Earl of Huntingdon, who was in 1662 only twelve years old. In October 1662 the new corporation reported to Lord Loughborough that 'though the late alterations amongst us might have seemed to raise some discontented thoughts, yet we truly declare ... this corporation was never so unanimous or better satisfied than now it is in all the late elections'. ${ }^{14}$

In January 1665 the Leicester corporation received new letters patent. At no time between the Restoration and the Revolution was the threat of an attack on chartered privileges far away. At the outset, even before the purge of 1662, Lord Loughborough had threatened that if the corporation did not restore to both the profits and place of town clerk Edward Palmer (who had been dismissed in 1646 for actions done at Loughborough's behest), ${ }^{15}$ he would 'make the king acquainted with it, and with them that were the putters of him out, and that when he came to renew your charter move the king to stop your desires'. ${ }^{16}$ In 1663 the first steps were taken for the review of the town's privileges, in line with the general policy of the government, ${ }^{17}$ when the corporation was told that proceedings by way of quo warranto were intended against them, but by friendly offices had been postponed..$^{18}$ Acting under advice, they considered what improvements they might ask for: a confirmation of the trade privileges; a new horse market; and above all a strengthening of their jurisdiction in the liberties, suburbs, and fields by the exclusion of the county officers 'by a special clause of non intromittant'. ${ }^{19}$

7 I $_{3}$ Chas. II, St. II, c. I. cl. xiii.

8 K. G. Feiling, Hist. of the Tory Party, I660-I7 44 (1924), III; see also J. H. Sacret, 'The Restoration Government and the Municipal Corporations', E.H.R. xlv. 238 .

9 Leic. Boro. Rec. $1603-88,606-7$; for the Bale family, Nichols, Leics. ii. 539; for the Faunts, ibid. iii. 347; iv. I 75; for the Merrys, ibid. iii. 275 ; iv. $855-6$. The Ortons are more difficult to identify: see ibid. iii. 395,460 ; iv. 464. For William Whalley, see ibid. iii. 223 ; ii. 736,737 .

10 C 19/52, Ret. of Indentures of Parl. Elections.

II E. S. de Beer, 'Members of the Court Party in the
House of Commons, 1660-78', Bull. Inst. Hist. Res. ii. 8.

12 Leic. Boro. Rec. 1603-88, 606 7.

13 Ibid. 479-8o. Winstanley, who had been appointed in 1653 , surrendered his office in 1662 and was succeeded by Robert Harding, recorder $1662-80$ : ibid. 597.

${ }_{14}$ Leic. Boro. Rec. 1603-88, $48 \mathrm{I}$.

15 Ibid. 597.

17 E.H.R. xlv. 257.

18 Leic. Boro. Rec. $1603-88,487,490,492$; the corporation seems to have feared interference from the county justices.

19 Ibid. 490-I. 


\section{A HISTORY OF LEICESTERSHIRE}

Perhaps prudently at the time, this last suggestion was not pressed, although it touched upon an issue which a hundred years later was to be of the greatest importance, and was not finally to be settled until the reform of $1835^{-6}$.

The letters patent of 20 January ${ }_{1} 66_{5}$ were remarkable chiefly for two things. The first, which was noted by Nichols, was the great emphasis on the oaths of allegiance and supremacy. ${ }^{20}$ The other was the provision that the appointment to certain offices, of a legal and judicial sort, of 'recorder, steward, solicitor or common clerk', was to depend on royal approval and licence, ${ }^{2 I}$ an instalment of that programme of detailed control by the Crown which the Commons had refused in the debate on the Corporation Act. Accordingly, a month or so later, the king formally approved the appointment as town clerk of John Hackle in succession to Edward Palmer. ${ }^{22}$

The strong insistence on the qualifying oaths and sacramental test had the disadvantage that the pretence of conscientious refusal could be made the excuse for refusing office. In $166_{5}$ Edward Billers, William Warburton, and William Orton were actually summoned from Leicester to the Privy Council, and detained in custody, because they refused to take the usual oaths and to pay the consequent fines. ${ }^{23}$ In times of special disturbance, the government was attentive to the enforcement of the oaths and test, and in 1680 , when it made inquiry at Leicester, was told, with a reference back to these events of $\mathrm{I}_{6} 6_{5}$, that subscription was being exacted rigorously. ${ }^{24}$

The letters patent of ${ }^{6} 66_{5}$ made no reference to the parliamentary representation of the borough. Its history at this time remains in important respects obscure. From the time of Henry VII until the Restoration burgesses had been elected in the Common Hall, the commonalty as a whole being excluded. In February I66I the mayor, in the course of a discussion with Lord Loughborough about the election soon to be held, hoped that this would continue. He requested that Lord Loughborough would recommend someone well known in the town, for the recommendation of a stranger might provoke the commonalty to interference in the election, which would thus be more difficult to carry through successfully. ${ }^{25}$ Whatever the true inwardness of this plea, the party of the narrow vote, and presumably also Lord Loughborough and the government, were in the outcome to suffer some disappointment. A double return was made involving three gentlemen, none of them strangers to the town. John Grey was already known as a member, and had family connexions with the Earl of Rutland. ${ }^{26}$ Sir William Hartopp was a well-established county landowner, living at Rotherby. ${ }^{27}$ The third, Sir John Pretyman, was lord of the manor and patron of the living of Loddington. 28 Hartopp's name was in both returns, so that the issue lay between Grey and Pretyman.

For whatever reason, the House of Commons determined in favour of Pretyman, ${ }^{29}$ and against the corporation who claimed that the franchise (on which Grey had been elected) was restricted to themselves, excluding the commonalty of the borough. Their testimony on Grey's behalf availed them nothing. ${ }^{30}$ Perhaps it was a sign of their displeasure that Pretyman seems never to have been made a freeman. He seems to have been very much a Church-and-King country gentleman, zealous against a Puritan minister at Kibworth, 'that indemnity-pleading Captain Yaxley'.3I Pretyman and Hartopp seem alike to have been regarded as sound by the government. Pretyman for a

20 Nichols, Leics. i. 433-4.

21 Leic. Boro. Rec. $1603-88,502-3$.

22 Ibid. 493; Cal. S.P. Dom. I 664-5, 297 (6 Apr. 1665).

23 P.C. $2 / 58$, pp. 376-8 (26 Feb. 1666); ibid., p. 299

(29 Nov. 1665); ibid., p. 354 (26 Feb. I 666); Leic. Boro.

Rec. $1603-88,498,505-7,510$.

${ }_{24}$ Leic. Boro. Rec. $1603-88,552-3$.

25 Ibid. 470-1.
26 See below, n. 4 I

27 C 2 I $9 / 52$, ret. dated 29 Apr. 1661; Nichols, Leics. ii. I63, 423; Leic. Boro. Rec. 1603-88, 532.

28 Nichols, Leics. iii. $329-30$.

29 C.F. viii. 25 I (17 July I66I).

30 Leic. Boro. Rec. I603-88, 473, 478-9; Nichols, Leics. i. 432.

${ }^{31}$ Nichols, Leics. iii. 65 I. 
time held the office of Receiver of First Fruits and Tenths, but was found in December I 663 to be indebted to the Crown in respect of the moneys of that office, $£$ I $9,8649 s .9 d$. After long processes his estate at Loddington was impounded in $167 \mathrm{I}$ on account of the $f_{1} \mathrm{I} 6,000$ or more still owing. ${ }^{32}$ By $\mathrm{I} 676$ he was regarded as having no known connexions with the court, and Hartopp only by way of the Duchy of Lancaster. ${ }^{33}$

In other ways Pretyman was not an ideal member. In 1670 he was suspended for abuse of privilege by using it to get out of the King's Bench prison a certain Robert Haimes, whom he untruthfully made out to be his own menial servant. ${ }^{34} \mathrm{He}$ returned to his duties only when the House was satisfied that he really could not produce the person of Haimes. ${ }^{35}$ On this affair Hartopp made a remark which reflects how much the borough seats were part of the county scheme of things: 'I am confident he will not be expelled the House: and I am glad of it, for a new election would not only have divided the corporation but all the gentlemen in our county would have given a prejudice to each other.' 36 Five years later Pretyman himself had to be delivered out of the same prison..$^{37} \mathrm{He}$ died in $1676,{ }^{38}$ though news of his death seems to have been rather slow in reaching the corporation.

The election of his successor led to some coolness between the corporation and the Earl of Huntingdon. The corporation, perhaps embarrassed by not knowing whether Pretyman was alive or dead, received coldly the earl's provision of a new candidate, a Mr. Finch. Finch was presumably of the family of the Earl of Nottingham, the Lord Chancellor, for the Earl of Huntingdon clearly thought that he was showing great favour to the corporation. The corporation's unfriendly response not only brought upon themselves the threat of a quo warranto, but also very nearly incurred a determination of their franchise in the Commons. Robert Harding, the recorder, commented that if the corporation would only be unanimous in the hall, 'the rest when they know it will obey you'. ${ }^{39}$ In the end, Finch neither forced himself nor was forced on the corporation, and John Grey returned again to the Commons as a member for Leicester. 40

After the general election of 1678 , Leicester was represented in the Habeas Corpus Parliament by John Grey and Sir Henry Beaumont. Grey in this election had the support of the Rutland interest, which was mobilized for him by his nephew Lord Roos, who was himself returned for the county but unseated on a petition in favour of Sir John Hartopp.4I Beaumont had the reputation of a thorough royalist. He held lands at Stoughton and Thurnby. ${ }^{42}$ Throughout the three parliaments of 1678,1679 , and $168 \mathrm{I}$, and in all the heat of the exclusion controversy, Grey and Beaumont continued as members for Leicester. ${ }^{43}$ The corporation declared firmly for the court and was busy against conventicles. 44 They hastened to subscribe the Abhorrence, with which the mayor and aldermen journeyed up to London and which two of them took to the Earl of Rutland.45 In the eyes of the dominant party in the Commons they were thus to be counted enemies of liberty, and 'Tories'. None the less, when the first exclusion bill was read a second time in the Commons, Grey voted with the two county members for it. The 'loyal' Beaumont was absent. 46

\footnotetext{
32 Leic. City Mun. Room, 7 D 35/3, tripartite indenture, 25 June 1672 , vesting the manor of Loddington in trustees, in accordance with the provision of the statute, an Act for sale of part of the estate of Sir John Prittiman for satisfaction of a debt by him due to the king, 22 Chas. II, c. 10; C. F. ix. 140, I 41, I 53, I 55, I 57 .

33 A. Browning, Thomas, Earl of Danby, iii. 82, 109.

${ }^{34}$ C. . . ix. I 16,155 , 156.

35 Ibid. I 60.

36 Leic. Boro. Rec. I603-88, 522.

${ }^{37}$ C.F. ix. $316,317,320$.

38 Ibid. 384

39 Leic. Boro. Rec. I603-88, 545-6. The candidate was
}

possibly Heneage Finch, who became Solicitor General in I 670 and was removed from that post by James II, or his eldest son Daniel, later 2nd Earl of Nottingham and 7th Earl of Winchilsea: P. Finch, Hist. of Burley on the Hill, I $56,16_{3}$.

${ }_{40} \mathrm{C}_{219 / 52}$.

41 Hist. MSS. Com. Rutland, ii. 33, 35 .

42 Nichols, Leics. ii. $848,860,865$.

$43 \mathrm{C} 219 / 56,60,64$.

44 Leic. Boro. Rec. I603-88, 557.

${ }_{46}$ A. Browning and D. J. Milne, 'An Exclusion Bill Division List', Bull. Inst. Hist. Res. xxiii. 2 I 4. 


\section{A HISTORY OF LEICESTERSHIRE}

The whiggish majorities in the Commons made inevitable another attack by the Crown on the municipal corporations. By a remodelling of charters everywhere, the court strove to prevent there ever again being built up such an opposition as Shaftesbury had organized for exclusion. The Leicester corporation was as a whole well-affected, but even there, in the corporation as well as in the town at large, there were ill-disposed men. In I684, pressure to surrender its charters was put upon the corporation by the Earl of Huntingdon, who had only just become Lord Lieutenant. This was done partly by direct correspondence with the mayor, but for the most part through a clerical intermediary and confidant, the earl's chaplain, Dr. John Geary. Geary was at that time Rector of Swepstone, had recently been made Archdeacon of Stowe in Lincoln diocese, and was a little later, in virtue partly of the earl's good offices, to become Archdeacon of Buckingham. Through him the earl conveyed promises, threats, exhortations, and advice; from him the earl got detailed advice about people and conditions in Leicester. ${ }^{47}$

The Leicester corporation was more than once warned of the dangers of delay, and that it was about the last to make a surrender, which might give a very bad impression at court. On the other hand, the earl thought that 'if Leicester doe surrender, if they desire any enlargement of privileges I belive they may be obtained'. He had moreover his own concerns, the appointment alternis vicibus of steward and bailiff as well as 'a designe which ... I once had ... for myselfe', to which Dr. Geary was one of very few people to be privy, presumably that of making himself recorder, with power to name a deputy. He was glad to conclude that in these affairs 'my Lord Ferrers has no more hand in it than my Lord of Rutland'. ${ }^{48}$ Indeed, delays might bring danger to his own plans, as well as threaten harm to the interests of the corporation.

Geary, armed with greater knowledge of the earl's plans than he could rightly convey to the men of Leicester, visited the town, and met there with some dislike of the surrender, overcome only in part by a process of 'sweeting', which included a gallon of sack to the mayor's wife, which with similar gifts from other persons made her and some others quite merry. 'My staying two or three days amongst them proselited them all.' In the end the surrender was voted in the Common Hall, 45 votes to 4.49 Four men were reported by name as voting against the surrender, Bentley, Brooksby, Harris, and one of the Bents, presumably John. Others, thought Geary, wished them well in their opposition, but dared not declare themselves, among them 'Buxston, Wallin, Dudley'.50 Even when the surrender had been voted, its execution was delayed, until a new mayor was not merely elected on the St. Matthew's Day following, but also sworn in on the next Michaelmas Day (until when 'he is but a tantum non'), and qualified by Communion the Sunday after. ${ }^{5}$ ' This was particularly irritating to the earl, who wished to get the surrender back to the king when he came back from Newmarket on 25 September, anxious perhaps to forestall any move from Ferrers or Rutland. Neither the persuasions of Dr. Geary, nor even the alarming appearance of a quo warranto 'directed to Mr. Carter', could hurry up the corporation, although a Mr. Newton, a 'great servant of theirs' (almost certainly John Newton, a local vicar of apparently contentious disposition), was sent on a special embassy to Swepstone to seek help and

${ }^{47}$ This acct. of the 1684 negotiations is based on a series of letters in the Huntingtơn Libr. Univ, of South California, Huntingdon MSS. The libr. provided microfilms and gave permission to quote. For the text of the correspondence see R. W. Greaves, 'The Earl of Huntingdon and the Leic. Charter of 1684', Huntington Libr. Quarterly, $\mathrm{xv} .37 \mathrm{I}-9 \mathrm{I}$.

${ }_{48}$ Huntingdon to Geary, 6 and 18 Sept. 1684.
49 Leic. City Mun. Room, Hall Papers, 1680-5, no. 131 ; on the question whether the surrender should be sealed within a fortnight after Mich. there was a minority of 5 ; ibid., no. 135 ; Leic. Boro. Rec. $1603-88,561$.

50 Geary to Huntingdon, Io Sept. I 684.

${ }^{51}$ Geary to Huntingdon, 23 Sept. 1684; Andrew Freeman, Mayor of Leic. to Huntingdon, I3 Sept. 1684. 
influence. ${ }^{52}$ The earl was able to assure the king that the surrender was a truly voluntary act, and 'not the effect of the quo warranto', and so to secure a stay of proceedings upon the writ. ${ }^{53}$

When at last the new mayor was 'completed'-_'Thomas Ludlam, 'a wonderfull loyall person and picked out on purpose for the designe'54 - the order for surrender was put into execution, but by a wrongful procedure. Not unnaturally fearful lest they should make any mistakes, the mayor and corporation, on the advice of Brown their solicitor, decided to bring up to London a blank form ready prepared, together with the seal of the corporation, with which the mayor might in London seal 'such instruments as may be acceptable to His Majesty'. ${ }^{55}$ 'The form was good, probably one which had been sent by the earl himself, but surrender had to be made, as the AttorneyGeneral himself advised, by a document sealed actually in the Common Hall.56 'The mayor and his colleagues therefore hastened back to Leicester, having enjoyed magnificent hospitality at the earl's house in Gerard Street. On 29 October the seal of the corporation was in due form at last affixed to the surrender, which Mr. Chamberlain Abney brought back to London. Surrender could at last be made to the king on the corporation's behalf, by either the earl or the recorder. ${ }^{57}$ Early in November the recorder wrote to tell the mayor that he had presented the surrender and the petition for a new charter, and that the earl was 'now upon the inquiry after men and principles' ${ }^{58}$

He had from the outset been concerned about 'men and principles', as had the corporation themselves. So soon as surrender was pressed upon them, by the Earl of Huntingdon and Dr. Geary, and as well by the Earl of Rutland and others, 59 the mayor and 'several members of both companies' had met to consider what things they might ask for, to be added to the privileges they already had. They suggested an additional fair, to be held on the Saturday before Twelfth Day; that they might have the reversion of the perquisites of the court leet and the immunities thereunto belonging; and, most important, that the election of burgesses of Parliament for the borough might be settled 'in both companies as formerly'.60 'The earl's ideas were in some ways more drastic: the recordership for himself, a reduction of the companies in size to $\mathrm{I} 2$ aldermen and 24 common councilmen (simply 'by continuing all such at present as are good men and for the future to let them lessen to that number'), ${ }^{6}$ and (this being mentioned only after he had entertained the mayor and his colleagues in Gerard Street) perhaps 'associate justices. . . gentlemen in the towne and within five miles of it that will be fit to be inserted'. ${ }^{62}$ Otherwise it was expected that all that had been surrendered would be granted again, 'the king only reserving to himselfe a power of approbation in the governing part'. ${ }^{63}$

The earl had not been altogether favourably impressed by the deputation which had waited upon him in London. Of one or two he knew something. On all he sought Geary's advice. 'For Noble hee is now in London and though he may goe to Broadgate sometimes I doe verily beleeve he will not vote amiss tho he will bee dead probably before another Parliament.' Joseph Cradock had married a Hastings, ${ }^{64}$ so that to leave him out would reflect upon the earl, but he was not regarded by Geary as in any way improved by this alliance, being still 'rich and peevish'. Geary mentioned also Edmund

\footnotetext{
52 Geary to Huntingdon, 16 Sept. 1684.

53 Huntingdon to Geary, 6 Oct. 1684; Leic. Boro. Rec. I $603-88,559-60$.

54 Geary to Huntingdon, I6 Sept. I684.

55 Browne to Huntingdon, 13 Oct. I684; Leic. Boro. Rec. $1603-88,560$.

56 Huntingdon to Geary, 2 I Oct. I684.

57 Leic. City Mun. Room, Hall Papers, I680-5, no. I 42; Leic. Boro. Rec. $1603-88,56 \mathrm{I}$.
}

58 Leic. Boro. Rec. I603-88, 56r.

59 Andrew Freeman to Huntingdon, I 3 Sept. I684.

60 Leic. Boro. Rec. I603-88, 560.

6I Huntingdon to Geary, 6 Oct. I68.4.

62 Huntingdon to Geary, 2 I Oct. I684.

63 Huntingdon to Geary, 6 Oct. I684.

64 Nichols, Leics. iii. 278 (Jane, dau. of Hen. Hastings of Humberstone). 
Johnson, 'a very rich dyer . . . looked upon to be presbyterianly inclined'. On most of these matters Geary had found the men of the town to be divided, especially in their opinions about persons, and as to the way of removing them, 'many being desirous that they should be incorporated by all the names of the old members and then after a little by the king's command to be removed and this was the way at Coventry'. On several other problems Geary gave the most direct advice. For one thing the men of the town, however divided on some points, were perfectly united in hatred of the idea of associate justices, with 'a perfect averseness and great dislike among them all against any country gentlemen to be joyned with them, and they all seriously declare they had much rather their corporation were totally destroyed than such a thing done'. He strongly urged the earl if he became recorder to keep Nathan Wright as his deputy, for Wright was a loyal person, of great weight in the town. In spite of the solicitations of Henry Halford for the post of steward, ${ }^{65}$ William Major should be kept in that office on account of his considerable estate in the town, and his many relations. ${ }^{66}$ There was, as he pointed out, the less need to be exact about persons at this stage, since the charter would provide that any who should at any time displease the king could by royal order be removed.

The new charter was issued on ro December I684. The privileges of the corporation as a whole remained much as before. ${ }^{67}$ It is interesting to observe how the susceptibilities of the townsmen as reported by Geary were taken into account. As the earl had told him a few days in advance, 'I shall bee recorder, the removes will not be above I 2 or I 3 without associate justices'. ${ }^{8}$ 'Thomas Ludlam was named as mayor, and Nathan Wright as deputy-recorder, Henry Halford as steward of the Court of Record, and William Major as bailiff of the liberty. ${ }^{69}$ Of the four who had voted against the surrender, and the others who had been named as suspect in Geary's report, not one remained in the body as reconstituted, not even John Bent, who had tried to excuse himself to Geary as having been 'drawne in' 70

On the other hand, for all the regard which was had to the sentiments which Geary had reported to the earl, there were significant alterations. The companies were reduced in size, though not so far as the earl had at first thought, by the reduction of the 48 to 36 , the aldermen remaining at 24 . The chamberlains were abolished, and their duties taken over by two bailiffs. The power of electing burgesses to Parliament was not confined to the companies as they had wished, but extended to inhabitants paying scot and lot. Finally, as was only to be expected, the Crown was given, in the most explicit terms, powers of removal of all officers and members of the hall at pleasure. ${ }^{7 r}$

It seems clear that the provisions of the new charter represented some sort of balancing between what the earl wanted, and the feelings in the town. No doubt also, account was taken of the wishes of the other gentry of the county, from Rutland and Ferrers downwards. This may indeed account in part for the continuation of the wider franchise, in spite of the greater ease with which the government could have manipulated the narrower one. Possibly here, the interest of the gentlemen of the county was influential. The narrow franchise would certainly have eliminated much of that power which in one way or another, such as by the ownership of tenements in the borough, they were able to exert in the return of members to the Commons. Moreover,

\footnotetext{
65 Halford to Huntingdon, 5 Oct. 1684.

${ }^{66}$ Geary to Huntingdon, 31 Oct. I 684 ; Huntingdon to Geary, 21 Oct. I 684.

67 Leic. City Mun. Room, Hall Papers, 1680-5, nos. 157 , I63; Leic. Born. Rec. I603-88, 56 I.

68 Huntingdon to Geary, ? Nov. 1684 .
}

69 Leic. Boro. Rec. $1603-88,572-3$.

70 Geary to Huntingdon, 3 I Oct. I 684

7 Leic. Boro. Rec. I603-88, 564-9; Nichols, Leics. i. 433-4; S.P. $44 / 335$, pp. $239-40$; S.O. $7 / 76$; S.P. $44 / 71$, p. 37 . 
although the ruling motive in these events was a political one, to prepare for a future Parliament which should be amenable to the court, other considerations may also have entered in. The reduction of the company of 48 to 36 was probably defensible on grounds of efficiency. Indeed, the corporation of Shrewsbury actually asked for their companies to be reduced to the numbers originally thought of by the Earl of Huntingdon for Leicester, of 12 and $24 .^{72}$

The charter of I 684 upheld the statutory defences of the Church of England. 'The recorder will direct Hackle how to prepare things for swearinge all the companies. . . . They must all afterwards receave the Sacrament and take the oaths at the next sessions. ${ }^{73}$ At last stability might seem to be secured. ${ }^{74}$ In fact, the currents of disapproval of the régime were to grow stronger, as it seemed to increase in arbitrariness. 75

This new charter had not been long in force when Charles II died on 6 February I $685 .{ }^{76}$ His successor, in speeches the text of which was carefully recorded in the minute books of the Leicester corporation, promised to uphold the rights of the Church of England.77 The Earl of Huntingdon was prompt to send to Leicester a form of loyal address to the new king, and at the same time to put them in mind of the approaching elections for the first Parliament of the new reign. 'I suppose Sir Henry Beaumont will offer himself for one, and whether you may not find a fitt man and inhabitant of your town and a member of your corporation to be the other I leave you to consider, possibly you may do yourselves much right in it.' 78 Indeed the earl wrote more often than not in a fashion somewhat admonitory. When he reported the king's gracious reception of the loyal address and good opinion of Nathan Wright, the deputy-recorder, he referred also to the arrest of a seditious person in the town, and remarked that 'it would be very unsafe for you if he should run away'.79

In the Parliament of 1685 Leicester was represented by Sir Henry Beaumont and Thomas Babington of Rothley. ${ }^{80}$ In no small degree as a result of the manipulations of the previous three or four years the House of Commons met in a spirit of great loyalty to the Crown, which was only dissipated by James II's favour towards Roman Catholics and Dissenters. He set about using the same methods that Charles II had used, but in the opposite direction, to abase the Church interest by a new regulation of the municipalities. ${ }^{81}$

This work seems to have begun for Leicester in February I688, when by order taken in the Privy Council eleven aldermen, sixteen of the common councilmen, the bailiff, the town clerk, and the town solicitor were put out, and new men brought in. These new men included all those whom Geary had named as against the surrender of I684, the rich dyer Edmund Johnson, Bentley, Brooksby, Bent, Wallin, Dudley, Harris, and Buxton. Significantly they were dispensed from taking the oaths for the defence of the Church of England which had been expressly enjoined in the charter of $1684 .{ }^{82}$ On 22 and 27 April there were new removals and appointments, until in all 33 persons who had been named in the charter of 1684 were turned out. ${ }^{83}$ So purged, the corporation welcomed the birth of the Prince of Wales, and arranged on 27 June a day of feasting at the house of Joseph Cradock the mayor, who was apparently now less 'peevish'. Bells were rung and bonfires blazed in the town. ${ }^{84}$

72 S.P. $44 / 71$, p. 53 .

73 Leic. Boro. Rec. I603-88, 562.

75 D. J. Milne, 'The Results of the Rye House Plot and the Revolution of I688', Trans. R.H.S. (5th ser.), i. 99107.

${ }_{76}$ His death is noted in Leic. City Mun. Room, Hall Bk. 6 Feb. $1684 / 5$.

77 Ibid. Hall. Bk. I 587-1 707, pp. 878-80.

78 Ibid. Hall Papers, I680-5, no. I 80.
79 Ibid. no. I 78 .

80 C $219 / 68$.

8i S.P. 8/1 (King Wm.'s Chest), Earl of Nott. to the Prince of Orange, 2 Sept. 1687 reporting the King's general failure.

82 P.C. $2 / 72$, p. 6r6; Nichols, Leics. i. 452 ; cf. Leic. Boro. Rec. $1603-88,587$.

83 P.C. $2 / 72$, pp. 653,654 .

84 Leic. Boro. Rec. $1603-88,588-9$; Hist. MSS. Com. Hastings, ii. 185 . 


\section{A HISTORY OF LEICESTERSHIRE}

This reorganization was all very well on paper, but in Leicester, as in many other places, 'several of the new aldermen of the dissenting party . . . refused to act'. Sir Henry Beaumont as a good Tory deplored the putting out of 'loyal and complying persons'. 'As to some in the list', he complained, 'as Palmer, Pare, and Deakins, they are my especial friends and tenants, entirely to be governed for His Majesty's service. Since never any person so vile as he that hath Huckles his place, his name being Creswell, an old rebel, of which he glories to this day' ${ }^{85}$ Creswell was soon found unsatisfactory, and dismissed in July 1688.86

A truncated corporation, a purged body, made a new surrender of the town's privileges. A new charter was issued on ${ }_{1} 5$ September 1688, at the same time as a number of others. ${ }^{87}$ The Earl of Huntingdon, one of King James's right-hand men, was busy again. Many of the changes made in 1684 were continued in the charter of $\mathrm{I} 688$. The companies were kept at 24 and 36 , the two bailiffs still did the work formerly given to chamberlains, and the Earl of Huntingdon remained as recorder, with power to appoint his deputy who was not this time named in the charter. The new charter strongly asserted, as the former had done, the Crown's rights of removal.

In other respects, by no means unimportant, the charter of I688 went contrary to that of I684. The mayor, aldermen, councilmen, and all other officers named, and their successors after them, were 'by virtue of the prerogative dispensed, pardoned, remitted, and exonerated' from taking the oath of supremacy, or any other of the oaths and tests which had been imposed for the defence of the Church of England. The new charter, moreover, completed the purge begun the previous February. Only four aldermen and four councilmen of 1684 remained in the corporation as reconstituted by this new charter. The charter-mayor, John Carr, had never before held civic office. ${ }^{88}$ It is noticeable also that seven of the promoti of February were missing from the body as then reconstituted. These men, two aldermen and five councilmen, may well have included those of the dissenting party mentioned by Beaumont as having refused earlier to act. The whole Quaker executive of the town appeared as nominated in this charter. ${ }^{89}$ Another sign of the difficulty of recruiting people to co-operate in the new policy was that the objectionable Creswell, who had been appointed first in February and then dismissed as unsatisfactory in July, returned to office, nominated in the charter of September to the place of town clerk.

The charter of I 688 made another radical change. As the old companies had so often asked, it restricted the parliamentary franchise to the mayor, aldermen, and common councilmen. In Henry Beaumont's words, 'elections that way will be the more secure, and more certain measures taken'. ${ }^{\circ 0}$ Even before the charter was completed the Presbyterian John Oneby, bailiff of the liberty since February I 688 and one of the returning officers, wrote from Barwell to the Earl of Huntingdon about the expected election: 'I hope we shall be in a condition to elect Sir W. Villiers and Sir H. Beaumont, persons of undoubted loyalty and fidelity.'91 As late as mid-September the Earl of Sunderland as Secretary of State conveyed to the Earl of Huntingdon the king's approval of these nominations. ${ }^{92}$

James II's charter has been almost completely unnoticed by Leicester historians. ${ }^{93}$ It does not seem ever to have been officially received at Leicester, or to have had the

85 Hist. MSS. Com. Hastings, ii. 184.

86 P.C. $2 / 72$, p. 616.

87 C $66 / 3317$; Leic. shares this patent roll with Derby, in which the Earl of Huntingdon was also interested.

88 The name occurs in Reg. of Freemen of Leic. II96$I 770$, ed. H. Hartopp, $135, x 6 \mathrm{r}$, possibly for this man.

89 Ex inf. Mr. R. H. Evans.
90 Hist. MSS. Com. Hastings, ii. 184 .

91 Ibid. 187.

92 Ibid. I $87-8$.

93 Nichols, Leics. i. $436-8$, seems to confuse the 2 charters of $\mathrm{I} 684$ and I 688 , and the latter with the P.C. order of Feb. 1688 . This order ejected Wm. Major from the office of bailiff and substituted John Oneby; cf. Leic. Boro. Rec. $I 603-88,587$, which has no ref. to the charter of James II. 
slightest effect, though it may perhaps have reached John Carr or other of the king's friends in the town, and been no more heard of. On the St. Matthew's Day which followed less than a week after the charter, it was not John Carr who was chosen mayor, but William Bentley, who was indeed named in the charter, but only as an alderman. On 17 October I 688 James II, by orders, the text of which was most carefully entered in the corporation's minute book, revoked all the amendments and reconstitutions which his brother and he had made in municipal liberties since $1679 .{ }^{94}$ There seems indeed to have been nothing else that he could do, if in some important places a breakdown of town government was to be avoided. ${ }^{95}$ At Leicester this meant a restoration to their places of those men who survived from the corporation as it had been immediately before the charter of I684. Accordingly Thomas Ludlam, who had been both the last mayor chosen under the previous dispensation, and continued as the first under the 1684 charter, again presided in the Common Hall, over companies nominally of 24 aldermen and 48 common councilmen. On 20 October there were with him 18 other aldermen and 40 of the common council. At this meeting William Bentley was for a second time that year chosen mayor. This time he took not only 'the usual oaths of the corporation', but also 'the oath of allegiance and supremacy, the oath mentioned in the Act for Regulating Corporations, and subscribed the Declaration for the Renouncing of the Covenant'. Aldermen Ludlam, Hood, Ward, and Cradock, who had served as mayors in the previous four years, were named as justices of the peace, notwithstanding that the last three had served under a charter now revoked. Similarly the hall decided that 'those persons as have been mayors shall have the precedency according to their places of seniorities of mayoralty'. The old chamberlains of I684 returned for this one meeting, where they handed over to the two men who had been named as bailiffs at the last St. Matthew's Day under the I 684 charter, and were now again to be called chamberlains. To make all regular, one of them, Joseph Roberts, junior in the 36 , had immediately before to be appointed by the aldermen to the company of 48 now restored. He, too, had to take the oaths of which James II had tried to rid himself. ${ }^{96}$

\section{$1689-1765$}

On 29 December 1688 the Prince of Orange addressed his letters throughout the kingdom for the calling of the Convention Parliament. To Leicester, ${ }^{97}$ as to the other boroughs, the letter was addresed to 'the chief magistrate or such others ... who have right to malse returns of members to serve in Parliament according to the ancient usage of the said burrough, before the seizure or surrender of charters made in the time of King Charles II'. Accordingly William Bentley as mayor and Thomas Palmer as bailiff of the liberty returned the names of Thomas Babington of Rothley Temple, and Lawrence Carter of the Newarke. ${ }^{98}$

The conditions of parliamentary conflict were in important respects changed by the Revolution. The influence of the Earl of Huntingdon was eclipsed.99 Sir Henry

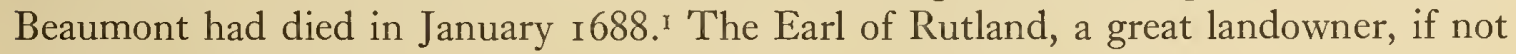
the greatest in the county, became lord lieutenant. ${ }^{2}$ Thomas Grey, second Earl of

94 Leic. City Mun. Room, Hall Bk. I 587-1707, pp. 997, 1 ooo (from Lond. Gaz., 18 Oct. 1688).

95 Cf. S.P. $31 / 4$, ff. I02-3, II 5 .

96 Leic. City Mun. Room, Hall Bk. 29 Sept. and 20 Oct. 1688.

97 For a comprehensive account of the corporation's history in the I8th and early I 9 th century, see R. W. Greaves, Corporation of Leic. I689-1836.

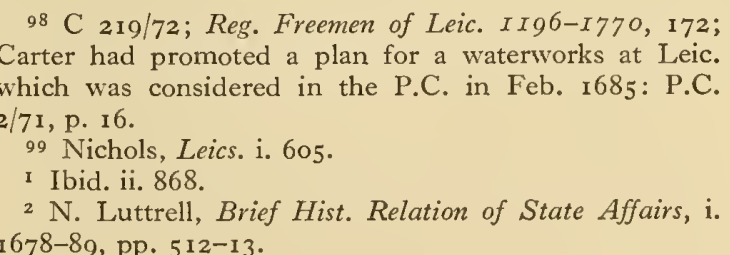




\section{A HISTORY OF LEICESTERSHIRE}

Stamford, a thorough Whig who had been under a cloud in the previous reign and for most of it had lived quietly at Bradgate, now came into his own. ${ }^{3}$ In 1697 he became Chancellor of the Duchy of Lancaster, as well as Lord Lieutenant of Leicestershire. ${ }^{4}$ To these two earls now, and no longer to the Earl of Huntingdon, the corporation had to look for protection and favour. ${ }^{5}$

The corporation of Leicester has been generally regarded as at this time disaffected to the Revolution. The truth seems to be that the Common Hall was not so much disaffected as diverse. At Michaelmas I 689 all the different groupings of the previous five years were represented in it. There was first a group of $30 \mathrm{men}$, including I2 among the aldermen, who had, at some time or another, been ejected by James II, presumably as unfavourable to his plans to favour Roman Catholics. A second group, rather more numerous, were persons who had been named in the charter of 1684 , all of whom may on that account be taken to be stout Church-and-King men, hostile to papists and dissenters alike. These were 18 of the aldermen and 22 of the common councilmen. There was, thirdly, a slightly larger group, 24 of the aldermen, and 28 of the common councilmen, who had been of the Common Hall immediately before the charter of 1684 . These included twelve men, who had been removed in 1684 , among them those notorious characters, Bentley, Brooksby, Harris, and John Bent. The first two mayors of the Revolution time were dissidents of $\mathbf{r} 684$, William Bentley and John Bent. Bentley had also been named for office under James II in both February and September I688; Bent, perhaps because he was more strictly 'protestant', only in February.

Some such mixture of elements was clearly not to be avoided in a small community, where recruitment for office was never easy, and made more difficult in disturbed times. It shows the folly of the proposals which were made in the legislature to purge the municipalities of all who had any part in surrendering charters. A municipal body of mixed complexion, under the rule of whiggish mayors, may well have seemed very suitable to the lord lieutenant and to the governments of I 688-90. Probably, however, the whiggery of Bentley, Harris, Brooksby, and Bent, in $1684-8$, when for the most part a royalist toryism reigned in Whitehall, had come as much from a spirit of local independence as from theological or political doctrines. No doubt in this it resembled the intransigent toryism and fierce Churchmanship of their Hanoverian successors, who were to face a central government of an opposite character, one which was accounted Whig and latitudinarian.

In the light of these different groupings in the Common Hall of I 689-90, it seems no longer possible to accept the judgement of those writers who, from the $\mathrm{I} 8$ th century onward, have regarded the Leicester corporation as thoroughly disaffected to the Revolution. There were, of course, signs and rumours of Jacobitism in the town. In I 690 John Newton, Vicar of St. Martin's, was accused by barber-surgeon Pollard of traitorously wishing God-speed to a rumoured French invasion, but the magistrates rebuked, apparently, not the parson but his accuser. ${ }^{6}$ Drunkards in the town drank the Pretender's health, and swore terrific Jacobite oaths. ${ }^{7}$ The corporation itself had its troubles with members elect who refused the qualifying oaths designed to protect the Revolution and Protestant succession, ${ }^{8}$ though these refusals may have sprung not

\footnotetext{
3 See Speech of the Earl of Stamford at the Quarter Sessions held for the Co. of Leic. Mich. I69o (1692).

4 Nichols, Leics. iii. 679.

5 See R. W. Greaves, Corp. of Leic. $I 689-I 836,62$, 90-92.

6 Leic. City Mun. Room, Quarter Sessions R. I600. In the reign of Charles II Newton had been accused of con-
}

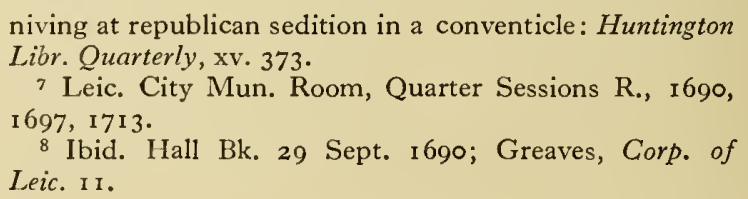

niving at republican sedition in a conventicle: Huntington Libr. Quarterly, xv. 373 .

7 Leic. City Mun. Room, Quarter Sessions R., I690, I 697 , I 7 I 3 .

8 Ibid. Hall Bk. 29 Sept. I690; Greaves, Corp. of Leic. $\mathrm{I} \mathrm{I}$. 
from seditious principles, but merely anxiety to avoid public service. On the whole, the corporation conscientiously administered these oaths. They swore to the Association of $1696 .{ }^{9}$ In the general uneasiness, however, it is not surprising that troops were quartered in the town, and even with the help of the Earl of Stamford were not easily to be got rid of. ${ }^{10}$

The Revolution brought no great change in the character of the burgesses of Parliament. They continued to be gentlemen from the county, often with family connexions in the town. At the first election after the Revolution, Babington was defeated. He was reported, rightly or wrongly, to be amongst those who had voted against recognizing William and Mary as king and queen. ${ }^{\text {II }}$ The new member was Sir Edward Abney, of Willesley Hall, elder brother to that Sir Thomas Abney who was Lord Mayor of London. ${ }^{12}$ Abney was re-elected in $1695 .{ }^{13}$ Lawrence Carter, his colleague, remained from the Convention Parliament to represent the town throughout the entire reign of William III, with the exception of the Parliament of $\mathrm{I} 695$, when he was replaced by Archdale Palmer of Wanlip. ${ }^{14}$ Lawrence Carter, recorder from 1697 to $1729,{ }^{15}$ though reported to hold high Church-and-King principles, ${ }^{16}$ was in 1702 to have the support of the Rutland interest, and to hold office under the Hanoverians. ${ }^{17}$ After Abney, Carter had as a colleague in the Parliament of 1696 and in the first of 1701 , Sir William Villiers of Brooksby, ${ }^{18}$ and in the second Parliament of $\mathrm{I} 70 \mathrm{I}$, the last of the reign, James Winstanley of Braunstone. ${ }^{19}$

It seems to have been during the reign of Anne that the Leicester corporation acquired that Tory label which (not altogether without exception) it kept until the reforms of I 836. Throughout Anne's reign, Leicester was represented in the Commons by James Winstanley of Braunstone, and Sir George Beaumont of Stoughton Grange. ${ }^{20}$ Beaumont was grandson to that Sir Henry who had sat for the town during the exclusion controversy and under James II. Winstanley remained as member until he died in r7 8 ; and Beaumont until he died, still a bachelor, in 1737.

Beaumont was an extreme Tory, who became a member of Bolingbroke's October Club. ${ }^{21} \mathrm{He}$ seems to have refused to stand for election in 1698,22 and worked against the Rutland interest in I70I. ${ }^{23}$ He flourished more happily under Anne. He 'tacked' in 1704 , and in 17 IO supported Sacheverell. ${ }^{24}$ During the Tory ascendancy of the last years of the queen he was appointed a commissioner of the Privy Seal in I7I 2, and in I 7 I 4 of the Admiralty. ${ }^{25}$ In the controversies about the French peace at the end of the reign he incuired some unpopularity in Leicester, which was used against him in an election: his voting for 'the bill relating to commerce' was interpreted as 'voting for transporting wool unwrought from France'. ${ }^{26}$

Winstanley his colleague had a Puritan ancestry, and perhaps partly for that reason was regarded by Throsby and subsequent writers as being the Whig to Beaumont's

9 Leic. City Mun. Room, Hall Papers, I 695-1700, no. Io.

10 Ibid. Chamberlains' Accts. I 692-3; Cal. S.P. Dom. I $694-5,253$.

${ }_{11}$ Browning, Thomas, Earl of Danby, iii. 168; Feiling, Hist. of Tory Party, I660-I7I 4, 497; Greaves, Corp. of Leic. 98 .

12 Nichols, Leics. iii. 528; C 219/76; Reg. Freemen of Leic. $I 196-1770,173$.

${ }_{13} \mathrm{C}_{219} / 80$.

${ }^{14}$ Ibid.; Reg. Freemen of Leic. II96-I770, 177. Both Palmer and Abney subscribed to the Association of 1696: Browning, Danby, iii. 203.

15 Nichols, Leics. i. 318 n., 319.

16 Thompson, Hist. of Leic. ii. 246.

17 See below, p. I22.
${ }_{18} \mathrm{C} 219 / 84,88$; Reg. Freemen of Leic. II96-I770, I8I; Nichols, op. cit. iii. 194-5.

${ }_{19} \mathrm{C} 219 / 92 ;$ Reg. Freemen of Leic. II96-I770, 185.

${ }^{20}$ C 219/96; Reg. Freemen of Leic. II96-1770, 193; C 2 I $9 / 100$, I04, I08, I 2 .

${ }_{21}$ J. Swift, Fournal to Stella, 13 Apr. I7 I ; Bodl. Libr. MS. Rawl. A. 286, f. 39.

22 Hist. MSS. Com. Rutland, ii. 262. 'Mr. Palmer of Carlton has some interest in the borough, and is desirous of coming forward if he can obtain the earl's support'; ibid. 163.

23 Ibid. 168

24 Greaves, Corp. of Leic. 99.

25 Nichols, Leics. i. 860-1; C 219/108, 112; C.f. xxii. 574 .

${ }_{26}$ Bodl. Libr. MS. Carte I I 7, f. 445. 


\section{A HISTORY OF LEICESTERSHIRE}

Tory. Actually, if the contemporary accounts of parliamentary divisions are not here misleading, he voted more than once with Beaumont in a decidedly Tory fashion, about occasional conformity, and even about Sacheverell. He was disliked by the dissenters, and was by one contemporary regarded with Beaumont as an October man. ${ }^{27}$ To judge by his hostile vote against the French commercial treaty, he is probably to be thought of as a Tory, but not an extreme one. ${ }^{28}$ The long continuance in the Commons of Beaumont and Winstanley, particularly of Beaumont, probably helped the dominance within the corporation of those who were strongest in their devotion to the Church of England and the Throne.

An important issue was settled by the determination which the House of Commons made of the disputed return of 1705 . In the previous election, of 1702, Lawrence Carter, notwithistanding support from Belvoir castle, had been defeated.29 Again in I 705 he was an unsuccessful candidate, but petitioned to have the return of Beaumont and Winstanley set aside. Both sides made the usual accusations of bribery, threats, and violence. The persons principally complained of, by Carter's witnesses, for indirect practices, were Thomas Ayres the mayor, 'Thomas Palmer the bailiff, 'Mr. John Orton, Mr. John Farmer, and others'. The Committee of Privileges reported in favour of Carter's petition. The House as a whole accepted every one of the committee's resolutions, except the vital one, which would have unseated Winstanley and brought in Carter. Beaumont and Winstanley were thus confirmed as members, but Winstanley only by the narrow margin of 190 to I 50 .

Three decisions were made in this determination which were of importance for the future politics of the borough. Everybody agreed that the franchise was in the freemen of the borough not receiving alms, and the inhabitants paying scot and lot. The Commons decided also that such freemen as had been made free at the charge of any of the candidates might not vote at the election; that persons living in the borough by certificate, not having gained a settlement by renting $£_{\mathrm{I}} \mathrm{O}$ a year or serving in an annual office, did not qualify for the vote simply by paying scot and lot; and finally that any person having a right to vote for two members, who had given a single vote, had not any right to come back and give a second vote afterwards. It was an important point that the freemen and the scot-and-lot-paying inhabitants were now determined as the voters, because whatever the control the corporation had over the number of freemen, it had no control over the increase of the scot and lot men, which magnified more or less as population grew. On the other hand, the simple restriction placed on the use of freemen created specially for election purposes could be easily evaded by corporation and candidates, especially as the freeman franchise was in no way limited to freemen who were resident in the borough. 30

The Hanoverian succession, more distinctly a Whig party affair than the Revolution, threw the Leicester corporation more decidedly on the side of opposition. One sign of the changed times, according to an obituary notice (used by Nichols), was that Sir George Beaumont, after the queen's death, 'suffered the same fate as the rest of her faithful servants. Nay, so far was the reign of party carried as even to turn him (together with a great number of other gentlemen of the best families in the county) out of the commission of the peace, though so great and general was the discontent on that account, he was with some others restored.' He had nevertheless, as Nichols closely paraphrased the obituary, 'the satisfaction to find that, however small his interest

27 A. Boyer, Quadrennium Annae Postremum (1718), iii. I 2 I.

${ }^{28}$ Greaves, Corp. of Leic. 99.
29 Hist. MSS. Com. Rutland, ii. I 7 I.

${ }^{30}$ C.F. xv. I $35^{-7}$; T. Carew, Historical Rights of Elections (I 755), $32 \mathrm{I}-4$. 
with men of power might be, yet among the people he represented it increased every day, and every contest, particularly the last, showed him much superior to every competitor. He died 9 April $\mathbf{4} 737$, having represented the town of Leicester constantly in every Parliament from the death of King William.' 31 'Throughout his life he persistently opposed the characteristically Whig measures-the Septennial Act, the Peerage Bill, the tobacco excise. ${ }^{32}$ His epitaph, reputed to be composed by Swift, had a 'Tory reference to Queen Anne's 'entirely English reign'. He was praised as 'a zealous advocate for the rights of the Church'.33

In spite of the affronts almost certain to be offered to Sir George Beaumont, the corporation behaved with correctness at George I's accession. ${ }^{34}$ They made elaborate arrangements for 'the greater solemnity of the day' of his coronation. These included processions to church and back, an ordinary at the 'White Hart', an evening party at the Gainsborough, and bonfires. ${ }^{35}$ 'The failure of the 'Fifteen elicited loyal expressions. ${ }^{36}$ None the less, there was no doubt present in the town, as Thompson maintained, 'a leaven of Jacobitism', ${ }^{37}$ open manifestations of which were inhibited by the quartering again of troops in Leicester, whose presence was almost certainly a sign of suspicions in Whitehall. Such Tory Churchmen as Samuel Carte, Vicar of St. Martin's, in whose family there continued a tradition of devotion, sometimes imprudent, to the Stuarts, disliked intensely the presence of the soldiers. ${ }^{38}$

It seems to have been after the Hanoverian succession rather than before that charges of Jacobitism were most consistently made against the corporation. At election times they were part of the invective whereby the Whig interest sought to discredit its opponents. The election of Thomas Noble as a colleague for Beaumont in the House when Winstanley died in $17 \mathrm{I} 8$ seems to have passed off quietly. ${ }^{39}$ Noble, though 'unanimously elected' at Leicester, was not altogether of Beaumont's way of thinking. He seems to have abstained from voting with Beaumont against the repeal of the Occasional Conformity and Schism Acts, which had been passed as High Tory measures just before the queen died, but joined him in opposition to the Peerage Bill. ${ }^{40}$ At the election of 1722 Lawrence Carter was returned as member, with Beaumont.4I

The year of Carter's election was the year also of a Jacobite demonstration, apparently not connected with the election, which brought upon the Common Hall the notice of the government. According to 'repeated advices from several persons of credit', so the government were informed, 'about two o'clock in the morning, seven or eight persons assembled at the Market Cross, ... . did there proclaim the Pretender by the name of King James the 'Third'. Since no account had been sent in by the magistrates themselves, the judges of assize were called upon to investigate. ${ }^{42}$ The town clerk in the following September was summoned to attend the Secretary of State in London with copies of examinations of witnesses. ${ }^{43}$ In this affair the county officers intervened, encouraged by persons in the town who were anxious to vilify the corporation as traitorous and Jacobite. The Duke of Rutland and the other members of the county commission of the peace in March 1723 alleged against the inhabitants of Leicester a whole train of Jacobite activity, 'by inlisting and swearing men into the Pretender's service, by proclaiming him king in several streets . . . by drinking his health, and by many other horrid crimes of the like nature, of which no notice was taken by the mayor or aldermen, who are acting justices

\footnotetext{
31 Bodl. Libr. MS. Rawl. J. $4^{\circ}$ 5, f. 252; Nichols, Leics. ii. 860; J. Throsby, Memoirs of Town and Co. of Leic. v. $70-72$.

32 Greaves, Corp. of Leic. 99-100.

33 Bodl. Libr. MS. Rawl. J. $4^{\circ} 5$, f. 252.

34 Leic. City Mun. Room, Hall Bk. 3 Aug. 1714.

35 Ibid. I I Oct. I 7 I 4.
}

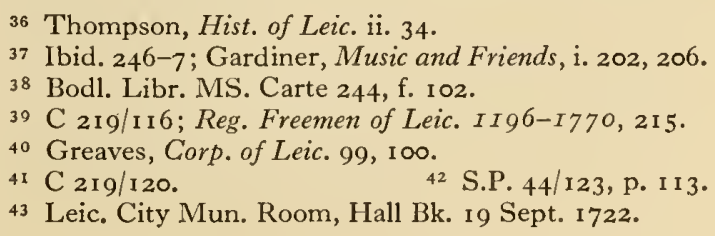




\section{A HISTORY OF LEICESTERSHIRE}

of the said burrough, until Your Majesty's justices for the county complained to the Lord Carteret of so shamefull a neglect'. Indeed, even when the judges had directed certain county justices to sit with the borough magistrates to examine witnesses, the borough magistrates had been obstructive. 'One of the said borough justices', it was alleged, 'drank the Pretender's health upon his knees.' 'The duke and the other county justices suggested therefore that some of their number should be empowered to act within the borough limits 'as His Majesty shall think fit',44 thus reviving in a very different context the Jacobite Earl of Huntingdon's idea of 'associate justices'. This suggestion was repeated in the next summer to the Duke of Newcastle. ${ }^{45}$ Both times it was rejected, after reference to the attorney-general. The corporation was well protected by its charters. A loyal address, sent off in August $\mathbf{I} 722,{ }^{46}$ possibly helped to convince the government that any such drastic measures were unnecessary.

In 1727 Lawrence Carter, who had been solicitor-general to George II as Prince of Wales, was appointed a baron of the exchequer, and so gave up his seat in the Commons. ${ }^{47}$ The new member was Thomas Boothby Skrymsher, a country gentleman with estates in Leicestershire at Tooley Park and Foston, but described in the return as of Norberry Manor (Staffs.). ${ }^{48} \mathrm{He}$ was perhaps more of a Whig than Carter, and held a place as Register-General of all Trading Ships belonging to Great Britain, under the Commissioners of the Customs. ${ }^{49}$ Skrymsher sat for Leicester only a short time, for in the year of his election George I died. At the general election following he was defeated by (as he alleged) the indirect and corrupt practices of the mayor and bailiff. George Wright was returned with Beaumont in his stead. Wright, variously described as of Gotehurst (Bucks.), and of Brooksby (Leics.), ${ }^{50}$ was a grandson of old Lord Keeper Nathan Wright, once recorder. As might therefore be expected, he had the reputation of being a thorough Tory. ${ }^{5 I}$ With Beaumont, he won the praise of the Common Hall by voting against Walpole's excise. ${ }^{52}$ Notwithstanding this, he had family connexions with government servants of the Hanoverian régime. ${ }^{53}$ He continued as member for Leicester until his death in 1765.54

One of the most striking features of the representation of Leicester in the I 8th-century House of Commons is the long continuance of the same members. Once established, they stay there until they die. Consequently, changes tended to produce all the more disturbance, seeing that a long-standing member, especially when well thought of in the Common Hall, increased his interest as the years passed. Thus when Sir George Beaumont, who had sat for Leicester for 35 years in seven different parliaments, died in I 737, the rival party could hope to exploit this break in a connexion of so long standing. They might hope, with the help of influences from the county, to secure the return of a Whig, provided that a candidate of sufficient local influence could be found. Their candidate was Rogers Ruding of Westcotes Hall. The corporation candidate was James Wigley, of Scraptoft Hall. A fortnight or so after the return of Wigley, 55 on 9 May 1737 , a petition on behalf of Ruding reached the House of Commons, from a great company of freemen resident in the borough and inhabitants paying scot and lot, complaining that 'William Brushfield mayor and Leonard Piddocke bailiff . . behaved themselves very

\footnotetext{
44 S.P. 44/123, pp. 229, 230. The representation from the county is signed by the Duke of Rutland as custos rotulorum, William Manners, Viscount Howe, James Montague, Thomas Abney, Thomas Byrd, William Hewitt, and Joseph Danvers.

45 S.P. $44 / 123$, p. 340.

46 Leic. City Mun. Koom, Hall Bk. I3 Aug. I722.

47 Throsby, Hist. of Leic. $83-84$; Hall Bk. 3 Feb. I726; C. Э. xx. 712 .

48 Nichols, Leics. iv. 778; C $219 / 120$.
}

49 New Present State of the Court of Great Britain (1742), I 90.

${ }_{50} \mathrm{C} 2 \mathrm{I} 9 / \mathrm{I}_{24}, \mathrm{I}_{2} 8$, I 32, I 36, I 40, 144; Reg. Freemen of Leic. $I$ I 6 6-I770, 248.

5I Nichols, Leics. iii. 2 I6, 217.

52 Leic. City Mun. Room, Hall Bk. 27 Dec. 1732.

53 Nichols, Leics. iii. 2 I 9.

54 C.Ұ. xxx. 463.

$55 \mathrm{C} 219 / 128 ;$ Reg. Freemen of Leic. II96-I770, 271 ;

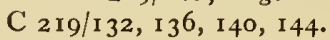


partially in favour of the said Mr. Wigley'. Ruding, they claimed, had been duly elected by a majority of the legal votes, and ought to have been returned. The petition came to nothing, ${ }^{56}$ and Wigley remained to sit for Leicester until he died in 1765 , only a little earlier than his colleague George Wright.

It was in connexion with this disputed return that the next great Jacobite scare of the century convulsed the town, and again brought in the potentates of the county. Very early on I February 1738, 'treasonable papers' were found posted up in various places, suggesting plans for the celebration of the Io June next. A play was suggested, 'with a most vile and treasonable title to it'. ${ }^{57}$ The local opposition party, the 'Friends of Government' as they styled themselves, sent copies of these papers as fast as they could to London by a special messenger. In London these papers were received by John Jackson, confrater of Wyggeston's Hospital, a latitudinarian and strong Whig, who had an old quarrel with the corporation for the part they had taken against him some years before in his quarrels with Samuel Carte, ${ }^{58}$ a High Church partisanship which he himself regarded as more political than theological in origin, as springing from 'the long resentment of some Jacobites' against him. ${ }^{59}$ Jackson was urged to lay these papers before the Secretary of State without delay. Thus the Duke of Newcastle was already informed, from the Whigs' point of view, before any account reached him from the mayor. ${ }^{60}$ The whole affair was touched with melodrama. Men were reported to have gone about the town in dead of night with faces blackened. On I February 1738 , the day the papers were posted, Robert Norton, the solicitor who had acted for the opposition in Ruding's petition, suddenly collapsed and died while being examined by the magistrates. ${ }^{61}$

The fame of these events was bruited through the land. The friends of the corporation published at Stamford as their account a lively pamphlet of remarks, called Faction Unmasked. The 'Friends of Government' replied with A Full and True Account, being an Answer to the Remarks of a Lying Faction. Along with much that is not dignified, edifying, or useful, there are several points of interest to be noted in these papers, and particularly in the arguments of the opposition. For one thing, Ruding's party complained of the corporation's use of non-resident freemen. "They had a mind to try the legality of the outvoters (which had not been determined by the House of Commons), whose voting they think a late innovation on the rights of the borough, and, by setting them aside, to confine the election for the borough to the burgesses and other inhabitants of it, who pay scot and lot, agreeably to the direction of the last charter of the corporation.' This was, as time was increasingly to show, indeed a point of some importance. They added the equally interesting observation, that 'the great manufacture of the borough' abounded with 'Friends of the Government, who are the most considerable and wealthy part of it', so that on the resident votes alone the corporation candidates would be rejected.62 The political reference to the growing manufacture is prophetic.

The corporation took the view that there was certainly a plot, but a Whig plot not a Jacobite one, whose purpose was by branding them as Jacobite to discredit them with the government, and so to prejudice Wigley's holding his seat. The opposition on the other hand connected these events with what had happened in I 722. They asked that the county magistrates should be authorized to sit with those of the borough 'from time

${ }^{56}$ C.F. xxii. 879, 892; after a prorogation 6 days before the petition was due to be heard, there is no further ref. in C. F., but the petition seems to have been persevered with, at least locally.

57 Gent. Mag. I 738, viii. ro6.

58 Theology, xxix. 276-82.

59 Memoirs of the Life and Writings of the Revd. Mr. Fohn fackson ( 1746$), 65$.

60 S.P. $44 / 130$, p. 300 . The memorial to the Secretary of State was signed by Wm. Ruding, John Jackson, Thomas Abney, James Montague, I. Woolaston, Walter Ruding, Joseph Danvers, and Wm. Hewitt.

6i Throsby, Memoirs, v. $8 \mathrm{I}-83$.

${ }^{62}$ A Full and True Acct, $\Theta^{\circ} c$. (1738), 5-6. 


\section{A HISTORY OF LEICESTERSHIRE}

to time ... to examine any evidence in relation to the discovery of the authors and abettors of the said treasonable papers'. They urged this because the Whig affidavits made to magistrates of the county had been 'directly contrary to the other affidavits' made before those of the borough. ${ }^{63}$ As in 1722 the Secretary of State made inquiries of the mayor, who replied, probably wisely and with a sense of proportion, that he now had 'all the light into the fact that we can possibly come at' ${ }^{64}$

The whole affair was really rather absurd, and yet, for the historian, not so trivial as it was silly. The truth was very likely revealed in the pages of the Gentleman's Magazine. ${ }^{65}$ The papers were nothing more than a practical joke, in dubious taste, perpetrated perhaps by the correspondent to the magazine himself, William Bickerstaffe, a local divine, who thought more highly of his wit than it deserved. Whatever the origin of the papers, they were used by the corporation's enemies in the town, in alliance with men of the same party in the county, in their battle against the corporation's ascendancy in the parliamentary politics of the borough.

James Wigley, out of whose election the whole uproar arose, seems to have been most worthy and benevolent. He was a country gentleman of great estates, with lands in Leicestershire at Scraptoft, Burbage, Walcote, Hinckley, Stoke Golding, and Hallaton. His will reveals him as a kinsman also of the Leicester Topps, one of whom was mayor in $1746-7$; as a friend of Sir Thomas Cave of Stanford Hall and Thomas Boothby of Marston; and as a benefactor to the poor of Humberstone, Bushby, Thurnby, Houghton, Walcote, and Burbage. ${ }^{66} \mathrm{He}$ was, said Throsby, 'a gentleman distinguished for his humanity, and possessing in an exalted degree the friendly virtues'.67 Like George Wright he was in politics an 'independent', and of a 'Tory' reputation.

After the Jacobite rumours which had arisen at the time of Ruding's efforts to unseat Wigley, there were again in 1744 rumours of treasonable papers, and again correspondence with the Secretary of State, but much less stir. The corporation promptly sent off a loyal address, which was conspicuously lacking in what Thompson called 'Jacobite reservations'. It was strongly Protestant in tone. 'As Protestants and as Englishmen we cannot but have a grateful sense of the many blessings we enjoy under Your Majesty which we could not hope for under a popish prince introduced by a popish army.' 68 In the startling events of the 'Forty-five, with the Pretender as far south as Derby, the corporation seems to have done little more than send out messengers to 'wait for and send accounts of the motions of the rebells at the charge of the corporation' ${ }^{69}$ Writers hostile to the corporation's politics emphasized that the only steps to resist the Scots should they reach Leicester were taken by dissenters who drilled in the burial ground of the Great Meeting. Rumour had it that the corporation, or important members of the body, secretly prepared an address of welcome to the Pretender, which was burnt when the invasion failed. Throsby, with a greater sympathy, reported that the mayor, surrounded by those of his brethren who had resolution enough to stay at home, waited to see what would happen, 'all in continual fear'. Some 'who favoured the old cause . . . prayed fervently in secret for the success of the Prince's arms' ${ }^{70}$ After the battle of Culloden, the carnage of which distressed Throsby, the corporation made a profession of thanks for 'that great and signal deliverance'.71

There seems to have been no great political disturbance at Leicester after these events until the general election of I 754. In I754 the local 'Friends of Government'

63 S.P. 44/130, p. 300.

${ }^{64}$ S.P. $44 / 130$, pp. $310-1$ r.

${ }_{65}$ Gent. Mag. 1738 , viii. ro6.

66 Principal Probate Registry, P.C.C. 3 I4, Rushworth.

67 Throsby, Memoirs, v. 156.

${ }^{68}$ Leic. City Mun. Room, Hall. Bk. 22 Feb. I743/4;
Gent. Mag. I744, xiv. 80, 107

69 Leic. City Mun. Room, Hall Bk. 24 Nov. I745; Chamberlains' Accts. 1745-6.

$7^{\circ}$ Throsby, Hist of Leic. I 52.

${ }_{71}$ Leic. City Mun. Room, Hall Bk. Io May 1746. 
made a determined effort to break the corporation's control of the parliamentary representation of the borough, by putting up a candidate in the opposition interest, encouraged in this enterprise by discontent in the body of the freemen at the plans of the Common Hall for inclosing the South Fields. Their candidate was Robert Mitford, a member of an old Northumberland family, and a major in one of the recently formed new regiments. ${ }^{72}$ There followed 'a violent contest fraught with much mischief'. Before polling began, the corporation enrolled some 800 persons as freemen, ${ }^{73}$ but not of course directly at the expense of any candidate. The members of the Common Hall voted, according to the published poll book, all of them for Wright and Wigley, except four whose names do not appear at all.74 The Corporation was thus fairly solid in the Tory interest. Gardiner, writing as an ardent early-Victorian Liberal, and apparently seeing nothing but necessary connexion between the Liberalism of his day and the Hanoverian whiggery, reported on the authority of his father that a mob of 300 colliers was imported from Coleorton (where the Beaumonts had mines), 'armed with bludgeons in which iron spikes had been inserted to support the 'Tory cause', singing in the meanwhile Jacobite songs which called down damnation on the Hanoverian dynasty. They attacked the Whig committee room, so that the gentlemen there fled. 'My father was . . . astonished to see so heavy a man as Sir Arthur Hazlerigg get over the garden wall, which he did with great agility, and took refuge in the house of Mr. Pares.'75 'The persons who are returned', the House of Commons was told, 'were chosen under the influence, and are the representatives only, of a riotous, seditious, and treasonable mob of colliers, and other persons joined with them.' 76

On the other hand, an opposition mob, led by a Winstanley, after due notice given in the local papers, pulled down the corporation's fences in the South Fields, as a protest against inclosure. ${ }^{77}$ Riots of a more seriously damaging sort continued in the South Fields long after the election fever had died down. ${ }^{78}$ At the election itself, the local inclosure was almost certainly the cause of much of the violence, if not even of the occurrence of a contest.

According to the complaints of the defeated party, Wright and Wigley were only returned (apart from the usual indirect practices) by this extraordinary violence, and by the use of the outvoters. They claimed that on the resident votes alone Mitford would have been returned. 'This contention seems hardly to be borne out by the poll-book, at least if the inhabitant voters of the town as a whole and not merely of the borough limits are taken into account, for they seem to have given a small majority to Wright and Wigley.79 It is of some point to notice also that most of the outvoters were Leicestershire men, and that among them the corporation candidates had a bigger majority than among the voters from the town. Thus Wright and Wigley, though members of long standing, and fortified by the mayor and his brethren and their considerable electoral armoury, had amongst the town voters a majority that was only small, and therefore was precarious. Both sides indeed called in men from the county, but already in $\mathrm{I} 754$ it is clearly becoming more important for the corporation party, than for the 'Friends of Government', to call in outside voters, from Leicestershire and even beyond, to redress the changing balance in the town.

\footnotetext{
${ }_{72}$ Gent. Mag. I 755, xxv. 333-4; Court and City Reporter ( 1754 ), 148 .

${ }_{73}$ Reg. Freemen of Leic. I I96-I770, pp. xxxiv, I 89, 3 I 6.

74 Since 2 of these voted as good 'tories' in 1768 , it seems that Gardiner's 'liberal minority' was not very large: Poll Bk. I 754 .

75 Gardiner, Music and Friends, i. 207.
}

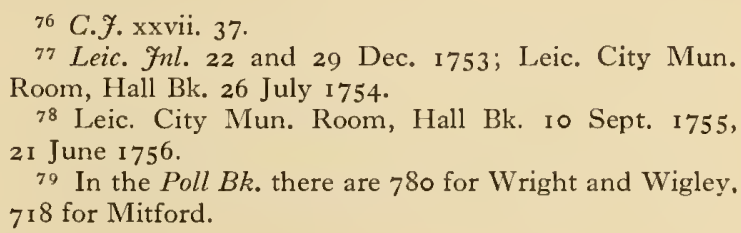




\section{$1765-1818$}

An important result of the Revolution had been to put an end to constant interference from the Privy Council and other officers of the central government in the local affairs of corporations and counties. There are numerous signs in Leicester from about the middle of the $\mathrm{I} 8$ th century that the town was outgrowing the local institutions it had inherited from earlier times. Its population was clearly increasing. The municipal freedom as a means of economic regulation was clearly becoming obsolete, as the failure of the corporation in Green's case in $175^{\circ}$ had shown. ${ }^{80}$ Even the appearance of the town was changing quite rapidly. The High Cross was dismantled.81 Those 'monuments of Gothic barbarism', 82 the town gates, were taken down. ${ }^{83}$ In the South Fields, the corporation gave land for an infirmary in 1766,84 but in 1812 refused it for a large school for the education of the poor. ${ }^{85}$ Provision was made for a fine new pleasure walk. ${ }^{86}$ In 1792 a committee deliberated on the laying out of a grand new square, to be called Brunswick Square, and the opening of a spacious carriage way by the 'Saracen's Head', a project which was held to be 'more pregnant with material advantages to the town than any which had ever been submitted to the consideration of the Common Hall' 87 In these years, the Leicester Fournal commented more than once on the improved dignity and appearance of the town, attributing much of this to the initiative of one or two forceful mayors. The final inclosure of the South Fields under the Act of 1804 opened the way for the planning of more new streets. ${ }^{88}$

Since the corporation was the owner of much property in the town (quite apart from its holdings in the county) these developments involved a good deal of consultation, which put a great quantity of work on the Common Hall and on its officers, both paid and unpaid. There was much buying, letting, and selling of corporation land, increased by the bequests of Gabriel Newton. ${ }^{89}$ Thus in 1794 a new professional officer appeared among the corporation's servants, in a land steward. ${ }^{90}$ In addition there was much work for the town solicitor, for most of the period Caleb Lowdham, ${ }^{91}$ and the town clerk. In I 8 I I the corporation rents being much increased by the inclosure of the South Fields, which helped to create a handsome surplus of revenue over expenditure, the salaries of these officers were increased. 'The situation of the town clerk is one of great responsibility as well as of great labour and constant attention . . . on his talent and integrity', as the Common Hall agreed, 'much of the merits of their official conduct must depend.'92 In 1813 a long tenure by members of the Heyrick family came to an end, and a remarkable character, most important in the later history of the unreformed corporation, Thomas Burbidge, was appointed town clerk. ${ }^{93}$ At the same time there was a good deal of experimenting in forming new standing committees of the Common Hall, for Alderman Newton's foundation, on income and expenditure, and most important and at times very powerful, a South Fields Committee. ${ }^{94}$

The growth of the town aggravated problems of public amenity. For centuries inhabitants had been compelled to make some provision for lighting, watching, and cleansing the streets, for securing a water-supply, and for maintaining the poor, by the

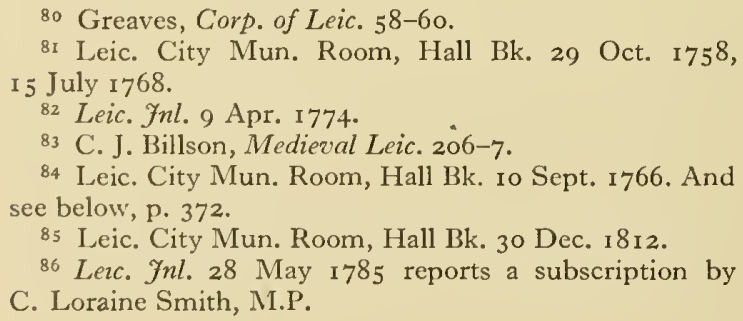

87 Leic. City Mun. Room, Hall Bk. 7 Dec. 1792.

88 Greaves, Corp. of Leic. 85-86. And see below, p. 373 .

89 T.L.A.S. xix. $359-60,366$.

90 Greaves, Corp. of Leic. 78.

91 See W. E. Beasley, Early Hist. of an old Leic. Firm of Attorneys (1930).

92 Leic. City Mun. Room, Hall Bk. 26 Feb. I8II.

93 Ibid. 20 Sept. I 8 I 3.

94 Greaves, Corp. of Leic. I7-19. 


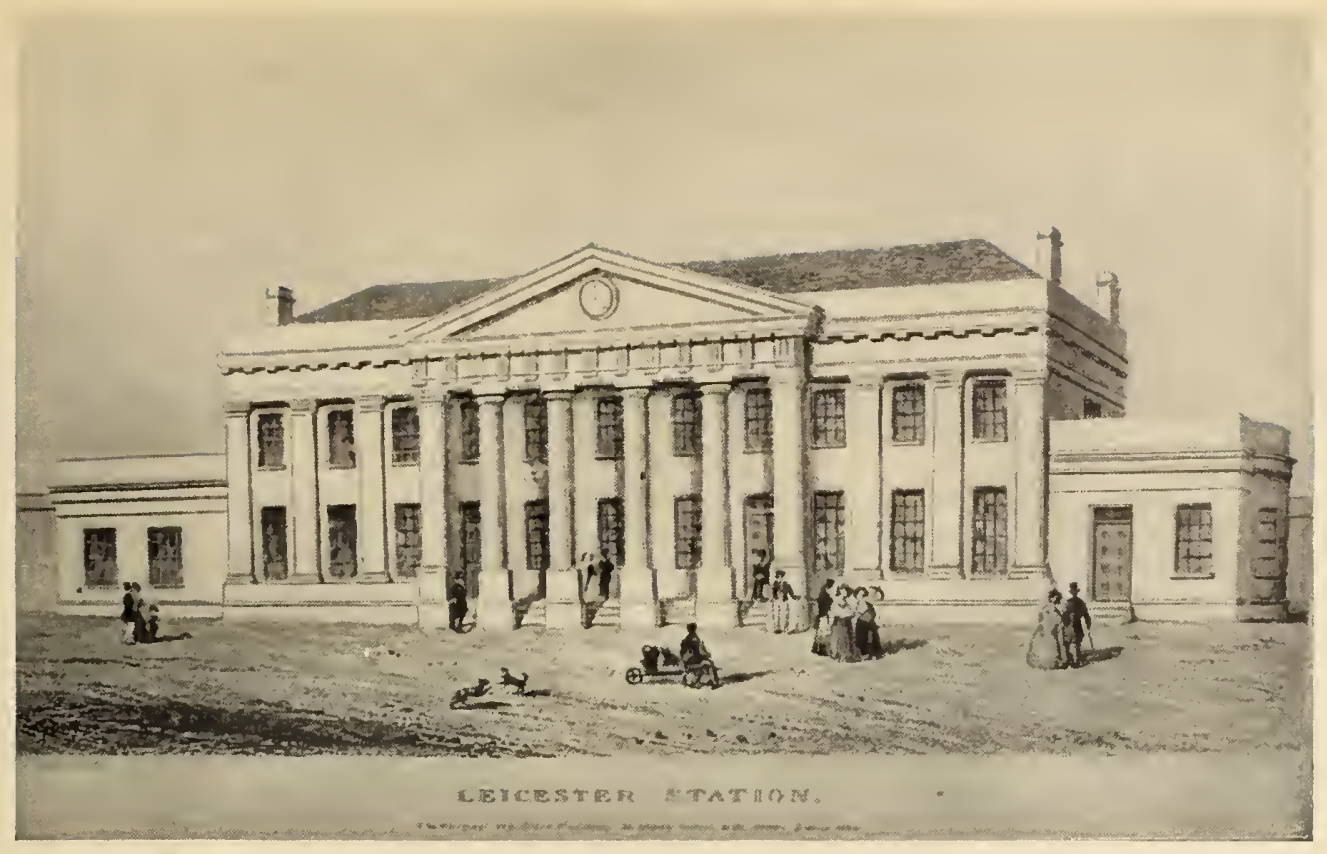

Campbell Street Station in i 840

(replaced by London Road Station, 1892)

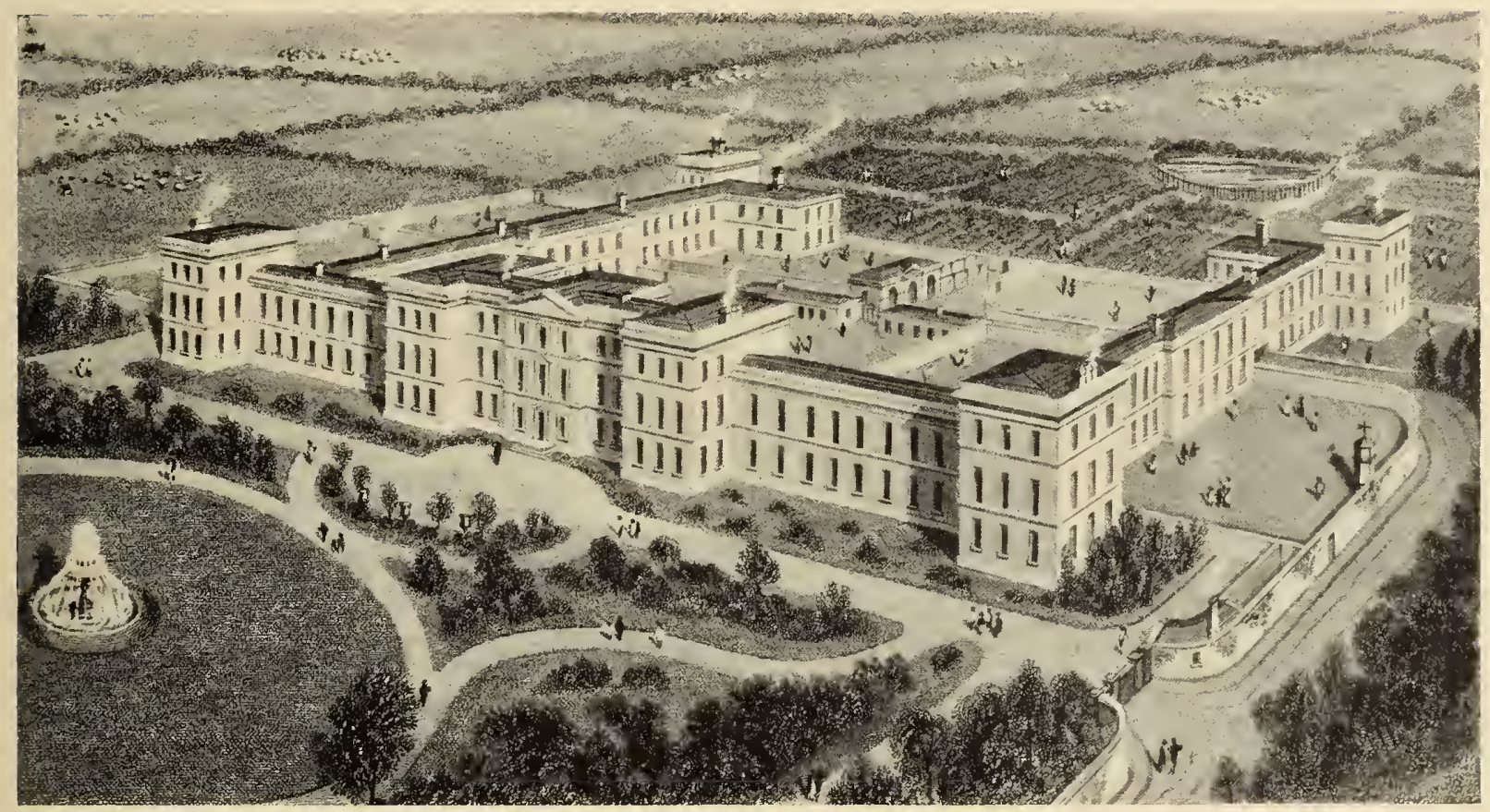

The Leicestershire and Rutland Lunatic Asylum, $c$. I 849 (later University College, Leicester) 

cumbersome judicial processes of indictment and presentment, before the justices in quarter sessions, who in the maintenance of order, cleanliness, and decency were the effective rulers of the borough. Even in the earlier part of the century, when this procedure was not as ineffective as it later became, there was inevitably tension between the justices and the parish officers. None the less, efforts to get the whole town organized as one administrative unit failed. In 1708 the corporation supported a petition for a local Act to get a union of the parishes of the town for a workhouse, but without any success. ${ }^{95}$ A century or more later a project which had been first suggested in $1792^{96}$ was taken up by St. Martin's vestry in 1804 for a workhouse on the Shrewsbury plan. ${ }^{97}$ 'The opposition of St. Margaret's vestry apparently helped to defeat this. ${ }^{98}$ In the same way, a plan of $1749-50$ for a body of improvement commissioners, with power to levy a rate for lighting, watching, and cleaning the streets, and maintaining the public pumps and wells, not merely in the borough itself but also in 'the parts adjoining', had no success, perhaps for the usual reason of parochial jealousies, perhaps also because of opposition from the county. ${ }^{99}$

If this attempt to bring the borough proper and 'the parts adjoining' under one rating authority had succeeded, the long contest with the county magistrates about jurisdiction in the liberties would have been avoided. About $175^{\circ}$ the borough magistrates had taken advantage of the Acts of $1739^{-} 4^{\mathrm{I}}$ to levy a borough rate. This step had the important implication that the revenues of the corporation were to be used for corporation purposes, and not as general public money, except by the grace of the corporation. 'The borough rate was collected by the parish officers, so that special arrangements had to be made for those parishes which lay partly in the borough and partly in a liberty. The Bishop's Fee for instance had paid formerly to the county rate. Consequently, with the imposing of a borough rate, the 'parish of St. Margaret had paid its proportion for the whole parish to the borough treasurer, who has repaid to the overseers what they have paid to the county rate in respect of the Bishop's Fee, which is very trifling in comparison to its proportion to the borough rate'.2 Usage in the Bishop's Fee was not in fact quite consistent. The borough magistrates had billeted soldiers on houses which had been licensed by the county, had supervised weights and measures there, and had at least for a time appointed a constable to appear for this district at the borough sessions, though he had not actually done anything there. ${ }^{3}$

In 1765 the borough magistrates laid claim to an exclusive jurisdiction in the Bishop's Fee and in all the other liberties. ${ }^{4}$ Whatever the legal niceties, there was clearly foresight in this claim, for though there may not have been at this time more than a hundred houses in Humberstone Gate and in part of Gallowtree Gate, and some few in Coal Hill and Churchgate, it was already obvious that these places would be built up in an easily foreseeable future. Alarmed by these developments, the county magistrates took legal opinion of an eminent counsel, Charles Yorke. His opinion, dated r 766 , was decisively in favour of the borough claim. 'Upon the whole (as at present advised) I think that the jurisdiction throughout all the lands of the parishes in question is in the borough justices exclusive of the county justices, and that the concurrent jurisdiction hitherto exercised (which must be disagreeable and inconvenient to the inhabitants and to the gentlemen comprising both jurisdictions) has been erroneously exercised by the county

95 Leic. City Mun. Room, Hall Papers, I70I-9, no. 210 ; Hall Bk. 30 Jan. I 707/8; C.F. xv. 529, 546, 553, 593, 609; Greaves, op. cit. 42 .

96 Leic. Fnl. 17 and 24 Feb. 1792.

97 St. Martin's Vestry Bk. 3 and I 3 July 1804 (in the cathedral).

98 Leic. Fnl. 27 July I804.

LEIC. IV
99 C.F. xxv. 927; Nichols, Leics. i. 40; Thompson, Hist. of Leic. ii. 79; Leic. City Mun. Room, Hall Bk. I Dec, 1749 .

1 Greaves, Corp. of Leic. 37.

2 Leic. City Mun. Room, Misc. XI/3, f. 2.

3 Ibid. ff. 3-4.

4 Ibid. Hall Bk. 26 Apr., I 8 Oct. I 765 . 
justices without due warrant of law.' 5 It was expressly to assert this claim that Mayor Fisher in 1766 , and his successor Mayor Holmes in 1767 , under the inspiration apparently of William Burleton who had been appointed recorder in $1766,{ }^{6}$ refused to have the town mace sloped in token of submission at the entrance to the Castle View, when they went in state to take oath to respect the rights of the Duchy of Lancaster. 'The borough claim was perhaps weakest in the Castle View. In I 768 the town clerk, John Heyrick, and Thomas Pares, steward of the duchy, agreed that the oath should be taken privately. ${ }^{7}$

Acting on Yorke's opinion, the county magistrates withdrew, and the borough magistrates behaved in the liberties as if they were in point of jurisdiction simply a part of the borough. 'The overseers of the parish of St. Margaret's refused to contribute to the county rate. In that parish in I 77I an attempt was made by the county to test the rightfulness of the borough claims. Francis Nedham, Constable of Gartree hundred, demanded $f .32$ s. Iod. towards the county rate, and after some months delay distrained upon Davis, an overseer of St. Margaret's parish. Davis, however, had not been an overseer at the time of the first demand from the constable, so that upon this technical irregularity the case broke down. ${ }^{8}$ In 1775 another attempt was made, when the corporation proceeded against the inhabitants of the Newarke for putting posts and a chain across the road. 'The defendants carried this case by certiorari to King's Bench in I 779, but had again to stay proceedings on the ground of a technical irregularity, this being that only specified individuals could be presented for a nuisance, and not so indefinite a group as the inhabitants of the Newarke. 'The solicitor for the county, Thomas Pares, and Caleb Lowdham, solicitor for the borough, agreed that the action should be abandoned without prejudice. 9

The next attack on this problem came in $\mathrm{I} 786$. John Blankley, who was apprenticed to a master in the Bishop's Fee, disobeyed his master's just command, and was therefore arrested and committed on a warrant from two county justices, Clement Winstanley and Robert Burnaby. 'The case was argued on the text of the charters and previous usage, and carried to the King's Bench. Judgement was given against the borough magistrates in 1789 , chiefly on the ground that there were no words in the charters which expressly excluded the county justices from the Bishop's Fee and other liberties. There was no such clause of non intromittant as had been thought of in Charles II's time. Moreover, not only were the texts ambiguous, but the usage of the past did not tell in the corporation's favour. Consequently jurisdiction in the liberties was held to be concurrent. ${ }^{10} 0$ This decision still left uncomfortably doubtful the levying of the rates. In I8I I the corporation by invitation joined with St. Mary's parish to contest the levying of a county rate on property in the South Fields, corporation land lying outside the borough limits. In I8I 5 , it was at last decided in King's Bench, in the case of Bates versus Winstanley and Another, against the corporation, that the liberties paid to the county. II Thus the general borough rate, which had been levied regularly since about $175^{\circ}$, and the gaol rate, which the borough magistrates began to levy apparently some ten years

${ }_{5}^{5}$ Leic. City Mun. Room, Misc. XI/3, f. 3 ; ibid. press 5, box I, nos. I0-16: the co. got this opinion, not the boro. as erroneously stated in Corp. of Leic. 36 .

6 Ibid. Hall Bk. 9 June I 766.

7 D.L. 41/92; Leic. City Mun. Room, press 5, box I, no. 9: the corp. was advised that whatever might be claimed for the other liberties, the Castle View could not be regarded as falling within the jurisdiction of the borough 'as that place is not particularly mentioned nor is part of any of the parishes mentioned in the charter'.

${ }^{8}$ Leic. City Mun. Room, press 5 , box I, no. 9; ibid.
Hall. Bk. 26 Sept. 177 I.

9 Ibid. press 5, box I, no. I2; Hall Bk. 7 July I775; Quarter Sessions R. I773.

ro Ibid. Misc. XI/I I ; C. Durnford and E. H. East, Rep. of Cases in the Ct. of King's Bench, iii. 279-86; Nichols, Leics. i. 567; Ist Rep. Royal Com. Municipal Corp. in Eng. and Wales, App. Pt. III, H.C. (I I 6), p. I 889 (I 835), xxv.

II G. Maule and W. Selwyn, Rep. of Cases in the Ct. of King's Bench, ii. 429-37; Ist Rep. Royal Com. Municipal Corp. op. cit. p. I898; Leic. City Mun. Room, Hall Bk. 29 July I 8 I I. 
later (instead of, as formerly, maintaining the gaol out of funds at the disposal of the Common Hall), fell on the inhabitants of the borough jurisdiction only, still the largest but certainly a diminishing proportion of the inhabitants of the town.

The death of James Wigley in June 1765 was followed by that of George Wright in January 1766 . This made an unusually complete break in the parliamentary representation of Leicester. Opportunity was thus given for renewed party conflict, particularly in view of the expected general election, due in 1768 . Wigley seems to have been replaced, at the first of the by-elections, without any great agitation, by another Leicestershire gentleman, Anthony James Keck, of Stoughton Grange, ${ }^{12}$ the old home of Sir George Beaumont. The second by-election was attended by storms.

Even before Wigley's death, intrigues were afoot to prepare for a change, at the general election or before. On 5 June $\mathrm{I}_{7} 65$ Thomas Hall, Rector of Shackerstone, wrote to John Heyrick, the town clerk, a letter whose contents he asked to be kept secret, on behalf of 'a certain person (whose name you shall speedily know, if this letter meets with your approbation) of very large fortune, who is desirous of a seat in Parliament for your borough, at the ensuing election; or so soon as a proper opportunity may offer. He chiefly resides in London; but has a good estate in this county, and in his political principles, he exactly agrees with the gentlemen of your corporation.' The offer was made to the town clerk of a present for himself of $£_{5} 00$ for his good offices, and 'a compliment of $\oint_{\mathrm{J}} \mathrm{I}, 500$ at least to the corporation, to be employed, as they think proper; and to do every act of friendship, that shall make him worthy of their esteem'. 'This friendly approach met, however, only with the most angry refusals. A draft of Alderman Simpson's reply contained the strongest expressions. So far from keeping the offer secret, he wrote: 'I rather think it will be thought proper to publish it, that the world may know our hearts are free and not to be seduced by bribery, and that though there may be men with their pelf to barter for our integrity and independency our souls abhor the traiterous deed.' The town clerk regretted to Hall that 'your notions of honour so ill agree with mine'. ${ }^{13}$ Not until after the election of 1766 did Hall reveal on whose account he had written.

The first two candidates to appear were both local men, Robert Bakewell, the recorder, and Edward Palmer. Palmer withdrew on Bakewell's receiving a better show of hands. At the same time an express message from London announced a new candidate in John Darker, a rich London merchant. On the first day's poll, Bakewell had a small majority, but the next day he decided to retire, so that 'the London votes, consisting of 120 ', were stopped at Dunstable by express. ${ }^{14}$ Darker was thus returned as the new member. ${ }^{15}$ Soon after, Bakewell was dismissed from the recordership for insulting the mayor in open session, for addressing opprobrious epithets to Alderman Phipps and Alderman Beale, and for other misdemeanours. He severed all connexion with the corporation. ${ }^{16}$

No doubt many cross-currents went to make this disturbance. Both Bakewell and Darker had local links. Bakewell had a comfortable estate at Swepstone. ${ }^{17}$ Darker was a native of Stoughton, who had made a fortune in the City and possessed himself of wide estates in Leicestershire and Northamptonshire. In Leicestershire he held among other places Melton Mowbray and Queniborough manors, and estates at Wigston Magna and Eye Kettleby. He seems mostly to have lived at Gayton (Northants.). In London he was a person of consequence, being Treasurer of St. Bartholomew's Hos-

${ }_{12}$ C.F. xxx. 463; C 219/144; Reg. Freemen of Leic. II96-I770, 236; Leic. Fnl. 4 Jan. 1766.

${ }_{13}$ Leic. City Mun. Room, I09'30/34/4, 5, 6.

${ }_{14}$ Leic. Fnl. 25 Jan., I Feb. 1765.

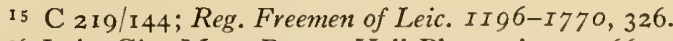

I6 Leic. City Mun. Room, Hall Bk. I I Apr. I 766.

17 Nichols, Leics. iii. 1037. 
pital. ${ }^{18}$ As might be expected from such a character, he seems to have acted with vigour in the politics of Leicester.

Both he and Bakewell appealed as candidates to the trading interests. Bakewell expressed his aim as to 'promote the trade independency and welfare of the inhabitants... and my brother freemen in general'. ${ }^{19}$ It may well have been that he had links with the local opponents of the corporation, for in 1774 he spoke of himself as having stood in I 766 to strike a blow for electoral purity, taking advantage of the 'late Act of Parliament' which had 'restored the freedom of elections'. ${ }^{20}$ 'This may have explained why the dominant party dubbed his supporters as 'Presbyterians'. ${ }^{21}$ Darker on the other hand stood as a definite Church-and-King man. ${ }^{22}$ He was to earn the reputation of being very much an independent. 'He was as free within the walls of the House of Commons as the passing air.' 23 But it does not seem all to have been churchmanship and liberty. Before the election, Alderman Thomas Phipps, with an eye to the traders of the town, had suggested that there should be a parliamentary candidate who could 'advance several thousands to be employed in manufacture and to extend our trade into foreign parts'. ${ }^{24}$ A month later Darker, elected as the new member, offered a large sum of money for the use of manufacturers on loan without interest. ${ }^{25}$ The election over, Thomas Hall took opportunity of private business which he wished to transact with the town clerk, to make some explanation of their earlier correspondence. His candidate, he said, was 'no other, entre nous, than your last identical member'. Nor was the money which had then been offered intended as any sort of bribe by the gentleman for whom he acted, but only as 'an instance or testimony of gratitude and friendship'. 'In the present case, he did not intend to contest the election: (though after, as he had offered himself, his honor called upon him to do it) so that bribery and corruption, which imply the perverting of justice, and proving or bringing over any one by base and sinister means if I am right in my etymology, could not be imputed here; for where no contest is, there is no need of bribery and corruption.'26

The return of John Darker (who seems most likely to have been the 'last identical member'), with a general election so soon to come, brought anything but electoral peace to the town, or harmony in the Common Hall. Even the town clerk was suspected of being prone to favour the Bakewellites, no doubt because Bakewell himself had marriage connexions with the Heyricks. ${ }^{27}$ It proved necessary for the town clerk to clear himself from the 'imputation of having departed from principles he had always professed', in letters to J. P. Hungerford, ${ }^{28}$ who acted as intermediary between him and Alderman Phipps. Heyrick explained that he had been made town clerk at a time when the corporation had been united, and that Bakewell had been 'an instrument (amongst others) of bringing about the resignation of the late town clerk'. Moreover, when Bakewell appeared first as a candidate, he had stood on the corporation interest, with the support of the aldermen and the Forty-eight. 'I have always avowed myself', wrote the town clerk, 'to be in the true old independent interest which so eminently characterises and I hope ever will the county and town of Leicester.' 'If Mr. Bakewell thinks proper to change sides (which by the by seems to be the case) I certainly shall oppose him, with as much warmth as I espoused him.'

Heyrick's explanations throw an interesting light on the busyness of Darker's party

18 Nichols, Leics. iii. $376-8$ I ; iv. 377,$405 ;$ ii. $247,278$.

I9 Leic. Fnl. 25 Jan. 1766.

20 Ibid. 8 Oct. 1774 .

${ }^{21}$ Leic. City Mun. Room, 109'30/34/8.

22 Leic. Inl. 25 Jan. 1766.

${ }_{23}$ Nichols, Leics. iv. 405 .

24 Leic. Inl. 18 Jan. 1766.

\footnotetext{
25 Ibid. 5 Feb. 1766.

26 Leic. City Mun. Room, 109'30/34/7.

27 Bakewell in his will (Principal Probate Registry, P.C.C. 5 Holman) left $£ 100$ to his 'kinsman William Herrick and his wife'.

28 M.P. for Leics. in 1775 and $1780 ;$ V.C.H. Leics. ii.
} 
after his election. 'Since the election of Mr. Darker two parties have appeared amongst us, the Darkerians and the Bakewellites, and each has held frequent meetings at public houses in support of their interest. The former have received with open arms such persons as have withdrawn themselves from Mr. Bakewell and his interest, and stigmatised all those who still professed themselves his friends as Whigs and Presbyterians ... . I should observe that the Darkerians insist that each proselite to their interest should appear at the meetings as a test of the sincerity of his present profession.'29

There was indeed involved in all this the political allegiance of the office, as distinct from the person, of town clerk. Alderman Phipps sent back to Heyrick the message that 'as to the clubbs he thought them at present necessary for political reasons, but saw none, why any reflexion should be cast upon you for not appearing at them; though at the same time, he observed, that he thought it proper for you to be a little more open in your sentiments'. To promote a reconciliation he suggested the town clerk's dining with Lord Denbigh and other friends. 'My only motives', wrote Hungerford, 'for communicating our conversation to $\mathrm{Mr}$. $\mathrm{P}$ - $-\mathrm{s}$ were to reinstate you in the good graces of the corporation.' 30 The town clerk begged to be excused from waiting on Lord Denbigh, on the ground that 'strong efforts will be made by each party at the ensuing election of a mayor-which party will prevail I don't know. But I've got to work closely with whatever mayor it is.' Moreover, in his opinion, the present conflict in the body was merely for power and not of principles. 'My obligation is to the whole body of the aldermen for they unanimously elected me; I must repeat my firm persuasion that the contest between them and the rest of the body corporate is merely for power and that had lenient measures been pursued all contest had ceased. . . Such is the present disposition of the town that I can't wish any friend of mine to propose himself at present to either part of the corporation as a successor to Mr. Keck.'3I

The mayoralty itself became a prize in the contest of factions. Two candidates were put forward at the election of a new mayor on St. Matthew's Day I766, John Fisher for the majority, Clement Stretton for the rest. As a part of this battle, a fortnight or so before this election, one of the aldermen of the minority party, James Sismey, and one of the common councilmen, John Pocklington, were dismissed by the Court of Aldermen from their places in the corporation, Sismey nominally for non-residence, and Pocklington for insolvency. When' they turned up at the guildhall on St. Matthew's Day, their votes were contumeliously rejected. Alderman Chambers, the out-going mayor, told Sismey that he belonged to the wrong party, and 'would vote for a Presbyterian'. Alderman Phipps threatened to commit him for intrusion in an election where, having been dismissed, he had no right. The reasons given for the dismissals were clearly the merest pretexts, so that Sismey and Pocklington easily enough secured their reinstatement by mandamus.32 In consequence of their depositions, John Fisher was called upon by the King's Bench to show by what warrant he claimed to be Mayor of Leicester. He returned to the court the explanation that he was chosen by 40 votes as against 29 for Clement Stretton, the votes proferred by Sismey and Pocklington not being counted. 33

Thus the next general election, that of 1768 , came at a time when in Leicester the prospects were particularly good for opposition. Bitter quarrels divided the Common Hall. The town's burgesses in the previous parliament were of no long standing. The manufacturers of the town had suffered from the American troubles following upon the

29 Leic. City Mun. Room, 109'30/34/8.

30 Ibid. 109 ' $30 / 34 / 9$.

31 Ibid. I 09' $30 / 34 / 10$.

32 K.B. 1/16, Mich. 7 Geo. III (1766); ibid. Hil. 7
Geo. III ( 1767 ); Leic. City Mun. Room, Hall Bk. Io Nov. 1 766, 25 May, 16 June 1767; Greaves, Corp. of Leic. 10. ${ }_{33}$ K.B. I/16, Hil. 7 Geo. III; Leic. City Mun. Room, Hall Bk. 25 May 1767. 


\section{A HISTORY OF LEICESTERSHIRE}

Stamp Act of 1765 , which none the less the corporation had upheld by resolutions in the Common Hall, and Anthony Keck by his vote in the Commons. ${ }^{34}$ Old grievances were alive in the South Fields. There were the more recent contentions about jurisdiction in the liberties, in which such persons as 'Thomas Pares, the solicitor for the county side and Steward of the Duchy of Lancaster, were 'Whigs' in politics. In the very year of the election, the corporation disputed with Lord Strange, chancellor of the duchy, the right to nominate poor persons to places in Trinity Hospital, a useful piece of patronage. ${ }^{35}$

The election of 1768 was hotly fought; very hotly at Leicester. The corporation candidates were Palmer and Darker. The opposition brought in the Hon. Booth Grey, second son of the Earl of Stamford, and his friend Col. Eyre Coote, who had served the East India Company as a soldier in Bengal. Grey and Coote addressed the freemen as defenders of their liberties. Coote drew attention to the enrolling of some 900 freemen in the nine months before polling-day. ${ }^{36}$ These votes could not indeed be polled in this election, owing to the Durham Act, but the fees for enrolment would help the corporation to meet the heavy expenses to which the contest would put them. ${ }^{37}$ The poll was spread over a fortnight, according to Throsby a fortnight of terrible violence, ${ }^{38}$ but according to the Leicester fournal all passed off reasonably quietly. ${ }^{39}$ 'The compiler of a poll book, which was dedicated to 'the worthy gentlemen of the minority of the corporation', referred to Grey's 'most affable and generous behaviour', which 'added such weight to the power of the magistracy, that there was not the least riot or disturbance'. 40

Backed by the influence of the Duke of Rutland and the Earl of Stamford, and aided by local discontents about the South Fields and dislike of the Stamp Act, the two 'Whig' candidates were returned. ${ }^{41}$ 'The corporation, though presumably supported by friends in the county such as apparently Lord Denbigh, suffered the first great political defeat of their history. It was now their turn to complain of bribery and the undue weight of out-voters. As usual, however, the successful candidates had a majority of the town votes, though not a large one. ${ }^{42}$ The voting of the Common Hall was itself divided. Of the eleven aldermen who had voted in September 1766 the dismissal of Pocklington and Sismey, the nine who still remained in office voted for Darker and Palmer.43 A large minority, seven aldermen including Sismey and Pocklington and 2I common councilmen, had gone, apparently in a body, to vote on the first day of the poll for the victorious 'Whig' candidates.

The leaders of the corporation, at their first Common Hall after the election, chose the most direct way of insuring against another such beating. They resolved to offer the freedom to gentlemen of 'known constitutional principles'. ${ }^{44}$ Within little more than a year some 250 had been enrolled, mostly, as one would expect, gentlemen and parsons in Leicestershire.45 A second spurt was made in the mayoralty of Joseph Chambers, $1769-70$, when there were created 103 honorary freemen. ${ }^{46}$ In the two years preceding the next election there was a mere dozen in all. 47 The main basis of the whole enrolment was the diligent exploitation of the county connexions of the body.

The corporation was thus strengthened for the election of 1774 . A contest was

\footnotetext{
${ }^{34}$ Greaves, Corp. of Leic. 103; Leic. Fnl. 1 8 Jan. I766 reports a petition from 'the principal manufacturers of this borough' praying for a repeal of the Stamp Act.

35 T.L.A.S. xxi. $155-7$.

${ }_{36}$ Reg. Freemen of Leic. II $I 96-I 770,328-63$ : of these 717 were in the mayoralty of John Fisher.

37 Greaves, Corp. of Leic. 56.

38 Throsby, Memoirs, v. 129-31.

39 Leic. Fnl. 9 Apr. I768.

40 Poll $B k$. I 768 , printed and sold by John Ireland.
}

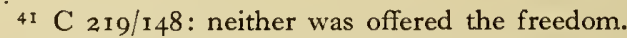

${ }^{42}$ It is calculated from the poll bk. that the borough votes were distributed as follows: Grey 830 , Coote 814 , Darker 771, Palmer 753; the total poll was Grey 1,366 , Coote I, 334, Darker I, 284, Palmer I, 260 .

43 K.B. I/I6, Hil. 7 Geo. III, affidavit of service of rule nisi.

44 Leic. City Mun. Room, Hall Bk. 3 May 1768.

45 Reg. Freemen of Leic. II $96-1770,328-64$.

46 Ibid. $365-8$. $\quad 47$ Ibid. $1770-1930,3-5$. 
threatened by Robert Bakewell, who stood against Grey and Darker. When they joined forces against him, they were both of them denounced by him as introduced into the borough by corruption. ${ }^{48}$ The retirement of that 'ambitious disappointed man', however, averted a contest. ${ }^{49} \mathrm{~A}$ more or less stable arrangement seemed to be now established, in an electoral compromise, whereby Grey and Darker were returned for the borough, not only in this election of $1774,{ }^{\circ}$ but again unopposed in $1780 .{ }^{51}$ Grey, for all his reputation for whiggery at Leicester, was apparently well liked as a member. $\mathrm{He}$ 'exercised on every occasion an independency of spirit which did honour to his birth'. He was 'neither the slave of the minister nor the tool of opposition'. ${ }^{52}$

Quite possibly the peculiar confusion which the accession of George III brought into English politics, accentuated by the American problem, had some part in the dissensions at Leicester in 1766-8.53 The Leicester corporation strongly declared itself as a firm supporter of the monarch. The Wilkite agitations roused them to a loyal address, expressing the 'utmost concern and abhorrence' to see 'the bewitching spirit of licentiousness under the sacred name of liberty disturbing the peace of your Majesty's government'. ${ }^{4}$ 'They declared themselves in favour of strong measures against the Americans. 'We have not been inattentive to the late parliamentary deliberations, and ... view with full approbation the conduct of our representatives.' 55 In 1776 , rejoicing over the capture of New York, they could 'not reflect without astonishment and indignation upon the professed designs of those political enthusiasts abroad, seduced perhaps and encouraged by false patriots at home'. ${ }^{6}$ When they received the letter from Christopher Wyvill's Yorkshire committee, they made clear their dislike of any tampering with the constitution. 'When we are braving the exertions of a world in arms . . . the most undivided attention of the whole legislative body is required to secure a safe and honourable peace, or if that cannot be effected, every nerve of every Briton should be uplifted to prostrate the numerous foes confederated against us.' They took the unusual step of explicitly instructing their members to oppose any attempted alteration in the representation of the people. 57 'They highly approved the king's dismissal of Fox and North, and condemned Fox's India Bill as a 'precedent dangerous to every charter and grant within your Majesty's dominions ... We thank your Majesty for a proper exertion of your authority on so alarming an occasion. ${ }^{58}$ Finally, in February 1784 , they resolved to present the freedom to William Pitt, on account of 'his firm and manly support of this constitution in this time of imminent danger when daring and ambitious men would wrest from the best of kings his just right to the appointment of his own ministers'.59 'The way was thus prepared for a transformation, at least for the time, of the old compromise of I774 and I780 into a more positive alliance between the Rutland interest and the corporation. This was based on support of the younger Pitt.

The year I 784 saw two parliamentary elections at Leicester. The first was a byelection in February, brought about by the death of John Darker. ${ }^{60} \mathrm{~A}$ local gentleman, Shuckburgh Ashby, of Quenby Hall, was returned unopposed. ${ }^{61}$ He was already well known in Leicester, as the donor of the clock over the Exchange. ${ }^{62}$ He was a devout person, in whom, to judge by the benefactions he made both during his life and in his will, faith was joined with an eminently benevolent disposition. ${ }^{63}$ He held the seat but

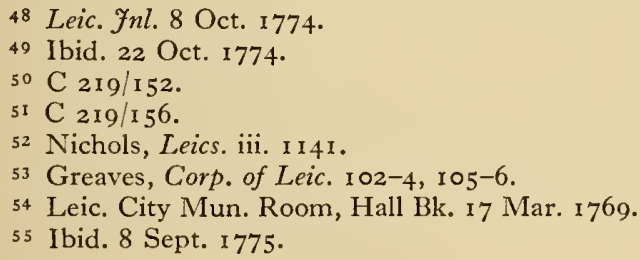

48 Leic. Inl. 8 Oct. I 774 .

49 Ibid. 22 Oct. 1774

5I $\mathrm{C} 219 / 156$.

52 Nichols, Leics. iii. I I 4 I.

54 Leic. City Mun. Room, Hall Bk. I7 Mar. 1769.

55 Ibid. 8 Sept. I 775 .

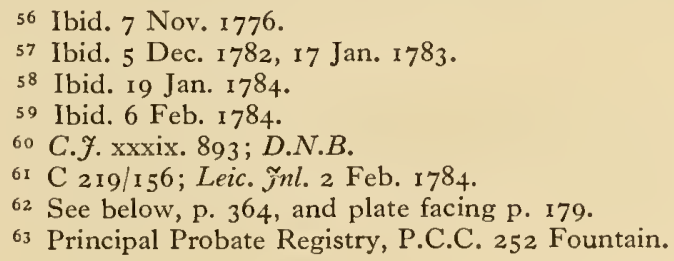


a short time, for Parliament was dissolved, and a general election held in April. The election reflected in its result the unwonted concord of the Rutland party and the corporation. John Robinson, in his electoral calculations, had reckoned upon the borough as returning two members in the government interest, ${ }^{64}$ a thing which indeed could hardly have been expected to happen since the days of Queen Anne.

Even so, there was a fierce battle, mitigated only by the withdrawal of one candidate from each side. Surprising as it may seem, the two men to withdraw were the members from the previous Parliament, Shuckburgh Ashby and Booth Grey. The new members were Charles Loraine Smith, a county gentleman from Enderby, and John Macnamara, ${ }^{65}$ who was represented as $\mathrm{a}_{\circ}$ "constitutional Whig', and a supporter of Pitt, ${ }^{66}$ being also a client of the Duke of Rutland. Both seem to have been popular with the corporation, who voted them their thanks for resisting the faction of Fox in $1788-9$ on the regency question. ${ }^{67}$ At the next election, in 1790 , there were again the beginnings of a contest, and again a compromise withdrawal. The corporation candidates were Samuel Smith, a member of a considerably important banking and parliamentary family, who had East Indian connexions, and a nabob, Nathanael Brassey Hallhead.68 They were supported in their nomination by Thomas Babington of Rothley Temple and other gentlemen of town and county. The 'Whig' nominees were 'Thomas Boothby Parkyns and Louis Montolieu, who were supported by Booth Grey, Ruding of Westcotes Hall, Clement Winstanley, John Pares, and others, a strong contingent of the gentlemen opposed to the corporation interest. ${ }^{69}$ The parties being more or less evenly matched, and the violence of the mobs becoming excessive, Montolieu and Hallhead withdrew, Hallhead to find a seat at Lymington (Hants). ${ }^{70}$ They felt it their duty 'to sacrifice all selfish considerations to the public tranquillity', and to retire 'in favour of colleagues whose more intimate connection with you gives them a prior claim to the support of their several friends'. ${ }^{11}$ 'The party mobs, angered by these withdrawals, then joined forces, and in their madness, 'threatened to burn down and demolish the town'.72 Troops were called in to restore order. The Common Hall gratefully voted their captain and lieutenant the freedom, and ordered that both officers and men be 'rewarded by $\mathrm{Mr}$. Mayor in such manner as he shall think fit'. ${ }^{73}$ Smith and Parkyns thus became the new members. ${ }^{74}$ Smith was awarded the freedom some four years later,75 but Parkyns apparently not at all.

Samuel Smith was in some ways a different type of burgess from the usual. Like Darker he was a City man. A younger son of Abel Smith, the banker of London and Nottingham, he was himself a partner in Smith, Payne \& Smith. He lived in Nottinghamshire, but had Leicestershire connexions, for a grandfather had been high sheriff, and held Gaddesby Manor, part of Rothley Soke, whose lord was Thomas Babington. ${ }^{76}$ Parkyns was re-elected in 1795 without difficulty, on his securing a commission as a lieutenant-colonel, being jointly proposed by Alderman Mansfield and Clement Winstanley. ${ }^{77}$ Both members were re-elected, in the Pittite interest, in $1796,{ }^{78}$ after a contest in which the opposition candidates were Walter Ruding of Westcotes and Bertie Greathead of Guy's Cliffe (Warws.). ${ }^{79}$ Smith continued to represent Leicester through

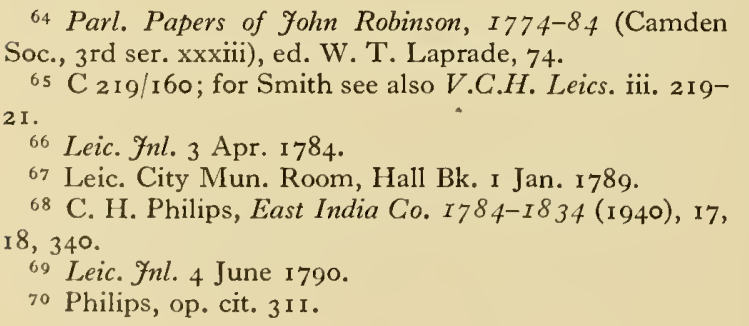

71 Leic. Inl. 2 July 1790.

72 Throsby, Hist. of Leic. I 70; Gardiner, Music and Friends, i. 208.

73 Leic. City Mun. Room, Hall Bk. 26 July I 790.

${ }_{74} \mathrm{C}_{219 / 164 .}$

75 Reg. Freemen of Leic. I770-1930, 69.

76 Nichols, Leics. iii. 97 I.

77 Leic. Fnl. 6 and 13 Feb. 1795.

${ }_{78} \mathrm{C} 219 / 168$.

79 Thompson, Hist. of Leic. ii. 25 I. 
six Parliaments, until the dissolution of I818.80 Parkyns (now Lord Rancliffe in the Irish peerage) died in $\mathrm{I} 800$. He was replaced by 'Thomas Babington of Rothley 'Temple, a definite 'Tory, of evangelical persuasion, who was interested in putting down slavery and the slave trade. ${ }^{81}$

The election of $\mathrm{I} 800$ is in several ways of particular interest in the political history of Leicester. It reflects the change which has been gradually coming over the political opposition there. With the growth of the town in population and industry, the local and manufacturing element in the opposition to corporation ascendancy increased in importance at the expense of the influence exercised by the Whig sympathizers among the gentlemen of the county. This meant that it became increasingly radical in temper, touched by rationalistic principles, sympathetic to the French Revolution, and influenced by the Benthamites and the left-wing dissenters. An early reaction in Leicester to the French Revolution had been the forming of a Constitutional Society restricted to the voters for the county and borough, 'in the interest of Mr. Pitt'. ${ }^{82}$ Its stewards were Charles Loraine Smith and Thomas Babington. At its first feast, in I790, the mayor and corporation attended, among a company of 900 persons. The first three toasts indicate its character: 'May the established religion never be annihilated under the mask of patriotism ... The mayor and corporation of Leicester and a perpetual free independency in the borough ... The members for the borough, and may it never want members with principles like the present.' 'The company expressed dislike of Fox's regency plans, and toasted 'navigation and prosperity to the county of Leicester'. By such means the supporters of Mr. Pitt sought to 'counteract the effects of the Revolution Club'.83 'The Revolution Club, while agreeing that Parkyns was an excellent man, at the same time drank to the 'total overthrow of all the despots from the petty constables to the imperial Catherine', as well as to the praise of the French Revolution, Tom Paine, and parliamentary reform. ${ }^{84}$ In 1794 a highly radical Revolution Society was started by George Bown, ${ }^{85}$ and in 18 I 6 a Hampden Club. ${ }^{86}$ There was also a small discussion group for a time called the Adelphi Club. The corporation entered fully into all the fears of the time lest modest proposals for reform should cloak sinister designs of revolution. In $\mathrm{I}$ 792, under the influence of government, they arranged the prosecution and imprisonment of Richard Phillips, a radical bookseller, the leader in the Adelphi Club, for selling Paine's Rights of Man, and of George Harley Vaughan, a local schoolmaster, for passing on seditious literature. ${ }^{87}$

Along with the increased influence of a radical minority in an unpopular opposition went the increased influence also of dissent, particularly of the more left-wing sort. Dr. Priestley, when he visited Leicester, stayed at the house of John Coltman, a wellto-do manufacturer who was an active radical. ${ }^{88}$ The corporation indeed identified nonconformity with dangerous politics. In January I 790 dissenters' deputies from seven midland counties met at Leicester to resolve against the 'Test Acts, and to appoint delegates for a national meeting. They had the support of some 'gentlemen of the Established Religion', Sir Egerton Leigh, Bt., and Thomas Arnold, M.D., being specially noticed by their 'presence and concurrence'. ${ }^{89}$ 'The gentlemen of the Common Hall, on the other hand, in their views narrow and timorous, and in their temper arrogant and assertive, resolved 'That the unprecedented combination of dissenters and

${ }^{80} \mathrm{C}_{219 / 172,177,182,187 .}$

${ }^{81} \mathrm{C}_{219 / 168,172,177,182, \mathrm{I} 87 .}$

82 Leic. Fnl. 13 Nov. I 789 ; J. Wilson, Biog. Index to the Present Ho. of Commons (1806), 32-34.

${ }_{83}$ Leic. Fnl. 12 Mar. 1790; Thompson, Hist. of Leic. ii. I $94-7$.

84 Leic. Herald, 10 Nov. 1792.

LEIC. IV
85 Leic. Fnl. 23 May I 794.

${ }^{86}$ H. W. C. Davis, The Age of Grey and Peel (1929), $180-3$.

87 A. T. Patterson, Radical Leic. 67-68, 7 I-73; Greaves, Corp. of Leic. I06-1 2.

${ }_{88}$ Gardiner, Music and Friends, i. 63.

${ }^{89}$ Leic. Fnl. 29 Jan. 1790. 


\section{A HISTORY OF LEICESTERSHIRE}

their repeated attempts to obtain a repeal of the Test and Corporation Acts, call for the exertion of all such friends to the constitution as think it worth preserving, to use their utmost endeavours to prevent so dangerous an innovation'; and 'that the thanks of this corporation be given to all those members of the House of Commons who voted, on the two former occasions, in defence of our valuable constitution-that they be intreated to exert themselves again in the same noble manner, and that the members of this county and borough be requested to give them all possible assistance'. ${ }^{0}$

In the by-election of 1800 it was clear that the more radical forces were becoming organized and assertive. The opposition candidate was John Manners, brother of Sir William Manners, a considerable local landowner. In the disappointed expectation of a general election for 1800 , a second candidate was found to stand with Manners, in Augustus Butler Danvers of Swithland Hall, but in the end nothing came of his candidature. Local opinion recognized in this contest a new character. The Leicester foumal declared that the struggle was no longer between 'high' and 'low' parties, but between loyalty to the constitution and Jacobinical principles.91 Manners, proposed as he was by Robert Brewin, a tanner, declared in a public advertisement that the election was 'a contest between the rich and poor, the oppressors and the oppressed', so that the publisher of a poll book felt it necessary to counteract this dangerous doctrine, and to emphasize, 'for the information of posterity, that the year I 800 was a season of scarcity: and that during the winter, spring and summer preceding the election, the wants of the poor of Leicester had been relieved by the wealthy inhabitants with persevering and unexampled liberality'.92 Examination of the poll book shows, moreover, that the dissenting interest at this time was far from united on the radical side. On the whole, only the most left-wing voted for Manners. Such substantial dissenters as 'Robert Brewin Esquire, of Northgate Street,' and John Coltman, woolcomber of Friar Lane, voted for Babington, as did also such opposition figures as John Pares and Thomas Pares the younger, all of these being persons who before many years had passed were to become the leaders in the radical opposition in the town. The poll for Manners included, on the other hand, Cockshaw, the doughty radical printer and engraver, and Joseph Whetstone, the enterprising worsted maker of Northgate Street. Manners, though at the bottom of the poll, had a good proportion of the votes, and on the town votes was in a minority of only $24 .{ }^{93}$ The Times correspondent reported that 'at the close of the Leicester election Mr. Manners had nearly thrown Mr. Babington out by calling on him for his qualifications at a period when though well-qualified, he had scarcely time to produce it' ${ }^{94}$ At the next contest, in the general election of $\mathrm{I} 802$, the radical candidate was a man 'well-known in the literary world, and who had just arrived from London', a certain Felix M'Carthy, who was proposed by Robert Brewin, the tanner. ${ }^{55}$ M'Carthy, 'an impecunious Irish Foxite liberal', introduced to all appearance hastily, and lacking the useful assets of land and connexion, gained only a few votes, and on the fourth day retired..$^{6}$

The election of 1807 revealed some uncertainties, at least in the corporation. Smith's relations with the body were not wholly smooth, in spite of his having given them a portrait of Pitt. For one thing he had voted in the House for a reforming motion of the Whig member Brand in April 1807 . What was worse, he was suspected of inclining

90 Leic. City Mun. Room, Hall. Bk. 23 Feb. 1790.

is Leic. $7 n l .5$ Dec. I 800 ; for Danvers, see Patterson, Radical Leic. 98.

92 Poll Bk. I 800 , published by John Ireland, 'Publisher's Address to the Reader'.

93 Babington I,572, Manners I,418; of the town votes,

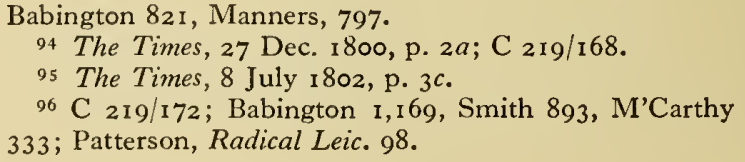


towards concessions for Roman Catholics, for which according to a report in the Leicester fournal he had been actually censured in the Common Hall. None the less when John Macnamara appeared in the town as a candidate, the corporation put aside any differences with Smith, and devoted themselves to keeping out Macnamara, so that there arose an unusual difference between the Tories of the Fournal and those of the corporation party. To secure Smith's return, the numerous freemen who had been enrolled for just this sort of occasion were mobilized to vote. 'The corporation, according to the fournal, thus 'resorted to measures the most coercive and disgraceful, prostituting the freedom of the town, at the shrine of gross venality and corruption. . . . Where or of what value is the boon to that person who serves seven years to obtain that freedom or purchases at a high price, if to answer a temporary and unworthy end the constituted authorities thus sport with their high trust reposed in them?' They denied that any man so elected was the representative of the freemen of Leicester. Macnamara withdrew, so he explained, rather than disturb 'the great commercial concerns of the ensuing day', the day of the May fair. He claimed to be in a minority of but nineteen votes, but Smith and Babington were in fact returned more comfortably. ${ }^{97}$

The election of 1812 was marked by yet another interesting radical attempt. Until the day before polling day, there appeared no opposition to Smith and Babington, but then a group calling themselves 'Friends to peace, reform, and religious liberty' announced their intention to put up as a candidate Roscoe of Liverpool, who was in due course nominated at the hustings by 'Bailey, a cobbler or shoemaker in Church Gate', and Jonathan Atherstone, 'a dyer in the town'. 'Being interrogated as to their authority for so doing, a banker's clerk of the name of Pagett stated that he had corresponded with Mr. Roscoe on the subject.'98 No doubt the friends to peace hoped to gain from the discontent in the town and around at the serious disturbance which had been wrought in the American trade by the Orders in Council. ${ }^{99}$ 'They had the influential support of Ruding of Westcotes, ${ }^{\mathrm{I}}$ who was rumoured to finance the radical Leicester Chronicle. ${ }^{2}$ Their members included the ministers of the two chief dissenting chapels, as well as other forceful local radicals. ${ }^{3}$ Paget was destined to be a thorn in the side of the corporation, and to become the first Mayor of Leicester in the reformed corporation of 1836. In William Roscoe, these radicals had a most interesting candidate, a lawyer, essayist, and historian, and a former member for Liverpool, elected there in 1806 but unseated in $1807 . .^{4}$ At Leicester his poll was small. None the less Paget and his friends might well feel that their 400 votes, which amounted to a third of those cast for the corporation candidate who was at the head of the poll, and nearly half those of the other, at a time when 'peace, reform, and religious liberty' were as cries at a very low value, gave hope for the future. ${ }^{5}$

Manners, M'Carthy, and Roscoe had all of them failed at the polls, and perhaps had never really been expected to succeed. The campaign of agitation continued, in spite of these defeats. The history of Leicester politics in the next twenty years is the history of the radicals' perseverance, advance, and ultimate triumph. Peace, when it came, was welcomed by the corporation with illuminations, a public dinner, and a ball. ${ }^{6}$ During the years after the peace, difficult as they were, the Leicester radicals agitated persistently for parliamentary reform. They attacked the corn laws.7 A usual method was

\footnotetext{
97 Leic. Fnl. I 5 May I 807 ; Reg. Freemen of Leic. I770I 930, I I 4-28; Babington 1,804, Smith I,378, Macnamara I, 022 .

98 Leic. Fnl. 9 Oct. I 8 I 2.

99 Ibid. 28 Feb. I 8 I 2 : petition to Prince Regent presented by the Earl of Moira, in the Commons by Babington and Smith.
}

\footnotetext{
I Leic. $7 n l$. 14 May I8I3.

2 Ibid. 30 July I 8 I 3 .

3 Ibid. It May I8I3

4 D.N.B.; Patterson, Radical Leic. Io I-3.

5 Smith I, I 16, Babington 967, Roscoe 4I 2.

6 Leic. City Mun. Room, Hall Bk. 25 Apr. I 8I 4.

7 Leic. Fnl. 3 Mar., 7 July i 8I 5, 6 Mar., 29 Nov. 18 I6, 3 Jan. I 817.
} 
to ask the mayor to call a public meeting of the citizens, which he felt obliged to refuse. A requisition of December $18 \mathrm{I} 6$ was particularly interesting, as bringing out with great clarity the issues at stake. The requisitioners condemned 'the present enormous military establishment', 'sinecure places and unmerited pensions', indeed all extravagance in government. They demanded economy, and 'for the people, their inalienable right - a full, fair, free and equal representation in the Commons House of Parliament annually elected'. 8 To this requisition the mayor returned what was described in the minutes of the Common Hall as a "judicious and spirited answer . . . which answer merits the highest approbation of the Hall, and has entitled the magistrates to the thanks of every friend to his country'. In their answer the magistrates referred to meetings elsewhere which had 'ended in riot, sedition, and bloodshed!'. They could not but express their regret that any of their fellow townsmen should 'lend the sanction of their names to the unfounded supposition that the government or the Parliament are insensible to the distresses of the people'. Annual parliaments they denounced as a delusion, calculated to mislead the people and subvert the constitution. ${ }^{9} \mathrm{~A}$ meeting was in fact held, quite peaceably, but without the mayor and justices. ${ }^{10}$

\section{$1818-35$}

There was again a complete change in the representation of Leicester at the general election of $18 \mathrm{r} 8$. The new members were both local men. John Mansfield, a former mayor, was a partner in banking with Thomas Babington. Thomas Pares, also a banker, as well as a barrister, belonged to the firm of Pares \& Heygate. Both, according to the Fournal, were of sufficiently 'exalted station not to hanker after the loaves and fishes'. Of Mansfield's principles as a corporation Tory there could be no doubt. Pares stood as a 'Constitutional Whig', who was devoted to the principles of the revolution of r 688 . He had very close family connexions with other hereditary leaders of the local opposition. His grandfather Thomas Pares had been Steward of the Duchy of Lancaster in $176_{5}-6$, and the husband of a daughter of Norton, the opposition lawyer who had expired so dramatically before the magistrates in February I738. The new member had as a brother-in-law, and as a partner in Pares \& Heygate, the banker's clerk of the name of Paget. II Ominously, he was seconded at the hustings by the radical hosier John Coltman.

This result the Fournal put down to weakness and misjudgement in the corporation. According to its account, the body had decided that of the two previous members one must go, and that that one must be Smith, although he was their 'oldest member . . . who had expended thousands in supporting their cause, and had served them honourably for twenty-eight years'. ${ }^{12}$ According to a London version, Smith only heard he was rejected after the resignation of Babington, and left the town in disgust. ${ }^{13}$ Babington had withdrawn on pretext of ill health, and then threw himself into the county election, in which he lost ground by favouring concessions to papists. The return of Mansfield and Pares seems indeed to have been the result of weakness and indecision in the Common Hall. It was noticeable that there had been no special creation of freemen for this election. ${ }^{14}$

The return of Pares proved from the Tory point of view deplorable. He upheld extreme reforming measures, even Roman Catholic relief. ${ }^{15}$ When radicals

\footnotetext{
8 Leic. Fnl.. 20 Dec. I 816.

9 Leic. City Mun. Room, Hall Bk. 3 Feb. I8I 7 .

ro Leic. Inl. 20 Dec. I 816.

II C. J. Billson, Leic. Memoirs, 9-13, I 8-24; C 219/192.

12 Leic. Fnl. 12 Jan. 1818.

${ }_{13}$ An Impartial Statement of all Proceedings connected
} with the Progress and Result of the Late Elections ... I8I8, I 65, I 66, 524, 538 .

14 Reg. Freemen of Leic. $1770-1930$, I 37-40: only i 8 in the mayoral year $1816-17$, all local, and 35 in $1817-18$. is Leic. Fnl. 28 May i8ig. 


\section{THE CITY OF LEICESTER}

met in Leicester to denounce Peterloo it was thought remarkable that he was not there. ${ }^{16}$ Generally, he was held to have 'descended from the pinnacle of independence' to become a radical demagogue. ${ }^{17}$ ' $M r$. Pares has been uniformly in opposition to every measure suggested by ministers for the welfare and protection of the country.' 18

This situation, and George III's death calling for a new election in I 820 , roused the Fournal to take up the cause of the independent freemen against the corporation, which by its 'imbecile conduct' had reduced them to apparent bondage. Probably in the person of Price its editor, an approach was made to Sir William Manners, who had no one in his own family to put forward, but referred with apparent certainty to a London gentleman 'of large fortune and strictly independent constitutional principles' who would be willing to stand, and announcement was made of this in the press, whereupon Mansfield met the corporation and asked for their undivided support, notwithstanding this new 'independent Blue' candidate. When this was refused him, he resigned, so that a deputation from the Common Hall hurried off to London to find another candidate. As they came back having found none, Mansfield then withdrew his resignation. The Fournal, furious that Sir William Manners had added to his 'previous political follies' by giving a pledge which was not upheld by the gentleman he had named as an independent candidate, agreed none the less that 'his escapade has had a good effect which he did not contemplate'. It had precipitated 'an explanation between Mr. Mansfield and the corporation', which, by ending in Mansfield's resignation, 'dissolved the compact between the body corporate and Mr. Pares, and opened the way for a new candidate with every prospect of success'. To find such a candidate proved too much for the Fournal as it had done for the corporation. Nathanael Atcheson of London, who was first approached, was engaged for the borough of Petersfield (Hants). Edmund Yates of Tring Park, whom he suggested, once a business colleague of Peel, excused himself on grounds of health. Sir Frederick Fowke and J. Stockdale Hardy both declined to stand. Thus, for all that more than 5,000 freemen had voluntarily enrolled in 'the independent Blue interest', there was no 'independent Blue' candidate. Pares and Mansfield were consequently again returned. The fournal complained angrily that the borough was still virtually disfranchised, by having members who on vital issues voted in opposite ways. 'Given another month, the independent freemen would have emancipated themselves from the thraldom under which they have fallen.' 19 To discredit Pares, the fournal waged a disgraceful campaign against his uncle, an elder Thomas Pares, a bachelor of antiquarian interests, who had bought and removed as long ago as I805 ancient wood and glass from the chapel of Wyggeston's Hospital. The Fournal represented this perfectly honest transaction as sacrilege and theft. ${ }^{20}$

Embarrassed by a reforming representative in the Commons, whose return they had at the first abetted, the corporation were assailed at home by attacks from the radical opponent, and held up to public odium and ridicule. The free grammar school was in a low state, so that the Hall had to appoint a committee to inquire whether it provided any benefit to the freemen at all adequate to what it cost. ${ }^{21}$ The mayor and corporation were drawn into an attack on the Master of Wyggeston's Hospital for taking to his own enjoyment the great increases in the returns from the hospital lands, which brought them no merit but only a snub from the duchy. ${ }^{22}$ There were complaints that Sir Thomas White's money was loaned only to such freemen as voted with the corpora-

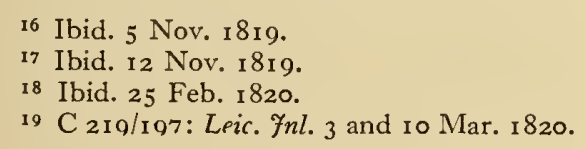

20 Leic. Fnl. Mar.-Apr. 1821; T.L.A.S. xxi. 165-7.

21 Leic. City Mun. Room, Hall. Bk. I Feb. I822; Leic. Inl. 8 Feb. 1822 .

22 T.L.A.S. xxi. 167-73; see below, p. 403. 
tion. Tories as well as others disliked the increasing of these loans from $£ 50$ to fioo. 23

The attacks most damaging to the corporation were made in two other directions, in connexion with the lighting, watching, and cleansing of the town, and with the building of a new gaol paid for out of a rate levied specially for the purpose on the borough. For several years it had been usual for the recorder to compliment the inhabitants on the improvement in the streets, which had been made possible by the way in which canal transport had cheapened the flagstones for paving. None the less in 1788 , when the recorder had made his compliments, there were 34 bills of indictment found true against householders for neglect of their pieces of pavement. ${ }^{24}$ The old arrangements were clearly insufficient. In I $8 I_{4}$ the aldermen of wards met, not for the first time, nor for the last, to consider special measures for winter watching. ${ }^{25}$ Finally in October $\mathrm{I} 820$ a step of decisive importance was taken. The corporation resolved that in open committee they should consider the propriety of applying for an Act of Parliament for lighting, watching, and cleansing the town. ${ }^{26}$ As an earnest of good intentions, the magistrates were later empowered to order such 'gas lights for the Exchange and other public buildings as they shall think proper, and in other such situations (if any) as they may think ought to be lighted by the corporation'.27 'The committee, however, reported against any application for a bill. One reason was that the charges of such a scheme, supported as it would be by a rate, would fall largely on propertyless persons, whereas 'the watching and lighting of the town ought to be borne by the wealthier part of the inhabitants exclusively'. There was much debate in the Common Hall on this adverse report, but any firm decision was frustrated by the withdrawal of ten of the members, so that the Hall had to adjourn. ${ }^{28}$ At the same time, as was entirely to be expected, news of the plan spread in the town, as well as of the divisions in the Common Hall, with the result that the mayor was asked to call a public meeting to discuss the whole problem. ${ }^{29}$ Paget and Coltman and their friends, who promoted this requisition, were certain that something, but not what the Common Hall was proposing, should be done.

The public meeting was used by them simply as a platform to discredit the corporation. Thomas Paget opened with an attack, in some ways unfair, on the whole scheme, and classed it with the borough rate and the efforts to establish jurisdiction in the liberties as yet another example of corporation avarice. A member of the corporation joined in the attack on the plan, pointing out that, when allowance was made for the lamps and watchmen already existing in the town, the scheme involved spending over $£ 3,000$, levied by a rate, on 40 or 50 additional lamps and a handful of watchmen. The plan was consequently defeated. The mayor signed the report 'only in compliance with the resolutions of the meeting'. ${ }^{30}$ One interesting feature of the affair was that half the directors of the Leicester Gas Company, which had started in I82I, had signed the requisition, and all were identified with the opposition in the town.3I Thus the scheme collapsed. Leicester remained one of the only four towns in England of those visited by the reforming inquiry of 1833 not to have improvement commissioners. ${ }^{32}$ The opponents of the corporation justified their stand by arguing that corporation money should be used for public purposes, and embodied this doctrine in a resolution of the meeting. ${ }^{33}$

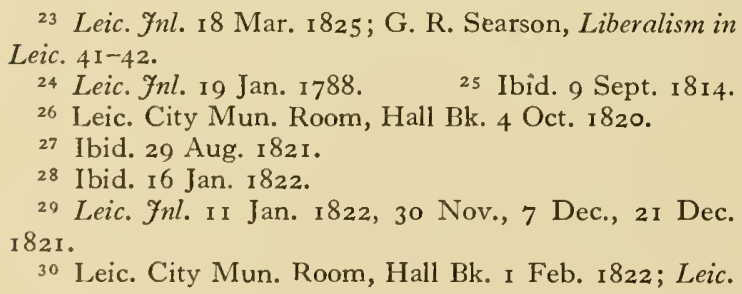

fnl. 8 Feb. 1822

31 J. Storey, Historical Sketch ... of Leic. 92: these directors were Matthew Babington, John Hill, M.D., Samuel Miles, Thomas Paget, surgeon, Harvey Barber, James Cort, Benjamin Cort, Geo. Lockwood, and Onesiphorus Raworth.

32 S. and B. Webb, Statutory Authorities, 302-3.

${ }^{33}$ Leic. Inl. 25 Jan. I 822; Greaves, Corp. of Leic. 33-34, I6I-5. 
Another attempt to get an Act in I83 I came to nothing. ${ }^{34}$ Consequently the parishes of St. Margaret's, St. Martin's, and St. Mary de Castro took advantage of a general lighting and watching Act of 1830 to make their own arrangements. ${ }^{35}$

In 1824 the opposition opened their next campaign, this time working largely through the vestries, whose relations with the magistrates were generally bad. ${ }^{36}$ Throughout the agitation of 1824 , and in the years after, the borough rate was the general issue. The particular occasion was the building of the borough gaol. Peel's act of r 823 mentioned among seventeen gaols to be repaired that of Leicester, and authorized the justices to levy a special rate for this end. ${ }^{37}$ Thus the legislature itself sanctioned the principle that the public, and not the corporation out of its funds, should pay for the new gaol. In March I 824 a petition to the Commons, 'signed by upwards of sixteen hundred rated inhabitants', set forth 'the injustice of only one half of the town in extent being liable to the expense of maintaining and providing a gaol and house of correction sufficient for the classification required by Act of Parliament, for those parts of the town which are not contributory to the borough rate' ${ }^{38}$ Indeed, it was later urged that inhabitants 'removed from the old borough into the new in order to avoid the rate . . ; of seventytwo persons of whom the corporation is composed, thirty only are domiciled in the borough, the rest reside in the liberties'. ${ }^{39}$

At the same time as the petition to the Commons, a new attack was launched in St. Martin's vestry, Paget being again a ringleader. A meeting of inhabitants was called, who authorized the vestry clerk to make 'a respectful application to the town clerk for a copy of the expenditure of the borough rate, offering to pay for it, and if he objected to furnish an account, then to take a copy of the orders made at the last sessions'. 40 'The town clerk refused this request. 'The magistrates would be ministering to their own degradation .... if they submitted to it.' Faced with this refusal, St. Martin's vestry sought the co-operation of the other vestries. St. Nicholas's and All Saints' came in, but St. Mary's kept out. ${ }^{41}$ A mandamus was actually obtained, ${ }^{42}$ inspection made, and a report given to St. Martin's vestry. ${ }^{43}$ There were some criticisms, but assurances of mutual consideration passed between the town clerk and the vestry. No doubt the approach of an election in which the rights of papists would be an issue made the vestry less amenable as an instrument of local politics for Paget and his friends.

The political equality of Roman Catholics was undoubtedly a prospect as displeasing to many dissenters as it was to the corporation, as well as an issue on which divisions in the Common Hall might be healed. Thus the Catholic Question is of more importance in the politics of Leicester than the repeal of the Test and Corporation Acts had been, greatly though that was disliked.44 In I82 I and I 822 petitions had been organized against Roman Catholic relief, to be presented by the Duke of Rutland, and by John Mansfield, who was the one soundly 'Protestant' burgess for the town. ${ }^{45}$ In December I 822 more practical steps were taken. On the initiative of Alderman Slater and Alderman Ireland the Common Hall, nemine contradicente, resolved that it was 'highly expedient to increase the number of freemen of the borough of Leicester'. A large committee was therefore formed, of the mayor, the aldermen, the chamberlains, and the

\footnotetext{
34 Leic. City Mun. Room, Hall Bk. 5 Sept. I 83 I.

35 St. Martin's Vestry Bk. 20 Dec. I 83 I (in the cathedral); St. Margaret's Vestry Bk. 29 Dec. I 8 I (at Vestry Hall, Humberstone Gate); Leic. City Mun. Room, Hall Bk. 27 Aug. I 832.

36 Greaves, Corp. of Leic. 43-47.

37 Act for consolidating and amending the laws relating to the building and regulating of certain gaols and houses of correction, 4 Geo. IV, c. 64 ; S. and B. Webb, Eng. Prisons, 75 n.; Greaves, Corp. of Leic. 39-4I.
}

38 C.F. Ixxix. 205; Leic. Fnl. I9 Mar. 1834.

39 Ist Rep. Royal Com. Municipal Corp. in Eng. and Wales, App. Pt. III, H.C. (I I6), p. I9I9 (1835), xxv.

40 St. Martin's Vestry Bk. I, 8, 22 Apr. I 824.

41 Ibid. 29 Apr. 1824 ; Leic. Fnl. 7 May 1824.

42 Leic. Fnl. 2 Dec. 1825.

43 St. Martin's Vestry Bk. 20 Apr. I826; Leic. Inl. 2 I Apr. 1826.

44 Leic. City Mun. Room, Hall Bk. 2 I Mar. I 828.

45 Ibid. I I Apr. I 821,22 May I 822. 


\section{A HISTORY OF LEICESTERSHIRE}

eight senior common councilmen, to prepare a list of 'gentlemen of such sound con stitutional principles as they may deem proper to be presented for the consideration of the Hall'. ${ }^{46}$ This work went busily forward, so that by September I 824 it was getting difficult to think of fresh names. Rather than 'let an entire mayoralty pass without presenting a list', a smaller list was now put forward, and the whole Hall became a committee for the purpose. ${ }^{47}$ In all about 2,000 persons were approached, of whom some 800 accepted the honour offered them. These 800 included gentlemen and clerics, mostly from Leicestershire, but the new enrolments went further afield than those of 1754 and after 1768 had done. Among them were lace-makers and other persons from Nottingham, ${ }^{48}$ where there was a radical corporation, and where Paget and his Leicester friends became honorary freemen, ${ }^{49}$ each corporation thus calling in the enemies of the other to serve in its electoral battles. Indeed, in Leicester polemics to hit at the Nottingham corporation was to hit at the Leicester radicals. Two letters were addressed by Burbidge the town clerk to the honorary freemen now enrolled. In December 1822 they were offered the freedom. The corporation, it was explained, would pay all charges, except a small sum which it was hoped would be regarded as a small sacrifice in so great a cause. The second letter, in May I 826, indicated which of the candidates to vote for. ${ }^{50}$

At last, in 1826, Parliament was dissolved. The rival papers, Fournal, Chronicle, and Herald, rapidly worked themselves into a fine electoral fury. The Fournal, considering that the corporation was weak and vacillating, warned the Tory electors that 'without a zealous and active co-operation on your parts, it is possible that this ancient and loyal borough may become a non-entity in the preservation of the sound principles of the constitution in church and state'.5I Zealously but unadvisedly it promoted the candidature of C. G. Mundy, a Leicestershire J.P., unhappily suspected of favouring the corn laws. He refused to stand. ${ }^{22}$ The Common Hall had indeed been more active than the tirades of the Fournal allowed. In August I 825 a secret committee of the magistrates, exclusive of mayor and recorder, had been set up 'to take such steps and adopt such measures as they may think proper on behalf of the corporation'. 53 'Their most important duty was to find a man to stand in the True Blue and Protestant interest, both Mansfield and Pares having unexpectedly resigned.

Gentlemen of a parliamentary stamp were less willing to serve the corporation than their opponents. An opposition candidate was first in the field, William Evans, a cotton manufacturer, member for Retford in the last parliament, and a reformer. ${ }^{54}$ Next was Robert Otway Cave, of a good Leicestershire family, a Canningite, a Protestant, but suspected of favouring emancipation. ${ }^{55} \mathrm{~A}$ fortnight passed before the corporation found a candidate to be a zealous advocate for Church, king, and constitution. This candidate was Sir Charles Abney Hastings, of Willesley Hall. His entry into the town, drawn in his carriage by the populace, was the occasion of a fracas. ${ }^{56}$

Even now the outlook was none too good, for only Hastings was firm against Roman Catholic claims. The successful canvas of Evans in the end persuaded Cave to accept the alliance of the corporation party. He undertook to vote for a repeal of the corn laws, and not to vote for any Roman Catholic relief. This arrangement pleased the corporation, for Evans had declared his intention if elected to expose in the House the municipal corruption of Leicester.

${ }^{46}$ Leic. City Mun. Room. Hall Bk.," 8 Dec. I 822.

47 Ibid. 3 Sept. 1824.

48 Reg. Freemen of Leic. I770-1930, 146-69.

49 Leic. Fnl. 24 Jan. 1823.

50 The Times, 15 Sept. 1827, p. $3 a$; Ist Rep. Royal Com. Municipal Corp., App. Pt. III, pp. I910-14; 16 Parl. Deb. N.S. I200-I; R. Read, Modern Leic. 232 sqq.

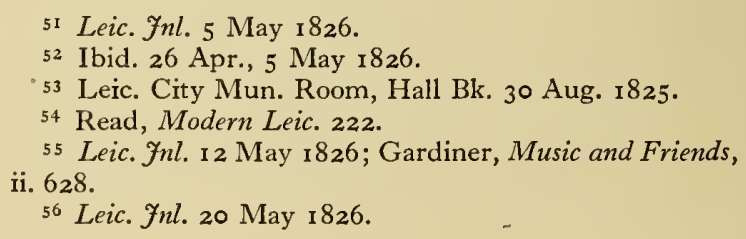


On 12 June the election began. Hastings was proposed by Alderman Gregory and seconded by E. T. Vaughan, Vicar of St. Martin's, who was a fervid enemy of emancipation. Hastings in his speech denounced the corn laws, negro slavery, and concessions to papists. Vaughan justified his taking part by the suppression of Convocation. Evans was proposed by 'Thomas Babington, and seconded by John Coltman. Evans told the meeting he was strongly attached to the established religion, but considered Roman Catholic relief necessary to the salvation of Ireland and the security of Britain. He, too, denounced slavery and the corn laws. Cave was proposed by Thomas Wood and J. B. Robinson. He paid tribute to the work of the ministers Huskisson, Robinson, Peel, and Canning. 'As an Englishman and a Protestant with landed estates in Ireland, I feel that I owe much to my Roman Catholic tenants, but whatever doubts and scruples I have entertained upon this subject, having ascertained in my canvas the almost unanimous opinion of the electors, I have deferred to that opinion.' He also expressed abhorrence of the slave traffic. The next day polling began. There was some objection to the methods adopted, that votes should be taken in pens, two adjoining for Hastings and Cave, a third for Evans, votes being taken in rotation from each, of which 'the palpable effect would be to poll two votes for the corporation candidates, to the single plumper for Mr. Evans'. To balance this, the Liberals persuaded Denman, who was returning through Leicester.from the contest at Nottingham, to stand as a candidate, whereupon the town clerk in derision proposed 'Cobbett and Hunt . . . for the fun of the thing'. The mayor and bailiff agreed to modify the arrangements of pens, which they defended as designed to prevent confusion and riot. ${ }^{57}$

Every stratagem, and some violence, was employed during the ten days of polling spread over a fortnight. ${ }^{58}$ At the end, Hastings and Cave were returned by large majorities. ${ }^{59}$ The corporation held a dinner to celebrate this 'signal and glorious victory, most decisive and complete'. ${ }^{60}$ The victory, however, brought in its train consequences which for the corporation were very disagreeable indeed. There were of course the usual charges and countercharges of corruption and violence. The opposition initiated a campaign of exposure. Proceedings were taken in King's Bench to get the payment of $f_{1}, 340$ to the high constable for his services during the election declared illegal, but the court upheld the magistrates. ${ }^{61}$ In March 1827 a radical member, Sikes, moved for an inquiry into the proceedings of the corporation, especially in enrolling honorary freemen and using corporate funds for electioneering. Hastings and Cave defended the corporation, and Peel, who had been briefed by Hastings, objected to the time of the House being wasted by a meddlesome local faction. ${ }^{62}$

The expense of the election left the corporation in most serious difficulties. Another secret committee, consisting this time of the magistrates, was appointed and given wide powers. ${ }^{63}$ These difficulties were the greater because Cave refused to pay, in addition to the $£ 3,000$ which he had already spent, $£ 4,000$ more. This the corporation expected him to do in accordance with the agreement which had been made, not immediately by the candidates but by committees of friends acting for them-namely, for Hastings, by 'Thomas Burbidge the town clerk, together with William Dewes, and James Liptrott Greaves; and for Cave, by Edward Chesney, De Lacey Evans, and Joseph Philips. ${ }^{64}$

57 Ibid. 16 June i 826.

${ }_{58}^{8}$ For further details see R. W. Greaves, 'Roman Catholic Relief and the Leic. Election of 1826 ', Trans. R.H.S. 4 th ser., xxii. $200-23$.

${ }_{59} \mathrm{C} 219 / 202$; Hastings 2,773, Cave 2,768, Evans 2,063, Denman r, 8 I r. 60 Leic. Fnl. 30 June 1826 .

61 Ibid. 22, 29 June I827; Leic. Chron. Io Feb. 1827.

${ }^{62}$ B.M. Add. MS. 406 I 2, f. 73 , Hastings to Peel, 17 Mar. 1827 : text of the petition in one column, 'Answers on the part of the corporation and returning officers' in another; 16 Parl. Deb. N.s. I198-1216; Leic. Chron. 24 Mar. 1827; Leic. City Mun. Room, Hall Bk. 20 Mar. 1827, thanks of the Common Hall to Cave and Hastings for defending the body in the Ho. of Commons.

${ }_{63}$ Ibid. Hall Bk. 20 Mar. I827.

64 Leic. Election. The Corp. and Mr. Otway Cave (1828); Leic. Ref. Libr. has a substantial collection of pamphlets and broadsides in a bound vol. of election literature, 1826 . 
An arbitrator was appointed to settle the dispute. This was George Harrison, a former Secretary to the Treasury. ${ }^{65} \mathrm{He}$ was regarded by Cave as a mere creature of the corporation. The corporation had, as it turned out, been put to the expense of $£^{27,000}$ in this election. ${ }^{66}$ Evans's campaign had cost him $£_{22,000.67}$ Throughout all these transactions, at every stage, much was spent in legal bills, particularly in bills owed to the town clerk. In legal expenses, the town clerk received payments in connexion with the quarrel with Otway Cave during the years I $827-30$ amounting to $£ 947$ igs. $2 d$., besides $£ 30$ I 7 s. as expenses for two visits to London which had occupied in all 62 days. ${ }^{6}$

The corporation was thus forced to look into its finances, and to urge economy. ${ }^{69}$ Above all, in September 1827 , the investment committee was given large powers to borrow. ${ }^{70}$ In March 1829 a loan on the mortgage of part of the corporation estates was arranged of $£_{1} \mathrm{o}, 000$ at 4 per cent. from the Rev. Henry Palmer, of Carlton Curlieu. ${ }^{71}$ News of this transaction soon leaked out, and was useful ammunition to the radical opposition, who made the best of it.

Moreover, as it turned out, these outlays were wasted. Of the 2,000 persons who had been invited, only 800 had been enrolled, and of these only 444 voted for both corporation candidates. The corporation had anyhow clear majorities on the town votes, while Evans had received many out-votes. ${ }^{72}$ Cave always admitted that at the time of the election the town as a whole was 'Protestant'. ${ }^{73}$ 'The corporation's influence in the town, exercised through the parish officers, seems to have been at least as useful to it as the honorary freemen. Then, too, the quarrel with Cave turned him into an inveterate enemy. He became the most valuable mouthpiece of the local opposition in the Commons, bringing before the House complaints from Leicester about the borough rate, ${ }^{74}$ the gaol, 75 and Sir Thomas White's charity. ${ }^{76}$ It seemed to Peel that Cave 'had been put forward by a party in that place to bring before the House all their local contests'. ${ }^{77}$ Another activity of Cave's which served also to keep the iniquities of the Leicester corporation before the public, was that he took up the project of a bill to restrain corporations from the political use of municipal funds. ${ }^{78}$ Finally, Cave showed himself no friend to the constitution, as the corporation understood it. He voted in support of the repeal of the Test and Corporation Acts in $1828 .{ }^{79}$ Even worse, he introduced into the House petitions from Leicester in favour of Roman Catholic emancipation, justifying himself by the assertion that opinion in the town had changed.80 Above all he voted for that objectionable measure, the Roman Catholic relief bill, which he had been elected in the corporation's view expressly not to support, and which the Common Hall denounced as 'inconsistent with the spirit of the Constitution-dangerous to the civil and religious liberties of the people-and injurious to the stability of the Throne'.81

The next election, that of 1830 , showed in yet another way how disastrous was the legacy of 1826. Even though parliamentary reform was an issue which aroused all the political and religious prejudices of the body, the most that could be expected was to restore the old compromise, with the return of Hastings and Evans, ${ }^{82}$ a bitter contest

65 Leic. City Mun. Room, Hall Bk. 27 Aug. I828.

${ }_{66}$ Leic. Inl. 24 Aug. 1827; 16 Parl. Deb. N.s. I 300.

${ }_{7}$ Gardiner, Music and Friends, iii. I3.

68 Leic. City Mun. Room, Chamberlains' Accts. 182230.

69 Ibid. Hall Bk. 27 Aug. 1828.

70 Ibid. 17 Sept. 1827.

71 Ibid. 22 Mar. 1829.

72 Ist Rep. Royal Com. Municipal Corp., App. Pt. III, 1890; Reg. Freemen of Leic. I770-1930, p. xiii, following Cockshaw's poll bk.; The Times, 2 I June I826, p. $3 a$; the respective figures of the county, 'foreign', and town votes for each candidate, taken from Thomas Combe's poll bk., are given in Reg. Freemen of Leic. $1770-1930$, p. xiii: Hastings, 824, 738, I, 21 I ; Cave, 848, 725, I, I05; Evans, 5 I6, 449, I,098; Denman, 472, 386, 953.

7320 Parl. Deb. N.s. 358.

74 Ibid. 390-I.

75 Leic. Fnl. I 8 July i 828 .

76 I9 Parl. Deb. N.s. I649.

77 I 4 Parl. Deb. N.s. I 762.

${ }^{78}$ For details see Trans. R.H.S. $4^{\text {th }}$ ser., xxii. $218-20$.

79 Leic. Fnl. 7 Mar., 9 May 1828.

8020 Parl. Deb. N.s. $358,579,7$ o .

81 Leic. City Mun. Room, Hall Bk. 2 Feb. 1829.

${ }_{82} \mathrm{C} 219 / 207$. 
being avoided by the withdrawal of Cave. In the next election, in I $83 \mathrm{I}$, the corporation could do even less. Without apparently any resistance from the body, two reformers were returned, in William Evans and Wynn Ellis, who both had the support of a Political Union. ${ }^{83}$ Thomas Paget was at the same election returned as a member for the county. During the winter it became clear that the last hope of obstructing parliamentary reform was in the House of Lords. To that House therefore the corporation addressed two petitions, one in September, ${ }^{84}$ the other in March, ${ }^{85}$ solemn and urgent. In that of March, they doubted whether the Commons truly reflected the sense of the country, lacking as they did a due proportion of persons of sound principles, since 'Gentlemen of those principles were not found to do their duty to the country by standing forward as candidates'. They foresaw the destruction of the true liberties of the people, 'which never did, and never will long survive the wreck of the 'Throne and the Altar'.

The election of December i 832 was thus fought under quite new conditions. The Reform Act of 1832 had established a uniform franchise in the towns of the $f$ io householders. The existing resident freemen were allowed to keep their votes as long as they should live. The non-residents were disfranchised. The Boundaries Act specified the parliamentary borough as including 'the old borough . . . and the space over which the magistrates of the old borough . . . exercise jurisdiction concurrently with the magistrates of the county of Leicester, including the Castle View' ${ }^{86}$ 'These changes seem to have distinctly favoured the opposition cause. The constituency was by the elimination of the outvoters reduced to half. The Liberals, with rallying points in the chapels, had better technique in registration, one of the most important electoral innovations of this time. The Conservatives had been reminded of the importance of registration by the fournal. ${ }^{87}$ The corporation being so discredited, the Conservatives tried to find a broader basis than merely corporation influence. In September I832, 50 gentlemen in the Conservative interest dined at the White Lion. They were the nucleus of a new Conservative Society, the opposite number to the Liberals' Reform Society, which had grown out of the Political Union of $\mathrm{I} 83 \mathrm{I} .{ }^{88}$ As part of these efforts no doubt, the town clerk contrived to earn $f_{397}$ I 5 s. 3 d. in the year ending in September I 832 on his 'special bill for business respecting the registration and under the Reform Act.' ${ }^{89}$ Nevertheless, in spite of the hopes of the Fournal for the True Blue cause, and the expectation of such friends of the corporation as J. L. Greaves, who put great hopes in the forcefulness of 'Tom Burbidge to lend them his vigour and lead them on', 90 the first election under the new order returned for Leicester two reformers in Wynn Ellis and William Evans, by comfortable majorities over Boughton-Leigh the Conservative.91 The defeated party held that the victory was won by bribes. The ultra-Tory Leicester Herald declared that it had taken reform to introduce 'unblushing venality into Leicester'. 92 The balance of influence was indeed shifting, from the corporation and some old families, to the master stockingers, men of wealth and considerable employers of labour.

The reformers' triumph in December I 832 meant that parliamentary reform would be followed by municipal reform. Indeed in this year the Leicester magistrates had already had their power severely curtailed by St. Margaret's select vestry act, which expressly prevented their interference in the finances of the parish. ${ }^{93}$ On I 4 September

83 Leic. Fnl. I I Nov. I 83 I, I 8 May I $832 ; C$ 219/2 I 2 ; Patterson, Radical Leic. chap. x.

84 Leic. City Mun. Room, Hall Bk. 29 Sept. I 83 I.

85 Ibid. 29 Mar. I 832.

86 Greaves, Corp. of Leic. I 22-3.

87 Leic. Fnl. Io Aug. I 832 . For the use of the terms 'Liberal' and 'Conservative' see Patterson, Radical Leic. 196-7.

88 Ibid. 7 Sept. 1 832; Patterson, Radical Leic. 192-3.
89 Leic. City Mun. Room, Chamberlains'Accts. I831$2, \times 832-3$.

90 Ibid. I o9'30/4/80, J. L. Greaves to C. C. Macaulay, I 4 Oct. I 832 .

91 C 219/217; Evans I,692, Ellis 1,583 , BoughtonLeigh $x, 276$.

92 Leic. Herald, I9 Dec. 1832 .

93 Greaves, Corp. of Leic. 46-47. 


\section{A HISTORY OF LEICESTERSHIRE}

I $\delta_{32}$ Whitcombe and Cockburn, two of the commissioners inquiring into municipal corporations in the midland circuit, arrived in Leicester. On their first day there, they dined at the house of Robert Brewin the manufacturer, with Paget, his brother-in-law, Berry the minister of the Great Meeting, the leading radical lawyer Stone, and others of the same party. ${ }^{94}$ Here indeed was the last and the greatest of chances utterly to discredit the old corporation. The next day, by courtesy of the county magistrates at the castle, the inquiry began. It was a public show. The direction of the corporation's defence was in the hands of Thomas Burbidge, the town clerk, who dominated it.95 None the less, the Leicester corporation did not, like five other bodies, refuse all information, for all that they clearly regarded it as a great concession to give any information at all to a body they held to be unconstitutional. Burbidge did not like giving information which he had obtained in a confidential capacity to a public meeting, but in the end answered questions about the history, constitution, income, and expenditure of the body, apparently satisfactorily. ${ }^{96}$ According to the Chronicle, the most interesting facts to be elicited were the offer of the freedom to 2,000 persons before the election of 1826 , and Palmer's mortgage after it. This transaction Burbidge defended as justified by the desire of the body to uphold right principles, and its right to do as it wished with its own lands, which were private property, 'and not that of the public at large' ${ }^{97}$ Then came a stream of hostile witnesses, persons chiefly who had harried the corporation in the previous ten years, such as Paget, and the manufacturers Brewin and Coltman. Among them was Cockshaw, a printer who had recently been prosecuted by the magistrates for an attack on their administration of justice and their use of municipal funds. ${ }^{98}$ Burbidge objected to the evidence of these persons as 'improper', and was therefore allowed to call witnesses of his own. Attack was now aimed at the partiality of the magistrates, in whose defence a counter-declaration was signed by 800 householders expressing confidence in them. ${ }^{99}$

At the beginning of the second week the commissioners and the corporation openly quarrelled. Burbidge refused to hand over the hall books for the last twenty years and the chamberlains' accounts for the last ten, as well as other documents demanded of him. He was willing that they should be consulted privately at the commissioners' lodgings, but not amid scenes of noise and public clamour at the castle. In the end, the Common Hall authorized the town clerk to refuse delivery of the documents. ${ }^{\text {I }}$ The corporation in their public defence of this refusal maintained that the inquiry was conducted not impartially but in a spirit of hostility. The commissioners in the view of the corporation had no authority to hold public meetings 'to subject its officers and members to public interrogations, so framed as to extract if possible grounds to assail their character and property and to induce a false belief that they have betrayed the trusts reposed in them', and in particular to stir up old troubles, 'such as the merits of an election for Parliament warmly contested seven years since'. 'From meetings so convened and conducted, persons of respectability and intelligence naturally shrink.' 2 Whitcombe at first threatened to treat the corporation's claim that these inquiries were unconstitutional as a libel on the House of Commons, but in the end yielded the corporation's right to act as they thought proper. After a few more witnesses, including Matthew Babington, had been heard on the election of 1826 and one or two other matters, the commissioners left the town. ${ }^{3}$

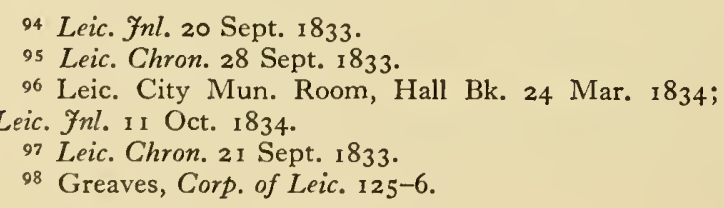

99 Leic. Chron. 2 I Sept. 1833.

I Leic. City Mun. Room, Hall Bk. 24 Sept. 1833 .

2 Leic. Chron. 28 Sept. I 833 .

3 Leic. Inl. 18 Oct. 1833 ; Leic. City Mun. Room, Hall Bk. 17 Oct. I 833 . 
In the following March an account was sent to the commissioners of the sales of corporation property and the use of the purchase money, which was held to show that between $\oint_{17}$,000 and $\oint_{1} 8,000$ had been raised since I810 by sales, and over $£_{20,000}$ spent in 'purchases and beneficial improvements of the corporation property' and for public purposes as specified. Other particulars were given about local charities, the admission of freemen, and the charters. Here was 'the best practical answer to the insinuations so liberally made against the corporation that they had sold largely from the corporation estates, and had spent or embezzled the purchase moneys'. ${ }^{4}$

Once the commissioners had gone the corporation settled down to a more normal course, administering Alderman Newton's bequests, ${ }^{5}$ making grants to the organists of St. George's and other churches, ${ }^{6}$ and the lunatic asylum, ${ }^{7}$ and carrying out improvements at the East Gates. ${ }^{8}$ They twice addressed the Crown in defence of the Church of England. ${ }^{9}$ The Church question indeed seems to have dominated the election of 1834 . The proposals for the Irish bishoprics and a motion to admit dissenters to the universities (supported by Wynn Ellis) seemed to portend a general attack on the Establishment. Io A leading article in the Fournal in May I 834 had for its title 'The Church is in Danger'. It declared that 'the dissenters have thrown off the mask-they have declared their object to be the total separation of Church and State; in other words they want to have their share in the plunder of the temporalities of the Church, and make their lowbred ill-educated soi-disant clergy equal in point of rank and consequence to those of the Church of England'. I In addition, in these two years, the Conservative cause had been organizing itself. The Fournal noted with pleasure in February I 833 that 'several Conservative clubs have been formed in Leicester among the working classes'. ${ }^{2}$ 'The corporation itself, as might be expected, heartily approved in December I 834 of William IV's 'recent exercise of the royal prerogative in dismissing his late ministers'. ${ }^{3}$

At Leicester as elsewhere in the election of 1835 the Church cry was raised more effectively than at any time since the reign of Anne. The Conservative candidates, Goulburn (recorder of the town) and Thomas Gladstone, emphasized it at the hustings. ${ }^{14}$ Gladstone said that the interests of the Moravians and Wesleyans were bound up with those of the Church of England. Both the Conservative candidates were returned, the reformers rejected. ${ }^{15}$ The Fournal was jubilant. 'In spite of the most profligate system of bribery on the part of the Radical party, the two Conservative candidates have been returned by a majority of I77.' The victory was in the Fournal's opinion due largely to the exertions of the Conservative societies. ${ }^{16}$ The opposition paper, the Chronicle, on the other hand, reported Wynn Ellis as emphasizing the great array of influence mobilized against the Liberal cause: the personal connexions of the Gladstones and Goulburns, the enormous power of a corrupt corporation, and the influence of the Church. The Chronicle noted also that the boys of the 'Green (or rather Blue) Coat School enjoy a holiday in celebration of the success of their patrons'. ${ }^{17}$ Burbidge, too, had been active in the election, and claimed to have laid out $£ 233$ in journeys to London in December I 834, on 'particular business'. ${ }^{18}$ It was noticeable also that immediately after this election, as after that of 1826 , a finance committee had to be appointed 'with a view to the better management of the corporation funds'. ${ }^{19}$ A petition to unseat Goulburn on the

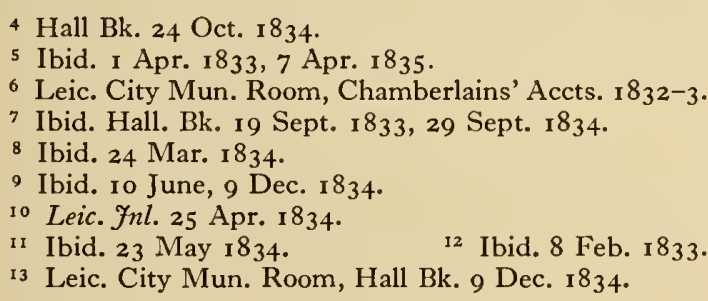

${ }^{14}$ Leic. Inl. 2 Jan. 1835 .

I 5 219/222; Leic. City Mun. Room, Hall Bk. 24 Feb. 1835 .

${ }_{16}$ Leic. Inl. 9 Jan. I 835 ; Goulburn I,483, Gladstone I,473, Evans I,431, Ellis I,306.

17 Leic. Chron. 17 Jan. 1835 .

I 8 Leic. Town Hall Rec. Council Minutes, 9 Nov. I 836, I 9 July I 837 .

19 Leic. City Mun. Room, Hall Bk. 7 Apr. I 835 . 
ground that he lacked the necessary property qualification was defeated on a technical error, according to the Liberals, by the trickery of Burbidge. ${ }^{20}$

In spite of some Tory gains, the Whigs and Liberals still had a majority in the Commons, so that Peel's short ministry soon ended. Even had it continued, some measure of municipal reform would have come. In March I835 the Municipal Commissioners published their report, which stimulated the demand for reform. They denounced the financial mismanagement and political exclusiveness of the Leicester corporation. The corporation, they informed the world, had great wealth, yet did little to ease public burdens. ${ }^{21}$ Nobody was ever admitted to civic office, unless he were of the corporation party, 'however wealthy, however intelligent, however respectable'.22 Political exclusiveness, they held, had vitiated the distribution of corporation charities. They mentioned particularly that of the fathers of the 45 boys admitted to Alderman Newton's Greencoat School in $\mathbf{1 8 3 2 - 3}$, all but two had voted for the corporation candidates. ${ }^{23}$ Political faction, they claimed, had perverted justice. ${ }^{24}$ Finally, they made great play with the election of $\mathbf{I} 826$. 'No corporation ever interfered more extensively or openly in elections.'25 In fact their report was, broadly speaking, an official version of the opinions of Brewin, Paget, Coltman, Berry, Stone, Cockshaw, and their friends. It repeated what the Common Hall had in I 833 denounced as 'the false and scandalous charges . . . made by a party of calumniators in this town' ${ }^{26}$

Lord John Russell's bill provided for the radical reconstruction of 183 corporations, Leicester being one. As it passed the Commons, it provided for town councillors to be elected for three years, one-third retiring annually, by ratepayers of three years standing. Regard was had to the rights of freemen living. When the bill reached the Lords, the House was persuaded to hear evidence at the Bar on behalf of the corporations. Burbidge was up in London, working hard with other town clerks against the bill, and later claimed $\$ 900$ as money spent in this work. ${ }^{27}$ The Common Hall, under the influence of a character so indefatigable, took this opportunity to be heard. A petition was drawn up, which denounced the bill on various grounds. To begin, it had its origin in a report which was unjust. It was dangerously democratic, especially in the three-year ratepaying qualification for municipal voters. It involved interference with ancient property rights, such as those of the freemen, hitherto safeguarded by charter. So great interference with charter rights was indeed dangerous to the lords themselves, whose titles to their own properties were so very generally similar to those of the corporations to theirs. Moreover, there was here proposed not only an insidious attack on property, but also a serious diminution of the royal prerogative, by the abrogation of privileges royally granted. Finally there was an ecclesiastical argument which was especially relevant to Leicester. A considerable part of the estates held by the corporation came from the bequest of that stout Athanasian Alderman Newton for the education of boys in the principles of the Church of England. Newton had selected the corporation as his trustees because he trusted their lasting adherence to strict Church principles. It was thus a 'fraud of the gravest character' to take these estates and to give them to persons of 'principles totally opposite'. On all these grounds the reform now proposed was a monument of 'transcendental injustice'. ${ }^{28}$

The petition was received, and representatives were heard, from Leicester and other

\footnotetext{
20 The Times, 13 Jan. 1835 , p. $4 d$; Leic. Chron. 4 Apr. 1835; 27 Parl. Deb. 3 rd ser., 267-70, 464, 544; Rep. Sel. Cttee on Bribery at Elections, H.C. (547), paras. 2120 sqq. (1 835 ), viii.

21 Ist Rep. Royal Com. Municipal Corp., App. Pt. III, p. 1919

22 Ibid., p. I909.
}

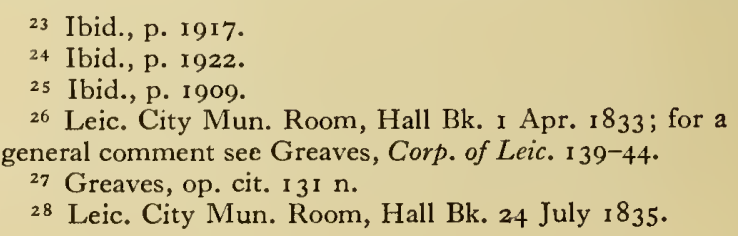


corporations. ${ }^{29}$ The bill, modified by the addition of second chambers of aldermen, passed into law. The holding of periodical elections and the technique of registration were now introduced into municipal life. In October 1835 the Fournal warned its readers that the battle for the control of the new corporation would be fought in the registration courts. ${ }^{30}$ An attempt was made by the radicals to disfanchise the recipients of Sir Thomas White's money, but the revising barristers maintained that a loan of that sort was a different thing from poor relief.3I By I 8 December the registration was complete. ${ }^{32}$ To the revising barristers fell also the duty of applying to Leicester the provisions in the Act for dividing large towns into wards. Burbidge suggested that the wards should continue as in times past and his suggestions were to some extent followed, four wards remaining as formerly, though the number was reduced from ten to seven. The area covered by the others was more equally divided than in the old days. ${ }^{33}$ There was finally one ancient and important problem liquidated by the new Act. The municipal borough was made identical with the parliamentary borough, so that there was no more to be any problem about the scope of municipal authority such as had vexed the old corporation in what had been the liberties, now at last firmly brought into the municipal area. The Act left the question open of continuing commissions of the peace in those boroughs which had had them before the reform. This was provided for Leicester in the new régime, on application of the new council, in accordance with the Municipal Reform Act, by a charter of March 1836.34

The elections for the new town council took place on 26 December I 835. The Conservative organization, the Central Constitutional Municipal Committee, published a list of candidates, a mixed bag of 'moderate Whigs and temperate Conservatives'. ${ }^{35}$ In this list of 42 men were only ten of the old corporation, and only one of the last eight mayors. ${ }^{36}$ There were some, standing under these moderate auspices, who in times past had taken part in the attacks on the corporation. The Conservatives thus had hopes that by carefully dissociating themselves from the now discredited old corporation, there might be elected a moderate council, not dominated by the 'Socinian faction'. These hopes were thoroughly disappointed. The first municipal election was a sweeping victory for the Liberals. Only four of the 42 candidates of the Central Constitutional Municipal Committee were elected, and all of these in No. 4 Ward, East St. Margaret's. ${ }^{37}$ This resounding defeat was explained by the old corporation as due to apathy in their ranks, and the framing of the reform in such a way as to make a Conservative victory almost impossible. ${ }^{38}$ It was to be noticed also that two-thirds of the new council were dissenters. 39

In the meantime the old corporation prepared for its end, by granting in October out of corporation funds annuities to various of its officers, to the high bailiff, the superintendents of markets, the mace-bearer and the four sergeants-at-mace, the town crier, the beadle, and two bellmen, amounting in all to nearly $£ 500.4^{40}$ In December the Hall voted pieces of plate, to Alderman Firmadge of 50 guineas, to Alderman Rawson of I 00 guineas, and to the town clerk of 300 guineas. The corporation pipe of wine was voted to the Infirmary. The salaries of various officers and servants were ordered to be paid them for the current year. ${ }^{4}$ On the eve of Christmas, finding that the gifts voted at the previous Halls were being made 'a handle for doing injury to the general Con-

\footnotetext{
29 L.F. Ixvii. 328.

31 Ibid. 4 Dec. 1835 .

32 Ibid. I 8 Dec. I 835 .

33 Ibid. I 6, 23 Oct. I 835 .

34 C $66 / 447$ I, no. I 7 .

35 Leic. Fnl. 25 Dec. 1835 .

36 Leic. Chron. 26 Dec. 1835 .
}

30 Leic. Fnl. 30 Oct. 1835 .

\footnotetext{
37 Joseph Philips, Charles Inman, Geo. Lockwood, Wm. Miles; for a list of the new corp. see Greaves, Corp. of Leic. I 58-9.

38 Leic. $7 n l$. I Jan. 1836.

39 Greaves, Corp. of Leic. I36.

40 Leic. City Mun. Room, Hall Bk. 22 Dec. 1835 .

${ }^{41}$ Ibid. 22 Dec. I 835 .
} 


\section{A HISTORY OF LEICESTERSHIRE}

servative cause', the town clerk, the mayor, the two aldermen, and the steward came forward to decline what they had formerly been awarded, and were thanked by the Hall for a loyalty to the general Conservative cause that was above any pecuniary consideration. ${ }^{42}$ Three days later, on the feast day of St. John the Evangelist, the two companies made a last ceremonial parade, to the charity sermon for the widows of St. John's Hospital. 43

On 29 December I835, as the new Act directed, the newly elected corporation were sworn in. As Burbidge saw it, the old corporation 'which had existed from time immemorial was doomed to final dissolution'. A newly fabricated body was put into its place. Finally, on New Year's Day 1836, that pillar of the Great Meeting, that hammer of the old corporation, Thomas Paget, was elected and sworn in as mayor. 'Thereupon the head was placed upon the new body, and it then received its perfect corporate existence.' 44

42 Leic. City Mun. Room, Hall Bk. 24 Dec. 1835.

43 Ibid. 27 Dec. 1835 . 


\section{SOCIAL AND ADMINISTRATIVE HISTOR Y 166O-1835}

Leicester in the I660's, p. I53. Local Government and Administration, p. I60. The Town Fields, p. 165. The Occupations of the People, p. I66. The Relief of Poverty, p. I87. The Leicester Newspapers, p. 189. The Growth of Leicester, 1670-1835, p. 191.

\section{LEICESTER IN THE $166 \mathrm{O}^{\prime} \mathrm{S}$}

' 10 the old and raged citty of Licester, large and pleasantly seated, but despicably built, the chimnies flues like so many smiths' forges.' So wrote John Evelyn when he visited Leicester in August I654. ${ }^{1} \mathrm{~A}$ more graphic account was given by Thomas Baskerville of his visit to the town during the reign of Charles II, possibly in $1675:^{2}$

As to Leicester, it is now an old stinking town; situated upon a dull river inhabited for the most part by tradesmen, viz. worsted combers and clothiers, for the streets being then a sweeping and cleansing against the judges coming in the next morning the stinking puddles of — and water being then stirred, made me go spewing through all the streets as I went to see it, yet it hath formerly been a town of good remark for here is an ancient house or palace called the Duke of Lancaster's palace, ${ }^{3}$ as also a large hospital built by some of these dukes, ${ }^{4}$ and an old piece of building which they call Janus's temple. ${ }^{5}$ Here is also an old bridge over the river which they call Richard III's bridge 6 by which some say he is buried. Here are in the town five churches, of which three as I remember have handsome spires, and are to be seen a good distance from the town. The 'Red Lion' where we lay is the best and greatest inn of the town, and was then taken up by the sheriff and his men; it hath in it a gallery or dining room of great length with a long table in it to entertain people, the floor of it, which was the first I saw of that kind, being made of plaster, like that of Paris.

Twenty years later Celia Fiennes visited the town, and gave a more favourable picture: ${ }^{7}$

Leicester town stands on the side of a little rising ground, though at a distance from the adjacent hills it looks low, but it's a good prospect. It has four gates, the streets are pretty large and well pitched, there are five parishes. The Market Place is a large space very handsome with a good Market Cross and Town Hall. ${ }^{8}$ The town is old timber building except one or two of brick. There is indeed that they call the Newark which is encompassed with a wall of good thickness and two great gates with towers as the town gates are; in which they keep their arms and ammunition. The walls are now only to secure gardens that are made of the ruined places that were buildings of strength. In this Newark which is a large piece of ground are severall good houses some of stone and brick in which some lawyers live ffrank; there is also a new pile of building all of brick which is the Guild Hall ${ }^{9}$ where the assizes are kept twice in the yeare and the sessions quarterly. St. Martin's church is one of the biggest--there is none very big and none fine. They have a water-house and a water mill to turn the water in deep leaden tubbs or cisterns for their use: there are wells in some streets to draw water by a hand wheele for the common use of the town.

Such were the varying impressions made on three visitors to the town in the second half of the I 7 th century. In I 660 the borough's houses extended well beyond the walls. The walls were still standing in I645 though they were not fit to withstand any determined assault; ${ }^{10}$ and after the Restoration there seems to have been no attempt to

I Diary of Fohn Evelyn, ed. E. S. de Beer, iii. I 22.

2 Hist. MSS. Com. I 3 th Rep. App. II, Portland, ii. 307-9.

3 Leicester castle.

${ }_{4}$ Trinity Hospital.

5 The Jewry Wall.

LEIC. IV
6 Bow Bridge.
7 Fourneys of Celia Fiennes, ed. C. Morris, I62-4.

8 Presumably the Gainsborough: see below, p. I 79 .

9 Leic. castle in fact, not the building usually known as the Guildhall.

Io V.C.II. Leics. ii. I I5-17; C. J. Billson, Medieval 


\section{A HISTORY OF LEICESTERSHIRE}

repair the ravages of the siege. The exact condition of the walls varied considerably from place to place, but they were surrounded by a ditch which was not completely filled up until the middle of the I 8 th century. ${ }^{\mathrm{II}}$

In $1660^{12}$ the general plan of Leicester was still that of the medieval town. ${ }^{13}$ The line of the walls and of the roads leading out of the town, the continuing influence of the siting of the dissolved religious houses, and the nature of the town's site all prevented drastic changes. By $\mathbf{I} 660$ the relatively simple pattern in which trade and traffic had converged on the centre of the walled area was being altered. The centre of gravity was shifting eastwards from the High Cross towards the Saturday market place and the East Gate, where it has remained ever since. The background to this eastward move is obscure, but several factors in it seem to have been the relative decline of the castle in the life of the town, the greater activity of the Saturday market in the south-east quarter of the town at the expense of the Wednesday market around the High Cross, and changes in the directions of the main roads leading into the town from the north and south, which tended to reduce the value of the central position of the High Cross. ${ }^{14}$ While medieval traffic from Loughborough and the north followed the left bank of the Soar and used the North Bridge and the North Gate to approach the centre of Leicester, ${ }^{15}$ by the end of the I 7 th century the normal route ran along the left bank of the Soar only as far as the village of Belgrave where the Soar was crossed and the approach to Leicester made by Belgrave Gate and the East Gate. ${ }^{16}$ In the south there were changes of no less importance. The main road to London in medieval times emerged from the South Gate and led almost due south to Welford and Northampton, but by 1660 the normal route was the present London Road leaving Leicester by Gallowtree Gate, and linking a number of substantial villages on its way to Market Harborough. ${ }^{17}$

The effect of these changes in the major approaches to Leicester was very important in the growth of the town. The north of it became a backwater, and although the High Cross continued to receive all the west-bound traffic, the centre of gravity was shifted to the streets outside the East Gate (Gallowtree Gate, Belgrave Gate, and Humberstone Gate) and to the Saturday market place nearby. The great coaching inns of the I 8 th century ${ }^{18}$ were mainly in this area, and it is still the focal point of the modern city. The estates in the borough of the Dominican, Franciscan, and Augustinian friaries passed into lay hands at the Dissolution but were not built on for some time. The lands of the Black Friars in the north-west quarter of the town and those of the Augustinian Friars across the West Bridge were, it is true, on low-lying ground which was unattractive for new building as long as better sites were still available, as they were in the $\mathrm{I} 8$ th century. The boundaries of these open spaces can still be picked out on maps as late as $1828 .{ }^{19}$ The Grey Friars land was in a much better position for conversion into building plots, since it lay very near the commercial heart of the town. Even so, it was not until I 7 I I

\footnotetext{
it Billson, Medieval Leic. 205-6.

12 This paragraph and the next three were contributed by Mr. C. T. Smith.

13 See above, p. 31. For the topography of the 17 thcent. town, see Billson, Medieval Leic,, Agnes FieldingJohnson, Glimpses of Ancient Leic., and D. Charman, 'Leic, in I 525', T.L.A.S. xxvii. There are 3 maps for the period: John Speed's, dated 1600 , in his Theatre of the Empire of Gt. Brit., which is very distorted and contains some misleading identifications of streets; a map attributed to Stukely, printed in his Itinerarium Curiosum (1722); and the Van der Gucht map of $c$. 1750 (see B. L. Gimson and P. Russell, Leics. Maps, 16). The last 2 vary in detail but appear to be based on an accurate survey probably made
}

shortly after I7II, possibly in I718: Leic. City Mun. Room, Hall Bk. I5 Jan. I712; ibid. Chamberlains' Accts. 17 15-20, f. 223 .

14 Billson, Medieval Leic. 24, 34; P. Russell, Leics. Road, 7-13, 29-32.

${ }_{15}$ e.g. W. Kelly, Royal Progresses and Visits to Leic. $343-4$.

I6 W. Stukeley, Itinerarium Curiosum (1722), plate 91 J. Ogilby, Britannia, plate 4o. See also V.C.H. Leics. iii. 71 .

17 Russell, Leics. Road, I i ; V.C.H. iii. 70, 74

18 See Billson, Medieval Leic. 34-40.

19 'T. and G. Ellis, Map of Leic. (1828). And see below, pp. 343,387 . 
that the legacy of Grey Friars was split up and part of it set aside to form a new street. ${ }^{20}$ By 1720 building had begun, and by the end of the century a whole block of handsome Georgian houses, many of which are still standing, graced the narrow flanks of the New Street. ${ }^{21}$

Perhaps the most obvious features of Leicester at the end of the $\mathrm{I} 7$ th century and in the early $\mathrm{r} 8$ th century was the concentration of building in quite a small part of the former walled area. ${ }^{22}$ Rather more than half of the walled area of about 160 acres was devoid of any building at all. This was in the northern part of the town, where there were only orchards and gardens and the 'back lanes' which led to them or linked up the rows of houses along Churchgate, High Street, and Sanvey Gate. This was the part of Leicester in which two medieval parishes, St. Peter's and St. Michael's, had existed in addition to the surviving one of All Saints'. ${ }^{23}$ By I670 the part of the town which lay to the north of the Swinesmarket, Belgrave Gate, and St. Nicholas' contained only a quarter of the total population. ${ }^{24}$ The uneven distribution was partly caused by the nature of the town's site. Like most other settlements in the Soar valley, Leicester has as its foundation a gravel river-terrace which ensures for it a dry site well away from the flood-plain of the Soar. The castle, the High Cross, St. Martin's, and St. Nicholas' all stand on a gravel bench rising abruptly some I 5 to 30 feet above the flood-plain, which was at its narrowest at the West Bridge, where an easy crossing was possible and a bridge practicable. To the north and south of this dry and well-drained site the ground falls to the alluvium of the Soar or its tributaries. The greater part of the I 7 th-century town was therefore built on dry and healthy foundations well above river level and the land to the east and south-east. In the north the boundary between the older river gravels and the alluvium is less well defined. ${ }^{25}$ No more than a few feet separate St. Margaret's Church from the level of the river, and the North Gate is little higher than the river level above the North Mills, though High Cross Street (the old High Street) occupies a spur of rising ground as far north as All Saints' Church. ${ }^{26}$ All the land to the north of Sanvey Gate and some of that which lay within the North Gate must have been subjected to fairly frequent flooding in the days when the Soar was unregulated. Occasional references in the borough records suggest this, as, for example, in 1672 when a case of drowning in the floods in North Gate was brought to the attention of the corporation, and in I744 when it was thought necessary to raise and level the pavement in part of Church Gate. ${ }^{27}$ As long as Leicester remained a small town of some 4,000 to 6,000 people there could have been little incentive to build in these unattractive parts of the town. When it did begin to expand, it grew in the direction of the main approaches rather than spreading over the orchards and closes which were liable to occasional flooding or belonged to charities which were either unwilling to sell their property or unable to grant building leases.

In 1660 , then, from the West Bridge and the ruins of the castle overlooking the Soar to the bustling inns which had recently grown up about the East Gate, a cluster of inns, churches, and public buildings picked out the river gravel-terrace at a point where it was highest, driest, and closest to the River Soar. Trade, wealth, and activity were focused here around the Market Place and the points at which the main roads into the town converged. This was undoubtedly the core of Leicester. Other evidence than can be culled from contemporary maps or such records as yield topographical information

20 Nichols, Leics. i. 299.

21 Ibid. 533 .

22 See map, p. 196. See also above, p. 53.

23 See below, pp. 388-9.

${ }^{24} \mathrm{E}_{\mathrm{x}} 79 / 240 / 279, \mathrm{~mm}$. I-2, I3, I6; Stukeley, Itinerarium Curiosum (1722), plate $9 \mathrm{I}$.

25 C. Fox-Strangeways, Mem. of Geol. Surv. Leic. (1903),
56.

${ }_{26}$ The present street levels are artificial and the Soar has been regulated, so that it is impossible to give exact figures.

27 Leic. Boro. Rec. I603-88, 539; Leic. City Mun. Room, Hall Bk. 6 April, 2 May, and 29 June 1744 . 


\section{A HISTORY OF LEICESTERSHIRE}

is hardly needed to substantiate that fact, but the same sources tell us comparatively little of the quality of building, the density of population, or the wealth of the inhabitants in the rest of the town.

In the late $I$ th century the town was divided into ten wards, all within or adjacent to the walled area. ${ }^{28}$ Two wards lay beyond the north wall, and two others immediately beyond the east wall. Besides the ten wards, three other parts of the town were included in the hundreds of the county, and were outside the borough for administrative purposes, though their exact position was the subject of much dispute. Abbey Gate to the northwest of the walled area was in West Goscote hundred, the Bishop's Fee to the east was in Gartree hundred, and in the south-ivest of the town, Leicester castle with the Newarke was in Guthlaxton hundred. ${ }^{29}$ None of these three districts was populous, and they accounted for only 79 of the 1,024 households recorded in the borough in I 670, but together with the four wards already mentioned they brought the total of recorded households outside the walls at that date to 423 , or just over 42 per cent. ${ }^{30}$

The hearth-tax returns of $1670^{31}$ are a valuable directory of the borough's inhabitants, and an indication of their wealth. Here are enumerated the heads of households in the ten wards of the borough and in the three liberties, together with the numbers of their hearths. They are not only the most complete directory of the borough's inhabitants for any date before the I 9 th century, ${ }^{32}$ but also provide evidence about the distribution of wealth in the city, and the relative opulence or poverty of the different wards. They also reveal to some extent the wealth of the ruling class, the mayors and members of the corporation. The distribution of the $\mathrm{I}, 024$ households listed is shown in Table I. The total may represent a population of about 5,000 , though such a figure is of course at best only an approximation. Leicester's population had grown from about

TABLE I

Distribution of Households, I670

\begin{tabular}{|c|c|c|c|c|c|c|}
\hline \multicolumn{4}{|c|}{ Ward or Liberty* } & $\begin{array}{l}\text { Households } \\
\text { taxed }\end{array}$ & $\begin{array}{c}\text { Households } \\
\text { exempt } \dagger\end{array}$ & $\begin{array}{l}\text { Total of } \\
\text { households }\end{array}$ \\
\hline I. Mr. Allsop's ward & . & . & . & 49 & 26 & 75 \\
\hline 2. Mr. Callis's ward . & . & . & . & 70 & 20 & 90 \\
\hline 3. Mr. Noble's ward. & . & . & . & 35 & 2 & 37 \\
\hline 4. Mr. Baker's ward . & . & . & . & 86 & 2 & 88 \\
\hline 5. Mr. Deacon's ward & . & . & . & 82 & 9 & 9I \\
\hline 6. Mr. Southwell's ward & . & . & . & 28 & 35 & 63 \\
\hline 7. Mr. Palmer's ward & . & . & . & II 4 & 45 & 159 \\
\hline 8. Mr. Clay's ward . & . & . & . & 64 & 17 & $8 \mathrm{I}$ \\
\hline 9. Mr. Townsend's ward & . & . & . & 60 & 25 & 85 \\
\hline I0. Mr. Overinge's ward & . & . & . & 93 & 83 & 176 \\
\hline I I. Bishop's Fee & . & . & . & 32 & o & 32 \\
\hline 12. Abbey Gate. & . & . & . & 13 & 17 & 30 \\
\hline 13. Castle and Newarke & . & . & . & 17 & o & 17 \\
\hline Total & . & . & . & 743 & $28 I$ & $\mathrm{I}, 024$ \\
\hline
\end{tabular}

* In 1664 these wards, or corresponding ones of different names, covered the following areas, though their exact boundaries cannot be ascertained: I. Sheepmarket, Loseby Lane, and Holyrood Lane. 2. St. Nicholas' parish with Applegate and Black Friars. 3. Both sides of Gallowtree Gate and the Coal Hill. 4. Saturday Market to the East Gate and Cank Street. 5. Parchment Lane, Swinesmarket, and the High Cross. 6. Sanvey Gate from St. Margaret's to Northgate Street. 7. Churchgate to the Round Hill, Goswell and Belgrave Gates. 8 . High Cross to Northgate Street, St. John's Lane and St. Peter's. 9. Northgate Street from North Gate to North Bridge and Soar Lane. Io. St. Mary's parish and from the South Gate to the High Cross including Bakehouse Lane and Redcross Street (see H. Hartopp, Hcarth Tax Returns, Leic. Michaelmas 1664 , passim).

$\uparrow \quad$ i.e. on grounds of poverty.

28 See note to Table I for the approximate extent of each ward.

29 For these liberties see below, pp. 344-7, 350, $45^{1}$.

30 E I79/240/279, mm. I-2, I3, I6.

31 Ibid.
32 The next fullest hearth-tax return is that of Michaelmas 1664 , which contains 892 names. It has been used to supply information about the approximate area of each ward: H. Hartopp, Hearth Tax Returns, Leic. Michaelmas 1664 . 
$3,480^{33}$ in 1600 , while that of the surrounding countryside had remained more or less constant. ${ }^{34}$ The distribution of wealth in the borough as exemplified in the hearth tax returns is shown in Table II. The classification of householders in this table is intended

TABLE II

Number of Hearths in relation to Households, I670

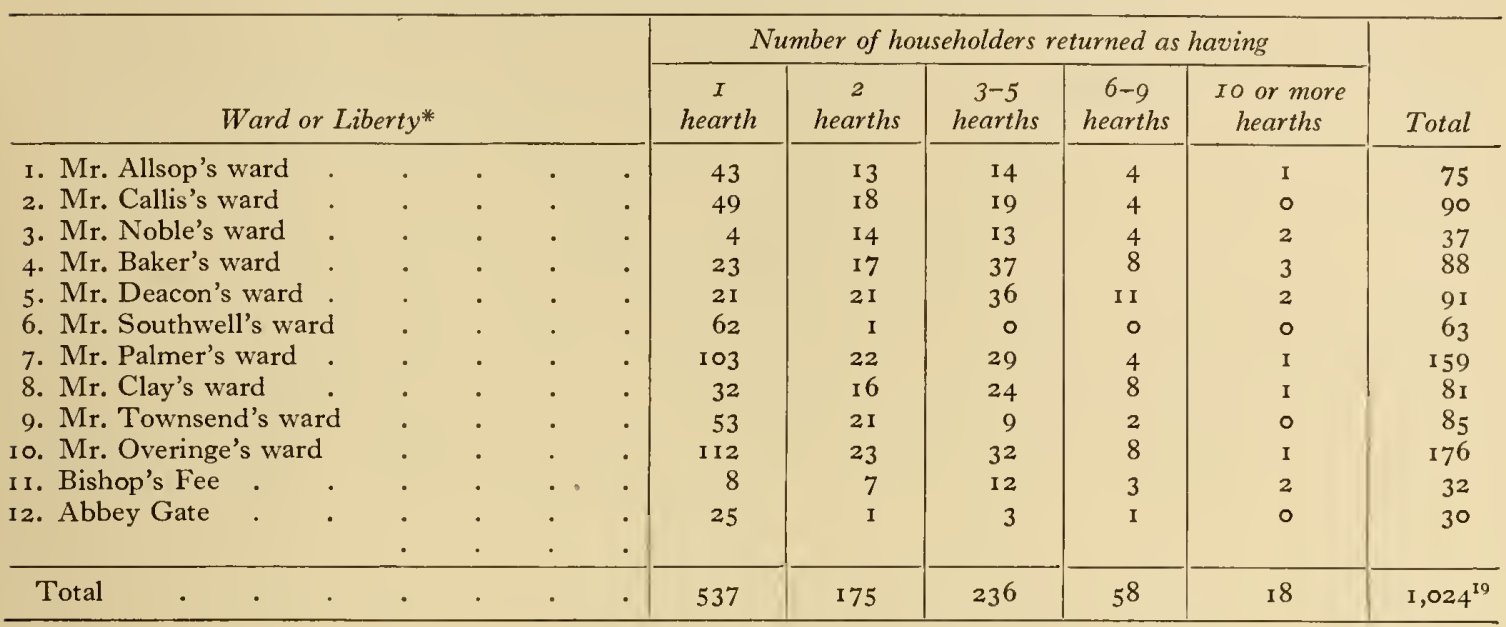

* See note to Table I.

to indicate the size of the different classes in so far as they occupied houses in accordance with their economic and social position. Of the I,024 households, 537 , or 52 per cent., had only one hearth. Of these 28I were exempt from the tax. These are the undoubted poor, who are called 'paupers' in some hearth-tax returns. 35 The remaining 256 persons with I hearth were not 'paupers', but were probably members of the ordinary labouring population. The next group, those with 2 hearths, numbered I75, or I 7 per cent. of the total. Those with I or 2 hearths include some who can be indentified as artisans or tradesmen who were freemen of the borough. For example, Jerman Pegg, who was taxed on 2 hearths in Alderman Noble's ward, was a joiner and a freeman; ${ }^{36}$ Roger Lewin, taxed on 2 hearths in Alderman Callis's ward, was a butcher and a freeman;37 William Walker, taxed on I hearth in Alderman Baker's ward, was a cooper and a freeman. ${ }^{38}$

Above such people were those living in houses with from 3 to 5 hearths. Altogether they numbered 236 , or 23 per cent. of the householders. They may be regarded as people more or less comfortable in their economic circumstances. They included several ex-mayors and future mayors, whose occupations included those of baker, brewer, fellmonger, apothecary, and woollen draper. ${ }^{39}$ Above these again is a group of $5^{8}$ householders, including many members and future members of the corporation, occupying houses of from 6 to 9 hearths. ${ }^{40}$ The highest class, with io hearths or more, numbered

${ }_{33} \mathrm{~J}$. Throsby, Antiquities of Leic. 409.

34 V.C.H. Leics. iii. $142-5$.

35 Hartopp, Hearth Tax Returns, I664, 6, 8, Iо, I I.

${ }_{36}$ Hartopp, Reg. of Freemen of Leic. II $96-1770,15 \mathrm{I}$; E $179 / 240 / 279, \mathrm{~m}$. I.

${ }_{37}$ Reg. of Freemen, 158, 173; E 179/240/279, m. I.

${ }_{38}$ Reg. of Freemen, 140, 1 53; E 179/240/279, m. I.

39 e.g. in Allsop's ward were Wm. Allsop, baker, taxed on 4 hearths (H. Hartopp, R. of Mayors of Leic. I07); Geo. Bent, baker, 4 hearths (ibid. I 14-I5); Edmund Townsend, brewer, 3 hearths (ibid. I08); Wm. Southwell, fellmonger, 4 hearths (ibid. ro8). In Baker's ward were Wm. Callis, apothecary, 3 hearths (ibid. 107); and Francis Noble, woollen draper, 4 hearths (ibid. I05). See E 179/240/279, mm. I-2.

40 e.g. in Baker's ward were Thomas Overinge, ironmonger, taxed on 6 hearths (R. of Mayors of Leic. 108-9); Andrew Freeman, baker, 6 hearths (ibid. I 09); Henry Pate, innholder, 6 hearths (ibid. I23). In Callis's ward was Wm. Deane, tailor, 6 hearths (ibid. I09); in Deacon's ward Wm. Franke, mercer, 6 hearths (ibid. 103-4). Smiths and ironworkers included Edw. Astell, 6 hearths and 2 forges, in Noble's ward, and Daniel Smith, 7 hearths and 2 forges, in Overinge's ward. See E I79/240/279, mm. I-2. 


\section{A HISTORY OF LEICESTERSHIRE}

only i 8 . Prominent in this group were several innholders, ${ }^{41}$ but it also naturally included the most successful men of business in the town. ${ }^{42}$ Rather more than 7 per cent. of the whole number of householders recorded were taxed on 6 or more hearths.

The hearth-tax returns of 1670 therefore suggest that of perhaps 5,000 people in Leicester, rather more than half were of the labouring class, some 40 per cent. were in a somewhat better position, and about 7 per cent. formed an upper class of men who were comparatively wealthy. ${ }^{43}$

For this period the register of admissions to the freedom of the borough, mostly by apprenticeship, is a valuable guide to the relative importance of the different occupations, within certain limits. ${ }^{44}$ During the decade $1660-9$ there were 238 admissions to the freedom, drawn from 49 different trades (see Table III). There were 23 butchers, I 9 tailors, I7 cordwainers, I 5 slaters, plasterers, and tallow-chandlers, I 5 mercers, I3 bakers, I2 fellmongers, and Io blacksmiths. ${ }^{45}$ During the decade $1670-9$ there were 205 admissions, drawn from 46 trades. Among these were 23 tailors, 16 cordwainers, I 5 bakers, I 5 fellmongers, and I 3 butchers. ${ }^{46}$ There are eleven trades in the $1660-9$ list which do not appear in the $1670-9$ list, whilst in the latter there are eight new trades, of which the most important is that of hosier, which first appears in 1677.47 Leicester

\section{TABLE III}

\section{Occupations of freemen of the borough admitted $1660-79^{48}$}

\begin{tabular}{|c|c|c|c|c|c|c|c|c|c|c|}
\hline & & & & & & & \multicolumn{2}{|c|}{$1660-9$} & \multicolumn{2}{|c|}{$1670-9$} \\
\hline \multicolumn{7}{|c|}{ Occupation } & $\begin{array}{l}\text { Number of } \\
\text { admissions }\end{array}$ & $\begin{array}{l}\text { Percentage of } \\
\text { total admissions }\end{array}$ & $\begin{array}{l}\text { Number of } \\
\text { admissions }\end{array}$ & $\begin{array}{l}\text { Percentage of } \\
\text { total admissions }\end{array}$ \\
\hline Textile manufactu & $\operatorname{are}^{*}$ & . & . & - & . & - & 25 & I I & 28 & 14 \\
\hline Clothing trades $\uparrow$ & . & . & . & . & . & . & $5^{6}$ & 23 & $4^{8}$ & 24 \\
\hline Food and drink tr & ades & . & . & . & . & . & 48 & 20 & 44 & 21 \\
\hline Leather trades & . & . & . & . & - & . & 9 & 4 & 5 & 2 \\
\hline Agriculture . & . & . $\quad$. & . & . & . & . & I 8 & 8 & 20 & 10 \\
\hline Building and meta & al-worl & rking crafts & . & . & - & . & 36 & I 5 & 20 & Io \\
\hline Personal services & . & . $\quad$. & - & . & . & . & 8 & 3 & 7 & 3 \\
\hline Retail and trade & . & . & - & . & . & . & 9 & 4 & 7 & 3 \\
\hline Miscellaneous & . & . & . & . & . & . & 8 & 3 & 20 & 10 \\
\hline Unknown . & $\cdot$ & $\cdot$ & . & - & - & . & 21 & 9 & 6 & 3 \\
\hline Total & . & . & . & . & . & . & 238 & 100 & 205 & 100 \\
\hline
\end{tabular}

* Including weavers, fellmongers, jersey combers, shearmen, dyers, hosiers, and silk weavers.

$\dagger$ Including mercers, tailors, collar-makers, haberdashers, haberdashers of hats, woollen drapers, and cordwainers.

emerges clearly as a town with no predominant industry or trade. It was economically a well mixed community with a wide variety of trades producing consumer goods, and it was still a market-town with a strong agricultural character.

The social importance of the different occupations during the late $\mathrm{I} 7$ th century can best be ascertained by an analysis of the trades followed by the mayors and by the members of the Twenty-four and the Forty-eight. There were three successive mayors in $\mathrm{I} 66 \mathrm{I}, \mathrm{I} 662$, and $\mathrm{I} 663$ who were woollen drapers, ${ }^{49}$ but from $\mathrm{I} 664$ onwards there are

41 e.g. Gabriel Newton, taxed on 14 hearths, and Joseph Craddock, 2 I hearths, in Noble's ward, and John Pares, Io hearths, in Palmer's ward. See $R$. of Mayors of Leic. I I7-18, 123, I42, and E I79/240/279, mm. I-2.

42 e.g. Ric. Palmer, a successful vintner ( $R$. of Mayors of Leic. I06), taxed on 17 hearths in Bishop's Fee, and John Wilkins, whose mechanical genius made him a successful clockmaker (ibid. 121), taxed on 15 hearths in Overinge's ward; see E I79/240/279, mm. I-2, I3, I6.

43 Compare W. G. Hoskins, Industry, Trade and People in Exeter, $1688-1800$, who gives 45 per cent., 44 per cent., and I I per cent. for similar classes in Exeter in 1672 .

44 See above, pp. 76-77, for the value of figures derived from this source.

45 These statistics are derived from Reg. Freemen of Leic. II96-I770, 143-53. The occupations of slater, plasterer, and tallow chandler seem to have been regarded as a single trade: see below, p. 184 .

46 Reg. Freemen of Leic. I I 96-I 770, I 53-63.

47 Ibid. 159.

48 Figures based on Reg. Freemen of Leic. I I96-I770, I $43-63$. 
no instances of two consecutive mayors being drawn from the same trade. ${ }^{50}$ Among the aldermen of the Twenty-four in 1660 there were no fewer than 7 mercers and 3 woollen drapers. Altogether 12 different trades were represented among the aldermen. ${ }^{\text {II }}$ Among the councilmen of the Forty-eight in 1660 , there were 9 mercers and 5 butchers, but 24 different trades were represented.52 The mercers were thus the most prominent amongst the socially important trades, but no single occupation was really predominant.

The 1670 hearth-tax return is useful also in giving information about the relative size of houses. Table IV shows the distribution of hearths, taxed and untaxed, among the wards. For the borough as a whole 2,426 hearths are enumerated, taxed and untaxed,

TABLE IV

Distribution of Hearths, 1670

\begin{tabular}{|c|c|c|c|c|c|c|c|c|}
\hline \multirow{2}{*}{\multicolumn{4}{|c|}{ Ward or Liberty* }} & \multicolumn{3}{|c|}{ Hearths } & \multirow[b]{2}{*}{ Households } & \multirow{2}{*}{$\begin{array}{c}\text { Average number } \\
\text { of hearths } \\
\text { per household }\end{array}$} \\
\hline & & & & Taxed & Exempt $\uparrow$ & Total & & \\
\hline I. Mr. Alsopp's ward & . & . & . & I 35 & 26 & I6I & 75 & $2 \cdot I$ \\
\hline 2. Mr. Callis's ward & . & . & . & I 59 & 20 & I 79 & 90 & $2 \cdot 0$ \\
\hline 3. Mr. Noble's ward & . & . & . & 145 & 2 & I 47 & 37 & $4^{\circ} \mathrm{O}$ \\
\hline 4. Mr. Baker's ward & . & . & - & 287 & 2 & 289 & 88 & $3 \cdot 3$ \\
\hline 5. Mr. Deacon's ward & . & . & . & 337 & 9 & 346 & $9 \mathrm{I}$ & $3 \cdot 8$ \\
\hline 6. Mr. Southwell's ward & . & . & . & 29 & 35 & 64 & 63 & $\mathrm{I} \cdot \mathrm{O}$ \\
\hline 7. Mr. Palmer's ward & . & . & . & 246 & 45 & $29 \mathrm{I}$ & I 59 & $\mathrm{I} \cdot 8$ \\
\hline 8. Mr. Clay's ward . & . & . & . & I 98 & 17 & 215 & $8 I$ & $2 \cdot 6$ \\
\hline 9. Mr. Townsend's ward & . & . & . & I I 2 & 25 & 137 & 85 & $I \cdot 6$ \\
\hline Io. Mr. Overinge's ward & - & - & - & 260 & 83 & 343 & 176 & $I \cdot 9$ \\
\hline I I. Bishop's Fee & . & . & . & I 14 & o & I 14 & 32 & $3 \cdot 6$ \\
\hline 12. Abbey Gate & . & - & - & 27 & I 7 & 44 & 30 & $I \cdot 5$ \\
\hline I3. Castle and Newarke & $\cdot$ & - & - & 96 & o & 96 & I 7 & $5 \cdot 6$ \\
\hline Total & . & . & - & 2,145 & $28 I$ & 2,426 & I, 024 & $2 \cdot 4$ \\
\hline
\end{tabular}

* See note to Table I.

$\uparrow$ i.e. on grounds of poverty.

giving an average of $2 \cdot 4$ hearths per household, compared with $2 \cdot 6$ recorded at Exeter at a similar assessment in 1672.53 Of the 2,426 hearths in the town, 2,145 were taxed and 28I were discharged from payment on the ground of the householders' poverty. The $28 \mathrm{I}$ householders thus discharged, each assessed on one hearth only, formed 27 per cent. of the total number of householders recorded in the borough in 1670 , compared with nearly 40 per cent. similarly discharged at Exeter in 1672.54 The preceding table shows that at Leicester, as at Exeter, ${ }^{55}$ wards fell into definite groups when considered from the point of view of their wealth. Six wards at Leicester were well above the average, six well below, and one about average. Southwell's ward was by far the poorest; it lay outside the walls, on both sides of Sanvey Gate, from St. Margaret's Church to Northgate. ${ }^{56}$ Only I of the 63 households in the ward had more than I hearth. Leicester castle, with the Newarke, was the wealthiest part of the town; only 4 of the 17 households there had fewer than 4 hearths, and most of the householders were designated 'Mr.' in the returns, possibly a sign of a relatively high social status.

With the restoration of Charles II came the restoration of the Anglican church. That the dissenters at Leicester, a strongly Puritan town under the Commonwealth, did not submit quietly. can be seen from the calendar of prisoners for March I666, which contains a list of seven persons detained 'for suspicion of breaking into the parish church of

\footnotetext{
so Ibid. I o6 sqq.

${ }^{51}$ Leic. Boro. Rec. I603-88, 606; Reg. Freemen of Leic. II $96-1770$, passim.

52 Leic. Boro. Rec. I603-88, 606; Reg. Freemen of Leic. II96-I770, passim.
}

53 Hoskins, Industry, Trade and People in Exeter, I 19. 54 Ibid. I I 5-I6. 55 Ibid. I 16-I7.

56 This was Townsend's ward in 1664 , and presumably occupied the same area in 1670 : see Hearth Tax Returns, Leic. Michaelmas, I664, 20, and E I79/240/279, m. I d. 
St. Martin's in the said borough, and defilinge the communion vessells with their excrements'. ${ }^{57}$ For the sessions of April and September 1666 there were many cases of persons tried for not attending divine service, ${ }^{58}$ and in $1670-1$ Robert Atton, one of the Forty-eight, was dismissed for reasons which included his refusal to come to church on Sundays. ${ }^{59}$

\section{LOCAL GOVERNMENT AND ADMINISTRATION}

In 1660 the corporation of Leicester consisted of the mayor, 24 aldermen, and 48 councilmen. The mayor was always chosen from the Twenty-four, and the two chamberlains, who were in charge of the corporation's finances, were chosen from the Fortyeight. The town officials included two bailiffs, ${ }^{60}$ the town clerk, the recorder, the town solicitor, the steward, and a retinue of mace-bearers, common sergeants, and other minor functionaries. ${ }^{6 I}$ Ten of the aldermen were appointed by the corporation to administer the ten wards, assisted by a constable and a thirdborough for each ward. ${ }^{62}$ There were also various commissions and committees, usually consisting of the mayor and chamberlains with several other members, set up temporarily or permanently to carry out certain definite functions; there were, for example, at various dates committees for letting the town lands, for regulating the South Field, for markets, finance, and pavements. ${ }^{63}$ At the beginning of this period the mayor was receiving a salary of $£ 40$ a year, which by 1835 had risen to $£^{2} 424$ s. Iod. The mayoralty naturally involved the expenditure of money and time, especially as the volume of business continually increased. The finances were in the hands of the two unpaid chamberlains, who were appointed annually. Frequently the office involved its holders in financial loss, and there were often long delays in making the yearly audit. The great amount of work which fell to these honorary officers, who though often conscientious were not always efficient, meant that they relied a great deal upen the corporation's professional officials, who thus acquired great influence in the conduct of municipal affairs. ${ }^{64}$

Thornas Baskerville's description of the rough and insanitary state of Leicester's streets, as they were at the time of his visit in the reign of Charles II, has already been quoted. ${ }^{65}$ The responsibility for street repairs rested primarily on the owners of property fronting the streets, and on the parishes in cases where the owners failed to take.effective action. ${ }^{66}$ The corporation in its public capacity had no responsibility for street repairs, but as the owner of a great deal of property in the town it was liable for the repair of the streets upon which its property abutted, 67 and orders were frequently given for the repair of streets for which the corporation was responsible. ${ }^{68}$ In addition the corporation at times made contributions in the general interest for repair of street surfaces, the widening of streets, the building of culverts, and the removal of obstructions. ${ }^{69}$ In 1697 the aldermen of the wards were ordered to call the constables to their assistance to inspect their wards 'to see how the streets are kept in repair, and to cause the constables to take an account of in writing of the persons that make neglect'. In 17 I6,

57 Leic. City Mun. Room, Hall Papers, I665-70, no. 18.

58 İbid. nos. 80-82. 59 Ibid. $1670-5,17$.

60 In practice there was only one bailiff, and his functions were purely nominal: R. W. Greaves, Corp. of Leic. 21 .

6r Leic. City Mun. Room, Chamberlains' Accts. 16605, p. 9.

62 Greaves, op. cit. 23-24; Leic. Boro. Rec. I603-88, 259 ; Nichols, Leics. i. 395.

63 Greaves, op. cit. 17-1 8, 23-25; Leic. Boro. Rec. I603$88,259$.

${ }^{64}$ Greaves, Corp. of Leic. I2, I3-17.
65 Hist. MSS. Com. I3 Rep. App. II, Portland, ii. 3078 ; see above, p. I53.

66 For the general position, see S. and B. Webb, King's Highway, I 4 sqq.

${ }^{6}$ A list of $175^{8}$, giving the streets for which the corporation was responsible, is printed by Nichols, Leics. i. 469.

68 Leic. City Mun. Room, Hall Bk. I Feb. I717, 12 Feb. I725, 28 Feb. I 728, 22 May, 29 June, I 2 Aug. I 744, 12 Nov. 1763 , I 6 Jan. I 800, 3 I Mar. I 800, May I802 (p. 338).

69 Ibid. 22 Oct. 1697. 
and again in 1730 , the alderman, with their constables, were ordered to inspect their wards, noting which streets were out of repair and what parts of the highways ought to be maintained by the corporation. ${ }^{70}$ In addition the corporation at times made contributions ex gratia for the repair of street surfaces, the construction of new streets, the widening of street culverts. ${ }^{71}$ The corporation's actions in financing street repairs and improvements were sometimes less generous than appears at first sight. At times contributions were made to the cost of repairs only on condition that for the future the parish involved would bear the whole responsibility for the street in question, and the corporation was sometimes actuated by a desire to increase the revenue derived from its own property. ${ }^{72}$ In general the corporation seems to have been anxious to reduce its liability for street repair to a minimum, and on several occasions during the i 8 th century it was involved in litigation with parishes about responsibility for repairs. ${ }^{73}$ The practice of ordering aldermen to report on the condition of the streets in their wards has already been mentioned. Later in the I8th century the chamberlains seem to have had discretion to pay for street repairs up to a certain sum yearly, ${ }^{74}$ and by about i 800 a regular pavement committee of the corporation developed, with authority to deal with the streets for which the corporation was liable. ${ }^{75}$

The road from Market Harborough to Loughborough, running through Leicester along Gallowtree Gate and Belgrave Gate, was from 1726 onwards under the care of a turnpike trust. In 1774 the turnpike trustees gave orders that the part of the road which ran through Leicester should be paved, and in I 774 a causeway, made apparently of rough stone blocks, was constructed. ${ }^{76}$ In the I790's part of the turnpike through Liecester was repaved with granite setts.77

The parishes do not seem to have been very effective in maintaining the streets until the Igth century, though before that date they occasionally paid for repairs to individual streets. ${ }^{78}$ At times improvements were effected by public subscription; thus in 1782 the removal of a row of huts in Belgrave Gate was paid for by a fund raised by the officials of St. Margaret's parish;79 in 1787 some kind of public fund seems to have been raised for street paving; $;^{80}$ and in I79I Southgate Street was paved and provided with footways, apparently again as a result of public subscription. ${ }^{81}$ In the igth century some parishes were more active; in $\mathbf{1} 822$ St. Mary's, after being indicted for neglect in repairing streets, decided to carry out repairs at the expense of a rate, and in 1832 St. Margaret's parish gave orders that street repairs were to be financed from the rates. ${ }^{82}$ The general result of all these efforts seems to have been that by about 1830 most of Leicester's streets were paved in some fashion, ${ }^{83}$ many of them with stone setts or cobbles. ${ }^{84}$

Until the Igth century the lighting of the borough's streets was even less adequate than the paving. The first evidence for any kind of street lighting occurs in 1768 , when the inhabitants of Gallowtree Gate raised a fund amongst themselves for oil lamps to illuminate their street, ${ }^{85}$ and in 1770 Belgrave Gate was similarly provided with lamps by its inhabitants. ${ }^{86}$ In 1777 the trustees of the Loughborough to Market Harborough

70 Ibid. 19 Oct. 1716, 5 May 1730.

71 Ibid. 14 Sept. I789, 2 Sept. I 794, 3 I Dec. I798, 5 Aug. 1808, 28 Mar., I May, 1820, I 7 Mar., 2 June, 3 Sept., 1824,24 Mar. 1834.

72 Greaves, Corp. of Leic. 30.

73 Ibid. 29-30.

74 Leic. City Mun. Room, Hall Bk. 26 Sept. I 720.

75 Greaves, Corp. of Leic. 29.

76 Russell, Leics. Road, 87.

77 Ibid. 89 . The decision to repave had been made in I $787:$ V.C.H. Leics. iii. 8 I.

78 Vestry Bk. and Accts. of Churchwardens of St. Mary's, Leic. ed. J. R. Abney, 24, 26, 40, 43, 44, I I 2 et passim.
79 Thompson, Hist. of Leic. ii. 173.

$80 \mathrm{~J}$. Throsby, Hist. of Leic. I70. It was perhaps in connexion with this that flagstones from Yorks. were being brought to Leicester in 1787 for street paving: Leic. $7 \mathrm{nl}$. 17 Nov. 1787 .

81 Thompson, Hist. of Leic. ii. 199.

82 S. and B. Webb, Statutory Authorities (1922), 303.

83 Curtis, Topog. Hist. Leics. I I 5 .

84 See the street surfaces in the engravings, after drawings by John Flower, published in Views of Ancient Buildings in the Town and Co. of Leic. (1820).

85 Thompson, Hist. of Leic. ii. 136.

86 Ibid. ii. 139 . 


\section{A HISTORY OF LEICESTERSHIRE}

turnpike, which ran along both streets, became responsible for the lamps, and remained so until gas lighting was introduced. 87 In 1770 the corporation ordered six street lamps to be erected at its expense. 88 The failure to obtain any general Improvement Act for the borough made it impossible to carry out any systematic plan for street illumination. In I $82 \mathrm{I}$ a gas company was set up at Leicester, and the corporation then authorized the magistrates to place gas lamps on the Exchange and other public buildings, and at any other points where they might consider that lights should be provided by the corporation. ${ }^{89}$ In 1822 the corporation decided to subscribe towards the cost of lighting the Saturday market place with gas, and to place gas lights at the High Cross and Northgates. ${ }^{90}$ In 183 I-2 the three most important parishes, St. Mary's, St. Martin's, and St. Margaret's, each assumed control of the lighting arrangements within its own boundaries and some further gas lamps were installed. ${ }^{91}$ The gas supplied seems to have been unsatisfactory in quality. ${ }^{22}$

The streets were not only dark at nights, they were dirty. The corporation did make some attempt to deal with the problem of street cleansing. During most years in the late $\mathrm{I} 7$ th century fees were paid for sweeping the streets and removing the dirt. ${ }^{93}$ In I 686 a permanent scavenger was appointed to clean the streets, and in I689 the town beadle was given the task of sweeping those streets for whose repair the corporation was responsible. ${ }^{44}$ In the 1730 's scavenging was controlled by the aldermen in their respective wards, and paid for by a scavengers' rate. ${ }^{95}$ It is not clear how long these arrangements continued, ${ }^{96}$ but in any case the provision for street cleansing seems to have been quite inadequate. In 1774 the trustees of the Loughborough to Market Harborough turnpike found it necessary to forbid the residents in Belgrave Gate and Gallowtree Gate to deposit garbage in the roadway, and from 1776 onwards the trustees made their own arrangements for removal of refuse from the section of their road that ran through Leicester. ${ }^{97}$ In 1813 it was said that the Horsepool, near the Welford Road, had become so choked up with filth as to be a serious nuisance. ${ }^{98}$ In scavenging, as in other public services, the cumbersome system of administration, perpetuated because of repeated failures to obtain an Improvement Act, prevented the evolution of any efficient system of dealing with the problems created by the borough's expansion.

The maintenance of public order in Leicester was, in $\mathbf{6} 660$, one of the many duties of the petty constables, of whom there was one for each of the ten wards of the town. ${ }^{99}$ Each constable had the power to call upon the inhabitants of his ward to perform the duty of watch and ward, though the duty was difficult to enforce. ${ }^{I}$ This inadequate provision for the town's security was supplemented on critical occasions by a greatly increased guard, ${ }^{2}$ and various attempts were made to strengthen the police system generally. In 1688 the corporation appointed a bellman to watch the town at night, ${ }^{3}$ but this arrangement does not seem to have become permanent. In 1706 two bellmen were appointed for the same purpose; this time the appointments were lasting, and the two bellmen survived until $\mathrm{I} 835 .{ }^{4}$ In the winter of $\mathrm{I} 748-9$ an unusually large number

87 Russell, Leics. Road, $85-86$.

88 Greaves, Corp. of Leic. 27.

89 Leic. City Mun. Room, Hall Bk. 29 Aug. I 82 I.

90 Ibid. 28 Aug. I 822.

91 Ibid. 27 Aug. 1832; Greaves, Corp. of Leic. 34.

92 Greaves, op. cit. 27; Leic. Inl. 1o Dec. 1830.

3 e.g. Leic. City Mun. Room, Chamberlains' Accts. $1660-5$, p. 9 .

94 Ibid. Chamberlains' Accts. 1688-9, 1689-90; Hall Bk. Whit Mon. 1686, I 8 May 1730.

95 Greaves, Corp. of Leic. 29.

96 Ibid. $29 \mathrm{n}$. The Corporation was still paying for having the streets swept in 1757: Leic. City Mun. Room,
Chamberlains' Accts. 1 757-8.

97 Russell, Leics. Road, 87-88.

98 Leic. City Mun. Room, Hall Bk. 6 July 18 I3.

99 Leic. City Mun. Room, Hall Papers, $1660-2$, nos. 5, I I3; Greaves, Corp. of Leic. 24, where the no. of wards is given as 12 . In the late 17 th cent. there were only 10 : see above, p. 69, Nichols, Leics. i. 395, and E $179 / 240 / 279$.

1 Greaves, op. cit. 27.

2 Leic. Boro. Rec. $1603-88,494,549$.

3 Greaves, Corp. of Leic. 26. In $165^{8}$ the corporation, apparently continuing an existing arrangement, appointed 2 men to patrol the town at night: Leic. Boro. Rec. I603$88,448.4 \quad 4$ Greaves, op. cit. 27. 
of cases of housebreaking occurred, with the result that the corporation offered a reward of $£ 20$ to anyone arresting a burglar. 5 The inclusion of powers to establish a more efficient watch in the local bill which the corporation endeavoured to have passed into law in I 749-50 seems also to have been due at least partly to the same outbreak of crime. ${ }^{6}$ Although it failed to obtain increased powers by a special Act, the corporation did provide that each alderman should appoint an adequate night watch; the watchmen were to be paid Is. each a night, and the system was to last until I March I 749.7 Though the arrangement was prolonged beyond that date it did not become permanent, ${ }^{8}$ and the system of policing remained unsatisfactory. When disorders of any kind took place, as in 1773,1787 , and 1795 , the constables and the borough authorities proved quite unable to check violence. 9 'This state of affairs was of course not an exceptional one, and Leicester was perhaps no more deficient in the means for maintaining order than were most other towns.

In the early i 9 th century some steps were taken to improve matters, and by 1833 the ward constables of the town, with their assistants, numbered 30 and there were also about 40 general constables, the whole under a chief constable with a salary of $f_{5} \circ \mathrm{a}$ year. ${ }^{10}$ This, however, was still an inadequate force.

The borough had also to maintain the means of punishing offenders. There were stocks in each ward, in the charge of the constables, ${ }^{\text {I I }}$ and the town also possessed a ducking stool, situated at the West Bridge, and apparently last used in $1786 .{ }^{12}$ The most important instrument of correction, however, was the town gaol. The old borough gaol, built in $\mathrm{I} 6 \mathrm{I} 4,{ }^{\mathrm{I3}}$ stood at the junction of High Cross Street and Causeway Lane. ${ }^{14}$ By the late $\mathrm{I} 8$ th century the prison was in a very unsatisfactory state. Howard, the philanthropist, who inspected it in 1782 , described it as very close and never whitewashed, with 'very offensive' sewers. On a later visit, in 1787 , he found that there was no improvement. ${ }^{15}$ It is to the credit of the corporation that unlike many other public bodies they took notice of Howard's strictures, and in 1793 a new prison was built to the design of the well-known architect John Johnson. ${ }^{16}$ An Act of 1823 provided for the repair of a number of prisons, including that of Leicester, and authorized the borough justices to levy a special rate for the purpose. ${ }^{17}$ Using their powers under this Act, the Leicester justices began to rebuild the town gaol, ${ }^{18}$ and a large debt was incurred. The contract for the new prison had been-allotted to a member of the corporation, and the new gaol rate was very unpopular. ${ }^{19}$ The county gaol, built in $\mathrm{I} 79 \mathrm{I}$, stood in Highcross Street near the town gaol, and this was taken over by the borough justices in 1828 , the county having recently replaced it by a new one. ${ }^{20}$ The borough then gave up both the old town gaol and the still incomplete new structure. ${ }^{2 \mathrm{I}}$ The prison thus acquired in $\mathrm{I} 828$ remained the borough gaol until transferred to the Home Office under an Act of 1877.22

Precautions against fire in the borough.were to some extent controlled by the corporation. ${ }^{23}$ In $\mathrm{I} 68 \mathrm{I}$ the purchase of a fire engine was ordered by the corporation, ${ }^{24}$ but after

5 'Thompson, Hist. of Leic. 76.

6 C.F. xxv. 927-8, 941, 970 ; and see above, p. 129.

7 Thompson, Hist. of Leic. ii. 76.

8 Greaves, Corp. of Leic. 27.

9 Thompson, Hist. of Leic. ii. I47-8, I 88-9, 2 I4-15.

10 Greaves, Corp. of Leic. 26.

II Ibid. 25; Leic. City Mun. Room, Hall Bk. 3 Aug.

1733, i I Oct. 1743 .

I2 Thompson, Hist. of Leic. ii. I 82.

13 Leic. Boro. Rec. I603-88, I 50-I.

I4 [Susannah Watts], Walk Through Leic. (I 804), frontispiece map.

15 Nichols, Leics. i. 53 I.

${ }^{16}$ Ibid. and plate xxviii. There was also a town bride- well next to the gaol in I 79I: Throsby, Hist. of Leic. 379. It had been in existence in 1666 : Leic. City Mun. Room, Hall Papers, $166_{5}-7$, no. 124.

${ }^{17} 4$ Geo. V, c. 64.

18 Greaves, Corp. of Leic. 40 ; and see above, p. I 43.

19 Greaves, op. cit. 40-4I ; and see above, pp. I42-3.

20 Watts, Walk Through Leic., frontispiece map. A view of the county gaol is in Nichols, Leics. i. 326 .

${ }_{21}$ Greaves, op. cit. 40; Billson, Medieval Leic. 46

22 J. Storey, Hist. Sketch of Boro. of Leic. 45.

${ }_{23}$ See above, p. 73, for fire precautions at an earlier period.

${ }_{24}$ Leic. Boro. Rec. $1603-88,555-6,558$. 
this nothing further seems to have been done until I 744. Then the corporation offered to subscribe fio towards the cost of buying 'one of Mr. Newsham's new invented engines for extinguishing fire', the rest of the cost of $£ 55$ to be met by subscriptions from private individuals. ${ }^{25}$ As the private subscribers proved able to meet the whole cost of one engine, the corporation decided to buy a second one for $£ 40 .{ }^{26}$ There is no record of further engines being purchased. In 1797 the Phoenix fire office presented a fire engine to the borough. ${ }^{27}$ In 18 io a committee was set up to concert the keeping of fire engines with the various fire offices, ${ }^{28}$ and during the early i 9 th century precautions against fire, in Leicester as elsewhere, seem to have been largely in the hands of the fire insurance companies, though the corporation fire engines still existed, and were 'played' four times a year. ${ }^{29}$

One further need of the town that required municipal supervision was the watersupply. Water was obtained from two main sources, the conduit and the public and private wells, though many houses also had arrangements for collecting rain water. ${ }^{30}$ The conduit, which had been built in 1612 , bought fresh water to the Market Place from springs outside the town in St. Margaret's Field. ${ }^{31}$ It was kept in repair by the corporation. ${ }^{32}$ In every ward of the town there were public wells, cared for by annually elected well reeves who collected from the householders the sums required to maintain the wells in good order. A by-law enacted in 1759 authorized the establishment of pumps at all Leicester's public wells and provided that there should be in each ward two pump reeves, who were empowered to levy a pump rate. ${ }^{33}$ As the $\mathrm{I} 8$ th century progressed the corporation seems to have become less and less inclined to spend money on the conduit, and in 177 I the townsfolk had themselves to pay for the building of a new cistern. ${ }^{34}$ Until well after 1835 the water-supply of the town was quite inadequate and various schemes were put forward for its improvement. In the late 17 th century waterworks had been set up at the Castle mill to pump water through earthenware pipes to buildings in the town. Both this scheme and a similar one projected in the 18 th century came to nothing. ${ }^{35}$ As late as 1845 it was said that Leicester was dependent on pumps and private wells, so that the water-supply was quite insufficient for purposes of cleanliness. ${ }^{36}$

The defects of the borough's administration during the period ending in 1835 cannot be attributed solely to the inefficiency of a corrupt and oligarchic corporation, for the division of power that existed within the borough made any vigorous action difficult. Many functions, notably poor relief and road maintenance, remained the responsibility of the individual parishes. ${ }^{37}$ 'The parishes were supervised, through the cumbersome proceedure of presentment and indictment at quarter sessions, by the borough justices of the peace, who were always senior members of the corporation, and who were the most effective body in matters concerning the government of the whole town. Finally there was the corporation itself, with its power to enact by-laws, and its general responsibility for the welfare of the borough. ${ }^{38}$ The situation was further complicated by the existence of the liberties, areas which, although part of the town, were not under the undisputed control of the borough authorities, and which ultimately escaped from

\footnotetext{
25 Leic. City Mun. Room, Hall Bk. 29 June 1744. For Ric. Newsham's inventions, see D.N.B.

26 Hall Bk. Io Aug. I 744 .

27 Ibid. 18 Dec. 1797.

28 Ibid. 9 Mar. 18 Io.

29 Leic. City Mun. Room, Chamberlains' Accts. 18323; 2nd Rep. Com. on Health of Towns, App. (2) [610], p. 268, H.C. (I 845), xviii.

30 See e.g. advertisements for houses in Leic. $Z_{n l}$. I 9 Apr. I799, I I Sept. I 80I, I Nov. 182 I.

Greaves, Corp. of Leic. 3I ; Nichols, Leics. i. 486 n., 533 .
}

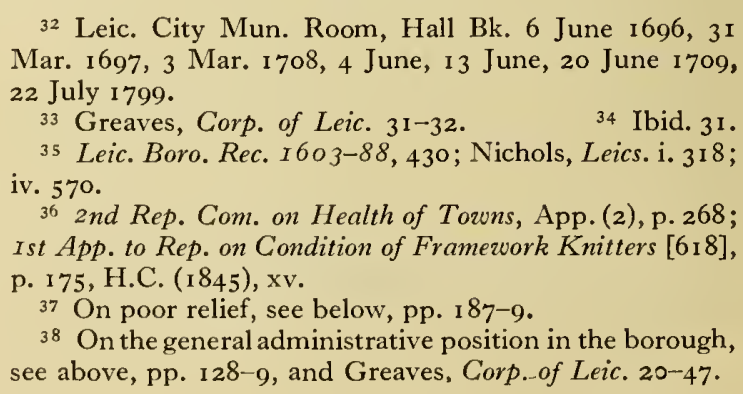

32 Leic. City Mun. Room, Hall Bk. 6 June 1696, 3 I Mar. I697, 3 Mar. I 708, 4 June, I 3 June, 20 June I 709, 22 July 1799.

33 Greaves, Corp. of Leic. 31-32. 34 Ibid. 31 .

35 Leic. Boro. Rec. I603-88, 430; Nichols, Leics. i. 318 ; iv. 570 .

${ }_{36} 2$ nd Rep. Com. on Health of Towns, App. (2), p. 268; Ist App. to Rep. on Condition of Framework Knitters [618], p. 175, H.C. (1845), xv.

37 On poor relief, see below, pp. $187-9$.

38 On the general administrative position in the borough, see above, pp. 128-9, and Greaves, Corp.of Leic. 20-47. 
borough control altogether. As the liberties included some of the wealthiest parts of Leicester, the borough's lack of any clear right to levy rates in them was a serious disadvantage, apart from the more obvious difficulties caused by the existence of such areas outside the corporation's jurisdiction. ${ }^{39}$

Various attempts were made by the borough authorities to remedy the ineffective system under which the town was administered. The steps taken to obtain a union of the Leicester parishes for poor-relief purposes will be described elsewhere. ${ }^{40}$ In I $749-50$ an unsuccessful attempt was made to obtain a local Act, giving powers to light and clean the streets, to maintain the public wells and pumps, to keep an adequate force of watchmen, and to levy rates for all these purposes. ${ }^{4 I}$ An attempt, largely actuated by the justices' desire to obtain sufficient funds for the upkeep of the town gaol, was next made to extend the rating powers of the borough justices by levying a general borough rate, and by asserting the borough justices' rights of jurisdiction over the liberties. After prolonged litigation the borough justices failed to establish their right to exercise control over the liberties. ${ }^{42}$ Later, in 1822 and in 1831 , further attempts were made to obtain a local Act for the improvement of the town, but without success. ${ }^{43}$ Leicester thus remained one of the few English towns of any size without such an Act.

\section{THE TOWN FIELDS}

By the beginning of the $\mathrm{r} 8$ th century the South Field was the only one of the town fields in which the freemen as a whole had any interest. Common rights in the West Field if any existed had apparently come to an end in the 12th century. ${ }^{44}$ The East Field was inclosed in 1764 . By the 18 th century it had come to be considered as largely the concern of St. Margaret's, the important and independent parish in which the field lay. The history of the East and West Fields has been dealt with elsewhere. ${ }^{45}$

With the South Field, however, both the corporation and the general body of freemen were closely concerned. The field, with the adjacent meadows, covered some 600 acres, much of which was included in the Newarke Grange farm bought by the corporation early in the 17 th century. ${ }^{46}$ Even in the 18 th century, though the town was becoming partly industrialized, townsmen still possessed their own beasts, and valued their common rights. The growth of larger farms in the South Field appeared to endanger these rights, and consequently arouse the freemen's opposition. As early as 1675 the freemen petitioned against the infringement of their pasture rights. ${ }^{47}$ Some idea of the size of the farms in the fields, and of the rents paid for them, can be gathered from the $2 \mathrm{I}$-year leases made in I 7 I I of the corporation's property in the South Field. Of the six farms into which the corporation's lands were divided, two were of 4 yardlands, one of $3 \frac{1}{2}$ yardlands, and two others of 3 yardlands; the size of the remaining farm is not precisely stated. The rents varied from $£, 52$ to $£ 24 .^{48}$

The corporation's policy in the South Field was often discussed in the Common Hall, and the Hall Books are full of resolutions, orders, and inquiries concerning the management of the land. ${ }^{49}$ In the early 18 th century the corporation was divided within itself about the best policy, 'whether to enclose or lay down to herbage' or to make no change. ${ }^{50}$

${ }^{39}$ On the position of the liberties, see above, pp. 16 , 57, and below, pp. 343-7, 387-8.

40 See below, pp. $187-9$.

${ }^{41}$ C.F. xxv. 927, 928, 941, 990; Nichols, Leics. i. 447 ;

Greaves, Corp. of Leic. 32-33; and see above, p. 129.

42 See above, pp. I29 sqq.

${ }^{43}$ Greaves, Corp. of Leic. 33; and see above, pp. 142 sqq.

44 See below, p. 38 r.

45 See below, pp. 334-5, 38 I. ${ }^{46}$ See below, pp. 370-1.
47 Nichols, Leics. iv. 347.

48 Ibid. i. $441-2$.

49 Leic. City Mun. Room, Hall Bk. 3 I Mar. I699, I 9 Sept. I 705, 2 July, 27 July, 20 Sept. I708, 9 Feb., 27 Mar. 1711, 22 Feb. 1712, 9 May 1720, 26 July 1751, 2 I Jan. 1756,6 Apr. I 758,25 May I 770, I 8 Feb. I 778 , 22 May I781, I 5 July, 27 Nov. I795, I Apr., io June I 796,31 May i 800.

50 Ibid. 23 July I708; Greaves, Corp. of Leic. 81. 


\section{A HISTORY OF LEICESTERSHIRE}

There was much opposition to inclosure, which would have ended the freemen's rights of common. A proposal to obtain an inclosure Act in 1708 , though supported by a majority of the corporation, failed to take effect. ${ }^{51}$ In I 7 I I there were protests about a plan to divide the corporation's property in the field into six large farms, and in I 730 the corporation, presumably because of the extensive opposition, decided against inclosure. ${ }^{52} \mathrm{~A}$ violent contest arose from the granting in $175^{2}$ of a lease of $55^{8}$ acres of land in the field and adjacent meadows to three members of the corporation, Oliver, Phipps, and Ayre, who undertook to inclose the land in three large farms at their own expense. ${ }^{53}$ Although it was provided that the fields were to be laid open from each September for the usual period for freemen to turn in their stint of cattle, ${ }^{54}$ much opposition was aroused, and the situation was made worse by a proposal of the corporation in I 754 to exclude such of the freemen as it saw fit from pasturing their livestock in the field. Violence occurred, and fences in the field were burnt down. ${ }^{55}$ Attacks were made on the houses of members of the corporation, who were divided amongst themselves about the wisdom of the policy that had been pursued. ${ }^{56}$ In consequence of these events new leases were made of the corporation property in the South Field, and the corporation compensated the three lessees for the damage they had suffered. It was specified in the new leases that only such freemen as the corporation saw fit should enjoy common rights, 57 but in practice the rights of the whole body of freemen seem to have been respected, and the animosity aroused by the corporation's actions subsided. In $1777-8$, and again in $\mathbf{1 7 9 5}$, alterations were made to the way in which the field was divided, but on neither occasion was any opposition aroused. 58

In 1804 the South Field was finally inclosed by Act, after agreement had been reached between the corporation and the freemen.59 By the inclosure award, not issued until I 8 I I 453 acres, free of common rights, were allotted to the corporation, and I 25 acres were allotted to the freemen in compensation for their loss of common rights. ${ }^{60}$ Some land was sold to pay for the expense of inclosure, and lesser allotments were made to other proprietors. The award seems to have been considered fair and satisfactory by all the parties concerned. ${ }^{61}$ Financially, the corporation certainly profited for its income in rents from the South Fields rose from $f_{96} 6$ in $\mathrm{I} 804$ to $£_{\mathrm{I}}, 894$ in $\mathrm{I} 8 \mathrm{I}$ o. ${ }^{62}$ The inclosure had important consequences for the later growth of the town, which are discussed below. ${ }^{63}$

\section{THE OCCUPATIONS OF THE PEOPLE}

After the Restoration it continued to be necessary for all traders in Leicester to be freemen of the borough. ${ }^{64}$ In the markets a partial freedom was granted to certain outsiders, all or most of them butchers, which allowed them to trade in the borough on market days only. ${ }^{65}$ During the century after 1660 the companies or guilds of the various trades continued to exist; each still had its warden and stewards appointed yearly, and new members were sworn in upon the ordinals of their trades. ${ }^{66}$ The freedom gave its

\footnotetext{
51 Leic. City Mun. Room, Hall Bk. 23 July 1708; Greaves, op. cit. 81 ; Nichols, Leic. iv. 347.

52 Greaves, op. cit. 81.

53 Leic. City Mun. Room, Hall Bk. 2 Nov. I752; Greaves, Corp. of Leic. 82; Nichols, Leics. iv. 347.

54 Hall Bk. 6 Apr. I758; Greaves, op. cit. 82 .

55 Greaves, op. cit. 81-82; Throsby, Hist. of Leic. 1578.

56 Throsby, op. cit. 158 ; Nichols, Leics. iv. 348 .

57 Throsby, op. cit. I 59-60.

58 Greaves, Corp. of Leic. $82-83$.

59 Ibid. $84-85$; Nichols, Leics. iv. 348-9.

60 Leic. Town Hall Rec. South Fields Inclosure Award.
}

${ }^{61}$ Greaves, Corp. of Leic. 85 ; Nichols, Leics. iv. 349.

62 Greaves, op. cit. 85 .

63 See below, pp. 199 sqq. For the subsequent management of the land allotted to the freemen, see below, p. 373

64 See above, p. I05.

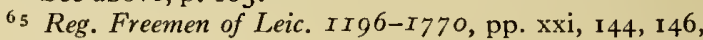
I $47, I_{49}, I_{50}, I_{53}, I_{54}, I_{55}, I_{5} 6, I_{64}, I_{66}, I_{76}, I_{77}, I_{94}$ 195 et passim.

66 Ibid. 535-48. The companies existing after 1660 were those of the bakers, butchers, carpenters, cordwainers and shoemakers, joiners and turners, glovers and fellmongers, slaters, plasterers and tallow-chandlers, smiths and cutlers, tailors, and weavers. 
holder the right to trade or practise a craft in the borough, and opened the way to participation in civic life and to certain charitable benefits. ${ }^{67}$ Until the middle of the I 8 th century the corporation tried to insist that all persons carrying on trades or crafts in the borough should take out their freedoms. In I 705 , for example, the corporation appointed a committee to meet the hosiers who were not freemen, to consider proposals for them to take out their freedoms. ${ }^{68}$ In $\mathrm{I} 724$ the corporation was considering sueing glovers who practised their trade within the town without being freemen, ${ }^{69}$ and in 1726 orders were given for the chamberlains to inquire about all non-freemen who were working in the borough, since the corporation was contemplating their prosecution . ${ }^{\circ 0}$ In the $1730^{\circ} \mathrm{s}$ and I 740's the resistance of certain craftsmen to the corporation's demand that everyone practising a trade or craft within the borough should become a freeman led to much litigation. Finally in $\mathbf{1} 749$ the corporation met with a decisive defeat in the courts when it proceeded against a non-free watchmaker called George Green.71 The result of this case made it impossible for the corporation in future to oblige inhabitants of the town to take up the freedom by the threat of legal proceedings. There was no sudden decline in the numbers of persons taking the freedom, but while the population of the town increased very considerably in the late 18 th and early I 9 th centuries, ${ }^{72}$ the number of freemen failed to increase correspondingly, and in 1835 only one in ten of the population was a freeman. ${ }^{73}$ It was perhaps because of the reduced importance of the freedom that the companies of the various crafts seem to have died out about the middle of the I 8 th century, though for lack of evidence the circumstances of their decline are extremely obscure. ${ }^{74}$

By the middle of the I 8 th century it had thus become fairly well established that any trade or craft could be practised in the borough by those who were not freemen. This fact of course greatly reduced the corporation's control over the economic life of the borough, since it could no longer regulate entry into the various occupations.

One further aspect of the corporation's control of economic affairs was its control of apprenticeship. One way of obtaining the freedom was by serving an apprenticeship. The binding and making free of apprentices, and their transference from one master to another, took place before the mayor, ${ }^{75}$ and so long as apprenticeship remained an important institution the corporation was thus able to exercise some measure of supervision over the entry to the various occupations. During the last years of the $\mathrm{I} 7$ th century there was a dispute about whether the period of apprenticeship was invariably to last seven years or not. ${ }^{76}$ In 17 I 8 the corporation laid down that every apprentice must serve for seven years in one single trade, but this rigid position was soon abandoned, and the corporation, though attempting in general to uphold the principle of a seven-year period of servitude, made concessions in individual cases. ${ }^{77}$ Table $\mathrm{V}$ shows that.in the period I $720-1835^{78}$ the number of apprentices bound in each decade varied little. As the population increased very greatly during the same period, the real importance of apprenticeship was obviously declining. The decreasing importance of apprenticeship, ${ }^{79}$ like the failure to make possession of the freedom compulsory on all traders and artisans, naturally reduced the corporation's power to control the town's economic affairs.

\footnotetext{
67 e.g. Sir Thomas White's charity, which provided interest-free loans to assist young men setting up in business: see below, p. 4 I 3 .

68 Leic. City Mun. Room, Hall Bk. 5 Jan. 1705.

69 Ibid. Io July 1724 .

zo Ibid. 6 May 1726.

71 Reg. Freemen of Leic. II96-I770, pp. xxi-xxii Thompson, Hist. of Leic. ii. 5 I-52, 76-79; Greaves, Corp. of Leic. 57-89; Nichols, Leics. i. 447-8.

72 See below, pp. 192-3.
}

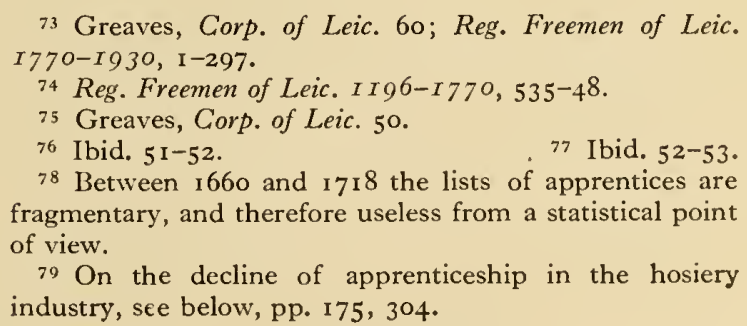




\section{A HISTORY OF LEICESTERSHIRE}

\section{TABLE V}

Numbers of Apprentices Bound, I720-I83580

\begin{tabular}{ll|ll|ll} 
I $720-9$ & 458 & I $760-9$ & 549 & I $800-9$ & 578 \\
I $730-9$ & 526 & I $770-9$ & 454 & I 8 10-I 9 & 5 I \\
I $740-9$ & 498 & I $780-9$ & 449 & I $820-9$ & 526 \\
I $750-9$ & 494 & I $790-9$ & 581 & I $830-5$ & 253
\end{tabular}

\section{(a) The Hosiery Industry, I660-I835}

The production of hand-knitted stockings was a well-established and highly organized industry at Leicester by the middle of the 17 th century ${ }^{81}$ and in 1674 was said to use 200 todds of wool a year in Leicester and the adjacent villages. ${ }^{82}$ It is generally agreed that the stocking frame was first introduced to Leicester by Nicholas Alsop, but the date of introduction has been variously given as $1670^{83}$ and $\mathrm{x} 680,{ }^{84}$ and there seems to be no reliable evidence on the point. The date of about 1670 is probably the more accurate, for in 1674 a petition was made to the mayor and corporation directed against divers freemen trying to engross the spinning and knitting of wool into stockings wholly to themselves and turn it into a monopoly'. ${ }^{85}$ Whether the stocking frame was introduced by that time is not clear. Hosiers at Leicester are mentioned in 1665,86 but there is no evidence that they were making use of frames. It is possible, however, if the earlier date is accepted for Alsop's arrival in Leicester, that the petition was part of the opposition to his frame. Alsop first appears in the borough records in 1648 when he was apprenticed as Nicholas Alsop of Wanlip to a Leicester mercer, Edward Noone. ${ }^{87}$ In 1656 Alsop was admitted to the freedom of the borough. ${ }^{88}$ The first of his apprentices to be made free was John Scampton in $\mathbf{1 6 6 3}$. Alsop was then described as a mercer. ${ }^{89}$ There is then a gap of 24 years until 1687, when Joseph Parker, another apprentice of Alsop, was made free; again Alsop is described as a mercer. ${ }^{90}$ In 1693 , when John Lewin, another of his apprentices, was made free, Alsop was described as a hosier. ${ }^{91}$ In the remaining references to Alsop in the Freemen's Register he is described as a framework-knitter. ${ }^{22}$ The gap of 24 years between 1663 and 1687 might indicate that he left Leicester for a time, and returned between 1670 and 1680 , though on the other hand he was a member of the Forty-eight in $1684,{ }^{93}$ which would suggest a fairly long residence before that date. The first mention of a hosier in the Freemen's Register is in 1677 , when Thomas Top, an apprentice of Daniel Pougher, hosier, was made free. ${ }^{94}$ Between 1677 and $1700 \mathrm{I} 7$ different freemen and one woman are described as hosiers in the register, although there is no consistency, for the same men are called hosier, woolcomber, or framework-knitter. Of these 18,3 had been apprenticed to hosiers, 2 to fellmongers, and 3 to weavers; the trades to which the remainder were apprenticed, where known, are varied and not connected with the textile trades. Of the i 8 early hosiers, 8 came from Leicester, I (Nicholas Alsop) from the county, and the place of origin of the other 9 is unknown. ${ }^{95}$

80 The figures are derived from the lists printed in $R e g$. Freemen of Leic. II96-I770, 386-534, and ibid. I770$I 93^{\circ}, 43 I^{-6} I_{5}$; on the popuiation during the same period, see below, p. 19I-3.

81 See above, p. 90.

82 Leic. Boro. Rec. I603-88, 536-8. A todd was $28 \mathrm{lb}$.

83 W. Gardiner, Music and Friends, ii. $8 \mathrm{I}$ I.

84 Throsby, Hist. of Leic. 402 ; Thompson, Hist. of Leic. i. 436 .

85 Thompson, Hist. of Leic. i. 431-43; Leic. Boro. Rec. I $603-88,536-8$.

86 Leic. Boro. Rec. I603-88, 496.

87 Reg. Freemen of Leic. II96-I770, 374.

88 Ibid. I 39 .

90 Ibid. I7 I.

92 Ibid. I80, I83, 189, I 94, 202.
93 Leic. Boro. Rec. I603-88, 562.

9+ Reg. Freemen of Leic. $1196-1770$, I 59. Earlier the Pougher family had been connected with the hand-knitted hosiery trade: see above, p. 90.

95 Reg. Freemen of Leic. I I96-I770, I60, I70, I91, 213 (Samuel Hammont); I 48, I 59, I 72, I 79 (Daniel Pougher); I 53, I 67, 38 I (John Armeston); I 50, I 68, I 74, I 77 (John Davie); I 5 I, I68, I77, I78 (Robt. Worth); I 37, I69, I73 (Ric. Hill); I38, I 56, I65, I 73 (Ralph Miles); 1 39, I47, I 7 I, I 75, 374 (Nicholas Alsop); I 58, I 78, I 82 (Geo. Laxton); I 59, I 79, I 8I (Thos. Top); I 50, I79 (Thos. Alsop); 1 58, I 80, I 97 (Jas. Norris); I 68, I 82 (John Palmer); I 55 , I 84, I85, 377 (Abstinence Pougher); 146, I77, 377 (Geoffrey Hinman); 378 (Eliz. Browne: perhaps a hand knitter); $185,379,404$ (Thos. Laxton); 152, 379 (Thos. Aires: and see his will, L.R.O. Probate Rec. Wills, I697). 


\section{THE CITY OF LEICESTER}

In the first half of the 18 th century the growth of the hosiery industry was rapid. The rising importance of the textile trades generally at Leicester up to the middle of the $\mathrm{I} 8 \mathrm{th}$ century can be seen by the fact that the freemen working in these trades rose from being I 3.7 per cent. of all the freemen listed in the register in $1670-9$ to 41.3 per cent. in I 740-9. ${ }^{96}$ Similarly out of the total number of newly admitted apprentices in the years I 720-9, 46 per cent. were apprenticed in the textile trades; in the period $1730-49$, 54 per cent. of new apprentices belonged to the same trades. ${ }^{97}$

Attempts were made to bring the young hosiery industry of the midlands under the control of the chartered Framework Knitters' Company, in which the London hosiers were predominant. ${ }^{8}$ In January $\mathbf{1} 700$ the framework-knitters of Leicestershire, Derbyshire, Nottinghamshire, and the ajdacent parts petitioned the House of Commons against the company's unreasonable and vexatious by-laws. ${ }^{99}$ In 17 I 5 the company, as part of an attempt to enforce its control over the industry in the midlands, brought an action against two Leicester framework-knitters, Thomas Derbyshire and William Browne, who had bound and made free apprentices before the Mayor of Leicester instead of before the officers of the company. Leicester corporation, perhaps feeling that its own control of apprenticeship in the borough was being challenged, decided that Derbyshire and Browne, together with any other framework-knitters who might be sued by the company, should be defended at the town's expense. ' The company's efforts were ineffective, and Browne at least continued to bind apprentices before the Mayor of Leicester. ${ }^{2}$ Despite this repulse, the company maintained deputies, who admitted new members, at Leicester in the $1720^{\prime}$ s. $^{3} \mathrm{~A}$ further attempt by the company to assert its control was made in $\mathbf{1} 727$, when Thomas Gregory, a Leicester frameworkknitter, was summoned to take up membership of the company. Gregory failed to do so, and the company resolved to proceed against him in the courts. ${ }^{4}$ This attempt also

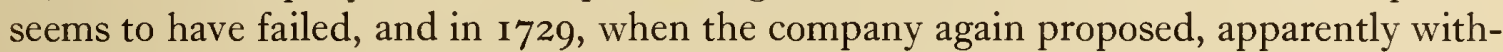
out result, to prosecute unadmitted framework-knitters, it was said that independent workers always received the greatest encouragement and protection at Leicester. ${ }^{5}$ In I753 Richard Garle, a Leicester stocking manufacturer, stated that the company had not exercised any control in Leicester for twenty years past. ${ }^{6}$ It was resolved in 1753 by a committee of the House of Commons, set up in response to petitions from the midlands hosiery areas, including Leicestershire, that the company was a harmful monopoly, whose by-laws were injurious to the hosiery industry and in many cases illegal. ${ }^{\text {This }}$ virtually brought the company's attempts to control the industry to an end.

The stocking frame was a relatively expensive piece of machinery; in the late $\mathrm{I} 7 \mathrm{th}$ and early i 8 th centuries it was sometimes valued at $£_{1} \mathrm{O}$ even after having been in use for some time. ${ }^{8}$ It is therefore not surprising that framework-knitters were not always able to buy frames, and that there grew up a class of merchant employers who owned and rented out frames, and undertook the marketing of the finished product. The practice of renting out frames dates from the early beginnings of the Leicester hosiery industry,

\footnotetext{
96 The rise was fairly constant in the intervening periods, the percentages for each decade being 11.8 in $1680-9,19.8$ in $1690-9,24.8$ in $1700-9,30.7$ in $1710-19,39.3$ in $1720-$ 9, 42.9 in $1730-8$ : Reg. Freemen of Leic. II96-I 770 , I 53285. These figures only relate to newly admitted freemen, not to the total number of freemen existing at any given time, but since large numbers of new freemen are mentioned in the register, the increased proportion of textile workers is nevertheless significant. For similar figures for before 1660 , see above, p. 77 , where their reliability is discussed.

97 Reg. Freemen of Leic. I I 96-I770, 386-469.

98 On the company's origin and character, see J. D.
}

Chambers, 'Worshipful Co. of Framework Knitters', Economica, ix. 296-306.

99 C.F. xiii. 13 I.

I Nichols, Leics. i. 445.

2 Reg. Freemen of Leic. Ir69-1770, 394, 396, 397.

3 C.F. xxvi. 781-82; F. A. Wells, Brit. Hosiery Trade, 40.

4 C. $\%$ xxvi. 787 .

5 Ibid. $78 \mathrm{I}-2$.

6 Ibid. $781,787$.

7 Ibid. xxvi. 788

8 L.R.O. Probate Rec. Inv. of Nicholas Alsop 1707; V.C.H. Leics. iii. 2 n.; C.F. xxxvii. 372. 


\section{A HISTORY OF LEICESTERSHIRE}

for Nicholas Alsop's will (drawn up in I 706) mentions rents arising from three frames. ${ }^{9}$ It is evident from Alsop's will, and from his probate inventory drawn up in $1707,{ }^{10}$ that he was acting as a merchant employer, renting out frames, collecting finished hosiery, and marketing it in London. Abstinence Pougher, a hosier who died in I 702, was conducting a business of the same sort. In his house in Parchment Lane, near the East Gate, and in his warehouse in the same street, he had at his death considerable quantities of wool, yarn, and stockings. Evidently he controlled the spinning of wool into yarn, for he also had wool in the spinners' hands. ${ }^{I}$ In 1753 Richard Garle stated that he was a hosiery manufacturer of Leicester, and had a hundred frames for hiring out, and that there were about a dozen manufacturers in the town operating on the same scale. ${ }^{\mathrm{I} 2}$ It is impossible to say what proportion of frames was owned by the operatives themselves, and what proportion was hired out either by merchant employers, or by persons not otherwise connected with the industry who bought frames and hired them out as an investment. Complaints made by the Leicester framework-knitters in I77 I imply that it was then usual for the operatives to hire frames, normally for $9 d$. a week. It appears from statements made at the same time that the framework-knitters generally paid to have the stockings they made seamed up by others. From statements made to a committee of the House of Commons in 1778 it appears that it was then usual for the framework-knitters to collect the raw material from the manufacturers, and presumably they also carried back the finished work. ${ }^{13}$ By the late 18 th century, if not earlier, the merchant employers, as distinct from the operatives, were known as hosiers. ${ }^{14}$

The stocking frame itself underwent no basic change during the $\mathrm{I} 8$ th century, but many minor improvements were introduced, and two of them were connected with Leicester. In I 78 I a Mr. Dalby of Leicester, together with a Mr. Ash, obtained a patent for a device by which elastic work was manufactured.15 In I79I William Dawson, a Leicester framework-knitter, invented a device, known as Dawson's Wheels, which was applied to the existing warp machine ${ }^{16}$ and greatly improved the manufacture of fancy hosiery. ${ }^{17}$

Little evidence is available about the remuneration of operatives or their conditions of work in the early days of the Leicester hosiery industry. Up to the middle of the $\mathrm{I} 8 \mathrm{th}$ century the industry seems to have been expanding, and to have been free from unemployment. In 1753 it was said that the number of operatives available was not sufficient to meet the demand. ${ }^{18}$ Some twenty years later the position of the framework-knitters was evidently far from satisfactory. In I 77 I they complained that by intensive work a framework-knitter could earn $9 s$. a week, which, after deductions for frame rent and for needles and seaming, left a net weekly income of only $7 s .3 d$. in summer, or $6 s .6 d$. in winter, when additional deductions had to be made for fuel and candles. These were the earnings of the more successful workers. ${ }^{19}$ Earlier in the century Ios. a week was said to be the average earning in Leicestershire. ${ }^{20}$ The framework-knitters seem to have obtained no satisfaction in I77I, and two years later their distress was the origin of serious disturbances. There had been a scarcity of food for several years ${ }^{21}$ and in the winter of $1772-3$ food prices were high. Forty-four of the chief Leicester hosiers undertook that for three months from the end of February I 773 they would not reduce their

\footnotetext{
9 L.R.O. Probate Rec. Will of Nicholas Alsop, 1706. Frame renting is mentioned in a by-law of the Framework Knitters' Co. of 1663: Wells, Brit. Hosiery Trade, 74.

10 L.R.O. Probate Rec. Inv. I 707.

Ir L.R.O. Probate Rec. Will and Inv, of Abstinence Pougher, I 702 .

${ }_{12}$ C. $\mathcal{F}$. xxvi. 787 ; Wm. Gardiner, Music and Friends, ii. 811 .

3 Thompson, Hist. of Leic. ii. 142; C.J. xxxvi. 741 .
}

14 Thompson, op. cit. ii. 142.

15 Gardiner, Music and Friends, ii. 214.

16 See Wells, Brit. Hosiery Trade, 94.

17 Gardiner, Music and Friends, i. 234; ibid. ii. 815-16.

18 C.F. xxvi. 787.

19 Thompson, Hist. of Leic. ii. 142.

$20 \mathrm{~W}$. Felkin, Hist. Machine-Wrought Hosiery and Lace Manufactures (1867), 72.

21 D. G. Barnes, Hist. Eng. Corn Laws, 38-43. 
rates of payment below the level prevailing at Christmas I772. Despite this riots occurred at Leicester when in March I773 a frame of a new type was brought into the town. A large mob, including many framework-knitters from the county areas around Leicester, assembled and destroyed the new frame, which, in an endeavour to dispel the operatives' suspicions, had been exhibited in the Corn Exchange. 'The Leicester hosiers, presumably overawed, promised those who had taken part in the riot that they would not seek patents for any new type of frame, or introduce any machinery which would displace labour. ${ }^{22}$ At a later period framework-knitters might have turned naturally to trade unionism as a remedy for their distress, and indeed associations of framework-knitters did come into existence during the I 770 's. ${ }^{23}$ In the late I 8th century, however, the operatives tended rather to seek relief through the state regulation of their industry, either by a new Act of Parliament, or by the enforcement of the by-laws of the Framework Knitters' Company. In 1778 a petition was made to the House of Commons by the framework-knitters of several areas, including Leicester, asking for an Act to be passed for regulating the industry by fixing wage rates. ${ }^{24}$ Subscriptions were raised to defray the expenses of passing the Act, and meetings were held in the town in its support, one at least under the auspices of the Framework Knitters' Company. ${ }^{25}$ Owing to the hosiers' opposition, however, no Act was passed.26 In I779 framework-knitters from several districts, again including Leicester, renewed their petition for an Act to regulate the industry, and in particular to prevent the continuance of various frauds and abuses which were perpetrated upon the operatives. A bill was introduced, but failed to pass into law. ${ }^{27}$ It was feared that this failure might lead to rioting at Leicester, but no disturbances took place although there was much violence at Nottingham. It is doubtful how far the Leicester framework-knitters were in favour of the bill. ${ }^{28}$ Evidence given by a Leicester framework-knitter in 1778 suggests that conditions were then rather worse than in $\mathrm{I} 77 \mathrm{I}$; in $\mathrm{I} 778$ it was said that the average net earnings of a workman, after frame rent and minor charges had been deducted, were about 5 s. $6 \mathrm{~d}$. a week at Leicester, and that earnings had been declining since 1756 or 1757 . The frame rent in 1778 was said to be Is. a week, and framework-knitters were said to have to work fifteen hours a day. ${ }^{29}$

While seeking to have their industry regulated by statute, the midland frameworkknitters sought at the same time to use the moribund Framework Knitters' Company. It seems very doubtful whether the company had been regarded favourably by the operatives at an earlier period, but by the I 770's they had evidently come to regard it as at least a useful instrument in their struggle for better conditions. ${ }^{30}$ Towards the end of I 778 a number of framework-knitters from Leicester and other centres of the industry were enrolled as members of the company, and in April I779 a Court of Assistants was set up by the company at Leicester to carry on the enrolment. The company, however, seems to have done nothing to assist the operatives. ${ }^{31}$ By restricting the entry of new workers through apprenticeship regulations the company might at least have kept down the size of the labour force, but it had altogether failed to control the growth of the industry in the midlands. Though the idea of legislation was to be revived later, for long after the failure of I 788-9 it was unsuccessful. The framework-knitters were thus at the mercy of economic forces, and their bargaining position was a weak one. The

\footnotetext{
22 Thompson, Hist. of Leic. ii. 147; Leic. Fnl. 20 Mar. 1773 .

${ }_{23}^{773}$ Wells, Brit. Hosiery Trade, I o6, I Io; and see below, p. 175 .

24 C.尹. xxxvi. 635 .

25 Thompson, Hist. of Leic. ii. 163-5.

26 C.F. xxxvi. 728, 740; Wells, Brit. Hosiery Trade, 91-
}

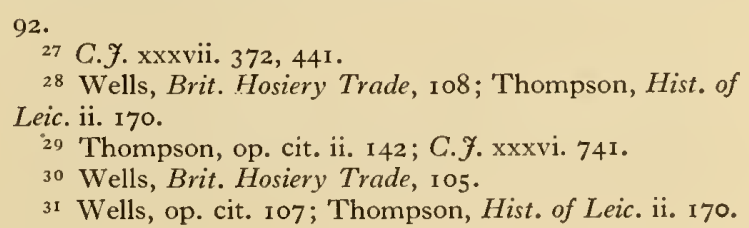




\section{A HISTORY OF LEICESTERSHIRE}

craft was easily learned, 32 so that before long the industry acquired a larger labour force than could be employed except in times of unusual prosperity.

In 1787 a further attack upon a new machine was made at Leicester. In I 785 Joseph Brookhouse, of Church Gate, Leicester, invented a method of spinning worsted by machinery. Such spinning had once largely been done by the framework-knitters' wives and families, but Hargreaves's 'spinning jenny' had been introduced to Leicester about I777. About I780 the 'jenny' ceased to be used at Leicester, as it had been made obsolete by Arkwright's invention for spinning by rollers. It seems uncertain whether Arkwright's machine was used at Leicester, though the thread from it was evidently employed. ${ }^{33}$ It appears that Hargreaves's and Arkwright's inventions were not used to produce worsted thread, ${ }^{34}$ so that both were presumably of interest only to the Leicester hosiery industry in so far as it used other types of thread. To obtain the necessary capital Brookhouse entered into partinership with John Coltman, a hosier, and Joseph Whetstone, a spinner said to have employed between I,000 and I,500 persons in spinning. ${ }^{35}$ The new methods aroused much opposition, and finally in December 1787 a large mob attacked Whetstone's house in Northgate Street, and although fired on by Whetstone and his supporters broke in and did much damage. The mayor, arriving after the riot had been in progress for some time, was fatally injured while trying to read the Riot Act. Coltman's house was also attacked, and the machine, which had been taken to Market Harborough for safety, was pursued there by the rioters and ciestroyed. The result was that for some twenty years worsted spinning was not carried on in Leicester, though it became an important industry in some other east midland towns, ${ }^{36}$ a fact which as early as 1788 was causing some anxiety at Leicester. ${ }^{37}$

There is some evidence about the size of the Leicester hosiery industry during the I 8 th century. In 1712 it was said that 20,000 todds of wool were used yearly in the manufacture of stockings at Leicester, ${ }^{38}$ and in 1716 there were about 7,600 people employed in the industry in the town. ${ }^{39}$ There are said to have been 600 frames in Leicester in $1714,{ }^{40}$ and according to another estimate there were 500 in $1727 .{ }^{4 I}$ In the period $1730-50$ the hosiery industry at Leicester grew rapidly, ${ }^{42}$ and in $175 \mathrm{I}$ Leicester was described as its most important centre in England. 43 Two years later there were estimated to be 1,000 frames in the town. ${ }^{44}$ In I 79I it was stated that the borough contained over 70 hosiery manufacturers, and that some 6,000 persons were employed in the various branches of the industry. 45 The number of frames in Leicester was estimated at 1,600 in 1812,46 and at 6,000 in 1831.47

In the I 8 th century the stockings manufactured at Leicester were in general not of the finest quality, though production was on a larger scale than elsewhere. ${ }^{8}$ Worsted was the most important material used. 49 Knitted gloves and mittens also came to be

${ }^{32}$ C.F. xxvi. 787 .

33 Gardiner, Music and Friends, i. 231 ; ibid. iii. II 4 ; Wells, Brit. Hosiery Trade, 65.

${ }^{34}$ Wells, op. cit. 65.

35 Thompson, Hist. of Leic. ii. I 86.

${ }^{36}$ Ibid. ii. 185-9; Nichols, Leics. i. 450; Gardiner, Music and Friends, i. 82-84. A slightly different account of Brookhouse's invention, stating that it was first used at Melton Mowbray in 1788 , is given in Wells, Brit. Hosiery Trade, 65, based on Gardiner, Music and Friends, i. 83, but Thompson's account, based on contemporary newspapers, is to be preferred.

37 Greaves, Corp. of Leic. $72 \mathrm{n}$.

38 Nichols, Leics. i. 62 I. It is not clear whether part of this was used in the country areas nearby.

39 Greaves, Corp. of Leic. 57; see Defoe's remarks on the industry, in Tour Through Engl. and Wales (1927), ii.
488.

40 This statement is made in Rep. Cond. Framework Knitters, [609] p. 15, H.C. (1845), xv. It is not known how reliable this statement is.

4I Wells, Brit. Hosiery Trade, 56.

${ }^{42}$ C.F. xxvi. 787 .

43 Nichols, Leics, i. 620.

${ }_{44}$ Rep. Cond. Framework Knitters, 15.

45 Throsby, Hist. of Leic. $40 \mathrm{I}-2$; where it is also stated that 3,000 frames were kept in employment by the Leicester manufacturers, but it is not clear whether all these were in the town itself.

${ }_{46}$ V.G.H. Leics. iii. 3; J. Blackner, Hist. Nott. 239-40.

47 White, Leics. Dir. (1846), 66.

${ }_{48}$ Nichols, Leics. i. 620; Throsby, Hist. of Leic. 403.

49 [Watts], Walk Through Leic. I 47 ; Wells, Brit. Hosiery Trade, 56,65 . 
made at Leicester; their manufacture was well established by 1778 , when the House of Commons was told that framework-knitters normally received $4 s$. or $5^{s}$. for a dozen worsted gloves, and that a workman of moderate skill could make two dozen a week. ${ }^{50}$ The Leicester glove trade in the I770's was largely for export, and it was much harmed by the American War of Independence and the disturbances that preceded it. ${ }^{5}$

The period of the great French wars, from I79I onwards, was at first a time of prosperity for the hosiery industry. From 1790 to 1810 the demands of the armed forces for manpower caused some shortage of labour in the industry,,$^{22}$ and this period was perhaps the time of greatest prosperity that the framework-knitters ever experienced.53 Some idea of the level of wages prevailing from about I790 to I8Io can be derived from the evidence given about the hosiery industry in 1845 . One Leicester framework-knitter said in 1845 that in the I 790 's he had been able to produce about $2 \frac{1}{2}$ dozen hose a week, for which he was paid Ios. a dozen. From the gross wages of 25 s. a week thus obtained, $3 s .7 d$. or $3 s .8 d$. had to be deducted for frame rent, the seaming of stockings, and other charges, leaving a net income of rather more than $£_{\mathrm{I}}$. These rates were for the production of ribbed hose. ${ }^{54}$ Another framework-knitter said that in the years $1805^{-7}$ he was earning $\mathbf{I}_{5}$ s. a dozen, though he did not state what type of stocking he was making at that time. ${ }^{55}$ James Coleman, of Belgrave Gate, said that about I 800 he was earning $9 s$. a dozen, ${ }^{56}$ while another Leicester framework-knitter said that at the beginning of the I 9 th century he was earning $2 \mathrm{I} s$. a week, producing wrought hose. ${ }^{57}$ Workers producing the type of stockings known as 'cut-ups', 58 which were introduced in the I790's, could, according to one statement made in 1845 , earn $\mathrm{I} 2 \mathrm{~s}$. a dozen in the opening years of the I 9 th century. ${ }^{59}$ In $179 \mathrm{I}$ it was said that workers could earn $20 s$. to $30 s$. a week owing to the shortage of labour: these wages seem very high, however, and may have been exceptional. About 1797 it was said that the earnings of Leicester framework-knitters varied from $7 s$. to $2 \mathrm{I} s$. a week. ${ }^{60}$ Such earnings are considerably greater than those prevailing in the period $1820-45$.

It was during the I790's that societies of employers first appear in the Leicester hosiery industry. In 1792 a Hosiers' Association was formed in an attempt to prevent the embezzlement of yarn given out by hosiers to their employees, ${ }^{61}$ and it seems to have met regularly. ${ }^{62} \mathrm{~A}$ society of worsted makers, with the similar object of preventing the embezzlement of wool or yarn, was in existence in $1794,{ }^{63}$ and in 1796 was negotiating with the woolcombers about their wages. ${ }^{64}$

Certain new types of product were introduced into the hosiery industry at Leicester at the end of the 18 th and the beginning of the Igth century. The most important was the 'cut-up' or 'straight-down' type of stocking, which although inferior in quality could be produced more cheaply than the old type of wrought hose. ${ }^{65}$ Cut-ups were being produced at Leicester in the $1790^{\prime} \mathrm{s}^{66}$ and possibly as early as $1778 .{ }^{67}$ Their manufacture

50 C.F. xxxvi. 74I. $\quad$ 5I Ibid. 740 ; ibid. $x x x .462$.

52 Rep. Cond. Framework Knitters, 26; F. M. Eden, State of the Poor (1928), 228.

53 J. L. and Barbara Hammond, Tozn Labourer (I 919 ), 225 .

${ }_{54}$ Rep. Cond. Framework Knitters, 50; Ist App. to Rep. Cond. Framework Knitters [6 18], p. I32, H.C. (1845), xv. Ribbed hose were a rather elaborate product, manufactured on a machine invented by Jedediah Strutt: see Wells, Brit. Hosiery Trade, 63.

55 Rep. Cond. Framework Knitters, 26.

56 Ibid. 84 .

57 Ibid. I I . Wrought hose were stockings shaped on the frame in the actual process of knitting, i.e. they were fully fashioned and contrasted with the much cheaper and inferior type of stockings known as 'cut-ups' or 'straight- downs', which were cut out of a strip of knitted fabric, roughly shaped with scissors, and seamed up, or in the case of a particularly inferior variety shaped by being stretched on a leg board and steamed: see Wells, Brit. Hosiery Trade, 95-96, 10 I-2.

58 See preceding note.

59 Rep. Cond. Framework Knitters, I05; A. T. Patterson, Radical Leic. 57.

60 Eden, State of the Poor, 227.

61 Leic. Fnl. I 3 Apr. I 792. 62 Ibid. I I Oct. I 793.

63 Ibid. 7 Mar. I794. 64 Ibid. 8 Jan. I796.

65 See Wells, Brit. Hosiery Trade, 95-96, I0I-2; Ist App. to Rep. Cond. Framework Knitters, 33.

66 Rep. Cond. Framework Knitters, 102, 105; Ist App. to Rep. Cond. Framework Knitters, 63; Patterson, Radical Leic. 57.
67 Leic. Fnl. 7 Mar. I 778. 


\section{A HISTORY OF LEICESTERSHIRE}

seems always to have been centred at Leicester itself, very few being produced in the adjacent rural areas. ${ }^{68}$ About 1796 the Leicester hosiers began to use knitted fabric for the manufacture of shirts, ${ }^{69}$ and shortly before 1804 the production of cotton socks, which were very cheap, was established at Leicester. Wage-rates in the sock manufacture were higher than in most other branches of the hosiery industry. ${ }^{70}$ In the 1790 's the manufacture of fancy hosiery on the newly modified warp machine ${ }^{7 \mathrm{I}}$ became important at Leicester. In I79I new and elaborate products called machine pieces, apparently made on the old warp machines, had been introduced into Leicester. Workers making them were said to earn as much as 2 guineas a week. ${ }^{72}$ For some time high wages were paid to those engaged in the fancy hosiery branch, but by 18 io changes in fashion had ruined the trade. ${ }^{73}$ About 1806 the manufacture of knitted braces and cravats was begun at Leicester. ${ }^{74}$ At a rather later period, in 1817 , the making of knotted hose was begun at Leicester. 75

The general prosperity of the hosiery industry had evidently been somewhat impaired by i 809 , when wages, according to a statement in I 845 , were reduced by $6 d$. a dozen, though the reduction seems to have been only temporary. ${ }^{76} \mathrm{By} 18 \mathrm{I} 2$ the distress amongst framework-knitters at Leicester and elsewhere was severe, and they petitioned the House of Commons to investigate the state of the hosiery industry. The frameworkknitters' aim was to obtain an Act which would forbid various frauds and abuses from which the operatives suffered.77 A bill was in fact introduced, and delegates were sent by the Leicester framework-knitters to support it, but it was opposed by the hosiers, and failed to become law. ${ }^{78}$ The attempt to obtain legislation to control conditions in the industry thus failed once again, and the position of the operatives degenerated further, especially when, after the long period of warfare ended in 1814 , the demand for knitted goods for military purposes ceased and many framework-knitters were discharged from the army. In I8I 4 the Leicester framework-knitters asked for an increase in rates of pay, stating that while prices had for long been rising their rates of pay had remained stationary, or had even been reduced. They even said that their condition had been depressed since $\mathbf{I} 795$, except for short periods, but this was probably an exaggeration. ${ }^{79}$ The plea seems to have had little result. At a general meeting of those concerned in the hosiery industry at Leicester in 1816 it was stated that the industry was then in a worse condition than for 30 years past. 80 The position of the framework-knitters was made worse at this time by the practice followed by overseers of the poor at Leicester of paying premiums to the hosiers for employing paupers. The overseers themselves even employed pauper framework-knitters to produce hosiery, and by conducting their business without seeking profit, or even at a loss, competed on favourable terms with the framework-knitters who were not in receipt of poor relief.81 Out-door relief was often given to framework-knitters who, though working, did not earn enough to subsist on. ${ }^{82}$ Such practices of course tended to pauperize the whole body of framework-

68 V.C.H. Leics. iii. 5.

69 Ist App. to Rep. Cond. Framework Knitters, I 50, I54; Patterson, Radical Leic. 52.

${ }^{0}$ [Watts], Walk Through Leic. 147. W. Felkin, Hist. Machine-Wrought Hosiery and Lace Manufactures, 436, gives the date at which the production of socks began at Leic. as 1810 , and seems to imply that they were made of a mixture of cotton and wool. It is clear, however, that socks were already being manufactured at Leic. in 1804 .

71 See above, p. 170.

72 Throsby, Hist. of Leic. 403.

73 Wells, Brit. Hosiery Trade, 93-94.

74 Patterson, Radical Leic. 53. It is there stated that Berlin pieces for trousers were made at Leic. from $c .1808$. But Berlin pieces were for gloves: Ist App. to Rep. Cond.
Framework Knitters, 127.

75 Felkin, Hist. Hosiery and Lace Mftures. 441. Knotted hose were especially durable because the stitches were fastened, and therefore less liable to run into holes than other types of material: Gardiner, Music and Friends, ii. 813.

${ }_{76}$ Ist App. to Rep. Cond. Framework Knitters, 132.

77 C.F. Ixvii. 203, 339, 346 .

78 Ibid. 399, 476, 492, 495-6, 5 I I-12, 523-4, 542; J. L. and Barbara Hammond, Town Labourer (1919), 229.

79 Leic. $7 n l .8$ Feb. 18 I 4 .

80 Ibid. 19 Apr. $1816 ;$ C.. . 1xxi. 313 .

81 Greaves, Corp. of Leic. 74-75; Hammond, Town Labourer, 245; Eden, State of the Poor, 228.

82 Ist App. to Rep. Cond. Framework Knitters, 34, 107; 2nd Rep. Poor Law Com. H.C. 595, p. 398 (1836), xxix (1). 
knitters. From I 8 I 5 to I 8 I 7 wages declined, and the rate for one type of worsted stockings fell from $7 s .6 d$. a dozen to $6 s^{8}{ }^{83}$ In $\mathrm{I} 8 \mathrm{I} 7$ some relief was obtained by the operatives, as the overseers of the poor agreed to cease employing paupers, except those actually in the workhouses, in framework-knitting, and agreed also not to give any relief to persons working below the usual rates of pay. At the same time the hosiers agreed to increase rates of pay but this success was only temporary. ${ }^{84}$ An unsuccessful strike of the Leicester framework-knitters followed. Some of the strikers were charged with offences against the Combination Acts, but they were leniently treated by the borough justices, who were not unsympathetic towards their plight. ${ }^{85}$ In I 8 I9 the Leicester hosiers and frameworkknitters jointly petitioned the House of Commons, complaining of the production of 'cut-ups', and asking for remedial action. ${ }^{86} \mathrm{~A}$ select committee was appointed, and the facts it ascertained showed how great the distress in the hosiery industry was; wages for the makers of worsted stockings had fallen from I 4 s. in I 8 I 4 to 7 s. in I 8 I 9, for a full week's work of 15 hours a day, and in one Leicester parish alone, St. Margaret's, there were 6I stockingers, who with their families made up a total of 300 people, all receiving regular relief. ${ }^{87}$ Nothing, however, was done by Parliament. It was probably the failure of this attempt to obtain redress from the legislature that led to the formation at Leicester towards the end of $18 \mathrm{I} 9$ of a Framework Knitters Union.88 This was not the beginning of combination amongst the Leicester hosiery workers. A union already existed amongst the Leicester woolcombers in $179 \mathrm{I}{ }^{89}$ As early as 1787 the prices to be paid for work were agreed between the hosiers and the framework-knitters, ${ }^{90}$ and such an agreement implies some degree of unity and combination amongst the operatives. In I790 the framework-knitters in Leicester and Leicestershire, together with those of Nottinghamshire and Derbyshire, had an association which was negotiating with the hosiers about wage-rates, and in 1794 the Leicester framework-knitters formed a society for recovering absconding apprentices.9I Leicester was included in the general association of framework-knitters formed in $1813,{ }^{92}$ and to carry out the strike of 1817 there must have been some kind of organization, though no union seems to have existed.93 There had been further attempts, too, in the early igth century to use the Framework Knitters' Company as a means for improving the condition of the operatives. In 1805 the frameworkknitters of Nottingham, Derby, and Leicester complained to the company about the excessive numbers of apprentices kept by certain employers, ${ }^{94}$ and in 1806 the company appointed deputies at Leicester and other places. ${ }^{95}$ In 1808 an agitation was in progress at Leicester, aimed at ensuring that all entrants to the industry should for the future serve a full apprenticeship. ${ }^{96}$ This method of restricting the number of workers in the industry proved a failure in 1809 when the prosecution of a Burbage hosier for carrying on the craft of framework-knitting and instructing others in it, without having been apprenticed himself, was unsuccessful. ${ }^{97}$ This was the last attempt of the frameworkknitters to make use of the old chartered company, which had never been a suitable instrument to protect and advance the operatives' interests. ${ }^{98}$ By the late 18 th century those of its liverymen who had any connexion with the hosiery industry were nearly all hosiers. ${ }^{99}$ Over a considerable period the framework-knitters had attempted to make use

83 Ist App. to Rep. Cond. Framework Knitters, 55.

84 Greaves, Corp. of Leic. 75; Hammond, Town Labourer, 246-7; Patterson, Radical Leic. I I 6-17.

85 Greaves, op. cit. 74; Hammond, op. cit. 249.

86 C. $\mathcal{~}$. lxxiv. 123.

87 Rep. Sel. Cttee. on Frantework Knitters' Petition, H.C. r93, pp. r8, 4r (1819), v.

88 Leic. Fnl. ro Sept. I 819.

89 Ibid. 2 Dec. I79I. In 1803 and 1817 advertisements were published declaring that employers would refuse to

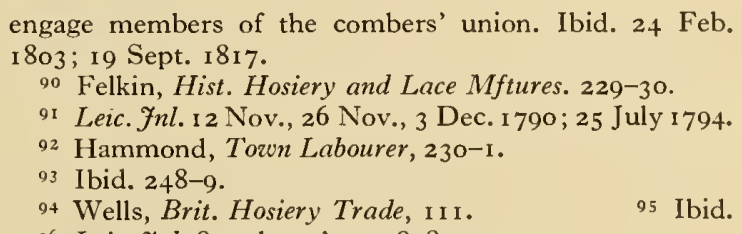

95 Ibid.

99 Ibid. 107. 
of the company, partly it would seem because of the continuing prestige of the chartered body even in its decaying state, and partly because, at a period when trade unionism was still in its early days and its possibilities were still unrealized, the operatives were ready to turn to any institution which seemed capable of relieving their distress.

If the chartered company had proved ineffective, attempts to obtain from Parliament an Act to regulate the hosiery industry and to remove the abuses under which the framework-knitters suffered had been quite fruitless. In the late I8th century the idea of controlling an industry, either by statute or through a chartered company, had of course already ceased to be in accord with the generally accepted economic theories, and in the I 9 th century was even less acceptable. Under such circumstances operatives had little alternative but to turn to combination to improve their position. It is noteworthy that the Leicester framework-knitters during the early i gth century did not resort to violence at all, unlike those of Loughborough and Nottingham.

A framework-knitters' union of some permanence was established at Leicester in I8I 9. The union's articles provided that each adult male member was to pay $6 d$. a week subscription when in work, and each boy or woman member $3 d$. a week, in return for $8 s$. and $4 s$. a week respectively when unemployed. ${ }^{I}$ The union appears to have been basically a friendly society. It was supported by the lord lieutenant, the Duke of Rutland, the corporation, the officers of the Leicester parishes, the borough members of Parliament, and others. The union included framework-knitters from the rural areas around the borough, but its main strength seems to have lain in Leicester. There its members were organized in thirteen districts, each with its own treasurer and stewards. The union owed much to the advice and support of the Baptist minister, Robert Hall. ${ }^{2}$ At first the new union, aided by a widespread strike which took place in the midland hosiery industry in I8I9, had much success. By the end of I 8 I $9 f 6,000$ had been contributed to its funds, wages amongst the Leicester stockingers had risen by $4 s$. a week, and employment was increasing. This improvement lasted only two years. In I82 I conditions degenerated, a strike of framework-knitters took place, and in the first three months of the year $£^{6} 6,182$ were paid out by the union in relief to the unemployed. To meet these difficult circumstances the union borrowed $f_{\mathrm{I}} \mathrm{I}, 55^{\circ}$. Some improvement took place, and by 1822 it was possible to repay the debt out of contributions. From 1823 , however, wages continued to decline. ${ }^{3}$ According to evidence given in 1845 , a worker producing 'cut-ups' in I 823 could produce nine dozen hose a week, for which he would be paid at the rate of $2 s .5^{d}$. a dozen; frame rent and other deductions totalled $5^{s}$. I $\frac{1}{2} d$. a week, so that the worker's net wages were $\mathrm{I} 6 s .7 \frac{1}{2} d .{ }^{4}$ The Leicester union was not in a good position to deal with the worsening situation, for subscriptions had fallen off, and the union had recently made an unsuccessful attempt to produce hosiery itself. A new framework-knitters' union was organized at Leicester in 1824 to replace the one founded in $1819 .{ }^{5}$ Strikes took place at Leicester in 1824 and in $1825,{ }^{6}$ and in 1825 legal proceedings were taken against some framework-knitters who had been involved in acts of violence and intimidation. 7 Some advance of wages was obtained in $\mathrm{I} 825,{ }^{8}$ but the winter of $1825-6$ was a time of acute depression, the union's funds became exhausted, and the operatives were quite unable to resist wage reductions. ${ }^{9}$ Though the Combination Acts had been repealed in 1824 , so that for the future trade unions were not in themselves

Leic. Fnl. 10 Sept. 1819.

2 Ibid. 24 Sept., 22 Oct., 29 Oct. 1819; Hammond, Town Labourer, 251-3; Patterson, Radical Leic. 126; Greaves, Corp. of Leic. 76; Wells, Brit. Hosiery Trade, 125.

${ }^{3}$ Ist App. to Rep. Cond. Framework Knitters, 55; Wells, op. cit. 125; Leic. Fnl. I 3 Sept. 1822.
4 Rep. Cond. Framework Knitters, 26, 102.

5 Patterson, Radical Leic. I34-5.

6 Leic. $7 n l .9$ Apr., 4 June, I I June I824, 6 May 1825.

7 Greaves, Corp. of Leic. 77; Patterson, Radical Leic. I 39.

8 Rep. Cond. Framework Knitters, 132.

9 Patterson, Radical Leic. I 40. 
illegal, the severe struggles of $1824-5$ seem to have destroyed the Leicester frameworkknitters' power of resistance and organization, so that it was more than a decade before trade unionism was revived amongst them. Some slight improvement in trade took place at Leicester in $1827,{ }^{10}$ but despite periodic minor improvements the general circumstances of the hosiery workers remained very depressed. In 1830 it was said that a very industrious workman could make $2 \frac{1}{2}$ dozen hose-apparently wrought hose-a week, for which he would be paid $3 s .6 d$. a dozen, giving a gross weekly income of $8 s .9 d$. Frame rent at is. a week would have to be deducted from this, together with smaller sums for such things as needles and oil. It was reckoned that a man earning at such a rate, after paying all deductions and his house rent, would have only is. $9 d$. a week left for food for himself and his family. ${ }^{11} \mathrm{~A}$ report made in $\mathrm{I} 833$ by one of the factory commissioners shows what the circumstances of the Leicester framework-knitters then were. The commissioner described the small and ill-ventilated shops in which some of the framework-knitters laboured, and noted that with few exceptions their whole appearance was sickly and emaciated. ${ }^{12}$ Framework-knitters' wages at Leicester were commonly supplemented by poor relief in the early I $830^{\prime}{ }^{13}$

The main cause of the distressed condition of the hosiery workers was an excess of labour, aggravated by the fact that since i 800 large numbers of women had become framework-knitters. ${ }^{14}$ The hosiery manufacturers of the day were inclined to blame the depressed state of the industry on foreign competition, which they claimed had deprived them of their export markets, but it seems very doubtful whether there was any truth in their contention. The demand for worsted hosiery, which was Leicester's most important product, seems to have been fairly steady during the I 830's. ${ }^{15}$ The hosiery workers themselves seem to have attributed their distress mainly to the production of 'cut-ups', but this view also appears to be unsubstantiated. ${ }^{\mathrm{I} 6}$

Besides low wages and insufficient employment, the hosiery workers had other grievances about the way in which the industry was conducted. The exaction of frame rent was a cause of many complaints. ${ }^{17}$ The rent was a constant charge which always had to be deducted from the operative's gross earnings, ${ }^{18}$ and it usually had to be paid even when the frame was out of use from such causes as illness, and irrespective of the amount of work done. ${ }^{19}$ The practice of charging frame rent meant that it was to the advantage of the owners of frames, who were usually the hosiers, to keep as many frames operating and paying rent as possible, a situation which favoured the retention in the industry of a large number of under-employed persons. ${ }^{20}$ At the end of the I 8 th century the usual rent for a frame was $9 d$. or Iod. a week. ${ }^{21}$ Higher rents were charged for the wider frames introduced about $\mathrm{I} 800$, and in $\mathrm{I} 845$ it was said that frame rents varied from $9 d$. to $3 s$. a week. ${ }^{22}$ Another major grievance of the Leicester hosiery workers was the prevalence of the truck system. At Leicester trucking seems to have begun about I 820 and to have been fairly general in $1845 .{ }^{23}$ The Leicester framework-knitters petitioned in favour of the Truck Act of 183 I which, however, failed to suppress the practice entirely. ${ }^{24}$ The truck system was closely linked with middlemen, whose growing

10 Leic. $7 n l .7$ Sept. 1827 .

11 Ibid. 8 Feb. 1830 .

12 Ist Rep. of Children's Employment Com., H.C. 450, p. 540 ( 1833 ), xx.

${ }_{13}$ 2nd Rep. Poor Law Com., H.C. 595, p. 398 (1836), $\operatorname{xxix}(\mathrm{I})$.

14 Rep. Cond. Framework Knitters, 129-30; Wells, Brit. Hosiery Trade, 1 34-6; Ist App. to Rep. Cond. Framework Knitters, 17.

15 Wells, op. cit. I $3 \mathrm{I}-4$.

16 Wells, op. cit. 98-99, 1 о -4; Patterson, Radical Leic. 124.

LEIC. IV
17 Rep. Cond. Framework Knitters, 77.

18 Ibid. 7 I.

19 Ibid. 45 .

20 Ibid. 130.

21 Ibid. 50; Ist App. to Rep. Cond. Framework Knitters, 132.

22 Rep. Cond. Framework Knitters, 14.

${ }_{23}$ Ibid. 72, 77, 79; Ist App. to Rep. Cond. Framework Knitters, I 6 .

24 Leic. $\mathcal{F n l}, 23$ Sept. 1831 . The Act (1 and 2 Wm. IV, c. 37 ) was not the first against trucking. 


\section{A HISTORY OF LEICESTERSHIRE}

activity was considered by the framework-knitters to be a cause of hardship. The middlemen intervened between the hosiers and the framework-knitters, giving out yarn and collecting finished work. They seem to have first appeared at Leicester during the years of depression after the Napoleonic wars, from about I 816 onwards, ${ }^{25}$ and by 1845 had become a normal part of the organization of the industry at Leicester. ${ }^{26}$ Their position no doubt gave them opportunites for perpetrating various minor frauds upon the operatives, ${ }^{27}$ but on the other hand they did perform a useful function in saving the frameworkknitters their weekly journeys to the hosiers' warehouses, and it seems very doubtful whether the rise of the middlemen really made the circumstances of the operatives worse than it would otherwise have been. Much evidence about middlemen and their activities is to be found in the 1845 Report on the Condition of the Framework Knitters. ${ }^{28}$ Much of the evidence in the report relates to a period later than that covered by this article, and the position of the middlemen in the hosiery industry is dealt with elsewhere more fully. 29 'The practice of concentrating the frames in shops, instead of leaving them to be operated by the workers in their own homes, was a further cause of some hardship to the framework-knitters, as the shops were often crowded and ill ventilated. ${ }^{30}$ Such workshops seem to have grown up at Leicester from about I825 onwards. ${ }^{31}$

The depressed condition of the hosiery trade led in I 845 to a parliamentary inquiry. That inquiry, and its results, lie outside the scope of the present article, and are discussed below. 32

From the earliest days of framework-knitting the connexion between dissent and the hosiery industry at Leicester was very strong. Nicholas Alsop, reputed to have introduced the stocking frame to Leicester, was certainly a Whig, and probably a dissenter. ${ }^{33}$ The Pougher family, who were prominent in the industry during the late $\mathrm{I} 7$ th century and the first half of the I 8 th, ${ }^{34}$ were leading dissenters, and Abstinence Pougher was one of the prime movers in the foundation of the Great Meeting, Leicester's most famous dissenting church, in 1 708.35 'The Great Meeting's registers of births and baptisms for the I 8 th century contain the names of many men who became prominent hosiers. ${ }^{36}$ Of the twelve original trustees of Leicester's first Baptist chapel, built in Friar Lane about I719, three were hosiers and two framework-knitters.37 The prominent hosier John Coltman, together with another hosier, William Lewis, played a leading part in the foundation of the Millstone Lane chapel, the first Methodist place of worship in Leicester, ${ }^{38}$ and one of the chief supporters of the Harvey Lane chapel, the centre of the Particular Baptists, was Richard Harris, one of the town's leading hosiers during the first half of the I 9 th century. 39 'The existence of a large and influential body of dissenters in the hosiery industry was attended with important political consequences. These, however, have been dealt with above. ${ }^{40}$

\section{(b) Other Textile Trades}

The hosiery trade was the only branch of textile production to become vitally important at Leicester in the period here being considered. Lace-making was carried on throughout

25 Ist App. to Rep. Cond. Framework Knitters, 36.

26 Ibid. $36,63,74,104$.

27 V.C.H. Leics. iii. Io.

${ }_{28}$ Rep. Cond. Framework Knitters, [609] H.C. (1845), xv.

29 See below, p. 303 .

30 Wells, Brit. Hosiery Trade, 130-1; ist App. to Rep. Cond. Framework Knitters, 23.

31 Ist App. to Rep. Cond. Framework Knitters, 82.

32 See below, pp. 303 sqq.

33 Thompson, Hist. of Leic. ii. 17.

34 See above, p. I68; and see Reg. Freemen of Leic. I I 96-I 770, pp. Xxxvii. 172, I $84-5,188$, I 92, I93, I 96,
2I8, 221, 242, 3 I 5, and Thompson, op. cit. ii. 258 .

35 A. H. Thomas, Hist. of Great Meeting, Leic. 28, 29, 3 o.

36 Great Meeting Reg. vol. i, $1711-40$, and vol. ii, I 743-85 (Gen. Register Office, Somerset House); Gardiner, Music and Friends, i. I ; ibid. ii. 8I I ; A. H. Pagett, Gt. Meeting Epitaphs, 119 ; and see below, p. 393 .

37 J. W. Smith, Hist. of the General Baptist Ch. at Friar Lane, 13-14. On the Friar Lane chap. see below, p. 391.

38 Thompson, Hist. of Leic. ii. 264-5; Gardiner, Music and Friends, ii. 8 Io.

${ }_{39} \mathrm{~T}$. Lomas, Memoir of the late R. Harris, passim.

40 See above, p. 137. 



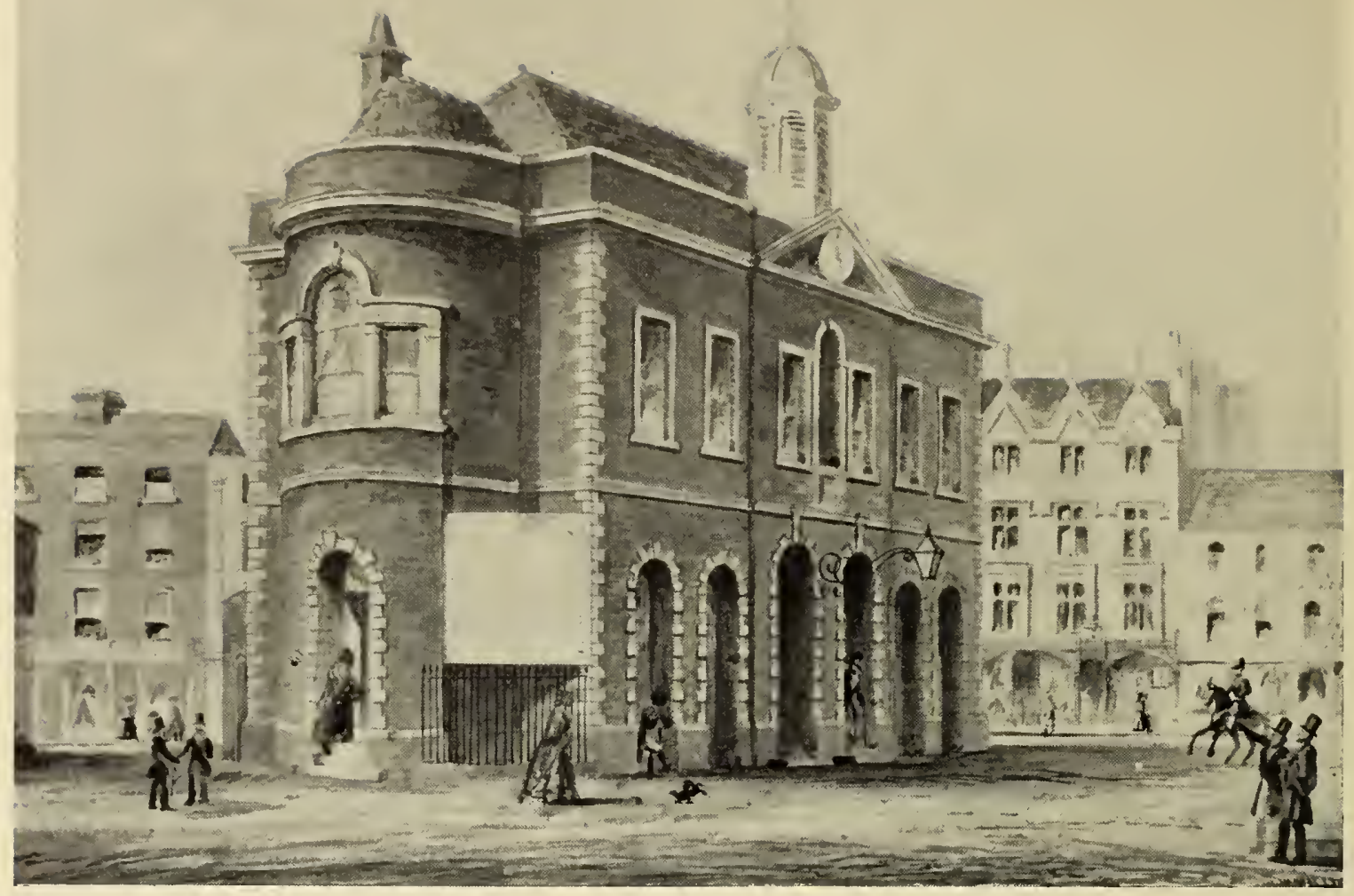

The Old Corn Exchange, or New Gainsborough built $\mathrm{I}_{748}$, demolished $\mathrm{I}_{5} \mathrm{I}$

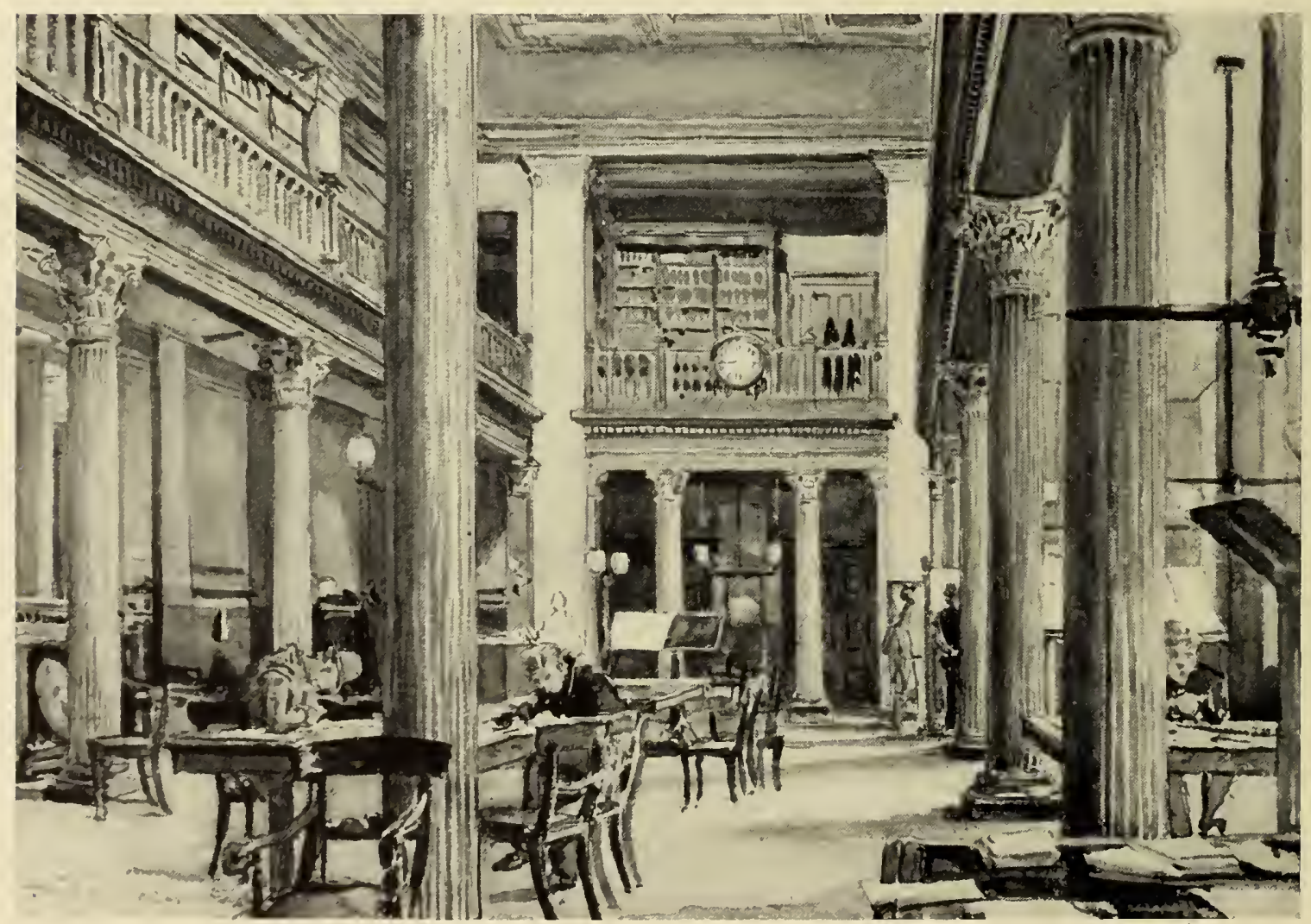

The News Room, Granby Street opened I 838 , demolished I90 I 


\section{THE CITY OF LEICESTER}

the period, ${ }^{41}$ but never seems to have become of any great importance. Weavers are listed amongst the freemen of Leicester until the late 18 th century, but they are not very numerous. ${ }^{42}$ Occasionally Leicester weavers are described as belonging to some particular branch of their trade, such as silk-weaving or tammy-weaving, ${ }^{43}$ but no specialized form of weaving became established in the town as a distinct industry, and weaving never approached the hosiery industry in importance.

\section{(c) Trade and Commerce}

In 1660 retail trade at Leicester was centred in the markets, and considerable sums were spent by the corporation from time to time in improving the amenities for traders. 44 The Saturday market, ${ }^{45}$ held on the site of the present ${ }^{46}$ Market Place, was the most important one. Considerable improvements were effected to the Saturday market place during the $\mathrm{I} 8$ th century. The shops there, which were owned by the corporation, were rebuilt in 17 I $_{4}-15,47$ and the Hall Book for September I 7 I 5 gives a list of the tenants of 26 newly built shops, stating their trades and the rents they paid. Five of the tenants were bakers and three were glovers; some others seem to have been craftsmen rather than traders; there were, for example, a carpenter, a slater, ${ }^{48}$ and two shearmen. Rents varied from $\oint_{\mathrm{I}} \mathrm{I} 2 \mathrm{~s} .6 \mathrm{~d}$. for corner shops to $\oint_{\mathrm{I}}$ a year for those which were least advantageously placed. ${ }^{49}$ Besides the shops, the Saturday market contained stalls, which were apparently less substantial structures. In $\mathrm{I} 7 \mathrm{I} 7$ the corporation was renting out stalls 6 feet long for Ios. a year. ${ }^{50}$ In 1726 the shambles in the Saturday market were rebuilt. ${ }^{51}$ In 1747 the old building called the Gainsborough was demolished, together with the adjacent shambles and some minor buildings, and the new Exchange was erected. Its upper rooms were used by the magistrates; the lower ones were intended for the butchers, in place of the old shambles, but were only used by them for a short time. By I 79 I it was already being felt that the Exchange should be pulled down, as the Market Place was by then too small for the amount of business being done, and the space occupied by the Exchange was needed. The Exchange, however, survived until the middle of the r 9 th century..$^{22}$ In the second half of the 18 th century many new buildings were put up around the Market Place, and between 1800 and I 830 many new retail shops were built bordering on it. ${ }^{53}$

The old Wednesday market in High Cross Street continued to be held throughout the period with which this article deals. ${ }^{54}$ This market, which was for the sale of butter, eggs, fruit, and vegetables, was only of minor importance. ${ }^{55} \mathrm{~A}$ small pavilion which had

41 Reg. Freemen of Leic. II96-I770, I48, I53, 163, I66, 201, 386, et passim; Patterson, Radical Leic. I66; R. of Mayors of Leic. I 30 ; L.R.O. Probate Rec. St. Margaret's Peculiar, Inv. of Ric. Moseby, 1690.

42 Reg. Freemen of Leic. $1196-1770,153,163,166$, $210,240,251,256,258,260,261,264$, et passim.

43 Ibid. 160, 165, 240, 254. For inv. of a silk-weaver, with a silk loom and wheel, see L.R.O. Probate Rec. Inv. of Robt. Saunders, 1705. Tammy weavers produced cloth of which both the warp and weft were made from combed, as distinct from carded, wool.

44 Greaves, Corp. of Leic. 63 ; Leic. City Mun. Room, Hall Bk. I6 Apr. I714, 5 and 8 Apr. I715. The stalls and shambles in the Saturday market, previously the property of the Duchy of Lanc., had been granted to the corporation by Eliz. I in 1589: Leic. Boro. Rec. I509-1603, 249-50.

45 Held on Sat. except when Sat. was Christmas or Boxing Day. On the earlier hist. of the Leic. markets, see above, pp. 45,56 .

461956.

47 Leic. City Mun. Room, Hall Bk. 5 Apr. I715, I6 Sept. I715, 27 Apr. I7I6.
${ }^{48}$ But possibly acting here as a tallow chandler: see below, p. 184 . 50 Ibid. I Mar. I7 I7.

51 Ibid. 4 July 1726 , 1o Mar., Io and 12 Oct. 1727.

52 Throsby, Hist. of Leic. 376-7; 'Thompson, Hist. of Leic. ii. 3I; Billson, Medieval Leic. 46-9; White, Leics. Dir. (1846), 8I ; Nichols, Leics. i. 51 3. Another shambles, built near St. Nicholas's ch. in I682, was still in use in I 728 , but disused by 1784 : Leic. Boro. Rec. $1603-88,55^{8}$; Throsby, op. cit. 37I-2; Nichols, Leics. i. 51 $3^{-14}$; Leic. City Mun. Room, Hall Bk. I9 Aug. I728, 6 Dec. 1784. Shambles had existed near St. Nicholas's in the Middle Ages: see above, p. 44. An engraving of the Exchange built in 1747 is given in Nichols, Leics. i. 326 . Two views of the Market Place before 1747 are in R. Read, Modern Leic. 6, 15.

53 Throsby, op. cit. 377; Curtis, Topog. Hist. Leics. II4-I5. A view of the Market Place in 1812 is given in Leics. and Rut. Notes and Queries, i. I3o.

54 On its earlier hist. see above, pp. 46-47. It existed until I884: J. Storey, Historical Sketch ... of Leic. 133-4.

55 Storey, op. cit. 133; Nichols, Leics. i. 532. 


\section{A HISTORY OF LEICESTERSHIRE}

stood in High Cross Street since I 577 and was used by the market people was pulled down in 1773 and replaced by a simple pillar. ${ }^{56} \mathrm{Coal}$ and hay were sold in the space outside the East Gate. ${ }^{57}$ In 1763 the corporation gave orders that a new market for fat and lean cattle and sheep was to be held on Wednesdays, in the Saturday market place. ${ }^{58}$ In 1774 the cattle market was removed to Horsefair Street, on what was then the southern edge of the town, where it remained until well into the I 9 th century. ${ }^{59}$ Leicester possessed other livestock markets. The pig market, which in the I6th century had been held in Parchment Lane, ${ }^{60}$ was removed several times in the 18 th and early 19 th centuries, ${ }^{61}$ and was finally transferred to Loseby Lane, where it was established by I 8 I $5 .{ }^{62}$ The sheep market, which had been held in the Saturday market place from I 506 onwards, was removed about I 825 to an area south of Horsefair Street, the site of the present Town Hall. ${ }^{63}$ In 1823 the corporation authorized the holding of a market during the week. ${ }^{64}$ Some idea of the importance of the Saturday market can be obtained from the statement made in 1830 that provisions in great quantities were brought into the market every Friday night and Saturday morning from as much as 50 miles away, although large quantities of fruit and vegetables were produced by the market-gardens in the immediate vicinity of Leicester. ${ }^{65}$

The annual fairs provided opportunities for business on a yet more extensive scale. The charter of 1684 included the grant of a fair on the Saturday before Palm Sunday for livestock and all other forms of merchandise. ${ }^{66}$ This fair was not a new one: it had been held in 1627 and its origin is unknown. ${ }^{67}$ The great May and October fairs of medieval origin continued to be held, ${ }^{68}$ together with the midsummer and December ones founded in 1540.69 Much trading in livestock was carried on at these in the late 18 th century and in $\mathbf{I} 794$ five additional fairs for livestock were established by the corporation. ${ }^{70}$ Another

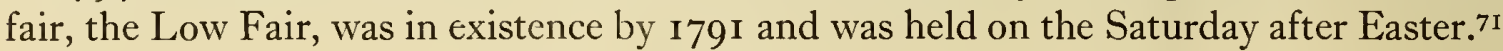

Even as late as 1830 the Saturday market place remained the centre of the town's retail trade, and sites for shops around it were considered particularly valuable. ${ }^{72} \mathrm{By}$ that date, however, the streets radiating from Coal Hill'3 (High Street, Gallowtree Gate, Belgrave Gate, and Humberstone Gate) were already becoming important for their retail shops. In Gallowtree Gate and Humberstone Gate especially, many new buildings were erected in the first thirty years of the 1 th century. ${ }^{74}$

The purveyance of food and drink was an occupation which involved a relatively large number of people at Leicester, including some of the wealthiest and most influential members of the community. ${ }^{75}$ Many mayors in the period between I660 and I835 were drawn from the victualling trades. ${ }^{76}$ Edmund Townsend, Mayor of Leicester in I 666, may be taken as an example. His probate inventory, drawn up in I678, lists goods to a total value of $f_{594}$ i is. $6 d$., including i 2 gallons of ale and i 56 quarters of malt,

${ }^{56}$ Throsby, Hist. of Leic. 92, 365; Nichols, Leics. i. 501 . There is an engraving of it in Throsby, op. cit. 62.

57 i.e. around the site of the present clock tower. Nichols, Leics. i. 532; Throsby, op. cit. 406; A. Fielding Johnson, Glimpses of Ancient Leic. (2nd ed. I906), 234.

${ }_{58}$ Greaves, Corp. of Leic. 64; Thompson, Hist. of Leic. ii. II 3 .

59 Thompson, op. cit. ii. I 54; Billson, Medieval Leic. I 2 I.

60 The modern New Bond Street and East Bond Street.

${ }_{61}$ Leic. City Mun. Room, Hall Bk. I4 Feb.; 15 June 1798.

2 Nichols, Leics. i. 533.

3 Leic. Boro. Rec. I327-I509, 376-7, 379; White, Leics. Dir. (1846), 81.

${ }^{64}$ Greaves, Corp. of Leic. 64.

${ }^{25}$ Curtis, Topog. Hist. Leics. I1 5 . See also the remarks made about the large quantities of produce sold in the Leicester markets in $\mathrm{I} 76_{3}$ : E. Bowen and T. Kitchen, Large English Atlas ( 1763 ), plate 22.

${ }^{66}$ Leic. Boro. Rec. I603-88, 577.

67 Wm. Burton, Description of Leics. (1627), 150.

${ }^{68}$ See above, pp. 46-47.

${ }^{69}$ See above, p. 56 .

zo Thompson, op. cit. ii. 21 2; Throsby, Hist. of Leic. 378.

71 Throsby, Hist. of Leic. 378. For the later history of the fairs, see below, p. 284 .

${ }^{22}$ Curtis, Topog. Hist. Leics. I 15.

${ }_{73}$ The site of the present clock tower.

${ }_{74}$ Curtis, op. cit. I1 $15 . \quad{ }^{75}$ See above, pp. $157-8$.

76 For more than a third of the period $1660-1835$ the mayor belonged to one of the trades connected with food and drink; innholders and graziers are included: $R$. of Mayors of Leic. $105^{-93}$. 
valued in all at $\oint_{\mathrm{I}} \mathrm{II}$ I9s.77 Another mayor, Edmund Sutton of the Newarke, was a maltster. His probate inventory, made in $1690,{ }^{78}$ lists goods to a total value of $£_{1} 1383^{s .9}$., including Io quarters of dry malt worth $£^{8}$, and 8 quarters of green malt worth $£^{6}$, besides a good deal of livestock. In contrast to these two prominent citizens is a victualler of a later period, William Mapwell, whose probate inventory taken in I799 listed goods to a total value of $£ 496 s .9 d .79$ Until 1835 it was essential for all beer-sellers of the borough to take up their freedoms, for they had to go before the magistrates to obtain a licence. This was the only trade in which the old freemen's monopoly was maintained until $1835{ }^{80}$ The butchers and the bakers each had their own craft companies, which died out about the middle of the i 8 th century. ${ }^{81}$

The various branches of the clothing trade were well represented in Leicester. The glovers and fellmongers were members of a single company, which existed in $\mathrm{I} 660$, but for which there is no evidence at any later date. ${ }^{82}$ The tailors' company, under its annually elected steward and wardens, continued to exist until at least $\mathrm{I} 755^{\circ}{ }^{83}$ A mercers' company is mentioned in $\mathrm{I} 660-\mathrm{I} .{ }^{84}$ The percentage of freemen admitted between $\mathrm{I} 660$ and 1835 who were recorded as members of the clothing trades varied from 7 per cent. to 23 per cent. of the total admitted in any one year, ${ }^{85}$ and the number of apprentices bound to the trades during the same period varied from 7 per cent. to 18 per cent. of the number bound in any one year. ${ }^{86}$ The percentage of those in the clothing trades, as revealed by the Freemen's Register, was not so high in the igth century as in the three decades after the Restoration, when, judging by the admissions of new freemen and the numbers of new apprentices bound, the clothing trades were the most prominent in the town. No fewer than 9 of the 26 mayors who held office in the years 1660-88 were occupied in the clothing trades. ${ }^{87}$ Richard Weston, mayor in $\mathbf{1} 703$, may be taken as an example of a prominent mercer. He possessed land and messuages at Illston, Great Glen, Smeeton Westerby, and Belgrave, and in St. Mary's parish, Leicester. His probate inventory, made in I 7 I I, listed goods to a value of $f_{3}, 683$ I 7 s. I I $\frac{1}{2} d$., including a large variety of goods in his shop and warehouse, and in various rooms in his house. The stock in his shop included buttons, mohairs, sewing and stitching silks, buckram, canvas, tapes, threads, linen and woollen cloths such as Hollands and calicoes, serges, tammys, druggets, calamancoes, ribbons, silver and gold lace, galloon and threads, a 'Velvett' and a cloth pall, 4 cloaks, and sundry 'haberdashery wares'. The whole was valued at $£ 482$ I $7 s$. Iod. In his warehouse, next to the shop, was a similar array of goods, valued at $£ 5495^{s}$. I I $\frac{1}{2} d$. Besides goods connected with the mercery business his stock included starch, sugar, pepper, raisins, treacle, rice, tobacco, paper, 'flamboys and torches', and 75 gallons of oil. ${ }^{88}$

The probate inventory of Joseph Wallin, a tailor, gives an excellent view of a Leicester tailoring business in the middle of the 18 th century. The inventory was made in June I750, and shows that Wallin's chattels were estimated to be worth in all $£$ I $427 s .5^{2}$., including shop goods valued at $\oint_{\text {II }} 55^{s} .2 d$. The stock was listed in great detail. It included buckram, Irish linen, dowlas, shirts, coats, 'stay bodies', and metal buttons.

77 L.R.O. Probate Rec. Inv. I 679.

78 Ibid. Inv. I 690 .

79 Ibid. St. Margaret's Peculiar, Wills, I 799.

80 Greaves, Corp. of Leic. 60.

81 Reg. Freemen of Leic. I I 96-I770, 535-8.

82 Ibid. 542 .

83 Ibid. $546-8$.

84 Leic. City Mun. Room, Chamberlains' Accts. I66o5, p. I2.

85 Reg. Freemen of Leic. II 96-I770, I 43-368; ibid. I770-I930, I-297.
86 Ibid. II $96-1770,372-534$; ibid. I770-I930, 43I6I5. The reg. of apprentices is lacking for the periods $1651-77$ and $1683-1717$, and for $1678-83$ the record is defective. The figures given for apprentices relate to the years $1678-83$ and $I 717-1835$. It should be noted that the record of freemen's admissions is not a fully accurate guide to trades practised (see above, pp. I66-7), and that the importance of apprenticeship declined towards the end of the period under consideration.

87 R. of Mayors of Leic, I05-19.

88 L.R.O. Probate Rec. Will and Inv. I7I I. 


\section{A HISTORY OF LEICESTERSHIRE}

There were also parcels of old waistcoats, old quilts, old breeches, new greatcoats, men's new waistcoats, boys' new waistcoats, new quilts, new leather breeches, women's new short cloaks, new drill frocks, blue serge, drill, fustian, shag, tammy, and remants. ${ }^{89}$

John Bassford, glover and leather-seller, may be taken as an example of a wealthy trader engaged in the clothing trades, at the end of this period. His probate inventory, drawn up in $\mathrm{I}_{3} \mathrm{I}$, lists stock in trade valued at $f_{5.522} 9 \mathrm{s.} 2 \mathrm{~d}$., book debts totalling $£ 200$, $£ 92 \mathrm{I} 7 \mathrm{~s}$. in cash, leasehold estates valued at $£ \mathrm{IIO}$, and two shares in the Oakham canal, valued at $£ 70$. The total value of his goods was estimated to be $£_{1}, 2004 s .8 d .90$

\section{(d) The Building Crafts ${ }^{91}$}

In I660 Leicester was a town of timbered buildings, but before the end of the I 7 th century the manufacture of bricks had begun in the neighbourhood. In I699-1700 the corporation leased to Edward Broughton 4 acres of land in the South Field, to dig clay for brickmaking. ${ }^{22}$ The first mention of bricklaying in the Freemen's Register occurs in I 696 , when John Kirk, described as the son of Joshua Kirk, brickmaker of Leicester, was apprenticed to Thomas Hartwell, a bricklayer of Leicester. ${ }^{93}$ Celia Fiennes, writing in 1698,94 commented on the handsome brick houses in the Newarke, and on the new brick building at the Castle, though she described the town as mostly built of timber. After Joshua Kirk the next brickmaker to appear in the Freemen's Register is Edward White of Leicester, who is mentioned in $1702 .{ }^{95}$ The trade of brickmaker does not appear again in the register for over 30 years after I702, although some bricklayers occur. ${ }^{96}$ The Presbyterian (later Unitarian) church known as the Great Meeting, built in $\mathrm{I} 708$, is the earliest brick building in Leicester of which the actual date of erection is known, ${ }^{97}$ though not the earliest to be built in the town by many years. During the second half of the i 8 th century bricklayers appear fairly frequently in the Freemen's Register. ${ }^{98}$ In view of the great expansion of the town during the 18 th and early 19 th centuries, and of the fact that during the I8th century much of the timber building in the town was replaced by brick, ${ }^{99}$ bricklayers and other craftsmen connected with building must have been employed in considerable numbers, and brickmaking was still being carried on on a large scale near Leicester in $1832 .{ }^{I}$ More information is available about wage-rates in the building trades than about those in other occupations at Leicester. In considering this subject, it must be observed that master craftsmen occasionally charged more for their own services than for those of their journeymen, but such differences in pay, where they occurred, were only $2 d$. a day in favour of the masters. ${ }^{2}$ The wages noted in the following paragraphs are those of journeymen.

Bricklayers were sometimes paid by piece rates. In I $72 \mathrm{I}$ the churchwardens of St. Mary de Castro paid bricklayers at the rate of $5^{5}$. for every 1,000 bricks laid, ${ }^{3}$ and a year earlier the borough chamberlains paid for bricklaying at the rate of $4 s .6 d$. a thousand. ${ }^{4}$ In such instances it is difficult to estimate the actual earnings, but in most cases bricklayers were paid by the day. In I 7 I 5 a case occurs of bricklayers being paid at the rate of Is. $2 d$. a day, ${ }^{5}$ and in the I 720 's the usual rate seems to have been Is. $4 d$. a day. ${ }^{6}$

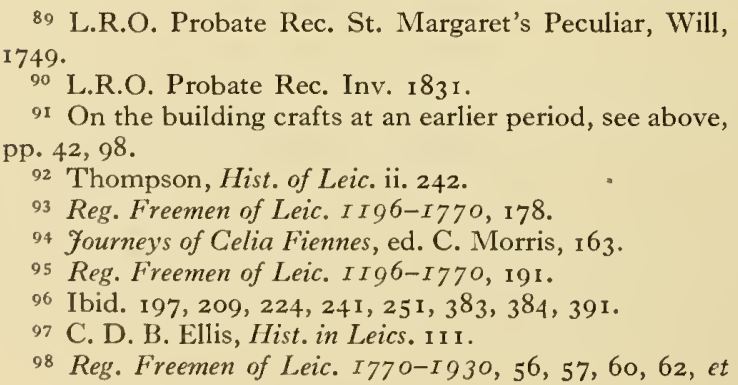

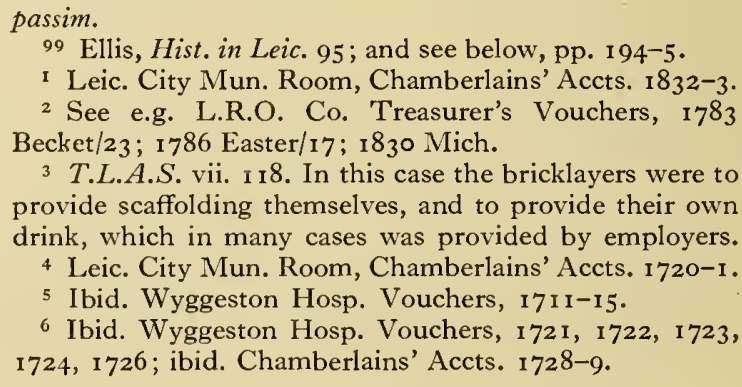
Becket/23; 786 Easter/17; 1830 Mich.

3 T.L.A.S. vii. 118 . In this case the bricklayers were to provide scaffolding themselves, and to provide their own drink, which in many cases was provided by employers.

4 Leic. City Mun. Room, Chamberlains' Accts. I720-I.

5 Ibid. Wyggeston Hosp. Vouchers, I 7 I I-15.

6 Ibid. Wyggeston Hosp. Vouchers, I 721 , 1722, 1723 , 1724, 1726; ibid. Chamberlains' Accts. 1728-9. 


\section{THE CITY OF LEICESTER}

These rates are rather below those paid to other craftsmen in the building industry. By the $175^{\circ}$ 's the normal pay had risen to Is. $8 d$. a day, ${ }^{7}$ about the same as other craftsmen were paid at Leicester. During the late I 8 th century wages rose further, though slowly. In the period $1770-90$ the usual daily pay of a bricklayer seems to have been $2 s$. or 2s. $2 d .^{8}$ During the French wars wages rose rapidly. In I $7922 s .4 d$. a day was being paid to bricklayers, ${ }^{9}$ in $1793-52 s .6 d .{ }^{10}$ and at the start of the I 9 th century $3{ }^{s .}{ }^{11}$ No examples of bricklayers' rates of pay have been found between I 802 and I 8 I 5 , when an instance occurs of $4^{s .6}$. being paid. ${ }^{\mathrm{I} 2}$ This was probably unusually good pay, for in $\mathrm{I} 8 \mathrm{I} 7^{\mathrm{I} 3}$ and I $819,{ }^{14}$ when further examples have been found, the rate was 3 s. Iod. Instances of unusually high rates occur in $1822^{15}$ and $1824,{ }^{16}$ but $4 s$. a day seems to have been usual in the late 1820 's. ${ }^{17}$ It would of course be unwise to attach too much importance to unusually high rates being paid on particular occasions; factors which are not revealed by the available evidence, such as the need for specially skilled work, may have been responsible. ${ }^{18}$

Masons, who perhaps did bricklaying in the $\mathrm{I} 7$ th century before bricklaying emerged as a separate craft, are not mentioned at all frequently in the Freemen's Register during the period I660-I $835 .{ }^{19}$ Examples of the wages paid to them are also not plentiful. In I660-I an instance occurs of a mason being paid at the rate of $I s$. a day, ${ }^{20}$ and in the I 690's there are two cases of Is. $2 d$. being paid. ${ }^{21}$ In $1747^{-8}$ the rates of $2 s$. and $2 s .4 d$. occur, ${ }^{22}$ and in 1779 the rate, exceptionally high for the time, of $5^{s .23}$ During the years between i 810 and I 833 , for which some twenty examples of masons' wages have been found, the rate of pay varied between $4 s$. and $5 s$., with an average of just under $4 s .6 \mathrm{~d} .{ }^{24}$ In general, masons' wages seem to have been rather above those of other building craftsmen.

Carpenters are mentioned with great frequency in the Freemen's Register, ${ }^{25}$ and no doubt during a period when many of the town's houses were still timber-framed there was a considerable demand for their services. Thirteen examples have been found of the wages paid to carpenters during the years I660-I7I 4 inclusive; in twelve cases the rate paid was $I s .2 d .{ }^{26}$ and in the remaining case $I s .4 d .{ }^{27}$ In the four examples found for the years $I 7$ I $5^{-20}$ the rate is $I s .4 d .,{ }^{28}$ and in all the cases that have been noted for the years I $720-40$ it is Is. $6 d^{29}$ In the two cases found in the I 740's the rate is Is. $5 d$. a day, ${ }^{30}$ but in the $175^{\circ}$ 's, Is. $8 d .{ }^{31}$ and in 1762 the rate of 1 s. Iod. occurs. ${ }^{32}$ In $1770-90$ the rate was either $2 s$. or $2 s .2 d$. a day. ${ }^{33}$ After I 790 carpenters' wages, like those of other craftsmen,

7 Ibid. Wyggeston Hosp. Vouchers, 1755, I757-8.

8 L.R.O. Co. 'Treasurers' Vouchers, I778 Mich/24; 1778 Easter $/ 26 ; 1779$ Easter $/ 20 ;$ 1781 Easter $/ 22 ; 1782$ Easter/24; 1783 Becket/23; 1785 Easter/27; 1786 Easter/ I $7 ; 1787$ Easter/1 $8 ; 1789$ Easter/1 8 .

9 Ibid. 1792 Easter/1 5 .

10 Ibid. I793 Easter/I 5 ; 794 Easter/3 I ; I 795 Easter/3I.

"I Ibid. 1800 Easter/35; 1802 Easter/29. Rates occur of 2s. $8 d$. (ibid. 1798 Easter/35), and $2 s$ rod. (ibid. 1799 Easter/17).

12 Ibid. I 8 I 5 Easter $/ 20$.

13 Ibid. I 8I 7 Easter/I I.

14 Ibid. 1819 Easter/7.

is Ibid. 1822 Easter/9.

16 Ibid. 1824 Easter/15.

17 Ibid. 1827, Easter/20; 1829 Easter/16.

18 See on this point Eliz. Gilboy, Wages in 18 th Cent. Eng. 251.

19 Reg. Freemen of Leic. $1196-1770$ and ibid. $1770-$ I930, passim.

20 Leic. City Mun. Room, Chamberlains' Accts. 16605 , p. I3.

21 Ibid. $1689-90 ; 1693-4$.

22 Ibid. $1747-8$.
${ }_{23}$ L.R.O. Co. 'Treasurers' Vouchers, I 779 Mich./24.

${ }_{24}$ Ibid. I8II Easter/14; I8I2 Becket/28; I8I 3 Mich./19; I8I4 Mich./14; I8I5 Becket/24; I816 Easter/7; I8I7 Easter/11; 1818 Easter/2; 1819 Easter/7; 1820 Easter/6; I 82 I Easter $/ 11 ; 1822$ Easter/10; 1823 Becket/17; I 824 Easter/28; 1826 Easter/27; 1827 Easter/20; 1832 Easter; I 833 Easter.

${ }_{25}$ Reg. Freemen of Leic. II96-I770 and ibid. I770r930, passim.

${ }^{26}$ Leic. City Mun. Room, Wyggeston Hosp. Vouchers, I694-1701 ; 1707; I 710; I 711-15; Ibid. Chamberlains' Accts. 1689-90, 1693-4; Accts. of Churchwardens of St. Martin's, ed. 'T. North, 25.

${ }_{27}$ Accts. of Churchwardens of St. Martin's, 44.

28 Leic. City Mun. Room, Wyggeston Hosp. Vouchers, I 7 I I-1 $5,1715^{-20}$.

29 Ibid. $1721,1722,1724,1725,1726,1729-30,1736$

30 Ibid. $1741-2,1743$.

31 Ibid. I 756, 1757, I 757-8.

32 Ibid. 1762.

33 L.R.O. Co. Treasurers' Vouchers, 1778 Easter/24; 1779 Easter/13， 14; 1780 Easter/26; 1781 Epiphany/23; I 782 Easter/13; I 786 Easter/23; 1787 Becket/19; 1788 Easter/31; 1789 Easter/27; 1790 Easter/II. 
rose rapidly. By i 800 the usual rate seems to have been 3 s., ${ }^{34}$ and two cases of carpenters' wages in $1813^{-1} 4$ show a rate of $4 s$. $10 d .{ }^{35}$ Of the six examples that have been found for the years I8I8-3I, four were $4 s$. a day, ${ }^{36}$ one was $4 s .4 d .,{ }^{37}$ and one $4 s .6 d .{ }^{88}$ In 1824

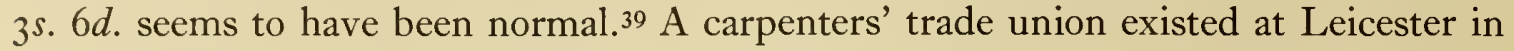
the $1790^{\prime}$ 's ${ }^{40}$ and in 1824 there was a carpenters' strike in the town, one of the series that occurred throughout the country in that year as a result of the repeal of the Combination Acts. ${ }^{41}$

Plumbers and glaziers seem to have constituted a single trade. In the Freemen's Register there are numerous instances of men described as 'plumber and glazier'.42 Though instances occur in the register of men being described simply as 'glazier', ${ }^{43}$ it is evident that these were sometimes, and probably usually, plumbers too; John Hall, for example, who was paid $£ 2$ a year by the corporation in the I66o's for looking after the town conduit, is described as a glazier, but he must also have been a plumber. ${ }^{44}$ Such evidence as is available for the wages of plumbers and glaziers suggests that they were paid at a rather higher rate than carpenters. In the years I696-1720 four examples of the wage rates of plumbers and glaziers have been found; in three of these the rate was Is. $6 d$. a day, ${ }^{45}$ and in the remaining one $I s .2 d . .^{46}$ In the period $1750-95$ the rate seems to have been stationary, $2 s .6 d$. being recorded on nine occasions, ${ }^{47}$ though rather less was sometimes paid..$^{48}$ After 1795 wages rose sharply to $3 s .6 d$. in $1805-9,{ }^{49}$ and to 45 . as the usual rate in $1810-35 .{ }^{50}$

At Leicester the slaters, plasterers, and tallow-chandlers all belonged to a single company, to the ordinal of which they were sworn.5I The company is mentioned in I657. It was controlled, like the other craft associations at Leicester, by a steward and two wardens, all elected yearly. It still existed in 1755 , but there is no further record of it, and it presumably died out, like the companies of the other Leicester occupations. ${ }^{52}$ Long after I755, persons described as 'slater, plasterer, and tallow chandler' continue to appear in the Freemen's Registers. ${ }^{53}$ 'The three occupations seem to have been practised together by some persons, ${ }^{54}$ though on the other hand slaters and plasterers appear in some records of payments as though the two trades were quite distinct from each other. There is, however, an obviously close connexion between slating and plastering, and it is possible that slaters and plasterers turned to the making of tallow candles during the winter, when there would be little building work. ${ }^{55}$ The wage-rates

${ }^{34}$ Payments of 3 s.: ibid. 1797 Easter/21; 1799 Easter/ I 8; I 800 Easter/27; of 2s. 6d.: ibid. I79 I Easter/I7; 1793 Easter/29; of $2 s .8 d$. : ibid. 1794 Easter/I 7; 1795 Easter/1 7 .

35 Ibid. I8I 3 Mich./1 5; I 814 Easter $/ 24$.

36 Ibid. I 8 I 8 Mich./2; I820 Easter/II; I824 Mich./12.

37 L.R.O. Co. Treasurers' Vouchers, I 830 Easter.

38 Ibid. 1828 Easter/I 7 .

39 Leic. Inl. 4 June 1824

40 Ibid. I4 May 1790.

41 Ibid. 4 June 1824

42 Reg. Freemen of Leic. II 96-I770, 196, 204, 207, 212, $218,229,384,391$; ibid. I770-I930, 67, et passim.

43 Ibid. II96-I770, I43, I6I, I 52, I 53, 22 I, 237; ibid. I 770-I930, 5I, 58, 65, et passim.

44 Leic. City Mun. Room, Chamberlains'Accts. I66o5, p. I2.

45 Ibid. Wyggeston Hosp. Vouchers, I694-I70I ; I 7 I 5-20.

46 Ibid. Chamberlains' Accts. I720.

47 Ibid. Wyggeston Hosp. Vouchers, I756; L.R.O. Co. Treasurers' Vouchers, I780 Easter/22; I78I Easter/I 8; 1784 Easter/I7; I785 Easter/36; I787 Easter/I7; I791 Easter/19; 1792 Easter/24; 1793 Easter/16; I 794 Easter/27.

48 Leic. City Mun. Room, Wyggeston Hosp. Vouchers, I 76I-62 (2s. 3d.); L.R.O. Co. Treasurers' Vouchers, I 778 Easter/39 (2s.); 1779 Mich./15 (2s.).
49 Three instances found: L.R.O. Co. Treasurers' Vouchers, I 805 Easter/I 2; I 806 Easter/ 16 ; I 809 Becket/24. 50 L.R.O. Co. Treasurers' Vouchers, I810 Mich./12; I 8I3 Mich./I6; I8I8 Easter/3; I8I9 Becket/6; I827 Mich./23; I 829/Becket/I 5 ; I830 Mich.; I831 Easter; I 835 Epiphany; I 835 Easter. Higher rates were sometimes paid, e.g. $4 s .2 d$. : ibid. I 826 Mich. $/ 27$.

5I Reg. Freemen of Leic. II 96-I770, 543.

52 Ibid. 543-5.

53 Ibid. I770-I930,67, I I 5, et passim. Not much importance can be attached to the exact expressions used in the Freemen's Reg. to describe the slaters, plasterers and tallow-chandlers. Both before and after 1755 such phrases occur as 'slater, etc.' (ibid. I I $96-1770,144,159,224,225$, 234,388 ), or 'slater, plasterer, etc.' (ibid. $146,225,228$, 23 I), besides the simple description 'slater' (ibid. 232, 234, $242,243,248,337,349,353,382$ ).

54 e.g. the probate inventory of Thomas Beaumont (L.R.O. Probate Rec. Inv. 1710) describes him as a slater, but shows he possessed stocks of tallow and equipment for making candles. The inventory of Thomas Woodland (ibid. Inv. I67I) describes him as a chandler, but his goods included slate pins.

55 This suggestion has been made by Dr. W. G. Hoskins. 
of slaters and plasterers seem from the available evidence to have resembled fairly closely those of the other building crafts. Thirteen examples of slaters' pay have been found for the years $1695^{-17} \mathrm{I} 3$, and in all save one case the rate was Is. $2 d$. a day. ${ }^{56}$ From 17 I 5 to about $\mathbf{I} 75^{\circ}$ the rate was $\mathrm{I} s$. $4 d$. or Is. $6 \mathrm{~d}$. a day..$^{57}$ In the I750's and 1760 's the three instances that have been found are of $I s .8 d$. a day, and in $1770-90$ there are seven of $25 .^{58}$ After $\mathbf{I} 790$ wages in this craft, as in others, rose more rapidly. From 1790 to 1800 they fluctuated between $2 s$. and $3^{s .},{ }^{59}$ and from $\mathrm{I} 800$ to $\mathrm{I} 8 \mathrm{I} 5$ between $3^{s}$. and $4 s .{ }^{60}$ From I 8 I 5 to 1835 there are ten examples of $4 s$. a day, together with three of $4 s .6 d$. and one of $3 s .9 d .^{61}$ The occasional examples of plasterers' rates of pay that have been found ${ }^{62}$ suggest that in general their wages closely resembled those of the other building trades, but not enough evidence has been found to describe their pay rates in detail.

The wages of labourers in all the building trades at Leicester seem to have resembled each other very closely during this period, and it is not possible to discover different trends or fluctuations in the labourers' remuneration in any one building trade as distinct from that prevailing in any other. Consequently the wage rates of labourers in all the building trades may be considered together. In the late $\mathbf{I} 7$ th century and until about I 740 the normal rate of pay was Iod. or is. a day, examples of both those rates being found throughout the period;63 occasionally lower wages were paid, ${ }^{64}$ but apparently such cases are exceptional. During the period I740-60 labourers' wages, in the instances that have been found, were $I s$. a day. ${ }^{65}$ About 1780 they were $I s$. $4 d$. a day, ${ }^{66}$ and between $\mathrm{I} 785$ and $\mathrm{I} 790$ they varied from $\mathrm{I} s .4 d .{ }^{67}$ to $\mathrm{I} s .6 d .{ }^{68}$ In $\mathrm{I} 792 \mathrm{I} s .8 d$. was being paid, ${ }^{69}$ and from 1793 to 1795 the rate was Is. Iod.70 About I 800 it seems to have been $2 s$. a day. ${ }^{71}$ In the period $1810-30$ labourers' wages fluctuated between $2 s .6 d$. and $3 s .4 d$. ; no distinct pattern is discernible in the fluctuations. The average of the instances discovered was $2 s .8 d .7^{72}$

\section{(e) The Metal-Working Trades ${ }^{73}$}

Not a great deal of information is available about the organization of the metalworking trades, or the earnings of workers in them, during this period. The probate

${ }^{56}$ Leic. City Mun. Room, Wyggeston Hosp. Vouchers, bundle I694-170I, for I695, I697, I698, I700, I70I; Wyggeston Hosp. Vouchers, I707, I708, I 709, I7 I0, I 7 I I ; ibid. bundle I7II-I5, for I7I3; Wyggeston Hosp. Receipts, I 689; Leic. City Mun. Room, Chamberlains' Accts. I698-9.

57 Six cases of Is. $4 d$ : Leic. City Mun. Room. Wyggeston Hosp. Vouchers, bundle I7II-I5 (I7I5); bundle I 7I 5-20 (I7I6, I719); I738; I738-9. I 2 cases of is $6 d$ : ibid. I $721,1724,1725,1726,1728-9,1729-30,1738$, I 738-9, I 739-40, I 74I-2, I 743 .

58 Leic. City Mun. Room, Wyggeston Hosp. Vouchers, I 757; I 76 I-2. L.R.O. Co. 'Treasurers' Vouchers, I 778, Easter/27; I 778 Mich./17; I 779 Easter/Io; I781 Easter/I; I 782 Easter/I $9 ;$ I 783 Becket/34; I786 Easter $/ 24$. One case of $2 s .6 d$. occurs : ibid. 1783, Easter/14.

59 Six instances found: $2 s .2 d$. in $179 \mathrm{I}$ (L.R.O. Co. 'Treasurers' Vouchers, I79I Easter/23); 2s. 6d. in I794, I795, I 799 (ibid. I794, Becket/I3; I795 Easter/I 8; I799 Easter/1 5); 2s. $8 d$. in 1796 and 1797 (ibid. 1796 Easter/22; I 797 Easter/20).

60 Seven instances have found: $3^{s}$. (ibid. 18 o I Easter $/ 30$ ); 3s. I $d$. (ibid. I 8 I O Easter/I 8 ); $3 s$. 2d. (ibid. I 8 I I Easter/I2); $3 s .8 d$. (ibid. I 809 Easter/I5); 3s. Iod. (ibid. I806 Easter/17; I81 2 Easter/22; I 81 4 Easter/26).

61 Ibid. I 8 I 6 Easter/9; I 8I7 Easter/5; I820 Easter/9; I 822 Becket/I6; I 827 Becket/I6; I 829 Becket/I4; I 830 Mich.; I 83 I Mich.; I 833 Mich.; I 835 Mich. (4s.). Ibid. I 823 Mich./13; I 826 Easter $/ 28 ;$ I 828 Easter/19 (4s. 6d.). Ibid. I 824 Becket/I 9 (3s. $9 d$.).
62 e.g. Is. a day (Leic. City Mun. Room, Wyggeston Hosp. Acct. R. I672-3); Is. 6d. a day (ibid. Wyggeston Hosp. Vouchers, I 726); $3 s$. (L.R.O. Co. 'Treasurers' Vouchers, I787 Becket/I3); 2s. (ibid. I 788 Easter/24; I 789 Easter/I9).

${ }_{63}$ Leic. Boro. Rec. I603-88, 530; Vestry Bk. and Accts. of St. Mary's, Leic. ed. J. R. Abney, I04; Leic. City Mun. Room, Wyggeston Hosp. Receipts, I689; Wyggeston Hosp. Vouchers, I 694-I700 (I695, I697, I698, I 700), I 706-I I (I707, I 708), I 7 I I-I 5 (I I I4, I 7 I 5), I I I 5-20 (I7I8, I 7 I9, I720), I 72I, I 722, I723, I 724, I 725, I 726, I 728-9, I 729-30, I 738, I 738-9.

${ }_{64} 8 d$. (Leic. City Mun. Room, Wyggeston Hosp. Vouchers, I $72 \mathrm{I}$ ) and $9 \frac{1}{2} d$. (ibid. I $694^{-1} 700$, for 1698 ).

65 Ibid. I 739-40, I74I-2, I 743, I 757.

66 Eleven instances: L.R.O. Co. Treasurers' Vouchers, I778 Easter/26, 27; I778 Mich./17; I 779 Easter/Io, 21; I779 Becket/2I; I 780 Becket/21; I 782 Easter/I9; I 783 Becket/34; I 784 Easter/2 I ; 1785 Easter/I6.

67 Ibid. I787 Easter/I8; I 788 Easter $/ 24$.

68 Ibid. I 785 Easter/27; I 789 Easter/I $9 ;$ I 790 Easter/I 4.

69 Ibid. I 792 Easter/I 5 .

70 Three examples found: ibid. I793 Easter/1 5; 1794 Easter/3 I ; 795 Easter/3I.

71 Ibid. I 798 Easter $/ 35 ;$ I 800 Easter/35; I 802 Easter/29.

72 Ibid. I 8 Io Easter/I6; I 8 I I Easter/I4; I8I 3 Mich./2 I; I814 Mich./18; I82.2 Easter/9; I823 Easter/I3; I 824 Easter/I $5 ; 1829$ Easter/I 6 .

73 On the metal-working trades at an earlier period, see above, pp. 97-98. 
inventories, which provide a useful source of information about the preceding period, are of declining value for the years after 1700 . Blacksmiths and braziers occur frequently in the Freemen's Register, as might be expected, throughout the period, ${ }^{74}$ and more specialized craftsmen, such as gunsmiths, ${ }^{75}$ tinplate-workers, ${ }^{76}$ pewterers, ${ }^{77}$ goldsmiths, ${ }^{78}$ and silversmiths, ${ }^{79}$ are listed occasionally. The smiths and cutlers were members of a craft company, which like the other Leicester companies was presided over by a steward and two wardens, elected yearly. The company is last mentioned in $\mathrm{I} 738,80$ and presumably ceased to exist then, or soon afterwards. Framesmiths, the forerunners of the important branch of the engineering industry concerned with the manufacture of hosiery machinery, appear early in the $\mathrm{I} 8$ th century, ${ }^{8 \mathrm{I}}$ and needle-makers and sinkermakers, both producing equipment needed by the hosiery industry, appear at rather later dates. ${ }^{82}$ Before the end of the 18 th century the metal-working trades at Leicester were thus already being influenced in their development by the town's staple industry. The growth of the engineering industry in the town from the end of the $\mathrm{I} 8$ th century onwards is dealt with elsewhere.83

\section{(f) Agriculture}

Although the town of Leicester attracted a large proportion of the trade of the surrounding countryside, it must be remembered that many of Leicester's inhabitants were themselves engaged in agriculture. Until I 804 the freemen still had the right to pasture their livestock in the open South Field, and even after that date there remained an area set aside as pasture for freemen's animals. The disputes which arose over the corporation's handling of its property in the South Field show the extent to which, during the i8th century, the freemen valued their pasture rights. ${ }^{84}$ One of the town parishes, St. Margaret's, maintained a parish bull until at least $\mathrm{x} 828.85$ Until the I 9 th century the corporation usually included several representatives of the agricultural interest, ${ }^{86}$ and it was not exceptional for members of various trades to have considerable farming interests. The mayor in 1705 , for example, Thomas Hartshorne, although a bookseller, seems to have abandoned that trade in favour of farming. His probate inventory, drawn up in September I708, contains no mention of books, but lists wheat, barley, oats, peas, and hay, valued at $£ 200, \mathrm{I} 2 \mathrm{I}$ sheep, Io horses, and 3 cows, besides carts, wagons, ploughs, harrows, and other implements of husbandry. ${ }^{87}$ John Pares, mayor in 1695 , an innholder and vintner, had a farm in addition to his inn. At his death his property included 8 horses and mares, 4 cows, 4 hogs, 79 sheep, 3 carts, 2 ploughs, a wagon, corn, and hay. ${ }^{88}$ Less important tradesmen had their agricultural interests too. The probate inventory of 'Thomas Timson (d. I 724), a blacksmith of the Bishop's Fee, included, besides the tools of his trade, sheep valued at $f_{\mathrm{I}} 5$, out of possessions valued in all at $£ 32$ I $8 s .{ }^{89}$ Many other examples could be given of tradesmen or craftsmen who were engaged to some extent in agriculture in the town fields. ${ }^{90}$ The town population, too, included some who were fully engaged in agriculture, and some of those occupied

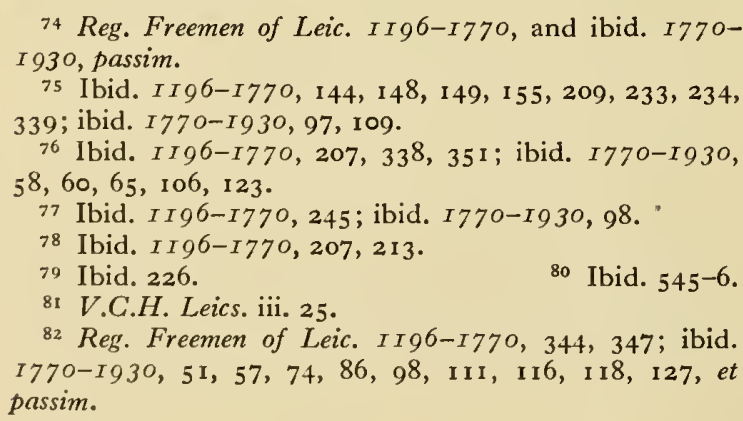

74 Reg. Freemen of Leic. II96-I770, and ibid. I770I930, passim.

75 Ibid. II96-I770, I 44, I 48, I 49, I 55, 209, 233, 234, 339 ; ibid. $1770-1930,97$, 109.

76 Ibid. $I I 96-I 770,207,338,35 \mathrm{I}$; ibid. $I 770-1930$, $58,60,65,106,123$.

77 Ibid. II96-I770, 245 ; ibid. I770-I930, 98.

78 Ibid. $1196-1770,207,213$.

79 Ibid. 226.

81 V.C.H. Leics. iii. 25.

82 Reg. Freemen of Leic. II96-I770, 344, 347; ibid. I770-I930, 51, 57, 74,86, 98, III, I16, I18, 127, et passim.

83 V.C.H. Leics. iii. $25^{-3}$ o.

84 See above, pp. $165^{-6}$.

85 E. Morris, St. Margaret's Select Vestry, 24.

86 Greaves, Corp. of Leic. 77.

87 L.R.O. Probate Rec. Inv. 1708.

88 Ibid. Inv. I7 I5.

89 Ibid. St. Margaret's Peculiar, Inv. 1724.

90 e.g. L.R.O. Probate Rec. Inv. of John Savage, pewterer, 17I7, Hen. Pate, gentleman, 1705: ibid. St. Margaret's Peculiar, Will of John Truville, baker, I 733 ; ibid. Robert Willowes, shearman, I737; ibid. Inv. of Francis Warberton, hosier, 1740; Will of Wm. Hartewell, mason, I 664 . 
in farming were amongst the wealthiest citizens of Leicester.91 In some cases inhabitants of the town were engaged in farming, as distinct from merely owning, lands outside the borough in the adjacent parishes. ${ }^{22}$ Throughout the period I7I $8-1835$ some apprentices were always being bound to agriculture, although the number never rose above 3 per cent. of the total number bound in any one year. ${ }^{93}$

\section{THE RELIEF OF POVERTY}

The hearth-tax returns of 1670 show that 28 I householders in the borough of Leicester were exempt from paying tax because of their poverty, and that 256 paid tax only on one hearth. All these may be classed among the poor, making a total of 537 households, or about 53 per cent. of the households recorded in Leicester. ${ }^{94}$ In the late 17 th century there was thus at least potentially a considerable poor relief problem at Leicester, and the problem increased with the growth of population and the increasing dependence of the town on a single great industry. At Leicester, as in other places, the system was that each parish had to provide for its own poor, supervised by the borough justices. The supervision was, in general, lax and ineffective, though that did not prevent much friction between the justices and the parishes. ${ }^{95}$ Various attempts were made to form a union of the Leicester parishes for poor law purposes. In I708 a bill providing for the establishment of a town workhouse controlled by a board of six guardians was introduced into the House of Commons, but, though supported by the corporation, was rejected. ${ }^{6}$ Leicester thus failed to obtain a special Act to deal with poor relief problems at a time when a number of other towns succeeded. In I792 it was again suggested that a town workhouse should be established, but the proposal, though strongly supported, failed owing to the opposition of the large and populous parish of St. Margaret's. The project was revived again in 1810 , but failed through the same cause. ${ }^{97}$

The administration of poor relief at Leicester therefore remained in the hands of the individual parishes throughout this period. Leicester.consisted of six parishes, St. Mary's, St. Margaret's, St. Martin's, St. Nicholas's, St. Leonard's, and All Saints', and of several small extra-parochial liberties. ${ }^{98}$ In the late $I 7$ th and early $I 8$ th centuries poor relief at Leicester was controlled, in the usual way, by unpaid overseers of the poor, appointed yearly. The poor were assisted by out-relief, which often took the form of payments for specific purposes, such as rent, clothing, of burial. 99 In the early I8th century the Leicester parishes began to build workhouses. In St. Margaret's some parish houses were built in I7I4. They were apparently designed only to house the poor, and not to provide premises where they could be set to work. The object was to reduce the amount that had to be paid for the rent of houses occupied by paupers. In I 723 the parish houses were enlarged and converted to a workhouse. ${ }^{\mathrm{I}}$ The course of events in St. Martin's was similar. In I 720 the parish decided to erect houses in Millstone Lane to contain the poor, and before the end of 1724 the five houses that had been built had been converted into a workhouse. ${ }^{2}$ In October 1724 the workhouse contained

9I See e.g. L.R.O. Probate Rec. Will and Inv. of Edmund Sutton, I690; ibid. Inv, of Philip Abney, I697.

92 e.g. Edmund Townsend, mayor, farmed at Evington, Glen Parva, and Scraptoft, besides having interests in Gosling Close, in the borough fields: L.R.O. Probate Rec. Inv. I678. John Bent, slater, farmed at Enderby; ibid. Will and Inv. I 7oo. Geo. Bent farmed at Illston on the Hill: ibid. Inv. I 709.

93 Reg. Freemen of Leic. I I96-I770, 382-534; ibid. I770-I930, 43I-6I5.

95 Greaves, Corp. of Leic. 43-46.

${ }_{96}$ C.F.xv. 529, 546, 558, 593, 609, 612; Greaves, op. cit. 42; Thompson, Hist. of Leic. ii. 22-23.

\footnotetext{
97 Greaves, op. cit. $42-43$.

$98 \mathrm{On}$ the liberties, whose position varied at various periods, see above, pp. 129-30, and below, pp. 343-7, 387 . 99 c.g. Vestry Bk. and Accts. of St. Mary's Leic. ed. J. R. Abney, 55, 76-82, 84-88, I 31-32; St. Leonard's Overseers of Poor Accts. Mich. I 703 (in custody of St. Leonard's par.).

I Nichols, Leics. i. 556.

2 Ibid. i. 585 ; St. Martin's Churchwardens' Acct. Bk. I645-I744, pp. I076, I I09, I I26 (in custody of St. Martin's par.); Nichols, Leics. i. 585 ; Accts. of St.Martin's, ed. T. North, 220-I. The date is given as 1714 , in error, in S. and B. Webb, Old Poor Law (1927), 245 n.
} 


\section{A HISTORY OF LEICESTERSHIRE}

28 persons, employed mostly in spinning and in knitting stockings. ${ }^{3}$ In St. Mary's, the building of parish houses was decided on in I $722 . .^{4}$ St. Mary's workhouse is mentioned in $1725 .{ }^{5} \mathrm{St}$. Leonard's parish decided to rent a building for use as a workhouse in I 742. ${ }^{6}$ All Saints' parish had a workhouse by I 746.7 By I776 all six parishes possessed workhouses, though the three extra-parochial liberties of Blackfriars, the Newarke, and Castle View were without any. The six parish workhouses could accommodate a total of 326 persons. ${ }^{8}$ In converting their parish houses to workhouses, St. Martin's, St. Mary's, and St. Margaret's were perhaps inspired by Knatchbull's Act of $1723,{ }^{9}$ which specifically empowered parishes to erect workhouses. The motive for building them at Leicester as elsewhere seems to have been a desire to reduce the poor rates. ${ }^{10} \mathrm{It}$ is not clear to what extent the Leicester workhouses were intended to replace out-relief altogether. In St. Martin's parish it was resolved in I 733 that no out-relief should be given. II How long this system continued is not known, but it had certainly been abandoned by I770, when there were 55 people in the workhouse, but 76 receiving out-relief. ${ }^{12}$ In St. Leonard's out-relief was being given in the late I740's, though a workhouse was established in $1742 .{ }^{13}$ Out-relief was being given in St. Mary's in I749, though the parish had a workhouse. ${ }^{14}$ The Leicester workhouses seem to have been usually farmed out to contractors who undertook to relieve all the poor of the parish, with certain reservations, in return either for a fixed sum weekly or monthly, or for a fixed weekly payment per head of those relieved. St. Martin's workhouse was farmed almost continuously from I 740. ${ }^{15}$ Agreements were made for farming St. Mary's workhouse in 1762,1767 , I778, I793. ${ }^{16}$ All Saints' workhouse was farmed in 1756 , and apparently until I8I4. ${ }^{17}$ In 1803 the workhouses of St. Mary's, St. Martin's, St. Margaret's, and All Saints' were all being farmed. ${ }^{18}$

The growing seriousness of the problem of poor relief at Leicester is shown by the increasing sums spent. In 1776 the total amount raised in the six Leicester parishes was $f 2,923,{ }^{19}$ but for the year ending April I 803 it was $f 7,105 .{ }^{20}$ For the year ending in March I 835 the expenditure in poor relief in the same six parishes was $£_{\mathrm{I}} \mathrm{I}, 493 .{ }^{21} \mathrm{In}$ St. Martin's parish, the sum paid to the contractor who farmed the poor rose from $£ 300$ a year in $\mathrm{I} 75^{\circ 22}$ to $\mathrm{f}_{\mathrm{I}} 3$ a week, or about $f_{676}$ a year, in $\mathrm{I} 786,{ }^{23}$ and $£_{2} \mathrm{I}$ a week, or about $f_{\mathrm{I}}, 090$ a year, in $\mathrm{I} 800 .{ }^{24}$ The growing expense of poor relief, and the increasing seriousness of the problem of pauperism, led to various measures to improve the administration of the poor law. One was the appointment of salaried officials to assist the overseers. As early as 1740 St. Martin's parish decided to allow $3 s .6 d$. a week to George Heighton,

\footnotetext{
3 Nichols, Leics. i. $5^{85} \mathrm{n}$.

4 T.L.A.S. vii. I I 8.

5 St. Mary's Poor Relief Accts. 1720-6, I725 (in custody of St. Mary's par.).

6 St. Leonard's Overseers of the Poor Acct. Bk. I72653, Io Apr. I 742 (in custody of St. Leonard's par.).

7 All Saints' Overseers of the Poor Acct. Bk. I746 (in Leic. City Mun. Room).

8 Rep. Sel. Cttee. on Returns of Overseers of Poor, in H.C. Rep. (Ist Ser.), ix, p. $3^{8} 5$.

99 Geo. I c. 7.

1o Nichols, Leics. i. 556,585 .

II St. Martin's Churchwardens' Acct. Bk. I645-1 744, p. 1242 (in custody of St. Martin's par.).

12 St. Martin's Churchwardens' Acct. Bk. I 745-1 782, I 3 July I 770 (in custody of St. Martin's par.)

13 St. Leonard's Overseers of Poor Account Bk." I72653 , e.g. 29 Nov. I 746 (in custody of St. Leonard's par.).

I4 Leic. City Mun. Room, St. Mary's Vestry Accts., acct. of money and bread distributed 22 Dec. and 29 Dec. I 749.

15 St. Martin's Churchwardens Acct. Bk. I645-I744, p. I 357 ; ibid. I745-82, 29 Aug. I750 and 25 June I 754 ;
}

ibid. $1782-1825,3$ Jan. 1804 et passim (all in custody of St. Martin's par.); one agreement has been printed in S. and B. Webb, Old Poor Law (1 927), 286-7 n.

I6 St. Mary's Vestry Bk. I 758-8 I, I 2 Oct. I 762, I 9 Oct. 1767,20 July 1778 (in Leic. City Mun. Room); St. Mary's Vestry Bk. I757-I8I6, 24 Apr. I793 (in custody of St. Mary's par.).

I7 All Saints' Overseers of Poor Acct. Bk. 1746-73, 27 Apr. 1756 (in Leic. City Mun. Room); All Saints' Vestry Minute Bk. I8I3-I4, Io Oct. I 8 I4.

18 Abstract of Answers and Returns ... relative to Expense and Maintenance of Poor, H.C. I75, pp. 262-3 (18034), xiii.

19 Nichols, Leics. i. 3 I 3, 323, 549, 557, 590, 608.

20 Abstract of Returns, 262-3.

21 2nd Rep. Poor Law Com. H.C. 595, p. 53I (1836), $\operatorname{xxix}(\mathrm{I})$.

22 St. Martin's Churchwardens' Acct. Bk., I 745-82, 29 Aug. I750 (in custody of St. Martin's par.).

${ }^{23}$ Ibid. I782-I825, 2 May 1786 (in custody of St. Martin's par.).

24 Ibid. 20 Apr. 1800. 
a former master of the workhouse, so long as he should take care of 'all certificated persons and all people that shall intrude in St. Martin's parish',25 and in I 749 the same parish appointed the master of the workhouse to assist the two existing overseers. ${ }^{26}$ In I $752^{2}$ St. Martin's appointed a permanent overseer with a salary of $£_{1} 5$ yearly. ${ }^{27}$ Similar steps were taken in other parishes at a later date; St. Margaret's appointed a permanent overseer in I800, and St. Nicholas's did the same in I8I6.28 Even in the small extra-parochial liberty of the Newarke, where there was no workhouse, it was found desirable to appoint an overseer in I8I9. ${ }^{29}$ In I 797 St. Martin's parish set up a committee to assist the existing officials. ${ }^{30}$ Poor-relief policy was discussed in St. Martin's vestry in 1804 , and again in $1806,{ }^{31}$ and in 1812 the parish decided to adopt Gilbert's Act of $1782^{32}$ so far as it concerned the poor law administration of individual parishes. A committee of thirteen was set up to carry out the decision, and in September I 8 I 2 the parish decided to recommend to the borough justices two persons for appointment as guardians of the poor, at a yearly salary of $£_{\mathrm{i}} \mathrm{O}$ each, and one man for the post of master of the workhouse at $£ 30$ yearly, together with persons to fill the offices of visitor and treasurer. ${ }^{33}$ The Sturges Bourne Vestry Act of $1819,{ }^{34}$ which authorized parishes to set up committees with powers to control the overseers of the poor, was adopted by St. Margaret's, All Saints', and St. Mary's parishes. ${ }^{35}$ St. Margaret's went further, and in 1832 obtained a special Act ${ }^{36}$ which placed the control of parish affairs, and especially the control of poor relief, in the hands of a select vestry consisting of the incumbent, parish officers, and twenty elected representatives of the inhabitants. ${ }^{37}$ The establishment of the parish committees, and of St. Margaret's select vestry, may have been partly due to a simple desire to improve the management of parochial business, but the main motive was the wish of the parishes to reduce, or even destroy, the borough justices' power of intervention in parochial affairs, and particularly their control of the overseers. 'The justices' actions reduced the power of the parishes to manage their own affairs, and involved them in expenses which they would have preferred to avoid. Tension between the justices and the parishes was made worse by the fact that the justices were drawn exclusively from the strongly Tory and Anglican corporation, while in the parishes Radical and dissenting elements, led by the growing class of wealthy hosiery manufacturers, were active. ${ }^{38}$

\section{THE LEICESTER NEWSPAPERS}

Up to I 835 three newspapers of importance were published in Leicester, the Leicester Fournal (at first the Leicester and Nottingham Fournal), the Leicester Chronicle, and the

\section{Leicester Herald.}

The Leicester and Nottingham Fournal published its first number on I 2 May I753. It contained only four advertisements, and the price was $2 d$. The paper, issued weekly, consisted of four small pages mostly filled with news from London, with some very slight paragraphs on local affairs. There was nothing in the nature of a leading article. The fournal had no distinctive features, but was an average provincial newspaper of the

25 Ibid. I645-1744, pp. I 126, I325 (in custody of St. Martin's par.).

26 Ibid. $1745^{-82,} 28$ Mar. 1749.

27 Ibid. 3 I Mar. 1752.

28 Greaves, Corp. of Leic. 45; St. Nicholas's Churchwardens' Accts. I8I6, i I Jan. (in Leic. City Mun. Room).

29 Overseers of the Poor Bk. for the Newarke, I 8 12-19, I6 Apr. I8 99 (in custody of St. Mary's par.).

30 Greaves, Corp. of Leic. 44.

3I St. Martin's Churchwardens' Acct. Bk. I 782-1825,

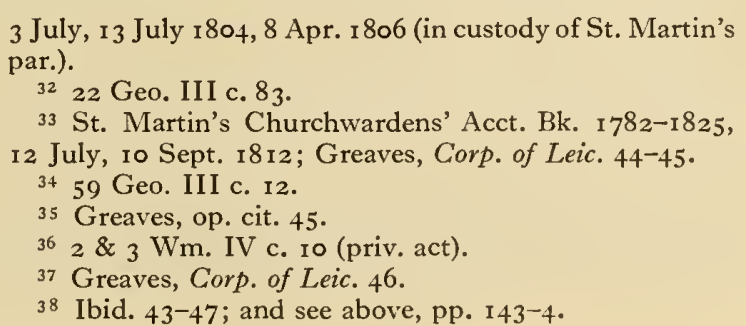

3 July, I 3 July I 804,8 Apr. I 806 (in custody of St. Martin's

33 St. Martin's Churchwardens' Acct. Bk. I 782-I825,

3459 Geo. III c. 12.

${ }_{36} 2$ \& 3 Wm. IV c. Io (priv. act)

38 Ibid. $43-47$; and see above, pp. I $43-4$. 


\section{A HISTORY OF LEICESTERSHIRE}

period. 39 There were three columns to each of the four pages. The first three pages contained the London news, although the third page had half a column of local information. Frequently the Leicester news was left out for lack of space. Throughout its history the Fournal was 'Tory in its outlook, and favoured the corporation. By 1773 the price had risen to $3 d$., and the space devoted to local news had expanded to a column and a half. 40

At the beginning of ${ }_{1} 787$ the paper changed its name to the Leicester Fournal. It had rarely contained any Nottingham news. When the duty on newspaper was increased in 1789 , the price of the fournal rose to $3 \frac{1}{2} d .4 \mathrm{I}$ In 1797 , with a further increase of the duty, the price rose to $6 d$., and it was stated that 'No advertisements will be inserted unless previously paid for because of losses incurred on that account.' ${ }^{22}$ From I 753 the editor was John Gregory, who was succeeded by his son, another John. In I 803 the younger Gregory took John Price into partnership, and in 1806 , when the younger Gregory died, Price took over as sole editor. ${ }^{43}$ Further rises in price took place, to $6 \frac{1}{2} d$. in $\mathrm{I} 8 \mathrm{ro}$, and to $7 d$. in ${ }_{18}$ I $_{5}$, both due to tax increases. ${ }^{4}$ The newspaper did not greatly change between I 753 and I 835 , though by the later date there were as many as nine columns of advertisements. Price died in $\mathrm{I} 83 \mathrm{I},{ }^{45}$ but his family remained owners. ${ }^{46}$ From $\mathrm{I} 832$ onwards the paper contained a 'Police Report', dealing with the sessions on 'Tuesdays and Fridays of the borough magistrates. ${ }^{47}$

The second paper to be published in Leicester was the Leicester Herald, which had a short life from May I 792 to April I795. The editor was Richard Phillips, a bookseller at the corner of Gallowtree Gate and Humberstone Gate. ${ }^{48}$ The original price was $3 \frac{1}{2} d .{ }^{49}$ Phillips was a man of liberal, even Radical, opinions, and the paper reflected his views. He was imprisoned in 1793 for selling seditious publications, including the works of 'Tom Paine. ${ }^{50}$ In 1795 Phillips's premises were burnt down, and he shortly afterwards removed to London. ${ }^{5}$ 'The Herald seems to have ceased publication before the fire. ${ }^{52}$

A paper called the Anti-Gallican was produced at Leicester for a short time in I794. It was 'Tory in outlook and noted for its violent tone. 53

The Herald's place as the mouthpiece of liberal opinion was taken by the Leicester Chronicle, printed and published by George Bown, of the Market Place, Leicester, who had been charged with seditious practices in $1794 .{ }^{54}$ The first issue was published in November I8I0.55 The Chronicle was soon at rivalry with the Leicester Fournal, and consistently supported the liberal opposition to the corporation. ${ }^{6}$ During the first two years of its existence the form of the paper changed several times, but in January I 8 I 2 the first issue was published of a new series, and then and for some time afterwards the paper consisted of eight small pages of three columns each. ${ }^{57}$ In I $_{8}$ I 5 the format of the paper was altered to the four pages of five columns each favoured by the Leicester Fournal. 58

The last paper to appear during this period was the Leicestershire Herald and General Advertiser, which first appeared in July 1827 , costing $7 d$.; it contained four pages of

39 Thompson, Hist. of Leic. ii. 82.

40 Leic. Fnl. for 1773 (file penes Leic. Mercury).

${ }^{41}$ Leic. Inl. 24 July 1789.

42 Ibid. 6 July 1797.

${ }_{43}$ Ibid. 18 Mar. 1803; 29 Aug. 1806; H. Harto"pp, $R$. of Mayors of Leic. 167-8.

44 Leic. Fnl. 8 June I810; I Sept. 1815.

45 Ibid. 29 July 1831.

46 Ibid. I83 I, passim.

47 Ibid. 17 Feb. 1832 , and subsequent issues.

48 Thompson, Hist. of Leic, ii. 82 .

49 Leic. Herald, I792, passim.
50 Thompson, Hist. of Leic. ii. 207-8.

51 Ibid. 2 I 5-16.

${ }_{52}$ Patterson, Radical Leic. 77.

53 Thompson, Hist. of Leic. ii. 212-1 3.

54 Leic. Chronicle, ro Nov. 18 10; Thompson, op. cit. ii. 21 2. An earlier Leic. Chron. had been briefly published in the I 790's: Patterson, op. cit. 67.

55 Leic. Chron. Io Nov. I 8 io.

${ }_{56}$ Leic. Chron. passim (file in Leic, Ref. Libr.).

57 Ibid. 4 Jan. I 812.

${ }_{58}$ Ibid. 18 Mar. 1815. 


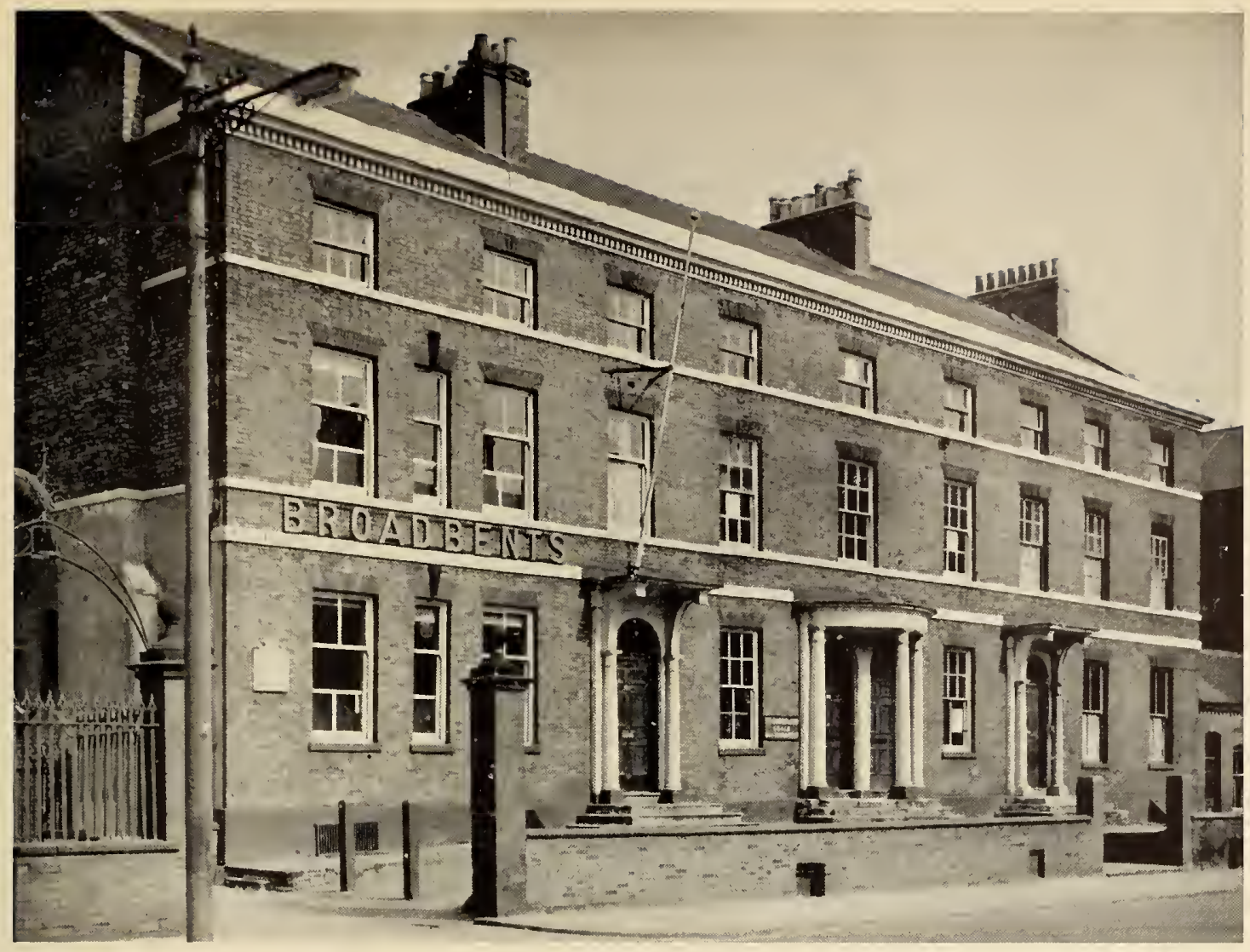

Spa Place, Humberstone Gate

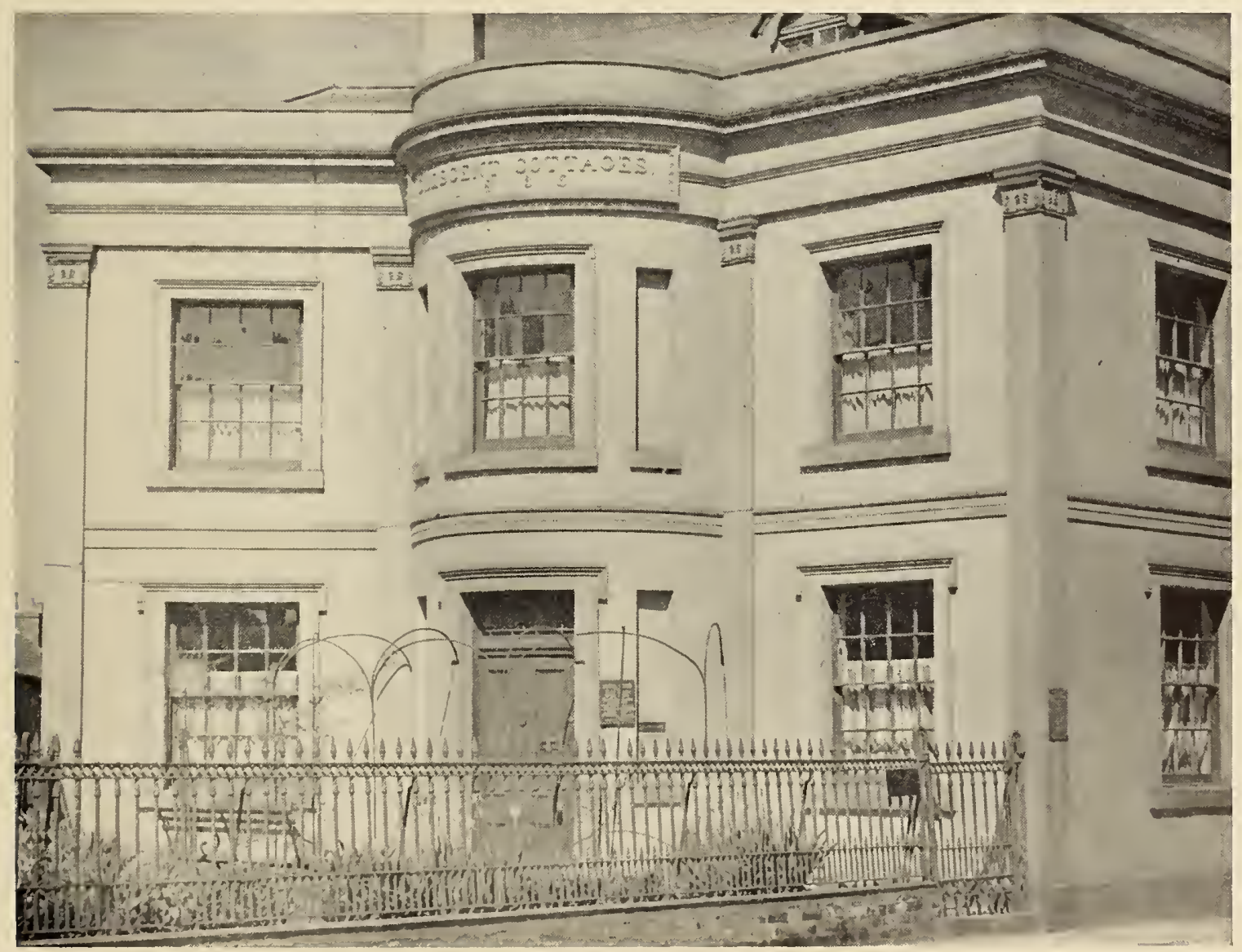




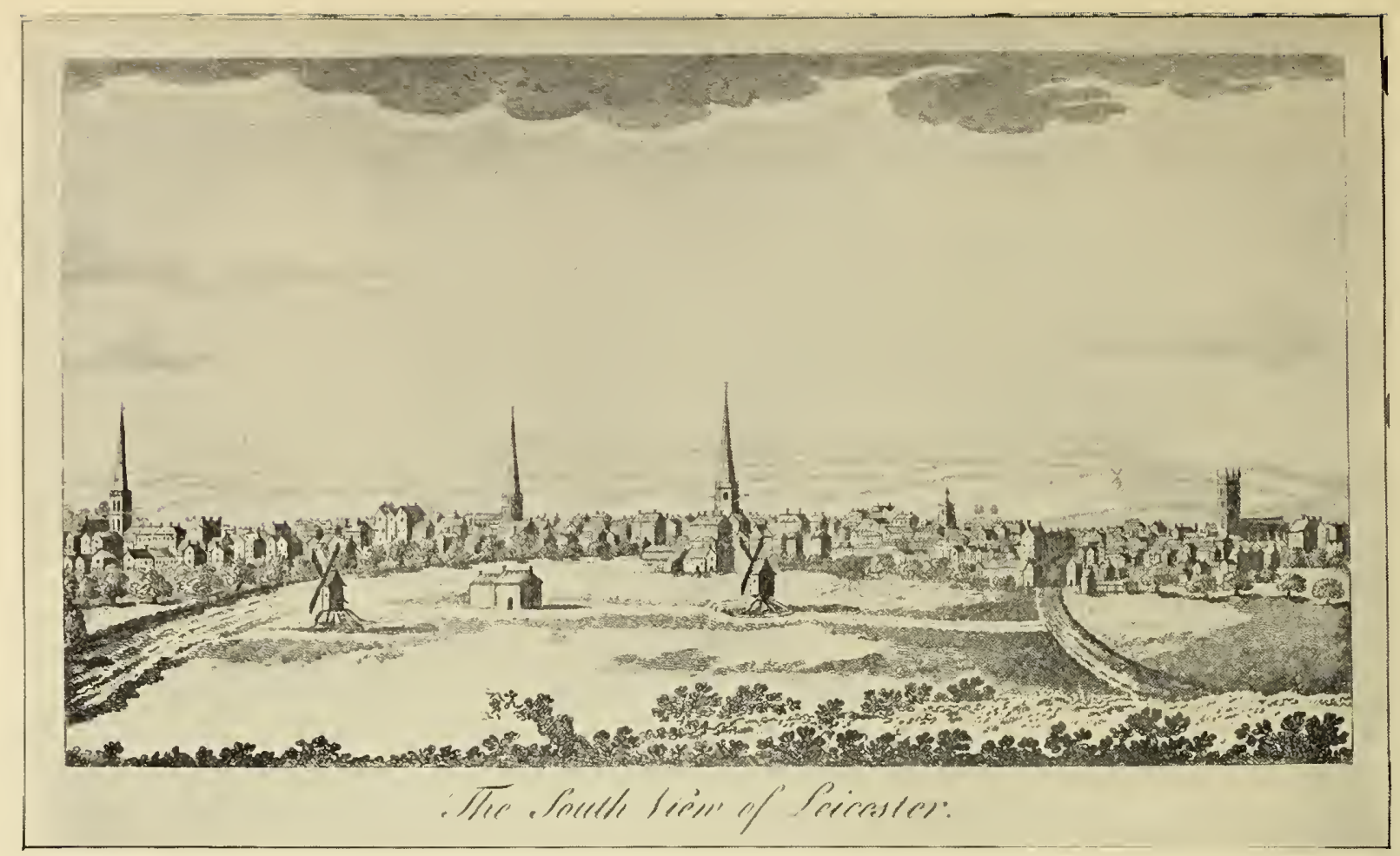

General View of Leicester in i 804

showing the South Field and the London road in the foreground

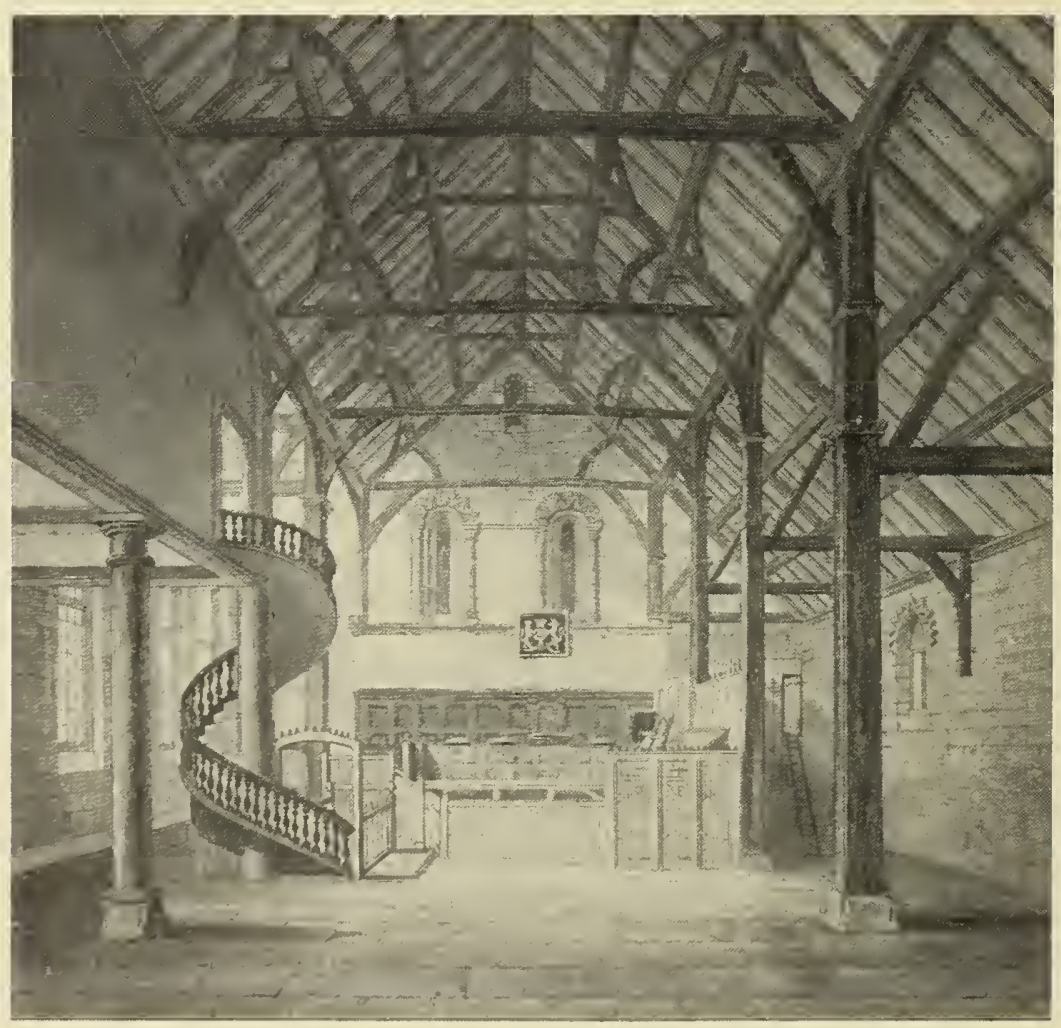

Tiie InTERIOR OF Leicester CASTLE IN I 82 I 
five columns each, and was printed by H. J. Wilkinson of Gallowtree Gate.59 The publication of the newspaper on Wednesdays was a new departure which the first leading article justified by pointing out that hitherto there had been no news available in the town between one issue of the existing papers, and the next. The paper was a Tory one, supporting the corporation and the monarchy.

\section{THE GROWTH OF LEICESTER, $167 \mathrm{O}-1835^{60}$}

From I670 to the I720's there was an increase in the population of Leicester such as had not been seen since Elizabethan times. In I7 I2, Samuel Carte, Vicar of St. Martin's and a locally renowned antiquarian, put the population of the town at I,209 families, though he omitted to assess the numbers in St. Leonard's parish and in the Newarke. ${ }^{61}$ If an approximate correction is made of these omissions, which were not very serious in proportion to the total population of the town, a revised estimate puts total numbers at about I,360 families, or perhaps 6,000 people. Carte's evidence, taken with that of the hearth-tax figures, suggests an increase of not less than 30 per cent. between 1670 and I 7I2. This estimate is confirmed by statistics drawn from the parish registers, ${ }^{62}$ which show that the average number of baptisms in the years I 7 I I-I 3 was 35 per cent. greater than that in $1669-71$. The number of baptisms suggests in a general way the trends of total numbers, though this correlation is prevented from being a precise one by variations in the birth-rate, in the age structure of the population, in the failure to baptize all new infants, and in the extent of nonconformity. Nevertheless, a comparison between the number of baptisms and the occasional censuses of the town made in the 17 th and I 8 th centuries ${ }^{63}$ suggests a variation in the crude baptismal rate between 30.7 and 32.8 per 1,000 , if the abnormally low ratio of $28 \cdot I$ given by the incomplete ecclesiastical census of 1676 is excluded. In the last quarter of the 17 th century and the first quarter of the 18 th, baptisms rose by over 60 per cent., which implies a considerable increase in population. The immediate causes of this growth were to be found at least partly in a higher rate of survival. The evidence of the parish registers, though treacherous, goes some way to establish that this was a period when the excess of births over deaths was much greater than it had been in the plague years in $1660-70$, or than it was later in the second quarter of the I 8 th century (see Table VI). Until about I 685 the burial-rate had been high and had been exceeded only slightly by the number of baptisms. In eight

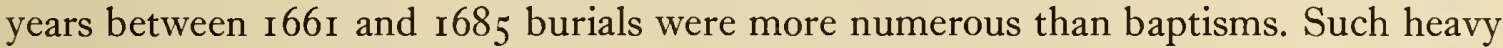
mortality occurred much more rarely in the next generation, and the excess of baptisms over burials was regularly over 25 per cent. The plagues of the period I660-70 were not repeated, and more people seem to have survived the rigours of early childhood.

The greater healthiness of the late $\mathrm{I} 7$ th century lasted until well into the early i 8 th, but the toll of deaths began to rise fairly sharply after $17 \mathrm{r} 9$ and they began once more to exceed the number of baptisms. As many as $4 \mathrm{I} 6$ burials are recorded in the single year $\mathrm{r} 724$, amounting perhaps to something of the order of 5 per cent. of the total population of the town. For approximately 30 years after 1730 the number of baptisms varied little, and it was not until I $760-70$ that a sharp upward trend was set in motion. Throughout Leicestershire the period I730-60 was one of high mortality and nowhere was this more

59 Leics. Herald and General Advertiser, 18 July 1828 ; and see subsequent issues (file in Leic. Ref. Libr.).

60 This section was contributed by Mr. C. T. Smith.

61 Nichols, Leics. ii. 534 .

62 i.e. of All Saints', St. Leonard's, St. Margaret's, St. Martin's, St. Mary de Castro, and St. Nicholas's in the custody of the parishes concerned.
63 Bishop Compton's Census of 1676 (W. G. D. Fletcher, 'Religious Census of Leics. in 1676 ', T.L.A.S. vi. 296-303), which omits St. Margaret's parish; Carte's estimate of I7r2 (Nichols, Leics. ii. 534); an estimate of I 785 ('Throsby, Hist. of Leic. 409); and an estimate of 1792 (Nichols, Leics. i. 534). 


\section{A HISTORY OF LEICESTERSHIRE}

marked than in Leicester itself. The pressure of the new fatal diseases lifted slightly in the 70 's but the death-rate remained high until I 800 , even though the population was then increasing at an unprecedented rate.

TABLE VI

Average Annual Baptisms

\begin{tabular}{|c|c|c|c|c|c|c|}
\hline Decade & St. Martin's & St. Mary's & St. Nicholas's & All Saints' & St. Margaret's & Total \\
\hline$I 66 I-70$ & 52 & 24 & I 3 & $2 I$ & $3^{6}$ & I 46 \\
\hline $167 I-80$ & 53 & I7 & 9 & I6 & 44 & I 39 \\
\hline$I 68 I-90$ & 52 & 32 & I I & 22 & 57 & 174 \\
\hline$I 69 I-I 700$ & 52 & 30 & I4 & 24 & 46 & I 66 \\
\hline I7OI-IO & 59 & 28 & I3 & 22 & 53 & 175 \\
\hline I 7 I I -20 & 65 & 44 & I 8 & 23 & 66 & 216 \\
\hline $1721-30$ & 68 & 59 & I6 & I8 & 67 & 228 \\
\hline I $731-40$ & 57 & 73 & I 5 & 35 & 66 & 246 \\
\hline$I 74 I-50$ & 52 & 72 & I 4 & $4^{8}$ & 56 & 242 \\
\hline I $75 I-60$ & 53 & 70 & I 6 & 39 & 71 & 249 \\
\hline $176 I-70$ & 64 & 90 & 17 & $5^{8}$ & 100 & 329 \\
\hline I $77 \mathrm{I}-80$ & $8 I$ & 104 & 20 & 74 & I 17 & 396 \\
\hline I $78 \mathrm{I}-90$ & 84 & 107 & I9 & 78 & 123 & 4 I I \\
\hline I $79 I-I 800$ & $8 I$ & II9 & 27 & $8 I$ & I 91 & 499 \\
\hline
\end{tabular}

\section{Average Annual Burials}

\begin{tabular}{|c|c|c|c|c|c|c|}
\hline I $66 \mathrm{I}-70$ & $5^{6}$ & 22 & IO & 34 & 39 & I $6 I$ \\
\hline I $67 \mathrm{I}-80$ & 48 & I6 & 9 & 19 & 40 & I 32 \\
\hline$I 68 I-90$ & 45 & 28 & 3 & I 8 & 38 & 132 \\
\hline I $691-I 700$ & 52 & 22 & 9 & 20 & 39 & 136 \\
\hline $1701-10$ & 59 & 25 & 9 & 24 & 42 & 147 \\
\hline $1711-20$ & $6 I$ & 33 & 12 & $2 I$ & $5^{6}$ & \\
\hline $1721-30$ & 79 & 57 & 22 & 16 & 87 & \\
\hline $1731-40$ & 66 & 53 & I 4 & $3 I$ & $8 I$ & 24 \\
\hline $174 I-50$ & 76 & 66 & 16 & $5 \mathrm{I}$ & 78 & \\
\hline $1751-60$ & 72 & 78 & I7 & 48 & 86 & 301 \\
\hline $1761-70$ & 64 & 92 & 17 & 78 & 102 & 353 \\
\hline $1771-80$ & 70 & 93 & I 8 & 63 & IO3 & 347 \\
\hline$I 78 I-90$ & 84 & I I 7 & I 8 & 82 & 105 & 404 \\
\hline I $791-1800$ & 76 & I2I & I 6 & 86 & 127 & 426 \\
\hline
\end{tabular}

Average Annual Excess of Baptisms over Burials

\begin{tabular}{l|r|r|r|r|r|r}
$1661-70$ & -4 & 2 & 3 & -13 & -3 & -15 \\
$1671-80$ & 5 & 1 & 0 & -3 & 4 & 7 \\
$1681-90$ & 7 & 4 & 8 & 4 & 19 & 42 \\
$1691-1700$ & 6 & 8 & 5 & 4 & 7 & 30 \\
$1701-10$ & 12 & 3 & 4 & -2 & 11 & 28 \\
$171-20$ & 4 & 11 & 6 & 2 & 10 & 33 \\
$1721-30$ & -11 & 2 & -6 & 2 & -20 & -33 \\
$1731-40$ & -9 & 20 & 1 & 4 & -15 & -1 \\
$1741-50$ & -24 & 6 & -2 & -3 & -22 & -45 \\
$1751-60$ & -19 & -8 & -1 & -9 & -15 & -52 \\
$1761-70$ & 0 & -2 & 0 & -20 & -2 & -24 \\
$1771-80$ & 11 & 11 & 2 & 11 & 14 & 49 \\
$1781-90$ & 2 & -10 & 1 & -4 & 18 & 7 \\
$1791-1800$ & 5 & -2 & 11 & -5 & 64 & 73 \\
\hline
\end{tabular}

It is clear that Leicester's growth in the I 8 th century was by no means an even one, and that there was a whole generation in which numbers failed to increase at all. Stimulated by a revival of prosperity and a low death-rate, the town of about 5,000 in I 670 had become one of 6,000 by I 712 and perhaps 8,000 by about I730, before the impetus of early-I8th-century growth was lost, and the heavy mortality characteristic of the second quarter of the I8th century produced a sag in the population curve which lasted until about I 760 . From then until the end of the century the rate of increase was 20 per cent. a decade and the population of Leicester was more than doubled between I760 and I80I, when the first census reported about I7,000 people. This rate was 
exceeded during the first 30 years of the igth century when the population rose to nearly 40,000 in $1831 .{ }^{64}$

Natural increase was only one factor in the growth of population, and migration contributed much. Its importance is implicit in the parish register statistics, since the excess of baptisms over burials throughout the period is far too low to account for the rate at which the population grew. It is, however, more difficult to estimate what proportion of the total population was made up of migrants than to discover their origins. Analysis of those marriage registers which give the origins of bride and groom suggest that approximately a quarter of those married in Leicester came from outside the town; information about origins is only available for three parishes, and in them only for limited periods in the late $I 7$ th century; 65 the Freemen's Register gives full information about the origins of new freemen only from I 697 to 1702 , during which period 38 per cent. of them came from outside the town; $; 6$ and the more continuous and longer record of the Register of Apprentices from I 678 to I 682 and I 7 I 8 to I 770 suggests a figure of 50 per cent. for apprentices up to 1720 falling to $3^{8}$ per cent. in $175^{0-70.67}$ It is, in short, impossible to find evidence covering a representative cross-section of age and social position which can give an adequate estimate of the proportion of migrants in the whole population. Nevertheless, each of the sources points to a high rate of migration, varying from a quarter to a half, though the groups from which the statistics are drawn represent sections of the population which were more likely to move. The late $17^{\text {th }}$ and early I 8 th centuries produced the highest proportion of migrant apprentices.

'The Register of Apprentices permits a closer analysis to be made of the origins of migrants. Most came from within the county. Over the whole period rather more than half of the migrants came from villages within a ten-mile radius of Leicester, and the remainder were fairly equally divided between the outlying parts of the county and the rest of the country. From 1678 to 173057 per cent. of the migrant apprentices had come from less than ten miles away, but for the years $175 \mathrm{I}-70$ this proportion fell to 49 per cent., with a corresponding increase in the number of those who came from farther afield. Although, as we have seen, the proportion of migrants fell slightly in the later part of the century it is quite clear that the average range of movement had extended. It may be suspected that the improvement of the road system in the 18 th century was not without effect on the growth of Leicester. With the exception of the Fosse Way, all the principal roads which touched Leicester were turnpiked by $1770,{ }^{68}$ and by 1830 Leicester was served by more than 50 stage coaches daily, and there were over 230 local carriers. ${ }^{69}$

Several points of interest attach to the distribution of the origins of the immigrants from Leicestershire. ${ }^{70}$ Most came from a group of large and prosperous villages strung out along the Soar valley, but apart from this large group, more came from the purely agricultural eastern part of the county than from the west, where a flourishing rural hosiery industry supplemented the opportunities that were to be had in agriculture. All but a few of those who came from farther afield came from the surrounding counties or from London. There was an occasional representative from places as far away as Kent and Lancashire, and even two young men who hailed from Virginia and were apprenticed in $\mathrm{I} 730$ and $\mathrm{I} 735$ to a relative of theirs, a prominent citizen of the town. With one or two exceptions, however, the range from which Leicester drew its inhabitants in the

64 V.C.H. Leics. iii. I 79.

65 Par. regs. of St. Mary's (1660-74), All Saints' (166o83 ), and St. Martin's (1669-8I).

66 Reg. Freemen of Leic. II $96-1770$, ed. H. Hartopp, I79-94.

LEIC. IV
68 V.C.H. Loics, iii. 9I.

69 Curtis, Topog. Hist. Leics. I I 4 .

70 See Reg. Freemen of Leic. 


\section{A HISTORY OF LEICESTERSHIRE}

I 8 th century was a very local one. The majority were born in the town, and lived and died in it. Of the rest over a half were within a few hours' walk of their birthplace, and only a few individuals (no more than 27 apprentices from I 678 to I 770 ) could claim that their origins lay entirely outside the midlands.

Leicester increased its population threefold during the i 8 th century, but the records and maps of the town show no substantial changes in its physical extent. There was much new building, ${ }^{71}$ though little new ground was broken. Between the map of $1722^{72}$ and the map of $1792^{73}$ published by Throsby there are few differences of importance. In the early stages of growth and during the long depression of the hosiery trade from about I760 to 1790 existing buildings seem simply to have become more overcrowded.74 In addition, English families appear to have been larger on the average in I 80 I than they were in I670, so that the demand for separate houses did not increase at the same rate as the population.

The activity of the $\mathrm{I} 8$ th century was concerned mainly with the rebuilding of much that had become unsafe and decayed. Georgian brick replaced much that had been halftimbered. The most spectacular achievements were the removal of the town gates in 1774,75 the replacement of the old Gainsborough by the Exchange in $1747^{-8}$, on the same site overlooking the Market Place, ${ }^{76}$ and the building of the Assembly Rooms a few years later near the site of the East Gate, ${ }^{77}$ and of a new town gaol ${ }^{78}$ and the infirmary. ${ }^{79}$ All of these were swept away in the orgy of Victorian building, and other than a few houses, mainly in New Street or near it, there is very little evidence now of I 8th-century building.

New domestic building was irregular and piecemeal, but it filled in many of the gaps which were obvious in the town of 1700.80 There was much solid achievement in the north of the town, which continued to be the part of Leicester in which the poorer artisans and labourers were housed. Quite early in the I 8 th century the hovels in Sanvey Gate belonging to the corporation were rebuilt. ${ }^{8 I}$ By I 800 houses were just beginning to appear ${ }^{82}$ in the north-western part of the town which had been so long devoted to orchards and gardens, though it was not until the I 850 's that the area was completely built up. In the south of the town the most outstanding achievement was the creation of New Street out of the Grey Friars land. ${ }^{83}$

The character of the building in New Street and of the houses which had been built on corporation land near the bowling green which had been opened in $173^{6}-7^{84}$ made it clear that this was still the most select residential part of the town, as it had been in I 670, and it was therefore no accident that when the corporation proposed in 1785 to establish a public walk for the people of Leicester, they should choose a strip of land which started from this area of the town. ${ }^{85}$ The New Walk, as it came to be called, began at the junction of a recently built street with the Welford Turnpike, which had been created twenty years earlier. ${ }^{86}$ It followed closely the boundary hedge which separated the South Fields from the inclosed fields of St. Margaret's parish, but lay entirely within the former as far as the turnpike on the London road. The New Walk therefore had a number of factors to recommend it. On the one hand the corporation's interests

\footnotetext{
7I For rebuilding around the Market Place, see above, p. 179 .

72 See above, p. 154, n. 13.

${ }_{73}$ Throsby, Ilist. of Leic. map facing p. I.

74 In 1670 only 30 families out of 1024 were recörded as sharing houses (E I 79/240/279, mm. I-2, I3, I6); in 1801 the proportion was four times as great (Census, i 801 ).

75 Throsby, IIist. of Leic. 355.

76 See below, p. 364 .

77 See below, p. 362 .
}

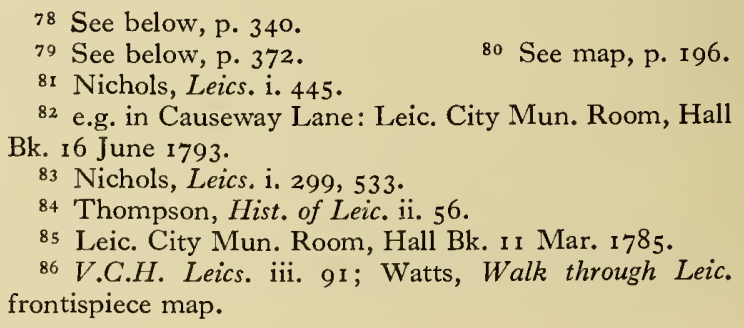


in the South Fields enabled it to appropriate land there, and on the other hand it connected the fashionable part of Leicester with the open countryside at a point where high land approached most closely to the town, giving wide and pleasing views from almost anywhere along its course. Its very creation added a further incentive to later residential building along its line.

The establishment of the New Walk was one of the few occasions in the late 18 th century when the unreformed corporation displayed an element of public spirit. It was largely the prospect of substantial gain that stimulated the unsuccessful plans of 1792 to divide the Horsefair Leys and the adjacent land into small building plots, and to construct an imposing square in which land would be reserved for a new town hall. 87 In the event it was not until I 807 that parts of the Horsefair Gardens and the bowling green were sold in building lots and the present streets in that area were marked out. 88 There was little of the attention to formal planning which had been obvious in the 1792 plans, and the new streets were laid out economically along existing boundary lines. By r 8 ro most of the Horsefair Leys and the bowling green gardens had been sold in small lots for building. ${ }^{89}$ The corporation had embarked upon a policy of selling land at a high profit for building that was to have tremendous consequences both for its own finances and for the way in which this part of the town was to grow in the first half of the rgth century.

In the first half of the igth century the town began to stretch long tentacles along the main roads to the north-east and south-east. What amounted to a new town, and, indeed, was often called New Leicester, sprang up in the north-east quarter to the north of Humberstone Gate. The turn of the century marked the beginning of a new phase in the physical growth of the town, just as the I 760 's marked the beginning of a new phase in the growth of population. The two went hand in hand, though there was a substantial time-lag between them as families grew and as overcrowding became more obvious in the late 18 th century. In general, the early I 9 th century was marked not only by the most rapid rate of growth of population in the town's history but also by the predominant importance of framework-knitting, still organized on a domestic basis and in the early years of the century enjoying a marked prosperity..$^{\circ}$ Neither the boot and shoe industry nor the factory system were prominent in the first half of the century, and it was only when these did become important that the growth of Leicester began to take on a different character again. ${ }^{91}$

The directions of physical growth in the first half of the igth century were very largely controlled by two factors: the building of the Leicester-Loughborough canal, completed in $1794,{ }^{92}$ and the inclosure of the South Fields under an Act of $1804 .{ }^{93}$ One concentrated the flow of working-class people into the neighbourhood of Belgrave Gate, the other permitted a southward expansion of better housing parallel to the New Walk and up to the brow of the hill near the London road turnpike. From the first the canal was successful, particularly in the carriage of coal and other heavy traffic. The toll receipts on the Leicester-Loughborough road dropped by a third between 1793 and I 795, and it was not until I 830 that they recovered their former level. ${ }^{94}$ In $1792^{95}$ there was virtually no building north of Sanvey Gate, except along North Gate Street which linked the town with the North Bridge over the Soar. The construction of the Leicester Navigation entailed the cutting of a short canal, which left the Soar about a mile north

87 Leic. City Mun. Room, Hall Bk. 26 July and 17 Dec. 1792.

88 Ibid. 17 May and 29 Oct. 1807.

89 Ibid. 5 Aug. 1806, 3 Mar. 1807, 26 Feb. 18 1 I.

90 See above, p. I 73 .
91 See below, pp. 290 sqq.

92 V.C.H. Leics. iii. 01.

93 C.F. lix. 256.

94 P. Russell, Leics. Road, I I 3-14.

95 Throsby, Hist. of Leic. map facing p. I. 


\section{A HISTORY OF LEICESTERSHIRE}

of the North Bridge, and rejoined the river just south of the bridge. Along the line of this canal there had grown up by 1828 a line of industrial establishments:96 Frog Island, between the canal and the river, was the site of tan-yards and bleaching-yards,

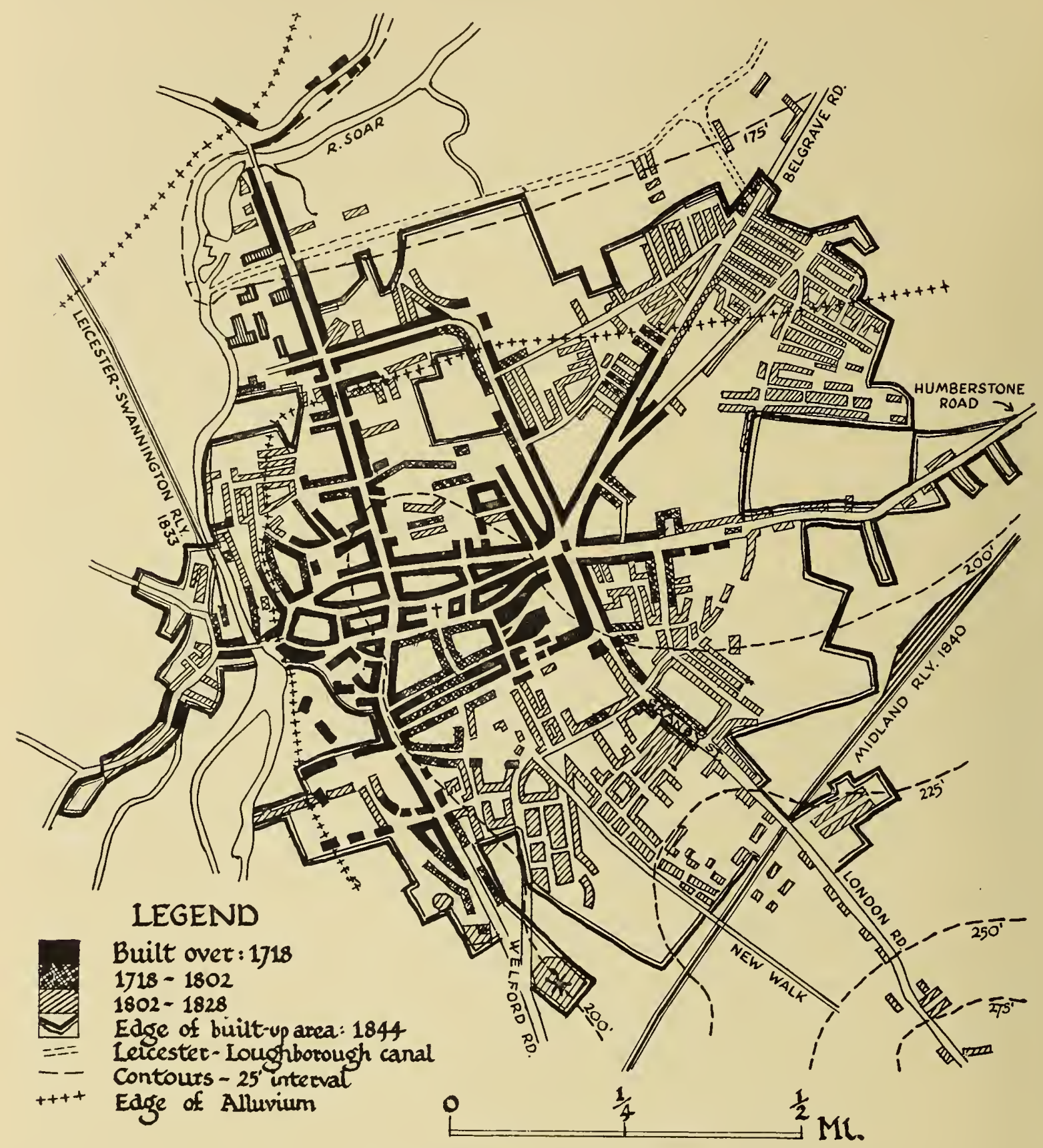

\section{EXPANSION $1718-1844$}

while the main groups of wharves lay to the east of the canal's junction with the river, and it was here, along the strip of the canal nearest to Belgrave Gate, that the public wharf was built, together with lime-kilns, iron-foundries, and, in I $82 \mathrm{I}$, the gas-works. ${ }^{97}$ Population and housing followed industry towards the canal. To build on the low, level

${ }_{96}$ T. and G. Ellis, Plan of Leic. (1828).
97 Curtis, Topog. Hist. Leic. I1 13,115 ; Watts, Walk $\quad 1836-95,92$; White, Dir. Leics. (1846), 190-1.

through Leic. I I J. Storey, Hist. Sketch of Boro. of Leic. 
land on either side of Belgrave Gate was the obvious course open to those who wished to provide for the housing needs of a population which was increasing at the rate of 800 or 900 a year, but it was also almost the only course and many residential streets were laid out immediately south of the canal before I828. On the Abbey Meadows farther north, flooding was a serious menace, and the meadows were in any case subject to common rights. To the west of the town and the river there were only a few houses at the foot of the West Bridge in I792, but between then and 1828 much building took place along both banks of the newly navigable river. To the south the corporation land in the South Fields was being carefully preserved for other purposes. On the other hand, St. Margaret's Fields to the east of the town had been inclosed in $1764 .{ }^{98}$ Common rights had been abolished and there were no obstacles in the way of any individual landowner who wished to sell to the speculative builder. Even before I794 houses had begun to string out along Belgrave Gate and Humberstone Gate, and the arrival of the canal in that year therefore helped to strengthen a tendency which was already apparent. 99

As early as 1805 , when an excellent survey was made of the lands in St. Margaret's parish, ${ }^{1}$ it is clear that the framework for the street development of the next 30 years was already determined. Between Humberstone Gate and Belgrave Gate lanes and paths which had been laid down on inclosure were later made into roads from which dreary, close-packed streets branched off, usually parallel to the long axis of the fields they replaced, in order to compress the maximum number of houses within the minimum of space. St. Margaret's parish, excluding Knighton, which had accounted for 30 per cent. of Leicester's population in 1700 and about the same in 1790 , contained rather more than 60 per cent. in the years $1830-50$ as a result mainly of this steady expansion of building to the east and north-east.

The second factor which had far-reaching effects on the growth of the town in the first half of the igth century was the inclosure of the South Fields. The expansion of the town to the south and south-east was impossible until the common rights of the freemen had been extinguished by inclosure. Before the inclosure award of I 8 I I there- was scarcely a building in the South Fields, even though the demand for housing was pressing against the boundaries nearest the town. As soon as the award was issued and the lands were allotted to the corporation, the freemen, and a few private owners, the extension of building could and did proceed into those parts of the South Fields which were most conveniently placed near the town.

As a result of rights confirmed in the $\mathrm{I} 3^{\text {th }}$ century, and of the acquisition of the Newarke Grange in the 17 th century, and of other 16 th- and $I 7$ th-century purchases, ${ }^{2}$ the corporation held almost all the land in the South Fields, and the main limitation on its monopoly was the pasture rights of the freemen. It was these common rights, highly valued by the freemen, which had stood in the way of earlier inclosure of the South Fields, and under the award of I 8 I I the freemen received 125 acres out of the 600 allotted. ${ }^{3}$ Their lands were in the remote parts of the fields. Almost all the remaining lands were allotted to the corporation, including the land which lay nearest to the town and the New Walk. ${ }^{4}$

The inclosure of the South Fields removed the only remaining obstacle of importance to urban expansion, which was untrammelled by any obvious natural barriers. The importance of this can be seen if Leicester is compared with two other midland cities,

\footnotetext{
98 R. Greaves, Corp. of Leic. 85-86; Nichols, Leics. i. 556-7. $\quad 99$ Throsby, Hist. of Leic., map facing p. I. I Leic. City Mun. Room, map of St. Margaret's par. $84-85$

2 See below, pp. 371-2.

3 See above, p. 166 .

4 Nichols, Leics. iv. 348-50; Greaves, Corp. of Leic.
} surveyed by J. Eagle. 
Nottingham and Coventry, both of which suffered in the Igth century from the constriction caused by the existence of common fields, which made building impossible until the common rights were extinguished. 5 It was true that there were few open spaces in Leicester in which 'the labouring poor' could take what leisure they had, but 'Leicester has (by inclosure) got the means of expansion, has made use of it and is comparatively healthy and the people well off, whereas in some parts of Nottingham they are crowded together in a way that is alarming to think of' ${ }^{6}$

It must have become clear to the corporation from the sales of the bowling green and the Horsefair Gardens at the turn of the century that the piecemeal sale of small plots of land for building could be a highly profitable business. To extend this policy to those parts of the South Fields which were ripe for development was an obvious conclusion. As soon as the Inclosure Act had been passed the corporation could come out into the open, as it did when its South Field Committee reported in 1806 'it will be prudent so to mark out the streets and lots in the Bowling Green Garden so as not now to destroy or injure any plan which may be hereafter proposed for building'. 7 Any plan which involved building near the bowling green would inevitably involve part of the South Fields.

Almost as soon as the award was issued in $18 \mathrm{I} I$, the corporation began to nibble at the land nearest to the town. By January of the following year land near New Walk had been bought from one of the members of the corporation in order to lay out a street parallel to New Walk and thus to bring into the building market part of the South Fields and a piece of privately owned land between New Walk and London Road. At the same meeting of the Common Hall the new road was topically named Wellington Street, and the sales of public land began. ${ }^{8}$ From the time of the inclosure award to the end of the unreformed corporation in 1835 , the South Field Committee, to whose hands the business was entrusted, consistently followed the same policy as far as it profitably could. In I 8I 4 the committee observed that 'much land eligible for building on and adjoining the streets which have already been laid out, still remains unsold, and as it now lets for $£^{6}$ an acre, and the clear produce of it would be at least $f_{2}, 25^{\circ}$ an acre, the committee recommends that those parts be sold as long as customers can be found and either new property bought or any scheme of public advantage be undertaken'. ${ }^{9}$ Apart from a provision that a small piece of land near the New Walk should be reserved for gardens, there was no restriction on sales right to the end of the old corporation's régime. The tentative regulation of elevations and building standards which had been planned to secure uniformity and elegance in the abortive plans for Brunswick Square at the end of the 18 th century was discarded or forgotten. The fact that some of the resulting building, in the Crescent and along Regent Street, for example, was among the best there is in Leicester today can be attributed to the climate of the age rather than to conscious guidance by authority. Ostensibly the corporation devoted the proceeds of its land sales to the purchase of valuable properties in the town, gifts to a few charities, the making of some half-hearted improvements in the amenities of the town, and to the elimination of its liability to land tax and of the rents it owed to the Duchy of Lancaster. But the obvious and dominant aim was to use the capital gains from the sale of land to increase the annual income of the corporation. ${ }^{10}$

There were, however, more sinister motives, hidden by the silence of the records and only partially brought to light by the inquiries of the parliamentary commissioners into

5 2nd Rep. Com. on State of Large Towns [602] and [6ro], H.C. (1845), xviii.

6 Rep. Cttee. on Commons Inclosure, H.C. 583 , p. 4136 (1844), v.
7 Leic. City Mun. Room, Hall Bk. 30 Dec. 1812, I6 Mar. 1826 . 8 Ibid. 6 Jan. and 30 Dec. I812.

9 Ibid. 28 Sept. I8I4.

Io Ibid. 24 Mar. 1834; and see above, p. 149. 
the government of the town in $1833 .{ }^{\text {II }}$ There was doubt about how much land had actually been sold. The corporation records proclaim, and the town clerk insisted in I 834 , that not more than $13 \frac{1}{2}$ acres had been alienated for building since inclosure. Yet several highly reputable inhabitants of the town were willing to depose before the commissioners in 1832 that within the previous 25 years the quantity of land sold must have been of the order of 25 to 30 acres. They based their estimate on the number of new streets built in the South Fields since inclosure, 'which form an extensive portion of the suburbs of the town': A land surveyor estimated from a new and excellent map of St. Mary's parish ${ }^{12}$ that 26 acres had been sold, excluding the area of the main streets. It seems that these estimates were probably more correct than the records of the corporation, since the sale of property was one of the subjects on which the corporation refused to answer the commissioners' questions. It was suspected, probably justly, that some of the proceeds of sales had been used to finance the parliamentary election of I $826 .{ }^{13}$ Individual members of the corporation profited from the sale of lands in the South Fields. Apart from the many publicly recorded sales to members, there were believed to be a considerable number of secret sales at low prices. ${ }^{14}$ Although it was said in 1833 that none of the land in the South Fields was worth less than $5^{s}$. a yard, and much was worth more, members of the corporation were said seldom to pay more than $5^{s}$. for it. A witness stated that he bought land from an alderman and common councilman at 50 to 60 per cent. above the price paid for it to the corporation. Some was sold at twice the price. ${ }^{15}$

This then, was the process by which much of the building in the South Fields was achieved up to 1835 , whether on the flat land to the west, where working-class houses and hosiery. warehouses were springing up, or on the rising land to the south where some of the best houses in the town were being built.

The Leicester of 1835 was a very different town from that of 1660 . The manufacture of hosiery had expanded until in 1830 it was said to be almost the only manufacture of the town. ${ }^{16}$ Since $\mathrm{I} 800$ the engineering industry had been growing steadily, though in I 835 it was still far from being as important as it later became. ${ }^{17}$ The manufacture of boots and shoes was just beginning to develop as an industry of some importance. ${ }^{\mathrm{I} 8}$ Steam power was already appearing, and by 1830 there were 24 steam engines in full operation at Leicester, not counting those engaged in grinding corn. ${ }^{19}$ About ${ }_{1} 8{ }_{3} 8$ there were said to be nearly 50 steam engines in the town. ${ }^{20}$

The growth of the town, and the expansion of its industries, would have been impossible without a corresponding development of its communications. The improvement of roads in the I 8 th century and the building of the canal have already been discussed. ${ }^{21}$ At the very end of this period the railway appeared, and in 1832 the Leicester \& Swannington Railway gave Leicester its first satisfactory communications with the west Leicestershire coalfield. ${ }^{22}$ Its effects on the town's industry and topography, however, were not felt until later.

Whether the architecture and general appearance of the town had improved as much as its population had increased was a matter about which contemporary observers were divided. William Cobbett, who visited Leicester in 1830 , described the town and its setting in very flattering terms. ${ }^{23}$ On the other hand another and perhaps more dis-

II Rep. Com. on Municipal Corps. Appendix, pt. III.

H.C. 1 16, pp. I $903^{-4}$ (1835), xxv.

12 Boro. Surveyor's Office, map of St. Mary's par. I828.

13 See above, p. 145 .

14 Leic. City Mun. Room, Hall Bk. 30 Dec. I812, 16 Mar. 1826.

Is Rep. Com. on Municipal Corps. Appendix, pt. III, pp. 1903-4.
${ }_{16}$ Curtis, Topog. Hist. Leics. 98.

17 V.C.H. Leics. iii. 26-27. 18 See below, p. 314.

19 Curtis, Topog. Hist. Leics. I 14.

20 Gardiner, Music and Friends, ii. 573.

21 Above, pp. 193, 195.

22 V.C.H. Leics. iii. I IO-I 4.

${ }_{23}$ Wm. Cobbett, Rural Rides, ed. G.D.H. and Margaret Cole ( 1930 ), ii. 663. 


\section{A HISTORY OF LEICESTERSHIRE}

passionate observer, writing in the same year, remarked: 'While the town in less than thirty years has expanded to twice its former bulk, too little, it must be confessed, has been gained in elegance and beauty. The new streets have been laid out without much, if any, regard to taste and regularity, and the new buildings are in general destitute of ornament and uniformity.' 24 Certainly much new building had been done in the streets radiating from the former East Gate, ${ }^{25}$ and in some other places such as the New Walk, apart from the newly built areas on the edge of the town. The town gained some handsome new houses, some of which survive to the present day. ${ }^{26}$ On the other hand in the I 820 's many older buildings remained, picturesque but decrepit, their timbered upper stories projecting over the narrow roadways, ${ }^{27}$ and many new streets were being built, especially in St. Margaret's parish, in which the houses were small, crowded together, badly constructed, and built on ground almost impossible to drain properly. ${ }^{28}$ Leicester was already acquiring some of the aspect, and many of the problems, of the Victorian industrial town.

24 Curtis, Topog. Hist. Leics. 1 I 5.

25 See above, p. 180.

26 e.g. Spa Place, parts of Humberstone Gate, or the northern part of the New Walk.
27 See engravings, after drawings by John Flower, in Views of Ancient Buildings in the Town and Co. of Leic. (1826).

28 See below, pp. 262-3. 


\section{PARLIAMENTARY HISTOR Y SINCE 1835}

i $835-67$, p. 201. 1867-1914, p. 224. 1914-56, p. 241 .

\section{$1835-1867$}

$\mathrm{B}$ ETWEEN the two Reform Acts of 1832 and 1867 the politics of Leicester reveal a distinct character and possess a dramatic theme. Their character was distinguished by the effective predominance of the Reformers who secured an almost unchallenged mastery of the reformed municipal government and established in the parliamentary representation a monopoly that in 35 years was only broken twice. The dramatic theme lies in the conflicts that heaved beneath the surface of this apparently smooth and easy triumph: conflicts that were fought not between formal political parties, Reformers and Conservatives, but between the Reformers themselves, between the different and sometimes rival groups composing the reforming coalition; conflicts that could be subdued in face of the common enemy but which were sharpened beyond concealment in response to the social distress and religious discontent of the age, so that in these years the party experienced a complete cycle of revolution beginning in unity, dissolving, not smoothly, into discord and eventually outright war between its component elements, and in the end recoiling from disaster into a new and lasting concord.

The Reform Act of 1832 did not consummate a political and social revolution in Leicester. Before it was passed the wealthy nonconformist businessmen who led the Reformers had already broken the old corporation's hold over the parliamentary representation of the borough and the passing of the Act made their success in the future only more likely, not assured beyond doubt. The Reformers profited, it is true, from the clauses eliminating the outvoters, who used to be counted solidly among their opponents, and extending the parliamentary boundary to include the 'new borough' which was thought to be in their favour. ${ }^{I}$ Yet the character and, except for the outvoters, the size of the electorate hardly changed. Except in so far as the influence of the corporation was reduced it was not more democratic. It remained a fairly small, manageable body that numbered 3,063 in December 1832 and, though growing slightly, was no more than 5,736 in $1867 .{ }^{2}$ The conditions in which elections were conducted changed only in one respect: voters were now required to be registered, a change that had some importance in encouraging the formation of permanent political organizations. ${ }^{3}$ Otherwise, elections continued as before, or if anything with more noise, greater vigour and violence, and less scruple. ${ }^{4}$ The system of open voting remained in force and with it the traditional methods of influencing electors by intimidation, treating, and open bribery, so that elections continued to require a generous expenditure of hard drink and hard cash. The uncontested election of $\mathrm{I} 84 \mathrm{I}$ cost, it was said, at least $£ 3,727 ;^{5}$ corruption

I R. W. Greaves, Corp. of Leic. $1689-1836$, 122-3.

2 Leic. Boro. Poll Bk. I 2 and I 3 Dec. I8 32 ; Leic. Chron. 12 Oct. 1867.

3 J. A. Thomas, 'The System of Registration and the
Development of Party Organization, 1832-1870'. History, xxxv. $8 \mathrm{I}-98$.

4 See e.g. T. Cooper, Life of Thos. Cooper written by Himself, 154-5. 5 Leic. Chron. 6 Mar. 1847.
$\mathrm{Dd}$ 
cost the members their seats in $1847,{ }^{6}$ and not until 1859 did 'purity principles' really begin to prevail.?

For the Reformers, the Reform Act was not an end in itself, but a stage in a process that had begun with their capture of the borough's representation and could not end at least until they had won a still more important prize, the government of the town itself. It was natural, therefore, that they should throw themselves into the elections for the first reformed Parliament with the same energy and sense of unity that had won their victory in $\mathrm{I} 83 \mathrm{I}$; and it was inevitable that they should win once more. They now enjoyed such electoral advantages as the Reform Act gave them: they still kept in being the Political Union that had organized their former campaign; their candidates were the sitting members, Wynn Ellis and William Evans, known and tried men, and their supporters were still exalted with triumph. By contrast, their opponents had little to offer: the establishment of a Conservative Registration Society ${ }^{8}$ to organize their voting strength was balanced by the difficulty of finding a candidate who would be both strong enough to rally their dismayed followers and rich enough to risk his money in a forlorn hope. When the Conservatives at last found a candidate, J. Boughton-Leigh of Brownsover (Warws.), a gentleman and landowner, their slender chances had already been ruined by delay. The election gave another triumph to the Reformers. ${ }^{9}$

The success of the Reformers seemed inevitable: its permanence seemed assured by the extent of their majority; and yet in little more than two years they found themselves beaten and humiliated. The fault did not lie in the first place with the local leaders. They showed zeal enough in exploiting their victory and directing the weapon of public agitation against the next target, the old corporation. Throughout 1833 a campaign of public meetings, well supported by the Leicester Chronicle, and a petition to Parliament, bitterly indicting the old order, kept the town in a ferment of excitement which culminated in the visit of the Commissioners of Inquiry sent down by the government to report on the municipal corporation. ${ }^{10}$ But the impetus of the movement died away as the Whig government failed to satisfy the hopes of a quick and sweeping change. Artisans, disillusioned by the new Poor Law and the treatment of the Dorchester labourers, tended to lose interest in politics and turn to trades unionism. ${ }^{\text {II }}$ Dissenters, who had opened in 1834 their long and bitter campaign against payment of church rates, found themselves fobbed off with a half-hearted and abortive bill that discredited the government's intentions. Even the cause of municipal reform moved slowly. No wonder the Reformers lost heart and lost ground! No wonder their opponents gained what had been lost! For the wise leadership of Peel, his moderation, his acceptance of the Reform Act, his policy of 'conservative' as opposed to 'destructive' reform, was beginning to tell; and it was now supported by a temporary revival of the old Tory spirit, roused by the call to defend the Church. The local campaign against church rates and the ecclesiastical policy of the Whig ministry, timid though it seemed to the dissenters, convinced churchmen that the Establishment was in danger. The cry was taken up by the corporation and the press; the opponents of reform began to rally. The Conservative Society, founded in 1832 , revived its activities and even organized Operatives' Conservative Societies to win over the working men. ${ }^{12}$

At this point, at the end of 1834 , the Whig government fell; and the humiliating

\footnotetext{
${ }^{6}$ A. T. Patterson, 'Electoral Corruption in Early Victorian Leic.', History, xxxi. I13-24.

7 See e.g. speech of T. Macaulay reported in Leic. $7 n l$. 28 May 1859.

8 Leic. $尹$ Inl. 23 June 1848.

? The election is described by G. R. Searson, $A$ Quarter of a Century's Liberalism in Leic. $1826-50,36-37$. The poll
}

was Evans 1,663 , Ellis 1,527 , Leigh 1,266: Leic. Boro. Poll Bk. I 2 and I 3 Dec. $I 832$.

to Greaves, Corp. of Leic. I 24-8; Searson, op. cit. 38-4I.

11 S. Maccoby, Eng. Radicalism, $I 832-52$, chapter vi.

12 Leic. $7 n l .23$ May 1834,2 Jan. 1835 . 
circumstances of its fall completed the discomfiture of the Reformers. In two years their confidence and harmony had been destroyed. In like measure the advent of Peel's government heartened their opponents. The corporation energetically seized this last opportunity to escape disaster. Against the general election that must soon come they mobilized the forces of corporate and clerical influence to secure the registration of their supporters and did it so well that they caught the Reformers napping: ${ }^{13}$ indeed, the Reformers admitted afterwards that they had not yet woken up to the discovery that since the Reform Act 'the battle of the elections must be fought before we got to the hustings - in the Registration Courts'. ${ }^{14}$ 'The Conservatives used also the methods of intimidation and bribery to an extent of which one of their leaders, in a cooler and much later hour, declared himself ashamed. ${ }^{15}$ Equally important and more reputable was the acquisition of two well-connected and capable candidates. Edward Goulburn had already acquired a standing in Leicester as recorder of the borough and enjoyed the reflected glory of his elder brother, whom Peel had just appointed Home Secretary and whose devotion to his leader was likely to please at least one section of the party. The other candidate was Thomas Gladstone, the bearer of a name which his younger brother had already made prominent, though not yet great, and which promised hope to the 'stern unbending Tories'. Neither Goulburn nor Gladstone, as it turned out, was to make an effective political career, but they appear to have been active canvassers and were certainly vigorous and lively speakers. They exploited to the full the unpopularity of the new Poor Law and the theme of the 'Church in danger', and contrasted the temperate reform promised in the Tamworth Manifesto with the destructive radicalism of the sitting members, particularly of Ellis. ${ }^{16}$

Such were the circumstances in which the election of January 1835 took place and, although the Reformers once again put up Evans and Ellis and enjoyed the resources of corruption and intimidation, they could not make headway against the apathy of their supporters and the spirit of their opponents. Goulburn and Gladstone beat them by majorities of $\mathrm{I} 32$ and $\mathrm{I} 62$ respectively. ${ }^{\mathrm{I}}$

The Conservatives had won, but not enough to save the government and the corporation. The Reformers had lost, but were saved from the worst consequences of defeat. Peel failed to secure a majority; the Whigs returned to power and now took up in earnest the question of municipal reform.

The Municipal Corporations Act of September I835 did not affect only the local administration of Leicester. In destroying the old corporation, in replacing it by the new, elected corporation, it achieved a greater revolution than the Reform Act itself in the parliamentary politics of the borough. It was a revolution all the more striking because, with the first municipal election held under the terms of the Act in December I835, the Reformers established a supremacy so thorough-going that it was hardly challenged before the end of the century. In every way-in its origins, provisions, and consequences-the Act struck at the fortunes of the Conservatives. The report of the Commission of Inquiry from which it originated had provided the most damaging evidence to discredit the old order and all those connected with it, and what powerful propaganda it could make against the Conservatives was only too well demonstrated

13 Ibid. 24 Oct. 1834.

14 Speech of J. F. Winks: Leic. Chron. 24 Aug. 1839. The activities of the corporation and clergy are related in ibid. 17 Jan. 1835 , and Greaves, Corp. of Leic. 129-30.

15 T. Macaulay, reported in Leic. Chron. 28 May 1859. Evidence of part of the expenses may be found in the proceedings relating to the bankruptcy of Clarke, Mitchell, Philips \& Smith's Bank. £2,018 14s. 6d. was shown to have been spent in this election on behalf of the Con- servatives. This was possibly only part of the whole: ibid. 3 Oct. I 846 . I,3 Io: Leic. Boro. Poll Bk. Fan. I835. A comparison of the poll bks. for 1832 and 1835 shows that the Reformers had lost 336 electors who either abstained from voting or were omitted from the register, and had gained 208 new electors. The Conservatives had lost 200 electors and gained 3 I I new ones. 


\section{A HISTORY OF LEICESTERSHIRE}

in the first municipal elections. Although in the long run the Act itself, in abolishing the old corporation, freed the Conservatives from an embarrassment, its immediate effect was to deprive them of their most effective political organization. And the Act finally had the consequence, as a result of the municipal elections, of transferring to their opponents the imponderable advantages of respectability, prestige, and influence that the exercise of official authority must carry with it.

The Municipal Corporations Act had another result that should equally have affected the two parties. In introducing annual municipal elections it stimulated political activity and organization in a way that impinged as much upon parliamentary as local politics. For from the first these elections took on an avowedly political colour: the parties that disputed the representation of the borough now contested with equal heat and greater frequency the government of the town; and so their electoral machinery was kept in constant motion. Thus the parliamentary politics of Leicester struck roots deep into every ward of the town; and not only into the wards but into the parishes too, since the vestries, parish officers, and guardians were chosen as the result of elections fought no less openly on the same political lines and by the same political parties. The ascendancy which the Reformers were to establish in the parliamentary representation was founded on the control they established over the wards and parishes. ${ }^{18}$ The Conservatives, however, appear to have profited less from this extension of political activity: in the parishes, their connexion with the Church put them mostly on the defensive, while their opponents were inspired by the crusading vigour of dissent; and in municipal affairs their fortunes were still more blighted by the record of the old corporation. In this respect, as in others, municipal reform weakened the Conservatives.

Encouraged by their municipal success, the Reformers determined to win back the borough at whatever cost. The defeat of 1835 had shocked them out of their apathy and restored their unity. This time, when the death of William IV in I 837 made a general election necessary, they were not caught napping. In readiness they had organized the Reform Society, which had taken the place of the former Political Union, and brought it into closer association with the ward societies that had been created to fight the first municipal elections. ${ }^{19}$ In good time they brought their candidates before the electors. They were Samuel Duckworth, a barrister, something of a careerist but noted for his fidelity to the Whig government and recommended by his friendship with the former Liberal member for South Leicestershire; ${ }^{20}$ and John Easthope, a more interesting man who had made a fortune and achieved political influence as the proprietor of the Morning Chronicle. ${ }^{2 I}$ The conduct of the election was put into the hands of William Biggs, a young and energetic hosier, chairman of the Reform Society, who had already shown his fighting spirit in 1832 and was now determined, as it was reported later, to make this campaign his 'masterpiece' ${ }^{22}$ No effort and no expense were spared and the Conservatives complained afterwards, with some justice, that 'there never was before. so profuse and lavish an expenditure and such a system of debauchery'. ${ }^{23}$ The cost was estimated as $£ 3,500$ for each member. ${ }^{24}$ When the Conservatives petitioned against the election on the grounds of this corruption Biggs found it convenient to have urgent business in America. ${ }^{25}$

Industry in the registration courts and generosity in the ale-houses did not in them-

${ }^{18}$ See speech by J. F. Winks: Leic. Chron. 24 Aug. I 839.

19 Leics. Mercury, 19, 26 Nov. I 836.

20 Ibid. I 8 Feb. I837. Duckworth seems to have used his parliamentary position to advance his legal career. In I 839 he was appointed a master in chancery: Leic. Chron. 16 Mar. 1839.

21 Leics. Mercury, 29 Apr. 1837. For Easthope see

D.N.B.; Leic. Ghron. and Leics. Mercury, 23 Dec. 1865; Hist. of The Times, i. 463 .

${ }_{22}$ For the career of Wm. Biggs see Leic. Chron. and Leics. Mercury, 8 Oct. I $88 \mathrm{x}$.

${ }^{23}$ Leic. Ghron. 14 Apr. 1838.

24 Leic. Inl. 19 Feb. 1847.

25 Leic. Chron. 14 Apr. 1838, 6 Mar. 1847. 
selves suffice to win an election. An issue was needed. The Reforming candidates produced a substantial programme which called for a national system of education, household suffrage, triennial Parliaments, the ballot, 'justice for Ireland', and the abolition of compulsory church rates; ${ }^{26}$ but as the election was not precipitated by a great national question they had also to develop other themes. They stigmatized their opponents as reactionaries, 'the faction of the King of Hanover', who had recently withdrawn the constitution of his kingdom, admirers of Don Carlos and Don Miguel, who led the clerical parties in Spain and Portugal, and, with greater force, partisans of the old corporation. ${ }^{27}$ The electors were warned that to vote for Goulburn and Gladstone would be to risk the return of the old corporation and the corruption and maladministration with which it was charged. To point the danger a balance sheet was drawn up to express the contrast between 'What the Tory Corporation did' and 'What the new Corporation has done' in the year and a half of its existence; and in this way the Reformers tried in part to turn the election into a plebiscite for or against the old municipal order. ${ }^{28}$ This challenge was taken up by the Conservatives. They put the local issue, however, in a different form: in their view the election would decide whether the town was to be Christian or governed by a 'Socinian clique';29 but although they polled almost as many votes as had enabled them to win in $\mathrm{r} 835$, they were heavily defeated. The Reformers won by $35^{\circ}$ votes. ${ }^{30}$ The Leicester Chronicle attributed this success partly to the effect of municipal reform in schooling the electorate to exercise the franchise and establishing the system of wards as 'so many citadels of liberty'; partly, also, to the organization of a volunteer police to prevent the system of kidnapping which, it was alleged, had prevailed at the last election. ${ }^{3 \mathrm{I}}$

With this victory the Liberals, as they may now be called, secured a lasting hold on the borough: once only, before the century ended, did they lose even one of the seats, and that only in a by-election and when divided among themselves. Henceforward the Conservatives seemed to regard the odds against them as almost hopeless. They could no longer use the corporation as an electioneering agency: their churchmanship gave them little help in a town where nonconformity was going from strength to strength; their reliance on country gentlemen to fight their contests weakened their appeal to a predominantly industrial constituency, and their membership of gentry, professional men, and shop-keepers lacked the funds to compete with the moneyed power of the Liberals. The Conservatives decided, after the election of 1837 , that the party could not stand the cost of another such election. ${ }^{32}$ At most they could hope to profit from the divisions of their opponents. They could do this in two ways: by exploiting the differences between the working men and their employers they could build up a ToryRadical alliance; by working on the fears of the more cautious Reformers they could build up a Conservative-Whig alliance. Neither could be achieved easily. The Operatives' Conservative Societies seem to have been too intermittent to maintain sufficient contact with the working men: the Conservatives in general, as property owners, allowed their suspicion of these potential allies to master their political ambitions; and although from time to time they made tentative approaches there was little chance, before the second Reform Act, of a solid alliance founded on a real sympathy with the industrial and social grievances of the workmen. ${ }^{33}$ Alliance with the more Whiggish

26 Leics. Mercury, 20 May 1837.

27 Leic. Chron. 29 July 1837.

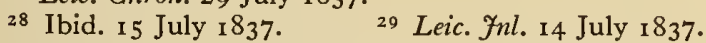

30 Duckworth 1,816, Easthope 1,816, Goulburn 1,454, Gladstone I,453: G. R. Searson, Leic. Municipal, Boro. and Co. Poll Bk. I883, 97.
31 Leic. Chron. 29 July 1837.

32 See report of T. Macaulay's speech in Leic. Chron. 28 May 1859.

33 Sir Henry Halford's championship of the frameworkknitters after I 845 seems to have won only a small response from the Conservatives of the borough. 


\section{A HISTORY OF LEICESTERSHIRE}

reformers provided a more palatable and, in terms of votes, a more profitable alternative: but parties so divided by religion and memories could only be reconciled by some exceptional crisis or a long process of evolution. Either way, the hopes of a more than transient success must be slight, and this feeling explains the apathy that prevented the party from adopting either course with consistency or vigour. Although the Conservative Society remained in being and was strong enough in 1842 to give birth to a Municipal Registration Society to manage municipal elections, ${ }^{34}$ its leaders had frequently to complain of the passivity of their following and even to admit, in the middle of the century, that it was not fair to ask a Conservative to contest the seat, so likely was he to lose his money. ${ }^{35}$

The Liberals did not suffer from apathy. They continued to improve their electoral machinery. The Reform Society provided the animating force of the party: it controlled its funds, selected candidates, and maintained a paid agent. ${ }^{36}$ It kept in touch with electors in general. Its committee of eighteen members was elected annually by a general meeting of subscribers ${ }^{37}$ and its efforts were seconded by similar organizations established in the wards, which were controlled by secretaries and elected committees of their own. ${ }^{38}$ When, at election time, candidates were brought forward, they were not imposed on the party by the central committee without further formality, but submitted to the approval of delegates elected by the wards and to a general meeting of the Liberal electors. ${ }^{39}$ The impression given is of an organization in close touch with the electorate and readily mobilized for action, so much so that in 1856 a Liberal leader, William Parker, could boast that they had 'a machinery for working the wards in connexion with the Liberal interest so complete that at the last election they were able in one day to compute the force they should have'. ${ }^{40}$ 'The principle of the 'caucus' was developed in Leicester long before it was perfected in Birmingham.

The Liberals had to fear not apathy but enthusiasm, the danger that the forces that had carried them to power might burst the frame of their coalition. As a whole they remained clearly more radical than the leaders of the Whig party, united in a common distrust of the aristocracy and the established church; but the issues that were to dominate the next decade and more-religious equality, extension of the suffrage, Chartismexposed markedly different degrees of radicalism and strained their unity.

In spite of these differences all Liberals could unite until I 846 on one issue, that of Free Trade. ${ }^{\mathrm{I}}$ The industrial depression that set in during 1838 provided a more pressing argument for repealing the Corn Laws: repeal would relieve both workmen and manufacturers and allow the hosiers of Leicester to beat their dangerous foreign competitors. ${ }^{42}$ In particular it was suggested that the competition of the Saxon hosiers for the American market could not be met as long as the Corn Laws stood. The Anti-Corn Law movement, begun in Manchester, found a ready response in Leicester. The Leicester Anti-Corn Law Association was founded in December I 838,43 and under the guidance of two leading manufacturers, John Biggs and Richard Harris, 'the Cobden and Bright of the Midland Counties', 44 began to organize a systematic agitation intended to revive the spirit of 1832.45 Between I 839 and I 84 I the public, electors and non-electors alike,
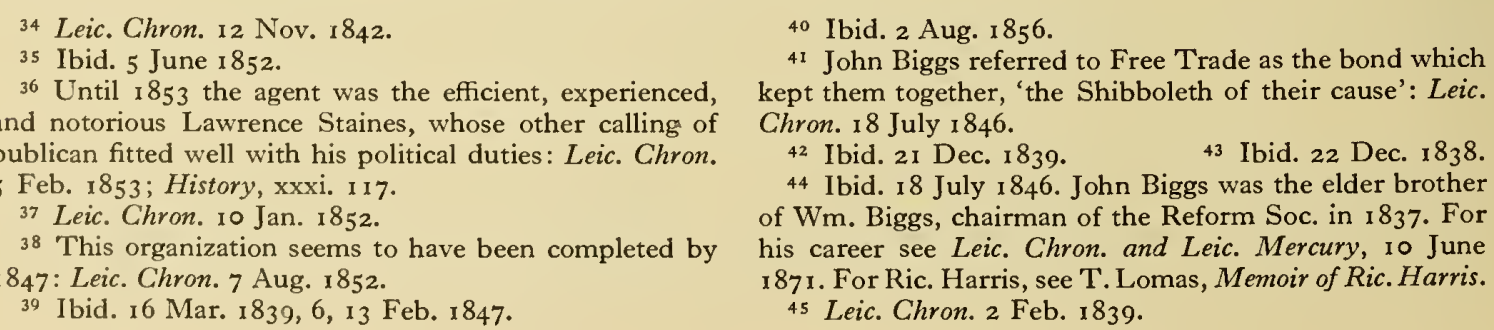
were aroused by a programme of lectures, public petitions, meetings, and open-air demonstrations, culminating in the great demonstration of June I84I, when 4,000 persons crowded into the Market Place. ${ }^{46}$ Employers were encouraged to contribute to the funds of the league, 47 and the working men were mobilized in an Anti-Corn Law Association of their own, founded in $\mathrm{I} 840.48$ The campaign continued at a steady pace during 1842 and although it afterwards fluctuated, slowing down during the next two years when trade improved slightly, and quickening with renewed vigour in the depression of $\mathrm{I} 845$, it remained a considerable force in the politics of the borough until the triumph of 1846 brought it to an end. On the whole, although it was condemned by some working men as a stunt to divert them from their proper political aims, the AntiCorn Law movement kept together Liberals of all classes and opinions at a time when other issues were driving them apart.

One of these issues was the campaign for religious equality. In principle, the Liberals, being as much as anything a nonconformist party, agreed that political emancipation must be accompanied by religious emancipation, but differed over the means, speed, and thoroughness of the process. This difference appeared clearly over the question of church rates. The injustice of compelling nonconformists to contribute to the upkeep of the established church was generally admitted: a remedy for this grievance was an accepted part of the Liberal programme; 49 but they did not agree on how the remedy could be achieved. On the whole, the more wealthy and respectable Liberals were cautious, content to obey the law until the Whig government could be persuaded to change it. Others advocated forcing the government's hand by open defiance of the law. This difference of opinion coincided with a difference of religious denomination. The Unitarians, who had hitherto provided the intellectual, political, and social leadership of Protestant nonconformity, stood solidly for moderation. The pressure for direct action came particularly from the Independents or Congregationalists and from the Baptists. After 1835 two of their ministers, Mursell and Miall, both young and fervent, came forward as the leaders of a nonconformist crusade directed in the first place against church rates, ultimately against the Establishment itself. ${ }^{50}$ In ${ }_{1} 8{ }_{3} 6$ Miall declared his refusal to pay church rates in the future; leading members of his congregation followed his example and defied the law; the ecclesiastical authorities replied by levying distress on their goods. ${ }^{5}$ So opened a contest which embittered relations between Church and dissent for the next thirteen years. On the part of the dissenters the contest was not purely passive. They went over to the offensive in an attempt to cut out church rates at the source by winning control of the parish vestries and voting down any attempt to authorize a levy. It was a long struggle: the last vestry was captured, the last rate levied, only in $1849 . .^{52}$ Meanwhile, these militant nonconformists had to face the opposition of equally intransigent churchmen. In St. Martin's parish, the stronghold of the die-hards, no quarter was given and there the cause had its first martyr in William Baines, whose resistance to payment cost him seven months in Leicester prison. ${ }^{53}$

The church rate contest led the more militant dissenters to consider wider issues. At the beginning in 1836 , they had founded, on Miall's initiative, a Voluntary Church Society: its immediate object was to abolish church rates, but its ultimate and declared

\footnotetext{
46 Ibid. 5 June I 84 I.

47 The sums that were contributed illustrate the financial strength of the Lib. party. In I 846 R. Harris \& Sons subscribed $£ 500$, John Biggs \& Sons $£ 500$, Thos. Stokes $\&$ Nephew $£ 200$, Brewin \& Whetstone $£ 200$, and other manufacturers in proportion: Leic. Chron. 7 Feb. 1846.

48 Leic. Chron. 7 Feb. 1846.

49 e.g. in the election of 1837 : Leics. Mercury, 20 May I 837 .
}

5o Mursell was minister of Harvey Lane Bapist chapel, later Belvoir St. chapel, 1826-73: see A. Mursell, Life of Revd. F. P. Mursell. Miall was minister of Bond St. Independent chapel, I 834-40: A. Miall, Life of Edward Miall.

51 Leics. Mercury, 23 July, 24 Dec. 1836.

52 Leic. Chron. 25 Aug. 1849.

53 Ibid. I 4 Nov. I 840,26 June I 84 I. 
aim was to achieve the disestablishment of the Church, to put an end to ecclesiastical privilege. ${ }^{54}$ Its importance was more than local. Through it Miall hoped to use the bitterness that church rates were now arousing elsewhere to awaken the crusading spirit of nonconformity as a whole, seeing the Leicester society as the first step in a national campaign. Leicester became for a short time a centre of nonconformist propaganda, which in 1844 fulfilled its immediate purpose with the formation of the British Anti-State Church Association, later and better known as the Liberation Society. ${ }^{55}$ Miall had then become a national figure and had left Leicester to found and edit a new dissenting journal, The Nonconformist ; ${ }^{6}$ but in his short career in the town he had successfully aroused at least a section of the dissenters and created a spirit of not only religious but political importance. As in the 17 th century, religious radicalism led readily to political radicalism. Clerical privilege went hand in hand with aristocratic privilege: equally obnoxious, both must be uprooted. The combination of religious and political extremes appeared clearly at an early stage in the movement, in the foundation of a new weekly journal in Leicester. Hitherto, Liberal opinion had been represented by the Leicester Chronicle, but the followers of Miall and Mursell considered it too moderate and in $18{ }_{3} 6$ founded a rival newspaper, the Leicestershire Mercury, which became the champion of both uncompromising dissent and uncompromising radicalism in politics. The relations between the two Liberal newspapers - usually bitter - reflected the strain to which these new religious and political pressures were subjecting the unity of their party.

The political views of militant dissent found expression particularly in the demand for a further instalment of reform. Although the Liberals in Leicester as a whole were united in their belief that the Reform Act had not gone far enough and in the demand for household suffrage, 57 in practice, the moderate section, represented by the Leicester Chronicle and most of the old leaders, was not prepared to press the Whig government hard..$^{8}$ Uncompromising dissenters, on the other hand, had no reason to be tender to a government which had done so little to relieve them of their disabilities and every reason to place their hopes of emancipation in an extension of the suffrage, which would break the power of privilege. The intransigent temper which led to the church rate contest led also to a new reform movement which now began to bring pressure on the Liberal party. Its influence had already been felt in the election of 1837 when Duckworth and Easthope had clearly committed themselves to household suffrage and the ballot; but even that did not satisfy some like Mursell and Miall themselves who stood out for manhood suffrage. ${ }^{59}$ Both of them attended the conference of 1842 at which the Complete Suffrage Union was founded, and at one time they succeeded in having manhood suffrage adopted into the programme of the Anti-State Church Association. ${ }^{60}$ In I 842 a local branch of the Complete Suffrage Association was founded; 6 ir and, with the support of the militant nonconformists now keenly engaged in the church rate contest, it maintained a steady pressure within the Liberal party in Leicester and attempted to revive the union between the middle and working classes that had been achieved during the struggle for reform.

This radical pressure did not originate only in dissent: it arose also in response to Chartism. As in other parts of the country the Chartist movement in Leicester had a complex origin. Its original impetus was provided, as in London, by the more intelligent

\footnotetext{
${ }_{54}$ Leics. Mercury, 29 Oct. I836.

55 Miall, Life of Edward Miall, 92.

${ }^{56}$ Ibid. $37-50 . \quad 57$ e.g. in the election of 1837 .

58 This can be seen in the speeches of Robert Brewin and Thos. Paget in the public meeting of 12 Feb. 1838 and
}

the editorial comment of the Chron.: Leic. Chron. i 7 Feb. I 838 .

59 Ibid. 13 and 20 Nov. 184 I.

6o Miall, Life of Edward Miall, 84-86, 142-3.

${ }^{61}$ Leic. Chron. 12 Mar. 1842. 
artisans, who had founded in 1836 a Leicester Working Men's Association, on the lines of that in London, with similar educational and radical political aims. ${ }^{62}$ This action expressed their discontent with the consequence of the Reform Act and marked their rejection of the middle-class leadership which they had hitherto been content to follow but were now ready to criticize. ${ }^{63}$ By themselves they made little progress until other causes turned working men in general to politics. The most important of these was the depression that struck the hosiery industry early in 1838 . The framework-knitters, who belonged to an overmanned and dying branch of the industry, suffered the greatest distress; and this was only the beginning of a depression that was to continue at least into $1843 .{ }^{64}$ The immediate effects of hard times were to exaggerate the defects of the industry's organization, to sharpen the longstanding grievances of frame rent, charges for standing, and other vexatious deductions, and to embitter relations between framework-knitters and employers. ${ }^{65}$ Although Mursell had tried to arouse the public conscience by a series of burning letters on the 'rights of labour' which he contributed to the Leicestershire Mercury, ${ }^{66}$ and though the Working Men's Association had tried to form a joint committee of masters and men to consider the problems of unemployment and low wages, ${ }^{67}$ by the summer of ${ }_{1} 83^{8}$ attempts at conciliation and relief had broken down. ${ }^{68}$ The men were thrown back on their own resources.

This meant political action. For in Leicester they had no effective trades unions and the system of public relief had at that moment become more harsh. The effects of the new Poor Law of 1834 had not at first been felt in Leicester, but at the end of 1837 the guardians attempted to introduce its most important principles, giving out-relief only to the sick and aged, and relieving the able-bodied only in the workhouse, where man and wife were separated and the poor subjected to 'tests' like grinding corn or breaking stones considered to be degrading. ${ }^{69}$ 'The tests called for a physical effort for which the framework-knitters were not fit:70 incarceration in the 'Bastille' affronted the independent spirit of men who were not yet subject to the discipline of a factory; above all the ban on out-relief deprived an over-manned industry of a form of unemployment pay that in the past made conditions just tolerable. The attempt to apply the new system set off a bitter agitation among the workmen.71

The aspirations of the Working Men's Association, the grievances of the hosiery workers, the agitation against the new Poor Law, stimulated by unemployment and hunger, found common expression in Chartism. The People's Charter, published in May 1838 , promised social relief through political reform. During the summer and autumn the new movement absorbed into itself all the other forms of agitation; and the leaders of other movements, such as John Seal of the Working Men's Association, John Swain, chairman of the Operatives' Committee, and John Markham, chairman of the Anti-Poor Law Committee, appeared in new guise as leaders of Leicester Chartism. ${ }^{72}$ In October 1838 they formed the Leicester and Leicestershire Political Union to advance the cause of the People's Charter. ${ }^{73}$ At first, and on the whole, Chartism in Leicester was less violent than in the north of England. For the most part the advocates of 'moral force' prevailed, except during the more stormy period of Cooper's leadership. Relations between employers and employed were perhaps less bitter because these dis-

62 Leics. Mercury, ${ }_{3}$ Aug. $1_{3} 6$.

63 Ibid. 8 Apr. 1837.

64 Letter of John Swain: Leic. Chron. 2 I Apr. 1838; ibid. 6 Jan. 1844 .

${ }_{55}$ These grievances are described by Thos. Cooper:

The Life of Thos. Cooper by Himself, I39-42.

66 Leics. Mercury, Feb. 1838 .

67 Leic. Chron. 31 Mar. $188_{3} 8$.
68 Leics. Mercury, 23 June $18_{3} 8$.

69 Leic. Chron. 24 Feb. 1838.

70 Life of Thos. Cooper, 183 .

7 Leic. Chron. 24 Feb. $188_{3} 8$.

72 Leics. Mercury, 8 Oct. I836; Leic. Chron. 24 Feb., 2 I Apr. $18_{3} 8$.

${ }_{73}$ Leic. Chron. 13 Oct. $18{ }_{3} 8$. 
tinctions were less sharp and more graduated than under factory organization-John Swain, for example, was himself an employer on a small scale, a framework-knitter who had prospered enough to own a few frames of his own ${ }^{74}$-and were to some extent transcended by the common bond of nonconformity: John Markham, the most prominent Chartist, was a Methodist preacher. 75 Although the Chartists received no active support, they received much sympathy from middle-class Radicals like Mursell, which helped to mitigate the antagonism of classes. ${ }^{76}$ Their leaders, also, had good reasons for caution, for they understood the local weakness of the movement. Although they could attract crowds in thousands to open-air demonstrations, they could not achieve a large, permanent, subscribing membership. Estimates of their numbers varied between 300 and 700,77 and Markham in 1840 advocated a cautious policy of waiting because they 'were comparatively but a handful here'. ${ }^{8}$ 'This evidence of comparative weakness is borne out by the remarkable way in which Leicester appeared to be subordinated to Loughborough in the Chartist politics of the county. It was a Loughborough, not a local, man who was sent to the Convention in 1839.79

It was not at first the physical power of Chartism that was feared in Leicester, but its voting power. Although the Chartists had few votes-perhaps twenty ${ }^{80}$ - even these were valuable when two or three hundred made a good majority. They were still more valuable in the particular conditions of 1839 . In March Duckworth resigned his seat ${ }^{81}$ and made a by-election necessary at a time very unseasonable for his party, when its unity was openly strained by differences of opinion over church rates and the suffrage. ${ }^{82}$ Uncertain of their own unity the Liberals felt acutely the danger of an alliance between Conservatives and Chartists. ${ }^{83}$ Fortunately for them the Conservatives were handicapped by the difficulties of finding a candidate. Only after much search and at the last minute did they bring forward C. H. Frewen, a local landowner. He was young and inexperienced, and although he struck hard at the new Poor Law his pledge 'to maintain the institutions of the country' could not attract the Chartists. ${ }^{84}$ Meanwhile the Liberals, quick off the mark, had brought back Wynn Ellis, who skilfully tried to appease radical and dissenting opinion. He declared himself more radical than the Whig government, hoped that the Poor Law would be modified, and advocated as his programme repeal of the Corn Laws, abolition of church rates, triennial Parliaments, vote by ballot, and extension of the suffrage; questioned on the last he replied that 'there could be no harm and no risk in giving a vote to a man who has a house over his head'. ${ }^{85}$ His party was appeased, the Chartists not outraged. There was no alliance with the Conservatives, and the Chartists withdrew the nomination of their own candidate, the ultra-radical Perronet Thompson. ${ }^{86}$ Ellis won by nearly 300 votes. ${ }^{87}$

Although the immediate political challenge of Chartism was averted, the threat of physical force kept the town in a state of anxiety during the spring and summer of I 839 when the Chartists were following the fortunes of their National Petition and Convention. In May and August the influence of the moderate leaders seemed for a while to be shaken, their meetings were marked by violent language, ${ }^{88}$ and in August the magistrates for the first time feared that the local police force might not be able to maintain

74 Leic. Chron. 8 Sept. $18{ }_{3} 8$.

75 Life of Thos. Cooper, 163 .

${ }^{76}$ Ibid. I 80-I.

77 The number estimated in 1838 was 600-700: Leicss. Mercury, 9 Mar. 1839 . Thos. Cooper, speaking in 1842 , estimated the number at 300 , but as his object was to claim credit for the subsequent increase this figure must be taken with caution: Leic. Chron. 9 July 1842.

78 Leic. Chron. I8 Apr. I840.

79 Ibid. 2 Mar. 1839.
${ }^{80}$ Life of Thos. Cooper, I 50. The Leic. Inl. estimated them at 85 in I 841 : Leic. Fnl. I 2 Feb. 1841.

8I On being appointed a master in chancery: Leic. Chron. I6 Mar. I 839.

${ }_{82}$ Leic. Chron. I7 Feb. I838, 2 Feb. 1839.

83 Ibid. 23 Mar. 1839 .

84 Ibid.

86 Ibid. 23 Mar. 1839.

87 Ellis I,666, Frewen I,371: Leic. Boro. Poll Bk. 1839.

88 Leic. Chron. 4 May, 25 May, 31 Aug. 1839. 
order. ${ }^{89}$ The sense of crisis, however, quickly subsided; the advocates of moral force regained their ascendancy ${ }^{90}$ and even the bad winter of $1839-40$, when a quarter of the population was said to be receiving relief, produced no disturbances. ${ }^{91}$ With the movement temporarily discredited by the failure of the National Petition and Convention, it seemed as if Chartism might be absorbed into the middle-class movements. One possibility was that their energies might be diverted into the Anti-Corn Law agitation. During I 840 the Anti-Corn Law leaders constantly stressed the common interest that repeal possessed for the middle and working classes, and in March formed the Working Men's Anti-Corn Law Association.92 'This approach succeeded in part, but not enough; many Chartists regarded it as a trap. ${ }^{93}$ The other possibility was that Chartism might be absorbed into the radical campaign for political reform that had begun as early as I 83894 and now took on a new vigour under the pressure of Chartism and militant dissent. 95 Now the initiative was taken by one of the younger Liberal leaders, William Biggs, who proposed to resume in earnest the campaign for triennial Parliaments, the ballot, and household suffrage, to which the party was officially, but hitherto it seemed half-heartedly, committed, and appealed to the Chartists to make common cause by dropping the demand for universal suffrage and being content with either the modification or abolition of the property qualification. He advocated this policy vigorously, first at a public meeting of Reformers in May $1839,{ }^{96}$ and then in two letters to the Leicester Chronicle. 'The first, in June, repeated proposals made by O'Connell to the Chartists of Birmingham: it was here that he suggested abolition of the property qualification. The second, in November, took the form of an open letter to Joseph Hume and contained a detailed plan for redistributing seats and extending the suffrage to householders in large towns. ${ }^{97}$ In April I 840 at a meeting of leading Liberals and Chartists he launched a petition for the extension of the suffrage, and Markham, the Chartist leader, responded enough to advise the Chartists to support it in the interests of unanimity. ${ }^{8}$ Yet the attempt to win over the Chartists failed. Their apparent quiescence during the rest of the year made Biggs's policy less urgent and less welcome: the interest of the middle classes was more taken up with the Corn Laws and the church rate contest, which was now moving to its height with the imprisonment of Baines:99 it was difficult to frame proposals broad enough to satisfy the Chartists, ${ }^{\mathrm{I}}$ yet sufficiently narrow to appease the fears of the more cautious Liberals, like Thomas Paget; ${ }^{2}$ and finally the Leicester Chartists discovered a new leader and a new intransigence.

The new leader who came forward in I84I was Thomas Cooper. Although he shared the passion for self-education and self-improvement that distinguished the other Chartist leaders like Markham, he came into the movement in a different way. They had entered gradually through the Working Men's and Anti-Poor Law Associations: he plunged into it. They had a lifetime's acquaintance with the conditions of industry: he ran into them with a shock that jarred his soul. Cooper experienced an emotional, not an intellectual conversion. He had long been acquainted with the Chartist programme, had long accepted the Six Points, ${ }^{3}$ but it was not until he came to Leicester at the end of $184^{\circ}$ and saw the rags and bones of the Leicester stockingers that suddenly he felt impelled to their cause. ${ }^{4}$ For, although born in Leicester, he had spent his life

89 H.O. $40 / 44$.

90 Leics. Mercury, 24 Aug. 1839.

91 Leic. Chron. 22 Feb. 1840.

92 Ibid. 29 Feb., 2 I Mar. 1840.

93 Ibid. 29 Feb. 1840.

94 Ibid. Io Feb., I 7 Feb. 1838 .

95 Ibid. 25 May 1839.

96 Ibid.
97 Ibid. 8 June, 2 Nov. 1839 .
98 Ibid. 18 Apr. I 840.

99 Ibid. I4 Nov,, 2 I Nov. I 840,30 Jan. I 84 I.

I Several Chartist speakers condemned Biggs's movement for household suffrage as an attempt 'to murder the Chartist cause': Leic. Chron. 18 Apr. I 840.

2 Ibid. 23 Mar. 1839 , 20 June 1840.

3 Except the ballot: Life of Thos. Cooper, 136.

4 Life of Thos. Cooper, 134 . 
in the country, and, although he had indeed known poverty, it was nothing like the poverty of an industrial town. ${ }^{5}$ Like so many converts he quickly showed himself more zealous than the older Chartists. Cooper had an ardent nature that threw him wholeheartedly into any cause that engaged his sympathy and he was now driven forward not only by the cause of social justice but by an imperious passion for leadership. ${ }^{6}$ Already experienced as a teacher, preacher, and journalist, widely read and full of confidence, he quickly rose to the top, editing the local Chartist newspaper, conducting meetings, acting as secretary, and infusing a new life into the movement. ${ }^{7}$

The change in leadership soon led to a change in Chartist tactics. In his revulsion from the social conditions which he had discovered, Cooper was more hostile than the older leaders to the employers whom he held responsible, and less ready to compromise with the middle classes and the Liberals. Impatient of political economy he did not believe that any benefit would come from repeal of the Corn Laws. ${ }^{8}$ He had therefore less compunction in working with the Conservatives, and the danger which the Liberals had feared in 1839 became a reality in $184 \mathrm{I}$. The existence of this new alliance was demonstrated first at the Nottingham by-election in April, when a contingent of Chartists went over to support the Conservative candidate; ${ }^{9}$ and afterwards in Leicester at the general election in July. On this occasion, although the Chartists determined to demonstrate their independence by nominating Cooper, he was to withdraw and his followers were to support the Conservative candidates. ${ }^{10}$ So a Tory-Radical alliance was achieved; but its achievement in $\mathrm{I} 84 \mathrm{I}$ did not trouble the Liberals as much as its threat in 1839 because they did not expect any serious Conservative opposition; and so it turned out. The only consequence of the Chartist intervention was to add some life to the process of nomination, for the Conservatives failed to find any candidates willing to stand the expense of a poll. Wynn Ellis and Easthope were elected unopposed, having advocated a programme of repeal of the Corn Laws, abolition of church rates, and amendment of the Poor Law. II

Cooper did not achieve his authority over the Chartists without opposition. Some of the former leaders disapproved of his policy, particularly of his loyalty to O'Connor; others were alienated by his autocratic and passionate temper. In January I 842 a bitter quarrel with Markham led to a permanent division. ${ }^{\mathrm{I2}}$ Nevertheless, Cooper seems not only to have retained the greater part of his following but to have increased it by an imaginative policy which made his Shakesperean Association part adult school, part a sort of Salvation Army. ${ }^{13}$ In July I 842 he was claiming 3,000 members. ${ }^{\mathrm{I}}$ He succeeded also in increasing the importance of Leicester and himself in the Chartist movement as a whole. During I 842 he began to extend his leadership over the county, speaking in the villages and holding a great 'camp-meeting' at Mountsorrel.15

The Chartist revival led to new attempts to achieve an understanding between the middle and working classes. This course was suggested in October I 84 I by Seal, one of the dissident Chartists who had quarrelled with Cooper; it was taken up by Mursell, the most thoroughgoing of the middle-class leaders. ${ }^{16}$ At this point William Biggs once more tried to take the lead, proposing to create a union based on a 'Midland Counties Charter', which differed from the Chartists' Six Points by establishing an age limit for

5 Life of Thos. Cooper, 134-9, 143.

6 'I cannot avoid throwing my whole nature into an undertaking, when once I enter upon it, either from a sense of duty or for self-gratification': ibid. 73 .

7 Life of Thos Cooper, $147^{-8}$.

8 Leic. Chron. 25 Sept. I 84 I.

9 Life of Thos. Cooper, $148-9$.

10 Ibid. $152-3$.

II Leic. Chron. 3 July I 84 I; Leic. Fnl. 2 July I841; Life

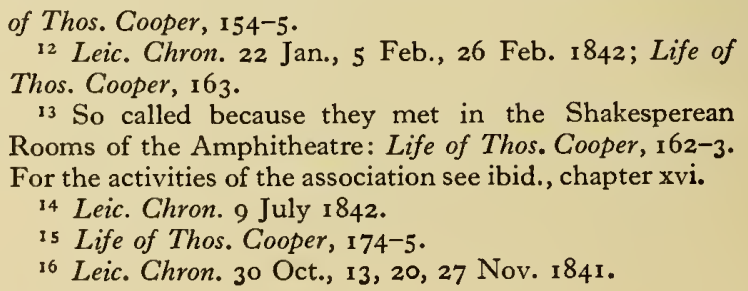


the suffrage and suggesting triennial Parliaments. ${ }^{17}$ However, this local initiative did not succeed and the local movement became absorbed in the Complete Suffrage movement associated with Miall in London and, more closely, with Sturge in Birmingham. A Complete Suffrage Association was founded in Leicester in March $1842^{18}$ and received the expected support of the more radical dissenters, not only of Mursell, but of J. F. Winks, a Baptist preacher and publisher of religious books. Winks was an old friend of Cooper but no Chartist, who had hitherto reserved his pugnacity for the church rate contest and taken a rather more cautious opinion about the suffrage than Mursell. ${ }^{19}$ In providing a means by which the extreme Radicals could exert a more effective political pressure the association had some success, but it failed in its immediate object: for although it was supported by the leaders of the Working Men's Anti-Corn Law Association, even Markham, despite his breach with Cooper, refused to join and Cooper denounced any who went over as renegades. ${ }^{20}$

This effort at reconciliation had been made at a difficult time. Already under Cooper's leadership the tone of the Chartists had become more menacing. Since the summer of $184 \mathrm{I}$ they had tried to turn every political meeting into a Chartist demonstration and the violence of Cooper's language had created stormy scenes, particularly in the meetings of the Anti-Corn Law League. ${ }^{21}$ In February 1842, for example, a crowded meeting of the Working Men's Anti-Corn Law Association was in effect broken up by Cooper, who was left in possession of the hall haranguing his followers. In the summer of 1842 the temper of the Chartists was still more inflamed when trade, bad enough during the winter, ${ }^{22}$ came to a standstill. The condition of the unemployed became desperate, a despair reflected in the rapidly falling sales of the Chartist newspaper and the closing of Cooper's educational classes: one of the Chartists asked, 'What the hell do we care about reading, if we can get nought to eat ?'23 The distress gave a new impetus to the Chartist cause but at the same time weakened Cooper's control over it. His following was swollen by unemployed only vaguely associated with the movement, terming themselves or being called Chartists for want of a better description. It was the economic grievances of these men, not Chartism as such, that precipitated the crisis of August 1842 .

Already a state of fear had been created by the bands of workmen marching through the streets, singing Chartist songs, begging money from passers-by, or entering churches during service for the same purpose. ${ }^{24}$ Then in April, the corn mill which the guardians had recently introduced to provide a more stringent test for poor relief provoked a bitter opposition that developed into violent riots lasting several days. ${ }^{25}$ Finally in August great strikes broke out in the north of England and the Potteries, and were quickly associated with an attempt to make the Charter the 'law of the land'. Their example soon spread to Leicester. First the colliers of Whitwick and Snibston struck; then the glove hands; then the Chartists, exhorted by agitators like Duffy, an Irishman from Lancashire, tried to turn the movement into a general strike for the Charter. For a week the town was threatened with riots as groups of strikers tried to force others to join them and marched the streets in procession, while the magistrates swore in special constables, called out the yeomanry, and kept cavalry standing to in the Market Place. Faced with this firm show. of authority the strikers were soon discouraged. After a few scuffles in the Market Place and the Welford road and after a body of four or five

\footnotetext{
17 Ibid. 4 Dec. I84I, 5 Feb., 26 Mar. 1842.

18 Ibid. I 2 Mar. 1842 .

19 Ibid. I 3,20 Nov. I84I; Leic. Chron. and Leics.

Mercury, 2 June I 866; Life of Thos. Cooper, I33.

20 Leic. Chron. 2 Mar., 2 Apr., 30 July I 842.
}

21 Leic. Chron. 19 Feb. 1842.

22 Ibid. II Dec. I84 I.

23 Life of Thos. Cooper, 172.

24 Ibid. I71, I75-7; Leic. Chron. I I June I 842.

25 Leic. Chron. 30 Apr., 7 May, I 8 June, 2 July I 842. 


\section{A HISTORY OF LEICESTERSHIRE}

hundred men who had marched out to join their fellows in Loughborough had been dispersed at Mowmacre Hill by police and yeomanry, the movement subsided. ${ }^{26}$ The strikers went back to work; among the Chartists 'all was discord and jealousy'. ${ }^{27}$

The suppression of these disturbances was distinguished by its moderation. For the most part the rioters were bound over to keep the peace; a few were fined Ios. ${ }^{28}$ Nevertheless, the Chartists had suffered a severe defeat. Events in Leicester had disheartened them; events outside Leicester cost them their leader. Cooper had taken no part in the local disturbances in August, having hurried north to Manchester to attend a conference of Chartist leaders. On the way, however, he had been involved in riots in the Potteries: found guilty of sedition and conspiracy, he was sentenced in April i 843 to two years' imprisonment. ${ }^{29}$ 'This, as it turned out, meant the end of Cooper's career in Leicester. Although it did not mean the end of Chartism in the town, his departure and the improvement that took place in trade at the end of 1843 markedly reduced its activity.

A peaceful interlude followed, partly disturbed by the still lively contest over church rates and the agitation of the Anti-Corn Law League. In I 846 the repeal of the Corn Laws brought that agitation to an end: it put an end also to the period of peace, for it permitted the Liberals to quarrel among themselves. The divisions that were soon evident were in part only a local reflection of the national confusion of parties, which the Conservatives also felt, being divided themselves between Peelites and Protectionists. ${ }^{30}$ The divisions of the Liberals, however, had also deep local causes. Since the Reform Act the question of suffrage and disestablishment had tended to divide them with increasing sharpness into two factions, moderates and extremists, and even, as some observers reported, into four, Whigs, moderate Liberals, Radicals, and universal suffrage men. ${ }^{3 \mathrm{I}}$ After I 846 the moderates, cooled perhaps by their experience of Chartism and taking their cue from the new Whig ministry, became if anything more cautious, maintaining that the country had 'become weary of all the isms' and that the government must devote itself now to uncontroversial objects, on which all parties could unite, such as sanitary reform, prison discipline, and education. ${ }^{32}$ By contrast the extremists were encouraged by the achievement of repeal to press still harder, and could count on the powerful reinforcement of those repealers who were now ready to turn their energies to new objects. The most important of these reinforcements were the brothers John and William Biggs. Although the older brother, John, had, except in the Anti-Corn Law movement, played a lesser political part, in the next fifteen years he came forward as by far the most prominent political figure in the borough. He was wealthy and ambitious to play the part appropriate to a merchant prince, ${ }^{33}$ sturdy, sanguine, lavish in his generosity, terse in speech, and able to command popularity with an ease denied to his more didactic and prosy brother. ${ }^{34}$ Although he did not at once throw in his lot unreservedly with the Complete Suffrage and Anti-State Church party, he now moved steadily away from the moderates. In this he was prompted not only by his own political optimism and appreciation of the Complete Suffragists' voting strength, but by differences over local policy. Since 1843 a sharp conflict had broken out in the town council over a proposed improvement bill and had divided the Liberals in much the same way as did the national issues. Whereas the moderates, led now by the wealthy and

26 Leic. Chron. 20, 27 Aug. 1842.

27 Life of Thos. Cooper, 219.

28 Leic. Chron. 27 Aug. 1842.

29 Life of Thos. Cooper, 235-6.

30 Leic. Fnl. I Sept. 1848 .

31 Leics. Mercury, 23 Mar. I861.

32 Leic. Chron. I I July I 846.

\footnotetext{
33 Note his evident desire to emulate 'the merchant princes of Derby, the Medici of their day': Leic. Chron. I 5 Nov. 1845 .

${ }^{34}$ For John Biggs see Leic. Chron. and Leics. Mercury, Io June I871, I9 Apr. I873; Revd. C. C. Coe, Sermon preached in memory of John Biggs (Leic. I871), Leic. City Ref. Libr., Pamphlets $\mathrm{O}_{3}$, vol. ii.
} 
THE CITY OF LEICESTER

prudent worsted-spinner, Joseph Whetstone, advocated a cautious system of sanitary improvement, their opponents, John and William Biggs at the head, wanted a thoroughgoing scheme of civic embellishment. ${ }^{35}$ The squabble between 'economists' and 'expenders', which openly divided the Liberals in the municipal elections of 1846 , quickened their other disputes. ${ }^{36}$ The new alignment so created became evident in the general election of $\mathrm{I} 847$.

The first sign of change appeared in the repudiation of the sitting members. Easthope had forfeited much nonconformist support in refusing to vote against Graham's Education Bill of I 843 which was thought to bestow dangerous privileges on the established church;37 and both Ellis and he too fully identified themselves with Russell's cautious Whig ministry of 1846 to satisfy the now powerful militant wing of the Leicester Liberals. The members had not only offended the rank and file; a dispute had also broken out between them and a number of the local leaders, John Biggs in particular, over the expenses incurred in the election of $\mathrm{I} 84 \mathrm{I}$, a dispute bitter enough to provoke a lawsuit. ${ }^{38}$ Although Easthope and Ellis still received the support of moderate opinion as expressed by the editor of the Leicester Chronicle, ${ }^{39}$ they could not prevail against the party machine now controlled by John Biggs and his fellow leaders. With suspect haste, meetings of Liberal electors were held in the wards and delegates elected to a general meeting which resolved on a change of candidates. 40 The choice of new candidates took longer. John Biggs and Whetstone had both been considered and declined:4I it was rumoured that the delegates had approached John Bright but he had turned the offer down because of the constituency's bad name. ${ }^{42}$ Mursell and the Complete Suffragists had been campaigning for the last year in favour of George Thompson, an extreme Radical who could also be counted on to resist any further proposals for state education such as had been suggested in 1843 and 1846.43 In the end the delegates adopted Sir Joshua Walmsley and Richard Gardner, men who could be expected to sympathize with the commercial and industrial interests of the town. Although Walmsley came from Liverpool where he had distinguished himself as a prosperous corn-merchant and as mayor, he had close connexions with Leicestershire, having an interest in collieries in Snibston and Whitwick; and through them and the affairs of the Midland Railway he had enjoyed a long acquaintance with John Ellis, the important coal-merchant and railway director, who also took a prominent place in the local Liberal party. ${ }^{44}$ Railway politics were thought to have played some part in his nomination. ${ }^{45}$ Gardner, who was regarded as more radical than Walmsley, ${ }^{46}$ was a Manchester mill-owner, brought into contact with the local Liberal leaders through his work for the Anti-Corn Law League. ${ }^{47}$ Their programme was designed to appeal to Radicals of all types. They took care to appease the militant dissenters by opposing government grants for religious purposes-a clear reference to the controversy over the Maynooth grant of I 845 which had roused violent indignation in Leicester ${ }^{48}$ - by advocating the neutrality of the state in the matter of religious education and asserting their hostility to the privileges of the established church. They appealed to Complete Suffragists and Chartists alike by accepting complete suffrage 'in principle' - indeed five of the Six Points of the Charter ${ }^{49}$-and proposing the reform of the Poor Law and the laws of settlement. ${ }^{\circ}$ At this time, in the

35 Leic. Chron. 25 Oct., I 5 Nov. I 845 , I 4 Nov. I 846.

36 Ibid. 31 Oct. 1846.

37 Ibid. 20 May 1843 .

38 Ibid. I 3 Mar., 5 June 1847.

39 Ibid, 6 Feb. 1847.

40 Ibid. 6, I3, 20 Feb. I 847.

41 Ibid. 20 Feb. 1847.

42 Ibid.
44 Ibid. 6 Feb., 3 I July I 847.

45 Ibid. 22 May, 3 I July 1847.

46 Ibid. 24, 3 I July 1847.

47 Ibid. I 5 May 1847.

48 Ibid. 12 Apr. 1845.

49 They objected to payment of M.P.s: Leic. Fnl. 30 July i 847 .

43 Ibid. Io Apr. I 847. 
spring and early summer of $\mathrm{I} 847$, a new industrial depression had brought the hosiery trade to a standstill and sent the parties of unemployed again parading the streets begging charity. ${ }^{51} \mathrm{~A}$ second time, social distress found expression in Chartism which now enjoyed its last brief revival. It discovered a new leader in George Buckby, a hottempered and outspoken framework-knitter, who directed his agitation chiefly against the great grievance of frame rent. ${ }^{22}$ This agitation had been stimulated by Muggeridge's Report on the Framework Knitters of 1845 and the subsequent attempts of Sir Henry Halford, Conservative member for South Leicestershire, to introduce a bill to abolish frame rent. ${ }^{53}$ Frame rent then, as well as the Six Points of the Charter, became an issue at this election and in order to avoid the danger of a Tory-Chartist coalition Walmsley and Gardner were obliged to express their sympathy with the stockingers' case. ${ }^{54}$

The danger to the Liberal candidates did not in fact come from the Chartists. Although the Conservatives had also shown sympathy with Halford and the frameworkknitters, 55 they now saw a greater advantage in trying to exploit the grievances of the dissident Liberals, the Whigs and moderates who agreed with the Chronicle in denouncing Walmsley and Gardner as dangerous ultra-Radicals imposed on the party by 'a coup de main which is unparalleled in the annals of local electioneering'. ${ }^{56}$ The alliance on this occasion was to be between Conservatives and Whigs. For, with this in mind, the Conservatives took care to distinguish between the 'Destructive Party' 57 and the Whigs, and in token of their moderation adopted only one candidate, James Parker, Q.C., of Rothley Temple. As Peelite, Free Trader, and a connexion of the old Whig family of Babington, he might be expected to win over the dissident Liberals; as country gentleman, independent of the hosiers, one who 'did not come on the money-grinding system' and readily condemned frame rents, he stood some chance with the Chartists. His letter to the electors contained a many-sided appeal: he would protect the church while showing sincere respect to the dissenters; uphold the cause of 'Protestant Truth' against the Romanists; defend Peel's commercial measures; accept a national system of education and support legislation 'to improve the moral and social condition of the people'. ${ }^{58}$ With this programme the Conservatives hoped to beat Gardner as the more radical of their opponents. They failed. Buckby, the Chartist leader, having allowed himself to be nominated to demonstrate his independence, at once withdrew and advised his followers to vote for Gardner and Walmsley. ${ }^{59}$ The dissident Liberals, alienated though they were from their own party, were not yet won over to the other side and abstained from voting. ${ }^{60}$ Gardner and Walmsley were returned but with a significantly lower majority than Duckworth and Easthope had won in the last general election in $1837^{61}$

The new members did not long enjoy their victory. The Conservatives brought a petition alleging corruption, proved their case, and Walmsley and Gardner were unseated. ${ }^{62}$ It was improbable that the election of $\mathrm{I} 847$ had been conducted more lavishly than usual-in fact it was distinguished 'by a sobriety as novel as it was creditable'63 but the Conservatives were able to obtain evidence by taking advantage of a dispute between a number of publicans and the Liberal managers and on this occasion felt in a strong position to press their charges home because for once they were not involved themselves. ${ }^{64}$ Their success was not perhaps without fruitful results as it may well have

51 Leic. Fnl. 30 Apr., 28 May 1847.

52 Ibid. 2 Apr. I 847 ; Leic. Chron. 31 July 1847.

53 Leic. Chron. 3 July I 847.

54 Ibid. 3 I July I 847.

55 Leic. Fnl. I 5 Jan. I 847.

56 Leic. Chron. 3 I July I 847.

57 Ibid. 24 July I 847.
${ }_{58}$ Leic. Inl. 23,30 July 1847 .

59 Leic. Chron. 3 I July I 847.

61 Walmsley I ,647, Gardner I, 602, Parker I,483: Searson, Leic. Municipal, Boro. and Co. Poll Bk. I883, 98.

62 Leic. Inl. 26 May I 848.

${ }_{6} 3$ Leic. Chron. 3 I July 1847.

64 History, xxxi. I I9-20. 
served to awaken public feeling against corrupt practices, but it won the Conservatives no immediate advantage. For the new election, held in September 1848 , the Liberals brought forward two unbeatable candidates, Richard Harris and John Ellis, to conduct the contest on 'Purity Principles'. ${ }^{65}$ They were not only townsmen but men so respected that even the Fournal could find nothing to say against their characters. ${ }^{66}$ Although, in face of this opposition, Parker decided not to stand again, a number of Conservative electors with some Whig support put up Henry Paget of Birstall, who came forward on 'old Whig principles', but he received only half-hearted support from his own side and did not press the contest to a poll. Harris and Ellis were elected unopposed. ${ }^{67}$

Meanwhile, during the spring and summer of 1848 , the town had experienced an outbreak of agitation and disorder that recalled the events of $\mathrm{I} 842$, with which indeed it had much in common. Since 1847 , unemployment and poverty had been reviving the force of Chartism and at the same time swelling its ranks with many temporary adherents. Then in 1848 the European revolutions of February and March stirred Chartism into life all over the country and encouraged the organization of a new National Petition and National Convention. The new Chartist campaign aroused the enthusiasm of the Leicester working men, who kept the town in a tense excitement during April, May, and June. Buckby, elected as delegate to the Convention, was sent off with a demonstration attended by several thousand: ${ }^{68}$ rumour spread that the Chartists were arming for violent revolution and as Io April, the day of presenting the National Petition, approached, the town's authorities swore in 400 special constables, called out the pensioners, stored ammunition in the county gaol, and kept in touch with London by telegraph. ${ }^{69}$ These precautions were superfluous. The Chartists, though numerous, were predominantly peaceful and displayed little of the class antagonism that marked the events of 1842 . Later in the month middle-class reformers had sufficient confidence to try to organize a joint campaign with them and on 27 April all the leading Liberals of the town combined with the Chartists in a great reform meeting which launched, with marked amity, a new petition for the extension of the suffrage. ${ }^{70}$ This harmony continued into the next month. Then in the middle of May the peace was suddenly and harshly broken. The riots that now broke out did not form part of a Chartist insurrection and bore only an indirect relation to Chartism, in that they originated in the same source of poverty and unemployment. Since the beginning of the year the extent and duration of industrial depression had been straining the resources of the Poor Law; and the application of the law had strained equally the temper of the unemployed. In February they had broken into riot in protest against labour tests and the refusal to grant relief entirely in money. These disturbances were suppressed without difficulty; $;^{71}$ but on 15 May new regulations introduced by the guardians provoked a far more formidable outbreak. For four days the town experienced a state of siege, and order was not restored until the end of the week, when yeomanry and other troops had been brought in..$^{2}$

Although the Poor Law riots were not Chartist they affected the fortunes of Chartism. It was not easy to discriminate and they therefore destroyed much of the sympathy that had been shown for Chartism as recently as April. They also divided the Chartists themselves: extremists, like Buckby, were encouraged to talk of violent insurrection as in 1839 ; moderates, like Markham, insisted all the more vehemently on repudiating violence. ${ }^{73}$ Deprived of middle-class sympathy, weakened by divisions, diminished in

\footnotetext{
65 Leic. Fnl. I Sept. 1848.

66 Ibid.

${ }_{68}^{6}$ Leic. Chron. 8 Apr. 1848.

${ }^{69}$ Leic. Fnl. 14 Apr. 1848.

LEIC. IV
}

$$
\begin{aligned}
& { }_{71} \text { Leic. } 7 n l .4 \text { Feb. } 1848 . \\
& 72 \text { Leic. Chron. } 20 \text { May I } 848 . \\
& 73 \text { Ibid. } 17 \text { June } 1848 .
\end{aligned}
$$


number and appeal as trade slowly revived during the summer, the Chartist movement faded away. In June the advocates of physical force could still frighten the public authorities; but after the Whit Monday meeting had passed off quietly the danger was over. ${ }^{74}$ Although as late as 1853 attempts were made to resuscitate the Charter, ${ }^{75}$ the movement was no longer an effective political force in Leicester by the end of I848. Its leaders turned to other activities. Buckby continued to agitate but only as spokesman of the framework-knitters, and in 1856 emigrated to the United States. ${ }^{76}$ Others, like Markham, continued their political career on the radical wing of the Liberals.

There was ample opportunity for such a career in the following years. The decline of Chartism and the virtual end of the church rate contest, when in 1849 St. Martin's parish was brought into conformity with the other parishes of Leicester, 77 did not lead to political stagnation. The breach among the Reformers between their moderate and Radical wings and their subdivisions, which had appeared in the election of 1847 , now became deeper. Their relationship was still irritated by municipal discord between 'economists' and 'expenders'78 and it was exasperated further when Radical leaders like John Biggs alarmed religious interests in adopting the cause of national secular education. ${ }^{79}$ Deeper, if unavowed, motives were also at work. The moderates shared the disillusionment that was so widely experienced on the Continent after the European revolutions had failed in 1848 . They manifested a cautious and defensive mood in relation, at least, to domestic politics. In 1852 , for example, the Chronicle, which claimed to speak for them, considered that the problem for Liberals was less 'What shall we try to get?' than 'What shall we do to hold our own?'. ${ }^{80}$ Louis Napoleon's coup d'état and the plebiscite that sanctioned his dictatorship warned them afresh of the danger in political experiment and universal suffrage. ${ }^{81}$ They were therefore less prepared than ever to tolerate the attempt of the Radicals to use the political organization of the Liberal party to monopolize the representation of the borough. As the moderates were a minority ${ }^{82}$ they could only maintain their influence as long as the party observed the understanding, which they claimed had been implicitly accepted in the past, that the Liberal candidates should represent the two wings equally. ${ }^{83}$ The refusal of the Radicals to respect this understanding appeared therefore as a form of political dictatorship, even a personal dictatorship, as in the next ten years John Biggs emerged as their indisputable and unrivalled leader.

The election of John Ellis and Richard Harris in 1847 had been acceptable to both groups, but it soon became clear that the Radicals would take the first opportunity to bring back Walmsley and Gardner. Walmsley maintained a close interest in the borough and the establishment there of a branch of his newly formed Parliamentary and Financial Reform Association served not only to unite Radicals and former Chartists in a common reform movement but to keep his name before the voters. ${ }^{84}$ It was hardly surprising therefore that in the general election of $185_{2}$ Walmsley and Gardner should once more be invited to stand for the Liberals, ${ }^{85}$ nor that when they stood it should be with a programme substantially that of Walmsley's movement-vote by ballot, redistribution of seats according to equal electoral districts, triennial Parliaments, removal of taxes on raw materials, substitution of direct for indirect taxation, religious equality, a national system of education 'without compulsory inculcation of any religious creed',

74 Leic Chron. 17 June 1848.

75 Ibid. 6 July, 19 Nov. 1853.76 Ibid. 20 Dec. $185^{\circ 6}$.

77 Ibid. 25 Aug. 1849.

78 Ibid. 3 Nov, 1849.

79 Ibid. 19 Apr. 185 I.

80 Ibid. 28 Feb. 1852 .

82 Ibid. 3 Jan. 1852 .

\footnotetext{
82 'This is evident from their failure to dominate the electoral organization, and is suggested by the smaller circulation of the Chronicle in comparison with the Mercury: Leic. Chron. I 8 Aug. I 855 .

83 Leic. Chron. 9 Apr. 1859.

84 Ibid. 9 Feb. I 850 , I I Oct. I 851 .

85 Ibid. 13 Mar. I 852 .
} 
and electoral rights made 'coextensive with payment of taxes and settled residence'. ${ }^{86}$ Except in substituting a householder and lodger franchise for universal suffrage, this programme had much in common with the Six Points of the People's Charter. For the moderates it had too much: they objected particularly to the proposals for the franchise which went far beyond the cautious measures of Lord John Russell's recently introduced Reform Bill, of which the Chronicle had been able to approve. ${ }^{87}$ Condemning the requisition of the candidates as the work of a 'Chartist clique', they at last broke openly with the radical section of their party and formed a new Liberal committee 'to secure the independence of the Borough from dictation'. ${ }^{88}$ Led by Whetstone and James Thompson, editor of the Chronicle, who had already distinguished themselves at the head of the 'economists' in municipal politics, supported by the founding fathers of the party, Thomas Paget and Robert Brewin, who came out of retirement to throw the weight of their reputations into the campaign, ${ }^{89}$ they put up two candidates of their own, James Wilde, a barrister and nephew of Lord Truro, a former Lord Chancellor, and Geoffrey Palmer, the Whig son of a Conservative Northamptonshire gentleman. Wilde and Palmer stood as supporters of Lord John Russell, pledged to Free Trade and 'steady, not intemperate reform', 90 but their chances depended not on their positive programme but on their ability to negotiate a defensive alliance with the Conservatives. The character of the candidates, who were both Anglicans, and the confusion of parties in national politics made such an alliance possible. As many Conservatives were Free Traders, the issue of Protection no longer stood between them.91 When the Conservatives met, their committee took the view that as it was not fair to invite a Conservative candidate because of the great risk he ran of losing his money, and as the differences between the moderates and themselves were so small, they ought to vote for Wilde and Palmer. ${ }^{22}$ So the electoral alliance was achieved. The Chronicle regarded it as an achievement of great significance and looked forward to the time when the Liberal Conservatives and moderate Reformers would 'eventually merge into one party'.93 At present it did not succeed. In July $\mathrm{I}_{5} 5_{2}$ Gardner and Walmsley were elected with majorities of over 500.94 Their opponents attributed their defeat to popular intimidation and lavish expenditure.95 Earlier Whetstone had complained that there was a welldrilled body of three or five hundred freemen ever ready to sell their votes, ${ }^{96}$ but his party's attempts to produce evidence broke down and they had to withdraw the election petition that they presented in November. 97

The radical victory did little to revive agitation for reform. Frame rents and the truck system continued to excite the framework-knitters, whom Walmsley and John Biggs tried to appease, Walmsley by voting for Sir Henry Halford's Payment of Wages Bill of I853, Biggs by dramatically announcing his own 'Discontinuance of Frame Rents without Act of Parliament'. ${ }^{88}$ Ineffective attempts were made to revive Chartism. ${ }^{99}$ But the outbreak of the Crimean War now forced these domestic issues into the background.

The war transcended the cause of reform and created a temporary regrouping in local politics. Although the moderate Liberals had supported Aberdeen's conciliatory policy to the last against the attacks of both Radicals and Conservatives, ${ }^{\mathrm{I}}$ when war came they readily accepted it and it reconciled them with the Radicals. Liberals had

86 Ibid. 5 June 1852 .

87 Ibid. I4 Feb. 1852 .

88 Ibid. 20 Mar., 22, 29 May 1852.

89 Ibid. 29 May 1852 .

90 Ibid.

9 Ibid. 3 Apr. 1852 .

92 Ibid. 3 Apr., 5 June 1852 .

93 Ibid. 24 July 1852.

94 Walmsley 1,673 , Gardner I,673, Wilde I, I 6 ,
Palmer I, I 4: Searson, Leic. Municipal, Boro. and Co. Poll Bk. I883, 98.

95 Leic. Chron. I 7 July I 852 .

96 Ibid. 20 Mar. 1852.

97 Ibid. 27 Nov. $1852,9,16$ Apr. 1853 . For a full acct. see History, xxxi. 120 sqq.

98 Leic. Chron. 2 Apr., 7, I 4 May I 853,23 June I $8_{55}$.

99 Ibid. I6 July, I 9 Nov. 1853 .

I Ibid. 8 Oct. 1853 . 


\section{A HISTORY OF LEICESTERSHIRE}

long been agreed in their hostility to Russia: in 1849 the sympathy with Hungarian independence and the resentment at Russia's part in its suppression had been such that even the Chronicle had been ready to advocate war if necessary to 'protect Europe from the aggressive movements of the Russian Emperor'. ${ }^{2}$ 'They could agree therefore, once war had broken out, in demanding its effective prosecution. But, as in the country at large, the war also divided Radicals among themselves. Their more important leaders like John Biggs, Mursell, and Markham had condemned Russian 'aggression' immediately after the occupation of the Danubian principalities and supported Palmerston's demands for vigorous action. ${ }^{3}$ Others, of whom the most important was John Biggs's brother William, now M.P. for Newport (I. of W.), followed the lead of Bright and the peace party. 4

The peace restored former alignments and, although it could not revive reforming enthusiasm on the old scale, ${ }^{5}$ it soon revived the rivalry of moderates and Radicals. In June I 856 the death of Gardner made a by-election necessary. John Paget, a lawyer, son of the old Liberal leader Thomas Paget, better known as author of the New Examen, came forward as a Whig. ${ }^{6} \mathrm{He}$ was a promising candidate but found himself opposed by a better. This time John Biggs himself stood for the Radicals. ${ }^{7}$ Except in the matter of the suffrage there was little to choose between their programmes, and the contest depended on personal reputation. Paget could not hope to fight against Biggs's influence in the town and withdrew: no Conservative could be found to come forward; and John Biggs was elected without a poll. ${ }^{8}$

The general election of 1857 found the moderate Liberals more determined. Not that they wished to oppose John Biggs who was defending his seat, but they found it more difficult than ever to tolerate Walmsley when the ward delegates of the Reform Society once more put him forward. The cause of their hostility was not purely political, for, on the issue of Chinese policy over which Palmerston appealed to the electorate, both groups were in agreement. More important was the religious feeling aroused not only by Walmsley's advocacy of secular education but recently and more formidably by his attitude to the Sabbath, as President of the Sunday League. According to his critics his suggestion for opening the British Museum and the National Gallery on Sunday afternoons would "exchange the quiet and decorous Sunday of England for the "Vanity Fair" of France and Germany'. 9 The opposition to him was therefore as much religious as political, and the candidate of the moderates, John Harris, son of the Richard Harris who had been M.P. for the borough in $\mathbf{1} 848$, received the support of Radicals like the Quaker John Ellis and of almost all the dissenting ministers, although he himself was a churchman. ${ }^{\text {Io }}$ The weight of nonconformity allied with conservatism was only counterbalanced by the dubious support which the licensed victuallers, alarmed by Harris's association with the temperance movement, offered to Walmsley. II It was not enough. After a sharp contest, marked by some popular violence, Harris, supported it was said by 700 liberal and 900 conservative votes, was returned by a majority of $17^{8^{12}}$ and now shared the representation with John Biggs. Walmsley, for local and personal reasons, had shared the fate common to Radicals in other parts of the country.

After this election the moderates hoped for one of two possibilities: either that their alliance with the Conservatives would lead to the formation of a permanent new party, ${ }^{13}$

2 Leic. Chron. 4, 25 Aug., 6 Oct. I 849.

3 Ibid. 8 Oct. 1853 .

4 Ibid. 30 July 1853 .

5 Ibid. 26 Apr. 1856.

6 Ibid. 7 June 1856 .

7 Ibid. 14 June 1856 .

8 Ibid. 2 I June 1856 .
9 Ibid. 23 Feb. $1856,14,21$ Mar. 1857.

Io Ibid. 2 I Mar. I 847.

II Ibid. 28 Mar. I 857 .

I2 Harris I,6 18, Biggs I,603, Walmsley I,440: Searson, Leic. Municipal, Boro. and Co. Poll Bk. I883, 98; Leics. Mercury, I6 Feb. I 86 I.

${ }_{13}$ Leic. Chron. 28 May 1859. 
or that the Radicals would accept their defeat and restore the unity of the reforming party on the old basis. ${ }^{14}$ Both hopes were thwarted; the former by the remarkable recovery that the Conservatives experienced in 1859 , inspired by the formation of a Conservative government and by Disraeli's attempt to give the party a policy on reform; the second by the determination of John Biggs and the Radicals to avenge their defeat. Reform was in the air once more and the moderates found themselves outbid by both their rivals. The results of the last election had convinced the Radicals of the need to launch a new reforming movement. ${ }^{15}$ In the same year they had established a new organization of the non-electors ${ }^{16}$ which was merged at the end of $185^{8}$ in the reforming movement founded by John Bright in Birmingham. ${ }^{17}$ Even the critical Chronicle had to remark on the sensible and moderate language of the working men, on their readiness to co-operate with the middle classes, and on the absence of the social hostility that had marked the days of Chartism. ${ }^{18}$ The Conservative government also, abandoning the policy of uncompromising resistance, had introduced the Reform Bill of 1859 . The moderates, meanwhile, had nothing to offer but caution: the Chronicle believed that it would be dangerous if the electorate of Leicester were more than doubled.19 So the general election of 1859 found them without a policy, except on Sabbath observance, and faced by opponents on both sides. Once again the Radicals tried to win a monopoly of the representation and John Biggs brought forward Joseph Noble to stand with him. It was a shrewd choice as Noble was a local doctor, respected by his professional colleagues, popular in the town, and serving that year as mayor. ${ }^{20}$ The Conservatives, in introducing a true candidate of their own for the first time since 1839 , made a meritorious choice in W. U. Heygate, son of a country gentleman, by profession a barrister and a director of St. Martin's Savings Bank, an able speaker, and already known in Leicester as a Liberal Conservative, pledged to the principles of the Conservative Reform Bill. ${ }^{2 I}$ The moderates again put up Harris to defend his seat, but the continued support of all the dissenting ministers except two could not outweigh the handicap of his views on temperance and his defects as a speaker. ${ }^{22}$

The chief formal issue at the election was electoral reform. Nevertheless, there was striking agreement on the subject: all the candidates agreed on its necessity, though disagreeing on its extent. The Radicals stood for household suffrage and the ballot; Harris and Heygate appealed to the caution of moderate men. But between moderate and extreme Liberals local issues were still more important. Fundamentally the chief motive of Harris's supporters was resentment at the claim of John Biggs and the Radicals to speak for the whole Liberal party, which they regarded as a form of political dictation. ${ }^{23}$ This time, however, the religious appeal of the Sabbatarian question could not readily be mobilized, for Biggs and Noble were not so vulnerable as Walmsley. Lacking this cause the moderates failed in a very close contest and Biggs and Noble were returned. ${ }^{24}$

In spite of the moderates' disappointment the result was not at first sight without promise. The common front which Harris and Heygate had formed against the Radicals appeared as yet another step towards the formation of a united moderate party. ${ }^{25}$ Nevertheless, it was an illusion. Religious differences and political memories still fought against a thorough reconciliation between Whigs or moderates and Conservatives.

14 Ibid. 9 Apr. 1859.

15 Ibid. I I Apr. 1857 .

16 Ibid. 2 May 1857.

17 Ibid. I I, I 8 Dec. I 858 .

18 Ibid. 9 May 1857.

19 Ibid. 9 Apr. I859.

20 Ibid. I6 Apr. I859, I2 Jan. I86I.
21 Ibid. 23 Apr. 1859.

22 Ibid. 21 May 1859.

23 Ibid. 30 Apr., 7 May 1859.

${ }_{24}$ Biggs 1, 584 , Noble 1,496, Heygate I, 479, Harris 1,397: Searson, Leic. Municipal, Boro. and Co. Poll Bk. I $883,98$.

25 Leic. Chron. 28 May 1859. 


\section{A HISTORY OF LEICESTERSHIRE}

Neither group was ready to surrender its identity and each wanted union under its own aegis. Yet the election of 1859 made the Conservatives less prepared than ever for such a surrender. For the most striking result of the election had been the achievement of their candidate in leaving Harris well behind and nearly defeating Noble. The instinct of self-preservation now taught the Conservatives not to merge with the moderate Liberals but to exploit the division between them and the Radicals; and as an assertion of their independence they celebrated Heygate's achievement by founding a new Conservative Society. ${ }^{26}$

The Liberals were not blind to their danger. Even at the last election there had been a half-hearted attempt to reconcile their two wings. ${ }^{27}$ Now, early in I86I, the sudden death of Dr. Noble made the threat acute, since the by-election made possible a threecornered contest in which the Conservatives could exploit the Liberals' differences to the full. The Conservatives saw their opportunity, made no concessions to the moderate Liberals, and again put up Heygate. ${ }^{28}$ This decision marked the end of the entente between moderates and Conservatives that had been in existence more or less since 1847. Its corollary, Liberal reunion, was not so easily achieved. It was attempted as the election drew near, but the Radicals, though offering to accept a moderate, would not accept Harris against whom there was now deep personal bitterness; and at heart still hoped to dominate the representation. ${ }^{29}$ Heygate therefore found himself opposed by two Liberals, Harris and P. A. Taylor. Taylor was a Radical of a younger generation, of the type of J. S. Mill in whose circle he moved, emphatically an individualist, humanitarian, and internationalist, appearing as 'a champion of universal suffrage and direct taxation and as an admirer of Mazzini'. He had already made a reputation as chairman of the Society of Friends of Italy and treasurer of the London Emancipation Society. He was a man of substance, a partner in the firm of Courtauld. ${ }^{30} \mathrm{He}$ suffered the handicap, however, of being young, a stranger to the town, and a friend of Walmsley whose Sabbatarian laxity he shared. ${ }^{3 I}$ In consequence, in an election which failed to excite the old reforming enthusiasm, the Radical voters did not deploy their whole strength: some even, not ready to put their trust in Taylor, voted for Heygate rather than Harris, the representative of a timid though prosperous class of business-men and factory-owners, who seemed less likely to do something for the small householder and citizen..$^{32}$ Equally, many moderates found Heygate a more attractive candidate than Harris. The result in February I86I was a crushing Conservative victory, the first since $1835 .{ }^{33}$ The announcement provoked the first excitement of the election when an angry crowd had to be driven from the Market Place by the police. ${ }^{34}$

The defeat of the Liberals taught both wings a final lesson. Neither could stand on its own. The Radicals were forced to abandon their attempt to dominate the borough, the moderates to choose between absorption into a Conservative party which they could not feel at home in nor hope to lead, and tolerance of radicalism in a reunited Liberal party in the leadership of which they would enjoy at least a share. Immediately after the election they resumed negotiations and in June I86I formed a United Liberal Registration Society. ${ }^{35}$ The agreement which healed the wounds of the last fourteen years had as its basis the old compromise by which the borough would be shared equally between the two. ${ }^{36}$ By means of this coalition the Liberals were to dominate the borough for
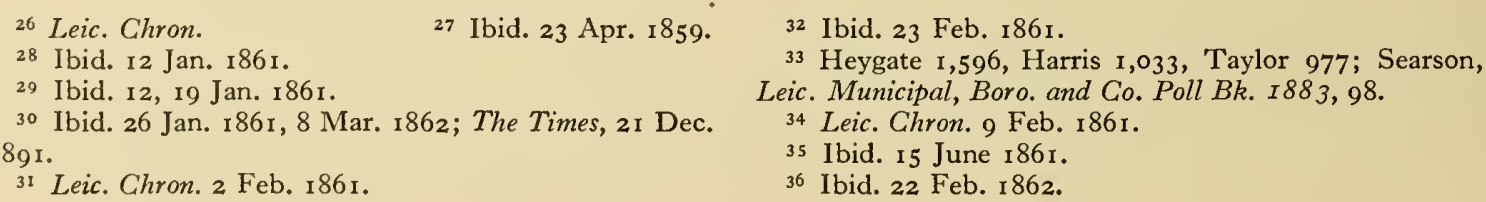
over 30 years. Its immediate result was to end the confusion which had clogged local politics since the repeal of the Corn Laws. So the moderate leaders made in their way the same sort of choice as Gladstone in national politics, and by its own local and devious ways Leicester achieved the clarification of its party system that was becoming evident in the country at large.

Reconciliation had its price nevertheless. The agreement amounted to a defeat for John Biggs who had been the heart and soul of the Radicals and probably the chief source of their funds. His popularity, lavish generosity, and political leadership had earned him the jealousy of the moderates who attributed his zeal to personal ambition. Whether he felt this as a defeat of his hopes or whether his next actions were determined by the financial collapse which now destroyed his fortune is not clear. All that is known is that he took no part in the reconciliation, ${ }^{37}$ resigned his seat eight months later on the ground that he no longer had leisure for politics, ${ }^{38}$ and for the remaining ten years of his life maintained an absolute political silence. ${ }^{39}$ In 1873 , two years after he died, the statue that now stands in De Montfort Square was erected by public subscription after popular agitation had condemned as inadequate the proposal to commemorate him by a medallion in the cemetery. 40

In accordance with their understanding the moderate Liberals accepted a Radical in place of John Biggs, and in February I 862 P. A. Taylor was returned unopposed. ${ }^{4}$ The alliance, consolidated by this act of good faith, was celebrated by the union in 1864 of the rival Liberal newspapers as the Leicester Chronicle and Leicestershire Mercury ${ }^{42}$ with James Thompson as proprietor. ${ }^{43}$ Next year the general election provided an opportunity of testing its strength.

In Leicester, if not in the country at large, the dramatic issue at the election of ${ }^{8} 86_{5}$ was electoral reform. It was now remarked by the Liberal leaders that the apathy of the last few years was passing and they set out once more to mobilize opinion by public meetings, town petitions, and the foundation of a new Parliamentary Reform Association. 44 This issue did not disturb the unity of the party because the new association was tactfully not committed to a specific degree of reform $; 45$ because it was becoming evident even to the moderates that the present electorate was likely to grow more conservative as time went on and the party, as one speaker put it, 'needed new blood' if it was to survive, ${ }^{46}$ and because the popularity of Gladstone, of which there was remarkable evidence, transcended all divisions. ${ }^{47}$ In harmony, then, the Liberals put up Harris and Taylor with the promise of a large instalment of reform. ${ }^{48}$ Heygate, who stood again for the Conservatives, appealed chiefly to moderates as a 'Liberal Conservative', not opposed to 'any rational scheme of Parliamentary Reform' with a suffrage based on 'intelligence, property, and education', but hostile to the enfranchisement of the $f^{6}$ householder. Unlike his opponents he also made an issue of foreign policy, criticizing Palmerston's handling of the Schleswig-Holstein dispute and advocating a policy of 'non-interference' in the Continent. 49 The election, held in July i $86_{5}$, the last on the old franchise, was hard fought: the poll was the largest yet and the Liberals won by only the moderate margin of some 250 votes. 50

The reconquest of the borough inspired a revival of Liberal enthusiasm. The following year was enlivened by an organized agitation in support of the government's reform

\footnotetext{
37 Ibid. 23 Mar., I5 June I86 I.

38 Leics. Mercury, 8 Feb. 1862.

39 Coe, Sermon preached in memory of John Biggs.

40 Leic. Chron. and Leics. Mercury, 9 Apr. 1873.

41 Leic. Chron. 22 Feb. 1862.

42 Ibid. Io Sept. I 864.

43 Leic. Chron. and Leics. Mercury, 29 Oct. I 864.
}

44 Ibid. 25 Feb., 4 Mar., I Apr., 6 May 1865.

45 Ibid. I Apr. 1865.

46 Leic. Chron. 23. Mar. I86 I.

47 Leic. Chron. and Leics. Mercury, 25 Feb. 1865.

48 Ibid. 24 June I 865.49 Ibid. I July I 865.

50 Harris 2,295, Taylor 2, I99, Heygate 1,945: Searson, Leic. Municipal, Boro. and Co. Poll. Bk. I883, 98. 
bill that recalled and in some ways surpassed that of 1832 . The failure of the bill, the advent of a Conservative government, the progress of Disraeli's bill were accompanied at every stage by popular demonstrations on an unprecedented scale. ${ }^{5 \mathrm{I}}$

\section{$1867-1914$}

The Reform Act of 1867 made no change in the representation of Leicester but increased the number of electors from $5,73^{652}$ to $15, I^{6} \mathrm{I}^{53}$ in a population of over $80,000.54$ The swamping of the old electorate did not, however, produce immediately the revolutionary results that moderates had earlier feared. For the next 25 years working men remained content to take their leaders and political philosophy from the middle-class Radicals. The trades unions sought to influence politics only when they feared a direct challenge to their interests, as in the Criminal Law Amendment Act of 187 I, and then acted through the Liberal party. ${ }^{55}$ 'The nearest approach to a working-class party can be found in the formation in I87 I of the Democratic or, as it began to call itself a year later, Republican Association. ${ }^{56}$ Although this received some support from advanced Radicals like the Revd. A. F. Macdonald, Unitarian minister of the Free Christian church in Wellington Street, 57 it was led by working men, like Daniel Merrick, a prominent trades unionist who was president of Leicester Trades Council for several years and one of the first working men to be elected to the town council. ${ }^{8}$ But it sought to achieve purely political objects - universal suffrage, the ballot, household suffrage for women ${ }^{59}$ : its mission, it conceived, was 'to educate the people in the principles of political economy, moral virtue and social advancement';60 and it acted in practice as a Radical wing of the Liberal party. It does not appear to have survived for more than ten years. Apart from this, the only evidence of independent activity by working men appears in elections to the School Board. ${ }^{6 I}$ The attempts made elsewhere by the Labour Representation League to put up working men for Parliament evoked no response in Leicester.

Although the enlarged electorate gave rise to no new political party, the problems of arrangement created by it forced the existing parties to adopt methods of organization that in time changed the character of local politics. It was not only that the colourful electioneering methods of the old days - treating, intimidation, bribery-were no longer adequate or acceptable, but that the development of party organization tended to deprive politics of their variety since it diminished the importance of local issues and the influence of individuals. The need to mould politics into this new institutional form was first appreciated in Leicester as elsewhere by the Liberals. The first step-taken in I 873-was the modest one of establishing a Liberal Club which should provide rooms for meetings and a centre of political life, transcending the more specifically electoral aims of the Registration Society. ${ }^{62}$ Then in 1876 a new constitution was adopted which replaced the Registration Society by a democratic association on the Birmingham model with a central committee of 200 on which the ward associations were represented in the

${ }^{51}$ Leic. Chron. and Leics. Mercury, 24 Mar., 23 June, 7 July, 4 Aug., 3 Nov. I866, I6 Feb., 2 Mar., 29 Apr. I 867 .

52 Ibid. 12 Oct. 1867

53 Searson, Leic. Municipal, Boro. and Co. Poll Bk. 1883,98 .

54 The pop. rose from 68,056 in 1861 to 95,220 in 1871 : V.C.H. Leics. iii. I 79.

55 Leic. Chron, and Leics. Mercury, 7 Dec. I872, 3 I Jan. 1874 .
56 Ibid. 4 Mar. I87 I, I3 Jan. I872.

57 Ibid. 2 Sept. 1871. Macdonald left Leic. in 1877: ibid. 20 Mar. 1877. For the Wellington St. Chapel, see below, p. 394 .

${ }^{58}$ Leic. Chron. and Leics. Mercury, 3 Aug. 1872, 22 Sept. I 877 .

59 Ibid. 4 Mar. I87 I.

60 Ibid. I June 1872 .

61 Ibid. 31 Dec. 1870 .

62 Ibid. I9 Apr. 1873 . 
proportion of one to every hundred members. ${ }^{63}$ This in turn was managed by a small executive committee. The novelty of the system did not lie in the democratic organization of the wards and central committee which gave to the humblest elector the opportunity to participate in the formation of policy; in Leicester as in Birmingham these methods had been anticipated long before. ${ }^{64}$ It lay rather in the efficiency and comprehensiveness with which it was operated. The result was to make it more difficult for power to be monopolized by a small clique of wealthy party leaders; but while securing more fully the freedom of the individual elector and providing a means of harmonizing a variety of interests, it tended to suppress the personal differences and rivalries that had been tolerated in the more homely system of the past.

If the 'caucus' system benefited the electorate at the expense of the individual politician, the creation of party organization on a national scale increased the effectiveness of the local association at the expense of its independence and initiative. The formation of the National Liberal Federation in 1877 and the entry of the Leicester Liberal Association into it tended to submerge the individual contribution of the borough under a common pattern of activity. It marked the beginning of a new period in which as in I 832 Leicester took its lead from Birmingham and felt the powerful influence of Joseph Chamberlain. Though second to Birmingham, Leicester was nevertheless one of the first of the great towns to adapt its organization to the requirements of a mass electorate and soon claimed to be the most effective in operating it. ${ }^{65}$

The Conservatives adapted their organization more slowly. The new Conservative Society of I 867 did little more than revive the former Registration Society. 66 The Conservative Working Men's Association of I 869 was more important and for some years provided the driving force of their organization. ${ }^{67}$ At last in 1878 their opponents' 'rage for organization' forced the Conservatives to copy their methods. Again Leicester took for its model Birmingham where a Conservative version of the caucus had just been created. With the help of representatives from Birmingham and Liverpool a new Conservative Association was founded with a central committee on which the wards were represented. ${ }^{68}$ Later this was federated with the National Union of Conservative Associations. ${ }^{69}$ These developments were followed in 1880 by the foundation of a Conservative $\mathrm{Club}^{70}$ and the formation in 1886 of a branch of the Primrose League.7I

Although increasingly tending to conform to a national pattern, the politics of Leicester remained for many years yet on their old basis. The Liberals, heirs of the Reformers of 1832 , continued to be the party of the manufacturers, lower middle class, and artisans, united by nonconformity, still a not always easy coalition of moderates and Radicals, though as a whole more radical than the Liberal governments of the age. The Conservatives represented more diverse social interests still predominantly united by loyalty to the Church. On both sides denominational passions, aroused by the Education Act of I 870, exacerbated political controversy as vigorously as ever. After the establishment of school boards in 1870 , elections to them were hotly contested on political lines and, like the church rate contests of old, had the effect of enlisting militant dissent in the cause of radicalism. ${ }^{72}$ These contests also impelled both parties to more elaborate

63 Ibid. 2 I Aug. I876, 30 Apr. 1887. The central cttee. was enlarged to 300 in $\mathrm{I} 88 \mathrm{I}, 500$ in $\mathrm{I} 886,650$ by $\mathrm{I} 894$, and $\mathrm{I}, 000$ by $\mathrm{I} 900$. In I $88 \mathrm{I}$ the representation of the wards was increased to one for every 75 members: ibid. 8 Oct. I88 I, 30 Jan. I886, Io Mar. I894; R. Read, Modern Leic. 259.

64 For Leic. see above, p. 206. For Birmingham, see C.

Gill and A. Briggs, Hist. of Birmingham, ii. 16 $65^{-6}$.

65 Leic. Chron. and Leics. Mercury, 24 May 1884.

66 Leic. Fnl. 20 Dec. 1867.
67 Leic. Chron. and Leics. Mercury, I 8 Dec. I 869, I 2 Nov. I 870 .

68 Ibid. 22 July 1878 ; Gill and Briggs, Hist. of Birmingham, ii. 176 .

69 In the reorganization of I 886 the Leic. Assoc. was federated to the Midland Union of Conserv. Assoc. : Leic.

Chron. and Leics. Mercury, 7 May 1887.

70 Ibid. I Sept. I 880.

7 I Ibid. 20 Feb. 1880.

72 Ibid. 3 I Dec. I870, 2 I Mar. 1883. 


\section{A HISTORY OF LEICESTERSHIRE}

organization on a national as well as local level. To fight these elections, both nonconformists and churchmen formed associations, which were linked respectively with the National Education League - another product of Birmingham-and the National Educational Union. ${ }^{73}$ In this way the school boards formed as much a part of the local political scene as the board of guardians and the town council. Their political role was frankly recognized by one of the Liberal leaders when he welcomed the nonconformist victory of 1874 because 'it would throw new life and vigour into the Liberal party' and 'pave their way to victory at the next general election' ${ }^{74}$ In such conditions the Liberation Society renewed its agitation for disestablishment ${ }^{75}$ and nonconformist ministers like the Unitarians Page Hopps and Macdonald continued to take an active part in Liberal and Radical politics.

The immediate political effect of the Reform Act of I 867 was to reinforce the Liberal domination of the borough and to shatter the Conservative revival that had so marked the last years of the old electorate. In the general election of 1868 the new electors of Leicester, as elsewhere, voted predominantly Liberal. Harris and Taylor, standing again for the two wings of their party, were able to agree on an immediate programme in demanding revision of the rating clauses of the Reform Act, a redistribution of seats, disestablishment of the Irish church, and a national system of education. ${ }^{76}$ Taylor, however, sounded a more radical note in pressing for universal suffrage as an ultimate aim and demanding an attack upon aristocratic privileges in the form of changes in the composition of the House of Lords and in 'the tenure and transference of landed property'.77 Moderate leaders like E. S. Ellis, chairman of the Midland Railway and son of John Ellis, and T. T. Paget, son of Thomas Paget, who was at this time defending his seat in the southern division of the county, ${ }^{78}$ admitted publicly that Taylor went much farther than they but accepted him because they believed that he 'represented the views of a large part of the constituency' and they all shared a common loyalty to Gladstone. ${ }^{79}$

The election found the Conservatives, by contrast, disheartened, divided between the advocates of orthodox Conservatism and Tory Radicalism. In consequence they put forward no official candidate, but left the field to the unorthodox candidature of J. Baker Greene, a London barrister. ${ }^{80}$ Though Greene claimed to be an independent and a 'Liberal in the fullest sense of the word'81 he enjoyed the patronage of Charles Brook of Enderby Hall, a retired manufacturer who, with Lord John Manners, was one of the founders of the Leicester Conservative Working Men's Association and its first president. ${ }^{82}$ Certainly it was as a working men's candidate that Greene stood ${ }^{83}$ and one of his nominators was in fact a newly enfranchised working man. ${ }^{84} \mathrm{He}$ advocated legislation on trades unions, the establishment of courts of arbitration and conciliation, and modification of the Poor Law; and warned the working men against Taylor as an employer. Although claiming to be a Liberal he would not support unconditionally the disestablishment of the Irish church. ${ }^{85}$ Whatever its merits in attracting Radical votes, ${ }^{86}$ this programme received 'only half-hearted support from most Conservative leaders who, in advising their followers to vote for Greene, recommended him only as 'lesser of two evils'. ${ }^{87}$ In such circumstances it was not surprising that Greene was soundly defeated. 88

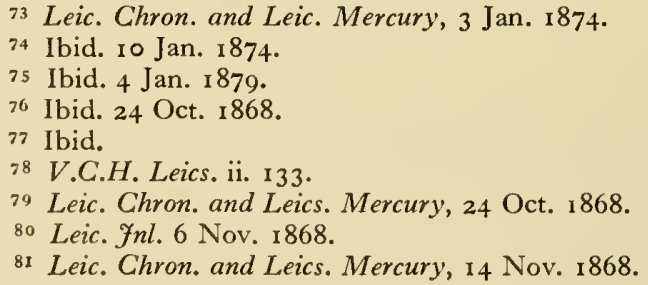

82 Ibid. I 3 Dec. 1869 , I 3 July 1872 .

83 Leic. Fnl. 13 Nov. 1868.

${ }^{84}$ Leic. Chron. and Leics. Mercury, I4 Nov, 1868.

85 Ibid.

86 Ibid. 4 June 1870.

87 Leic. Fnl. I 3 Nov. 1868; Leic. Chron. and Leics. Mercury, 27 July I 878.

${ }_{88}$ Taylor 7,143, Harris 6,776, Greene 2,494: Searson, Leic. Municipal, Boro. and Co. Poll Bk. $1883,98$. 
In spite of this set-back to the Conservatives, the swing of the pendulum that in national politics was to sweep Disraeli into power in 1874 restored their fortunes in Leicester also, though with less effect. For all its achievements Gladstone's administration discontented all sides during its last years-nonconformists by the Education Act of 1870 , trades unions by the Criminal Law Amendment Act of 1871 , patriots by the Alabama arbitration, the general public and the liquor trade by the Licensing Act of I 872 -and the dissolution of 1874 was the recognition of the Liberal government's unpopularity, not the consequence of an important issue of policy. This meant that in spite of Gladstone's attempt to introduce the important issue of income tax, the general election of 1874 was fought on the record of his administration, that is in terms very advantageous to his opponents. The election therefore found the Conservatives very much more active than in I868. Although their candidate, J. H. B. Warner of Quorn Hall, Loughborough, was selected by the Conservative Working Men's Association, ${ }^{89}$ his orthodoxy recommended him to the whole party. His social programme did not go farther than the reform of the Poor Law and he made his chief appeal to patriotic sentiment in referring to the Ashanti war and the Alabama arbitration, to Anglicanism in standing for the union of Church and State and the 25th clause of the Education Act, and to the brewers and the public in condemning the Licensing Act.90

The Liberals were taken at a disadvantage by the surprise which the dissolution had caused them. It was an awkward moment because Harris had just announced his retirement unexpectedly and a successor had to be chosen in haste. ${ }^{91}$ For this a number of candidates were considered, Gladstone, Miall, and E. S. Ellis among them.92 The most serious offer was that made to Joseph Chamberlain, who was already personally known in Leicester through his work for the National Education League, ${ }^{93}$ but he had already promised himself to Sheffield. ${ }^{4}$ After some delay the committee finally chose Alexander McArthur, a London merchant engaged in the colonial trade, who had enjoyed a previous experience of politics in the Legislative Assembly and Council of New South Wales. ${ }^{95}$ Although McArthur was regarded as a moderate in comparison with Taylor, who was standing again, both candidates gave expression to the nonconformist and radical discontent with the Liberal administration. McArthur, as an 'advanced Liberal', put forward a programme which had much in common with Chamberlain's 'New Radicalism' 96 - assimilation of the county to the borough franchise, reform of the land laws, abolition of clause 25 of the Education Act, legislation against intemperance. ${ }^{97}$ Taylor was highly critical of the government and dismissed Gladstone's income tax proposals as insignificant. 98 These tactics did little, however, to rally the Liberal voters or to heal the divisions that the question of denominational teaching in particular had created among them. ${ }^{99}$ At most they had the comfort of knowing that the trades union leader, Merrick, had advised working men to vote for the Liberal candidates as they were ready for the revision of the Criminal Law Amendment Act. ${ }^{I}$ On the other hand, they were faced with the formidable opposition of the licensed victuallers and, over the Education Act, of the Roman Catholics. ${ }^{2}$ 'This opposition and their supporters' apathy did not suffice to defeat Taylor and McArthur when the election took place in February $\mathbf{1} 874$, but, in a heavy poll, the Liberals increased their votes only by some 300 , the Conservatives by as many thousands. ${ }^{3}$

\footnotetext{
89 Leic. Chron. and Leics. Mercury, 31 Jan. 1874.

90 Ibid. 91 Ibid. 92 Ibid.

93 Ibid. 4 Dec. 1869.

94 J. L. Garvin, Life of Foseph Chamberlain, i. 164

95 Leics. Chron. and Leics. Mercury, 31 Jan. 1874,13 May I 893, 7 Aug. r 900 96 Garvin, op. cit. i. 154

97 Leics. Chron. and Leics. Mercury, 31 Jan. 1874.
}

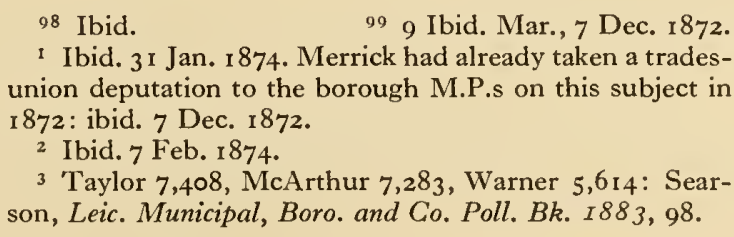
union deputation to the borough M.P.s on this subject in 1872: ibid. 7 Dec. 1872 .

2 Ibid. 7 Feb. 1874 .

3 Taylor 7,408, McArthur 7,283, Warner 5,614: Searson, Leic. Municipal, Boro. and Co. Poll. Bk. I883, 98. 
The most important political developments during Disraeli's period of administration were connected with political organization and foreign policy. The reorganization of the Liberal and Conservative parties in these years has already been noted. ${ }^{4}$ It took place in the midst of the public excitement aroused by the Near Eastern crisis, which gave to the Liberals the opportunity to awaken their old militancy. In I 876 and still more in 1877 and 1878 they organized demonstrations on a large scale in which the moral fervour of nonconformity was aroused in condemnation of the government's foreign policy. ${ }^{5}$ This force, mobilized by the new Liberal organization, carried the party through the general election of April i 880 .

In this election the dominant issue was that of imperialism, whether the electorate would approve or reject the forward foreign and colonial policy of Disraeli. Other questions were raised-Irish Home Rule, temperance, workmen's compensation, the land laws, and the game laws ${ }^{6}$ - but they were not matters that touched the deepest emotions. Both parties were swept by the current. Its first effect had been to stimulate the Conservatives to undertake the reorganization of 1878 , to force them to remain content no longer to leave the initiative in the hands of the Working Men's Association, and to attract more men of position to the service of the party. ${ }^{7}$ Such confidence was engendered that they now, for the first time since 1837 , put forward two candidates, J. H. B. Warner, who stood again, and William Winterton, a local timber merchant whose devotion to municipal affairs had earned him the distinction of being elected mayor in 1876 in a predominantly Liberal council, the first Conservative to hold the office since the Municipal Corporations Act. ${ }^{8}$ Both men concentrated attention on foreign and colonial policy and congratulated the country on being now a 'first-class power' ${ }^{9}$ Unfortunately for the Conservatives, the electors of Leicester, moved by the disasters of the Zulu and Afghan wars, experienced the revulsion from imperialism that ran through the whole country. Taylor and McArthur found no difficulty in arousing an enthusiasm unequalled since the reform demonstrations of 1867 . The popularity of Gladstone was striking: the production of his portrait led to scenes of almost revivalist fervour. ${ }^{10}$ United in the common moral indignation aroused by Gladstone's Midlothian campaign, organized with unprecedented efficiency, aided by the economic discontent of the years of depression, the Liberals overwhelmed their opponents in the keenest election yet fought, in which nearly ${ }_{15}, 000$ voted in an electorate of $18,500 .{ }^{\text {II. }}$.

The impression left by this result was so strong that when P. A. Taylor retired in June $\mathrm{I} 884$ on account of age and ill health, having represented the borough for 22 years, his Liberal successor was returned without opposition. ${ }^{12}$ The new member, J. A. Picton, had already acquired a reputation both in Leicester, when he was a Congregational minister there, and nationally as the author of a eulogistic study of Oliver Cromwell. In politics he was an uncompromising Radical of Taylor's stamp, a man of high intellectual ability and much oratorical power, well qualified, it was hoped, to 'possess the confidence of the large working-class section of the constituency'. ${ }^{13}$ Nevertheless the retirement of Taylor marks the end of the golden age of Liberalism in Leicester just as his advent

\footnotetext{
4 See above, pp. 224-6.

5 Leic. Chron. and Leics. Mercury, 5 Sept. 1876, 5 May

I 877 , i I Jan. I 878 .

6 Ibid. 20 Mar. 1880

7 Ibid. 27 July 1878 .

8 Ibid. 20 Mar., 3 Apr. I880; Searson, Leic. Municipal, Boro. and Co. Poll. Bk. I883, I 4 .

- Leic. Chron. and Leics. Mercury, 20 Mar. 1880.

10 Ibid. 27 Mar., 3 Apr. r 880.

11 Ibid. 3 Apr. I880. The poll was Taylor ro,675, McArthur ro,438, Winterton 4, I86, Warner 3,820: Searson, Leic. Municipal, Boro. and Co. Poll Bk. I883, 98.
}

\begin{abstract}
12 Leic. Chron. and Leics. Mercury, 16 Feb., 2 I June I 884 .

13 Ibid. and 28 June I $884 ; D . N . B$. I $90 I-I I$, I 8 . Among the other candidates considered by the Liberal cttee. were Joseph Arch, Herbert Spencer, and G. J. Holyoake. The latter's nomination reflected the interest taken in Bradlaugh, whom he had supported over the question of the parl. oath. Leic. was one of the strongholds of the Secularists who built the Secularist Institute there in $1873: \mathrm{J}$. McCabe, Life and Letters of G. F. Holyoake, ii. 79, I 56; G. J. Holyoake, 60 Years of an Agitator's Life, ii. $255-7$.
\end{abstract}




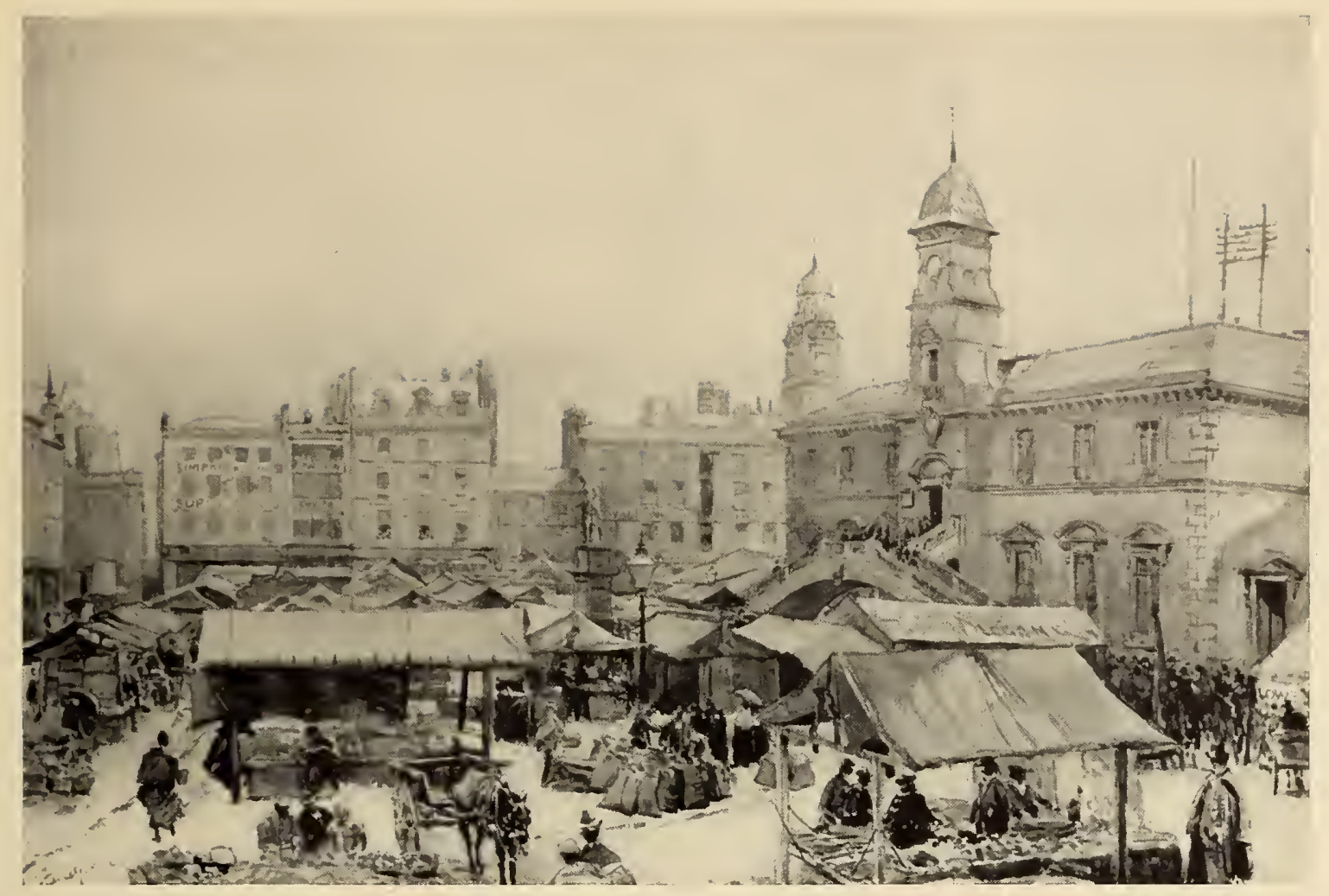

The Market Place, with the new Corn Exchange, $c$. 1879 

marked its beginning. The hosiery strikes of January I $884^{14}$ and February I 886 , the latter accompanied by riots that might have become serious but for the efficiency of the police, ${ }^{\mathrm{I}}$ were signs of increasing social tensions: and so in a different direction was the popular agitation of 1884 directed against the Lords' rejection of the Franchise Bill, when the speakers at a massive demonstration held in July echoed the note of class warfare already sounded elsewhere by Chamberlain. ${ }^{16}$

As yet these were only portents. The future of the Liberal party appeared bright. The Franchise and Distribution Acts of 1885 , while not directly affecting the borough, ${ }^{17}$ were triumphs which held out the promise of extending their supremacy to the county; and even the tragedy of Gordon and the evacuation of the Sudan could hardly shake their hold on the town. Nevertheless the general election of I 885 revealed that Leicester was influenced by the wave of conservatism that swept the English boroughs in general. Although the Conservatives were handicapped by delay in finding a candidate and only at the last moment brought forward William Millican, a local architect and surveyor, town councillor, member of the council of the National Union of Conservative Associations, and lieutenant-colonel in the Rifle Volunteers, ${ }^{18}$ they had an advantage in being able to appeal strongly to ecclesiastical and imperial sentiment. Millican replied to the Radicals' campaign for disestablishment and their educational programme by raising the old cry of 'the Church in danger', which succeeded in winning over a number of Liberal churchmen. ${ }^{19}$ At more length he condemned the Liberal government's foreign and colonial policy, especially in the Sudan, contrasting it with his party's faith in imperial development and unity - a faith which also led him to insist that the Irish union must be maintained. In other respects his campaign reflected something of Lord Randolph Churchill's influence in his criticism of Free Trade and his recommendations in general terms of social reform for the 'content and happiness of the working class'.20 'The Liberals, McArthur and more especially Picton, not content with Gladstone's modest Four Points ${ }^{2} \mathrm{I}$ - though accepting them-tried to rouse their following against the great landed interests and against aristocratic privilege, without, however, going so far as Chamberlain in his 'unauthorised programme'. ${ }^{22}$ Embarrassed perhaps by the defection of the Irish vote under Parnell's instructions, they maintained some reserve about Ireland. The election was keenly fought and although, inevitably, the Liberals won it, they did not win by the majority they expected: in an electorate 3,000 larger than in 1880 , their majority was 2,000 lower. ${ }^{23}$ The election was marked by the strictness of party discipline which reduced to a trifling figure the number of divided votes.

The same discipline was evident during the political crisis of 1886 , in which the Leicester Liberal Association remained loyal to Gladstone and accepted the policy of Home Rule for Ireland. ${ }^{24}$ Nevertheless it was not so complete as to prevent all division within the party. Although the association as a whole refused to follow Chamberlain, a small but important party of Liberal Unionists broke away. The following of these Unionists among the rank and file appears to have been small, but among their leaders appeared some of the most important employers and manufacturers in the town, like Fielding Johnson, Simpson Gee and the brothers Faire, and Canon Vaughan, the most

14 Leic. Chron. and Leics. Mercury, 9 Feb. I 894.

15 Leic. Daily Post, 12, I 3, I6 Feb. 1886.

${ }_{16}$ Leic. Chron. and Leics. Mercury, 26 July 1884.

17 Proposals to include Belgrave and later Evington in the parl. borough were considered but abandoned after strong Liberal opposition: Leic. Chron. and Leics. Mercury, 6 Dec. I 884,7 Feb. I 885 ; review of year I885 in Leic. Daily Post, I Jan. I 886.

18 Leic. Daily Post, 4 Nov. 1889.
I9 Ibid. 27 Nov. 1885.

20 Ibid. I7, I 8 Nov. I 885 .

2I Reform of parl. procedure, local govt., land laws, and electoral registration: Leic. Chron. and Leics. Mercury, 14 Nov. 1885 .

22 Leic. Daily Post, i 8 Nov. I 885.

23 Picton I I,480, McArthur I1, 1 21, Millican 6,75 I : Leic. Chron. and Leics. Mercury, 28 Nov. $188_{5}$.

24 Ibid. I 9 June I 886. 
influential churchman of the day. ${ }^{25}$ In spite of this their defection had slight immediate consequences, as the election of 1886 showed. This time the Conservatives did not imitate the tactics of I 86 I when they exploited their opponents' divisions to put in their own candidate. ${ }^{26}$ Instead they left the initiative to the Liberal Unionists, though working with them and promising support, ${ }^{27}$ calculating, reasonably enough, that victory could be won more easily under Liberal than under Conservative colours. The election was therefore conducted by a Liberal Unionist committee and the candidate found through their central office in London. He was Robert Bickersteth, a member of a wellknown evangelical family distantly connected with Leicestershire, and had been M.P. for North Shropshire. ${ }^{28}$ Compared with McArthur and Picton he suffered the disadvantage of being late in the field and a stranger to the town; and while he could count upon Liberal abstentions as well as upon Unionist votes he was also handicapped by Conservative distrust. ${ }^{29}$ In the election, which was fought entirely on the issue of Home Rule, the Liberals retained their majority in a lower poll. ${ }^{30}$

The breach with the Unionists was not therefore serious enough to threaten the Liberal hold on the borough as yet, and was not likely to be so long as the Liberal Unionists still regarded themselves as Liberals and looked forward to an eventual reconciliation. The foundation of a separate Liberal Unionist Association was attempted only after a year's delay and by a number of members the decision was accepted reluctantly. ${ }^{3 I}$ This meant that they also found it difficult to work with the Conservatives from whom many of them were still divided by religious differences.32 Although Chamberlain had renounced the last hope of Liberal reunion at the end of $\mathbf{1} 89 \mathrm{I}$, it was still possible as late as 1893 for Lord Randolph Churchill to complain that relations between Conservatives and Liberal Unionists in Leicester 'have not been quite so close lately as undoubtedly they ought to be-as they are in every other part of the country'. ${ }^{33}$ This mistrust and lack of liaison led to an extraordinary fiasco in the general election of 1892 . In this year, McArthur having retired after representing the borough for eighteen years, the Liberals put up Picton and Sir James Whitehead, Bt., a London merchant who had been Lord Mayor in I 888 and earned his baronetcy by his services on the Mansion House Conciliation Committee during the dock strike. ${ }^{34}$ Although chosen like McArthur to represent the moderate and commercial interest, Whitehead claimed in some ways to be as advanced as Picton. Certainly he accepted the 'Newcastle programme' without reservations $^{35}$ and his choice reflects the growing importance attributed to labour relations. The Conservatives, adopting the policy of $\mathbf{1} 886$, tried to conduct the campaign through the Liberal Unionists. Here all was uncertainty. They had hopes of a very good candidate in Alderman (later Sir Thomas) Wright, then mayor; but it was not known whether he would stand. Days were wasted while he made up his mind. At last he turned down the offer; ${ }^{36}$ he alleged the greater importance of his municipal duties, but his reconciliation with the Liberal party in 1894 suggests that he had other reasons for not committing himself. His refusal left the Liberal Unionists at a loss, the Conservatives with no time to find an alternative, and the Liberals with the pleasure of seeing their candidates returned unopposed. ${ }^{37}$ This result did not do justice to the influence and determination of the Liberal Unionists. Although the Liberal press looked forward to

\footnotetext{
25 Leic. Daily Post, 28 June 1886. They founded a caucus of 15 , and when they formed their association in I 887 they hoped for a membership of 2,500: Leic. Chron. and Leic. Mercury, 3 July I886, I6 July 1887.

26 See above, p. 222.

27 Leic. Chron. and Leics. Mercury, 24 June 1893.

28 Leic. Daily Post, 28 June, I July 1886.

29 Ibid. 7 July 1886.
}

30 Picton 9,914, McArthur 9,68I, Bickersteth 5,686;

Leic. Chron, and Leics. Mercury, Io July 1886.

${ }^{31}$ Leic. Daily Post, I 6 July i 887.

32 Leic. Chron. and Leics. Mercury, 3 I Dec. 1892.

33 Ibid. 24 June 1893.

34 Leic. Daily Post, 27 June I 892.

${ }^{36}$ Ibid. 18 June, 27 June 1892 , I 5 Aug. 1894.

37 Leic. Chron. and Leics. Mercury, 9 July 1892. 
their early dissolution ${ }^{38}$ and some, like Sir Thomas Wright and H. Simpson Gee, returned for a while to their old allegiance, ${ }^{39}$ they continued to survive and maintain a separate organization. Moreover the reopening of the Home Rule issue during Gladstone's last ministry drove them to co-operate more effectively with the Conservatives with whom they were to work closely in all subsequent elections. The foundation in 1893 of the Constitutional Club as a common meeting-place for both Conservatives and Liberal Unionists ${ }^{40}$ may be taken as marking the point at which the breach with the Liberals and alliance with the Conservatives was recognized as permanent. From that time the Liberal Unionists acted in effect as part of the Conservative party.

The division which Home Rule had thus precipitated among the Liberals broke their formal unity for the first time since $\mathrm{I} 862$. If immediately it affected them less than their former disunion, since it did not cost them control of the borough, in the long run its significance was greater. The disagreement of the past had not led to a permanent withdrawal. Now the Liberals found themselves weakened by the permanent secession of a group which was considerable in influence if not in numbers. This meant that for the first time a number of leading employers and business men were to be found working for practical purposes with the Conservative party. Although the Irish question provided the catalyst, this regrouping of the political elements had long been prepared by social and economic developments. The nonconformist manufacturers had achieved the emancipation from aristocratic and ecclesiastical privilege for which they had fought from the beginning of the century. Religious and social barriers were broken down. They now sent their sons to public schools, to Oxford and Cambridge; 4 I they no longer suffered the old scruples about accepting honours and titles. ${ }^{42}$ Further, the end of mid-Victorian prosperity had modified their faith in Free Trade. Millican's criticism of it in 1885 and his appeal to the commercial advantages of imperial unity no doubt reflected this change of opinion; and it is noteworthy that a number of the Liberal Unionists, like Sir Samuel Faire, were later among the strongest supporters of Chamberlain's campaign for tariff reform.43 By such processes the way was prepared for cooperation with the Conservatives and, more important, for the assimilation of the business world into it that transformed the local Conservative party between 1885 and 1918 , so that it ceased to be little more than an appendage of the county, and became representative of the dominant industrial and commercial interests of the town.

This development was connected with another that directed a much more serious threat against the Liberals - the adoption of independent political action by the working men. Hitherto such action had been confined to the school board contests and occasional intervention in parliamentary elections. It had been generally the practice for the Trades Council to put pressure on the Liberal candidates by addressing particular inquiries to them; they had not however attempted to nominate representatives of their own. This passive acceptance of Liberal leadership appears to have changed to distrust at the time of the Unionist secession. This change was the result partly of a long social evolution that had lately increased its pace: the withdrawal of employers to the county or to select residential suburbs like Stoneygate, the greater segregation of classes, the growing divorce between management and ownership, and the replacement of the semi-independent framework-knitter by the factory operative. It was also the result partly of economic troubles which found expression in the strikes of the period, and more

38 Ibid. 31 Dec. 1892.

39 Leic. Daily Post, 5 Aug. 1894.

40 Leic. Chron. and Leics. Mercury, 24 June 1893.

${ }^{41}$ See the biog. details in W. Scarff, Leics. and Rut. at Opening of 2 oth Cent. passim.

42 It was said that Joseph Whetstone's 'republican austerity' had led him to refuse a knighthood at the time of Queen Victoria's coronation: Leic. Chron. and Leics. Mercury, I 8 Jan. I868. Contrast the titles granted in a later generation to Sir Thos. Wright, Sir Edward Wood, and Sir Samuel Faire.

43 Leic. Chron. 16 Dec. 1904, I Apr. 1905. 
especially of the workers' confidence in their own strength. The change made itself felt first in the attempts to obtain working men's representation through the Liberal organization, the method of 'Lib-Lab' alliance of which the outstanding exponent in the country was Henry Broadhurst, secretary of the Labour Representative League since I 873. Leicester was slow to respond to Broadhurst's movement; the first sign of his influence can be seen in the Trades Council's tentative recommendation of a parliamentary candidate to the Liberal committee in $1884 \cdot{ }^{44}$ Although this achieved nothing, in the next two years the Liberals showed themselves more sensitive to the views of the trades unions. Two of the leading members of the Trades Council, Daniel Merrick and George Sedgewick, took part in the nomination of McArthur in the election of $\mathrm{x} 886 ; 45$ and in the same year on the recommendation of the council Sedgewick was appointed J.P. for the borough. ${ }^{46}$ These conciliatory gestures did not prevent and perhaps encouraged the more emphatic adoption of a 'Lib-Lab' policy, of which the principal advocate in Leicester was William Inskip, a trades-unionist of national importance as secretary of the Boot and Shoe Union and a member of the parliamentary committee of the Trades Union Congress. ${ }^{47}$ In 1887 Inskip presided at a meeting, addressed by Broadhurst, which inaugurated the Leicester District Labour Association. The object of the new organization was to gain direct representation on the town council, board of guardians, and school board, not necessarily by nominating working men but by securing the election of candidates approved by them. As yet it was not intended to press for working men to represent them in Parliament, but some influence might be exerted over parliamentary elections. ${ }^{48}$ Although given only a cautious welcome by the Liberal press, ${ }^{49}$ the Labour Association was able to work harmoniously on the whole with the Liberal Association. After I 890 with Liberal acquiescence a number of its candidates were elected to the school board and the town council.50 Just as it was achieving some mild success this 'Lib-Lab' policy was challenged by the more aggressive and distinctly socialist ideas that were beginning to influence the young men in Leicester as in other parts of the country. In I 892 , a year in which industrial relations were 'none too cordial', 5 I a meeting, presided over by a member of the Trades Council, decided to form a branch of the Fabian Society. ${ }^{52}$ By 1894 a number of socialist societies were in existence, a Labour Club, an Anarchist Society, branches of the Social Democratic Federation and the Christian Socialists. ${ }^{53}$ At the May Day demonstration of 1893 , the first held in Leicester, these views found expression in the widely voiced demands for independent political action and the withdrawal of Picton, who had voted against the Miners' Eight Hours Bill on the grounds that there should be no legislative interference with individual rights. Joseph Potter of the Trades Council said of Picton that 'he was, or had been, a parson and was a capitalist. 'They might as well send a leopard in sheep's clothing amongst a flock of sheep as send a capitalist to represent the workers in Parliament.' Resolutions were passed welcoming 'the growing international union of labour against the thraldom of capitalism' and declaring that 'the only possible remedy for the poverty and misery existing today is the ownership and control of the land and instruments of industry by the co-operation of labour'. ${ }^{4}$ In its official capacity the 'Trades Council had not recognized this demonstration but it could not ignore the pressure being brought against it. Its

\footnotetext{
44 Leic. Chron. and Leics. Mercury, 12 Mar. I884.

43 Ibid. 3 July 1886.

46 The Trades Council had put forward the names of both Sedgewick and Merrick: ibid. I 2 Mar., Io July I 886. This was one of the earliest of such appointments in the country: H. Broadhurst, Henry Broadhurst, M.P. I 36. Sedgewich was also appointed later as an assistant inspector of mines: ibid. 137 .
}

\footnotetext{
47 Leic. Chron. and Leics, Mercury, I7 Mar. 1894.

48 Leic. Daily Post, 7 Dec. 1887.

49 Leic. Chron. and Leics. Mercury, 10 Dec. 1887.

50 W. Howard, 50 Years of Progress.

${ }^{51}$ Leic. Chron. and Leics. Mercury, 31 Dec. 1892.

52 Ibid. 16 Apr. I 892.

53 Ibid. 14 Apr. 1894; Leic. Daily Post, 22 Aug. 1894.

54 Leic. Chron. and Leics. Mercury, 13 May 1893.
} 
first response was to adopt a more independent policy in municipal elections; in those of November 1893 it ran two independent candidates without consulting the Liberal ward committees. 55 Then early in the next year it revealed a sharper temper in parliamentary matters. In March Picton had given notice that he intended to retire on account of ill health ${ }^{56}$ and the Liberal sub-committee, clearly sensitive to developments, had unanimously proposed the acceptance of no less a man than Henry Broadhurst. ${ }^{57}$ This choice of a working man, the leading exponent of the 'Lib-Lab' alliance, did credit to their broadmindedness and they had some reason to suppose that it would secure the approval of the Trades Council. Indeed, Broadhurst's name, among others, had been suggested at a meeting of the Trades Council held to consider the question. ${ }^{8}$ But the proposition met two difficulties. One was that Broadhurst was unacceptable to those who had come under the influence of the Independent Labour Party, his rival for the control of the trades union movement. ${ }^{9}$ The other was that even if the Trades Council would accept Broadhurst, they would only do so as their own nominee. This Liberal gesture to the working men therefore provoked an indignant reply from the Trades Council who sent off an angry letter to Broadhurst instructing him to accept nomination only from themselves. ${ }^{60}$ The Liberals could not admit this claim, which would strike at the roots of their organization. Regardless of the protest they adopted Broadhurst by the usual procedure and he stood as a 'Liberal-Labour' candidate. ${ }^{61}$

Although the Trades Council had asserted its independence, the Liberals could dismiss it as a gesture intended to appease the extremists and without practical significance, since no one was likely to take the risk of running another working men's candidate against Broadhurst. But before the by-election could take place, the position was complicated by the sudden and unexpected retirement of the junior member, Sir James Whitehead. ${ }^{62}$ As the government whips required a speedy replacement, the Liberals had hurriedly to find another candidate to meet the unusual emergency of a double by-election. After some controversy they adopted W. Hazell as partner for Broadhurst. Hazell well represented the social idealism of the age. He aspired to be a model employer and had introduced co-ownership into his printing works at Aylesbury; he had founded the Self Help EmigrationSociety, patronized the Children's Fresh-Air Mission, and maintained a small farm for reclaiming penniless youths. On issues like factory acts, housing, the Miners' Eight Hour Bill, and employers' liability he claimed to be in advance of many Radicals. Yet he was not adopted without opposition. As treasurer of the Peace Society he was not entirely acceptable to Liberal imperialists. Others had wanted a local man. ${ }^{63}$ More important was the opposition that his adoption met from the Trades Council.

The initiative in this came from the I.L.P., which had been founded the year before and already acquired a following in Leicester. ${ }^{64}$ Since then the I.L.P. had been attempting to win over the Trades Council to its policy of independent political action. Although early in 1894 the Liberal press began to complain of the way in which the Trades Council was being captured by the extremists, ${ }^{65}$ the I.L.P. had not yet won a decisive victory. A number of the older men like Inskip remained loyal to the older policy and even among the younger and more aggressive some, like the president George Banton, who was to be the most important local Labour leader for the next 30 years, had not yet been convinced that a change was practicable. But the retirement of Whitehead opened

55 Ibid. 24 June I 893 .

56 Ibid. Io Mar. 1894 .

57 Ibid. 17 Mar. 1894.

58 Ibid. Io Mar. I894.

59 Ibid. 25 Aug. I 894.

LEIC. IV
60 Ibid. 17 Mar. 1894.

61 Ibid. 24 Mar., 2 I Apr. 1894.

62 Ibid. 18 Augg. I 894.

63 Ibid. 25 Aug. I894.

64 Ibid. I 3 May I 893.

65 Ibid. 14 Apr. 1894 


\section{A HISTORY OF LEICESTERSHIRE}

up new prospects. Those who would be reluctant to oppose Broadhurst might have no objection to opposing Hazell. The I.L.P. now saw its opportunity. In August I894 Tom Mann led a deputation to Leicester to sponsor a candidate and quickly won the support of the Labour Club and the socialist societies, aided perhaps by unemployment and the agitation aroused by the hosiery strike that was in progress at the time. It still remained to convince the Trades Council. The initial meeting was held on 20 August when 'Tom Mann appeared before the Council to put his case. Banton from the chair put forward a number of objections: the present system worked well enough; they could obtain more or less what they wanted in municipal elections and on the school board; Hazell and Broadhurst were satisfactory parliamentary candidates, not likely to be defeated by an independent; and above all the Trades Council was 'not overflushed with funds'. In reply Mann appealed to their sense of loyalty, reminding them that Hazell was an employer, pointed out that his proposal had already found much spontaneous support in the town, and clinched his argument by promising help from the emergency fund of the I.L.P. He then brought forward his candidate, Joseph Burgess, editor of the Workman's Times, who claimed an intimate knowledge of the problems of the hosiery trade and was already well known as a Labour leader in the north. Impressed by the practical nature of the proposal, the waverers seem finally to have been won over by allegations - apparently unfounded - about Hazell's attitude to trades unions. After some discussion a resolution against taking independent political action was defeated by $2 \mathrm{I}$ votes to $17 .{ }^{66}$ The Trades Council recommended Burgess's candidature and so took the decision from which in time the Leicester Labour party arose.

Although the Liberals maintained that as Burgess had few funds and no organization they had little to fear from him, the Conservatives were heartened by the hope that in splitting the Radical vote he would enable them to repeat the success of $\mathrm{I} 86 \mathrm{I}$. In this hope they put forward J. L. F. Rolleston, a local surveyor and land agent, a strong imperialist whose forceful arguments for the acquisition of new markets overseas were calculated to appeal to manufacturer and working man alike. Between Conservatives and Liberals imperialism and the maintenance of the House of Lords provided the chief differences. On social issues like the miners' eight-hour day, Rolleston was prepared to go almost as far as Broadhurst and Hazell. ${ }^{67}$ Burgess stood as a thorough-going Socialist for the nationalization of land and means of production; and his attack was directed not against Broadhurst, whom the Trades Council was prepared to accept, but against Hazell who stood condemned as an employer. ${ }^{68}$ Much was made about the non-union character of Hazell's printing house at Aylesbury, described by the Leicester Typographical Society as 'one of the worst rat-houses in the country'. ${ }^{69}$ It was a spirited election, fought as bitterly as a general election and marked by thorough organization on all sides. The I.L.P. for their part tried to make up for their handicaps by bringing down a zealous contingent of speakers, among them Keir Hardie, J. H. Clynes, and Tom Mann. ${ }^{70}$ Although they failed to prevent a Liberal victory, Hazell had a majority of only 2 I 7 over Rolleston. The Liberal votes had been lost not to the Conservatives who polled few more than in 1885 but to the I.L.P. To the surprise of his opponents, Burgess had won well over 4,000 votes. ${ }^{71}$ It was clear that the I.L.P. had come to stay. The result confirmed the Trades Council in its resolution and a vote of censure was passed on those members like Inskip who had supported Hazell. ${ }^{72}$ The day after the election a

66 Leic. Chron. and Leic. Mercury, 25 Aug. 1894; Leic. Daily Post, 2.0, 22 Aug. 1894; Midland Free Press, 25 Aug. I 894 .

${ }_{67}$ Leic. Daily Post, 21 Aug. 1894.

${ }_{68}$ Midland Free Press, 25 Aug. 1894.
69 Ibid. I Sept. 1894.

70 Leic. Daily Post, 30 Aug. 1894.

71 Broadhurst 9,464, Hazell 7,184, Rolleston 6,967, Burgess 4,402 : Leic. Chron. and Leics. Mercury, 1 Sept. 1894. ${ }^{72}$ Midland Free Press, 15 Sept. 1894. 
permanent branch of the I.L.P. was founded: its object was the 'nationalization of the whole of the means of production, distribution, and exchange'. No member of any other political organization was eligible for membership. Its first president was George Banton and other members of the Trades Council were elected to the chief posts. ${ }^{73}$

The general election of 1895 appeared hardly more than a repetition of the election of I 894. No new issue had been introduced on the fall of the Liberal administration and the experiences of the double by-election had done nothing to encourage the local parties to change their tactics. They adopted the same candidates and the candidates issued more or less the same programmes as before. At most their recent practice had improved their organization and clarified their views. Rolleston reaffirmed his advocacy of a vigorous imperialist policy and social measures at home in the form of old-age pensions and better housing for the poor; to the national policy of his party he added, as his personal contribution, the advocacy of bimetallism. Burgess distinguished between his ultimate objective of thorough-going Socialism which would be accompanied by the transformation of Parliament into a 'paid convention of the People's delegates' and his immediate programme of 'palliatives', which included the nationalization of land values, the grant of compulsory powers of purchase to local authorities, the eight-hour day in industry, pensions at the age of fifty, the nationalization of transport, free education at all levels, a progressive income tax with extinction of unearned income, and universal suffrage. The Liberals, Broadhurst and Hazell, likewise accepted the necessity of old-age pensions, the payment where required of Members of Parliament, and land reform, but put their emphasis on the disestablishment of the Welsh Church and the reform of the House of Lords. ${ }^{74}$ An 'immense distribution of literature' and a heavy poll, taken on a Saturday, achieved a result hardly different from that of $1894 .{ }^{75}$ Yet even if the Liberals, in retaining their seats, fared better than their party as a whole, Hazell's margin had narrowed to less than Ioo votes. Burgess lost a few hundred, but this could be explained by tactical mistakes, like the offence given to religious susceptibilities by Sunday meetings and to trades unionists by a proposal to forbid the employment of children under the age of fifteen. ${ }^{76}$ More significant than this loss was the ability of the I.L.P. to maintain a poll of more than 4,000 votes. It was clear that this new force was not transient and, although not able to win a seat itself, yet strong enough to threaten the moderate Liberals with the loss of theirs.

The danger became real at the general election of 1900 . No reconciliation or understanding had been achieved between Liberals and Labour. The Trades Council and I.L.P. had reasserted their independence by resolving to join the newly founded Labour Representation Committee ${ }^{77}$ and adopting its secretary, J. Ramsay MacDonald, as their parliamentary candidate. ${ }^{78}$ The Liberals themselves had suffered from the divisions among their national leaders and still more from those caused by the South African War. The local association as a whole accepted the leadership of Campbell Bannerman, ${ }^{79}$ but a small number of Liberal imperialists had criticized their attitude to the war $^{80}$ and tended to throw in their lot with the Liberal Unionists who were now experiencing a slight revival. ${ }^{81}$ As in the rest of the country the Conservatives profited from an election intended to exploit the patriotic sentiments that the war had aroused. With the county regiment and yeomanry on active service, part, indeed, for so long besieged in Ladysmith, the town could hardly have taken a detached view of the fighting; and for a year

73 Ibid. I, 15 Sept. 1894.

74 Ibid. 6, 13 July 1895.

75 Broadhurst 9,792, Hazell 7,753, Rolleston 7,654, Burgess 4,009: Leic. Chron. and Leics. Mercury, 20 July 1895.

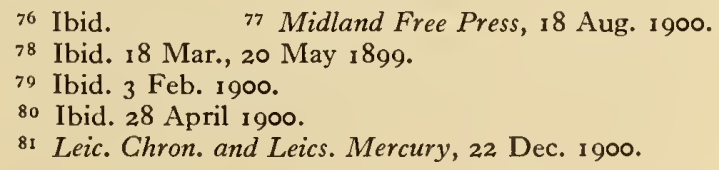

81 Leic. Chron. and Leics. Mercury, 22 Dec. 1900. 


\section{A HISTORY OF LEICESTERSHIRE}

past the war had almost driven from the local newspapers the ritualist and the vaccination controversies that had engaged their attention immediately beforehand. The relief of Ladysmith and of Mafeking was celebrated with abandon;82 the I.L.P.'s campaign against the war aroused hostile demonstrations; and at least one of their meetings was broken up by rowdies. ${ }^{83}$ Even the Trades Council was disunited on this question. ${ }^{84}$ As the war provided almost the sole issue of the election, the Conservatives enjoyed unusual advantages and made the most of them. Sir John Rolleston's ${ }^{85}$ candidature was supported by a letter from Chamberlain alleging that the return of Radicals would indicate that the people of Leicester were opposed to the war and to the annexation of the Boer Republics'. His meetings were marked by a 'distinct khaki flavour' and conducted in the midst of an enthusiasm excited by patriotic airs and songs. ${ }^{86} \mathrm{His}$ opponents tried to divert attention to other issues, especially the Conservative government's failure to introduce social legislation, ${ }^{87}$ but Hazell's position in particular was threatened by his policy towards the war. He neither opposed it sufficiently to please some of the Radical voters, who were reported to prefer MacDonald's outright condemnation, nor supported it so as to please all those moderate Liberals whom he was supposed to represent. 88 More serious was the attitude in the Trades Council of a militant minority who voted against the resolution to support MacDonald and Broadhurst and determined to give their second vote to the Conservatives. ${ }^{89}$ Although the loss in this way of nearly $\mathrm{I}, 000$ votes could not hurt Broadhurst, whose majority was secure, their transfer to Rolleston determined the precarious fate of Hazell. Broadhurst was safely returned for the Liberals but Hazell was beaten by over 500 votes. ${ }^{90}$ A Conservative now represented Radical Leicester for the first time in 40 years, and he did so because the division in the Radical ranks had reproduced the circumstances of I86I. History, however, was not exactly to repeat itself. The seat which the Liberals had now lost they were never again to win.

When the long domination of the Liberals began to end, the party had to face the prospect of disintegration as Radicals felt and moderates resisted the attraction of Labour. Their partial failure in the election of 1900 provoked a crisis in their affairs which revealed the tension to which they were subjected. The Radicals put the blame for their defeat upon the unenterprising leaders who had lost touch with the Radical working men and maintained control by a 'miserable system of wire-pulling'; who had not dared to reach an understanding with the I.L.P. and lacked sympathy with recent developments in municipal government. These criticisms were directed particularly at the president of the Liberal Association, Sir Israel Hart. Although bound to recognize his long service and munificence, they charged him with being an old-fashioned Liberal, in municipal matters 'the greatest Tory of them all', who had opposed the acquisition of new undertakings such as electric light and tramways by the corporation. These charges obtained sufficient support to provoke Hart's resignation.9I 'The Radicals, however, failed to commit the party to an understanding with the I.L.P.: the executive still proposed to run two candidates at the next election; and an influential minority wanted to put up Sir Israel Hart, whom the executive could not now accept. ${ }^{22}$ In June I90 I Sir Israel announced his intention of fighting the next election regardless of the executive;93 after a number of conferences with Labour representatives, the executive itself failed to

82 Midland Free Press, 3 Mar., 26 May 1900.

83 Ibid. 24 Feb. 1900

84 Ibid. 3 Mar. 1900.

85 He had been knighted in 1897: Leic. Daily Post, I 1 April 1919.

${ }^{86}$ Leic. Chron. and Leics. Mercury, 29 Sept. 1900.

87 Midland Free Press, 22 Sept. 1900.

88 Ibid. 29 Sept. I900.
89 Ibid.
90 Broadhurst 10,385, Rolleston 9,066, Hazell 8,528, MacDonald 4,164. 923 votes were split between Rolleston and MacDonald: Leic. Chron. and Leics. Mercury, 6 Oct. 1900. A brief acct. of the election appears in Broadhurst, Henry Broadhurst, M.P. 255-8.

91 Midland Free Press, 9, 23 Feb. I901.

92 Ibid. 23 Feb, I901.

93 Ibid. 22 June 1901. 
achieve an agreement which would satisfy moderates by passing off Broadhurst as the Labour candidate and introducing a true Liberal for the second seat. ${ }^{94}$ In the middle of I 902 it seemed likely that at the next election many Radicals would support MacDonald: the remaining votes of the party would be divided between the official Liberal candidate and Sir Israel Hart; and the Conservatives would win both seats. ${ }^{95}$ At this point the Education Act of 1902 did more than anything to restore the party's unity and sense of purpose. By the privileges that it appeared to grant to the established church, it aroused the long dormant ardour of militant nonconformity. From the spring of 1902 onwards the Free Churchmen began to mobilize their forces and in the next three years organized an agitation unequalled since the contest over church rates. Mass meetings were held at which Liberal leaders and the massed pastorate once more sat side by side on the platform: ${ }^{96}$ the Liberation Society took on new life, ${ }^{97}$ and a Citizens' League encouraged respectable citizens to defy the law and make their protests in hundreds before the borough magistrates. ${ }^{98}$ As the conviction spread that the Liberals had not yet fulfilled their mission of destroying aristocratic and clerical privilege and blended with the newer mission of social reform, the party found itself impelled by an imperative demand to ensure success by reaching an understanding with Labour at whatever cost.

This would not easily be secured. An extreme section of Labour had shown clearly in the last election that they considered the Conservatives more palatable than the Liberals. The conference of I 90 I had broken down on their opposition and next year the overtures of the Liberals had been defiantly answered by the adoption of MacDonald as Labour candidate.$^{99}$ But this attitude was soon to be modified by events. The implication of the Taff Vale decision and the disinclination of the Conservative government to provide a remedy to protect trade union funds imposed on trades unionists as on nonconformists an imperative mission. ${ }^{1}$ Common sense pointed to an understanding with the Liberals and its teaching was reinforced by the advice of MacDonald, who had always been regarded as a cautious member of the I.L.P. and had not reiterated in the last election the note of class warfare that Burgess had sounded in the two earlier campaigns. His adoption in itself marked a change of tactics towards moderation; a local commentator remarked: 'It is whispered in my ear that Mr. M. is a better man than the party to which he is allied: and that he has no iconoclastic disposition towards the Liberal party'. ${ }^{2}$ Not that MacDonald was ready to concede much, certainly not to give up his own candidature nor to operate under Liberal colours. He differed from the extremists only in his readiness to accept an electoral compact by which Liberals and Labour agreed to put up only one candidate each and instruct their followers to give their votes to both.

Although Radicals had long been pressing for it and some had combined with the trades unionists and Socialists to support MacDonald's adoption, ${ }^{3}$ an understanding of this sort demanded a large sacrifice from the Liberals. The agreement of i 86 I which restored unity in similar circumstances had succeeded in containing moderates and Radicals within a single organization. Now the Liberals were expected to acquiesce in the surrender of one of the seats to an independent organization with which they would be in no more than a temporary and precarious alliance. Labour, however, would accept no other terms, and as time passed their ability to bargain increased as their movement grew stronger. The publication of a Labour newspaper, the Leicester Pioneer, the eloquent and energetic campaigning of MacDonald, the success of a Labour Missionary

\footnotetext{
94 Ibid. I 5 June I901, I Feb., 26 Apr. 1902.

95 Ibid. I Feb. 1902.

96 Ibid. 3 May, 27 Sept., I Nov. I 902.

97 Ibid. I I Apr. I903; Leic. Chron. and Leics. Mercury, 7 April I 906.
}

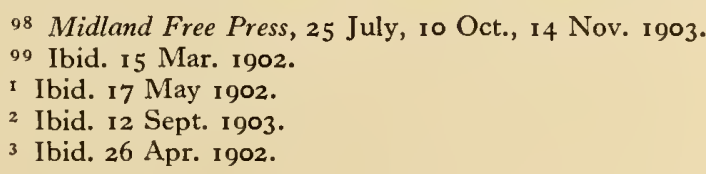


Week, ${ }^{4}$ and the formation in May 1903 of a local Labour Representation Committee (in effect a local branch of the Labour party, although it did not bear that name $)^{5}$ all pointed the need for an accommodation. It was at last achieved in September I903 on the initiative of Edward Wood, the new president of the Liberal Association, who had accepted office on the understanding that he would have a free hand to negotiate. ${ }^{6}$ By its terms the Liberals agreed to run only one candidate and to give their second vote to MacDonald; in return, Labour agreed to support the Liberal candidate. ${ }^{7}$ This amounted to a complete surrender by the moderate Liberals, for, although Broadhurst, the sitting member, represented the Radical section of the party, they could hardly give him up and replace him by a moderate. If, then, this 'progressive Alliance' achieved its aim, Leicester would be represented by two Labour members, one of the old school, one of the new.

It was one thing for the leaders to make the agreement, another to secure its acceptance. On the Liberal side there was still the risk that Sir Israel Hart would carry out his threat to stand on his own. He had already appointed a political secretary ${ }^{8}$ and begun his campaign. ${ }^{9}$ With rumour of a general election to be held in the coming November or March, ${ }^{10}$ the prospect appeared dangerous, until at the last moment, in a letter read out by Lord Rosebery at a meeting dedicated to Liberal reconciliation, Sir Israel renounced his claim to stand. I The Liberals could now be certain that their electoral discipline would enable them to carry out their share of the bargain. They could be less sure of Labour's ability. Although MacDonald gave the alliance his blessing, it was difficult to overcome the bitterness of his followers. Tempers were still sharpened by municipal politics to which the truce did not extend, and by the unemployment of 1904 and $1905 .{ }^{12}$ The sympathy shown by all classes, however, softened the latent antagonism, particularly on the occasion of the march of the Leicester unemployed to London, in which an Anglican clergyman, F. L. Donaldson, Vicar of St. Mark's and for the last ten years the leader of a small body of Christian Socialists, distinguished himself by accompanying the marchers and sharing at least some of their hardships. ${ }^{13}$ Other issues too, like the importation of Chinese labour to South Africa, reconciled Labour to any understanding that would prevent the return of the Conservatives. ${ }^{14}$ By the spring of 1905 the Liberals could feel assured that the understanding would be respected. In March not only MacDonald but other leaders like Arthur Henderson were advising the Leicester party not to 'plump' but to vote for 'both progressive candidates'. ${ }^{\text {I }}$ Even so Labour maintained a prickly sense of their independence which they refused to compromise by undertaking a joint electoral campaign or holding joint meetings for both candidates; ${ }^{16}$ and the Social Democrats condemned outright the policy of the Labour Representation Committee. ${ }^{17}$

The Conservative government held on long enough to unite all its opponents in a common front and Chamberlain's campaign for Tariff Reform provided yet another issue on which Labour and Liberal could agree. ${ }^{18}$ On the other hand, it did not appear to divide the Conservatives in Leicester so deeply as elsewhere and when Sir John Rolleston announced himself a convert he received the hearty support of the Liberal Unionists whose leaders, like Sir Thomas Wright and Sir Samuel Faire, were also promoters of the Tariff Reform League. ${ }^{19}$ When the general election was at last held in

4 Midland Free Press, 30 May 1903.

5 Ibid. Io June I 905.

6 Ibid. 6 Jan. 1906.

7 Ibid. I2 Sept. 1903.

8 Ibid. I Aug. I903.

9 Leic. Daily Post, 27 July 1903.

so Ibid. 22 July I903.

II Midland Free Press, 4 Nov. 1903.
12 Leic. Chron. and Leics. Mercury, 30 Dec. 1905.

13 Midland Free Press, 3, I0 June 1905.

14 Leic. Chron. and Leics. Mercury, 4 Mar. 1905.

is Ibid.

16 Ibid. 6 Jan. I906.

17 Ibid. I3 Jan. 1906.

18 Ibid. 6 Jan. 1906.

I9 Ibid. I April, 16 Dec. 1905. 
January 1906, Rolleston tried to make it turn chiefly on this issue and that of Ireland, declaring himself against Free Trade and Home Rule. He dismissed briefly the agitation about the use of Chinese labour in South Africa; on the Education Act of 1902 he stood on the defensive, appealing to his supporters to rally to 'save the Bible' in the schools. On this occasion, however, the moral fervour upon which he had been able to rely in 1900 was overwhelmingly manifest on the side of his opponents in whom the dissenting ardour of the older generation burned alongside the social idealism of the new to revive the crusading spirit of 50 and 60 years back. The campaign had hardly begun before it was evident that the Conservatives were being borne down in a tide of enthusiasm: Labour leaders and nonconformist preachers vied with one another in moral denunciation of the evils of imperialism, protection, and armaments, of intemperance and bad housing, of the exploitation of labour, the crippling of trades unions, and the perversion of education, and Rolleston had a hard fight in some wards even to obtain a hearing. ${ }^{20}$ It was reported to be the most excited election for 50 years. ${ }^{21}$ Fewer than 3,000 electors failed to vote, and Broadhurst and MacDonald were swept in by a majority of more than 7,000 , one of the largest in the country.22

Between the election of 1906 and the outbreak of war in 1914 the political allegiance of the borough continued to be determined by the relationship of the Labour party, as the Labour Representation Committee now called itself, and the Liberals. It remained an uneasy relationship, disliked by some on both sides. Liberals were disquieted by the steady advance which Labour made at their expense in municipal politics. When the municipal elections of 1909 deprived the Liberals for the first time of their absolute majority among the councillors there were those who drew the conclusion that they would do better not to 'coquette with the Socialist party'. ${ }^{23}$ Labour, too, was still divided between the moderate advocates of co-operation and intransigents, and had also to consider the militants outside their own ranks, like the Social Democratic Federation and later the British Socialist party. ${ }^{24}$ For the time being, however, the sense of solidarity created in 1906 maintained the Progressive Alliance. It was first tested immediately after the general election, when Broadhurst retired on account of ill health and financial difficulties. He felt able to do so now because the government's majority was so secure that there was no risk in running an untried candidate. Untried, indeed, he had to be since the election had left a dearth of Radicals without seats. In making their choice, the Liberals went back to an older tradition, choosing a manufacturer, Franklin Thomasson, 'a thorough nonconformist and splendid Radical', whose father had been Radical M.P. for Bolton, whose mother was related to John Bright, and whose training could satisfy the commercial interests and whose reputation as employer the trades unionists. He was sound on Home Rule, Free Trade, the Education Act, and the Taff Vale decision, a temperance reformer and opponent of compulsory vaccination, and he was prepared to go as far as women's suffrage and nationalization of the land. The composing staff of Tribune, a paper which he had lately begun to publish in London, sent a message in his support to the trades unionists of Leicester. ${ }^{25}$ In these circumstances the understanding held firm and Thomasson was elected by a sound majority over Rolleston. Even so, the Liberals complained of some lassitude and of Labour abstentions. ${ }^{26}$

In the next three years the Conservatives had some hope of exploiting the differences

20 Ibid. 6, I3 Jan. I 906.

21 Midland Free Press, 20 Jan. 1906.

22 The number of voters on the register was $25, \mathrm{I} 35$. The poll was: Broadhurst I 4,745, MacDonald I 4,685, Rolleston $7,504.426$ votes were given to MacDonald alone and 260 split between him and Rolleston: Leic. Chron. and Leics.
Mercury, 20 Jan. 1906.

23 Leic. Chron. and Leics. Mercury, 6 Nov. 1909.

24 Ibid. 2 Jan. I909.

25 Ibid. 24 Mar. 1906.

26 Ibid. 7 Apr. 1906. The poll was: Thomasson 10,766, Rolleston 7,206: Midland Free Press, 7 Apr. 1906. 


\section{A HISTORY OF LEICESTERSHIRE}

between their opponents. The Tariff Reform League conducted an active propaganda to convert the working classe ${ }^{27}$ and Rolleston warned the middle class about the dangers of Socialism, against which the House of Lords must be preserved as their sheet anchor. ${ }^{28}$ Their hopes were such that they decided to run two candidates in the next election. Rolleston retired to the calmer politics of East Hertfordshire ${ }^{29}$ and was replaced by Foster Fraser, a journalist. ${ }^{30}$ In November I 909 the Conservatives introduced a second candidate to oppose MacDonald, E. A. Bagley, one of three Unionist working men who fought the election of I9IO. Bagley was a moulder by trade, a trades unionist who stood particularly in the interests of Tariff Reform and recommended Protection to the working classes as a remedy for unemployment. It was said that he was supported by a fund of $£ 6,000$ raised by the Standard. ${ }^{31}$

The issues on which the election of I9Io was fought thwarted these tactics. The Lords' rejection of the budget put the issue in the stark form of 'the peers versus the people', consolidated the understanding of Liberals and Labour, and revived the crusading spirit of 1906 . The moral forces which had won that election were once more let loose. Again the nonconformist pastors threw themselves into politics. One distinguished himself with a sermon on the text 'Stand fast, therefore, in the liberty wherewith Christ hath made us free and be not entangled again with the yoke of bondage', in which he appealed to his hearers 'to arise and let every man wield his sword in the sacred name of liberty' against the power of hereditary veto, the moneyed powers, and 'the most sinister of them all, the power represented by drink'. ${ }^{32}$ The Free Churchmen as a body delivered a public protest against the action of the Lords. ${ }^{33}$ MacDonald used hardly different language. This was 'a sacred cause', 'a fight of the old Cromwell kind'; 34 they would 'march in the hope, the consciousness, the faith in eternal righteousness, which makes weak men strong and downtrodden men mighty'.35 'The Liberal candidate did not make quite the same appeal. Thomasson, whom ill health and pressure of business had forced to stand down, ${ }^{36}$ had been replaced by E. Crawshay Williams, a politician of a very different type from that customary to Leicester. He was a young man, not yet 30 , educated at Eton and Oxford, who had left the university after speaking against the South African war, served in the army, and travelled widely, accompanying Lord Curzon to Persia. He now appeared as a protégé of Winston Churchill, whom he served as private secretary at the Colonial Office and the Board of Trade. ${ }^{37}$ Although he claimed to be 'Radical to the core' and advocated women's suffrage and even the nationalization of communications, mines, and the land, ${ }^{38}$ he rejected the pacifist tradition: he stood for a strong navy and army. ${ }^{39}$ Although not as capable as MacDonald of moving the heart of nonconformity, he showed himself a competent speaker, ${ }^{40}$ and he could also draw for support on the eloquence of Churchill, who came down to Leicester to denounce 'the swift increase of vulgar, joyless luxury' and point to the 'awful gap between rich and poor'. ${ }^{4 I}$ With such talents and feelings engaged and with militant suffragettes to add a spice of novelty, the election was fought in the greatest excitement. 'Never', it was reported, 'was so much money spent on bill posting; never were the hoardings adorned with a greater variety of cartoons' ${ }^{42}$ Bagley, however, failed to divert the votes of Labour; and the Conservatives were again overwhelmed.43

27 Leic. Chron, and Leics. Mercury, I Jan. I 910.

28 Ibid. 30 Jan. I 909.

${ }^{29}$ He was elected M.P. for East Herts. in 1910: Leic. Daily Post, I I Apr. I919.

${ }_{30}$ Leic. Chron. and Leics. Mercury, 2 Jan., 6 Mar. 1909.

31 Ibid. 6 Nov., 4 Dec. 1909.

32 Ibid. 8 Jan. I910.

${ }^{33}$ Ibid. I 5 Jan. I9ro.

${ }^{34}$ Ibid. 25 Dec. 1909.
36 Ibid. 2 Jan. 1909.

37 Ibid. 20 Feb. 1909, 22 Jan. I9ro.

${ }_{38}$ Ibid. I I Dec. 1909.

39 Ibid. 20 Feb. 1909.

${ }^{41}$ Ibid. I I Sept. 1909.

42 Ibid. 8 Jan. I 9 ro.

43 Williams 14,643, MacDonald 14,337, Fraser 8,548, Bagley 8,192. Only $4 \mathrm{I}$ votes were split between MacDonald and Bagley: ibid. 22 Jan. r9ro. 
The general election of December I9ro almost repeated that of January. The great issue was the reform of the House of Lords. Labour, however, had a greater stake in the result than before, since they must fight the Osborne judgement which threatened the political subscription of trades unions. ${ }^{44}$ Otherwise the chief difference lay in the Conservatives' decision not to repeat the experiment of running two candidates. They found it difficult enough to bring forward one. For this election they adopted'A. Myddelton Wilshere, a barrister and lecturer at Bristol University. His tactics consisted in diverting attention to Tariff Reform and Colonial Preference, dismissing the question of the House of Lords as not a genuine issue; 45 but, although this lacked the enthusiasm of the earlier election, he could not prevail against the forces which had succeeded then. Williams and MacDonald were returned with a large though slightly reduced majority. ${ }^{46}$

In the last years of peace, two important developments could be noticed. One was the reviving strength of Conservatism, the other the growing reluctance of Labour to maintain their unwritten understanding with the Liberals. Both became evident in the byelection of 1913 , made necessary after Crawshay Williams had been cited in a divorce case and resigned his seat. ${ }^{47}$ On behalf of the Conservatives, Wilshere made the Insurance Act the main point of attack, blaming the government for increasing the size of the bureaucracy and cost of living and for neglecting the interests of the friendly societies. This was closely followed by his attack on Home Rule and Welsh disestablishment. ${ }^{48}$ The Liberals adopted a lawyer, Gordon Hewart, the future Lord Chief Justice. ${ }^{49} \mathrm{His}$ prospects were, however, put in doubt by his failure to satisfy the queries put to him about the Insurance Act by the Friendly Societies' Council, ${ }^{\circ}$ and still more by the action of the local Labour party, who, as soon as the election had been announced, resolved to put up George Banton, their doyen. ${ }^{\text {I I }}$ Although the opposition of MacDonald and the decision 'on financial grounds' of the national executive of the I.L.P. and the Labour party not to endorse him forced Banton to withdraw, the attempt had sufficed to raise the hopes of the militants. On hearing of Banton's withdrawal, the local branch of the British Socialist party met at midnight and adopted E. R. Hartley of Bradford as 'Socialist-Labour' candidate. Thwarted himself, Banton sent Hartley a message of support. The threat of this rival candidature might have had graver results if the Liberal officials had not obtained a message issued in the name of the executive committee of the Labour party which stigmatized this action as 'a grave violation of National Party discipline' and 'a graceless disregard of Mr. Ramsay MacDonald's position', and advised Labour voters not to support Hartley. ${ }^{52}$ Although this instruction was later disavowed by the executive as unofficial, 53 it served its purpose and Hewart was elected, though by a relatively small majority. ${ }^{54}$

\section{4-1956}

The outbreak of war in I9I4 brought formal politics for the time being to an end. Nevertheless events during the next four years had a profound effect on the course of politics in Leicester. The local Labour party gravely compromised its future by the equivocal attitude that it adopted to the war and by the divisions that the war created in its ranks. The majority naturally followed the leadership of MacDonald: first, at the very beginning, they protested against the war in the name of the International Working

44 Leic. Chron. and Leics. Mercury, 3 Dec. I 9 Iо.

45 Ibid. 26 Nov. 19 Io.

46 Williams 13,238 , MacDonald 12,998, Wilshere 7,547:

ibid. Io Dec. I9 10.

47 Leic. Fnl. 13 June 1913.

48 Ibid. 20, 27 June I9I3.

LEIC. IV
49 Ibid. 20 June I9I 3.

5 I Ibid. 20 June I 913 .

52 Ibid. 27 June I9I3.

53 Ibid. 25 July 1913.

54 Hewart 10,864, Wilshere 9,279, Hartley 2,580: ibid. 4 July 1913 .

50 Ibid. 27 June I9 13. 


\section{A HISTORY OF LEICESTERSHIRE}

Class Movement'; 55 then in the autumn of I9I 4 they accepted MacDonald's argument that they must resign themselves to it because they could not risk defeat, that they 'could only get out of it by going through with it'. ${ }^{56}$ In I9I7 the outbreak of the Russian Revolution and MacDonald's new change of course, his outright advocacy of pacification and negotiated peace, revived the critical spirit of I9I4. The May Day celebrations of I9I 7 were devoted to welcoming the Russian achievement of democracy, to venting popular dislike of the hardships and restrictions that war imposed, and to demanding the restoration of civil and industrial liberties.57 May Day I9I 8 was made the occasion for the expression of similar political criticism. ${ }^{8}$ This was not a policy that would win the approval of all local leaders or their followers. In I9I 4 the Trades Council had been deeply divided 59 and as the war progressed the local Labour party found itself torn between loyalty to the war and loyalty to MacDonald and the I.L.P., a division which found expression in the formation of a rival political organization. This, which went under a number of names such as the British Workers' League and the National Democratic Labour party, was a national movement promoted particularly by members of the Social Democratic Federation, who began in I 9I 7 to organize a branch in Leicester. Old campaigners like Joseph Burgess, the first Socialist to stand for the borough, came down to speak on their behalf, and J. F. Green, formerly a clergyman and more recently treasurer of the Social Democratic Federation, was adopted as their prospective parliamentary candidate. ${ }^{60}$ Clashes between the rival parties served to break up the May Day meeting of I9I8.6I Thus, although the Labour party succeeded in reconstituting its unity, it came out of the war discredited by what many regarded as its unpatriotic conduct and with a rival party well established in the town.

The events of war-time also had their effect on the Liberals. It was not merely that the Russian Revolution and the problems of reconstruction at home introduced issues on which they could not maintain their unity. The war had also completed the breakdown of the local understanding with the Labour party on which their political achievement depended, and the national alliance with the Conservatives negotiated in the course of the war was confirmed when their member, Sir Gordon Hewart, accepted the office of Solicitor-General in the Coalition Government. More important, the conditions of a coalition, in conjunction with the new constituencies created by the Representation of the People Act (I9I8), ${ }^{62}$ imposed upon the Liberal party a proportionate loss of influence at the next general election. This act affected their fortunes in three ways. By extending the parliamentary borough to include the whole of the municipal borough as it had been enlarged in $\mathrm{I} 89 \mathrm{I}$, it brought into it a number of suburban districts, like Stoneygate, that were regarded as generally Conservative in temper. By dividing the former two-member borough into three single-member constituencies, East, South, and West Leicester, it made more difficult the traditional tactics by which the Liberals had been able to keep moderates and Radicals within the same allegiance by supporting two candidates of different tendencies. ${ }^{63} \mathrm{In}$ addition it increased the total electorate to I I 4,230 , of whom more than a third were women.64 The disappearance during the war or in the years immediately following it of the local, independent

55 Midland Free Press, 8 Aug. I9I4.

56 Ibid. 24 Oct. 1914.

57 Ibid. 7 May 1917. The welcome did not extend to the 'Lenin party which was composed of thoughtless anarchists ....

${ }_{58}$ Leic. Jnl. 31 May 1918.

59 Midland Free Press, 5 Sept. I9I 4.

60 Leic. Daily Post, 9, 12, 2 I June 1917.

of Leic. $7 \mathrm{nl}$. 3 I May 1918.

627 and 8 Geo. V c. 64 .
${ }_{63}$ The constituencies consisted of the following wards: East: Belgrave, Latimer, Spinney Hill, West Humberstone; South: Aylestone, Castle, Charnwood, De Montfort, Knighton St. Martin's, Wycliffe; West: Abbey, Newton, St. Margaret's, Westcotes, Wyggeston: ibid. schedule 9, part I (2).

64 The electorate was as follows: East: $37,687,(22,080$ men, I 5,607 women); South: 35,909 (20,649 men, r 5,260 women); West: 40,634 (23,76I men, I6,873 women): Leic. Daily Post, 30 Dec. I918. 
Liberal press deprived the Liberal party of an important means of bringing this new electorate into their orbit.

Although the results of the general election of 1918 were never in doubt, the very arrangements by which it was conducted reflected the weakened position of the Liberals. Of the three coalition candidates put up for Leicester, only one, Sir Gordon Hewart who stood for East Leicester, was a Liberal; the others were a Unionist, T. A. Blane for South, and for West, standing as a member of the Patriotic Labour Coalition, J. F. Green of the British Workers' League. The Liberals were to enjoy only one-third, not as before one-half of the representation. This coalition had to meet the opposition of Labour in each constituency, an opposition consisting of J. Ramsay MacDonald in West Leicester, and in East and South of two local men, George Banton and F. F. Riley, who had more or less consistently followed his lead during the war. ${ }^{65}$ In these conditions, the election was inevitably fought on the war record of MacDonald and his associates. ${ }^{66}$ The imputations laid against their patriotism lost them the support even of some Labour leaders and trades unionists of long standing like Chaplin and Salt; ${ }^{67}$ and although the election was very quiet ${ }^{68}$ and the poll moderate, the Labour candidates were severely defeated. ${ }^{69}$ In the opinion of the Leicester Daily Post 'the cancer of pacifism is removed and Leicester stands vindicated to the world'.70

The stigma attached to the Labour party did not long survive the glow of military victory. With over 12,000 men on the dole and a total of 15,000 unemployed in 1921 , Leicester experienced to the full the harsh economic conditions of the period and the Labour party gathered the consequent harvest of protest.7 ${ }^{71}$ The extent of its recovery was strikingly demonstrated in the East Leicester by-election of 1922 , made necessary by the appointment of Sir Gordon Hewart as Lord Chief Justice. ${ }^{72}$ The difficulties and decline of the Liberals were revealed in equal measure. Although the coalition was still in being, a section of the Liberals had for some time resented the restrictions it imposed on them. As early as 1920 Asquith's Free Liberals and the League of Young Liberals had won a following in the executive of the local party, who had begun to criticize Hewart's participation in the government and threatened to nominate an independent candidate. ${ }^{73}$ Now, on Hewart's retirement, they took their opportunity and put forward R. Wilberforce Allen as a Free Liberal. ${ }^{74}$ But this assertion of independence could only be achieved at the cost of splitting their party. Already the supporters of Lloyd George, Sir Jonathan North among others, had formed a separate association of Liberal-Coalitionists and now they too put up a candidate in co-operation with the Conservatives. ${ }^{75}$ This was E. A. Marlow, a boot manufacturer of Northampton. ${ }^{76}$ While the Liberals were divided, George Banton, who was again the Labour candidate, received support from outside the traditionally Labour ranks, notably from a number of Free Churchmen. $77 \mathrm{He}$ was also favoured by circumstances, not only by the bitterness of the unemployed who had recently vented their feelings in demonstrations and a riot outside the Poor Law office, ${ }^{78}$ but by the general reduction of wages in the boot trade and the lockout of the engineers, all of which revived the militant spirit of his followers. ${ }^{79}$ In an election which was particularly concerned about unemployment, with the issue lying between the methods of state interference advocated by Banton ${ }^{80}$ and Marlow's defence

65 Leic. Fnl. 6 Dec. I9I8.

66 Ibid. 13 Dec. 1918.

67 Leic. Daily Post, 30 Dec. 1918.

68 Leic. Fnl. 27 Dec. 1918.

69 The poll was as follows: East: Hewart 18,024 , Banton 6,697; West: Green 20,570, MacDonald 6,347; South: Blane I 8,498 , Riley 5,463 : ibid. 3 Jan. I 9 I 9.

70 Leic. Daily Post, 30 Dec. 1918.

7 [Leic.] Pioneer, 16 Sept. I $921,5$.
72 Leic. Daily Mercury, 4 Mar. I 922, I.

73 Leic. Daily Post, 24 April, 25 Sept. 1920.

74 Leic. Daily Mercury, 16 Mar. 1922, 7.

75 Ibid. 6 Mar. 1922, I ; Leic. Daily Post, 9 May I921.

76 Leic. Daily Mercury, I I Mar. 1922, 8.

77 [Leic.] Pioneer, 24 Mar. I922, 8.

78 Ibid. 23 Sept. 1922, 4; 7 Oct. 1922, 4, 5 .

79 Leic. Daily Mercury, 3 I Mar. 1922, 4, 5 .

80 Ibid. 15 Mar. 1922, 7,8 . 


\section{A HISTORY OF LEICESTERSHIRE}

of private enterprise and economy, ${ }^{81}$ the Liberals found difficulty in elaborating a distinct programme. Allen's campaign in support of Free Trade, the League of Nations, and some degree of workers' control in industry ${ }^{82}$ aroused little enthusiasm and he finished bottom of the poll. Banton, on the other hand, won an absolute majority over both his opponents. ${ }^{83}$ In spite of the exceptional circumstances, this result laid down the pattern that local, like national, politics would take in the future. Labour had now taken over the part of the great alternative party and although the Liberals might still stand a chance in a straight fight, they would find that if they had to fight both a Labour and a Conservative candidate, their vote would be hopelessly split between Socialist and anti-Socialist.

These political conditions were well illustrated later in the year in the general election of November, caused by the Conservatives' decision to withdraw from the coalition. Although the followers of Lloyd George and those of Asquith still remained divided, calling themselves respectively National and Free Liberals, ${ }^{84}$ their disunity did not materially affect the result, since they did not come into direct opposition. Nevertheless the Liberals' predicament remained and their voters were called upon to play quite different parts in the three divisions, each of which was contested by a Liberal candidate. In East Leicester Capt. H. A. Evans stood as a National Liberal, enjoying in the end Conservative support as the anti-Socialist opponent of Banton who was defending his seat: the Free Liberal Wilberforce Allen had now transferred himself to South Leicester and was fighting a straight contest as the 'progressive' candidate against the Conservative, W. G. Waterhouse Reynolds, a local man, adopted after Blane had decided to retire; and in West Leicester a Free Liberal, G. E. Spero, a local doctor, was opposing both the government candidate, J. F. Green, who stood again as a National Democrat, and Alfred Hill, a veteran of the local Labour party and the Boot and Shoe Union. ${ }^{85}$ The issues at stake were mainly those of the by-election earlier in the year, issues of economic policy and unemployment. The Liberals found that where they were directly confronting either of their rivals they could either narrowly win, as Evans did in East Leicester, where he defeated Banton by I,300 votes, or narrowly lose, like Allen who lost South Leicester to Reynolds by 109 votes; but in West Leicester where they fought on two fronts they came bottom of the poll. ${ }^{86}$ The result on the whole brought little comfort to the Liberals, since before the year was out their only successful candidate, Evans, had joined the Conservatives. ${ }^{87}$ Labour on the other hand had barely lost their seat in East Leicester and had now won West Leicester. But the most striking feature of the election was the failure of any single party to achieve an overwhelming dominance such as the Liberals had maintained in the past, and it was this fine balance, rather than their intrinsic voting power, that allowed the Liberal party to remain a significant political force.

The next two general elections, following closely on one another in 1923 and 1924, showed how fine this balance was and how sensitive it made the electorate to small changes of mood. In the first, unemployment was again the chief issue and the three Conservative candidates, Evans, Reynolds, and Alfred Instone, the shipping and airline proprietor, who stood respectively for East, South, and West Leicester, all solidly supported protection, the economic remedy to which Baldwin had committed his party. ${ }^{88}$ In reply the local Labour party adopted with equal spirit the device of the capital levy,

\footnotetext{
81 Leic. Daily Mercury, 16 Mar. 1922, 3-4.

82 Ibid. 18 Mar. 1922, 7.

83 Banton 14,062, Marlow 8,710, Allen 3,825: ibid. 31 Mar. 1922, 3 .

${ }_{84}$ Leic. Daily Mercury, 23 Oct. 1922, 4; 30 Oct. 1922, 7.

85 Ibid. 4 Nov. r922, 10.
}

86 The poll was as follows: East: Evans 15,164 , Banton 13,850; West: Hill 12,929, Green 8,137, Spero 7,631; South: Reynolds 12,534 , Allen 12,425: ibid. I6 Nov, I922, 3 .

87 Leic. Mail, 7 Nov. 1923, 4.

88 Ibid. I9 Nov. 1923, I; 22 Nov. 1923, passim. 
to which they had in effect committed themselves in adopting Pethick Lawrence, its chief exponent, as their candidate in West Leicester, Hill having retired. ${ }^{89}$ Where Pethick Lawrence led, Banton followed in East Leicester.90 In these conditions, a Liberal revival seemed possible, especially now that the adherents of Lloyd George and Asquith had reunited, for they would oppose the capital levy as readily as the Conservatives and the cause of Free Trade would revive the old battle-cry of their faith and appeal to a country that was not prepared for the innovation of protection. In this hope, they contested each seat, putting forward Allen again in South Leicester, J. Henderson Stewart in East Leicester, and in West Leicester no less a man than Winston Churchill. The campaign in West Leicester set the pace for the other divisions and held the interest not only of Leicester but of the whole country by the intensity with which it was conducted and the contrast between the two chief contestants, Churchill and Pethick Lawrence. Each in his way provided a model of speaking, Churchill dramatically eloquent and powerful, Pethick Lawrence cool, quiet, and academic. Pethick Lawrence's coolness was not shared by his supporters, who conducted a bitter personal attack upon Churchill and his career, condemning him as 'a public danger'. ${ }^{11}$ Strong feelings were aroused on either side and the election as a whole was marked by bitterness and rowdyism. ${ }^{22}$ It was not marked, however, by the Liberal revival that Churchill had hoped to lead. They won, admittedly, South Leicester, where Allen with the undivided support of all the opponents of protection ousted Reynolds by over 4,000 votes: but the two other seats were both won by Labour, because they succeeded in maintaining their support while the anti-Socialist vote was divided. ${ }^{93}$ Although Churchill had not come bottom of the poll, the result bitterly disappointed him: according to another candidate, when the count was known there 'were tears rolling down his face and if ever a man's face showed black sorrow and despair it was his' ${ }^{94}$ It was his last contest as a Liberal.

Less than a year later in October I 924 a small change in political alignment produced a large change in the political representation of Leicester. Because this general election was brought about by the Liberals' decision to bring down the first Labour government, political alliances could be made which reversed the conditions of the previous year. On this occasion, in East and West Leicester, the Labour candidates, Banton and Pethick Lawrence, had to face a straight fight with a united opposition. The Conservatives and Liberals agreed to support joint candidates, 95 Capt. Loder the Conservative in East Leicester, ${ }^{96}$ and in West Leicester the Liberal M. A. Gerothwohl, a leading authority on foreign affairs whom Lloyd George had recommended.97 This pact did not satisfy the more Radical section of the Liberal party ${ }^{98}$ and, although as a gesture of alliance, Loder's nomination papers were signed by prominent members of the Liberal executive, ${ }^{99}$ the president of the Leicester Liberal Federation, S. Gimson, would do no more

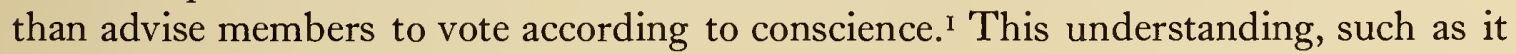
was, did not extend to South Leicester, where the Conservatives put up Capt. Charles Waterhouse of Bakewell (Derb.), to oppose Allen, the Liberal member. Here again the conditions of the last election were not repeated, for this division, which in 1923 had experienced the only straight contest, was now to be the only Leicester seat contested by all three parties. In reply to the Liberal pact ${ }^{2}$ and for the first time since their heavy

89 Ibid. I 7 Nov. I923, I.

90 [Leic.] Pioneer, I 4 Dec. I 923, 2.

91 Ibid. 30 Nov. 1923, 3 .

92 Leic. Daily Mercury, 7 Dec. I 923, I.

93 The poll was as follows: East: Banton 13, 162, Evans 8,247, Henderson Stewart 7,998; West: Pethick Lawrence 1 3,634, Churchill 9,326, Instone 7,696; South: Allen 14,692, Reynolds 10,672: Leic. Mail, 7 Dec. 1923, 3 .

94 Henderson Stewart, recalling the election 12 years

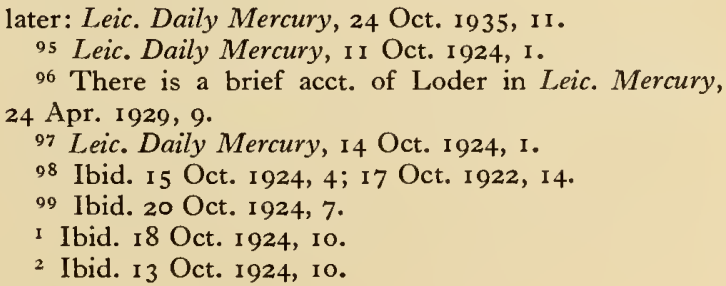


defeat in I9I 8, Labour decided to put up a candidate and nominated a young Cambridge graduate, a journalist and Fabian, H. B. Usher. ${ }^{3}$ In this election, which turned on the record of the late Labour government, its handling of the Campbell prosecution and the Russian treaty, the Labour party stood mainly on the defensive against accusations that they had tampered with the course of justice in withdrawing Campbell's prosecution and in handing money to Russia were investing in a 'fraudulent bankrupt' and underwriting international Communism. ${ }^{4}$ These charges were reinforced in the last week of the campaign when the Conservative government published the Zinoviev letter and speculations about the 'Red Plot' filled the front pages of the local and national newspapers. Although this scare, coming at the last minute, stiffened the tension of the election, which was already disturbed by outbreaks of rowdyism, ${ }^{5}$ there is no evidence that it determined the result. In both East and West Leicester, the Labour candidates increased their vote by more than 2,000; in West Leicester it was enough to re-elect Pethick Lawrence with a majority of 737 , but in East Leicester Banton was defeated by the even smaller margin of $42 \mathrm{I}$. In South Leicester Usher did so well that he effectively split the vote which had returned the Liberal candidate the year before, and Waterhouse the Conservative was comfortably elected. ${ }^{6}$ In 1923 Leicester had been represented by two Labour and one Liberal members. In 1924 the change in Liberal tactics in East and West and Labour's response to them in South Leicester sufficed to produce the disproportionately drastic result by which the town was now represented by one Labour member and two Conservatives.

Of the events of the next five years only two require notice. One, the General Strike of 1926 , created some discomfort and disorganization, but although 12,000 came out it led to no disturbances and seems to have left no lasting impression on the political life of the borough. ${ }^{7}$ The Equal Franchise Act of $1928^{8}$ had more direct political significance since it increased the electorate by 36,193 and enabled women voters for the first time to outnumber men. ${ }^{9}$ Neither event had much ascertainable significance on the general election of I 929 which was determined here as in the rest of the country by the failure of the Conservatives to discover an imaginative election programme and by the conditions of prosperity and optimism that made the experiment of a Labour government more acceptable. This time no pact was made between any parties and the three of them fought each constituency of the borough. In East Leicester, J. V. Loder defended his seat against two new candidates, E. F. Wise, a man of local origin and a member of the I.L.P., who stood for Labour, ${ }^{10}$ and the Liberal F. Lawson, a boot manufacturer of Wellingborough. II In South Leicester Waterhouse and Usher opposed one another again and the Liberals put up H. G. Purchase, a London barrister. ${ }^{\text {I2 }}$ Pethick Lawrence was opposed in West Leicester by P. V. Emrys Evans, the Conservative candidate, a stockbroker who had had administrative experience in South Africa and the Foreign Office, ${ }^{13}$ and C. W. Hartshorn, a local baker, builder, and Liberal town councillor. ${ }^{14}$ In spite of some noisy Conservative meetings, ${ }^{15}$ the campaign was said to be the quietest known. ${ }^{16}$ Only the Liberals, who had adopted Lloyd George's plans for curing unemployment, committed themselves to a really controversial programme, ${ }^{17}$ and the election for the rest turned on the unexciting merits of the Derating and Safeguarding Acts: ${ }^{18}$

3 Leic. Daily Mercury, I 5 Oct. I924, I ; 26 Apr. I 929, I 3.

4 Ibid. 17 Oct. I 924,6 , I I.

5 Ibid. 22 Oct. I 924, I ; 25 Oct. I 924, I.

6 The poll was as follows: East: Loder i 6,090, Banton I 5,669; South: Waterhouse I5,005, Usher 8,912, Allen 6,079; West: Pethick Lawrence 16,047, Gerothwohl I 5,3 I0: ibid. 30 Oct. I 924, 3 .

7 Leic. Mercury, 3-14 May 1926, passim.

8 I 8 and I9 Geo. V, c. I2.
? Leic. Mercury, 29 Apr. 1929, 5.

ro Ibid. 20 May I 929, I I ; 28 Oct. I 93 I 4.

I I Ibid. 9 May I929, $8 . \quad$ I2 Ibid. 20 May I929, 8.

I3 Ibid. 17 May 1929, 13.

I4 Ibid. 6 Apr. I 929, I.

I5 Ibid. 17 May I929, I 5; 30 May I929, 7.

I6 Ibid. I 8 May I 929, I $2 ; 22$ May I 929, 5.

17 Ibid. I4 May I929, I7; 18 May 1929, 12.

18 Ibid. I6 May I929, I 5; 27 May I929, 8. 
the poll was high, nearly 80 per cent. of the electorate voting. ${ }^{19}$ Labour won a striking success. It was not only that in East and West Leicester they obtained an absolute majority over the other parties, but even in South Leicester their candidate nearly doubled his vote, and Waterhouse the Conservative candidate was only re-elected by a majority of $2,145.20$

In voting so extensively for the Labour candidates in 1929 , Leicester followed the trend of the country as a whole. Two years later it did so again in decisively rejecting them. The town responded to the economic crisis of I93 I and the formation of the National Government much as the country did at large. The two Labour members and the local Labour party refused to follow MacDonald ${ }^{2 I}$ and prepared to fight the general election of October in all three divisions. For South Leicester they put up John Dugdale. ${ }^{22}$ After some hesitation the Liberals decided to support the National Government and negotiated a pact with the Conservatives by which they agreed-and this revealed the measure of the Liberal decline-to run a common list of two Conservatives and one Liberal. ${ }^{23}$ The Conservatives were Waterhouse again for South Leicester and for East Leicester A. M. Lyons, a barrister ;24 the Liberals chose E. H. Pickering, a local resident who had been formerly a professor of English in Japan and was now a Unitarian minister. ${ }^{25}$ The issues appeared clear enough, whether the National Government was to be given a vote of confidence and the country to accept the cuts in unemployment benefits and wages and the abandonment of Free Trade. ${ }^{26}$ In this respect there was nothing exceptional about the campaign in Leicester. Less common perhaps was the intervention here of J. Corah, a leading hosier, who, commenting publicly on the recent improvement in local trade, attributed it to confidence in the National Government and let it be known that if the government was confirmed his firm would consider large extensions to its factories. ${ }^{27}$ Assisted also by a formidable propaganda which culminated on the eve of the election with a half-page advertisement in the local newspapers promising 'The Dawn of a New Era', ${ }^{28}$ the National candidates swept the board. None of the Labour candidates polled as many as half the votes of their opponents. ${ }^{29}$

The conditions which had secured the success of the National candidates in the last election no longer obtained in the general election of 1935 . The number of unemployed was falling, and was said to be the lowest for five years, ${ }^{30}$ the economic crisis was receding, the Liberals had left the government, and the Labour party was reviving. Although unemployment, the means test, and tariffs still provided subjects of political controversy, interest had turned now from domestic to foreign affairs. Abyssinia had been invaded, the authority of the League of Nations was at stake and Baldwin had appealed to the country to support a policy of rearmament. Lyons and Waterhouse defended their seats in East and South Leicester as National candidates. ${ }^{31}$ As Pickering, the retiring National Liberal member for West Leicester, had gone into opposition, ${ }^{32}$ he was replaced by the Hon. Harold Nicolson, who stood, somewhat controversially, as a National Labour candidate, a description by his own account indicating that he represented the left wing of the government, not that he was a Socialist; 33 his nomination was proposed by a Conservative and seconded by a Liberal. ${ }^{34}$ Labour contested all three

\footnotetext{
I9 Ibid. 3 I May I 929, 9 .

20 The poll was as follows: East: Wise 22,533, Loder I 3,80I, Lawson 8,054; South: Waterhouse I 8,343, Usher 16, 198, Purchase 8,8 I i; West: Pethick Lawrence 22,635, Evans 10,691, Hartshorn 7,617: ibid. 3 I May 1929, I 8.

21 Leic. Mercury, 25 Aug. 1931, 5.

22 Ibid. 6 Oct. I93 I, 5 .

23 Ibid. 7 Oct. I93 I, I0; I3 Oct. I93I, I.

24 Ibid. 6 Oct. I 93 I, 5 .

25 Ibid. 8 Oct. I93 I, I.

26 Ibid. I 5 Oct. I93 I, 4, 19.
}

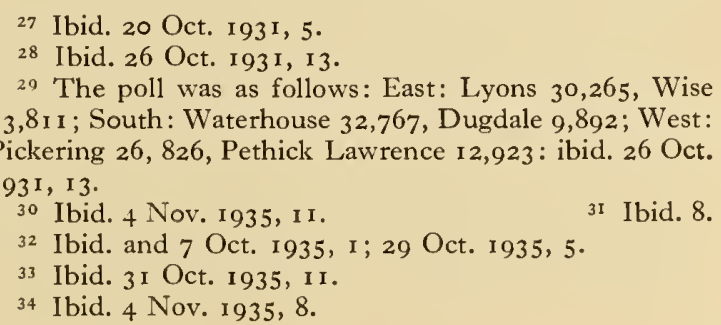




\section{A HISTORY OF LEICESTERSHIRE}

divisions, with F. Gould, a national organizer to the Boot and Shoe Union, in East, H. L. Maddock, a London barrister, in South, and a journalist, J. Morgan, in West Leicester. ${ }^{35}$ The Liberals also would have fought all three seats if negotiations for a candidate in South Leicester had not broken down at the last moment. ${ }^{36}$ In the event they had to be satisfied with fighting East and West Leicester, putting forward respectively F. Lawson again and Major E. Crawford, an advertising consultant. ${ }^{37}$ The debate lay in the main between the National candidates' advocacy and Labour's condemnation of rearmament. All parties expressed loyalty to the League of Nations: the difference between them lay in emphasis. The National candidates refused to stake everything on the League, wishing it, in the words of Harold Nicolson, to be a 'League of modesty' and not 'of violence', ${ }^{38}$ and maintained that without rearmament the country was not strong enough to risk anything but collective action in its defence. ${ }^{39}$ The Labour argument was that loyal adherence to the principles of the League would make rearmament unnecessary and that a bellicose policy, such as Morgan and Maddock attributed to Churchill, would lead to war with Germany, ${ }^{40}$ whereas a 'right way' was to 'appeal to the German people, by reasonable treatment, by granting them access to raw materials and the markets of the world'. ${ }^{4 I}$ It would seem that with regard to the League the one party lacked the faith but willed the means to make it effective, whereas the other had the faith but refused the means. Only the Liberal candidates, so far as can be judged from their speeches, were thoroughgoing in both respects; and they had little expectation of putting their views into effect. In this election the intervention or influence of other parties than the formal contestants was notable. All the candidates paid attention to the League of Nations Union, and the Peace Ballot which it had organized provided useful arguments against rearmament. ${ }^{42}$ The I.L.P., ${ }^{43}$ the Leicester Co-operative Society, ${ }^{44}$ and the national executive of the Free Church Council4s all gave their support to Labour. A less welcome intervention came from the local branch of the British Union of Fascists, who tried to disturb a few meetings; their members, however, were insignificant and their interruptions ineffective. ${ }^{46}$

The election took place in November. All three National candidates were returned but only Waterhouse in South Leicester had a comfortable victory. Lyons's majority was reduced to 2,910, and in West Leicester Nicolson beat his Labour opponent by no more than 87 votes. ${ }^{47}$ Although the representation was unchanged, the Labour party had recovered much of the ground that it had lost in $193 \mathrm{I}:$ its organizers even maintained that but for the wet weather which reduced the poll to 70 per cent. they would have gained I seat if not 2.48 The Liberals, on the other hand, continued to decline: one of their candidates suffered the loss of his deposit; the other just avoided it. 49

This was the last election before war broke out in 1939 and for ten years Leicester continued to be represented by the National members elected in I935. In 1945 the borough experienced in the fullest measure the revival that carried the Labour party into office. In the general election of that year Labour won all three seats and established a hold on the electorate that had not been substantially challenged by 1956.50 The

35 Leic. Mercury, 4 Nov. $1935,8$.

36 Ibid. 30 Oct. I 935, I ; I Nov. I 935, I.

37 Ibid. 4 Nov. 1935,8 .

39 Ibid. 28 Oct. I 935, 4 ; I Nov, I 935, 9.

40 Ibid. 2 Nov. 1935, 7 .

4 Ibid. 7 Nov. 1935, 8.

42 Ibid. I Nov. I 935, passim.

43 Ibid. 7 Nov. $1935,15$.

44 Ibid. 9 Nov. 1935, 7; 12 Nov. 1935, 10.

45 Ibid. 8 Nov. I935, I.

46 Ibid. I4 Oct. 1935, I I ; 2 Nov. I935, 6; 6 Nov. I 935 ,
47 The poll was as follows: East: Lyons 20,442, Gould 17,532, Lawson 3,509; South: Waterhouse 24,868, Maddock 13,395; West: Nicolson I 5,821, Morgan 1 5,734, Crawford 4,62 I: Leic. Mercury, i 5 Nov. I935, 6.

48 Ibid. I. 49 Ibid

50 The poll was as follows: East: T. Donovan, K.C. (Lab.), 28,41 4, A. M. Lyons, K.C. (Cons.), 1 5, 1 82, M. G. Galloway (Lib.), 6,306; South: H. W. Bowden (Lab.), 1 9,54 I, C. Waterhouse (Cons.), 18,373, T. A. Pratt (Lib.), 5,509; West: B. Janner (Lab.), 20,563, Hon. H. G. Nicolson, C.M.G. (National), 13,348, J. A. Kirby (Lib.), 4,639: Leic. Mercury, 26 July I 945, 1. 
representation, however, was modified by the Representation of the People Act (I948), which enlarged the parliamentary borough, made it once more co-extensive with the county borough (extended in 1935), and divided it afresh into four divisions, NorthEast, South-East, South-West, and North-West.5I In the general elections of I950, I95 I, and I955 the Labour party won three of these divisions and the Conservatives won South-East Leicester. ${ }^{52}$ These results in effect confirmed the election of 1945 and reflected more faithfully the proportionate electoral strength of the two great parties, since in that election the Labour candidate had won South Leicester by only a slender majority. These elections also confirmed the decline of the Liberal party. In I 950 all their candidates lost their deposits and in $195 \mathrm{I}$ and 1955 they did not contest the election. In I95 I a little over a quarter of the Liberal votes seem to have been given to the Labour party and a little over two-thirds to the Conservatives. The election of 1950 was the first in which a Communist contested a Leicester seat.

The most obvious characteristic of local politics in the last century and a quarter was a fidelity worthy of the Semper Eadem of the civic arms. Except in the period of uncertainty between the First and Second World Wars Leicester gave its political allegiance predominantly to the left. Nevertheless this constancy must be allowed to obscure neither the changes associated with the decline of the Liberal party, the Conservative revival, and the rise of Labour which distinguished the period between i 885 and I 945 from the 50 years before; nor the moderation with which its allegiance was usually tempered. The politics of the town were marked throughout by a distaste for extremes. The attempt made in the time of John Biggs to win it entirely for Radicalism failed and was followed by over 40 years of compromise which divided the representation equally between moderate and advanced Liberals; and after the decline of the Liberals the representation remained on the whole divided, though unequally, between the Conservative and Labour parties. The Labour movement only began to make effective progress when it diluted the uncompromising Socialism that coloured its earlier electoral campaigns; and, later, neither Fascists nor Communists obtained an appreciable following. Although political life was generally intense, not complacent, it was rarely violent.

The contribution of Leicester to national politics was not negligible. It took an active and sometimes a leading part in the agitation for reform, in the Anti-Corn Law League, the Chartist movement, the activities of the Liberation Society. It was closely connected with the heart of the Labour movement during its formative years. There was hardly a 'progressive' movement that did not receive a welcome and support. On the other hand, Leicester was rarely distinguished by great political initiative or outstanding political talent. Only one important movement, the Liberation Society, can be said to have had its origin there. Those of its politicians who achieved a national reputation, Thomas Cooper, P. A. Taylor, Henry Broadhurst, Ramsay MacDonald,

5I II \& 12 Geo. VI, c. 65 , schedule I.

52 The poll in 1950 was as follows: NE.: T. Donovan, K.C. (Lab.), 25,303, H. A. Taylor (Cons.), r 4,908, M. J. Moroney (Lib.), 4,257, F. Westacote (Com.), 327; SE.: C. Waterhouse (Cons.), 20,964, S. K. Lewis (Lab.), 14,823, C. A. Newport (Lib.), 5,024; SW.: H. W. Bowden (Lab.), 23,399, Mrs. Dorothy Russell (Cons.), 14,727, T. A. Pratt (Lib.), 4,720; NW.: B. Janner (Lab.), 23,505, N. Nicolson (Cons.), 15,912, R. A. Burrows (Lib.), 5,036: Leic. Mercury, 24 Feb. 1950, I; 25 Feb. I950, I. The poll in I95 I was as follows: NE.: Sir A. L. Ungoed-Thomas (Lab.), 26,209, W. Browne (Cons.), 17,478; SE.: C. Waterhouse (Cons.), 23,853, E. Taylor (Lab.), 16,225; SW.: H. W. Bowden (Lab.), 24,340, E. Wall (Cons.), 17,347; NW.:
B. Janner (Lab.), 25,1 84, W. J. Heyting (Cons.), I9, I 25: Leic. Mercury, 26 Oct. I95 I, I; 27 Oct. I95 I, 1. The poll in 1955 was as follows: NE.: Sir A. L. Ungoed-Thomas (Lab.), 22,264, Thelma Street (Cons.), 17,094; SE.: C. Waterhouse (Cons.), 26,070, E. Masters (Lab.), I4,529; SW.: H. W. Bowden (Lab.), 2I,487, Mrs. Dorothy Russell (Cons.), I6,998; NW.: B. Janner (Lab.), 22,807, F. A. Tomlinson (Cons.), 19,297: Leic. Mercury, 27 May I 955, I. Sir A. L. Ungoed-Thomas had won NE. Leicester in a by-election in Sept. 1950 held after T. Donovan had retired from politics on his elevation to the judicial bench. The poll was as follows: A. L. Ungoed-Thomas (Lab.), 18,777, H. A. Taylor (Cons.), 13,642: Leic. Mercury, 29 Sept. 1950, 1. 


\section{A HISTORY OF LEICESTERSHIRE}

were not bred in the town, and MacDonald, who alone reached high political office, had been repudiated before he attained it. It may be that Leicester was too independent, its spirit too egalitarian, its resources too evenly distributed to produce or tolerate the counterpart of a Joseph Chamberlain. John Biggs was the only man who might have aspired to such a personal ascendancy and he was thwarted by financial failure and the jealousy of his compeers. Otherwise, with the exception perhaps of Sir John Rolleston's connexion with the Conservative party, political leadership was collective rather than personal. 53

53 The most noteworthy politician of local origin was A. J. Mundella, but he left Leicester on reaching manhood and his career has no place in the political history of the borough. 


\section{SOCIAL AND \\ ADMINISTRATIVE HISTORY SINCE 1835}

I835-1860, p. 251. I860-1914, p. 275. I914-1945, p. 295. 1945-1955, p. 301.

\section{$1835-1860$}

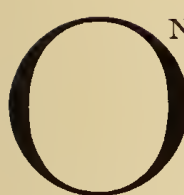

N 28 December.I835 the councillors for the borough of Leicester were for the first time elected in accordance with the Municipal Corporation Act, ${ }^{\mathrm{I}}$ and with the choice of aldermen on 29 December and finally with the election and swearing-in of the mayor on I January i 836 the reformed corporation was fully constituted and entered upon its municipal duties. ${ }^{2}$ The new borough council consisted of 42 councillors, six elected by each of the seven wards into which the borough was divided, and of fourteen aldermen chosen by the councillors. The mayor was elected by the council from among its members. ${ }^{3}$

The reforms of 1835 marked in Leicester both the rise to power in borough government of a different party and the beginning of a new period in the scope and methods of municipal activity. 'The triumph of the Liberals was singularly complete so far as control of the borough council was concerned. Of the councillors elected in I835 only four were Tories, ${ }^{4}$ and for the rest of the 19 th century the corporation was dominated by the Liberal party. The new borough council was much more broadly based than the unreformed corporation. After 1835 the council was elected by all rate-paying householders who had resided in the borough for three years or more, whereas in the old corporation vacancies had been filled by co-optation. The old corporation had been strongly Anglican ${ }^{5}$ but of the 56 aldermen and councillors chosen at the end of 1835 , 40 were dissenters and only 16 Anglicans. ${ }^{6}$ It would be inaccurate to suppose that the changes of 1835 placed the control of municipal affairs at Leicester in the hands of a class altogether new to the exercise of such power, for in general there was little difference in occupation or social status between the members of the old and the new corporations. The hosiers, the leaders of Leicester's most important industry, were well represented in both bodies; the old corporation, in 1835 , contained at least 12 hosiers out of a total of 66 members, ${ }^{7}$ while the new corporation that came into power at the beginning of $183_{3} 6$ had 19 hosiers among its 56 members. ${ }^{8}$ Of the 12 persons who held the office of mayor from I 820 to I 835,6 were hosiers, ${ }^{9}$ as were 5 of the 12 who filled the office from 1836 to $185^{\circ} .^{10}$ Both the old and the new councils included a number of

I $5 \& 6 \mathrm{Wm} .1 \mathrm{~V}, \mathrm{c.} 76$.

2 J. Storey, Hist. Sketch of Boro. of Leic. 2-3; R. W. Greaves, Corp. of Leic. I 35.

3 The original arrangement of wards, as made by the revising barristers, was at first disallowed and a new scheme drawn up. Eventually the first was allowed with some minor alterations: Rep. Com. on Boundaries and Wards of Certain Boros. pt. ii, H.C. 238 (1837), xxvii; A. T. Patterson, Radical Leic. 2 I 4.
4 Greaves, Corp. of Leic. 134. 5 Ibid. 8, 95 sqq.

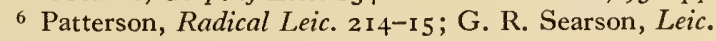
Municipal, Boro. and Co. Poll Bk. I883, 20.

7 Greaves, op. cit. 154-7: includes I retired hosier. Occupations of some members cannot be certainly identified, and the no. of hosiers may be larger.

8 Patterson, op. cit. 215.

9 H. Hartopp, R. of Mayors of Leic. I 87-93.

10 Ibid. I94-20I. 


\section{A HISTORY OF LEICESTERSHIRE}

retailers. " I The difference between them lay not in any transfer of power from one class to another, but in the fact that while the old corporation had been close and exclusive, with its membership in practice tending to be confined to a small number of families and their dependants, ${ }^{12}$ the new corporation was recruited from a much wider circle,

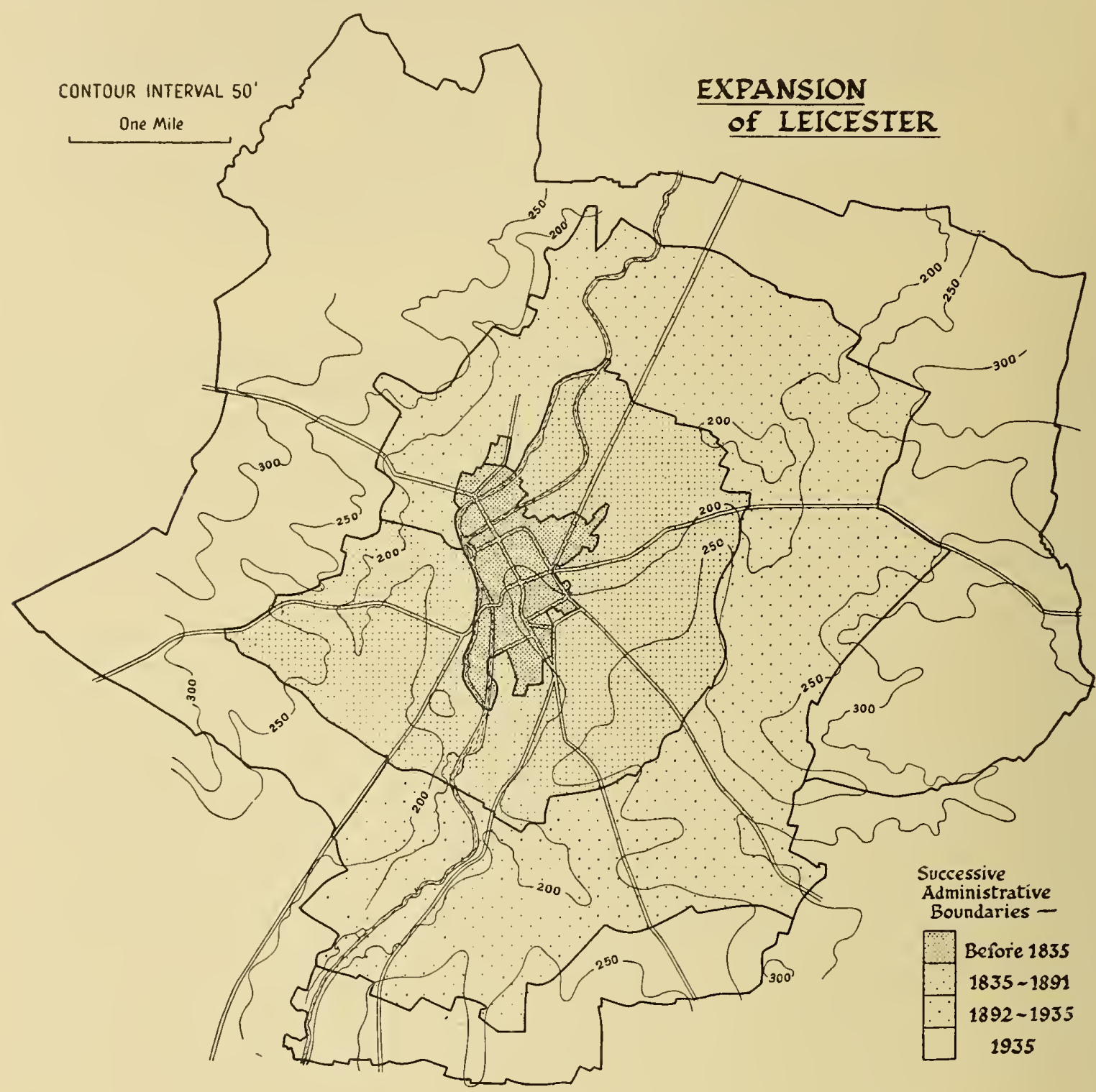

and in particular included numerous representatives of the large class of dissenting industrialists who were so important in Leicester's trade and manufactures, especially in the hosiery industry. ${ }^{13}$ Even this difference should not be exaggerated, for a certain tendency towards oligarchy was manifested by the prominence within the new corporation of members of the Unitarian Great Meeting, perhaps the most important dissenting place of worship in Leicester. The first seven mayors under the new dispensation were all drawn from the Great Meeting congregation and for more than twenty years after 1835 many of the leading members of the corporation, such men as Thomas Paget, Thomas Stokes, the brothers John and William Biggs and Joseph Whetstone, were also Unitarians. ${ }^{14}$

"I Cf. Greaves, Corp. of Leic. $154-7$ and Patterson, Radical Leic. 215.

12 Greaves, op. cit. $157-8$.

13 Ibid. 136, 143; and see above, p. 178 .

14 Patterson, Radical Leic. 2 I 4. 
The reforms of 1835 marked the beginning of great changes in the scope and the methods of municipal activity, but here too the consequences of introducing a new system of municipal government should not be exaggerated. If a notable feature of the old borough administration had been the lack of permanent officials and the entrusting of important functions to unpaid and sometimes incapable amateurs, ${ }^{15}$ the officials of the new corporation were neither numerous nor highly paid. The town clerk continued to be the borough's chief permanent officer. The new corporation, not surprisingly, at its first meeting displaced the old town clerk, Thomas Burbidge, who had been a bitter Tory partisan, ${ }^{16}$ and appointed in his stead Samuel Stone. ${ }^{17}$ Stone was a solicitor of notable ability. His Fustices' Manual became a standard work of which many editions were published and he was the author of several other books on legal subjects. ${ }^{18}$ He was, however, just as much politically committed as his predecessor Burbidge had been. Stone was one of the Great Meeting congregation and came from a family long connected with it. ${ }^{19}$ After he began to practise as a solicitor in 1826 , Stone soon came to be regarded as the special legal adviser of the Liberals in Leicester. ${ }^{20} \mathrm{He}$ played an important part in the struggle against the corporation in the years before $183^{66^{21}}$ and it was generally realized that despite his very real talents he owed his appointment primarily to his party connexions. ${ }^{22}$ Like Burbidge, Stone continued to practise as a solicitor throughout his term of office, and like Burbidge he accumulated lesser posts, becoming clerk to the borough magistrates, clerk and solicitor to the local board of health when that body was set up in I 849 , and solicitor to the trustees of the Leicester General Charities. ${ }^{23}$ Like Burbidge too, Stone was accused of exercising undue influence upon the corporation's policy. ${ }^{24}$ Though it is difficult to decide how far such charges were justified, it would be surprising if a man of Stone's ability had not exercised some influence, and it is evident that even some of the Liberals felt that Stone's position, as both town clerk and a solicitor in private practice, at times placed him in an unduly advantageous position. ${ }^{25}$ After Stone retired in 1872 , he was succeeded by George Toller, who was similarly a solicitor in private practice and closely linked with the Liberals, for he sat as a Liberal member of the council, first as councillor and then as alderman, from $185^{\circ}$ to 1872 and was twice mayor. ${ }^{26}$ In consequence for many years after 1835 the chief municipal officer was not politically an impartial servant of the borough. The town clerk's salary was fixed at $f_{4} 400$ in 1836 , but he was in addition entitled to fees from the corporation for legal business. ${ }^{27}$ The staff of his department was very small by later standards and as late as 1874 numbered only three. ${ }^{28}$

The control of municipal finance, very defective under the old corporation, was from I 836 in the hands of the council's finance committee, which was presided over by Joseph Whetstone. ${ }^{29}$ Apart from the committee, the care of the borough's finances was in the hands of the borough treasurer and the borough accountant. In I836 Samuel Kirby (d. I 854) was appointed borough treasurer; ${ }^{30}$ he was a partner in one of the local

15 See above, p. I6o.

I6 For Burbidge see Greaves, Corp. of Leic. II7-I8, 1 25, I 30, I 3 .

17 Storey, Boro. of Leic. 3.

18 Among his other works were The Town Councillor's Manual and The Education Act Manual: A. Fielding Johnson, Glimpses of Anc. Leic. (2nd edn. 1906), 380-1.

19 A. H. Paget, Epitaphs in Great Meeting, Leic. I61, 201 ; Reminiscences of Eliza Spurrett (1938), 9-10, I6-17.

20 Leic. Chron. and Leics. Mercury, I 4 Feb. I874, p. I.

2I Patterson, Radical Leic. 2 I 4.

${ }_{22}$ Leic. Chron. and Leics. Mercury, I4 Feb. I874, p. I0.

23 Storey, Boro. of Leic. 260; White, Dir. Leics. (1846), 74; Ret. of Salaries of Officers of Corp. of Leic. for 1857 , $I_{858}, I_{59}, 2-3$ (Leic. City Ref. Libr., Pamphlets $\mathrm{O}_{3}$, xiv); Examination of Thos. Burbidge, Esq., 5-9 (Pamphlets

O 3, i).

${ }_{24}$ Greaves, Corp. of Leic. 125; L. Brown, Revenge of Whigs, 2 I, 22 (Leic. City Ref. Libr., Pamphlets O I, xiii).

25 See indirect attack on Stone by Joseph Whetstone:

Leic. Inl. 22 Jan. $1849,3$.

${ }^{26}$ R. of Mayors of Leic., 210-2; Leic. Chron. and Leics. Mercury, I 7 Oct. I 885; Storey, Boro. of Leic. 260.

27 Ret. of Salaries of Officers of Corp. of Leic. for 1857 , $I 858, I 859,7$.

28 Storey, Boro. of Leic. I75.

29 Patterson, Radical Leic. 2I7; Rep. of Finance Cttee. appointed by Council ( 1836 ), (Leic. Ref. Libr., Pamphlets $\mathrm{O} 2$, xiii).

30 Storey, Boro. of Leic. 259. 


\section{A HISTORY OF LEICESTERSHIRE}

banks, the head of which was Thomas Paget, first mayor of the reformed corporation. ${ }^{3 I}$ Paget himself succeeded Kirby and was followed by his son T. T. Paget. ${ }^{32}$ It appears that during the Igth century the borough treasurer was not one of the corporation's permanent officials, but rather its banker, holding the corporation's funds and handling some of its financial business upon terms much the same as those which normally prevailed between bankers and their clients. He received no salary but was allowed to keep a balance of $£_{5}, 000$ free of interest. ${ }^{33}$ It is no doubt significant that after $\mathrm{I} 835$ the borough's finances ceased to be dealt with by the local banking firm of Mansfield and Babbington, which had acted for the old corporation ${ }^{34}$ and had strong Tory connexions. ${ }^{35}$ The actual keeping of the council's accounts was done by the borough accountant who as late as 1860 was assisted only by one part-time office-boy; ${ }^{36}$ from I 837 to 1849 the accountant was George Bown, a Radical. ${ }^{37}$

For the sake of economy the new corporation abolished a number of lesser posts. Of these the most important was that of the land steward, who up to 835 had managed the corporation's estates; his functions were taken over by the estates committee of the council. ${ }^{38}$ The offices of the mace-bearer, four sergeants-at-mace, two bellmen, town crier, six town waits, beadle, and mole-catcher were abolished. ${ }^{39}$ In those minor posts that survived the existing officials were mostly replaced by supporters of the triumphant Liberal party. ${ }^{40}$ Although the corporation's officials were relatively few in 1836 , the old Town Hall was inadequate to accommodate them and they had to be provided with offices in various parts of the town. ${ }^{4} \mathrm{I}$

The scope of the new corporation's activities also was at first very restricted and it was not until some ten years after 1836 that large measures of town improvement were taken in hand. This was partly because the council's powers to effect improvements were very limited, but chiefly because the financial position of the borough in ${ }_{1} 8{ }_{3} 6$ was so difficult that no expensive schemes for dealing with its problems could be contemplated. The finance committee, appointed by the corporation early in 1836 to investigate the extent of the borough's liabilities and resources, discovered that the corporation's total known debts were $£ 22,700$, including a mortgage on part of the South Fields of fio, 000 which the old corporation had raised to cover its heavy outlay in bribery and other political expenses in the election of 1826 , and another loan of $£_{1} \mathrm{i} 0,000$ secured on the borough rates, which had been raised to defray the cost of building a new gaol.42 How serious a burden these debts were may be seen from the fact that the corporation's income in $\mathrm{I} 836$ was about $£ 3,500$ from its estates and about $£ \mathrm{I}, 200$ from rates. ${ }^{43}$ In addition to this heavy debt, the new corporation was faced with a large claim for compensation for loss of office from 'Thomas Burbidge, the former town clerk, and with claims by charities for sums which had been held in trust by the old corporation. After long and expensive litigation, the borough was obliged to pay substantial compensation to Burbidge and more than $f 7,000$ to the charities. ${ }^{44}$ The old corporation had also put

\footnotetext{
${ }^{31}$ V.C.H. Leics. iii. $5^{1}$; Rep. of Finance Cttee. (1836), $6-7$.

${ }^{32}$ Storey, Boro. of Leic. 259.

${ }_{33}$ Boro. of Leic. Ret. of Salaries of Officers (1888), 4-5 (Leic. City Ref. Libr., Pamphlets $\mathrm{O}_{3}$, xiv); Ret. of Salaries of Officers of Corp. of Leic. for $1857,1858,1859,2,3,6$, (Leic. City Ref. Libr., Pamphlets $\mathrm{O}_{3}$, xiv).

${ }^{34}$ Greaves, Corp. of Leic. I40.

35 Ibid. I 4 ; Patterson, Radical Leic. 89.

36 Leic. Fnl. 27 Jan, 1860, p. 8.

${ }^{37}$ Patterson, op. cit. 70, 74, 221 ; Storey, Boro. of Leic. 263.

${ }^{38}$ Rep. Finance Cttee. ( $\left(8_{3} 6\right), 5,6-7$.

39 Ibid. 7-8; Leic. Town Hall Rec., Hall Bk. 1835-9, ff. $22-27,55$.
}

40 Patterson, Radical Leic. 221; White, Dir. Leics. $(1846), 7$ I. These included the officials of the boro. gaol and markets, keepers of the Town Hall and Exchange, inspector of nuisances, 2 messengers, and 3 court bailiffs: White, op. cit. 75

${ }_{41}$ The town clerk's dept. was for some years housed in a few small rooms in New St.: Storey, Boro. of Leic. 175; White, Dir. Leics. (1877), 390. The boro. accountant at one time operated from a room in Silver St.: Leic. $¥ n l$. 27 Jan. 186o, p. 8; Leic. Trade Protection Soc. Dir. Leic. (I 870$), 54$.

${ }_{42}$ Rep. Finance Cttee. (1 836), I3, 14.

43 Leic. Town Hall Rec., Hall Bk. $1835-9$, ff. 39, 68.

44 Patterson, Radical Leic. $218-20$. 
its successor at a disadvantage by granting 15 -year leases of much of the borough property. 45 'The town's financial circumstances were consequently difficult in 1836 and the only policy conceivable was one of strict economy and careful management. The new corporation decided to liquidate its debts by sales of land. ${ }^{46}$ It was estimated in I 836 that the abolition of various minor offices and the cutting-off of the salary hitherto paid to the mayor and of sundry pensions would save the borough $\oint_{\mathrm{I}} \mathrm{I}$, 00 a year. ${ }^{47}$ Small economies were effected by discontinuing the subscriptions previously paid to the infirmary and to Leicester races and the allowances made to the Anglican clergy in the town..$^{48}$ As it had been decided to put an end to the civic feasts which had been a feature of the old régime, the town's large stock of plate, crockery, cutlery, glass, and table linen was sold, and in the momentary enthusiasm for clearing away everything connected with the pomp, carousals, and corruption of the unreformed corporation the town's I th-century great mace, with some lesser pieces of civic regalia, was also auctioned. ${ }^{49}$ The new corporation's financial policy was successful in relieving the town from its pecuniary embarrassments. In the twenty years after 1836 , more than $£, 50,000$ was raised by the sale of 62 acres of corporation land and a further $\oint_{1}$ I , 60o was obtained for royalties paid for the working of clay on the borough estates. ${ }^{\circ}$ By I 839 only $£ 7,000$ of debt remained unpaid ${ }^{51}$ and in $\mathrm{I} 84 \mathrm{I}$ the last debts inherited from the old corporation were liquidated. ${ }^{52}$ Despite considerable sales of land the income from the borough estate was by good management increased; in the year ending I September 1845 the estate produced a gross revenue of $£ 3,200$, compared with one of $£_{2}, 906$ ten years earlier. ${ }^{53}$

This financial stringency greatly limited the activities of the new corporation for the first ten years of its existence and no far-reaching plans of town improvement could be carried out. One urgent problem which had much impeded the old corporation had been solved by the Municipal Corporations Act, under which the liberties, for long the cause of so much dispute, ${ }^{54}$ were finally included in the borough, so that, whereas the authority of the old corporation had been excluded from certain important sections of the town, the new corporation controlled and could levy rates on the whole urban area. ${ }^{55}$ Another problem which was urgently requiring solution by 1836 , that of policing the town, was promptly dealt with. Early in 1836 the borough council appointed Frederick Goodyer, an officer of the Metropolitan Police who had been recommended by the Home Office, as superintendent to organize a force, originally consisting of 50 men, on the lines of the London police. ${ }^{56}$ The new police were a considerable burden on the corporation's finances, costing in the period immediately after 1836 about $£ 3,000$ a year, ${ }^{57}$ the heaviest single charge on the town's income. The police headquarters were at the Town Hall, where a house was built for the head constable in $18{ }_{3} 6 . .^{8} \mathrm{~A}$ borough fire brigade, consisting of a superintendent and ten men, also came into existence, although it was less important than the Midland Counties Fire Office Force, which consisted of a Superintendent, two subordinate officers, and 28 firemen. ${ }^{59}$ As regards street

45 Rep. Finance Cttee. (1836), 12, 13.

46 Leic. Town Hall Rec., Hall Bk. $1835-9$, f. 39.

47 Ibid.

48 Ibid., f. 29.

${ }^{49}$ Cat. of Anc. and Modern Plate etc. of Corp. of Leic. sold Fan. and Feb. 1836 (Leic. City Ref. Libr., Pamphlets O I , xviii); W. Kelly, Gt. Mace of Leic. 39-43.

50 Rep. of Town Clerk as to Estates of Boro. of Leic. (1856), 3, 5, 6 (Copy in Leic. City Ref. Libr.).

5I Patterson, Radical Leic. 220.

52 Leic. Inl. 22 Jan. I 849 , p. 3 .

53 Rep. as to Town Estates ( 1856$)$, 6; White, Dir. Leics. (1846), 72 .

\footnotetext{
54 See above, pp. I6, 57, 129.

55 For map and details of boundaries see Rep. Com. on Boundaries and Wards of Certain Boros. pt. ii, H.C. 238 (1837), xxvii.

56 Patterson, Radical Ltic. 222-3.

57 In the financial year I $837-8$ the cost of the police was $£ 2,556$, out of a total municipal expenditure on general account of $f 6,928$ : Abstract of Accts. of Treasurer of Boro. of Leic. ( $1837-8), 8,9$, I I ; ibid. (I $838-9$ ), 8 ; ibid. (I83940), 9.

${ }_{58}$ T. H. Fosbrooke and S. H. Skillington, Old Tozon Hall, Leic. $65^{-66}$.

59 T. Cook, Guide to Leic. (I843), 25.
} 


\section{A HISTORY OF LEICESTERSHIRE}

lighting, another function very inefficiently performed by the old corporation, the Leicester parishes placed themselves under the provisions of the Lighting and Watching Act of $1833^{60}$ so far as it concerned street lighting. ${ }^{61}$ As a result, the street lighting seems to have improved, for in 1846 it was noted that the town was well lighted by gas. ${ }^{62}$

More extensive measures of town improvement had to be deferred. In particular the new council could do little to cope with the town's growing difficulties over health and sanitation. The council's powers under the Municipal Corporations Act did not enable it to deal with such matters, and when in I839 it was proposed to set up a committee of the council to consider obtaining a town improvement Act the proposal was defeated. The opposition to it was led by Thomas Paget and Joseph Whetstone and was probably moved by a desire to avoid any strain on the borough's still precarious finances. ${ }^{63}$ The project was again brought up in I 840 but without success ${ }^{64}$ and it was not until i 845 that the idea was seriously considered. ${ }^{65}$

Inside the borough the parishes still continued to exist after I 835 as local government units and they retained several important functions. They were responsible for the repair and lighting of highways ${ }^{66}$ and they were also the only public bodies in Leicester which made any provision of sewers, inefficient though these were. ${ }^{67}$ The parishes also retained the right to levy compulsory church rates and this was the cause of a bitter dispute. In 1836 Protestant dissenters in Leicester decided to offer resistance to the payment of church rates. ${ }^{68}$ In three parishes, St. Nicholas's, All Saints', and St. Mary's, the vestries were controlled by dissenters and decided against the levy of church rates. ${ }^{69}$ In St. Margaret's, the largest and most populous parish, the select vestry ${ }^{70}$ levied a church rate in 1836 and proceedings were taken against $2 \mathrm{I}$ dissenters who failed to pay. ${ }^{.1}$ In 1837 the dissenters obtained control of the select vestry which for the future declined to authorize the levy of a church rate. ${ }^{72}$ An attempt made by the vicar to coerce the vestry by proceedings in the Queen's Bench was unsuccessful.73 In St. Martin's parish the controversy was more prolonged. Until i 849 the vestry there was controlled by Anglicans who favoured compulsory church rates. Many dissenters in the parish refused to pay the rates and between 1845 and 1848 inclusive there were 87 prosecutions for non-payment. ${ }^{74}$ Especially strong indignation was aroused among dissenters by the case of William Baines who was imprisoned for some months in 1840-I for his refusal to pay the church rate. ${ }^{75}$ The levying of rates in St. Martin's parish and proceedings against dissenters for refusing to pay continued until the opponents of compulsory church rates obtained a majority in the parish vestry in 1849 . From then on no church rates were levied in Leicester. ${ }^{76}$

One other important duty, the administration of poor relief, rested not upon the council but upon the board of guardians. At Leicester this was the first of the bodies set up in the Igth century to perform a specialized function of local government. Under the Poor Law Amendment Act of $1834^{77}$ a board of guardians was set up in 1836 to administer poor relief throughout the Leicester Union, which originally comprised the parishes of St. Margaret, St. Martin, St. Mary, St. Leonard, and All Saints with the

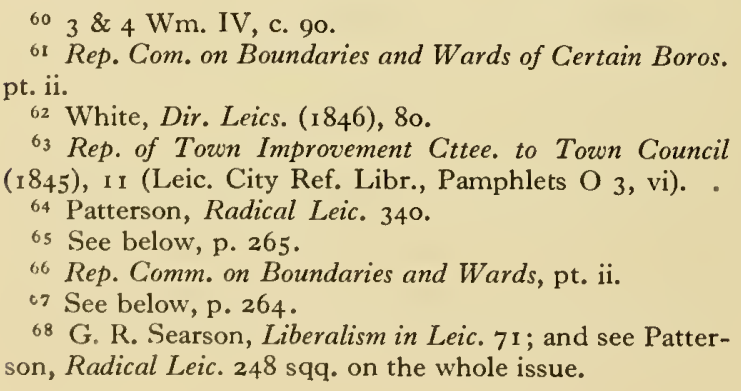

69 Searson, op. cit. 81 .

70 For the select vestry see below, p. 357.

71 Searson, op. cit. 72.

72 Ibid. 73 .

73 Ibid. $82-83$.

74 S. Stone, Statistics of Crime in Boro. of Leic. I8448 , 15 (Copy in Leic. City Ref. Libr.).

75 Searson, Liberalism in Loic. 92-96; Patterson, Radical

Leic. $25 \mathrm{I}-4$.

76 Searson, op. cit. 146.

$774 \& 5$ Wm. IV, c. 76. 
two small liberties of the Newarke and Castle View. ${ }^{78}$ Two small extra-parochial areas, Black Friars and Augustine Friars, remained outside the union until the end of I86I, and until that date there seems to have been no provision for poor relief in either.79 The election of guardians was, from the first, conducted on party lines. The system of plural voting for such elections, established by the act of 1834 , was very advantageous to the Conservative party, as it allowed owners and occupiers to have additional votes, up to a maximum of twelve, in proportion to the rateable values of their property. The Conservatives were thus enabled to maintain a majority on the board of guardians almost continuously from I 836 to $1845 .{ }^{80}$ Just as the Liberals used their control of the town council to fill municipal offices with their supporters, so the Conservatives used their dominance of the board of guardians to provide posts for their own political sympathizers. When first established the board appointed as its clerk an employee of Thomas Burbidge. In 1840 this clerk died and Burbidge himself was appointed to the vacant post, and when the Poor Law Commissioners refused to agree to his appointment, the guardians chose his son Joseph as clerk. ${ }^{8 I}$

Under the new system of poor relief introduced by the Act of 1834 the civil parish remained the unit for the levying of the poor rate, which in Leicester continued to be collected by the overseers of the poor in each parish or liberty, but the administration of the poor law was controlled by the board of guardians for the whole union under the supervision of the central Poor Law Commissioners. In 1838 the Leicester guardians built a new workhouse to accommodate 400 persons, ${ }^{82}$ on a rather elevated site which at that date lay just outside the town's built-up area. ${ }^{83}$ Perhaps because of their predominantly Conservative character, they were not at first in favour of the curtailment of out-relief or of a strict imposition of the workhouse test, and in consequence the workhouse was built at the least possible expense, though its size and cost nevertheless aroused unfavourable comment. ${ }^{84}$ Little attempt was made to put into practice the principles of the new poor law and, although in 1837 the Leicester hosiery industry was in a more than usually depressed state and large numbers of unemployed had to be relieved, ${ }^{85}$ the workhouse test was not enforced. At the end of 1837 , however, the guardians resolved to introduce the new system by withholding out-relief. At the same time they decided to enforce the separation of the sexes in the three existing parochial workhouses which, pending the completion of the new union workhouse, were still in use. ${ }^{86}$ These measures met with so much opposition from the working classes of the town that the guardians felt obliged to go on paying out-relief. ${ }^{87}$ Despite this concession, agitation against the new poor law continued ${ }^{88}$ and the full application of the workhouse test was for some years avoided. The winter of $\mathrm{I} 84 \mathrm{I}-2$ was one of severe depression in the hosiery industry ${ }^{89}$ and in January 1842 5,000 people in Leicester were being relieved by the guardians.90 Out-relief continued to be given but the guardians attempted to impose a labour test for those of the persons being relieved who were able-bodied, and this, together with the feeling that the relief given was not enough, led in the spring of 1842 to serious riots, which were only suppressed with the aid of troops.91 Meanwhile, in the hands of Joseph Burbidge, the guardians' affairs fell into a state of confusion

${ }^{78}$ Fielding Johnson, Glimpses of Anc. Leic. 382.

79 R. G. Waddington, Leic.: The Making of a Modern City, 139; Searson, Leic. Municipal, Boro. and Co. Poll Bk. 1883,73 ; and see below, pp. $343-4,387-8$.

80 Patterson, Radical Leic. 225-7; Searson, Leic. Municipal, Boro. and Co. Poll Bk. $1883,49-58$.

8I Patterson, op. cit. 226-7.

82 Leic. Union Rep. (1 $85^{8}$ ), 3 (Leic. City Ref. Libr., Pamphlets O I, xxiii).

83 Patterson, op. cit. 295; Fielding Johnson, Glimpses of
Anc. Leic. 397 ; see also below, p. 356 ; the site is now occupied by Hillcrest Hosp. in Sparkenhoe St.

84 Fielding Johnson, loc. cit.; B. G. Chamberlain, Rep. as to Admin. of Poor Law in Leic. Union (186I), 6 (Leic. City Ref. Libr., Pamphlets $\mathrm{O}_{3}$, xxi).

85 Patterson, Radical Leic. 298; and see p. 303.

86 Patterson, op. cit. 295. ${ }_{87}$ Ibid.

88 Ibid. 296.

90 Patterson, Radical Leic. 327.

91 Ibid. 328 ; and see above, p. 2 I3. 


\section{A HISTORY OF LEICESTERSHIRE}

reminiscent of the administrative methods of the unreformed corporation. In 1843 an investigation into the union's expenditure disclosed some corruption by officials and a general laxness in keeping and auditing accounts. As a result Joseph Burbidge, the board's auditor, the workhouse master, and two relieving officers were all dismissed. ${ }^{92}$ The discredit which this scandal brought upon the Conservatives, together with a close scrutiny of the voters' list by the Liberals, which resulted in the disqualification of many Conservative votes, led to a Liberal success in the election of guardians in 1845 , and for the future the Liberals were in a majority on the board. ${ }^{93}$

In the winter of $1847-8$ distress and unemployment in the town again became more acute than usual. During the six months ending at Lady Day I 848 I 9,000 persons were relieved out of a population approaching 60,000 , and a sum of over $\oint_{17}, 000$ was expended in relief.94 The total expenditure on relief for the whole of 1848 was over $£ 32,000.95$ The guardians attempted to enforce a labour test and opened stoneyards where able-bodied men seeking relief were put to work. The physique of frameworkknitters was proverbially poor and many of the men proved to be unequal to strenuous work. ${ }^{96}$ The labour test caused so much discontent that in May I 848 the unemployed broke out into riots which lasted for several days. 97 The large expenditure on poor relief, the difficulty of supervising men performing test labour, and the belief that many who obtained relief were actually doing some paid work had earlier led the guardians to appoint a committee to consider policy for the future. ${ }^{98}$ The committee decided in favour of the workhouse test and in order to enable this policy to be carried out it advised the building of a larger workhouse. ${ }^{99}$ These proposals met with widespread opposition, and when the elections were held for the new board of guardians in April I 848 all those who were in favour of a strict application of the workhouse test lost their seats, and a new board, pledged to resist the principles of the new poor law, was elected. ${ }^{1}$ Distress continued to be serious and the expenditure upon relief correspondingly high. In the year ending 25 March I849 a sum of over $£ 26,000$ was spent and nearly one in ten of the town's population was relieved. ${ }^{2}$ These facts forced the guardians to reconsider their views and they gradually became more favourable to the idea of enforcing the workhouse test. 'Towards the end of 1848 it was decided to build a larger workhouse as a preliminary to putting into force the principles of the new poor law. The new building, capable of accommodating I,000, was opened in September I $8_{5} \mathrm{I}$ and the workhouse test for all applicants for relief was introduced gradually. ${ }^{3}$ The years from I 85 I to I 856 saw no particular depression in Leicester but expenditure upon poor relief was never less than $£_{1} 5,000$ in any year. 4 When in the winter of $1857-8$ distress again became more severe, the guardians applied the workhouse test to nearly all applicants for relief. In case the workhouse should become full, extra accommodation was hired, though it was never needed. ${ }^{5}$ Out-relief continued to be given to a small number of married men whose families could not be conveniently removed to the workhouse; in such cases a labour test, generally of picking oakum, was imposed, and the maximum number of men employed at any one time was $73 .{ }^{6}$ The guardians were pressed to provide outrelief on a large scale but refused, 7 and this policy of refusing out-relief in all except a few cases was certainly successful in reducing expenditure. How effectively the new

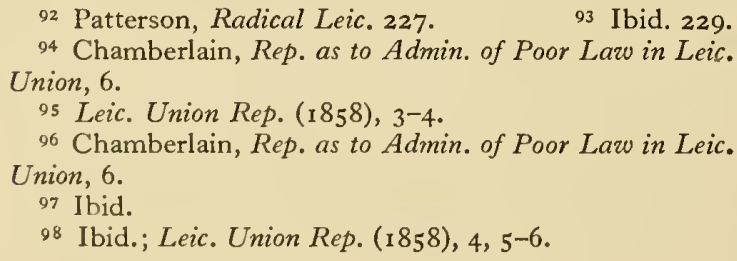


policy deterred persons seeking relief can be seen from the fact that in the period from I I January to 20 February I 858 , when distress was very severe, I,378 persons applied for relief and were offered accommodation in the workhouse, but only 202 accepted. ${ }^{8}$ Just over 3,000 were relieved during the last quarter of 1857 and the first quarter of I 858 , compared with just over i 9,000 in corresponding periods of $\mathrm{I} 847$ and I $848,{ }^{9}$ and expenditure on relief for the year ending 25 March I 858 was $£ 2 \mathrm{I}, 600$, compared with over $£ 32,000$ for the year ending in March I848. ${ }^{\circ}$ 'The Leicester guardians considered that these results proved the superiority of their policy over that which had been pursued earlier, and complacently compared their own activities with the conduct of the Nottingham guardians, who had continued to give out-relief on a large scale. ${ }^{\text {I I }}$ It is probable, however, that the depression of $1857-8$ was less severe at Leicester than that of ten years earlier. Had distress on the same scale as developed in I $847-8$ occurred again, the guardians could hardly have avoided giving relief outside the workhouse, but the absence during the second half of the I9th century of any depression as serious as that of $1847-8$ saved their policy from being put to a really severe test.

The recurrent periods of depression which affected Leicester during the first half of the I9th century were due immediately to fluctuations in the activity of the hosiery manufacture, from which a large proportion, probably a majority, of Leicester's inhabitants obtained their livelihood. The persistence throughout the first half of the century of under-employment, which sharpened in periodic crises to acute and widespread distress, made poor-law policy an issue which affected the lives and at times aroused the passions of so many of the town's population. Other industries were not altogether lacking. In 1835 Leicester already had two important iron-foundries and the beginnings of an engineering industry which was one day to be a main source of the town's prosperity. ${ }^{\mathrm{I} 2}$ The industry expanded rapidly in the middle of the century, though for long it was chiefly confined to supplying machinery for the making of local products, hosiery, footwear, and elastic web. ${ }^{13}$ In I 835 the manufacture of boots and shoes was just beginning to grow into an important industry in the town. During the middle years of the century it grew in size until by I 86 I it was employing 2,700 workers. ${ }^{14}$ The spinning of worsted yarn was also of some importance. It had long been extensively used in the Leicester hosiery industry, ${ }^{15}$ but the spinning of woollen yarn had only been carried on in the town since about $1820 .{ }^{16}$ Both types of yarn were already being produced in factories by $1835 .{ }^{17}$ The production of elastic web was begun at Leicester in 1839 and rapidly expanded. By I86 I there were twenty firms engaged in its manufacture, but the industry never became a major one. ${ }^{18}$

The hosiery industry was by far the most important single source of employment in the town. In 1833 there were said to be 28,000 persons, including many children, employed in this industry in Leicester, which had a population of nearly 40,000 in I 83 I. ${ }^{\text {I }}$ In I 835 the hosiery manufacture was depressed and stagnant. Earnings were low, though they varied between the different branches of the industry, and there was much unemployment. The prosperity of the industry fluctuated and there were periods of exceptional depression in I 837, I $839-42$, I $847-8$, and I $857-8,{ }^{20}$ although even when times were better employment was irregular and wages were low. ${ }^{21}$ In considering the general condition of Leicester it must be borne in mind that from the closing years of the Napoleonic Wars until about I 860 a large proportion of the town's inhabitants were

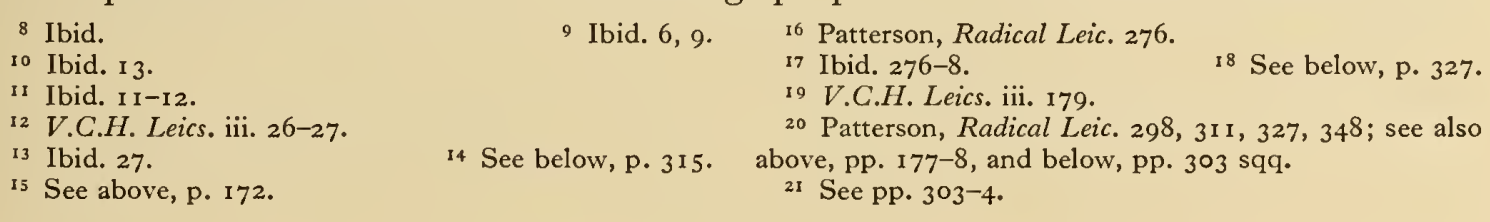


employed in an industry which even in its more prosperous periods was hardly able to provide them with a reasonable living.

The chronic depression which lay upon Leicester's chief industry did not prevent a rapid growth of the town's population from not quite 40,000 in I 83 I to over 60,000 twenty years later and to 68,000 in I $86 \mathrm{I} .{ }^{22}$ This expansion must have been largely due to the growth of the boot and shoe manufacture and, on a rather smaller scale, of the engineering and elastic-iveb industries, and it was assisted by the construction of new railway connexions. In I 840 the completion of the Midland Counties Railway linked Leicester with Nottingham and Derby to the north, and through Rugby to London in the south. ${ }^{23}$ Later lines joined Leicester and Peterborough in 1848 , and Leicester and Burton on Trent in I 849 , and in I 857 gave direct access to London through Market Harborough, Kettering, and Hitchin. ${ }^{24}$

Building was also going on rapidly in this period.25 The new corporation at first continued the sale of the South Fields land in building lots in order to pay off the heavy debts left by its predecessor. ${ }^{26}$ This policy was continued in the estate near the Aylestone and Welford roads until after $185^{\circ}$, but in general from then on the corporation ceased to make large and regular sales from the South Fields estate. From the first the new estates committee drew attention to the need to make conditions in the sales which would ensure high standards of building, ${ }^{27}$ and from I 850 the corporation had to approve the plans for each new factory, house, workshop or street. ${ }^{28}$ The earlier building parallel to New Walk had been of good quality but a group of streets of much poorer character had been built on privately owned land between the New Walk and London Road. The hosiery merchants, who occupied the streets laid out $c$. I8I 4 at the lower end of New Walk, were beginning to build factories and warehouses on land which not long before had been regarded as the best residential area in the town. New Street, which had served that purpose in the late 18 th century, was by 1835 already the preserve of the legal profession, which it still remains. ${ }^{29}$ Consequently the best new houses of the years I 830-50 were scattered along Granby Street and London Road. Those who lived there, some of the members of the corporation among them, naturally wished to see the upper part of the New Walk saved from the invasion of squalid streets and ramshackle houses. It was at least partly the fear that land values might suffer further degeneration that led the Corporation to oppose so strongly in 1836 the building of the Midland Railway through the South Fields. ${ }^{30}$ The land allotted to the freemen in the South Fields still retains much of its identity, though cut through by the railway. The Freemen's Meadow remained a common pasture until it was acquired by the city corporation in 1920 as the site for an electricity generating station. ${ }^{31}$ In spite of power stations, the main line of the Midland Railway, and some domestic building, the existence of parks, allotments, and other open spaces still proclaim the identity of the South Fields and their long association with the borough. The conditions of sale imposed by the borough strengthened the effect of the nature and position of the area in making the residential district built up in the more distant part of the South Fields a rich and middle-class one. Stoneygate, which stretched from here over the borough boundary into Knighton, was the wealthiest residential area of the town, while a middle-class district began to grow up on the rising ground known as Highfields. ${ }^{32}$

22 V.C.H. Leics. iii. 179.

23 Ibid. I $15-16$.

2s See maps, pp. 26I, 275. This paragraph and the next were contributed by Mr. C. T. Smith.

${ }^{26}$ Leic. Town Hall Rec., Hall Bk., 19 Aug. 1836.

27 Ibid.

${ }^{28}$ Under the Public Health Act, II \& I2 Vic. c. 63; see

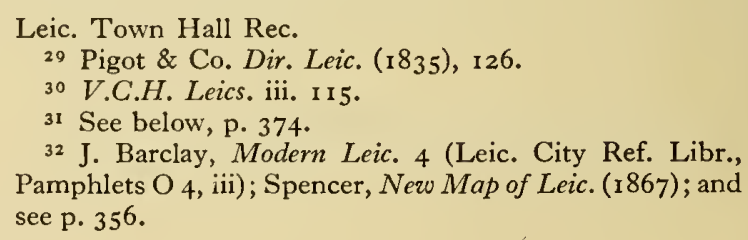


The most extensive area built over between 1835 and 1860 lay in the east of the borough in St. Margaret's parish, where many new streets were built along both sides of the roads leading to the villages of Belgrave and Humberstone, and along the main London road. The development of housing in this district was a continuation of the

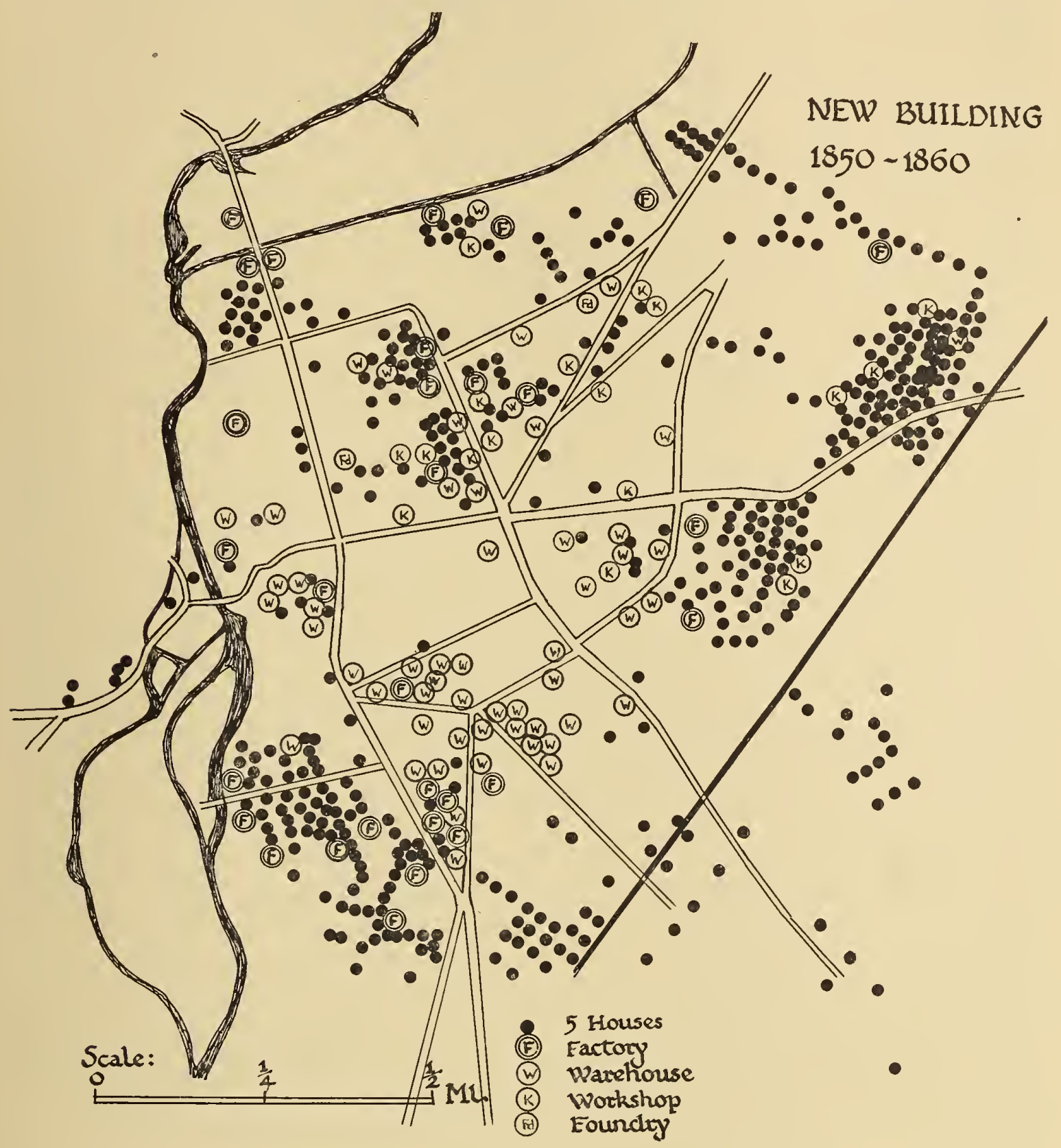

expansion which had taken place there in the years before $1835 .{ }^{33}$ Between 1850 and I 860 more than 600 houses were thrown up on both sides of Humberstone Road and it was this area that succeeded the canal region as the main area of new building for artisans and labourers. ${ }^{34} \mathrm{It}$ is tempting to see in this the attraction of the railway, which ran through this district, but since South Wigston, and not Leicester, was the important junction the railway line did not in fact strongly attract labour. Nor did it attract much industry in the I840's and 1850's, since the staple trades were not yet drawn into the factory system. To build along Humberstone Gate in the gap left between the railway

33 See below, p. 356; cf. Ellis, Map of Leic. (1828)

34 Leic. Town Hall Rec. and Spencer, New Map of Leic. (1867). 


\section{A HISTORY OF LEICESTERSHIRE}

and the built-up area was the obvious course open to the speculative builder, and the most important of the new streets had, in fact, been contemplated for twenty years before they were built. ${ }^{35}$ The large suburb which thus grew up in St. Margaret's parish was from the point of view of housing conditions and sanitation the worst part of the town, but almost as bad were two other areas largely built up between $18{ }_{3} 6$ and I86I, one along the east bank of the Soar in the Newarke and St. Mary's parish, the other on the opposite bank of the river, around West Bridge. ${ }^{36}$ Some of the land in the first of these two areas had been allotted to private owners on the inclosure of South Fields and was sold for building as the demand for land arose. Land held by the borough council was sold piecemeal for building from 1839 , without, in this case, stipulation as to building standards. ${ }^{37}$ It was an area in which the warehouses and workshops of the hosiers and the boot and shoemakers tended to expand from their earlier centres in Southgate Street and the lower end of New Walk. ${ }^{38}$ Thus Welford Road became the axis along which another working-class area began to emerge. The process of growth was by no means a simple outward movement on an ever-expanding periphery. Earlier building had left raw gaps in the close ranks of streets and houses, and these were only slowly filled in. One district within the old borough, the extra-parochial place called Blackfriars, had been largely built up in the very early igth century and there too housing and sanitation were deplorable. ${ }^{39}$ Part of the activity of the years $1850-60$ was still concerned with filling in the area between Belgrave Gate and the canal, and much of this late building here and in the Pingle between Northgate Street and the River Soar stood on the alluvium which was so often flooded in winter. There was still a good deal of building to go up in the ancient quarter of walled Leicester between the High Street and Sanvey Gate. In the years after I $85^{\circ}$ it was filling up, and the orchards and gardens which had stood there for centuries were slowly disappearing. William Gardiner described it vividly about 1838 , and wrote that it had earlier been vacant ground composed of tracts 'enclosed in every direction by walls made of mud and straw, forming dark and gloomy lanes'. He went on, 'Within the last twenty years the mud walls have begun to disappear and houses for working people give a more cheerful aspect to this solitary part of the town'. 40

Though the new working-class portions of the town were badly sited, the houses themselves on the average seem to have been rather better than those built in other industrial towns at the same period. In the middle of the Igth century some 'back-toback' houses, consisting of one room on the ground floor and one room above, were to be found, mostly in the northern part of St. Margaret's parish, ${ }^{41}$ and there were some houses of a worse character, like those containing a single small room and made out of converted pig-sties, mentioned in 1849 , which were still inhabited in 1855 , when they were condemned. ${ }^{42}$ Cellar dwellings were unknown, however, no doubt because the waterlogged soil on which so much of the enlarged town stood made anything of the sort impossible. ${ }^{43}$ By about I 840 the majority of working-class houses were two-storied, with two rooms on each floor; the newer ones were, at least by the standards of the time, satisfactory. ${ }^{44}$ It was said in 1845 :

35 Ellis, Map of Leic. (1828).

36 See pp. 347,383 ; W. Ranger, Rep.to Gen. Bd. of Health on Public Inquiry into Sewerage of Leic. 7 (Leic. City Ref. Libr., Pamphlets O 2, vii); Barclay, Modern Leic. 4, 5, 8, 9 ; 2nd Rep. Com. on Health of Touns, App. (2) [610], p. 267, H.C. ( 1845 ), xviii. 37 Leic. Town Hall Rec.

38 See I 9 th-cent, directories, e.g. Wright, Dir. Leic. (1882), 82-83.

39 Ranger, Rep. to Gen. Bd. of Health on Public Inquiry into Sewerage of Leic. 7.
40 W. Gardiner, Music and Friends, i. 89.

4 I 7 th Rep. Leic. Dom. Mission (1852), 8; 3rd Rep. ( 1848$), 7 ; 5$ th Rep. ( 1850$)$, 5-6 (series in Leic. City Ref. Libr.).

42 9th Rep. Leic. Dom. Mission (1 854), ro; Ranger, Rep. on Public Inquiry into Sewerage of Leic. 10: Rep. Medical Officer of Health ( 1855$), 9$.

43 2nd Rep. Com. on Health of Towns, App. (2), 267.

44 Ibid. 
In two-thirds of the town the streets, though not wide, are yet sufficiently so to be not unhealthy. They are scarcely ever placed back-to-back and the houses usually have a small court at the back and are generally tolerably airy, and well supplied with water for domestic purposes though not for cleanliness. We occupy a larger space of ground than any town in the kingdom in proportion to our population, there being gardens and some of them of very considerable extent even in the very centre of the town.45

In the areas into which the town had expanded the older and inferior houses were largely grouped round narrow courts, close and ill ventilated, with privies and sometimes workshops in the centre. ${ }^{46}$ In 1849 there were said to be 347 courts in Leicester, containing I,93 I houses. ${ }^{47}$ The older streets, too, were narrow, often only I 6 or I 8 feet wide; 48 streets of a later date were better, being 20 to 50 feet wide.49 In the 1840 's there seems to have been little over-crowding in Leicester's working-class districts and generally there was only one family to a house. ${ }^{50}$ Irish immigrants, in Leicester as elsewhere, were a source of trouble. They tended to concentrate in one part of St. Margaret's parish, around Belgrave Gate and Abbey Gate, and the houses that they occupied there were often overcrowded. ${ }^{51}$

Perhaps the worst characteristic of Leicester as it existed shortly before the middle of the I 9 th century was the state of the sanitation. The area of the old walled borough, though bordering on the river fairly closely, had been little troubled with flooding because it was situated on a gravel rise which was slightly but definitely elevated above the surrounding countryside. Of the new districts built during the I 9 th century, virtually all but the better-class areas of South Fields were built on low-lying land which provided little natural fall for sewers and was frequently exposed to flooding. ${ }^{52}$ One area, the part of St. Margaret's parish lying between the Soar, Sanvey Gate, Churchgate, Archdeacon Lane, Belgrave Gate, and the Willow Brook, was liable to be flooded from three sources: the Soar, the Grand Union Canal, and the Willow Brook. ${ }^{53}$ These floods not only caused great inconvenience by inundating streets and houses sometimes to a depth of 2 or 3 feet, ${ }^{54}$ but, forcing their way through the drains, they brought up sewage and, on receding, left behind them a deposit of insanitary mud.55 The more southerly parts of St. Margaret's parish were outside the region of flooding but suffered from another disadvantage. Over much of the district, the ground had been excavated to produce clay and the resulting pits had been filled in with rubbish on which buildings had been erected before the filling had decayed and settled. ${ }^{56}$ In consequence the central part of St. Margaret's parish, between the Belgrave and Humberstone roads, was perhaps the most unhealthy part of the town. 57

Several of the districts into which the town had expanded during the first half of the I 9 th century were thus by nature unsuitable for building. Only a far-reaching plan for drainage and flood prevention could have made such areas habitable, and it was not until after 1860 that the corporation was prepared to contemplate the execution of such a plan and possessed the financial means required. Indeed there is no indication that the

${ }^{45}$ Rep. Com. on Condition of Framework Knitters [609], p. 174 , H.C. (1 845 ), xv.

${ }_{46}$ Ist Rep. Leic. Dom. Mission (1846), 5; 5th Rep. (1850), 5-6; 2nd Rep. Com. on Health of Towns, App. (2), 267.

${ }_{47}$ Ranger, Rep. on Public Inquiry into Sezverage of Leic. 9.

48 2nd Rep. Com. on Health of Towns, App. (2), 266.

49 Ibid.; Ranger, op. cit. 9.

50 Ranger, op. cit. 9; and Rep. Com. on Health of Towns, App. (2), 267.

${ }_{51}$ 5th Rep. Leic. Dom. Mission (1850), 20, 21 ; 6th Rep. (1851), 7; 7th Rep. (1852), 9; 3rd Rep. (1848), 21 ; 8th Rep. (1853), I6; 9th Rep. (1854), ro, I I.

52 J. S. Crossley and G. Foxton, Rep. Cond. River Soar (1 852), io (Leic. City Ref. Libr., Pamphlets $\mathrm{O}_{3}$, vi); 'T. Hawksley, Rep. on Plans for Prevention of Floods (1 880),

3 (Pamphlets $\mathrm{O}_{3}$, vii); 2nd Rep. Com. on Health of Towns, App. (2), 267; W. Johnston, Diarrhoea of Leic. I I-I 4 (Leic. City Ref. Libr., Pamphlets $\mathrm{O}_{3}$, iv).

53 Ranger, Rep. on Public Inquiry into Sewerage of Leic. 7; Hawksley, Rep. on Plans for Prevention of Floods (1880), 3,5 .

54 Hawksley, op. cit. 3; Fielding Johnson, Glimpses of Anc. Leic. 408 .

55 W. E. Buck and G. C. Franklin, Rep. on Epidemic Diarrhoea (1 875), 46 (Leic. City Ref. Libr., Pamphlets $\mathrm{O}_{2}$, vi); Ranger, Rep. on Public Inquiry into Sewerage of Leic. 7 .

${ }_{56}^{6}$ Buck and Franklin, op. cit. 39.

${ }^{57}$ 6th Ann. Rep. Leic. Dom. Mission (1851), 7; Ranger, Rep. on Public Inquiry into Serverage of Leic. 7; 2nd Rep. Com. on Health of Towns, App. (2), 276. 


\section{A HISTORY OF LEICESTERSHIRE}

evils which would arise from building on the low-lying areas adjacent to the old walled borough were appreciated in any quarter until those evils had in fact materialized. In practice, there was no systematic provision for drainage and sanitation. Occasionally sewers were laid down by the owners of house property or by the parish authorities, but as sewerage was the responsibility of the parishes and not of the borough council there was no scheme for draining the town as a whole. Such sewers as existed varied widely in size; they gave off 'noxious gases' and because of their lack of fall and defective construction they became choked. A report of I 845 described the town's drains as 'more a menace than a relief' ${ }^{58}$ Most streets were quite without sewers. In 1849 it was reported that out of 242 streets and 347 alleys, courts, and yards, only i 2 were fully culverted and more than half were without any sewers at all.59 The streets were in some cases drained by open ditches; the whole of the Blackfriars area, for example, was drained by a long ditch which, when inspected in 1849 , was found to be choked with decaying animal and vegetable matter to depth of between 3 and 4 feet. ${ }^{60}$ Both sewers and ditches drained into the Soar and the canal, which were both badly polluted for several miles downstream from Leicester. ${ }^{61}$ Many houses in the working-class districts of the town were without even such drainage as the defective sewers and ditches provided, and had, as their only form of sanitation, privies draining into open cesspits, which were emptied at long intervals. ${ }^{62}$ In i 849 a surveyor employed by the corporation estimated the number of open cesspits at $2,900.63$

The general unhealthiness of the town caused by these insufficient sanitary arrangements was aggravated by Leicester's lack of an adequate water-supply. Until 1853 the town was without a proper supply of piped water. ${ }^{64}$ The only water available came from the conduit which conveyed water from a spring in St. Margaret's parish to the Market Place, ${ }^{65}$ from the Soar and from the Willow Brook, from a few public wells, and from the numerous private wells and rain-water cisterns. In I 849 there were estimated to be 2,800 wells in Leicester and about the same number of cisterns, in which rainwater from the roofs was stored. ${ }^{66}$ The well-water was contaminated because of seepage from cesspits and because the holes from privies had been dug right down to the water seam. ${ }^{67}$

The surfaces of streets continued after 1835 to be maintained by the parochial surveyors of highways, who levied a rate in each parish. In St. Margaret's parish, for example, the highways surveyor had fourteen miles of road to care for; in I 849 a rate of $4 \frac{1}{2} d$. in the pound, producing about $£_{\mathrm{I}, \infty}, \mathrm{o}$, was levied in the parish for road maintenance, but of this sum $£ 200$ was paid to the trustees of the Market Harborough to Loughborough turnpike, which ran through the parish and formed one of its main thoroughfares, in return for the trustees' work in maintaining the turnpike. ${ }^{68}$ In the extraparochial area of Blackfriars, a poor quarter of the town, it was thought that there was no power to appoint a surveyor or to levy a highway rate so that apparently no street repairs were done. ${ }^{69}$ The efforts of the parish surveyors were enough to keep the streets paved but only in a rather unsatisfactory manner. ${ }^{70}$ The borough council had no responsibility

\footnotetext{
${ }^{8}$ Ranger, op. cit. 12, 14; 2nd Rep. Com. on Health of Towns, App. (2), 268.

59 Ranger, op. cit. 14.

60 Ibid. 15; 2nd Rep. Com. on Health of Towns, App. (2), 268.

6r Ranger, op. cit. 15; 2nd Rep. Com. on Health of Towns, App. (2), loc. cit.; 6th Rep. Leic. Dom. Mission (185I), 7 .

62 Ranger, Rep. on Public Inquiry into Sewerage of Leic. I8; Ist Rep. Leic. Dom. Mission (1846), 5; 2nd Rep. Com. on Health of Torws, App. (2), loc. cit.
}

63 Ranger, op. cit. 17.

64 Storey, Boro. of Leic. 105.

65 See p. 164.

66 Ranger, op. cit. $20 ; 2 n d$ Rep. Com. on Health of Towns [602], p. I 1 2, H.C. (1845), xviii; ibid. App. (2), 268.

67 Ranger, op. cit. 17.

68 Ibid. 12-13.

69 Ibid. 12.

70 Ibid. I 2 ; 2nd Rep. Com. on Health of Towns, App. (2), 267. 
for street surfaces, though it paid for the paving of the new streets laid out on its own property in the south of the town. ${ }^{71}$ Street scavenging was similarly in the hands of the parish surveyors, except in the case of the Market Harborough to Loughborough turnpike, which was cleaned by the trustees. The other main streets were fairly well cleaned, but side streets and courts were dependent on the casual services of private scavengers, who removed dung and rubbish at irregular intervals for their own profit. ${ }^{2}$ No attempt was made to clean or drain the various open spaces in the town, which in consequence were filthy and waterlogged.73 Street lighting seems to have been adequate. The powers of the private company which supplied gas for street lighting were enlarged by Act in I 838.74

The difficulties which confronted Leicester were little different from those which other growing industrial towns faced at the same period. In some ways Leicester was perhaps more fortunate than other comparable towns: it occupied an unusually large area in proportion to its population; cellar dwellings were unknown and overcrowding uncommon; in general its housing seems to have compared favourably with that of other large towns. ${ }^{75}$ On the other hand a very high rate of mortality suggests that Leicester was even more unhealthy than other industrial towns. For the years from I 840 to 1842 the average yearly mortality was 30 in every I,000 of the population, a figure only exceeded by Bristol, Liverpool, and Manchester. ${ }^{76}$ It is probable that one cause of this very high death-rate was the prolonged depression in the staple hosiery industry, with the resulting low standard of living and constant undernourishment of much of the town's population, but bad drainage and sanitation were the most important reasons.

For some ten years after 1835 the new corporation found itself unable to deal vigorously with the town's problems. The rebuilding of the West Bridge in I 84I was the only important town improvement carried out during this period. 77 In 1845 the corporation, feeling that it was at last able to undertake larger schemes, set up a town improvement committee, which compiled a report proposing the building of a new Town Hall, the enlargement of the Saturday market place, the establishment of a livestock market outside the town, and some other measures of less importance. These improvements were to be financed by selling part of the town estate as building land. The report did not contain any proposals for rectifying the town's defects in drainage and sanitation. ${ }^{78}$ The proposals largely reflected the views of the committee's chairman, William Biggs, who with his brother John led a group which favoured expenditure on improvements of the type advocated in the report rather than on sanitation.79 Another party in the council, led by Joseph Whetstone, opposed the scheme on the grounds that it would involve more expense than the town could afford, and that sanitation was the matter most urgently needing attention. ${ }^{80}$ Whetstone's attention had first been directed to the problems of public health by Edwin Chadwick's Report on the Sanitary Condition of the Working Classes, published in 1842 , and he had become convinced of the need to improve the town's sanitation. ${ }^{81}$ While the two parties on the council were debating which problem should be dealt with first, an attempt was made to improve Leicester's defective

71 Abstract of Accts. of Treasurer of Boro. of Leic. (18378), I1, I4; ibid. (1838-9), I2; ibid. (1839-40), I2, I3, r4; ibid. (r $840-1)$, 15 .

72 2nd Rep. Com. on Health of Towns, App. (2), 268; Ranger, Rep. on Public Inquiry into Sewerage of Leic. 13; P. Russell, Leics. Road, 88.

73 Ranger, op. cit. 12.

74 Leic. Amending Act for lighting the town with gas, r 838 , I \& 2 Vic. c. 52 (priv. act); White, Dir. Leics. (1 846 ), 80 .
75 2nd Rep. Com. on Health of Towns, App. (2), 267; Ranger, op. cit. 9; White, op. cit. 79; 5th Rep. Letc. Dom. Mission (r 850), 5 .

76 2nd Rep. Com. on Health of Towns, App. (2), 269.

77 Patterson, Radical Leic. 336.

${ }_{78}$ Rep. of Town Improvement Cttee. to Council (1845),

(Leic. City Ref. Libr., Pamphlets $\mathrm{O}_{3}$, vi).

${ }^{99}$ Patterson, op. cit. $33^{8-41}$.

80 Ibid. 340-r.

81 Leic. Chron. 6 Jan. 1868. 
sanitation by private action. In 1845 the Leicester Water and Sewerage Company was formed, with the object of providing an adequate water-supply and of completely draining and cleansing the town. It was proposed that the company should receive about $f_{1}, 600$ a year from the borough rates for providing and maintaining drains and sewers. The company had a nominal capital of $f_{1} 5_{5} 0,000$, two-thirds of which was held by the Metropolitan Towns Improvement Company, formed not long before by Edwin Chadwick to carry out schemes for improving public health. ${ }^{82}$ The Leicester company came to an end, however, without effecting anything. ${ }^{83}$ The dispute within the council over town improvements ended in compromise. John and William Biggs and their supporters agreed to abandon for the time being the proposals to build a new 'Town Hall and cattle market, and the remainder of the plan put forward by the town improvement committee was then accepted by the whole council. ${ }^{84}$ By thus abandoning two important parts of the improvement plan the estimated cost of the scheme was reduced from $£ 50,000$ to $£^{25}, 000$, of which it was intended to raise $\oint_{10,000}$ by the sale of land and the remainder from the rates. ${ }^{85}$ The scheme as adopted made no provision for the improvement of sanitation or water-supply. In this failure to take action on matters of public health Leicester was not exceptional, for a majority of English boroughs were similarly inactive. ${ }^{86}$ The town council's existing powers were not great enough to allow it to carry out even the modest plan that had been agreed upon and in 1846 the council obtained an $\mathrm{Act}^{87}$ which authorized it to provide a new post office, to extend the Saturday market place and the cattle market, to establish recreation grounds and public bathing places, and to take steps to suppress drunkenness and disorder. The council was further empowered to finance these improvements by borrowing and by the levy of an improvement rate.

The new Act was put into execution with some vigour. A new post office was built; $; 8$ in 1848 property was purchased for the extension of the Saturday market place ${ }^{89}$ and the Exchange there was replaced by a new market hall in $185^{1} ;^{90}$ the cattle market was enlarged in $1849 .{ }^{91}$ These improvements were financed by a series of loans, the first of which was raised in January 1847,92 and by a special town improvement rate, first levied during the financial year $1847-8 .{ }^{93}$

Two other improvements carried out by the corporation should be mentioned. The very crowded state of burial grounds in the town had led to the formation in $\mathbf{I} 845$, by a body of dissenters amongst whom was William Biggs, of a private company to establish a cemetery, which was originally intended to be for nonconformists only. The company arranged to buy from the corporation about seventeen acres of land on the Welford road as a cemetery site. A strong party in the council, led by Joseph Whetstone, considered that it was essential to provide a new publicly owned graveyard for all denominations. ${ }^{94}$ Presumably the opposition to the cemetery company was part of the more general conflict over town improvement between the parties led by Biggs and Whetstone respectively. Whetstone's views prevailed, the company abandoned its plans, and an Act ${ }^{95}$ was obtained in 1848 empowering the corporation to establish a cemetery. The Welford Road site was brought into use as a cemetery in 1849 , part being consecrated for use by

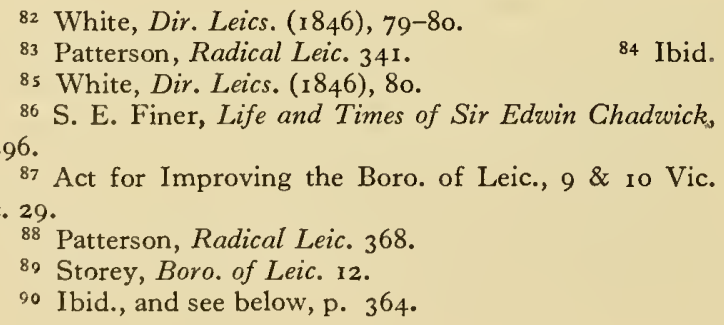

91 Patterson, op. cit. 368.

92 Patterson, loc. cit.

93 Abstract of Accts. of Boro. of Leic. (1847-8), 13-14.

94 Leic. Inl. 8 Jan. 1849, p. 3; 22 Jan. 1849, p. 3; 29 Jan. I 849 , p. 3 .

95 Act for establishing a cemetery in Leicester, 1848 , I I \& 12 Vic. c. 2 (priv. act). On the state of the town cemeteries, see W. Ranger, Rep. to General Bd. of Health on Burial Grounds at Leic. passim (Leic. City Ref. Libr., Pamphlets $\mathrm{O}_{3}$, ix). 


\section{THE CITY OF LEICESTER}

Anglicans and the remainder being set aside for dissenters. ${ }^{96}$ In 1848 the corporation, under the authority of a general Museum Act of $1845,{ }^{97}$ purchased the former Proprietary School building in the New Walk for a museum. It was opened in 1849 , and the Leicester Literary and Philosophical Society presented the contents of its own private museum to the corporation to form the beginning of the municipal collection. ${ }^{98}$

These developments, useful though they were, left the urgent matter of the town's sewerage and water-supply still untouched. The responsibility of the corporation for such questions was greatly changed by the passing in 1848 of the Act for Promoting the Public Health, ${ }^{99}$ which established a General Board of Health and authorized the creation of local boards to deal with matters of sanitation, street cleaning, and watersupply. In July i 849 a provisional order, subsequently confirmed, was made by the General Board applying the terms of the Act to Leicester, and the borough council was constituted a local board of health. Joseph Whetstone was the chief local promoter of this measure. ${ }^{I}$ In its new capacity the council took over from the parish surveyors of highways the duties of cleaning the streets and maintaining their surfaces, and it also became responsible for providing adequate sewerage and a satisfactory water-supply. In order to carry out its new duties the council established three new committees, the sewerage and highway committee, whose duties are sufficiently indicated by its title, the sanitary committee to deal with public nuisances, and a temporary committee to draw up a code of by-laws on sanitary matters. ${ }^{2}$ The finances of the local board of health were distinct from those of the borough council, and a separate rate, known as the general district rate, was levied to provide its funds. There continued to be a separate highway rate and there was also a special district rate for financing certain capital expenditure in matters of public health. ${ }^{3}$

The local board of health immediately set to work. Before the end of i 849 it was already dealing effectively with such nuisances as pig-sties within the town and defective drains and cesspools. ${ }^{4}$ During the next few years the medical officer of health and the inspector of nuisances appointed by the local board were able to remove many public nuisances and effected a noticeable improvement. 5 In September 1849 the local board commissioned Thomas Wicksteed, a well-known civil engineer, to draw up a report on the best method of draining the town and supplying it with water. ${ }^{6}$ Wicksteed's proposals were criticized by the General Board of Health whose most influential member, Edwin Chadwick, was an opponent of Wicksteed.7 It was agreed between the local and general boards that the proposals should be referred to Robert Stephenson, who advised that Wicksteed's scheme, with some minor modifications, should be adopted. ${ }^{8}$ Wicksteed proposed to construct an extensive series of sewers for the town, which were to lead to an outfall on the Soar downstream from the town. The solid matter in the sewage was to be precipitated in tanks and converted into manure, while the liquid por-

96 Storey, Boro. of Leic. 52-53; Patterson, Radical Leic. 368 .

$978 \& 9$ Vic. c. 43 .

98 Storey, op. cit. 32-33.

99 II \& 12 Vic. c. 63.

I Ret. of All Places that have petitioned the Gen. Bd. of Health for Application of Gen. Health Act, 1848 , H.C. 704, p. 8 (I852-3), xcvi; Fielding Johnson, Glimpses of Anc. Leic. 426.

2 S. Stone, Outline of Powers and Rules of Council as Local Bd. of Health (1849), I6 (Copy in Leic. City Ref. Libr.).

3 Ibid. 15.

4 4th Rep. Leic. Dom. Mission (1 849), 6.

5 Ibid. 8th Rep. (1853), 10, I6; I 2th Rep. (1857), 5. In 18462 doctors had been appointed sanitary medical officers for the boro.: Storey, Boro. of Leic. $26 \mathrm{r}$. In I 849 one of them became medical officer of health to the local Bd. of Health: ibid. The position was not a full-time office until I 885: Rep. Medical Officer of Health (1 885), 8.

${ }_{6}$ Storey, op. cit. I3; T. Wicksteed, Prelim. Rep. upon Sewerage, $\Xi^{\circ}$ c. for Boro. of Leic. (1850). (Copy in Leic. Univ. Coll. Libr.)

7 Finer, Sir Edwin Chadwick, 444-5. Wicksteed proposed to have the main sewers built of brick and to use glazed earthenware pipes only for the drains linking houses and sewers: Wicksteed, Rep. on Sewerage, 2o. Chadwick strongly supported the use of glazed pipes for all sewers: Finer, op. cit. 443 .

${ }^{8}$ Storey, Boro. of Leic. 13; W. Lee, Rep. to Gen. Bd. of Health on Main Sewerage of Leic. (1852), passim (Leic. Ref. Libr., Pamphlets $\mathrm{O}_{3}$, vi). 


\section{A HISTORY OF LEICESTERSHIRE}

tion was to be deodorized and discharged into the Soar. 9 Like others of his time, Wicksteed believed that sanitation could be carried on at a profit, and he calculated that the sale of manure would produce a net revenue of $£_{\mathrm{I}} \mathrm{O}, 000$ a year during the first fifteen years that the plan was in operation, and $£ 20,000$ a year during the next fifteen years. ${ }^{10}$ Accordingly he proposed that the treatment of the sewage should be carried out by.a private company with which he was connected. II The corporation agreed to this, and in I 85 I obtained an Act which authorized the construction of works as proposed by Wicksteed, and empowered the local board of health to sell or lease the sewage. ${ }^{12}$ The local board and Wicksteed's company then made an agreement by which the company undertook to treat the sewage for 30 years and to erect and maintain the buildings and machinery needed, in return for being allowed to dispose of the manure. It was further provided that the company might surrender their lease by giving up, without compensation, all the buildings and machinery then in use to the local board. ${ }^{13}$ Wicksteed's plans were carried out; the corporation constructed sewers at a total cost of some $f_{40,000}$ and the company set up works to deal with the sewage. ${ }^{14}$ The sewage works began operation in 1855 , but the sale of manure proved much less remunerative than had been expected, and eventually the company surrendered its lease, and the buildings and machinery were handed over to the borough. ${ }^{15}$ After this the corporation operated the works but at a cost of $f^{2}, 000$ a year, which was considered excessive. ${ }^{16}$ Though Leicester had acquired sanitation of a sort, the sewers do not seem to have been of a satisfactory construction. ${ }^{17}$

At the same period the town obtained a piped water-supply, which Wicksteed considered essential for proper sanitation. ${ }^{18}$ In I 846 the Leicester Waterworks Company was formed for providing the town with water, and in 1847 the company obtained an Act empowering it to construct a reservoir at Thornton, about seven miles away, and to supply water to Leicester by pipes. ${ }^{19}$ The company failed at first to attract enough capital to start operating and nothing was done until in I $85^{\circ}$ the borough council, urged on by Whetstone, made an agreement with the company. It was provided that the company should have a total capital of $f_{80,000 ;} £_{1} 7,000$ of this was to be subscribed by the corporation as the local board of health and the remaining $f_{6} 63,000$ by the general public; the local board was to guarantee a dividend of 4 per cent. a year until I 883 and would. be entitled to all net profits over $4 \frac{1}{2}$ per cent. for ever. After some opposition, both from ratepayers and in Parliament, a local $\mathrm{Act}^{20}$ was obtained in $\mathrm{I}_{5} \mathrm{I}$ authorizing this agreement. The reservoir at Thornton was completed and in December 1853 water was first brought to Leicester from it.2I Many houses, however, remained without piped water; as late as 1877 there were still 7,000 houses whose only water-supply came from wells and cisterns. ${ }^{22}$

The measures of improvement undertaken from I 845 onwards produced appreciable changes in the town's character. By 1860 the problems created by Leicester's great and continuing growth were being tackled, although they were very far from being completely solved. An examination of Leicester as it was about I 860 shows that it was much

9 Storey, op. cit. I3-I4.

10 Ibid. I4-I 5; Finer, Sir Edwin Chadwick, 300, 369.

11 Storey, op. cit. I3.

12 Leic. Sewerage Act, I 4 \& I 5 Vic. c. 2 (local act).

13 Storey, Boro. of Leic. 13.

14 Ibid. I3-I4.

is Ibid. I4-I 5 ; Rep. Medical Officer of Health (1 855), 7.

16 Storey, op. cit. I5.

17 Lee, Rep. on Main Sewerage of Leic.; J. Gordon, Rep. of further schemes for purification of Sewage of Leic. 5 (Leic. City Ref. Libr., Pamphlets $\mathrm{O}_{3}$, vii); J. Gordon, Rep. on system of New Main Trunk Sewers (I886), 3-4 (Pamphlets $\mathrm{O}_{3}$, vii); E. G. Mawbey, Rep. on Sewer Ventilation and Flushing (1 894), 4 (Pamphlets $\mathrm{O}_{3}$, xxi); Rep. Medical Officer of Health (I88 I), 25-29.

I 8 Wicksteed, Rep. on Sewerage, I 6.

19 Leic. Waterworks Act, I 847 , Io \& I I Vic. c. 282 (priv. act).

20 Leic. Waterworks Amendment Act, I 85 I, I4 \& I 5 Vic. c. 33 (priv. act).

21 Storey, Boro. of Leic. I04-5.

22 White, Dir. Leics. (1877), 290. 
larger and in some respects much healthier than it had been 25 years before. In I86I the town had a population of 68,000 as against about 44,000 in 1836.23 The death-rate fell from 30 in every $I, 000$ in 1840 to an average of 24 in every 1,000 in $1859 .{ }^{24}$ The working-class houses erected in about 1850 were decidedly superior to those erected earlier, although in some instances the need for haste in building to meet an ever-increasing demand led to weaknesses in construction.25 Much unsatisfactory accommodation remained, and it was estimated in 1864 that there were still I,500 back-to-back houses in Leicester. ${ }^{26}$. The improvement in the town's health manifested in the lower death-rate had been assisted by the removal of many public nuisances by the officials of the local board ${ }^{27}$ and by the fact that the streets were now regularly cleaned. ${ }^{28}$ Something had been done to improve road surfaces, and from I853 onwards the local board began to replace the rounded cobble-stones on the footpaths of the principal streets by flags and granite setts. ${ }^{29}$ The town was still without any public baths, though the corporation had power to provide bathing places under the improvement Act of I 846 , but in 1849 the corporation had agreed to subsidize two privately owned bath houses, one in the New Walk and one in Burley's Lane, in return for the owners' undertaking to provide cheap baths. ${ }^{30}$ The need for such facilities can be seen from the fact that in a period of eighteen months, from March I849 to September I850, more than 94,000 visits were made to the New Walk baths. ${ }^{31}$

By I 860, too, Leicester was beginning to experience a new prosperity and the prolonged depression which had affected the hosiery industry almost without a break since the end of the Napoleonic Wars was coming to an end. The hard times of $1857-8{ }^{32}$ were followed by a period of increasing though not altogether stable good fortune. ${ }^{33}$ Employment was generally good, though in the early I 860's there was usually a slack period in the first month or two of each year. ${ }^{34}$ By I 864 it was possible to speak of the 'almost universal prosperity' of Leicester, and in I 868 it was remarked that 'Leicester's lean stockinger has disappeared'. 35 This improvement in the town's economic position was partly due to the changed circumstances of the hosiery industry, which had been lifted out of its long depression by a renewed demand for its products and was about to undergo the transition to a factory organization. ${ }^{36}$ Leicester had also perhaps benefited from the growth of the two new industries, the manufacture of elastic web and footwear, which had relieved the town from its dependence upon one major industry. ${ }^{37}$ Unemployment was by no means at an end. In i 862, for example, a good year for industry, one person in every 36 of Leicester's population received poor relief. ${ }^{38}$ 'The widespread distress of earlier periods had, however, passed.

The improvement in Leicester's material circumstances by 1860 hardly extended to the habits of its population. One notable characteristic of the town's inhabitants was a marked readiness to resort to violence. This exhibited itself most spectacularly in occasional riots, such as those of 1848,39 or in outbreaks of public hooliganism, such as

23 V.C.H. Leics. iii. I 79; S. Stone, List of Mayors, $\Xi^{2} c$. of Boro. of Leic. (187 ), 28 (copy in Leic. City Ref. Libr.).

${ }^{24}$ Rep. Medical Officer of Health (1855), 6; ibid. (1859), 4.

5 I6th Rep. Leic. Dom. Mission (1861), 16; I7th Rep. (1862), 4; I8th Rep. (I863), I3; I9th Rep. (1864), 5; r 2th $\operatorname{Rep}$. (1857), 5 .

26 Ibid. I 9 th $\operatorname{Rep}$. (1 864), I4.

27 Ibid. I 2 th Rep. (I 857$)$, 5; 8th Rep. (1853), I0, I6.

28 Ibid. I2th Rep. (1857), 5 .

${ }_{29}$ Abstract of Accts. of Boro. of Leic. 1853, 29; ibid. 1854, 30-31 ; Barclay, Modern Leic. 4.

30 Storey, Boro. of Leic. 70-7I; Abstract of Accts. of Boro. of Leic. I $849^{-50}$, I9.
31 Abstract of Accts. of Boro. of Leic. 1849-50, I9.

32 See above, p. 259.

33 I 5th Rep. Leic. Dom. Mission (1860), 5-6; I6th Rep. (186I), 4; I7th Rep. (1862), 4, 6; I8th Rep. (1863), 3; I9th Rep. (I864), 5 .

34 Ibid. I7th Rep. (1862), 6; I9th Rep. (I864), Io; Leic. Inl. Io Feb. I 86o, p. 8; Ibid. 17 Feb. I 860, p. 8. 35 Barclay, Modern Leic. 3; $23 r d$ Rep. Leic. Dom. Mission ( 1868 ), 3 .

36 See below, p. 308 .

37 Leic. $7 n l .2$ Jan. I863, p. 5 ; and see pp. 3 I 5, 326.

38 Leic. Fnl. 2 Jan. 1862 , p. 5. For Eng. as a whole the corresponding figure was $\mathrm{I}$ in $2 \mathrm{I}$.

39 See above, pp. 217-18. 


\section{A HISTORY OF LEICESTERSHIRE}

that which caused the destruction of a balloon on the racecourse in 1864.40 The most convincing evidence of this tendency, however, is the constant flow of assault cases in the borough courts. During the decade $1847-57$ there were on an average more than 420 actions, civil and criminal, for common assault yearly, and more than 40 a year for assaults upon the police, at a time when the population of the town was about $60,000.4 \mathrm{I}$ This may be compared with the 283 actions for common assault in 1890 , when the population was about $170,000.42$ The violence illustrated by such incidents and such statistics was only one manifestation of the general roughness of life in the poorer districts of Leicester, and the annual reports of the Revd. Joseph Dare, who laboured for some 30 years, from I 845 to 1876 , in the poorer areas of the north and north-east of the town on behalf of the Domestic Mission attached to the Great Meeting, provide much detailed information about life in those quarters of the town. From these and from the local press it is clear that in the years around 1860 and earlier the poorer parts of the borough were characterized by widespread drunkenness and disorder. 43 There is no evidence to suggest that conditions in Leicester were in any way worse than those prevailing in other towns, but any survey of the borough's character would be incomplete without reference to this aspect of its life.

Nor can this state of affairs be surprising when the education of the population is considered. The available evidence indicates that about I860 slightly more than half the children attended school at some period of their lives, but in many cases the time spent there was so brief as to have been of little value.44 It was not altogether because of lack of room in the schools that so many children went untaught, for the existing schools were not filled. Many children were employed in the hosiery industry, mainly as winders on the stocking frames, in the boot and shoe industry and in the brick-yards. ${ }^{45}$ The employment of children in the hosiery industry as a whole was not regulated by law until 1864.46 In 1862 it was estimated that out of 120,000 persons employed in the whole country, only 4,063 came under the Factory Act of $1833,{ }^{47}$ and the boot and shoe industry and such occupations as brick-making remained outside statutory control until I $867 . .^{48}$ In 1867 it was stated that at Leicester children as young as seven or eight were still being employed in the brick-yards and in the manufacture of footwear. ${ }^{49}$ Such prospect of early employment naturally drew children away from school, while in times of depression their parents generally found it impossible to pay the small fees required by the day schools. 50

While a considerable proportion of manual workers in the town were without any formal education, many also had no contact of any importance with organized religion. There was no lack of religious bodies in Victorian Leicester. In I 846 there were 8 Anglican churches, with an estimated seating capacity of 12,000 , and 26 Protestant nonconformist and Roman Catholic chapels, with a total of about 16,000 sittings. ${ }^{51} \mathrm{By}$ I 877 eight new Anglican churches had been completed giving nearly 7,000 additional places and the number of nonconformist sittings had been increased to about $27,000.52$

$40 \mathrm{~J}$. and T. Spencer, New Guide to Leic. (1888), I 12.

4 S. Stone, Statistics of Crime in Boro. of Leic. I84757, 33 (Copy in Leic. City Ref. Libr.); cf. V.C.H. Leics. iii. 179 .

${ }^{42}$ Criminal and Misc. Returns of Leic. Boro. Police for I 890, table V (Leic. City Ref. Libr., Pamphlets O 3 , xxiii). In 1951 there were 36 convictions for common assault in a population of 285,000: City of Leic. Rep. of Chief Constable (1951), 25.

43 th Rep. Leic. Dom. Mission (1852), 1 1-12; 9th Rep. (1854), 9, I6; I 2th Rep. (1857), 6; I 4th Rep. (1859), 6-7; I8th Rep. (1863), 3; I9th Rep. (1864), 8; 20 th Rep. (1865), 13; 2 Ist Rep. (1866), 4-5; and see these reps. passim.

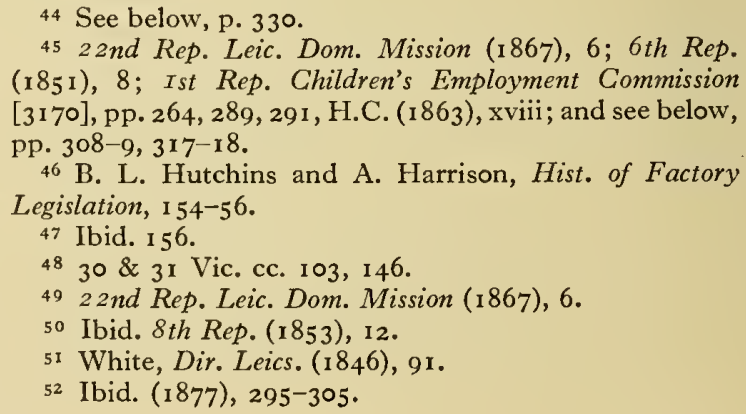


The building of new churches and chapels had hardly kept pace with the growth in the town's population, which had risen to 95,000 in I 871.53 The figures showing church and chapel accommodation do indicate, however, the predominance of nonconformists in the town. Sectarian feeling was strong, especially between the Anglicans and the Protestant dissenters; when, for instance, from I 87 I a school board existed at Leicester, the elections to it were conducted almost exclusively on denominational lines. ${ }^{54}$ Despite this religious activity and despite the existence in Leicester of a numerous and devout body of nonconformists who exercised great influence in municipal affairs, a substantial part of the town's population did not belong to any religious denomination. Joseph Dare, whose work for the Domestic Mission attached to the Great Meeting gave him a thorough acquaintance with the poorer quarters of the town, estimated on several occasions that about half the population never attended any place of worship. ${ }^{55}$ His statements are based only on personal observation and not on any form of census, but his reports from 1846 to 1876 leave little doubt that there was then a considerable body of persons who neglected religious observance. During the hard times before 1860 this neglect seems to have been partly due to the poverty of the hosiery workers, who were often unable to dress in a fashion sufficiently respectable for attendance at church or chapel, ${ }^{56}$ but widespread indifference and scepticism were also an important factor. 57

The public houses and beer shops were perhaps the most important places of recreation in the middle of the I 9 th century. In 1849 there were 246 public houses and 94 beer shops in the borough; 58 by 1867 there was estimated to be one public house for every 300 of the population, and the justices then decided not to license any new ones. ${ }^{59}$ Shops for retailing beer could be opened without licence, however, merely on payment of an excise fee, ${ }^{60}$ and in 1867 there were between 160 and 170 of these shops in the town. ${ }^{6 \mathrm{I}}$ It is of course difficult to ascertain just how much drunkenness occurred under these conditions. In the decade $1847-57$ there were on the average just under 260 persons a year convicted for being drunk and disorderly, ${ }^{62}$ but there are no statistics of the less militant forms of drunkenness, and it might be unwise to take too literally the strongly worded attacks by such reformers as Joseph Dare on widespread intoxication and drunken brawling in the poorer areas of the town. ${ }^{63}$ From about 1855 it became increasingly common for public houses to have a large saloon attached to them where customers were entertained by singers and comedians. One such saloon, described in I 865, was capable of holding 600 people and it was said to be visited by about I,000 every Saturday night. A charge of $2 d .-6 d$. was made for admission and customers were expected to order drinks in addition. ${ }^{64}$ The first working men's club in Leicester was opened in I 866 with the idea of providing a more respectable place of entertainment than the existing public houses. By November 1866 it had more than 400 members. ${ }^{65}$

Opportunities for outdoor recreation were limited. In I 839 the corporation had set aside a small close in the South Fields beside the Welford road as a recreation ground ${ }^{66}$

${ }^{53}$ V.C.H. Leics. iii. I79.

54 Leic. Chron. and Leics. Mercury, I0 Jan. I874, pp. 7-9; Leic. Chron. 7 Jan. I871, pp. 2, 5, 8; 14 Jan. I871, pp. 3, 5. For sectarian feeling, see, e.g., Dare's strictures on the Anglican clergy: e.g. 2nd Rep. Leic. Dom. Mission (1847), 19; 3rd Rep. (1848), 9; see also p. 330.

55 8th Rep. Leic. Dom. Mission (1853), 9; I2th Rep. (1857), 6; I7th Rep. (1 862), 5; 24 th Rep. (1 869) I I.

${ }_{56}$ Rep. Com. on Condition of Framework Knitters, App.

I [6I8], pp. I I I-I 2, H.C. ( 1845$)$, xv, et passim; Ist Rep.

Leic. Dom. Mission (1846), 6, 7, 12.

57 Ibid. I th Rep. (1857), 6, 7; 5th Rep. (1850), I2; I7th Rep. (1862), 5 .

${ }_{58}$ Ranger, Rep. on Public Inquiry into Sewerage of Leic.

\footnotetext{
592 and Rep. Leic. Dom. Mission (1 867), 9.

${ }^{60} \mathrm{~S}$. and B. Webb, Hist. of Liquor Licensing in Eng. (1903), I32.

61 2 2nd Rep. Leic. Dom. Mission (1 867), 9.

62 Stone, Statistics of Crime in Boro. of Leic. 1847-57,

63 9th Rep. Leic. Dom. Mission (1854), I6; Ist Rep. (1846), 10; 3rd Rep. (1848), 8; I 2th Rep. (1857), 6; I 4th Rep. (1859), 6-7; I9th Rep. (I864), 8.

${ }_{64}$ I 2 th Rep. Leic. Dom. Mission (1857), 6; I8th Rep. (1863), 3; 20th Rep. (1865), 9, 10-12.

65 Ibid. 2 Ist Rep. (1866), 6.

66 Patterson, Radical Leic. 338; 2nd Rep. Com. on Health of Towns, App. (2), 269.
} 33. 


\section{A HISTORY OF LEICESTERSHIRE}

to serve the growing working-class population in the Newarke and on the western side of the South Field. For many years the only other open space available to the population as a whole was St. Margaret's Pasture, an area of about I 9 acres on the east bank of the Soar. It was owned by the parish and controlled by the select vestry, and until i 878 the parishioners had rights of common there. ${ }^{67}$ 'The pasture was used as a playground for the crowded district in the north of St. Margaret's parish, though before Wicksteed's sewerage schemes took effect the pollution of the river and the canal, between which the pasture lay, made it less attractive. ${ }^{68}$ The practice of nude bathing in the river beside the pasture was common and drew down strong censures. ${ }^{69}$ Until the town racecourse, now Victoria Park, was thrown open to the public in 1866,70 the Welford Road recreation ground and the pasture were the only freely available open spaces in the town. For those who were able to pay a fairly heavy subscription there was the Wharf Street cricket ground, opened in 1825 on a site near Humberstone Road, not far from the centre of the borough and in an area rapidly being built up. ${ }^{71}$ The ground possessed a bowling green as well as a cricket pitch and was used for entertainments of various kinds such as dances and exhibitions of fireworks. ${ }^{72}$

In 1835 Leicester possessed only one theatre, in Hotel Street. In 1836 this was pulled down and replaced by another occupying the same site but facing Horsefair Street; the new building was soon given the name of the Theatre Royal. ${ }^{73}$ In $\mathrm{I} 840$ a second theatre was built in Humberstone Gate. The new building, the Amphitheatre, was often used for circus performances, for which special provision was made when it was constructed. ${ }^{74}$ Lightly built and heavily mortgaged, the Amphitheatre was not a success, and in 1849 it was closed. ${ }^{75}$ The Theatre Royal remained and was still in use in 1956 . It was the only theatre in Leicester from 1849 to 1877 , when. the Opera House was opened. ${ }^{76}$ Concerts and other entertainments were held in the New Hall in Wellington Street, originally built as a meeting-place for the Liberals in $183 \mathrm{I},{ }^{77}$ and in the large Temperance Hall in Granby Street, built in $1853 .{ }^{78}$

It is impossible to state even approximately what proportion of the population of Leicester was literate in the middle of the igth century, but there were sufficient readers to maintain several local newspapers and to ensure a considerable circulation for cheap periodicals. In I 850 the penny weekly publications of the 'Newgate Calendar' class, dealing chiefly with lurid stories of crime and violence, were being sold at a rate of over I,300 a week. At the same date some I, roo penny weeklies of a less objectionable kind were sold each week. Of these the London fournal seems to have enjoyed the largest circulation. In addition, about 120 cheap atheistical periodicals, of which The Reasoner was the most important, were sold weekly. ${ }^{79}$ No precise figures are available for any later date but it is evident that such publications continued to circulate in Leicester on a considerable scale. ${ }^{80}$ It is interesting to note that in I 868 complaint was made that The Police News, apparently then the chief weekly periodical purchased in the town, was illustrated with crude woodcuts depicting scenes of violent crime and that these were considered likely to encourage brutality. ${ }^{8 \mathrm{I}}$

67 Storey, Boro. of Leic. I23; see also p. 357.

68 Patterson, op. cit. 173; 7th Rep. Leic. Dom. Mission (1852), 10.

69 I 2 th Rep. Leic. Dom. Mission (1867), 9; I6th Rep. (186I), I6; 2 2nd Rep. (I867), 4; 24 th Rep. (I869), Io; 29th Rep. (1874), 6.

70 Ibid. 2 Ist Rep. (1866), 3.

7t Patterson, Radical Leic. I73; Ellis, Map of Leic. (1828).

72 White, Dir. Leics. (1846), 94; r2th Rep. Leic. Dom. Mission (1857), 6.
73 Patterson, op. cit. 245; and see p. 363.

74 Fielding Johnson, Glimpses of Anc. Leic. (1906), 403, 404 ; C. J. Billson, Leic. Memoirs, 245.

75 Patterson, op. cit. 246 ; not 1848 as Fielding Johnson, op. cit. 403; Leic. Fnl. I Jan. I 849, p. 2.

76 Billson, op. cit. 120; and see below, p. 362 .

77 White, Dir.Leics. ( 1846$), 94$; and see below, pp. 352-3.

78 White, Dir. Leics. (1877), 310 ; and see below, p. 352.

79 5th Rep. Leic. Dom. Mission (1850), I $3-14$.

80 Ibid. 28 th Rep. (1873), 7; $23 r d$ Rep. (I 868), I6-17.

81 Ibid. 23 rd Rep. (1868), 16-17. 
The local newspapers provided more reputable weekly reading. In I 835 Leicester had three weekly newspapers, the old-established Leicester fournal, which was Tory in outlook, the Liberal Leicester Chronicle, and the Leicester Herald and General Advertiser, a rather less influential Tory paper. ${ }^{82}$ The Chronicle had been owned and edited since I 8 I 3 by Thomas Thompson, who remained in control until his retirement in I 864 , when his son James, the author of a scholarly history of Leicester who had already been writing most of the editorials for many years, became owner and editor. Under the Thompsons the Chronicle supported the more moderate section of the Liberals, both in national and local politics. It favoured, for example, Joseph Whetstone's proposals to treat sanitation as the most urgent need when schemes of town improvement were being actively considered after I 845 . James Thompson was educated by Charles Berry, minister of the Great Meeting, and was thus linked with the Unitarian group which dominated local politics after 1835 . At one time he sat as a Liberal councillor for East St. Margaret's ward. ${ }^{83}$ In July ${ }^{2} 836$ publication of a fourth paper was begun, the Leicestershire Mercury, which expressed the views of the more advanced section of the local Liberals. ${ }^{84}$ The Mercury was published and apparently edited by Albert Cockspur, a printer who had earlier been prosecuted for his publication of a pamphlet criticizing the old corporation. ${ }^{85}$ In October I 864 the Chronicle and the Mercury were united under James 'Thompson's control and ownership. ${ }^{86}$ 'The amalgamation of the two newspapers which had each expressed the views of one of the main sections of the Liberal party in Leicester was made easier by the reunion, a little earlier, of the two wings of the party, which had hitherto been much divided. ${ }^{87}$ The combined paper was published as the Leicester Chronicle and Leicestershire Mercury. ${ }^{88}$

The Leicester Advertiser, which began publication in I 84I, adopted a neutral attitude politically. ${ }^{89}$ A new paper of a Conservative character, the Leicester Guardian, was established in $\mathrm{I} 857$ by T. B. Cleveland ${ }^{\circ}$ but it never seems to have become influential and apparently ceased publication about I 876.91 More important was the South Midland Free Press, a paper originally published at Kettering but moved to Leicester in $1859 .{ }^{92}$ The Free Press was a Radical paper. Thomas Emery, who edited it until his death in $\mathrm{I} 868$, had earlier been a bookseller in Belgrave Gate, and played a prominent part in the affairs of the St. Margaret's select vestry. He was at one time a supporter of Owenite socialism, and was inclined to atheism, as James Thompson himself had at one time been.93 These papers were all published weekly and the town had no daily newspaper until I 872.94

Until I 870 Leicester had no municipal library. 95 'The Domestic Mission attached to the Great Meeting possessed a library, but in 1865 it was said that it was 'abused rather than used'. ${ }^{96}$ 'There was also usually at least one privately owned circulating library in the town. ${ }^{97} \mathrm{~A}$ more ambitious institution was the General News Room, established by a body of shareholders in 1838 in handsome new premises in Granby Street. ${ }^{98}$ In I 839 the proprietors came to an agreement with a bookseller, Thomas Combe, by which the

82 See above, p. I 89 , for their earlier hist.

${ }^{83}$ Memoir of $M r$. Fames Thompson, 9, 10, 14, 26, 29 (Leic. City Ref. Libr., Pamphlets O I, viii); Leic. Chron. and Leics. Mercury, 2 I Jan. I871, p. 6; Leic. Fnl. 6 Jan. I 860, p. 7.

84 Files of newspapers in Leic. City Ref. Libr.; S.

Barker \& Co. Dir. Leics. and Rut. (1875), го .

85 Patterson, Radical Leic. I 99, 230.

86 Barker, Dir. Leics. and Rut. (1875), 103.

87 See above, p. 222.

88 Barker, op. cit. I03; files of newspapers in Leic. City Ref. Libr.

${ }^{89} \mathrm{Ex}$ inf. F. Hewitt \& Son Ltd.; Leic. Fnl. $6 \mathrm{Jan}$. I 860,7 .

90 Barker, Dir. Leics. and Rut. (1875), I03.

LEIC. IV

91 Ibid. I03, I92; White, Dir. Leics. (I 877), 3 I 5.

92 Barker, op. cit. I03.

93 Midland Free Press, 22 Aug. I 868; White, Dir Leics. (1877), 315; Memoir of Fames Thompson, 12. It was said that Emery's 'obituary notices were amongst his best literary efforts': Free Press, loc. cit.

94 White, Dir. Leics. (1877), 315.

95 For the Old Town Hall Library, see below, p. 365 .

96 Ist Rep. Leic. Dom. Mission (1846), 17; 28 th Rep. (1873), I 8; 20th Rep. (1865), 26.

97 White, Dir. Leics. (1 846), 97; Patterson, Radical Leic. I 7 I; Spencer, Nezw Guide to Leic. (I888), I 38.

os White, op. cit. 96 ; see illustration above, plate facing p. 179 . 


\section{A HISTORY OF LEICESTERSHIRE}

circulating library which he had carried on since 1800 should be removed to the News Room, and for the future should be a part of that institution.99 Membership of the General News Room was expensive, and the subscription to the news room alone was f. I I Is. 6d. for the public and $f_{\mathrm{I}} 6 s$. for shareholders; those who wished to use the library had to purchase a share in it at 6 guineas and pay I guinea subscription. ${ }^{\mathrm{I}}$ These charges were later reduced and in $\mathrm{I} 860$ the combined subscription for news room and library seems to have been $\AA_{\mathrm{I}} 5^{s .}{ }^{2}$ The General News Room survived until the end of the Igth century when its building was demolished to allow Granby Street to be widened. ${ }^{3}$ It seems to have enjoyed moderate prosperity and usually had about $25^{\circ}$ members. ${ }^{4}$ A less successful institution of a similar kind was the Athenaeum, founded in I 845 to provide a coffee room and news room for the lower middle class, who might find the General News Room too expensive. ${ }^{5}$ In 1849 the withdrawal of 120 subscribers, caused by the financial difficulties of the time, placed the Athenaeum in a serious position and it closed in $1850 .^{6}$

The Leicester Mechanics' Institute, founded in 1834 , was intended to provide somewhat similar facilities for the working classes, together with easy opportunities for education. ${ }^{7}$ The institute's history has been dealt with elsewhere ${ }^{8}$ and here it is only necessary to mention that it provided courses of study of various subjects, which were well attended at first though they gradually lost support. A considerable library was built up, amounting by I 870 to some 5,000 volumes, and from about I 855 onwards this was perhaps the most active part of the institute. There were about 500 members in the early days of its existence, but by $1857-8$ the number had fallen to 200 and the institute expired from lack of support in 1870.9

By 1860 two societies which were to play a permanent and important part in Leicester's cultural life had been firmly established. The Leicester Literary and Philosophical Society was founded in I 835. It was intended to form a meeting-place for men. of all opinions at a time when there were bitter party and sectarian divisions in the town, and politics and theology were therefore debarred at the meetings, and it was provided that the annual president was to be chosen alternately from the Conservative and Liberal parties. ${ }^{10}$ A very wide variety of subjects were discussed at the meetings of the society which were held monthly at first and after I 838 fortnightly. II The Society seems to have begun its collection of antiquities in $\mathrm{r} 840$, and this was presented to the borough as a nucleus for the town museum in $1849 .{ }^{12}$ The Literary and Philosophical Society survived the economic difficulties of I 848-9 and continued to be one of the town's most active and influential cultural institutions. In the period I $850-70$ it usually had about I 50 members. ${ }^{13}$

The Leicester Architectural and Archaeological Society was founded in 1855 . Its most important early interest was architecture, especially ecclesiastical architecture. As an extension of this interest it gave advice on the repair and restoration of churches, often unheeded, and was active with more success in the preservation of historic buildings. The society was as much concerned with the county as with the town and in general seems to have attracted less attention in Leicester than did the Literary and Philosophical Society. ${ }^{\mathrm{I}}$

99 Fielding Johnson, op. cit. 398-9.

I White, Dir. Leics. (1846), 96-97.

2 Leic. Fnl. 27 Jan. 186o, p. 5.

3 Fielding Johnson, op. cit. 399.

4 Leic. Fnl. 27 Jan. I 860, p. 5; 23 Jan. I863, p. 5. 239.

5 White, Dir. Leics. (1846), 97; Patterson, Radical Leic.

${ }^{6}$ Leic. Fnl. I Jan. I 849 , p. 3 ; Patterson, loc. cit.
7 V.C.H. Leics. iii. 252.

8 Ibid. 253-4. 9 Ibid.

Io F. B. Lott, Centenary Bk. Leic. Literary and Philosophical Soc. 2, 8-9, 38.

II Ibid. I 4, I 5 .

I2 Ibid. 31-39; Storey, Boro. of Leic. 32-33.

13 Lott, op. cit. $43,47,54,64$.

14 Leics. Arch. Soc. I855-1955, 5, 6, I 5-1 8. 


\section{$186 \mathrm{O}-1914$}

The years from I 860 to I9I4 were in general a period of prosperity, expansion, and improvement in Leicester. The borough's population swelled with immense rapidity from 68,000 in $\mathrm{I} 86 \mathrm{I}$ to just over $\mathrm{I} 42,000$ in $\mathrm{I} 89 \mathrm{I}{ }^{\mathrm{I}}{ }^{5}$ In the decade $\mathrm{I} 86 \mathrm{I}-7 \mathrm{I}$, the time of

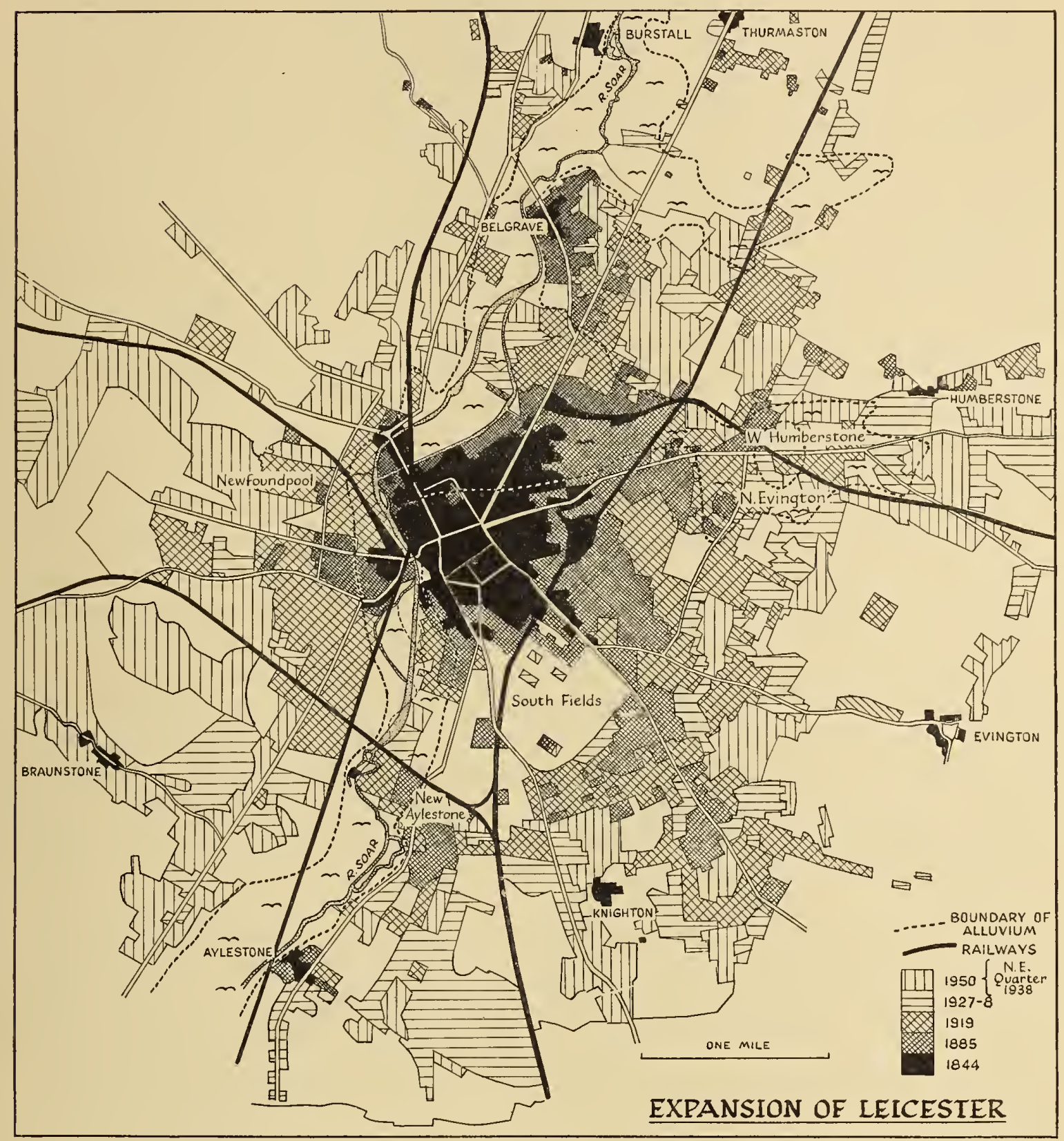

most rapid growth, the population increased by 39.9 per cent. ${ }^{16}$ Under the Leicester Extension Act of $\mathrm{I} 89 \mathrm{I}$, which came into force in January I 892 , the borough was much enlarged and areas with a population of 32,500 in I 89 I were added to it, so that the total population of the borough as enlarged was $\mathrm{I} 74,600$ in $\mathrm{I} 89 \mathrm{I} .{ }^{\mathrm{I}}$ By I $9 \mathrm{II}$ the population had risen to $227,000 .^{18}$

Most of the increase during the Igth century came from the excess of births over

15 V.C.H. Leics. iii. 179.

16 Rep. Medical Officer of Health (1907), 12.
17 V.C.H. Leics. iii. 1 79, 180.

18 Ibid. 179. 


\section{A HISTORY OF LEICESTERSHIRE}

deaths within the town itself, but migrants from the county and from outside contributed a substantial proportion. In I 85 I 45 per cent. of the people living in Leicester had migrated there from elsewhere, and this was a proportion which seems to have held good for the rest of the century, though it can be calculated only for I85I and for I9I I, when 62 per cent. came from outside the town. ${ }^{19}$ The statistics for those who had migrated to Leicester from beyond the county boundary are more continuous, however, and indicate that from I86I to I90 I they were increasing in numbers and in the proportion they bore to the total population. In $185 \mathrm{I}$ and $\mathrm{I} 86 \mathrm{I} 20$ per cent. came from beyond Leicestershire, but in I89I and I90I the proportion was 28 per cent., most of them from surrounding counties, but more particularly from the rural counties to the south and east of Leicester. ${ }^{20}$ The volume of migration to Leicester tended to increase, except in the last decade for which birthplace statistics are available (I90 I-I I), but the average range showed no parallel increase, and there was in fact a tendency for the relative importance of newcomers from the most distant counties to fall off towards the end of the period. ${ }^{2 I}$

A rate of increase which amounted to a third of the total population every ten years and which was sustained for 40 years was impressive enough, but what mattered in terms of the physical expansion of the town were the total numbers to be housed. It is impossible to say exactly how many new houses were built over the whole period, but the number of occupied dwellings increased by some 30,000 between I86I and I90I, a figure three times as large as the increase between I80I and I86I, and twice as large as the total number of houses in the town in $\mathrm{I} 86 \mathrm{I} .{ }^{22}$ Though this growth seems so rapid, the town hardly did more than maintain its position in relation to other towns. In $185 \mathrm{I}$ Leicester was the biggest town in the east Midlands, rather larger than its chief rival, Nottingham, and half as large again as Derby. ${ }^{23}$ By I89I Nottingham was considerably larger than Leicester, ${ }^{24}$ and in the 20 th century it has retained its lead, although no other town in the east Midlands approached Leicester's population in numbers. During the late I 9 th and early 2oth centuries Derby remained little more than half the size of Leicester, and Coventry and Northampton substantially less than half. ${ }^{25}$ In its own county Leicester was without a rival. Loughborough, the next largest town in Leicestershire, never had during the period from I 835 to I9I 4 a population more than a quarter the size of Leicester's. ${ }^{26}$

For the town's chief industries the period was on the whole one of growth and success, characterized in hosiery and footwear manufacture by a general transition from domestic to factory production. ${ }^{27}$ The growth of population would in itself have provided much extra work for the borough council even if the scope of its activities had not been extended at all. The second half of the igth century was, however, a period when new tasks were being laid upon municipalities and when higher standards were beginning to prevail in various spheres which were already the responsibility of local authorities.

In the field of public health, in particular, Leicester corporation was faced with serious problems. After the completion of Wicksteed's sewerage scheme, ${ }^{28}$ little was done in the way of town improvement for some years and by 1860 action was badly

\footnotetext{
19 Census, 1851 ; Census, I9I r. This paragraph and the next were contributed by Mr. C. T. Smith.

20 Census, 1851-1901; for comparable figures for the I 8 th cent. see above, p. 193.

21 Migrants from the South-west of Eng. constituted 2.8 per cent. of all migrants to Leic. in $1851,2.1$ per cent. in 1871 , and 2.3 per cent. in 1911 : Census, 1851 ; Census, I $87 \mathrm{r}$; Census, r91 1 .
}

${ }^{22}$ Census, $1801-1901$, and for the period from 1844 see map, p. 275

23 Census, $185 \mathrm{r}$.

24 Census, r891. Nottingham's boundaries were extended in 1877 : Rec. Boro. of Nott. ix 256-7.

${ }^{25}$ Census, $1891-1911$.

${ }^{26}$ V.C.H. Leics. iii. $179,192$.

${ }^{27}$ See below, pp. 308,316. $\quad{ }^{28}$ See above, p. 268. 
needed in several directions. Most serious perhaps was the need to cope with the recurrent floods caused by the overflowing of the Soar and its tributaries. Flooding had long been a cause of much annoyance and of some danger to public health, ${ }^{29}$ and during the middle years of the Igth century the damage and inconvenience had been aggravated by the growth of residential areas in the low-lying parts of the town, and by the obstruction of the river valley at and below Leicester by mill dams and railway embankments and by numerous minor encroachments on the river itself, all of which hindered the free passage of flood water down the river. ${ }^{30}$ There were disastrous floods in the spring of 1867 , and these perhaps hastened the corporation's action, for in the same year it decided that major alterations were necessary, both in the course of the river itself and in its weirs and sluices. ${ }^{31}$ To obtain the powers to execute this plan and to effect other town improvements contemplated at the same time the corporation in I 868 procured the Leicester Improvement, Drainage, and Markets Act ${ }^{32}$ by which it was empowered to widen and deepen several stretches of the river bed, to cut a completely new channel for the Soar at two points and to make alterations in the system of weirs which controlled the passage of the river through the town. ${ }^{33}$ In I 874 and again in 1876 the corporation obtained further powers to widen and deepen both the Soar and the Union Canal and to alter the river's course at various points. By the 1876 Act it was also empowered to widen and deepen the Willow Brook, a small tributary of the Soar which ran through the northern part of the borough. ${ }^{34}$ It proved impossible to carry out the works authorized by these three Acts within the times specified; as a result and also because it became clear that further alterations to the river were needed, the corporation obtained a further Act in I88I, which sanctioned additional floodprevention works, including the cutting of new channels for the Soar at three points and important alterations to the Willow Brook. ${ }^{35}$ The whole undertaking was completed in $\mathrm{r} 89 \mathrm{I} .{ }^{36}$

The flood-prevention scheme was the largest single undertaking in the field of public works carried out by Leicester corporation in the igth century. The total cost was some $£ 300,000^{37}$ and the magnitude of this sum in terms of the corporation's finances can be gauged from the fact that in 1890 the rateable value of the borough was $f_{52} 2,000 .{ }^{38}$ The project involved long and complicated negotiations for the purchase of riparian property and of water rights, and in one case the corporation's acquisition of land by compulsory purchase led to bitterly contested litigation. ${ }^{39}$ The works not only ended the flooding that had affected large areas of the town but greatly altered the channels along which the Soar flowed. $4^{\circ}$ In connexion with the alterations to the river it was found desirable to rebuild the West Bridge and the Braunstone Gate Bridge, ${ }^{41}$ and two new bridges were built across the Soar at Mill Lane and Walnut Street, in the southern part of the town. ${ }^{42}$ In 1898 , after the flood-prevention scheme was complete, a third bridge was built between the Newarke and Braunstone Gate. ${ }^{43}$ These three bridges much improved communications between the east and west banks of the Soar in the area south

29 See above, p. $26_{3}$.

30 Hawksley, Rep. on Plans for Prevention of Floods (1867), 3, 9, ro (Leic. City Ref. Libr., Pamphlets $\mathrm{O}_{3}$, vii); Griffith, Rep. on Fuly Floods (188o), 5 (Pamphlets $\mathrm{O}_{4}$, ii); Buck and Franklin, Rep. on Epidemic Diarrhoea, 29.

31 Leic. Fnl. I 5 Feb. 1867, p. 6; 22 nd Rep. Leic. Dom. Mission (1867), I 3; Storey, Boro. of Leic. 75.

32 I \& 32 Vic. c. 24 (priv. act).

33 Storey, Boro. of Leic. 75-76.

34 Ibid. 77-78; Leic. Flood Prevention Act, 1874, 37 \& 38 Vic. c. 62 (priv, act); Leic. Additional Flood Works Act, I $876,39 \& 40$ Vic. c. 26 (priv. act).
35 Storey, op. cit. 8I-83; Leic. Additional Flood Works Act, I 88I, 44 \& 45 Vic. c. 72 (priv. act).

${ }_{36}$ Rep. Medical Officer of Health (189I), 48.

37 Storey, Boro, of Leic. 91.

${ }^{38}$ Abstract of Accts. of Boro. of Leic. (1 89 I), 40.

39 See Storey, op. cit. $88-89$, and for the negotiations generally, ibid. 76-87.

40 Map showing old and new courses in Griffith, Rep. on Fuly Floods; cf. Ellis Map of Leic. (1 828), and modern map.

4 I Storey, Boro. of Leic. 82, 86, 91.

43 Leic. Mercury, 6 July I955; T.L.A.S. ix. 4
42 Ibid. 90. 


\section{A HISTORY OF LEICESTERSHIRE}

of the town centre. Before their construction there had been no road bridge between the West Bridge and Aylestone, a distance of about $2 \frac{1}{2}$ miles. ${ }^{44}$

For much of the second half of the I 9 th century the municipal authorities were engaged in a long struggle to provide the borough with an efficient system of sewerage and sanitation. Wicksteed's sewerage scheme, ${ }^{45}$ though it had improved the town's health considerably, proved as time went on to be increasingly inadequate. The sewers themselves seem to have been badly constructed and particularly to have had too little fall, ${ }^{46}$ but the worst defect was the failure of the works set up by Wicksteed to deodorize the liquid sewage before discharging it into the Soar in an efficient manner. In consequence of this failure the river became badly polluted downstream from the works, and as early as I 867 it was remarked that for several years previously the stench from the river in the summer had been most obnoxious. ${ }^{47}$ It was long, however, before the situation was effectively remedied. A proposal to experiment with the irrigation system of sewage disposal, brought forward in 1870 , was not adopted because it was thought to be too expensive, ${ }^{48}$ and in $1873-4$ another scheme to improve the sewers and sewage works was considered but abandoned because the Local Government Board did not approve it. 49 In 1875 another plan for treating the sewage by irrigation was dropped because of its cost and it was not until I 885 that a thorough reform of the sewerage was set in hand. In the meantime the existing sewage works were extended in 1877.50

That this postponement of radical changes was at all possible was due to the adoption of the pail-closet system. The increasing use of water-closets in Leicester had been hindered by the refusal of the water company to supply water for a closet alone and its insistence that no water would be supplied unless it was taken for all purposes. ${ }^{51}$ It was also found that in the poorer areas of the town water-closets were not properly used and were soon out of order. ${ }^{2}$ In 187 I the corporation decided to introduce the pailcloset system, which had been successful in various northern towns, ${ }^{53}$ and some 7,000 pail-closets were eventually installed. ${ }^{54}$ This development certainly did much to relieve the defective sewers, but difficulties arose in the removal and disposal of the night soil. At first, up to 1873 , this had been removed by contractors, but the system proved unsatisfactory, and the task was then undertaken directly by the local authority although it proved to be very expensive. 55 The night soil was loaded upon railway wagons in a siding in Freak's Ground, but the nuisance caused by this led in 1878 to legal proceedings against the corporation. ${ }^{56}$ Subsequently the sewage was loaded on to canal barges but this caused complaints that the canal was being polluted. 57 The pail-closets were in fact never a satisfactory substitute for an adequate sewage system. ${ }^{58}$

It was eventually the pollution of the Soar by the existing Leicester sewage works that made a complete reorganization essential. An inspection of the condition of the river in September $\mathbf{1} 884$ revealed serious pollution. This led to a report by the Local Government Board insisting on the need for the corporation to take immediate steps to

${ }^{44}$ For the flood prevention works, esp. the financial aspect, see Storey, Boro. of Leic. 75-92; Crossley and Foxton, Rep. Cond. River Soar: Prevention of Floods: Rep. by Boro. Surveyor (1882); Hawksley, Rep. on Plans for Prevention of Floods (1867); Hawksley, Rep. on Plans for Prevention of Floods (1880); Griffith, Rep. on Fuly Floods. 45 See above, p. 268.

46 Johnston, Diarrhoea of Leic. I I sqq.; Gordon, Rep. on System of New Main Trunk Sewers (1 886), 3-4; Mawbey, Rep. on Sewer Ventilation and Flushing (1894), 4, 5, 7; Rep. Medical Officer of Health (1881), 25, 28-29.

47 Trans. Leic. Literary and Philosophical Soc. 1835-79, 279.

${ }^{48}$ Storey, Boro. of Leic. 15.
49 Ibid. $16-17$.

so Ibid. 17.

51 Rep. Medical Officer of Health (1856), 8; ibid. (1866), 12.

52 Clarke, Rep. to Urban Sanitary Authority of Boro. of Leic. 3, 6 (Leic. City Ref. Libr., Pamphlets $\mathrm{O}_{3}$, vi).

53 Storey, Boro. of Leic. I 8; Clarke, op. cit. 9, I I, I 2.

54 Rep. Medical Officer of Health (1889), 45.

55 Leic. Chron, and Leics. Mercury, 14 Mar. 1874, p. 4.

${ }_{56}$ See below, p. 45 I.

57 Rep. Medical Officer of Health (1886), 27-28; ibid. (1893), $8 \mathbf{2}$.

${ }^{58}$ Rep. Medical Officer of Health (1889) 46 ; ibid. (I89o), 33. 


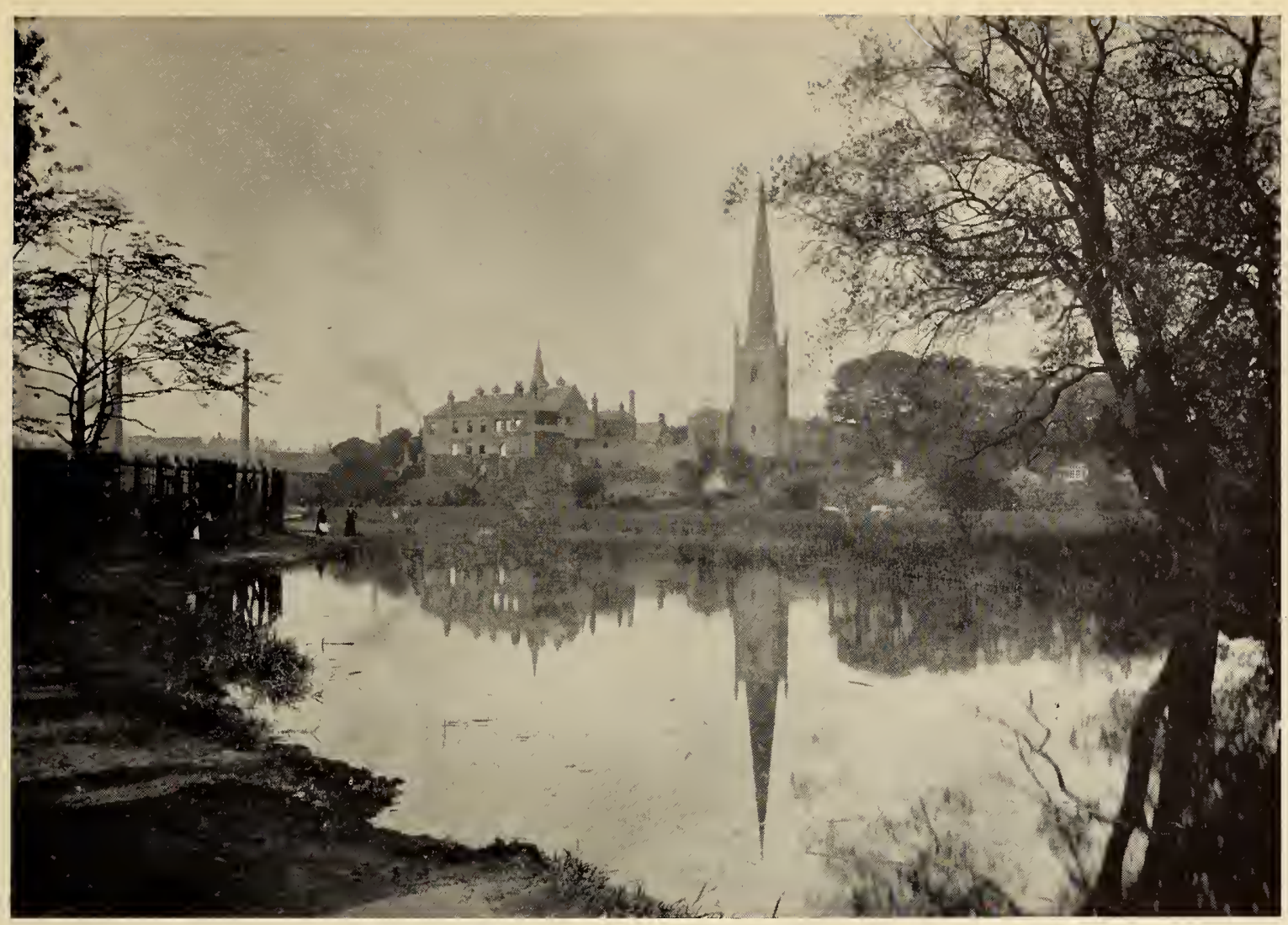

The Castle and St. Mary's Church

seen from the river before the flood-prevention works of $c$. I 890

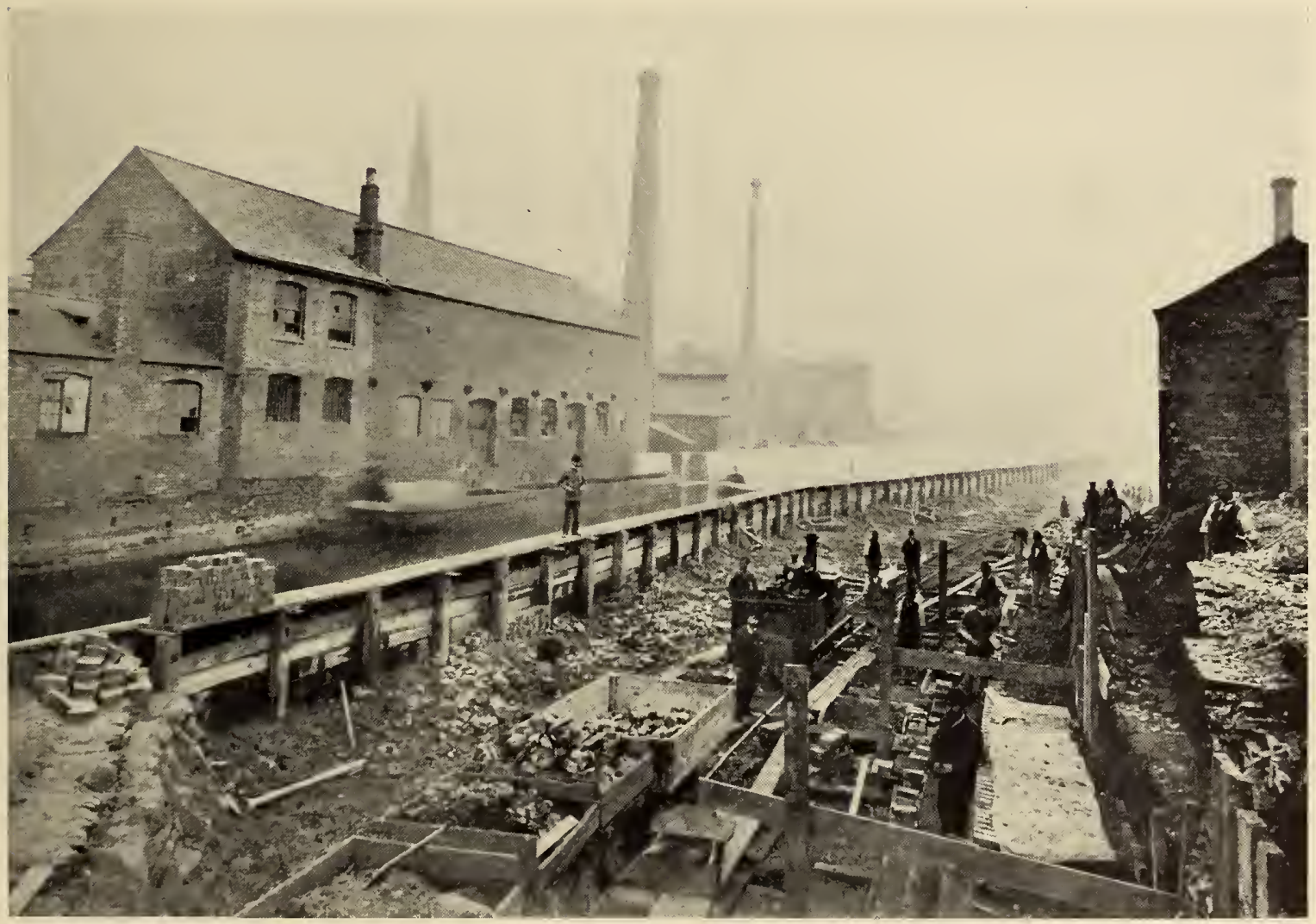

Flood-Prevention Works in Progress south of west bridge 


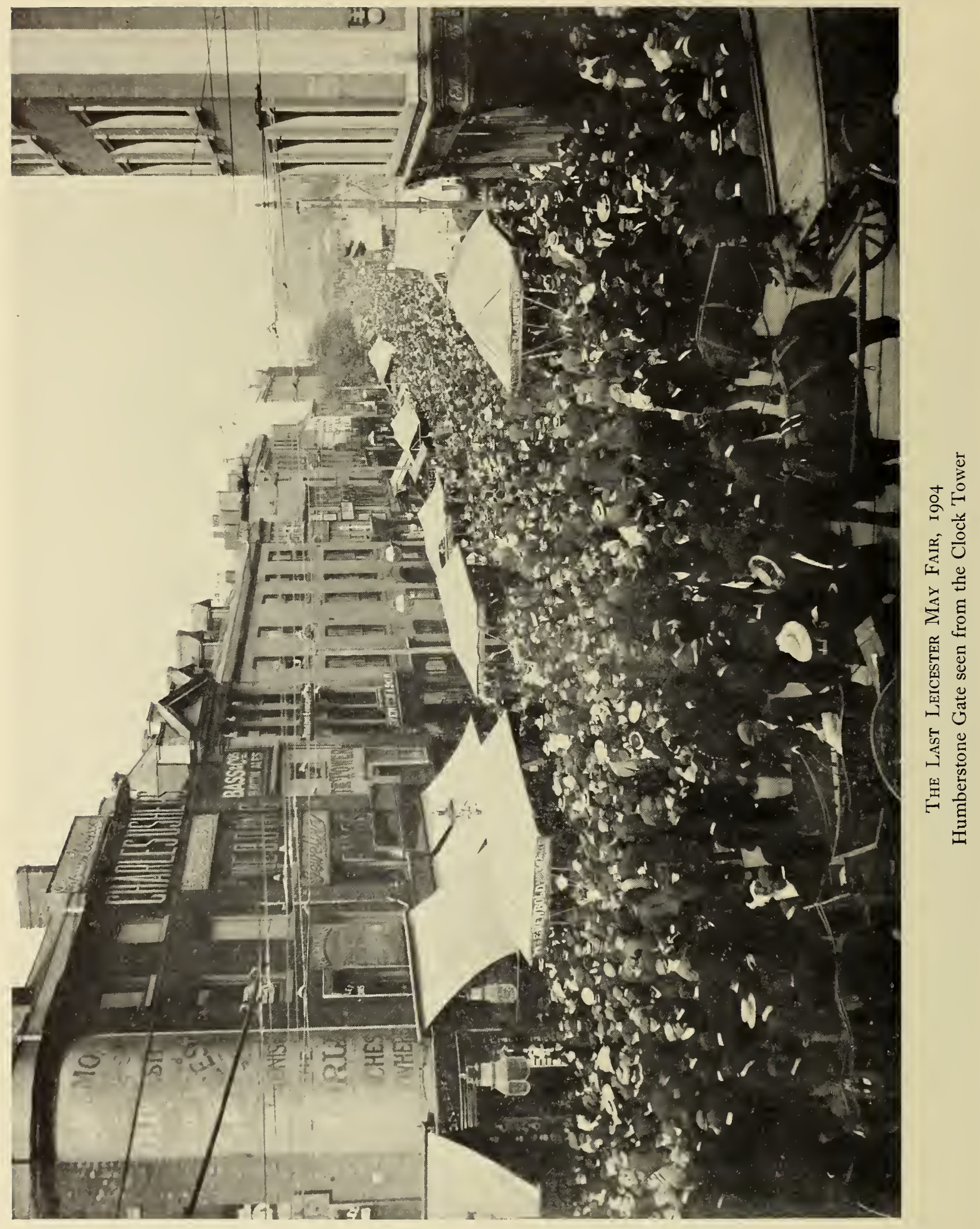


deal effectively with the sewage. 59 In November I 884 the borough surveyor, Joseph Gordon, presented a full report on the situation, suggesting eight possible schemes. ${ }^{60}$ Only two were seriously considered, one for the establishment of a sewage farm at Beaumont Leys, not far from the north-west boundary of the town, and the other for a sewage farm at Thurmaston, about three miles to the north. Gordon favoured the Thurmaston plan but after much investigation and consideration the corporation decided on Beaumont Leys, ${ }^{61}$ and arranged to purchase 100 acres there as a site for the works and to lease about $\mathrm{I}, 260$ acres to be used for irrigation. ${ }^{62}$ Pumping the sewage to the new works began in September $1890 .{ }^{63}$ From I 886 onwards a new system of main sewers was constructed.64 The construction of this and of the sewage works made it possible for the town council to decide in $\mathrm{I} 89 \mathrm{I}$ to replace gradually all pail-closets by water-closets, ${ }^{65}$ but it was not until 1895 that it compelled all owners of property to make the change. ${ }^{66}$ The work of conversion was carried on during the next few years, part of the cost being borne by the municipality. ${ }^{67}$ These extensive works for the first time gave Leicester a really adequate system of sanitation. It is an indication of the way in which the work was done that no radical change was necessary until after the Second World War. In I 956 Beaumont Leys sewage farm was still serving the city, though the corporation were planning new works at Wanlip. ${ }^{6}$

Some other activities of Leicester corporation in matters connected with public health must be briefly mentioned. In I 865 the council decided to build an asylum for the town's pauper lunatics, who had hitherto been accommodated in the Leicestershire and Rutland Asylum in the town, and in other institutions. A site was purchased at Humberstone and the building was opened in I869. It was enlarged in I883 and I 890 . The architect of the original building was Edward Loney Stephens, the borough surveyor. ${ }^{69}$ In 187 I the town council ordered the erection on its property at Freak's Ground of an isolation hospital. It was led to take this step by an outbreak of scarlet fever and by the fear of a smallpox epidemic. The buildings were intended to be temporary only and were built of corrugated iron..$^{70}$ They nevertheless remained in use until the building of the new isolation hospital at Gilroes in $1900 .{ }^{71}$ In 1879 the corporation acquired by $\mathrm{Act}^{72}$ the power to compel doctors to inform the medical officer of health of cases of any of a number of important infectious diseases. At the time only four other municipalities possessed such powers, the acquisition of which at first aroused much opposition from local doctors, although the results proved to be really beneficial. ${ }^{73}$

The improvement of the town's health, brought about partly by the activities of the local authority and partly by such factors as the rising standards in housing and the increasing prosperity of the town as a whole, was reflected by the decline in the deathrate. For the ten years $1860-9$ the average death-rate was 25.2 in every 1,000 of the population, while for the years $1900-9$ it was 14.6 in every $I, 000.74$ The mortality at Leicester during the last quarter of the igth century and the early years of the 20 th compared favourably with that of most other large industrial towns in Britain, ${ }^{75}$ and

\footnotetext{
59 Storey, Boro. of Leic. 18-I9.

60 Ibid. I9; J. Gordon, Rep. on various schemes for a further purification of the sewerage of Leic. (1884), passim (Leic. City Ref. Libr., Pamphlets $\mathrm{O}_{3}$, vii).

61 Storey, op. cit. 20-21; J. Gordon, Special Rep. on Sewage Disposal (1885), passim (Leic. City Ref. Libr., Pamphlets $\mathrm{O}_{3}$, vi).

62 Storey, loc. cit.

${ }^{6}$ Rep. Medical Officer of Health (1890), 31 .

64 Ibid. (I 890 ), 29-30; ibid. (I 89 I), 49; ibid. (1887), 34; ibid. (1888), 30; Gordon, Rep. on System of New Main Trunk Sewers (1886), passim; Storey, Boro. of Leic. 23-27. ${ }_{5}$ Rep. Medical Officer of Health (1891), 5 I.
}

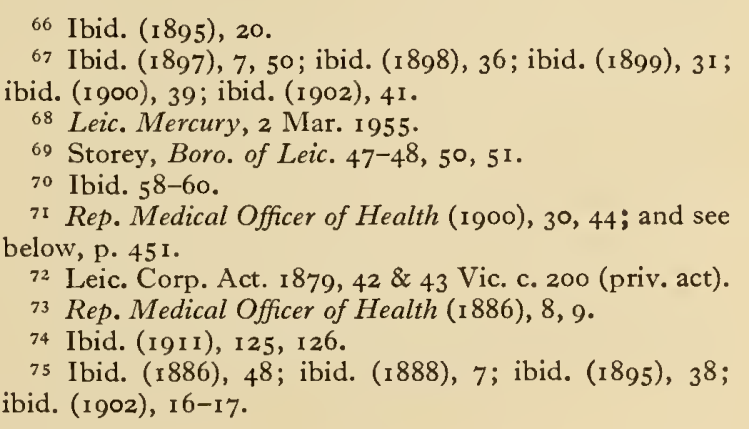


the death-rate would have been lower still had it not been for the ravages of the disease known as summer diarrhoea. Long investigation was carried out at Leicester and elsewhere to discover the causes of this illness, but without success. ${ }^{76}$ No remedy was forthcoming, and Leicester for long suffered more from this disease than almost any other town in England. ${ }^{77}$ The influence of this disease upon the death-rate can be seen from the fact that in the decade I 866-75 just over I I per cent. of all deaths in the town were due to diarrhoea..$^{78}$ The districts most affected were the low-lying areas in the north and central parts of St. Margaret's parish 79 and the mortality among infants was especially heavy. ${ }^{80}$ Between 1890 and 1899 an average of 290 children under a year old died of summer diarrhoea yearly. ${ }^{81}$ In the early years of the 20 th century the number of deaths per $\mathrm{I}, 000$ of the population from this disease began to decline, apparently because of the cumulative effects of continued improvements in sanitation and in the general cleanliness of the town, and in particular there was a marked fall in the infant mortality from the disease. ${ }^{82}$ By I9I 2 , when for the first time for many years there was no summer epidemic of diarrhoea, the disease was no longer a serious menace to the town's health. ${ }^{83}$

In the case of summer diarrhoea Leicester was prominent because of its sufferings from a disease which defeated the efforts of medical science. In the case of smallpox the town became famous for its refusal to adopt the preventive methods which were considered efficacious by most medical authorities. Although the vaccination of infants was made obligatory in $\mathrm{I} 853$, it was not until after the passage in 1867 of an Act providing for the more stringent enforcement of compulsory vaccination that opposition developed at Leicester. ${ }^{84}$ Previously vaccination had been generally accepted, and in I 863-4, when a smallpox epidemic occurred in the town, nearly 4,000 additional vaccinations and revaccinations were performed. ${ }^{85} \mathrm{~A}$ substantial proportion of children born remained unvaccinated, but this does not seem to have been due to any organized resistance. ${ }^{86}$ In the years after 1867 considerable opposition grew up, mostly due to a belief that vaccination might infect children with skin diseases. ${ }^{87}$ In I 869 the Leicester Anti-Vaccination League was formed 88 and by $187 \mathrm{I}$, when an Act was passed under which vaccination could be still more rigorously enforced, the agitation had become sufficiently effective to provoke a strong protest against it from the town's medical officer of health. ${ }^{89}$ This was followed by legal proceedings against parents for failing to have their children vaccinated; between I 868 and I 889 there were more than 6,000 such prosecutions in Leicester; 3,65 I persons were fined and 64 imprisoned for non-

\footnotetext{
${ }^{76}$ Rep. Medical Officer of Health (1867), 14-15; ibid. (1868), 22-24; ibid. (1878), 8-38; ibid. (1884), 23; ibid. (1886), 19; ibid. (1887), I8 sqq.; ibid. (1888), $21-26$; ibid. (1889), 2 I sqq.; ibid. (I 900), I6; ibid. (I 902), 59; J. Sloane, Rep. on Infant Diarrhoea of Leic. (Leic. City Ref. Libr., Pamphlets $\mathrm{O} 3$, vii); R. Weaver, Sanitary Inquiry into probable causes of yearly epidemics (Pamphlets $\mathrm{O}_{2}$, iv); Buck and Franklin, Rep. on Epidemic Diarrhoea (1 875); A. McCook Weir, Infantile Mortality and Summer Diarrhoea (1 876) (Pamphlets O I, xiii); W. Johnston, Rep. on principal zymotic diseases during 1877,21 sqq. (with Rep. Medical Officer of Health (1877)).

${ }_{77}$ Rep. Medical Officer of Health (1900), 32; Johnston, op. cit. 2 I , 23, 24, 5 I.

${ }_{78}$ Rep. Medical Officer of Health (1876), 7 .

79 Ibid. (1897), 16; ibid. (1900), 32; Buck and Franklin, Rep. on Epidemic Diarrhoea, 43.

${ }^{80}$ Rep. Medical Officer of Health (1897), I 7 ; ibid. (1898); I 7 ; ibid. (1 899), 22.

81 Ibid. (1900), I6.

82 Ibid. (I902), 45; ibid. (1903), 25 ; ibid. (1907), $31-$ 32 ; ibid. (1908), 39 ; ibid. (1909), 35; ibid. (1910), 39 ; Rep. on Epidemic Diarrhoea in I904, 5, I 5 (bound up at end of Rep. Medical Officer of Health (I904)). Deaths per $\mathrm{I}, 000$ of the population from this disease numbered $\mathrm{I} \cdot 68$
}

in $1884-8,1 \cdot 3$ in $1889-93,1 \cdot 0$ in $1894-1903,0.79$ in $1904-$ 8: Rep. Medical Officer of Health (1909), I 24. Numbers of infants dying from the disease in every thousand born were $4 \mathrm{I}^{\circ} 9$ in $1806-1900,28 \cdot 4$ in I90I-5: ibid. (I907), $2 \mathrm{I}$.

${ }_{83}$ Rep. Medical Officer of Health (1912), 9.

84 Act for compulsory vaccination, I853, I6 \& I7 Vic. c. 100; Vaccination Amendment Act, 1867, 30 \& 31 Vic. c. 84 .

85 4th Rep. Royal Comm. on Vaccination [C. 6527], p. 4 I 3 , H.C. (1 893 ),

80 The proportions of vaccinations to births were 43.5 per cent. in $1862,54.5$ per cent. in $1863,61.7$ per cent. in $1864,40^{\circ} 7$ per cent. in 1865,48 per cent. in 1866 , and $41^{\circ} 5$ per cent. in 1867 . The high figures of 1863 and 1864 were due to epidemics: figures from 4th Rep. Royal Com. on Vaccination, p. $4 \mathrm{I} 3$, where estimates of deaths before vaccination are made (apparently under I per cent. except in I 867, when just over I per cent.). The Leic. statistics are incomplete before 1862 .

87 4th Rep. Royal Comm. on Vaccination, I63, I69, I 7 I, I 72 ; 2 th Rep. Leic. Dom. Mission (1869), I 4 ; J. T. Biggs, Leic.: Sanitation versus Vaccination, 102.

${ }_{88}$ Biggs, op. cit. 79.

89 Rep. Medical Officer of Health (1871), 5, 6-9. 
payments of fines. ${ }^{90}$ Prosecution only made the opposition stronger. ${ }^{91}$ The duty of enforcing the law in this matter rested upon the Board of Guardians, and in January I 883 the Leicester guardians declined to authorize proceedings against a number of people who had failed to have their children vaccinated.92 The triennial election to the board held in April was fought very largely on this issue, a majority opposed to vaccination was returned, and until the end of 1883 there were no more prosecutions. Some of the guardians later changed their attitude, and in 1884 prosecutions were resumed. At the next election in $\mathrm{x} 886$ a board almost entirely pledged to oppose compulsory vaccination was elected, and declined to authorize prosecutions again. ${ }^{93}$ From I 886 to 1898 the law about vaccination was virtually in abeyance at Leicester. ${ }^{94}$ The number of primary vaccinations fell sharply. In 1870 the number of registered vaccinations was 81.7 per cent. of the number of births. In I 886 this fell to 23. I per cent. and in I889 to 3.6 per cent. ${ }^{95}$ The corresponding figures for England and Wales as a whole in 1873,1886 , and I 887 were 60.2 per cent., 54.9 per cent., and 53.9 per cent. ${ }^{6}$ From I 889 to I 899 the number of primary vaccinations never reached 300 in any one year, although there were more than 4,500 births in every year during that period. ${ }^{97}$ In 1898 a new Act ${ }^{98}$ provided that children might be exempted from vaccination if their parents had conscientious objections to it, and also gave larger powers to the Local Government Board to control the process of public vaccination. This arrangement was not generally considered acceptable by the opponents of compulsory vaccination, but more than i 1,000 certificates of exemption under the Act were applied for in Leicester during I 898, the great majority of them presumably for children born during the time when compulsory vaccination was in abeyance in the town. At the end of 1898 the vaccination officer for Leicester retired and the guardians refused to appoint a successor. They feared that a new officer might without their consent begin prosecutions of parents who had neither had their children vaccinated nor secured exemption, for from 1898 , under the Act of that year and an order subsequently made by the Local Government Board, it was possible for the vaccination officers to take such action without the consent of the board of guardians. The Leicester guardians persisted in their refusal to appoint a vaccination officer and in I 899 the Local Government Board obtained a writ mandamus ordering the guardians to make the appointment. 99 The guardians remained contumacious and only gave way when a writ of attachment was issued against them. ${ }^{\mathrm{I}} \mathrm{A}$ new and active vaccination officer was appointed and in I $90 \mathrm{I}$ he obtained a conviction, upheld on appeal to the High Court for failure to comply with the Act of I 898 . Further prosecutions followed but the law was not put into operation very vigorously. ${ }^{2}$ From I 90 I to 1907 resistance to vaccination continued. After I90I the number of vaccinations increased, perhaps partly because of a smallpox epidemic in the town in $1902-4,{ }^{3}$ but despite this most children born in Leicester in $190 \mathrm{r}-7$ were neither vaccinated nor exempted, as is shown in Table I. After the enactment in 1908 of legislation which made it much easier for parents to secure exemption from vaccination for their children, the controversy gradually became less acute. In consequence of the changed legal position the number of exemptions

90 4th Rep. Royal Comm. on Vaccination, 415.

91 For the following section, see Biggs, op. cit. I 50 et sqq.

92 4th Rep. Royal Comm. on Vaccination, 174.

93 Ibid. $163-4,173$.

94 Ibid. 152, 174-5, 238; Rep. Medical Officer of Health (1887), 16; ibid. (1890), 49; ibid. (1893), 67; ibid. (1894), 52 .

95 Rep. Medical Officer of Health (1900), 22; 4th Rep. Royal Comm. on Vaccination, 465. Those vaccinated were not of course necessarily born and vaccinated the same year.
96 I7th Annual Rep. Local Govt. Bd. I887-8 [C. 5526], p. 338 , H.C. (i 888 ), xlix.

97 Rep. Medical Officer of Health (1899), 63; ibid. (1900), 22.

98 Vaccination Act, 1898,61 \& 62 Vic. c. 49.

99 Biggs, Sanitation versus Vaccination, 320, 322-5.

I Ibid. 341-2.

2 Rep. Medical Officer of Health (1902), 30, 31 .

3 Ibid. (1902), 21, 26-27; Rep. on Smallpox Epidemic at Leic. I 903 (bound up with Rep. Medical Officer of Health (1903); there is a similar rep. for 1904). 
TABLE I

Vaccinations, $190 \mathrm{r}-7^{4}$

\begin{tabular}{c|c|c|c|c|c}
\hline Year & Births & Primary vaccinations & $\begin{array}{c}\text { Primary vaccinations } \\
\text { as percentage of } \\
\text { births }\end{array}$ & Exemptions & $\begin{array}{c}\text { Exemptions as } \\
\text { percentage of } \\
\text { births }\end{array}$ \\
\hline 1901 & 6,169 & 357 & $5 \cdot 8$ & 500 & $8 \cdot 1$ \\
1902 & 6,313 & 1,237 & $19 \cdot 6$ & 1,500 & $23 \cdot 8$ \\
1903 & 6,018 & 2,487 & $41 \cdot 3$ & 1,029 & $17 \cdot 1$ \\
1904 & 5,981 & 1,282 & $21 \cdot 7$ & 1,044 & $17 \cdot 4$ \\
1905 & 5,888 & 987 & $16 \cdot 8$ & 1,112 & $18 \cdot 9$ \\
1906 & 5,865 & 1,073 & $18 \cdot 3$ & 1,080 & $18 \cdot 4$ \\
1907 & 5,534 & 1,093 & $1,9 \cdot 7$ & 1,256 & $22 \cdot 7$ \\
\hline
\end{tabular}

granted in Leicester in 1908 was nearly double that in 1907 , and in subsequent years the numbers remained much higher than they had previously been (see Table II). ${ }^{5}$ The number of vaccinations declined and there continued to be many infants who were neither vaccinated nor exempted.

TABLE II

Vaccinations, $1908-14^{6}$

\begin{tabular}{c|c|c|c|c|c}
\hline Year & Births & Primary vaccinations & $\begin{array}{c}\text { Primary vaccinations } \\
\text { as percentage of } \\
\text { births }\end{array}$ & Exemptions & $\begin{array}{c}\text { Exemptions as } \\
\text { percentage of } \\
\text { births }\end{array}$ \\
\hline 1908 & 5,680 & 659 & 1I.6 & 2,401 & $42 \cdot 3$ \\
1909 & 5,431 & 660 & $12 \cdot 1$ & 2,367 & $43 \cdot 6$ \\
I910 & 5,380 & 564 & $10 \cdot 5$ & 2,335 & $43 \cdot 4$ \\
1911 & 5,222 & 475 & $9 \cdot 1$ & 2,964 & $56 \cdot 7$ \\
1912 & 5,182 & 447 & $8 \cdot 6$ & 3,173 & $64 \cdot 2$ \\
1913 & 5,278 & 436 & $8 \cdot 2$ & 3,391 & $64 \cdot 2$ \\
I914 & 5,144 & 293 & $5 \cdot 7$ & 3,438 & $66 \cdot 8$ \\
\hline
\end{tabular}

Agitation against compulsory vaccination was not confined to Leicester, though in few other places was there such stormy feeling in the matter. The agitation is interesting because it shows the persistence into the 2oth century of that spirit of 'nonconformist' independence and of resistance to constituted authority that had at an earlier period earned for the town the name of 'Radical Leicester'. The agitation was important too in the history of public health, for it was largely the resistance to compulsory vaccination that led to the elaboration at Leicester of a new method for dealing with smallpox. The Leicester opponents of vaccination believed that while it failed to give security against infection and was itself dangerous, immunity from smallpox epidemics could be secured by paying thorough attention to all aspects of hygiene, especially sanitation, and by the prompt isolation of any cases of smallpox that might occur and of any persons suspected of being in contact with such a case. ${ }^{7}$ The practical application of these views and the treatment of smallpox cases gave rise to a new system of dealing with the disease. This became known as the 'Leicester method' and consisted briefly in removing every case of smallpox as soon as detected to the isolation hospital, and in inducing all members of the patient's family and persons with whom he or she had been in contact to submit to a period of quarantine. ${ }^{8}$ This system was first used in $1877^{9}$ and its operation

\footnotetext{
4 Rep. Medical Officer of Health (1906), 42, 49; ibid. (1907), 7, 25 .

6 Rep. Medical Officer of Health (1908-14). 5 Ibid. (1908), 25.

7 4th Rep. Royal Comm. on Vaccination, passim; Biggs, Sanitation versus Vaccination, 80, 1 12-1 7, 122, 156-70.

${ }^{8}$ 4th Rep. Royal Comm. on Vaccination, $157-60$;
}

Johnston, Rep. on principal zymotic diseases during 1877 (Copy in Leic. City Ref. Libr.); T. Windley, Leic. and the Smallpox (1902), passim (Leic. City Ref. Libr., Pamphlets $\mathrm{O}_{3}$, xxiv); Rep. Medical Officer of Health (1886), ro; ibid. (1887), 15; ibid. (1888), 12-17; ibid. (x892), 117.

9 Johnston, op. cit. I I ; Windley, op. cit. 4-5. 
was made much more effective in 1879 when the corporation obtained power to compel doctors and householders to give notice of cases of infectious disease. ${ }^{10}$ The system was largely successful in preventing smallpox epidemics at Leicester, despite the presence in the town of many unvaccinated children. Serious outbreaks of smallpox did take place in $1892-3$ and in $1902-4,{ }^{11}$ but otherwise, although cases were reported almost yearly from I 886 , the disease was prevented from spreading. ${ }^{12}$

Leicester's experience in dealing with smallpox did not fully justify the views of those who supported compulsory vaccination or of those who opposed it. The opponents of vaccination failed to make good their contention that vaccination was altogether ineffective as a safeguard against smallpox. On the other hand it was proved that it was possible for a town to have a considerable proportion of its population unvaccinated and yet to escape disastrous visitations of the disease. One of the arguments advanced in favour of compulsory vaccination was that the existence of any number of unvaccinated persons would cause epidemics and that such persons were an actual danger to public health. The demonstration that by the methods used at Leicester the spread of smallpox could be checked, even in a community with many unvaccinated people, was important in bringing about a change in public opinion about the need for compulsory and universal vaccination.

The corporation's activities in the years from I 860 to I9I 4 included the execution of many schemes for widening streets especially in the centre of the town. It is impossible to describe these developments in detail13 but two of the most important may be mentioned. In a very central position at the East Gates was the town's most important road junction, which had been obstructed since about $\mathrm{I} 750$ by a large detached building. ${ }^{\mathrm{I}} 4$ In I 862 this was demolished, partly at the expense of private individuals, leaving a considerable open space, ${ }^{15}$ in the centre of which a Gothic clock tower was built in I868. ${ }^{16}$ The High Street, though for centuries one of the town's main thoroughfares, had always been narrow, ${ }^{17}$ and had by 1900 become quite inadequate for the amount of traffic that passed along it. Between I 898 and 1902 the corporation purchased much property on both sides of the $\operatorname{road}^{18}$ and in 1902 many of the buildings were demolished and the street greatly widened. ${ }^{19}$

The removal of several of the markets, too, contributed to making the flow of traffic through the town easier. The Saturday market was left in its ancient market-place though steps were taken to improve the means of access to it. ${ }^{20}$ The Wednesday market for fruit and vegetables, held in High Cross Street, became a great obstruction to traffic there and despite some opposition the corporation in 1884 secured the insertion in a local Act of a clause providing that the market should in future be held in the Saturday market place, where a certain area was to be set aside on Wednesdays for the sale of fruit and vegetables. ${ }^{21}$ The hay market was removed from the East Gates, as part of the scheme for improving the traffic conditions there, and was in future held in Humberstone Gate. ${ }^{22}$ A more important step was the construction of a livestock market. The old site of the cattle and sheep market, on ground adjoining Horsefair Street, was con-

so See above, p. 279 ; in 1897 the council obtained, under the Leic. Corporation Act, r $897,60 \& 6$ I Vic. c. 218 (priv. act), the power to pay persons who were away from work when in quarantine for smallpox: Rep. Medical Officer of Health (1 901), r9.

II Ibid. (1892), 85; ibid. (1 893), 8; ibid. (1902), 21-27; ibid. (1903) and (1904), smallpox reps. attached; Windley, Leic. and the Smallpox, 7-8.

I2 e.g. Rep. Medical Officer of Health (1886), i 6.

I3 For details see Storey, Boro. of Leic. 7-1 I; Leic. Council Minutes, 1897-1914, passim.

I4 See below, p. 35 I.
I5 East Gates Improvement (1871), 14-15 (copy in libr. of Univ. Coll. Leic.).

16 Ibid. 39-43; see also frontispiece, and below, p. 35 I

17 For a view of High Street before widening see Leic. Mercury, I 3 July I 955.

I 8 Abstract of Accts. of Boro. of Leic. (1899), I45; ibid. (1 900), I 59; ibid. (1 903), 235.

I 9 Waddington, Leic. The Making of a Modern City, I 2, 38 .

20 Storey, Boro. of Leic. 6-7. 21 Ibid. 133-4.

22 East Gates Improvement, 49, 4I, 33, 31; Leic. Inl. 8 Mar. 1867 , p. 8. 


\section{A HISTORY OF LEICESTERSHIRE}

venient enough when it was on the southern outskirts of the town, but by about I86o the area had been enclosed by streets and there were complaints of the hindrances to traffic and the danger to public health caused by the driving of large numbers of animals to the market. ${ }^{23}$ The corporation decided that the market would have to be removed and in I 866 obtained from Parliament power to construct a new market on some land belonging to the borough on the Welford road. ${ }^{24}$ In I 866 there was little opposition to this move ${ }^{25}$ but the transfer of the market was delayed for some years and when, in I $87 \mathrm{I}$, it was imminent, strong opposition was aroused amongst local farmers, who feared that a market away from the centre of the town would fail to attract buyers for their stock, and from traders with premises near the existing market. I 2,000 people signed a memorial to the corporation opposing the removal of the market. ${ }^{26}$ It was found, however, that the corporation was legally obliged to remove the market and the new livestock market was opened in 1872.27 It remained on the same site in 1956 .

Of the fairs existing at Leicester before 1835 , the additional livestock fairs established in $1794^{28}$ seem all to have been abandoned by $1870 .{ }^{29}$ The two ancient fairs, held in May and October, ${ }^{30}$ still existed in $195^{6}$ for the sale of livestock, ${ }^{3 I}$ but the pleasure fairs connected with them were suppressed in 1904. ${ }^{32}$ The fairs in July and December, granted to the town by Henry VIII in I 540,33 also still existed in 1956 as livestock fairs. ${ }^{34}$

In the late Igth century the corporation's work in the sphere of public utilities expanded very greatly. Its first action in this field, the acquisition of the water company, has already been mentioned. 35 For many years the corporation remained merely a shareholder. The growth of the town's population made the reservoir at Thornton inadequate, and after the shortage of water had been severely felt in I863 and I 864 it was decided to build a new reservoir at Cropston, about four miles to the north-west of Leicester. To carry this out an Act ${ }^{36}$ was obtained in 1866 authorizing an increase in the company's capital and the new reservoir was duly built. ${ }^{37}$ In 1874 , partly because of the company's proposals to raise additional capital, the corporation decided to buy the whole undertaking. ${ }^{38}$ In spite of some legal difficulties agreement was reached in 1877 between the corporation and the company, and an Act authorizing the transfer was obtained. ${ }^{39}$ 'The borough thus became the sole owner of the water undertaking. By ${ }^{8} 88_{5}$ it was necessary to obtain additional water-supplies and the corporation tried and failed to gain permission through Parliament to take water from a stream in Charnwood Forest. ${ }^{40}$ In 1890 the corporation was empowered by Act ${ }^{41}$ to construct a new reservoir at Swithland in Charnwood,42 but this was not completed until I894, and in I 893 Leicester was faced with a serious water shortage, only overcome by obtaining water from a colliery at Ellistown. ${ }^{43}$ The Swithland reservoir only met the needs of the growing town for a few years, and in I 898 a plan was brought forward to supply Leicester with water from the River Derwent in Derbyshire. ${ }^{44}$ Other towns, of which Derby, Nottingham, and Sheffield were the chief, also had claims on the Derwent's water ${ }^{45}$ and

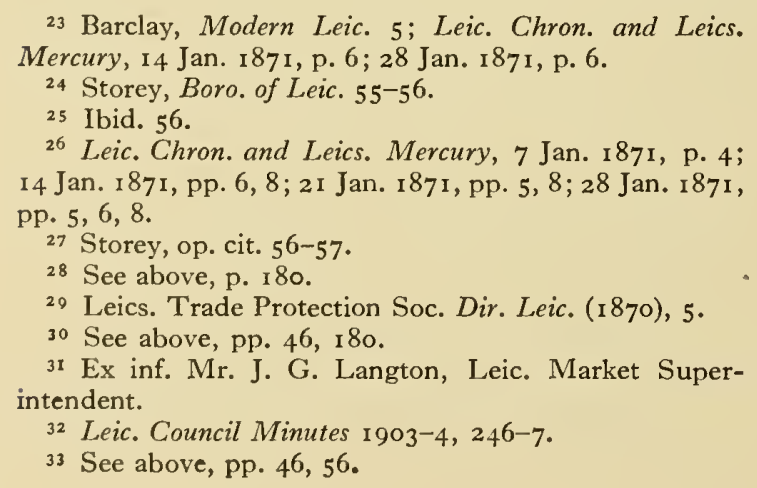

${ }^{34}$ Ex inf. Leic. Market Superintendent.

35 See above, p. 268.

${ }_{36}$ Leic. Waterworks etc. Act, 1 866, 29 \& 30 Vic. c. 27 (priv, act).

37 Storey, Boro. of Leic. I05.

38 Ibid. I06-7.

39 Ibid. 108-10.

40 Ibid. III-I3; the water was required by Loughborough.

${ }^{41}$ Leic. Corp. Act, I 890,53 and 54 Vic. c. 36 (priv. act).

42 Storey, op. cit. I 16-18.

43 Ibid. I19, I20; City of Leic. Civic Affairs (1938), 109.

44 Civic Affairs, Io9.

45 Ibid. 
in consequence an Act ${ }^{46}$ was obtained in $\mathrm{I} 899$ providing for the division of the water from the Derwent and from the Ashop, an adjacent stream, between Leicester, Derby, Nottingham, and Sheffield. The works made necessary under this Act, including two large reservoirs in the Derwent Valley, were completed in I9I2. The Derwent continued to be an adequate source of water for Leicester until after I945, though additions had to be made to the works in the Derwent valley between the two world wars. ${ }^{47}$

Leicester corporation acquired the town's gas company at much the same time and in much the same circumstances as it acquired the water undertaking. Gas had been supplied to the town by a private company since 1821.48 For more than 50 years the only gas works were in Belgrave Gate, but in 1877 the increased demand for gas led the company to plan the construction of a large new plant in Aylestone Road, on the southern outskirts of the town. ${ }^{49}$ The corporation at first opposed this proposal, which involved the purchase of municipal land, but in I 877 an agreement was reached by which the corporation was to buy the gas undertaking. In the next year the undertaking came under municipal ownership and the council set up a gas committee to manage it. In view of the urgent need to increase gas production the corporation decided to carry out the plan to build new works in Aylestone Road, and the construction had in fact begun before the corporation became the owner. Large additions were made to this plant in I884, I 885, and I 887.50 These repeated increases in the size of the works reflect the rapidly growing demand for gas; the amount supplied to consumers in 1890 was almost four times that supplied in $1870 .{ }^{51}$

Although the corporation had obtained in 1879 the power to use municipal funds for electric street lighting, ${ }^{52}$ no steps were taken to supply electricity to the town until I 889 . In that year the corporation, knowing that several private companies were likely to apply to the Board of Trade for permission to supply the borough with electricity, obtained such permission for itself. ${ }^{53}$ At first electricity was only supplied to the commercial and business quarter in the centre of the town and in that area the supply began in I 894.54 The electricity works were situated by the gas works on the Aylestone Road site and were controlled by the gas committee of the council.55

The third public utility to pass into municipal control was the system of street tramways. The growth of Leicester itself and the increasing tendency for persons who worked in Leicester to live in the villages just outside the borough boundary made it necessary to provide some form of public transport between the centre of the town, its outskirts, and the adjacent villages: the town's first omnibus services seem to have been those started in 1863 which ran south-east from the town centre along the London road and to the north along Belgrave Gate. ${ }^{56}$ In 1872 two private companies announced their intention of seeking powers to construct tramways in Leicester, and after some negotiations the council came to an agreement with one of them, the Leicester Tramway Company, by which it was agreed that the company should pay the corporation $f_{5} \circ 0$, and that the corporation should also take half of the profits over $12 \frac{1}{2}$ per cent. 57 The formation of the Leicester Tramway Company was the work of a group which had already had success in operating trams in the north of England. ${ }^{8}$ 'The company's first tram

\footnotetext{
46 Derwent Valley Water Bd. Act, $1899,62 \& 63$ Vic. c. 269 (priv. act).

47 Civic Affairs, I Io.

48 See above, p. I62.

49 Storey, Boro. of Leic. 92-93. The works in Belgrave Gate had been built in I $82 \mathrm{I}$, close to the canal, but they were never provided with railway communications and when the railways became the best means of transporting coal this was a serious disadvantage: Leic. Gas Undertaking ( $189 \mathrm{r}), 7$ (copy in libr. of Univ. Coll. Leic.).

so Storey, op. cit. $93-94,95-96,97$, Ioo.
}

5 I Leic. Gas Undertaking, 6.

52 Leic. Corporation Act, I879, 42 \& 43 Vic. c. 200 (priv. act).

53 Storey, Boro. of Leic. I03.

54 Ibid. 103-4; Kennedy, Rep. on schemes and tenders for Electric lighting of 'limited area', Leic. (1893), (Leic. City Ref. Libr., Pamphlets $\mathrm{O}_{3}$, xvii).

55 Storey, op. cit. I03-4.

${ }^{6}$ Spencer, New Guide to Leic. (1888), I 12.

57 Storey, op. cit. I71. 58 Spencer, op. cit. I 18. 
service, between Leicester and Belgrave, was opened in 1874 , and two others, along London Road and Humberstone Road, began operating in the following year. ${ }^{59}$ In 1877 the company obtained an Act ${ }^{60}$ authorizing it to extend the London Road line and to build two new ones from the town centre, one along Aylestone Road to the southwestern suburbs and the other to the northern suburbs beyond the Soar. ${ }^{61}$ These extensions were all completed before the end of 1878 . In I 884 the company was authorized to make further additions to its lines, but very little was actually done. ${ }^{62}$

The tramway company had taken over as its headquarters part of the defunct Amphitheatre, which provided a spacious building in a central position. By i 888 about 50 tramcars were in use and the company also operated two routes with horse buses and provided vehicles for hire. ${ }^{63}$ In 1876 an experiment in the hauling of cars by a light steam engine made by a Loughborough firm was carried out, but although the tests seem to have been technically successful nothing further was done. ${ }^{64}$

Under an Act of $1870^{65}$ the corporation had certain powers to acquire the tramway by compulsory purchase and by a clause specially inserted in the Leicester Corporation Act of $1890^{66}$ it had obtained full powers to operate tramcars. By i 900 it was evident that radical alterations to the Leicester tramways were required; the routes needed to be extended and it was time that electric trams, long used on the Continent and already in operation in many other English towns, should be introduced. ${ }^{67}$ The corporation therefore set up a special sub-committee to study the issues involved. This committee, after making an exhaustive study of tramways on the Continent and elsewhere in Britain, advised that the Leicester undertaking should be purchased by the corporation, that electric trams, operating on the overhead trolley system, should be introduced, and that existing lines should be reconstructed and extended. ${ }^{68}$ These proposals were carried out. The corporation purchased the trams in I $90 \mathrm{I}$, the conversion to electric trams was completed by I 904, and several new routes were brought into operation. ${ }^{69}$

Although the corporation maintained a small fire brigade, the chief responsibility for extinguishing fires seems to have rested with the fire insurance offices ${ }^{70}$ until I 872 when the brigade maintained by the Sun Fire Office was united with the municipal force to form an enlarged borough fire brigade. ${ }^{71}$ From that time onwards the fire brigade remained a public responsibility.

The control of public education was to become perhaps the most important function exercised by local authorities. The history of education in Leicester has been treated in a separate article. ${ }^{72}$ Here it may be briefly mentioned that the establishment of a school board for Leicester in 187 I created in the borough a public body which like the Board of Guardians was separately elected, independent of the borough council, and charged with one particular sphere of public activity. Under the Education Act of 1902 the school board ceased to exist and was replaced by a committee of the council.

Although as early as I 895 the town clerk of Leicester commented unfavourably on the disposition of the central government to limit the activities of the local authority, the ancient duty of providing a borough prison was the only task of which the municipality was relieved during the igth century. The prison inherited from the old corporation was largely reconstructed in $185^{8-9}$ and a new wing was added in $1867-8$. In 1878 , how-

\footnotetext{
59 Storey, op. cit. I7 I Rep. of Tramways Sub-Cttee. on Electric Tramways for Leic. (1900), I3 8 (copy in Leic. City Ref. Libr.).

${ }^{60}$ Act for incorporating Leic. Tramway Co., 1877,40 \& 4 I Vic. c. I70 (priv. act).

6I Storey, Boro. of Leic. I 7x-2; Rep. of Tramways SubCttee. loc. cit. $\quad 62$ Storey, op. cit. 172.

63 Spencer, New Guide to Leic. (1888), I I 8-19.

64 The Engineer, 31 Mar. 1876, p. 232.
}

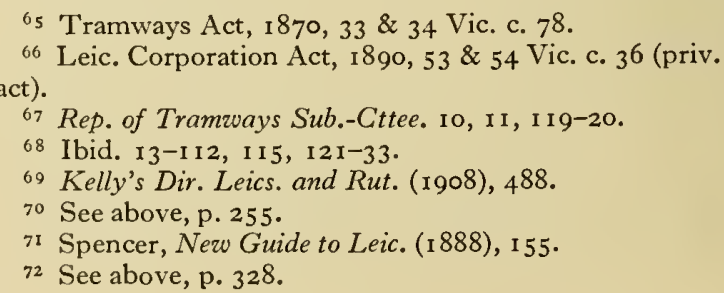


ever, the ownership of and the responsibility for the borough gaol was transferred from the corporation to the Home Secretary. The council, though no longer the owner of the prison, remained responsible for the outstanding debt, then more than $£ 7, \infty 00$, which had been contracted through expenditure on it. ${ }^{73}$ In 1878 the Home Office decided that the borough gaol should no longer be used for civil prisoners, the county gaol being sufficient for both the town and county. It was proposed to use the borough gaol as a military prison, but the council exercised their statutory right to buy back the gaol at a fixed price, on its disuse as a civil prison. The council's hope that the prison site, a large one near the centre of the town, could be advantageously sold, was not, however, realized. ${ }^{74}$

The late Igth century saw major alterations in Leicester's local government arrangements. In I 89 I the borough was greatly enlarged by the Leicester Extension Act. ${ }^{75}$ The increase in population and the spread of the urban area which led to this development have been discussed below. ${ }^{76}$ The town council had appointed a committee to consider the enlargement of the borough in 1880.77 Such an extension could have been effected by an order of the Local Government Board, but the council decided to proceed by Act of Parliament as it feared that the board might not agree that the extension should be also for sanitary and school board, as well as for municipal, purposes. ${ }^{78} \mathrm{~A}$ bill was accordingly brought in, but it met with much opposition from neighbouring local authorities, from the railway companies, and from many private individuals, and it was rejected in $\mathrm{I} 886$ by a committee of the House of Commons. ${ }^{79}$ Application was made again to Parliament in $1890 ; 80$ opposition was shown by the Leicestershire County Council and by several lesser local authorities, ${ }^{81}$ and the bill was strongly criticized in a long report by the Local Government Board.82 On the other hand, property owners in the areas concerned seem mostly to have been in favour of the bill..$^{83}$ Resistance to the bill was reduced by special concessions made by the corporation to the inhabitants of Belgrave and Knighton, two of the parishes which it was proposed to include in the borough. 84 The bill also met with considerable opposition in both houses of parliament and the corporation was obliged to give up its proposals to include certain agricultural areas in the borough, but eventually the bill was passed and received the royal assent in July I 89 I. 85

By the Extension Act the area of the borough was increased from just over 3,000 acres to just over 8,500 , and its population from I 42,000 to I $74,000 .{ }^{86}$ The districts brought into the borough were the two small civil parishes of Freak's Ground and Newfoundpool, the greater part of the parishes of Belgrave, Knighton, Leicester Abbey, and Aylestone, and small portions of the parishes of Humberstone, Evington, and Braunstone. The last three villages remained outside the borough. ${ }^{87}$ The extended borough was divided by the Act into I 6 wards, each to elect three councillors, and the number of aldermen was increased from 14 to 16 . In November I 89 I the existing aldermen and councillors retired; fresh elections in the 16 new wards took place and new aldermen were chosen. ${ }^{8}$ Under the Act important changes were made in the rating system. Before

73 Storey, Boro. of Leic. $45,137$.

74 Ibid. 46-47.

$7554 \& 55$ Vic. c. 100.

76 See p. 292.

77 Storey, op. cit. I 46.

${ }^{8}$ Leic. Extension Act, Rep. of Parl. Sub-Cttee. to Town Clerk, 4 (Leic. City Ref. Libr., Pamphlets $\mathrm{O}_{3}$, xxiv).

79 Storey, Boro. of Leic. 147.

80 Ibid. I 5 I.

81 Ibid. I 55-9; Leic. Fnl. 6 Feb. I 89 I, p. 6; I3 Feb. I 89 I, p. 7 ; I 3 Mar. I89 I, p. 5.
82 Storey, op. cit. I 56-9; Leic. Extension Act, Rep. of Parl. Sub-Cttee. 6-Io.

83 Storey, op. cit. 1 54, I 58; Leic. Fnl. 23 Jan. I 89 I, p. 3 ; 6 Feb. I891, p. $2 ; 27$ Feb. I89 I, p. 7.

84 Storey, op. cit. I 52-3, I 54; Leic. Fnl. 23 Jan. I 89 I,

p. 3 ; 1 3 Feb. I 89 I, p. 3 ; 27 Feb. I891, p. 7 .

85 Storey, op. cit. I 55-64.

86 Ibid. I66-7; V.C.H. Leics. iii. I 79.

87 V.C.H. Leics. iii. I 79-80; and see the Act, $54 \& 55$ Vict. c. 100.

88 Storey, Boro. of Leic. I64-5. 


\section{A HISTORY OF LEICESTERSHIRE}

I 89 I the corporation had levied watch and borough rates, for which land not occupied by buildings was rated at its full rateable value as was all other property. It had also in its capacity as the urban sanitary authority levied a general district rate, for which land not occupied by buildings was only rated at a quarter of its rateable value. ${ }^{89}$ The Act provided that for the future the corporation should levy all required rates as general district rates over the whole of the new borough, so that watch and borough rates were abolished. ${ }^{90}$ This arrangement was of course very favourable to the owners of land not occupied by buildings, and was adopted to avoid laying an undue burden of local taxation on the considerable area of agricultural land newly included in the borough. Rates were, of course, still levied separately by the board of guardians and the school board.

The I 89 I Act, though not so comprehensive as the corporation had at one time desired, ${ }^{91}$ brought within the municipal boundary the districts into which the town's population had been spreading, together with agricultural land sufficient for Leicester's expansion for 40 years to come.

The administrative system of the borough was simplified by the amalgamation in I 896 of all the civil parishes within the borough into a single parish, and the vesting in the corporation of all the powers and duties of a parish council.92 This change was made by the Local Government Board at the instance of the corporation. ${ }^{93}$ The aims of the alteration were to reduce the costs of administration and to ensure that a uniform poor rate should be levied throughout the borough. Previously each parish had had to raise the funds to pay for its own poor, even though poor relief was administered by the guardians. Under this system the level at which poor rates were collected naturally varied from one parish to another. ${ }^{94}$ Under the Local Government Act of r 888 Leicester became a county borough. ${ }^{95}$

The growth of the town and the expanding scope of the municipality's functions led inevitably to a great increase in the corporation's administrative and financial staff. It was during the last quarter of the igth century, rather than in the years immediately after 1835 , that the local government service in Leicester began to assume its modern shape. First, the Town Clerkship underwent a change. When the veteran Samuel Stone ${ }^{96}$ retired in 1872 , after holding the office since 1836 , he was succeeded by George Toller, who himself retired a few weeks later, on grounds of ill health. ${ }^{97}$ It seems that there had been differences between Toller and members of the council. The council next appointed Thomas Standbridge, son of a town clerk of Birmingham. Standbridge was a man with no private practice, and indeed no previous connexion with the town, ${ }^{98}$ who may be considered the first of the modern, professional town clerks of Leicester. His appointment was not a success, and when he had been in office for about a year several members of the council advised him privately to resign. He failed to take this advice and in 1874 after a debate in the council a resolution was passed calling for his resignation. Apparently it was felt that he had been neither conscientious nor efficient. It is possible that both Toller and Standbridge lacked the ability required of a successful town clerk, but it may be conjectured that one cause of the difficulties that arose in I $872-4$ was that at a time when the town clerk's duties were so rapidly growing, his department was not expanding at all. In 1874 his only staff was a chief clerk, with a

89 Storey, Boro. of Leic. I 52.

91 Ibid. 163

90 Ibid. $152-3$.

Mercury, loc. cit.

92 Local Govt. Bd. Order no. 32, 945.

93 Leic. Chron. and Leics. Mercury, 2 June I 894, p. 3 ; Leic. Council Minutes, $1894-5,38,44,75$ sqq. The guardians of the poor who had previously been elected by the parishes were from 1894 elected by the I6 wards: Leic. Council Minutes, 1894-5, 62-63; Leic. Chron. and Leics.

94 Leic. Council Minutes, I 894-5, 78-79.

955 I \& 52 Vic. c. 4 I ; Storey, Boro. of Leic. 6.

96 See above, p. 253.

97 Storey, op. cit. 26o; Hartopp, R. of Mayors, 202; Leic. Chron. and Leics. Mercury, 29 Aug. I 874, p. 2.

98 Leic. Chron. and Leics. Mercury, 29 Aug. 1874, p. 2 ; Storey, op. cit. 260. 
salary of $f_{\mathrm{I}} 60$, and a junior clerk earning I $4 s$. a week. ${ }^{99}$ Such municipal activities as the flood prevention scheme, the removal of the markets, and the new system of sanitation involved the town clerk in much labour, both in the legal business entailed by the purchase of large quantities of real property and in the management of the parliamentary business connected with the passage of local Acts. Samuel Stone had been able for a while to perform the duties of town clerk and clerk to the borough magistrates without any additional assistance. These offices were never combined after 1872 , but even if Stone's successors had been as able and experienced as he was, the growing volume of business falling upon the town clerk would have necessitated a much larger staff. ${ }^{\mathrm{I}}$

After Standbridge's resignation in 1874 , the council appointed John Storey as town clerk. ${ }^{2}$ He had served in the town clerk's department under Stone and Toller and had been Standbridge's chief clerk. ${ }^{3}$ He was not a qualified solicitor when appointed and there was a separate town solicitor from 1875 to 1885 . His appointment was at first intended to be temporary, but he remained in office for twenty years. ${ }^{4}$ Under Storey the town clerk's department expanded considerably although it still remained modest in size. By I 888 it consisted of the town clerk himself, two administrative assistants, and four clerks. The town clerk's salary was then $£ \mathrm{I}, \infty \circ 0$, and in addition the gas and water departments each paid him $£ 5^{\circ}$ and he received a further $£ 5^{\circ}$ as clerk to the visitors of the borough asylum. Storey's successor James (later Sir James) Bell was another professional local government official and had been in the service of the Birmingham corporation. ${ }^{5}$

Other departments grew in a similar way. In 1860 the borough accountant carried on his work almost unassisted, ${ }^{6}$ but by 1888 he had nine clerks and assistants. There were also fifteen rate-collectors, apparently working part-time. ${ }^{7}$ The accountant's salary was then $f 400$. His duties seem to have comprised no more than the actual keeping of accounts. Financial policy remained the province of the council's finance committee, and in $1885-7$ and again in $1894-5$ the important task of funding parts of the borough debt was performed by the town clerk. ${ }^{8}$ The borough treasurer continued to be a banker, not a municipal official. In I90 the offices of treasurer and accountant were combined and for the future were held by an official who was known as the borough treasurer. ${ }^{9}$ It was not, however, until I 924 that it was decided that the borough treasurer should be recognized as the corporation's chief adviser on financial policy. ${ }^{\mathrm{I} 0}$

By I 888 the borough surveyor had a staff of I 4 clerks and draughtsmen, io foremen and clerks of works, and 3 building inspectors. I The number of officials charged with safeguarding the public health had also increased. The medical officer of health, who also acted as public analyst, had become a full-time salaried official of the corporation in I $885 .{ }^{\mathrm{I} 2}$ There were only two sanitary inspectors as late as I 883 , when, in an attempt to relieve them of some of their burdens, the chief building officer was created chief sanitary inspector as well, so that he might give some attention to public health. ${ }^{13}$ Further increases were inevitable; by I 888 there were four inspectors under the chief sanitary inspector; ${ }^{14}$ by 1895 there were seven, and in that year the first woman health visitor

99 Leic. Chron. and Leics. Mercury, 29 Aug. I874, pp. $2,7,9$.

Storey, op. cit. 260 .

2 Leic. Chron. and Leics. Mercury, 3 Oct. 1874 , p. 2.

3 Ibid. and 29 Aug. 1874, p. 2.

4 Storey, op. cit. 260, 26I ; Leic. Chron. and Leics. Mercury, 3 Oct. 1874 , p. 2.

5 Boro. of Leic. Ret. of Salaries of Officers (1888), 6-7

(Leic. City Ref. Libr., Pamphlets $\mathrm{O}_{3}$, xiv).

${ }^{6}$ See above, p. 254.

7 Ret. of Salaries of Officers (1888), I2-15. Cf. a staff of
165 in the boro. treasurer's dept. in 1955 : Leic. Mercury 2 I July I 955 , p. I 6.

8 Storey, Boro. of Leic. I $35-42$.

9 Leic. Council Minutes, 1900-I, 289.

so Ibid. 1923-4, 295-6.

II Ret. of Salaries of Officers (1888), 8-I I ; the boro. surveyor had a salary of $£_{1}$, ooo and was provided with a horse and carriage.

12 Rep. Medical Officer of Health (1885), 8.

13 Ibid. (1 883), 42.

14 Ret. of Salaries of Officers (1888), 16-17. 


\section{A HISTORY OF LEICESTERSHIRE}

was appointed. ${ }^{15}$ Before the end of the I 9 th century the size of the staff in the older branches of the local government service had therefore increased considerably, although the number of officials was still relatively small. In addition, a number of new departments were created as the corporation took over the public utilities and the work of the school board.

One consequence of the increase of the borough's administrative and other staff was the building of a new town hall. Such a step had been advocated in the early days of town improvement, ${ }^{16}$ and in 1845 proposals were made to build a new town hall, preferably in the Market Place, though sites in Friar Lane and at the junction of Horsefair Street and Gallowtree Gate had been considered as alternatives. ${ }^{17}$ For many years nothing was done, though the question was discussed at intervals. ${ }^{18}$ In I 87 I the council finally decided to build a new town hall in Friar Lane, but differences arose among members of the council over the methods employed to select a plan for the new building, and in 1872 it was decided not to proceed with the Friar Lane plan, but to build a new town hall on a site, previously part of the old cattle market, in Horsefair Street. ${ }^{19}$ This plan was carried through and the new Town Hall was opened in $1876 .{ }^{20}$ The building originally contained, besides a council chamber and offices for the borough officials and the school board, two courts of law and a house for the head constable, and premises for the Fire Brigade. ${ }^{21}$ Before the end of the I 9 th century the growth of the administrative departments was already straining the accommodation at the new 'Town Hall. The attics had to be used as offices, and in 1892 a new station was built in Rutland Street for the Fire Brigade and its rooms in the town hall used to house the public health officials. ${ }^{22}$ In 1894 the chief constable's house was taken over as offices too.

The actual built-up area of the town took its present shape during these years, expanding to a wide area outside the boundaries of the old town. Large new residential suburbs were created on the outskirts ${ }^{23}$ and at the same time much rebuilding was done in the centre. This was partly due to a desire to use these central sites, hitherto occupied by older houses of poor quality, for industrial and commercial purposes, and partly to the road-widening schemes of the corporation. In the process of rebuilding much poor cottage property built in the early I 9 th century was demolished. ${ }^{24}$ The picturesque if sometimes inconvenient timbered houses which had survived in the older parts of the town were nearly all swept away and some buildings of historic interest and architectural merit were also destroyed. The surviving portion of Lord's Place, once the town house of the earls of Huntingdon, for example, was demolished when the High Street was widened in $1902,{ }^{25}$ and the General News Room in Granby Street was another victim of road-widening, in I90 I. ${ }^{26}$ 'The new houses built between I 860 and I9I 4 were in general superior to those built earlier in the 19 th century in point of sanitation and soundness of construction, ${ }^{27}$ and working-class houses in Leicester were rather better

${ }_{15}$ Rep. Medical Officer of Health (1895), 36, 41.

${ }^{16}$ Leic. City Mun. Room, Hall Bk. 28 Sept. 18 I 4. Fosbrooke and Skillington, Old Town Hall, 66, seem to be mistaken in thinking that Alderman William Firmadge, the architect, was paid for making plans for a new town hall on I May I 820; on that day the council ordered that he should be paid for strect improvements: Leic. City Mun. Room, Hall Bk. I May i 820.

17 Rep. of Town Improvement Cttee. to Town Council (I 845$), 5$.

${ }_{18}$ Storey, Boro. of Leic. $64-65$; Leic. Fnl. 20 Jan. I 860,

p. 8 ; 5 Mar. 1867 , p. 5 .

19 Storey, op. cit. 65-66.

20 Ibid. 68; and see below, p. 363 .

${ }_{21}$ Spencer, New Guide to Leic. (1888), i 30 ; Storey, op. cit. 70.
22 Storey, op. cit. 70, I31; Kelly's Dir. Leics. and Rut. (1908), I24; Leic. Chron. and Leics. Mercury, 2 June 1894,3 .

${ }^{23}$ e.g. N. Evington, Newfoundpool and Westcotes; see below, pp. $383,436,456$.

${ }^{24}$ e.g. in the Yeoman Street area, in St. Margaret's parish, when the wholesale market was built there: Rep. Medical Officer of Health (1899), 28. Old houses were demolished in Blackfriars and St. Nicholas's parish, when the Great Central Rly. was built: ibid. (1890), 23. See also ibid. (1 899), 1 2-1 3; 20th Rep. Leic. Dom. Mission (1 865), 7. 25 Fielding Johnson, Glimpses of Anc. Leic. 168; and see p. $283 . \quad 26$ Ibid. 399 ; and see p. 352. ${ }^{27}$ 16th Rep. Leic. Dom. Mission (1861), 16; I9th Rep. (1864), 5; 29th Rep. (1874), 6; Rep. Medical Officer of Health (1 888), 35; ibid. (1905), 69-70. 


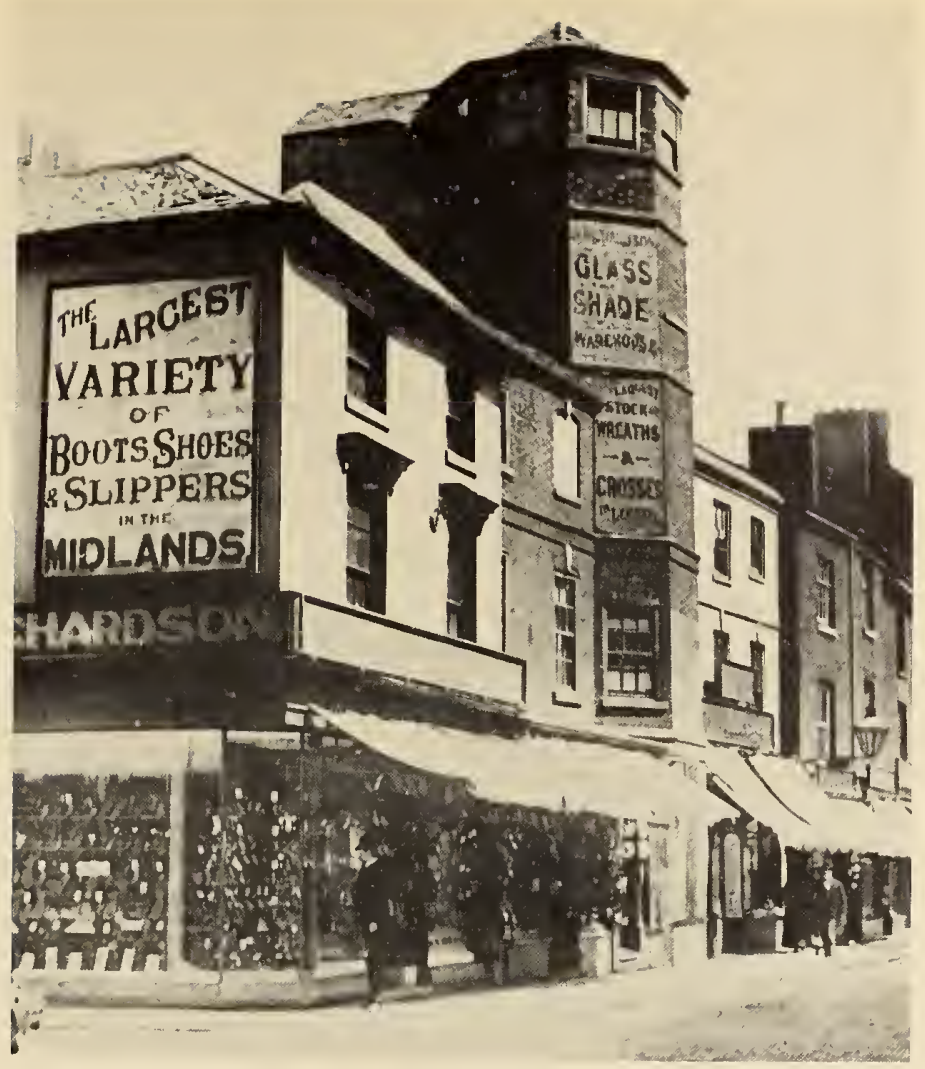

High Street

with the Earl of Huntingdon's tower, the last surviving part of Lord's Place, finally demolished in 1902

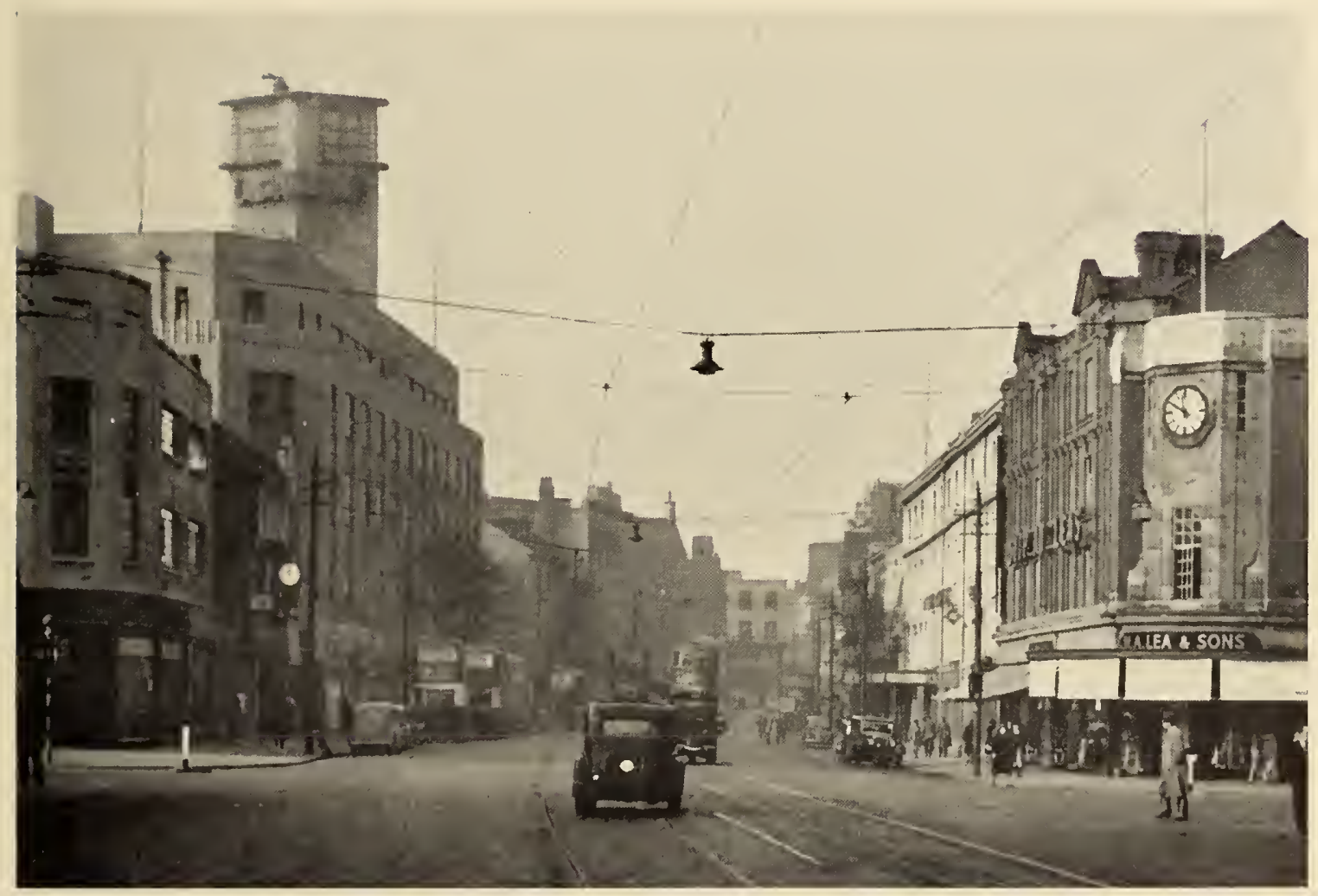

Humberstone Gate from the east, $c$. 1938 

than those in many other industrial towns. ${ }^{28} \mathrm{~A}$ good deal of inferior house property, erected before the enactment in 1859 of the first Leicester by-laws regulating building construction, still remained; in particular about 300 back-to-back houses survived until the demolitions of $193 \mathrm{I}-9 .{ }^{29}$ Both in the new suburbs and in the rebuilt streets around the centre of the town, the architecture was undistinguished. Leicester became a town of brick buildings, preponderantly of I 9 th century date, substantial but lacking in any local character.

A development which affected the central streets of Leicester was the strong tendency of the more wealthy residents to give up their houses in the centre and migrate to the outskirts, especially to the prosperous suburb of Stoneygate on the southeastern edge of the town. This was a development which had begun well before the middle of the igth century. Samuel Stone, for example, had built himself a large house in Stoneygate in I $848,{ }^{30}$ and some ten years earlier John Biggs built his new house opposite Victoria Park. ${ }^{31}$ Even in 1860 the main streets in the centre of the town still contained many substantial houses, ${ }^{32}$ but soon after that date the movement away from the centre became more pronounced. ${ }^{33}$ The breaking-up of estates accelerated the process by putting land for building into the market. By I $_{8} 85$ Stoneygate had become a considerable suburb, largely consisting of fair-sized mansions, and scattered houses of a kind similar to those first built on the Stoneygate estate reached as far as the boundary of Oadby parish. ${ }^{34}$ Farther west, private builders had by-passed the obstacle presented by the public ownership of the South Fields and were already laying out their streets in Clarendon Park by i 885.35 Across the river both Danet's Hall and Westcotes had succumbed to the demand for building land and the patches of housing which had clustered around the bridges in 1844 were being rapidly extended by the end of the I 9 th century. The west was, in fact, the most active area of new building between 1885 and I 9 I $4 \cdot{ }^{36}$

The movement outwards was not confined to the richer classes. Even by I 844 building had spread along Humberstone Gate and Belgrave Gate for the best part of a mile, and this was still the zone in which dense ranks of poor housing continued to grow in the next 40 years. The tendency for houses to be strung out along the main roads, leaving the intermediate spaces to be filled in later, was well marked between the Humberstone and London Roads in I 885, and it was a tendency which was accentuated by the availability of cheap tramway services along the main roads from $1874 .{ }^{37}$ No doubt this development was caused not only by the attractions of the suburbs but also by the increasing value for commercial purposes of sites on the chief streets in the centre of the town. By the end of the century the streets in the centre of the town were occupied almost exclusively by shops, inns, and offices, and few buildings of any antiquity survived. ${ }^{38}$

Even beyond the tentacles of building along the main approaches to the town, there were, by I 885 , isolated patches where farmers had profited from the demands of the speculative builder. Near the railway and straddling the road, the new settlement of West Humberstone depended for its existence on the railway stations and the tramways which served it. A little to the south another settlement was being created at North

28 Ibid. (1872), 22; ibid. (186I), I I.

29 Leic. Council Minutes, 1932-3, 69; ibid. 1934-5, 312 sqq., 240 sqq.; ibid. 1935-6, 93-96, 248-9; ibid. 19367, 101-2, 209-10; 1938-9, 173-6; Rep. Medical Officer of Health (1901), 33 .

30 Reminiscences of Eliza Spurrett (1938), 19; the house, Elmfield, still exists.

${ }^{31}$ Patterson, Radical Leic. 323; Leic. Mercury, 7 Nov. I $93^{\circ}$.
32 I. C. Ellis, I 9th Cent. Leic. 143, 220; Leic. Inl. 3 Jan. I 862 , p. I.

33 Barclay, Modern Leic. I 3.

${ }^{34}$ See below, p. 444 .

${ }_{35}$ Kelly's Dir. Leics. and Rut. (1 888), 548-50.

${ }^{36}$ See below, p. 383 .

37 See above, p. 285.

${ }^{38}$ Wright's Dir. Leic. (1902); G. Clarke Nuttall, Guide to Leic. (1905), 25-34. 


\section{A HISTORY OF LEICESTERSHIRE}

Evington, also outside the boundaries of the borough. In Belgrave parish the process had gone much further, and the village was almost submerged in the flood of new housing. ${ }^{39}$ It was this steady encroachment of building into adjacent parishes that led to the extension of the borough in $1892 . .^{\circ}$ Between $\mathrm{I} 87 \mathrm{I}$ and $\mathrm{I} 88 \mathrm{I}$ the population of the adjacent parishes grew from 4,699 to $18,87 \mathrm{I}$ and in the next ten years to $33,272.4 \mathrm{I}$

From I 885 to I9I 4 piecemeal growth continued to change an agricultural landscape

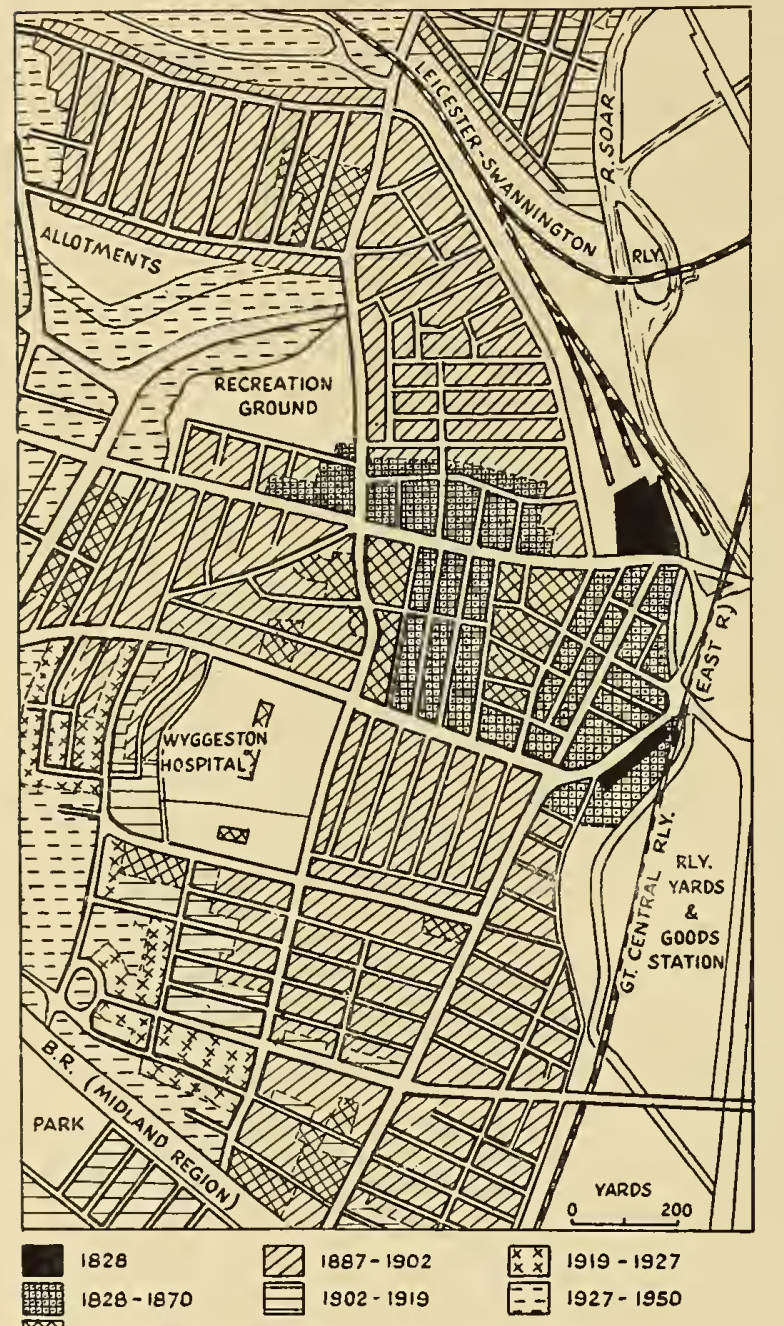

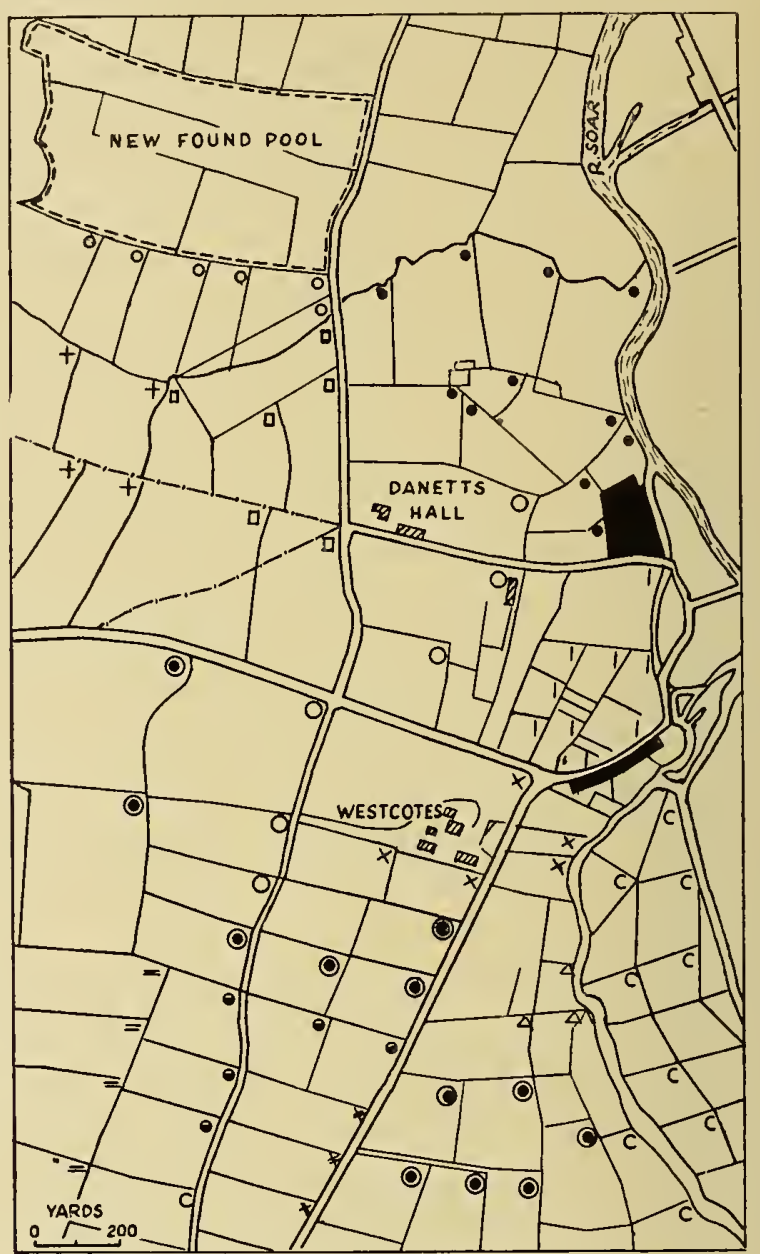

Based on R. Unicume's Survey of St. Mary's Parish, 1828. Symbols indicate the ownership of individual fields.

EXPANSION OF BUILDING WEST OF THE RIVER SOAR

into one of pavement and brick. Fields and farms, and even former administrative areas sometimes retained a vestige of identity in the process by which streets were laid down in rectangular blocks to maximize the profit to be drawn from them. ${ }^{42}$ As an example of this process of growth, one may quote the fate of the small extra-parochial place of Newfoundpool which came into the hands of the builder between I885 and I89I. By the latter year the boundary of built-over land coincided exactly with administrative boundaries that had stood for centuries. ${ }^{43}$ Even in 1955 the area retained its identity, not merely in the architectural individuality of late Victorian housing set in a matrix of the semi-detached villas of the inter-war years, but also in its street names-Hawthorne, Alma, Rowan, Ruby, Ivanhoe, Sylvan, Oban and Newport-the initial letters of which spell out proudly the name of their author. ${ }^{44}$

\footnotetext{
39 See below, p. 424 .

40 See above, p. 275 .

41 V.C.H. Leics. iii. $180-94$.

42 See map, p. 275 ; this paragraph and the next two were
}

contributed by Mr. C. T. Smith.

43 E. C. Mawbey, Map of Boro. of Leic. 1891 (Copy in Leic. Ref. Libr.).

44 See p. 456. 
The rate at which the town extended its grip on the surrounding countryside was undoubtedly increasing in the years before the First World War, even though the rate of building and of population increase had both been falling off since I90 I. The average density of building was, in fact, declining. The tramways, especially when they were extended and electrified, permitted new building at a far greater range from the centre than had formerly been possible. It was a tendency encouraged by the demand for more garden space attached to individual houses, though there was not yet the extreme dispersion made possible by the flexibility of motor transport. In addition, a greater sense of civic consciousness demanded that the inhabitants of a town which now covered four or five square miles should have access to some open space. Apart from the tiny recreation ground set apart in the South Fields and the public right of access to the racecourse, no provision had been made, but in the last quarter of the igth century and the early years of the 2oth land was bought and set aside by the corporation for parks and recreation grounds. ${ }^{45}$ Partly because of its foresight in the provision of open space and partly because of the accident which preserved the South Fields from continuous building, Leicester acquired a reputation for the extent of the open spaces within the town, but this meant that new building was pushed even farther out from the centre.

In the period between 1860 and I9I4 the hosiery industry lost its predominant position in Leicester's economic life, and in terms of numbers employed the boot and shoe industry became the most important in the town. ${ }^{46}$ In I9II, I 5,727 persons were employed in hosiery, and 23,495 in footwear. Engineering, the town's third industry, employed 6, I62.47 An important factor in the town's prosperity was the complementary nature of the labour requirements in the main industries. The hosiery industry had come to employ many more women than $\mathrm{men}^{48}$ while the reverse was true in the footwear industry, ${ }^{49}$ and the engineering industry employed men almost exclusively. ${ }^{50}$ The location of the various industries in the town changed during the i 9 th century. In I794 persons engaged in the hosiery trade were scattered fairly evenly through the built-up area. ${ }^{51}$ Forty years later the Swannington Railway and the canal had had a discernible effect on the grouping of the heavy trades, but it was still difficult to see any systematic pattern in the location of the hosiery trade. ${ }^{22}$ By 1846 a rough distinction could be made between the framework-knitters and the hosiers. The master framework-knitters were to be found very largely in the poorest parts of the town, mainly in the mean, ugly streets by the canal and in the North Gate. The hosiers had their warehouses and offices in the better parts of the town, for the most part in the streets which had been built in the first twenty years of the century to the south of the old town. ${ }^{53}$ When steam power was introduced into the hosiery industry the location of the industry took on a new aspect. Factories and larger workshops were erected by the hosiers in and around the region where they had formerly lived and where the warehouses were, and particularly among the new houses being built in $1850-60$ in the nearby area to the south of the Newarke. ${ }^{54}$ The industry became localized in this new district and remained there to the end of the century, though there was, in addition, a number of factories in the areas where the framework-knitters had been so numerous in the north and north-east of the town, or again where new building was going up while the transition from a domestic to a factory industry was being accomplished.55 This basic pattern is still dominant in

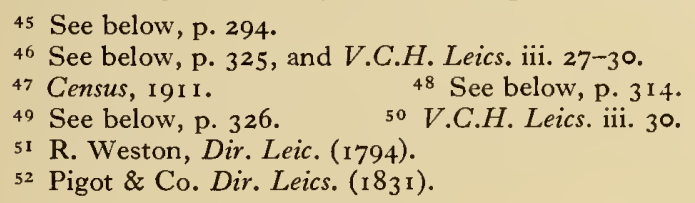

53 White, Dir. Leics. (1 846), 182-3, 185-6.

54 See below, p. 374 .

55 Spencer, New Guide to Leic. (1888), frontispiece map; Mawbey, Map of Boro. of Leic. (1891); Wright, Dir. Leic. (1882), 228; White, Dir. Leics. (1846), 340-416. 


\section{A HISTORY OF LEICESTERSHIRE}

spite of the general tendency, shared to some extent by the hosiery industry, to move towards the outskirts of the town or to the planned industrial area in the east.

It is less easy to analyse the location of the boot and shoe manufacture, though it appears again that what mattered was the relation between industrial evolution and the growth of the town. In I 835 the distribution of the trade reflected little more than the distribution of population. The industry did not become concentrated in one area and in the middle of the 2 oth century is still to a very large extent unlocalized though it has in the inter-war years tended to gravitate towards the planned industrial quarter in the Evington Valley Estate, in company with the immense variety of new industries which have supplemented the traditional staples since I9I 8 .

The improvements in public health which took place between I860 and I9 I 4 have already been described. They were paralleled by equally important but less tangible reforms in other spheres. By I9r4 Leicester was not only a healthier but a more orderly town than it had been in the middle of the 19 th century. The drunken brawling which had characterized some quarters of the borough disappeared, ${ }^{56}$ the amount of violence declined 57 and a better feeling grew up between the police and the general public. ${ }^{58}$ The last serious outbreak of rioting in the town took place on the occasion of the hosiery workers' strike in $\mathbf{I} 886.59$ It is not easy to determine the precise causes of this improvement. The prosperity which the town generally enjoyed no doubt had some effect in softening the harshness of life, and higher standards of living probably helped to bring about higher standards of behaviour. ${ }^{60}$ The introduction of compulsory education, which had a noticeably improving effect upon the town's children, probably exercised in the long run a far-reaching and beneficial influence. ${ }^{61}$ The provision of parks and other amenities no doubt helped to make Leicester a more peaceful town. The town acquired its first public park of any size in $\mathbf{I} 880$ when the races were moved to a new course at Oadby and the old racecourse, which occupied land long owned by the corporation, was transformed into Victoria Park. ${ }^{62}$ A second large park, the Abbey Park in St. Margaret's parish, very near to the most crowded district of the town, was opened in $1882 .{ }^{63}$ Two further parks were opened before r9r4: Spinney Hill Park for the rapidly growing suburb in the south-east of the town in $1886,{ }^{64}$ and Western Park on the western edge in $1901 .{ }^{65}$ The first municipal swimming bath was completed in 1879 in Bath Lane and others were opened in $189 \mathrm{I}$ and 1898 in Vestry Street and Cossington Street. ${ }^{66}$

The first daily local newspaper in the borough was the Leicester Daily Post, a moderate Liberal publication, founded in $1872 .{ }^{67}$ It was edited at first by Joseph Wood, a Congregational minister, whose management was not a success financially. ${ }^{68}$ The Post also published a weekly edition. James Thompson, the owner of the weekly Leicester Chronicle and Leicestershire Mercury, began publication of the Daily Mercury, an afternoon paper, in $1874 .{ }^{70}$ The ownership of both Thompson's papers passed in the same year to Francis Hewitt, who was also the owner of local papers at Loughborough and

\footnotetext{
5627 th Rep. Leic. Dom. Mission (1872), 6, 7 .

57 In 1890 , a typical year for the end of the I 9 th cent., there were 283 proceedings for common assault in the boro.: Criminal and Misc. Statistical Returns of Leic. Boro. Police, I 890, 7 (Leic. City Ref. Libr., Pamphlets $\mathrm{O}_{3}$, xxiii); cf. above, p. 270 .

58 Criminal and Misc. Statistical Returns, I885, 4 (Leic. City Ref. Libr., Pamphlets $\mathrm{O}_{3}$, xxiii).

59 Leic. Daily Post, I 2, I 3, I6, I 7 Feb. I 886.

60 3oth Rep. Leic. Dom. Mission (1875), 7-8.

61 Ibid. 6.

62 Spencer, New Guide to Leic. (1888), I 41

63 Storey, Boro. of Leic. 124-9. Its construction caused
}

strong criticism: R. Read, Modern Leic. 24-25.

64 Leic. Daily Post, 25 Aug. I886; Storey, op. cit. 12930 .

65 Nuttall, Guide to Leic, I00-I.

66 Storey, op. cit. 71-75; Kelly's Dir. Leics. and Rut. (1900), I I7.

67 White, Dir. Leics. (1877), 3 I 5.

${ }^{68}$ Ellis, I9th Cent. Leic. I 75, I 77. Wood later became a Unitarian.

69 White, Dir. Leic. (1877), 31 5; newspaper files in Leic. City Ref. Libr.

70 Newspaper files in Leic. City Ref. Libr. 
Melton Mowbray. ${ }^{71}$ Besides these new daily papers, the older weekly publications, the Leicester Fournal, the Guardian, the Advertiser, and the Midland Free Press, all still existed until after I 890 , and from time to time other short-lived journals appeared. A daily evening paper, the Leicester Evening News, owned and edited by a prominent Liberal, G. R. Searson, was being published in 1875 but seems to have ceased publication by 1877.72 Other local newspapers which had only a brief existence were the Leicester Times, published for a short period about 1900,73 the Leicester Sporting News, published between about I 888 and I902, and the Saturday Herald, which had a short existence about I 896.74 The local newspapers, however, tended to become fewer and their ownership more concentrated. The Guardian and the Advertiser were by 1870 both owned by William Cox, who also owned a local paper at Loughborough, and an interest in the Fournal. ${ }^{75}$ About 1875 the Guardian ceased publication. ${ }^{76}$ The Leicester Daily Post was acquired by Hewitt, 77 and it with the Chronicle and Mercury and the Daily Mercury was owned first by Hewitt and then by a joint stock company, F. Hewitt \& Son Ltd., until after I $945 .{ }^{.8}$ The company acquired the Advertiser in 1920.79 All the Leicester newspapers remained under local control until the Daily Mercury was acquired by the Kemsley press after the Second World War. The Midland Free Press which was owned and edited by Thomas Windley, a leading member of the borough council since $\mathrm{I} 86 \mathrm{I},{ }^{80}$ came to an end in $1912,{ }^{81}$ and the old-established fournal ceased to be published in-1920.82 Of the surviving papers, the Daily Mercury became an evening paper in I92 I, changing its name to the Leicester Evening Mercury, ${ }^{83}$ and the weekly Chronicle and Mercury had changed in I9I5 into the Illustrated Leicester Chronicle.84 The Leicester Daily Post ceased to be published in $192 \mathrm{I}$ and was replaced by another evening paper, the Leicester Evening Mail.85 In 1955 no morning daily paper was published in the town.

In 1862 the corporation passed a resolution in favour of establishing a free library in the town, but no practical steps were taken until I 869, when it was decided to levy a $\frac{1}{2} d$. rate for the purpose. Shortly afterwards the corporation was able to buy a suitable building, the New Hall in Wellington Street, and it was opened as a public library in I $871 .{ }^{86}$ The new institution seems to have been widely used by the manual workers of the town. ${ }^{87}$ The New Hall eventually became too small for the growing stock of volumes, and in 1905 the library was transferred to a new building in Bishop Street, the cost of which was borne by a gift from Andrew Carnegie. 88 The first branch library was opened in $1883,{ }^{89}$ and there were five branches before the end of the r 9 th century. ${ }^{90}$

\section{$1914-1945$}

The outbreak of war in I 914 brought about some momentary unemployment, which it was at first feared might become serious. ${ }^{91}$ 'The situation soon changed, however, and by October 1914 some shortage of labour was already evident.92 Much of the town's

7 Leic. Daily Post, 3 May r882; Wright, Dir. Leic. (1882), 236. ex inf. Leic. Mercury.

72 Barker, Dir. Leics. and Rut. (1875), 192; Leic. Daily Post, 3 I Oct. I892; White, Dir. Leics. (1877), 3 I 5.

73 Wright, Dir. Leics. and Rut. (1900), 205; Wright's Dir. Leic. (1 902), 354.

74 Wright, Dir. Leics. and Rut. (1896), 33 I Kelly's Dir. Leics. and Rut. (1888), 644; Wright's Dir. Leic. (1902), 354 .

75 Leics. Trade Protection Soc. Dir. Leic. (1870), 163; Wright, Dir. Leics. and Rut. (1896), 33 I, 433.

${ }_{76}$ Barker, Dir. Leics, and Rut. (1875), I92; White, Dir. Leics. (I877), 3 I 5 .

77 Wright, Dir. Leics. and Rut. (1896), 331.

78 Wright's Dir. Leic. (1920), 476; Kelly's Dir. Leics. and Rut. (1908), 372, $37 \mathrm{I}$; ibid. (1922), 43 I.

\footnotetext{
79 Ex inf. F. Hewitt \& Son Ltd.

80 Hartopp, $R$. of Mayors, 220.

81 File of Midland Free Press in Leic. City Ref. Libr.

${ }_{82}$ File of Leic. $\exists_{n l}$. ibid.

83 File of Leic. Evening Mercury, ibid.

84 Ex inf. F. Hewitt \& Son Ltd.

${ }^{85}$ File of Leic. Daily Post, in Leic. City Ref. Libr.

${ }^{86}$ Storey, Boro. of Leic. 38-39; and see below, p. 352.

${ }_{87} 28$ th Rep. Leic. Dom. Mission (1873), I I, I2, I 8; 29 th

Rep. (1874), 9; 3Ist Rep. (1876), 7.

${ }_{88}$ Civic Affairs (1938), 80.

89 Storey, Boro. of Leic. 4I-42.

90 Ibid. 42-43; Kelly's Dir. Leics. and Rut. (1908), I24.

91 F. P. Armitage, Leic. I9I4-I9I8, 33-34; Leic. Council Minutes, I9 13-14, 397.

92 Armitage, op. cit. 34.
} 
engineering industry became engaged in the manufacture of munitions. ${ }^{93}$ In general the experience of Leicester during the war was similar to that of most other industrial towns. Recruiting was carried on, at first with small results but eventually with much success. ${ }^{94}$ For those not in the forces the period was one of full employment and rising wages, since not only the engineering industry, but the hosiery and footwear industries were exceptionally busy. ${ }^{95}$ Under the leadership of Alderman Jonathan North, ${ }^{96}$ mayor I 9I4-I 8, the town was much engaged in raising money for various purposes connected with the war and in caring for sick and wounded servicemen. ${ }^{97}$

In 1919 Leicester became a city. ${ }^{98}$ In 1889 the corporation had petitioned the queen for this privilege, but the request was refused. The issue was revived after the extension of the borough boundaries in I89 I but again without result. ${ }^{99}$ In 1928 the mayor was authorized by letters patent to assume the style of lord mayor. ${ }^{\mathrm{I}}$

Leicester suffered perhaps less severely than most industrial towns from the economic vicissitudes of the inter-war years. In I 920 unemployment in Leicester began to be serious and became worse as the year went on, affecting both the hosiery and boot and shoe industries, in both of which there was also considerable short-time working. ${ }^{2}$ From this depression the city recovered and by the end of 1922 the number of unemployed had fallen to about $2,700 .^{3}$ Some degree of unemployment persisted. In I 930 , with the general deterioration of the country's economic position, it increased sharply, and from that date until 1939 there were seldom fewer than 10,000 unemployed in Leicester (see Table III). This degree of unemployment was very moderate in comparison with that which prevailed in the depressed areas between the world wars. Leicester was relatively prosperous and its population continued to expand, though less

TABLE III

Unemployed Persons, I922-394

\begin{tabular}{|c|c|c|c|c|c|}
\hline \multirow[b]{2}{*}{ Year } & \multicolumn{2}{|c|}{ Number of unemployed } & \multirow[b]{2}{*}{ Year } & \multicolumn{2}{|c|}{ Number of unemployed } \\
\hline & Fune & December & & Fune & December \\
\hline 1922 & 3,215 & $2,74 \mathrm{I}$ & I 93 I & 16,225 & 10,886 \\
\hline 1923 & 2,644 & 3,519 & 1932 & 16,120 & 16,204 \\
\hline 1924 & 1,724 & 4,201 & 1933 & 12,030 & I I, I I I \\
\hline 1925 & 4,657 & 2,647 & I934 & I $4,14 \mathrm{I}$ & 13,350 \\
\hline 1926 & 9,137 & 5,404 & I 935 & 12,693 & 10,353 \\
\hline 1927 & 3,473 & 3,603 & 1936 & 9,6 I 9 & 9,612 \\
\hline 1928 & 7,952 & 7,264 & I 937 & 8,284 & I I , 709 \\
\hline 1929 & 6,302 & 6,689 & 1938 & 13,562 & 10,602 \\
\hline 1930 & I 2,29 I & 14,806 & I 939 & $8, \mathbf{1} 29$ & 5,172 \\
\hline
\end{tabular}

rapidly than in the I 9 th century; it rose from 234,000 in $\mathrm{I} 92 \mathrm{I}$ to 229,000 in $1931 .{ }^{5} \mathrm{By}$ I 939 the population of the city as enlarged in 1935 was $261,000 .^{6}$

The General Strike of 1926 caused no serious disturbances in the town. As elsewhere, transport and printing workers struck. ${ }^{7}$ Workers in the hosiery and boot and shoe industries did not take part in the strike, though many factories in both industries were

93 V.C.H. Leics, iii. 29.

94 Armitage, Leic. I9I 4-I9I8, 24-3I, 78-9I.

95 Ibid. 31-32, I02, I I 2, I26, I 46, I 47, 2 I 3,276 et passim; see also below, p. 325 .

96 Knighted 1919.

97 Armitage, Leic. I9I 4-I9I8, passim.

98 Leic. Council Minutes, 1918-19, 194, 233.

99 Storey, Boro. of Leic. I 43-5.

1 Leic. Council Minutes, 1927-8, 301.

2 Leic. Daily Post, 9 July I 920, p. I; 17 July, p. 3; 2oth July, p. 3 ; 3 Sept., p. I ; 8 Sept., p. I ; 15 Sept., p. I ; 24 Sept., p. I; I Oct., p. I ; 2 Oct., p. I ; 5 Oct., p. I; 6 Oct., p. I; 7 th Oct., p. I ; 29 Oct., p. I ; I I Dec., p. 3 ; Leic. Council Minutes, I 920-I, 58-59; ibid. I $921-2$, I 15 .

3 See below, Table III.

4 i.e. the total no. registered on a single day in June and a single day in December each year at Leic. Employment Exchange and Leic. Youth Employment Office: ex inf. Statistics Division, Ministry of Labour and National Service.

5 V.C.H. Leics. iii. 179.

6 National Registration of Eng. and Wales, I 939, Population Statistics, 54.

7 Leic. Mercury, 3 May 1926, p. 7; 4 May 1926, p. I. 
forced by shortage of coal to work short-time and some to close. ${ }^{8}$ In the engineering industry there were at first few strikers, ${ }^{9}$ but on I I May all members of the Amalgamated Engineering Union in Leicester were summoned to strike by their union, and the industry was in consequence largely brought to a standstill. ${ }^{\circ}$ Apart from the General Strike, which was of course not due to local factors, Leicester remained free from serious disputes during the period between the wars.

Because of the high level of activity in the town's chief industries, hosiery and footwear manufacture and engineering, the problems which confronted the city between I9I 8 and 1939 were those of growth rather than of depression. There was urgent need to provide many more houses. In I9I 4 the corporation had decided that it would be necessary to begin building houses under the Housing of the Working Classes Act, ${ }^{11}$ as the houses at moderate rents erected by private builders had for some time not been adequate to meet the demand. ${ }^{12}$ Because of the outbreak of war, no municipal houses were then built and when in I9I9 it again became possible to contemplate building on a large scale, the need for houses had, of course, increased. In October I9I9 the council had a list of 1,455 persons in the city who wanted houses, and it was estimated that I, 500 working-class houses would have to be built during the next four years. It was thought that most or all of the required houses would have to be provided by the municipality. ${ }^{\mathrm{I}}$ In I9I9 the Coleman Road Estate in North Evington and Tailby Estate in West Humberstone, both to the east of the town, were bought for housing. ${ }^{14}$ Under the Housing Act of $1919^{15}$ the corporation built 746 houses to let, mostly on the two newly purchased properties. These houses were nearly all completed by October I $924 .{ }^{16}$ Under the Housing Act of $1923^{17}$ a further $6{ }_{3} 8$ houses were built to let. ${ }^{18}$ It was evident, however, that building on an altogether larger scale would be needed. By May i 924 the council had received 5,700 applications for houses. ${ }^{19}$ It had become increasingly difficult to find sites within the city boundaries and it was thought advisable for the corporation to acquire large, compact blocks of property on which houses in sufficient numbers could be built with speed and economy. ${ }^{20}$ Accordingly the council by a succession of purchases in 1920-5 acquired a large area to the south of the city, partly within and partly without its boundary, and comprising the Saffron Lane Estate and Park Estate. ${ }^{21}$ In I 925 it bought the Braunstone estate of over I,000 acres, mostly lying outside the boundary.22 On these two estates and on several smaller ones the building of new houses was pressed forward vigorously. ${ }^{23}$ To accelerate construction I,500 concrete houses were built. ${ }^{24}$ Between 1919 and the end of March 1929 4,500 houses were completed by the corporation, more than 3,000 of them under the 'Wheatley Act' of $1924 .{ }^{25}$ In addition, nearly 2,000 houses had been built by private enterprise but with the assistance of a state subsidy. ${ }^{26}$ Despite this large amount of building the demand for more working-class houses continued, and between March 1929 and March 1939 a further 4,600 houses were built by the corporation and another 900 by private builders assisted

8 Ibid. 5 May I926, p. I; 7 May I926, p. 8; I I May I 926, p. I.

9 Ibid. 4 May I926, p. I.

Io Ibid. I I May I 926, p. 4.

${ }_{11} 53 \& 54$ Vic, c. 7 o.

12 Leic. Council Minutes, 1913-14, 333-6. In April I9I4 38,306 houses in the boro. were let at weekly rents, when the estimated population was 232,664: ibid. $334-5$; Rep. Medical Officer of Health (1914), p. ix.

13 Leic. Council Minutes, I918-19, 302.

14 Ibid. $178-9$.

15 'Addison Act', 9 \& 10 Geo. V, c. 35

${ }_{16}$ Leic. Council Minutes, $1923^{-4}, 236$.

${ }_{17}$ I $_{3} \& I_{4}$ Geo. V, c. 24 .

18 Waddington, Leic. The Making of a Modern City, 82;
Abstract of Accts. 1 928-9, p. x.

I0 Leic. Council Minutes, $1923-4,239$.

20 Ibid. 238,285

21 Ibid. I919-20, 205; ibid. I922-3, I32; ibid. 1923-4, 217-19; ibid. I 924-5, 98 .

22 Ibid. 1924-5, 370-72; and see below, p. 432 .

23 Plan of estates in Civic Affairs (1938), 37.

${ }^{24}$ Leic. Council Minutes, 1923-4, 284, 286; ibid. 1925-6, 272 ; ibid. I $928-9,59,76$. Two experimental steel houses were erected, but no more were built because of the cost: ibid. 1924-5, 37I; Leic. Mercury, 6 Jan. 1925, p. Io; 24 Jan. I 925 , p. I3.

25 Housing (Financial Provisions) Act, I 4 \& I 5 Geo. V, c. 35 ; Abstract of Accts. $1928-9, \mathrm{p} . \mathrm{x}$.

26 Abstract of Accts. 1928-9, p. x. 


\section{A HISTORY OF LEICESTERSHIRE}

by the subsidy. ${ }^{27}$ Before the outbreak of war in 1939 plans were made to build many more municipally owned houses, notably on a large estate at New Parks, acquired by the corporation through a succession of purchases in $1933-7 .{ }^{28}$ The war postponed the execution of these plans. The construction of extensive housing estates with a distinctive character to the south and south-east of the city was a new development in Leicester's urban growth and one that was to become increasingly important after I945.

The constant need for more houses was due not only to the increase of population, which was only moderate in the years between the wars, ${ }^{29}$ but also partly to the destruction of houses in slum clearance and in the construction of new roads. At Leicester, as elsewhere, a defect in municipal plans for housing between 19 I 9 and 1929 was the failure to provide houses at rents low enough to be within the reach of the poorest. ${ }^{30}$ Between 1929 and 1939 the corporation's efforts in the sphere of housing were largely concentrated on replacing slums, and nearly 2,700 houses were built for that purpose. ${ }^{3 \mathrm{I}} \mathrm{By}$ contrast rather more than 1,600 were built for general working-class use under the Housing Act of 1924 between 1929 and 1932 , when the Act ceased to operate. ${ }^{32}$ In I 929 the corporation proposed under the Housing Act of $1925^{33}$ to clear and reconstruct a slum area adjoining Belgrave Gate, but owing to the legal complications which impeded action under that statute nothing was accomplished. ${ }^{34}$ In 1930 the corporation decided to carry out slum clearance under the Housing Act of that year and between I 930 and I939 a large area in St. Margaret's parish and smaller areas in other central parts of the city were cleared by demolition. ${ }^{35}$ The area in St. Margaret's was used to provide sites for a new bus station, a large municipal car park, and some new dwellinghouses. ${ }^{36}$ Plans for the further demolition of unsatisfactory property were cut short by the outbreak of war in I939. Besides rehousing those displaced by this clearance, the corporation built between I928 and I939 some 270 houses to accommodate tenants displaced by new road construction in the central districts of the city. Despite the large number of houses built between the wars, it was estimated that in 19396,000 more working-class houses were needed in the city. ${ }^{37}$

The provision of housing was perhaps the most important task undertaken by the municipality in the years between the wars. Traffic congestion in the city, if less serious in its social consequences, was a problem whose solution required bold measures on the part of the municipal authority. By 1920 the quantity of road traffic on some of the roads in the centre of the city was already causing serious difficulties. ${ }^{38}$ The streets most affected were Granby Street, Gallowtree Gate, and Belgrave Gate, all of which carried through the centre of Leicester traffic between the London area and places to the north and north-west of the town, and in 1920 a joint report by two committees of the corporation advised that these streets should be widened. ${ }^{39}$ This proposal would have involved the destruction of many valuable buildings on the city's main streets and it was not

27 Abstract of Accts. 1938-9, p. xvi.

28 Leic. Council Minutes, 1932-3, 330-1, 336; ibid. I $934-5,164,160-1,317,326,384$; ibid. I $935-6,64-66$, 204 ; ibid. $1936-7,340,390,436,43^{8}$.

29234,000 in $1921,239,000$ in 1931 : V.C.H. Leics. iii. 179.

30 Waddington, Leic., The Making of a Modern City, 86-87.

3t Abstract of Accts. 1938-9, p. xvi.

32 Ibid.; Civic Affairs (1938), 36.

33 'Chamberlain Act,' I5 Geo. V, c. I4; Leic. Council Minutes, 1928-9, 12 1-2, 124 .

34 Ibid. I929-30, 370-I.

3520 \& 2 I Geo. V, c. 39 ; Leic. Council Minutes, 193 I-

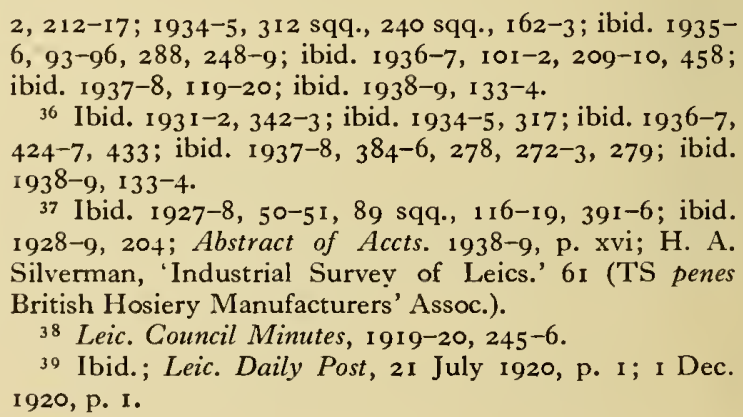

37 Ibid. 1927-8, 50-5I, 89 sqq., 1 I6-19, 39I-6; ibid. 1 928-9, 204; Abstract of Accts. 1938-9, p. xvi; H. A. Silverman, 'Industrial Survey of Leics.' 6r (TS penes British Hosiery Manufacturers' Assoc.).

38 Leic. Council Minutes, I 919-20, 245-6.

39 Ibid.; Leic. Daily Post, 2 I July 1920, p. I ; I Dec. 1920, p. I. 
carried out. Instead a more far-reaching plan to construct several new routes in the city centre by widening some existing streets and by constructing new ones was put forward. 40 This project was supported by a large majority of the corporation, and in 1924 it was decided to promote a bill to obtain the powers needed to carry it out. ${ }^{41}$ There was, however, much opposition in the city, as it was considered in some quarters that the scheme was too grandiose; it was also feared that labour would be diverted from house-building, and that the great expenditure involved would increase the rates at a time when the economic situation was uncertain. ${ }^{42} \mathrm{~A}$ minor scandal that occurred in connexion with the management of the city farm at Beaumont Leys gave to the opponents of the scheme the opportunity to argue that municipal activities were often inefficient. ${ }^{3}$ At a town meeting held to discuss the proposed bill the opponents of the street improvement plan were in a majority, ${ }^{44}$ and a poll of the city in January 1924 resulted in a substantial majority against it. ${ }^{45}$ It was therefore decided not to proceed with the full proposals but to introduce a modified plan, ${ }^{46}$ which provided only for the widening of a stretch of Belgrave Gate, and for the construction of a new main road, partly along the line of existing side streets, to carry north-south traffic through the centre of the city. $47 \mathrm{~A}$ bill empowering the corporation to carry out this lesser scheme was approved by a town meeting and by a majority of electors in a town poll, ${ }^{48}$ and the bill became law during I $925 .{ }^{49}$ The construction of the new road, Charles Street, was completed in I 93 I, ${ }^{\circ}$ and traffic congestion in the centre of the city was much relieved, but the obvious need for further measures led to a new corporation plan, generally resembling that rejected in I 924 , for the building of several new roads which would form a ring round the very centre of Leicester. ${ }^{51} \mathrm{~A}$ beginning was made on the building of one of the new streets, but little was accomplished before the outbreak of war in 1939.52

In I922, after some previous discussion, a plan was brought forward for the building of an outer highway running round the outskirts of the city along a roughly circular route, most of which lay outside the municipal boundaries as they then were. ${ }^{53}$ Differences about the proposal arose between the city corporation and the adjacent local authorities, through whose districts the projected road was to run. ${ }^{54}$ It did not prove possible to do very much before 1939 towards the building of the road, though short stretches of it were constructed before 1939 where its route passed through the new corporation housing estates. 55

In the years between the two wars some subjects that had given rise to serious problems at earlier periods again required action. The existing means of sewage disposal became inadequate owing to the growth of the city's population, and in 1924 legal action was taken against the corporation because of the pollution of the Soar by sewage. ${ }^{56}$ In consequence large additions had to be made to the sewage works. 57 The Town Hall became increasingly inadequate to accommodate the staff of all the corporation's departments, so that the municipal officials had to work in premises scattered all over the city. In 1926 the education department offices, for example, were divided between

40 Leic. Council Minutes, 1922-3, 323-33.

41 Leic. Mercury, 9 Jan. 1924, p. 3.

42 Ibid. I 2 Jan. I 924 , p. I 3 ; 14 Jan. I 924, p. 4; 24 Jan. 1924, pp. 6,$7 ; 26$ Jan. 1924 , pp. 4 , Io.

43 Ibid. 24 Jan. 1924, p. 6; Leic. Council Minutes, 19234,136 sqq.

44 Leic. Mercury, I I Jan. I924, p. I.

45 Ibid. 29 Jan. 1924 , p. 4 ; Leic. Council Minutes, $1923^{-}$ $24,103$.

46 Leic. Mercury, 29 Jan. 1924, p. 4.

47 Ibid.

48 Leic. Mercury, 9 Jan. 1925, pp. 5, 6; 29 Jan. 1925, p. 6.

49 Leic. Street Improvement Act, 1925, I 5 \& 6 Geo. V, c. 36 (priv. act); a clause licensing the corp. to set up a safe deposit was not passed: Leic. Mercury, I I July i925, p. 5 .

50 Leic. Council Minutes, 1931-2, 346; Civic Affairs (1938), 19.

51 Civic Affairs (1938), I9 and plan on p. 20.

52 Ibid. 21 ; Leic. Council Minutes, 1934-5, 387-8; ibid. 1936-7, 419, 414 sqq.; ibid. 1938-9. I34.

53 Ibid. I 92 I-2, 194 sqq.

54 Ibid. I $95-6,234-5$.

55 Ibid. I $934-5,+31-2$; ibid. I937-9, 332-5.

56 Ibid. 1923-4, 110.

57 Ibid. I I I ; ibid. I $927-8,369$. 


\section{A HISTORY OF LEICESTERSHIRE}

the Town Hall and four other buildings. ${ }^{8}$ A special committee of the corporation, which was set up in 1927 to consider the problem of administrative buildings, rejected on grounds of expense two schemes for the erection of large blocks of offices, and decided in favour of making minor alterations to the existing Town Hall. ${ }^{59}$ It was, however, decided to build a new police headquarters, so that the police left the Town Hall, ${ }^{60}$ and the education department was transferred to a building in Newarke Street. ${ }^{61}$ These arrangements were not sufficient and in 1933 it was decided to build large new municipal offices in Charles Street, which was then under construction. ${ }^{62}$

An important administrative change took place in 1930 when the board of guardians was abolished and its functions transferred to a new public assistance committee under the Local Government Act of $1929 .{ }^{63}$ By 1930 the guardians had long since ceased to be the only official agency for dealing with poor relief and unemployment. They were, however, perhaps the most important of the elected local authorities set up during the I 9 th century to perform specific tasks and their disappearance marks the completion of the process of concentrating the responsibility for performing all the tasks of local government in the city corporation.

Between the two wars the population of the borough as constituted under the 189 I Act decreased, as new residential districts outside the municipal boundary replaced older ones within it. There were estimated to be 245,000 persons in the borough in 1919 and 24I,000 in $19344^{64}$ The lesser density of the new areas meant that the expansion of the built-up area of Leicester was disproportionately great in relation to the rise in population. The large housing estate built by the corporation at Braunstone, which in a few years engulfed almost all of that hitherto rural parish and which lay very largely outside the city, was a notable example of this growth. ${ }^{65}$ The corporation also acquired for various municipal purposes other large properties just outside the city. ${ }^{66}$ In consequence it became necessary to consider extending the city boundary again and in 1935, after an agreement between the city and county authorities about the areas to be included within a new city boundary had been made, this was done. ${ }^{67}$ The complete civil parishes of Gilroes and Braunstone Frith', large parts of the parishes of Evington, Humberstone, Braunstone, Leicester Frith, New Parks, and Beaumont Leys, and smaller portions of the parishes of Anstey, Birstall, Thurmaston, and Kirby Muxloe were brought within the city. ${ }^{68}$ By these changes the area of the city was increased from 8,582 . acres to 16,977 acres, ${ }^{69}$ and its population increased from 241,000 to $261,000.70$

During the period from I9I 8 to I939 the hosiery industry was the most important in Leicester from the standpoint of the numbers employed. The boot and shoe industry had lost its predominant position by 1923, and thenceforth until 1939 its importance in relation to hosiery and engineering continued to decline. In 1939 the hosiery industry was employing more persons at Leicester than any other, more in fact than the footwear and engineering industries combined, though the engineering industry was growing rapidly. ${ }^{71}$

During the Second World War Leicester escaped a major attack from the air, though
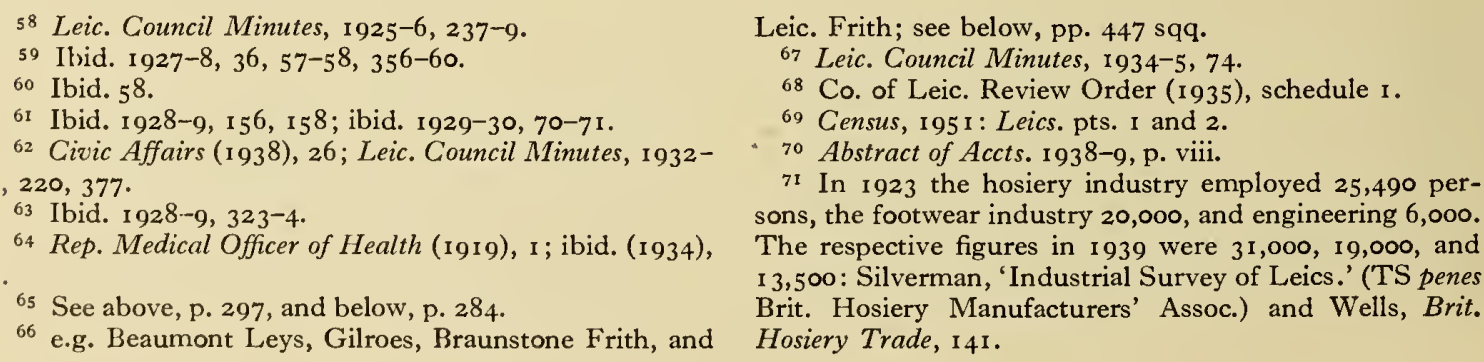


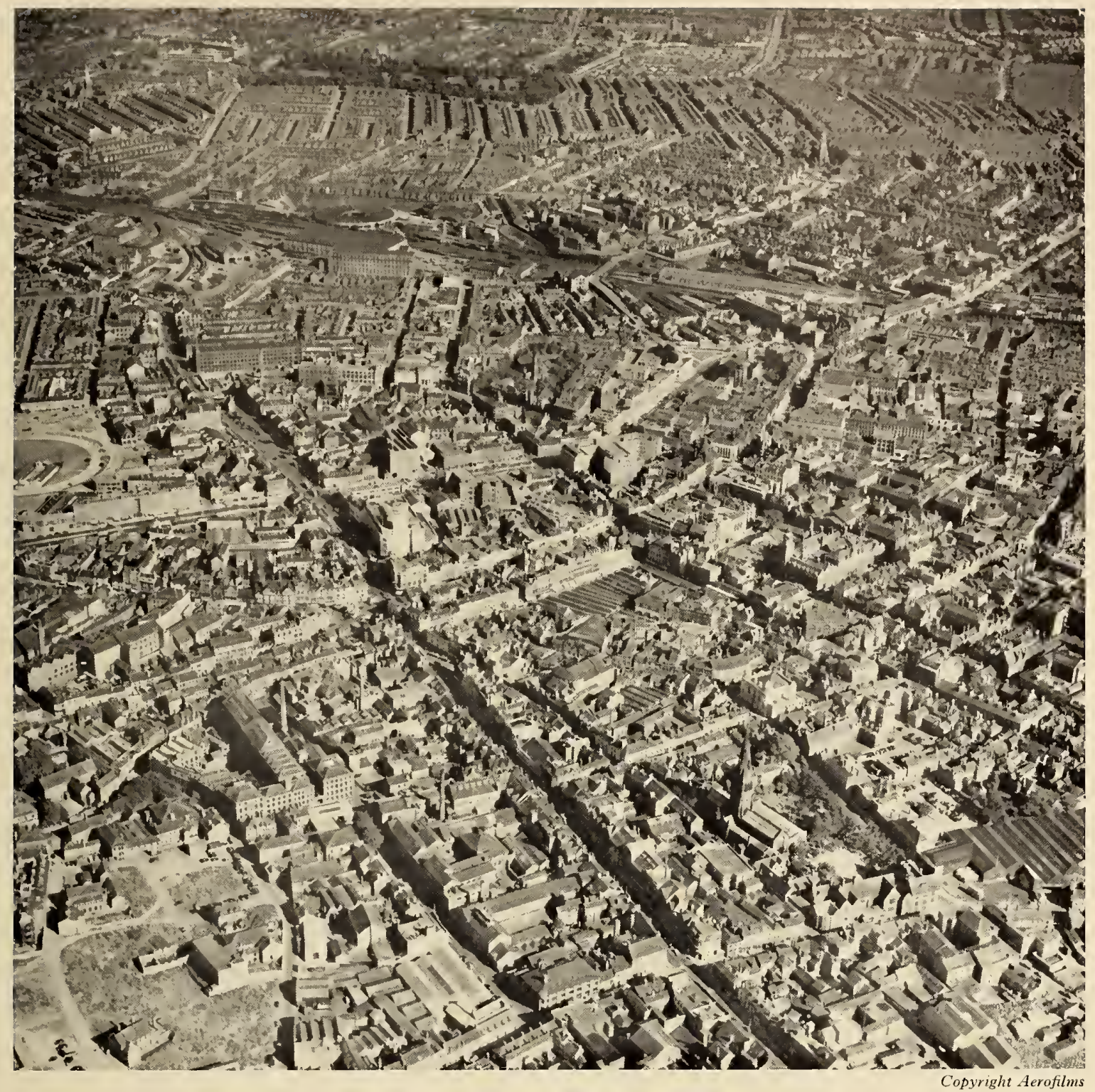

Central AND SOUth-EAst Leicester From THE AIR, 1953

The view is east-south-east and shows High Street running diagonally across the foreground with St. Martin's Church to the right. Its continuation at left centre is Humberstone Gate, and near it on the lefthand side of the photograph is the Lee Street car park. The town hall can be seen at the right centre. The London-Midland railway line runs across the top of the photograph with London Road Station at the right-hand end. A little above the centre of the photograph is St. George's Church, among trees, Beyond the railway line the two church spires in the top left-hand and right-hand corners are those, respectively, of St. Saviour's Church and St. Peter's Church. Spinney Hill Park lies between them 


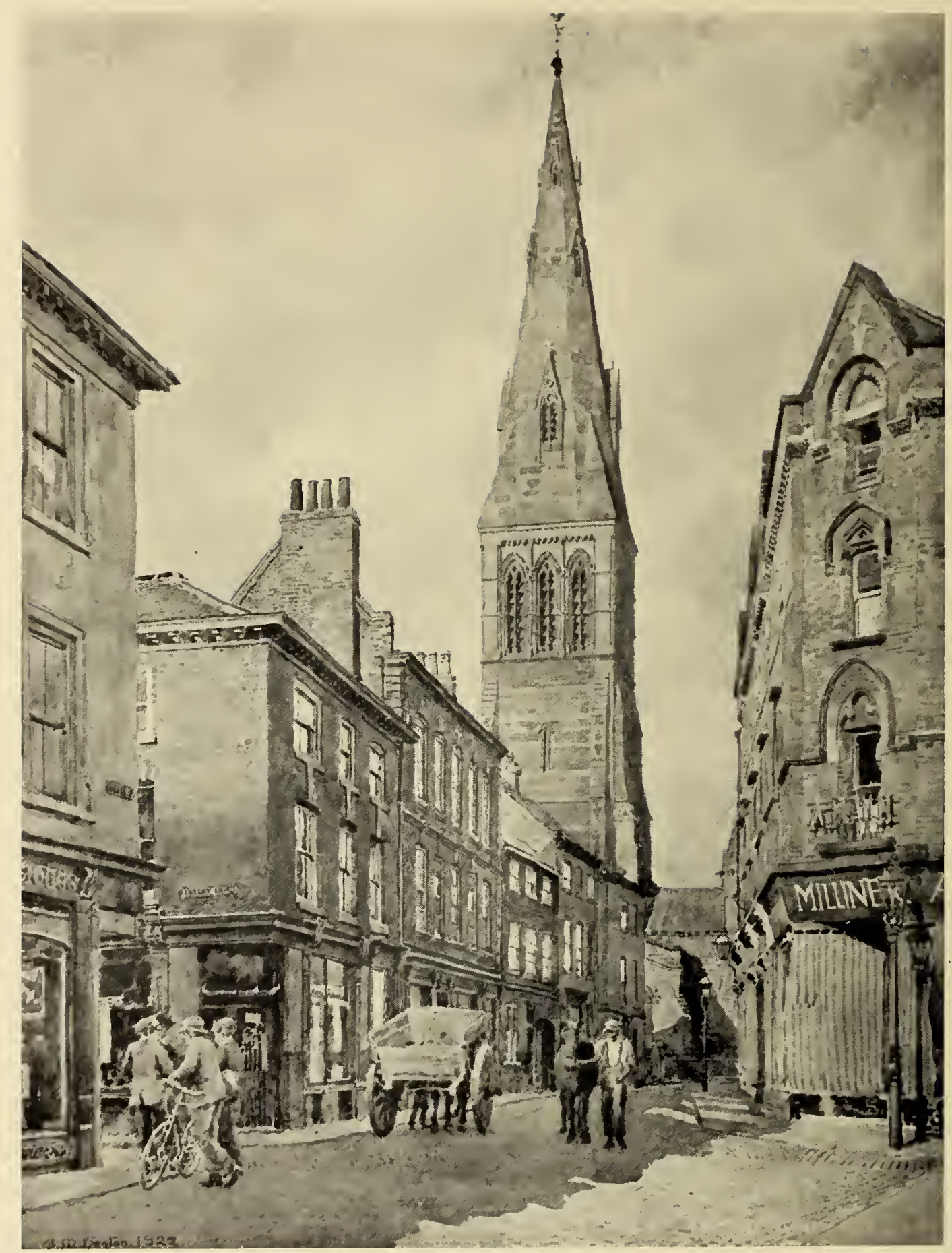

St. Martin's Church, I922

as seen from the junction of Loseby Lane with Silver Street and Guildhall Lane 


\section{THE CITY OF LEICESTER}

some damage and loss of life was caused by a raid on i9 November I940, and the city suffered minor attacks on other occasions. ${ }^{72}$ The need for munitions led to a considerable expansion of the local engineering industry and to the transfer to that industry of many workers previously engaged in hosiery and footwear. Engineering consequently became of greater relative importance than ever before in Leicester's history. ${ }^{73}$

\section{$1945-1955$}

In 1945 the problems which confronted the city after I9I 8 had again to be faced. The need for more housing was particularly acute, as was the necessity for far-reaching measures to deal with traffic congestion. The construction of Charles Street before the Second World War ${ }^{74}$ had somewhat relieved the pressure of traffic, but in Leicester, as in Britain as a whole, the continued increase in the number of vehicles made the existing roads inadequate and raised almost insuperable problems. In the case of Leicester historical factors caused some peculiar difficulties. In the area of the old walled borough the medieval street plan still survived in 1955 largely unchanged, and though some streets had been widened the district still remained one of relatively narrow thoroughfares ill adapted to modern traffic. At the very centre of the modern city an extremely awkward road junction existed on the site of the old East Gate. There in the Middle Ages four roads, Churchgate, Belgrave Gate, Humberstone Gate, and Gallowtree Gate converged from outside the town walls, while inside the walls the High Street ran up to the gate and was joined just inside it by three lesser streets, Cheapside, Silver Street, and Bond Street. ${ }^{75}$ Though the gate and walls had disappeared the streets remained, and along them traffic converged towards the centre. The main highways leading into the city were more adequate than its central streets, largely because of road improvements carried out in the years before the war. ${ }^{76}$ But even on these outer roads the quantity of traffic was so great as to cause frequent congestion and delays at certain times of the day.

These difficulties would have been less acute had it been possible to carry out earlier proposals to complete an outer ring road round the city and to construct new roads in the city centre. The fulfilment of these plans was impossible both during the war and in the years immediately after 1945 , when most of the resources available for construction work had to be devoted to housing. Some relief was afforded by the final withdrawal of tramcar services in 1949 and their replacement by motor buses. 77

In 1945 it was necessary to put aside for some years any hope of resuming the clearance of unhealthy areas and to concentrate on the provision of new houses. Between the end of the war in 1945 and the end of 1954 just over 8,000 houses were built in Leicester by the corporation. Private builders completed $2,500 .{ }^{78}$ In 1955 municipal building on a large scale was still continuing and there seemed little prospect that the demand for council houses would abate. It was, however, possible to resume the work of slum clearance, and in I955 a large area was cleared in St. Margaret's parish, adjacent to the district cleared in I930-9. By $195^{\mathrm{I}}$ the city's population had risen to $285,000,79$ and between $195^{\circ}$ and 1955 more large new residential districts sprang up just outside the city boundary, especially in the south, where the corporation acquired a large estate on the boundary for housing in $195 \mathrm{I},{ }^{80}$ and in the east, where the rapid

\footnotetext{
72 Leic. Blitz Souvenir, 5-7 et passim.

73 V.C.H. Leics, iii. 30.

74 See above, p. 299. 75 See below, pp. 35 I, 36 I sqq.

76 See Leic. Council Minutes, 1920-39, passim.
}

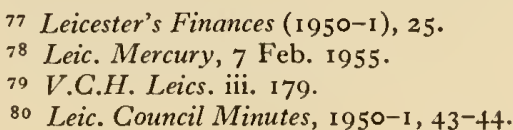




\section{A HISTORY OF LEICESTERSHIRE}

spread of housing, both municipal and private, threatened to engulf the hitherto separate villages of Scraptoft and Thurnby. These extensions led the corporation to propose another extension of the city boundary, but by 1955 no such measure had been put into force.

After 1945 nationalization deprived Leicester corporation of its gas and electricity undertaking, which had in the past made substantial contributions of money in aid of rates. ${ }^{81}$ The municipal hospitals were transferred to the Ministry of Health in $1948 .^{82}$ Between I 945 and 1955 education absorbed half of the corporation's income every year. ${ }^{83}$ After education, the provision of housing should be considered the most important municipal activity from I945, and involved much capital expenditure. ${ }^{84}$ The maintenance of law and order and the protection of public health, which were once the two most important municipal tasks, were still duties which the corporation had to perform, and which, though in general attracting little public attention, remained vital to the wellbeing of the city's inhabitants.

The expansion of the city, that has been traced above, was due of course to the continuous enlargement of its important industries. Of those industries hosiery and engineering were the most important industries between I 945 and I955. In the middle of I 955 , out of $\mathrm{I} 73,000$ persons at work in the city, 28,000 were employed in the manufacture of hosiery and 27,000 in engineering and metal-working. At the same time, I 8,000 were employed in the boot and shoe industry, which had never regained the predominant position held by it in the late I 9 th and early 20 th centuries. ${ }^{85}$ After the war Leicester maintained its position as the largest town in the east Midlands after its close rival Nottingham, 86 and it was in 1955 the 12 th largest town in England and Wales. ${ }^{87}$ In Leicestershire it was by far the largest town, and its continuing expansion into the surrounding countryside was in I 955 causing serious problems.

By 1955 little remained of the Leicester that had grown up in the first half of the igth century. The central districts of the city consisted largely of late-Victorian brick buildings, diversified by a few more modern buildings in brick or concrete. Outside the Victorian core stretched the 2oth-century suburbs, largely residential, with the great municipal housing estates conspicuous among them. Between I 835 and I 955 the city's economic circumstances had changed no less than its physical composition. A state of long-continued distress and depression had given place to one of equally prolonged boom and prosperity. Perhaps, too, the character of the inhabitants had been modified by the altered conditions. The old spirit of individualism and nonconformity, if not altogether lost, had been much softened. By the middle of the 20 th century Leicester had acquired a general character which it shared with other industrial towns of the east Midlands, a character marked by a high level of industrial and commercial activity, by a high general standard of living, and by the absence of any extreme or distinctive movements in politics, religion, or culture. The Leicester of I955, wealthy, healthy, and bustling, was very different from the Leicester of a century earlier.

${ }_{81}$ The electricity undertaking contributed $£ 88,1_{5} 8$ to the relief of rates between its beginning in 1894 and its transfer to the British Electricity Authority in I948: Leicester's Finances, I $947-8, \mathrm{p} . \mathrm{xx}$. The gas undertaking contributed $£_{1}, 082,260$ between 1878 and its transfer to the Gas Council in 1949: ibid. 1949-50, 305.

82 Leic. Council Minutes.

83 Leicester's Finances, 1945-6, p. x; ibid. I946-7, p. x; ibid. $1947-8$, p. x; ibid. $194^{--9}$, p. x; ibid, 1949-50, 10; ibid. I950-I, I2; ibid. I95I-2, I2; ibid. I952-3, I2; ibid. I953-4, I2.

${ }_{84}$ In the year ending Mar. 1953 the total gross capital expenditure on housing was $£ 9,430,000$ : Leicester's Finances, $1945^{-6}$, p. xvii; ibid. $195^{2-3}, 20$.

85 Leic. Evening Mail, 8 July 1955, p. 9; V.C.H. Leics. iii. 30

87 Whitaker's Almanack (1955), 664-5. 


\section{HOSIERY MANUFACTURE}

THE condition of Leicester's staple industry in I 835 was one of almost complete stagnation. I 'The stockinger and the manufacturer generally seemed to have been left in the backwash of industrial progress.'2 The causes of this condition were many, and it should be remembered that not all parts of the industry would be equally affected by them at the same time. While the framework-knitters who used the machine which produced only one stocking at a time had been in a pitiable condition for years, those who used the multiple machines were rather better off, and it was generally accepted that the glove branch, probably owing to the efforts of its union, provided better wages than any other. ${ }^{3}$ Periodically in the I820's and I830's some temporary stimulus would restore one section of the industry to a reasonable state for a short while. ${ }^{4}$

Leicester was the most important centre of the hosiery trade. William Felkin's estimates of the numbers of frames in the various centres of the industry in $\mathbf{I} 844$ show $\mathbf{I} 8,494$ frames working in Leicester, compared with 14,595 in Nottingham, the chief centre of the cotton branch. Leicester specialized in woollen hosiery, although 6,446 frames were making cotton stockings, compared with II,457 in the woollen branch. 5

When in 1845 R. M. Muggeridge completed his report on the condition of the framework-knitters, he formulated nine resolutions and conclusions about the industry, which together formed, in his view, the reason for its low state. ${ }^{6}$ This report was the result of nearly two years' work in the centres of the industry after his appointment as a commissioner to inquire into it. The order for the inquiry followed the presentation of a frameworkers' petition to Parliament in 1843 and their demand for legislative action to restore the fortunes of their trade. ${ }^{7}$ The characteristics of the framework-knitting industry had been for a generation reacting unfavourably against its expansion or progress, and wages were becoming less and less adequate.

Muggeridge's first conclusion about the industry was that in spite of the Truck Act of 1831 , trucking was still extensively practised. Evidence was given to the commissioner by 'Thomas Bell, the secretary of the Leicester Anti-Truck Society. ${ }^{8}$ This had been formed in $\mathbf{1} 844$ for the purpose of putting down trucking in the borough, where it existed especially among small hosiers and middlemen. It was estimated, how accurately cannot be known, that trucking affected one-fifth of the town workers and four-fifths of those in the county. The members of the society, who were with one exception manufacturers, gave a reward of $\oint_{\mathrm{I}} \mathrm{I}$ to anyone securing a conviction under the Truck Act, and some of them undertook to find work for men who lost their positions as the result of giving evidence against a truck master. Between I 844 and i 846 , twenty cases had been brought before the magistrates, and con-

1 For the earlier history of the industry, see above, pp. $168 \mathrm{sqq}$.

2 F. A. Wells, Brit. Hosiery Trade, 128.

3 Ibid. 138 .

4 An example is given in A. T. Patterson, Radical Leic. I65-6.

5 G. R. Porter, Progress of the Nation, ed. F. W. Hirst victions were secured in all but one of these. The method of trucking practised was an indirect one, whereby a shop was owned, not by the employer but by his wife or son, who would be on hand on Saturday nights when wages were paid to collect what was owing for goods provided on credit earlier in the week. It was generally felt that frame rents were not to be regarded as trucking, but it was said that workmen were frequently forced to take work at a low rate of wages because they were already in debt to their masters, who were truck masters. Middlemen were apparently more inclined towards the trucking system than were manufacturers. ${ }^{9}$

The commissioner's second conclusion was that the hosiery industry was depressed because of low earnings. Evidence about wages was given by fiftytwo employees in Leicester, and by the masters. The evidence of the two groups is conflicting (see table): from that of the employees it was found that 67 per cent. earned less than 15 s. gross, and 96 per cent. less than I $^{s}$. net (i.e. when all charges had been deducted); from the masters' evidence 67 per cent. earned less than i $5 s$. net. Although with one exception the masters provided no lists of the weekly wages of the lower-paid workers, other evidence and the comments of the leading masters themselves and of other

\section{Percentage of Employees in Different WAGE-GROUPS}

(According to the conflicting evidence of masters and employees)

\begin{tabular}{|c|c|c|c|}
\hline \multirow[b]{2}{*}{ Wage } & \multicolumn{2}{|c|}{ Employees' evidence } & Masters' evidence \\
\hline & Net wage & Gross wage & Net wage \\
\hline Under ios. & 73 & $42 \cdot 3$ & $45 \cdot 3$ \\
\hline IOs.-I $5^{s .}$ & 23 & 25 & $21 \cdot 6$ \\
\hline I $5^{s .-20 s .}$ & 4 & 25 & $19 \cdot 5$ \\
\hline $20 s .-25 s$ & . & $3 \cdot 8$ & $10 \cdot 6$ \\
\hline $25 s .-30 s$ & . & $3 \cdot 8$ & $2 \cdot 7$ \\
\hline
\end{tabular}

observers indicate that the workmen were nearer the truth about wages than were their masters. Joseph Biggs, one of the most important local manufacturers, said that wages varied between $9 s$. and $25 s$. a week, and could exceptionally be as much as 35 s. a week, but that such wages were for a 48-hour week and the average working week was considerably less than 48 hours. ${ }^{\text {Io }}$ Nearly all the witnesses, masters and men alike, agreed that wages had declined since 18 I $_{5}$, the year of the war-time peak of production. In I84I William Biggs had estimated average earnings to be $6 s$. or $7 s$. a week, and, after the various deductions had been made, not half of what they had been in I 8 I 5. Wages paid for one type of stocking had fallen from $7 s .6 d$. a dozen in $18 \mathrm{I} 5$ to $4 s .6 d$. in $184 \mathrm{I},{ }^{\mathrm{II}}$ those for another type from $15 s$. a dozen to $7 s .3^{d} .^{12}$ In 1843 it was estimated that a man working on a wide frame could make IIs. or I2s. a week, and one working a

\footnotetext{
(I9I2), 386.

Rep. on Condition of Framework Knitters [609], pp I 29-30, H.C. ( 1845 ), xv.

7 Wells, Brit. Hosiery Trade, I 36 and $\mathrm{n}$.

8 Ist Appendix to Rep. Cond. Framework Knitters [6,8],

pp. I I 8-2 I, H.C. (I 845 ), xv.

9 Ibid. 2. Io Ibid.69. II Ibid. 55. 12 Ibid. 26.
} 


\section{A HISTORY OF LEICESTERSHIRE}

narrow frame only $7 s .{ }^{13}$ Poor wages were widely attributed by the workmen to the introduction of 'spurious' hosiery, 'cut-up goods', or 'straight-down hose', which, instead of being fashioned, were knitted straight and shaped on a legging machine. These could be produced more cheaply than fashioned goods. ${ }^{14}$

However, in spite of the overwhelming impression given in the report that wages in 1845 were half what they had been 30 years earlier, it does not seem that the reduction can have been anything like as great as the witnesses to the commission claimed. Rather it seems that wages had remained stationary for the whole of the period, and Cobbett in $182 \mathrm{I}$ refused to believe that the level of wages could possibly be so low-if it were true the framework-knitters should 'all have been dead long ago'.' ${ }^{15}$ Rather the situation seems to have been that although wages themselves had not fallen, the standard of living of the framework-knitters had deteriorated excessively. There seems to have been no longer any incentive to preserve the outward decencies of cleanliness or dress, and the frameworking families of Leicester were generally shabby in appearance, ill fed, and ill housed. A doctor from Nottingham declared that he could always tell a stockinger by his appearance: 'there is a paleness and a certain degree of emaciation and thinness about them'. ${ }^{16}$ Muggeridge's report contains example after example of the poverty and wretchedness of the stockingers of Leicester.

Their misery was increased by the irregularity of their employment, and the workers in the glove trade suffered apparently more from this than those in other branches. Thomas Toone, a worker in the glove branch, stated: 'I have been out as much as five or six weeks together and never earned a farthing. Some years, I have known the time when I have been out six months and never earned a halfpenny; other years, I have been employed or partially employed the year round.' 17

Irregularity of work was intensely aggravated by the overcrowding of the industry. "For a series of years past', remarked Muggeridge, 'the supply of Frame-work Knitters has almost invariably exceeded the demand for them; and hence the value of their labour has been progressively, if not constantly, diminishing, except in a very few of the fancy branches of the trade where considerable skill is required, and in which, consequently, the number of competitors for employment has been proportionately lessened.' 8 Allied closely with the problems of low wages and overcrowding was the extensive employment of women in the industry, which, it was claimed, reduced wages even further. Almost all the children of framework-knitters and many whose parents were not in the industry were employed in some branch or other of the hosiery trade. ${ }^{19}$ There were many jobs, such as winding, seaming, and stitching, which required little skill and which it was necessary to have done as cheaply as possible. Both women and children were employed at this sort of work, the children usually at winding, the women at

${ }^{13}$ Ist App. to 2nd Rep. of Children's Employment Commissioners [43 1], p. FI4, H.C. (1843), xiv.

I4 See above, p. I73, n. 57 ; this formed the subject of part of the petition of $1843:$ Rep. Cond. Framewark Knitters, 1-2; see also Ist App. to Rep. Cond. Framework Knitters, $10-11$.

15 Wells, Brit. Hosiery Trade, I29. ${ }^{16}$ Ibid. 129-30.

17 Ist App. to Rep. Cond. Framework Knitters, I 17

18 Rep. Cond. Framework Knitters, 26. sewing. Children were early put to the frames and a large number of women worked frames. In 1845 children generally began winding or sewing between the ages of five and seven and graduated to the frames at about ten or eleven. Children occasionally began stitching as soon as they could be taught to hold a needle. By this date children probably no longer began work at the frames at seven or eight, as they had once done, having the seats and treadles raised for them. The main reason for their no longer doing so was the introduction of the heavy wide frames, which made several stockings at once, and which required more strength on the part of the operative. ${ }^{20}$

If a child was engaged in seaming, he was bound to no set times of work, but if he did winding, he must be at work while the frame operative was working, although he might begin and leave off half an hour before the others. It usually took one winder to keep three or four frames supplied and he might work anything between twelve and sixteen hours a day, sometimes more. The wages of the winder were paid by the frame operative, whether the work was done in a frame shop or in the operative's own home. If the knitter worked in a shop, the winder was paid from a deduction made by the middleman from the wages of the operative. This usually amounted to about $4 \frac{1}{2} d$. or $6 d$. from each knitter, so that the winder might earn between Is. and Is, 6 d. a week. ${ }^{21}$

In the 1840's apprenticeship, if it can be said to have existed at all, did so in a very much debased form. A witness in 1843 described a system whereby boys were apprenticed at twelve or fourteen until they were twenty-one. They were usually boarded and lodged by their masters and were required to earn a certain amount for them before they began to earn anything for themselves. ${ }^{22}$ The Mayor of Leicester, trying a case in 1836 of a frameworkknitter's apprentice charged with neglecting his work, described the system as 'legalised slavery': the boy was required to earn I3s. a week for his master before he got anything for himself, which was as much as any grown man could make by working overtime. ${ }^{23}$ This system was exceptional, however, and apprenticeship, for all practical purposes, was extinct by $\mathrm{I} 840$.

The most characteristic feature of the hosiery industry as revealed in the report was the system of frame renting, which arose from the fact that a declining number of frames belonged to the men and women who worked them. The fact, in itself, that the manufacturer charged a rent for the hire of his machine is not remarkable, and had that been all, it is certain that deductions from wages would not have been such an object of complaint as they were in I845. The frame rent was not the only deduction which was made from the gross wages of the framework-knitter, who complained to the commissioner at least as much of the 'charges' as of the frame rent. The petitioners of 1843 asked for an inquiry into 'the enormous exactions of frame rent and other oppressive charges' to which they were subject. ${ }^{24}$ When the

I9 On employment of children see Wells, op. cit. I 35 and Rep. Cond. Framework Knitters, 102, 106.

20 Wells, op. cit. I $5 \mathrm{I}-2$

21 Ist App. to Rep. Cond. Framework Knitters, 8, 3 I, 33 44. One winder in 1843 earned $6 s$. $5 \mathrm{~d}$. a week, but he was I 5 and the case is noted as being exceptional: Ist App. to 2nd Rep. Children's Employment Com. p. Fo6.

22 Ibid. 254. ${ }_{23}$ Wells, Brit. Hosiery Trade, 82.

24 Text printed in Rep. Cond. Framework Knitters, $1-2$. 


\section{THE CITY OF LEICESTER}

framework-knitter worked in his own cottage, the charges upon his wages were not unduly great, although even then there were complaints of abuses. When the frame shop was the work-place, then the charges were particularly oppressive and very much more liable to abuse. The evidence of masters and workmen from Leicester often gave the amounts of the various charges. Of the 30 witnesses who stated the amount of their frame rent, 8 paid is. a week and 8 paid $2 s$. and the average of the 30 was Is. Iod. Forty-five Leicester men gave the sum of their charges. Here the average was $3 s$. Iod. a week, and the individual sums ranged from $2 s$. to $5 s .3 d .25$ Twenty-three of the men were within a penny or two of the average. These charges were for winding, standing in the shop, taking in and putting out, and seaming. Additional charges could include sums for needles, lighting, and heating. One witness stated that 'the hands complain that they have to work, on an average, two full days for the charges, before they begin to earn one penny for themselves, or the support of their families'.26 A list, published by the Leicester Board of Guardians in 1847 , showing the nominal earnings of 500 framework-knitters, showed that they earned in one week $f_{\mathrm{I}} 94$, from which the deductions were $£_{77}$, leaving $£_{\mathrm{I} I 7}$, or $4 s$. $8 d$. as the average weekly earnings of each man. ${ }^{27}$ The commissioner thought that the amount of this deduction was 'regulated by no fixed rule or principle whatever; that it is not dependent on the value of the frame; upon the amount of money earned in it; or on the extent of the work made; that it has differed in amount at different times, and now does so at different places; that the youthful learner, or apprentice, pays the same rent from his scanty earnings as the most expert and skilful workman'. ${ }^{28}$

Two abuses arose from the system of frame renting. The first was from the sub-letting of frames, whereby the hosier charged the middleman a weekly rent for the frames, and the latter reimbursed himself by charging the hands in some cases the same, in others an increased rent. This system of sub-letting became almost invariably associated with the practice of 'spreading the work'. That is to say that the manufacturer gave out to the middleman sufficient work to keep occupied the frames which the middleman rented from him, while the middleman spread the work over the manufacturer's frames and those which he either owned himself or rented from someone else. These were known as 'independent frames'. The practice of spreading the work became even more profitable as a result of the second abuse of frame renting, which was the deduction of full rent and charges even when full employment was not given. The middleman would spread the work over more frames than he had work for, while charging full rents from all those who were thus partially employed, and very often from those who were not employed at all. In the main, the Leicester manufacturers who gave evidence at the commission

25 These figure exclude two men who were working the new rotary machines and who paid charges of $10 s$. and $8 s .6 d$., and two loom hands who paid $8 s$. and $9 s .6 d$.

${ }_{26}$ Rep. Cond. Framework Knitters, 71.

27 W. Felkin, Hist. Machine-Wrought Hosiery and Lace Manufactures, 457.

28 Rep. Cond. Framework Knitters, 45, 48.

29 Ist App. to Rep. Cond. Framework Knitters, 40.

30 Rep. Cond. Framework Knitters, 53.

3s Ist App. to Rep. Cond. Framework Knitters, 87. denied charging full rent in times when work was scarce, but the case against the middlemen is quite clear. According to the knitters, too, it was generally not customary to reduce the rent at times when the frame was being altered to produce a different type of hosiery or even when it was being repaired. John Curtis, a Leicester knitter, said: 'I have worked at different places where I have actually been brought in debt for altering frames; that is, I have taken a frame which has been quite out of working order, and $I$ have been getting the frame to work to the best of my knowledge, and I have been at it till Saturday night, dark hour; and I have gone in [to the warehouse] not with the expectation of the master taking full charges, but he has begun to set it down without my having earned a halfpenny, so that, in fact, I have paid for setting his machinery going,'29 Some manufacturers even argued that frame renting was a means of securing constant employment, as the employer, needing the frame rent, would have to give work out. Muggeridge observed that this principle seemed 'unsound', as the overwhelming evidence showed that it was by no means observed. 30

Investment in hand frames was a profitable way of employing spare capital in the hosiery districts, and many individuals, otherwise unconnected with the trade, were led to invest in them. Charles Cox, a hosiery middleman, told the commission that he rented frames from a builder named Cook, a 'letter of independent frames', but otherwise unconcerned with the hosiery trade. ${ }^{3}$ ' The greatest difficulty for the man who wished to invest in frames was that of finding work for them himself or finding someone else who could provide it. That was by no means easy, as many knitters who owned their own frames discovered; they were glad to pay the half-rent which the hosiers asked of them simply in order to get some work. But for anyone who could find the initial capital and was prepared to take the risk, investment in hand frames could be very profitable. Outstanding examples of quick profits are those of an undermaster who made $£^{2} 5^{\circ}$ from the rent and charges on 30 frames, and another who gained $f_{500}$ in a year from 60 glove frames which he had bought for f500.32 The charges which the framework-knitters paid were, for the most part, charges which the middleman himself had to meet, although it was apparently the habit to pay the winding boys less than the charge taken from the knitter to cover winding, and undoubtedly, in a large number of cases, the middleman did not pay to the knitters the prices for their work which he received from the warehouse. 33 If the business was carried on as fairly as the manufacturers would have us believe, such startling profits as are described by Felkin would never have been possible.

Felkin also showed the commission that the rent of the frames was generally high in comparison with their cost. ${ }^{34} \mathrm{~A}$ new frame might cost anything up to $f_{2}$ or more, but the value of a frame would depend

32 Felkin, Hosiery and Lace Mftures. 457.

33 Demands for 'tickets of work' were often voiced at the inquiry. Such a ticket, giving particulars of the work and its price, would be handed to the middleman and passed on to the operative. The manufacturers would have cooperated in the scheme: Rep. Cond. Framework Knitters, 57-59. In 1846 a bill to bring this into force failed to pass : Felkin, op. cit. 473 .

${ }_{34}$ Rep. Cond. Framework Knitters, 46. 


\section{A HISTORY OF LEICESTERSHIRE}

upon its age, type, and condition, and upon the state of the industry at the time. In times of slack trade, a frame might be picked up for a very small sum at an auction. It was not unusual to find a frame being bought for a few shillings which, when trade revived, could be rented for $2 s$. or more a week. A frame used by James Shaw in I 845 had been bought for $f_{\mathrm{I}} \mathrm{I}$ and he had been using it for the last four years at a weekly rent of $2 s .9 d .{ }^{35}$ Another man in Leicester had worked the same frame for 30 years, during which time he had been paying a weekly rent of $9 d$. He estimated that only about $£ 6$ or $£ 7$ had been spent on it in repairs in all that time. ${ }^{36} \mathrm{~A}$ framesmith of Leicester was prepared to admit to making 9 or Io per cent. profit yearly on the capital cost of his frames, after paying for the repairs. ${ }^{37}$ The commissioner said that the largest owners of frame property estimated that the rents paid an interest of about $7 \frac{1}{2}$ per cent. on the capital invested. He personally regarded this as a very low estimate, "but assuming it to be correct, it nevertheless is an amount which falls extremely heavy upon the workpeople, by whom it is exclusively paid'. 38

After giving these reasons for the stagnant state of the hosiery industry in I845, Muggeridge made three recommendations. He said that the numbers of workers must be reduced if the hosiery industry was ever to be replaced upon an economic footing: alternatively, the scale of manufacture should be so expanded as greatly to increase the amount of employment available. He also suggested that more tastefully designed and better made hosiery would probably revive trade, and emphasized that improved quality was bound to be insisted upon by the consumer. ${ }^{39}$

His report, for all its size, does not really give a very complete picture of the hosiery industry. By 1845 two of its most characteristic features were combining with the system of frame rents to cripple production almost completely. These were that the industry was still largely a domestic one and that it was organized by the middlemen.

In one important respect the industry of 1835 differed from that of the late 18 th century: the middleman had appeared. In 1845 a witness before the commission, speaking of the period of the Napoleonic Wars, said: 'every stocking-maker who was a householder took his own work in, and fetched his own work out from the warehouses. I have no recollection of any such man working under another man. They finished it, and took it back to the warehouse themselves .... in fact I do not recollect there being any middlemen at all.' 40 'The general feeling reflected in the evidence was that the middlemen had appeared about $1812-16$ and that they became numerous about 1819 and 1820 . The middlemen undoubtedly brought advantages to both sides, but from the knitters' point of view the success of the change was not unqualified, and it was in answer to complaints made to the commissioner that William Biggs set out to him the advantages brought by the middlemen:

If every workman had a separate account with the warehouse as they would like to have, they would lose some time on Monday and some on Saturday in bringing in and taking out their work, and they would necessarily lose other time in preparing it and superintending its finish, for all of which services they do not make proper allowances; in fact it would be relinquishing all the advantages of the division of labour. Beyond that, if it were to be adopted, and every workman were to come to the warehouse, the detail of it would be so irksome and infinite that no amount of business could be carried on. In giving out orders it would be excessively teasing and annoying to have to subdivide a large order among 100 or 150 hands, and to give a hundred directions, not half of which would be appreciated. ${ }^{41}$

There was in addition less chance of the material being embezzled or otherwise lost, which a manufacturer showed was still a problem in $1845 .{ }^{42}$ The position of the middleman varied a good deal in individual cases, both in his relations with the manufacturer and with the knitter, and in many ways the putting out system favoured the undertaker class and enabled persons who were able but not over-scrupulous to rise to positions of some importance in the industry'.43 In spite of the advantages claimed by Biggs for the system of middlemen, the habits of the stockingers died hard, and the traditions of not working on Mondays or Saturdays persisted even though the operatives no longer had to spend those days waiting at the warehouse to give in or take out their work.

At this time the work of the framework-knitter was carried on either in his own home or in shops containing several frames, and when the hosiery manufacturer spoke of the factory system, he meant this concentration of frames into shops. Felkin estimated that in 1844 the average number of frames under one roof was rather more than three. 44 Of the knitters from the town who worked in shops and gave evidence before the commissioner, 19 per cent. worked in shops of io frames or less, 35 per cent. in shops of I I to 20 frames, 28 per cent. in shops of 21 to 40 frames, and 18 per cent. in shops of 4 I frames or over. The firm of John Biggs \& Sons, one of the largest in the town, employed in 1845900 to 1,000 frames, divided among 90 or 100 middlemen, some of whom had as many as 30,40 , or $5^{\circ}$ frames, although the majority rented between 3 and I0.45 There was apparently a tendency for these frame shops to increase in size: twenty years earlier by far the greater number of frame shops had only three or four frames. In I 845 Thomas Collins had 120 frames, 55 in his own shop, and the rest in various small shops;46 Rawson \& Fields had 500 frames, the largest number in any shop being $8 ; 47 \mathrm{~W}$. H. Walker's firm had 400 to 500 , chiefly in small shops, although their largest held 60.48 In spite of the tendency for these shops to grow slightly, the general appearance of the hosiery industry at this time is one of a domestic industry. Although the frame shop existed, it was organized on the same principles as the cottage.

The reasons for the survival of the domestic

I have had three or four men in prison for it.'

43 Wells, Brit. Hosiery Trade, 72.

44 Felkin, Hosiery and Lace Mftures. 464.

45 Ist App. to Rep. Cond. Framework Knitters, 74.

46 Ibid. 76.

47 Ibid. 167.

48 Ibid. 160 .

42 Ibid. 77, evidence of Thomas Collins: "These last four years I was looking over my book . . . and I find that I am 3400 and some odd pounds of yarn down, embezzled. 


\section{THE CITY OF LEICESTER}

system, at a time when most other textile industries in this country had gone over to factory production, are obvious. The hand frame had remained virtually unaltered for over Ioo years and had been quite unaffected by the development of steam power. The manufacturers seem to have been satisfied enough with the old system and had little or no encouragement to give to the principles of factory organization, although those of them who had a large concentration of frames seem to have made a great success of this way of working. But for the most part the hosiery workers themselves disliked the factory system with its discipline of regular hours. ${ }^{49}$

One of the reasons which was given by the manufacturers in 1845 for the decline in their industry was that their foreign trade in hosiery had been so much reduced in recent years. William Biggs said that in 1845 about Io per cent. of the hosiery produced in Leicester went for export, as against 30 per cent. about twenty years previously. ${ }^{50}$ The report quotes a letter from a hosiery agent in New York, written in 1843 , which stated that within the previous few years the market there for Leicester hosiery had almost disappeared, partly because of a deterioration in quality, partly because of undercutting by German cotton hose. ${ }^{51} \mathrm{~A}$ manufacturer spoke to William Biggs to the same effect, and added that he had imported German gloves and hose into Britain and had sold them profitably in spite of the import duty upon them. ${ }^{52}$ Biggs considered that foreign competition in overseas markets, and to an increasing extent in Britain, was the cause of the hosiery industry's depressed state. ${ }^{53}$

The attitude of the manufacturers seems to be one of helpless self-justification, and from other sources it seems clear enough that hosiery exports between I 8 I 4 , when the decline was said to have begun, and 1843 did not really decline at all, except in the case of silk hosiery, the production of which was negligible in Leicester. A decline in the value of the goods exported is noticeable, but this does not necessarily indicate that the manufacturers were any less prosperous, as it was largely accounted for by the decrease in the cost of raw materials. On the other hand, although there seem to be no grounds for accepting the idea of a general decline in the export of cotton and woollen goods, yet equally there was no sign of any expansion in the sale of hosiery either at home or abroad, and no prospect that any such expansion would take place. 54

The acute depression of the industry in the 1840 's was summed up a little sater in the century in these words:

Provisions were exceedingly dear, work was scarce and wages were so low that it hardly paid to be at work at all. ... Misery and want were stamped on all their [the stockingers'] careworn and anxious features, and the wretchedness was too severe to be portrayed, and too extensive to be relieved; there never was any previous distress like it. Thousands were starving and

49 Wells, Brit. Hosiery Trade, I28. One stockinger said that he would rather see his daughter beg than go into a factory: ibid. 135 .

50 Ist App. to Rep. Cond. Framework Knitters, 64.

51 Rep. Cond. Framework Knitters, 85.

52 Ist App. to Rep. Cond. Framework Knitters, 60.

53 Ibid. 59.

${ }^{54}$ Wells, Brit. Hosiery Trade, 132-3.

55 W. G. Jones, Leic. Stockingers, 5 (Leic. City Ref. Libr. Pamphlets O 3, vi). See Felkin, Hosiery and Lace hundreds worked at stone breaking at $4 d$. and a loaf a day, and it was no uncommon occurrence for a number of stockingers to act the part of a team $o_{1}$ horses, and draw a load of coals from the colliery pits. ${ }^{55}$

The manufacturer's view of the depression was expressed by William Biggs: 'Within the three years prior to $\mathrm{I} 84 \mathrm{I}$, ten manufacturers had declined business in Leicester on account of its unprofitable character-while 16 other firms had been overtaken with insolvency and bankruptcy within the same period. ... In one year, 1840 , there was fully onethird of the frames unemployed in Leicestershire.'s6

The depression seems to have been at its worst in $\mathbf{I} 839-4 \mathbf{I}$, with especially dreadful conditions in I 840.57 In I 84 I a meeting was held at Derby of masters representing the hosiery trade of the three Midland counties. At this meeting William Biggs moved a motion calling for parliamentary measures to save the industry from complete ruin. ${ }^{58}$ The depression continued very sharply until about $\mathrm{I} 844$. In I 843 a petition, signed by over 25,000 frameworkknitters in three counties, was presented to Parliament, asking for the appointment of a commission to regulate disputes between masters and employees, to fix wage-rates, and to make general rules for the guidance of those engaged in the industry. The result of this petition was Muggeridge's commission, but it was clear that the framework-knitters could expect no help from Parliament. ${ }^{59}$

Their own trade unions were ill organized and were only local. There was one in Leicester in the I 830's. The Sock Branch Union was formed in I 830 on the occasion of a strike by the Leicester sock hands for higher wages. This was successful, in spite of the fact that the strikers had no funds at that time, although contributions were made by members after the strike had ended. ${ }^{60}$ In $183^{8} 8$ an unsuccessful attempt was made to form a joint union of masters and employees in Leicester on the same principles as that at Hinckley. It is clear that there was little incentive for the masters, in the prevailing conditions of trade, to take part in any organization which was trying to raise wages. ${ }^{61}$ The only benevolent movements in which the masters took part were the allotment societies, of which there was one in Leicester. ${ }^{62}$ Until considerable mechanical improvements were made, it was very plain that there could be little improvement in the general condition of the industry.

The machines in use in the first half of the $19^{\text {th }}$ century differed only in detail from the machine as invented by William Lee at the end of the 16 th. The hand frame was the rule and the power-operated frame still a curiosity. There were, it is true, special difficulties in the application of steam power to framework-knitting, as Muggeridge remarked. ${ }^{63}$ By 1845 some at least of these difficulties had been overcome. Throughout the first half of the century attempts were being made to improve the frame, and Felkin

Mftures. 459-60, for description of a typical frameworkknitting family.

${ }_{56}$ Ist App. to Rep. Cond. Framework Knitters, 53, 55.

57 Rep. Cond. Framework Knitters, 96-97.

${ }_{58}$ Ist App. to Rep. Cond. Framework Knitters, 53.

59 Wells, Brit. Hosiery Trade, $136-7$.

60 Ibid. 137.

62 Ibid, I40, and White, Dir. Leics. (1846), 67.

${ }^{63}$ Rep. Cond. Framework Knitters, 25. 


\section{A HISTORY OF LEICESTERSHIRE}

speaks with praise of the work of John Heathcote of Loughborough and his partner Cordell, who devised the rotary frame and invented a way of narrowing the web by machine instead of by hand. ${ }^{64}$ This invention was closely followed by Brunel's 'tricoteur', 'the forerunner of the type on which the bulk of hosiery is now made'. ${ }^{65}$ Brunel's machine was never put into general use, for it produced an unfashioned tube of fabric, which had to be cut up, sewn, and then steamed into shape. There was a very considerable amount of prejudice against this practice, especially among the knitters themselves. ${ }^{66} \mathrm{By}$ the middle of the century several attempts had been made to drive a hosiery machine by steam power. The first known attempt was made by Warners of Loughborough in 1829 , but this was not successful and experiments there were abandoned. ${ }^{67}$ After I 844 Pagets of Loughborough introduced the steamdriven 'round' frames, which made knitted socks requiring only to be cut, shaped, and sewn into stockings by women and children. A larger machine was afterwards added, the steam-driven 'rotary', which worked much more quickly and which made the output of cheap knitted articles very much greater. ${ }^{68}$ Until some method of fashioning the stockings by machine could be successfully devised, it was still clear, in spite of these early attempts, that the hosiery industry would be a hand one.

Such, then, was the state of Leicester's staple industry in the middle of the Igth century-antiquated and overcrowded, showing all the abuses of the domestic industry, and one in which the manufacturers were fast losing control. As Muggeridge pointed out, there was a great contrast between the hosiery industry's stagnation, and the rapid growth during the igth century of the other British textile industries, and this despite the fact that the application of steam power to hosiery manufacture was certainly practicable. ${ }^{69}$ Thomas Collins of Leicester was a pioneer of the development of hosiery machinery. When the commissioner asked him whether he thought that it would be easy to apply steam power to the working of his frames, he replied, 'Oh quite easy', and continued that it was so much easier to work one of his frames than a hand frame: 'A child of three years of age could work one of my machines a day through in respect of strength.'70 The prevailing view of the manufacturers was expressed as usual by William Biggs: 'Some attempts have been made to introduce power, but to a very small extent; and I think it is not likely to succeed. 71 The commissioner also suggested that the gathering together of frames into factories was essential if the industry was not to decline further. ${ }^{72}$ Felkin later reported that although the manufacturers had been led to this suggestion with great care, owing to the decisive nature of Muggeridge's remarks, they did

64 Felkin, Hosiery and Lace Mftures. 243 sqq.; W. Gardiner, Music and Friends, ii. 573.

65 Wells, Brit. Hosiery Trade, I 4 I.

66 See above, p. 177.

67 Wells, op. cit. 142

68 In I 867 Pagets had just sold their early rotary machines which Felkin reported to have worked to a great profit: Felkin, Hosiery and Lace Mftures. 490.

${ }_{69}$ Rep. Cond. Framework Knitters, 91.

70 Ist App. to Rep. Cond. Framework Knitters, 77.

71 Ibid. 62 .

72 Rep. Cond. Framework Knitters, 92.

73 Felkin, Hosiery and Lace Mftures. 47 I. not favour the adoption of the factory system. ${ }^{73}$

After the year I845 certain forces were at work which made for changes in the organization of the industry. First, a general improvement took place in the types of the available machines, and there was an ever-increasing desire to see whether steam power could really be utilized to drive the stocking frame. The lead given by Pagets was followed by Matthew Townshend of Leicester, who patented a circular rib frame in 1847 and 1856 , and invented the latchneedle in $1847 .{ }^{74}$ The most striking advances were made by William Cotton, a Leicestershire man, who started in the factory of Cartwright \& Warner at Loughborough and later set up his own factory there. His first success came in 1864 , and the machine which then appeared has become known throughout the hosiery works as 'Cotton's Patent'. It provided the solution to the main difficulty in the way of the development of power-driven machinery for the hosiery trade, the automatic decrease in the numbers of stitches in the knitting courses. ${ }^{75}$

A second influence upon the hosiery industry was that the fifties and sixties of the last century were a time of general prosperity for the country as a whole, which was reflected in the increased standard of living, leading to an increased demand for hosiery in which the Leicester trade shared. Felkin could write in 1866 : "The demand for goods has been for some years beyond the power to supply them. This has partly arisen from the increased consumption. But it has been a consequence also of the well known fact in manufactures that as wages increase, less work is done; especially, when the time devoted to labour is simply controlled by the will of the workman. This consideration may at an early period become one of such importance as to bear strongly on factory, as contrasted with domestic employment of machinery.' 76

But the movement into factories and larger workshops was none too rapid. The new machines could not be produced with any great speed, and the cost of re-equipping the industry was too great to be undertaken by any but the largest manufacturers, to whom their frame rents were none the less a source of income not lightly to be given up. ${ }^{77}$ The hosiery workers succeeded in 1854 in getting a parliamentary committee of inquiry into frame rents and other deductions, but in spite of the unequivocal opinion of the committee that frame rents were undesirable, no Act was passed to abolish them, although it is certain that if this had been done, the transition to factory organization would have been greatly speeded up. ${ }^{78}$ A large rotary frame cost 200 or more and smaller ones more than fioo. But probably the greatest obstacle to change was the attitude of the framework-knitters themselves, whose spirit had been nearly annihilated by generations of extreme

74 Wells, Brit. Hosiery Trade, I 44; A Century of Techno$\log y$, ed. P. Dunsheath, 93 .

75 Wells, op. cit. 145-6.

76 Felkin, Hosiery and Lace Mftures. $47 \mathrm{I}$.

77 Wells, op. cit. 146. There was very considerable opposition to a bill of 1847 which proposed to abolish frame rents: Felkin, op. cit. 473.

${ }^{88}$ Wells, op. cit. 147. Rep. of Select Cttee. on Stoppage of Wages in Hosiery Manufacture [421], pp. 17-18, H.C. (1854-5), xiv, shows that some manufacturers had abolished frame rents and were adjusting wages accordingly. 


\section{THE CITY OF LEICESTER}

poverty, but who nevertheless clung to their independence and irregular habits of work. 'It was this obstinate clinging to liberty in working conditions that kept the hosiery worker in his squalid domestic workshop.'79 Few real changes in fact took place between the commission of 1845 and the Children's Employment Commission of 1862 . The opinion of one manufacturer in 1862 shows how slow was the change to factory production: 'I think that frames will gradually be still more concentrated in larger shops, and to some extent, though not for some kinds of goods, in factories, and also in or near towns. Many however will probably remain in villages on main lines of railway which have rapid communication with towns, which is now of more importance.'80 As late as I 866 Felkin thought that there had been little reduction in the number of hand frames in use. $^{81}$ William Biggs in I862, cautious as ever, doubted whether the whole industry would ever be concentrated in factories, and thought that highquality goods would continue to be made by hand. ${ }^{82}$

A gradual improvement was taking place in the conditions of places of work. In I 863 a witness before the Children's Employment Commission stated: 'The small shops in most cases adjoin to small houses, but do not form the living rooms as is the case in poor places. Still there is a general deficiency of ventilation here, and there is more attention paid to these things in new buildings; but of the others there are not many over $7 \mathrm{ft}$. high, and in a shop of that height and $30 \mathrm{ft}$. long by $\mathrm{I} 7 \mathrm{ft}$. broad there would be perhaps 20 people. There is no ventilation and the gas makes the air very hot and unhealthy in the evening.' ${ }^{3}$ At the same time the Leicester Medical Officer of Health said: 'In the course of my duty I am constantly in the stocking makers' shops in the town. The oldest of these are almost invariably low, and their ventilation in every way imperfect, but the newly built are better in these respects and larger.' 84 By I 892 a witness before the Royal Commission on Labour could say of the Leicester factories that their sanitary conditions were excellent. When a new factory was put up, the plans had to be submitted for the approval of the local authority. ${ }^{85}$

Prejudice against working in the factories existed for long after they were becoming more common. It was expressed very strongly in Leicester in the I 850 's. Even despite better conditions and higher earnings, the Leicester stockingers were loth to enter the factories themselves or to send their children. After twenty years of factory legislation the feeling persisted, and even in I870 manufacturers complained of the difficulties of attracting work-people into the factories. ${ }^{86}$

From their beginnings, conditions in the factories and large workshops compared most favourably with those in the small shops and in the frameworkknitters' houses. As a result of the Factory Acts, the

\footnotetext{
79 Wells, Brit. Hosiery Trade, I 47.

80 Ist Rep. Children's Employment Commissioners [3 I 70 ], p. 387 , H.C. (1863), xviii.

${ }_{81}$ Felkin, Hosiery and Lace Mftures. 558-9.

82 Ist Rep. Children's Employment Commissioners ( 1863 ), 385.

38 Ibid. 387 .

84 Ibid. 292.

85 2nd Rep. Royal Comm. on Labour, Minutes of Evidence, Group $C$, vol. ii [C. 6795-VI], p. I 7, H.C. (I892),
} xxxvi, part II. conditions of employment, especially the employment of children, were regulated, and there were never the abuses of child labour in the hosiery industry from which industries converted to factory organization at an earlier date had suffered. No child under the age of Io years could be employed in a factory, and the hours of women and young persons were fixed at from 6 a.m. to 6 p.m. in summer and 7 a.m. to 7 p.m. in winter, with $I_{2}^{1}$ hours for meals, leaving a legal maximum working day of $10 \frac{1}{2}$ hours. ${ }^{87}$ For those children who were not employed in factories conditions remained very much the same as they had been in 1843 , when it was estimated that out of 28,000 persons employed in the county of Leicester, 12,924 were under the age of $18 .{ }^{88}$ In I 863 children working on frames in private houses would start at $6 \mathrm{a}$.m. or 7 a.m. on Tuesday mornings and work each evening until 8 p.m. or 9 p.m., often later on Fridays. ${ }^{89}$ One employer did say, however, that he had noticed 'a great improvement as to the ages at which the young begin to wind and work in frames'. Better wages were also paid, the winding boys making as much as 3 s. or $4 s$. a week. ${ }^{90}$

Attempts were made in the middle of the century, especially in Leicester, to improve styles and patterns in the products of the industry. ${ }^{91}$ Biggs had said in 1845 that there were 1,300 frames in Leicester already employed in the 'fancy' trade. ${ }^{92}$

After I 870 the change to factory production became more rapid. The solution of the technical problem of the adapting of steam to hosiery machinery coincided with several other factors all having an influence on the change. The Factories and Workshops Act of I 867 subjected small workshops to the control of the factory inspectors. ${ }^{93}$ This was generally welcomed by the better employers, who were usually those already subject to the Acts, and had for long felt that it was wrong that one side of the industry should be controlled while the other was entirely free. The practical application of the Act to these small shops was by no means easy, especially at first, when there were not enough inspectors. The actual problem of finding small shops was a difficult one, tucked away as they were in the back streets and alleys of the town. 94 No statistics of the number of workshops in Leicester are available, but the number in the district was estimated at 5,000 , of which twothirds were devoted to the manufacture of handmade boots and hosiery. 95

Just as important was the passing of the Education Act of 1870 and its sequel of 1876 , which made attendance at school compulsory for children between the ages of 5 and 14 , with provision for partial exemption only after the age of 12.96 This deprived the framework-knitters of the services of their winders and seamers and led to an increase in the cost of production in the small shops, as compared with the factories, where the winding and much of the sewing could now be done by machinery.

86 Wells, Brit. Hosiery Trade, I 54.

87 Ibid. I 52 .

88 2nd Rep. Children's Employment Commissioners (Trades and Manufactures) [430], p. 2 I, H.C. (1843), xiii. 89 Ist Rep. Children's Employment Commissioners (1863), 291 .

90 Ibid. 387

91 Felkin, Hosiery and Lace Mftures. 472.

92 Ibid.

93 Wells, Brit. Hosiery Trade, I53. 94 Ibid. 153.

95 Ibid. $153 \mathrm{n}$. 96 Ibid. 156. 


\section{A HISTORY OF LEICESTERSHIRE}

Perhaps the most important factor in speeding up the transition to a factory economy was the abolition of frame rents by Parliament in 1875. This Act removed the main feature of the antiquated system of production, the foundation on which the hosiery industry had been built. Frame rents were held to be in contravention of the Truck Act of $\mathrm{r}_{3} \mathrm{I}$ and therefore illegal as early as 1844 , but a decision to this effect which had been made at Leicester Assizes was reversed in the Court of Appeal.97 A bill to abolish frame rents was again proposed in 1853 , but was rejected. 98 'The agitation against rents persisted in spite of this discouragement throughout the 1860 's, and frame rents were the subject of new investigation by the Royal Commission on Truck of 1871 . At first no workers could be found in Leicester to testify against their masters, sufficient indication of the importance attached by the owners of frames to their rents. From the report of the commission, it appears that during the I860's some Leicester masters had abolished frame rents and other charges, and that others had abolished rents only, taking a certain proportion of the wages of their employees instead. Many had established a system of fines, which, it was said, formed an excellent substitute for the old one and could with equal facility be turned into an abuse. Frame rents were not now usually charged for frames set up in the manufacturer's own premises, in which wages were adjusted to compensate the manufacturer for this. ${ }^{99}$ Where they were still paid, frame rents had not increased in the recent past, and although the figures given are not so full as those for 1845 , there had been some change since then. The employers who still charged frame rents argued that, if they were abolished, prices would rise and the industry as a whole would suffer. Some masters were accused by their workmen of the old practice of charging full rents when full employment was not given, and one man said of a master: 'If a man were ill for a month, he would charge the whole frame rent, and the gas which was never lit, and the winding too, though there was never any winding done. 'I Charges were still connected with the practice of 'spreading the work', when times were bad, and this, together with apathy during years of prosperity, had neutralized any incentive which there might have been for redundant workers to leave the industry. ${ }^{2}$

Frame rents still apparently provided a handsome return on capital. Samuel Odams, a leading Leicester hosier, told the commission on truck that he had made profits of up to $£ \mathbf{I}, 200$ a year on frame rents in the three years before $187 \mathrm{I}$. He admitted that he charged frame rents even when his operatives were ill, for he claimed that they would make illness their excuse if they knew no rent would be charged on the frequent occasions when they had been drinking. ${ }^{3}$ Apart from frame rents and the other charges, there seems to be little evidence of ordinary

97 R. Bindley, Hist. of Struggle for Abolition of Frame Rents and Charges, 5 (Leic. City Ref. Libr., Pamphlets $\mathrm{O}_{3}$, xxii).

${ }_{98}$ Ibid. It was opposed in the Commons by William Biggs, who described it as 'mischievous and impracticable'.

99 Ibid. 7. Much of what follows is derived from the same source.

Ibid. I 7.

2 One witness pointed out that Leic. framework-knitters could not move to Nottingham. because the type of work they could do was so different: ibid. 15. trucking in Leicester in 1871 , although it was then said to have been very prevalent 'some years ago'. Even after the abolition of frame rents, complaints of one sort and another about charges did not disappear altogether. As late as 1892 there were masters who tacitly took charges from their workers, who were in the habit of leaving money on the table when the week's wages were being paid. ${ }^{4}$ Fines were sometimes paid for such offences as being late at work. ${ }^{5}$ Even in 1897 the Webbs mentioned the hopes of the Leicester workers to abolish 'insidious forms of "truck" '.6

Increasing prosperity and developing factory organization accelerated the development of the trade unions. Strikes became more frequent in the industry, notably at Nottingham in the period I $85^{\circ}-70$, and there was a growing demand for the setting up of a joint body to regulate wages. One of those most vociferous in his demands for such an organization was William Felkin, who organized meetings in the hosiery districts to press for it. In I 860 the Board of Arbitration and Conciliation was set up in Nottingham under the chairmanship of A. J. Mundella, and played an important part in the adjustment of wage-rates necessitated by the trade depression which was the result of the American Civil War. ${ }^{7}$ A similar board was set up in Leicester in 1866,8 but the Leicester workers held themselves aloof from the scheme of setting up a national union to be known as the United Framework Knitters' Society, which was advocated in the same year. Only one delegate from the borough was among the 35 who attended the inaugural meeting. ${ }^{9}$

By r 890 something like 95 per cent. of the output of the industry was coming from power-operated machines. Ever since hosiery was first produced by steam, the employers had said that only the cheaper forms of hosiery would ever be able to be manufactured in this way, and that those articles which did not need to rely upon cheapness for their sale would have to be made by hand. They still asserted in 1890 that there was not so much elasticity in the power-made goods and that they were much less strong, but by 1890 they were employing hand frames very irregularly. With the exception of operatives still working to War Office specifications, only the very highest class of goods were still made by hand. There were an estimated 5,000 hand frameknitters in the Midland counties, of whom less than half belonged to the Hand Framework Knitters' Federation. ${ }^{\text {Io }}$ The officials of this organization still thought it possible that the industry might be revived and that 'if the genuine hand-made article were properly put before the public' and the public understood the worth of what it was buying, it would be willing to pay a little more for better workmanship. II

Whatever its apologists may have thought of the

3 Ibid. $36-37$.

4 2nd Rep. Royal Comm. on Labour, Mins. of Evidence, Group $C$, ii. I3. 5 Ibid.

6 S. and B. Webb, Industrial Democracy (I9II), 263.

7 Wells, Brit. Hosiery Trade, 16o-2.

8 Ibid. I 67.

9 Ibid. 169 .

10 2nd Rep. Royal Comm. on Labour, Mins. of Evidence,

Group $C$, ii. I 5.

11 Ibid. 16. 


\section{THE CITY OF LEICESTER}

prospects of the hand trade in 1890 , very few hand frames were being made, and those mostly for the glove branch rather than for stockings, while many hand frames were being given away or sold for a few shillings. Osmond Tabberer, of the well-known hosiery firm of Pool, Lorimer \& Tabberer, stated before the Royal Commission on Labour that, while his firm preferred the factory system, some home work was allowed, for the benefit of such people as the old women he mentioned who, though too old to go out to work, wanted to go on using their hand frames, and the firm was prepared to use their services. ${ }^{12}$ Another firm used about 50 or 60 hand frames for special kinds of work. ${ }^{13}$

The transition to factory organization affected trade conditions in many ways. The difference between the wages of a domestic worker and one working in a factory had been noticed as early as 1845 , when it was estimated at something between $2 s$. and $3^{s}$. a week. ${ }^{14}$ Factory wages went up as those of operatives working in their own homes dropped, and in 1862 it was estimated that a girl working two frames in a factory could earn about $9 s$. a week and a man between $12 s$. and I $5 s .{ }^{15}$ Men's wages showed considerable variations according to the ability of the worker and probably also according to the type of frame, and the sums named ranged between $7 s$. and over $£ \mathbf{I}{ }^{\mathrm{I} 6}$ In many cases wage-rates had doubled since 1845 . In the next twenty years they nearly doubled again. In 1890 a man working a machine which was more than twenty years old could earn from I 5 s. to I $8 s$. a week, a man on a new rotary frame from 2os. to $30 s$., and one on a Cotton's Patent or Rib Machine from $25 s$. to $30 s .{ }^{17}$ Between 1886 and $\mathbf{I} 89 \mathrm{I}$ it was estimated that of a chosen average sample of hosiery workers, no man earned less than I $_{5} s$. a week, $75^{\circ} 3$ per cent. earned between I 5 s. and 3 os., and $24^{\circ} 7$ per cent. over $30 s$, the average being $25 s .4 d$. The average wages for women were i is. $6 d$., for boys $9 s .6 d$., and for girls $8 s .3^{d} .{ }^{18}$ The wages of those who worked in the warehouses were slightly higher than those of the actual operatives, and the men and women in the warehouses were generally of a better class. ${ }^{19}$ Wages were regulated according to trade conditions by the employers, and every so often an employer would issue a new list. A widespread strike took place at Leicester in 1886 , when mobs threw stones and did damage to many of the hosiery factories in the town. The subject of dispute was a new wage list which had been issued by the employers, who were forced to agree to concessions. ${ }^{20}$

There was a very obvious irregularity in wagerates between one worker and another, and this was the subject of most of the disagreements in the industry at the end of the last century, especially as the wage-rates agreed upon by most employers would not be paid by all. A symptom of the unsettled state of the industry was the appearance of a new type of

12 Ibid. 17.

13 Ibid. I6.

14 Ist App. to Rep. Cond. Framework Knitters, 77. 385.

15 Ist Rep. Children's Employment Commissioners (1 863),

17 2nd Rep. Royal Comm. on Labour, Mins. of Evidence, Group $C$, ii. 13 .

18 Wages of Manual Labour Classes in U.K. [C. 6889], p. 470, H.C. (1893-4), lxxxiii, part ii.

19 Wells, Brit. Hosiery Trade, I 52.

20 Leic. Daily Post, 1 2-1 7 Feb. 1886. middleman, who farmed out work from the manufacturers and relied upon low labour costs for his profit. ${ }^{2 I}$ The breakdown of the Board of Arbitration shows to how small an extent collective bargaining was possible. ${ }^{22}$ To some extent these variations in the wage-rates were fair enough, as it was reasonable that a man whose machine was capable of producing more should be paid less per dozen than one who was working one of the slower, older machines. Even so, they were not adjusted to be fair. In 1892 women working obsolescent sewing machines could earn no more than $9 s$. to ros, a week, yet the average for this kind of work was over $14 s^{23}$ In 1908 women who were given as much as Is. 3 d. a dozen were earning about $7 s$. a week less than others on new machines who were only paid $3 d$. a dozen. ${ }^{24}$ Most women then earned less than half what a man could earn. There was never any suggestion that wages should be paid on a time basis, and presumably the old independence of the industry remained in this preference for piecework. This explains the indifference of the hosiery industry to the issue of the Normal Day. ${ }^{25}$

The period between $\mathrm{I} 860$ and $\mathrm{I} 880$ saw a decrease in the hours of work, and by 1890 the 54 - or $56 \frac{1}{2}$ hour week was usual in factories and workshops within the city. The hours were usually from 8 a.m. to $7 \mathrm{p} . \mathrm{m}$. in winter and $6 \mathrm{a} . \mathrm{m}$. to $5.30 \mathrm{p} . \mathrm{m}$. in the summer, although there were differences between individual firms. The Saturday half-holiday operated almost universally and had been usual in some factories since the 1850 's. Corah's works had given a half-holiday since before $1863 .{ }^{26} \mathrm{~A}$ witness in 1863 said that there had been a noticeable shortening of hours in the last few years, as the result of a change made by the railways: 'Carriers would wait for goods any time, up to $\mathbf{I} 2$ at night, and even up till the morning, and it was general then for warehouses to be open late. Now goods are usually sent from a warehouse at $5.30 \mathrm{p} . \mathrm{m}$. and for London or anywhere else they must leave not later than 8 . This prevents late work and people work harder during the day.'27 There had for long been a movement towards the standardization of working hours, which drew an interesting comment from the commissioner on Children's Employment: 'The obvious and acknowledged objection to the practice of ending the day's work at varying hours is that it renders attendance at evening school almost impossible; and exposes the young to greater temptations by necessitating their absence from home at late and indefinite hours.'28

In Leicester, we are told, there was a good deal of overtime work, especially on expensive machinery at certain seasons of the year. One speaker in 1892 opined that overtime should be abolished.29 The buyers were encouraged to send in their orders as late as possible, knowing that the men would work overtime to fulfil them. Irregularity of employment

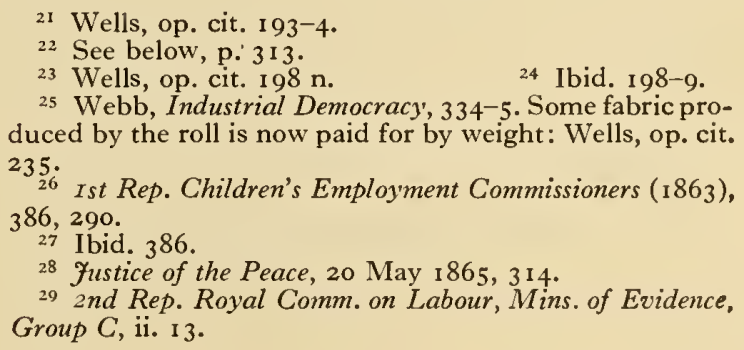

21 Wells, op. cit. I 93-4

22 See below, p.' 3 I 3

23 Wells, op. cit. $198 \mathrm{n}$ 235 


\section{A HISTORY OF LEICESTERSHIRE}

was increased by this habit, and many workers felt that some check on hours would be an advantage. ${ }^{30}$

The introduction of power-driven machinery was not equally advantageous to everyone. One of its first effects was to throw many of the older men out of employment altogether. Some were kept on as winders and odd-job men, and in 1890 about fourteen or fifteen old stockingers were selling firewood, by which they earned between Ios. and $12 s$. a week, preferring this frugal existence to the workhouse. Some employers had lent them capital to begin their business. ${ }^{3 I}$ The numbers employed in the industry were about the same in 1891 as in 1851 , although the output was so much greater. ${ }^{32}$

While the growth of factories made work rather more regular for those in them, since the owners of expensive machinery would clearly try to employ it to full capacity, the seasonal variations in the trade did not disappear: indeed many observers thought them more pronounced. The Leicester manufacture was still mainly in wool and worsted, and was thus in greater demand in winter. The busiest time was therefore in the second half of the year. This was followed by the Australian season which was expanding with the Australian colonies, and in spring and summer came the Canadian. In addition to the loss of the balancing markets in the United States, work was made rather more irregular in the I860's by the fact that 'manufacturers now work much more to order instead of to stock, and in some cases will not work at all unless they have orders. This is now universally the case with all the branches that depend upon fashion, and where fancy goods, etc. are manufactured.' 33

Any irregularities of employment in the hosiery industry would, whenever possible, be suffered primarily by the domestic workers, since the employers incurred no overhead charges in respect of them. Even in 1892 work had not become any more regular, for it could be said by a prominent Leicester employer that 'after the winter trade is over, and the spring orders are dealt with, there is slack time until the orders come in for the following winter'. ${ }^{34}$ Three months' short time was apparently common in the I 890 's. ${ }^{35}$ In March 1895 the Leicester and Leicestershire Amalgamated Hosiery Union said that in Leicester there were Io per cent. unemployed and not more than io per cent. on full time. ${ }^{36}$ For many years it remained true that rather than dismiss employees in the slack season the matters, sometimes by arrangement with the unions, preferred to work short time. This was the general practice until the outbreak of the Second World War.

One of the most prominent features of the modern hosiery industry which emerged during the latter part of the igth century is the employment of large numbers of women. There was a place for them in the old domestic system, but until the development of proper factories few women worked on frames. Their jobs were mainly sewing and, in some cases,

\footnotetext{
30 Wells, Brit. Hosiery Trade, 200.

2nd Rep. Royal Comm. on Labour, Mins. of Evidence, Group $C$, ii. I 4

32 J. Clapham, Econ. Hist. Modern Britain, ii. 5 I 3. 388.

Ist Rep. Children's Employment Commissioners (1863),

${ }^{34}$ and Rep. Royal Comm. on Labour, Mins. of Evidence,
} Group $C$, ii. I7. winding. Thomas Collins employed women in his shop in 1845 , mostly between the ages of 13 and 17 , and had more applications than he could fill. They earned between $9 s$. and $16 s$. a week. ${ }^{37}$ Frames at this time were much more usually worked by men. In I 85 I 4, I 88 men and I,979 women were employed in the industry in Leicester. ${ }^{38} \mathrm{By}{ }_{1} 87 \mathrm{I}$ the effect of the increasing factory system had been to reduce the number to 2,867 and I, 870 respectively. The number of children employed had also dropped considerably from 382 boys and 493 girls between the ages of 5 and 10 years in 1851 to 35 boys and 73 girls in 1871.39 From this time women gradually came to outnumber men more and more in the industry. From the first, complaints were made that the presence of women in the industry brought down the wage-rates. This argument was first expressed in I 845 , although then more in the country districts, 40 but as the century progressed it was heard more frequently. The Webbs described a typical dispute over the employment of men and women. In I 888 men working circular rib frames found that they were being put out of work by women who could do the work as well and who were being paid less. When protests were made the women said they would be dismissed if they asked for their wages to be made the same as those of the men. Even when it was decided that the women should work for $\frac{1}{4} d$. a dozen less than the men, many male workers were dismissed from the firm. ${ }^{41} \mathrm{~A}$ witness complained in I 892 that women were in competition both in and out of the factory: "The opinion of the workpeople in Leicester is that work should be done in the factories instead of at the people's homes.' He knew of numerous cases in which women worked in their houses for wages far below the 'statement price' (the price agreed upon between unions and employers and which operated in most of the factories), "the tendency of which is to reduce wages gradually in the factories; next, it has a tendency to turn the home into anything but a home, and has a demoralizing influence on the people. . . . It is simply another aspect of sweating. They do the work in such quiet out of the way places that you cannot get to know what they are doing, nor the price they are getting.' He further advocated restrictions upon the employment of married women in factories, on the grounds that they competed with single women, that they could generally afford to accept reductions in wages, and that 'the girls were driven to immorality to eke out their wages'. ${ }^{2}$ During the period between I 88I and 189 I the total number of hosiery workers in the country rose by $2 \mathrm{I} \cdot 6$ per cent., while the number of women rose during the same period by 44 per cent. and the number of men declined. By i 89I women outnumbered men by a ratio of 190 to 100.43 It was estimated that in 1905-6 there were 9,107 women employed in the industry in Leicester as against only 3,282 men, and the women were then earning between I $3 s$. and $19 s .{ }^{44}$ Women were by then beginning to work frames, but most of the women employed in
35 Wells, Brit. Hosiery Trade, 200.
37 Ist App. to Rep. Cond. Framework Knitters, 76-77.
38 Census, I 851 .
40 Ist App. to Rep. Cond. Framezork Knitters, I95.
41 Webb, Industrial Democracy, 502.
42 2nd Rep. Royal Comm. on Labour, Mins. of Evidence,
Group C, ii. I3.
44 G. R. Porter, Progress of the Nation, ed. Hirst, 390-1. 


\section{THE CITY OF LEICESTER}

factories were still doing the sewing and making-up processes that they had always done. An interesting comment upon this was made in I $91 \mathrm{I}$ :

The seaming and putting together of hosiery of late years has been almost entirely done by sewing machines. Formerly this was done by women in their own homes, and very largely in the country villages, but now there is very little hand seaming; what remains is done at a very low price, as it has to compete with sewing machines. The manufacturer prefers to seam the goods in his own factory, but out of consideration for, and at the strong request of the home worker, he still sends out a portion, for which he pays more than it would cost him in his factory. As a reward for his consideration he is stigmatized by the title of 'sweater' by those who do not understand the position of affairs. ${ }^{45}$

The last quarter of the I 9 th century was a difficult time for the hosiery industry. Apart from the internal difficulties caused by the change to factory production, the I 880's saw an increase in the amount of competition from Germany, which was now producing 'fancy' hosiery as well as the more common articles. What was left of the United States market was being further restricted by increased tariffs. ${ }^{46}$ At home the depression in trade and industry'hit the hosiery manufacturers hard, as the clothing industries are always among the first to feel the effects of a fall in purchasing power. Within the industry itself the greatly extended competition which had been encouraged in the years of prosperity became uncontrollable, and many of the new firms which had been set up were forced to go out of business. Dividends were generally small and losses frequent. ${ }^{47}$ As time went on, these unsettled conditions led to the decline of the Board of Arbitration, since 'No institution that existed to make regulations in the common interest could flourish in an atmosphere of mutual suspicion, where none could be sure that his neighbour would adhere to the terms of an agreement.'48 A Leicester witness before the Royal Commission on Labour of I 892, when asked whether his industry had a Board of Arbitration, said that there was one and that periodical meetings were held up to $\mathbf{1} 884$, but no dispute had been referred to it since 1886 'and then it was in such a state of decomposition as to be useless'. He went on to say that at the time they had no board but 'if any dispute arises there is no difficulty whatever in the two sides meeting and adjusting the differences before a strike takes place'. ${ }^{49}$

Although the trade unions were trying to deal with these problems, they had a difficult task, increased by their own administrative difficulties and by apathy within the industry itself.50 One of their major problems was that of the country worker. After I 890 decentralizing forces were at work in the hosiery industry, caused by increasingly efficient methods of communication and the practice of selling goods from samples instead of directly from large stocks, and their main manifestation was the spread of the industry into the county. ${ }^{5 I}$ The competition of the country worker became considerable as the

45 Leic. Chamber of Commerce Year Bk. (1911), 47.

46 On this see Wells, Brit. Hosiery Trade, 178-82.

47 Ibid. $175^{-6.6}$ 48 Ibid. I93.

49 and Rep. Royal Comm. on Labour, Mins. of Evidence, Group $C$, ii. 14 .

so Wells, op. cit. I 96.

sI On this see Wells, op. cit. 194-6.

52 Ibid. 196.

53 Ibid. 197; Trade Union Congress Official Souvenir, necessity of having a factory within the trading centre became less and less compelling, and this was increased because the country workers could be and were paid less than their more highly organized fellows in the towns. The unions had great difficulties in extending their power into the country districts, and the result was a good deal of rate cutting, which was practised by the smaller town manufacturers as well as those in the country. About nine-tenths of the disputes in the industry were caused by irregularity in prices. The chief local union was the Leicester and Leicestershire Amalgamated Hosiery Union, which was formed in 1885 and followed in 1889 by the National Hosiery Federation, with which it was associated. ${ }^{52}$ As the industry became less centralized, the union had to become all-embracing and the separation within it of the skilled and the unskilled worker had to disappear to provide a more unified control. Membership of the union was not then, and has not since become, great in proportion to the total numbers of operatives in the industry. On the whole, relations with the employers were fairly friendly, and negotiations took place on a somewhat informal basis. In 1903 the union had only I,600 members.53 'The Midland Counties' Hosiery Manufacturers' Association was formed in I 899.54

One of the most important developments in Leicester in the last century was the start of technical education for the hosiery trade. ${ }^{55}$ In 1885 the Chamber of Commerce was responsible for the beginning of classes in hosiery, science, and art, science and art being provided by Wyggeston Boys' School. The hosiery classes were the first of their kind in the county. In 1892 these were taken over by the borough council and from that time have been a most important part of the work of the College of Art and Technology. The college now (1955) runs full- and part-time day classes and evening classes in hosiery manufacture and design, and from the first the local manufacturers have welcomed the opportunities thus offered to their hands.

The hosiery industry in the present century has for the most part been peaceful and prosperous. There has been no strike of hosiery workers in the borough for over 40 years and good relations exist between management and employees. ${ }^{56}$ The First World War saw the end of steam power as the usual method of driving frames, and hosiery, as a light industry, was one which benefited most from the development of electric power, as well as of other methods of transport than the railways. ${ }^{57}$

Until the end of the last century, Leicester's hosiery was primarily of wool. The silk industry had died out in the 1860 's, ${ }^{58}$ but was revived after the First World War, especially as skirts became shorter and there was more incentive to buy silk stockings which could be seen. Silk itself was in turn superseded by nylon and other synthetic fabrics, and Leicester's previous specialization in one material for hosiery came to an end. Higher standards of Leicester, I903, 23.

54 Minute Book at Leicester Office. The Leicester Hosiery Manufacturers' Association in its present form dates from 1943. Before that it was part of the Leicester Chamber of Commerce.

55 Leic. Chamber of Commerie Hand Bk. (I9I I), 58.

56 Leic. Mercury', 8 Mar. 1955.

57 Working Party Rep. Hosiery, H.M.S.O. (I946), 7.

58 Felkin, Hosiery and Lace Mftures. 515. 


\section{A HISTORY OF LEICESTERSHIRE}

living were reflected after 1918 by increasing clothesconsciousness and by reduced patching and darning, and the greater demand which resulted brought down the costs of production.

In I 9 I I there were over Ioo hosiery manufacturers in the town, and a total of 15,727 employees, of whom 12, I 7 were women. 59 The war made great demands upon the industry and many new firms were founded at the end of it. ${ }^{60}$ By 192 I there were over 200 hosiery firms in Leicester, and in 1923 25,490 insured persons were employed in them. ${ }^{6} \mathrm{I}$ Employment figures rose steadily in the years before the Second World War. In 1937 there were 30,950 insured hosiery employees in Leicester and in 1939 $33,310 .{ }^{62}$ In 1937 the Leicester and Leicestershire Amalgamated Hosiery Union had only 5, 100 members out of the total labour force of city and county. ${ }^{63}$

In spite of the end of its specialization Leicester remained one of the two main centres of the hosiery industry in England. Out of fourteen new factories opened in 1933, eight were in Leicester. ${ }^{64}$ The Second World War brought new prosperity to the industry, but also great difficulties. Several firms found themselves working together under one roof, and 50 per cent. of hosiery operatives were doing other work or were in the forces. ${ }^{65}$ Production remained at a high level. In 19437 I million articles of hosiery, excluding stockings, were produced in the country and 240 million pairs of stockings and socks. Actual figures for Leicester's part of this total are not available, but it was probably about 25 per cent. ${ }^{66}$
After the war, some of the difficulties remained. There was in the first place a shortage of labour, which continued in 1955, chiefly because the war brought new industries to Leicester which made a permanent home in the town. ${ }^{67}$ This labour shortage forced employers to move once more out into the county and small new factories have appeared at several places. ${ }^{68}$ In addition, some homework has again begun. In 1946 it could still be said: "The domestic system of production still exists to some extent. In some districts the employer sends out wool and small knitting-machines to people working in their own homes. A fair amount of glove production is still carried on in the operatives' homes. Outworkers are also employed in certain finishing processes.' 69 The government working party in the same year ${ }^{70}$ stated that there was a shortage of factory space for the machinery necessary for increased output. It was then estimated that of the new factory space that the industry would require in I $946-5$ I for producing fully fashioned stockings, i i per cent. would be needed in Leicester. In 1946, however, Leicester produced 23 per cent. by value of the total British exports of hosiery, $£ 3 \frac{1}{2}$ million out of a total of $£_{1} 5^{\frac{3}{4}}$ million, and the total value of Leicester hosiery sold altogether in that year was $£ 24$ million. In the following year the total sale value had risen to E.32 million, 30 per cent. of the total value sold in the whole country; hosiery goods to the value of $£ 6$ million, or 28 per cent. by value of the town's total, were exported. 71

\section{FOOTWEAR MANUFACTURE}

BEFORE the end of the I8th century Leicester had only as many boot- and shoemakers as served to supply the needs of the town. From about 1793 their numbers increased, owing to the demand for standardized boots for the army, but for the next 50 years the trade remained a small one. ${ }^{\text {I }}$ In I 794 some shoemakers of the town, together with four masters accused of aiding them, were prosecuted for striking and 'combining to secure an advance in wages'. ${ }^{2}$ In 1806 comes an isolated example of what was later to become a common feature of the trade, the wholesale boot and shoe warehouse. William Morton advertised that 'master shoemakers may be supplied with any quantity on as good terms as at any manufactory in the kingdom'. ${ }^{3}$ The impetus given to the trade by the war seems to mark the transition from purely bespoke work to the making of shoes for stock, both in Leicester and in other towns. The bulk of the nation's demand for shoes was still, however, satisfied by the many bespoke shoemakers, by clogand patten-makers, or by individual makeshift

59 Census, 1911 ; Leic. Chamber of Commerce Hand Bk. (1911), 58 .

60 The firm of Chapman Fraser \& Co. may be taken as typical of the new firms which sprang up after the war: Leic. Mercury, 4 Mar. 1955.

${ }^{6}$ Leic. Chamber of Commerce Hand Bk. (1921), 28; Working Party Rep. Hosiery, 9.

${ }_{62}$ Working Party Rep. Hosiery, 9; Leic. Official Industrial Handbk. 29.

${ }_{63}$ Brit. Trade Unionism Today, ed. G. D. H. Cole, 553.

64 Wells, Brit. Hosiery Industry, $206 \mathrm{n}$.

35 Leic. City and County, 89.

${ }^{66}$ Leic. Official Industrial Handbk. 29. On the hosiery industry before the Second World War, see H. A. Silverman, 'Industrial Survey of Leics.' (Nuffield Coll. Social attempts to cover the feet. Bare feet were of course not unknown. Even in I 831 Leicester was not really a shoemaking town, although a higher proportion of workers engaged in making shoes per thousand of the population than in many other towns is noticeable. In I 83 I Leicester had 425 boot- and shoemakers, a proportion of $2 \mathrm{I}$ per thousand of the population. The corresponding figures for Northampton, by then an established centre of the boot and shoe industry, were 1,322 and 88 . Newcastle upon Tyne, a purely industrial town, had 14 boot- and shoemakers per thousand of its population. ${ }^{4}$

About this time, some of the town's shoemakers began to make, for the country trade, children's strap or ankle-band slippers and boots, which were known as 'cacks' and were made of brightly coloured morocco or black roan leather. ${ }^{5}$ In 1835 I I9 shoemakers were listed in the directory as against 58 in 1828,6 and this increase can probably be explained, at least in part, by the making of these new cheap shoes. There were apparently no wholesale shoe-

Reconstruction Survey, TS. lent by British Hosiery Manufacturers' Association).

${ }_{67}$ Working Party Rep. Hosiery, 100.

${ }_{68}$ Brit. Economy $1945-50$, ed. G. D. N. Worswick and P. Ady, 264

69 H. A. Silverman, Studies in Industrial Organisation, 9.

7o Working Party Rep. Hosiery, 22.

${ }^{7}$ Leic. Official Industrial Handbk. $3 \mathbf{1}$

I A T Patterson, Radical Leic. 88.

2 British United Shoe Machinery Co., Hist. Survey of Boot and Shoe Making (1932).

${ }^{3}$ Leic. 7 nl. 7 Feb. 1806

4 Census, 1831 .

5 Spencer, New Guide to Leic. (1888), 190.

${ }^{6}$ Pigot, Dir. Leics. (1828), 483 ; ibid. (1835), 217. 


\section{THE CITY OF LEICESTER}

makers in 1828 , but by 1835 there were at least two, and thereafter they increased steadily in number. The two men mentioned in 1835 were both pioneers of the boot industry in Leicester. One was Thomas Crick of Peacock Lane, known locally as the father of the industry, who in addition to running a warehouse was also engaged in bootmaking and in leather-currying and straining. $\mathrm{He}$ abandoned the latter activity when he became a large-scale manu-

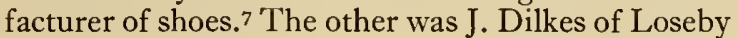
Lane, who was also a hosiery manufacturer and who later concentrated on children's shoes. ${ }^{8}$ Of the other early shoemakers, James Knott advertised himself in I 842 as a 'Fashionable Boot and Shoe Manufacturer', who supplied the trade as well as private customers and executed shipping orders. ${ }^{9} \mathrm{He}$ continued to appear with his son, Thomas, in the lists of boot and shoe manufacturers until I850. Other shoemakers mentioned as early as 1835 lived into the factory age and obtained a position in the industry: Samuel Cowling and the various members of the Staines family are particularly to be noted here. By I 84336 of the shoemakers had 'show shops' for the sale of ready-made boots. ${ }^{10}$ In 1846 , out of 200 shoemakers working in the town, only Thomas Crick is described as a wholesaler. ${ }^{11}$ In 1848 three firms called themselves wholesale manufacturers: W. Odames of Victoria Parade, J. Preston \& Co. who were also hosiery manufacturers, and Preston \& Charlesworth of Conduit Street. ${ }^{12}$ No record or accounts are known to have survived from the period before $185^{\circ}$ in Leicester from which any idea of the scale of operations of these early shoemakers could be obtained. The unit of production was in most cases presumably the family, with perhaps an apprentice or two. The making of shoes was performed entirely by the traditional hand-sewing method. Even the so-called manufacturers had neither machines nor power in their factories. The industry was probably organized in the same way as in Northampton, where the factories were little more than central shops, operating on a putting-out basis. ${ }^{13}$

In the mid-1850's in Leicester Thomas Crick was using rolling-machines for hardening leather and cutting-machines, both types being driven by steam. ${ }^{14}$ The date at which the leather-sewing machine, imported from America from about 1855,15 was first used in Leicester is not known. W. F. Thomas's machine for closing the boot upper was regularly advertised for sale in the Leicester newspapers in the years immediately before $1860 .{ }^{16}$ In Leicester the impetus for development came from the introduction in 1853 by Thomas and Throne Crick of the system of riveting the sole to the upper by machine, 'a very important step towards factory production'.17 This process, though known and used early in the

7 For Crick see Patterson, Radical Leic. 388; White, Dir. Leics. (1846), 133. The firm of T. Crick \& Co. has only recently been amalgamated with another company.

8 White, Dir. Leics. $(1846)$, I 43.

9 T. Cook, Guide to Leic. (1843), 143.

Io Ibid. I00-I.

I White, Dir. Leics. (1 846), $172-4$.

12 Post Office Dir. [Leics.] (1848), $2564-5$.

13 V.C.H. Northants, ii. 236.

14 J. A. Schumpeter, Business Cycles, i. 391 .

is J. A. Clapham, Econ. Hist. of Modern Britain, ii. 94;

T. Wright, Romance of the Shoe, $224 \mathrm{n}$.

16 Clapham, op. cit. ii. 94.

17 Ibid.

18 Ibid. 93-94.
I th century, had apparently been forgotten after the Napoleonic wars. ${ }^{18}$ Crick, probably inspired by the Northampton practice ${ }^{19}$ of using wooden pegs to fasten the sole, attached an iron plate to the sole of the wooden last, which helped to force iron rivets, instead of wooden pegs, through the sole. ${ }^{20}$ This allowed an increased and cheaper rate of production. It is related that shoes made in this way were not at first acceptable to the usual retailers, and that Crick had to dispose of his first products through a chimney sweep who kept a weekly market stall in a neighbouring town. ${ }^{21}$

Even more important, perhaps, than Crick's riveting process, was the Blake sole-sewing machine, invented in 1858.22 This machine sewed the inner sole, already attached to the upper, to the outer sole. It was known in England before the American Civil War, and British machine-makers, mainly in Leicester, sometimes improved upon it. ${ }^{23}$ The Blake sewer was not sold, but leased to the manufacturer, a distinctive feature of the industry which will be mentioned again. It is said that the machine was first introduced into Leicester by Stead \& Simpson about I 858. ${ }^{24}$ The footwear industry was also stimulated in these early days by the development of elastic web as a method of fastening boots and by the consequent popularity of the elastic-sided boot. ${ }^{25}$

These technological developments were unfavourably regarded by labour in the traditional centres of the industry, and strikes at Northampton and Stafford are said to have been one of the causes of the industry's growth at Leicester. These reasons are still open to discussion. No doubt the existence of a labour supply experienced in a tradition of homeworking methods attracted employers from outside the town. Stead \& Simpson extended their activities from Leeds, where they were finding difficulties in obtaining workers, first to Daventry and then to Leicester about $1853 .{ }^{26}$ The traditional explanations for the location of the industry in the Midlands are that the large tracts of grazing land provided the raw material of the industry and the remains of former forests yielded suitable bark for tanning. By I $85^{\circ}$ the importance of the latter factor for Leicester is doubtful, although the grazing country in the county no doubt supported some of the cattle for the industry. Only thirteen people were, however, employed in the leather trade in Leicester in I 861.27

Between I $85 \mathrm{I}$ and $186 \mathrm{I}$ the number of people employed in shoemaking in Great Britain fell from 274,000 to 250,000 , while in Leicester the number rose from $\mathrm{I}, 393$ to $2,74 \mathrm{I}$. In $\mathrm{I} 86 \mathrm{I} 40$ per thousand of the population of Leicester were employed in the industry, compared with I 52 per thousand in Northampton. ${ }^{28}$ It is possible that the 186 I figures

19 V.C.H. Northants, ii. 326.

20 Ibid. 328

2I Spencer, New Guide to Leic. (1888), 191 ; cf. E. Crew, Homecoming: The Story of Leic. (1910), 101, in which it is stated that D. Garner claimed to have invented this type of riveted shoe two years before Crick obtained his patent. The Crick patent is hung in the office of the Leic. Boot \& Shoe Manufacturers' Association.

22 Schumpeter, Business Cycles, i. 391.

23 Clapham, Econ. Hist. ii. 95.

24 Stead है Simpson Centenary, I834-1934 (priv. print., no pagination).

25 See below, p. 326

26 Stead $\xi^{\circ}$ Simpson Centenary.

${ }_{27}$ Census, 1851, 1861. 28 Census, 1851,186 I. 


\section{A HISTORY OF LEICESTERSHIRE}

underestimate the number of women and children engaged in the trade. By 1863 one leading manufacturer, after remarking that 'the wholesale boot and shoe trade in Leicester may be said to have come into existence within the last five years: up to that date there were only two or three wholesale manufacturers in the town', estimated there were then between two and three thousand women employed, chiefly in the large factories. 'I arrive at that number', he continued, 'by reckoning the number of sewing machines, which is tolerably well known, at over 800 , and taking a proportion of two fitters to each machinist, with a margin for those who are otherwise employed.' 29 The introduction of the sewing machine is no doubt reflected in the increase in the number of women under the age of twenty reported to be employed in the censuses of $185 \mathrm{I}$ and I 86 I. ${ }^{30}$ The number of apprentices, journeymen, and others in the employment of the 405 boot- and shoemakers listed in the directory of $186_{3},{ }^{31}$ or of the repairers - snobs, as they were and still are known in the trade-are not separately classified in either the local directories or the census returns.

That the industry was growing rapidly, contemporaries were aware. It was to this that they attributed much of the overcrowding and bad conditions in factory, workshop, and garret. ${ }^{32}$ In 1863 it was reported that there was a 'scarcity ... of operatives in the shoe manufactories of Leicester (which is now becoming a very important branch of business)'. ${ }^{3}$ Local directories, which by this time are fairly reliable, show the increase in the number of wholesale shoe manufacturers. There were 23 manufacturers in $\mathrm{I} 86 \mathrm{I}, 80$ in $1864, \mathrm{I} I 7$ in 1870 , and 193 in $1877 .{ }^{34}$ These figures do not, however, include some of the very smallest businesses nor the repairers.

It is not possible to assess the increase in output during these years. These figures are hidden in the records of family businesses or public companies, many of which have gone out of business or have been absorbed. Even where a firm has continued in business, the location of its records is frequently unknown. The available facts are scattered and vague. For example, during one week in $1863,5,496$ pairs of women's military heel boots were made by Crick, the largest employer in the town. 35 This tells us nothing of value. In 1878 it was observed that the growth in the number of firms 'does not represent the real ratio of the increase of trade ... in as much as twenty of the largest manufacturers of the day turn out more than the whole of the boot and shoe manufacturers of $1864^{\prime} \cdot{ }^{36}$ By i 87 I the total number of workers employed in the industry at Leicester was about II,ooo, exceeding the number at Northampton by about $\mathrm{I}, 000$. The Leicester figure remained higher than that at Northampton until at least I93I. In I87 I 63 per thousand of Leicester's population were employed in the industry, compared with I 30 at Northampton. ${ }^{37}$

29 2nd Rep. Royal Com. on Employment of Children [Cd. 34I 4 ], p. I65, H.C. (1864), v.

3058 in $1851 ; 352$ in 1861

3 White, Dir. Leics. (1 863), 282-5.

32 2nd Rep. Children's Employment Com. 165.

33 Factory Inspectors' Reports, April I.863 [3206], p. 39, H.C. (1863), xviii

34 E. S. Drake, Dir. Leics. (1 86I); Wright's Midland Dir. (1864); J. G. Harrod \& Co., Dir. Leics. and Rut. (1870); White, Dir. Leics. (1877); Wright, Dir. Leic. (1878).
The origins of the early factory masters in Leicester are varied. Some were boot- and shoemakers with long experience as craftsmen, safely reinvesting their savings in a few machines, housed in a small building or garret. Such a man was Isaac Townsend. Connected with the trade from the period of the cack, as late as $\mathbf{1} 89 \mathrm{I}$ he was still employing hand labour, except for workers on treadle-type cutting and sewing machines. He confined himself to the manufacture of women's and children's shoes for the home market. ${ }^{38}$ Others were members of one family or men who went into the business together with or without the help of capital. Samuel Lennard, who gained his experience as a boy with Walker \& Kempson, left to set up in partnership with his brothers. Later this partnership was dissolved but Lennard carried on in the business alone, eventually becoming the President of the National Federation of Boot and Shoe Manufacturers. In I 900 he became Mayor of Leicester. ${ }^{39}$ Richard Hallam, who left school at the age of 12 and entered the shoe trade as a clicker, went into partnership with T. B. Howard when he was 24.40 Thomas Crick's first manager, $\mathrm{J}$. Thornton, set up on his own in 1866 , and by $189 \mathrm{I}$ had a modest establishment of 150 employees, and was 'favoured by well known wholesalers who draw upon him'.4I Others began in different trades or different branches of the leather trade. G. Green is an example of the former: his firm is still among the leading manufacturers. Born in Market Harborough in 1816 , he was apprenticed to a printer in Leicester, but left to enter the corn business in his home town. In 1859 he ventured as a boot and shoe manufacturer in Leicester, and became mayor in $1894 .{ }^{42} \mathrm{~T}$. Hilton, on the other hand, served his apprenticeship in leather-dressing and in 1869 commenced business in that line. Seven years later he began making boots and shoes and by I 89 I he was 'one of the most enterprising and most prosperous men in the trade' and 'the only large manufacturer in Leicester who retails the whole of his productions'. He owned at that date 40 retail shops throughout the country, drawing his supplies from producers in Northampton, Kettering, and Bristol. 43

One firm of leading manufacturers, Stead \& Simpson Ltd., began as curriers and leather dealers in Leeds in I834. After a time they took up shoe manufacturing, 'disposing of their productions wholesale to the shopkeepers and dealers who were trading with them at that time in leather and bootmakers' requisites'. 44 About 1844 they set up a branch factory in Daventry and began work in Leicester, as curriers, in 1853 . They were foremost in introducing the Blake sewer into Leicester. By I 863 both branches were flourishing and to deal with the management and organization of the firm each of the partners brought in a nephew-H. Simpson Gee to control the branches and R. Fawcett to act as salesman and traveller. In 1863 they employed 120 women at Leicester.

35 2nd Rep. Children's Employment Com. 125.

36 Wright, Dir. Leic. (1878), I I.

37 Census, $187 \mathrm{I}$.

38 Leic. Illustrated in $I 89 I, 59$

39 Leic. Daily Post, I6 Sept. I901; H. Hartopp, $R$. Majors of Leic. $228-9$.

$4 \mathrm{I}$ Leic. Illustrated in $1891,58-59$.

42 R. Mayors, 224.

43 Leic. Illustrated in $1891,53$.

44 Stead E Simpson Centenary. 


\section{THE CITY OF LEICESTER}

Other firms were already established in the hosiery industry when the boot and shoe business began to be a promising sideline. J. Biggs \& Son, J. Langham \& Sons, and Pool \& Lorimer tried boot manufacturing as a subsidiary to their main concerns. ${ }^{45}$ Others in time turned over to it completely: J. Preston \& Sons and Walker \& Kempson are typical of this movement. W. Kempson came to Leicester as a boy and entered the hosiery business belonging to his uncle, T. Stokes. Later he went into partnership with W. H. Walker and in 1859 they entered into an agreement with W. Dicks, who had secured a patent, and opened a factory together. In 1863 they employed about 300 female workers at two factories. 46

The leading manufacturer of this first generation of factory masters was undoubtedly Thomas Crick. Beginning as a master craftsman he achieved a place of national importance in the industry. He had been engaged in the wholesale boot and shoe trade from its earliest days in the town: 'Mr. Crick was the first to introduce the wholesale boot and shoe manufacture into Leicester; that was 30 years ago', stated a witness in 1863 : 'there are now many others, but none employs so many on their own premises as he does.' 47 Crick's total number of employees at this time was about 420 women, mostly between the ages of 15 and 23 , and about 300 men and boys. ${ }^{4}$ Crick's factory was the only one in the country at this time in which steam power had been applied to the sewing machines. 'At Mr. Crick's factory in Leicester steam power is used, not only for rolling leather and cutting or stamping out the soles, as it is the case elsewhere, but also for pressing the nails into the heels, for pricking the holes in the soles, and for cutting the metal spriggs or nails used in rivetting.' Crick was soon to be the first man with I, ooo employees. Adult male labour was used mainly on the heavier machines, while women of various ages operated the sewing machines, including a few girls as young as 12 years. ${ }^{49}$

Throughout the second half of the igth century the organization of the industry was such that those with only small amounts of capital-'men of straw', as a witness to a later commission called themcould easily set up as manufacturers. Little machinery needed to be bought outright, other than sewing machines; sometimes not even these need be bought, but could be hired from the manufacturer to whom the workshop manager supplied his products. The expanding economy was able to absorb all those who wished to venture, even if some did fall out in times of depression. As a result the industry grew up in Leicester with many family firms, very few of which became public or private companies before the First World War. No real family fortunes were made in the industry, but some modest, comfortable sums were accumulated.

Until well after $\mathrm{r} 880^{\circ}$ 'factory boot making was far from being a complete power industry'. There was, in $\mathrm{r} 87 \mathrm{r}$, a total of only 335 horse-power in $\mathrm{r} 39$ factories in this country. ${ }^{\circ}$ "Though the gas engine was coming into use during the next decade, steam

45 Drake, Dir. Leics. (I 861), 74-75; C. W. Webb, Corah's of Leic. 40.

${ }_{46}^{46}$. Mayors, 212 ; Leic. Daily Post, 12 Oct. 1893. The firm failed after the slump: Kelly's Dir. Leics. and Rut. (1932), 649; ibid. (1936), 81 1.

47 2nd Rep. Children's Employment Com. I65.

48 Ibid.

49 3rd Rep. Royal Com. on Employment of Children [Cd. 341 $4^{-\mathrm{i}}$ ], p. I25, H.C. (1864), v. remained the obvious power: few machines at this stage could be made really automatic: and new light ones for the various sub-processes were constantly being experimented with. So only the heaviest and most permanent machines, such as those for cutting butts or doing very stiff sewing, were, as yet, regularly power driven. The rest, as shewn in contemporary designs, all have handles or treadles.'5I

In such factories, clicking, the most skilled operation, was carried out almost entirely by men, together with the cutting of linings, which was the task of juniors in training. Clicking demands skill and a knowledge of the differences in thickness, shade, markings, and quality of leather. Women and girls were employed in large numbers, both in and outside the factory in the next process, the closing of the uppers by sewing machines. Some witnesses in the I 860's believed that such machine work was being done more in the homes of the workers and the garrets of the small masters than in factories. ${ }^{52}$ But leading manufacturers in the town did employ many women in their factories, some of whom in one factory were girls from a neighbouring village, learning to use the machines. When proficient they were able to do their work at home. ${ }^{53}$ This work, as well as the making and finishing which was given out to the country districts, was known as 'basket work'. 54 Trade union agitation against it became strong in the late I880's and early I 890 's, ${ }^{55}$ but the system was advantageous to the manufacturers in that it enabled them to obtain the necessary labour more cheaply because of its lack of organization.

The machines used by the women in the town and in the country villages were hired from the employer, just as stocking frames were hired. In 1864 the rents were said to vary from is. to $2 s$. $6 d$. a week, according to the value of the machine. ${ }^{56}$ Thomas Crick was not in favour of this system, but a man called Stanyon, who at one time had as many as 120 machinists on his premises, preferred to give his work out. He retained only about 20 women on the premises in case of any sudden order or emergency. He explained his position by saying, 'I would not go back to the old system, for I get a better class of girls, whose parents would not like them to work in the factory.' His machines were let out at a rate of Is. a week, sometimes in two and threes. 'The cost of a machine', he continued, 'is $f_{\mathrm{I}} \mathrm{I}$ or $f_{\mathrm{I}} \mathbf{2}$, and reckoning that they get knocked to pieces in 2 or 3 years, it answers my purpose.' Occasionally he allowed the machinist to buy the machine at the end of a year, with an allowance made for rent already paid. Walker \& Kempson and Stead \& Simpson also hired out machines. 57

Whether the uppers were closed in factories or homes, they were collected together at the factory warehouse to be given out again with an appropriate number of soles and a certain amount of rivets and thread. Even until after 1890 the bulk of the actual 'making' was done outside the factory in small workshops. ${ }^{8}$ Where the soles were attached to the

so Census, $187 \mathrm{I}$.

5I Clapham, Econ. Hist. ii. 95.

52 3rd Rep. Children's Employment Com. 163.

53 Ibid. 165.

54 For the industry in the administrative county of Leics, see V.C.H. Leics, iii. 23-25.

55 S. and B. Webb, Industrial Democracy (I9I I), 78.

56 2nd Rep. Children's Employment Com. 167.

57 Ibid. 58 Clapham, Econ. Hist. ii. I 95-6. 


\section{A HISTORY OF LEICESTERSHIRE}

uppers by wax-thread sewing, a class of men grew up, who were known as 'sewers to the trade'. The Blake machines upon which they worked were hired out upon a royalty basis, on the number of shoes made. ${ }^{59}$ The royalty system was, it was said, established for three reasons; first, because of the fear that if too many of the first type of machine were installed, outlets for improved versions would be limited; secondly, as an incentive to energetic men of small capital; and thirdly, in the belief that a sure, steady, if smaller revenue was better than an uncertain but immediately larger amount. There is no doubt that this policy of leasing machinery did make entry into the industry easier.

The other method of 'making' was that of riveting, which was cheaper, but produced an inferior shoe. ${ }^{60}$ It catered for a more extensive, though more fluctuating demand than that for sewn shoes, and it was this system which to a very great extent supplanted in Leicester the use of the awl and waxed thread of the craftsman shoemaker. Usually ' 6 or 8 men will hire a room together and have 3 or 4 "sweaters" lads helping them by scraping off bottoms and rasping the heads off'. ${ }^{61}$ An assistant employment commissioner visited several of these finishers' and makers' workshops in Leicester in 1862: 'In one of the former, I 3 men were working, and in another, IO; in each case there were children of 1 I or 12 years old.' In a third, he found 'as many as 20 were working in two rooms, 7 or 8 being boys of about 12 '. One room was 'tolerably ventilated and not very dirty', but 'the other three were in all respects detestable; the ceiling and walls black with gas soot; the faces of the workpeople, men and boys alike, colourless and grimy: the children literally in rags of the dirtiest description, the heat of the atmosphere almost unbearable'. ${ }^{62}$ The homes of the men who let out benches to different journeymen were described as 'miserable hovels' and their workrooms as 'dreadful places, underground kitchens', though the generic term, garret masters, was applied to them all. When several riveters worked together, the room was fitted with long narrow tables, like shop-counters, divided up into compartments called benches, each large enough to allow a man and a boy to stand at it side by side. To each bench were fitted two iron rods upon which movable lasts were placed. Iron lasts replaced the iron-plated variety in 1865 and an upright last with a universal joint so that the boot could be turned in any direction was also introduced. A man who lived at this time maintained that because the iron lasts were too heavy to be carried to and from the workers' homes, another impetus was given to the factory and workshop system. When the laster had lasted up, or fitted the material over one of his lasts, lightly tacking the sole to the upper, he then passed it on to his boy, who drove the nails into the holes which he made by a light pricking machine, which was usually operated by hand or foot though steam was used in a few factories. One member of the handsewn school described this work as being morc like carpentering than bootmaking. ${ }^{63} \mathrm{~A}$ man working by

59 Cf. B. E. Hazard, Organisation of Boot and Shoe Industry in Massachussetts before 1875,121 sqq.

60 An advertisement in the Stafford Mercury, 4 April I 863 , stated that riveted shoes were 20 per cent. lower in price.

${ }^{61}$ and Rep. Children's Employment Com. $\times 67$ 62 Ibid. himself would last up and rivet a dozen pairs of shoes in a day of 10 hours and $I \frac{1}{2}$ dozen if he had a boy to nail for him, whereas the Blake sewer worked by a treadle could turn out 200 pairs in a ro-hour day and 300 if it was worked by steam. ${ }^{64}$ In America it is said to have reduced the cost of sewing on soles from 75 to 3 cents a pair, that is by about 96 per cent. ${ }^{65}$

On completion of the 'making' process, the boots or shoes were then finished. The conditions in which this process was carried out were known throughout the trade to be exceptionally bad and unhealthy. 'They are packed as close as they can sit, on each side of a low table, on which are several broad gas flames, always burning to heat their burnishing and other irons', and the finishers were described in 1863 as amongst the 'most degraded of the working population'. ${ }^{66}$

Thus at this primary stage in the division of labour, specialized workmen, each with their distinctive occupational names, were appearing, and their organization was to become even more complex in the modern factory system. As more and more operations came to be performed by machines there was no longer any need for the apprentice who learnt to make a shoe from beginning to end. Apprenticeship began to decline from the first expansion of the industry, although in the years after I860 some forms of quasi-apprenticeship reappeared. Machinists could be apprenticed at the age of I 4 or I 5 years for 2 or 3 years, receiving between $5 s$. and $9 s$. weekly. Others paid a small sum to an adult for the use of a machine. Occasionally some were bound to foremen but in general the apprentices either learnt from the machinist or worked without payment in a factory for a few months. ${ }^{67}$ The sewing machines were in general worked by girls, while bootmaking work was more suitable for boys, for whom there was seldom any formal apprenticeship, except in the bespoke trade, usually only to small masters. ${ }^{68}$ In the wholesale factories, boys were taken on under a form of apprenticeship to learn clicking. They earned between Ios. and 20s. a week but lived in their own homes. Journeymen in the sewn trade sometimes took learners under agreement for 2 or 3 years, "but for rivetting, so little teaching is required, that they are said to pick their boys out of the street'. Finishers also took boys under agreement for a short period. The riveters' boys earned between $2 s .6 \dot{d}$. and $5 s$, a week at 'chamber work', but in the factories sums of $8 s$. or $9 s$. were not unknown and conditions of work for these young clickers were fairly good. 69

"The introduction of the sewing machine seems to have considerably affected the employment of children in the boot trade by enabling two or three machinists of 14 or 16 years old, with the aid of one little girl of 9 or Io years, to do as much "stabbing" as 30 children would have done under the old system.'70 Children were often presented when ridiculously young to employers as candidates for employment. 'I have asked some if they think we keep an infant school', said one witness. 'Many', he continued, 'use

\footnotetext{
63 3rd Rep. Children's Employment Com. 125.

64 Ibid. 130. 65 Schumpeter, Business Cycles, i. $39 x$.

6o 2 nd Rep. Children's Employment Com. 167.

67 Ibid., pp. Ixviii. 85

68 3rd Rep. Children's Employment Com. 123.

69 Ibid. passim.

70 2nd Rep. Children's Employment Com. 84.
} 


\section{THE CITY OF LEICESTER}

their children just as farmers use their cattle, to get what they can out of them, and have no regard for their health and education.'7 I A schoolmaster in the town stated that 'several of these boys had come from distant places, being drawn hither by the briskness of the trade'. ${ }^{2}$ Most of the younger children in the trade were employed in small jobs of neatening and finishing, such as tying off the ends of thread left by the machinists, while older girls sometimes worked as fitters. Apprenticeship was almost unknown by I 892 and neither employers nor trade unions ever attempted to revive it. ${ }^{73}$

A distinctive feature of the modern boot and shoe industry is its distribution system. In I93 I in Great Britain there were as many as $\mathrm{I}_{3}, 855$ distributing units as compared with 1,054 manufacturing units. ${ }^{74}$ This vast network has developed from the crude marketing methods of the mid-Igth century, when the manufacturers were the chief distributing agents. As the industry expanded, specialized footwear factors appeared. George Oliver is typical of this type in Leicester. ${ }^{75}$ Apprenticed to a boot- and shoemaker in Barrow upon Soar, he wandered between various boot centres until in $\mathbf{I} 860$ he opened a retail shop in Willenhall (Staffs.) and in I886, with his brother, Charles, another in Neath (Staffs.). Other shops followed and in 1869 he set up a factory in Wolverhampton to supply his shops, but decided to concentrate on distribution after $\mathrm{i} 875$. The factory was closed and Oliver set up a large warehouse in Leicester; at the time he had 30 branches, which had increased to over Ioo by $\mathbf{1} 889$, when he advertised himself as the largest boot retailer in the world.

J. Wedgewood Heath, Mayor of Leicester in I92 I, and H. P. Tyler are others who became important factors in the town. The former came to Leicester at the age of 20 after being apprenticed to a draper. Five years after finding employment in Leicester he opened a business on his own account. ${ }^{76}$ Tyler's firm was founded about I 861 ; by I 89 I he had some Ioo branches. 77 Stead \& Simpson became a limited company in $1899^{78}$ and with Freeman, Hardy \& Willis inaugurated a new policy, of extending the retail side of their business by opening shops direct to the public, an important step in the history of the industry. By I 934 Stead \& Simpson had 186 retail shops in the British Isles. This method of marketing, which tended to eliminate the middleman although the factor still remained important, was soon copied by other firms in Leicester and Northampton.

Boots and shoes varied little in style, colour, and design before I90o. The larger manufacturers, competing in the same wholesale market, tended to eliminate the less efficient firms, but this process was slow because there was an ever-increasing demand and in many cases independent retailers favoured certain manufacturers. In order to overcome the limitations which were placed upon size and expansion by these features of the industry, many of the

71 Ibid. 166.

72 Ibid. I67. Most of the immigrants were of course from neighbouring counties.

${ }^{73}$ 2nd Rep. Children's Employment Com. 0 o.

${ }^{74}$ H. C. Hillman, 'Size of Firms in the Boot and Shoe Industry', Econ. Fournal, xlix. 285.

75 Olivers $(1860-1950), \mathrm{I}-10$.

76 R. Mavors, 241.

77 Leic. Illustrated in $1891,60$.

78 Stead $\Theta^{\circ}$ Simpson Centenary.

79 Econ. Fournal, xlix. 290. wealthier manufacturers integrated retail shops of their own, and at the same time some of the distributive concerns began to make their own shoes. This increase in the number of retailers conditioned and promoted variety and fashion manufacture in two ways. First, the extensive advertising by the multiple retailer of a wider choice of shoes endangered the independent retailers, who in their efforts to save themselves were forced to order styles of shoes different from those offered for sale by the multiple retailer. Secondly, as the multiple retailers gained an increasing proportion of the distribution, they in their turn were able to obtain a wider choice of shoes. Thus the extent to which fashion manufacture rules the trade "must be explained primarily with reference to the attempt of both producers and retailers to establish for themselves a semi-sheltered market, thus leading the public rather than being led by it'. ${ }^{79}$

This movement was especially applicable to Leicester with its specialization in women's and children's shoes. 'The number of manufacturers and employees continued to rise. There were 198 shoe manufacturers in 1880,210 in 1890,233 in 1896 , and 225 in $1900 .{ }^{80}$ The increase in the number of employees in the industry was more marked. It rose from about 13,000 in I88 1 to about 24,000 in $189 I$. The ratio per thousand of the population in the same period rose from Io6 to 138 . In Northampton the approximate numbers were 10,500 in $I 88 \mathrm{I}$ and I 3,000 in 1891 , the ratio per thousand of the population being 188 and $165 .{ }^{81}$ In 1901 a distinction was made in the census figures. The number of male shoemakers in Leicester, over ten years of age, was I7,770. It will be observed that the expansion had markedly slowed down in this decade and a similar position was apparent in Northampton, where the number of men was i I , I67.82

Meanwhile, technical innovations were continually introduced. Leicester shoe-machinery firms were designing their own models and improving on the American machines which flowed into the country from 1870 onwards. Hitherto, machinery had only helped in 'making' in the narrowest sense of the word. ${ }^{83}$ Now came the machines which were to accelerate production and require widespread division of labour. In 1872 the first Goodyear weltsewing machines were introduced into England. ${ }^{84}$ Invented in 1862 , they were said to be 54 times as fast as stitching by awl and thread. 85 With this machine and the Goodyear chain stitcher it was claimed that a boot similar in quality to a handsewn boot could be produced, and boots produced on these machines eventually superseded cheap hand-sewn and welted work. By 1899 , the improved version, first introduced into Leicester by Royce Gascoigne \& Co., could do in I 8 seconds what had formerly been done in an hour. ${ }^{86}$ More and more processes were afterwards performed by machines, ${ }^{87}$

80 Wright, Dir. Leic. (1880); Wright, Dir. Leic. (1 890); Wright, Dir. Leics. and Rut. (1896); ibid. (1900).

$8 \mathrm{r}$ Census, $\mathrm{r} 88 \mathrm{r}$, $189 \mathrm{r}$.

82 Ibid, roor.

83 Clapham, Econ. Hist. ii. 95.

$8+$ V.C.H. Northants. ii. 328.

85 Schumpeter, Business Cycles, i. 39 r.

86 T. Wright, Romance of the Shoe, 248

87 V.C.H. Northants. ii. 328 ; Econ. Fournal, xlix. 279 n.; Schumpeter, Business Cycles, i. 391 . 


\section{A HISTORY OF LEICESTERSHIRE}

aided by a system of standard sizes and half-sizes, until in the 2oth century some processes became entirely automatic.

Before the reaction of labour to the introduction of machinery and its effect upon wages is discussed, it will be as well to examine its influence upon the size of the manufacturing unit, and the way in which machinery was supplied. Before Igoo, with the increasing use of machinery, competition between manufacturers of footwear machinery came to be based not upon cost but upon the varying output capacity of each machine. This affected the size of the manufacturing unit, as the machine manufacturers made no attempt to coordinate the technical functions of their machines and the factory had to have a large number of machines, each with a specialized function. 88

The tense competition between the machine firms resulted in the formation of the British United Shoe Machinery Co. Ltd. (B.U.S.M.C.), in I899. This was an amalgamation of the Leicester firm of Pearson \& Bennion, the leading firm in the town, with the British interests of various American shoe machinery companies in alliance with the United Shoe Machinery Co. of America, ${ }^{89}$ and although half English, all the voting power of the new company lay in America. 90 The B.U.S.M.C. system was not to sell machines but to lease them, and today, apart from sewing machines, which are usually purchased, only a very small proportion of the machinery in a boot factory is owned by the firm. For some time after the formation of the B.U.S.M.C. there were only two free firms of any importance, the Gimson Shoe Machinery Co. and the Standard Engineering Co., both of Leicester. After fruitless and costly attempts to remain outside the combine, Gimson's joined the B.U.S.M.C. in $1931,{ }^{91}$ leaving the Standard Engineering Co. virtually alone in the field of independent production. ${ }^{92}$

The B.U.S.M.C. secured the patents of a small number of important machines, which were only leased on condition that others, made by the combine but for which it had no patent, were used as well. This system was known as a tied leasing agreement and by it the B.U.S.M.C. forced other machine firms either to close down or seek absorption into the company, the predominance of which grew steadily. In I9Io about 20 per cent. of boot machines were acquired by the manufacturers from firms other than the B.U.S.M.C., but by 1936 it controlled more than 90 per cent. of the machines used. ${ }^{93}$ Despite this monopoly the Standard Engineering Co. has increased its sales.

The B.U.S.M.C. has, however, decreased the size of the manufacturing unit by producing machines with well-balanced output capacities in a team smaller than was formerly needed. The cost of machinery leased from the B.U.S.M.C. is exactly the same for small firms as it is for large, as the payments are assessed at a fixed sum per I, ooo turns performed by the machine. Whether a factory con-

88 Econ. Fournal, xlix. $28 \mathrm{I}$.

89 Story of Leic. ed. Feilden, 69; and see V.C.H. Leics iii. 28

Clapham, Econ. Hist. iii. 183

9 I The Shoeman's Guide, viii and ix (1931-2).

92 H. A. Silverman, Studies in Industrial Organisation (1946), 218 .

94 Econ. Fournal, xlix. 282. sists of 40 or 400 machines the cost per pair of shoes is identical, and thus the larger firms have been prevented from achieving economies of scale by spreading their machine costs over a larger output. This has made for smaller plants, and it was estimated that the best size of plant for men's shoes needed $5^{0}-60$ workers (in this respect only) and 40-5o for women's shoes. At this scale of production direct labour costs amounted to $2^{-2} 5$ per cent., machine charges 2-3 per cent., other overhead costs $4-5$ per cent., and raw materials $50-60$ per cent. of the total costs of production. ${ }^{94}$

Since the hides from which leather is made are a by-product of livestock raising, the demand for which is conditioned by the demand for meat, and since the meat is worth ro-I5 times the hide, the supply and prices of hides are determined by factors other than leather consumption.95 Market imperfection in the selling of shoes has resulted in much dependence upon fashion production, especially in women's shoes which particularly concern Leicester. 'The effect of this fashion production, which is to keep firms small, is especially noticeable in Leicester. ${ }^{96}$ Another feature of the industry which accounts for the survival of small and medium-sized firms in the town is the lack of competition in the shoe-machinery industry, owing to the monopoly of the B.U.S.M.C. The leasing policy of the combine meant that new firms could enter the industry with only a modest capital outlay, and manufacturers endeavoured to shelter their markets by the development of individual and distinctive styles of shoes. 'The proprietors frequently manage in person and for their remuneration largely depend on profits; this system of payments by results, in conjunction with the active competition between firms, contributes to the efficiency of the industry.' 97

Conditions of work have been mentioned above. The good employers tended to draw labour away from the factories and workshops where conditions were less good, and improvements in factories and workshops were necessary if an employer was to keep his workmen. Witnesses to the various inquiries at the end of the igth century admitted that the introduction of machines and the factory system had improved the wages of operatives in full employment. 'I consider', said one, 'the factory system I, ooo to one preferable to the home system', 98 but so much bootmaking was done at home and by the piece in 1886 that trustworthy statistics of bootmakers' earnings could not be compiled, even for the great centres of the industry. ${ }^{99}$ For Leicester some figures are available. In 1863 in the Leicester factories, which all seem to have worked much the same hours, the machinists could make I2s.-14s. weekly and an average fitter Ios.-I2s., 'without overworking themselves'.1 The hours were from 8 a.m. to $8 \mathrm{p} . \mathrm{m}$. in the winter and $6 \mathrm{a} . \mathrm{m}$. to $6 \mathrm{p} . \mathrm{m}$. in the summer. At Crick's firm in the same year, earnings could reach as much as 20 . weekly and about 60 hours a week was the usual time worked. ${ }^{2}$ The

\footnotetext{
95 Ibid. 283.

96 Silverman, Studies in Ind. Organisation, 1 99-200.

97 Board of Trade, Working Party Rep., Boots and Shoes ( 1946), 3 .

98 3rd Rep. Children's Employment Com. 13 1.

99 Clapham, Econ. Hist. ii. 96.

1 and Rep. Children's Employment Com. I6 5.

2 Ibid. 167.
} 


\section{THE CITY OF LEICESTER}

nailers working on the factory premises were generally hired by the riveters, who paid them between $5 s$. and $9 s$. a week, and the riveters themselves might earn as much as 50 . a week, less deductions and payments to their assistants. ${ }^{3}$ In ${ }^{2} 885$ shoemakers working in homes were not thought to earn an average of more than 23s. a week. ${ }^{4}$ In 1878 the Leicester Board of Arbitration carried a resolution calling for a uniform statement of wages in the town. 5

At the time of the 1895 conflict, one employer in Leicester maintained that he had paid his clickers an average of $29 s$, a week during the past year, to which one of his workmen replied that none of them had drawn as much as $f_{\mathrm{I}}$ in any one week. ${ }^{6}$ The same workman stated that in the year there had been only 30 weeks of full employment and 22 of short-time and holidays. In a short-time week, the hours had ranged from 20 to 34 , instead of the usual 54 . Lasters and finishers were said to have averaged 3 Is. $8 d$. a week, with a recognized minimum of $28 s$. $^{7}$

Trade was difficult at this time. In October I 893 it was reported that nearly all the factories in the Leicester and Northampton districts were working halftime and that unemployment was higher for that time of year than ever before. ${ }^{8}$ The industry had reached the peak of its growth and was beginning to react to external fluctuations of economic activity. Earlier, in 1880 , it was stated with some truth that Leicester had suffered less than almost any other town from the general stagnation that affected English industry: "this applies especially to the boot and shoe trade . . .; while several smaller houses with insufficient capital and appliances have necessarily succumbed to the keen race of competition, those firms which have devoted their attention to the production of high class articles, and consequently paid an enhanced scale of wages, have received a larger share of orders, and this kept their workpeople in constant and profitable employment'. 9

In December I 893 it was estimated that from ro to 12 per cent. of the workers in the footwear industry were quite without work, while about 40 to $5^{\circ}$ per cent. had been working short hours. I0 'The corporations of both Leicester and Northampton organized relief schemes. There had been an improvement in Leicester in the early spring of 1893 but by August many were working half- or threequarter-time.

In the Leicester footwear factories there seems to be no evidence of trucking in the form of 'tommyshops', but outworkers had to take part of their payment in leather or 'grindery' (i.e. tacks, wax, and thread), or 'findings' (i.e. buckles, buttons, and laces); ${ }^{I I}$ these furnishings had to be purchased by the workmen from their employers in most English towns. A riveter probably spent five or six shillings a week on material, the cost of which was deducted from his wages. There was difficulty in purchasing this material as cheaply from the employer as elsewhere. One example of this occurred in I888, when

${ }^{3} 3$ rd Rep. Children's Employment Com. I 3 I.

4 Fifty Years, being the Hist. of the National Union of Boot and Shoe Operatives $(1874-1924), 20$.

5 Ibid. I 8.

6 Leic. Chron, and Leics. Mercury, I I Mar. 1895

7 Royal Com. on Labour [Cd. 7063], p. 470, H.C. ( $893 / 4)$, v.

8 Ministry of Labour Gazette, Oct. 1893.

9 Wright, Dir. Leic. (I 880), p. xiii. an employer charged Is. for a pound of brass rivets, which could be bought elsewhere for $6 d$. In I 892 the charge averaged about $9 d$. a pound for the same article. ${ }^{12}$

'These deductions, together with charges of about Is. a week which were made to finishers for gas, were supposed to secure economy in the use of rivets and fuel. Where the grindery was provided by the employer, the rivets were weighed out in quantities sufficient to complete the work in hand. If any were wasted the operative had to pay for them in order to buy others. Another reason advanced for the charges was that the shoemakers were 'largely a migratory people' who might abscond with the furnishings. One witness admitted that while this was to some extent true, the objection was not a serious one. The union objected to this system. One of its aims was to obtain room, light, and grindery free of charge. Leicester, through its Board of Arbitration, was the first centre in which all finishers were admitted to the factories, where these services were provided without cost to the operatives. Thus by 1892 it was stated that under 5 per cent. of the workers in Leicester were employed outdoors. ${ }^{13}$

The main reasons for the introduction of the factory system were the needs for uniformity of output, economy of time, labour, and materials, and for supervision. Other contributory causes were the development of heavy machinery, the use of power to run it, and trade-union agitation.

The Amalgamated Society of Cordwainers, formed in the 18 th century, was drastically reorganized in I862, and became the Amalgamated Society of Boot and Shoe Makers in $1874,{ }^{14}$ when the machinists split off to form the National Society of Boot and Shoe Riveters and Finishers, ${ }^{15}$ later the National Union of Boot and Shoe Operatives (N.U.B.S.O.). The introduction of machinery after $\mathrm{I} 85^{\circ}$ was at first resented by the men and there was a lot of thoughtless opposition. Though in some places hand shoemakers struck against it at first and probably suffered as a consequence, on the whole it did very little harm to them. The wages of these craftsmen went up, ${ }^{\text {I6 }}$ but the new methods were disliked, and the idea of the factory system was abhorrent to the hand workers. Monday had been the traditional 'shoemakers' holiday'.

'The policy of the cordwainers' union, no doubt conditioned by the experience of the handloom weavers and in Leicester by the framework-knitters, was not to attempt to compete with machine products. As easy processes passed into machine operations they abandoned them and concentrated upon maintaining the particular qualities of their own special article. The society refused to oppose the introduction of machinery and advised those of its members who could not get handwork at the established rates to accept factory work. It encouraged the new factory workers to organize themselves and thus avoid unfair competition from cheap labour, and as early as $186_{3}$ a resolution was passed 'that men

10 Min. of Labour Gazette, Dec. 1893.

II Wright, Romance of the Shoe, 225.

12 Royal Com. on Labour, Mins. of Evidence, Group $C$, vol. ii [C. 6795-vi], p. 20, H.C. (1892), xxxvi, Pt. II.

13 Ibid. 27.

14 Webb, Industrial Democracy, 417. For the rules of the N.U.B.S.O. see ibid. 147.

is V.C.H. Northants. ii. 329.

16 Clapham, Econ. Hist. ii. 459. 


\section{A HISTORY OF LEICESTERSHIRE}

employed in the riveting and finishing peg work, and those working in factories, be recognized and can belong to any section or form sections by themselves'. ${ }^{17}$ In a short time the society found itself composed of two classes, craftsmen and factory workers. As the numbers of the latter began to exceed those of the 'seat workers', as they were called, policy decisions became more difficult. By 1874 the old society had proved incapable of dealing with the employers' attacks on the local unions or of coping with changed industrial conditions. ${ }^{18}$ In that year the machine workers seceded to form their own union, the present N.U.B.S.O., encouraged to do so by the handcraft workers. Since then the two unions have remained on friendly terms, refusing to allow competition among themselves or to be played off one against the other.

Two months after its formation at Stafford N.U.B.S.O. had 35 branches with a total membership of 4,204 . The Leicester branch stood at I,397, the largest single branch, which it still was in $\mathbf{I} 955$. The headquarters of the union were transferred to Leicester in 1876 . Membership of the branch continued to grow. In IgO3 I I, 000 operatives were members of the union out of a total of 27,000 , and another branch had opened in the town especially for clickers and pressmen, with a membership of 2,463 . On the other hand, local membership of the cordwainers' society stood at 25 in $1903 .{ }^{19}$

The manufacturers of the town, constantly forced to deal individually with labour problems and disputes, decided in 187 I to create an effective organization to protect themselves and to enforce a better discipline in the industry. The Leicester Boot and Shoe Manufacturers' Association came into being, under the presidency of W. H. Walker. Among its aims were the protection of members from harmful practices by traders, and the issuing of trade reports. ${ }^{20}$

The policy of conciliation, which is a distinctive feature of the industry's history, was early established. ${ }^{21}$ This meant that there was some tradition of arbitration upon which to build a settlement in the dispute of $\mathbf{I} 895$. The union, in its first quarterly report, maintained that it was 'in the interests of the trade as well as the welfare of our union [that] we urge upon the officers and members, the need of cultivating a firm faith in the policy of referring disputes to boards of arbitration for mutual settlement, for we believe that arbitration means the safety of trade societies'. ${ }^{22}$ In 1878 the Leicester Arbitration Board was set up, to be followed quickly by similar boards in other centres. ${ }^{23}$ Formed of equal numbers of locally elected employers and unionists, the board had referred to it 'every question, or aspect of a question, affecting the relations of employers and workmen individually or collectively'. ${ }^{24}$ In the event of disagreement the matter was referred to an independent umpire, agreeable to both sides, and in the early days usually a leading manufacturer from an-

\footnotetext{
17 Webb, Industrial Democracy, 418.

8 G. D. H. Cole and others, Brit. Trade Unionism Today, 415 .

${ }_{19}$ 'Trade Union Congress, Official Souvenir (Leic. 1903), 23.

20 Inf. from Leic. Boot Manufacturers' Assoc.

2I Fifty Years, 13.

22 Webb, Industrial Democracy, I 85-7.

23 Story of Leic. ed. Feilden, 67.

24 E. Brunner, 'Origins of Industrial Peace: The Case
}

other town. The board's activities were thought to minimize disputes and strikes, but were not altogether effective. In 1883 a strike was averted only by the intervention of the Mayor of Leicester, Sir Thomas Wright, and this led to the establishment of the National Conference in 1892 , with Sir Thomas as the neutral chairman and the later Lord James of Hereford as independent umpire, to deal with national questions affecting the whole industry. The National Conference was constituted like the local arbitration boards and held its first meeting at Leicester in August $\mathbf{1} 892$, with representatives from the N.U.B.S.O. and the Federated Associations of Boot and Shoe Manufacturers of Great Britain. This federation had been formed in 1891 , with headquarters at Leicester, after the lead had been given by manufacturers in the town, with J. Griffin Ward of Stead \& Simpson as first president. The local manufacturers' associations could no longer feel at any disadvantage in fighting the union's claims. ${ }^{25}$

The disputes in the industry were not so much over the actual introduction of machinery as over the way in which that machinery was to be used. The only way in which the workers could protect themselves from being driven to produce more for the same payment was deliberately to restrict output on the new machines, and the union imposed fines of $2 s .6 d$. to $f_{\mathrm{I}}$ if a certain output was exceeded. ${ }^{27} \mathrm{The}$ employers' principal journal stated: 'The spirit of comradeship is carried to a ridiculous extent. . . . It seems to be a settled policy with the men, not to earn as much money as possible per week, but as much as possible per job, in other words to keep the cost of production running as high as possible. ${ }^{2} 28$ One of the more enlightened employers suggested that if the piecework system were adopted and only expert men employed on the machines, the result would be better work and lower costs for the employers and higher wages for the operatives. ${ }^{29}$

Among the grievances connected with the new machinery was the practice of 'basket work', the sending out of work to country villages, where labour was cheaper, or to another town. ${ }^{30}$ The union's policy was to insist that the agreed wages be paid to such outworkers, and that factories should be set up in the country districts, a policy designed to bring together the unorganized country workers and so strengthen the union's position. The union also objected to the substitution of labour by unskilled juniors for that of skilled adults, which led to the flooding of the labour market with boys. ${ }^{3}$ I It asked for a limitation of one boy to each five men employed. ${ }^{32}$

The manufacturers, on the other hand, were anxious to exploit the advantages of machine production because they found themselves being beaten by the technically superior American factories, whose products were successfully competing in established British markets. They also objected to the union's demand for a minimum wage on the grounds that

of the Brit. Boot and Shoe Industry', Oxford Econ. Papers, i. 254.

${ }_{25}$ Brunner, op. cit. 254

${ }^{2} 26$ Webb, Industrial Democracy, 397.

27 Brunner, op. cit. 25I.

28 Webb, op. cit. 398.

29 Ibid. 400.

30 Brunner, op. cit. $25 \mathrm{I}$

${ }^{31}$ Webb, op. cit. 483 .

32 Ibid. 484 . 
productivity would be lowered. The system of arbitration which should have settled these disputes broke down when trade became bad in the early I 890 's. Between $\mathrm{I} 89 \mathrm{I}$ and $\mathrm{r} 894$ seven local arbitration boards were dissolved. ${ }^{33}$ The men objected to their slowness, while the employers were also dissatisfied because of the time taken to ensure that they were not committed to some new principle. They had intended the boards to deal with questions of interpretation only, not to be a market in which new bargains might be struck. The question of increased wages could not be brought up every two months at these boards. The National Conference met five times between 1892 and 1894 to settle wage claims, and to consider the demands of other centres for indoor working by all employees: in $189 \mathrm{I}$ Leicester led the way in this, the employers agreeing by 137 to 3 to confirm this principle on the understanding that no manufacturer should be omitted from the agreed rules. ${ }^{35}$

By the early I89o's, then, the union was in a powerful position: at that time it was the fourth largest union in Britain. The manufacturers resented its growing power and especially what they considered to be its unwarrantable interference in the internal organization of their factories. ${ }^{36}$ Their attack began in November I 894 with their submission of seven proposals which the union had either to accept or reject within eleven days. This ultimatum, which came to be known as the 'Seven Commandments', included the proposals that wage-rates should not be changed at intervals of less than two years, that the introduction of piecework in lasting and finishing should be indefinitely delayed, that the internal management of the factories was the function of the employers alone, and that the union should impose no restriction on output. The union delayed its reply until the end of January r 895 , when it rejected the proposals as 'illegal, unjust, unworkable, and therefore impracticable', but suggested that the proposals should be subjected to arbitration. In the meantime the employers had withdrawn from the National Conference and they now refused the union's proposal. The union maintained that a strike was inevitable, and began preparations by levying I $s$. a week on its members. After big meetings had been held by the operatives, like the one at Leicester on 30 January 1895 which was attended by about 5,000 union members, the union put in notices to three firms in Northampton and six in Leicester demanding minimum wages of $28 \mathrm{~s}$. a week for clickers and $26 \mathrm{~s}$. for pressmen, increases of $2 s .6 \mathrm{~d}$. and $3 s$. per week respectively. ${ }^{37}$ In addition, the Leicester branch of the union put a motion to the local board, "that this board decides that all work cut in Leicester shall be made and finished in Leicester, and paid for in accordance with the prices and conditions at present prevailing in Leicester'. 'These requests were met by a general lockout which began on 6 March. ${ }^{38}$

The actual stoppage, then, came on side issues of

33 Brunner, op. cit. 255 .

34 Webb, op. cit. $187-8$.

35 Fifty Years, 25-27.

36 For the strike see Brunner, op. cit. 256 sqq.

37 The firms on which notices were served were Wilkes Bros. \& Johnson, J. J. Morris, Johnson \& Bailey, A. H. Simpson, Andrews, Belgrave Rubber Co.: Leic. Chron. and Leics. Mercury, 2 Mar. 1895. minor importance. 39 'The clickers and pressmen in the Midlands had only recently been drawn into the N.U.B.S.O. which, according to the spokesman of a rival union, the National Union of Bootclickers, whose members, I,650 in 1892 , belonged mainly to London and district, was doing nothing for them so that many were gradually leaving. ${ }^{40}$ Possibly the union wished to show that it could still do something for them: the clickers at any rate were craftsmen as yet little affected by machines. It perhaps also wished to ensure their solidarity with the older members in the event of a strike. The lockout lasted three weeks. For the firms outside the association trade remained brisk and work plentiful, but three-quarters of the shoe factories in the Leicester district were closed both to union and non-union labour. A local estimate of the numbers out of work at the peak of the dispute was $22,000 .{ }^{4 I}$ 'The affair cost the union $f 5^{6}, 3^{8} 3$ in strike pay, of which $£_{\mathrm{I}} \mathrm{6}, 979$, or some 30 per cent. of the total, was laid out in Leicester. ${ }^{42}$ A sum of $f_{\mathrm{I}} \mathrm{I}, 049$ was subscribed by various friends and by other unions. ${ }^{43}$

A settlement was finally reached which has regulated labour conditions in the industry ever since. 'The 'Terms of Settlement' laid down that piecework in the industry was undesirable, that the local boards of arbitration were to be reconstituted with revised regulations, that certain subjects were to be outside the jurisdiction of these boards, and that a financial guarantee that the agreement would be honoured was to be arranged. 44

No provision was made for the National Conference, but by joint consent it was re-established and took place every two years, its functions clearly being to deal with questions of principle which could only be raised there. The local boards were confined to matters of interpretation and purely local affairs. The immediate solution of local grievances, before they can spread or accumulate, has contributed much to the success of the boards and to the efficient honouring of the Terms of Settlement, which, in spite of their vagueness, marked an important step forward for the industry, largely because of the sensible way in which they have been interpreted.

Meanwhile, at the end of the I establishment of co-operative factories was an important local development. The first known attempt to set up a co-operative factory was the floatation of the National Co-operative Boot and Shoe Manufacturing Co., Ltd. in 1876 , in which union members were invited to take shares. ${ }^{45}$ 'The directors included four Leicester riveters and the secretary of the N.U.B.S.O. Nothing seems to be known of what became of this co-operative shoe factory. In September I 886 about 60 working men, mostly connected with the union, attempted to form themselves into a Productive Society. Business began in July i 887 with a share capital of $£, 220, f_{1}$ oo of which was subscribed by the local branch of the union. The first 'factory' consisted of three small rooms in which $2 \mathrm{I}$ workers ( 4 on uppers, $\mathrm{I} 7$ on bottoming)

38 Brunner, op. cit. 257

39 Ibid. 256.

40 Royal Com. on Labour, Mins. of Evidence, Group C, vol. ii, p. 24.

$4 \mathrm{I}$ Leic. Chron. and Leics. Mercury, I I Mar. I 895.

42 Fifty Years, 44. 43 Ibid. $43-44$

44 The 'Terms of Settlement' are printed ibid. $35-42$.

45 E. O. Greening, A Pioneer Co-partnership, passim. 


\section{A HISTORY OF LEICESTERSHIRE}

made shoes, mainly by hand. Removals to improved premises were made in $\mathrm{I} 889$, and $\mathrm{I} 895$, with extensions in $\mathrm{I} 898$. The original trade-mark of this society was 'Eagle', but in 1894 the co-partnership took its present name of 'Equity'. In the division of profits its rules provided for the payment of 5 per cent. interest on capital, for the usual depreciation charges, and for reserves. The remaining profits were divided between committee workers, shareholders, an educational fund, a provident fund, and a special fund for inventors. Shares, the nominal value of which was $f, \mathrm{I}$, were transferable, but no member could hold less than one, or more than I00.46 By I 889 there were 443 members: 184 were co-operative societies, 4 were trade unions, and the rest were mainly workers. The rules remained unaltered until i 896 , when changes were made in the division of profits.

By 1892 the members numbered 750 , and the share capital was $f 4,900$. Of the 400 customers on the books, all were co-operative societies. The number of employees in that year was 220 , all of whom were shareholders. Eighteen men were employed by the week at an average weekly wage of $30 s . ; 92$ men by the piece at $26 s . ; 9$ females by the week, and 14 by the piece at an average of $17 s .6 d$. per week. It was to provide 'the most regular work of any firm in the kingdom'. 47 'The hours of work seem to have been always less than those generally prevailing in the town. One historian of the copartnership has stressed the importance of its capital formation policy in the early years, by obtaining the highest profit possible on a shoe. 'It was more important ... to make a large profit than do a great deal of trade.' 48 Saving and reinvestment was the main theme of the management's decisions. They refused to manufacture cheap shoes which realized only a small profit per pair. Similarly, they refused to make men's and women's shoes with the crude equipment available because the quality of the women's wear, for which they were acquiring a reputation, would have declined, with a subsequent fall in trade in times of depression. The later history of the copartnership is largely a story of increasing sales and profits, with a few periods of depression. 49 The number of workers employed rose to 320 in 1900 , but by 1926 had fallen to 166 . A leading trade unionist observed that it was not strictly co-operative but it rather had the character of a large limited liability company. ${ }^{50}$

In 1872 the Co-operative Wholesale Society began the production of boots and shoes in Leicester. This was the second industry in which it ventured as a manufacturer. Though not co-operative in the strict sense, by $1886-7$ the Leicester C.W.S. had I,ooo members, a share capital of $f_{1}, 100,000$, and transacted business to the value of $\AA_{150}$,ooo per annum, of which some $£ 20,000$ profit was distributed to members. In 1894 the Society opened the Wheatsheaf (C.W.S.) shoe factory at Knighton Fields. ${ }^{5}$ It was quick to introduce American machinery, to

${ }^{46}$ Greening, op. cit. Io. It is interesting to note that when capital was more abundant the soc. asked Ear Brassey to withdraw the loan capital which he had deposited in earlier, more stringent days.

47 Royal Com. on Labour, Mins. of Evidence, Group C, vol. ii, p. 28 .

${ }_{48}$ J. H. Plumb, Hist. Leic. Co-operative Boot and Shoe Manuf. Soc. 26.

49 Ibid. I 53.

so Royal Com. on Labour, Mins. of Evidence, Group C, the detriment of other firms such as 'Equity', who were attempting to compete with it in supplying the various co-operative societies. It is interesting to observe that the first reaction of the co-partnership to this threat was to tighten up conditions and discipline and to reduce piecework rates. The market for boots and shoes was expanding, however, and 'Equity' began supplying dealers other than cooperative societies.

With the threat of the 1895 dispute, the number of firms in the manufacturers' association increased from $I_{1} 5$ in 1894 to $I_{3} 6$ in the following year. ${ }^{52}$ But as trade revived and conditions became more settled, the membership dropped to I I9 in 1896 . In that year the local arbitration board was reconstructed under the Terms of Settlement. It still had work to do, for there were several cases in which the men attempted to introduce piecework prices and restrict the output of machinery, and illegally stopped work when their demands were refused. In these cases the union disclaimed responsibility and expressed disapproval. The union submitted the 'one boy to five men' demand to the board, as well as a minimumwage demand for workers aged between 18 and 20 , but the employers were not in favour of restriction. During 1897 the employers were still complaining that there was a 'systematic and concerted action to limit output on the part of the employees'.53 In addition, the union had issued instructions that the operatives were not to work overtime, except at 'time and a quarter'. In 1898 a piecework rate for lasting-machine operatives was agreed upon, workmen's compensation was introduced, and the manufacturers' federation was incorporated as a limited liability company.

By I9oo the boot and shoe trade had 'shared in the improvement which has taken place in the state of trade in the country generally, and in consequence, manufacturers have been able to maintain a condition of more regular employment in their factories'.54 In I 897 an American combine was formed to raise the price of leather, with the result that British manufacturers' profits dropped because they could not raise prices to meet the rise in the cost of their raw material. 55 Leicester manufacturers agreed upon a limited policy of an agreed rise in prices. ${ }^{56}$

Between 1890 and 1903 the British boot and shoe industry lost markets as the result of poor quality and finish, and recovered them only after the adoption of American production methods, styles, and finish, and of half-sizes. ${ }^{57}$ Trade in Leicester in the last part of the I9th century was affected by the slump in markets and short-time was the rule rather than the exception. This was aggravated by the seasonal nature of the town's trade, where the emphasis on the production of women's and children's shoes meant that the season began in the spring and that except in a few factories employment was less regular than in those towns which made all kinds of footwear. Returns to the Board of

\section{vol. $i i$, p. 28 .}

5 I Ibid.

52. Leic. Boot and Shoe Manuf. Assoc. 24th Rep. (1897); these are held by the soc. at its office in Granby St., Leic., where the writer was allowed to use them.

53 Ibid. 25th Rep. (1898).

54 Ibid. 27th Rep. (1900).

55 Greening, Pioneering Co-partnership, 123.

${ }_{56}$ Leic. B. \& S. Manuf. Assoc. 27th Rep. (1900).

57 Economist, 3 May 1913. 


\section{THE CITY OF LEICESTER}

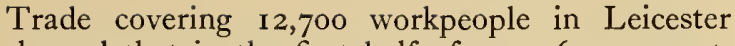
showed that in the first half of 190367 per cent. worked full-time: this figure was reduced to 47 per cent. in the second half. The manufacturers repeatedly expressed their conviction that prices of shoes would have to go up, ${ }^{8}$ while realizing that price rises proportionate to increased costs could not be made. The manufacturers' association submitted in I905 that 'combination ... ought to be successfully used in making a determined effort to secure a reasonable return for the capital employed ... not only for those who provide the capital, but also for the large numbers of workpeople and others whose livelihood depends for its remunerative employment in the trade'. ${ }^{99}$ In 1895 membership of the association had numbered 135 firms, but in 1905 was only 87 , although 27 new firms had been admitted in the meantime. The withdrawal of 75 firms was said to be entirely due to discontinuance of business. ${ }^{60}$ The decline of membership continued steadily to 70 in I9I 5, after which the First World War brought some outsiders into the association. The highest war-time membership was 107 in 1918. At the same time the association was assisting its members to obtain reasonable terms for the use of patented machinery and to relieve the industry from the arbitrary and unreasonable conditions inserted in machinery leases. ${ }^{61}$

Meanwhile the union was active on the board of arbitration. 'The clickers' statement, which only a few firms had adopted by 1900 , was revived in 1902 with a minimum of $29 \mathrm{~s}$. a week. Three years later a piecework statement for the town was agreed upon after much difficulty. The union, while urging nonunionists to become members, also asked employers to dismiss non-unionists. The unauthorized strikes continued, 3 in 1906,5 in 1907 , and 4 in 1908 . These strikes, disapproved of by the union, were financed by collections made from the men out of work. ${ }^{62}$ In the strike of $1905^{-6}$, the strikers were expelled from the union in accordance with the Terms of Settlement.

From 1908 to I9I4 trade in the town's productions was steady but not on a high level. The manufacturers' association protested against a proposed tariff increase by the French government in 1908 . In the same year it was agreed that female workers were to be included in the Terms of Settlement. The arbitration board continued its activities in these years, dealing, for example, with $I 75$ cases of dispute from 1909 to 1913 . The more technical and intricate character of the difficulties involved accounted for much of the increased work of the board. Strikes continued. In I9 Io there was a big strike at Simon's factory and the premises were picketed. A notice was issued, signed by the local representatives of the federation and the union, to the effect that the

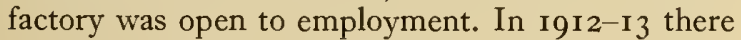
were nine strikes in factories of members of the association, provoked by causes such as the reinstatement of dismissed workers, dismissal of foremen and managers, refusal to work with non-unionists,

${ }_{58}$ e.g. Leic. B. \& S. Manuf. Assoc. 30th Rep. (1903). This is repeated in following years.

59 Ibid. 32nd Rep. (1905).

60 Ibid.

${ }^{61}$ Ibid. 3oth Rep.

62 Ibid. 33rd Rep. (1906).

63 Ibid. 40th Rep. (1913).

${ }^{64}$ Ibid. 39th Rep. (1912). displacement of men by newly introduced machinery, or, as the association reported, 'by other issues affecting the rights of employers to maintain discipline in their factories'.63 An agreement upon a $52 \frac{1}{2}$-hour week was agreed upon and came into operation in 1909 .

'The reports of the manufacturers' association in the years before 1912 continued to emphasize the need for collective action if rising costs were to be covered by increased prices. In I9I 2 they regretted 'that owing to the keenness of competition and no doubt, to a large extent, in consequence of the system of fixed retail prices', manufacturers were prevented from obtaining adequate increases in prices. ${ }^{64}$ 'Many efforts', they said, 'have been made in recent years by collective action ... with this object, but the results have not enabled the committee to conclude that collective efforts are likely to be more effective in the future ... than in the past, and [they hoped] ... that the necessities of the situation which will be intensified when the National Insurance contributions become payable will cause every manufacturer to realize that he cannot carry on a successful business unless he adopts a firm policy with regard to prices and obtains the necessary advances. ${ }^{\prime} 65$

The outbreak of the war in I9I4 disorganized business and finance in the industry by causing a partial suspension of business. But confidence returned and business revived until military, naval, and civilian demand far exceeded supply. During the first six months some 20 per cent. of male operatives in the town were mobilized and many women were taken into the industry. ${ }^{66}$ Efforts to increase output were continuous; more power was adopted, more operatives employed, and war bonuses given to indoor and outdoor workers. Although leather supplies became more difficult, Leicester was more affected by a labour shortage and 'Equity' lent workers to private factories to help ease the situation.

In the two immediate post-war years the boot and shoe industry benefited from the boom. The demand from the home market outran all powers of supply. New machinery was introduced, factory discipline was tightened up, and workers could no longer be allowed time off for a football match. ${ }^{67}$ When the slump came in I920-I and strikes occurred in a number of industries, trade was bad for the Leicester boot and shoe industry. The number of workmen employed locally declined and a great deal of shorttime prevailed. The difficulties at home were aggravated by a depressed export trade. By the spring of I 223 trade improved and the local manufacturers felt that they had now reached the 'bottom of the downward curve'. 68

A serious strike of women workers occurred in May 1922 when I, I 00 women in 22 firms ceased work for a week. The strike took place at the busiest time of the year and meant that a number of male operatives had to stand down for some days. Although trade improved in the following years, times were still regarded as difficult, for under-employment in other industries lowered effective public

65 Ibid.

66 Census, I911, r921.

67 Greening, Pioneer Co-partnership, 180.

68 Leic. B. \& S. Manuf. Assoc. 52nd Rep. (1923). This shows for the first time that the assoc. was aware of the trade cycle. 
demand, which was to some extent diverted to the very cheapest brands of footwear. 'The mid-I920's were perplexing years for the manufacturers, for it was becoming increasingly difficult to forecast the public taste in fashionable footwear. ${ }^{69}$ For example, in 1925 there was an insistent demand for the Cossack type of women's boots, which rapidly declined two years later. In addition the increased import of cheaper grades of footwear had a detrimental effect on the Leicester trade.

The General Strike and the coal stoppage of 1926 resulted for the industry in short-time which continued for some months. ${ }^{70}$ Fortunately gaiters became extremely popular and provided work for the clicking and closing departments. In $\mathbf{1 9 2 8}$ it was observed that 'a number of firms, of long and honourable connexion with the trade, have been compelled to cease manufacture. In some cases, the causes of failure must be attributed to reckless trading. Notwithstanding, there is reason to believe that many manufacturers have increased output, and that in aggregate, the volume of shoes produced in Leicester last year was higher than in previous years.' 71 In the year $1927-8$ I 5 firms ceased production. Membership of the local manufacturers' association had continued to decline from the war-time peak of 107 to 81 in 1928 . This decline continued thoughout the depression years of the I930's to its lowest figure of 60 . It may be said that this reflects in some way the process of concentration which resulted from high-output machinery and improved organization, but although the extensive mechanization of processes substantially increased the productivity of the labour force, demand did not keep pace with it. ${ }^{72}$ Between 1913 and 1939 the number of plants in the industry declined from 1,073 to 673 . With the exception of Rossendale and Leicestershire, the decrease in every main centre of the industry exceeded 20 per cent. In Leicester the number of firms fell from 165 to 94 , a decline of 43 per cent. ${ }^{73}$

'The censuses of production of 1924,1930 , and I 935 give approximate estimates of the output, value, and relative importance of the Leicestershire area, for no distinction is made in the census between town and county. The total value of the output of Leicester city and county was $f_{1} I, 868$ in 1924 , and $f_{1} 10,95^{\circ}$ in 1930 . The total output as a percentage of the total British output was $25^{\circ} 02$ in $1924,25^{\circ} 93$ in
1930, and 24.79 in 1935. In each case these figures are a little over two-thirds of the similar figures for Northampton city and county. ${ }^{74}$

These figures conceal an important development in the industry: the tendency for the county areas to expand at the expense of the towns. This delocalization was assisted by cheaper labour, the use of semiautomatic machinery, lower rates and rents in the rural areas and the development of an economic roadtransport system. This drift began about the time of the 1895 dispute. The dangers of uncontrolled migration were alluded to by a factory inspector in 1906: "No less than 3I of the smaller towns and villages are now executing work formerly done in Leicester: a serious matter for the elder workpeople of that town.' 75 Another change taking place within the industry in the 2 oth century is the steady decline in the number of male operatives and a rise in the number of females, a large proportion of the increase being in the administrative staffs. By I93 I there were 11,705 employed in the industry in the administrative county of Leicester, and 17,342 in the county borough; in the county, 7,506 were male and 4,199 were female, and in the borough I I, 384 were male and $5,95^{8}$ were female. ${ }^{76}$

In common with most industries, footwear suffered in the depression of the early 1930's.77 Within the industry, the struggle against the non-federated firms was intensified. 'It is becoming more and more evident,' said the local manufacturers' association, 'that it is to our home markets that the manufacturer has mainly to look for his business and here the menace of the non-federated firms ... is a problem to which both manufacturer and operative should give their serious and undivided consideration, with a view to finding ways and means of putting an end to the unhealthy element in the industry.'78

With the spring of 1934 , the expansion of output began, although turnover in value did not expand in proportion to the volume of output. By I 936 recovery was under way. Employment was much improved, hours of work more regular, and wages higher than in previous years. 'The recession of $1937-8$ brought difficulties which had just been resolved when the outbreak of war in September 1939 ushered in a time of great prosperity for the boot and shoe industry of Leicester, a prosperity which has continued almost unbroken up to $\mathbf{I} 955$.

\section{ELASTIC WEB MANUFACTURE}

THE elastic web industry in Leicester dates from I839, when Caleb Bedells, an inventor in the hosiery firm of Wheeler \& Co. of the Abbey Mills, announced that he was about to commence the production of 'an improved caouchouc webbing' and

\footnotetext{
69 Leic, B. \& S. Manuf. Assoc. 55th Rep. (1926).

70 Ibid. 56th Rep. (1927).

71 Ibid. 57 th Rep. (1928).

72 Silverman, Studies in Industrial Organisation, 203.

73 Ibid. 205

74 Census of Production, I024, 1930, 1935

75 Rep. on Factories and Workshops [Cd. 3586], p. 51, H.C. (1906).

${ }_{76}$ Census, I931. The total number employed in Gt. Brit. was 173,353 . In Northants. admin. co. there were 23,555 and in Northants, boro. 14,043 .

77 For estimates of unemployed see $\mathrm{Bd}$. of Trade, Working Party Rep. Boots and Shoes, 4.
}

opened a factory in Southgate Street. ${ }^{2}$ At first designed for use in braces, the new webbing was quickly adapted for the wrists of gloves and the tops of stockings, and in such articles as boots, fasteners for ladies'veils, hair-nets, and other garments. In

${ }^{78}$ Leic. B. and S. Manuf. Assoc. 59th Rep. (1930). On the industry between the wars see also H. A. Silverman, 'Industrial Survey of Leics.' (Nuffield Coll. Social Reconstruction Survey, 'TS. lent by Brit. Hosiery Mfturers' Association).

I Some use has been made in the compilation of this article of material collected by Mr. C. Ashworth, formerly of University College, Leic.

2 A. T. Patterson, Radical Leic. 381 ; R. Read, Modern Leic. 269. Elastic web had been manufactured since about I 830 . A patent for the manufacture of elastic fabric had been granted to J. V. Desgrand of London in 1832 . 
I 840 John Briggs, a glove manufacturer, applied for and received a patent for making elastic-wristed gloves and within four years he had $33^{\circ}$ frames manufacturing them. ${ }^{3}$ The discovery that by vulcanizing rubber (i.e. treating it with sulphur) it could be made resistant to heat and cold, served to popularize the new industry. 4 Whereas in 1846 only Briggs and Bedells had been manufacturing elastic web, by 1861 there were twenty firms. ${ }^{5}$ In 1853 Messrs. Hodges \& Turner became the first to use steam power in the trade. ${ }^{6}$ Only sixteen firms were listed in 1863 , but by 1877 there were no less than 47 firms in the borough of Leicester alone, with one at Belgrave and several in the north of the county. ${ }^{7}$

Protits were quickly made in these early days and improvements in the industry made it a remunerative one. In 1863 it was stated that the new industry was responsible for the recent growth of the population of Leicester, ${ }^{8}$ but although the manufacture of elastic web undoubtedly attracted some of the immigrants to Leicester the development at the same time of the hosiery and the boot and shoe trades must have played a much more important part in the growth of the town. Although by 1877 it seemed as though the elastic web industry was going to be one of the major industries of the borough, it failed to maintain its early progress. At first wages were high ${ }^{9}$ and profits easy, and the industry was stimulated by the popularity of the elastic-sided boot. After this went out of fashion the industry declined, although elastic webbing was still in demand for various uses, and the continuity of the industry is maintained by such firms as that of Archibald Turner. This firm, with that of Luke Turner, was founded by one of the pioneers of the industry, and inhabits the fine Gothic factory in King Richard Road. Archibald Turner's was the only Leicester firm to exhibit in the Paris Exhibition of 1878 , when Leicester goods were held to be as good as those produced by either France or Spain. ${ }^{\text {I0 }}$

The decline of the industry at the end of the last century has been attributed to various causes. Strikes were apparently common, but their causes are unexplained, ${ }^{I I}$ although it is probable that the early boom in the industry had an unsettling effect upon both employers and employees. The Leicester Elastic Weavers' Trade Protection, Sick Benefit and Funeral Society was formed before I 878 . The rules

3 Patterson, op. cit. 381 .

4 Vulcanization was discovered in America about 1843 .

5 White, Dir. Leics. (1 846), 124; E. S. Drake, Comm. Dir. of Leics. ( $186 \mathrm{I}$ ), 8o-8I.

6 Spencer, New Guide to Leic. (1888), I 89.

7 White, Dir. Leics. (1863), 294; ibid. (I 877), 756-7.

8 Ibid. (1863), 136.

9 Although wages dropped after the initial boom they remained higher than in any other part of the hosiery industry; Patterson, Radical Leic. $38 \mathrm{I}$.

so G. Gadd, Artizan Delegate's Rep. on the Elastic Webs, Paris Exhibition (1 878).

II White, Dir. Leics. (I 877 ), 276.

12 Rules of Leic. Elastic Web Weavers' Trade Protection, provided for contributions of $6 d$. weekly, if the member was working for two days or more, which seems to imply that short-time was not unknown. ${ }^{12}$ The number of firms had fallen to 30 by 1888.13 By I902 there were only I 8 firms and the number of factors and merchants had dropped from 15 in 1877 to 6 in 1902.14 One of the new firms which appeared during the last decade of the last century was that of Faire Bros., whose fine terra-cotta factory in Rutland Street was designed by Edward Burgess in $\mathbf{1} 898.15$ In I9I I it was stated that in spite of the drop in numbers, the industry employed between ten and fifteen thousand workers, who produced nine-tenths of the country's elastic web products, ${ }^{16}$ but the industry seems to have suffered a serious set-back in the First World War. By I9zo there were only eleven firms and the total employment in I92 I was apparently as low as $3,500 .^{17}$ In 1936 only nine firms were manufacturing elastic products in the borough and by $195 \mathrm{I}$ this number had been reduced to four. ${ }^{18}$ There are still a few factories outside Leicester.

Technical developments have been made in the industry since its commencement and from an early stage firms have been set up to supply the rubber thread which other firms weave into elastic web and other fabrics. One of the first firms of this kind was that of W. \& A. Bates who began in a factory in Charlotte Street but shortly afterwards moved to the present St. Mary's Mills. They supplied square-cut rubber thread for webbing, but between 1925 , when the firm became part of the Dunlop organization, and $193^{\circ}$, a round thread was produced and named 'Lactron'. Soon a multiple thread was perfected, consisting of three strands of 'Lactron' with a trefoil section. By 1932 a thread of extreme fineness named 'Lastex' was produced, which could be woven with finer and finer threads to make a much sheerer elastic fabric. ${ }^{\mathbf{9}}$

The elastic web industry in Leicester now manufactures surgical and medical requisites, braces, belts and suspenders, elastic and elastic fabric. During the Second World War much of the output of the factories was devoted to making aircraft parts, such as braided rubber shock-absorbers and rings. ${ }^{20}$ Most of the workers are men, women being employed only as winders, warpers, and examiners, never as weavers. A great part of the output of webbing is exported to Mexico in particular and to South Africa. ${ }^{2 I}$

Sick Benefit and Funeral Soc. (1878).

13 Spencer, New Guide (1888), roo.

${ }^{14}$ Wright's Dir. Leic. (1902), 329; White, Dir. Leics. (1 877), 756-7.

${ }_{15}$ The Builder, lxxii. 500.

16 Leic. Chamber of Commerce, Handbook (I9I I), 63

I7 Wright's Dir. Leic. (1920), 431; Leic. Official Handbook (I 92 I ), 65; Chamber of Commerce, Handbook ( I 92 I), 38.

is Kelly's Dir. Leics. (1936), I I 16; ibid. (I95 I), 800.

I9 City of Leic. Industrial Handbook (195 I), 39. For the mill, see below, p. 397.

20 City of Leic. Industrial Handbook (I95 I), 40.

${ }^{21}$ Leic. Mercury, 22 Oct. I 954. 


\section{PRIMARY AND SECONDARY EDUCATION}

\section{ELEMENTAR Y EDUCATION ${ }^{1}$}

THE earliest school of which we have any knowledge (apart from the Free Grammar School and its monastic predecessors $)^{2}$ is mentioned in 1653 . In that year, John and Robert King's schools were involved in a case, tried before the mayor and the borough justices, concerning the dissemination of anti-Cromwellian songs. ${ }^{3}$ We know nothing further about these schools, but they probably provided elementary education. In 1687 we hear of another school, when the Common Hall ordered that 'Mr John Hardy senior bayliff shall pay unto Mr Henry Hargrave twenty pounds heretofore given to him towards building a loft in St. Martin's church for the gentleweomen schollars to his wife'. ${ }^{4}$ 'This school was probably the forerunner of the young ladies' seminaries of the I 9 th century. By the early I 8 th century there were several charity schools in Leicester. According to Nichols, the first Leicester charity school was one for 24 boys; it was conducted first by a Mr. Stephenson, and later by his daughters, and already existed in I $7 \mathrm{II}$. In I 720 it was said that ten poor boys were being taught at Leicester at the cost of the Registrar, and ten poor girls at the cost of the Commissary. A school for ten poor boys of St. Margaret's parish was established in 1716 , but the boys seem to have been taught at the Free Grammar School on weekdays, and to have been separately instructed only on Sundays. ${ }^{5}$ The oldest school to continue into comparatively modern times was that founded by the Great Meeting, probably not long after it settled in its permanent home in East Bond Street in 1708 , although the earliest recorded reference to a teacher in the church mirute books is in $173^{6.6}$ The school existed independently until I 870 , when it was taken over by the School Board, and shortly afterwards closed, having accomplished its purpose: to provide an education for the children of nonconformists. It probably began as a dame school, with about twenty children, but seems

I Inf. about the period I870-I903, unless otherwise stated, is from the triennial reps. of the Leicester School Board and more especially from the final rep. of 1903 which summarized the work of the board throughout its existence. There is a complete set of these reps. at the offices of the Leic. Education Cttee. Inf, about the period from I 903, unless otherwise stated, is from the reps, of the Leic. Education Cttee., of which there is a complete set in the cttee.'s offices, and from a list of all schools under the control or care of the cttee., which was provided for the purposes of this article.

2 See below, p. 332 .

Leic. Boro. Rec. I603-88, 4I 5 .

4 Ibid. 587 .

5 Vichols, Leics, i. 5I 3; [Cox], Magna Britannia (1720), ii. 1393. The school maintained by a private gentlewoman, mentioned by Cox, was probably that founded by Stephenson and continued by his daughters. A document compiled I705-23 mentions a public school (presumably the Free to have grown rapidly. In 1760 the meeting was raising money to pay for 'Such children's schooling whose parents don't come to the Meeting', 7 and who, like the rest, would be clothed and educated at the expense of the congregation. When it closed the school was attended by about 700 children. ${ }^{8}$

Sunday schools, too, seem to have been begun by the nonconformist churches, and the first to be permanently established was again that at the Great Meeting, founded in 1783 , although there had been some Sunday teaching in the borough before that. ${ }^{9}$ In 1778 , a John Moore was teaching poor children on Sundays. ${ }^{10}$ The idea was quickly taken up by the Anglican churches, and although only St. Mary's had a Sunday school by 1788 , a letter to the Leicester Fournal in that year suggested that a similar school should be set up in every parish. ${ }^{11} \mathrm{~A}$ subscription list had been opened in 1786,12 and some teaching must have begun then also, for in I79I a meeting held in the vestry of St. Martin's Church resolved that 'the past five years experience has shown the Leicester Sunday schools to be very advantagious'. Earlier in the year a sermon was preached for the benefit of Sunday schools of all denominations. ${ }^{13}$ By I 792 there were at least 16 such schools, ${ }^{14}$ but by I 795 it is possible that the foundation of more day schools had tended to draw some children away from the Sunday schools, as it was decided that if a Sunday school was not regularly attended by more than twenty children, it should be closed. ${ }^{15}$ Sunday schools continued at the main churches and chapels in the town. In 1807 I Io children were being taught on the Lancaster system at the Sunday school at Friar Lane chapel. ${ }^{16}$ Between Ioo and I 50 children were clothed and taught yearly at St. Martin's and 80 at the Great Meeting, where reading, writing, and mathematics were the main subjects. ${ }^{17}$ In 1813 I 50 children were taught at St. Mary's: of these 120 were also clothed, and the total of children in the school had risen to 200 by I 8 I $9 .{ }^{18}$ In 1835 five Baptist and one Congregational Sunday schools established the Leicestershire and Rutland Sunday School Union, which had 20

Grammar School) and two other schools in All Saints' parish. It also mentions a Sunday school for 24 boys in St. Margaret's parish, presumably the school in that parish mentioned in the text: Assoc. Archit. Soc. Rep. E' Papers, xxii. $296-7$.

6 A. H. Thomas, Hist. of Gt. Meeting, 65 sqq.

7 Ibid. 67.

8 White, Dir. Leics. (1877), 318.

9 E. Gittings, Cent. Bk. of Gt. Meeting Sunday Sch.

10 A. T. Patterson, Radical Leic. 20.

I Leic. Fnl. 5 April I 788.

12 Ibid. 28 Aug. 1786 .

13 Ibid. 6 May and I I Jan. 179 I.

14 Ibid. 9 Nov. I 792.

Is Ibid. I 2 June I 795 .

I6 Ibid. Io July I 805 .

17 Ibid. 8 and 24 May I 811 .

18 Ibid. I 2 Nov. I8I3; 12 Nov. 1819. 
schools in Leicester affiliated to it by 1840 , with a further $2 \mathrm{I}$ in the county. ${ }^{19}$ In I 882 the Sunday School Memorial Hall in the New Walk was built.20

Sunday schools were begun to meet the needs of poor children, especially those who had to work, and there are many references in the Report on the Condition of Framework Knitters to the attendance of framework-knitters' children at such schools. ${ }^{21}$ For those who could attend a day school, even for a short time, another expedient was found, and the Great Meeting school, already mentioned, was the first charity school in Leicester to have a long existence.

By the end of the I 8th century the Anglican church had begun to found charity schools of the same type. The first of these was that attached to the church of St. Mary de Castro, founded by the efforts of the vicar, Thomas Robinson, who had for some years before the permanent foundation of the school in I 785 been paying for the education of about 5 o poor children in his parish, and who organized the regular payment of subscriptions for the new school among his friends and parishioners. ${ }^{22} \mathrm{H}$ is school was founded to educate and clothe 50 poor children whose parents were inhabitants of the parish or of the Castle or Newarke liberties. He gave some land in the parish, not far from the church, as the school's site. A schoolmaster, John Wood, was appointed and provision made for the management and collection of subscriptions. In I 79 I it was stated in the Leicester fournal that 240 children had been through the school and that there were then about 80 pupils in two separate schools. The girls were taught reading, sewing, and seaming, and the boys reading, writing, and accounts. All the pupils were given clothing at Easter. ${ }^{23}$ 'The Sunday school was continued and was also opened as an infants' school in 1845 , when the whole establishment catered for 80 boys and 40 girls. ${ }^{24}$ In 1869 , then affiliated to the National Society, the school was rebuilt on a new site in Castle Street, and the two figures of a boy and girl, dressed in the uniform of the school, which had been presented by two of the trustees, were transferred to the new building, where they are still to be seen. ${ }^{25}$ By 1877 the school was so liberally supported that it was able to take $45^{\circ}$ pupils. ${ }^{26}$ It came under the management of the Leicester Education Committee, and was closed down in 1932.

Five years after the foundation of St. Mary's School, the Vicar and churchwardens of St. Martin's conveyed a piece of ground in Friar Lane to trustees for the erection of a charity school. ${ }^{27}$ Clothes were provided for the children, and the school has always been known as the Bluecoat school. In I812 evening classes for older children were begun, in the hope that this would 'promote the peace of the town'.28 Like St. Mary's School, the new one was supported by subscriptions and later affiliated to the National

19 H. Ranger, Cent. of Work for the Young, I 5.

20 Now a hosiery warehouse : see ibid. 30-33. The architect was James Tait: Spencer, New Guide to Leic. (I888), 107.

2I Rep. Condition of Framework Knitters [609], H.C. (1 845$), \mathrm{xv}$.

${ }_{22} 32$ nd Rep. Com. Char. Pt. 5 [163], pp. I I 4-1 5, H.C. (1839), xv; Nichols, Leics. i. 5 I 4.

${ }_{23}$ Leic. Fnl. 22 April I791.

24 White, Dir. Leics. (1 846$)$, 100.

25 Ibid. (1877), 317; for the figures see R. Gunnis, Dict. Brit. Sculptors, I660-185I, 106.

${ }_{26}$ White, Dir. Leics. $(1846)$, 100.
Society. By the end of the I 9 th century it had become a boys' school, although in 1846 it was educating girls as well as boys, and was in that year attended by roo children on the foundation, who received both education and clothing, and by a further 80 who were taught free. ${ }^{29}$ New buildings were erected in 1870 , and in 1877 there were over 400 pupils. ${ }^{30}$ 'The school still exists as a secondary modern school with a grant from the City Education Committee, and is the oldest school in Leicester with a continuous record to the present day.

In 1805 one authority estimated that there were over I, ooo poor children in St. Margaret's parish who received no form of education, ${ }^{31}$ and shortly afterwards Richard Davies, the last head master of the Free Grammar School, then curate of the parish, began his efforts to found a parish charity school, which was opened in the following year. Four years later the school building in Churchgate was completed and conveyed to trustees. ${ }^{32}$ By I82 I it had Ioo pupils. 33 In 1834 a new National school was built in Canning Place and attached to the church. ${ }^{34}$ In I846 the old school had I7o pupils, and the new one, where each child paid $2 d$. a week, more than twice as many. ${ }^{35}$ By 1870 all the boys had been transferred to the Churchgate building and the girls and small children were taught at Canning Place. The Churchgate school was closed in I 928, and the building sold, while the Canning Place school was completely rebuilt with some help from the borough education authorities, as the Board of Education was prepared to recognize neither school under their old organization. Canning Place school was reopened in 1929 and was closed finally about I945.

The money for these charity schools was raised by public subscriptions and by the proceeds of collections made at the annual charity school sermons. In I 8 Io the Leicester fournal commented upon the children's 'simplicity of dress and appearance together with their decent and modest demeanour' at the service. ${ }^{36}$ At the service in 1814 the same paper reported that "the assemblage of upwards of three hundred children from the different schools in the town, all neatly and decently attired, presented an interesting and grateful spectacle'.37 Later in the year, however, the paper printed some figures regarding the state of education in the borough: 'although the charitable institutions of this town are numerous, still they are not sufficient for the population, it being ascertained on the lowest estimate that there are upwards of two thousand poor children without the means of efficient education and only about four hundred and sixty who receive daily instruction at the expence of $f, 600$ annually'. ${ }^{38}$

From this time until I 870 the foundation of new schools proceeded without any unusual features. In I 87 I there were 26 denominational schools, and the

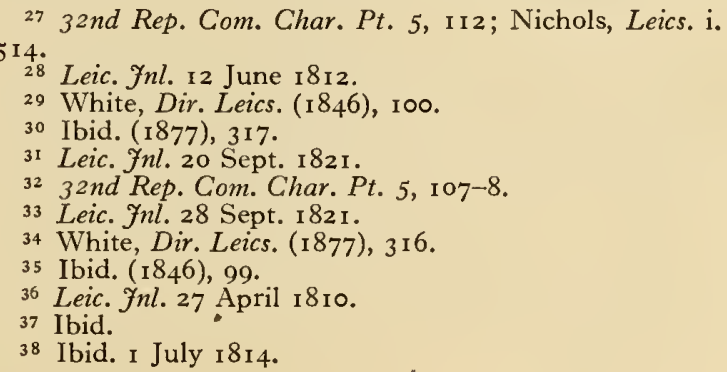




\section{A HISTORY OF LEICESTERSHIRE}

Anglicans and nonconformists vied with one another to teach the children. The first National Anglican school was the so-called county school, near St. Nicholas's Church, founded in 18 I 4 on land given by the king, and under the patronage of the Duke of Rutland and other eminent persons. It was designed to be a 'model' school for the county, and provided training for young teachers. Between its foundation and I 826 it educated some 2,00o children. ${ }^{39}$ Schools were not founded in great numbers in the first part of the century, 9 only between I 800 and 1845 , but between 1846 and 187023 new schools were built.

With considerable difficulty an Infants' School Society was founded in 1828 , but it could only open one school at first, in Newarke Street.40 The first nonconformist British school, the rival to the National school, was not opened until I832.4I In I 849 the educational position in Leicester was still far from satisfactory. In a report drawn up for the use of the mayor, Joseph Dare, who was in charge of the Unitarian school in All Saints' Open, estimated that only one-third of the juvenile population of the borough, or 5,099 children, attended a day school. Of these, I,824 went to Church of England schools, which he admitted were by far the most numerous and efficient, 795 went to nonconformist schools, I Io to Roman Catholic schools, I, 598 to private schools of some kind, and 772 to infants' schools. 'The average period of attendance of a working-class child at a day school was only two years. ${ }^{22}$ The addition of new church schools between 1846 and 1870 provided a further 2,800 places, and there were also some new nonconformist schools. In 187 I there were 26 denominational schools in the borough, which sought government grants after the passing of the Education Act in the previous year and which were considered to give a good education. A further five schools sought no grant and six others were held to be totally unsuited to receive one. There were also 3 I dame schools. A few years earlier only 13 of the borough schools were in receipt of government aid, including the Parochial Union school in Sparkenhoe Street, founded about I850. This school seems to have taught a wider variety of subjects than the average school, and received a favourable report from Her Majesty's Inspector in 1853 , when it had 27 boys and $5^{\circ}$ girls in attendance. 43 Some of the schools known to have existed in Leicester before I87 I do not figure at all on the list of that year. There had been, for instance two schools in Gallowtree Gate and Osborn Street, supported by the Gallowtree Gate Independent chapel,44 which are not mentioned, and there may have been others like them, with only a very short existence, which have left no mark in any record or printed sources.

In 1870 the first really satisfactory attendance figures are available, from the report on education by Samuel Stone, the Town Clerk. 45 The position as he estimated it is shown below (see table). Stone estimated from the figures of the r86r census that there were $I 8,480$ children in the borough between the ages of 3 and 13 , or 14,400 between the ages of 5 and 13 . About 3,ooo more school places would there-

\footnotetext{
39 White, Dir. Leics. (1877), 316 ; A. Fielding Johnson, Glimpses of Anc. Leic. (2nd ed. 1906), 386; T. Combe \& Son, Dir. Leic. (1826), p. xxii.

40 Patterson, Radical Leic. I6r.

41 Ibid.

42 Ibid. $371^{-2}$
}

fore be needed to fulfil the requirements of the Forster Act, and it should be noted that the Board of Education were to consider that 6 of the existing schools were not giving decent education. The I87 I census estimated that the number of children between the ages of 3 and 13 was 16,337 . The only wards in the borough with surplus school accommodation were East St. Mary's and St. Martin's.

\begin{tabular}{|c|c|c|}
\hline & Accommodation & Attendance \\
\hline $\begin{array}{l}23 \text { Church schools. } \\
5 \text { Schools under 'un- } \\
\text { certified' teachers } \\
2 \text { Roman Catholic schools } \\
4 \text { Schools under 'un- } \\
\text { certified' teachers } \\
\text { I Ragged school } \\
3 \text { Workhouse schools } \\
42 \text { Dame schools. }\end{array}$ & $\begin{array}{r}6,500 \\
2,900 \\
475 \\
720 \\
330 \\
\ldots \\
1,250\end{array}$ & $\begin{array}{l}5,500 * \\
2,525 \\
362 \\
\\
440 \\
160 \\
180 \\
\ldots\end{array}$ \\
\hline & 12,175 & 9,147 \\
\hline
\end{tabular}

* A further 850 places to be provided 'shortly'.

The Education Act of I 870 provided for the creation of school boards in places where the existing elementary education was held to be insufficient to cope with the needs of the population under the requirements of the new Act, and consequently a school board was created for the borough of Leicester. In the first ten years of its existence the board built nine new schools and a further sixteen were built between 1880 and 1903 . Ideas were formulated as early as 1876 for the creation of a so-called Industrial School for children whose homes were held by the local authorities to be totally unsuitable, whose parents steadfastly refused to send them to school, or who were criminally inclined. The school was opened at Desford in I88I, where 200 boys could lead an active outdoor life and where they were educated so that they could be found employment or apprenticeship when they left. The experiment seems to have been a complete success. Later a hostel was set up in Leicester for old boys of the school who were working in the town but this was closed during the Second World War.

In 1882 the board schools were providing education for II,507 children, as opposed to the I I,306 who were receiving their education at denominational schools. The report of the chairman in that year stated that each school place created by the board had cost a total of $f_{0} 8 \mathrm{rgs}$. $7 d$., a low average compared with other towns in the country. Fees paid were $2 d$. a week, and an average of over go per cent. of passes in examinations had been recorded in reading, writing, and arithmetic during that year. The number of children in the board schools continued to rise steadily, and by 1903 there were 31,793 children in these schools as compared with 13,326 in the voluntary schools. Attendance figures also showed a steady improvement; 85 per cent. was reached in 1890 and by 1903 the figure was 93 per cent. in the upper departments and 89.6 per cent. in junior and infant departments. The board had had to contend

43 Mins. Cttee. of Council on Education; Schools of Parochial Unions in Eng. and Wales [184r], pp. 84-85 (1854), li.

${ }_{44}$ White, Dir. Leics. (I846), Ioo; Fielding Johnson, Glimpses of Anc. Leic. 386.

45 S. Stone, Rep. on Elementary Education Act, 16-17. 


\section{THE CITY OF LEICESTER}

with the usual amount of discontent with the idea of compulsory education in its early days, and there were a considerable number of prosecutions of parents who refused to send their children to school, and hid them at home to work.

In 1892 the School Board, with the co-operation of the Leicester Savings Bank, established savings groups in all its schools, a move which proved to be a great success. The development of the type of syllabus taught in the schools is interesting. The early schools taught the three R's and the usual English History and Geography. In 1890 elementary science for the boys and domestic economy for the girls were introduced, and cooking had been taught to the girls for some years before that. ${ }^{46}$ Art and all kinds of handicrafts were taught from a fairly early date, and the introduction of the Froebel system of teaching infants came early to Leicester, owing to the efforts of Mrs. William Evans, the first woman to be appointed to the board. ${ }^{47}$ In 1890 swimming was introduced, as an out-of-school sport. As early as I 885, nine years before it was made compulsory, Leicester was making provision for the education of the deaf and dumb, when a class was set up at the Board's school in Milton Street. In I888 a second class was established at Elbow Lane school. Two years later, an experiment was made towards the education of the blind, when a class for blind children was formed, also at Elbow Lane, but this was not a success. In 1894 the whole of the school at Archdeacon Lane was given over to the education of the deaf and dumb, and three years later, some classes were started for mentally retarded children. They were given nine lessons each day, each lesson lasting for I 5 minutes and mostly of a practical nature but the teachers were instructed to persevere with reading and writing. In 1903 the deaf school was transferred to a building in Short Street, hired from the Friends' Adult School. A more permanent school was later set up in Churchgate and in 1927 both blind and deaf children were sent from this school to the newly purchased 'Stoneleigh', a house in Stoneygate Road, where the present school (I955) for deaf and partially sighted children is situated. By the end of the First World War, there were classes for mentally defective children at the Willow Street and Elbow Lane schools, but in 1924 these children were moved to a new school at the house in Narborough Road, called St. Mary's Fields. In I932 the school for educationally sub-normal children in Duxbury Road was opened and some of the children from St. Mary's Fields were transferred to it. A school for maladjusted children was opened in I932 at the 'Manor House' in Haddenham Road. The Western Park open air school for delicate children was opened in $193^{\circ}$. Education for children who are physically handicapped and in hospital is provided at the Royal Infirmary, the General Hospital, and the Isolation Hospital.

46 Leic. Sch. Bd. Instructions to Managers and Regulations (1897) includes a section on subjects taught.

47 F. E. Skillington, Plain Man's Hist, of Leic. I I112.

8 Leic. Education Cttee., Rep. on Grouping of Elementary Schools, I92I-9.
In I903, under the provisions of the Education Act of 1902, the School Board was disbanded and the Education Committee of the borough council set up. Administrative changes in the present century include the grouping of all elementary schools in the city carried out between I92 I and I929, so that each school now (1955) caters for a particular age group of children. 48 Most of the mixed schools have been re-arranged so that boys attend one and girls another. New schools were erected in the suburbs as demands grew, although the need for new schools was very great after the Second World War. This need has been met energetically, although in 1955 more schools were still needed. Under the chairmanship (1 9o6-37) of Sir Jonathan North the Education Committee between the wars worked especially to provide secondary education on a wider scale. Although 18 new elementary schools were provided between the wars, and a further five came under the control of the Education Committee by the County of Leicester Review Order of I935, when the city's boundaries were extended, I I others were closed, mainly in the centre of the town. By 1944 the Education Committee had to advise the town council that 5 infants' schools, 7 junior schools, and 5 secondary schools were 'obsolete and inadequate' and should either be replaced or completely rebuilt. ${ }^{49}$ The emergency programme planned in 1944 called for the erection of ro new schools as soon as possible and the improvement of others by rearrangement. Seventeen new schools were opened in $1945^{-55}$; some of these were new buildings for previously existing schools, but others were new foundations. The standard of the architecture and planning of new schools both before and after the war is very high, and these buildings are of great credit to the borough and the committee. In 1954 there were 57 schools giving elementary education at either junior or infant stage which were wholly maintained by the Education Committee. A further 8 schools were denominational and receive transitional aid from the committee, while three further denominational schools were controlled by the committee although keeping their denominational character. Four Roman Catholic schools were aided by the borough, and three of these were the only schools remaining in the borough which provided education for children of all ages. There were 30 secondary schools, many of which, although counted as separate schools, were branches of the same, since there were no mixed secondary schools in Leicester. One secondary school was denominational, transitionally aided by the committee. In addition to these, the committee was responsible for the 9 grammar schools in the borough. ${ }^{50}$ The total number of pupils in the care of the Leicester Education Committee in 1952-3 was 30,640 in primary schools and 13,459 at grammar and secondary schools. ${ }^{51}$

49 Leic. Education Cttee., Rep. on Post-War development of Education.

50 In 1955 a proposal to set up a comprehensive school on the New Parks estate aroused much criticism and no decision about the future had been made by Nov. 1955 .

51 Leic. Finances (1952-3), 17. 


\section{THE FREE GRAMMAR SCHOOL AND THE WYGGESTON HOSPITAL BOYS' SCHOOL}

THE earliest education in Leicester was provided by the Abbey of St. Mary in the Meadows, and a public grammar school probably existed in the town from the early 13 th century. ${ }^{52}$ The canons also maintained an almonry school, but by the I6th century it seems that both these schools had lapsed, the former from decay, aggravated by the dissolution of the abbey, the latter solely from that cause. The Free Grammar School was founded by Thomas Wigston, canon of the Newarke College, who died in I 537, and whose impulse to found such a school for the borough had perhaps been formed during his executorship of his brother William's will.53 William Wigston, a pious and wealthy merchant, died little more than six months before Thomas and left one-third of his considerable income to be used for charitable works at the discretion of his executors. It seems clear that Thomas Wigston urged Agnes, William's widow, and their fellow executors to agree that some of William's money should go towards the payment of a schoolmaster and the permanent foundation of a school. Between I 545 and I $_{557}$ the school came into being and was endowed. It was already in existence when the town was visited, some time before I $55^{\circ}$, by John Leland. ${ }^{54}$ 'The lands purchased for the support of the school were conveyed to the master and brethren of Wyggeston's Hospital who were to be the controlling trustees, with power to appoint and dismiss the master, whose salary was to be $£$, I a year. Further land in Humberstone and Aylestone was purchased in $155^{8}$ for the support of a second master.

In 1564 , after representations made by the corporation and probably by Henry, Earl of Huntingdon, the queen granted the yearly sum of $f$ io out of the revenues of the Duchy of Lancaster for the support of a schoolmaster to be appointed by the corporation, which thus had the option either to increase the stipend of Wigston's schoolmaster or to appoint a rival. 55 After a short period of ill feeling and vindictiveness between hospital, corporation, and school, things seem to have settled down. The hospital also at this time underwent serious reorganization at the hands of Huntingdon and was in no position to offer resistance. ${ }^{56}$ The school was housed in the decayed church of St. Peter, but in I 573 the corporation decided to pull down the church and with the materials and proceeds of the sale of parts of it to erect a new building for the school on the old site. ${ }^{57}$ These premises, used by the school for the next 300 years, still stand at the end of what is now called Free School Lane. ${ }^{58}$ New statutes were drawn up, embodying ideas which may largely be ascribed to

52 M. C. Cross, Free Grammar Sch. of Leic. 5.

53 Ibid. 7. Much of the following is also taken from this source.

54 Leland, Itin. ed. Toulmin Smith, i. 16.

5532 d Rep. Com. Char. Pt. 5, 2-3.

56 See below, pp. 400-1. 57 See below, p. 388.

58 The building is of rubble, in 5 bays. It has a tiled roof with 5 dormer windows and there are 4 mullioned
Huntingdon himself, and sealed in the form of an indenture between the earl, the corporation, and the hospital.59 The master was now to receive $£_{20}$ annually, the sum of the original figure provided for him in the endowment and the queen's gift. A syllabus and a rigorous time-table were drawn up. ${ }^{60}$ School was to begin at 50 'clock in the morning and there were relatively few holidays. The master and ushers were still nominally appointed by the hospital but in fact from this time onwards the mayor and corporation were 'the effective managers of the school'. They remained so until I $84 \mathrm{I}$, and during this period the school met with every possible change in fortune. There were no fewer than seventeen headmasters between 1617 and 1678 when, with the appointment of William Thomas, of Emmanuel College, Cambridge, the school settled down to a time of consolidation and prosperity. Thomas remained at the school for 34 years, although for the last eleven of these he held two Leicester livings, as well as his headmastership. In this period after the Restoration, the school was dominated by the High Tory corporation, and acquired a markedly Anglican complexion. The growing body of nonconformists in the town formed their own school at the Great Meeting, although for higher education boys whose parents were not of the Established Church continued to attend the grammar school until the next century. From I739 to 1762 , under the headmastership of Gerrard Andrewes, the school enjoyed its most successful and brilliant period, but after his death its decay was rapid and unchecked. Although the headmaster's salary had several times been increased by the corporation, satisfactory candidates for the post were hard to find: Another difficulty was the curriculum which by statute had to be taught, but whose classical bias was considered by many parents to be totally unsuited to the needs of the future citizens of an industrial town. Although for the first few years of the headmastership of the Revd. Richard Davies the school seemed as though it might revive, the violent political and religious struggles of the early igth century entirely prevented this. When Davies came to the school in I8I6 there were 14 free scholars and none of the private pupils whom the headmaster was allowed to take and who boarded with him. Although Davies raised the numbers to as many as 25 free scholars and I 5 boarders in three years, the revival was only temporary and by the time that Davies died in I 84I there were no pupils and the Free Grammar School had ceased to exist.

Although plans were made as early as 1842 for the refounding of the school, they came to nothing; the old building was sold in 1860,61 and boys on the foundation of the grammar school were sent to the new Collegiate School, ${ }^{62}$ whose headmaster was allowed to draw a salary as headmaster of the grammar School. Mill Hill School received these boys after the Collegiate School closed down, and when Mill Hill closed the boys were sent to a new school in Trinity Lane. In 1877 I 3 free scholars were being

windows below. There were originally 6 bays, but one was demolished when Free School Lane was widened. The building is now a carpet warehouse. See plate facing p. 393 . 59 Leic. City Mun. Room, $3 \mathrm{D}_{42} / 9 \mathrm{r}$, printed in Cross, Free Grammar Sch. 1 5-20.

60 Reconstructed in Cross, Free Grammar Sch. 26-27.

61 White, Dir. Leics. (1877), 3 r6.

62 Ibid. 315-16; for the Coll. Sch. see below, p. 334 . 
educated under the old grammar school trust. In 1873 , however, after a review of the resources of Wyggeston's Hospital, which had greatly increased in value during the centuries, it was decided in Chancery that the surplus could and should be used to found a new Wigston school. ${ }^{63}$ In the same year the Wyggeston Hospital Boys' School was established, and given a grant of $£ 2$,ooo yearly from the hospital funds.

In 1890 the Charity Commissioners merged the endowments of the old free school with the new foundation, which also provided funds for a girls' school.64 The Revd. James Went was appointed the first headmaster, and for nearly 40 years he guided the school's fortunes. ${ }^{65}$ New buildings were erected in High Cross Street, near the site of the old Wyggeston Hospital, and opened in $1877^{66}$ The school grew rapidly. On the first day in 1877 I60 boys attended, 67 in 1893 there were 460 , and when the school celebrated its jubilee in 1927 there were 978.68 The school came under the control of the Education Committee of the borough council in 1909 and from that date the governors have been appointed by the committee. ${ }^{69}$ In 1919 T. Fielding Johnson presented the school with about 30 acres of land, on the north side of Victoria Park, on which were buildings forming part of the temporary military hospital set up during the war. Although the premises were not exactly suited to the purposes of the school, the following two years saw the removal there of the whole establishment. A swimming bath was built in 1923 and in 1932 a new assembly hall was opened, part of a design for new buildings by James Miller which is as yet incomplete. ${ }^{70}$ Further additions have, however, been made, including the erection in 1937 of the dining hall. There were 876 pupils at the school in I952. The school is no longer supported by the endowment made by the hospital, but under a scheme of the Ministry of Education in November 1950, the $f 2,000$ is still (1955) paid to the schools and is applied in special benefits for the pupils.

\section{THE WYGGESTON HOSPITAL GIRLS' SCHOOL}

THE same scheme which refounded the Wyggeston Hospital Boys' School provided for a girls' school under the same foundation, under the management of five ladies, to act in co-operation with the governors. ${ }^{71}$ There were to be 200 day scholars, and in most respects the curricula and general arrangements were to be the same as for the boys' school. New buildings were erected in Humberstone Gate, between Clarence Street and Hill Street. ${ }^{72}$ The architect was'Edward Burgess, who had designed schools for the local school board since its inception. The premises were opened in 1878 , and Miss Ellen

${ }_{63} \mathrm{G}$. Cowie, Hist. of Wyggeston's Hosp. 63-66.

64 Ibid. 103-4. One of the most important parts of the endowment was the Hayne bequest of 1640; Cross, Free Grammar Sch. 24-25.

65 Wyggeston Grammar Sch. Fubilee I927, 43-45.

${ }^{66}$ Cowie, Wyggeston's Hosp. 72.

68 Wyggeston Grammar Sch. Fubilee, 43.

69 Ibid. 42 ; further inf. from same source and from reps. of Leic. Education Cttee.
Leicester was appointed the first headmistress. There were four assistant mistresses and I 50 pupils. The numbers of both staff and girls grew rapidly and there were 683 pupils in 1928, when the present building by Symington and Prince in Regent Road was opened. ${ }^{73}$ The junior school had previously been housed in the former St. Mary's Vicarage in the Newarke, but the new building was designed to house all departments. There were 708 pupils in 1952 .

\section{ALDERMAN NEWTON'S SCHOOLS}

IN I76o, Alderman Gabriel Newton, a prominent and wealthy member of the corporation, with which he had been associated for rather more than fifty years, conveyed to the mayor and corporation of Leicester land in several places in the county for the foundation of schools in various English towns and villages. ${ }^{74}$ The corporation was given the right of visitation in these schools, and in addition the remaining income from some land at Cadeby, which was to be devoted in the first instance to the proposed school at Northampton, was to be used for the apprenticing of boys of Anglican parentage in Leicester itself. By his will, proved in 1762 , Newton left a sum of $f 3,250$ to be invested by the corporation to found a school for the education and apprenticeship of 35 or more boys of indigent or necessitous Anglican parents in Leicester without regard to any particular parish. 75 The founder laid great stress in his will upon what was to be the spirit of the school for the next 75 years, and the will reveals 'plainly the influence of the political and ecclesiastical controversies of Newton's lifetime'. ${ }^{76}$ 'The marked emphasis upon the Athanasian Creed which Newton held to be "the compleatest body of divinity ever composed since the time of the apostles, and a full answer to all heretical objections to the doctrines and tenets of the Church of England,' 77 and upon music and the liturgy which he loved is reflected in the provision in his will that the boys were to attend church, were to be taught the psalms and to tone the responses during the service. Finally they were to be provided with suits of peacock green, and the name 'Greencoat School' survived until the original school was closed in I 884. Although the corporation had considerable difficulties in obtaining the money (legal conflicts continued for over forty years), by $\mathrm{I}_{7} 85$ a school was opened with 35 boys, a schoolmaster, and a singing master, in the old Shambles near St. Nicholas's Church. A committee of the corporation was evolved for the administration of the foundation, a task which it accomplished with faithful attention to the wishes of the founder. By 1808 the legal difficulties had been overcome, as the corporation had been able to produce evidence of 40 years' occupation and use of the property in question. The number of pupils increased to $100 .{ }^{78}$ When in 1835 it appeared clear

70 Leic. Mercury, 25 Nov. I930.

71 Cowie, Wyggeston's Hosp. 66-67.

72 Ibid. $75-76$.

73 Leic. Mercury, 12 Sept. I928.

74 R. W. Greaves, Origins and Early Hist. of Alderman Newton's Foundation, I6.

75 Ibid. 17.

77 Ibid. I8; further inf. from same source.

76 Ibid.

78 Patterson, Radical Leic. 20. 


\section{A HISTORY OF LEICESTERSHIRE}

that the passing of the Municipal Corporations Act would transfer power in Leicester from the highchurch Tories to the nonconformist Liberals, one of the main arguments produced by those who opposed the bill in the town was that it would be both dishonest and illegal for a school which had been founded upon such strict Anglican principles to be administered by dissenters. Although the school did in fact come under the control of the new corporation it maintained its prosperity for a considerable part of the century. Rebuilt in its old position near St. Nicholas's Church in 1808 , the school moved in 1869 to a new building of perpendicular Gothic, by Goddard and Paget ${ }^{79}$ in St. Martin's. Neither funds nor buildings proved sufficient for the growing number of applicants for admission and the school was closed in 1884 . With the aid of the Charity Commissioners, the new school was planned in 1885 to be a higher grade elementary school and it was opened three years later. Under the headmastership of James Muston, rapid development in the higher forms towards increased specialization in scientific subjects took place. ${ }^{80}$ The elementary department was closed in I906, when the school came under the control of the Education Committee. It is now (I955) a grammar school, and the earlier bias towards scientific subjects was removed after Muston's retirement in I923. In I 920 the school was moved to the former Wyggeston School buildings in High Cross Street and the foundation increased to provide for the foundation of a girls' school in the following year, when the girls' school was opened in the former boys' building in St. Martin's. Both schools were considerably enlarged in the following years, although there has been no signal increase in the numbers of pupils attending. There were 516 boys and $25^{8}$ girls in 1924 , as against 523 boys and 200 girls in $195^{2}$.

\section{THE CITY BOYS $\mathrm{SCHOOL}^{81}$}

The City Boys' School was opened in 1920 , when the former Newarke school was divided, and was at first housed in the former Great Meeting school building in East Bond Street. In I 928 it moved to the buildings recently vacated by the Wyggeston Girls' School in Humberstone Gate, which have since been extended. There were 294 pupils in 1924 and 474 in I952.

\section{THE COLLEGIATE SCHOOL AND THE COLLEGIATE SCHOOL FOR GIRLS}

THE serious alarm felt in the town during the I830's at the decay of the Free Grammar School during the later days of the headmastership of Richard Davies led to the formation of a company to found a new

\footnotetext{
79 R. Read, Modern Leic. 54-55.

80 Greaves, Newton's Foundation, 33-34.

$8 \mathrm{r}$ Reps. of Leic. Education Cttee.

82 C. J. Billson, Leic. Memoirs, 82 sqq
}

school, the shareholders having the right to send their sons to it, in the proportion of one child for every share, up to a maximum of four. ${ }^{82}$ The first general meeting of shareholders was held in 1835 , and among the decisions as to future policy was one declaring that at least the headmaster and the second master should be members of the Church of England and graduates of either Oxford or Cambridge. In the same year the school was erected in College Street. This limiting clause meant that considerable alarm was felt by the extensive nonconformist element in the borough that the new school was not going to fulfil the need for an undenominational school, as it had at first promised to do. The plans went through, however, and in $18{ }_{3} 6$ the Leicester and Leicestershire Collegiate School was opened. One hundred and six pupils attended on the first day, and the numbers seem to have remained constant as long as the school survived; in 1863 there were Ioo including the grammar school boys (see above). By this date, although its early success had been great, the school was beginning to feel the effects of too hasty building, in that there was a heavy mortgage on the College Street buildings. In 1866 the headmaster resigned and the shareholders decided to close the school and leave the mortgagee to sell the property. The school building was later partly used as the Wycliffe Congregational Church. The name of the school has been continued in that of the Collegiate School for Girls, founded privately in I 866 and purchased from the then owner, the headmistress, in 1922 by the Education Committee. ${ }^{83}$ 'This school is now a girls' grammar school, with an attendance of 385 in 1952 , an increase of 40 on the figure in I922. It was still partly housed in the former Collegiate School building in 1955 .

\section{THE GATEWAY SCHOOLS}

THE Gateway School for Boys was established in I 928 by the Leicester Education Committee, for boys between the ages of I I and 16 , whose interests were not primarily academic. ${ }^{84}$ Emphasis was therefore laid on education of a technical nature. The school was at first housed in Skeffington House and an adjoining building in the Newarke, but in 1939 it moved to new buildings in Fairfax Street, added on to the former St. Mary's Lodge or Home, built about 1770 . There were 270 boys at the school when it opened in 1928 . By 1935 there were 430 and in 1952 there were 6I3. In I946 a parallel school for girls was formed out of the old Art Secondary School, in the latter's former buildings in Wigston Lane, and moved to the former High Cross secondary school buildings in Elbow Lane in $1954 .{ }^{85}$

\section{THE NEWARKE GIRLS' SCHOOL ${ }^{86}$}

THE Nervarke Girls' School was originally established as a mixed secondary school with premises in New-

83 Reps. of Leic. Education Cttee.

$84 \mathrm{Ex}$ inf. Leic. Education Cttee.

85 Reps, of Leic. Education Cttee.

86 Ibid. 
arke Street. In I9I9, after the retirement of the then headmaster, the Newarke school was converted into an all-girls' school, with 500 pupils. In I 932 the school was moved for a short time to the new premises recently built for the Gateway School in Fairfax Street, although retaining the Newarke Street building. In I 939 a new building was completed in Fosse Road South, and the move was able to take place just before the outbreak of the Second World War. There were 603 pupils in 1952 .

\section{THE PROPRIETARY $\mathrm{SCHOOL}^{87}$}

THE alarm felt in nonconformist circles in Leicester about the foundation and limitations of the new Collegiate School in 1835 led to the foundation of a second and similar company in the same year. The school was opened in 1837 in a grand classical building by Joseph Hansom in the New Walk. It began with 128 boys, but the fees charged were too low for the venture to be a financial success. The company made a great loss even in its first year. Although the fees were increased, the school was trying to pay the headmaster a salary which it could not possibly afford, and it was unable to carry on for more than ten years. In 1847 Leicester Corporation bought back the site, which it had previously sold to the company, together with the school building; the latter is now the Leicester Museum.

\section{PRIVATE SCHOOLS}

LITTLE information exists about the foundation of private schools. Some have already been noted under elementary and grammar school education, and any unendowed school which existed in Leicester during the 17 th and early 18 th centuries must of course have been privately owned and maintained. Until the I 9 th century there are no lists of private schools and it is difficult to form any accurate idea from the directories about the number which existed even late in the century. In the classified lists of inhabitants, some teachers seem to have been listed as individuals even when teaching in a school which had been founded by one of the societies. As far as can be judged, there were 48 private schools in Leicester in 1846 , of which I 5 took boarders. ${ }^{88}$ In addition there were 2 I teachers of music, languages, and dancing. In 1877 there were 57 private schools, and of these, the 3 I dame schools which have already been noted as existing in I87 I probably formed a considerable proportion. ${ }^{89}$ By the end of the First World War there were 35 private schools, and they are thereafter noted yearly in the reports of the Education Committee. ${ }^{90}$ Of these, 20 were classed as elementary, I 2 as 'Preparatory-Secondary', and the remaining 3 as secondary. There were about 2,00o pupils in attendance at these schools in all; the smallest, one of the nine owned and organized by one teacher, containing I 3 pupils. The Education Committee inspected these schools from that date. There were only I9 such schools in the borough in I $953,{ }^{91}$ and of these only 6 were recognized by the Ministry of Education as giving efficient education. Two took boarders, including Stoneygate School, a preparatory school founded over 70 years earlier by G. B. Franklin, and still carried on by his descendants. ${ }^{92}$

\section{SCHEDULE OF SCHOOLS}

THE following schedule does not include grammar schools, which have been dealt with separately; it does include all other schools known to have been at any time under the control of either the Leicester School Board (after I 870) or the Leicester Education Committee (after I903), schools founded by national societies (e.g. British schools), all Anglican church schools, and all other major schools which are known to have taken day pupils and not to have been simply Sunday schools. The schedule has been drawn up mainly from the reports of the Leicester School Board and the Leicester Education Committee and from directories of the borough of Leicester.

The columns in the schedule indicate: (I) name of school; (2) date of foundation; (3) type of school at foundation; (4) date of closure; (5) type of school in 1955, or at closure. The date 1935 in brackets after the name of a school in col. I indicates that it came under the control of the Education Committee only in I 935 under the terms of the County of Leicester Review Order of that year, which extended the borough boundary. Where a school is listed as a Board School in col. 3 it was controlled by the Leicester School Board unless otherwise stated in the notes. Where the school was in existence in 1955 the word 'date' appears in col. 4 .

Abbreviations used: B., Boys' School; Bd. Sch., Board School; G., Girls' School; I., Infants' School; J., Junior School; Sec., Secondary Modern School.

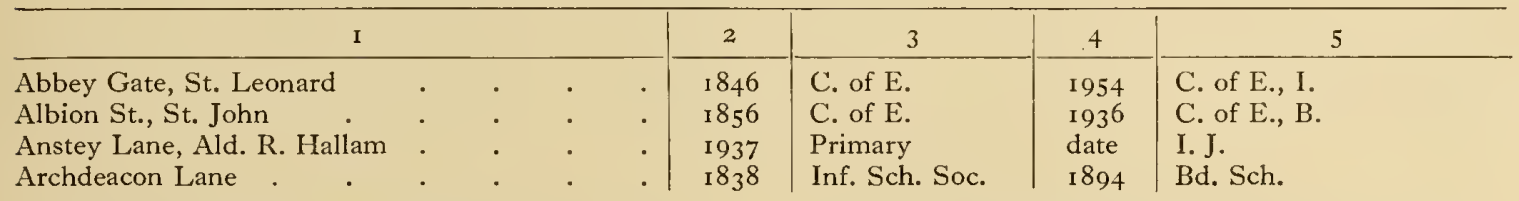

87 Billson, Leic. Memoirs, 88 sqq.

88 White, Dir. Leics. (1 846), I69, 195.

89 Ibid. (1 877$), 842-3$.
90 Rep. Leic. Education Cttee. (1919-23), 19.

91 Ex inf. Leic. Education Cttee.

92 T.L.A.S. xviii. 3, 28-30. 
A HISTORY OF LEICESTERSHIRE

\begin{tabular}{|c|c|c|c|c|c|c|c|c|c|}
\hline & I & & & & & 2 & 3 & 4 & 5 \\
\hline Avenue Rd. . & . & . & - & - & & 1894 & Bd. Sch. & date & I. J. \\
\hline Aylestone Rd. & - & - & . & . & • & 1880 & Bd. Sch. & I 882 & Bd. Sch. \\
\hline Balfour St. . . & . & . & - & - & • & I933 & Primary & date & Fosse Sec. (part). ${ }^{\mathrm{I}}$ \\
\hline Belgrave, Loughborough & Rd. & . & - & - & . & I86I & National & date & C. of E., I. J. \\
\hline Belgrave Gate, St. Mark & . & . & . & . & . & 1874 & C. of E. & date & C. of E., I. J. \\
\hline Belgrave Rd. . & . & . & . & . & . & 1875 & Bd. Sch. & date & I. J. \\
\hline Belper St., Hugh Latime & & . & - & - & - & I 888 & Bd. Sch. ${ }^{2}$ & date & I., Sec., B. \\
\hline Benbow Rise . & . & - & • & . & . & I937 & Primary & date & \\
\hline Bow St., Christ Church & & - & . & . & . & I 840 & National & I 947 & C. of E., B. \\
\hline \multicolumn{10}{|c|}{ Braunstone Frith, see New Parks } \\
\hline Braunstone Hall . & . & . & - & . & - & 1932 & Primary & date & $\mathrm{J}$. \\
\hline Braunstone Park & . & . & . & . & - & 1950 & Primary & date & I. \\
\hline Bridge Rd. . . & . & . & • & . & . & ז889 & Bd. Sch. ${ }^{3}$ & date & I. \\
\hline Brunswick St., St. Matth & ew & - & - & . & - & I 869 & C. of E. & date & C. of E., I. \\
\hline Caldecote Rd. (1935) & & . & . & . & - & 1930 & Primary & date & I. J. \\
\hline Canning Place, St. Marga & aret & . & . & . & . & 1834 & C. of E. & I939 & I. J. \\
\hline Caroline Place, St. Mark 4 & & . & . & . & . & I 873 & C. of E. & I9OI & I. \\
\hline Castle St., St. Mary & . & . & . & . & . & I 785 & Charity & I932 & C. of E., G. \\
\hline Catherine St. . & . & . & . & . & . & 1880 & Bd. Sch. & date & I. J. \\
\hline Charlotte St., All Saints & . & . & . & . & . & 1819 & Inf. Sch. Soc. & I 898 & National. \\
\hline Charnor Rd., Forest Lod & lge & . & . & . & . & 1950 & Primary & date & I. J. \\
\hline Charnwood St. & . & . & . & . & . & 1875 & Bd. Sch. & date & I. J. \\
\hline Chester St., St. Matthew & . & . & 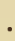 & - & . & 1869 & C. of E. & date & C. of E., I. \\
\hline Christow St. . . & . & . & . & . & . & 1877 & Bd. Sch. & date & I. J. \\
\hline Churchgate, St. Margaret & & . & . & . & . & 1807 & Charity & I 928 & C. of E., B. \\
\hline Clarendon Park Rd., St. & John & . & & . & . & I 890 & C. of E. & date & C. of E., I. J. \\
\hline Clyde St. $\quad$ • & . & . & . & . & . & 1867 & Wesleyan & 1928 & Primary. \\
\hline Coleman Rd. . & . & . & . & . & . & I 922 & Primary & date & I. J. \\
\hline Colton St., St. George 5 & . & . & . & . & . & 1828 & C. of E. & date & I. J. \\
\hline Cort Crescent & . & . & . & . & . & I 938 & Primary & date & I. J. \\
\hline Curzon St., St. Matthew & . & . & . & . & . & I 852 & C. of $\mathbf{E}$. & I 936 & C. of E. \\
\hline Dannett St., St. Paul & . & . & & . & . & c. 1926 & C. of $\mathrm{E}$. & c. 1937 & C. of E. \\
\hline Deacon St., St. Andrew & . & . & . & . & . & I 865 & C. of E. & date & C. of E., J. \\
\hline Dudley Avenue, Thurnby & y Lod & & & . & . & I953 & Primary & date & \\
\hline East Bond St., Gt. Meeti & ing $^{6}$ & . & . & - & . & $\begin{array}{c}\text { before } \\
1736\end{array}$ & Congregational & I 873 & Bd. Sch. \\
\hline Eastcourt Rd., Overdale & . & . & • & . & . & I 953 & Primary & date & I. \\
\hline Elbow Lane, High Cross & . & . & . & . & . & 1874 & Bd. Sch. & date & Sec. G. \\
\hline Ellesmere Rd. (1935) & . & . & . & . & . & I934 & Sec. & date & Sec. B. \\
\hline Ellis Avenue . & . & . & . & . & . & I 899 & Bd. Sch. & date & Sec. B. G. \\
\hline Evington (1935) . & . & . & . & . & . & I $84 \mathrm{I}$ & National & date & C. of E., I. J. \\
\hline Evington Drive, Mayflow & & . & . & . & . & $195 \mathrm{I}$ & Primary & date & J. \\
\hline Evington Valley Rd. & . & . & . & - & . & 1935 & Primary & date & I. \\
\hline Folville Rise (1935) & . & . & . & . & . & I 934 & Sec. & date & Sec., G. \\
\hline Fosse Rd. & . & . & . & . & . & I 904 & Primary & 1927 & Primary \\
\hline Friar Lane, St. Martin & . & - & & . & - & I 789 & Charity & date & C. of E., Sec., B. \\
\hline Gervas Rd., Thurnby Lo & dge & . & . & . & . & 1952 & Primary & date & \\
\hline Gillman Rd., New Parks & Ho. & . & & . & . & I95 I & Primary & date & $\mathrm{J}$. \\
\hline Gipsy Lane, Northfield H & Ho. & . & • & - & . & 1936 & Primary & date & J. \\
\hline Gladstone St.7 & . & . & . & . & . & I 880 & Bd. Sch. & I 883 & Bd. Sch. \\
\hline Gladstone St., St. Luke & & . & & . & . & 1874 & C. of E. & 1930 & C. of E. \\
\hline Glenfield St., Christ the & King & . & . & . & . & I95 I & R.C. & date & R.C., I. J. \\
\hline Gopsall St., St. Peter & . & . & . & . & . & 1876 & C. of E. & date & C. of E., J. \\
\hline Granby Rd. & . & . & & . & . & г 889 & Bd. Sch. ${ }^{8}$ & date & I. J. \\
\hline Green Lane . & . & . & & - & - & 1895 & Bd. Sch. & date & I., Sec., B. \\
\hline Grove Rd., St. Saviour & . & . & & . & . & 1882 & C. of E. & date & C. of E., I. J. \\
\hline Gwendolin Rd., Crown & Hills & . & & . & & 1950 & Sec. & date & Sec., B. G. \\
\hline Hamelin Rd., Wycliffe & . & . & $\cdot$ & - & . & I 929 & Primary & date & I., Sec., B. G. \\
\hline Harrison Rd., Rushey M & lead & . & & & & 1904 & Primary & date & I., Sec., B. G. \\
\hline Harrison Rd., St. Patrick & & . & & & & 1937 & R.C. & date & R.C., all age. \\
\hline Hattern Avenue, Woodst & ock & . & & . & & I95 I & Primary & date & I. J. \\
\hline Hazel St. . & . & . & & . & & 1882 & Bd. Sch. & date & I. J. \\
\hline Headland Rd., Linden & . & . & & - & . & I 952 & Primary & date & I. J. \\
\hline Hill St. $\quad$. & . & . & & • & & $\mathrm{I} 83 \mathrm{I}$ & British & г 893 & British \\
\hline Hinckley Rd. & . & . & & . & & 1913 & Primary & date & I. J. \\
\hline Holy Bones, County Sch. & & . & & • & & 1814 & National & I 904 & National \\
\hline Humberstone (1935) & . & . & . & . & 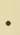 & 1857 & National & date & I. J. \\
\hline Imperial Avenue & . & 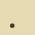 & & • & & 1933 & Primary & date & I. \\
\hline Ingle St. $\quad$. & . & . & . & . & & $\mathrm{I} 89 \mathrm{I}$ & Bd. Sch. ${ }^{9}$ & date & I. J. \\
\hline
\end{tabular}


THE CITY OF LEICESTER

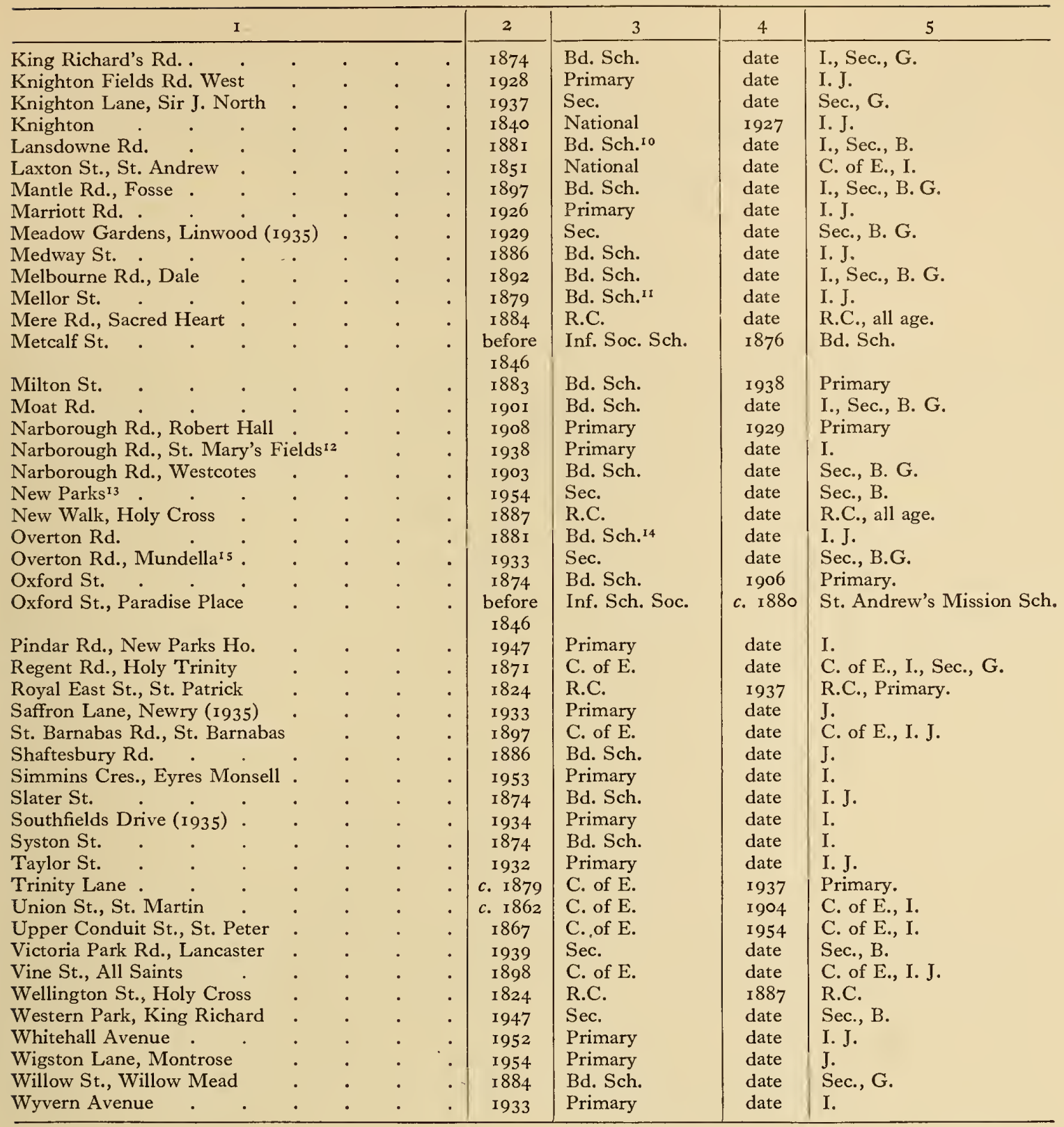

I Aylestone Sch. Bd.

II Belgrave Sch. Bd.

12 Sometimes known as Haddenham Rd. Sch.
${ }_{3}$ Braunstone Frith J. Sch. temporarily from I954.

${ }_{4}$ West Humberstone Sch. Bd.

I5 Originally known as Tailby Estate Sch. 


\section{PARISHES IN THE ANCIENT BOROUGH}

\section{ALL SAINTS'}

All SAINTS' parish extends over the northern part of the walled borough of Leicester and for a distance beyond. The boundary runs from High Cross Street, along a line just south of Free School Lane to a point to the west of Churchgate. From there it goes north through the houses behind Churchgate to Sanvey Gate, along Sanvey Gate and some distance up Northgate Street At a point just south of Pingle Street it goes eastwards to the end of Berkley Street and follows a winding course roughly along the lines of Craven Street and Slater Street to Frog Island. From there it goes south until it reaches the canal and turns west to enclose a very narrow strip of land along the canal on the north side. It then runs through the buildings west of Northgate Street to reach the river at the west end of Soar Lane. It turns east again along the south side of Soar Lane and goes down Great Central Street to Friars Causeway, and then through houses to rejoin High Cross Street. I

The chief thoroughfare is High Cross Street, from Sanvey Gate to Peacock Lane, formerly High Street, which was part of the main road north and south during the Middle Ages. ${ }^{2}$ High Cross Street is probably the magnus vicus which is mentioned in two charters of the I 2 th century dealing with burgage tenements, one probably early in Henry II's reign. ${ }^{3}$ Its more usual name, alta strata, occurs from the beginning of the 14 th century. ${ }^{4}$ In this street were some of the more important public buildings, and in it the Wednesday market was held, at the junction with the present High Street.5 In the Middle Ages these public buildings consisted of the two prisons belonging to the borough and the county, and at a later date the Free Grammar School. ${ }^{6}$ St. John's Hospital7 and All Saints' Church also stood in the

\footnotetext{
The boundary is marked on T. and G. Ellis's Plan of Leic. (1 828).

2 For Highcross Street see C. J. Billson, Medieval Leic. $4-5$.

${ }_{3}$ Doc. Illustrative of Soc. and Econ. Hist. of Danelaw, ed. F. M. Stenton, 246, 259.

4 e.g. Leic. Boro. Rec. IIO3-I327, 309.

5 For the market and the High Cross see p. 36 I.

6 See p. 332. For a photograph of the old grammar school, see plate facing p. 393 .

7 V.C.I. Leics. ii. $40-4 \mathrm{I}$ and see p. 408.

8 See below.

9 Billson, Medieval Leic. 45.

Io Ibid.

II Leic. Boro. Rec. I603-88, I50-1; J. Thompson, Hist. of Leic. i. 344.

12 T.L.A.S. xxv. I 53; H. M. Colvin, Biog. Dict. of Eng. Architects, 324. The building is illustrated in Nichols, Leics. i, plate xxviii.

$13 \mathrm{~J}$. Throsby, Hist. of Leic. 385 . Firmadge also appar-
} ently took charge of the new building: cf. R. Gunnis, Dict. street; many inns were there, and at least one large house was built there in the later Middle Ages. ${ }^{8}$

Of the two prisons, that built by the borough was probably the earlier, and it seems likely that it existed in $1297 .{ }^{9}$ Formal recognition of the right to have a prison was not given until $\mathrm{I} 375 .^{\mathrm{I0}}$ About $\mathrm{I} 6 \mathrm{I} 4$ a new house of correction was established on the site of the old St. John's Hospital at the corner of High Cross Street and Causeway Lane. 11 This in turn was rebuilt by John Johnson in $\mathrm{I}_{793} \mathrm{i}^{\mathrm{I} 2}$ The old gaol was demolished in 1792, and William Firmadge was the mason in charge of operations. ${ }^{13}$ While this demolition was taking place the remains of the hospital were uncovered. ${ }^{14}$ Johnson's prison in turn was taken down in 1837 and small houses were built on the site. ${ }^{15}$ These still exist (nos. 8I-87). Now very much decayed, they are of white stucco with some pleasant moulded decoration. Between I824 and 1828 the corporation were debating, against violent opposition, the question of building another gaol, and they actually accepted a plan from Firmadge, then an alderman, for a new prison and bought land in Causeway Lane next door to the existing prison. ${ }^{16}$ Finally the problem was solved by the purchase of the county gaol ${ }^{17}$ which stood a little farther up the road, at the corner of High Cross Street and Free School Lane. A county gaol was built between I300 and I309, near to the Shire Hall. ${ }^{18}$ It was probably not until the 16 th century that a new building was erected on the site occupied by the county gaol until the I 9 th century. By the I8th century the gaol was in such an appalling state as to be roundly condemned by Howard the prison reformer, and in $1790-2$ it was rebuilt. ${ }^{19}$ The architect of the new building was George Moneypenny of Derby. ${ }^{20}$ The surveyor was William Harrison, who

of Brit. Sculptors, I 44. This probably accounts for Miss Watts's statement that he was the architect: [Watts], Walk through Leic. 34.

I4 Throsby, op. cit. $385-8$

15 A. Fielding Johnson, Glimpses of Anc. Leic. (2nd ed. 1906), 302. It was abandoned in 1828 when the borough purchased the old county gaol: see below.

16 A. T. Patterson, Radical Leic. 157-8. Ellis's map of I 828 marks the site of the proposed new gaol. The council had great difficulty in selling this land, which is surprising in view of the demand for building land.

17 White, Dir. Leics. (1 846), 76.

18 Billson, Medieval Leic. $42-43$. The Shire Hall stood near St. John's Hospital, but very little is known about it (see V.C.H. Leics. ii. 92 but for Northgate Street read High Cross Street). Leics. had a county gaol under Hen. II: Trans. R.H.S. 5 th ser. v. 2.

19 Billson, op. cit. 44.

20 Colvin, Biog. Dict.Eng. Architects, 392; [Watts], Walk through Leic. 29-30; Nichols, Leics. i, plate xxviii. 


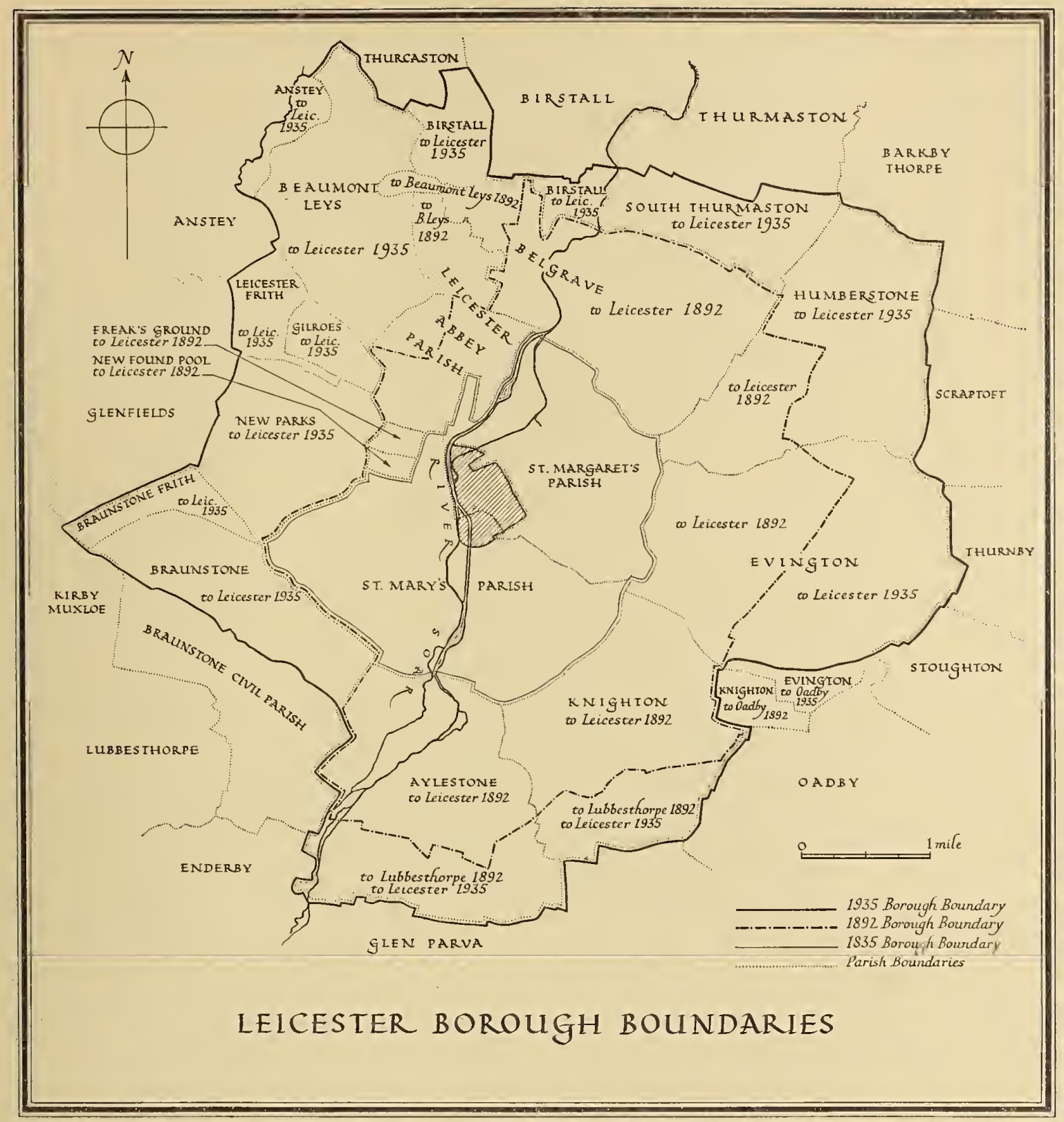




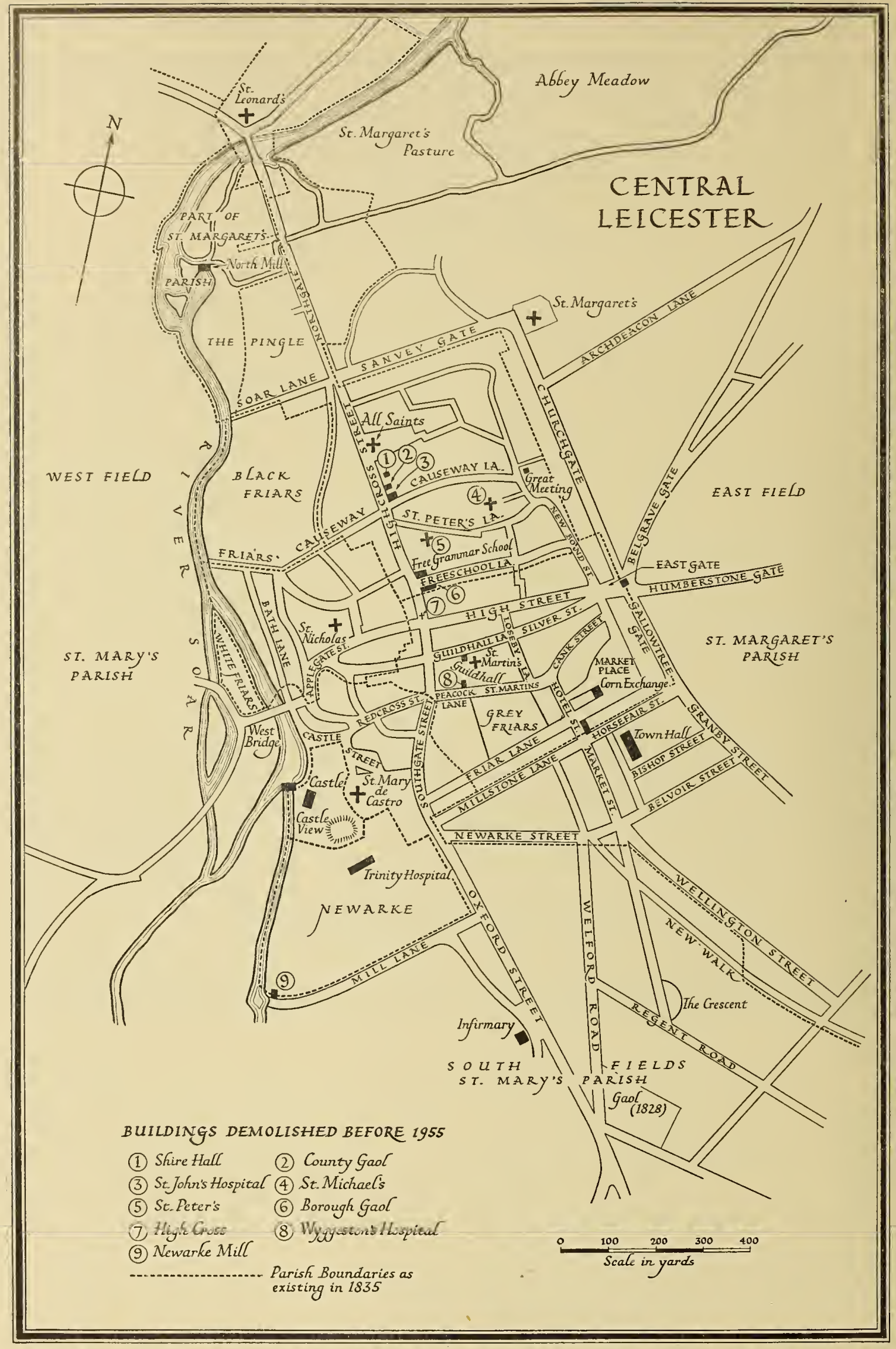

Map of Leicester showing the principal streets referred to in the text, and the sites of important buildings. The map does not represent the town as it existed at any one date. 
received a salary of $f_{0} 500$ a year. ${ }^{21}$ In 1803 the gaol was altered by a Leicester architect, William Oldham. ${ }^{22}$ When the new county gaol was built in Welford Road, this building was bought by the borough authorities, who built a bridewell next to it. The cost of purchase and altcrations was very largely responsible for the borough debt in 1835 , about $£_{1} 7,000$ out of the total debt of $f, 27,000 .{ }^{23}$ Between I 858 and I 860 further alterations were made, when a new wing for male prisoners was erected. ${ }^{24}$ In $\mathrm{I} 867-8$ a new female wing was built. ${ }^{25}$ After the prison had been taken over by the Prison Commissioners in $\mathbf{1} 878$, they decided to close it. The building was bought back from them by the borough in 1879 for fio, $3228 s .,{ }^{26}$ and subsequently demolished.

At the beginning of the I 9 th century High Cross Street preserved a largely medieval appearance. In Flower's print of about I 830, ${ }^{27}$ Moneypenny's gaol stands out in contrast against the other rather dilapidated timber-framed buildings, which predominated on that side of the road. One house, dated I7I7, still stands. On the opposite side, Flower's print shows I8th- or I9th-century fronts, with bow-fronted shop windows. One notable housc of this type still survives (no. I 8). The front dates from about 1760 and is of red brick with stucco bands. The 'Tower of the Winds'-type pilasters are superimposed over the bands. The central window on the first floor has a pediment and a panel of balusters below. There is a good wooden doorcase with an open pediment and traceried fanlight. Down a side passage it is possible to obtain a view of the rear elevation, which is of two stories, as opposed to three at the front, and probably dates from the very early years of the 16 th century. It is timber-framed and the upper story oversails the lower. The ground floor windows, extending the whole way along the building, have timber mullions. ${ }^{28}$ No. 59 is a lateI 8 th-century brick house with a very large semicircular fanlight. No. 90 dates from the early i 9 th century and is a stucco house with a rusticated lower story, moulded cornice, and small parapet.

Free School Lane leads off High Cross Street to the east. It is probably to be identified with the medieval Dead Lane (mortua venella), which was a blind alley. The name occurs first at the beginning of the 14 th century, ${ }^{29}$ and was replaced by that of Free School Lane when the school was built in $1573.3^{\circ}$ St. Peter's Lane runs roughly parallel with it, farther north. It also appears for the first time at the beginning of the 14 th century. ${ }^{31}$ Miss Watts stated that it was known at the beginning of the last century

2I L.R.O., Orders relating to co. gaol, I 790-2. The Harrison family continued to work as architects in Leic. until the present century.

22 L.R.O., Orders relating to co. gaol, I 790-2. The acct. for the alteration of $180_{3}$ is at the end of the vol.

23 Patterson, Radical Leic. 210 ; and see above, p. 254. 24 J. Storey, Hist. Sketch of Boro. of Leic. 45. 25 Ibid.

26 On these transactions see ibid. $45-47$; and see above, pp. $286-7$.

${ }_{27}$ Print in J. Flower, Views of Anc. Buildings of Leics.

28 This house is traditionally supposed to be that of

Roger Wigston, brother of the founder of Wyggeston's Hosp. It had some fine painted glass which is now in Leic. Museum, in Skeffington House: Billson, Medieval Leic. 208.

29 Leic. Boro. Rec. I IO3-I 327, 256; Billson, op. cit. 6. 30 See above, p. 332 .

${ }_{31}$ Leic. Boro. Rec. IIO3-I 327,367 ; Billson, op. cit. 6. as Womans Lane, but she is the only authority for this. ${ }^{32}$ Farther south ran Causeway Lane, known in the Middle Ages as St. John's Lane or Gaol Lane. ${ }^{33}$ St. John's Hospital stood on its north side, at the corner with High Cross Street. The present St. John's Hospital ${ }^{34}$ only occupies part of the original site, as the old borough gaol was built on the corner, and there are now also houses on the site. A little farther down the main street is Cumberland Street, which was the beginning of the lane described in I 303 as 'venella qui se extendit ab alta strata versus ecclesiam sancti Petri et versus 'Torchmere', and of which East Bond Street forms a part. ${ }^{35}$ 'Torchmere is impossible to place on a modern map. It was probably an open piece of ground with a pond in the north-eastern part of the walled town, most of which was up to the Igth century open ground with orchards and gardens. ${ }^{36}$ In the last century the area between High Cross Street and Churchgate was filled with a tangle of lanes and streets. At the end of the 18 th century a bowling green and gardens were opened near what is now Vauxhall Street, and was a popular resort for some years. It was known as the New Vauxhall and was designed to take the place of the old Vauxhall Gardens near the West Bridge which were put up for sale in I 797.37 Dr. Arnold's asylum also stood in this area. ${ }^{38}$

The road called Northgate Street originally included the whole of the road to the North Bridge, but during the last century the part between the canal and the bridge became known as Frog Island, from the strip of land of that name. ${ }^{39}$ During the Middle Ages it was chiefly inhabited by dyers and fullers. Outside the North Gate to the west ran Soar Lane, which was known as Walkers or Fullers Lane (vicus fullonum). ${ }^{40}$ The name Soar Lane appears in the I $5^{\text {th }}$ century, but the road was still sometimes known as Walkers Lane at the end of the I6th century.41 North of Soar Lane was a close called the Pingle. The name survives in Pingle Street, and the land was laid out for streets at the very beginning of the I gth century, as a result of the building of the canal. ${ }^{42}$ The same kind of development took place on the other side of Northgate Street. There were a tannery and a bleach yard by the canal by 1828.43 One of the first factories to be built in Leicester was one for spinning cotton in Northgate Street, probably built in 1792.44

The industrialization of the northern part of the parish increased the population, and new streets were built wherever it was possible, on the Pingle and between High Cross Street and Churchgate, for

32 [Watts], Walk through Leic. 25.

33 Billson, Medieval Leic. 5.

34 See below, p. 408.

35 Billson, op. cit. 5-6. Elbow Lane was the name given to the road from Cumberland St. to New Bond St., now called East Bond St. The present Elbow Lane is further west: cf. Ellis, Plan of Leic. (1828), and Spencer, Map of Leic. (1 867 ).

36. Ellis, Plan of Leic. (1828).

37 [Watts], Walk through Leic. 25-26; Fielding Johnson, Glimpses of Anc. Leic. 307.

38 Watts, op. cit. 26; Fielding Johnson, op. cit. 305.

39 Cf. Ellis, Plan of Leic. (1828), and Spencer, Map of Leic. ( 1867 ).

40 Leic. Boro. Rec. IIO3-I $327,38 \mathrm{I}$ n.

4 I Billson, Medieval Leic. I 7 .

42 Patterson, Radical Leic. 40.

43 Ellis, Plan of Leic. ( 1828 ).

44 Patterson, op. cit. 88. 


\section{A HISTORY OF LEICESTERSHIRE}

instance. In $1_{5} 6_{3}$ there were only 66 families living in the parish. 45 At the beginning of the 18 th century the population was $\mathbf{I}, 020.46$ The first census gives $2,8_{3} 8$, and the population rose steadily throughout the last century until its highest figure was reached, 6,867 in 1891.47 During this century it has declined and was 4,306 in 1931.48

GUILDS. The guild attached to the hospital of St. John the Evangelist and St. John the Baptist seems to have started with a gift in I 355 when the feoffees of Peter of Grendon the saddler assigned property to the hospital for the souls of Peter and his family and all the benefactors of the hospital. The chaplain was to be chosen from among the brethren of the hospital but he took his oath in the borough court. ${ }^{49}$ The date of the establishment of the guild itself is not known. The will of a chaplain of the guild was proved in $1442.5^{\circ}$ In 1477 the chaplain's duties were set out in an agreement between the hospital and Richard Wigston, steward of the guild, in which Peter of Grendon and his wife are specifically mentioned. Richard Wigston and his successors with the advice of the master of the hospital were to choose the guild priests, whose duties were to include the saying of mass in the guild chapel and also twice weekly in the chapel of St. John in Belgrave Gate. The priest would be supported between them, the master finding meat and drink or $40 s$. yearly, the steward paying the balance of his salary and finding him a chamber in the hospital. ${ }^{1}$ Nothing further is known of this guild, which probably decayed with the hospital after $\mathbf{I} 548$.

The guild of the Assumption which was attached to All Saints' Church was founded in the I $4^{\text {th }}$ century by twenty brethren. ${ }^{52}$ Apparently before this there were no chaplains except the vicar. A chaplain was employed to say mass for the guild and as its popularity increased a second chaplain was appointed in $1389 .{ }^{33}$ The guild was still in existence in 1528 , but nothing further is known of it. 54

CHURCH. The church of All Saints was probably one of those which formed the endowment of the college of St. Mary de Castro, and which were granted to Leicester Abbey in I I $43 .{ }^{55}$ By I 220 it was appropriated to the abbey. ${ }^{56}$ At the Dissolution it passed to the Crown, which transferred it in 1867 to the Bishop of Peterborough, ${ }^{57}$ from whom it passed to the Bishop of Leicester who now holds it. ${ }^{88}$ The priest's stipend in 1222 was $20 \mathrm{~s}$. with the equivalent of a canon's daily corrody, ${ }^{59}$ and the living was said to be worth Io marks in 1217 and 6 marks in $1254 .{ }^{60}$

45 B.M., Harl. MS. 6 I8.

46 Assoc. Archit. Soc., Rep. Eீ Papers, xxii. 206.

47 V.C.H. Leics, iii. I 79.

48 Census, I93 I : Ecclesiastical Areas.

49 Leic. Boro. Rec. I327-1509, pp. lxii, 100-2. For the hosp. see V.C.H. Leics, ii. 40-4I.

50 A. Gibbons, Early Linc. Wills, I 72.

II Leic. Boro. Rec. I327-I 509, 282-3.

52 T.L.A.S. xxvi. I00-1.

53 Ibid. xiv. $167^{-9}$.

s5 V.C.II. Leics. ii. $13,45$.

Rot. Ifugonis de Welles, ed. W. P. W. Phillimore,

For a list of vicars presented by the abbey see A. Hamilton Thompson, Leic. Abbey, $157-60$.

57 Nichols, Leics. i. 552 ; Lond. Gaz. I867, p. 29 I I.

58 Leic. Dioc. Cal. (1954), 89.

59 Rot. Hugonis de Welles, ii. 286.

60 Val. of Norw. ed. W. E. Lunt, 530.

6I Valor Eccl. (Rec. Com.), iv. I 48.
It was valued at $£^{8} 3 s .8 d$. in $1535 .{ }^{61}$ In I 59 I the parish of the decayed church of St. Peter was absorbed by All Saints', although only after protests by St. Martin's. ${ }^{62}$ The assizes were held in the church in 1593 owing to the plague in the centre of the town. ${ }^{63}$ With the additional $f 5$ which he received from St. Peter's, the vicar's stipend was unchanged until the living was augmented in 1762 and 1802 by grants from Queen Anne's Bounty. The living was worth $£_{1} 48$ yearly in $1831 .{ }^{64}$ After the death of the vicar in 1947 no successor was appointed and the church was served by the Archdeacon of Leicester as priest in charge. ${ }^{65} \mathrm{He}$ was appointed vicar in I $9544^{66}$

Nothing definite is known of the structure of the church until the end of the r6th century, when a complaint was made that the roof needed attention, and it seems to have been repaired. ${ }^{67}$ The tall pews were cut down in 1637 after the archdeacon's visitation. ${ }^{68}$ For the next hundred years the church seems to have been kept in good condition, but in 1797 the archdeacon discovered weeds growing out of the walls, a leaking roof, and a dangerously decayed chancel. ${ }^{69}$ In 1829 the chancel was rebuilt. ${ }^{70}$ The roofs were renewed throughout by Henry Goddard in 1855.71 The nave was restored by Goddard and Paget in $1875,{ }^{72}$ and the tower in $\mathbf{I} 894$ by W. Bassett Smith of London. ${ }^{73}$ Part of the roof collapsed into the chancel in 1940.74

The church of ALL SAINTS stands in High Cross Street, with its west end immediately on the street, and the churchyard to the south and east. It seems possible that an earlier building was cruciform, of 12 th-century date, and that in the $14^{\text {th }}$ century or late in the $13^{\text {th }}$ the church was rebuilt on a different plan. Of the original church the only remains are the west door and the base of the tower, which, it is suggested, may originally have been centrally placed, although this is by no means certain. The I4th-century rebuilding evidently took place gradually, as the various parts of the work differ in detail. In the 15 th century the clerestory was added and the church reroofed.

The church now consists of nave and chancel, north-east tower, and north and south aisles. The length of the north side is about 5 feet greater than that of the south, as the west front slopes along the line of High Cross Street outside. The west doorway is Norman, with detached shafts and two rows of chevron ornament.75 The door itself is a good

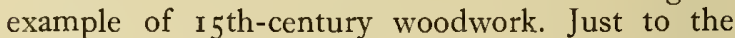
right of the door is an aperture through the wall,

62 Leic. Boro. Rec. I 509-I603, 271. For St. Peter's parish see p. 388

63 P. Hepworth, 'All Saints', Leic.' T.L.A.S. xxvi. Ior.

64 White, Dir. Leics. (1 846$), 85-86$.

65 T.L.A.S. xxvi. I I 3.

66 Ex inf, the Ven. C. L. Matthews, Vicar of All Saints'.

67 Leic. Boro. Rec. I509-1603, 303; T.L.A.S. xxvi. 97.

68 Leic. City Mun. Room, I $\mathrm{D}_{41} / 18 / 9$.

69 Ibid. I D $41 / 18 / 22$.

70 Spencer, New Guide to Leic. (1 888), 64, where the chancel is unjustifiably described as an 'eyesore ... of bald brickwork'. 'The architect of the chancel is unknown. In the church safe is a tracing of what is probably the architect's sketch; the original is lost.

71 Spencer, op. cit. 64 .

72 T.L.A.S. v. I4.

73 Ibid. viii. I 31 ; plans in ch. safe.

74 T.L.A.S. xxvi. 113.

75 For the church see below, plate facing p. 346 . 
which gives a view of the altar. Its purpose is doubtful. ${ }^{76}$ The north aisle has two lead rainwater heads, dated $\mathbf{I} 709$ and $\mathbf{I} 855$ respectively. The chancel is brick.

'The distinctive feature of All Saints' is the tower which rises from the north-east end of the church. The base is probably Norman, with very thick walls and pairs of half-round pilasters at the corners, visible both inside and out. It rises in three stages, finishing in a battlemented parapet. There are beam-holes for a first-floor chamber with-a small round-backed fireplace in the west wall. The slender tower arch and lancet cut across the floor level of this chamber.

The chancel is partly paved with I 4 th-century tiles. ${ }^{77}$ In it are monuments to Matthew Simons, High Sheriff (d. I7 I4), to Alderman Gabriel Newton (d. I 762), the founder of the Greencoat School, and to several members of the Forrester family, of the early I 9 th century. ${ }^{.8}$ The pulpit dates from the I 5 th century, and fragments of a screen of the same date have been re-erected near the font. The mayor's seat, dated $\mathrm{r} 680$, is in the north aisle, and is the only one of its kind to survive in Leicester. The font at the west end of the nave dates from the 13 th century and has a round bowl, decorated with trefoils and foliage, very similar indeed to the one in St. Mary de Castro. The base is modern. Above the south door is a clock surmounted by two compartments, each containing a small figure which strikes a bell at the hour. Below the figures is a painting of Father Time placed there when the clock was restored in I 899; the clock probably dates from about $1620,7^{79}$ and was formerly fixed above the west door. There are six bells: (I) I 595; (2) undated, pre-Reformation; (3) I6 I I, cast by Edward Newcombe; (4) I 586, cast by Robert Newcombe; (5) undated, cast by John de Stafford towards the end of the I 4 th century, recast by John Taylor of Loughborough I894; (6) I945, cast by Taylor of Loughborough. The whole ring was rehung in 1946.80

The registers date from 1575 . There is no ancient plate. The churchyard contains some fine Swithland slate headstones of the 18 th and I9th centuries. ${ }^{81}$

CHARITIES. In $16{ }_{12}$ William Norrice granted a yearly sum of ${ }^{5} 5$. from a garden in Soar Lane to be distributed to $4 \mathrm{I}$ poor people on St. Bartholomew's day after evensong. 82 'The donor's conditions were so troublesome, 'impracticable and absurd', ${ }^{83}$ that in 1837 the charity had been in abeyance for some years.

Before 1785 Joseph Wright left 25 s. a year for the purchase of Io pairs of women's shoes. The money was charged on land called 'Coltmans' and a garden in Elbow Lane. In 1837 the money was paid (the ground now having been built over) partly to the poor widows of St. John's Hospital and partly to the parish. 84

John Saunders left at an unknown date two annuities for the parish. The first, of $6 s .8 d$., was to be given in bread yearly on Good Friday and was payable out of land in the parish. The second, of $3^{s .} 4 d$. yearly, was to be paid towards the repair of the church. ${ }^{85}$ It is mentioned in 1832 as the church's only endowment. 86

Payments are made to the parish by Leicester Corporation under the Ive and Courteen charities, and by the Trustees of Leicester General Charities for the Heyrick bread charity. ${ }^{87}$

\section{BLACK FRIARS}

The extra-parochial liberty of Black Friars lay in the north-west of the old walled borough of Leicester. It became a civil parish under the Act of $\mathbf{1} 857^{1}$ and was amalgamated with Leicester in 1896 when the borough became a single civil parish. ${ }^{2}$ In 1896 it covered 16 acres. ${ }^{3}$ It was bounded by the River Soar, Soar Lane, the former Back Lane, and Bath Lane. The eastern part of the area is now occupied by the Central railway station, and the remainder is mostly covered by streets of I 9 th-century terrace houses.

In the Middle Ages Black Friars was occupied by a Dominican friary, founded in the $13^{\text {th }}$ century. ${ }^{4}$ The friary was perhaps founded in this spot because in the second half of the $13^{\text {th }}$ century the north-west

76 M. P. Dare, 'On a perforation recently discovered in All Saints' Ch. Leic.' Assoc. Archit. Soc. Rep. Eं Papers, xxxvii. $138-43$.

77 N. R. Whitcomb, Medieval Floor-tiles of Leicester, passim.

78 Gunnis, Dict of Brit. Sculptors, I06, 207, 431.

79 T.L.A.S. xxvi. I2 I ; 'Restoration of Anc. Clock of All Saints' Ch. Leic.' Peterborough Dioc. Mag. (I9oo)

T.L.A.S. xxvii. 3 I.

80 T.L.A.S. xxvi. I I $5-18$.

81 On these, see ibid. I25-6.

82 32nd Rep. Com. Char. Pt. 5 [163], pp. I $03-4$, H.C. (I839), xv.

83 White, Dir. Leics. (1877), 330

$8432 n d$ Rep. Com. Char. Pt. 5 , Io 4

86 Leic. City Mun. Room, 245'5o/r.

district of Leicester was less densely populated than other parts of the town; this has been attributed, though without any proof, to devastation caused in the siege of I I 73. "The friary must have been of some size, as three provincial chapters of the Dominican order were held there in the I 4 th century, and at the same period the house contained thirty or more friars, ${ }^{6}$ but very little is known about its buildings. It has been suggested that the friars acquired St. Clement's parish church, which stood in the northwest part of the town, but that is unlikely.7 The friary was surrendered to the king in 1538,8 and its site and buildings were granted in 1546 to Henry Grey, Marquess of Dorset and later Duke of Suffolk.?

3 Census, $180 \mathrm{I}$

4 V.C.H. Leics, ii. 34. It already existed in 1284

5 On this view, and for the population of the area, see C. J. Billson, Medieval Leic. 2-3. On the siege, see V.C.H. Leics. ii. 81. And see above, pp. $3,53$.

6 V.C.H. Leics. ii. 34 .

7 Ibid. 34 , and below, pp. 388-9.

8 V.C.H. Leics. ii. 35 .

9 L. छ. P. Hen VIII, xxi( 1 ), pp. 760-71. Dugd. Mon. vi (3), I 846 , places the Leic. Dominicans on an island in the Soar, which was in fact the site of the Augustinian Friars' house. Dugdale's statement is based on Leland, Itin. ed. Toulmin Smith, i. I6, who refers to the friary on the island as the Black Friars, a name usually given to the Dominicans, but which might be applied to Augustinian friars. There can be no doubt about where each friary stood: see Cal. Pat. 1 301-7, 268; 1 334-8, 278; L. छ P. Hen. VIII, xx( I), 656; Leic. Boro. Rec. II03-I327, 371 ; $1327-1509,284$, 307,355 . 


\section{A HISTORY OF LEICESTERSHIRE}

It has not been possible to trace the descent of the property after that time, but for much of the 18 th century the Rudings family, of Westcotes, were important landowners in Black Friars. ${ }^{10}$

From the Dissolution until the early I9th century Black Friars was almost uninhabited. "1 The canalization of the Soar, which ran down one side of the Black Friars, led to the building up of the area. From $c$. 1805 onwards many new houses were built in the area, ${ }^{12}$ and by 1837 it was very largely covered with buildings, though a little open ground still remained in the north-west corner. ${ }^{13}$ In 1821 the population was 597 , and ten years later it had risen to I, I 52.14 The line of the Great Central Railway from London to the north, built under an Act of 1893 and opened in $1899,{ }^{15}$ ran through Black Friars, and the large station built to serve the new line occupied a considerable space in the liberty.

There seems to be no doubt that Black Friars was always considered to be within the borough. During the I8th-century disputes between the borough and the county magistrates the county never claimed to have any rights of jurisdiction in Black Friars. ${ }^{16}$ The district does not seem to have maintained its poor separately in the 18 th century. ${ }^{17}$ In 1803 it is listed as an area maintaining its own poor. ${ }^{18}$ When the Leicester Poor Law Union was formed in 1836 Black Friars was not included in it. ${ }^{19}$ For the next 26 years Black Friars was not included in any union, and seems to have had no arrangements for the poor relief of its inhabitants, a situation all the more serious because by $\mathbf{I} 837$ it had become a poor and densely populated district. ${ }^{20}$ In 1849 it was reported that the liberty's inhabitants had no power to appoint a surveyor of the highways, or to levy rates for road maintenance. ${ }^{2 \mathrm{I}}$ 'The sewerage arrangements, as described at the same date, were deplorable. ${ }^{22}$ This state of affairs was remedied by the establishment of a Local Board of Health, which assumed responsibility for the highways and for the public health of the whole borough, ${ }^{23}$ and by the inclusion of Black Friars in the Leicester Union as a separate civil parish in 1862.24

For ecclesiastical purposes Black Friars was extraparochial until it was included in St. Nicholas's parish in 1880.25

\section{CASTLE VIEW}

CASTle View was a liberty consisting of the precincts of Leicester castle. The exclusion of the borough's authority from the castle no doubt originated in the fact that it was the seat of the town's overlords, the earls of Leicester and later the earls and dukes of Lancaster. The existence of this franchise, near the centre of the town but yet outside the borough boundary, became in time a source of grievance to the corporation. Castle View is not mentioned in Elizabeth I's charter of I 599, by which other liberties near the town were, subject to some reservations, placed under the borough's control, ${ }^{1}$ but during the 18 th century the borough authorities made attempts to bring Castle View under their jurisdiction. ${ }^{2}$ During the struggle for control the borough authorities refused in 1766 and 1767 to have the mace lowered in salute within the castle precincts when the mayor went to take the oath of allegiance on appointment. In 1767 the Duchy of Lancaster's steward refused to allow the mayor to enter the castle unless the mace was lowered, on the grounds that the castle was outside the borough's jurisdiction. Subsequently it was agreed that the

10 Nichols, Leics. i. 296.

II John Speed, Map of Leics. (1610); J. Throsby, Hist. of Leic. frontispiece map; [Susannah Watts], Walk Through Leic. (I804), frontispiece map; Nichols, Leics. i, maps facing pp. 6, 9; and see above, pp. 53, I 54 .

I2 A. T. Patterson, Radical Leic. 40.

${ }_{13}$ Rep. Com. on Boundaries and Wards of Certain Boros., Pt. 2, H.C. 238 ( 1837 ), xxvii.

14 V.C.H. Leics. iii. 179.

15 V.C.H. Leics. iii. $124-5$.

16 In 1832 Black Friars was reckoned as part of the ancient borough of Leicester: Rep. Com. on Proposed Division of Cos, and Boundaries of Boros., Pt. 3, H.C. I41, p. 87 $(1831-2), x x i x$.

17 It is not listed in Rep. Sel. Cttee. Appointed to Consider Returns Made by Overseers of Poor, Rep. of H.C. (Ist Ser.), ix, pp. 385,619 .

${ }_{18}$ Abstract of Returns Relative to the Expense and Maintenance of the Poor, H.C. I75, p. $262(1803-4)$, xiii. oath should be sworn privately. ${ }^{3}$ Castle View was finally brought within the borough under the Municipal Corporations Act. 4

Leicester castle stands on a slight hill overlooking the river, west of the castle church of St. Mary. ${ }^{5}$ Three parts only of the medieval structure remainthe mound, the hall and some cellars, with gateways and some fragments of the enclosure wall. The mound of the Norman castle, which was probably thrown up in 1068 , stands rather to the south of the present hall and slightly nearer to the Newarke. It is now about $30 \mathrm{ft}$. high and about roo ft. across at the top, and was lowered about I 840 by I 2 or I $5 \mathrm{ft}$. The Norman castle was of the motte and bailey type, and the first buildings which stood upon the motte were certainly of wood, although these were replaced by others of lead and stone, probably by Robert de Beaumont at the beginning of the I2th century. At the same time some domestic buildings were probably erected in the bailey, which extended northwards from the motte. The building of the stone hall in the bailey is generally attributed to Robert le Bossu, son of Robert de Beaumont, who suc-

19 See above, p. 257.

20 Rep. Com. on Boundaries and Wards ( 1837 ).

$21 \mathrm{Wm}$. Ranger, Rep. to the Gen. Bd. of Health on a Public Inquiry into the Sewerage of Leic. 12 (Leic. City Ref. Libr. Pamphlets $\mathrm{O}_{2}$, vol. vii). Leic. $7 \mathrm{nl}$. I Jan. I849, p. 2 .

22 Ranger, op. cit. I 5.

23 See above, p. 267 .

24 See above, p. 257

25 Lond. Gaz. I 880, 4303.

I Leic. Boro. Rec. I 509-1603, 363-4.

2 See above, pp. 129-30.

3 R. W. Greaves, Corp. of Leic. $37-38$

$45 \& 6 \mathrm{Wm}$. IV, c. 76; Rep. Com. on Boundaries and Wards of Certain Boros. Pt. 2, H.C. 238 (1837), xxvii. 5 The hist. of Leic. castle is largely based upon 'Leic. Castle', by L. Fox, in T.L.A.S. xxii. I 25-70. For illustrations of the castle see above, plates facing pp. 57, I 91, 278 . 
ceeded his father in I I 8 . On stylistic grounds the hall can probably be assigned to the middle of the I2th century. It now consists of a nave and aisles of six bays, with thick walls of Dane Hills sandstone. The building was divided by timber arcades, some of which survive, although obscured by modern alterations. The original entrance was probably in the southern bay of the east wall, which has now been removed. The original south gable remains, with two round-headed windows resting on a string-course.

In I 73 the castle was held against royal forces by the Earl of Leicester's vassals in the revolt against Henry II which broke out in that year and in which the earl played a leading part. The castle was surrendered to the king in II 74 and was ordered to be dismantled. ${ }^{6}$ It seems probable that the buildings within the fortifications were not destroyed as the great hall seems to date from a period earlier than I I74. The castle continued to be used as a residence by the earls of Leicester. In 1265 it was granted to Edmund, Earl of Lancaster and Leicester. Throughout the I $3^{\text {th }}$ and I $4^{\text {th }}$ centuries the earls and dukes of Lancaster continued to use Leicester castle as a residence and as one of their chief administrative centres. After I 399 the castle was used less as a house than as an estate office.7 The Earl of Lancaster's prison in the castle is first mentioned in $1298 .^{8} \mathrm{It}$ was used for the detention of prisoners taken on the earl's lands. ${ }^{9}$ The castle prison is last mentioned in I $323 .{ }^{10}$

Of the other domestic buildings known to have existed, nothing remains except the cellar known as John of Gaunt's cellar, dating from the I 4 th century, but there were other buildings, including a great chamber, a dancing room and a chapel to the north of the hall, and a kitchen block to the south between the hall and the existing cellars. This was converted to a coach-house in I7 $5 .{ }^{\text {II }}$ The sites of other buildings, including the treasury and other official rooms and the extensive stables, are unknown. The Castle Mill stood on the river to the north-west of the castle. ${ }^{12}$

The enclosure wall, part of which still stands, was built in the early 15 th century. St. Mary's Church had been included in the original bailey, but the new wall ran between the church and the castle to the turret gateway and then westwards to the river. Some fragments of the wall survive to the north of the castle but its exact course is hard to determine because of the lack of remains on the north-east side.

Two of the castle gates still stand. The turret gate was built in 1422-3 and connected the castle enclosure with the Newarke. It was of two stories, with

6 T.L.A.S. xxii. $136-7$; V.C.H. Leics. ii. $8 \mathrm{I}-8 \mathrm{z}$.

7 T.L.A.S. xxii. I 38 , I 49-53, 157.

8 Leic. Boro. Rec. IIO3-I327, 36I-2; L. Fox, Leic. Castle, $2 \mathrm{I}-22,25 ;$ C. J. Billson, Medieval Leic. 4I-42.

9 Leic. Bor. Rec. I I O $3-1327,361-2,373$.

ro Ibid. 377; Fox, Leic. Castle, 22.

II Cf. T.L.A.S. xxii. I6o, and The Builder, xxv. 488 .

12 See below, p. 395.

13 35th Annual Rep. Leic. and Leics. Soc. of Architects, frontispiece. See above, plate facing p. 57 . an entrance and lodge below and a portcullis chamber and other rooms in the upper story. This gateway was partially destroyed in an election riot in I 832. The other gateway stands close to the north door of St. Mary's Church, to which it was joined by houses until these were demolished in $1848 .{ }^{13}$ It is probably the structure which was repaired and virtually rebuilt in I $446-7$ after a fire had badly damaged the former building. ${ }^{14}$ This gatehouse is a timbered building of three stories with a slate roof. The archway itself is of moulded wood. The approach to the entrance was probably once narrowed by a barbican. The Castle House stands close to the entrance. It is an early-Igth-century house of red brick, with a Tuscan porch in stucco, behind which is a dignified entrance surmounted by a fanlight.

After the end of the I $5^{\text {th }}$ century the castle fell into decay, and surveys made during the 16 th and 17 th centuries speak of ruined and derelict buildings. In 1650 the castle was put up for sale, but returned to the Crown at the Restoration. About I 690 the east wall of the hall was taken down and rebuilt in brick, and although the other surviving buildings were leased privately from 1660 onwards, the hall remained in Crown hands and was used as an assize court, a practice dating from at least $1273 .{ }^{15}$ About I 82 I the hall was divided into two courts and various other rooms, ${ }^{16}$ so that its original internal structure is now almost wholly obscured. In 1875 the castle site, excluding the buildings but including the mound, was purchased by the county, and in 1888 the county justices bought the hall and the neighbouring houses, which had been the subject of negotiations with the Crown since about $1803 .{ }^{17}$ Most of the other buildings were destroyed in the i 8 th century. The interior of the hall was again altered in 1856 , under the supervision of William Parsons, the county surveyor. ${ }^{18}$ The castle remained in 1956 the property of the county and was still used as a court of law. In 1926 the area between the castle and the river was opened as a garden, thus making possible the preservation of fragments of the boundary wall and enhancing the interest of the castle site. This area had formerly been used as a corporation rubbish dump. ${ }^{19}$

Besides the castle itself, the liberty of Castle View included a few houses built round the castle to the north and north-east. In I 801 the population of the liberty was 52 . By 1831 it had risen to 127 and in I89I, the last year in which a separate census figure for Castle View was returned in the census, the population was $136 .{ }^{20}$ Castle View ceased to exist as an administrative unit in 1896.21

\footnotetext{
14 T.L.A.S. xxii. 155 .

I 5 Ibid. I 38, I 58-6I; Leic. Boro. Rec. I I03-I327, I I 4.

I6 J. Thompson, Leic. Castle, 32.

17 L.R.O. Leic. Castle Conveyances.

18 L.R.O., Letters and accounts relating to the alterations.

19 Leic. Mercury, Io May 1926.

20 V.C.H. Leics, iii. I 79, 185.

21 See above, p. 288.
} 


\section{THE NEWARKE}

THE liberty of the Newarke was a small rectangular district lying on the east bank of the Soar, to the south of the old walled area of the borough and at the edge of the gravel terrace on which Leicester is built. 'The western part of the Newarke is sited on the alluvium of the river's immediate valley; the central and eastern portions on the gravel. Two ancient entrances to the area survive: the turret gateway, from the castle, ${ }^{I}$ and the I4th-century Magazine Gate, standing at the eastern limit of the liberty. The Magazine Gate, originally the entrance to the walled precinct of the Newarke College, is a stone building of two stories, without trace of a portcullis or other fortifications. A wide moulded arch forms the road entrance into the Newarke and there were domestic rooms above. The high parapet has been restored in modern times, and the gate is joined up at the back with the part-facsimile structure of the Drill Hall and the other buildings forming the headquarters of the Territorial units of the Royal Leicestershire Regiment.

The site of the hospital and college of the Newarke lay within an area formed by an enclosure wall, which ran eastwards from the river along the line of Mill Lane and Bonners Lane, behind Oxford Street to the Magazine Gate and behind the present Newarke Houses and the Chantry House to the river. ${ }^{2}$ The hospital still survives in the form of the Trinity Hospital, but no trace of the college remains, beyond a few arches still preserved in the basement of the College of Art and Technology which stands on the site. The church and collegiate buildings were destroyed shortly after the dissolution of the college in I 547.3 The College of Art and Technology was built in 1897 by S. Perkins Pick, and considerably extended before the Second World War.4

Of the other historic buildings within the Newarke the Chantry House is perhaps the most notable. This is a three-storied building of Charnwood stone, begun in I 5 II-I 2 for the chantry priests who were supported by William Wigston to say services in the collegiate church. Various additions were made to it between the I6th and I 9 th centuries. ${ }^{5}$ This was acquired by a private trust in I9I 2 at the same time as it obtained possession of Skeffington House next door, and subsequently both buildings were taken over by Leicester corporation. ${ }^{6}$ The Chantry House was restored in $1953^{-6}$, for use as the medieval section of the museum of Leicester and Leicestershire social history at present in Skeffington House. The latter dates from $c$. I 590-I600. It is of three stories, with a fine stucco front, and an eastern side wing added in the last century. The house has a crenel-

I See above, p. 345 .

2 Map in S. H. Skillington, The Nervarke and its Associations, facing p. I\%.

3 V.C.H. Leics, ii. 5 I. For the discovery of the remains, see Leic. Mercury, 4 and 5 Sept. I 935. And see below, p. 406.

${ }^{4}$ The Builder, 1xxii. 504. The extensions were made by the same firm: Leic. Merc. I7 Sept. I 928.

5 A. Hamilton Thompson, Hist of Hosp, and New Coll. of St. Mary in the Newarke, Leic. 230; for the history of the building see T.L.A.S. xxxi. $62-63$. For a recent photograph, see above, plate facing p. 56 .

Kelly's Dir. Leic. (1938), p. xvi; and inf. from museum authorities; C. J. Billson, Medieval Leic. 204-5. lated parapet and the windows are plain and modern. The side extension continues the crenellation and is composed of a series of chamfered bays. The two front doors have plain shallow cases with segmental arches and plain cornices. The central door is topped with a stone ball and there are similar balls on the gables. The fine central staircase was probably added during alterations in $176 \mathrm{I}$ by William Wright. ${ }^{7}$

The so-called 'Rupert's Tower', which stood in Bonners Lane until its demolition about 1933 , so far from being a fortification was a purely domestic building dating from the 14 th century. ${ }^{8}$ In the west of the area are some streets of red brick houses, built about 1860 . The area of the liberty was 18 acres in I 891.9

In $133^{\circ}$ the district which was to become the liberty of the Newarke was possessed by Henry, Earl of Lancaster. At that date it does not seem to have existed as a distinct unit, and it is not possible to state definitely who may have owned the land in earlier periods ; it may, however, be reasonably conjectured that the land had been owned by Henry's predecessors, the earls of Leicester and Lancaster, who had possessed the nearby castle since the I 2 th century. In I330 Earl Henry founded a hospital at Leicester, and gave it a site immediately to the south of the castle, and just outside the borough walls. The earl's foundation was much enlarged by his son, Henry, Duke of Lancaster, who increased the size of the hospital and added to it a large and richly endowed chantry college. ${ }^{10}$ The dean and canons of the college claimed exemption from the borough jurisdiction, and in 1360 the king confirmed that the college and its precincts were so exempt.II For the future the precincts formed a small liberty. The college was known as St. Mary's of the New Work, or Newarke, to distinguish it from the older college of St. Mary de Castro inside the borough.

The College of the Newarke was dissolved under Edward VI, ${ }^{12}$ and in 1548 its site and buildings were granted to John Beaumont, of Grace Dieu, and William Gies. ${ }^{13}$ In 1552 Beaumont was obliged to surrender all his lands to the Crown, which presumably then regained the Newarke. ${ }^{14}$ In 1600 the Newarke (except presumably the ground occupied by the hospital buildings) was being leased from the queen by Henry Beaumont. 15 Subsequently the property became divided amongst various owners, though the Beaumont family long retained a footing there, and Sir Thomas Beaumont possessed a mansion in the Newarke in $1670 .{ }^{16}$ By I 642 the Newarke gatehouse was in the possession of the county, which used it as a magazine for storing arms for the trained bands. ${ }^{17}$

7 Inf. from museum.

8 T.L.A.S. xxi. I 88-9o.

9 Census, I89 I

10 For details of the coll. see V.C.H. Leics. ii. 48 sqq.

II See above, p. 17 .

12 V.C.H. Leics, ii. 50-5 I.

13 Cal. Pat. 1547-8, 300-I.

14 Farnham, Leics. Notes, vi. $32 \mathrm{I}-2$.

15 Leic. Boro. Rec. I 509-I603, 423.

16 E. $179 / 240 / 279$.

17 V.C.H. Leics. ii. I I I. This seems to correct the statement made by Throsby and others that the county only obtained the Magazine Gate in 1782 : J. Throsby. Hist. of Leic. 355 . 


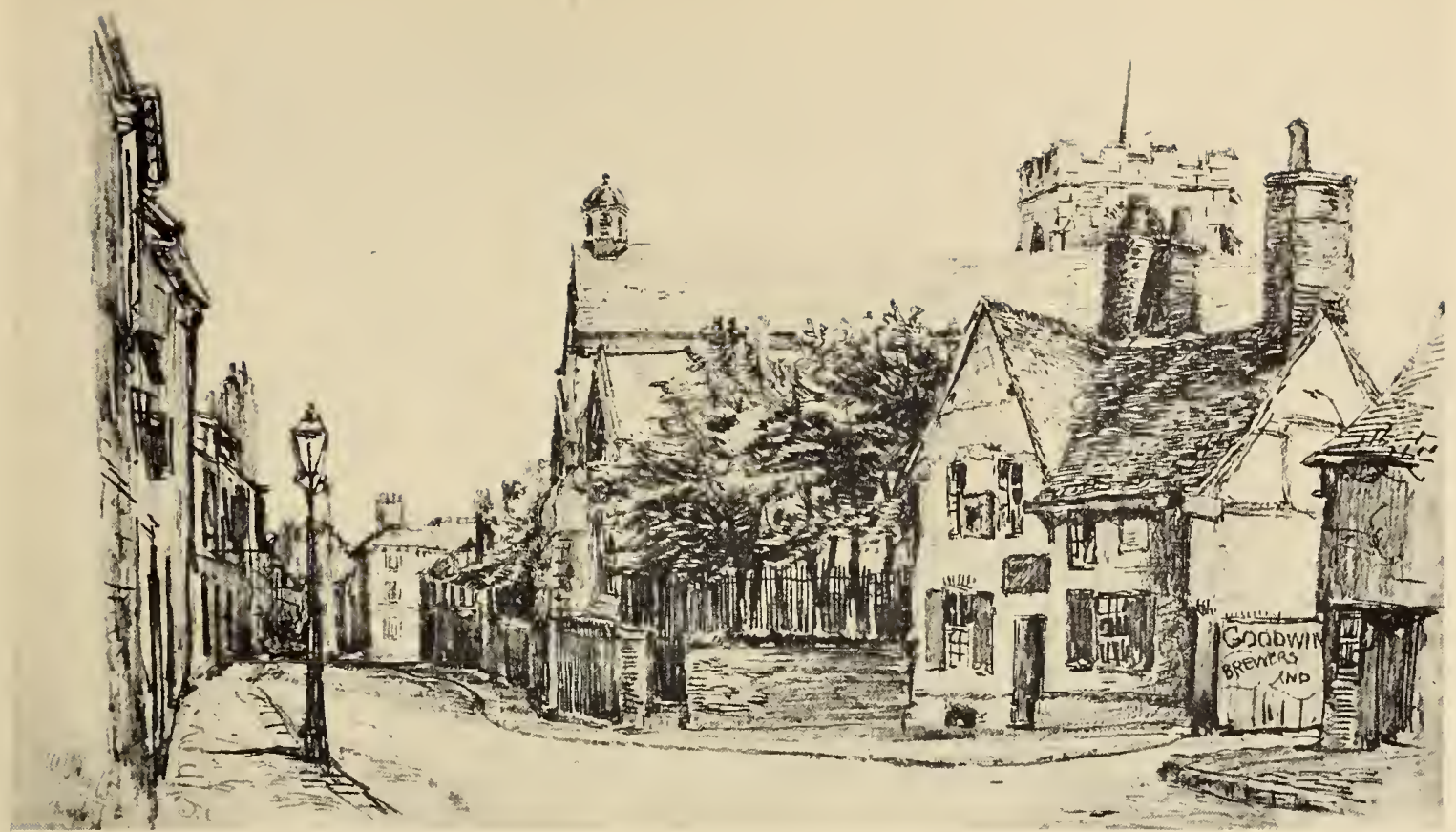

High Cross Street and All Saints' Church, c. i 879

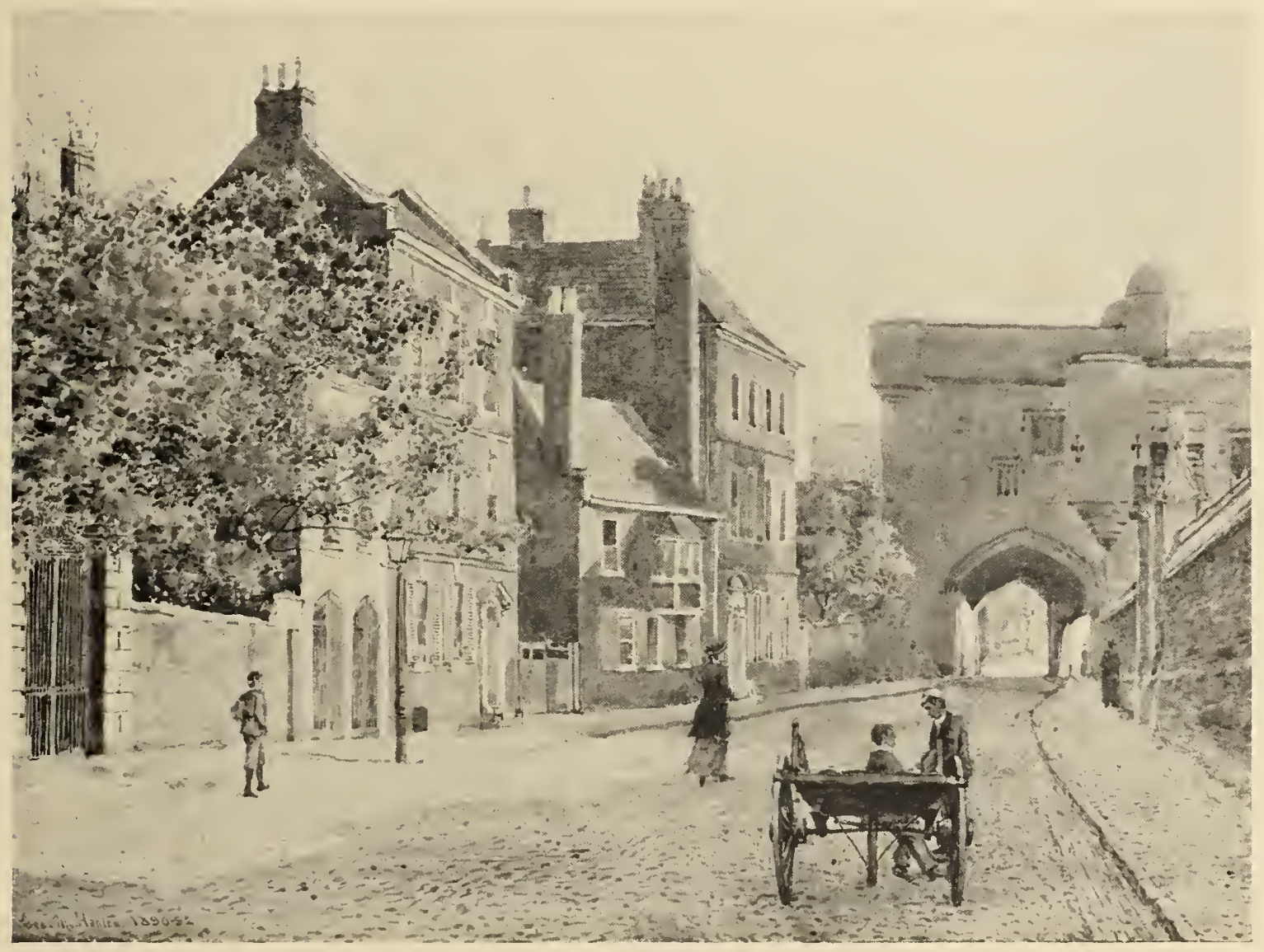

The Newarke, I $890-2$ 


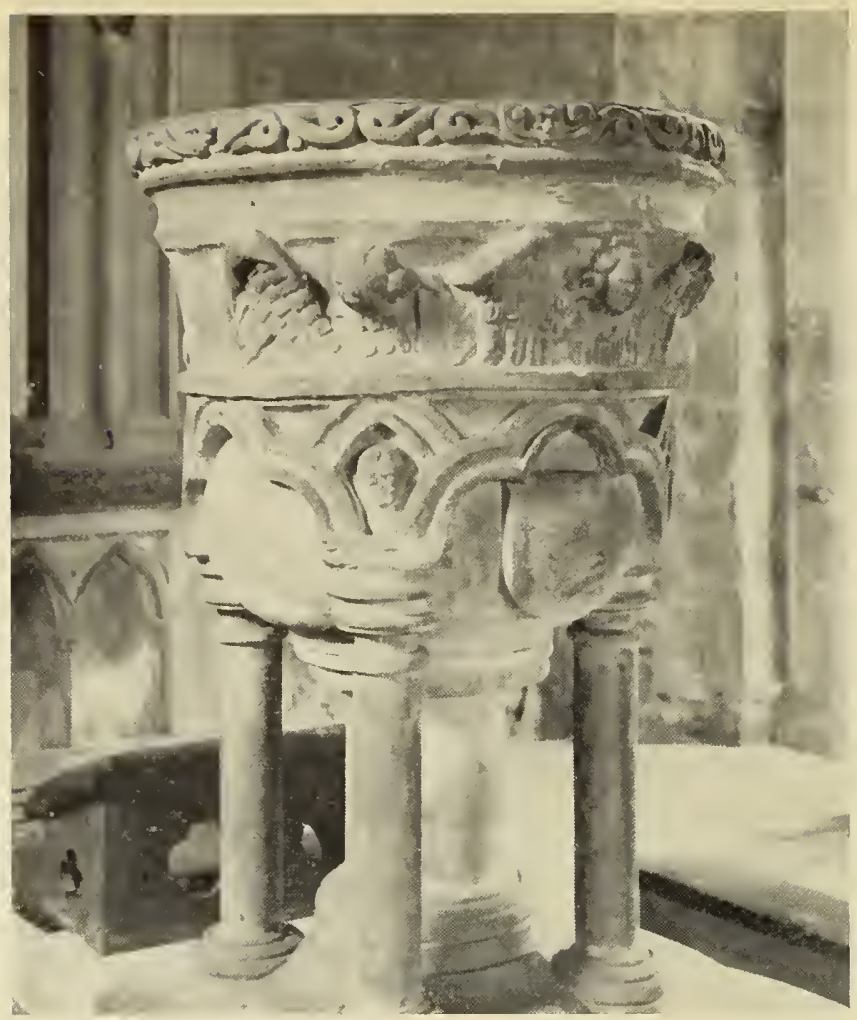

ST. Mary's Church: tiie font

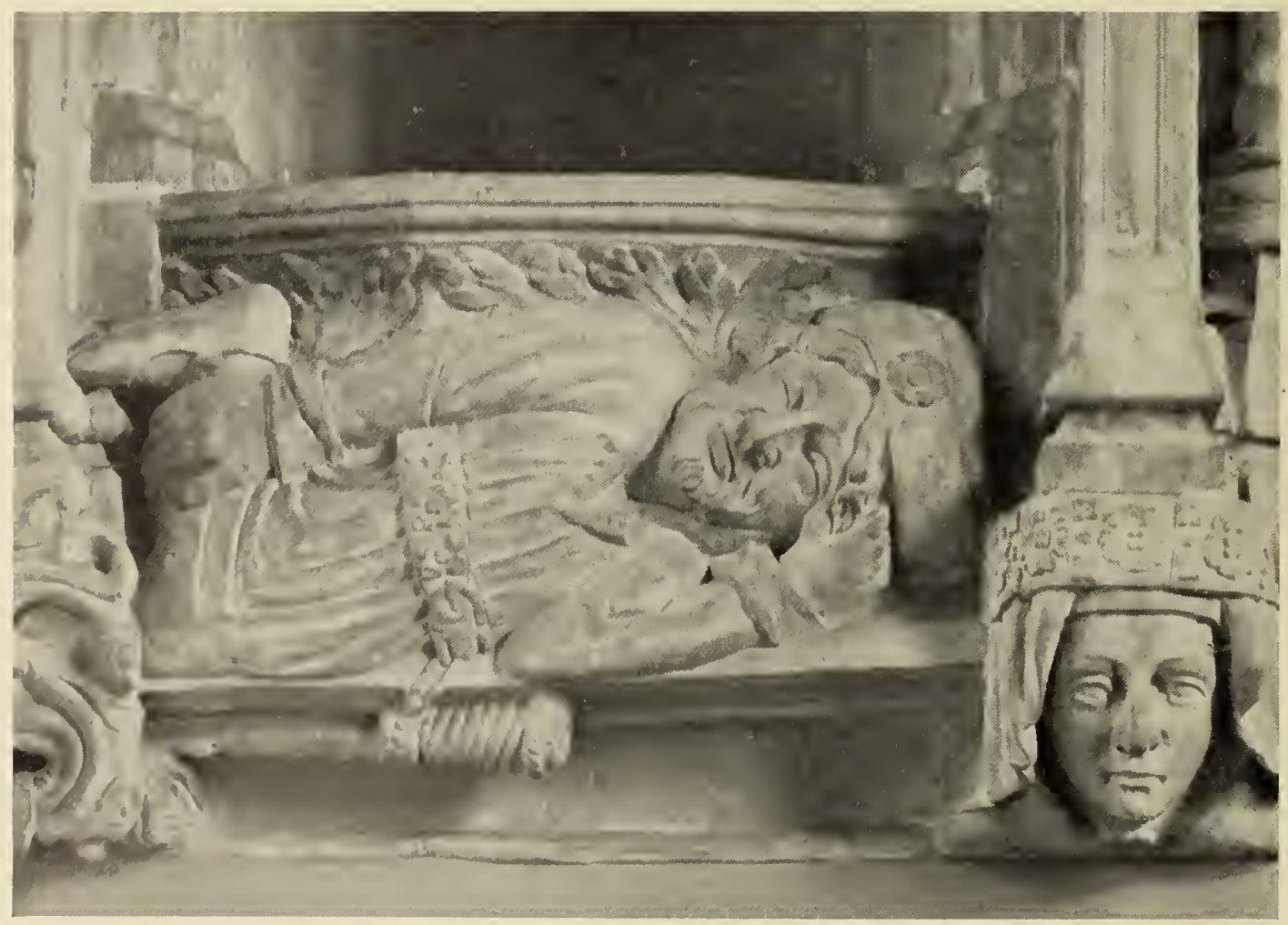

ST. Margaret's Church : The 'Bossu' Niche 
In 1813,1859 , and 1862 further purchases of land in the Newarke were made by the county, to provide buildings for the militia, and later for the volunteer and Territorial forces of Leicestershire. ${ }^{18}$

For ecclesiastical purposes the Newwarke was for long extra-parochial. So long as the college existed its clergy no doubt performed all the necessary religious functions for those dwelling in the precincts. In 1652 attempts were made to place the Newarke ecclesiastically within the parish of St. Mary de Castro, which enclosed the liberty on three sides, but the inhabitants repulsed these efforts, saying that they were not sure 'how farr wee may like or effect any particuler minister of any one church or parishe', and protesting that they were not in law liable to contribute to the maintenance of any minister. ${ }^{19}$ 'The Newarke became part of St. Mary's parish for ecclesiastical purposes in $187 \mathrm{I}^{20}$

While the liberty was still in the hands of the college the liberty was wholly occupied by the college precincts. Under Edward VI the dean and each of the twelve canons had a house, and the clergy who served the various chantries in the college church occupied three further houses. The college church was described by Leland as fair, though not large; a cloister adjoined it. The precincts also contained the hospital, a treasury, and a library. The whole area was surrounded by a wall, with the main entrance through the gatehouse which still exists. ${ }^{2 I}$ The church and many of the other buildings fell into decay soon after the college's suppression. ${ }^{22}$

From the 17 th century until well into the I 9 th, the Newarke was the residence of some of Leicester's wealthiest inhabitants. Possibly it was the existence of the substantial houses built for the dean and canons that first attracted the richer townsmen to the liberty, but the place also had the advantage of being extra-parochial, with in consequence few poor rates, and of being at once close to, and rather secluded from, the town itself. It was probably in the Newarke that the earliest dwelling houses to be built in Leicester entirely of brick were erected. ${ }^{23}$ According to the Hearth Tax returns of 1670 there were then in the Newarke and the adjacent liberty of Castle View I 6 houses (excluding Trinity Hospital), with a total of 89 hearths, an average of more than 5 hearths to each house. None of the inhabitants was excused payment of tax on account of poverty, and only two of them had only one hearth. ${ }^{24}$ Celia Fiennes, visiting Leicester in 1698 , remarked on the fine brick and stone houses in the Newarke, ${ }^{25}$ and Nichols described the liberty as the handsomest part of

18 White, Leics. Dir. (1877), 23 ; L.R.O., purchase deeds of Newarke property.

${ }^{19}$ Leic. Boro. Rec. $1603-88,402-4$. The clergy of St. Mary de Castro had given up their rights in the coll. precinct in 1334: Hamilton Thompson, Hist. of Hosp. and New Coll. in the Newarke, 99.

${ }^{20}$ Kelly's Dir. Leics. and Rut. (1881), 547.

${ }_{21}$ Assoc. Archit. Soc. Rep. छं Papers, xxx. 538-40; see also above, p. 345 .

22 Hamilton Thompson, op, cit. 230

${ }_{23}$ Celia Fiennes, Fourneys, ed. C. Morris, 163.

24 E. $179 / 240 / 279$.

25 Celia Fiennes, op. cit. 163.

${ }_{26}$ Nichols, Leics. i. 349.

27 C. J. Billson, Leic. Memoirs, 20-21 ; White, Dir. Leics. (1877), 389.

28 White, op. cit. $342,349,351,372,387$; and see existing houses.
Leicester. ${ }^{26}$ Until well into the I9th century the Newarke continued to house some of the town's most prominent inhabitants, ${ }^{27}$ but as Leicester expanded the liberty ceased to be on the edge of the town, and about 1860 its south-west portion was built up with streets of terrace houses. ${ }^{28}$ 'The character of the Newarke was largely destroyed when in I 898 a new bridge was built across a branch of the Soar to link the Newarke with the west bank of the river. ${ }^{29}$ 'The construction of this bridge turned the passage through the oldest and most attractive portion of the liberty into an important through road. The drastic demolitions necessary to create a highway of adequate width led to the destruction of many of the old houses ${ }^{30}$ and the formation of a large open space, some of which has subsequently been utilized as a bus station.

The origin of the Newarke as a separate liberty has already been described. ${ }^{31}$ After the dissolution of Newarke College the area remained outside the jurisdiction of the borough until I 599, when a royal charter placed it under the borough authorities. ${ }^{32}$ This grant to the town was not without ambiguities, and in I60o Henry Beaumont, the lessee of the Newarke, refused to allow the borough to collect a subsidy in the liberty. ${ }^{33}$ The dispute continued for several years, but the borough was unable either to make good its claim that the charter of I 599 gave it control of the Newarke, or to obtain a new charter which would place its rights beyond dispute. ${ }^{34}$ Further attempts made in the I 8th century by the borough to acquire exclusive jurisdiction in the Newarke also failed. 35 The Newarke in consequence remained an independent liberty until the I 9 th century. The administration of the poor law in the district has been dealt with elsewhere. ${ }^{36}$ Under the Municipal Corporations Reform Act of I 835 the Newarke was brought within the borough. ${ }^{37}$ It survived for some years with a similar status to the old borough parishes as a unit for the collection of poor rates. ${ }^{38}$

CHARITIES. The history of Trinity Hospital, which although situated in the Newarke was an institution which served a much wider region, has been discussed elsewhere. ${ }^{39}$ 'The liberty has no other charities. In 1800 an asylum was set up in the Newarke, for the maintenance of poor girls and for training them in domestic service. It accommodated twelve girls at a time.40 The asylum was demolished in 1927 , when extensions to the College of Technology were made. ${ }^{4}$ I

29 T.L.A.S. ix. 4 , and plan facing p. 5 .

30 See the water colour by Henton in Newarke Houses Museum, Leic. showing the site as it was before alteration; and e.g. 3 Ist Rep. Leic. and Leics. Soc. of Architects (19034), drawings of nos. I -3 the Newarke; Leic. Merc. 23 Nov. I 926, for demolition of the 'Guest House'.

3 See above, p. 346 .

32 Leic. Boro. Rec. I 509-1603,364; and see above, p. 57.

33 Ibid. 423 .

34 Ibid. 434,443 ; and see above, p. 57

35 See above, p. 129.

36 See above, pp. $187-9$

375 \& 6 Wm. IV, c. 76; Rep. Com. on Boundaries and

Wards of Certain Boros. Pt. 2, H.C. 238 (1837), xxvii.

38 See above, p. 257.

39 See below, p. 406

40 White, Leics. Dir. (1846), Ioo.

4 I Leic. Mail, 5 Jan. 1927. 


\section{ST. LEONARD'S}

THE whole of the ancient parish of St. Leonard lies close to the banks of the River Soar. In I89I it was estimated to cover 36 acres. ${ }^{1}$ The greater part lies on the river's west bank, but St. Leonard's also includes a small part of the district known as Frog Island on the east bank. 'The soil is alluvium. 'The area became part of the new Leicester civil parish in 1896 , but remained a separate parish for ecclesiastical purposes. In 1931 its population was $2,692 .^{2}$

St. Leonard's lies well outside the old walled area of Leicester, the eastern boundary of the parish being some 300 yards from the site of the town's North Gate. Within the parish boundaries the Soar is crossed by the North Bridge, which is known to have been in existence by 1305 , and may well have been built by the middle of the 13 th century. ${ }^{3}$ Northgate Street, linking the east end of the bridge with the North Gate, Abbey Gate, running north-east from the west end of the bridge to St. Mary's Abbey, and Wood Gate, running from the bridge northwestwards into Leicester Forest, have always been the principal streets of the parish. It was probably the existence of a crossing over the Soar that first led to the growth of a detached suburb in what became St. Leonard's parish. It is not known when first a distinct settlement arose, but the parish of St. Leonard was already established by $1220 .{ }^{4}$ During the Middle Ages the parish must have been largely dominated by St. Mary's Abbey, which appropriated the church, ${ }^{5}$ and which in the 12 th century and later obtained considerable grants of land in St. Leonard's, including a carucate which had once belonged to the moneyers of Leicester. ${ }^{6}$ After the Dissolution these lands were granted away by the Crown in $\mathbf{I} 545$ to three speculators, Richard, Roger, and Robert Taverner,7 who probably disposed of them piecemeal.

By the end of the I6th century houses had been built along both sides of Northgate Street from the North Gate to the North Bridge, so that St. Leonard's was connected with the town by a continuous strip of buildings. ${ }^{8}$ The parish, however, remained poor and scantily populated. From the end of the I6th century until about I 860 the dwellings in the parish consisted only of houses along both sides of Abbey Gate, a few more in Wood Gate, and those houses at the north end of Northgate Street (known as Frog Island) which fell within St. Leonard's. ${ }^{9}$ In I6 I I it was said that the parishioners were in general so poor that only four of them were sufficiently prosperous to contribute towards the repair

1 Census, 1891

2 Census, I 93 I: Ecclesiastical Areas.

V.C.H. Leics, iii. 86. 238 .

Rot. Hugonis de Welles, ed. W. P. W. Phillimore, i.

Ibid.; A. Hamilton Thompson, Leic. Abbey, 16o-2

Nichols, Leics. i, App. 54.

7 L. छळ. P. Hen. VIII, xx(I), p. 309.

8 Nichols, Leics. i, map facing p. 9.

Ibid. maps facing pp. 6, 9; T. and G. Ellis, Plan of Leic. (1828); [S. Watts], Walk through Leic. frontispiece map; J. Throsby, Hist. of Leic, 404-5 and frontispiece map; Rep. Com. on Boundaries and Wards of Certain Boros. Pt. 2, H.C. 238 ( 1837 ), xxvii.

io Leic. Boro. Rec. $1603-88$, I 16; B.M. Harl. MS. 6 I 8. 11 V.C.H. Leics. iii. 179. of the church. ${ }^{\text {I0 }}$ In 1801 the parish's population was only 390 , and in I86I it was still only 44 I. II Subsequently, however, owing to the building of a number of small residential streets leading off Abbey Gate and Wood Gate, the population rapidly increased, and in I88 I it was 3,046. ${ }^{2}$ By the end of the I 9 th century the parish had been almost entirely built up. ${ }^{13}$

During the Middle Ages, St. Leonard's parish, or at least that part of it which lay to the west of the Soar, seems to have been regarded as lying outside the borough of Leicester. A list of the town's wards with their boundaries, made in 1484 , includes the part of St. Leonard's on Frog Island, but does not mention the remainder of the parish, lying to the west of the river. ${ }^{\mathrm{I}} 4$ Further evidence that the Frog Island portion of the parish was considered in the Middle Ages to lie within the borough is to be found in the fact that the town paid for the repair of the North Bridge in $13^{6} 5^{-6},{ }^{15}$ for if the Frog Island portion had been outside the borough boundaries, the North Bridge would have been wholly outside, and is unlikely then to have been maintained by the borough. By the reign of Elizabeth I, St. Leonard's was definitely outside the borough, ${ }^{16}$ but was brought within the borough by the royal charter of I599, saving the rights which might have been granted previously to others. ${ }^{17}$ In spite of this grant, the county justices exercised jurisdiction in the parish in the 18 th century and perhaps earlier, and it was finally decided that they and the borough justices should have concurrent jurisdiction there as in the other liberties. ${ }^{18}$ Frog Island remained under the control of the borough. ${ }^{19}$ Under the Municipal Corporations Act ${ }^{20}$ the whole of the parish was brought within the borough. ${ }^{2 I}$ Although the church ceased to exist in the 17 th century, the parish continued to be administered by its own officers. The administration of the poor laws in the parish has been dealt with elsewhere. ${ }^{22}$

CHURCH. Before I220 St. Leonard's Church was appropriated by Leicester Abbey. ${ }^{23}$ It is not known when the abbey obtained the advowson, but if St. Leonard's already existed in II43, when the abbey was founded and endowed by Robert, Earl of Leicester with all the churches of Leicester, ${ }^{24}$ it would have been acquired by the abbey. St. Leonard's remained appropriated to Leicester Abbey until the Dissolution. ${ }^{25}$ In $123^{8-9}$ it was said that the Vicar of St. Leonard's received yearly the corrody of a canon

I2 Ibid.; Spencer, New Guide to Leic. (1888), frontispiece map.

${ }_{13}$ Wright's Dir. Leic. (1 g02), frontispiece map.

${ }_{14}$ Leic. Boro. Rec. I327-I 509, 306-8.

15 Ibid. 140.

16 Ibid. $I 509-1603,233 . \quad 17$ Ibid. 364.

18 Nichols, Leics. i. 323; for further details see R. Greaves, Corp. of Leic. 36-39 and above, p. I 30

19 Rep. Com. on Division of Cos. and Boundaries of Boros. Pt. 3, H.C. I4I, p. $87\left(1831^{-2}\right)$, xxix.

${ }^{20} 5 \& 6 \mathrm{Wm}$. IV, c. 76 .

${ }_{21}$ Rep. Com. on Boundaries and Wards of Certain Boros. Pt. 2, H.C. 238 (1837), xxvii.

22 See above, pp. $187^{-9}$.

23 Rot. Hugonis de Welles, i. 238

24 V.C.H. Leics, ii. 13.

25 Ibid. 17. 
of the abbey and a salary of $f_{2} \mathrm{I} .{ }^{26}$ In $\mathrm{I} 254$ the stipend of the vicar was held to be insufficient. ${ }^{27}$ In 1437 it was decided that the living was too poor to support a vicar, and that the church should in future be served by a stipendiary chaplain, and after this the parish seems to have been without a vicar for some considerable time. ${ }^{28}$ In 1509 John Birmingham, who was described as the Vicar of St. Leonard's, was accused of having allowed a parishioner to die unconfessed and without the eucharist, and with having been negligent of his duties in other ways. ${ }^{29}$ Presumably the appointment of vicars had been resumed, though Birmingham's position is not precisely defined. In I 5I7 it was said that the chancel of St. Leonard's was in disrepair, and that the lights were not kept burning in the church. ${ }^{30}$ In 1526 , when John Barton was vicar, it was reported that the church furnishings were deficient, and that quarrelsome and gossiping persons attended the services. ${ }^{31}$ After the Dissolution the advowson was in the hands of the Crown until it was given to the Bishop of Peterborough in $1867 .{ }^{32}$ After the creation of the see of Leicester in 1926 the patronage was transferred to the new bishop. ${ }^{33}$ The living was valued at $£ 6$ in $1535^{34}$ and augmented in 1737 by a gift from Queen Anne's Bounty. It was worth $f_{40}$ in 1831.35

Early in the $17^{\text {th }}$ century the church fabric was evidently dilapidated, for in I6I I the mayor and bailiffs of Leicester appealed to the Bishop of Lincoln to permit a ruined portion of the church to be pulled down; the aisle roof had apparently collapsed and was in danger of pulling the rest of the structure down with it. The mayor stated that the part of the church which was sound was sufficiently large to accommodate the parishioners, and asked the bishop to permit the materials from the ruined portion to be used to repair the rest. ${ }^{36}$ In 1639 a brief was issued for the repairing of the steeple, ${ }^{37}$ and some repair work was carried out in I 642.38 The church was destroyed soon afterwards; it is said to have been demolished during Fairfax's siege of Leicester in I645 because the church tower commanded the North Bridge. ${ }^{39}$

For some 200 years St. Leonard's parish was without a church. A separate register was kept, and the graveyard remained open until i $856 .^{40}$ In I $65^{\circ}$ the cure was being served by the Vicar of All Saints'.4I The Vicar of All Saints' continued to officiate in St. Leonard's until the early roth century, when it seems to have become usual for the Vicar of St. Margaret's to be in charge. ${ }^{22}$ St. Leonard's remained a distinct parish, and was never merged with St. Margaret's or All Saints'. ${ }^{43}$ Later in the I 9 th century the vicarage of St. Leonard's was usually held by the

26 Rot. Rob. Grosseteste, ed. F. N. Davis, 404.

$27 \mathrm{Val}$. of Norw. ed. W. E. Lunt, 250

28 Nichols, Leics. i. 322; Hamilton Thompson, Leic. Abbey, I62.

${ }_{29}$ T.L.A.S. xxvi. 98 ; Assoc. Archit. Soc. Rep. छ Papers, xxviii. 660-I.

30 Visitations in Dioc. Linc. ${ }_{5} I 7-3 I$, ed. A. Hamilton Thompson, i. 32

31 T.L.A.S.xxvi. 99; Assoc. Archit. Soc. Rep. E๐ Papers, xxviii. 201

32 Lond. Gazette, I867, p. 29 I I.

33 Kelly's Dir. Leics. and Rut. (1 928), I 3 I.

$34 \mathrm{Val}$. Eccl. (Rec. Com.), iv. I 48.

35 White, Dir. Leics. (1 846$), 90$.

36 Leic. Bara. Rec. I603-88, i 6.

37 Copy in custody of St. Leonard's par. Over f6o was collected from various sources: inf. from par. accts. communicated by Mr. Jack Hill.
Vicar of All Saints' or St. Martin's.44 In I83I the value of the living was $f_{40} .^{45}$

Plans for rebuilding the church of St. Leonard were discussed as early as $1815,{ }^{46}$ but nothing was achieved until the great increase in the parish's population in the late I gth $^{\text {th }}$ century made a new church in the northern part of Leicester essential. In I 874 a separate vicar for St. Leonard's was inducted, and from that time onwards services were held in the parish school, 47 which had been built in the churchyard in 1846.48 The foundation stone of a new church, designed by $\mathrm{F}$. W. Ordish, was laid in 1876,49 and the new building was consecrated in 1877.50 The incumbent of St. Leonard's is now (1956) largely responsible for the adjacent extra-parochial areas of Gilroes, Leicester Abbey, and Beaumont Leys.

Until the Dissolution the tithes belonged to Leicester Abbey; in I 535 they were valued at $f_{2} 23.4 d .51$ At the Dissolution the tithes fell to the Crown and were granted away before 1646 , when they were in the possession of a lay impropriator, William Rudyard. The parishioners were then refusing to pay tithes, possibly because they had no church. 52 The tithes were commuted in $185^{\circ}$ for annual payments of $£ .3$ to the vicar for the small tithes and $f_{1}$ 2s. for the great tithes to the impropriator, who was then a barrister, Nicholas Simons of Lincoln's Inn. ${ }^{53}$

The church of ST. LEONARD is built of Mountsorrel granite with stone dressings. It consists of nave, chancel, and south aisle. The original design also included a north aisle, tower, and spire, but these were never built, as difficulty was found in paying even for the work which was done. The building is an austere example of the I 3 th-century style. Two pieces of stone from the old church are preserved, together with the font. In 1896 the foundations showed signs of collapse and the fabric was strengthened. 54

The registers date from $\mathrm{I} 682$ and are incomplete. There are no records of marriages until I 813 , baptisms and burials are missing for I 7 I $4-30$, and burials for I790-3. 'The plate, consisting of a silver cup, paten, and flagon, was given in 1877 . There are no bells.

CHARITIES. Robert Auceter, by will proved I633, left property in Abbey Gate which was to be subject, among other payments, to a charge of $20 s$. yearly for the poor of St. Leonard's parish. Up to 1828 the payment was regularly made. Arrangements were made to revive it in $\mathbf{1} 837.5^{55}$ The charity is now managed by the corporation and 20 . for bread is paid from nos. I-7 Littleton Street. ${ }^{56}$

38 Ex inf. Mr. Hill. 39 Nichols, Leics, i. 322.

40 Ibid.; par. reg. in custody of St. Leonard's par.

$4 \mathrm{I}$ Nichols, Leics. i. 322.

42 Ibid. 323; Curtis, Topog. Hist. Leics. 108.

43 Curtis, op. cit. I08.

44 Ibid., White, Dir. Leics. (1846), 90

45 White, loc. cit.

46 Nichols, Leics. I. 323 and plate xxiii.

47 White, Dir. Leics. (I 877), 297 ; par. regs.

48 White, op. cit. 316. 49 Ibid. 297.

50 Kelly's Dir. Leics. and Rut. (1 888), 554.

5 I $\mathrm{Val}$. Eccl. (Rec. Com.), iv. I 46.

52 Leic. Boro. Rec. I603-88, 343 .

53 L.R.O., Tithe Award, St. I.eonard's par

54 T.L.A.S. viii. 248.

55 32nd Rep. Com. Char. Pt. 5 [163], p. I05, H.C. (I839), xv.

${ }^{56}$ Leicester's Finances (I 952-3), 354-5. 


\section{A HISTORY OF LEICESTERSHIRE}

William Springthorpe, who held various parish offices in the mid-I 7 th century and who died in I689, left the profits of the herbage of St. Leonard's churchyard and $6 s$. charged on a house in the parish to the poor of the parish. ${ }^{57}$ This charity was paid throughout the I 8th century, but may have been in abeyance when the Charity Commissioners made their report, as there is no mention of it. There was no church by the time that Springthorpe died and it may have been felt that the profits of the churchyard were suitable for a charity, although how he came to be in a position to give such profits to the poor remains unexplained. The income from the herbage probably ceased to be paid when the churchyard was built over. ${ }^{88}$ The $6 s$. rent-charge is now paid from the Old Robin Hood Inn in Woodgate, formerly the Fleece. In I93 I the charity came under the management of trustees appointed by the corporation and a yearly sum of $6 s .8 d$. is now paid by them in two parts, one of which goes to St. Leonard's and one to the Abbey Gate Baptist Mission, the only free church in the parish. The money is used to buy shoes for two poor widows. 59

St. Leonard's parish used to receive $f_{2}$ yearly from Gilroes and from Sherman's Ground ${ }^{60}$ The former was paid up to about $175^{\circ}$ from at least the end of the I 7 th century, but in $175^{\circ}$ the occupier of the land refused further payment. The payment from Sherman's Ground was also refused in $175^{\circ}$, when the parish levied a distress on the occupier, and the payments continued until at least $I 783$. By 1837 the charity had been lost and the commissioners make no mention of it. A similar sum was paid from Freak's Ground from about I7 9 by its owners, the corporation, which owed considerable arrears in I837.61 The payment had then been reduced to fI I $s$. It seems never to have been revived. The origin of all these payments is unknown.

The parish also receives one-third of the Countess of Devonshire's Charity, and a payment under Heyrick's Charity for bread from the Trustees of the Leicester General Charities. ${ }^{62}$

At the end of the I 7 th century a charity left by a Mr. Smart for eight $2 d$. loaves to be given to the poor at Christmas is mentioned. ${ }^{63}$ There are no records of this charity ever having been dispensed.

The histories of the Countess of Devonshire's Hospital $^{64}$ and of St. Leonard's Hospital ${ }^{6_{5}}$ are dealt with elsewhere.

\section{ST. MAR GARET'S}

THE ancient parish of St. Margaret consisted of two parts: that within the borough boundary, which is the area under consideration in this section, lay entirely outside the walled town and extended over the East Field of Leicester. The remaining part was the chapelry of Knighton, which is discussed separately since it lay outside the borough boundary until

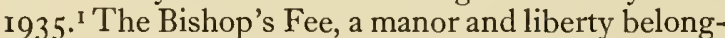
ing to the Bishop of Lincoln, ${ }^{2}$ was included in the part of the ancient parish within the borough, but its exact boundaries are not clear and its constitutional position was doubtful from its earliest existence. It is not known how it came into the hands of the Bishop of Lincoln and the suggestion that it had belonged to the Anglo-Saxon bishopric cannot be substantiated. Neither is it at all clear to what extent the liberty was manorialized, although the bishop had a grange near St. Margaret's Church, the 'curia' referred to $c .1205 .{ }^{3}$ It was probably the ruins of this building, or perhaps even the vicarage, which Leland saw and erroneously described as an episcopal palace. 4 There seems to be no recorded occasion on which a Bishop of Lincoln actually stayed in Leicester during the Middle Ages. The episcopal house at Liddington (Rut.) was normally used. ${ }^{5}$ The position of the Bishop's Fee in relation to the town

\footnotetext{
57 Ex inf. Mr. Jack Hill and Mr. O. R. Berry.

58 See above, p. 349 .

Leicester's Finances (1 952-3), 354-5 and ex inf. Mr.

60 Inf. from par. acct. bks. supplied by Mr. Hill and Mr. Berry

4132 d Rep. Com. Char. Pt. 5, 104.

62 See below, pp. 412-13

${ }_{63}$ Ex inf. from Mr. Berry.

64 See p. 410.

65 V.C.H. Leics. ii. 41-42.

For Knighton, see below, p. 443 .

For the descent of the Bishop's Fee, see below, p. 353.
} Hill. was evidently felt to be difficult and dangerous even by the I 2 th century. Efforts by the earls of Leicester from I I43 onwards to gain control of the land outside the East Gate were rendered unsuccessful by the settlement of $c$. 1217 mentioned below. ${ }^{6}$ Thereafter the struggle was between the Bishop's Fee and the borough and it turned largely upon the question of the borough's right to levy taxes in the liberty, a point which emerged as early as I086. In I 322 Belgrave Gate was held to lie within the borough, although the possibility of its being drawn outside through its proximity to the Bishop's Fee was clearly exercising the town authorities. ${ }^{7}$ The rest of the area was largely exempt from the borough's financial exactions, but the bishop's burgess tenants were still subject in some legal matters to the jurisdiction of the borough court. The administrative and geographical unity of the Bishop's Fee seems to have been more important than its possible manorial unity. ${ }^{8}$ The persistent quarrels between the Bishop's Fee and the borough have been described elsewhere. ${ }^{9}$ They continued throughout the town's history until the town finally gained control of the whole of the east suburb in $1835^{10}$

The area of the civil parish, excluding Knighton, was $\mathrm{I}, \mathrm{I} 38$ acres in 1891.11 The civil parish was dis-

3 Reg. Antiquissimum, ed. C. W. Foster, iii. 217.

4 Leland, Itin. ed. Toulmin Smith, i. I 7.

5 See e.g. Rotuli Roberti Grosseteste, ed. F. N. Davis, pp. $x-x i i$.

6 See below, p. 353; Leic. Boro. Rec. IIO3-I327, p. xviii.

7 Ibid. $33 \mathrm{I}$.

8 Ibid., p. xx.

9 See above, pp. 16, I 29-30.

10 A. T. Patterson, Radical Leic. 214.

II Census, i $89 \mathrm{I}$. A small part of the parish had been transferred to All Saints' in I 885 : Local Govt. Bd. Order I 7,498. 


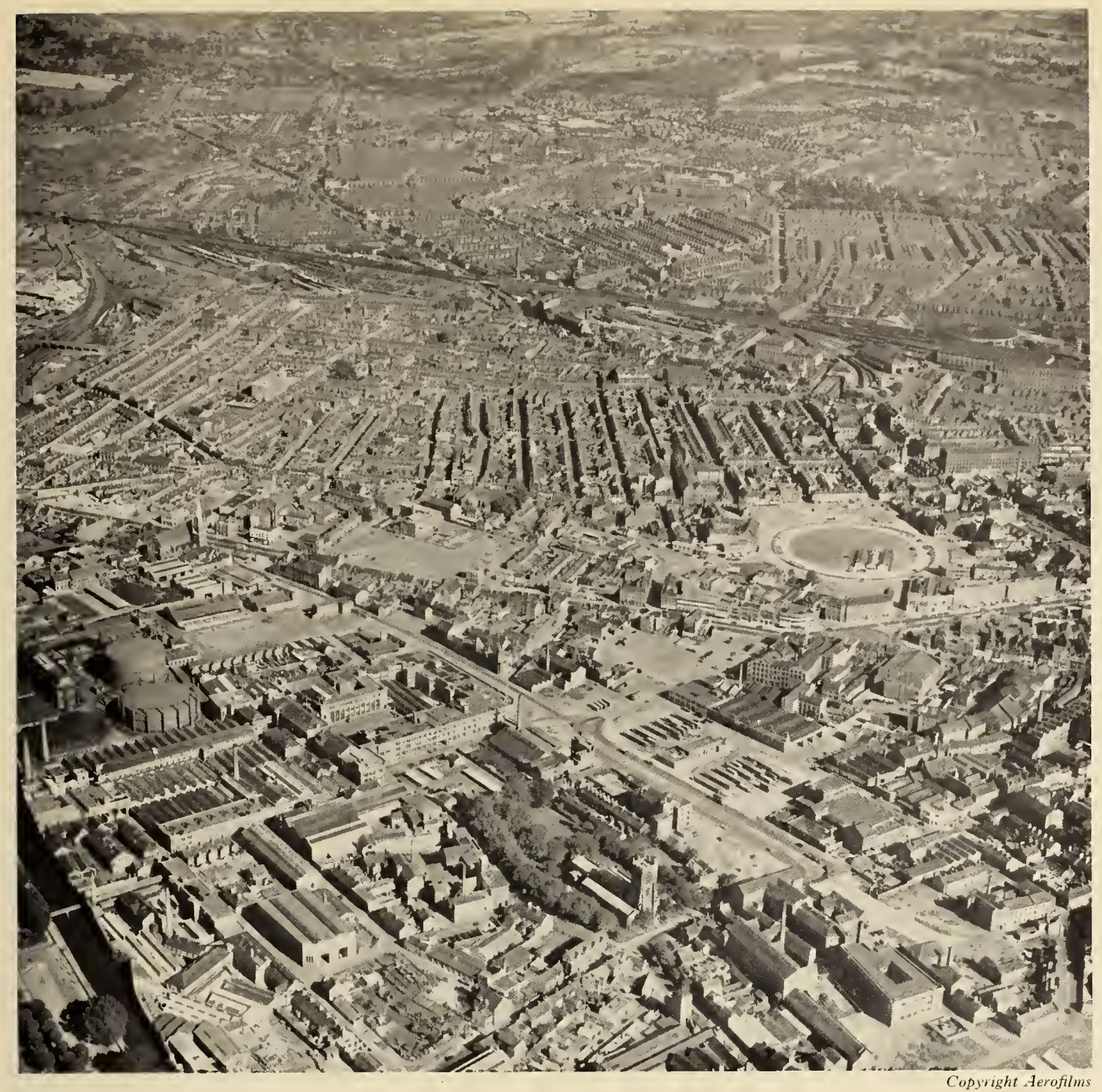

St. Margaret's Parish from the air, i953

The view is east-south-east, and shows St. Margaret's Church in the centre foreground with the bus station behind it and to the right. The canal is in the bottom left-hand corner and the gas-works above. Belgrave Gate runs horizontally across the centre of the photograph, making its junction with Archdeacon Lane near St. Mark's Church, just beyond the gasometers. The large rectangular building above and to the right of St. Mark's is the Taylor Street primary school, near which can be seen St. Matthew's Church. In the centre, the building beyond the open space on the far side of Belgrave Gate is Christ Church, and the prominent circular feature on the right is the Lee Street car park. Behind it are the engine-sheds on the London-Midland railway-line, with Spinney Hill Park beyond. The church with the light-coloured spire to the left of the park is St. Saviour's 


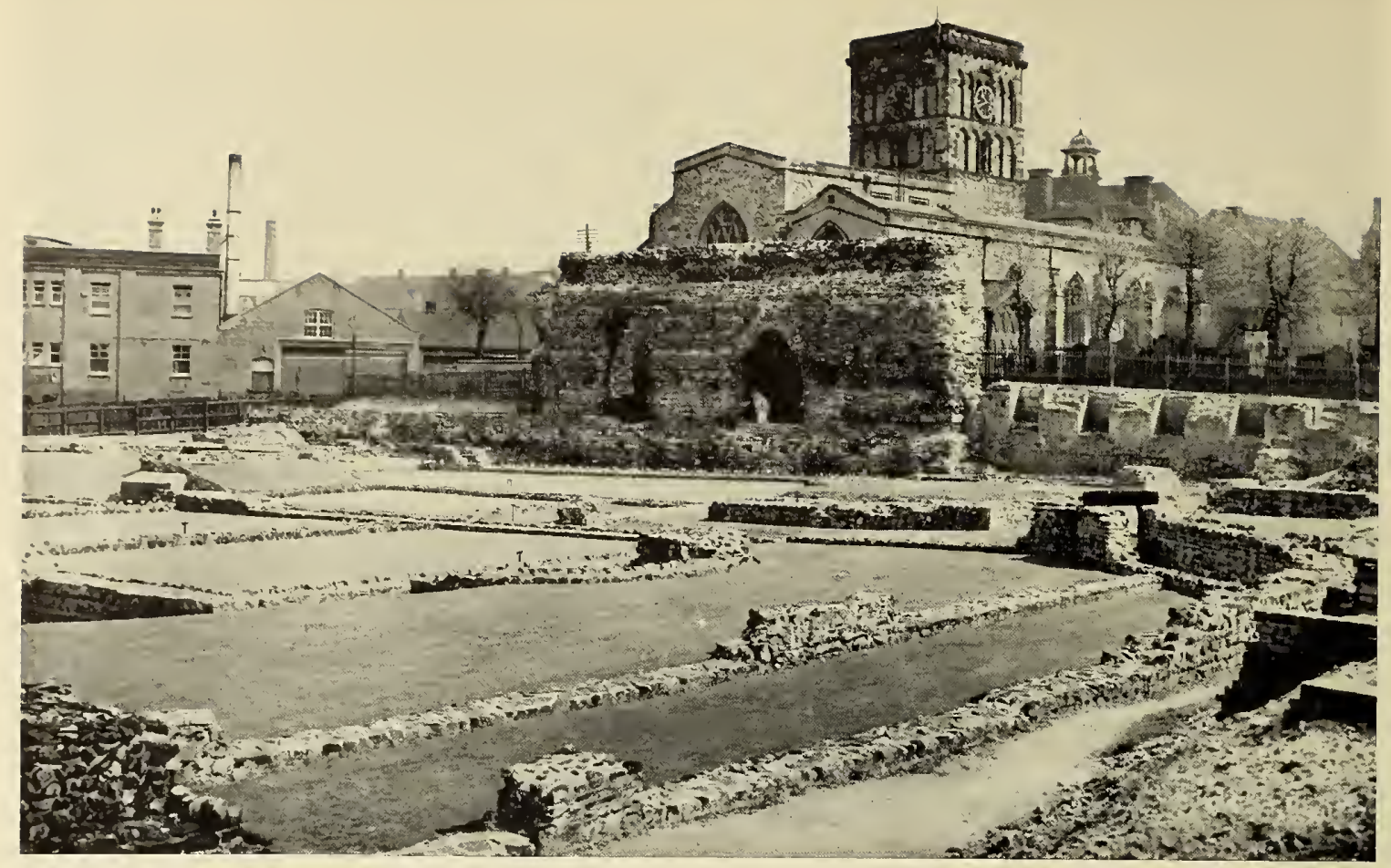

St. Nicholas's Church and the Jewry Wall

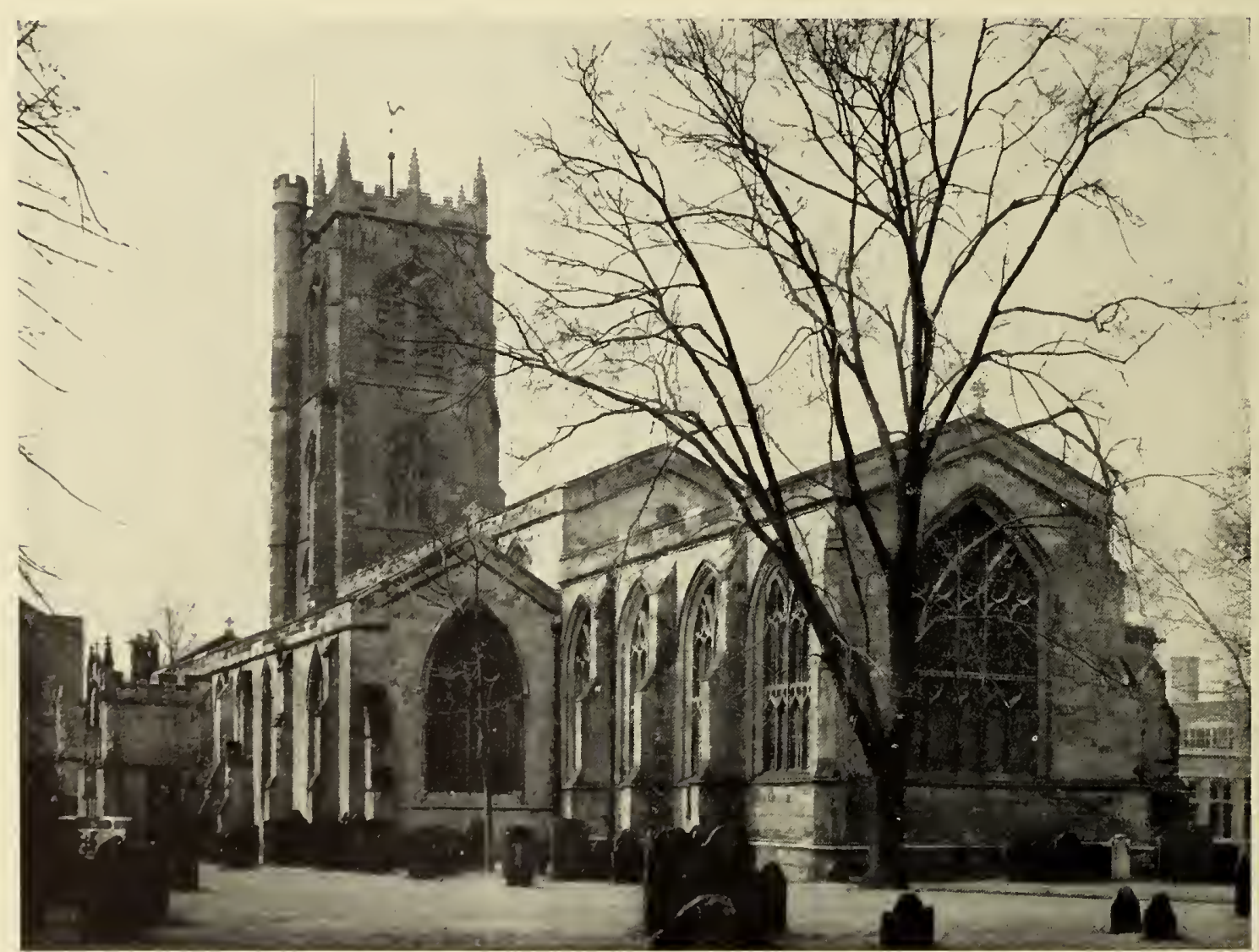

St. Margaret's Church from the south-East 
solved in 1896 when the whole borough of Leicester was made into a single civil parish. ${ }^{12}$ The part of the ancient parish within the borough boundary was bounded by the Soar on the north, the Gartree road to the west and south-west, and by the line of Mere Road on the east and south-east. To the west, the parish boundary ran down New Walk and Wellington Street, crossed to Newarke Street, Oxford Street, Millstone Lane and Horsefair Street to Gallowtree Gate. From there it ran north along the line of Churchgate and Sanvey Gate, a little way along Northgate Street and then by a winding course through the streets to the east to reach the river by the North Mill and follow it eastwards to Belgrave Lock. ${ }^{13}$ There is some doubt as to whether St. Margaret's Pasture and the Abbey Meadow were in the ancient parish or not. They were held not to be by the Inclosure Commissioners in 1764 and again by the Tithe Commissioners in 1850 . Both these authorities stated that the pasture and the Abbey Meadow were part of the chapelry of Knighton. ${ }^{14}$ Under the Divided Parishes Act of 1882 , part of the Abbey Park (formerly Abbey Meadow) and St. Margaret's Pasture were transferred from Knighton parish to St. Margaret's. ${ }^{\text {I5 }}$

The focal point of the east suburb in the Middle Ages lay at its western edge, by the East Gate of the borough, at the place where the Clock Tower now stands. In the Middle Ages, this spot was known as the Berehill, the name being in use as early as $1260 .{ }^{16}$ The Berehill was a mound outside the gate, which was surmounted by a cross, and it later became known as the Round Hill, Roundel, or Coal Hill, the place where coal was for many years brought to be sold from the pits. A pair of stocks also stood there. The cross was repaired in $15^{6} 5^{-6}$ but was demolished in 1575 or 1576 , together with the cage which stood by it. The purpose of this cage is uncertain, but it seems most likely to have been an instrument of punishment associated with the stocks. A new cage was built on the spot in I6oo. About $175^{\circ}$ Assembly Rooms were built on the site, consisting of a large upper room supported upon a colonnade, which also contained shops. The building faced Humberstone Gate, and the shops, which were at the back, looked into High Street. ${ }^{17}$ About I 805 the whole building was converted into shops and also housed a coal-weighing machine. ${ }^{18}$ During the last century there was considerable agitation for the removal of the building, which obstructed the road in the very centre of the town, and it was finally demolished in $1862 .{ }^{19}$ In I 868 public subscriptions were raised for the erection of the Clock Tower as a memorial to four

12 Local Govt. Bd. Order 32,954 (1896).

13 The boundaries are marked on T. and G. Ellis, Plan of Leic. (1828).

14 L.R.O., St. Margaret's Incl. Award; Knighton Tithe Award; for a discussion of this, see below, p. 354

15 Census, $180 \mathrm{I}$.

${ }_{16}$ Leic. Boro. Rec. IIO3-1327, 92 ; much of the following is taken from the acct. of the Berehill in C. J. Billson, Medieval Leic. 20-2 I ; see also Leic. Boro. Rec. I 509-1603, 26, I I6, I61, I66, I67, 422 .

17 A. Fielding Johnson, Glimpses of Anc. Leic. (2nd edn. I 9o6), 234. John Bass was responsible for the building: East-Gates Improvement (Leic. $187 \mathrm{I}$ ), 6.

18 Patterson, Radical Leic. 90; [S. Watts], Walk through Leic. 5 .

I9 East-Gates Improvement, I 5.

20 For the monument see J. Simmons, City of Leic. I 8 ;

The Builder, xxvii. 8; White, Dir. Leics. (I877), 278; and men considered to have been the greatest benefactors to the borough, Simon de Montfort, Earl of Leicester, William Wigston, Sir Thomas White, and Alderman Gabriel Newton. The competition for the design was won by the Leicester architect, Joseph Goddard. The tower, which is $80 \mathrm{ft}$. high, is a fine example of Victorian Gothic monumental architecture. The main part is built of Ketton stone, but the four statues at the base are of Portland stone and the pillars at the angles of the tower are of polished granite and serpentine. The total cost was $f_{\mathrm{I}} \mathrm{I}, 000 .{ }^{20}$

From the Berehill, four streets radiated into the suburb. To the north, Churchgate led to St. Margaret's Church, along the line of the town ditch, but the name seems not to have been used until the late

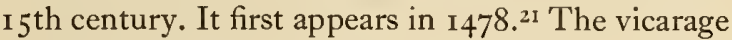
is in Churchgate, next door to the church. It is an I 8th-century house of two stories, with a slate roof and a moulded stone cornice and parapets. An earlier vicarage, clearly in a very bad state, was repaired by prebendary John Lound in $1568 .{ }^{22}$ In 1323 the vicar's servant was charged with killing another man and his goods were valued. The vicarage then consisted of a hall, granary and kitchen, as well as cellars and stables, and seems to have been of considerable size. ${ }^{23}$ Archdeacon Lane (first mentioned in 1465$)^{24}$ and Plowman Lane (mentioned in 1305$)^{25}$ ran off Churchgate to the east. Churchgate led into Sanvey Gate, which ran from east to west just outside the borough's north wall. The earliest name for this street (first mentioned I322) was the 'Skeyth', a Danish word, meaning 'course' or 'race-course', and it was perhaps the scene of horse-racing. By the 1 $5^{\text {th }}$ century it had become known as Senvey Gate, and it has since acquired a false etymology as the sancta via. ${ }^{26}$

Belgrave Gate, which was not within the Bishop's Fee, is first mentioned in 1287,27 and Barkby Lane, later to be one of the first areas to undergo intensive development, was so called at least as early as $\mathbf{1} 352 .{ }^{28}$ Belgrave Gate led to the parish boundary, over two arms of the river, and past St. John's Hospital and the Spital Hill, also known as the Cock Muck Hill. ${ }^{29}$ Belgrave Gate was later part of the LeicesterLoughborough turnpike, but was taken over by the borough in about $1855 . \cdot^{30}$

The Haymarket, which joins Belgrave Gate and Humberstone Gate, behind the Berehill site, was known as Gosewellgate in the Middle Ages, the name occurring as early as 1305.31 This name was still in use in the 17 th century but was changed when the hay market was held there in the I 8th century. ${ }^{32}$ Humberstone Gate, later part of the Uppingham

see above, frontispiece.

21 Billson, Medieval Leic. I 8-19.

22 Nichols, Leics, i. 560.

23 Leic. Boro. Rec. IIO3-1327, 378-9.

24 Ibid. $I 327-I 509,284$.

25 Ibid. IIO $-1327,288$.

26 Ibid. 399. On the derivation see E. Ekwall, Dict. Eng. Place-Names (1951), 404; T.L.A.S. xviii. I 29-30. The usual etymological explanation is given in Billson, Medieval Leic. I 6-I 7

27 Cat. Anc. D. ii. B. 1949.

28 Wyggeston Hosp. Rec. 312.

29 Billson, Medieval Leic. map facing p. I 8 ; for the Spital see below, pp. 408-9.

30 P. Russell, Leics. Road, I 45.

31 Leic. Boro. Rec. IIO 3-I 327, 288.

32 Billson, Medieval Leic. I9; J. Throsby, Hist. of Leic. 406. 


\section{A HISTORY OF LEICESTERSHIRE}

turnpike, is mentioned in $1286^{33}$ and Gallowtree Gate in $1290 .{ }^{34}$ Spa Place (nos. $36-42$ ) is the sole block of any interest remaining in Humberstone Gate. It is a terrace, set back from the street, consisting of four large I 8 th-century brick houses. The two centre doors lead out of a semi-circular Tuscan porch and all four doors have traceried fanlights. The houses were probably built in or about 1793 when advertisements for the spa (a chalybeate spring) first appeared in the Leicester newspapers. ${ }^{35}$ Miss Watts, writing of this 'range of new and handsome buildings', says that 'though furnished by the proprietor with neat marble baths and every convenient appendage for bathing' the spring was 'not found sufficiently impregnated with mineral properties to bring it into use'. ${ }^{36}$ 'The venture failed a few years after the houses were built and only their name remains to remind Leicester of their origin. From I 798 the building was used as a General Baptist college, founded by the Revd. Dan Taylor and endowed with property in Nottingham. 37 It was closed c. $1860,,^{38}$ since when the houses have been separately occupied.

The whole of the road from the East Gate to the parish boundary by Victoria Park Road was known as Gallowtree Gate, taking its name from the gallows which used to stand at the end of Evington Footpath. ${ }^{39}$ 'The part of the road which is called Granby Street seems only to have been so named at the very end of the I 8 th century. Throsby does not use the name, but it is mentioned by Miss Watts, who says that 'many ranges of buildings ... [ [have] ... been here erected within the last fifteen years', and this probably also marks the change in the name..$^{\circ 0} \mathrm{New}$ streets in the area were laid out in $1808-9$, Bishop Street (formerly Bishopsgate) and Belvoir Street being the most important. The new streets ran westwards to link Granby Street with the newly laid-out Bowling Green Street. This area was regarded as a good residential suburb and remained so until the middle of the Igth century.4I The Liberal Club in Bishop Street (closed 1936) was built from designs by Edward Burgess in $1885^{-8.42}$ The section of Granby Street from Belvoir Street to the junction with London Road was the original part, but the name is now applied to the whole stretch from London Road to Horsefair Street. Gallowtree Gate, Granby Street, and London Road all formed part of the Loughborough to Market Harborough turnpike, and the parishioners of St. Margaret's were called upon to provide labour for road repairs as late as the beginning of the I 9 th century, although by that time

33 Leic. Boro. Rec. IIO3-I327, 389 . Humberstone Gate was the site of the May and Oct. fairs until 1904: see above, p. 284

34 Leic. Boro. Rec. $x x_{0}-x 327,2$ I 4.

35 Fielding Johnson, Glimpses of Anc. Leic. $400 n$. For a recent photograph see above, plate facing p. I go.

36 [Watts], Walk through Leic. 5-6.

37 White, Dir. Leics. (1 846 ), 92-93.

38 Leic. City Ref. Libr., Pamphlets $\mathrm{O}_{3}$, vol. xxi; cf. White, Dir. Leics. (1863).

39 Billson, Medieval Leic. 19-20.

40 [Watts], Walk through Leic. I 29.

41 Patterson, Radical Leic. 87; Leic. Inl. 24 April I8 82 . cf. Patterson, op. cit. 365.

42 Spencer, New Guide to Leic. (1 888), I62; Leic. Mail, 22 Oct., 28 Dec. 1936.

43 Russell, Leics. Road, 11 7-I 8.

44 Ibid. I 45,146

45 Ibid. I 45-6; Leic. Mercury, I 5 June 1955.

46 Russell, op. cit. I62. most of their services were commuted for a money payment. ${ }^{3}$ 'The borough took over the maintenance of the road as far south as De Montfort Street in I $855 .{ }^{44}$ The London Road toll bar, which stood by the Marquis Wellington public house at the top of the hill, was removed in $185 \mathrm{I}$ and another one built at the southern edge of Victoria Park.45 Granby Street was widened in I $868^{46}$ and about the end of the century many new buildings were erected. The first part of the Grand Hotel was built by Cecil Ogden in $1899 ; 47$ the second part, facing Belvoir Street, was built soon afterwards by Amos Hall. 48 The Midland Bank, one of the most startling buildings in the town, is by Joseph Goddard and was built in $1870-2$, in a singular blend of the Gothic and Oriental styles. 49 The National Provincial Bank is by William Millican and was built in $1870.0^{50}$ The Institute for the Blind is by J. B. Everard and was completed in $\mathbf{I} 882.5 \mathrm{I}$ Of the three coffee-house buildings in the parish, the only survivor is the former Victoria coffee-house in Granby Street built by Edward Burgess in I 888,52 its striking Turkishstyle dome now sadly blackened. The whole character of the street was changed at the end of the I gth century. Of the buildings which were demolished, the former News Room, at the north corner of Belvoir Street and Granby Street, is probably the greatest loss. It was built in 1838 by the Leicester architect William Flint and was demolished in I901.53 There are some early Igth-century house-fronts on the east side of the street. The former Temperance Hall, now the Essoldo Cinema, was built by James Medland in I $852-3.54$ The formation of the company which promoted its erection was largely the work of Thomas Cook, the excursionist, whose own temperance hotel had been established next door to the hall since $184 \mathrm{I} .{ }^{55}$ 'The building has a very striking façade of three giant Corinthian columns on a rusticated base, supporting a deeply moulded pediment. The bold lines of the design were broken in 1955 by an awning of metal and plastic and a large neon sign. As the 'Temperance Hall, the building was the headquarters of the Leicester Temperance Society, but was also used as a general public hall for lectures, meetings, and concerts. ${ }^{56}$

The City Lending Library stands at the corner of Wellington Street and Belvoir Street and was opened in 1871.57 The building in which it is housed was erected in $\mathbf{I} 83 \mathrm{I}$ by William Flint as a meeting hall for the Liberal opposition party in the town, the Town Hall having been closed to them by the corporation..$^{8}$ After the passing of the Municipal Cor-

47 The Builder, lxxvii (2), 420.

48 W. Scarff, Leics. and Rut. at Opening of 20 th Cent. I 53.

4928 th Rep. Leic. and Leics. Soc. of Architects (I900-I), I 3 .

50 Spencer, New Guide to Leic. (1888), I6o.

5 I Ibid. I $49 . \quad 52$ Leic. Daily Post, 2 I Dec. I 888.

53 Fielding Johnson, Glimpses of Anc. Leic. 398; H.-R. Hitchcock, Early Victorian Architecture in Eng. i. 175.

54 J. Pudney, The Thomas Cook Story, I06-7 and illus. on p. 63 ; J. Simmons, Leic. and its Univ. Coll. 50; Spencer, Guide to Leic. (1864), ro.

55 Pudney, op. cit. 62; Leic. Mercury, I 7 Aug. I 955. The building still stands, but its two lower floors have been refaced.

${ }_{56}$ Spencer, New Guide to Leic. (1888), I 36.

57 White, Dir. Leics. (1877), 3 I 2-I 3.

${ }_{5} 8$ Fielding Johnson, Glimpses of Anc. Leic. 367; cf. H. M. Colvin, Biog. Dict. Eng. Architects, 206, where it is confused with the News Room; White, Dir. Leics. (1 846), 94 . 
porations Act, the New Hall, as it was called, became a public lecture- and concert-hall, also housing the Leicester Mechanics' Institute and, until I 848 , the museum of the Leicester Literary and Philosophical Society. ${ }^{59}$ 'The building has a plain classical façade in cream stucco, divided into three bays by groups of paired pilasters. There is a double doorway in the central bay in a projecting porch. The cast-iron railings in front of the building are of a pleasant and simple design. By I 905 the building was too small to house the whole of the library and all but the lending section was moved to a new building in Bishop Street, built with funds given by Sir Andrew Carnegie. 60

In Welford Place, just to the east of Wellington Street, is the office of Samuel Stone, the solicitor and town clerk (1835-72), also built to designs by William Flint, in I842.6I It too is a two-storied stucco building, with five windows on each floor, of which the centre three break forward. The windows are divided by Ionic columns. The central door is in a moulded stucco case with a small cornice on console brackets. The building is fronted with contemporary cast-iron railings. Also in Welford Place is the Leicestershire Club by Joseph Goddard, built in 1876.62 The streets to the south of Belvoir Street largely consist of warehouses and small houses, dating from the period of expansion in the early I gth century.

There are many important industrial and commercial sites in the parish. The Gas Works, near Thames Street off Belgrave Gate, were established in $\mathbf{1} 821.63$ The wholesale vegetable market in Halford Street was completed in 1902 by Walter Brand. ${ }^{64}$ Of the factories the two most important are probably Gimson \& Co.'s Vulcan Works, built in I 878 over an area of 3 acres to the south of Humberstone Road near the railway,65 and Corah's St. Margaret's Works, which was begun on its present site in $\mathrm{I} 865.66$ The architect of the first part was William Jackson of Lowesby Lane. The open yard of the factory then stretched as far as the canal, but nearly the whole of a very large site is now covered with buildings. Extensions to the original building were made on about nineteen separate occasions up to I941. ${ }^{67}$ The parish contains many more factories. Faire Bros.'s building in Rutland Street is an interesting late I gthcentury building in terracotta, designed by Edward Burgess in 1898.68

MANOR. In Io86 Remigius, Bishop of Lincoln, held ro carucates of land in Leicester. 'These are not described in Domesday in the section which deals generally with the borough. At least part of the hold-

\footnotetext{
59 F. B. Lott, Story of Leic. Mechanics' Inst. I 2.

60 Inscr. on building; and see above, p. 295.

6 I 42 nd Rep. Leic. and Leics. Soc. Architects (1914-15),

i2 Ibid. 28 th Rep. (I 900-I), I 3.

63 J. Storey, Hist. Sketch of Boro. of Leic. 92

64 Scarff, Leics. and Rut. at Opening of 2 oth Cent. I 5 I.

5 R. Read, Modern Leic. 270-2; V.C.H. Leics. iii. 27.

66 Corah's of Leic. I $9^{-20}$ and illus. on p. 21 . The former

building, by Wm. Flint, was in Granby St. next to the Midland Bank.

67 Corah's of Leic. 105-7 and plan on p. I06.

68 The Builder, lxxii. 5oo.

69 V.C.H. Leics. i. 309.

70 e.g. Leic. Boro. Rec. I I03-1327, I I2; White, Dir.

Leics. ( 1846$), 50$.
} 29.

ing was outside the walls, and from the fact that it is all described in carucates it seems likely that it was entirely extra-mural.69' This estate was known from an early date as the BISHOP'S FEE, and the name remained in use until the I 9 th century. 70 In Io86 the bishop had seventeen burgesses, who, it is clear from the entry, were not paying geld with the borough. About I I 38, Robert le Bossu, Earl of Leicester, gave ten more burgesses to the then bishop, Alexander, in satisfaction for damage inflicted upon the bishop's property by the earl and his men. 'These ten burgesses lived within the walls.7r Between I I 43 and c. I2I7 a complicated series of transactions took place, whereby Bishop Alexander granted his manor of Knighton and his lands in the suburbs of Leicester to the earl, who in turn granted them to Leicester Abbey. ${ }^{72}$ A settlement was made in $1203-4$, when the bishop was granted lands in Asfordby, Seagrave, and 'Thurmaston as compensation for the lands granted to the earl, but it was reversed in 12 I 8 , when the status quo of I I 43 was restored and Knighton manor and the Bishop's Fee were restored to Lincoln. About I230 the Countess of Winchester held land from the bishop to the value of $\frac{1}{2}$ knight's fee; at the same date nine other knights' fees in various parts of the county were linked with the bishop's Leicester manor. ${ }^{73}$

The bishops of Lincoln continued to hold their manor outside the East Gate until I 547, when it was granted to the king with other lands.74 'The Bishop's Fee does not seem to have been granted out again until it was given to William Parr, Marquis of Northampton, shortly before his death in 1571.75 In I $_{5} 83$ the queen was holding it again, ${ }^{76}$ and six years later she granted it to John Wells and others. ${ }^{77}$ In 1604 it was in the hands of John Sedley, who granted it in that year to Sir Henry Harrington. ${ }^{78}$ Harrington died in 1607 and the manor passed to his son-in-law, Sir Richard Morrison, who was asked in 1612 to declare by what right he held it. ${ }^{79}$ About I 628 it was held by William Cavendish, Earl of Devonshire, and after his death in that year by his widow, Christian, in trust for her younger son, Charles. ${ }^{80}$ Charles Cavendish was killed during the Civil War, ${ }^{81}$ but the manor remained in the possession of the earls of Devonshire until at least the end of the 17 th century. ${ }^{82}$ After $168_{3}$ the descent is lost until 1764 when the manor was in the hands of Lord William Manners. ${ }^{83}$ There is no indication of how it came into his possession. 'The earls of Dysart obtained it through the marriage of Louisa, Countess of Dysart in her own right, to John Manners of Grantham Grange (Lincs.), Lord William's illegitimate son and his heir, in $1765 .{ }^{84}$ The earls of Dysart remained the

${ }_{71}$ Reg. Antiquissimum, ed. Foster, ii. I6-I7.

72 These transactions are summarized and the docs. printed ibid. iii. $213-17$.

73 MS. Queen's Coll. Oxf. 366, f. I 8.

74 Cal. Pat. I $547-8$, I 53.

75 In the grant to Wells cited below, n. 77, the fee is described as being late the property of Northampton.

76 Nichols, Leics. i. 567.

$77 \mathrm{C} 66 / 1347$.

78 C.P. $25(2) / 313,2$ Jas. I, Trin

79 Nichols, Leics. i. 567 ; iv. 875 .

80 Leic. Boro. Rec. I603-88, $258,264$.

81 Burke, Peerage (I 896 ), 433.

82 In 1683 it was settled in trust for the sons of $\mathrm{Wm}$

Earl of Devonshire: Leic. City Mun. Room, I $7 \mathrm{D}_{47 / 1 .}$

83 L.R.O., St. Margaret's Incl. Award.

84 Complete Peerage, iv. 565-6. 


\section{A HISTORY OF LEICESTERSHIRE}

owners until 1877 , when the corporation of Leicester purchased the fee simple of their holding, then reduced to some 92 acres. $^{85}$

ECONOMIC HISTORY. Very little is known of the administration of the Bishop of Lincoln's estates in Leicester. About 1230 the bishop then held 6 carucates in demesne, with five free tenants, each of whom provided a man to perform harvest duty in the autumn. No mention of any villein is made. The bishop had a flock of 200 sheep. ${ }^{86}$ In view of this lack of information, the economic history of St. Margaret's parish centres upon the East Field. The East Field was the largest of the fields which lay round the borough of Leicester. It extended from Belgrave Gate to the line of the Gartree road and north-west along the parish boundary to the junction of Belgrave Road and Melton Road. 'The area of the East Field, and of a meadow adjacent to it, just before the inclosure under an Act of 1764 , was 773 acres. ${ }^{87}$ The field was divided into three parts, or separate fields, upon which rotation of crops presumably took place. The three divisions were wedge-shaped, the first (Nether Field) lying between the Belgrave and Humberstone roads, and the second and third between the Humberstone and Gartree roads. The northern part of this section was called the Middle Field and the southern, at least after 1612 when the conduit head was built there, ${ }^{88}$ Conduit Field. Underground pipes led from here to the conduit in the Market Place, and until the Igth century this was the town's only artificial water-supply. The conduit was abandoned in 1841.89

The meadow attached to the East Field lay to the north, between the Belgrave road and the river, extending to the parish boundary. Of this meadow, one part, the Abbey Meadow, between two arms of the Soar, seems at one time to have been attached to either the East Field or to the manor of Knighton, but passed into the possession of Leicester Abbey. The precise date at which the abbey acquired it is unknown, but it seems probable that it was in I I 43, at which time the Bishop of Lincoln's lands outside the East Gate as well as at Knighton had been granted to the founder of the abbey.90 It is, however, not definitely known that the Abbey Meadow ever belonged to the bishop, and before being acquired by the abbey it was perhaps the property of the earl and his successors. But in view of the fact that in 1764 and 1850 the Abbey Meadow was held to be part of the chapelry of Knighton, ${ }^{91}$ it seems possible that it had been once attached to the bishop's manor there and that the Inclosure and Tithe Commissioners were recording information at those dates whose explanation lies in the 12 th century. In I650 a yardland at Knighton claimed pasture rights in the Abbey Meadow.92 The Abbey Meadow extended over most of the area between the two arms of the river, with the exception of the western end, which certainly belonged to St. Margaret's parish and was known as St. Margaret's Pasture. The Abbey Meadow formed part of the grant of Leicester Abbey property which was made to William Parr, Marquis of Northampton, in $1550 .{ }^{93}$ From that time its ownership descended with that of Leicester Abbey parish, although it was virtually part of the parish of St. Margaret, whose parishioners and the burgesses of Leicester had grazing rights there. The town races were run on the Abbey Meadow until 1742.94 The meadow was purchased from the Earl of Dysart by Leicester Corporation in 1877 in connexion with the flood prevention scheme and most of it was made into a public park, which was opened by the Prince of Wales in i 882. St. Margaret's Pasture was purchased at the same time and also forms part of the park, which was laid out by Barron \& Son of Derby. The architectural work was carried out by the Leicester architect, James 'Tait. 95 The common rights held by the parishioners of St. Margaret's in the Abbey Meadow and St. Margaret's Pasture were extinguished when the corporation purchased the land, $£ 2,000$ being paid in compensation for rights in the Abbey Meadow and $£ 3^{80}$ for those in the pasture. ${ }^{96}$

The other pieces of meadow attached to the East Field were Dent's Meadow and two closes known as the Leroes. Dent's Meadow lay to the north-west of the Abbey Meadow and was bounded by the Willow Brook, the river, the parish boundary, and the road to Belgrave. It was possibly named for Edward Dent, a freeholder of the East Field in the 17 th century. ${ }^{97}$ The Leroes lay to the south of Dent's Meadow. One was sold to the Leicester Navigation Company in $\mathbf{I} 793$ and was purchased in $\mathbf{1} 878$ by Leicester Corporation, ${ }^{98}$ which took over the Belgrave Gate Gas Works established there in 1821.99 The other was also sold to the canal company and then to the corporation. It was the site of the Lero refuse destructor from 1894 to $1936,{ }^{1}$ and of an electricity station, originally set up to provide current for the tramways, from I 904 to $1920 .^{2}$

The burgesses had rights of pasture in all these pieces of meadow. In a survey made about 1230 the fees to be paid for pasture were $2 d$. for each animal belonging to a burgess living within the walls and $\mathbf{I} d$. for those living outside. ${ }^{3}$ In the $\mathbf{1} 6$ th century disputes arose about the pasturing of hackney horses in the meadow between I August and I May. In $155^{2}$ Henry, Duke of Suffolk, was called in to arbitrate on this matter. His award provided that hackneys, up to the number of $4^{\circ}$, could be pastured at a cost of $4 d$. each. It seems, although the terms of this award are not quite explicit, that by this time the privilege of pasturing cattle was limited to the parishioners of St. Margaret's and St. Leonard's, the latter paying $2 d$. for every cow, up to two from each household. It may be, on the other hand, that St. Leonard's parish receives special mention in the
85 Storey, Boro. of Leic. I2I.

MS. Queen's Coll. Oxf. 366, f. I 8

Or 38 yardlands: T.L.A.S. xiv. I 4.

88 Fielding Johnson, Glimpses of Anc. Leic. 192

IVallace's Local Chronology of Leic. I 3

See above, p. 353.

1 L.R.O., St. Margaret's Incl. Award; Knighton Tithe Award.

Leic. City Mun. Room, I $\mathrm{D}_{31 / 55}$

3 Cal. Pat. 1549-51, 370; and see below, p. 451.
94 Fielding Johnson, Glimpses of Anc. Leic. 236.

95 Storey, Boro. of Leic. 12 I-9.

96 Ibid. 123.

97 T.L:A.S. xiv. I0-1 1 .

98 Ibid. I I; Storey, Boro. of Leic. 124.

99 Storey, op. cit. 92.

Boro. of Leic. Abstract of Accts. (1893-4), 108-9; ibid. (1935-6), I 19.

Leic. Mail Year Bk. (1925), 3 I ; City of Leic. Abstract of Accts. (1919-20), 233.

${ }^{3}$ MS. Queen's Coll. Oxf. 366, f. I 8. 
award because there was then doubt as to whether it was part of the borough or not, but this seems to be unlikely, considering the terms of the award. 4 In I6 33 these rights of pasturing horses and mares were reaffirmed by the borough authorities, probably because of the growth of separate farms within the fields. ${ }^{5}$ Before the passing of the Act for inclosing the East Field, in 1764 , the rights of the borough as a whole seem to have been extinguished. The inclosure award assumes that only the parishioners of St. Margaret's had pasture rights and then only in Dent's Meadow and in the open fields from the end of harvest-time until i I December. ${ }^{6}$ The inclosure commissioners did not consider the Abbey Meadow and St. Margaret's Pasture, which were held to be in Knighton manor. ${ }^{7}$

The allotment of land to the parish authorities at the inclosure was made in lieu of these rights in the open fields. St. Margaret's Parish Piece, as this was afterwards called, lay at the north-east end of the former Nether Field, and was in 1956 occupied by the Cossington Street Recreation Ground and a row of houses facing Belgrave Road. ${ }^{8}$ After the allotment was made, the land was let yearly by the vestry and the rental distributed, at first to the poor and later to the parish charity and Sunday schools, both Anglican and nonconformist. 9 'This practice was continued until I 892 , when a private Act of Parliament ${ }^{10}$ enabled the parish to sell the land to the corporation. The money thus obtained was invested and is used to provide pensions for elderly parishioners. ${ }^{\text {II }}$

In the inclosure award of 1764 fifteen allotments were made, varying in size from that of William Manners, the chief lord, who received over 300 acres, to one of only 2 roods. The East Field was estimated to contain 34 yardlands. There is very little mention of old inclosure except in that part of the fields immediately touching the built-up area of the borough. Mary Nedham, the tenant of the glebe, received an allotment of 93 acres. Other recipients were the churchwardens and overseers of St. Margaret's, who received the $\mathbf{I} 7$ acres of their Parish Piece, and the mayor and burgesses of Leicester, who received 4 acres as a corporation, and a further $4 \mathrm{I}$ as the trustees of the Trinity Hospital. The rest of the land went in allotments of under Ioo acres to various freeholders of the parish, and certain roadways were specified. The mere, or boundary between Leicester and Belgrave, was made the responsibility of St. Margaret's in exchange for another piece of land which was given to Belgrave. The tithes were commuted for $f_{1}$ I IO. ${ }^{12}$

The developments which followed the inclosure are very clearly shown upon a map of the parish which was made by John Eagle in 1805 , when the greater part of the parish was still pasture. ${ }^{13}$ In I 80 I only 50 acres of the whole parish were arable, 26 of them growing turnips; some were probably small

4 Leic. Boro. Rec. I 509-1603, 456.

5 Ibid. $1603-88,270$.

${ }^{6}$ L.R.O., St. Margaret's Incl. Award.

7 See above, pp. 272, 35I.

8 E. Morris, St. Margaret's Select Vestry, I I ; Storey, Boro. of Leic. 130-I.

9 Morris, op. cit. II-I2.

Io St. Margaret's Select Vestry (Parish Piece) Act, I 892; Storey, op. cit. I 30 .

II Morris, op. cit. I2-I3; Leic. Mercury, 4 Jan. I 924.

I2 L.R.O., St. Margaret's Incl. Award.

${ }_{13}$ 'This map is in Leic. City Mun. Room. allotments. ${ }^{14}$ Eagle's map shows houses along Belgrave Gate and Humberstone Gate, although even these were not very heavily populated as yet. The first area to be developed for both industrial and residential purposes is clearly shown on the map, between Belgrave Gate and the new canal, the Leicester Navigation. The development of this district went on for about 25 years after about I79I, stimulated by the canal and by the new public wharf. ${ }^{15}$ This also gave its name to Wharf Street, the most important of the new streets which appeared at the same time between Humberstone Gate and Belgrave Gate. One of the very first of these to be built up was the former Barkby Lane, now Bedford Street. ${ }^{16}$ The first part of Charles Street was built about $1800 .{ }^{17}$ These are the developments which are apparent on Eagle's map, and if this is compared with that of T. and G. Ellis of $1828^{18}$ the difference is remarkable. By 1828 , the whole of the area between the canal and Belgrave Gate was built upon as far east as the present Abbey Park Road, although there was still an area of 'intended streets' immediately to the north-east of St. Margaret's Church. To the south, the built-up area extended to the end of the present Charles Street, while to the east, the line of Rutland Street (Dogkennel Lane in $\mathbf{1} 805$ ) and Wharf Street was heavily built up on both sides. There are also some signs of ribbon development along Humberstone and Belgrave Gates. The building of St. George's Church, completed in $1827,{ }^{19}$ is an indication of the increase in the population of St. Margaret's parish. Farther to the south, up the road to London, the new streets were also beginning to appear: Northampton Street, Conduit Street, and Prebend Street were already partly built in 1828 and two other streets, then both marked as 'Occupation Road', were laid out. One of these was probably the road later known in part as Sparkenhoe Street and in part as St. Peter's Road. The other is not traceable, as its northern end is now blotted out by the line of the railway. More intended streets are shown running between the former Sand Pit Lane (now Willow Bridge Street) and Humberstone Road. One interesting feature of the development is that a great many of the new streets were laid out along the lines of the former field boundaries, especially on the south side of the parish. ${ }^{20}$ Southampton Street, Queen Street, Cotton Street, and Conduit Street are but a few examples.

The intensive development of the area between the canal and Humberstone Gate, with Wharf Street at its centre, seems to have been completed soon after I 828 . The differences between the maps of 1828 and $\mathrm{I} 857^{21}$ are by no means so striking as those between the maps of 1805 and 1828 . The building of the Midland Counties Railway in $1840^{22}$ took a considerable amount of the land which might otherwise have been used for house-building, and development

I4 T.L.A.S. xxiv, 149 .

I5 On the effect of the canal on the growth of Leic. see Patterson, Radical Leic. 39-40.

16 This is shown in Throsby, Hist. of Leic., map facing p. I

17 Patterson, op. cit. 87.

I 8 Issued with and ed. of Fielding Johnson, Glimpses of Anc. Leic. (1906).

i 9 See below, p. 359 .

20 This was suggested by Dr. G. M. Sarson of Leic.

in Patterson, Radical Leic.

22 V.C.H. Leics. iii. I 15 , 116. 


\section{A HISTORY OF LEICESTERSHIRE}

in the years $1828-57$ is very much more noticeable in the area to the south of the railway, where building was only beginning in 1828 . It may be noticed that the first intensive development in Leicester, in the area of Wharf Street, soon had its critics. As early as $18+7$ it was described by a Polish refugee then living in the town: "The numerous small, dark and dirty streets, with their miserable huts and pestiferous atmosphere ... are built in long rows called Wharf Street, Northampton Street, Sanvey Gate, Archdeacon Lane, Burley's Lane, Cumberland Row, and many more; and each of them, with its twenty still more miserable branches, constitute the size of the town; with its pale, thin, dull-looking people, who seem to be ready for eternity, yet are clinging to the streets.'23 Some of these houses and streets were pulled down when the new Charles Street was laid out in $1930-5,24$ and when Belgrave Gate was widened at the same time. Further work was done before the war, when the Lee Street car park was laid down upon the site of more slum property. ${ }^{25}$ In I956 the central area was filling with large new blocks of offices and shops. In I 955 work began upon the clearance of the Wharf Street area itself, which has thus completed the cycle from Industrial Revolution development to slum clearance. The site to be cleared has St. Matthew's Church at its centre. This is to be retained, but many of the smaller streets and alleys are to be obliterated to make way for large new blocks of flats. ${ }^{26}$

Development beyond the line reached by 1857 was perhaps encouraged by the building of the Great Northern Railway line from Tilton to Leicester in I 882 and the opening of the Belgrave Road Station. ${ }^{27}$ Only a small area had been laid out in streets beyond the station by i $886 .{ }^{28}$ Between Humberstone Gate and the Midland Counties Railway, 'third class' (working men's) houses were built, and in 1864 a speaker to the Leicester Literary and Philosophical Society lamented that there was as yet no outlet from Sparkenhoe Street to Evington Lane, so that the workers could reach the country. ${ }^{29} \mathrm{He}$ also demonstrated the rise in the value of land by showing that land in Queen Street was then selling for $f_{\mathrm{I}}$ a yard, which had been rod. a yard. Vacant lots in Humberstone Gate were quickly built up, and the abandoning of the old cricket ground in Wharf Street in $1860,{ }^{30}$ after which it was built up, is symptomatic of the 'land hunger' which was evident in the centre of Leicester in these years.

The development of the area to the south of the Midland Railway line took place between about i 860 and $\mathbf{I} 880$. Upper Kent Street was built up in $\mathbf{1} 862^{3 \mathrm{I}}$ and the same year saw sales of building land in Upper Conduit Street and Sparkenhoe Street. ${ }^{32}$ One of the

23 Quoted in Patterson, op. cit. 367.

24 Russell, Leics. Road, I 62.

${ }^{25}$ City of Leic. Abstract of Accts. (1937-8) and subsequent years; see also above, p. 298.

26 Leic. Mercury, 5 Jan., 26 Mar. 1955.

27 V.C.H. Leics. iii. 124.

28 Map in Spencer, New Guide to Leic. (1 888).

29 J. Barclay, Modern Leic. (Leic. City Ref. Libr., Pamphlets $\mathrm{O}_{4}$, vol. iii).

${ }_{30}$ V.C.H. Leics. iii. 283.

31 Leic. Fnl. 3 Jan., 19 Dec. 1862.

32 Ibid, 28 Nov, I 862.

33 White, Dir. Leics. (1 846), I 15 ; Fielding Johnson, Glimpses of Anc. Leic. 397.

34 R. Greaves, Corp. of Leic. 43 ; illustrated in Morris, first large buildings in this area must have been the Leicester Union Workhouse in Sparkenhoe Street, which was built by William Flint in $188^{833}$ to replace the old one, erected originally for St. Margaret's parish in 1810 , which had stood in the middle of Humberstone Gate, on or near the site of the present (1956) weighbridge. ${ }^{34}$ The old workhouse was sold in I 839, although it was not demolished until i 866-7, when the site was exchanged with the corporation for that of the present Vestry Hall, also in Humberstone Gate. ${ }^{35}$ Flint's workhouse in Sparkenhoe Street was rebuilt in $1850-1 .{ }^{36}$ This building is still in use and in $195^{6}$ was known as Hillcrest Hospital. Houses built in this area were of the 'second class', not working-class dwellings, but not large houses. The reason given for this by one authority was that the area was difficult to approach as in I 864 no street had yet been built to link Sparkenhoe Street with the London road. 37

Recent development in the parish has taken the form of residential estates on the outskirts and industrial building in the centre, large parts of which are now occupied by factories. In 1956 the building of many new factories, with some blocks of flats and offices, was being planned, especially in the Charles Street and Humberstone Gate areas and in Wharf Street, where extensive clearance for this purpose took place in 1955 .

In 1086 there were three villeins and twelve bordars living in the Bishop's Fee. ${ }^{38}$ In I 564 I 64 families lived in St. Margaret's parish, ${ }^{39}$ although 40 years later only 8 people paid subsidy. 40 This is surprising in view of the known prosperity of the parish in the earlier part of the I6th century. ${ }^{41}$ By I670 there were 34 houses in the Bishop's Fee, paying tax on a total of II 4 hearths, a very high average number of hearths to each house, which indicates the prosperity of this particular part of the parish. ${ }^{42}$ The inducement to escape from the control of the borough authorities and go to live in the Bishop's Fee was very strong. The part of St. Margaret's parish near the walls was one of the poorest areas of Leicester at the end of the I 7 th century. ${ }^{43}$ In I 80 I the population of the civil parish was 5,809.44 Throughout the last century it increased steadily until in $\mathrm{I} 89 \mathrm{I}$, the last year in which the population of the ancient parish is given separately, it was $92,929 . .^{45}$

PARISH ADMINISTRATION. St. Margaret's parish was governed by the usual parish officers until I 8I9, although these were more than usually independent of the borough owing to the peculiar position of the parish. The growth of population in St. Margaret's parish during the early I $g^{\text {th }}$ century meant that independent arrangements had to be made

St. Margaret's Select Vestry, 6; for the earlier hist. of the workhouse in this parish, see above, p. I 87 , and Greaves, op. cit. 45 .

35 Morris, op. cit. 7-8

${ }^{36}$ Leic. Union Rep. (1858), 3 (Leic. City Ref. Libr., Pamphlets O r, vol. xxiii).

37 Barclay, Modern Leic

38 V.C.H. Leics. i. 309.

39 Nichols, Leics. i. 556.

40 Leic. City Mun. Room, Farnham MS.

41 T.L.A.S. xxvii. 26.

42 E $179 / 240 / 279$.

43 See above, p. I 59.

44 Census, I $80 \mathrm{~J}$.

45 Jbid. I89I. 
for such things as keeping watch, for street lighting, and for the all-important relief of poverty. 46 The control of the workhouse was a particularly important matter. The very strong sentiment of independent parochialism led to the adoption of the Vestry Act of 1819 and the formation of the St. Margaret's Vestry, ${ }^{47}$ which made possible the election of a representative parish council and the appointment of a salaried overseer. The object of this was to reduce the power of the borough justices and to give the parish more say in its own financial affairs. The justices, however, still retained considerable control over the parish, and it seems clear that they encouraged the overseers to deceive the vestry and act independently. ${ }^{48}$ The vestry had almost as much difficulty in controlling the parish finances after adoption of the Act as it had had before. In spite of great opposition from the borough, the parish pressed for and obtained in 1832 an Act establishing a select vestry. ${ }^{49}$ By the terms of this Act the parish gained complete control over the parochial officers and the conditions of the Act were an adequate safeguard of parish funds. ${ }^{50}$ The vcstry consists of 20 persons, together with the vicar and churchwardens, who are appointed by the borough authorities from a list of 30 submitted by the parish. ${ }^{51}$

Gradually during the last century most of the duties of the select vestry were taken over by the borough. Poor Law administration was given over to the Leicester Board of Guardians in $1836^{52}$ and public health to the local board of health in 1849.53 The vestry still dealt in 1956 with the parish charities and with other purely parochial inatters, such as the election of churchwardens. ${ }^{54}$

CHURCHES. In Io86 the Bishop of Lincoln held two churches in Leicester, which were presumably St. Margaret's and its chapel of St. Mary Magdalene, Knighton. 55 'The dedication of neither is given in the survey and it is not known how they came into the possession of the bishop. Knighton remained a chapelry of St. Margaret's until I 878.56

By the beginning of the 13 th century St. Margaret's Church was a prebendal church of Lincoln Cathedral.57 It has been suggested that the prebend was united with the post of Archdeacon of Leicester but this does not seem to have been an invariable practice. ${ }^{58}$ The prebendary had the rights of pre-

46 On the relations between the parishes and the boro. see Greaves, Corp. of Leic. 26-45.

47 Ibid. 45 ; S. and B. Webb, Parish and County, I 58-9. 48 Greaves, op. cit. $45-46$.

492 William IV, cap. I (local and personal declared public).

50 Greaves, op. cit. 46-47.

5 I Morris, St. Margaret's Select Vestry, 2 I-22.

52 See above, p. 256.

53 Storey, Boro. of Leic. I 2 ; and see above, p. 267.

54 For the work of the vestry see Morris, op. cit. passim.

55 V.C.H. Leics. i. 309.

56 See below, p. 445.

57 Rot. Hugonis de Welles, ed. W. P. W. Phillimore, i. 238.

58 Rot. Ricardi Gravesend, ed, F. N. Davis, p, xxxviii.

Rob. Grosseteste held both archdeaconry and prebend: Assoc. Archit. Soc. Rep. $\S^{2}$ Papers, ix. I 20. John de Edyngton, prebendary, I349-66, was not archdeacon: cf. ibid. and Nichols, Leics. i. 561, J. le Neve, Fasti Ecclesiae Anglicanae (1854), ii. 6o, 168 .

59 Nichols, Leics. i. 561; White, Dir. Leics. (1 877), 299 ;

Kelly's Dir. Leics. and Rut. (1881), 543, 547.

60 Leic. Dioc. Cal. (1 954), 90. sentation to St. Margaret's vicarage and its chapelry until 1878 , when the prebend was dissolved, Knighton was created a separate parish, and the advowson of St. Margaret's Church was vested in the Bishop of Peterborough.59 The Bishop of Leicester now presents to the church. ${ }^{60}$

As a prebend, St. Margaret's parish was also a peculiar, free from the jurisdiction of the archdeacon, and the prebendary held his own court to enforce ecclesiastical discipline among the inhabitants. The business of the court had largely lapsed by the I 9 th century and few records of its proceedings survive from any age. ${ }^{61}$ In 1849 it was reported that no contentious business had been undertaken during the previous year, ${ }^{62}$ but the court continued to meet until I $857 .{ }^{63}$ The peculiar was dissolved in 1878.64

The vicarage was ordained in $1277^{, 65}$ the vicar being allotted various profits of the church, six marks from the prebendary and the profits of the land at 'Lethpol' or 'Lachepol' which had been given to the prebend during Grosseteste's episcopacy. ${ }^{66}$ The site of 'Lethpol' is not known, but it lay near St. John's Hospital, which gave it to the prebend.

The prebend was valued at $£ 20$ in $1254^{67}$ and at f.30 $13^{s .}{ }^{d} d$. in $1291 .{ }^{68}$ No valuation is given in the Valor Ecclesiasticus, but Nichols gives two valuations, one of $£_{33}$ and the other of $f_{27} 6 s .3 d$., both for $1534 .^{69}$ The vicarage was valued at $£_{17} 8 s .5 d$. in I $535^{70}$ and at $f_{44} 40$ in $1831.7^{71}$

The prebendary was entitled to the great tithes of St. Margaret's and of Knighton chapel. ${ }^{72}$ In 1535 these were farmed by the executors of Richard Sacheverell, 73 and in I654 the wife and executors of Thomas Cliapman, a sergeant at law, claimed the tithes from the estate of Dr. John Walcot, the late prebendary. ${ }^{74}$ One of Chapman's executors was Ambrose Saunders, whose descendants still farmed the tithes in 1764 , when they were commuted for firo.75 From before 1846 until after I 888 a Miss Fenwick was the impropriator, ${ }^{76}$ but in 1894 the Ecclesiastical Commissioners were repairing the chancel, for which the impropriator had previously been responsible. 77

In 1764 just over 93 acres of glebe were allotted to the incumbent at the inclosure of the common fields. ${ }^{78}$ These were then held by Saunders, the farmer of the tithes, in trust for a Mary Nedham. The land upon which St. George's Church was built

6I Leic. Museums and Art Gallery, Handlist of Rec. of Leic. Archdeaconry, 40-4I.

62 Leic. City Mun. Room, I $441 / 45 / 6-2$.

63 T.L.A.S. xiv. I 52.

64 White, Dir. Leics. (1877), 299; Kelly's Dir. Leics, and

Rut. ( I 88I), 547.

65 Rot. Ric. Gravesend, I 59-6o.

66 Rot. Rob. Grosseteste, ed. F. N. Davis, 390-I.

$67 \mathrm{Val}$. of Norw. ed. W. E. Lunt, 279.

68 Tax. Eccl. (Rec. Com.), 56.

69 Nichols, Leics. i. 560, 56 I ; cf. Valor Eccl. (Rec. Com.), iv. 2 I.

70 Valor. Eccl. iv. 48

71 White, Dir. Leics. (1 846$), 87$. On the need for more clergy in the parish in $183^{8}$ see Leic. City Mun. Room, I9D52.

72 Nichols, Leics, i. 56 I.

73 Leic. City Mun. Room, ID $50 /$ VIII/Ior. Sacheverell had farmed the tithes before I 527 : ibid. I oD $34 / 986$.

74 Cal. Cttee. for Compounding, p. 3208

75 L.R.O., St. Margaret's Incl. Award.

76 White, Dir. Leics. (1 846), 87; Spencer, New Guide to Leic. (1888), 77

78 L.R.O., St. Margaret's Incl. Award. 


\section{A HISTORY OF LEICESTERSHIRE}

was part of this allotment; the meadow which was attached lay to the north of the Abbey Meadow. 79

The guild of St. Margaret and St. Katherine had an altar in the church of St. Margaret. ${ }^{80}$ This guild was founded in $1355^{-6}$ to find two priests to celebrate mass twice a year for the brothers and sisters of the guild. The guild was a social and religious one of the usual type. About 1388 it possessed land in Leicester to the value of 14 marks a year. In $1545^{-6}$ the guild had a hall, on the east side of Churchgate, in which the chaplains lived, and most of its property was in St. Margaret's parish. The total gross value of the property was then $f_{20}$ I os. I $12 d$. The chaplain's stipends were $f_{1}$ Io $13 s$. $4 d$. a year, and when all expenses had been paid the guild was left with a profit of nearly $£ 7$ a year. The guild was dissolved before $155^{\circ}$, when the guildhall was granted to Edward Pease and James Wylson and part, at least, of the land to Robert Catlyn. ${ }^{81}$

The church of ST. MARGARET stands at the north-east corner of Churchgate. A church, presumably on this site, is mentioned in Domesday Book, ${ }^{82}$ but no trace of this remains in the present building, although fragments of an aisleless church, thought to date from pre-Conquest times, have been found beneath the present floor level, near the chancel steps. ${ }^{83}$ Other fragments discovered by excavation lead to the conclusion that in the late 12 th century extensions were made to the church in the form of transepts, ${ }^{84}$ traces of which (the responds for the arches and the outer wall of the east bay of the present nave) remain today. There was probably a central tower which was demolished when the transepts were built. ${ }^{85}$ The existing building dates from the $13^{\text {th }}$ to $15^{\text {th }}$ centuries. The present aisles are of the late 13 th and early I 4th centuries, although narrow aisles had been built earlier. Extensive additions and rebuilding took place in the $15^{\text {th }}$ century, probably in and about I444, when Bishop Alnwick of Lincoln ordered the levying of smoke farthings as contributions towards the reconstruction of the tower. ${ }^{86}$ At the same time as the tower was built, a clerestory was inserted above the nave and the chancel rebuilt and probably extended.

No further structural alterations seem to have taken place until the very beginning of the I $9^{\text {th }}$ century, when new tracery was inserted in the east windows of the aisles, 'in an abortion of the Batty Langley style', apparently by William Firmadge. ${ }^{87}$ The chancel was restored in 1846 , when the east window, which had been blocked up since the beginning of the century at the least, was repaired and filled with stained glass. ${ }^{88}$ In 1860 the chancel arch was taken down and rebuilt and parts of the outer wall of the church were refaced at the same time, the window arches and jambs renewed, and new tracery inserted. The architect of this restoration was Sir George Gilbert Scott, who designed the east windows of both aisles, to replace those inserted by Firmadge. The new windows were inserted in $18644^{89}$ In 1882

79 John Eagle's map, 1805 , in Leic. City Mun. Room.

80 Unless otherwise stated inf. in this para. is from T.L.A.S. xiv. I $5 \mathrm{I}-2, \mathrm{I} 62-6, \mathrm{I} 73-4$.

81 Cal. Pat. I 549-5 I, 44, 123.

82 V.C.H. Leics. i. 309.

83 T.L.A.S. xxviii. 29.

85 Arch. ${ }^{2}$ i. cxil. $163-4$. church see above, plate facing p. $35 \mathrm{I}$

86 Nichols, Leics. i. 558 . a further restoration was completed. This was carried out by George Street, one of his last works. He replaced the crumbling stonework of the outer walls, restored the porch, and added new interior roofs for the aisles and a new pavement. ${ }^{90}$ In 1894 the Ecclesiastical Commissioners repaired the outer wall of the chancel.91 A new clock was set in the tower in I $899 .{ }^{92}$

The present building consists of a chancel of four bays, nave, and north and south aisles each of seven bays, with a clerestory above the nave, west tower, south porch, and a new vestry on the north side of the chancel. The building is mainly of sandstone ashlar, almost entirely refaced, although some good detail and rich carving remain in the decorative stonework, especially on the coping and buttresses of the chancel and on the porch.

The tower rises to a height of some 108 feet. Its west wall is flush with the west wall of the church, so that the tower stands enclosed in the nave, supported upon two great pillars, which are also the two western pillars of the nave arcade. Of its four stages, the top two are diminished by weathered offsets, and the top one has four tiers of decorated arcading round the belfry windows. There are buttresses at the angles on each face, except at the south-west, which has a half octagon stair, splayed to circular a little below the parapet and topped with small battlements. From the foot of the top stage of the tower, the buttresses become diagonal and end at the base of the parapet. The tower rises to an embattled parapet, decorated with cinquefoil panels, pinnacles, and gargoyles. The belfry is lighted on each face by two pointed cinquefoil lights embraced under an ogee-headed hood mould. The third stage has three-light windows, in the centre of each of which is an openwork clock dial. There are two-light windows on the north and south faces of the second stage; the west face has a statue niche above the wide modern west window. Below this is the west doorway, the arch of which rests upon the carved heads of a king and queen. The door itself is modern, except for the upper panels.

The chancel is of four bays, divided on the outside by buttresses between the pointed four-light windows. The east window is similar but of five lights. There is a doorway in the second bay from the east on the south side, balanced on the north side by the entrance to the vestry. The pavement is of modern red and yellow tiles. The interior of the chancel is very richly carved and at either side of the east window are decorated niches for statues. There is a piscina on the south wall, adjoining a triple sedilia. The altar is dated 1935 . The reredos was designed by G. F. Bodley and was erected in 1899.93 The removal of the $\mathrm{i} 8$ th-century altar-piece revealed traces of the painting with which the niches beside the east window had originally been decorated. On the north side of the altar is a table tomb, with the alabaster figure of an abbot in full robes, John Penny, Abbot

87 The Builder, xxiii. I03.

88 Ibid: vi. 7; White, Dir. Leics. (1877), 298. For the appearance of the ch. at the beginning of the 19 th cent. see Nichols, Leics. i, plate xxxix.

89 White, op. cit. 299; The Builder, xxiii. I03.

90 T.L.A.S. v. $30_{3}$; Building News, I Oct. 1880.

91 T.L.A.S. vii. I 3 I.

92 Ibid ix 8.

93 The Builder, Ixxvii (I), 289. 
of Leicester. He died in 1520 , and the tomb, originally said to have been in the abbey, was probably moved to St. Margaret's after the Dissolution.

The nave and aisles are each of seven bays, with a window in each bay of the aisle. In the third bay from the west in the south aisle is the porch. This is of two stories, with a battlemented parapet and pinnacles, and windows in the south face above the door and at each side. The ceiling is vaulted and the door itself is probably the original one. The top floor of the porch still retains its fire-place. There is another doorway in the north aisle, the door of which has very fine I 3 th-century hinges. The pavements of nave and aisles are partly of modern tiles and partly of stone, including a number of memorial slabs. The carving of the chancel is repeated round the windows of the aisles. In the nave floor there is a I 5 th-century incised slab to William and Agnes Barbor, I444, and another which bears no name or date but which is incised with a hammer and tongs. ${ }^{94}$ The font is in the south aisle. It dates from the 15 th century and is octagonal, decorated with quatrefoil and trefoil panels. Near to it is a dug-out chest with iron fastenings. At the east end of the north aisle is a well, which very probably dates from the 13 th century. 95

The roofs throughout the church are of the kingpost type, with some 15 th-century timbers, although for the most part these were replaced in the last century. The eastern bay of the chancel has been decorated in colour.

The registers date from I6I5. There is no plate earlier than I844. The old plate was sold in 1848 , when most of that now in the church was purchased. 96 There are twelve bells: $(\mathbf{I}-4)$ cast by Thomas Eayre in 1738 ; ( 5 and $7-10$ ) by Hugh Watts in $1633 ;(6)$ by Thomas Eayre in 1739 ; ( 1 I-1 2 ) added in $1921 .{ }^{97}$ The original six bells were said to have been cast by Thomas Newcombe at the end of the I6th century. The first and second bells were originally cast in I 7 I I by Abraham Rudhall at Gloucester, but they were recast in 1738 when William Fortrey of King's Norton gave the third and fourth bells.

The former organ was built in 1773 and restored in 1923. A new organ, incorporating parts of the old one, was installed in $1954^{98}$

The chapel of ST. FOHN THE BAPTIST stood at the far end of Belgrave Gate, near the hospital of St. Mary Magdalen and St. Margaret, 99 but it belonged to the hospital of St. John and seems to have had no connexion with the other hospital despite many assertions to the contrary. ${ }^{1}$ It was in existence before 1382 , when it was the refuge and preachingplace of the Lollards William Smith and Richard Waytestathe, and later of William Swynderby. ${ }^{2}$ The

94 T.L.A.S. xxviii. 1 3,35 .

96 A. Trollope, Ch. Plate of Leics. i. 83.

95 Ibid. 3 I.

97 'T. North, Ch. Bells of Leics. $20 \mathrm{I}^{-2} ;$ Kelly's Dir. Leics. and Rut. (1936), 129.

98 Nichols, Leics. i. 559; Leic. Mercury, I6 Dec. I954.

99 Knighton, Chron. (Rolls Ser.), ii. I 82.

V.C.H. Leics. ii. 40; cf. Billson, Medieval Leic. 9I-02; and Leic. Boro. Rec. I509-1603 (index), where it is erroneously equated with the Spital.

2 Knighton, loc. cit.; K. B. McFarlane, $\mathcal{F}_{\mathrm{h} n}$ Wycliffe, I $03-4$.

McFarlane, op. cit. I 39.

Leic. Boro. Rec. I327-I509, 283.

Ibid. $1509-1603,251$.

Ibid. $1603-88,30$

Leic. City Mun. Room, 73'3o/7; cf. Leic. Boro. Rec. I603-88, 597 . chapel seems to have been deserted when Smith took up his abode there, and it was probably occupied by the Lollards until Archbishop Courtney's visitation of $\mathrm{I}_{3} 89$, which resulted in their prosecution and disgrace. ${ }^{3}$ In 1464 a composition between the guild of St. John and St. John's Hospital arranged that the guild was to hold a service twice weekly in the chapel. ${ }^{4}$ The chapel passed to the Crown at the dissolution of St. John's Hospital and formed part of the grant of the hospital's lands which was made by Elizabeth I to the borough in 1589.5 The chamberlains' accounts record that in $1603-4$ the chapel was let as a house to William Farmer for $40 s$. yearly. ${ }^{6}$ In I630 it was occupied by Thomas Chapman, who was made recorder of the borough in 1624 ; it was then still known as St. John's Chapel. ${ }^{7}$ Nothing more is known of it.

From the ancient parish of St. Margaret many new ecclesiastical parishes have been created to meet the needs of a growing population. The church of $S T$. $G E O R G E$ was the first new church to be built in the borough since the Middle Ages; it was built in I $823-7$ and the parish was separated from that of St. Margaret in $1853 .{ }^{8}$ The church was designed by William Parsons, ${ }^{9}$ the county surveyor, and stands on land which formed part of the glebe of St. Margaret's parish. The style is Decorated. In I 879 a new chancel was built and other alterations made, including the removal of the gallery; the architect of this restoration was A. W. Blomfield. An oak screen was built in the tower arch in 1892 to replace the gallery. ${ }^{10}$ The church was almost ruined by a fire in I9I I and in I9I3 the rebuilding was undertaken by W. D. Caroe. The nave was a total loss and the tower and chancel required heavy restoration. ${ }^{\text {II T The Bishop }}$ of Leicester is patron. 12

CHRIST CHURCH in Bow Street was built by public subscription in $\mathbf{1} 839$, when the parish was formed from that of St. Margaret. The architect was again William Parsons. ${ }^{13}$ The church, of red brick with no tower, was restored in 1876 and again in I $905,^{14}$ but is (1956) scheduled for demolition. The church was closed in January 1956 and the parish merged with that of St. Matthew. ${ }^{15}$ The living was in the patronage of trustees. ${ }^{16} S T . M A R K$ 'S Church in Belgrave Gate was built in $1870-2$ at the cost of W. Perry Herrick of Beaumanor to the designs of Ewan Christian. ${ }^{17}$ The church was built of Charnwood slate, with a tower and spire rising to a height of $\mathrm{I} 68 \mathrm{feet}$. There are stone dressings and the interior of the church is lined with red brick. In 1903 the church was extended westwards and restored. ${ }^{18}$ The parish of ST. FOHN THE DIVINE was formed in I 854 from that of St. George and the church was

8 White, Dir. Leics. (1877), 296, which has a full acct. of the ch. though the date of the formation of the parish is given incorrectly; Spencer, New Guide to Leic. (1 888), 78.

9 White, Dir. Leics. (1846), 86

I $T . L . A . S$. v. $226-7$; ibid. viii. 5 ; Spencer, loc. cit.; Building News, I 4 Nov. 1879 .

II T.L.A.S. xi. 49; Leic. Mail, 6 Oct. I 9 I I.

12 Leic. Dioc. Cal. (1954), 90

13 White, Dir. Leics. (1877), 295; D. T. Wilson, Sketch of Hist. of Christ Ch. Leic. (1

I4 Spencer, New Guide to Leic. (1888), 8o; Kelly's Dir. Leics. and Rut. (1936), 130.

I5 Leic. Mercury, 30 Jan. 1956

I6 Leic. Dioc. Cal. (1954), 89.

17 White, Dir. Leics. (1877), 209-300. Christian was architect to the Eccl. Commissioners: T.L.A.S. ii. 32.

i 8 Kelly's Dir. Leics. and Rut. (1936), I 30. 


\section{A HISTORY OF LEICESTERSHIRE}

built in I 853-4 in Ashwell Street, off London Road, to the designs of Sir George Gilbert Scott. ${ }^{19}$ As built, the church had a spire striped with bands of coloured brick, which received a good deal of criticism ${ }^{20}$ and has since been removed. ST. PETER'S parish was formed in 1874 from those of St. Margaret and St. George. The church, at the corner of Sparkenhoe Street and Highfield Street, was begun in the same year but was not completed until i 879 . The architect was G. E. Street and the church was built as a memorial to the first Earl Howe. ${ }^{21} S T$. HILDA'S Church in Melbourne Road was built in I 89I by the firm of Goddard and Paget and is a chapel to St. Peter's. ${ }^{22}$

In $1867 S T$. $M A T T H E W ' S$ parish was separated from that of Christ Church and the church in Chester Street was built by Sir George Gilbert Scott. ${ }^{23}$ It is a large building of Mountsorrel granite and is as yet (1956) incomplete, lacking the tower and spire which formed part of the original design. St. Matthew's and St. Peter's parishes were again divided in 1877 to form the new parish of $S T$. SAVIOUR. The architect of this church was once more Sir George Gilbert Scott. The church is of red brick and is perhaps the most successful of all Scott's Leicester churches. It was endowed by the Revd. F. G. Burnaby and was completed between 1875 and I 877.24 Previously part of St. Matthew's parish had been combined with part of St. George's to form the parish of $S T$. LUKE. The church in Humberstone Road was built in 1868 to the designs of Bellamy and Hardy of Lincoln, after a competition in which their plan was in fact placed third, but it was selected on account of the inexperience of the other two architects. ${ }^{25}$ The church was restored in $1892^{26}$ but was demolished in $1949 .{ }^{27}$ The parish was divided between Christ Church, St. George's and St. Matthew's. ${ }^{28}$ In 1937 a suggestion had been made that the church should be moved stone by stone to Braunstone to serve the new housing estate. ${ }^{29}$ In 1918 the parish of ST. FAMES THE GREATER was created from that of St. Peter. ${ }^{30}$ There had been a temporary chapel on the site of the church in London Road between I 88I and I899, when the present building was begun. The chapel had been built from the materials of the hall built for the Church Congress. ${ }^{31}$ The church was designed by Henry Langton Goddard and was completed in $1914.3^{32}$ The church of $S T$. $A L B A N$ in Harrison Road was built in 1905 on the creation of the parish from those of St. Mark and St. Michael and All Angels, Belgrave. Howard H.

19 White, Dir. Leics. (1877), 297; Spencer, Nezv Guide to Leic. ( I 888), 8o-82.

20 See e.g. The Builder, lxxii. 503.

21 White, Dir. Leics. (1877), 304; T.L.A.S. v. 227.

22 Kelly's Dir. Leics. and Rut. (1900), i $15 ;$ T.L.A.S. vii. 3 I 9 .

${ }_{23}$ White, Dir. Leics. (1877), 303; T.L.A.S. iii. 337.

24 White, op. cit. 304-5; T.L.A.S. v. 89-90; The Builder, 1xxii. 503.

25 White, op. cit. 297; Leic. City Mun. Room, Mins. of

Leic. Ch. Extension Soc. 22 May I 866.

26 T.L.A.S. viii. 5.

27 Ex inf. Leic. City Museum.

${ }^{28} \mathrm{Ex}$ inf. Leic. Dioc. Registry; Order in Council, 30 May I94I.

29 Leic. Mercury, I 2 Jan. I 937.

30 Kelly's Dir. Leics. and Rut. (1936), 131

3 I Spencer, New Guide to Leic. (I888), 9 I.

2 Kelly's Dir. Leics. and Rut. (1936), 130; W. Scarff, Leics. and Rut. at Opening of 20 th Cent. I 52 .
Thompson was the architect. ${ }^{33}$ The Bishop of Leicester is the patron of all these churches. ${ }^{34}$

CHARITIES. Robert Auceter by will proved in I 633 gave to the poor a yearly rent of $f_{\mathrm{I}}$ from his house in Northgate Street. In ${ }^{6} 656$, under the will of his widow, Elizabeth, the rent was recharged on a house near Belgrave Gate, now in Garden Street. The sum was still being paid in 1955, although it lapsed for a short time in the I9th century, and was distributed in the form of bread. 35

A house in Swan Street, Loughborough, known in the Igth century as the Grape Vaults, is first mentioned as the property of St. Margaret's parish in $\mathbf{1 7 8 6}$, although it is not known how or when the parish obtained it. In 1837 it was let for £II yearly, of which $5^{s}$. was given to the vicar, the rest being distributed among the poor at Christmas. In I 899 the house was sold and the proceeds invested in stock. ${ }^{36}$

John Bass by will proved in 1764 left $f, 5$ yearly from the profits of his coal and wood-weighing machine on the Coal Hill at Leicester. The money was to be distributed in the form of coal to the poor of the parish, and was paid until I 828 when the owners of the machine refused further payments. ${ }^{37}$

Sarah Ward left $£ 60$ by will in 1774 in trust for distribution to six poor widows on New Year's Day. The distribution lapsed for a time but was revived in 1837 and is still (1955) continued. ${ }^{38}$

John Nichols left $f$ IOO by will proved in 1815 to be invested and the interest distributed among poor housekeepers on St. Thomas's Day. It was duly distributed in 1955.39

In 1782 six houses on Cock Muck Hill, off Belgrave Gate, which had been used for housing the poor, were pulled down when Belgrave Gate was widened. They were rebuilt in the present Abbey Street, around an open court, and were used for six poor persons not receiving relief and appointed by the parish officers. These houses have also been demolished and three bungalows in Overton Road were in 1947 devoted to a similar purpose, under the control of the select vestry. As the occupants died the income was merged with the general charities fund. At an unknown date before 1782 Catherine Holmes left money to provide coal on St. Thomas's Day for the inhabitants of these houses. The money used to be charged upon a house in Belgrave Gate, formerly the Black Lion Inn, but in 1782 it was redeemed by a payment to the parish officers. ${ }^{40}$

33 Kelly's Dir. Leics. and Rut. (1936), loc. cit.

$3+$ Leic. Dioc. Cal. (1954), 89-9I.

353 and Rep. Com. Char. Pt. 5 [163], p. I07, H.C.

(1839), xv; Morris, St. Margaret's Select Vestry, 26-35; Morris, op. cit. (2nd edn. I 954), 35.

${ }_{36} 32$ nd Rep. Com. Char. Pt. 5, 106-7; Morris, St. Margaret's Select Vestry, 20.

3732 d Rep. Com. Char. Pt. 5, 107; for Bass, see also above, p. 35 I, n. 17.

383 and Rep. Com. Char. Pt. 5, ro6; Morris, op. cit. 18

3932 d Rep. Com. Char. Pt. 5, I o6; Morris, op. cit. I 8. I 9.

40 32nd Rep. Com. Char. Pt. 5, 108-9; Morris, St. Margaret's Select Vestry, 2-3; Morris, op. cit. (2nd edn. I954), 3. Nichols identified these houses with the Spital (Leics. i. 323), but this seems to be incorrect: see below, p. 409; Almshouses outside the East Gate, mentioned in I6I3I4, were probably the same as those on the Cock Muck Hill: Leic. Boro. Rec. I $603-88$, I 50. 
St. Margaret's parish also receives payments from Leicester Corporation under the Ive, Courteen and Blunt Charities, and from the Trustees of Leicester
General Charities under the Heyrick Bread Charity.4I

The charity originating from St. Margaret's Parish Piece is described above. ${ }^{2}$

\section{ST. MARTIN'S}

St. Martin's parish has always been an urban area within the borough walls: no part of it lay outside. The parish ceased to exist for civil purposes in 1896 : its area was 37 acres in 1891 . It is still an ecclesiastical parish. The ancient parish boundary runs south from the East Gate along Gallowtree Gate, up Horsefair Street and part of Millstone Lane, until it strikes through houses to join Friar Lane. From there it cuts across through more houses to Southgate Street, up which it runs to Redcross Street, and through more houses to meet Thornton Lane at the junction with Harvey Lane, and again through houses to the east end of St. Nicholas Street. From there it proceeds just south of Free School Lane and Bond Street to Churchgate, turning south to the East Gate. ${ }^{\mathrm{I}}$

The general street pattern has remained unchanged since the early Middle Ages. The main street is the High Street, from the East Gate to the former High Cross, at the junction with High Cross Street. It was known in the Middle Ages as the Swinesmarket and is first mentioned in the borough records in $1335^{-6.2}$ As the street grew in importance it became no longer desirable for the pig market to be held there and it was moved in I 524 to the present New Bond Street. ${ }^{3}$ After this the High Street gradually received its present name, the Old High Street becoming known as High Cross Street. ${ }^{4}$ Its importance in the I6th century is illustrated by the fact that it was in this street that Henry, Earl of Huntingdon chose to purchase his town house in I 569.5 This stood at the corner of New Bond Street and High Street, and was known as Lord's Place. It was demolished in $\mathbf{I} 902$ for street widening. The house and its grounds once occupied a very considerable quantity of ground, but by I902 all that remained was one of the stone turrets, encased in I 8 th-century brick. ${ }^{6}$ The street widening which occasioned the destruction of Lord's Place was stimulated by the building of the Great Central railway station in $1899,{ }^{7}$ and was carried on until the early years of the present century. The corporation purchased a large number of houses for demolition and nearly all the buildings in the street date from this time. ${ }^{8}$

At the western end of High Street stood the High Cross, the site of which is marked in the roadway. There was a cross here before 1278 , when it was

${ }^{41}$ See below, pp. 4II, 4I3. $\quad{ }^{42}$ See above, p. 355.

I T. and G. Ellis, Plan of Leic. (1 828); Census, I891.

2 Leic. Boro. Rec. I327-I 509, 22.

3 C. J. Billson, Medieval Leic. 120.

4 Ibid. 8.

5 Ibid. 209.

6 [S. Watts], Walk through Leic. 27-28; A. Fielding Johnson, Glimpses of Anc. Leic. (2nd edn. 1903), I66, where the probable extent of the property is discussed. There are drawings of the building before demolition in 3oth Ann. Rep. Leic. and Leics. Soc. of Architects; see also above, plate facing p. 290 . The site is marked by a plaque on a shop in High Street.

7 R. Waddington, Leic.: The Making of a Modern City, I 2 ; V.C.H. Leics. iii. 125. repaired, and it was rebuilt in $\mathrm{I} 3 \mathrm{I} 4 .^{9}$ It was the site of the Wednesday market of the town until $\mathrm{I} 884^{10}$ In 1577 a new cross was built, a little farther to the north, to act also as a shelter for the market women. This stood until 1773 , when most of it was taken down and sold, but one limb remained until 1836 , when this too was removed and set up in front of the Crescent in King Street. It is now (1955) in the garden of the museum in the Newarke, having been presented to the town in 1940.11

Parallel with High Street to the south run Guildhall Lane and Silver Street. Guildhall Lane was known in the Igth century as Town Hall Lane, and in the Middle Ages as Kirkgate, Kirk Lane, or St. Martin's Church Lane, and occasionally as Holy Rood Lane. ${ }^{12}$ The Guildhall, which was used as the Town Hall from at least the end of the 15 th century until $1876,{ }^{13}$ stands on the corner of Guildhall Lane and St. Martin's West, and consists of a miscellaneous group of buildings forming an open quadrangle. The largest and earliest of these is the Great Hall, which forms the north side of the quadrangle. The earliest part of the hall dates from the late I 4 th century, when the three eastern bays of the timberframed building were erected as the hall of the guild of Corpus Christi. About I450, two additional bays were added to the west, completing the fine, openceiled hall, upon the ceiling of which are painted coats of arms. The gallery at the east end of the hall was brought from another building in the town in I 842 , and the staircase was added in 1922. ${ }^{14}$ About I 500 a second, smaller hall was built, of a similar pattern, at right-angles to the extensions of the midI 5 th century and forming the west side of the quadrangle. It is possible, although not certain, that by this date the whole quadrangle was completed by the houses for the four guild priests on the east side and by kitchens on the south. The addition of the new hall may have been the result of the increasing use of the, Corpus Christi guildhall by the corporation for its meetings. These buildings continued to be used by the guild until it was dissolved in 1547 and in 1563 they were sold to the borough.

About 1593 alterations were made in the western range. A floor was inserted at the tie-beam level of the hall of I 500 and another above, creating two floors above the ground floor. The ground floor room

8 Boro. of Leic. Abstract of Accts. for 1900-3.

Billson, Medieval Leic. I I 7.

${ }^{\circ}$ J. Storey, Hist. Sketch of Boro. of Leic. I I3-I4; see above, pp. 46,283 .

I Billson, Medieval Leic. I I 7-I 8 . The Elizabethan cross is illustrated in Nichols, Leics, $\dot{\mathrm{I}}$, plate xxxi, and the earlyI th remains in John Flower's engraving in Viezs of Anc. Buildings in the Town and Co. of Leic. See also Illus. Leic. Chron. 6 July I940; Leic. Mercury, I 4 June I 955.

I2 Ellis, Plan of Leic. (1828); Billson, Medieval Leic. 9.

${ }_{13}$ The source for much of the following is T. H. Fosbrooke and S. H. Skillington, Old Town Hall, Leic.; see also P. A. Stevens, The Guildhall, Leic.

I4 Stevens, op. cit. 8. For a photograph of the interior of the Great Hall see above, plate facing p. 56 . 


\section{A HISTORY OF LEICESTERSHIRE}

became the mayor's parlour and was panelled in oak about $\times 637$, when the fireplace was added. In $x 953^{-4}$ the fireplace was restored and repainted in its original colours. ${ }^{15}$ The first-floor room, known as the Grand Jury Room, was also panelled in oak in 1637 and in I 955 was occupied by the library of the Leicestershire Archaeological Society. There is a large attic above.

The eastern range of the quadrangle, formerly the dwelling-houses of the guild priests, seems to have remained unaltered until $\mathrm{r}_{3} 6$, except for the creation of a bedroom for the recorder on the first floor in 1580 , and the alteration of a room to house the Town Hall Library in 1632 . When the borough police force was established in 1836 its headquarters were in the Guildhall and the lower story of the east range was converted into offices and cells. In 1842 the southern range was demolished and a brick house was built for the chief constable of the borough. Nothing is known of the early history of the south range. In $1922-3$ the Guildhall was restored by $T . H$. Fosbrooke, who removed the plaster with which the outer walls had been covered and exposed the timbers. With the exception of the lower floor of the east wing, which is stone-built, and the brick house to the south, the whole building is timber-framed, with roofs of Swithland slate. The Guildhall is maintained by Leicester Museum.

Silver Street was formerly known as the Sheepmarket, ${ }^{16}$ until the market was moved to the Saturday Market Place in I 506. ${ }^{17}$ By the end of the 16 th century it had received its present name, ${ }^{18}$ but renewed its old function when a sheep fair was held there in the 18 th century. 19 The Opera House, in Silver Street, was built by C. J. Phipps in $1876-7$ and was for many years a notable theatre under the management of Eliot Galer. ${ }^{20}$ It is now (1955) closed. Cart's Lane runs between Silver Street and High Street; the origin of the name is not known. Loseby Lane joins the west end of Silver Street with St. Martin's. Its first mention in written records seems to be in $1448,{ }^{21}$ but Billson suggests that it was named in the early I $4^{\text {th }}$ century for Henry of Loseby, who held property in St. Martin's parish about I $300 .{ }^{22}$ In the 18 th century the pig market was held there. ${ }^{23}$ Today the street retains more of an I 8th-century atmosphere than any other in the town. It has granite cobbles and most of its pleasant I 8 thand 19 th-century houses remain unaltered. No. I 7, in particular, is worthy of mention. Cank Street, St. Martin's, and Peacock Lane form the next series of streets running westwards parallel to High Street. Peacock Lane used to run as far as Cank Street, but from the middle of the Igth century the piece from New Street to Hotel Street has been known as St. Martin's. ${ }^{24}$ Peacock Lane was known in the

15 T.L.A.S. xxx. I $19-20$.

16 Wyggeston Hosp. Charters, 33 I (1 408).

17 Billson, Medieval Leic. I 20.

18 Leic. Boro. Rec. I 509-I603, 240.

19 Billson, op. cit. I 17.

Spencer, New Guide to Leic. (1888), I 32-4; J. D.

Horn, Illus. Guide to Leic. (1905), I $12 ;$ D.N.B., sub Phipps.

Wyggeston Hosp. Charters, 349.

22 Billson, Medieval Leic. I I.

3 Ibid. I 20.

4 Cf. Ellis, Plan of Leic. (1828) and Spencer, Map of Leic. (1 867).

25 Billson, Medieval Leic, Io.

26 See below, p. 405. 'The site of the chapel is marked by a stone slab in the grounds of Alderman Newton's Boys' School.
Middle Ages as St. Francis Lane, from the Franciscan friary which stood at the east end. The Peacock, after which the street was named in the 18 th century, was a piece of land lying near Redcross Street. 25 Wyggeston's Hospital stood at the corner of Peacock Lane and St. Martin's West until its demolition in $1875 .{ }^{26}$ The site of the hospital is now occupied by the grounds of the Alderman Newton's Boys' School. No. 2i St. Martin's is a good I 8 th-century house. Cank Street is named from the Cank, a public well which stood at its west end. ${ }^{27}$ It is first mentioned in $1313 .{ }^{28}$ From 1597 to $c$. 1763 the cattle market was held here. ${ }^{29}$

The street called Grey Friars, which runs from St. Martin's to Friar Lane, was constructed in $187^{2}-$ $3 .{ }^{30}$ It cuts through the site of Grey Friars, a large house built on the site of the Franciscan friary and owned by the families of Herrick, Noble, Pares, and Burnaby in turn from the 16 th century to the 19 th. ${ }^{31}$ In the north-east corner of the garden of this house Thomas Pares established his bank in 1800.32 The present bank building, owned by the Westminster Bank and one of the best pieces of modern architecture in Leicester, was erected by S. Perkins Pick in I901.33 The Trustee Savings Bank at the corner of St. Martin's is by Edward Burgess and was built in $1874 \cdot{ }^{34}$

Hotel Street takes its name from the building which is now the County Rooms, which was begun in $179^{2}$ and designed as a hotel but never used as such. ${ }^{35}$ The architect was the Leicester-born John Johnson and this is his most important building in his native town. The building was not completed until 17 September 1800 , when it was opened by a company for use as public assembly rooms. In I 817 the building was sold to the county justices for use as a judges' lodging during the assizes and possibly for an archive repository. ${ }^{36}$ Considerable alterations were undertaken after the sale and the interior arrangements and decorations date from this period, with the exception of the ball-room, which was designed by Johnson. The surveyor of the alterations in $1817-$ I 8 was Joshua Harrison, architect and carpenter. ${ }^{37}$

The building is of ashlar, now blackened with smoke, and is of two stories. The projecting front porch has paired Roman Doric columns and is flanked by four windows with flat arches. There are three second-story windows, each of three lights, with semi-circular heads, divided by Ionic columns. Flanking the central window are two niches, containing terra-cotta figures of the comic and lyric muses by J. C. F. Rossi, R.A. Above each niche is a carved panel of dancing figures. There is a flat roof behind a parapet, the stones of which were reversed after the sale to the county to hide the inscription

27 Billson, Medieval Leic. 10-I I.

28 Wyggeston Hosp. Charters, 301.

29 Billson, op. cit. 12 I.

30 Ibid, I 84

31 Ibid. $183^{-4}$; Leic. Mercury, 16 Mar. I955; C. J. Billson, Leic. Memoirs, frontispiece and illus. facing p. I.

32 V.C.H. Leics, iii. 30.

33 T.L.A.S. ix. 17 i ; J. Simmons, City of Leic. 27.

34 Spencer, New Guide to Leic. (1888), 160.

35 For the County Rooms see J. Simmons, 'A Leic. Architect', in Parish and Empire, 139-42; 'TS. notes compiled by W. Keay, F.R.I.B.A., county architect, I 925 , revised 1949 (copy in Univ. Coll. Libr. Leic.).

${ }^{36}$ Simmons, Parish and Empire, 141.

37 L.R.O., County Rooms papers. For an illustration see plate opposite. 


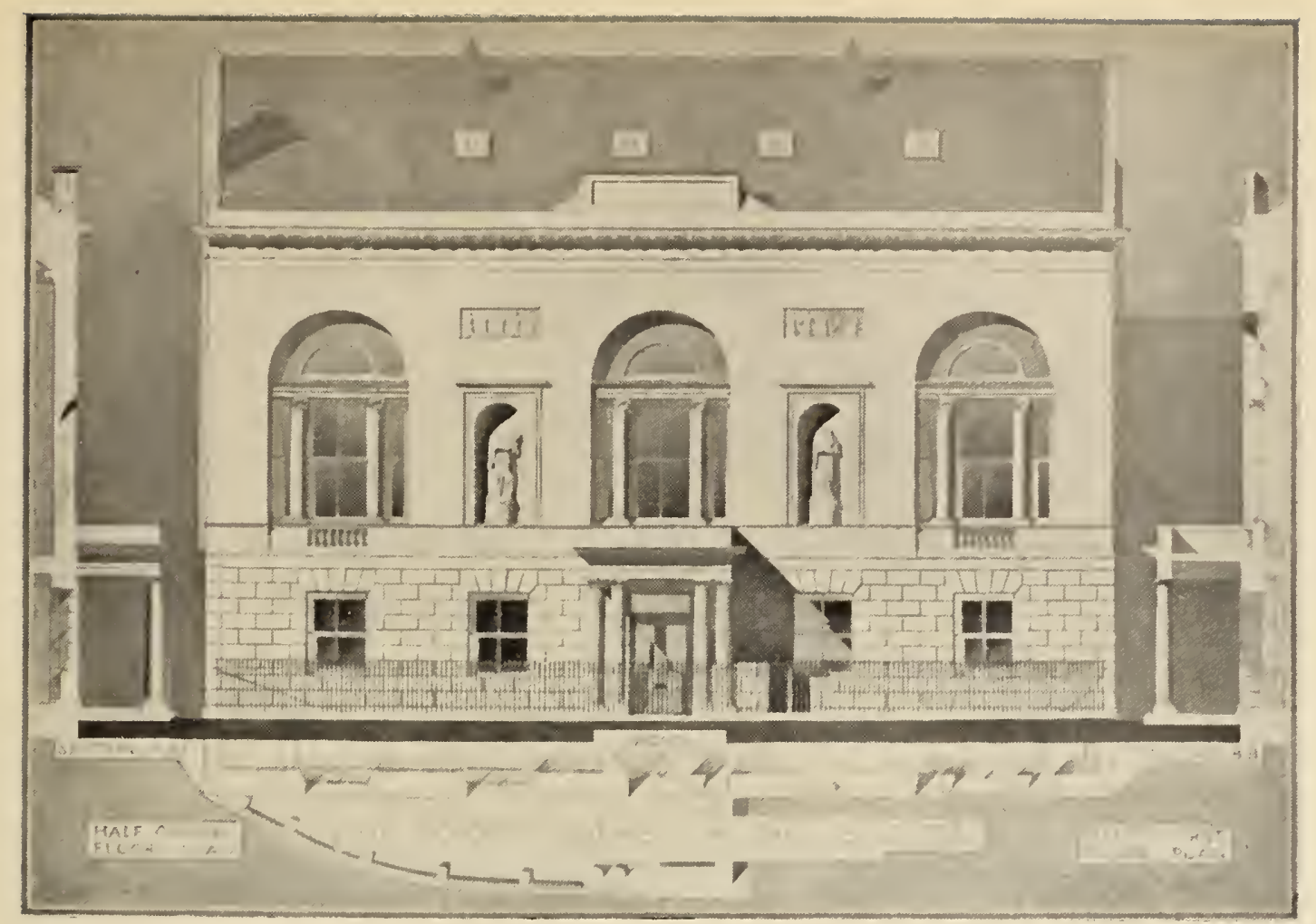

The County Rooms

built $1792-1800$

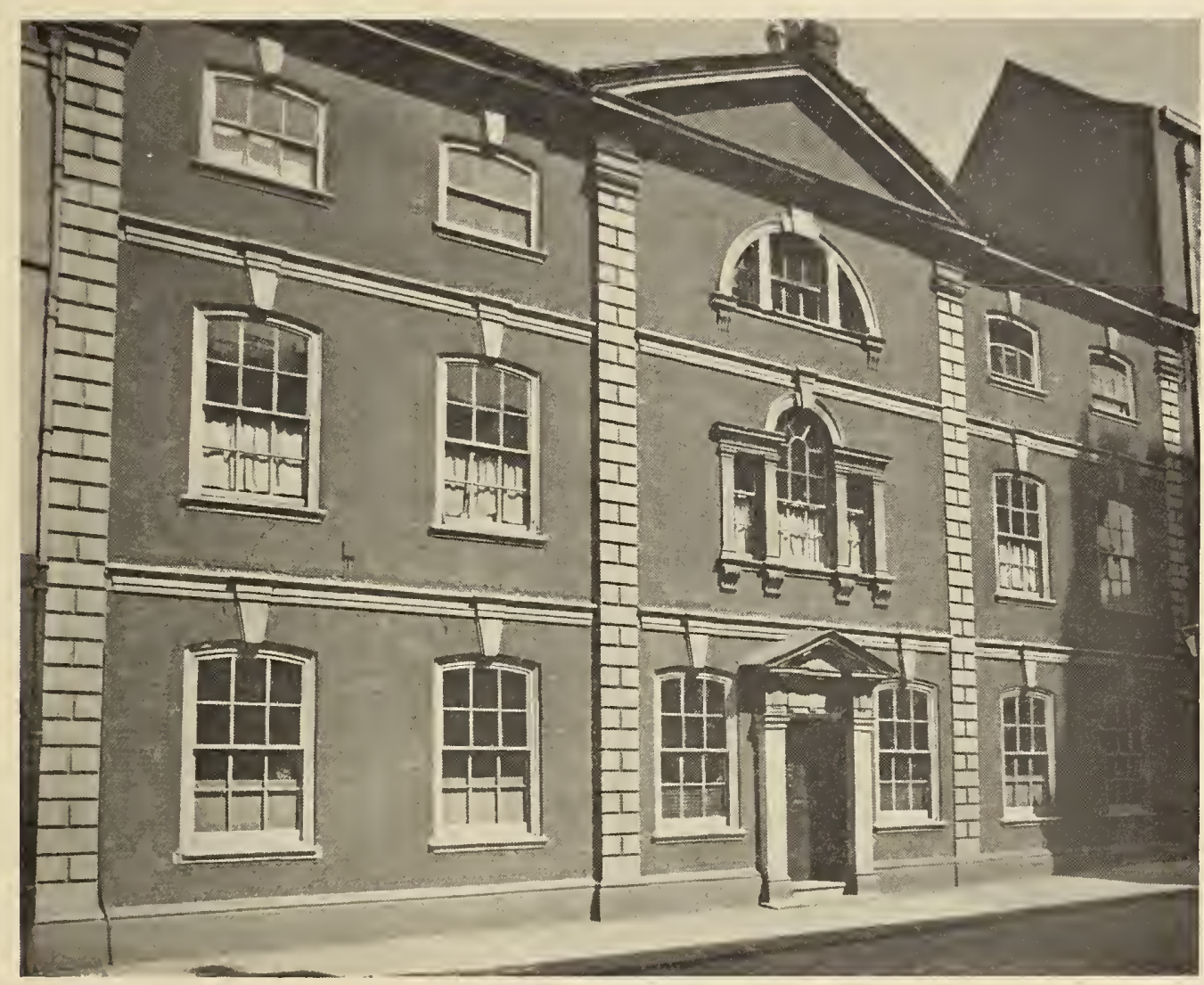

I7 Friar Lane 


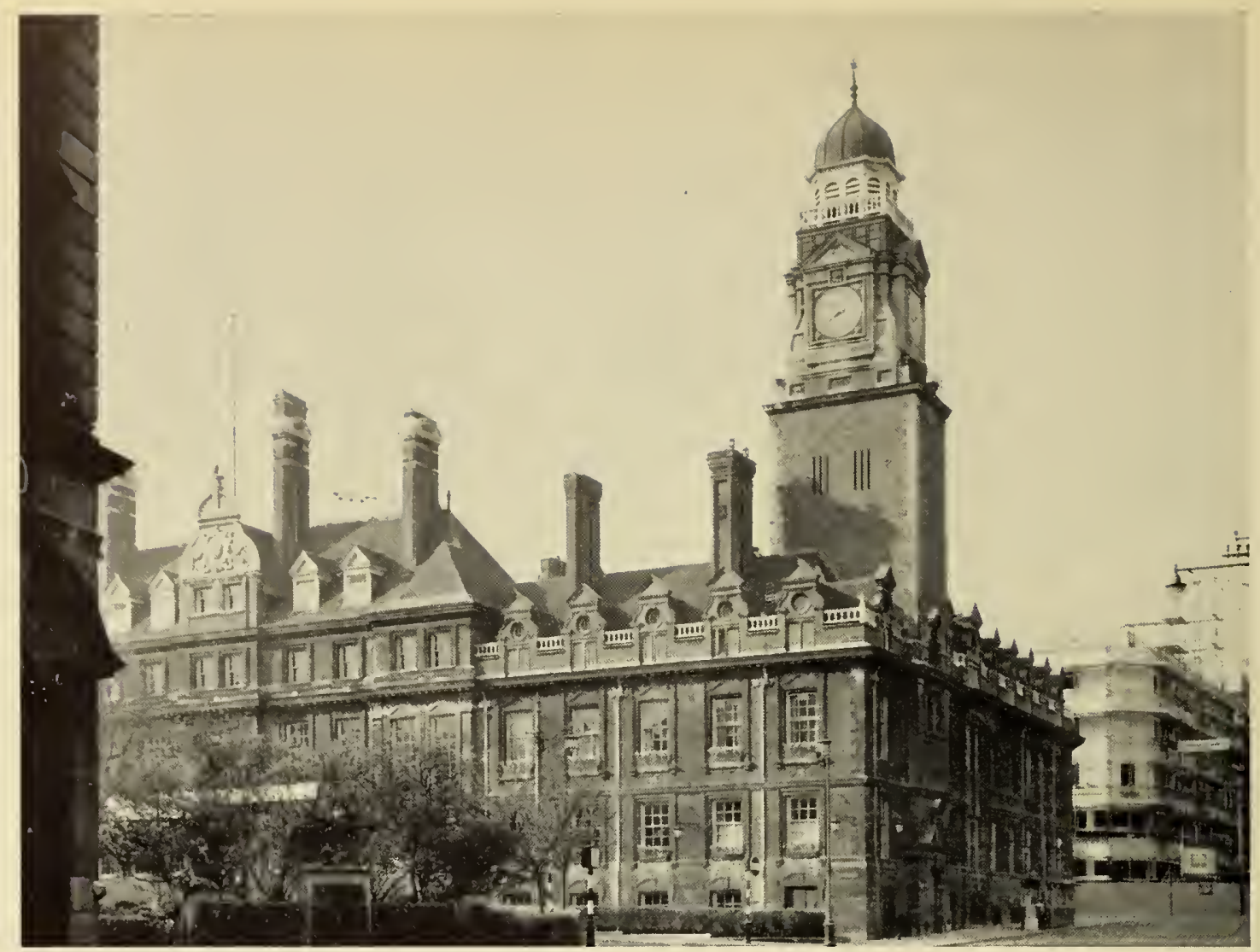

The Town Hali

built I $874-6$

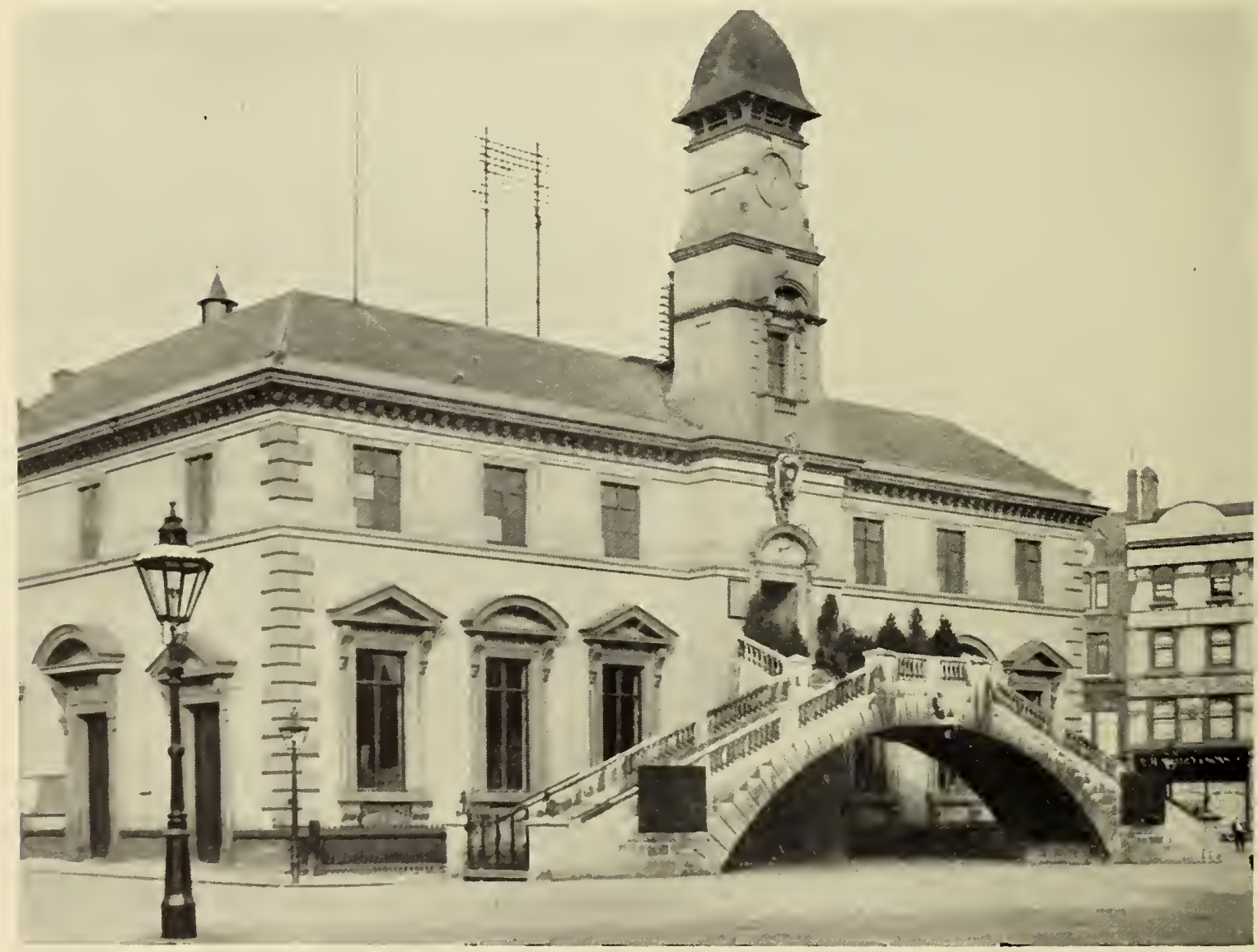

The New Corn Exchange

built 185 I-6 
'Assembly Rooms'. The original glazing bars have been removed and plate glass inserted in the windows.

The interior plan of the building is very simple. At the front on the ground floor are the dining- and drawing-rooms, with smoking-room and kitchens at the rear. The staircase rises opposite the front door, dividing in two and leading to the landing from which opens the ballroom. This runs along the whole length of the front of the house and is a magnificent room, decorated with figures in niches on the north and south walls, also the work of Rossi, and with paintings in circular panels on walls and ceilings by R. R. Reinagle. The ceiling has been replaced by one of acoustic tiles, and the rest of the room was decorated in pink and gold shortly before 1955. All the bedrooms are at the rear of the house. With the exception of the ballroom, all the original ceilings remain, including one of moulded plaster in the porch. 'The building is used by the Leicestershire County Council for meetings, and is still the judges' lodgings at the assizes.

New Street, to the west of Grey Friars and parallel with it, was laid out in 17 I I,${ }^{38}$ when it was still part of the site of the Franciscan friary. Like Loseby Lane, New Street preserves its I8th-century character. Nos. 12 and I4, in particular, should be mentioned. They were built as a pair, with a passage between the two fronts and projecting side wings.

Friar Lane is also named from the Franciscan friary. It is first mentioned by this name in $1391,{ }^{39}$ but the street had existed for some time before that date. Friar Lane also has some good I8th- and I 9 thcentury houses. No. I7 has been described as "the handsomest Georgian house now left in the old town' ${ }^{40}$ Nos. 18 to 28 are a terrace in light grey brick, with well-arranged and proportioned windows. The County Offices, on the corner of Grey Friars and Friar Lane, were completed in 1937 , to the designs of the firm of Pick, Everard and Keay.41

Millstone Lane is first mentioned as such in $\mathrm{I} 45^{2}, 4^{22}$ when it still lay at the very edge of the built-up part of the borough, with arable land bounding it to the south. In the I6th century it was sometimes known as Horse Fair Lane, for horses were bought and sold in the fields outside the South Gate.43 From I 774 until I 872 the cattle market was held here, and there was also a cattle fair here in the I 8 th century. 44 There are some fine Georgian houses in the street, especially No. 20. The Gas Offices at the corner of Pocklington's Walk are by Edward Burgess. 45 'The present Horsefair Street, to the east, was laid out at the beginning of the Igth century, on the site of the old Horse Fair Gardens. 46 The Theatre Royal, in Horsefair Street, was built in 1836 , by Samuel Beazley, who specialized in theatres, and William Parsons, the Leicester architect and surveyor. ${ }^{47}$ It replaced John Johnson's theatre, which had been

\footnotetext{
38 Billson, Medieval Leic. I 83 .

39 Wyggeston Hosp. Charters, 323 ; cf. Billson, op. cit.

40 Simmons, City of Leic. 25. For a photograph see above, plate facing p. 362 .

41 Ibid.; Leic. City Ref. Libr., Cable Coll, ix. 63.

42 Leic. Boro. Rec. I327-I 509, 259.

43 Billson, Medieval Leic. 8.

44 Ibid. I I 7 , I 2 I.

45 The Builder, lxxii. 498.

46 A. T. Patterson, Radical Leic. 87.

47 H. M. Colvin, Biog. Dict. Eng. Architects, 69, 445-6.
} I I. built in 1800,48 and occupies roughly the same site. The theatre has a simple classical façade of two stories, the lower rusticated and forming an arcade over the street. Above, Ionic columns support a simple pediment. The rear elevation faces the market and is of three stories. The Alliance Assurance building, in Horsefair Street, is by Goddard and Paget. ${ }^{\circ}$ 'The National Provincial Bank at the corner of Granby Street and Horsefair Street was built by William Millican in I 870.50 The Royal Hotel, also in Horsefair Street, is by Everard and Pick. ${ }^{51}$

The Town Hall stands in Town Hall Square and was built between 1874 and 1876 to the designs of F. J. Hames, a Leicester-born architect, who won the competition for the new building sponsored by the corporation in 1873.52 With the exception of the winning design, all the plans which were submitted were either Gothic or Classical in character. ${ }^{53}$ Hames suggested the building of a town hall which was clearly influenced by the Hôtel de Ville in Paris, and whose style is perhaps more reminiscent of the period of Queen Anne in England. In considering the various designs, The Builder remarked in 1873 , 'We should scarcely wish to see so important a building erected in this style. It may be urged that it harmonizes with the character of the Leicester streets; but that, perhaps, should be a reason against rather than for it; for the town sadly wants enlivening with regard to its architecture, and if this design were carried out, something should, at all events, be done, by a more striking treatment of the angles, to take away a little of the workhouse look which from some points it would inevitably present.' 54 Hames's building was erected as originally designed, and is one of the most distinguished buildings in the borough.

It is built of deep red Suffolk brick with dressings of Ketton stone. The site slopes away to the north and the angle has been offset by the clock tower at the north side of the building. 'This device, together with the fact that the details on the front are not always exactly repeated, relieves the building of that monotony which was feared by The Builder. The Town Hall now forms an open quadrangle. Side wings were added to the front, and the front elevation was exactly repeated in the new block built to face Bowling Green Street and to complete the quadrangle in I932. Hames's great council chamber was completely remodelled in 1932.55

The Market Place, now the site of the only retail market in the town, was formerly the Saturday Market and was so called as early as I 298. ${ }^{56}$ Various types of goods were sold in this area during the Middle Ages: the meat market was in the north-west corner, where the butchers still have their shops. There was a fish market by the I4th century. The first market hall was built in 1440 by the Duchy of Lancaster and was known as 'Le Draperie'; it was

48 Simmons, Parish and Empire, 142; Nichols, Leics. i, plate xxvii; R. Leacroft, Theatre Rojal, I 5, I 8, 21 sqq.

49 The Builder, lxxii. 499.

50 Spencer, New Guide to Leic. I6o.

51 The Builder, lxxii. 499.

52 Storey, Boro. of Leic. 66-68; and see above, p. 290.

53 The Builder, xxxi. 477-8. F. W. Ordish won the 2 nd prize, and George Gilbert Scott the 3rd: Storey, op. cit. 66. 54 The Builder, xxxi. 478 . For a recent photograph see plate opposite.

55 Leic. Mail, 25 Oct. 1932

56 For early hist. see Billson, Medieval Leic. I I 8-I9. 


\section{A HISTORY OF LEICESTERSHIRE}

granted to the borough in 1589 . Another public building is first mentioned in 1533.57 The origin of its name, the Gainsborough, is unknown, but it was a market hall and prison, and its upper story was used by the borough justices: it may in fact have been the same building as the market hall, to which as such there is no reference after the beginning of the 17 th century. ${ }^{58} \mathrm{~A}$ new Gainsborough was built in 1747 by the Leicester architect John Westley. ${ }^{59}$ This was demolished in $185 \mathrm{I}$ and rebuilt as a singlestory hall designed by C. Wickes. ${ }^{60}$ In $\mathbf{1} 855 \mathrm{~F}$. W. Ordish won the corporation's competition for a corn exchange with the design of the building which exists today. ${ }^{61} \mathrm{He}$ added to the top of the market hall the Corn Exchange with its clock tower and, instead of opening a staircase from the interior, he built a rusticated open bridge carrying an outside staircase. This design was not appreciated by his contemporaries and it was widely criticized.62 It is now unfortunately impossible to see the staircase clearly on account of the permanent stalls which stand in front of it.

'To the south of the old exchange and running up to Hotel Street was the lane called Cornwall or the Back Side, where carriages and agricultural implements were sold and which was widened when the exchange was demolished in 1851.63 The Conduit stood in the Market Place at the south end of Cheapside from 1612 until 1841 , being rebuilt in I 709. ${ }^{64}$ It was an octagonal building of brick, which covered a large lead cistern. In I $84 \mathrm{I}$ it was replaced by a tall iron column which supported a lamp and a tap. This remained until $\mathbf{I} 85^{2}$, when it was replaced by a statue by Edward Davis of the 5 th Duke of Rutland, in the pedestal of which there was also a tap. This last vestige of the old Conduit disappeared in 1872 , when the duke's statue was gilded and moved to stand in front of the Corn Exchange. ${ }^{65}$ The remains of the old Conduit were in 1955 in a garden in Wigston Magna. ${ }^{66}$

Besides the regular Saturday market, most of the other markets of Leicester have been at some time or other held in the Market Place. ${ }^{67} \mathrm{~A}$ cattle market was first mentioned in I $34 \mathbf{I}$ and was held in the Market Place in the later Middle Ages, ${ }^{68}$ but it was moved to Cank Street, Loseby Lane, and Cow Lane in 1597 . In 1793 it returned to the Market Place, where it was held until I804 when it was removed to the present Town Hall Square. The new Cattle Market in Welford Road was opened in 1872 .

57 Leic. Boro. Rec. I509-I603, 34; Billson, op. cit. 4649.

58 Billson, op. cit. I I 9.

59 Leic. City Mun. Room, Chamberlains' Accts. I 7478; Nichols, Leics. i, plate xxviii; Billson, op. cit. 48 . The building is illustrated above, plate facing $\mathrm{p}, 179$.

60 Trans. Leic. Lit. and Phil. Soc. I 835-79, 142.

61 36th Ann. Rep. Leic. and Leics. Soc. Architects (19089), where the original sketch is reproduced; see also Simmons, City of Leic. 26-27. A photograph of the Corn Exchange is reproduced above, plate facing p. 363 .

2 e.g. Spencer, New Guide to Leic. (1888), I I9; White, Dir. Leics. (1877), 292. The change in taste by the end of the century is reflected in The Builder, lxxii. 498 .

3 Patterson, Radical Leic. 5; see also Rep. of Town Improvement Cttee. to Town Council (1845) (Leic. City Ref. Libr., Pamphlets $\mathrm{O}_{3}$, vol. vi).

4 For the Conduit see Billson, Medieval Leic. II; Leics. and Rut. N. E' Q. i. 125-6; Leic. Mercury, 20 July I 955 .

65 Spencer, New Guide to Leic. (1888), 56. It now (1955) stands near the castle, opposite the West Bridge.
The sheep market was originally held in Silver Street, ${ }^{69}$ but was moved in 1506 to the Market Place, where it was held until it was transferred to Town Hall Square in the 19 th century. ${ }^{\circ}$ The pig market appears never to have been held in the Market Place. ${ }^{71}$ In the I 9 th century many improvements were made in the layout of the Market Place. Besides the widening of the Back Side, the building of the Corn Exchange, and the removal of the Conduit, in 1876 a passage was opened between Gallowtree Gate and the Market Place at the east end of Horsefair Street. ${ }^{72}$ The Fish Market, on the south side of the Market Place, was rebuilt by William Millican in $1877 .{ }^{73} \mathrm{In}$ spite of clearances the view of the Market Place is disappointing, for the stalls are now erected permanently and it is impossible to gain a clear view of either the Corn Exchange or the I8th- and Igthcentury houses which still remain. A brick gable with traces of timber work in it, to be seen in the arcade known as the Angel Gateway at the north-east corner of the Market Place, is all that remains of the Angel Inn, the best-known of Leicester's inns from the I6th to the I8th centuries. ${ }^{74}$ Cheapside, which leads from the Market Place to High Street, was only so named at the end of the i 8 th century. ${ }^{75}$

North from High Street runs New Bond Street. In the Middle Ages this was known as Parchment Lane or Street (vicus parcamenorum) ${ }^{76}$ or Parcheminergate, ${ }^{77}$ presumably from the residence there of parchment makers, who were established in Leicester as members of the guild merchant by the early I $3^{\text {th }}$ century..$^{78}$ After the pig market was moved there from High Street in 1524,79 Parchment Lane gradually became known as the Swinesmarket, although it was still called Parchment Lane in I 594.80 It retained the name of Swinesmarket even after the pig market was moved to Loseby Lane in the I 8 th century. ${ }^{81}$ At the beginning of the 19 th century Miss Watts remarked that the street 'may afford interest to the mind though not to the eye; for the reflective traveller will not regard as unimportant the humble dwellings of those manufacturers whose industry supplies the commercial wealth of the nation'.82 New Bond Street became the name of this street by $c$. 1860 ; the old name was still in use in 1846.83 .

ECONOMIC HISTORY. As a completely urban area, St. Martin's parish has until recent years been densely populated. In 1563 it had a population of 160 families. ${ }^{84}$ By the end of the 17 th century there were

66 Leic. Mercury, 20 July 1955.

67 See also above, pp. 46-47.

68 Billson, Medieval Leic. I $2 \mathrm{I}$; see also above, p. 46.

69 See above, p. 46.

70 Billson, op. cit. 120.

7 Ibid. I 20-I

72 Spencer, New Guide to Leic. (1 888), I I9; and see above, pp. $28_{3}-4$.

73 Spencer, op. cit. I20.

74 Simmons, City of Leic. 27.

75 Nichols, Leics. i. 533.

76 Leic. Boro. Rec. IIO3-I 327, 288.

77 Wyggeston Hosp. Charters, 297.

78 H. Hartopp, Reg. Freemen of Leic. II96-I770, 8, 9.

79 Billson, Medieval Leic. ${ }^{-8}$.

80 Ibid. 8 .

8 I See above.

82 [Watts], Walk through Leic. 26.

83 Cf. Ellis, Plan of Leic. (1 828 ) and Spencer, Map of Leic. ( 1867); White, Dir. Leics. (1846), I I 6, I 20.

84 B.M., Harl. MS. 6 i 8. 
at least 250 inhabited houses, ${ }^{85}$ perhaps more, and in 1709 the vicar calculated that there were $4 \mathrm{I} 6$ families, or about 1,984 persons of all denominations. ${ }^{86}$ By the end of the 18 th century there were 565 inhabited houses and 2,825 inhabitants. ${ }^{87}$ In I 801 there were 3,167 inhabitants, and the highest population figure was reached in 1821 , when there were 3,200 inhabitants. Thereafter there was a slow but steady decline as the parish became less and less the fashionable place in which to live, and its inhabitants, or the more wealthy of them, moved out into the new suburbs. ${ }^{88}$ By I 93 I the population of the parish was only 508.89

St. Martin's has always been a very wealthy area. In 1524,90 in the two wards which together covered the whole of the present High Street, $3^{8}$ per cent. of the taxpayers were rated at over $£ 6$ each, as compared with just over 20 per cent. in the High Cross, Southgate Street, and Friar Lane ward, the next wealthiest. In the 17 th century, the hearth tax returns show a high proportion of prosperity and a high average of hearths to each inhabited house. ${ }^{9 \mathrm{I}}$ In the ward which covered the Market Place and Cank Street 86 persons paid tax on an average of just under 3.4 hearths to each house, and only two houses were exempt because their occupiers were too poor to pay. The average in the New Bond Street and High Street ward was 3.5 hearths to the house, not counting one empty house with 4 hearths, and in the ward which covered Silver Street, Loseby Lane, and Guildhall Lane it was just under 3. The Town Hall and Wyggeston's Hospital had a total of I I hearths between them. There was one empty house in this ward and 2 additional hearths in outhouses. One or two names, however, are obscured in the original list of those exempted in this ward. Only about 37 houses in all these wards were excused payment. At the end of the I 8 th century, it was calculated that 520 out of $5^{6} 5$ houses paid window tax. Of the 45 exempted, some were empty. 92 This time was the peak of the parish's prosperity and the remaining houses which date from the late 18 th century and the early years of the 19 th are sufficient indication of the wealth which was concentrated in this relatively small area. In 1837 the Boundary Commissioners reported that St. Martin's parish contained a smaller number of houses and yet a larger amount of property than any other parish in the borough, and they proposed that it should be split up among several wards to disperse the high rateable value. ${ }^{3}$ At that time the total rental of the parish was over $f \mathrm{I} 4,000$, as compared with nearly $f \mathrm{I} 3,000$ in St. Mary's, which was a very much larger area and was already beginning to be exploited for new building. In St. Martin's I 25 persons were paying more than $f_{4}$ o yearly in rent, as compared with St. Mary's with 27, and only 109 in St. Margaret's, whose total rental was over $f 43,000.94$ Even when St. Martin's was beginning to lose some of its

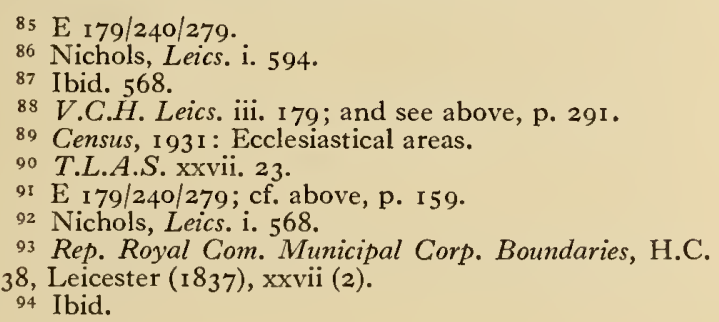

population a little later in the century, it was still extremely wealthy, with a high rateable value for poor rate in $1847, £ 22,1 \mathrm{II}$, as compared with the $\AA_{27}, 638$ of St. Mary's and the $f_{7} 79,900$ of St. Margaret's, a very much larger parish. The poor rate of St. Martin's was then levied at is. $7 \frac{3}{4} d$. in the pound. ${ }^{95}$

During the $\mathbf{1} 8$ th century the parish gradually developed a commercial character, although people still lived on or very near to their businesses, like Thomas Pares. ${ }^{96}$ It was the feeling that this was no longer desirable which led to the great fall in the population of the parish during the last century. Its I 8 th- and I 9 th-century houses have now very largely become offices. Something of the former graciousness still lingers about streets like New Street and St. Martin's, and forms a pleasant setting for Leicester Cathedral.

PARISH ADMINISTRATION. St. Martin's parish was governed by the usual parish officers. The administration of poor relief in the parish is described elsewhere. 97 In spite of being a stronghold of Toryism and regularly returning four Tory members to the corporation, it was the vestry of this parish which opposed the erection of the new borough gaol in I $823,{ }^{98}$ and demanded an investigation into how the borough rates were spent. Until the Liberals gained a majority in the vestry in 1849 , the battle over the payment of church rates was fought with great severity in St. Martin's, and the vestry was responsible for the prosecution and imprisonment of William Baines, a nonconformist tradesman, for his refusal to pay. ${ }^{99}$ After 1849 the payment of church rates was made a matter of voluntary subscription. ${ }^{\mathrm{I}}$

TOWN HALL LIBRARY. The 'Town Hall Library was formerly housed in the belfry of St. Martin's Church, and later in the chancel. ${ }^{2}$ It was moved to the Guildhall in 1633 , after the preparation of a room for its use, ${ }^{3}$ and remains there (I955). It is not known how the library was begun or how long it had been in existence when the new room was made ready for it, but it was evidently already the property of the borough. Its removal to the Guildhall drew attention. to the library and during the $I 7^{\text {th }}$ century it received many gifts of books, including one from Henry, Earl of Huntingdon (d. 1643). Few books were given after I669. The books are mainly of theological or ecclesiastical interest, but there are a number of political works and some early classical texts. 'The library's greatest treasure is the Greek MS. New Testament which was presented by Thomas Hayne in 1645 . The library fell into disuse and decay during the I8th century, but a new catalogue was prepared in I9I9 and the library is now carefully preserved in the Guildhall.

CHURCH. St. Martin's has for long been regarded as the principal church in the borough. In 1575 it

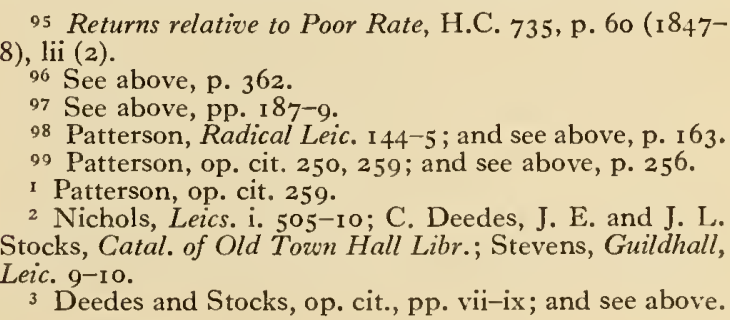




\section{A HISTORY OF LEICESTERSHIRE}

was ordered that two or three members of every household in the borough and its suburbs should attend the IVednesday and Friday sermons in the church. ${ }^{4}$ It was also specifically associated with the corporation, and the mayor was made responsible for the churchwardens' accounts by an order in the common hall in I 510.5 Nichols referred to St. Martin's as the principal church in the county ${ }^{6}$ and by the I 9 th century the assize sermons, archdeacon's courts, and bishop's confirmations were held there.7 The undoubted pre-eminence of St. Martin's made it the obvious choice for a cathedral, when it was proposed to create a see of Leicester in 1922 , although the claims of St. Margaret's were also pressed. ${ }^{8}$ In 1922 the church was made collegiate, with the Bishop of Peterborough as dean supported by a college of clerical and lay canons, to prepare for the creation of the new bishopric. ${ }^{9}$ By an Order in Council the see was created in 1926 in fulfilment of the Bishopric of Leicester Measure of the previous year. St. Martin's Church was hallowed as the cathedral in February 1927. ${ }^{10}$ Dr. Cyril Bardsley, who had been the first dean of the temporary college, was appointed the first bishop. "I Great emphasis was laid at the time upon the existence of the AngloSaxon see of Leicester from the 7 th to the 9 th centuries, which was thus recreated after a thousand years. ${ }^{\mathrm{I2}}$

The cathedral body now consists of a provost and college of canons, clerical and lay. The provost is also the Vicar of St. Martin's in its capacity as a parish church. ${ }^{13}$

The advowson of St. Martin's was presumably one of those given in I I o 7 to the college of St. Mary de Castro and transferred in II43 to Leicester Abbey. ${ }^{14}$ 'The church is first mentioned in 1220 , when it was already appropriated to the abbey. ${ }^{\text {I5 }}$ In 1225 a vicarage was ordained by Hugh of Welles, Bishop of Lincoln, and it was provided that the abbey was to supply a house and the same food as enjoyed by the canons, and to allow the vicar in addition the altarage and other perquisites. ${ }^{16}$ The advowson of St. Martin's belonged to the abbey until the Dissolution when it passed to the Crown. ${ }^{17}$ Although the parish presented its own vicars between 1646 and 1656 , the advowson remained with the Crown ${ }^{18}$ until it was granted to the Bishop of Peterborough in 1867.19 It is now (1955) vested in the Bishop of Leicester. ${ }^{20}$

In 1528 the parishioners complained that the clergy laughed and talked together during services and omitted to wear their surplices. The vicar generally

\footnotetext{
4 Leic. Boro. Rec. I509-1603, 162.

5 Ibid. 2.

6 Nichols, Leics, i. 500

7 White, Dir. Leics. (1 846$), 87$.

8 Hallowing of Dioc. of Leic. and its Cathedral, ed. F. B. Macnutt, 28.

9 Ibid. I 5 .

10 Ibid. I8-I9; see also Dioc. of Leic. Bk. of Coming of Age Celebration (1947).

11 Leic. Dioc. Cal. ( 1954), 36

12 Hallowing of Dioc. of Leic. 8 sqq.; V.C.H. Leics. i. 355 ; F. B. Macnutt, Early Dioc. of Leic.

${ }_{13}$ Leic. Dioc. Cal. ( 1 954), 37-38, 45-47.

14 V.C.H. Leics. ii. I 3,45

15 Rot. Hugonis de Welles, ed. W. P. W. Phillimore, i.

16 Ibid. ii. 300; A. Hamilton Thompson, Leic. Abbey, I 62.

17 Hamilton Thompson, op. cit. $162-4$, for list of vicars presented by the abbey.

18 Nichols, Leics. i. 59I.
} 238 . sent a Franciscan friar to visit the sick, and the friar was described as both neglectful and indiscreet. ${ }^{21}$

The value of the living before the appropriation

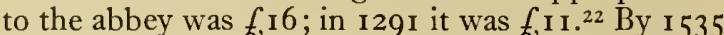
it had fallen to $\AA^{6}$ I $3 s .4 d$., and was said to be $\AA^{6} \mathrm{I}_{3} s .8 d$. in ${ }^{1} 5_{6} \mathrm{I},{ }^{23}$ but after the Dissolution the vicar leased from the Crown the profits which had previously belonged to the abbey for $£ 5$ yearly. He received an annual pension from the Crown of $\mathrm{E} 3$, which was still paid $c$. I $800 .{ }^{24}$ In 1705 the vicar calculated that his total profits were only $£ 32$ s. I I $\frac{1}{4} d$. This, however, was after he had paid a curate to read prayers on weekdays. ${ }^{25}$ In 1624 Christopher Tamworth of Gray's Inn left 200 marks for the purchase of land by the corporation. It was designed to pay for the holding of services in St. Martin's Church twice on each weekday. This benefaction is known as 'Tamworth's Prayers. ${ }^{26} \mathrm{~A}$ further $30 s$. yearly was given by John Stanley shortly after the Restoration, and this payment is made to the vicar by Leicester Corporation. ${ }^{27}$ In 1831 the vicarage was valued at fir ${ }^{28}$

In January I $457 / 8$ the abbey purchased a house next to the Guildhall for the use of the vicar ${ }^{29}$ and the vicars of St. Martin's lived there until I760, when the house was demolished to extend the burial ground.30 The vicar received a rent of Ios. yearly from the parish for the site of his old house. The Provost's House is in St. Martin's East. There is no glebe.

The guild of Corpus Christi was founded in 1343 as a social and religious guild attached to St. Martin's Church, with four chaplains and endowed with lands to the value of $f 20$ a year. ${ }^{31}$ In 1392 a licence from Richard II granted the guild power to amortize its lands, then valued at $f_{1} \mathbf{9} \mathbf{1 6}$ s. yearly. ${ }^{32}$ Soon after this the guild erected the first part of its hall on a piece of ground to the west of the church. ${ }^{33}$ The Corpus Christi guild was the most important in the borough and was so closely knit with the government of the town that its guildhall was used for meetings of the town council from the $15^{\text {th }}$ century and became the Town Hall after the Dissolution. The guild was dissolved in $1548,{ }^{34}$ when its total income from property was $£ 27$ I $s .7 \frac{1}{4} d .35$ There were then only two regular chaplains and another who celebrated the 'Jesus Mass', probably on Corpus Christi day when the guild feast was held. The chantry certificate states that without the chaplains the Vicar of St. Martin's would have been unable to carry out his parish duties. ${ }^{36}$ The property of the guild was said to be partly in decay so that rents were less than they

19 Lond. Gazette, i 867 , p. 29 I I.

20 Leic. Dioc. Cal. (1954), 89.

21 Assoc. Archit. Soc. Rep. and Papers, xxviii. $195^{-6}$

22 Val. of Norw., ed. W. E. Lunt, 530.

23 Valor. Eccl. (Rec. Com.), iv. I48; Leic. Boro. Rec. I 509-I603, 100.

24 Nichols, Leics. i. 591 .

25 Ibid. 593-4.

26 Leic. Boro. Rec. I603-88, 212-1 3, 225; $32 n d$ Rep. Com. Char. Pt. 5 [163], p. 30, H.C. (I 839 ), Xv.

27 See below, p. I 88 .

28 White, Dir. Leics. (1 846 ), 88

29 Nichols, Leics. i. 591.

30 Leic. City Mun. Room, I $\mathrm{D}_{41 / 18 / 21}$

31 T.L.A.S. xiv. 156 sqq.

32 Ibid. I 50-I

33 For the Guildhall and its connexions with the common hall, see above, p. $36 \mathrm{I}$.

34 T.L.A.S. xiv. I 5 I.

35 Ibid. I 70.

36 Ibid. I 7 I-2. 
should have been; in $1525-6$ decayed tenements were valued at over $£ 8 .{ }^{37}$ Part of the property of the guild was granted in 1549 to Robert Catlyn and part to Edward Pese and William Wynlove.,38

The date of the foundation of the guild of St. George is unknown. It is first mentioned in $\mathbf{1} 499$, when the common hall decreed that the members of the Forty-Eight should contribute to its unkeep. ${ }^{39}$ From this it might be deduced either that the guild was in financial difficulties or that it had been recently founded, but with insufficient property for its support. The annual festival of the guild was the ceremony of 'Riding the George', the guild procession in which men representing St. George and the Dragon took part. 40 The last reference to the guild seems to be in 1543 , when the master of the guild was fined for not riding the George. ${ }^{4 I}$ No certificate of the guild's property has survived, but a good deal of it, including the guildhall, seems to have passed to the corporation. The hall probably stood on the east side of St. Martin's Church. ${ }^{2}$ The annual procession seems to have been of much more interest than the size or importance of the guild would appear to merit.

The earliest known church of ST. MARTIN was a cruciform building of the izth century, with narrow aisles, which was, with the exception of its central tower, completely rebuilt in the $13^{\text {th }}$ century. In the late 13 th century or early in the 14 th an outer aisle was added to that already existing on the south side. In the early 15 th century the chancel was rebuilt ${ }^{3}$ and the north and south chapels added to it. The clerestory and west doorway date from the end of the $15^{\text {th }}$ century or early in the 16 th. In 1489 new stalls were built by a carpenter named John Nicoll. ${ }^{44}$ At the visitation of $15 \mathbf{2} 8$ the parishioners complained that rain was dripping into the choir, and repairs were presumably undertaken by the abbey. 45 One of the aisles was extensively repaired in $1545-6.46$ The chancel was repaired by the churchwardens in I6 $33 .{ }^{47}$ St. Martin's seems to have been maintained in good repair throughout the $I 7$ th and 18 th centuries, as befitted the principal church of the borough. In 1705 and 1724 galleries were built, and in 1737 part of the spire was taken down..$^{8}$ In 1787 a new clock was installed by the corporation. 49

During the last half of the igth century the church underwent extensive restoration and alteration, which has been continued since the recreation of the See. From 1846 to 1867 the church was repaired by John Raphael Brandon. New roofs were built over the chancel and aisles in $1847-8$, closely following the designs of the old ones. ${ }^{50}$ In 1848 the piers between the nave and the north aisle were replaced. Those of the south aisle were renewed in 1851 , when

${ }_{37}$ T. North, Chron. of Ch. of St. Martin, 213-14; cf. T.L.A.S. xiv. 171 .

${ }_{38}$ Cal. Pat. 1 549-51, 79.

39 Leic. Boro. Rec. I 327-1509, 355.

40 North, Chron. of Ch. of St. Martin, 237 sqq.

${ }_{41}$ Leic. Boro. Rec. $1509-1603,50$.

42 Ibid. 240, 277, 3 10; T.L.A.S. xiv. I 53; North, op. cit. $244-5$.

43 Charyte gives the date as I 409: Nichols, Leics. i. 590.

${ }^{44}$ Accts. of Churchwardens of St. Martin's, $1489-1844$, ed. T. North, 2.

${ }_{45}$ Assoc. Archit. Soc. Rep. छे Papers, xxviii, 195.

46 Accts. of Churchwardens of St. Martin's, $14-17$.

47 Nichols, Leics. i. 593 . ${ }_{48}$ Ibid. 585.

49 Leic. City Mun. Room, Hall Bk. 8 Jan. I 787.

50 White, Dir. Leics. (1877), 300. The roofs of the ch. the church was also re-seated throughout.51 The clerestory and west windows were also restored. Brandon's greatest achievement at St. Martin's was the rebuilding of the tower, which stood over the crossing on four great Norman pillars. These were replaced and the whole tower demolished about I86I, and replaced by a completely new tower and spire of Gothic design. These together reach a height of 220 feet and add dignity and proportion to the building. The new nave roof was completed in 1867 , when the spire was finished. ${ }^{22}$ The south aisle was restored at the end of the last century by J. L. Pearson. ${ }^{53}$ The Vaughan porch on the south side of the church is by G. F. Bodley and was built in 1897 in memory of Edward Vaughan and his three sons. The north aisle and porch were restored by G. E. Street. After the First World War the church's architect was Temple Moore, who designed a number of the interior fittings. Sir Charles Nicolson became architect when the church was created a cathedral and was assisted by William Keay of Leicester. The sacristy was built in 1927 and the vestries in 1939.54

The church now consists of nave, chancel, north and double south aisles, north transept, north and south porches and chapels, central tower, sacristy, and vestry. The chancel, of four bays, is lighted by an east window and by two north and one south windows. To the west of these, four-centred arches open into the St. Katherine and St. Dunstan chapels. In the south wall of the transept is a moulded cinquefoil piscina adjoining triple sedilia formed by continuing the window recess down to a stone seat. Also on the south side is a range of three early I6th-century stalls. The bishop's cathedra stands against the north wall. The altar and elaborately carved and gilded reredos are the work of Temple Moore, and, together with the east window by Christopher Whall, constitute the War Memorial.55 The most important memorial in the chancel is that to George Newton (d. 1746), the son of Alderman Gabriel Newton.

St. Katherine's Chapel was rebuilt in $1865^{56}$ and is maintained by the members of the Herrick family resident in America. It was known in the $17^{\text {th }}$ century as Herrick's or Reynolds's Chapel. ${ }^{57}$ It contains a number of finely carved memorial slabs commemorating the family; the earliest is of 1598 . In the south wall are the mutilated remains of a piscina. A medieval painting of St. Katherine which was on the north wall was obliterated in 1847.58 The chapel was restored by Nicolson in 1929. ${ }^{59}$ St. Dunstan's Chapel on the south side of the chancel was also rebuilt in $1865,{ }^{60}$ and was dedicated to the memory of the Needham family. It contains a number of

are illustrated in J. R. and J. A. Brandon, Open Timber Roofs of the Middle Ages, 45, 47. Other features which the architect discovered during restoration appear in his Analysis of Gothic Architecture.

5 I White, Dir. Leics. (I 877), 300.

52 Ibid.; Simmons, City of Leic. 29.

53 For this and following para. see S. T. Winckley, Cathedral Ch. of St. Martin, Leic. I3.

54 Leic. Dioc. Cal. (1954), 37.

55 Winckley, op. cit. I 3 .

56 Ibid. I6-I 7; North, Chron. of Ch. of St. Martin, 46-48.

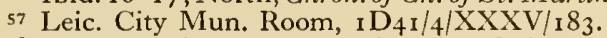

${ }^{8}$ Illustrated in North, op. cit., plate facing p. 46.

59 Leic. Dioc. Cal. (1954), 37.

60 Winckley, Cathedral Ch. of St. Martin, I 5-16; North, Chron. of Ch. of St. Martin, 42-46. 


\section{A HISTORY OF LEICESTERSHIRE}

I Sth-and I9th-century memorial tablets, and one to James Andrewe (d. 1638 ), which has an alabaster relief showing him in his study. This chapel was restored in 1930.61

The triptych in the north transept is by the Italian artist Vanni and was presented by Sir William Skeffington in 1790.62 Also in this transept is an unusually large dug-out chest, $7 \mathrm{ft}$. $6 \mathrm{in}$. long with six hinges, and a piece of fine I 5 th-century carving, consisting of nine traceried panels supporting a bookrest. There is a stair in the north-east corner. The screens between this transept and the chapels and crossing, and between the nave and chancel, as well as the wall panelling, are all modern.

The nave is stone-paved, of five bays. The modern gallery and organ-loft at the west end extend to the outer wall of the north aisle. They were designed by Sir Charles and Sydney Nicolson and completed in 1930.63 The font, presented in 1860 , stands under the gallery. ${ }^{64}$ In the north aisle, which is also of five bays, is a signed monument by Joshua Marshall to John Whatton (d. I656), coloured and gilded with busts of Whatton and his two wives. ${ }^{65}$

The south aisle is of six bays, so that there is no south transept. It is in two parts, divided by an arcade rather loftier than that into the nave. The brackets of the roof of the outer aisle rest on wall posts carved with standing figures, which are modern copies of those originally erected in the late I $3^{\text {th }}$ or early $14^{\text {th }}$ century. Three of the originals now stand against the south wall, supporting a table made from the inlaid sounding board of the Georgian pulpit. In the south wall of the outer aisle there are sedilia and a piscina similar to those in the chancel.

The north porch, though very much restored, dates from the $15^{\text {th }}$ century. It is of brick and timber, covered with a decorated plaster skin, and has a ceiling of wooden fan tracery. There was formerly an upper chamber to the porch. ${ }^{66}$

The tower contains the only Norman work left in the church, a short piece of billet work on the north side of the north-west pier. It rises in four stages, terminating in an octagonal broach spire, with gabled steeple lights at three intervals, a floriated finial and a weather vane. There is a clock above the windows. Inside the church the wooden ceiling of the tower is divided by beams resting on stone corbels.

Before the Reformation there were five chapels in St. Martin's Church. The Lady Chapel was in the outer south aisle and was used as the chapel of the Corpus Christi guild. ${ }^{67}$ After the Reformation it became the site of the archdeacon's court, which is still

61 Leic, Dioc. Cal. (1954), 37.

6. White, Dir. Leics. (1 846 ), 88

${ }_{63}$ Winckley, Cathedral Ch. of St. Martin, 8 and illustration on p. 22

64 Inscrip. on font. The carvings are reputed to be those of the Queen, the Bishop of Peterborough, and the donor's relatives: White, Dir. Leics. ( 1877 ), 301.

65 R. Gunnis, Dict. of Brit. Sculptors, 255.

6 North, Chron. of Ch. of St. Martin, 59.

For this chapel see North, op. cit. 38-4I; Winckley, Cathedral Ch. of St. Martin, I5; for the guild, see above, p. 366 .

North, op. cit. 48-5 I. The effigy of St. George which was carried through the streets once a year was kept in the chapel; for the guild, see above, p. 367.

60 Winckley, Cathedral Ch. of St. Martin, I7.

70 North, Chron. of Ch. of St. Martin, $5 \mathrm{I}-52$.
(I955) held there. St. George's Chapel, that of the guild of St. George, was probably at the west end of the outer south aisle, although very little is known about it. ${ }^{68}$ It has, however, been re-established in that place, and was fitted up as the War Memorial chapel of the Leicestershire Regiment by Temple Moore in $1921 .{ }^{69}$ St. Dunstan's and St. Katherine's chapels have already been mentioned. There was also probably a rood chapel, the altar of which probably stood in front of a large cross or rood somewhere in the church, which occasionally caused the church to be referred to as St. Cross. Offerings were certainly made at the foot of such a cross, but its position is unknown. ${ }^{70}$

There was an organ in St. Martin's before I 547 , when the instrument was dismantled and sold. Although restored after 1553 , it was again destroyed in 1562 or 1563 and the church probably remained without one until the end of the 17 th century. In I 753 the organ was repaired and moved to the west end, and twenty years later it was replaced by a new one built by Snetzler. This was restored in $1873 .{ }^{71}$ A new organ was installed in the new gallery in I $930 .^{72}$

'There were five bells in Henry VIII's reign. By I78I there were ten, which were then recast by Edward Arnold. Four of them were recast by Taylor of Loughborough in 1854.73 In $1936-7$ the whole ring was again recast by Taylor. Two more bells were added at the same time, ${ }^{74}$ bringing the present ring up to twelve.

The registers date from 1558 , and there are churchwardens' accounts from I $544 .{ }^{75}$ The earliest pieces of plate are a cup and paten dating from I $662.0^{76}$

The monuments in the cathedral are 'a memorial to the civic, social, and military life of Leicester during the last four hundred years' ${ }^{37}$ Besides those already mentioned there are monuments to John Throsby and Thomas North, among the historians of Leicester; and one to John and Frances Johnson, parents of John Johnson the architect, which was designed by their son and executed by John Bacon, R.A., in 1786.78

CHARITIES. Elizabeth Ossiter before I653 left a house in Abbey Gate for the relief of the poor of St. Martin's. By 1837 there was no longer a house on this site, but the land was let for $30 s$. yearly. ${ }^{79}$ It was sold in 1875 and the proceeds invested in stock, which now produces $\oint_{0} \mathrm{I} 34 \mathrm{~s}$. $8 d$. yearly. ${ }^{80}$

Thomas Topp by will dated I 7 r6 left £200 charged upon lands at Enderby to apprentice one poor boy from the parish every year. By the begin-

7 F. B. Macnutt and G. Slater, Leic. Cathedral Organ.

72 Winckley, Cathedral Ch. of St. Martin, I 8.

73 T. North, Ch. Bells of Leic. 202-3, 2 I0, 2 I I.

74 Winckley, op. cit. 23, 24-25.

75 Printed by T. North, Accts. of Churchwardens of St. Martin's, Leic. I 489-I844. The accts, for I 489-1 544, which were also printed by Nichols (Leics. i. 508-9), have now disappeared.

76 A. Trollope, Ch. Plate of Leics. i. $185^{-6}$.

77 Simmons, City of Leic. 29.

78 Gunnis, Dict. of Brit. Sculptors; 27; illustrated in Nichols, Leics. i, plate xliv.

79 ,32nd Rep. Com. Char. Pt. 5, 109-1o.

80 Information about the present position and recent history of the cathedral charities has been collected and supplied by Mr. S. Everett, lay canon of the cathedral. 
ning of the last century the rent was $£ 20$ yearly and was sufficient to apprentice two poor boys. ${ }^{81}$ Some of the land seems to have been sold as the parish now owns considerable numbers of shares as well as some land at Enderby, which together produce an income of $£ 5^{6} 1_{5} s$. $2 d$. yearly, which is used for general charitable purposes.

George Bent by will proved 1736 left $f 2$ r 2 s. charged upon a house in Guildhall Lane for the distribution of bread to the poor. ${ }^{82}$ This rent is still paid.

John Nichols by will proved 1815 left froo for distribution to poor parishioners. 83 The money was invested and produces $£ 32 s .4 d$. annually.

Benjamin Garland's gift of $5 s$. yearly is paid to the parish by Leicester Corporation. ${ }^{84}$ In 1837 the Charity Commissioners reported that this gift, then $3 s$. $6 d$., had not been paid for 30 years and that its origin was not known. The charity existed before I 786 , and was revived in the roth century. 85

The parish receives $£_{2} 86 s$. 8d. yearly for Richard Elkington's charity from the Trustees of Leicester
General Charities, and a payment under Heyrick's Bread Charity. The Corporation pays sums under the Hobbie, Courteen, and Ive charities. 86

The Lewis almshouses in Millstone Lane disappeared in the later part of the Igth century, probably when parts of the street were rebuilt. They stood originally near the churchyard of St. Martin's, but the original building, left by Hugh Lewis by will proved $16_{5} \mathrm{I}$ for the use of three poor widows, was sold in 1732 . The inmates were moved to a house in Millstone Lane, which was rebuilt in $1814 .{ }^{87} \mathrm{Mrs}$. Ward's charity, the date of which is unknown, was a payment of $25^{s}$. yearly from a close in St. Margaret's parish. Part of the land was conveyed to St. Margaret's Church at the beginning of the last century for the enlargement of the burial ground, and charged with the whole payment. It is not known how long the payment continued after 1837 , but it is now (1955) lost. ${ }^{88}$ Frances Power left by will in 1749 a house, the profits of which were to be used for teaching ten poor children. ${ }^{89}$ Nothing further is known of this bequest.

\section{ST. MARY'S}

The parish of St. Mary de Castro consisted ${ }^{\mathrm{I}}$ of a small area lying within the ancient borough walls, of the South Fields of Leicester, to the east of the Soar, with certain meadows in the Soar valley attached to them, and of the liberty of Bromkinsthorpe to the west of the Soar. The topography, manorial history, and economic history of Bromkinsthorpe are not closely connected with those of the rest of the parish, and are described separately at the end of the present article.

Within the borough St. Mary's parish occupied the south-west corner of the walled area adjoining the castle, which stood at the south-west angle of the town. The most important street in the parish has always been the thoroughfare joining the North and South gates, and running through the whole area within the walls. This important road, now known as Southgate Street for the southern portion of its length, and as High Cross Street for the rest, was in the Middle Ages known as High Street. ${ }^{2}$ The street is mentioned under that name in $1306,{ }^{3}$ but had in all probability existed for a considerable period before that date. In the 16 th century the name 'High Street' was transferred to another thoroughfare, previously

81 32nd Rep. Com. Char. Pt. 5, I I I.

82 Ibid. I I I see also p. 408.

83 32nd Rep. Com. Char. Pt. 5, I 12.

84 Ex inf. Mr. C. D. Wells of Leic. City Treasurer's dept.

85 32nd Rep. Com. Char. Pt. 5, 1 I 0.

86 See below, pp. 4II, 4I3.

87 32nd Rep. Com. Char. Pt. 5, I Io.

88 Ibid. I IO-I I.

9 Ibid. I 12.

I On the parish boundaries as they were $c$. 1830 , see T. and G. Ellis, Plan of Leic. (1828), and Rep. Com. on Boundaries and Wards of Certain Boros. Pt. 2, H.C. 238 (1837), xxvii.

2 C. J. Billson, Medieval Leic. 4, I I.

${ }^{3}$ Leic. Boro. Rec. IIO9-I327,397. Probably the magnus vicus at Leic. mentioned under Hen. II was the same street: F. M. Stenton, Doc. Illustrative of the Soc. and Econ. Hist. of the Danelaw, pp. cxix, 246, 259.

4 Billson, Medieval Leic. 8; Leic. Boro, Rec. I327- known as the Swinesmarket, 4 which has retained the name of High Street ever since. The name of Southgate Street was in use by about 1666 for the portion of the former High Street which lay in St. Mary's parish. 5 Of the other streets in the parish, Red Cross Street, leading off Southgate Street to the south, is first mentioned in $1557,{ }^{6}$ but the house known, no doubt from its sign, as the Red Cross is referred to in $1493-94,{ }^{7}$ and the street must have derived its name from this building. The present Castle Street, running from Southgate Street to the West Bridge, was known during the Middle Ages as Soar Lane, and under that name is first mentioned in $1458 .^{\circ}$ Perhaps to avoid confusion with the other Soar Lane, which lay outside the borough's north wall, this street was renamed St. Mary's Church Lane at some time before the late I 8 th century, ${ }^{10}$ but about I 800 it was given its present name of Castle Street. II The present Bakehouse Lane, leading off Southgate Street to the west, is mentioned in 1484 under the name of Fosbrooke Bakehouse Lane. ${ }^{12}$ Possibly the street's name derives from the existence in this part of the borough of several of the common bakehouses, where the town's inhabitants were obliged up to the I6th

I 509, 445; I509-I603, 25, 240; John Speed, Map of Leics. (16 10).

5 Leic, Boro. Rec. $1603-88$, 508. The part of the street immediately inside the South Gate was known as Castle Street in the late 18 th century: Nichols, Leics. i. 532.

6 Leic. Boro. Rec. I 509-1603,80.

7 Ibid. $1327-I 509,343,346$.

8 Not to be confused with the other street, also called Soar Lane, in the northern part of the boro. On the existence during the Middle Ages of the two streets with the same name, see Leic. Boro. Rec. I 327-I 509, 266; I 500I $603,89,453-4$.

9 Leic. Boro. Rec. I 327-I 509, 266, 267, 307; Billson, Medieral Leic. I3, I4.

10 Nichols, Leics. i. 532 .

II Ibid.

12 Leic. Boro. Rec. I327-I509, 307. It may be the Kephovenlane mentioned in 1343, I 348, I 352: Wyggeston Hosp. Rec. 306, 307, 312. 


\section{A HISTORY OF LEICESTERSHIRE}

century to do their baking. ${ }^{13}$ Only one street of any importance, Friar Lane, leads off Southgate Street to the east within St. Mary's parish. Friar Lane, which takes its name from the house of Franciscan friars that stood just outside the parish, is mentioned in $139 \mathrm{I} .{ }^{14}$

During the Middle Ages the main route from London and the south reached Leicester by means of the road from Welford, and entered the borough through the South Gate. So long as this route continued to be important Southgate Street must have been one of the chief roads of the town. In the I 7 th century, however, the route through the South Gate and along Southgate and High Cross Streets was superseded, for most of the traffic from south to north, by a new route running along the east side of the borough walls. ${ }^{15}$ This development must have much reduced the importance of Southgate Street. About I 8I 5 it was said of the street that 'The buildings in general are tolerable', ${ }^{16}$ but a drawing of the street, made about I 825 , shows that it then contained, besides some good buildings in the Regency style, a number of rather dilapidated timbered houses, with upper stories projecting over the roadway. ${ }^{17}$ At the present time (1956) Southgate Street remains a thoroughfare of some importance but its narrowness, and the fact that it leads into the tangle of congested streets that still occupy the area of the old walled borough, prevent it from carrying a really substantial amount of traffic. The part of St. Mary's parish that lies within the area of the old borough walls consisted in 1956 mainly of factories and warehouses, though there were some dwelling houses, mostly built in the Victorian period.

Outside the southern wall of the borough, but within St. Mary's parish, lay the great south field of Leicester, stretching from the line of the Roman Gartree $\operatorname{Road}^{18}$ on the east to the meadows bordering the Soar on the west, and from the borough wall ${ }^{19}$ on the north to the boundary of Knighton ${ }^{20}$ on the south. ${ }^{21}$ The total area of the south field itself was about 450 acres; 22 the meadows along the east bank of the Soar covered perhaps another I 50 acres. ${ }^{23}$ The

13 See above, pp. $43-44$.

14 Wyggeston Hosp. Rec. 323. The Friar Lane mentioned in 1392, which has sometimes been identified with the present Friar Lane (Billson, Medieval Leic. I I), was a street in the north of the borough, taking its name from the convent of Dominican Friars: Leic. Boro. Rec. I 327$1509,204,267,284,307$. The 'lane which leads to the church of the Friars Minors', mentioned in 1292 and 1306 (Leic. Boro. Rec. I I09-1327, 394, 397), was very probably the present Friar Lane.

15 V.C.H. Leics. iii. 73-74; Billson, Medieval Leic. 34 A street developed connecting the Welford road with the route running round the east side of the walls. This street, which is marked on Speed's Map of Leics. (I610), followed the line of the present Welford Road between the existing gaol and Welford Place. The older route, from Welford to the south gate, followed the line of the present Welford Road as far as the gaol, and then continued along the line of the present Oxford St.

I6 Nichols, Leics. i. 532.

$17 \mathrm{~J}$. Flower, Views of Ancient Buildings in the Town and Co. of Leic. 'Southgate Street, Leicester'

18 Approximately the line of the present New Walk and Evington Footpath.

19 Between the present Friar Lane and Millstone Lane. 20 Approximately the line of the present Victoria Park Road.

${ }^{21}$ See map in T.L.A.S. xiv. I6.

22 Ibid. 23 Ibid.

24 See ibid. and O.S. Geological Map, I in., Sheet 156.

${ }^{25}$ Leic. Boro. Rec. IIO3-I327, 387. whole area of some 600 acres made up by the open field and the adjacent meadows was commonly known as the South Fields. The land along the Soar formerly occupied by meadows is alluvium. The line of the former boundary between the meadows and the open fields coincides fairly well with the edge of the gravel terrace which borders the river's alluvial flood plain. ${ }^{24}$ The open field lay on the terrace, and on the rather higher region of Marlstone, largely covered with Boulder Clay, which lies to the east of the gravel, and farther away from the river.

The south field is first mentioned in $\mathrm{I} \mathbf{2 8 2},{ }^{25}$ but it may well have existed long before that date, as there was a considerable area of agricultural land attached to Leicester in $1086 . .^{26}$ In the I 4 th century the field was divided into wongs, or culture, in which lay arable strips of the usual type. ${ }^{27}$ In addition, it was divided into three open fields, the Gallowtree, Middle, and Rawdyke Fields, by means of which a triennial system of rotation of crops was apparently carried on. ${ }^{28}$ Of the meadows which lay between the south field and the Soar, that called the Cowhay is mentioned in a document of IIgI-I204. ${ }^{29}$ The Cowhay lay some distance outside the south gate, bordering on the Soar, to the west; to the east the Cowhay did not extend so far as the Aylestone Road..$^{30}$ Immediately to the south of the Cowhay lay another meadow, mentioned at the same time, the Oxhay, also known as Marymeadow. ${ }^{31}$ The location of a third meadow or pasture, Taskholm, mentioned in the same document, is uncertain, but it seems to have lain to the north of the Cowhay. ${ }^{32}$ Close Meadow and Bedehouse Meadow ${ }^{33}$ lay on a large island formed by two branches of the Soar. Close Meadow is mentioned in $\mathrm{I} 433,{ }^{34}$ and Bedehouse Meadow in 1546.35

By the late I 2 th century the greater part of the South Fields, both meadow and arable, seems to have belonged to the earls of Leicester, and it is likely that their extensive property in this area was originally acquired by Robert de Beaumont, probably the first earl, early in the century when he gained extensive possessions in Leicester that had previously belonged to the king and to the Grentemesnil family. ${ }^{36}$

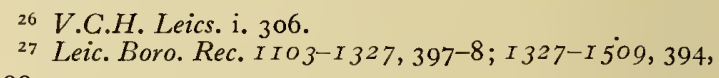
400.

28 Ibid. I509-I603, $217 ; 1603-88$, I $81-82 ;$ T.L.A.S. xiv. 16 .

29 Leic. Boro. Rec. Irog-r327, 5.

30 Ibid. $5 ; r_{327}-1509,251$.

31 Ibid. IIO $3-1327,5 ; 1327-1509,250$.

32 In a document of $c$. 1200 the Cowhay is described as lying between Oxhay and Taskholm (Leic. Boro. Rec. $I I 03-I 327,5)$. As the Oxhay lay to the south of the Cowhay, Taskholm presumably lay to the north. In T.L.A.S. xiv. I9, Taskholm is identified with land in the South Fields bought by Earl Simon de Montfort from Sir Andrew Lutterel, and said once to have belonged to Thomas Task; this land is, however, described as 4 virgates (Leic. Boro. Rec. IIO3-I327, 47, 57), and so was almost certainly arable, whereas Taskholm seems to have been meadow or pasture. Taskholm may perhaps have derived its name from Thos. Task, who may have owned it.

33 So called because it belonged to the Newarke hospital.

34 Leic. Boro. Rec. I327-I 509, 246, 252-3; Assoc. Archit. Soc. Rep. and Papers, xxx. 516; A. Hamilton Thompson, Hist. of the Hosp. and New Coll. in the Newarke, 2 IO

35 Assoc. Archit. Soc. Rep. and Papers, xxx. 517. The name Bedehouse Meadow was later used to mean the whole island.

36 E.H.R. liv. 386-7; Leic. Boro. Rec. $3_{327-I 509,3}$; and see above, p. 3 I. 
Earl Robert FitzParnell, at some date between I I9 I and 1204, granted the Cowhay to the burgesses of Leicester, subject to a payment to the earl of $3 d$. a year for every beast pastured there. ${ }^{37}$ The earl was in possession of the Oxhay when this grant was made. ${ }^{38}$ Earl Robert's grant was confirmed by his successor, Simon de Montfort. ${ }^{39}$ When the Hospital of St.Mary in the Newarke was founded by Henry, Earl of Lancaster and Leicester, in 1330 the endowment provided by the earl included 4 carucates at Leicester, ${ }^{40}$ and these were evidently in the south field.41 The hospital (later the College of the Newarke) also acquired, apparently as appurtenances to their 4 carucates in the south field, the Oxhay, Close Meadow, a close called Gosling Croft, and the right to the payment of $3 d$. a year from each beast pastured in the Cowhay. ${ }^{2}$ Further small quantities of arable and meadow, acquired by the college in $1368,1373,1392$, I405, and I424, probably lay in the South Fields also.43 The Newarke College thus became by far the largest landowner in the South Fields.

At an early date buildings and small inclosures began to spread southwards from the borough wall. Buildings outside the South Gate are mentioned in I273.44 Millstone Lane, which ran just outside the south wall of the borough, is mentioned in 1452,45 and by 1484 the houses outside the South Gate were sufficiently numerous to form one of the twelve wards into which the borough was then divided.46 St. Sepulchre's chapel, ${ }^{47}$ which stood some distance outside the south gate, ${ }^{48}$ and which was in existence by $1204,{ }^{49}$ presumably served the suburb outside the walls. The main road from the South Gate to Welford, and beyond it to London, was known as Peatling Gate, or Peatling Way, ${ }^{50}$ in the late $13^{\text {th }}$ and early 14 th centuries, ${ }^{11}$ but the section lying immediately outside the walls was known as South Gate in the 16 th and 17 th centuries. ${ }^{52}$ By 16 Io there were houses along both sides of the road for some distance outside the borough's South Gate. ${ }^{53}$ When Leicester

37 Leic. Boro. Rec. IIO3-I327, 5.

38 Ibid.

39 Ibid. $38-39$. This confirmation has given rise to many misconceptions, and it has frequently been stated that Simon granted much land in the South Fields to the burgesses. For a discussion of the errors that have arisen, see T.L.A.S. xiv. $17^{-1} 9$.

40 Thompson, Hist. of the Hosp. and New Coll. in the Newarke, I 3 .

4 I Leic. Boro. Rec. I327-I 509, 3; and see below, on the later property of the hosp.

42 Ibid. 234, 246-53. Gosling Croft lay in St. Mary's parish, but its location is unknown: ibid. 266. Its name perhaps came from Hen. Goscelin, who was holding land in the parish in 1282 : ibid. $I 103-1327,388$.

43 Thompson, Hist. of the Hosp. and New Coll. in the Newarke, 84, 88; Cal. Pat. 1367-71, I 04; 1371-4, 36I ; 1405-8, 109; 1422-9, 200; Rot. Parl. vi. 49. The property is stated to be in Leicester and its suburb, and was probably in the south field, as when dissolved the college seems to have held little land in the other fields of Leic.

44 Wyggeston Hosp. Rec. 297.

45 Leic, Boro, Rec, I327-I 509, 259.

46 Ibid. 308. There was a view of frankpledge for this area by $1375 / 6$ : ibid. I54.

47 Also called St. James's.

48 On or near the site of the present infirmary: Billson, Medieval Leic. 90-9I; Nichols, Leics. i. 328; Leic. Boro. Rec. I327-I509, 296, 308.

49 Dugd. Mon. vi. I079; Cal. Doc. France, ed. Round, 229; and see below, p. 376 .

50 Because it ran towards the villages of Peatling Magna and Peatling Parva, and perhaps was used as part of a route through them to Lutterworth and Watling St. was fortified by the Parliamentarians against Charles I some houses outside the South Gate were demolished, and an earthwork was thrown up to protect the town. ${ }^{54}$ In $1647-8$, after the danger from the Royalists was considered to be over, the earthwork was levelled at the corporation's expense.55

When the Newarke College was dissolved under Edward VI its extensive property in the South Fields, forming a large farm generally known as the Newarke Grange, fell into the hands of the Crown, which first leased the farm to Leicester Corporation and others, and then in 1613 sold all the property to the corporation. ${ }^{56}$ The arable thus acquired by the corporation in the south field amounted to I6 yardlands, 57 and there was in addition all the meadow land which had belonged to the Newarke College..$^{58}$ The corporation's arable holdings in the south field were enlarged by the purchase of two further yardlands from a Mr. Wightman, in or shortly before I $589,{ }^{59}$ the acquisition of two more yardlands from Richard and Francis Archer about $1602,{ }^{60}$ and the purchase of some further arable, apparently half a yardland, from Robert, Lord Spencer, in or just before $1622 .{ }^{61}$ With these minor purchases added to the Newarke Grange, Leicester Corporation became the only important landowner in the South Fields.

Although much the greater part of the south field was thus in the hands of a single owner, the arable continued until well into the I8th century to be divided into arable strips, and it was let by the corporation in farms made up of one or more yardlands each. ${ }^{62}$ The inclosure of the south field was delayed because of the rights which the borough freemen possessed to pasture livestock there. The grant of the Cowhay to the Leicester burgesses for pasture has already been described. It is possible that the burgesses had once enjoyed pasture rights over all the meadows in the South Fields, and that those rights had been curtailed in the I2th century by the earls of Leicester, for in 1433 the mayor, burgesses, and community of

5 I Leic. Boro. Rec. IIO9-I327, 388, 398.

52 Ibid. I 509-I603, 309, 3I3-I4; I603-88, 29, 372, 405 ; Speed, Map of Leics. (1610).

53 Speed, Map of Leics. (16ro).

54 Leic. Boro. Rec, I603-88, 334, 335, 343 .

55 Ibid. 378 .

56 Ibid. I $5 \mathrm{I}$; and see above, pp. 64, I65.

57 One half of the grange was said to be 8 yardlands: Leic. Boro. Rec. I603-88, 6, 24-25, 45, I $0_{4}-5$. The total would therefore be I 6 yardlands, the same amount as the 4 carucates originally granted to the college. In 1624 the corporation was said to have 20 yardlands in the south field (ibid. 209), but this included 4 yardlands which had not formed part of the grange (see refs. cited in nn. 59,60 below). T.L.A.S. xiv. 22 gives the grange arable as $21 \frac{1}{2}$ yardlands; it is not clear on what evidence this estimate is based, but it seems to include some land which though acquired by the corporation was not part of the grange.

8 On the meadow land, see Leic. Boro. Rec. I603-88, I05, and above.

59 Leic. Boro. Rec. I 509-I603, 253, 287, 332

60 Ibid. 27I-2, 300, 445, 446; ibid. I60 3-88, 42, 48-49.

61 Ibid. $1603-88,202,203,211$; Nichols, Leics. i. 347 , states that the land was bought from a Mr. Wadland; but Geo. Wadland was the tenant, not the owner

${ }_{62}$ Leic. Boro. Rec. I603-88, I $04-5,20 \mathrm{I}-2$; and see above, p. I 65 . In the South Field the arable of a yardland seems to have been rather more than 20 acres. In I6ro it was said that 3 virgates made up 21 acres of arable in all in each of the fields, and as there were 3 fields the arable of each virgate was apparently 21 acres: ibid. I0 -5 . An early I 7 th-century terrier of a virgate in the South Field lists a total arable, including headlands, of 25 acres I rood: ibid. I 8 I -2 . 


\section{A HISTORY OF LEICESTERSHIRE}

Leicester claimed that they were entitled to common of pasture for their stock in Close Meadow and Gosling Croft ; the College of the Newarke, to which the two fields belonged, denied this, and the arbitrators to whom the matter was submitted ruled in farour of the college. ${ }^{63}$ The right to pasture stock in the Cowhay was limited to freemen of the borough, ${ }^{64}$ and it does not seem that any others were strictly speaking allowed pasture rights there. ${ }^{65}$ About ${ }^{6} 6{ }_{4}^{8}$ the corporation decided to use the Cowhay as a horse pasture, and to make use of a meadow called Burgess Meadow ${ }^{66}$ as the cow pasture, but this seems to have been only a temporary arrangement. ${ }^{67}$ Besides pasture rights in the Cowhay, the free burgesses of Leicester enjoyed rights of common for their livestock on the arable of the south field. 'These common rights are mentioned in $1605,{ }^{68}$ but no doubt had been in existence from a much earlier period. The freemen's rights of common in the arable of course only allowed them to pasture their livestock there while crops were not actually growing; about $\mathrm{I} 675$ it was stated that by ancient custom the freemen's pasture rights began at Michaelmas, and lasted until Lady Day. ${ }^{69}$ In the I 7 th century a serious conflict of interests arose between the farmers who rented the arable from the corporation, and the freemen of the town. About I675 some freemen petitioned the corporation, saying that the farmers were harming the freemen's common rights by putting sheep into the fields before Michaelmas, contrary to custom, by putting more beasts into the fields to pasture than was usual, by hindering freemen from putting their animals in for pasture, and by damaging the pasture land in various ways. It was also complained that the farmers were failing to keep an adequate bull and boar, as they were by custom obliged to do. 70 These grievances were probably long-standing, as in 1605 the corporation had felt obliged to restrict the numbers of sheep that the farmers put into the south, ${ }^{71}$ and about I624 some inhabitants of Leicester petitioned the corporation, asking for the area available for pasture to be enlarged. ${ }^{72}$ In the I 8 th century the freemen's rights in the South Fields became an important issue. The long, and at times violent, struggle brought

63 Leic. Boro. Rec. I327-I509, 246-53. There had apparently been earlier disputes about the Cowhay: ibid. 60 .

64 Leic. Boro. Rec. I327-I509, 197.

65 Billson (T.L.A.S. xiv. 22) states that after I 467 unenfranchised persons were allowed to pasture their stock in the Cowhay, in return for a fee larger than that paid by the burgesses. Rules made in 1467 (printed Leic. Boro. Rec. $I 327-1509,292)$ seem to provide for fining unenfranchised persons who put beasts in the Cowhay. In I 505 it was agreed to allow the Leicester Dominicans to pasture 2 cows in the Cowhay (Leic. Boro. Rec. I327$I 509,375)$, but this was a special arrangement.

66 Its location is unknown. Later the name 'Burgess Meadows' was applied to all the meadows in the South Fields.

67 Leic. Boro. Rec. $1603-88,370$. The Burgess Meadow did not belong to the corporation at this time, and it is not clear on what basis the town was using it. Later, in $1663-4$, the meadow was bought by the corporation: ibid. 494 .

68 Leic. Boro. Rec. I603-88, 24

9 Ibid. 542. In 1804 it was stated that the commoning began on 12 Sept. and lasted until the next I 3 Feb. each year: Nichols, Leics. iv. 348 .

Leic. Boro. Rec, I603-88, 542. The custom of the farmers of the Newarke lands in the South Fields keeping a bull and boar for public use is mentioned in 1605 : ibid. 44. A bull continued to be provided by the corporation, as owners of the Newarkc lands, until the inclosure: Nichols, Leics, iv. 349 . about between the corporation and the freemen by the corporation's desire to inclose the fields has been described elsewhere. ${ }^{73}$ Here it may be remarked that in the I750's the corporation succeeded in dividing the arable of the south field into a small number of large farms, which were fenced, but that despite this degree of inclosure the freemen retained their rights of pasture over the arable area until $1804 .{ }^{74}$

One result of the freemen's continued enjoyment of pasture rights in this area was that the South Fields were not available for building purposes, and during the I8th century the urban area of Leicester expanded on the south very little. A map of Leicester drawn in 1792 shows houses stretching along the main road to Welford, the present Oxford Street, for some distance to the south of the site of the old South Gate, ${ }^{75}$ with some further buildings along Millstone Lane, just outside the old walled borough, and along Hangman Lane nearby. ${ }^{76}$ In 1785 a treelined promenade, later known as the New Walk, was laid out along the western boundary of the South Fields, following the line of the Roman road, 77 but no building was done along it until the I 9 th century. In I $_{7} 67$ Chapel Close on the main road to Welford was purchased as the site for the infirmary, but this seems to have been the only serious encroachment on the South Fields during the I 8 th century.

The site of Leicester Infirmary is the triangle formed by Infirmary Road and New Bridge and Knighton Streets. In I 766 Dr. William Watts of Medbourne, who afterwards lived at Danet's Hall, made frequent appeals in the Leicester fournal for the establishment of such an institution. A subscription fund was set up, Chapel Close was acquired, and in September 1768 the plans for the building were approved. ${ }^{78}$ The architect was not James Wyatt, as has frequently been stated, but his father, Benjamin Wyatt of Weeford (Staffs.), who designed the infirmary at Stafford about the same date. ${ }^{79}$ The building was completed in $\mathrm{I} 77 \mathrm{I} .^{80} \mathrm{~A}$ lunatic asylum by William Harrison was added in $I 78 \mathrm{I}$ and extended to designs by William Firmadge in 1794. The fever ward by William Kirk was built in $1818^{81}$ and numerous additions were made throughout the I 9 th century

71 Leic. Boro. Rec. I603-88, 24.

72 Ibid. 209.

73 See above, pp. I65-6.

74 L.R.O., Leic. South Fields Incl. Award; and see above, p. I 66 .

75 Demolished in 1774 : J. Thompson, Hist. of Leic. ii. I 53 ; J. 'Throsby, Hist. of Leic. 355.

${ }_{6}$ Throsby, op. cit., frontispiece map; [S. Watts], Walk through Leic. frontispiece map. Hangman Lane roughly followed the line of the present Ncwarke Street. It is mentioned in 1377 : Leic. Boro. Rec. $I 327-1509,389$.

77 Throsby, op. cit. 38 I-2; L.R.O., Leic. South Fields Incl. Award.

78 Thompson, Hist. of Leic. ii. $127-8$, г 30, I 3 I-3, 136 , 139,140 , described the negotiations for the erection of the infirmary; see also Leic. City Mun. Room, Hall Bk. ro Sept., 3 I Oct. I 766. For Chapel Close see below, p. 377.

${ }_{79}$ The plans are Leic. City Mun. Room, I $3 \mathrm{D}_{54 / 12 / 7-}$ ı ; for Wyatt see H. M. Colvin, Biog. Dict. Eng. Architects, 717-18. The building is illustrated in Nichols, Leics. i, plate xxviii.

80 Leic. City Mun. Room, Rep. Leic. Infirmary, I 77 I-2.

${ }_{81}$ The plans for these early alterations are Leic. City Mun.

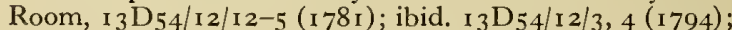
ibid. $\mathrm{I}_{3} \mathrm{D}_{54} / \mathrm{I}_{2} / \mathrm{I}, 2$ ( 1818 ). Alternativc plans for the asylum were made by $\mathrm{Wm}$. Henderson, who was clerk of the works for the original building: ibid. $1_{3} \mathrm{D}_{54 / 12 / 5}, 6$; Thompson, Hist. of Leic. ii. 136. 
and the first fifty years of the 20 th century. The original structure is so set about with modern buildings that it is hardly visible. It is of three stories, with a central bow-fronted block jutting forward between two side wings. It is of red brick with stone dressings.

The South Fields were inclosed under an Act of $1804,{ }^{82}$ by which the conflicting interests of the corporation and the freemen were dealt with in a manner satisfactory to both parties. The award ${ }^{83}$ made under about $\mathbf{1} 2$ acres were sold to defray the expenses of the inclosure. The land handed over to the freemen was to be managed by deputies elected by the freemen of the borough parishes. The freemen's land lay in three parcels, one of rather more than 36 acres, lying between the Soar on the west and Aylestone Road on the east, a second lying on the east side of Aylestone Road, and extending to Welford Road on the east and to the borough boundary on the south, totalling

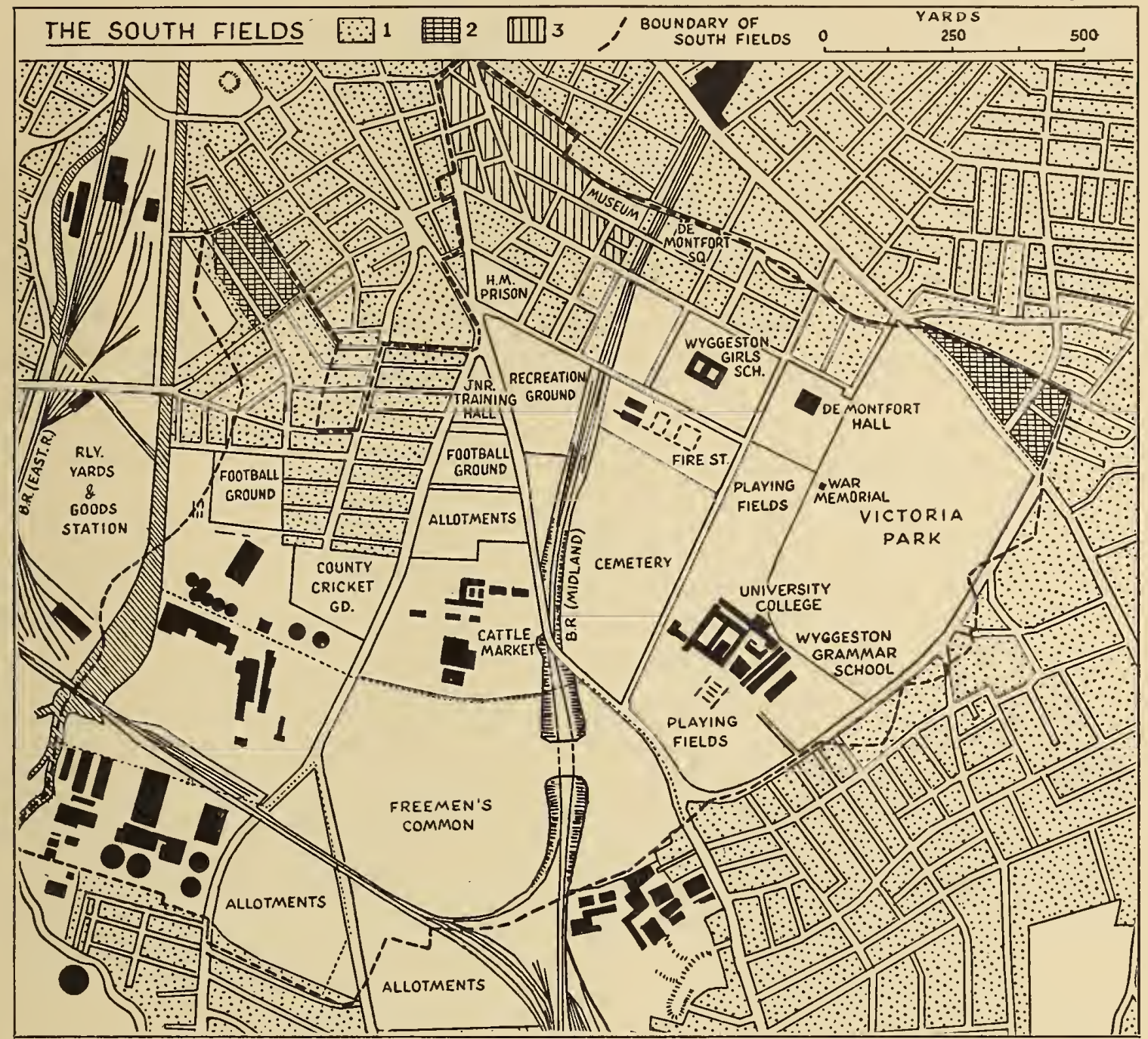

I. Land built up in $195^{\circ}$

2. Parts of the South Fields privately owned after in-

this Act gives the total area of arable as 490 acres, and the area of the Burgess Meadows, ${ }^{84}$ as the meadows in the South Fields were then named, as I 6 acres. One hundred and twenty-five acres were allotted by the award to the freemen in full satisfaction of their pasture rights, 14 acres were allotted to various minor landowners, 453 acres, free of all common rights, were allotted to the corporation, and

82 See Nichols, Leics. iv. 348-9, for details of the Act.

83 L.R.O., Leic. South Fields Incl. Award : summarized in T.L.A.S. xiv. $28-29$.

84 i.e. the meadows of the South Fields collectively, excluding the Bedehouse Meadow, which lay on an island in the Soar, and was not included in either Act or award. On closure.

3. Land sold by the corporation and built over by 1828 .

85 acres, ${ }^{85}$ and a small plot of just over 2 acres on Saffron Lane. 86

The inclosure of the South Fields made available for building a large district close to the rapidly growing borough, and it is not surprising that houses soon began to encroach upon the agricultural land. Part of the land sold to meet the cost of inclosure lay on the New Walk, and was sold in small plots suitable

the name 'Burgess Meadows', see Leic. Boro. Rec. I603$88,494,517$.

85 Small portions of this plot have been alienated, but the greater part of it still (I955) makes up the Freemen's Common.

${ }_{86}$ See H. Hartopp, Reg. Freemen of Leic. II96-I770, pp. xxv-xxvi; T. and G. Ellis, Plan of Leic. (1 828 ). 


\section{A HISTORY OF LEICESTERSHIRE}

for building. ${ }^{87}$ The handsome houses in the Regency style which still occupy much of the northern part of the New Walk were erected during the few years immediately after the inclosure award was issued in I 8 I I ${ }^{88^{\prime}}$ The corporation, which had already developed for building its property in the part of St. Margaret's parish adjacent to the South Fields, ${ }^{89}$ soon began to sell off for building its own land, which comprised the portion of the South Fields nearest to the town. ${ }^{90}$ By 1828 a considerable amount of building had been done in the north-east part of the South Fields, and many new streets, still without houses at that time, had been laid out on a rectangular plan. ${ }^{91}$ 'The Regency houses in the New Walk were joined by other houses in the same style, of which the most notable survivors are the Crescent, built in King Street about 1820 , and Crescent Cottages, built in the same street in I $836 .{ }^{92}$ A new county gaol, which provoked William Cobbett to make some strongly worded comments when he visited Leicester in 1830 , was built in $1825^{-9}$ on land beside the Welford Road bought from the corporation. The architect was William Parsons and the building, which is surrounded by high brick walls with massive corner buttresses, cost over $f 20,000.93$ The Leicestershire and Rutland Lunatic Asylum was completed in 1837 from plans made by William Parsons from models shown to the asylum committee in $\mathrm{I} 835$ by a Mr. Wallett, superintendent of the Dorset County Asylum. ${ }^{94}$ The site, at the top of Knighton Hill overlooking the town, was purchased from the corporation. The original block is a large and well-designed rectangular building in gault brick. The front elevation has four projecting wings, each with three windows, the recessed blocks between having eight windows at each side and seven in the central block in which is a projecting doorway under a pediment. Additions to the original design, in the form of long side wings in red brick, were made shortly after the opening of the asylum, and the building remained in use until the erection of the new asylum at Narborough in 1907 . During the First World War it was used as a military hospital and in I 918 was purchased by T. Fielding Johnson and presented to the University College of Leicester, which was opened in 1921 . Since 1945 the rapid expansion of the college has enabled many additions to be made. These include the south wing extension (1948-50),

${ }^{87}$ L.R.O., Leic. South Fields Incl. Award, and map.

88 See existing buildings.

89 Leic. City Mun. Room, Hall Bk. 26 July 1792,

5 Aug. I806; and see above, p. 195.

90 See above, p. 198.

91 Ellis, Plan of Leic. (1828). The chief streets laid out between the inclosure and 1828 were Hastings Street, King Street, Regent Road, Princess Street, the present Lancaster Road (once Cavalry Street), and the present (1956) University Road.

92 See inscription on Crescent Cottages, and Ellis, Plan of Leic. (1828). For a photograph of Crescent Cottages, see above, plate facing p. I 90 .

93 W. Cobbett, Rural Rides, ed. G. D. H. Cole, ii. 663; L.R.O., Gaol Accts. In $1844^{-6}$ further cells were added, and the governor's house, again by Parsons, was built to the east of the main gate: White, Dir. Leics. (1846), 76; L.R.O., Gaol Accts.

94 L.R.O., Quarter Sessions Order Bk. 6 Jan., 6 April, 29 June 1835,3 April, 26 June 1837; Leic. 7nl. 12 May I837. The asylum is illustrated above, plate facing p. 128 .

95 For the hist. of the college see J. Simmons, Leic. and its University College, 31-46; University College of Leicester, Calendar (1955-6), 9-12. the library extension (1953) and the Astley Clarke Laboratories (I95 I). In I954 the Percy Gee Building, which is to house refectories, common rooms, and the Students' Union, was begun. 95

The development of the South Fields as a residential district was cut short, in the first instance apparently by the building of the Midland Railway's line through the area in $1840 .{ }^{96}$ The railway's proximity made the South Fields less attractive to the more wealthy of Leicester's inhabitants, whose villas were beginning to spread out on the southern outskirts of the town. As a result those parts of the South Fields which were not already built on by 1840 , that is the whole area except the north and a zone bordering the New Walk on the east, were used either for housing of a working class character, or for various public purposes. The north-west part 97 of the South Fields was built up, mostly in $1850-65$, with streets of red brick terrace houses, ${ }^{98}$ which in 1956 still remained. In 1877 the corporation decided to set

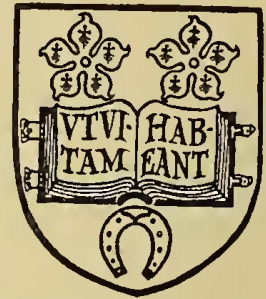

UNiversity COLlege, LeICESTER. Gules, an open book strapped proper and buckled and inscribed with the words 'Ut Vitam Habeant' in letters or between in chief two cinquefoils pierced ermine and in base a horseshoe also or. [Granted 1922] aside $I 8 \frac{1}{2}$ acres to the south of these streets as a site for gas works, ${ }^{99}$ which were built in the following year. ${ }^{1}$ Subsequently they were much extended and electricity plant was added. ${ }^{2}$ In I 920 some contiguous land, belonging to the Leicester freemen, and lying between the Soar and Aylestone Road, was purchased by the corporation as a site for an electricity generating station. ${ }^{3}$ Of the remaining land in the South Fields, the Leicester freemen still possess nearly all the 85 acres allotted to them between Aylestone Road and Welford Road at the inclosure.4 The small plot of some 2 acres owned by the freemen on Saffron Lane was sold to Leicester Corporation in I $924 .{ }^{5}$ 'The corporation's property, which remained very extensive despite sales of building land in the years after the inclosure, ${ }^{6}$ was gradually made use of for various public purposes. Fourteen acres on the Welford Road, near the southern boundary of

96 V.C.H. L,eics. iii. I I 5-16

97 The area enclosed by Mill Lane, Oxford Street, Aylestone Road, Walnut Street and the Soar.

98 J. Barclay, Modern Leic. (I 864), 8, 9 (Leic. City Ref. Libr., Pamphlets $\mathrm{O}_{4}$, vol. iii); Leic. $F$ nl. 24 Feb. 1860 , p. I; 2 Jan. I863, p. I; 15 Mar. 1867, p. I.

99 J. Storey, Hist. Sketch of Boro. of Leic. 96.

I Ibid.

2 See above, p. 285 .

3 Hartopp, Reg. Freemen of Leic. II $196-1770$, p. xxviii. This land, covering 36 acres, had been used as a common pasture for resident freemen and freemen's widows since the inclosure: ibid., pp. xxvi-xxvii.

4 Some of this land was alienated to the Midland Rly., whose line from Leicester to Wigston was built through the freemen's property in $1840: V . C . H$. Leics, iii. I 16 . In 1922 the freemen still possessed 78 acres in this area: Hartopp, op. cit., p. xxix. Under an Act of 1845 the land was broken up to form allotments, by which it was still occupied in I956: Hartopp, op. cit., p. xxvii.

5 Hartopp, op. cit., p. xxix; Leic. Council Mins. 1923-4, 218.

6 In 1856 the corporation still owned more than 424 acres in St. Mary's parish: Rep. as to Town Estates (1856) 5 (copy in Leic. City Ref. Libr.). 
St. Mary's parish, were sold to the county authorities in 1835 as the site for a lunatic asylum.7 Other land in the same area was used for a municipal cemetery, opened in $1849,{ }^{8}$ for a livestock market, opened in 1872,9 and for a fire station, opened in $1927 . .^{10}$ An area of about 70 acres in the south-east corner of the South Fields, after having been used as a racecourse from I 806 onwards, ${ }^{I I}$ was in I 884 laid out as a public park. ${ }^{12}$ The Bedehouse Meadows, where the Leicester burgesses had not enjoyed common rights, were sold by the corporation in 1896 to the Manchester, Sheffield, and Lincolnshire Railway, ${ }^{13}$ and have since been used for marshalling yards. The large island between two streams of the Soar, where the Bedehouse Meadows lay, was considerably altered in shape by the corporation's flood-prevention works, carried out in $1868-90.14$ 'The consequence of the failure to develop the South Fields as a residential district was the creation well inside the modern urban area of Leicester of a region still (in 1956) largely open.

PARISH ADMINISTRATION. That part of St. Mary's parish which lay within the town walls was always part of the borough, but the right of the borough authorities to exercise jurisdiction in the South Fields and Bromkinsthorpe was for long a subject of dispute. During the Middle Ages Bromkinsthorpe was certainly considered to lie within the borough. ${ }^{15}$ There does not appear to be any evidence to show whether the South Fields were under the control of the borough or not. By the end of the 16 th century the borough's rights of jurisdiction in the parts of the parish that were outside the walls were evidently felt to be insecure, for the charter which the corporation obtained from Elizabeth I in I 599 provided that the whole of St. Mary's parish should be under the jurisdiction of the borough. The charter, however, made this provision subject to the reservation that rights already granted to others should be preserved, and consequently the borough's rights in the South Fields and Bromkinsthorpe were not indisputable. ${ }^{16}$ During the $\mathrm{I} 8$ th and early $\mathrm{I} 9$ th centuries a prolonged conflict took place between the borough and the county justices over the right to levy rates and exercise jurisdiction in the two areas. The course of the quarrel has been dealt with elsewhere. ${ }^{17}$ The final result, only attained, after much litigation, in

7 L.R.O., Quarter Sessions Order Bk. 6 April I 835 ; and see above.

${ }^{8}$ Storey, Boro. of Leic. 53.

9 Ibid. 57.

10 Kelly's Dir. Leics. and Rut. (1936), 137.

11 White, Dir. Leics. (I 846 ), 95. From $c$. I 742 until the inclosure, horse races had been run in the part of the South Fields just outside the town, between the Soar and the Welford Road. Earlier still, the races had been run in the Abbey Meadow, in St. Margaret's parish: Throsby, Hist. of Leic. $36_{3}$; Nichols, Leics. i. 447.

${ }_{12}$ R. G. Waddington, Leic., The Making of a Modern City, 76. The races were removed to a new course at Oadby.

${ }_{13}$ Leic. Council Min. I895-6, 63, 66. The railway later became the Gt. Central.

${ }^{14}$ For details, see Storey, Boro. of Leic. 75-92; and see plans, showing old and new courses, in Griffith, Rep. on the Fuly Floods (1880) (Leic. City Ref. Libr., Pamphlets $\mathrm{O}_{4}$, vol. ii)

${ }_{15}$ Leic. Boro. Rec. IIO3-I327, 112, 291.

${ }^{16}$ Ibid. $1509-1603,363-4$. Disputes about jurisdiction in the South Fields began by $c .1650$ : ibid, $1603-88,374$

17 See above, pp. I 29-31.

18 Greaves, Corp. of Leic. ${ }^{8} 8-39$.
I 8 I5, was that the borough and county justices exercised concurrent jurisdiction in Bromkinsthorpe and the South Fields, while the county had an exclusive right to levy rates in both areas. ${ }^{18}$ The only parts of St. Mary's parish that remained wholly under the control of the borough were the portion lying within the old walled area, and a small district lying immediately outside the walls, and bordering on the South Fields. ${ }^{19}$ The South Fields and Bromkinsthorpe were brought within the borough for Parliamentary purposes under the Boundaries Act of 1832,20 and for municipal purposes under the Municipal Corporations Reform Act of I $835 .{ }^{21}$ St. Mary's remained a civil parish within the borough until I 896 , when the whole of Leicester was formed into a separate civil parish. ${ }^{22}$

The most notable feature of the internal administration of St. Mary's parish was the establishment of a close vestry. ${ }^{23}$ In I 577 it was decided at a parish meeting to set up a committee of thirteen leading parishioners, to take charge of parish affairs. ${ }^{24}$ The body thus set up, generally known as the vestry, ${ }^{25}$ conducted all the affairs of the parish, levying rates, ${ }^{26}$ electing the churchwardens, the overseers of the poor and of the highways, ${ }^{27}$ the parish clerk, ${ }^{28}$ and the sexton, ${ }^{29}$ and closely controlling expenditure. ${ }^{30}$ The thirteen vestrymen appear normally to have remained in office for life, though this is nowhere explicitly stated. Vacancies were filled by co-option. ${ }^{31}$ In 1657 the vestry made it a rule that no matters which were in dispute within the vestry were to be divulged to outsiders. ${ }^{32}$ The Ruding family, who were for long lords of the manor of Westcotes within the parish, usually supplied one member to the vestry. ${ }^{33}$ Such close vestries were of course established in many other English parishes. ${ }^{34}$ 'The parish adopted the Sturges Bourne Vestry Act of I8I9.35 'The administration of the poor law in St. Mary's has been dealt with elsewhere. ${ }^{36}$

CHURCHES. A college of secular canons was established in the church of St. Mary de Castro by Robert de Beaumont, Count of Meulan and probably the first Earl of Leicester; the date of foundation is said to have been II07. It is possible that a collegiate church had existed before the Conquest. ${ }^{37}$ The history of the college has been described in an earlier volume. ${ }^{38}$ The church, although collegiate, remained

I9 See borough boundaries as shown in T. and G, Ellis, Plan of Leic. ( 1828 ), and Rep. Com. on Boundaries and Wards of Certain Boros. Pt. 2, H.C. 238 (1837), xxvii.

${ }_{20} 2 \& 3$ Wm. IV, c. 32 ; Greaves, Corp. of Leic. 123.

${ }^{21} 5 \& 6 \mathrm{Wm}$. IV, c. $76 ;$ Rep. Com. on Boundaries and Wards of Certain Boros.

22 Local Government Bd. Order 32, 954.

23 'The churchwardens' accts. are extant from an unusually early date. The oldest, I490-I, are printed in T.L.A.S. vii. $153-9$, and others are printed in Vestry $B k$. and Accts. of Churchwardens of St. Mary's, Leic. ed. J. R. Abney.

24 Abney, op. cit. 123; Nichols, Leics. i. 308

25 Abney, op. cit., passim.

26 Abney, op. cit. 66,68 ; Nichols, Leics, i. 308.

27 Abney, op. cit. $18,19,20,22$, and passim.

28 Ibid. $75,206$.

30 Ibid. $4,54,89$, and passim.

31 Ibid. 54, 63, 68, 73, I I 3, I 2 I , 20 I, 203, and passim.

32 Ibid. I3. 33 Ibid. passim.

34 S. and Beatrice Webb, Eng. Local Government, Parish and County (1924), 1 78-88, for other examples.

35 See above, p. 189. 36 See above, pp. 187-9.

37 V.C.H. Leics. ii. 45 .

38 Ibid. $45^{-46 .}$ 


\section{A HISTORY OF LEICESTERSHIRE}

also parochial. An ordinance made in the middle of the I 2 th century by the abbot and canons ofLeicester Abbey, to whom the college had been made subordinate in or shortly after $\mathbf{I} \mathbf{I} 43,{ }^{39}$ provided that the church services were to be duly maintained, and that one of the college's clergy was to be a chaplain, whose function was presumably to conduct the normal parochial services. 40 About I220 the church was described as appropriated to Leicester Abbey. ${ }^{4}$ From 1238 at the latest it was the practice to institute a vicar for St. Mary's. 'The vicarage was said in 1238 to be worth at least 6 marks, including 2 marks from Leicester Abbey. ${ }^{42}$ 'The vicar was appointed by the Abbot of Leicester. ${ }^{43}$ In 1535 the vicar was receiving f8 a year from the abbey. 44

Under the Chantry Act of Edward VI the College of St. Mary de Castro was dissolved. ${ }^{45}$ Its possessions fell to the Crown, and were granted by Queen Elizabeth I in 1589 to Leicester Corporation. ${ }^{46}$ The college's property had included the small tithes of the parish, together with all offerings, and the revenue from the churchyard,47 all of which thus passed first to the Crown, and subsequently to the corporation. As the great tithes had come into the hands of Leicester Abbey, and had at the Dissolution also passed to the Crown, ${ }^{48}$ hardly any of the normal items of an incumbent's revenue were available in the parish. In 1548 , shortly after the college had been dissolved, Ralph Cowley, the last dean of the college, was appointed vicar by the royal commissioners charged with arranging for the continuance of schools, charities, and clergy previously maintained from the revenues of institutions dissolved under the Chantry Act. The commissioners provided that Cowley was to have a stipend of $£_{13} 6 s .8 d .49$ It would appear, however, that the only income received by the vicar was the $\AA^{8}$ which had been once paid by Leicester Abbey, and which after the abbey's dissolution continued to be paid out of the abbey lands. ${ }^{50}$ About I 580 the parishioners drew up a petition, which stated that owing to the small stipend the parish had been for some time served by unlearned ministers, and asked that the Crown should lease the property of the dissolved college either to the parish, or to the borough corporation, so that the stipend might be augmented from the property. ${ }^{51}$ The petition was

39 V.C.H. Leics, ii. 45 .

40 J. H. Round, Ancient Charts. (P.R.S. x), 59. 238 .

Rot. Hugonis de Welles, ed. W. P. W. Phillimore, i.

${ }_{42}$ Rot. Roberti Grosseteste, ed. F. N. Davis, 397. See list of vicars in A. Hamilton Thompson, Leic. Abbey, r66-8. The 2 marks continued to be paid until 1400 , when it was provided by the abbot and convent of Leic., with the bishop's consent, that the vicar and the dean of the college should in future be the same person, and that the dean should receive an addition to his stipend: Nichols, Leics. i. 303 .

43 Leic. Boro. Rec. I 509-1603, 37.

44 Ibid.; Valor Eccl. (Rec. Com.), iv. I48. By 1535 the dcan was no longer acting as vicar: ibid. 172 .

45 V.C.H. Leics. ii. 46.

46 Leic. Boro. Rec. I 509-I603, 249-5 I

7 Ibid. $36-37$; Nichols, Leics. i. 308

48 See below.

$4932 n d$ Rep. Com. Char. Pt. 5 [r63], pp. 4I-42, H.C. I 839$), \mathrm{Xv}$

50 Leic. Boro. Rec. I 509-I603, 452; I603-88, 273.

Ibid. $1509-1603,452-3$.

52 Ibid. $160.3-88,68-69,543-4$; Nichols, Leics. i. 308.

53 Leic. Boro. Rec. $1603-88,322,580$.

54 Ibid. 550-I, 555. There had earlier been a vicarage by the church, but it had apparently disappeared: Nichols, unsuccessful, but in 1603 the corporation, which had obtained the college's property, granted to the vicar the Easter offerings, the mortuaries, and certain small tithes, to hold during pleasure in return for some smail payments. ${ }^{52}$ Subsequently, from I 643 onwards, the corporation made a yearly grant of $f_{1}$ io to the vicar. ${ }^{53}$ In 1679 Anne Lacy settled, for a payment of $\mathrm{f2}^{20}$, a house in the Newarke on the vicar and parish for use as a vicarage, and the corporation made a grant of $f .5$ towards this. 54 The house in the Newarke fell into decay, and a new vicarage was built in $1934 .{ }^{55}$

Leicester Corporation presented to St. Mary's in $I 602$ and $I 603,{ }^{56}$ perhaps as the owners of the college property. In 1618 the Crown presented, ${ }^{57}$ and the Crown remained the patron until the advowson was transferred to the Bishop of Peterborough, whose diocese included Leicester, in $1867 .{ }^{58} \mathrm{After}$ the establishment of the see of Leicester in 1926 the Bishop of Leicester became the patron. ${ }^{59}$

From the early i $3^{\text {th }}$ century onwards the church of St. Sepulchre, in the South Fields, was a chapel dependent on the church of St. Mary, although it is uncertain how this situation arose. Hugh de Grentemesnil granted the church of St. Sepulchre to the Norman monastery of St. Evroul ${ }^{60}$ and the grant was confirmed about I 200 by Robert, Earl of Leicester. ${ }^{61}$ By I220 the church had passed to the college of St. Mary de Castro and was served by a chaplain from there. ${ }^{62}$ It was apparently not a parish church. ${ }^{63} \mathrm{It}$ stood outside the South Gate of the borough and was said to be the place where those hanged on the nearby public gallows were interred.64 During the I6th century the name St. James's seems to have been applied to the church as often as the name St. Sepulchre's. In I 5 ro the chancel was in need of repair ${ }^{65}$ and the church seems to have been allowed to decay during the rest of the 16 th century. At some point during that time it passed into the possession of the corporation and figures in the chamberlains' accounts of $1606-7$, when it was leased to Nathaniel Sampson for $26 s$. $8 d$. yearly, with an additional I $2 d$. for the tithe of the churchyard, which was paid to St. Mary's. ${ }^{66}$ By 1634 the building may have disappeared altogether, ${ }^{67}$ except for a few fragments of wall which were still standing in the lifetime of persons living at the beginning of the $\mathrm{I} 8$ th century. ${ }^{68}$

Leics. i. 308; Leic. Boro. Rec. I 509-I603, 51. The new vicarage had probably been one of houses of the canons of the Newarke.

55 J. R. Collins, Glimpse into the Past, 6.

56 Nichols, Leics. i. 3 I 1 .

58 Lond. Gaz. 1867, p. 2911.

59 Leic. Dioc. Cal. (1952), 94; Kelly's Dir. Leics, and Rut. (1928), 130.

60 Dugd. Mon. vi. I079; Cal. Doc. France, ed. Round, p. 229. The extant docs. do not make clear whether the grantor of St. Sepulchre's was Hugh or one of the early earls of Leic., but in view of Hugh's known connexions with St. Evroul, it seems highly probable that he was the grantor.

61 Cal. Doc. France, ed. Round, p. 229.

62 Nichols, Leics. i, pp. lv, 303; Rot. Hugonis de Welles, ed. W. P. W. Phillimore, i. 238 .

63 Rot. Hugonis de Welles, i. 238 . A doc. of ${ }_{13} 81$ refers to the 'parish' of St. Sepulchre, but this can only be an error: Leic. City "Mun. Room, 44'28/1 I o. Nothing suggests that St. Sepulchre's was anything more than a chapel.

64 Billson, Medieval Leic, 90.

65 Ibid. 9I; Assoc. Archit. Soc. Rep. and Papers, xxi. 314

60 Leic. Boro. Rec. I603-88, 68-69.

67 Billson, Medieval Leic. 91.

68 Nichols, Leics. i. 328. 
The last reference to the church seems to occur in I 663 -4 , when the corporation paid for paving done near to it. ${ }^{69}$ The site of the church can probably be correctly identified as that of the first infirmary buildings, which were built upon Chapel Close, purchased from the corporation. ${ }^{70}$ The suggestion, made by Nichols and others, ${ }^{71}$ that St. James's Church may be identified with the Hermitage which stood in the same area, does not seem to be tenable. Stukeley's map shows the Hermitage quite clearly as standing on the opposite side of the road from the site of the church $^{72}$ and the two are distinguished in the corporation records in the 17 th century. ${ }^{73}$

The two small extra-parochial areas of Castle View and the Newarke were annexed to St. Mary's for ecclesiastical purposes in $187 \mathrm{I}$ by Order in Council. ${ }^{74}$ The growth of the parish's population during the I 9 th century made necessary the establishment of several new churches. The first of these was that of Holy Trinity, built in $183^{8}$ to serve the population of the New Walk and the adjacent streets. The church was built at the cost of Thomas Frewen of Cold Overton, who also provided an endowment. Holy Trinity was originally a perpetual curacy, with Frewen as patron. The advowson remained in the hands of the Frewen family until about I 885 when it passed to the Peache Trustees, who still retained it in 1956. A separate parish was assigned to the church in $\mathrm{I} 86 \mathrm{I}$, and this parish was enlarged in $\mathrm{I} 886.75$ The architect of the church was Sidney Smirke,76 but his work has suffered much alteration; in 1855 the church was enlarged by Flint \& Wickes of Leicester, in I 87 I it was extensively altered so as to give the exterior a Gothic appearance by S. S. Teulon, 77 and in 1872 the spire was added. ${ }^{78} \mathrm{St}$. Andrew's Church, on Jarrom Street in the western part of the South Fields, was begun in 1860 , and consecrated two years later.79 The architect was Sir George Gilbert Scott. ${ }^{80}$ The building is of brick, in the Early English style, with an ingenious timber roof. St. Andrew's parish was formed in $1862 .{ }^{81}$ The advowson at first belonged to the Bishop of Peterborough, but was transferred to the Bishop of Leicester after the see of Leicester was established. ${ }^{82}$ St. Paul's Church, in the northern part of Bromkinsthorpe, was consecrated in $1871 .{ }^{83}$ It is a Gothic building of Enderby syenite, designed by F. W. Ordish and J. C. Traylen of Leicester.

69 Leic. Boro. Rec. I603-88, 494.

70 Thompson, Hist. of Leic. ii. I 33; Throsby, Hist. of Leic. 275 ; see above, p. 372.

71 Nichols, Leics, i. 328.

72 W. Stukeley, Itinerarium Curiosum ( 1 776), map facing p. 108 .

${ }^{73}$ Leic. Boro. Rec. $1603-88$, cf. pp. 58, I 9 I, 201-2 and pp. $68-69,494$

74 Kelly's Dir. Leics. and Rut. (1881), 347.

75 White, Dir. Leics. (1 846), 90; ibid. (I 877), 305 ; Kelly's Dir. Leics. and Rut. (I 88I ), 548; ibid. (I 888), 554.

76 Spencer, New Guide to Leic. (1888), 79. Thos. Frewen is said to have imposed his own ideas of church architecture upon the architect.

77 Ibid., J. A. Faithful, Short Hist. of Holy Trinity Ch.

Leic. (Leic. City Ref. Libr., Pamphlet O I, vol. xvi), 3. For a criticism of the church as it originally was see Spencer, Guide to Leic. (1868), 53.

78 Faithfull, op. cit. 3; The Builder, lxxii. 5०3.

79 White, Dir. Leics. (1877), 295-6.

80 Ibid.

81 Kelly's Dir. Leics, and Rut. (I 88 I), 548.

82 White, Dir. Leics. (1877), 296; Kelly's Dir. Leics. and Rut. (1 936), I 30 .

83 White, Dir. Leics. (1 877), 304.

${ }^{84} 36$ th Annual Rep. of Leic. and Leics. Soc. of Archi-
According to the original plan the church was to have included a massive tower and spire, but these were never completed. ${ }^{84}$ St. Paul's parish was created in $\mathrm{I} 872.85$ The advowson was originally in the hands of the Bishop of Peterborough, but like the advowson of St. Andrew's was later transferred to the Bishop of Leicester. ${ }^{86}$ In 1890 the church of the Martyrs, on Narborough Road in Bromkinsthorpe, was built by the Revd. Joseph Harris, and the parish was formed in the same year. ${ }^{87}$ The red brick church was designed by Ewan Christian. ${ }^{88}$ The advowson was at first in the hands of the trustees of Joseph Harris and his brothers. ${ }^{89}$ Subsequently, about 1920 , the advowson was held by the Bishop of Peterborough and the Principal of Ridley Hall, Oxford, who presented alternately. ${ }^{90}$ After the establishment of the diocese of Leicester in I 926 the Bishop of Leicester replaced the Bishop of Peterborough, ${ }^{91}$ and the advowson was in 1954 shared by the Bishop of Leicester and the Principal of Ridley Hall.92 All Soul's Church in Aylestone Road, in the western part of the South Fields, was built in 1907 , and was one of the last works of the architect G. F. Bodley. The parish was formed in the same year. ${ }^{93}$ The advowson at first belonged to the Bishop of Peterborough, but after the creation of the diocese of Leicester in 1926 the Bishop of Leicester became patron. ${ }^{94}$ The church of the Holy Apostles on Fosse Road, in Bromkinsthorpe, was built in 1906 to serve an ecclesiastical district created two years earlier. The original church, a temporary iron structure, was replaced by a permanent building by Pick, Everard \& Keay in I924, when the parish was created. The advowson, at first for a short time held jointly by the Bishop of Peterborough and the Principal of Ridley Hall, Oxford, came to the Leicester Diocesan Trustees, who in I 956 still remained the patrons. ${ }^{95}$ In I9 I 4 St. Anne's Church was built just inside the western boundary of Bromkinsthorpe to serve a newly created conventional district. In 1934 a permanent church was built to replace the original temporary one, and the parish was set up. The Bishop of Leicester has been from the first, and in 1956 still remained, the patron. ${ }^{96}$

The ancient parish church of ST. MARY DE CASTRO ${ }^{97}$ consists of nave, north and south aisles, chancel, tower, north chapel and vestry and south porch. The oldest surviving parts of the church date

tects $(1908-9), 26$. The illustrations to this article on Ordish's work include one of the finished design for the church; see also J. Simmons, City of Leic. 54.

85 Kelly's Dir. Leics, and Rut. (1936), I3I.

86 Ibid.; Kelly's Dir. Leics. and Rut. (I 88 I), 548.

87 Kelly's Dir. Leics. and Rut. (1936), I 3 I.

88 Ibid.

89 Kelly's Dir. Leics. and Rut. (1900), I I 5 ; ibid. (1908), I 23

90 Kelly's Dir. Leics. and Rut. (1922), 124.

9I Ibid. ( I 928), I 32.

92 Leic, Dioc, Cal. (1954), 90.

93 Kelly's Dir. Leics. and Rut. ( 1936), I 30.

94 Ibid. (I 908), I 22; ibid. (I925), I 32 ; ibid. (I928), I 3 I. The $\mathrm{Bp}$. of Leic. was still patron in 1956.

95 Kelly's Dir. Leics. and Rut. (1908), I 23 ; ibid. (1925), I32; ibid. (1928), I 33 ; Leic. Dioc. Cal. (1954), 89; Leic. Mail, 22 Dec. I924. In 1950 the mission ch. of St. Oswald was set up in the parish: Leic. Dioc. Cal. (1950), 93.

96 Kelly's Dir. Leics. and Rut. (1922), I 23; ibid. (1936), I 30 ; Leic. Dioc. Cal. (1954), 90.

97 This description of the church owes much to a talk given by Mr. C. A. Ralegh Radford, F.S.A., to the members of the Royal Arch. Institute on 4 July I955; see also R.A.I., Programme of the Summer Meeting 1955 at Leic. IO-II. 


\section{A HISTORY OF LEICESTERSHIRE}

from shortly after the refoundation of I I 07 , when a church was begun which was probably completed before I I43. It was perhaps cruciform, but no part of the centre remains. It had a long, aisleless nave and a square-ended chancel terminating 20 feet short of the present east end. Around the lowest stage of the nave ran an internal arcade of round-headed arches carried on columns with reeded capitals. This arcade remains on the west wall and at the west ends of the side walls. The second stage contained round- tal chapels, and the westernmost bay of all had no windows, as the canons' stalls were there. The sedilia in the chancel date from this time, as do the doors in the north and west walls of the north aisle, although these have been reset in their present positions. The nave was by then parochial. On the outside of the south aisle can be seen a short stretch of rough rubble masonry which marks the south wall of the south transept.

Early in the 13 th century a large rectangular chapel

\section{S? MARY DE CASTRO}

\section{LEICESTER}

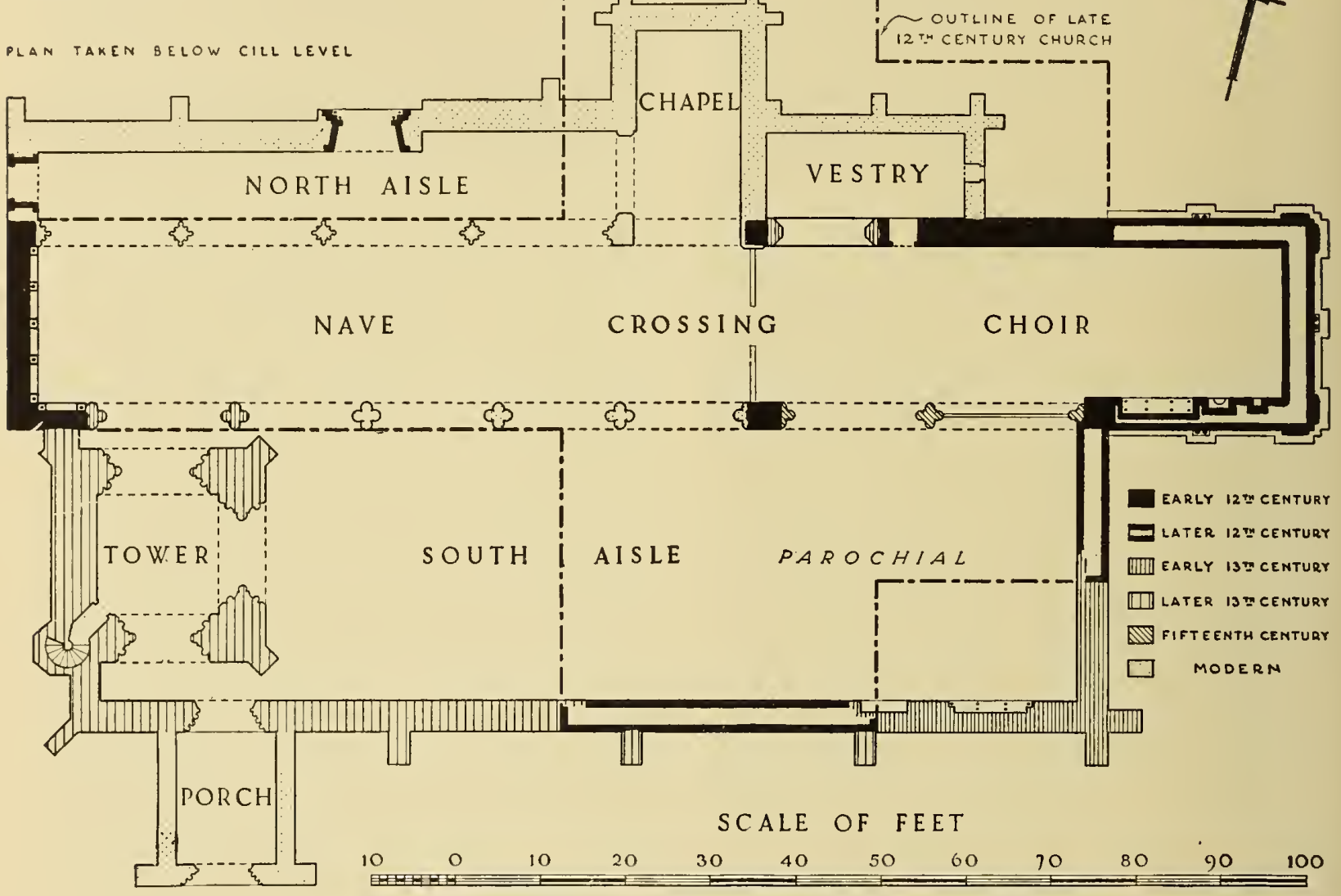

headed windows, with polychrome decoration of dark and light stone. On the outside of the church this stage was arcaded, with a window in every fourth arch, but this only survives at the west end of the south wall. There were also round-headed windows in the chancel, on both exterior walls of which are traces of the outside decoration: the windows were linked by blind arches filled with diaper work. The door in the north wall of the chancel also dates from this period.

In the last part of the 12 th century, probably about I $60-80$, the chancel was extended to its present length and two chapels in echelon were opened out of each transept. New windows were set in the chancel at a higher level, with chevron ornament on their external hoods. Most of this work that still exists is, however, a modern copy of the original. The sills of the three western windows of the chancel are set at a higher level in order to clear the roofs of the transep-

98 In 1313 a man working on the tower was killed when he fell between 2 ladders: Leic. Boro. Rec. I IO3-I 327, 375 . was built to the east of the south transept, in place of the former chapels in echelon and extending the full width of the transept. The sedilia in this part of the aisle are of this date. At the same time a small south aisle was added to the nave giving access to this new chapel. The lean-to roof of this aisle would have blocked the 12th-century windows, so a clerestory was added. The new chapel was probably parochial, and it looks as though the canons' choir had begun to encroach upon the nave, as the arches which were then cut through the walls of the chancel at the west imply that their stalls had been moved. In the second half of the I 3 th century the south chapel was extended westwards and a tower built in its west end, supported within the church itself on heavy freestanding pillars. 98 The large windows in the south aisle were inserted at the same time. The existing arches between south aisle and chancel were made in the 15 th century.

The tower may then have been still under construction. 
There is little or no evidence for the north aisle until the I $\mathrm{gth}$ century, when it was rebuilt by Sir George Gilbert Scott, only partly, it seems, on the original plan. The north chapel is dedicated to St. Anne. It was built in I 86I by Scott for the Noble family, the owners of Danet's Hall.99 A Danet's Chapel is mentioned in 1638 and there may have been a private chapel for the lords of the manor of Danet's Hall from a much earlier date. The south porch was built in $1860^{2}$ and the vestry in $1904 .^{3}$

The church has been much restored and altered. The south nave arcade was inserted, during alterations carried out after I 850 under the direction of Sir George Gilbert Scott, ${ }^{4}$ to replace a large brick arch which had carried the east portion of the clerestory since 1780.5 About the middle of the I 9 th century also the north arcade and clerestory were rebuilt, the tracery in all the windows was renewed, the south porch added, and roof largely repaired. Most of the outer walls have been repaired, and further alterations were carried out in 1930 and the years following. ${ }^{6}$

'The spire, which has undergone much reconstruction, was added to the tower at an unknown period. In I 685 five yards of the spire had to be taken down. Further extensive repairs were necessary in 1757 and $176_{3}$, and in $7_{8} 8$ the spire had to be entirely rebuilt. Further repairs had to be carried out in 1871 and 1916.7

Beneath the tower stands the mid-I 3 th-century font; it has a bowl-shaped basin on a circular stem, and is decorated with a trefoiled arcade of four arches, with carved heads between. ${ }^{8}$ In the nave is a panelled oak chest, finely carved, dating from the $\mathrm{I} 7$ th century. A number of I4th-century tiles in the floor of the tower include two bearing alphabets. The mayor's pew, made in I 49I, formerly stood against the north wall of the chancel. It was removed in $\mathbf{I} 845$, but a list of the borough's mayors marks the spot where the pew formerly stood. ${ }^{9}$

Leicester Corporation, after it had acquired the property of St. Mary's College, was responsible for the upkeep of the chancel. In I6ro the borough chamberlains note the payment of $14 d$. in fees when the corporation was summoned to the court of the bishop's commissary to show why the chancel had not been repaired. ${ }^{10}$ Similar summonses were answered in 1626 and 1632.11 In the latter year the chamberlains' accounts contain details of repairs to the chancel windows, ${ }^{12}$ but in ${ }_{1} 63_{3} 8$ the archdeacon ordered that the chancel should be repaired, especially

99 White, Dir. Leics. (1877), 302; and see tablet in chapel. A deed hanging in the chapel gives permission to the vicar for divine service, provided that the Danet family may at any time appropriate it for themselves.

1 Leic. City Mun. Room, $\mathrm{ID}_{41 / 18 / 9}$.

2 White, Dir. Leics. (1877), 302.

3 T.L.A.S. ix. 218.

4 White, Dir. Leics. (1877), 303. Scott's work was part of extensive reconstruction, begun 1844 , completed I $86 \mathrm{I}$.

5 Collins, Glimpse into the Past, 21. The brick arch in St. Nicholas's church is of similar design.

6 Collins, op. cit. 20-21.

7 Ibid. 20; Throsby, Hist. of Leic. 221-2. The architect was John Cheshire, a famous steeple builder: H. M. Colvin, Biog. Dict. of English Architects, I $38-9$; [Watts], Walk through Leic. 94.

8 See plate facing p. 347 .

9 Assoc. Archit. Soc., Rep. and Papers, xiii. $264-5$.

10 Leic. Boro. Rec. I603-88, 108.

i1 Ibid. 239, 275.

I2 Ibid. 276 .

13 Leic. City Mun. Room, I $\mathrm{D}_{41 / 18 / 9 .}$

14 Ibid. I D41/18/22. the east window, which had been stopped up with mortar and stones. ${ }^{13}$ In 1797 it was ordered that provision should be made for draining the churchyard so that the foundations of the building might be safe from harm by subsidence, and that the church should in future be kept cleaner.14 In 1832 Archdeacon Bonney noted that the corporation was responsible for what he called the north aisle, ${ }^{15}$ by which he apparently meant the chancel; this confirms a statement made at the visitation of 1775 that the old chancel was never used, though kept in repair by the corporation. ${ }^{16}$ By 1832 the great south aisle had by custom become the nave, and it remained so until the chancel and old nave were restored later in the igth century. ${ }^{17}$

The registers date from $\mathbf{1} 600$. The earliest existing pieces of plate are two silver cups and two patens, all dated I688, and a silver dish, dated I687. There are also two silver flagons, both of 1722 . Much earlier church plate has been lost. ${ }^{18}$ The church has eight bells. The oldest bears the date of I $_{3} \mathrm{I}$, and the other seven were all cast by T. Mears of London in 1830 .

The tithes of St. Mary's parish belonged to Leicester Abbey, except that the Norman abbey of St. Evroul received one-third of the tithes of 3 carucates. ${ }^{19}$ Leicester Abbey's possession of most of the parish's tithes was no doubt based on the grant to it, when founded in I I 43, of all the possessions of the older college of St. Mary. ${ }^{20}$ Robert FitzParnell, Earl of Leicester II90-I204, confirmed to St. Evroul the tithes of all his demesne lands at Leicester ; $^{21}$ it is probable that the tithes had originally been granted to St. Evroul by Hugh de Grentemesnil, the owner under William I and William II of much land at Leicester that later came to the earls of Leicester, and one of the joint founders of St. Evroul. ${ }^{22}$ At some unknown date the abbey of St. Evroul demised its tithes at Leicester at perpetual farm to Leicester Abbey, ${ }^{23}$ and after I4I 5 when St. Evroul's English possessions were transferred to Sheen Priory ${ }^{24}$ Leicester continued to farm the tithes from Sheen. ${ }^{25}$ In a document drawn up between I 52 and I 67 the Abbot and Convent of Leicester allocated most of the tithes of the parish to the canons of the College of St. Mary de Castro, ${ }^{26}$ who were still receiving them in $1535^{27}$ After the Dissolution the small tithes of the parish were possessed by Leicester Corporation. The corporation was receiving the small tithes by $1603-4,28$ but does not ever seem to have obtained a grant of them; at times the lack of any sound title to the small

15 Ibid. $245 / 50 / 1$.

16 Ibid. $1 D_{4} 1 / 18 / 21$

17 Ibid. 245/50/1

18 A. Trollope, Ch. Plate of Leics. 94-99.

19 Nichols, Leics. i. 303

20 V.C.H. Leics, ii. 3.

21 Cal. Doc. France, ed. Round, 229-30. It is not clear exactly what tithes were confirmed, as the charter mentions all the tithes of the earl's demesne at Leic., as confirmed to St. Evroul, but later speaks of St. Evroul as having twothirds of the tithes of the Leic. demesne lands. St. Evroul had two-thirds of the tithes from much other land of the earl in England; ibid.

22 E.H.R. liv. 386-7; Dugd. Mon. vi. 1078.

23 Nichols, Leics. i. $30_{3}$, App. 73.

24 See below, p. 448 .

25 Nichols, Leics. i. $78,86$.

26 J. H. Round, Ancient Charts. (P.R.S. x), 59.

27 Valor. Eccl. (Rec. Com), iv. 172. But the tithes seem to have been regarded as the abbey's property: Leic, Boro. Rec. I 509-1603, 37.

28 Ibid. $1603^{-88,} 31$. 


\section{A HISTORY OF LEICESTERSHIRE}

tithes caused the corporation some anxiety. ${ }^{29}$ Apparently it had assumed that it had the right to the tithes as part of the property of St. Mary's College, though the charter of Elizabeth I, which granted the college's possessions to the corporation, does not mention tithes at all.30 The great tithes of Westcotes were sold by the Crown, which had acquired them at the Dissolution, to Edmund Downinge and Peter Ashton in $1582 .{ }^{31}$ The Westcotes great tithes changed hands repeatedly until in 1652 they were sold to Walter Ruding, the lord of the manor, and his son, Walter Ruding the younger. ${ }^{32}$ From 1652 the great tithes remained in the hands of the Ruding family, and of the subsequent owners of IVestcotes, until commuted. ${ }^{33}$ The great tithes of nearly all the remaining land in Bromkinsthorpe also came into the possession of the owners of the land there. ${ }^{34}$ The great tithes of the South Fields were bought by the corporation in $1754,{ }^{35}$ and when the South Fields were inclosed in 1804 , all tithes there were extinguished, the corporation being allotted land in compensation. ${ }^{36}$ The tithes of Bromkinsthorpe were commuted in I 849; the corporation received $£ 797 s .9 d$. a year as owners of the small tithes and the landowners received $f_{\mathrm{I}} 6 \mathrm{I} \mathrm{I} 6 s .4 d$. as the owners of most of the great tithes; small sums were allotted to Clement Winstanley of Braunstone, to the devisees of Thomas Pares, and to the trustees of Wyggeston's Hospital for their rights in respect of the great tithes. ${ }^{37}$

CHARITIES. Most of the charities of St. Mary's have been lost. In $\mathbf{I} 786$ the parish was receiving Ios. a year from a house in the Market Place. The donor was said to be a Mr. Watts, but nothing further is known about this gift. The sum had increased to $16 s$. by $1837,{ }^{38}$ but no return for the charity was made in $1862-3^{39}$ and it has ceased to exist. It is possible that the payment derived from the gift made in or before I 649 by Julius Billers, who gave or bequeathed $f_{\text {, Io }}$ to the poor of the parish. The corporation of Leicester seems to have been responsible for the charity, for the $f_{1} \mathrm{Io}$ was paid over to it in $1648-9$ and in 1649 it was decided that Ios. should be distributed annually from the town's chamber until the $£_{\mathrm{I}}$ o should be laid out in the purchase of land.40 The payment of Ios. is recorded in the chamberlains' accounts in $165^{\circ}-1,{ }^{41}$ but nothing further is known of this donation.
John Nurse by will dated 1624 left $13 s .4 d$. to the parish to be paid out of a close in Sanvey Gate. The payment was in arrears in 1837 and has not been recovered.42 Joseph Wright's Charity of I $3 s .4 d$. a year, probably paid out of a house in Belgrave Gate, was established before $\mathbf{I} 786$ and lost before $\mathbf{I} 837^{43}$ William Ruding left $£ 50$ in 1748 , the interest of which was to be laid out in coal for the poor of St. Mary's. The interest had not been paid for many years before 1837 and has not been revived. 44 John and Ann Lacy by deed dated 1765 granted to trustees a new house in Grange Lane, off Oxford Street, the rent from which was to be given to five poor widows. In 1837 the house was in bad condition and the rent was being given to more than five persons. ${ }^{45}$ By I $862-3$ the house was ruined and no rent was paid. ${ }^{46}$ In 1716 Lucy Fownes left $f 20$ for the use of the poor in the parish. The money was used for the repair of the workhouse and for some years before 1837 no interest from the $f 20$ was distributed to the poor. In I 837 it was held that the workhouse must be considered as charged with the $£ 20.47$ This charity still existed in $1862-3$, when it was known as the Fownes or Clarke Charity and consisted of I Is. $6 d$. interest from $£ 20$ held in the Savings Bank, which was distributed to the poor. ${ }^{48}$ This charity also has ceased to exist.

Shortly before 1687 Mrs. Anne Lacey apparently left $f 10$ in trust with the corporation, which distributed the interest of I2s. to the poor of St. Mary's parish. A Mr. Sharman, probably William Sharman, gave $£_{1}$ Io or $£_{\text {II }}$ to the corporation before I677-8, the interest of which was to be paid to the poor of the parish. These two charities had lapsed before 1837 , but it was then held that they should be revived, there being no evidence that the principal sums had ever been returned to the parish. ${ }^{49}$ No return was made for these charities in $1862-3$ but they were still paid in 1955, and then produced about $£ 7$ a year, which was distributed in the form of bread tickets to the poor of the parish. ${ }^{50}$

St. Mary's parish receives 2s. from the Hobbie Charity, fI Is. $4 d$. from the Courteen Charity, and fi from William Ive's charity; all these payments are made by the corporation. A payment is made by the Leicester General Charities from the Heyrick Bread Charity. ${ }^{51}$

\section{BROMKINSTHORPE}

THaT part of St. Mary's parish which lay to the west of the River Soar formed the liberty of Bromkinsthorpe. The soil of the area is mostly Triassic Marl and Sandstone, but on the west bank of the Soar there

29 Leic. Boro. Rec. I603-88, 269.

30 Ibid. 374 ; ibid. $1500-1603,247^{-52}$.

3t Nichols, Leics. iv. 567

32 Ibid.

33 Ibid.; L.R.O., Bromkinsthorpe and Westcotes tithe award.

$3+$ L.R.O., Bromkinsthorpe and Westcotes tithe award.

35 Nichols, Leics. iv. 347 ; on leases made of tithes in earlier times see above, p. 376 .

${ }_{36}$ I.R.O., I,eic. South Fields inclosure award.

37 I.R.O., Bromkinsthorpe and Westcotes tithe award.

38 32nd Rep. Com. Char, Pt. $5\left[16_{3}\right]$, p. I I 3, H.C. (1839), xv. is a narrow zone of alluvium with, farther away from the river, gravel terraces. Boulder Clay, which forms the surface of so much of the adjacent region, is almost entirely absent.

39 Endowed Charities, Co. of Leic. Leic. City Ref. Libr., Pamphlets $\mathrm{O}$ 5, vol. i.

40 Leic. Boro. Rec. $1603-88,385,391$.

41 Ibid. 405 .

$4232 n d$ Rep. Com. Char. Pt. 5, I I 3.

44 Ibid. I I 4

46 Endozved Charities, Co. of Leic.

$4732 n d$ Rep. Com. Char. Pt. 5, I I 5

48 Endowed Charities, Co. of Leic.

$4932 n d$ Rep. Com. Char. Pt. 5, I I 3 ; for Sharman, see Leic. Boro. Rec. I603-88, passim.

5o Ex inf. Canon J. R. Collins, late Vicar of St. Mary's.

sI See below, pp. 4II, 4I3. 
The Roman Fosse Way' runs through Bromkinsthorpe, and the remains of a Roman villa have been discovered on a site near the centre of the liberty. ${ }^{2}$ It was probably the nature of the surface soil, free from the heavy clay which covers much land in the vicinity, that led to the establishment of a villa here, and it is also possible that the estate which presumably surrounded the villa occupied roughly the same area as the later liberty, though this can be no more than a conjecture. There is no information about Bromkinsthorpe for any date before 1086 , and it is therefore impossible to establish any connexion between the villa's estate and the later liberty.

In 1956 Bromkinsthorpe was largely a residential district, of a middle-class character. On its eastern side, bordering on the Soar, there are some warehouses and factories. The two main roads, once turnpikes, which run from Leicester to Hinckley and to Narborough respectively, have become the chief highways of the district. The lesser roads in general either follow the ancient lanes, ${ }^{3}$ or, more frequently, the field boundaries as they existed in the early igth century. 4 The only building of any note in the liberty is Wyggeston's Hospital. The present hospital buildings were completed in $\mathrm{r} 868$, and replaced the earlier hospital in the centre of the borough. 5 The hospital is a long range of buildings in the Victorian Gothic style, built of red brick with facings of Bath stone and a tiled roof. At the north end of the range stands the chapel, with a slender stone spire at its southwest corner, and an apse at the north end. The hospital stands in extensive and well wooded grounds. ${ }^{6}$

In 1086 it was said of Bromkinsthorpe that 'This land belongs to Leicester with all its customary dues'.7 The exact nature of the link between Leicester and Bromkinsthorpe at this time is, however, obscure. There does not appear to be any evidence that the Leicester burgesses ever exercised common pasture rights in the fields of Bromkinsthorpe, or that Bromkinsthorpe ever constituted one of the borough's open fields, in the way that the east and south fields did. It is, on the other hand, clear from the position in ro86, as stated in Domesday, and from the fact that during the Middle Ages Bromkinsthorpe seems always to have been considered as lying within the jurisdiction of the borough authorities, that there was a close connexion between the liberty and the borough, and that Bromkinsthorpe, though separated from Leicester by the Soar, was never a rural town-

The line of the Roman road is roughly that of the present ( 1956 ) Narborough Road. The present Fosse Road is of medieval origin: V.C.H. Leics. iii. 72 .

2 The site is bounded by King Richard's Road, Fosse Road Central, and Norfolk Street: F. J. Haverfield, Roman Leic. $44 ;$ V.C.H. Leics. i. 196.

3 e.g. the present King Richard's Road was originally a track, known as Watts' Causeway in the first half of the Igth century, from Bow Bridge to Danet's Hall: [Watts], Walk through Leicester, frontispiece map; White, Dir. Leics. (1846), 189, I 90 .

${ }^{4}$ Cf. 'T. and G. Ellis, Plan of Leic. (1828), and the modern street plan.

5 G. Cowie, Hist. Wyggeston's Hosp. $5^{8}$.

6 For a photograph see below, plate facing p. 393.

7 V.C.H. Leics. i. $3^{1} 4^{-1} 5$. This entry has been wrongly ascribed to Bruntingthorpe, and the ownership of Bromkinsthorpe at the date of the Survey has been attributed to Robert, one of the vassals of the Count of Meulan: ibid. 337. Farnham followed V.C.H. Leics. in correcting Nichols, who actually identified the two entries correctly: Farnham, Leics. Notes, i. 219 ; Nichols, Leics. iv. 565. It is unlikely that the rather distant village of Bruntingthorpe ship clearly outside the borough. In this Bromkinsthorpe may be contrasted with Knighton, which although within St. Margaret's parish for ecclesiastical purposes was never under borough control until I 892.8 It is possible that Bromkinsthorpe had once formed one of Leicester's open fields, and that the burgesses had possessed there common rights of which they had been deprived, perhaps by the action of Hugh de Grentemesnil at some date between the Conquest and 1086.

MANORS. In Io86 Hugh de Grentemesnil held 6 carucates of land at Bromkinsthorpe, together with a further 2 carucates there which belonged to the soke of Ratby. ${ }^{9}$ Four sokemen in Smeeton ${ }^{10}$ were attached to Hugh's land at Bromkinsthorpe. I Like most of Hugh's other lands in England, Bromkinsthorpe came in the I 2 th century into the hands of the Earls of Leicester. ${ }^{12}$ By the 13 th century two manors existed.

The manor of WALSH HALL, or DANET'S $H A L L$, was held from the earls of Leicester, and subsequently from their successors, the earls and dukes of Lancaster. The first mention of the family of Walsh, or Waleys, in connexion with Bromkinsthorpe occurs in $\mathbf{1 2 7 9}$, when William le Waleis is stated to have been a tenant of lands there formerly held from Simon de Montfort, Earl of Leicester. ${ }^{13}$ The Walsh family continued to be important landholders at Bromkinsthorpe until the I $4^{\text {th }}$ century. ${ }^{14}$ From the fact that the manor was subsequently known as Walsh Hall 15 it may be conjectured that the family was at one time possessed of it, but there is no other evidence that the lands which the Walshes held in Bromkinsthorpe constituted a manor. The ownership of the manor is not clear before 1428 , when it was being held by Richard Danet. ${ }^{16}$ The Danet family had been possessed of lands in Bromkinsthorpe for. more than 200 years before I428; Amaur Danet owned a mill there in $1200,{ }^{17}$ and during the 13 th and I 4 th centuries various members of the family appear as important landowners in Bromkinsthorpe. ${ }^{18}$ The Danet family continued to be lords of the manor ${ }^{19}$ until at least $I 647.0^{20}$ Subsequently, before I68I, the manor came into the hands of a family called Charlton, who were descended from the Danets. ${ }^{21}$ About I 700 the manor was acquired by the Watts family, who held it until $\mathrm{r} 769 .{ }^{22}$ After the death in that year of John Watts the property changed hands repeatedly;

could have belonged to Leicester "with all its customary dues'.

8 See below, p. 443 .

9 Ratby lies some 4 miles west of Bromkinsthorpe. It was held by Hugh in 1086 .

r 0 i.e. the hamlet now forming part of Smeeton-Westerby, about Io miles south-east of Bromkinsthorpe.

I $V . C . H$. Leics. i. 3 I $4^{-1} 5$; and see n. 7 above.

I2 E.H.R. liv. 387 . ${ }_{13}$ Nichols, Leics. iv. 565.

${ }^{4}$ Ibid. 570; Assoc. Archit. Soc. Rep. and Papers, xix. 262.

I5 Farnham, Leics. Notes, vi. 245, 246; Leic. Boro. Rec. I $327-1509,5,43$.

16 Leic. Boro. Rec. I327-I 509, 234.

17 Ibid. $I I 03-I 327,5$.

18 Ibid. I 327-I509, I87; Farnham, Leics. Notes, vi. 2,0-1 ; Feud. Aids. vi. 559; Assoc. Archit. Soc. Rep. and Papers, xix, 262.

I9 Farnham, op. cit. vi, 242-5.

20 Ibid. 246; Leic. Boro. Rec. I603-88, 36o, 375.

21 Nichols, Leics. iv. 570; Leic. City Mun. Room, I $7 \mathrm{D}_{44 / 3}$.

22 Nichols, Leics. iv. 570. 
it was first sold to a Mr. Weightman, and then passed by successive purchases to Samuel Unwin, to a Mr. Powell, and to William Bentley. ${ }^{23}$ Neither the Watts family, nor any of their successors, are referred to as lords of the manor, though they were the owners of the estate formerly held by the Danets, and the manor as such seems to have disappeared by the start of the I 8 th century. In I 804 Danet's Hall was bought by Dr. Edward Alexander, ${ }^{24}$ on whose death, in 1825 , it came to Elizabeth Kershaw, ${ }^{25}$ and subsequently to Dr. Joseph Noble. ${ }^{26}$ After Dr. Noble's death, the property was sold in 1861 to the Leicester Freehold Land Society for building. ${ }^{27}$

The manor of WESTCOTES in Bromkinsthorpe was for most of the Middle Ages held by Leicester Abbey. 'The abbey's holding originated in a grant of land by Robert FitzParnell, Earl of Leicester, ${ }^{28}$ and in a gift of a manor in Bromkinsthorpe by Ranulph Portarius, who became a canon of the abbey. ${ }^{29}$ 'The abbey also obtained a smaller grant of land in Bromkinsthorpe from Seward Pitefrid. ${ }^{30}$ The exact dates of these three grants are not known, but FitzParnell's must have been made between his accession to the earldom in II 91 and his death in 1204 ; in all probability FitzParnell's grant was made in or shortly before 1204, for it formed part of a complicated series of property exchanges between the earl, Leicester Abbey, and the Bishop of Lincoln.31 The manor in Bromkinsthorpe granted to the abbey by Ranulph may be the same property as the 7 virgates and I bovate outside the West Gate of Leicester confirmed to the abbey by Henry II in a charter granted between I I54 and I I62.32 The manor of Westcotes remained in the hands of Leicester Abbey until the Dissolution. On the surrender of the abbey in $153^{83}$ its lands came to the Crown. In 1557 a survey of the manor was made with a view to selling it to John Ruding, ${ }^{34}$ whose father, another John Ruding, in 1536 had leased the manor from the abbey for $8 \mathrm{I}$ years, ${ }^{35}$ but in August of the same year the Crown sold Westcotes to two speculators in monastic lands, Thomas Reve and Richard Budde, ${ }^{36}$ who in $155^{8}$ sold it to the younger John Ruding. ${ }^{37}$ The manor remained in the hands of the Ruding family until I82I, when Walter Ruding sold it to Thomas Freer, Clerk of the Peace of Leicestershire. ${ }^{38}$ Freer's son in turn sold the property to Joseph Harris, a Leicester solicitor, before I846.39 By the time of Harris's purchase of the property the manor as such seems to have ceased to exist.

23 Nichols, Leics. iv. 570-1.

25 Curtis, Topog. Hist. Leics. 32.

26 White, Dir. Leics. (I 846 ), I 52 ; A. Fielding Johnson, Glimpses of Ancient Leic. (1906), 365.

27 Fielding Johnson, op. cit. $365 ;$ Leic. Chron. I4 Sept. I861 ; Leic. City Mun. Room, IOD $52 / 303$.

28 Nichols, Leics. i, App. 55; Rot. Chart. (Rec. Com.), I45.

29 Nichols, Leics. i, App. 7I. Ranulph had obtained the land from Robert the son of William the son of Aufred, of Bromkinsthorpe.

30 Nichols, Leics. i, App. 54. Seward held the land from Robert le Bossu, Earl of Leic.

31 Reg. Antiquissimum, ed. C. W. Foster, iii. 2 I 5.

32 Nichols, Leics, i, App. 57-58.

33 V.C.H. Leics, ii. I 6.

34 B.M., Harl. MS. 606 , ff. 63 sqq.

35 Nichols, Leics. iv. 566 .

36 Cal. Pat. I $557-8,279$.

37 Nichols, Leics. iv. 566.

38 Curtis, Topog. Hist. Leics. 32: see Leic. City Mun. Room, 8D50 for 18 th- and I 9 th-century estate papers.
ECONOMICHISTORY. The possibility that Bromkinsthorpe had once formed one of Leicester's open fields, and that the burgesses had once enjoyed common rights there, has already been discussed. 40 An extent of Leicester Abbey's lands in Bromkinsthorpe, drawn up in 1381 , shows that the arable land was then divided into strips of the usual type.4I In 1448 there were three open fields in Bromkinsthorpe. ${ }^{42}$ Alongside the Soar lay several meadows. ${ }^{43}$ At the final inclosure of Leicester Forest in 1628 106 acres were allotted to the freeholders of Bromkinsthorpe in compensation for the rights of common pasture which they had hitherto enjoyed in Leicester Forest. The land allotted lay in the part of the forest which was immediately adjacent to the western boundary of Bromkinsthorpe. After this addition the total area of the west field, and of the meadows adjacent to it on the west bank of the Soar, was perhaps about 800 acres. ${ }^{44}$ Bromkinsthorpe seems to have been inclosed piecemeal during the 16 th and 17 th centuries. A late-I6th-century terrier shows strips in the open fields as already partly consolidated, and apparently some inclosure had by then taken place. 45 In 1628 there was still a considerable area of open land, 46 and the fact that at the inclosure of Leicester Forest in the same year holdings in Bromkinsthorpe were described in terms of virgates ${ }^{47}$ suggests that the arable fields were still largely open. When the inclosure was completed cannot be stated, but it was probably not long after 1628 .

Bromkinsthorpe is separated from the area of the old walled borough of Leicester by the River Soar, which until the flood prevention works of the late I 9 th century was here divided into several channels, running through a stretch of marshy ground. ${ }^{48}$ The existence of this natural barrier for long prevented the growth of any substantial suburb in Bromkinsthorpe. At first the only connexion between the walled borough and Bromkinsthorpe was by a rather circuitous route, running from the West Gate to cross the main channel of the Soar over the West Bridge, and then along the Augustine Friars island to Bow Bridge, which crosses a subsidiary channel of the river to link the island with Bromkinsthorpe. The West Bridge is mentioned in 1325 , though it probably already existed in the 12 th century. ${ }^{49}$ Bow Bridge existed by $1520 ;^{50}$ it may have existed earlier, and is traditionally said to have been used by Richard III in $1485 .{ }^{51}$ Braunstone Gate Bridge, which crosses the subsidiary channel of the Soar to the south of Bow

${ }^{39}$ Fielding Johnson, Glimpses of Ancient Leic. 366-7; White, Dir. Leics. (1846), I 40.

40 See above.

4I B.M., Cott. MS. Galba E. 3, f. 109.

42 Ibid., f. I I b ; Leic. Boro. Rec. I 509-I603, 454.

43 B.M., Cott. MS. Galba E 3 , ff. 9, Io; Leic. Boro. Rec. I $327-I 509,425$.

44 Nichols, Leics, iv, 786, 788, 79 I, 793; T.L.A.S. xiv. 6, 9; L. Fox and P. Russell, Leic. Forest, 1 37. There may have been some inclosure already in 1536 , when several closes are mentioned: Nichols, Leics. iv. 566.

45 Leic. Boro. Rec. I 509-I603, 454-5.

${ }^{46}$ Farnham, Leics. Notes, vi. 246.

47 Nichols, Leics. iv. 786 ; there were then said to be $30 \frac{1}{2}$ yardlands in Bromkinsthorpe; cf. the 31 yardlands said to be there in I279: ibid. iv. 565.

48 See above, pp. 277-8.

49 V.C.H. Leics. iii. 86.

50 Farnham, Leics. Notes, vi. 244, where Gerard Danet bequeathes fio for repairing the bridges between his house and the Austin Friars. See also Leland, Itin. ed. Toulmin Smith, i. I6.

${ }^{51}$ Nichols, Leics. i. 301 ; and see below, p. 388 . 
Bridge, and provides a more direct connexion between the southern part of Bromkinsthorpe and the walled borough, appears first on a map drawn about I 600. ${ }^{52}$ Until the 19 th century Bromkinsthorpe, despite its nearness to the town, remained almost entirely rural, and in 1802 the only houses, apart from the two mansions of Danet's Hall and Westcotes, lay along either side of Braunstone Gate, ${ }^{53}$ a road running from Braunstone Gate Bridge to the Narborough road.54 Even in the early I 9 th century Bromkinsthorpe still remained a pleasant country district, where the inhabitants of Leicester could stroll. ${ }^{55}$ The grounds of the two manor houses, Westcotes and Danet's Hall, were improved about this time. ${ }^{56}$ Gradually, however, buildings began to encroach. The first factory to be built in Bromkinsthorpe was a notable structure in the Igth-century Gothic style, the Bow Bridge Mills, which still exists. It is not known when this factory was built, but it already existed in 1828.57 During the first half of the 19 th century buildings encroached only slowly on the agricultural land and by $185^{2}$ the only part of Brom- kinsthorpe that had been built over was a small area immediately to the west of the two bridges over the Soar. ${ }^{8}$ The new streets in this area, built on the alluvium of the river valley, were liable to flooding, and were very inadequately provided with sewers. ${ }^{59}$ It was not until after I 860 that buildings began to spread rapidly in Bromkinsthorpe. Danet's Hall was sold for building in $1861,{ }^{60}$ and three years later the site of the hall and its grounds was already built over. ${ }^{61}$ Many other sales of land for building occurred in $1860-70 .{ }^{62}$ In 1886 the old mansion of Westcotes was demolished, and its grounds built over. ${ }^{63} \mathrm{By}$ about $\mathbf{1 9 0 0}$ the whole eastern half of Bromkinsthorpe, that is, the half that lay nearest to the borough centre, had been laid out in streets. ${ }^{64}$ By 1938 virtually the whole of Bromkinsthorpe had been built up. ${ }^{65}$

Other aspects of the history of Bromkinsthorpe, namely its administrative and ecclesiastical history and the history of the parochial charities in which it shared, have been described above, as they are part of the history of St. Mary's parish as a whole. ${ }^{66}$

\section{ST. NICHOLAS'S}

THE ancient parish of St. Nicholas, 16 acres in area and the smallest of the old borough parishes, lay in the west of the town. The civil parish became merged in the civil parish of Leicester in I 896 . I 'The boundaries of the present ecclesiastical parish, largely those of the ancient parish, were altered owing to the construction of the Great Central Railway at the end of the igth century. From the junction with St. Martin's parish just south of Free School Lane, the boundary of the ancient parish runs south-east through houses to the junction of 'Thornton Lane and Harvey Lane. From there it goes west to reach Applegate Street about half-way to the IVest Bridge. 'The boundary then runs along the line of the river to a point almost due west of the remains of Friars' Causeway. From there it runs to the east along the line of that street to about the top of Great Central Street, then south-east to Blue Boar Lane and south-west to its starting-point. ${ }^{2}$

The main thoroughfare of the parish is St. Nicholas Street, which joins High Street and Applegate

\footnotetext{
52 Leic. Boro. Rec. I509-1603, p. xvii; V.C.H. Leics. iii. 86 .
}

53 [Watts], Walk through Leic., frontispiece map. Braunstone Gate is mentioned in 1555: Farnham, Leics. Notes, vi. 245 .

54 A road roughly following the line of the Roman Fosse Way.

ss [Watts], Walk through Leic. 58.

56 Nichols, Leics. iv. 567, 57 I.

57 'T. and G. Ellis, Plan of Leic. ( 1828$)$

58 i.e. the area enclosed by King Richard's Road, the Soar, Braunstone Gate, Hinckley Road, and Leamington Street: J. S. Crossley and G. Foxon, Rep. on Condition of River Soar (1852) (Leic. City Ref. Libr., Pamphlets $\mathrm{O}_{3}$, vol. ii), frontispiece plan.

59 Crossley and Foxon, op. cit. Io; Wm. Johnston, Diarrhoea of Leic. (1 876) (Leic. City Ref. Libr., Pamphlets O 3, vol. iv), I 2; Griffith, Rep. on Fुuly Floods (I 880) (Leic. City Ref. Libr., Pamphlets $\mathrm{O}_{4}$, vol. ii), 7; Leic. Fnl. I 5 Feb. I 867 , p. 6.

60 J. and T. Spencer, New Guide to Leic. (I888), I I I ; for the house, see J. Throsby, Select Views in Leics. 262-5. 6I John Barclay, Modern Leic. (I 864) (Leic. City Ref. Libr., Pamphlets $\mathrm{O}_{4}$, vol. iii), 4.
Street and leads to the West Bridge. St. Nicholas Street was known in the Middle Ages as Hotgate, from the common ovens of the borough which were in the locality. ${ }^{3}$ Hotgate is first mentioned in 1297 and the name was Latinized as calidus vicus. ${ }^{4}$ In the I 7 th century the old name was still current, although the common ovens ceased to be used, 5 but by the early I 9 th century it had become known as St. Nicholas Street. ${ }^{6}$ Applegate Street still preserves its medieval name, although it was sometimes known in the past as Shambles Lane. ${ }^{7}$ There was a St. Nicholas Shambles at least as early as the end of the I $4^{\text {th }}$ century, when it brought in a yearly rent of $£ 35^{5}$. to the borough. ${ }^{8}$ Although in the 16 th century the Leicester butchers wished to confine their business to the Saturday Shambles, in the Saturday Market Place, their petition about the matter was evidently disregarded. ${ }^{9}$ A new shambles was built in $\mathbf{I} 68 \mathbf{I}_{-2 .} .^{10}$ Throsby refers to the street as Shambles Street, but it seems to have been generally known as Applegate Street at the beginning of the igth century. II

62 Leic. Fnl. 2 Mar. I86o, p. I ; 8 Feb. I867, p. I; I 5 Feb. I 867 , p. I ; 22 Feb. I 867 , p. I.

63 Spencer, New Guide to Leic. (1 888), I I2. Proposals that the house and grounds should be bought by the town for a park or public library were not accepted by the corporation: ibid. I I $2 ;$ T.L.A.S. vi. I 64 ; for the house see Throsby, Select Views, 324-6.

6+ Wright, Dir. Leic. ( 1902 ), frontispiece map.

65 Kelly's Dir. Leic. (1938), frontispiece map.

66 See above, pp. $360-80$.

I.C.H. Leics. iii. 179 n.; Census, I 891 .

2 The boundaries of the ancient parish are marked on T. and G. Ellis, Plan of Leic. (1 828 ), but should be compared with a modern map.

3 C. J. Billson, Medieval Leic. I 2; see also above, p. $4 \mathrm{I}$.

4 Leic. Boro. Rec. IIO3-I327, 358; I327-I509, $202 \mathrm{n}$.

5 Ibid. $1603-88$, 544; see also above, p. 94.

6 [S. Watts], Walk through Leic., frontispiece map.

7 Billson, Medieval Leic. 12-13; Leic. City Mun. Room, I OD $+7 / 4 / \mathrm{I}$ ( 1628).

8 Leic. Boro. Rec. 1327-1509, 163.

9 Ibid. $I 509-1603,452$. 10 Ibid. $I 603-88,55^{8}$.

II J. Throsby, Hist. of Leic. 405; cf. [Watts], Walk through Leic., frontispiece map. 


\section{A HISTORY OF LEICESTERSHIRE}

Blue Boar Lane joins High Cross Street and Great Central Street. It was known in the Middle Ages as Guildhall Lane or Mayor's Hall Lane, from the presence at its western end of the second of Leicester's common halls. ${ }^{12}$ This stood at the southern corner of the street, opposite the east end of St. Nicholas's Church. The borough purchased a building on this site for a common hall in $125 \mathrm{I},{ }^{13}$ and it remained in the possession of the town until at least 1694 , when the old Mayor's Hall still stood. It is not known when the hall was demolished. The present name of the street is derived from the Blue Boar Inn which until demolished in 1836 stood on the south side at the junction with High Cross Street. ${ }^{14}$ 'The 'Blue Boar' was one of the best-known inns in Leicester during the 16 th century, and is traditionally the house in which Richard III passed the night before the battle of Bosworth in $1485 .{ }^{15}$ Jewry Wall Street is named from the Roman remains so called. It is not known when the name originated, but in its more probable form, Jury Wall, it was in use at the end of the 17 th century. ${ }^{16}$ The explanation of the name which was widely accepted in the 18 th century and after, that this area of the town was the Jews' quarter, ${ }^{17}$ seems highly improbable. Of Talbot Lane little remains, as it was largely cut into by the construction of the Great Central Railway in 1899 . It was probably named from a piece of ground called the Talbot, which also gave its name to the 'Talbot Inn, which was probably standing at the end of the 15 th century. ${ }^{18}$ No. Io Talbot Lane dates from the I 8 th century and has an interesting staircase. Jester House, next door, is of the early I gth century. Deadmans Lane and its continuation, later called Sycamore Street, ${ }^{19}$ have now been lost in Great Central Street, which was partly an improvement and widening of existing streets and partly a completely new road cut through, when the railway was built, to connect the former Sycamore Street with St. Nicholas Street. ${ }^{20}$ Its construction necessitated the rebuilding of $\mathrm{St}$. Nicholas's school, and the demolition of houses in Holy Bones. The new school was designed by J. Stockdale Harrison and was opened in I906.21 Vaughan College, next door, was also designed at the same time by the same architect. ${ }^{22}$

Holy Bones, to the east of St. Nicholas's Church, was so named at least from the beginning of the 15 th century, ${ }^{23}$ most probably because it led to the churchyard. During the $\mathbf{1} 8$ th century and earlier large quantities of bones of cattle and other animals were dug up there, and these were assumed to be the remains of sacrifices at the Jewry Wall, then supposed

I2 Billson, Medieval Leic. I 4 .

13 The history of this hall is summarized ibid. 50- 56 . The earlier hall was also in this parish: Billson, Medieval Leic. I 4.

14 Plaque on 78 High Cross Street; Billson, op. cit. I79.

15 See Billson, op. cit. $177^{-99}$. No. 52 Granby Street was built as an exact copy of the 'Blue Boar'.

16 Leic. Boro. Rec. $1603-88,503$.

17 e.g. [Watts], Walk through Leic. 80; for the alternative theory see below, p. 385 .

I 8 Billson, Medieval Leic. I5.

9 Ibid.; cf. [Watts] op. cit., frontispiece map, and Ellis, Map of Leic. ( 1828 ).

20 The new road was built between $c .1898$ and I9oo, when there were already 4 factories there: Kelly's Dir. Leics. and Rut. (I900), I54. By I902 there were many more: C. N. Wright, Dir. Leic. (1902), 52.

${ }^{21}$ T.L.A.S. x. I $4^{-1} 5$.

2242 nd Rep. Leic. and Leics. Soc. of Architects (1914I5), 26 . to be a temple, and to have given the street its name. ${ }^{24}$ It is more likely that they came from the St. Nicholas Shambles. Bath Lane runs north along the river from West Bridge. It was named long before the public baths were built there in 1879 from plans by John Breedon Everard, the city engineer. ${ }^{25}$

St. Nicholas's parish is now mainly a commercial area of factories and warehouses, dominated by the railway. There are some houses, and in Thornton Lane is William Carey's cottage, the home of the Baptist missionary to India, which is now a museum, ${ }^{26}$ and is an excellent example of a working-class home of the type built at the end of the I 8 th century.

In 1563 i 20 families lived in the parish, ${ }^{27}$ but by the beginning of the I8th century there were only $90 .{ }^{28}$ In $\mathrm{I} 80 \mathrm{I}$ the population was 947 . It rose suddenly to $\mathrm{I}, 589$ in $18 \mathrm{I} I$. In $187 \mathrm{I}$ it reached its highest figure, I,925. ${ }^{29}$ In I 93 I the population of the ecclesiastical parish was $1,388^{30}$ and in 1949 it was estimated to have fallen to about $1,000 .{ }^{31}$

CHURCH. St. Nicholas's Church is probably built on the site of the basilica of Roman Leicester, although it is very difficult to say what lies beneath the church, since only the ground under the narrow passage between the church and the Jewry Wall can be excavated. ${ }^{32}$ Any explanation of the foundation and early history of the church must be largely conjectural. It seems very probable that the large early Saxon church which stood on this site was the minster or cathedral of the Saxon see of Leicester. The evidence of the fabric itself does not contradict the possibility that the building of the church coincides with the creation of the see. The first recorded bishop, Cuthwine, is known to have been in office from 679 , although the see itself was not permanently established until 737.33

The church was probably not dedicated to St. Nicholas originally, that dedication only having been adopted about $1220 .{ }^{34}$ References to two churches or chapels of St. Augustine and St. Columba, which have received a good deal of comment by historians of Leicester, ${ }^{35}$ have their origin in the Novum Rentale of Leicester Abbey made by Prior William Charyte at the end of the I 5 th century. Writing of the parish church of Cosby he states: 'Ecclesia de Cosby pertinuit ad ecclesiam sancti Augustini Leycestrie que quidem ecclesia sancti Augustini sita fuerat ad orientalem partem cancelle ecclesie sancti Nicholai Leycestrie. Et erat ipsa ecclesia constructa sub duabus tectis conjunctis super medias columpnas cuius una pars erat dedicata sancto Augustino et alla [sic] pars

23 Leic. Boro. Rec. I327-I509, 245.

24 See Magna Brit. et Hibernia (1 720), ii. I $35^{8}$, which seems to be the earliest ref. for the discovery of such bones. ${ }_{25}$ Cf. Ellis, Map of Leic. (1828), and J. Storey, Hist. Sketch of Boro. of Leic. 70-73.

26 See below, p. 391

27 B.M. Harl. MS. 6 I 8.

28 Assoc. Archit. Soc. Rep. छீ Papers, xxii. 299.

29 V.C.H. Leics. iii. I 80.

30 Census, r931. 35 .

E. C. G. Weeks, Hist. of St. Nicholas' Par. Ch. Leic.

32 K. M. Kenyon, Excavations at the Fewry Wall Site, Leic. (Rep. of Research Cttee. of Soc. of Antiquaries, no. xv), 4 .

${ }_{33}$ F. M. Stenton, Anglo-Saxon Eng. (2nd ed. I 947), 42;

Handbk. of Brit. Chronology, ed. F. M. Powicke, I 52.

34 Leic. Boro. Rec. IIO3-I327, 25.

35 Nichols, Leics. i. 328 and n.; Throsby, Hist. of Leic. 279-8o. 
Sancte Columbe. ${ }^{36}$ Charyte's evidence for this circumstantial statement is not known. It is possible that the original dedication of the church was to St. Augustine and that it had a chapel dedicated to St. Columba. It has always been assumed that the two supposed churches or chapels of St. Augustine and St. Columba were destroyed shortly after the Norman Conquest, but just as the Jewry Wall stood ruined at the west end of the church, so another ruin at the east end ${ }^{37}$ might explain the reference to St. Augustine and is that 'coumecherchiam' is a contraction of 'communiam serchiam', the duty of aiding the sheriff in finding strayed or stolen cattle, for which the burgesses would clearly have had to go out of the town. ${ }^{39}$

Whatever the truth of its very early history, it seems certain that the church of St. Nicholas, under its old dedication, was given to the college of St. Mary de Castro in IIO7 and passed to Leicester Abbey on its foundation in I I 43.40 The abbey had appropriated it before $1220^{41}$ and retained possession

\section{CHURCH of ST. NICHOLAS, LEICESTER}

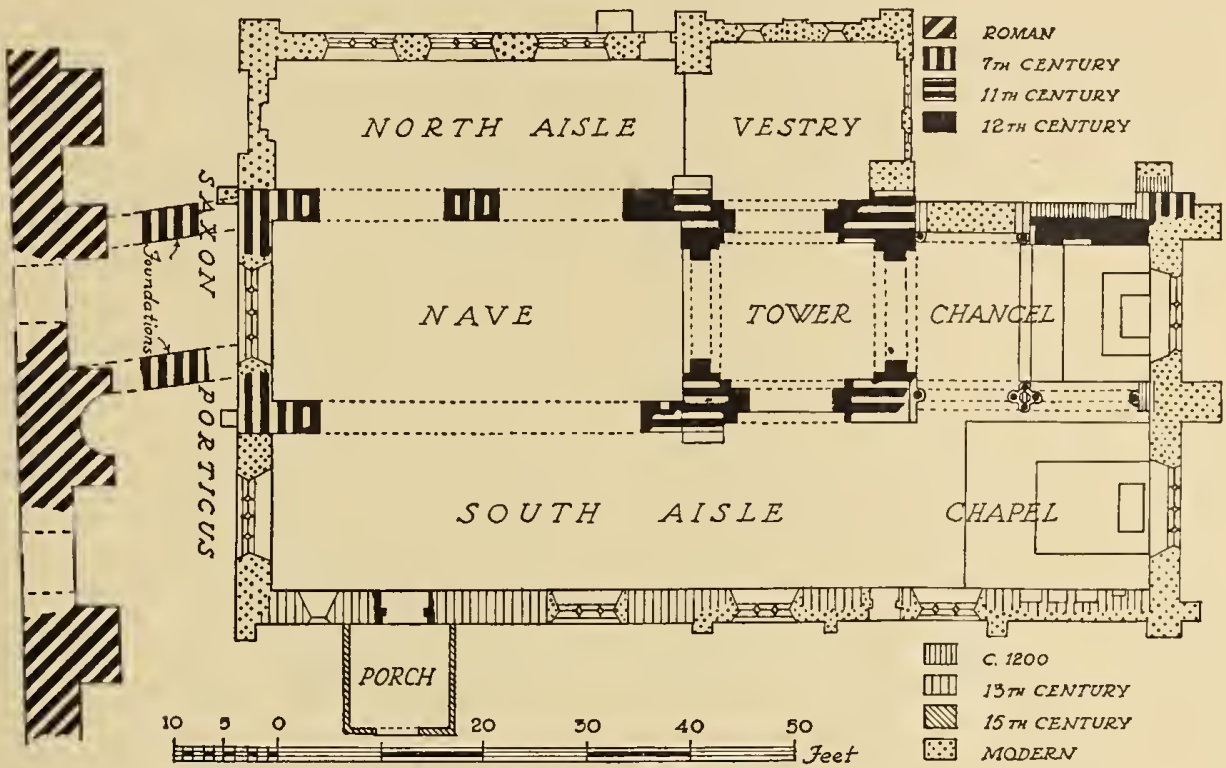

St. Columba's as a distinct building. It is also possible that the half-remembered change in the dedication of St. Nicholas's Church might have led Charyte or some earlier writer to assume that St. Augustine's Church was separate from that of St. Nicholas.

It has been suggested that St. Nicholas's Church, or churchyard, was the meeting-place of the jurats of the borough, who left their name as a result to the Jewry (or Jury) Wall. This theory was based upon an explanation offered by Mary Bateson of a passage in the charter of Robert, Earl of Leicester of the midI 2 th century, which freed the burgesses from pleading outside the town. The relevant passage runs 'neither for pleading nor for any other custom shall they go out of Leicester, except (tantummodo) ad coumecherchiam as was anciently established'. Miss Bateson suggested that 'coumecherchiam' was a corruption of 'communiam cherchiam', and by translating 'tantummodo' as 'only', she suggested that the passage meant that the burgesses should only plead at meetings in their own common churchyard. ${ }^{38} \mathrm{~A}$ more recent suggestion for the meaning of this passage

${ }^{36}$ Bodl. Libr, MS. Laud 625, f. $53 v$.

37 That there were ruins in what is now Holy Bones is clear from Magna Brit. et Hibernia, ii. 1358.

${ }^{38}$ Leic. Boro. Rec. IIO 3-I 327, 4.

39 Mr. R. E. Latham's suggestion.

40 V.C.H. Leics. ii. $\mathrm{I}_{3}, 45$.

$4 \mathrm{I}$ Rot. Hugonis de Welles, ed. W. P. W. Phillimore, i. 238.

${ }_{42}$ For a list of vicars presented by the abbey see A.

Hamilton Thompson, Leic. Abbey, I68-70.

43 Weeks, St. Nicholas' Par. Ch. $4 \mathrm{r}$.

${ }^{4}$ Leic. Dioc. Cal. (1954), 91. of it until the Dissolution, ${ }^{42}$ when the advowson passed to the Crown. The Crown continued to present until 1867 when the advowson was granted to the Bishop of Peterborough. 43 The Bishop of Leicester was patron in $1955^{.44}$

In $\mathrm{I}_{5} \mathrm{I}^{-2}-2$ it was proposed to unite the benefices of St. Nicholas and St. Mary, but this scheme came to nothing. ${ }^{45}$ In 1938 the church was deprived of its vicarage. Until 1948 it was served by a curate from St. Martin's, but the vicarage was then restored. ${ }^{46}$ During the Middle Ages the vicars received a pension of 6 marks from Leicester Abbey. ${ }^{47}$ Before its appropriation the vicarage had been worth Io marks. ${ }^{48}$ Two grants from Queen Anne's Bounty were made in I 7 I 4 and I 800 and two parliamentary grants in I8I3 and 1824 , but in spite of these augmentations the vicarage was worth only $£, 35$ in I 831 . 49 'The stipend was again increased in 1885.50

Little is known about the tithes of the parish after the Dissolution, except that in 1626 the corporation paid tithe to the vicar for the ground on which the pest-house stood. ${ }^{51}$ In 1853 these tithes, then amount-

45 Leic. Boro. Rec. I603-88, 40I-2, 404. The two parishes had been held together in 1603 ; Assoc. Archit. Soc. Rep. छ Papers, xxix. I 5 I. In the 18 th cent. St. Nicholas's was often held with St. Martin's: Nichols, Leics. i. 608.

46 Weeks, St. Nicholas' Par. Ch. 26-27.

47 Bodl. Libr., MS. Laud 625, f. 92 v.; Leic. Boro. Rec. I $509-I 603,37$.

${ }_{48} \mathrm{Val}$. of Norw. ed. W. E. Lunt, 530.

49 White, Dir. Leics. (1846), 90.

so Leic. City Mun. Room, $23 \mathrm{D}_{52 / 26 / 2}$.

51 Leic. Boro. Rec. $1603-88,235$. 


\section{A HISTORY OF LEICESTERSHIRE}

ing to $f_{2} 2 s .6 d$. yearly, were redeemed for a lump sum of $f_{55} .^{.52}$

The church of $S T$. NICHOLAS ${ }^{53}$ consists of nave and chancel, north and south aisles, and central tower. It is built immediately to the east of the site of the Roman forum, 12 feet separating the west end of the church from the Jewry Wall, and considerable use was made in building the church of the Roman material so close at hand.

The pre-Conquest remains of the church are the north and west walls of the nave and the wall above the Igth-century arch of the south nave arcade. Quoins of green sandstone of this early period survive at the south-west corner of the nave and at the base of the disused north-east angle of the chancel, which was the north-east corner of the early church. The ends of the middle pier of the north nave arcade are formed of large blocks of the same material. Above the north nave arcade are two small windows, the arches on both faces of the wall turned with two rows of Roman bricks. At the present time these windows are double-splayed but examination has shown that in both cases the inner ring of bricks on the outer side has been cut back and that the windows had originally only a single splay. These windows and the wall in which they are set date possibly from the 7 th century and certainly from before the Danish invasions. This early church extended for the whole length of the present nave and chancel (the northeast angle has been mentioned above), and it seems likely that the Jewry Wall formed the western wall of the porticus, which, as at Brixworth (Northants.), was probably continuous round the nave; the nave was probably entered through arches in the side walls. Traces of rough foundation walls between the west end of the church and the Jewry Wall were discovered at the excavation of that site. This western porticus may have been designed for the instruction of catechumens. 54

The second stage in the building took place in the last part of the IIth century, when building was carried out in brown sandstone, dressed with axes. At this time a central tower seems to have been built in stone to a height just above the roof line, and then probably completed in timber. The herring-bone arrangement of Roman tiles at the base of the tower dates from this time. A blocked opening in the north nave wall possibly led to a stair, and there may have been transepts to this church.

In the 12th century the tower was completed in grey limestone to its present height, two stories above and two below the roof line. The present arcade was cut in the north nave wall, and a similar arcade was probably cut in the south wall. That on the north (the only one surviving) is of two bays, the arches springing from the old central pier, which was redressed and chamfered. The wide blocked arch in the west wall and the south doorway with its simple hood and abaci with nail-head ornament are of

\section{Leic. City Mun. Room, 23 $552 / 23$.}

${ }^{33}$ For the church, see Arch. Fnl. cxii. 161-3. For a recent photograph of the church see above, plate facing p. $35 \mathrm{I}$.

${ }_{54}$ For Brixworth, see Arch. Fnl. cx, 202-5; Kenyon, fewry Wall, 8, 37. The Jewry Wall has always been held to belong to the ch.: Weeks, St. Nicholas' Par. Ch. 29.

55 Weeks, op. cit. 39

56 Throsby, Hist. of Leic. 232; Leic. City Mun. Room, ${ }_{1} \mathrm{D}_{47} \mathrm{I} / 4 / \mathrm{XXVIII} / 57$.

57 Nichols, Leics. i. 608. the same date, probably the first half of the century.

The chancel of the I2th-century church was narrower than the nave and its walls were pierced, probably for chapels, early in the I 3 th century. The south arcade still survives and is of two bays with pointed arches. That on the north is of one bay and is now blocked up. There seems to have been a sacristy farther east on the north side, where a piscina remains in the outer wall. The south aisle, which runs the full length of the church, was added about 1300 . The broach spire, which was demolished partly in 1805 and partly a short while later, ${ }^{55}$ was probably added in the late $I 3^{\text {th }}$ or early I 4 th century. The clerestory was built in the I 4 th or I $5^{\text {th }}$ century, when the nave walls were raised. The line of the original roof can be seen above the chancel arch. The timber-framed south porch was added in the 16 th century. In 1697 the north aisle was demolished as it was dangerous, ${ }^{56}$ and the north arcade was blocked. It is not known exactly when the aisle had been built. At the beginning of the last century the chancel was in use as a vestry and the altar was in the south aisle. 57 In I 825 a proposal was made to demolish the whole structure as it was held to be in an extremely dangerous condition. ${ }^{88}$ Owing to the poverty of the parish, however, no funds could be raised for the proposed rebuilding, and nothing was done. Extensive alterations took place a few years later, when the south nave arcade was taken down and replaced by a large brick arch which spans the whole of the former arcade. The architect of this restoration and alteration was an otherwise unknown Mr. Mortin. The corporation subscribed two sums of $\oint_{\mathrm{r}} \mathrm{oo}$ each towards the work. ${ }^{59}$ The church was reseated at the same time. Restorations were again carried out in I 873-6, when F. W. Ordish rebuilt the old north aisle $; 60$ this was not carried to the length of the south aisle, and its east wall ends on a level with the eastern pillars of the tower. The wall is roughly filled with rubble masonry. This new aisle is wider than the former one. At the same time the porch was renewed, the interior walls freed from plaster, the window mouldings renewed and various other replacements were made. A new pulpit was made to Ordish's design, based on one in northern Italy. The church was again restored in $1904-5$, when Charles Baker was responsible for securing the tower with steel supports and for restoring the outside of the tower, clerestory and north aisle. ${ }^{6 r}$ Further restorations took place in $1949 .{ }^{62}$ Nearly all the outer walls of the church show considerable signs of these various restorations, and most of the windows are modern.

There is an I8th-century sundial of Swithland slate on the south wall. The south aisle contains a mutilated piscina and triple sedilia. In 1929 this aisle was dedicated as a memorial chapel to Canon Edward Atkins. ${ }^{63}$

The font stands at the west end of the south aisle,

${ }_{58}$ On this see Weeks, op. cit. $15^{-17} ;$ Leic. Fnl. I I Nov. 1925 .

59 Leic. City Mun. Room, Hall. Bk. 2I Mar. I828, 27 Aug. I829.

60 Weeks, St. Nicholas' Par. Ch. 17-18; Leic. City Mun. Room, ${ }_{23} \mathrm{D}_{52} / 20$. The niche in the west wall on the north aisle came from the old Wyggeston's Hosp. chapel: Weeks, op. cit. 18-19.

61 Weeks, op. cit. 19-20.

62 Ibid. 20.

63 Ibid. 2 I. 
and dates from the last century. ${ }^{64}$ It is a square block of sandstone, with a scooped basin, supported on a single alabaster column. The old plate consists of a silver paten of 1706 , a cup of 1714 and a cup and flagon of 1736 . There are also three 18 th-century pewter plates and some I9th-century silver. ${ }^{65}$ The organ was installed in 1890.66 There are three bells, all by unknown bell-founders, but cast in 1617,1656 , and 1710. Only that cast in 1710 is now used. ${ }^{67}$ The registers date from $I_{5} 60$ and the churchwardens' accounts from $176 r$.

The churchyard was closed for burials in 1856 . Part of it was taken for street-widening in 1898.68

CHARITIES. Francis Palmer gave at an unknown date an annuity of Ios., charged upon a house in Jewry Wall Street, to be distributed among the poor. In 1837 the money was being distributed by the corporation. ${ }^{69}$ Sir William Wilson of Sutton Coldfield (Warws.) left, by will proved in I7 Io, a yearly sum of $£$ io from property at Sutton to be used for the apprenticing of poor children from the parish. The bequest was to take effect from 1792 ; in 1837 the children were being apprenticed mostly to framework-knitters. ${ }^{70}$ Mrs. Elizabeth Clarke left $f_{50}$ "by will in I 780 ' in trust for the poor. The parish added f5. The stock was apparently sold in I80 I to defray a debt of $\AA_{13}$ o for building at the workhouse. ${ }^{71}$ By will dated $\mathrm{r} 82 \mathrm{I}$ Thomas Read left $£_{50}$ in trust for bread for the poor on St. Thomas's Day. The interest was added to money received from the corporation and a substantial distribution of bread used to be made. ${ }^{72}$ One other charity, Smart's Charity for bread, was lost before $1837 .^{73}$ One-half of the John Norrice Charity is payable to the vicar by the Trustees of the Leicester General Charities. The corporation pay sums to the parish under the Courteen and Ive charities, which also receives a share of the Heyrick Charity for bread from the Trustees of the Leicester General Charities. ${ }^{74}$

\section{WHITE FRIARS}

THE extra-parochial liberty of the White Friars occupied the northern part of an island between two branches of the Soar. The southern boundary of the liberty was marked by Bridge Street, which ran across the island from the West Bridge, to a road called Duns Lane, near the island's eastern bank. The greater part of White Friars is now occupied by a railway marshalling yard. The area of the liberty was approximately I 5 acres. ${ }^{1}$

In the Middle Ages White Friars was occupied by a house of Augustinian Hermits, ${ }^{2}$ and it was no doubt from having been the site of a religious house that the area derived its status as an extra-parochial area for ecclesiastical and civil purposes. The Augustinian friary, while it existed, presumably stood virtually outside the normal parish organization. Whether during the Middle Ages White Friars was considered to be within the borough seems uncertain ; in 1306 the friars' church was outside the borough, but it is evident from the borders of the town wards as described in 1484 that part at least of the island on which White Friars stood was within the borough boundary. ${ }^{3}$ During the litigation over the borough's boundaries in the I8th century it never seems to

64 Weeks, op. cit. I 8.

65 Ibid. $42-45$.

66 Ibid. $47-48$.

67 Ibid. $5 \mathrm{I}$.

68 Ibid. 32: see also Leic. Mercury, I May 1940.

${ }_{69} 32 n d$ Rep. Com. Char. Pt. 5 [163], p. I I6, H.C. (I 839 ), $\mathrm{xv}$.

70 Ibid.

71 Ibid. I 6 -I 7

72 Ibid. I 7

73 Ibid.

74 See below, pp. 4I I, 4 I 3.

I This figure is an estimate, based on T. and G. Ellis, Plan of Leic. $(1828)$.

2 On the site of the friary, see Leland, Itin. ed. Toulmin Smith, i. I6. The term 'White Friars' was usually applied to the Carmelites, who never possessed a house in Leicester.

3 Leic. Boro. Rec. I327-I 509, 307; I 509-I603, 88-89; IIO3-I 327, 37I.

$45 \& 6$ Wm. IV, c. 76.

5 Rep. Com. on Boundaries and Wards of Certain Boros. Pt. 2, H.C. 238 (1 837 ), xxvii. have been disputed that White Friars lay within the borough, and the boundaries as established under the Municipal Corporations Reform Act 4 of 1835 included it in the borough. 5 In the igth century White Friars was usually described as an extraparochial place, 6 and from 1836 onwards it was certainly a distinct unit for poor relief purposes. ${ }^{7}$ White Friars ceased to exist as a unit for civil purposes in 1896.8

Little is known of the friary's buildings; they included a cruciform church of some size. ${ }^{9}$ The friary was surrendered to the king in $1538,{ }^{10}$ and granted in $\mathrm{I} 545$ to two speculators, John Bellowe and John Broxholme; ${ }^{11}$ in 1597 the property was in the hands of Robert Temple, who sold it in that year to Robert Heyrick, a Leicester ironmonger. ${ }^{12}$ About I 8 I 5 the owner was Joseph Craddock of Gumley. ${ }^{13}$ In 1830 the liberty was the site of a factory for the manufacture of braces; the owner, a Mr. Kelly, lived in a house adjoining. ${ }^{14}$ Shortly after that date most of the land was acquired by the Leicester and Swannington Railway, which established the Leicester terminus of the line there, and almost the whole of the White Friars was occupied by railway sidings and coal

6 Ibid.; Curtis, Topog. Hist. Leics. I00; it is returned as extra-parochial in the census reports up to $189 \mathrm{I}$ inclusive: V.C.H. Leics. iii. 179.

7 White Friars is not listed as a place maintaining its own poor in 1776 , or in $1788_{3}-5$, in the returns for the whole country printed in Rep. Sel. Cttee. appointed to consider Returns Made by Overseers of Poor, Rep. of H.C. (I st Ser.), ix, pp. 385,619 . In the returns relating to poor relief made for the whole country in 1803 the liberty of the Friars at Leic. is mentioned, but this was probably the larger liber ty of the Black Friars: Abstract of Returns Relative to the Ex. pense and Maintenance of the Poor, H.C. I75, p. 262 (I8034), xiii. When Leic. Poor Law Union was formed in 1836 White Friars was not included in it, perhaps in error, and the liberty remained outside the union until 1862: ste above, p. 257 .

8 See above, p. 288

9 Leland, Itin. i. 16.

10 V.C.H. Leics. ii. 35.

II L. छ P. Hen. VIII, xx(I), p. 656

12 Nichols, Leics. i. 301

13 Ibid. 302 .

14 Curtis, Topog. Hist. Leics. 103. 


\section{A HISTORY OF LEICESTERSHIRE}

merchants' offices and warehouses. ${ }^{15}$ British Railways were in 1956 the chief landowners in White Friars.

Bow Bridge joins IVhite Friars to the west bank of the Soar. This bridge is first mentioned in about I 600 , but probably existed already in the I 4 th century. ${ }^{16}$ Until the I9th century Bow Bridge was a stone structure of five arches. ${ }^{17}$ In 1863 the old bridge was demolished, and replaced by the existing iron one. ${ }^{18}$ Until I79I the river was crossed near to Bow Bridge by a footbridge, made up of a single gently curving arch. It is possible that it was the footbridge, from its shape, which was originally known as Bow Bridge. It was swept away by flood water in I79I, and never rebuilt. ${ }^{19}$ The courses of the two branches of the Soar which enclose White Friars were considerably altered by flood prevention schemes executed in the late igth century. ${ }^{20}$

For ecclesiastical purposes White Friars seems to have been regarded as part of St. Nicholas's parish by I $846.2 \mathrm{I}$

\section{LOST CHURCHES}

OF Leicester's medieval parishes, those of St. Peter, St. Clement and St. Michael, with their churches, had ceased to exist before 1600 , and have never been revived. The history of these churches is briefly treated in the following sections.

\section{ST. PETER'S}

St. Peter's Church stood at the corner of West Bond Street and St. Peter's Lane, ${ }^{\mathrm{I}}$ and may have been in existence before I 066 , although it is not mentioned by name until about $1200 .^{2}$ It is probable that like other churches in Leicester St. Peter's was given to the college of St. Mary de Castro in IIO7, and passed into the possession of Leicester Abbey in I $43 .^{3}$ The church had been appropriated to the abbey by $1220,{ }^{4}$ and a vicarage was ordained before I 226.5 For the rest of the Middle Ages the rectory of St. Peter's belonged to Leicester Abbey, ${ }^{6}$ and at the Dissolution it passed to the Crown. The dedication of the church was changed in 1443 , but no details of the change can be discovered, and the church continued to be known as St. Peter's. 7 In I 535 the vicarage was estimated to be worth $f_{2} 5$. yearly. ${ }^{8}$ In I $5^{6} 3$ the building was leased to Leicester Corporation, ${ }^{9}$ and was adapted as a school. ${ }^{10}$ The church had apparently begun to decay a considerable time before this, and was no longer used for ecclesiastical purposes. By I 563 there were only 27 families living in the parish.1 The annual value of the living was in I $56 \mathrm{I}$ again reckoned at $f_{2} 25^{s}$., with an additionai $4 s$. $6 d$. from tithes. ${ }^{12}$ In ${ }_{5} 6_{3}$ the bells were being listed, and in the following year one was sold to

I5 T.L.A.S. xxx. 64, 78; White, Dir. Leics. (1846), I 78 9 ; V.C.H. Leics. iii. 112.

${ }_{16}$ V.C.H. Leics. iii. 86

18 V.C.H. Leics. iii. 86

19 Nichols, Leics. i. 30 I-2.

20 See above, pp. 277-8.

21 White, Dir. Leics. (1846), 50; cf. ibid. (1877), 305.

White Friars is erroneously stated to be part of St. Mary's ecclesiastical parish in Census, $187 \mathrm{I}$ and $188 \mathrm{I}$.

1 P. Hepworth, 'All Saints', Leic.', T.L.A.S. xxvi. 96. In 1892 part of the church was unearthed during building operations.

2 Leic. Boro. Rec. IIO3-I327, го.

3 V.C.H. Leics. ii. 45.

${ }^{4}$ Rot. Hugonis de Welles, ed. W. P. W. Phillimore, i. 238.

5 Ibid. ii. 302

6 See A. Hamilton Thompson, Leic. Abbey, I 70-2, for a list of vicars presented by the abbey.

7 Assoc. Archit. Soc. Rep. छீ Papers, xxi. 300

8 Valor Eccl. (Rec. Com.), iv. I 48.

- C. J. Billson, Medieval Leic. 73-74. raise money for the repair of the school building. ${ }^{\mathrm{I} 3}$ But the fabric was too far decayed to stand up to continual repair, and in 1573 the queen sold the church fabric to the corporation for $f 35$, for the building of a 'substauncyall scoole howse meet and fitt for childarne to bee taught in'. ${ }^{14}$ In I 59I, after some dispute, the parish was united with that of All Saints. ${ }^{15}$ By ${ }_{16} 64$ the churchyard was a cabbage patch. ${ }^{16}$ The exact extent of St. Peter's parish is not known. Its topography is dealt with under All Saints'.

\section{ST. CLEMENT'S}

It is probable that the advowson of St. Clement's, like those of other churches in Leicester, was given by Robert de Beaumont to the college of St. Mary de Castro in I I07, and transferred to Leicester Abbey in $1143 .{ }^{17}$ In 1220 St. Clement's is recorded as being one of the churches in Leicester which belonged to the abbey, but the church, which was apparently already appropriated, then scarcely sufficed to support a priest. ${ }^{18}$ In $122 \mathrm{I}-2$ a vicarage was established at St. Clement's, the vicar being allowed a yearly stipend of $20 s$. and a corrody at Leicester Abbey, besides a corrody for his clerk. ${ }^{19}$ The only later mention of the church occurs in I33 I, when Philip Danet received a royal licence to give lands to the hospital of St. Leonard at Leicester so that the hospital might find a chaplain to perform the divine offices in St. Clement's Church. ${ }^{20}$ Nichols quotes a deed referring to a St. Clement's Lane which ran towards Black Friars from near All Saints' Church, and on which he supposed that St. Clement's lay. ${ }^{2 \pi}$

10 M. C. Cross, Free Grammar School of Leic. Io.

I B.M. Harl. MS. 6 I 8.

12 Leic. Boro. Rec. I509-I603, Ioo.

13 Ibid. I07, I I0-1 I; V.C.H. Leics. iii. 48. The churchyard had already been leased: T. North, Chron. of Ch. of St. Martin, 167 .

I4 Leic. Boro. Rec. I509-1603, 139-40. Demolition of the building had begun as early as 157 I when it was ordered that the timber from the church should be taken down and kept in safety with the lead: ibid. I33. In I 572, however, the corporation paid $5 s .6 d$. for 'watchinge of the leade certen nights at St. Peter's churche': ibid. 146. For the school, see p. 332 .

15 Ibid. $27 \mathrm{I}$

16 Assoc. Archit: Soc. Rep. E Papers, xxix. 518.

I7 V.C.H. Leics. ii. 45 .

18 Rot. Hugonis de Welles, i. 238.

19 Ibid ii 286; Hamilton Thompson, Leic. Abbey, 160.

20 Nichols, Leics. i. 295; V.C.H. Leics. ii. 34; Cal. Pat. I $330-34$, I 56 .

2I Nichols, op. cit. i. 295 ; Billson, Medieval Leic. 70-7 I ; see also J. Throsby, Hist. of Leic. 234. 


\section{THE CITY OF LEICESTER}

He advanced the theory that the church was given to the Dominicans, ${ }^{22}$ but there is no direct evidence of this, and such a development would certainly have been unusual, though perhaps not unknown elsewhere. ${ }^{23}$ St. Clement's had disappeared by $1526 .{ }^{24}$

\section{ST. MICHAEL'S}

The church of St. Michael was situated near the west gate of the borough, probably near the corner of the present Vauxhall Street and Causeway Lane. It is probable that the advowson of St. Michael's, like that of other churches in Leicester, was given to the college of St. Mary de Castro in II07, and subsequently, in I I 43 , to Leicester Abbey. ${ }^{25}$ The abbey certainly possessed the advowson by about $1220,{ }^{26}$ and retained it as long as the church continued to exist. ${ }^{27}$ Little information exists about the church; it had a priest and another cleric in $1200,{ }^{28}$ but about I220 it was said to be so poor that it was scarcely able to support a priest at all. ${ }^{29}$ It is not clear whether the church had been appropriated by 1220 or not..$^{30}$ Probably it had, for in I22I-2 a vicarage was established on the same terms as that at St. Clement's. ${ }^{31}$

By the end of the 15 th century St. Michael's had become very poor. There was no vicar in 1487,32 and the church was probably disused by about 1500 . It is not mentioned in the records of the episcopal visitation of Leicester made in $\mathbf{I}_{5} \mathbf{I} \mathbf{O}^{33}$ The parish seems to have been united with that of St. Peter's. ${ }^{34}$ The churchyard was sold to William Dethick, the town clerk, in $1592 .{ }^{35}$ In spite of the disappearance of the church mention was made as late as the early I 7 th century of St. Michael's parish. ${ }^{36}$ A guild was attached to the church during the $14^{\text {th }}$ century, but apart from two bequests made to it during that century nothing is known about it. ${ }^{37}$

\section{ROMAN CATHOLICISM}

THE very small Roman Catholic congregation at Leicester in the early $\mathbf{I}$ th century was probably served by a Franciscan priest from the Byerley family's chapel at Belgrave Hall. ${ }^{1}$ Until the establishment of the priory of Holy Cross in 1817 , there were very few Roman Catholics in the town. Only four members of the church were reported to be living in the town at the end of the I 7 th century, though it seems probable that the figures for the late I 8 th century ( 24 in 1767 and 37 in 1780 ) are not very reliable. ${ }^{2}$

The Dominican mission in Leicester has an almost unbroken record from $\mathrm{I} 777$, when the first mass centre was established in Causeway Lane. ${ }^{3}$ It seems likely that no regular services were held there until I 785 , and the chapel was abandoned periodically as the main centre of the Dominican mission for the county was still at Hinckley, and no resident priest was available for the borough itself. 4

In I798, under Father Francis Xavier Chappell O.P., the first permanent chapel, dedicated to St. Michael, was established on the upper floor of a building in an entry off Causeway Lane. 5 Consider-

22 Nichols, op. cit. i. 295 ; Billson, op. cit. 70-71.

23 W. A. Hinnebusch, Early Eng. Friars Preachers, $133 \mathrm{n}$. In nearly all the cases cited, however, the evidence is not strong: see V.C.H. Leics. ii. 34

24 It is not included in the churches of the deanery of Christianity at Leicester in 1526: $A$ Subsidy Collected in the Dioc. of Linc. in I 526 , ed. H. E. Salter, I I3 $\rightarrow$ I 4. St. Clement's is also omitted from the 1535 Valor: Valor Eccl. (Rec. Com.), iv. 148.

${ }_{25}$ V.C.H. Leics. ii. 45; Hamilton Thompson, Leic. Abbey, 168. On the site of the church, see Billson, Medieval Leic. 76-78.

${ }_{26}$ Rot. Hugonis de Welles, i. 238.

27 Hamilton Thompson, Leic. Abbey, I68, lists the incumbents known to have been presented by the abbey.

28 Leic. Boro. Rec. IIO3-I 327, 9.

29 Rot. Hugonis de Welles, i. 238. 30 Ibid.

3 Ibid. ii. 285-6; and see above, p. 388 .

32 Nichols, Leics. i. 347.

33 Assoc. Archit. Soc. Rep. E Papers, xxi. I09-12. St. Michael's is also not mentioned in the subsidy of 1526: A Subsidy Collected in the Dioc. of Linc. in 1526 , ed. Salter, I 13-I4; or in the Valor of I 535: Valor Eccl. (Rec. Com.), iv. 148 . able secrecy was always preserved about its exact whereabouts. Services were held there until I $850 .{ }^{6}$ The building remained in existence until 1939, as part of a factory. Early in the I9th century masses were said in a warehouse belonging to Richard Raby, a prominent Leicester Roman Catholic, near the old Vauxhall gardens; it seems that the Causeway Lane chapel had become too small to house the growing Roman Catholic population which sprang up probably as the result of the establishment of the permanent chapel.7

In I $_{1}$ I $_{5}$ Father Benedict Caestryck O.P. came to Leicester as head of the Dominican mission and during his period of office the first church of Holy Cross was built. The land was given by Richard Raby, and lay between New Walk and Wellington Street. The red brick church was begun in 1817 to the designs of Joseph Ireland. ${ }^{8}$ It was very small, having neither chancel nor Lady chapel, and no priory buildings were erected until 1824 , when Father Caestryck built a house for the priest to the south-east.9 The chancel and Lady chapel were built in 1848 . In $186 \mathrm{I}$ the quadrangle formed by the

34 Billson, Medieval Leic. 77-78; Leic. Boro. Rec. I $509-I 603,277$.

35 Leic. Boro. Rec. I 509-1603, 277. This seems to have been identifiable in $179 \mathrm{I}: \mathrm{J}$. Throsby, Hist. of Leic. 2.40.

36 Nichols, Leics. i. 327.

37 Leic. Boro. Rec. I 327-I 509, 339; T.L.A.S. xiv. I53; ibid. xxvi. 95.

I V.C.H. Leics. ii. 6I-62. 2 Ibid. 69.

3 Ibid. 62.

4 On the early history of Roman Catholicism in Leic. see also A. H. Kimberlin, Return of Catholicism to Leic. $I 746-1946$ (I946, priv. print. Hinckley), from which much material in this account is taken.

5 Kimberlin, op. cit. I6.

6 Ibid. 19; the chapel in Causeway Lane is not mentioned in the early directories of Leic. and is not marked on Spencer's map of 1867 .

${ }_{7}$ There were over 400 Roman Catholics in 1829: L.R.O., Return of Places of Worship, I 829; Kimberlin, op. cit. 17 .

8 Kimberlin, op. cit. 17-18; H. M. Colvin, Biog. Dict. Eng. Architects, 308.

9 Kimberlin, Return of Catholicism, I9. 


\section{A HISTORY OF LEICESTERSHIRE}

church and the priory buildings was completed in its present form. ${ }^{\text {Io }}$

The present church of Holy Cross was begun on a site slightly to the north of the old church in 1928

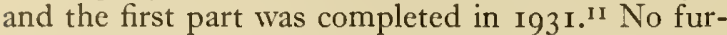
ther building has since taken place and the church now (I955) consists of choir, Lady chapel, and transepts. The old church is now known as Blackfriars Hall. The architects of the new church, which was completed while Father Fabian Dix O.P. was prior, were Arthur Young and Allan D. Reid of London. Holy Cross School was established in $1824 .{ }^{\text {I2 }}$

Many of the other churches in and near Leicester owe their foundation to the Dominican community. The first to be built was St. Patrick's, Royal East Street, which served a large settlement of Irish immigrants who had come to Leicester during the famine. ${ }^{13}$ It was established as a school-chapel in I 854 by Father Thomas Nickolds O.P. for the infants' school which had been opened in Belgrave Gate in $1824 .{ }^{14}$ The parish of St. Patrick was created in 1873 , when a new church was built. ${ }^{15}$ In 1940 the church was closed; the new parish church was the former chapel of ease of Our Lady at Belgrave. ${ }^{16}$
The church of the Sacred Heart in Mere Road was established in $\mathrm{I} 882$ by a missioner sent by the Roman Catholic Bishop of Nottingham. Before the church was built, services took place in the school, which was built in I884. The temporary church was built in I 890 , and the present building in I 924 . The school has been staffed since 1934 by the Sisters of St. Joseph of Peace, Newark, whose convent is also in Mere Road. ${ }^{17}$

On the west side of the city is the church of St. Peter, on the corner of Leamington Street and King Richard's Road. The present church was begun in I 905 and completed with the building of the north aisle in I9I8-I9. The mission had been established in 1896 and had had various homes, the last in Noble Street. The parish hall next to the church was built in $1935-7 .{ }^{18}$

The Dane Hills Home for Incurables is in the parish of St. Peter and was opened in 19o6. It is run by Dominican nuns, who first came to Leicester in I 875 to teach in the St. Patrick's and Holy Cross schools and later at the Sacred Heart School.19

St. Theresa's Convent of the Daughters of Divine Charity, in Fosse Road North, was opened in $1949 .^{20}$

\section{PROTESTANT NONCONFORMITY}

LEICESTER has been a flourishing centre of nonconformity since the $I 7^{\text {th }}$ century, although the origins of dissent in the borough are hard to trace. Public opinion in the town during the Civil War was very largely parliamentarian and puritan, ${ }^{\mathbf{I}}$ and it is clear that when George Fox paid his first visit to Leicester in 1648 he found a very considerable body of supporters. ${ }^{2}$ On that occasion he took part in a theological discussion with the Vicar of St. Martin's and made a number of conversions. In I63I the corporation had complained that 'papists, nonconformists, and sectaries' were being sheltered in the Newarke liberty. ${ }^{3}$ Three years later a James Bottomley was accused, in Laud's metropolitical visitation, of preaching dissenting views in All Saints' parish. ${ }^{4}$ The year following Fox's visit saw the convictions of Samuel Otes and Ralph London for the public avowal of their opinions against infant baptism. 5 In 1659 Humphrey Woolrich of Newcastle produced a tract, $A$ further testimony to truth; or some earnest groans for a righteous settlement by some baptized congregations in Leicester. ${ }^{6}$ It is not possible to tell how meetings were organized, if at all, at this date, and no information is available on this point until I669, when there were three meeting houses in the borough, all in St. Margaret's parish.7 About 40 'inferior' persons were stated to belong to two Anabaptist meetings and about the same number to a

10 Kimberlin, op. cit. 22; White, Dir. Leics. (1 877), 306.

II For the new ch. see Kimberlin, op. cit. 38 sqq.

I2 Ibid. I9. In 1887 a new school was built in New Walk: see p. 337 .

13 On the Irish immigrants in and after 1848 , see above, p. 263 .

14 Kimberlin, Return of Catholicism, 22-23, 19

15 Ibid. 23

16 Ibid. 53; Leic. Mercury, 4 Sept. I 940; see also below, p. 427 .

17 Kimberlin, Return of Catholicism, 53-54:

18 Ibid. 54-55.
20 Cath. Dir. (1950), 277; cf. ibid. (1949).

I See above, p. 67.
Quaker meeting. The same teachers and preachers were apparently working for both sects. ${ }^{8}$ William Judge, William Wells the younger, John Mugg, William Christian and a man from Kilby called Farmer were licensed to preach as Baptists, and Mugg, Christian, and Farmer were licensed as Quakers. In 1672 the house of Richard Coleman was licensed as a Baptist meeting place. Coleman had been a member of the Common Hall before the Restoration, and does not appear in the hall lists after 1660 , although he was steward of the fair in I66 I-2.9 In I67I and I682 the borough authorities descended upon two conventicles of dissenters and there was considerable discussion by the magistrates whether a supposed conventicle could be condemned when, as on the first occasion, the constable had heard no praying or preaching, but had broken in on suspicion alone. ${ }^{10}$ The visit of John Bunyan to Leicester in 1672 furnishes further information about the Leicester nonconformists. He had a licence to preach in the town as a Congregationalist, presumably to his Baptist friends, although the titles for sects are so loosely used at this date that they can have little real meaning. Tradition has it that he preached at a house or chapel on the site of the present Friar Lane meeting, ${ }^{\text {II }}$ although there is no evidence that the Baptists had a place of worship in St. Martin's parish at this date.

2 J. Thompson, Hist. of Leic, ii. 260.

3 Leic. Boro. Rec. $1603-88,259$.

4 Assoc. Archit. Soc. Rep. E ${ }^{\circ}$ Papers, xxix. 505.

5 Leic. Boro. Rec. $1603-88,385-6$. Otes was probably the father of Titus Oates: D. Ashby, Friar Lane, I3; D.N.B.

6 W. T. Whitley, Baptist Bibliography, i. 75 .

7 Orig. Rec of Nonconformity, ed. G. L. Turner, i. 69 where the cpiscopal returns are printed in abstract. All subsequent refs. to the year 1669 are from this source.

8 Ibid. ii. 760,772 .

9 Leic. Boro. Rec. 1603-88, 606-7, 605.

10 Ibid. $522-3,557$.

${ }_{11}$ Thompson, Hist. of Leic. i. 430 and n. A house in 


\section{BAPTISTS}

The General Baptist chapel in Friar Lane claims to date from $16_{5} \mathrm{I},{ }^{12}$ although a recent history of the chapel points out that the greatest likelihood is that the congregation of Baptists, which undoubtedly existed in the town at this date, met in a different place each Sunday. ${ }^{\mathrm{I} 3}$ That there was no meeting place in St. Martin's parish as late as $\mathbf{I} 669$ is indicated by the episcopal returns of that year. The names of the early leaders of the sect were Conyers Congrave and Thomas Rogers. About 1656 two Baptist missionaries were sent to Leicester from the conventicle at Fenstanton. In 1676 there were twelve dissenters in St. Martin's parish, but their denomination is not mentioned, ${ }^{14}$ and it is not until I 709 that there is a specific reference to Baptists in the parish. ${ }^{15}$ In that year it was reported that Thomas Davye and a man named Stanton ${ }^{16}$ were preaching on Sundays in a house which was probably the Friar Lane meeting. The chapel itself is not mentioned until I 19 when its trust deeds were drawn up, very shortly after a permanent chapel had been built. ${ }^{17}$ A piece of ground which lay between the chapel and two nearby cottages was to be used as a burial ground. This early chapel was behind the main frontage of Friar Lane, down a passage, so that it was completely hidden from the street. The meeting remained small and obscure until about 1780 , although there were as many as 43 members in 1750 . In 1783 , with the appointment of John Deacon as minister, the meeting suddenly revived, and its subsequent history is that of a lively and vigorous chapel. Deacon was a member of the Baptist New Connexion at Barton in the Beans, and under his leadership membership increased so strikingly that a new and enlarged chapel had to be built. In 1805 the houses which hid the building from the street were pulled down, and the chapel itself was again enlarged in I8I8, to provide a total accommodation for 1,000 persons. Three years later John Deacon's long ministry of nearly 40 years ended with his death. His epitaph, by Robert Hall, is on the north wall of the chapel. He was succeeded by no less eminent and successful a minister. Under Samuel Wigg, the work of conversion went on steadily in Leicester itself and in neighbouring villages, and the first marriage was celebrated in the chapel in 1837 . Further restoration and extension was undertaken in $184 \mathrm{I}$, and the chapel site was further opened up with the purchase and demolition in $185^{6}$ of the 'Queen's Head', an adjoining public house. Samuel Wigg died in I86 I. Under his successor, James Pike, the chapel was completely rebuilt in brick, to the design of Thomas

St. Nicholas St. bore a plaque stating that Bunyan lodged there but this seems to be conjecture. The house is now demolished: see Leic. Mercury, 6 April 1955.

12 Inscription on chapel.

13 Ashby, Friar Lane, 13-14.

14 Assoc. Archit. Soc. Rep. Eீ Papers, xxix. I 52

15 J. W. Smith, Hist. of Friar Lane, iz.

16 Probably Zacharias Stanton of Belgrave: Ashby, Friar

Lane, I 2.

17 Ibid. 22

18 Ibid. $35^{-3} 6$.

19 Ibid. 51 .

20 Leic. Mercury, 27 Mar. 1936. It was proposed to move the chapel stone by stone to Birstall. The dates of the opening and closing of chapels have been obtained,
Carter, in $186_{5}$. The Sunday school had been opened in 1796 .

At the end of the last century a large body of the congregation, with eight out of the ten deacons, seceded to form a separate church at the Memorial Hall in New Walk, because of the unpopularity of the then minister. After a break of six years, the two branches were reunited in I89I, soon after the sudden resignation of the minister in question. The ministry of James Bishop, between 1912 and I922, ensured the continued vigour of the Friar Lane chapel, at a time when it was threatened with the loss of many members, as more and more people went to live away from the centre of the town.

Two permanent secessions from Friar Lane led to the formation in 1794 of the meeting in Archdeacon Lane, ${ }^{18}$ and in ${ }^{1823}$ of that in Dover Street. ${ }^{19}$ These splits were both occasioned by disagreements with the minister over some point of organization, and there was little or no friction between the chapels once they had separated. Archdeacon Lane chapel was built in 1836 and closed shortly after 1936.20 The Dover Street chapel was purchased in I922 by the Independent Order of Rechabites, having been closed by the Baptists in I919. ${ }^{21}$ In 1955 it was being used as a theatre. Carley Street chapel was built in 1823 or 1824 , and closed in 1864 , but was reopened in 1876 by the combined efforts of the three other chapels. It was enlarged in 1882.22

The chapel in Harvey Lane, belonging to the Particular Baptists, is especially associated with the names of William Carey ( $176 \mathrm{I}-1834)$, the founder of the Baptist Missionary Society and its first missionary, and of Robert Hall (1764-I83I), the noted preacher. The date of the foundation of Harvey Lane chapel is unknown, but it was probably in existence from about $175^{\circ}$, when a sect of Particular Baptists retired from the Friar Lane chapel. ${ }^{23}$ After the erection of the chapel in Belvoir Street, this chapel, never a very large one, was used as a school and a mission chapel, and in 1863 it was rented from the Baptists by a congregation of Independents. It was reopened by the Baptists in the following year. The chapel was destroyed by fire in I92I, having again recently been made into a mission chapel, this time for the Victoria Baptist church. The work there was abandoned in 1932. The chapel had been rebuilt as a Memorial Hall in $1924,{ }^{24}$ but was sold and in 1955 was being used as offices. William Carey's cottage stands opposite the former chapel. ${ }^{25}$

Both General and Particular Baptists founded many other chapels in Leicester and from the 17 th to the Igth centuries they formed the largest body of dissenters in the borough. In St. Leonard's parish, the chapel in Abbey Gate was opened as a mission

unless otherwise stated, from a study of the directories of Leic, issued between I 835 and I 954. Mission chapels are not usually mentioned, Some of the chapels which only existed for a very short time may never have had their own buildings. Short histories of some chapels will be found in All Aboard, the magazine of the Mayflower bazaar for I 909 (copy in Leic. City Ref. Libr.).

21 Ashby, Friar Lane, 103.

22 Smith, Hist. of Friar Lane, I05; C. Howes, Leic, its Civic, Industrial, Institutional and Social Life, 226. Spencer, New Guide to Leic. (1888), 99-I oo.

23 Ashby, Friar Lane, 26.

24 Ibid. I03, I I3; Illus. Leic. Chron. I 8 Oct. I924.

25 Inscription on cottage; E. Williams, House of Memories, guide to museum. 


\section{A HISTORY OF LEICESTERSHIRE}

in $\mathbf{1 8 8 2 . 2 6}$ There were once four chapels in All Saints' parish: Burgess Street (before I 843, probably closed by 1848 ), Vine Street (before I 843 , sold to the Primitive Methodists in I86I), Soar Lane, a branch of Archdeacon Lane (before I 843 , being used by the Quakers in 1848 ), and the Strict Baptist chapel in St. Peter's Lane, known as the Ebenezer chapel and built in $1803 .{ }^{27}$ In St. Mary's parish the former 'Christian' chapel in Newarke Street, built in I835, was taken over by the Baptists and was destroyed in an air raid in November 1940. ${ }^{28}$ The large Victoria Baptist church at the corner of London and University Roads was built in $\mathbf{1} 867$ at a time when the suburban development was proceeding apace. ${ }^{29}$ The Robert Hall Memorial chapel was built by the architect Walter Brand in 1901.30 The chapel in Thorpe Street was founded in $\mathbf{I} 868$, as a branch of the Charles Street chapel, but was never regularly served, and by 1877 had become a Sunday school. ${ }^{31}$ The chapel itself had been built for another purpose in 1854 . In St. Margaret's parish the oldest chapel is that in Upper Charles Street, built in 1830 and united with the Belvoir Street chapel to form the United Baptist chapel in 1938.32 Belvoir Street chapel was built in 1845 , by the architect Joseph Hansom, and was named the 'Pork Pie' chapel from its shape. ${ }^{33}$ It was scheduled for preservation in 1950, purchased by the corporation, ${ }^{34}$ and became an Adult Education centre. Other chapels are those in Melton Street (from about 1860 to about I870), Navigation Street (also in existence about I 864-70), Trinity chapel in Alfred Street (built by a Mr. Harrison in 1840 and closed about I890), Erskine Street (built for a congregation from Alfred Street in 1873 ), ${ }^{35}$ the Tabernacle in Belgrave Gate ( 1869 , closed I92I), and Carey Hall in Catherine Street (1 897, designed by A. E. Sawday). ${ }^{36}$ The Archdeacon Lane Memorial church was opened in Buckminster Road in 1939.37 A new Baptist church was being built in 1955 for the Stocking Farm Estate.

The Evangelical Free Church, Melbourne Hall, was built in $\mathbf{I} 88 \mathrm{I}$ for the ministry of the Revd. F. B. Meyer, formerly the minister of Victoria Baptist church, from which he resigned in $1878 .{ }^{38} \mathrm{He}$ began preaching independently after his resignation, holding large meetings in the museum and other lecture halls. A large sum was raised by his very considerable body of followers for the building of a per-

26 There had been a meeting house in Abbey Gate in 1723 , but it is not known to which sect it belonged: L.R.O., Roll of dissenters' meeting houses, m. 4 .

27 Nichols, Leics. i. 547. Now (1956) a warehouse.

28 Leic. Blitz Souvenir, 27

29 C. Ellis, Hist. in Leic. 115 . The architect was a Mr. Tarring of London: Spencer, New Guide to Leic. (1878) 66

30 W. Scarf, Leic. and Rut, at Opening of 20 th Cent. 151 .

Spencer, Guide to Leic. (1 868), 65; see also ibid. (1888), 103, for the subsequent hist of the chapel.

2 'Leics. Churches', Leic. City Ref. Libr., Cable Coll., article on Charles St. chapel; Ashby, Friar Lane, 120.

33 H.-R. Hitchcock, Early Vict. Archit. in Eng. i. I34-5, discusses the chapel; see also Illus. Lond. News, 25 Oct. I 845 ; and see plate opposite.

34 Leic. Council Mins. I 945-6, 3 I I-12.

35 Hist. of Zion Chapel, Leic. $1873-1923,23$

36 Scarf, Leics. and Rut. 155.

37 Leic. Mercury, I 3 May i 939

38 F. B. Meyer, The Bells of $1 s, 19-21$.

39 Spencer, New Guide to Leic. (1888), 1 03-4.

40 E. E. Kendall, Doing and Daring, is a complete hist. of the ch. See also W. Y. Fullerton, $F$. B. Meyer, 46 sqq. manent church. Melbourne Hall was designed by Joseph Goddard; the Sunday schools were added in I $884^{39}$ Although independent the church is affiliated to the Baptist Union.40

\section{METHODISTS}

The earliest Methodist church was that in Millstone Lane, founded in 1753 and closed about $1865,{ }^{4 I}$ when its place had largely been taken by the newer chapel in Bishop Street, built in 1815.42 The foundation of the Millstone Lane chapel was probably the direct outcome of John Wesley's visit to Leicester in 1753, when he preached to a 'serious and attentive' audience in Butt Close, near St. Margaret's church, on 8 June. ${ }^{43}$ When he next visited Leicester in $1757,{ }^{44}$ the Millstone Lane meeting had been established under the care and guidance of John Brandon and the protection of William Lewis, a Presbyterian hosier, who owned the barn in Millstone Lane which was used for services. ${ }^{45}$ By 1768 a chapel had replaced the barn, and this was rebuilt and enlarged in 1878 , when the movement was well established and Leicester had been placed at the head of a circuit of ministers in the Midlands. ${ }^{46}$ A house in Southgate Street was appropriated for the use of the ministers in $1793 .{ }^{47}$ Wesley last preached in Leicester in 1793 , but he paid another visit to the town in 1794 .

Many other Wesleyan chapels were built in the I 9 th century: King Richard's Road (1880, by A. E. Sawday), ${ }^{48}$ Aylestone Road (1874, sold to be a furniture repository in 1953), Northgate Street (1885,49 closed about 1935), Humberstone Road (1863, by F. W. Ordish), ${ }^{50}$ Saxby Street (I 873 , by A. E. Sawday, purchased by Leicester Corporation in 1953 for use as an infant school), ${ }^{51}$ Wesley Hall in Mere Road (I90I), Newarke Street (about I 864, closed about I870), Metcalfe Street (about I860, closed by 1870 , when an infant school was being held in the building), and a chapel in Alexander Street, which was in existence before 1837 when it was sold to the Primitive Methodists.

Of the other branches of Methodism the Primitive Methodists had the largest number of chapels in the borough. The first Primitive Methodist sermon heard in Leicester was preached by John Benton in

41 Still in existence in 1868 , although not used for services: Spencer, Guide to Leic. (1868), 61 .

42 White, Dir. Leics. (1846), 93.

43 Fnl. of 7 . Wesley, ed. N. Curnock, iv. 72. On Wesley's hosts in Leic. see ibid. ii. 463 , n. I; iii. I64. The development of the movement in Leic. is described in Handbk. of Methodist Conf. at Leic. (1934), 46-49.

$44 \mathrm{Fnl}$. of 7 . Wesley, iv. 201 and n. 4.

45 Thompson, Hist. of Leic. ii. 264-5. With Lewis was associated John Coltman, a hosiery manufacturer living in the Newarke: T.L.A.S. xviii. 5 .

46 Thompson, op. cit. 266. In 1938 the foundations of this chapel were discovered: Leic. Mercury, I 8 July I 938; see also C. J. Billson, Medieval Leic. 2 Io.

47 Thompson, op. cit. 267.

48 Spencer, New Guide to Leic. (1 888), 97; Scarf, Leics. and Rut. 155.

49 Spencer, loc. cit.

50 Ibid. There is a detailed descr of this chapel in Wright's Midland Dir. (1864), p. xiv; see also Spencer, Guide to Leic. (1 864), for an appreciation of the architectural style. No coloured brick was used as Ordish felt that a simpler style was more suited to a chapel.

51 Scarff, Leics. and Rut. 155; Rep. Leic. Education Cttee. ( 1953 ). 


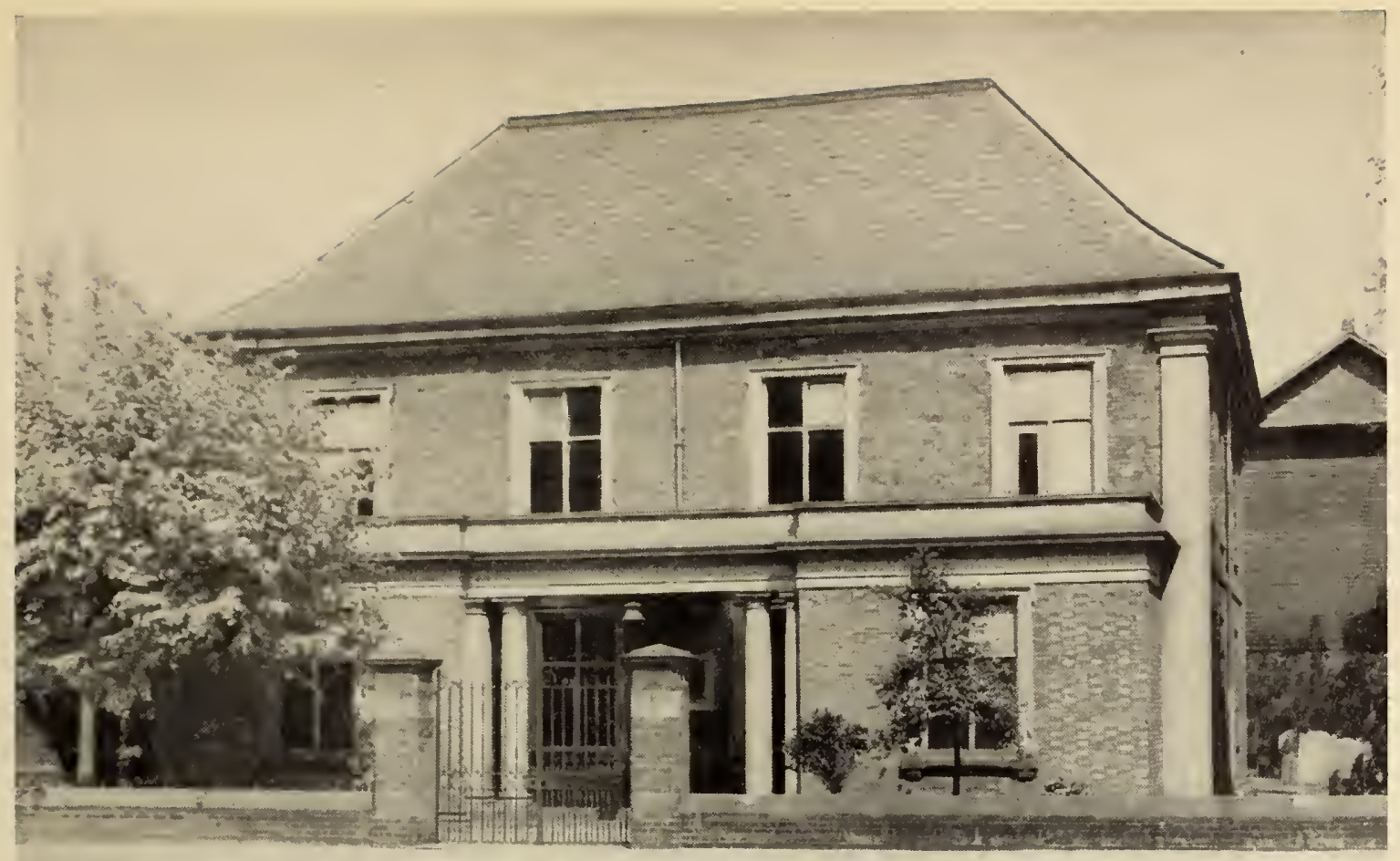

The Great Meeting (Presbyterian)

built $\mathrm{I} 708$

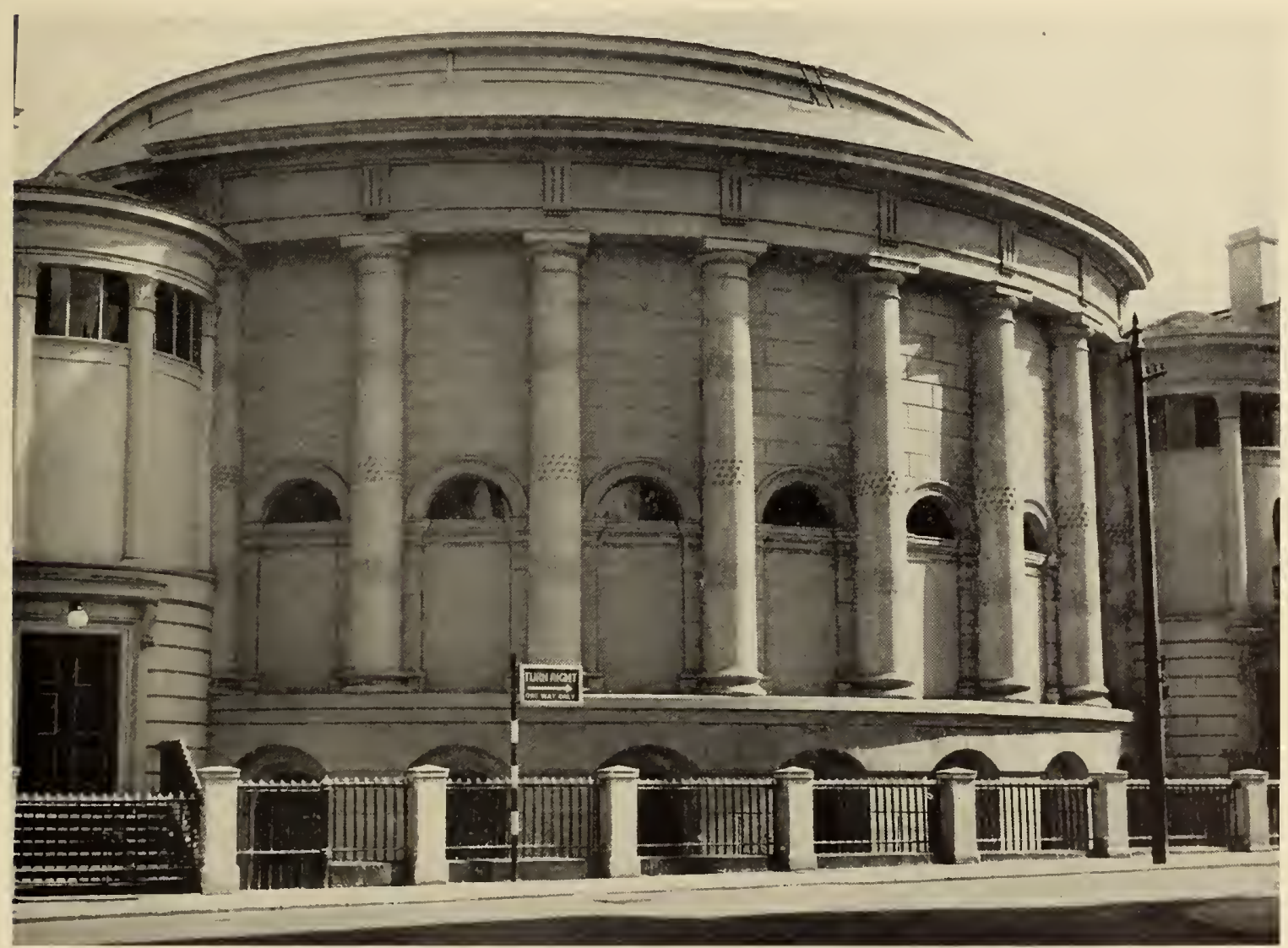

Belvoir Street Baptist Chapel

('The Pork Pie') 


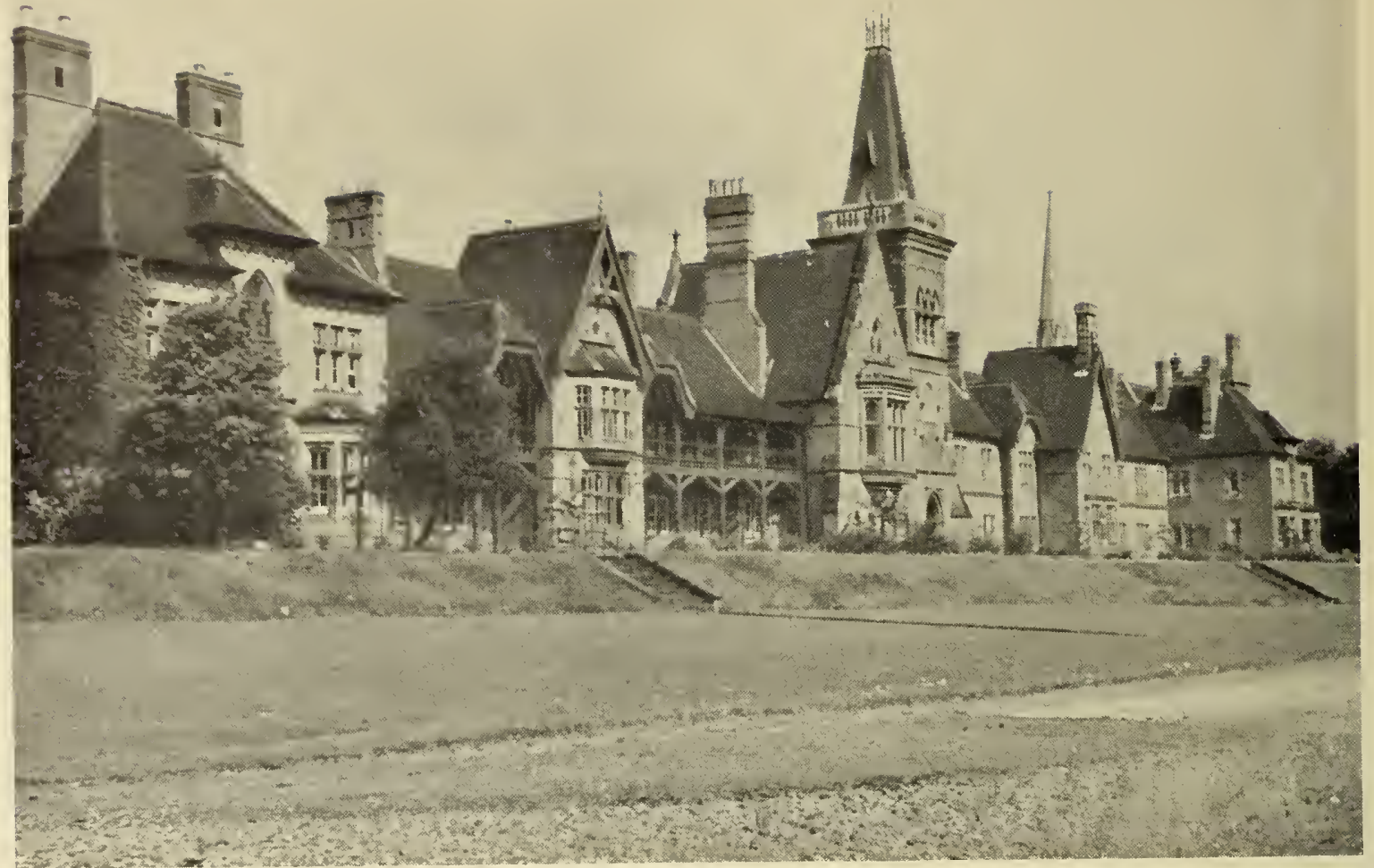

Wyggeston's Hospital

The new buildings of 1867

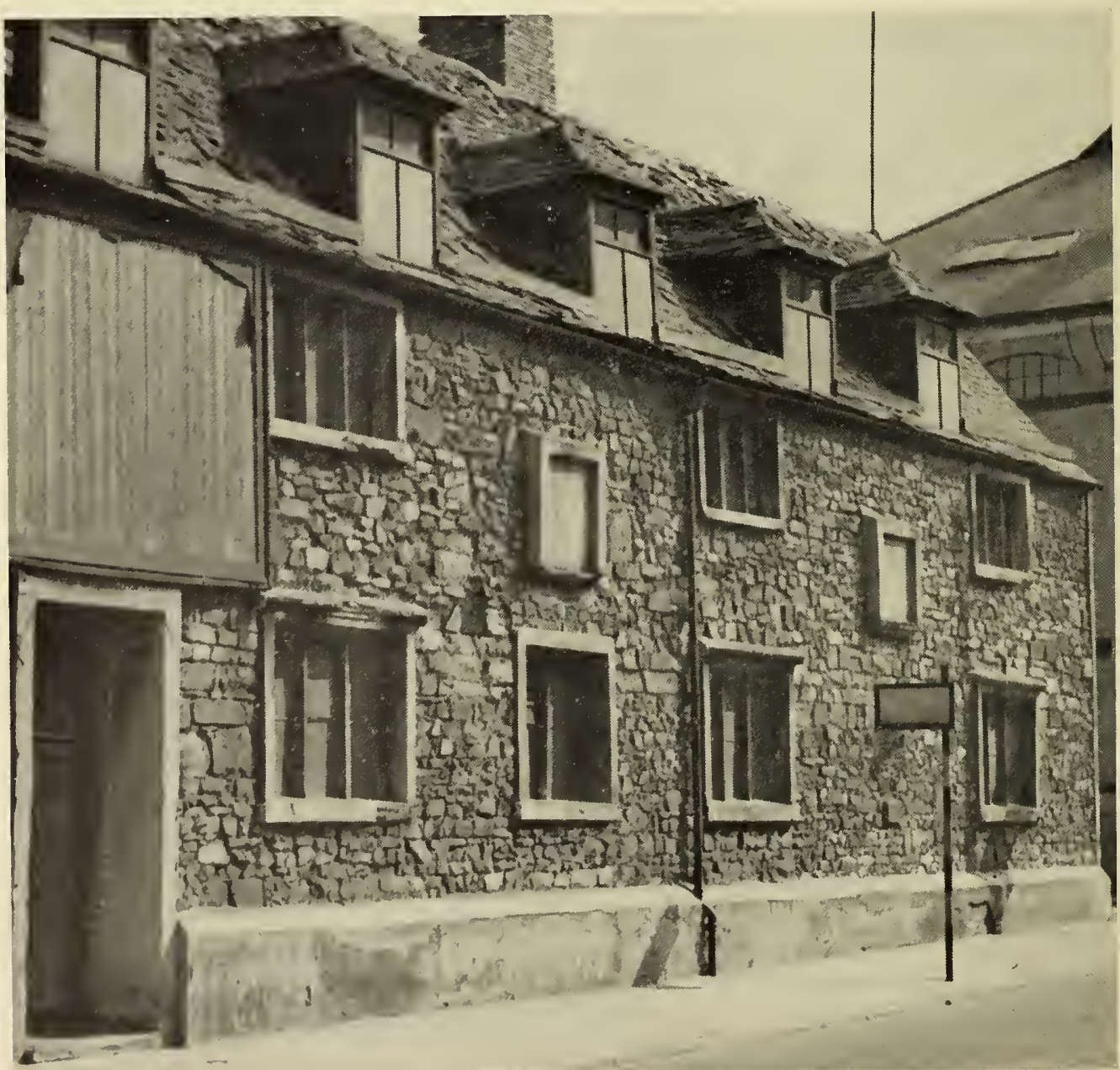

The Free Grammar School

built $c .1575$ 


\section{THE CITY OF LEICESTER}

I $818,{ }^{52}$ and in the same year the chapel in York Street, off Welford Road, was built. This was closed about 1875 , but in the interval other chapels had been built: these included George Street (I8I9, closed about I883), and the chapel in Alexander Street which was purchased from the Wesleyans in 1837 (closed I873). Other chapels were opened in Belgrave Gate (I 882, built to replace George Street, sold to Leicester Co-operative Society in 1937), ${ }^{53}$ Catherine Street (1888), ${ }^{44}$ St. Nicholas Street (built to replace Alexander Street, 55 closed. I 898 ), Hinckley Road (I898), Crown Street (I883), Curzon Street (1859), Gladstone Street (about I864, closed about I885), Humberstone Road (I 88 I), ${ }^{6}$ Chandos Street (about I 879, closed about I 887), Fosse Road North ( I898, the former St. Nicholas Street chapel re-erected on this new site), ${ }^{57}$ Melbourne Road (Highfields chapel, I884), ${ }^{58}$ Peel Street (purchased from the Congregationalists about 1873 , closed about I879), and Vine Street (purchased I86I, closed about I90o). A new chapel is to be built (1955) in Edgehill Road, partly with money raised by the sale of the former Belgrave Gate chapel.

The Methodists of the New Connexion had a chapel (St. Paul's) near the railway station in London Road, built in I86I and closed in I890. The building was then taken down and re-erected for other purposes in Rolleston Street, where in 1955 it formed part of a thread mill. A new St. Paul's chapel was built in Melbourne Road to replace that in London Road. The New Connexion also had chapels in Belgrave Gate ( $1864,{ }^{59}$ closed by 1870 ) and Granby Street (in existence before I80I, when it was sold to the Congregationalists). The Methodists of the Wesley Association had a chapel in Lower Hill Street (built I 833, demolished I 930). ${ }^{60}$ After I 907 the New Connexion and Association Methodists became part of the United Methodist Church and in Leicester used the Melbourne Road chapel. There was formerly an Independent Methodist chapel in Denman Street (opened before I 843 , closed about I 864 ).

\section{PRESBYTERIANS (UNITARIAN)}

In 1672 Gabriel Major and Timothy Wood were licensed to preach as Presbyterians in their houses in Leicester, and two further houses were licensed as meeting places for the sect, one belonging to William Billers and the other to George Long. ${ }^{61}$ In the same year Nicholas Kestyn or Kestian, a minister who had been ejected from Gumley under the Act of Uniformity, received a licence to preach as a Congre-

${ }^{2}$ Handbk. of 88th Ann. Conf. [of Primitive Methodist Ch.] in Leic. (1907), 7

${ }_{53}$ Leic. Mail, 24 Aug., 5 Nov. 1937.

s4 Spencer, New Guide to Leic. (1888), 106.

55 Ibid.

56 Ibid. 107.

57 Leic. Mercury, 18 April 1955; inscription on chapel.

58 Spencer, op. cit. 107.

59 Ibid. 98

60 Leic. Mail, 17 April r93o.

61 Orig. Rec. of Nonconformity, ed. Turner, ii. 758-9.

$62 \mathrm{~A}$. H. Thomas, Hist. of Gt. Meeting, I8. The author is wrong in stating (p. 2I) that Kestyn did not take up a licence to preach under the Declaration of Indulgence: cf. Orig. Rec. of Nonconformity, ii. 767 . gationalist, and it is his name which is most closely associated with the foundation of the Presbyterian (later Unitarian) meeting in Leicester. ${ }^{62}$ In 1680 the Presbyterians occupied a barn near the present Infirmary Square. ${ }^{63}$ Two years later the Congregationalists (or Independents) were reported to be holding services in a barn in Millstone Lane. ${ }^{64}$ There was a close connexion between the two sects by I692, for in that year Edmund Spencer was the preacher to both congregations. ${ }^{65} \mathrm{He}$ had married in I 667 Elizabeth, daughter of Nicholas Kestyn, and was then already living in St. Martin's parish, although there was no meeting place in the parish as early as that. In 1692 it was stated that he received a salary of $£ 30$ a year, probably contributed by the congregation. By the year 1704 the two sects had become one, based at the chapel near Infirmary Square. This rapidly became too small to house the growing congregation, and in 1708 the foundation stone of the chapel in Butt Close was laid. This chapel, known as the Great Meeting, is a brick and stucco building of two stories, with four front windows in moulded stone frames. The ceiling of moulded plaster was added in I786 and the chapel was altered inside several times, the last occasion being in I 866 , when the galleries were rebuilt and the whole chapel refurnished. Much of the original simplicity of design has been lost. The organ was erected in $\mathrm{I} 800$. The front has not been changed except for the addition of a modern vestibule. In I 866 a chancel was added at the rear. There are a number of beautifully carved grave stones of Swithland slate in the neighbouring burial ground. 66

In the late I 8 th and early I 9 th centuries the Great Meeting was one of the main centres of the demand for parliamentary reform. The first seven mayors of the reformed borough after 1835 were members of this congregation, as was one of the members for the borough, Thomas Pares. ${ }^{67}$

It has been said that the Great Meeting school was opened on I 5 July I 726 but the first recorded reference to a school-teacher is in 1736.68 The permanent school building dates from I 813 , and was enlarged in 1859 , but the school itself was closed shortly after the Education Act was passed in 1870 . In 1955 the school building, next to the chapel, was being used only for the Sunday school, established in 1783.69 In 1738 a house for the minister was built in High Cross Street opposite All Saints' church, but it was sold in $1868 .{ }^{70}$ John Burgess, a member of the congregation who died in 1799 , gave a house in Churchgate to be used by the ministers, but this was usually leased, and it too was sold in $1874 .{ }^{71}$

Although the Great Meeting is now Unitarian, it only became so at the beginning of the last century, the trust deeds of the chapel not placing any con-

63 Thomas, op, cit. 23. Elsewhere it is suggested that until the beginning of the 18 th cent. the Presbyterian headquarters were in Hangmans Lane, near Oxford St.: Leic. Daily Mercury, a Oct. I902. But these two references might be to the same place.

64 Thomas, op. cit. 25

65 Freedom after Ejection, ed. A. Gordon, 66, 356.

66 Thomas, Hist. of Gt. Meeting, 27. For a photograph of the Great Meeting see above, plate facing p. 392.

67 See above, pp. 252,362 .

68 Leic. Daily Mercury, 9 Oct. I902; Thomas, op. cit. 65

69 E. Gittings, Cent. Bk. of Gt. Meeting Sunday Sch.

70 Thomas, Hist. of Gt. Meeting, 42.

71 Ibid. 92. 


\section{A HISTORY OF LEICESTERSHIRE}

dition on the religious views of the congregation..$^{72}$ Another Unitarian chapel was built in Wellington Street about 1876 , but it was closed in 1901 , when a chapel in Narborough Road was opened.

\section{QUAKERS}

George Fox, as has been noted, found Quakers in Leicester when he visited the town in 1684 , and there has been a meeting there ever since, although never a very large one. Among the borough records are two letters of about $\mathbf{1}_{55}$ from Quaker prisoners in the town gaol, one apparently having been sent there for refusing to take off his hat in the presence of a magistrate. ${ }^{73}$ In or about I 669 , Samuel Brown's petition to be licensed as an apothecary was refused because he was a Quaker, ${ }^{74}$ although in 1699 another Quaker, Joseph Smith, was admitted to the freedom of the borough. ${ }^{75}$ There were said to be thirteen Quakers living in St. Martin's parish in $1709 .{ }^{76}$ A meeting house was built in $I 680-1$ and was still in existence in $177^{\circ}$, for it was enlarged or rebuilt in that year. ${ }^{77}$ In 1877 a new meeting house was built in Prebend Street (closed in 1956). By 1848 the former Baptist Chapel in Soar Lane had been taken over by the Quakers as an adult school and mission chapel, but this was abandoned about 1895 . In I79I it was said that the Quakers of Leicester maintained "more of the original simplicity of dress and manners characteristic of their body, than was to be seen in other towns'. ${ }^{78}$ When the Quakers of St. Martin's parish refused to pay church rates it was agreed that they should pay twice as much poor rate as the members of the church. 79

\section{CONGREGATIONALISTS}

The Congregational chapel in Bond Street was founded in I 800 , partly by a secession of those members of the Great Meeting who did not welcome the advance towards Unitarianism being made by the meeting at that time. ${ }^{80}$ Their first chapel was in Granby Street, on the site of the subsequent Charles Street Baptist school. This chapel was purchased in 1801 from the Kilhamites or New Connexion Methodists. The Bond Street chapel was built in 1803 and enlarged in 1821 and $1864 .^{81} \mathrm{~A}$ second chapel in Gallowtree Gate was built in 1823 and underwent considerable alterations during the last century before it was closed in $192 \mathrm{I}$, together with the attached Sunday school. The building was de-

72 White, Dir. Leics. (1877), 306.

73 Leic. Boro. Rec. $1603-88,42 \mathrm{I}-4$.

74 Ibid. 52 I.

75 Thompson, Hist. of Leic. ii. 621 .

76 Ibid.

77 Leics. and Rut. N. $\oint^{\circ}$ O. ii, I 95; L.R.O., Roll of dissenters' meeting houses, m. I. Spencer, Guide to Leic. (1868), 67, says that it was on the site of a meeting house built $c .1670$.

$78 \mathrm{~J}$. Throsby, Hist. of Leic. $38 \mathrm{I}$; Thompson, Hist. of Leic. ii. $267 . \quad 79$ Thompson, op. cit. 263.

80 Thomas, Hist. of Gt. Meeting, 53-55; E. M. Drew, Those Taking Part, ISO2-I952, hist. of Bond St. chapel from which much of the following is taken.

81 It was threatened with demolition in 1938 and it was proposed to remove its activities to Braunstone. The war intervened and this was not done: Leic. Mail, I5 Mar. I938; Drew, op. cit. 26-27. molished in 1927.82 Chapel Yard, on the West side of the street, is the only surviving indication of its existence. A Congregational chapel in London Road was built in $185^{8 ; 83}$ one in Oxford Street, replacing an earlier building of about 1815 , was built in $1863 ; 84$ one in Willow Street was opened about 1873 and closed about 1936; and the Union church in Humberstone Road at the corner of Newby Street was built in 1880.85 The Wycliffe church in College Street was acquired from the Collegiate School in I 866: the original Gothic building, erected in 1835 , was designed by a Sheffield architect named Weightman or Whiteman. The church was bought by the Leicester Education Committee in 1954 , but in 1955 was still used for services on Sundays. ${ }^{86}$

\section{PRESBYTERIAN CHURCH OF ENGLAND}

The Presbyterian church of St. Stephen used to stand on the site of the former Wyvern Hotel near London Road railway station and was built in 1869 . In 1893 the church was sold and demolished and a new building was erected at the corner of New Walk and De Montfort Street. The architect was A. R. G. Fenning. ${ }^{87}$

\section{SALVATION ARMY}

The 22nd opening of the Christian Mission (later the Salvation Army) took place in February $\mathbf{1} 877$. The first hall was in Foundry Lane, but the headquarters were afterwards moved first to Watling Street and then to Bread Street. The present hall in Kildare Street was opened in I935. There were five corps of the Salvation Army in Leicester in $195^{6}$. The divisional headquarters was in Halford Street. ${ }^{88}$

\section{CHRISTIAN SCIENCE}

The First Church of Christ, Scientist, at Leicester was established in $191 \mathrm{I}$, when the first services were held in a private house in the town. The church has been variously housed in Welford Road, Avenue Road, and Dover Street. In 1935 a building in Granville Road was purchased, but owing to the outbreak of war the rebuilding which was necessary to make the new auditorium was postponed until after the war. It was completed in 1952 and dedicated in 1956.89

82 Leic. Mail, 5 May 1927.

83 Designed by the minister, the Revd. R. W. McAll: see Drew, op. cit. I I.

$8+$ 'The present chapel was built as a memorial for the bicentenary of nonconformity. The architects were Shenton and Baker of Leic.: Spencer, New Guide to Leic. ( 1878 ), 66

85 Not 1888 , as in Drew, op. cit. 14 ; cf. Lond. Gazette, I 880 , p. I 912 .

86 Spencer, Guide to Leic. (I 868), 64; Billson, Leic. Memoirs, 83 ; Leic. Mercury, i I Oct. I 954.

87 Ellis, Hist. in Leic. I I 5 and n. I; G. B. Burnet, St. Stephen's Presbyterian Ch. of Eng. (I932); Leic. and Co. Liberal, Nov. I 927.

88 Ex inf. public relations officer, Salvation Army, Leicester.

89 Summary history in church dedication in programme supplied by Christian Science Society, Leicester. 
THE CAS'TLE MILL. There was a mill at Leicester by 1086 , when the Countess Judith was entitled to half of its profits. At the same date the Bishop of Lincoln possessed a mill, and a half right in a second one. It may be conjectured that the bishop was the owner of the remaining half of the mill of which the countess was part owner, so that between them the bishop and the countess held-two mills. One of these may have been that later known as the Castle Mill. The first definite reference to the Castle Mill occurs in $\mathrm{I} 30 \mathrm{I}$, when it presumably belonged to the Earl of Lancaster as owner of the castle. ${ }^{2} \mathrm{~A}$ second mill, known as the new mill, was built about $\mathrm{I}_{3} \mathrm{OO}^{3}$ and for some years afterwards both were farmed, together with the castle ovens and at times with the horse-mill in the present High Street. ${ }^{4}$ At some date after 1330 and before his death in I 345 , Henry, Earl of Lancaster gave the new mill to Newarke College, 5 and it later became known as Newarke Mill. ${ }^{6}$ Only one mill, valued at $f_{05}$, belonged to the castle in $136 \mathrm{I}$, when the Duke of Lancaster's property in Leicester was surveyed. ${ }^{7}$ Another new mill was built in $1377-8$, probably very close to the old one. It cost $f_{0} 6$ I os. $9 \frac{1}{2} d$. and was a timber structure with stone foundations and a thatched roof. Although the gear was made on the spot, the stones had to be bought. ${ }^{8}$ In 1399 the farm of the mills belonging to the Duchy of Lancaster at Leicester was valued at $f 8 .{ }^{9}$ In 1593 the two Castle Mills were being farmed by John Chippingdale, the Bishop of Lincoln's commissary, who came into conflict with the borough authorities about his right to compel the town's inhabitants to have their corn ground at the Castle Mills. Chippingdale assented to an agreement with the town to submit the matter to arbitration, but neglected to do so and continued to sue burgesses who ground their corn elsewhere. The town appealed to the Earl of Huntingdon to help them, but no decision is recorded in this dispute. ${ }^{10}$

In 1605 the mills were leased by Sir Edward Hastings, who reopened this vexed question by suing one Wyatt Fowler for not grinding his corn at the Castle Mill. A law-suit followed which seems to have resulted in a decision that the inhabitants of the borough need only grind at the Castle Mill when it was convenient for them to do so. ${ }^{\text {II }} \mathrm{By} \mathrm{I} 624$ Lord Grey was the duchy's tenant of the Castle Mill and the corporation leased it from him for $f 8$ yearly, provided that he paid the king's rent and handed the property over in good condition. ${ }^{22}$ After negotiations

I V.C.H. Leics. i. 306, 309.

2 Leic. Boro. Rec. II $0_{3-I 327,238 .}$

3 Ibid.

4 See below, p. 398 .

5 A. Hamilton Thompson, Hist. of Hosp. and New Coll. of St. Mary in the Newarke, 33.

6 For its later history, see below.

7 Leic. Boro. Rec. I327-I 509, 125.

8 T.L.A.S. xxii. I 48 , n. 69.

9 Leic. Boro. Rec. I327-I509, 273.

10 Ibid. I 509-I603, p. liii.

11 Ibid. $I 603-88,37,51,57,70$.

12 Ibid. 209.

$\mathrm{IX} / 3$.

3 Ibid. 250, 290, 296; Leic. City Mun. Room, Misc.

14 Leic. Boro. Rec. $1603-88,302$.

I5 Ibid. $342-3$

16 Ibid. 492.

17 Ibid. 430.

18 Ibid. $466,467-8$; Bodl. Libr., MS. Carte 78, f. 84 . which lasted for three years, the corporation arranged to purchase the mill from the Duchy of Lancaster, and by $1638 f_{3} 600$ had been paid for it. ${ }^{13}$ In 1632 besides the two watermills there was also a windmill attached to the Castle Mill, but whether as an independent structure or as an alternative source of power is not clear. In 1640 alterations were made to the 'wash at the Castle Mills', ${ }^{14}$ and in ${ }^{2} 644-5$ the malt mill was demolished ${ }^{15}$ and the rent of the mill diminished by 40 . as a result. ${ }^{16} \mathrm{~A}$ proposal in ${ }^{6} 656$ to erect an engine at the mill together with a new wheel in connexion with the piping of water to the High Cross does not seem to have been carried out. ${ }^{17}$ In $\mathbf{1 6 6 0}$ the town surrendered to the king a fee-farm rent of $f_{1} 17$ from the Castle Mills acquired during the Civil War, together with a present of $f, 300 .{ }^{18} \mathrm{At}$ this time the mill was rented by a John Turville, ${ }^{19}$ who complained to the corporation that the mill dam was so choked with mud from certain new trenches that 'the water comes not cleare to the mills and soe they are become of lesse yearly profitt'. He alleged that the corporation only charged him a high rent $(f, 38)$ because of the very high price which it had paid to the duchy for the mill. ${ }^{20}$

The Castle Mills were sold in 1685 to Lawrence Carter, later M.P. for the town, together with fishing rights in the Soar from Morehead to the West Bridge, upon the condition that Carter should be responsible for the fee-farm rent. ${ }^{21}$ The price paid was only $f_{1} \mathrm{r} 30$, so the corporation made a considerable loss. In I 7 I 8 the miller was ordered to lower his weir, which had been raised to the prejudice of the miller at the Newarke Mill. 22 In I 748 Thomas Carter bequeathed the Castle Mill, together with the Castle Mill shop in the Saturday Market, to Jane Flower. ${ }^{23}$ The function of this shop is not clear. It may have been used for the sale of flour, and probably was also an office where arrangements for grinding corn could be made. The Flower family held the mill as late as $\mathrm{i} 843,24$ but it had changed hands by 1846 when Joseph Pywell was the miller. ${ }^{25}$ In $\mathrm{x} 849$, when the mill was offered for sale, it drove four pairs of stones. ${ }^{26} \mathrm{By}$ I $87 \mathrm{I}$ it was in use for spinning. ${ }^{27}$ In 1872 the corporation purchased the mill in connexion with the flood prevention scheme, ${ }^{28}$ but it was still in use in 1875 , when it had attached to it a stall in the Corn Exchange. ${ }^{29}$ The mill ceased to function as a mill about 1876,30 when the weir and lock had been removed and the river deepened. ${ }^{31}$ In 1877 the weir was reconstructed

I 9 Leic. Boro. Rec. I603-88, 492. John Turville was perhaps the goldsmith who was paid for altering the plate on various occasions and who made a new mace in I 649: Leic. Boro. Rec. I6 03-88, 377, 398, 406, 469, 473, 494. He was chamberlain in $1652-3$ and coroner $1661-2:$ ibid. 601 , 603.

20 Leic. City Mun. Room, Chamberlains' Accts. I6605, p. 6; Leic. Boro. Rec. I603-88, 492.

${ }_{21} \mathrm{~J}$. Throsby, Hist. of Leic. $142-3$.

22 Leic. City Mun. Room, Hall Bk. I4 May I7 8.

23 Ibid. I $\mathrm{D}_{32 / 326 .}$

24 T. Cook, Guide to Leic. ( 1843 ), I 12.

25 White, Dir. Leics. (1846), 179.

26 Leic. Fnl. 8 Jan. 1849.

27 Leic. Chron. and Leic. Mercury, 4 Feb. I87 I.

28 J. Storey, Hist. Sketch of Boro. of Leic. 76.

29 Leic. Trade Protection Soc. Dir. Leic. (1875), 177.

30 Cf. ibid. and White, Dir. Leics. (1877), 479.

31 For the alterations see Storey, Boro. of Leic. $77,78$. 


\section{A HISTORY OF LEICESTERSHIRE}

and the island near the mill was removed. After these alterations and the subsequent canalization of the river had put an end to its activities as a mill, the Castle Mill was leased by the corporation until 1893 as a hosiery trimming factory. ${ }^{32}$

THE NEWVARKE MILL (Swan's Mill). The mill known throughout the later Middle Ages and during the I6th century as the Newarke Mill was originally the new mill of the castle, which was built about I 300 up-river from the main Castle Mill near the West Bridge. Mill Lane, which led up to the new mill, formed the southerly limit of the enclosed site of the Newarke Hospital and College, to which between 1330 and I 345 Earl Henry of Lancaster gave his new mill. The grant was confirmed to the college in 1360 , in a general charter of confirmation of their property, ${ }^{33}$ and the mill remained the property of the college until it passed to the Crown on the dissolution of the college in I 548. The mill was not mentioned in the grant made to John Beaumont of the site of the college in 1548,34 and presumably it remained in Crown hands. In I 554, three men, who may have been the farmers of the Newarke Mill, brought in an injunction to the mayor's court about the grinding of corn at their mill. It is not at all clear what the terms of this injunction were. In any case the borough authorities objected, as it was held that to use any other mill than the Castle Mill would be detrimental to the king and queen, and the three men agreed that the injunction should be considered void. ${ }^{35}$ In the reign of Elizabeth I the mill was leased, apparently in two halves, each attached to a portion of the Newarke Grange in the South Field. In 1576 half was leased by the queen to Robert Temple and William Worship, both of Leicester, and three years later Temple and his son Thomas leased it to Henry Newbold, the miller, for sixteen years. ${ }^{36}$ The other half of the mill was apparently leased to Francis Hastings with his part of the grange. ${ }^{37}$ 'The corporation bought Hastings's lease, and the Newarke Mill was included in the purchase of the grange by the corporation in $1613 .{ }^{38}$ The Newarke Mill remained in the possession of the corporation until the Igth century. In I 626 the mill was leased to William Palmer, with an attached windmill, and Palmer was licensed later in the year to sub-let it to Thomas Swan. ${ }^{39}$ From this time the old name seems to have disappeared completely, and the mill was known as Swan's Mill until the last century. In I74I the tenant of the mill, which then consisted of a water corn-mill, a windmill, and a mill shop, probably in the Market Place, paid a yearly

32 Abstract of Accts. of Boro. of Leic. (1889-90), 204; (1 $892-3), 206$.

${ }_{33}$ See above, p. 17, and Hamilton Thompson, Hist. of Hosp. and New Coll. of St. Mary in the Newarke, 33. ${ }_{34}$ It was valued at $f 86 \mathrm{~s}$. $7 d$. in 1545: Assoc. Archit. Soc., Rep. E' Papers, xxx. 516-17; Cal. Pat. 1547-8, 300-1.

${ }_{35}$ Leic. Boro. Rec. I509-I603, 81. Miss Bateson (ibid., p. liii) suggested that this injunction was perhaps one compelling the burgesses to grind their corn at the Newarke Mill. This seems very doubtful, as there is no record that the Newarke Mill ever enjoyed any such method of monopoly.

${ }^{36}$ Leic. City Mun. Room, 2oD $52 / 25 / 563$.

37 Ibid. $20 \mathrm{D}_{52 / 26 / 570}$

38 See pp. 63-64.

39 Leic. Boro. Rec, $1603-88,231-2$.

40 Leic. City Mun. Room, 3D $42 / 43 / \mathrm{I}$. rent of $£ 254^{40}$ This was raised in 1770 , when a new lease was made, to $f_{30}$ with an additional fI for tithes. ${ }^{41}$ In 1837 the corporation was involved in a dispute about the ownership of the mill, and several declarations were made to the effect that the mayor and corporation were in fact the sole owners. ${ }^{42}$ It was at this time that the mill was sold to Isaac Abell, 43 whose family were parchment-makers and who also owned considerable property in Frog Island and Mill Lane. ${ }^{44}$ The mill remained in use until it was repurchased in $\mathbf{I} 880$ with an adjoining dye-works and water rights by the corporation in connexion with the flood prevention scheme. ${ }^{45}$ The canalization of the River Soar meant the end of the mill's useful life; the building survived until i 893 , after which it was demolished and replaced by the Leicester Corporation destructor. ${ }^{46}$ The mill remained a flour-mill until its demolition.

NORTH MILL. The mill at the North Bridge apparently formed part of the endowment of the college of St. Mary de Castro and was therefore probably in existence at the beginning of the 12 th century. It was given to Leicester Abbey upon its foundation in I I 43.47 A mill called St. Leonard's Mill is mentioned in the borough records about 1292 . It then stood in the part of Frog Island which was in the parish of St. Margaret ${ }^{48}$ and may have been the same as the North Mill. The North Mill was definitely referred to in I30I, when the miller was convicted before the king's marshal of taking false tolls and was fined. ${ }^{49}$ Nothing is known of the North Mill for the rest of the Middle Ages. It presumably passed to the Crown at the dissolution of Leicester Abbey, and seems to have remained in royal hands until I 589 , when it was almost certainly one of the mills granted to the borough by Elizabeth's charter of that year. ${ }^{50}$ It had been leased to Stephen Harvey and George Tatam by the queen in $1587^{51}$ and the borough seems to have continued the lease; at least to Tatam, on a mortgage basis to raise money for the payment of the fee-farm. ${ }^{52}$ The mill was ordered to be redeemed in 1594 , the town to raise $f_{1}$ oo for this purpose and afterwards to rebuild the mill. 53 In 1602 the North Mill was one of the corporation properties which it was not allowed to sell. 54 When Edward Hastings tried to gain a monopoly for the Castle Mill at the same time, the North Mill was one of those which he suggested should not be used except with his special permission. ${ }^{55}$ In $1605-6$ the mill was leased for $2 \mathrm{I}$ years at a yearly rent of $£_{1} 10 .{ }^{56}$ The buildings of the North Mill seem to have resembled those of the other Leicester mills; in I6 I the mill

41 Ibid. $3 \mathrm{D}_{42} / 43 / 3$.

42 Ibid. $3 \mathrm{D}_{42} / 43 / 4,6$.

43 S. Stone, Rep. on Town Estate (1856), 6.

44 Leic. City Mun. Room, 3D42/2/1 74-207.

45 Storey, Boro. of Leic. 80 .

46 Abstract of Accts, of Boro. of Leic. (1 802-3), 220

47 Nichols, Leics. i, App. 54.

48 Leic. Boro. Rec. IIO3-I327, 392.

49 Ibid. 238 .

50 Ibid. $I 509-1603,25 \mathrm{I}$

5: Ibid.

52 Ibid. 277. Immediately after the charter was granted Tatam leased half the mill from the corporation: Leic

City Mun. Room, 20D52/27/632.

53 Leic. Boro. Rec. I 509-I603, 297

54 Ibid. 447

55 Ibid. $1603-88,37$.

56 Ibid. 56. 


\section{THE CITY OF LEICESTER}

consisted of two watermills and a malt-mill.57 The corporation remained the owners of the North Mill until it was closed in the I 9 th century. In the 18 th century the rent paid by Edmund Johnson was 30 guineas yearly. 58 Proposals to drive the mill with steam in $180 I^{59}$ and to rebuild it in $1819^{60}$ were not carried out. The corporation decided in $\mathbf{I} 82 \mathrm{I}$ to rebuild none of the watermills ${ }^{61}$ and contented itself with building a new mill-house at the North Mill for the lessee in 1824 ; the attached windmill was afterwards repaired. ${ }^{62}$ Further repairs were carried out in $1832-3 .{ }^{63}$ For a great part of the I 9 th century the milling family of Hitchcock were the corporation's tenants ${ }^{64}$ and it was from them that the corporation acquired the mill's rights in 1876 in connexion with the flood prevention scheme. ${ }^{65}$ After the completion of the scheme, water-power could no longer be used for the North Mill, but steam was installed by 1888 and was used in the mill until about I905.66 The mill was then closed as a corn-mill, but the name of North Mill is perpetuated by a firm of worsted spinners.

ST. MARY'S MILL. There is very good reason to suppose that the mill mentioned in the account of the manor of Bromkinsthorpe in Domesday Book is the one which afterwards became known as St. Mary's Mill, and which stood on the Soar just on the border between Aylestone parish and the South Field of the borough, about half-way between the present Narborough and Aylestone roads. ${ }^{67}$ In 1086 the mill was rendering 20s. yearly. In 1200 Amaury Danet had a mill on the site, ${ }^{68}$ and a mill there remained the property of the Danet family for centuries. In I 428 a dispute arose between Richard Danet and the Dean and canons of the Newarke College about a right of way to the mill which Danet claimed for his tenants through the meadow called Marymeadow, which belonged to the college. The mill was then being used both for grinding corn and for fulling. ${ }^{69}$ Little else is known about the history of the mill under the later members of the Danet family and their successors the Rudings ${ }^{70}$ until comparatively modern times. The mill was rebuilt in $\mathbf{I} 799$, and it was probably then that it became a hosiery mill.7I It was apparently still driven by water power, as the mill wheel was stated to be in bad condition. In the same year the mill was leased by Walter Ruding to John Rawson, a Leicester hosier, and other manufacturers, including turners and a worsted maker, for 50 guineas yearly rent. ${ }^{72}$ An inventory of the contents of the mill in $\mathrm{I} 8 \mathrm{I} \mathrm{I}$, when it passed from Rawson and his son to a millwright and machine-maker named John Pearson, lists five

57 Leic. City Mun. Room, Press 24/IX/I 4.

58 Ibid. Hall Bk. I2 Feb. $1724 / 5$.

59 Ibid. I4 Sept. I 80 I.

60 Ibid. 28 Aug. I8I 9.

6r Ibid. I I Feb. I 82 I.

62 Ibid. I 7 Sept. 1827.

63 Ibid. Chamberlains' Accts. 1832-3.

64 Pigot \& Co.'s Dir. Leics. (1828), 487 , has the earliest ref. to this family at the North Mill; White, Dir. Leics. (I 877 ), 450 .

65 Storey, Boro. of Leic. 79.

66 Kelly's Dir. Leics. and Rut. (1888), 583. The last ref. to the mill is in Wright's Dir. Leic. (I904), 5 I.

67 V.C.H. Leics. i. 3 I5. For the position of the mill see T. and G. Ellis, Map. of Leic. (1828).

68 Leic. Boro. Rec. IIO3-I327, 5.

69 Ibid. I327-I 509, 234.

70 See above, pp. $38 \mathrm{r}, 382$. spinning frames, machine-driven, valued at $£_{3} 375$, and the gear to drive them, valued at $f_{2} 27$ Ios. These frames were probably still driven by water power; the mill wheel is mentioned in the inventory and was then fenced in for safety. The mill employed at least ten girls, who seem to have lived at the mill, and the list of movable property included a Bible. 73 'The mill, which had reverted to being a corn mill driven by water, was advertised for sale in 1826.74 In 1846 it was occupied by a Henry Johnson. ${ }^{75}$ By 1877 it had passed into the hands of William Henry Bates, the elastic-web manufacturer. ${ }^{76}$ Elastic manufacture is still carried on there, and the firm is now part of the Dunlop organization. 77

WINDMILLS. As well as those windmills which were part of the Castle, Newarke, and North mills, there were also a number of free-standing windmills, mostly in the open country around the town. Of the Leicester windmills, only one, or rather one site, seems to have had a continuously traceable existence. This was in the South Fields at the top of Knighton Hill, where the present cemetery is, and a mill probably stood there as early as 1316 , when John Peke granted half an acre in the South Fields to Thomas Marrow. This strip was said to run 'from the Rawdykes across Peatlingway (the present Welford Road) to the furlong which leads to the windmills'. ${ }^{8}$ This windmill perhaps belonged to the castle, and may be the one which figures in the inquisition post mortem of Henry, Duke of Lancaster in 136r, when it was valued at nothing beyond reprises. ${ }^{79}$ The South Field windmill is mentioned several times during the ${ }_{1} 5^{\text {th }}$ century. ${ }^{80}$ In 1576 it was leased by William and Thomas Astill of Wigston to Henry Newbold, a Leicester miller, for 2 I years. ${ }^{81}$ About 1594 the borough purchased the windmill from a Mr. Wightman for $£_{2} 2$, perhaps as part of the larger purchase about that time of property in the South Fields. ${ }^{82}$ If the windmill had belonged to the Duchy of Lancaster in the I 4 th century it had evidently been alienated by the I6th. From I 594 it was leased from the corporation by various members of the Nurse family at a yearly rent of $33 s .4 d_{.83}{ }^{83}$ and in $1607-8$ it was called for the first time Nurse's windmill. ${ }^{84}$ There continued to be a windmill on this site until the Igth century, probably until the land upon which it stood became part of the municipal cemetery. ${ }^{85}$

A map of the watermills made at the end of the I6th or early in the 17 th century shows a windmill of the post type, then newly built and belonging to Sir Henry Hastings, not far from the river, between the Castle and the Newarke mills. ${ }^{86}$ In 1720 the mayor

${ }_{71}$ Leic. City Mun. Room, $3 \mathrm{D}_{42 / 10 / 2 .}$

72 Ibid. $3 \mathrm{D}_{42 / 10 / 1}$

73 Ibid. $3 \mathrm{D}_{42} / 2 / 65 \mathrm{I}$.

74 Leic. $\mathscr{F} n l$. 19 May 1826.

75 White, Dir. Leics. (I 846 ), I 79. The mill is not identifiable in any dir. before 1846 or between 1846 and 1877 .

76 White, Dir. Leics. (1877), 421

77 See above, p. 327.

78 Leic. Boro. Rec. IIO3-I 327, 398.

79 Ibid. $1327-1509,126$.

80 e.g. ibid. $44^{2}$.

${ }_{81}$ Leic. City Mun. Room, $20 D_{52 / 25 / 553 .}$

82 Leic. Boro. Rec. I509-I603, 298, 307; I603-88, 9; see above, p. $37 \mathrm{I}$.

83 Ibid. $1509-1603,307$

84 Ibid. $1603-88,67$.

85 See above, pp. $266-7$.

86 Leic. Boro. Rec. I509-I603, facing p. xvii. 


\section{A HISTORY OF LEICESTERSHIRE}

was ordered to treat with Josiah Wall, miller, about his mill in the South Field. ${ }^{87}$ There was a windmill in St. Margaret's parish in I $_{5} 85$, when John Coats transferred it to IVilliam Pole and his wife Thomasina.8s This was probably the forerunner of one of the group of mills which stood near the top of London Road by the old toll bar, near the present Victoria Park gates. John Prior's map of I 779 shows three mills at this place, as well as the mill already mentioned on the cemetery site and two others, further down the London Road, near the present London Road railway station. Another windmill stood on the west side of the town, between the river and the Narborough road. Miss WVatts, in her Walk through Leicester, written in 1804 , advises the traveller, if he wishes to obtain 'a full view of a fine prospect', from the top of London Road, to "turn aside from the road, and mount the steps of one of the neighbouring mills' ${ }^{89}$ On Greenwood's map of 1826 the mills are not named, but all may be identified with those named on Ellis's map of two years later, with the exception of Mount Pleasant Mill, which was perhaps then not built. ${ }^{\circ}$ Ellis's map shows five mills, together with that on the cemetery site: Tower Mill, at the far end of the present Conduit Street, Marston's Mill in Saxby Street, Whetstone's Mill in Highfield Street, Holmes's Mill between Mill Hill Lane and Evington Road, and Mount Pleasant Mill, close by between Evington Footpath and Evington Road. It seems clear enough that the mills had disappeared from the Leicester sky-line before 1850 . Two millers in London Road are mentioned in the directory of $1835,{ }^{91}$ but it is not clear whether they lived there or were using two of these mills. One was a John Kirk Holmes, who may have owned Holmes's mill. He is mentioned again in I 846 , but this time it is clearly stated that his house was in London Road, and the mills had probably become disused before that time. ${ }^{92}$

HORSE-MILL. A horse-mill, in the present High Street, then the Swinesmarket, was in existence by I3 I4, when it was farmed together with Castle Mill by John Caleys. ${ }^{93}$ It remained the property of the Duchy of Lancaster until the I $5^{\text {th }}$ century. If the horse-mill mentioned in deeds in 1482 and 1492 is to be identified with it, it seems to have been alienated by then. ${ }^{94}$ The horse-mill is mentioned in $1452^{95}$ and again in $1517-18$, when the corporation was renting a tenement next to it. ${ }^{96}$ By 1589 the queen again had possession of it and granted it in that year to the corporation, although she had previously leased it in ${ }^{5} 580$ to a William Spencer for $2 \mathrm{I}$ years. ${ }^{97}$ The corporation leased it out in 1589 , with two messuages, presumably standing adjacent. 98 The horse-mill still existed, as a malt-mill, in $1645^{-6,99}$ when it had the two tenements attached, and its fee-farm rent was granted to the Trinity Hospital in I $650 .{ }^{100}$

\section{HOSPITALS AND ALMSHOUSES}

\section{WYGGESTON'S HOSPITAL}

William Wigston (c. I $457^{-1536)}$ ), founder of this hospital, was a member of a prominent Leicester family of wool merchants who had risen to prosperity in the $15^{\text {th }}$ century. He inherited and maintained considerable commercial interests in Leicester, in Coventry, and at the port of Calais, of which he was mayor four times. He was Mayor of Leicester in I 499 and $15 \mathrm{IO}$, and represented the borough in Parliament in 1504 . He married twice but had no children. ${ }^{\mathrm{I}}$ In I 5 I 2 he established a chantry in the Newarke College, with a chaplains' house in the precincts, and completed the foundation early in $\mathrm{I} 5 \mathrm{I} 3 .^{2}$

By letters patent of $1513^{3}$ and $1514^{4}$ Wigston was authorized to found a hospital, for two chaplains and twelve poor men, which might receive in mortmain grants of land to the annual value of $£ .49$ I 3 s. $4 d$. A

87 Leic. City Mun. Room, Hall Bk. 23 Aug. I720.

88 C.P. $25(2) / 2648 / 2$.

89 [S. Watts], Walk through Leic. I27; J. Prior, Map of Leics. (I 779).

90 T. and G. Ellis, Map of Leic. (1828); C. and J. Greenwood, Map of Leics. (1826).

91 Pigot, Dir. Leics. (I 835), I 33.

92 White, Dir. Leics. (1846), I 43 ; cf. I. C. Ellis, Rec. of I 9 th Cent. Leic. 214,216

93 See above, p. 395

94 Leic. Boro. Rec. $1509-x 603,435,440$.

95 Ibid. 259.

96 Ibid. $1609-1603,7$

98 Leic. City Mun. Room, 20D52/30/690.

99 Leic. Boro. Rec. I603-88, 353. site in St. Martin's parish was purchased in 1513 , and in $15 \mathrm{I} 8$ buildings were erected to accommodate 24 poor, the founder having added $\mathrm{I} 2$ poor women to the original number. The first chaplains were William Fisher, master ( $5^{\mathrm{I}} 3^{-34}$ ), and John Thorpe, confrater $\left(I_{5} 3_{-2} \mathrm{I}\right)$. The first inmates were admitted in I $52 \mathrm{I} .5$

Most of the lands forming the endowment Wigston purchased between I 513 and 1520 . In I 52 I he conveyed to the hospital the manors of Castle Carlton (Lincs.) and Swannington, and lands in Leicester, Wycomb and Chadwell, Oadby, and Kimcote and Walton. ${ }^{6}$ This grant of lands, valued at $£ 40$ yearly, was confirmed by letters patent of I 522.7 Following a similar method Wigston later conveyed to the hospital other lands in Allington, Foston, and Harlaxton (Lincs.), and in Bromkinsthorpe, Great Bowden, and King's Norton. To complete the endowment Wigston conveyed to trustees for the hospital lands in Burton on Trent and Horninglow (Staffs.), and in

100 Nichols, Leics. i. 345 .

I For Wm. Wigston see Wyggeston Hosp. Rec., pp. xviixxiv; H. Hartopp, R. of Mayors of Leic. 47-50.

2 A. Hamilton Thompson, Hist of Hosp. and New Coll. of ... St. Mary in the Newarke, I 36-8; Wyggeston Hosp. Rec., pp. xviii-xxi.

3 L. छ๐ P. Hen. VIII, i (2), p. 966

4 Ibid., p. 1463 .

5 Wyggeston Hosp. Rec., pp. xxvi-xxvii

6 Leic. City Mun. Room, I OD $34 / 901$, I D 5o/VIII/36, 40. For details of individual purchases of land see Wyggeston Hosp. Rec. passim, and cal. of Wyggeston Hosp. rec. in Leic. City Mun. Room.

7 Leic. City Mun. Room, IoD34/14II, printed in Wyggeston Hosp. Rec. I8-29. 
Wigston Magna, Bottesford, Barkestone, Plungar, Belvoir, Easthorpe, and Redmile. In an early draft of his will Wigston provided for the hospital's continued enjoyment of these trust lands but the subsequent enactment of the Statute of Uses made further assurance unnecessary. ${ }^{8}$ In $15^{2} 5^{-6}$ when the endowment had virtually been completed the total income of the hospital was $£ 96$ I6s. $11 \frac{3}{4} d$., of which the rents produced $£ .92$ Is. $8 \frac{1}{4} d$. Expenditure in the same year was $£ 86$ 5s. $10 \frac{1}{4} d .9$ The hospital later received the sum of fioo for the defence of its lands under Wigston's will, and a 6o-year lease of the tithes of the South Field was bequeathed to the chaplains by his widow, Agnes (d. I 54I). ${ }^{10}$

No authentic copy of the ordinances which Wigston him-

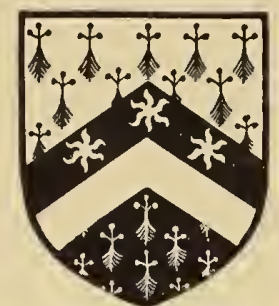
Per chevron ermine and ermines, a cherron per chevron sable and argent, upon the upper portion three etoiles or. [Leic. City Mun. Rm. IoD 34 / I I 96, / I 29 I, / I292]
William Wigston.

self made for the government and administration of the hospital survives, although a copy is known to have existed in the Igth century. A version of this is contained in a pamphlet published in Leicester after 1877 entitled The Will of William Wigston for the Government of the Wigston Hospital. ${ }^{11}$ The statutes were written in the summer of 1521 and were confirmed by John Longland, Bishop of Lincoln, in September 1 522, and by Richard Mawdely, Archdeacon of Leicester, in April 1 525. The hospital was to be called 'the Hospital of William Wigston, Junior', and dedicated to the Blessed Virgin Mary, St. Katherine, and St. Ursula and her Companions. The chaplains were to be appointed by the founder or his brother Thomas (canon of Newarke College, d. I 537) during their lives, and then by the Dean and Chapter of Newarke College, the Mayor and Justices, and the Abbot of Leicester-each having the power of nomination for terms of fourteen days successively until an appointment was made. The chaplains were to take oaths on admission to their offices, and to keep the statutes according to their 'plain, literal and grammatical sense'. The master was given control of the hospital's property and authorized to make leases of its lands. Leases were to be for terms of three years 'unless by the discretion of the master greater profit may come'. Fines for renewing leases and improvements in rents were to be converted to the hospital's use. The master's salary was to be $£ 8$, the confrater's $£ 6$; the master, but not the confrater, might hold a benefice outside Leicester to augment his salary. Both chaplains were to reside, although the master was permitted one month's leave of absence each year.

The twelve poor folk in whose name the hospital was incorporated were to be 'men, blind, lame, decrepit, paralytic, or maimed in their limbs, and idiots wanting their natural senses, so that they be peaceable not disturbing the hospital'. 'They were to be unmarried and without friends or relations to support them. In addition to these, twelve women, 'poor, aged, and of good report and honest conversation', were to be maintained in the hospital. The men

\footnotetext{
8 Ibid., pp. xxxv, 30-39.

9 Leic. City Mun. Room, r $\mathrm{D}_{50} / \mathrm{l} / 6$.

10 Wills printed in Wyggeston Hosp. Rec. 30-39, 46-49.

iI Pamphlet in possession of Mrs. F. E. Skillington of
}

were to be appointed by the founder or his brothers, and the women by the founder or his wife; after their deaths, all appointments were to be made by Newarke College, although the chaplains might fill vacancies when the college failed to appoint or made unsuitable nominations.

The chaplains were to say daily mass, either in the morning or evening at a time convenient for the poor ; on Sundays and principal feasts, matins, vespers, and other offices were to be recited in the presence of the poor. Attendance at the religious processions held in St. Martin's parish and keeping the obits of the founder's two wives were other offices enjoined on the chaplains. By a composition between the hospital, the abbey, and the Vicar of St. Martin's, the chaplains and poor were exempted from parochial jurisdiction and from the payment of tithes and other dues in return for an annual rent of $6 s .8 d$. to the Vicar of St. Martin's. 'The hospital was charged with the maintenance of two chantries in St. Martin's Church. The first was for Thomas Smyth, a Leicester draper, and was to last for seventeen years from Christmas I 525 and be paid for from money left by Smyth for the purpose; the second, for William Breyfield, to last for fourteen years from 1533 , was, however, to be maintained from the revenues. When these chantries ended, their priests were to be retained, if the revenues were sufficient, as additional chaplains to say mass for the founder's intentions.

Other ordinances governed the domestic life of the hospital. The poor men were to live in separate rooms on the ground floor, while the women were to have rooms on the upper floor with a common room in addition. No inmate might leave the hospital without permission. The men were to receive $8 d$. weekly, and the women $7 d$.; gowns were to be provided and a yearly sum of $\AA_{2} 2$ was to be allotted for new cloth. The care of the poor was entrusted to three of the stronger women, two for the men, the third for the remaining women. These women were charged with such duties as making the beds, cooking, and attending to the personal cleanliness of the inmates. 'They were to receive $8 d$. weekly and be allowed places in the hospital when they themselves became infirm.

The first years of the hospital were the most critical in its history. Throughout a period of continual political and religious change which threatened the existence of all foundations of a religious character and which in Leicester saw the dissolution of the abbey and Newarke College, the hospital preserved both its status and lands intact. That it did remain untouched was probably as much due to the newness and simplicity of the foundation, and to some extent to the vigilance and continuity in office of Walter Browne, master, and 'Thomas 'Thorpe, confrater, as to any statutory immunity.

In 1545 commissioners appointed under the first Chantry Act visited the hospital, and examined its endowment and financial state. They reported that its object was the maintenance of one warden, three chaplains and twenty-four poor to pray for the king and the founder. One chaplain was noted as a chantry priest. The chaplains and poor were 'resydent in good order and estate ... and all the seyde romes be full and none voyde'. ${ }^{12}$ The hospital, although liable Leic.; cf. 32nd Rep. Com. Char. Pt. 5 [163], pp. 76-78, H.C. $(1839)$, xv.

${ }_{12}$ A. Hamilton Thompson, 'Chantry Certificates for Leic.' Assoc. Archit. Soc. Rep. 'छ Papers, xxx. 498-505. 


\section{A HISTORY OF LEICESTERSHIRE}

for the payment of first fruits and tenths, was considered to be exempt from the Act and from the second Chantry Act which extended confiscation to every foundation for the commemoration of the dead. Thus, neither the association of two chantries supported from the revenues nor the retention of their chaplains as priests officiating for the founder's intentions obscured the primary purpose of the foundation. The religious changes, however, had one important effect on the hospital. With the dissolution of Newarke College in 1548 the Crown acquired the powers of supervision granted to the college by the founder; henceforward, the chaplains were appointed by letters patent under the seal of the Duchy of Lancaster, the chancellor acting as official visitor.

The revenues during this period, averaging between $£ 95$ and $£ 100$ yearly, provided adequately for the hospital's expenses. ${ }^{13}$ 'The chief outgoings were the allowances of the poor, totalling $£ 39 \mathrm{I} 3^{s}$.; the salaries of the master and confrater, raised in I $54 \mathrm{I}$ to $f 10$ and $f 8$ respectively; the salaries of the other chaplains, together $f_{1} 10 I_{3} s .4 d$.; payments for oatmeal, salt, fuel, and candles, averaging $f_{5}$; and fees, chief rents, ecclesiastical dues, repairs, and legal expenses, which amounted to some $£^{25}$ yearly.

In 1553 the chaplains obtained letters patent confirming the foundation licences. ${ }^{14}$ 'The object of this confirmation and its effect in defining the status of the hospital were, however, both confused by the religious changes of the reign of Mary. It was in this reign that the connexion between the hospital and a grammar school in Leicester originated. Agnes Wigston and Thomas Wigston, the founder's brother, had entrusted to certain friends, including Walter Browne, a sum of money to maintain a schoolmaster in Leicester. Lands in Allington and Denton (Lincs.), Hathern and Breedon (Leics.), and Netherseal and Overseal (Derb.), bought in I 545 with this money, were conveyed to the chaplains and poor in November $1557 .{ }^{15}$ From the income produced, the schoolmaster received $£$ Io yearly and the master and confrater took $7 s$. and $5 s$. respectively. In I $_{55} 8$, Browne and Thorpe purchased property in Humberstone Gate and Aylestone to support a second master. ${ }^{16}$

Walter Browne died in 1560 and was succeeded by Nicholas Harwar; in 1566 'Thomas Thorpe was succeeded by John Pott who combined the offices of confrater and schoolmaster. Of the two former chantry priests, Richard Wilcocks remained as 'curate' until 1573, while Nicholas Lubbenham, chaplain of the Breyfield chantry, was appointed Vicar of St. Martin's in 1557.17

During the hospital's early years most of its lands were leased for short terms in accordance with the founder's statutes. Soon, however, the practice grew of consolidating estates and leasing them for terms of 2 I years, three lives, or even 99 years. The practice of long-term leasing was not necessarily harmful so long as leases contained such safeguards as impeachment of waste and while the fines received were put to the

13 An almost complete series of hosp. accounts from I 520 to I $76 \mathrm{I}$ are in Leic. City Mun. Room, I D 50/I/I-I3I,

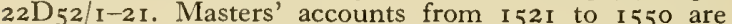
I $D_{50} / \mathrm{II} / \mathrm{I}-37$. All calculations as to income, salaries, payments to the poor, \&cc. are from these sources.

14 Leic. City Mun. Room, IoD $34 / 1416$.

15 Ibid. IoD $34 / 964$. For the hist. of the school see M. C. Cross, Free Grammar School of Leic., and above, p. 332.

I6 Leic. City Mun. Room, I oD $34 / 47$ I.

17 The last payment to a curate is in the $1572-3$ yearly hospital's own use. Two leases for 99 years, however, those of Castle Carlton (1564) and Swannington (1566) manors, resulted in grave financial loss and continual litigation. ${ }^{18}$ Although at first the increased rents benefited the hospital, the omission of safeguards in the leases, particularly in the case of the Swannington lease, and the inability of the hospital to profit from increases in land values rendered the leases uneconomic.

In 1567 the first of two inquiries into Harwar's administration was instituted. ${ }^{19}$ Commissioners were appointed to investigate the whereabouts of plate and jewels left by Browne to the hospital and the terms for which leases had been made. Harwar, however, refused to give evidence, and the commissioners were only able to record evidence of the Vicar of St. Martin's that the master had misappropriated I $_{\mathrm{I}} \mathrm{O}$ received from his predecessor. Harwar died before proceedings were taken against him. In August 1568 new commissioners of inquiry, including the Earl of Huntingdon, were appointed to review Harwar's administration in relation to the statutes, to investigate particular complaints, and to institute the new master. ${ }^{20}$ 'This inquiry revealed that Harwar had made long-term and improvident leases, that he had misappropriated $£ \mathbf{1} 66$ received from Browne, of which $f$ roo was money left by Wigston to the hospital, and $f_{1} 44$ received from wood sales, and that he had failed to account for $f 74$, the balance from i 567 , and for the receipts for the first half of 1568 . Pott was also found to owe money to the hospital but since the inquiry had fled overseas. ${ }^{21}$

The new master was Thomas Sampson, a wellknown preacher of Puritan views, who, returning from exile during Mary's reign, had received from Elizabeth several appointments, including a prebend in Durham Minster, the deanery of Christ Church, Oxford, and a prebend in St. Paul's. As master of the hospital, he was an active and able administrator, and although unsuccessful in an attempt to challenge the validity of the Castle Carlton lease, he succeeded in obtaining an agreement with the tenant of Swannington reserving certain timber for the hospital's use. Sampson also recovered from the Exchequer the annual payments for first fruits and tenths which, despite the exemption granted to hospitals in the Act of $\mathbf{I} 559,{ }^{22}$ Harwar had continued to make. ${ }^{23}$

One effect of the inquiries into Harwar's administration had been to reassert the founder's statutes. This reassertion, however, by revealing ordinances and provisions already invalidated by the Reformation changes was itself a cause of their replacement. The inquiries had also shown the need of a clearer definition of the master's powers, particularly with regard to leases. The necessary restatement of the statutes was effected when the Earl of Huntingdon, contemplating certain endowments in Leicester, among them the appointment of a town preacher, resolved to associate them with a reorganization of

account. For Lubbenham see Cal. Pat. I 555-7, 500.

${ }_{18}$ Leic. City Mun. Room, I D50/VIII/47a; I D53/r 6.

I9 D.L. 44/I 66.

20 D.L. 44/ 779.

21 For statement of debts owed at this time see Leic. City Mun. Room, roD34/1 408; for Pott see below, p. 406.

22 I Eliz. I, c. 4.

23 See Sampson's accounts passim; and Leic. City Mun. Room, I D 53/9; the certificate exonerating the hosp. from payments of first fruits and tenths is ibid. IoD $34 / 996$. 
the hospital. By letters patent of 1572 confirming the foundation, the earl, with Ralph Sadler, the chancellor, and George Bromley, the attorney general of the Duchy of Lancaster, were authorized to draw up new statutes. ${ }^{24}$ At the same time the chaplains were licensed to receive gifts of lands to the annual value of 100 marks. The new statutes were introduced in 1574 and were confirmed by an Act of Parliament of I 576.25 Except for one short interruption, during the Commonwealth period, they regulated the hospital until replaced in $\mathbf{I} 849$.

'The earl's statutes show changes, both of character and of detail, from those of the founder. Thus, they reflected his Protestant views and assured the proper use of his own endowments, and at the same time attempted to correct the former abuses in the administration.

The hospital was to be called 'William Wigston's Hospital' and was to be governed under the authority of the Crown, the chancellor and council of the Duchy of Lancaster being constituted official visitors. The master's control over the administration of the hospital was confirmed, but leases which he made were to be for terms of not longer than 2 I years or three lives, and the rents reserved were to be not less than had been paid in the previous twenty years. He was also to keep an inventory of the hospital's goods, and to survey its lands every seven years. 'The master's salary was to be $f \mathrm{I} 0$, together with 7 s. from the school lands and various allowances amounting to about fi5. In addition, he was now entitled to augment his salary by taking such fines as were reasonable for the renewal of leases. The confrater's duties were mainly concerned with the religious instruction of the poor, the nature of which was described in detail. Under his supervision, the poor were to attend St. Martin's every day for morning and evening prayers, while other evening prayers were to be recited in the hospital chapel. 'The confrater's salary was to be £I $36 s .8 d$., representing his former salary augmented by that of the curate, together with $5 s$. from the school lands.

The new statutes made few changes in the internal regulation of the hospital. The master was now authorized to fill vacancies, although in cases of neglect the confrater and the Mayor of Leicester might exercise the power in turn. No provision was made for any increase either in the number of the poor or in their weekly allowances, but when the capital of the hospital exceeded $£$ I 00 the master might distribute the surplus among charitable causes in Leicester.

In fulfilment of the licence granted in the letters patent of 1572 , the Earl of Huntingdon assigned to the hospital in 1576 three rent charges from his property in Leicester amounting to $£ 66 \mathrm{I} 3^{s .} 4 d .{ }^{26}$ This money was to be apportioned in this manner: $£$ Io to the master of the hospital ; $\oint^{6}$ I $3 s .4 d$. for new clothes for the poor; $£ 30$ to the confrater on condition that he should be 'a continual resident preacher' in Leicester and should also relinquish his share in the South Field tithes to the master; £io to the

24 Leic. City Mun. Room, IoD $34 / 1419$. The statutes are printed in Wyggeston Hosp. Rec. $54-83$.

25 C.F. i. I10, I1 2.

${ }_{26}$ Nichols, Leics. i. 484-6; Attorney General v. Wigston's Hosp. (1854), 10-14. See also Leic. City Mun. Room, $10 \mathrm{D}_{34 / 1001 .}$

${ }_{27}$ Leic. City Mun. Room, I $\mathrm{D}_{5} \mathrm{o} / \mathrm{VII} / 4 / 6-8$; $1 \mathrm{D}_{5} \mathrm{o} / \mathrm{X} /$ schoolmaster; and the remaining fio to endow two scholarships at the Universities and two at the free school itself.

The main effect of these changes was to enhance the advantages of the mastership at the expense of adequate provision for the poor. In particular, during a period when rents were generally rising throughout the country, the master's new right to take the fines for leases encouraged him to exact increasingly heavy payments rather than to raise rents and thereby increase the income of the hospital. Of more immediate damage was the failure to secure any income to pay for the allowances given to the master.

By careful management which involved the sacrificing of his personal allowances, Sampson was able to balance his accounts; but the defects in the new statutes were soon revealed under the administration of his son and successor, Nathanael, who steadily accumulated annual deficits of some $f_{1}$ I so that at his death in I6I I the hospital owed about $f 300$. The hospital's plight may be seen in the fact that rents produced in 1607 the same figure, $f_{1} I_{5}$, as in $\mathrm{I}_{573}$.

Inheriting this debt, John Herault de Saint Sauveur ( 16 I I-I3) obtained a commission of inquiry into Sampson's administration and took proceedings against his executors. It was found that he had pawned the hospital plate and embezzled money received from wood sales and from the goods of the poor. He had also granted leases at the instance of his friends. ${ }^{27}$ Herault tried to overthrow the Swannington and Castle Carlton leases, ${ }^{28}$ and his efforts were continued by his successor, Samuel Clarke (I6r3-4I), who obtained settlements improving the reserved rents. For an undertaking that his lease would not be questioned again, the lessee of the Swannington lands agreed to an increase of $f \mathrm{ro}$ in the yearly rent as well as a fine of $£ 500 .{ }^{29}$ In a similar settlement, the lessee of Castle Carlton agreed to make a rent charge of $f \mathrm{IO}$ 8s. in favour of the hospital. ${ }^{30}$

Clarke was non-resident and left the day-to-day running of the hospital in the hands of the confrater. The hospital was fortunate throughout its history in the character of the confraters, and Thomas Sacheverell and John Angel, both of whom held the post of town preacher, were able deputies and respected by the corporation. Clarke, however, exhibited all the failings of previous masters. An inquiry ${ }^{31}$ instituted after his death revealed that he had consistently taken the money received from the sale of the goods of the poor, accepted bribes for the admission of inmates, and removed hospital property to his house at Kingsthorpe (Northants.). He had also connived at inclosures of land at Norton, Snibston, and Leicester, to the hospital's detriment, and had offered tenants renewals of unexpired leases. During his mastership he received some $f, \mathrm{I}, 700$ in fines and f, $\mathbf{1}, 000$ from the South Field tithes. The original lease had been extended by Francis Hastings in 1582 for a further term ending in $1640 .{ }^{32}$ Clarke, claiming to have purchased the reversion, assigned the lease to his son shortly before his death. The hospital's doubtful title was further confused by the sequestra-

I 9-2I; D.L. $44 / 899$.

is case are Leic. City Mun. Room,

I 5 o/VII/4/6-8; D.L. 44/923.

29 D.L. $44 / 1197$

30 Leic. City Mun. Room, I D 5o/VIII/49.

3I Ibid. ID 50/VII/I/I4-34; D.L. 44/1 I 97

32 Ibid. I $550 / \mathrm{VIII} / 4$. 


\section{A HISTORY OF LEICESTERSHIRE}

tion of the estates of the principal contestants and by much cross-litigation. Finally, although the tithes were returned to the hospital by the Committee of Indemnity in $165^{\circ}$, three years later the master allowed its title to go by default. ${ }^{33}$ The hospital suffered little during the Civil War although successive masters were involved in the political struggle. William Chillingworth, a well-known controversialist and a royalist, was appointed in $164 \mathrm{I}$ but ejected by Parliament in January 1644 and died the same month. His royalist successor, John Meredith, despite a sequestration order in the following April, continued in office until the nominee of Parliament, Job Grey, was successfully intruded in 1646 . Both Grey and Angel, the confrater, actively supported the parliamentary cause only to be themselves ejected on refusing in 1650 to take the Engagement demanded by the Independents. ${ }^{34}$

While Chillingworth was master, the lessee of Swannington sought a renewal of his 99-year lease, and offered to pay,a new rent of $£ 40 .{ }^{35}$ His own tenants in the same lands also approached Chillingworth offering a $£ 400$ fine for leases directly from the hospital and urging him to contest the lease once again. ${ }^{36}$ Grey subsequently acceded to both their requests but, as the rents reserved in the new leases amounted to only $f_{2} \mathrm{I}$, his zeal little benefited the hospital. His successor, Richard Lee, considering that the hospital would derive more benefit by permitting the 99 -year lease to run its course, allowed judgement to be given against the hospital. ${ }^{37}$ The Swannington tenants thereupon stirred up complaints among the poor against Lee. A petition sent on their behalf in 1652 calling for a survey of the hospital lands was, however, set aside by the duchy court on legal grounds. ${ }^{38}$

Further petitions ${ }^{39}$ by the poor, by the confrater, William Simmes, and by the mayor and burgesses of Leicester complaining against Lee's administration led to the appointment in February 1656 of a commission of inquiry. 40 The main complaints, which Lee effectively answered, concerned the low rental value of the hospital lands, stated to be $£ 200$ compared with an estimated value of $f_{1}, 1,200$, the alleged oppression of the Swannington tenants, and the master's retention of most of the profits from the South Field tithes. The following June an Order in Council appointed Major General Whalley to examine the value and appropriation of the revenues and the condition of the foundation, and ordered no further leases to be made meanwhile. No evidence of this second inquiry is recorded.4I Towards the end of I 656 the mayor and corporation petitioned Parliament for a reform of the hospital and in November William Stanley, one of the members for Leicester, introduced a bill to regulate its government. Lee strongly contested the bill but it was read a third time in February

33 Leic. City Mun. Room, I $D_{50} / \mathrm{VII} / \mathrm{I} / \mathbf{1 4}^{-34}$.

34 Ibid. ID $50 / V I I / 3 / 3$; Leic. Boro. Rec. I603-88, 396.

35 Leic. City Mun. Room, I $\mathrm{D}_{50} / \mathrm{VII} / 4 / \mathrm{II}_{1}-23,26-27$, esp. 19-22.

36 Ibid. I $\mathrm{D}_{50} / \mathrm{VII} / 4 / 9$

38 Ibid. I D $50 / \mathrm{VII} / 3 / 5$.

39 For these petitions see Cal. S.P. Dom. 1655-6, 94 99, I 48, I74; Leic. City Mun. Room, Hall Papers, I653-5, pp. $76 \mathrm{I}-3,765,766$; ibid. $1655-6$, pp. I $78,237,238$; see also $\mathrm{ID}_{5} \mathrm{o} / \mathrm{VII} / 3 / \mathrm{I}-8$.

Leic. City Mun. Room, I D $50 / \mathrm{VII}_{3} / \mathbf{1}-8$; see also ibid. I $\mathrm{D}_{5} \mathrm{o} / \mathrm{VII} / 5 / \mathrm{r} 3$.

${ }_{41}$ Ibid. Hall Papers, $1655^{-6}$, p. I $78 ; 1 \mathrm{D}_{50} / \mathrm{VII} / 3 / 15$; D.L. $44 / 1203$.
I 657 and received the Protector's assent on 9 June.42 The Act placed the control of the hospital in the hands of 22 trustees and governors, who were to include the master and the Mayor of Leicester. ${ }^{43}$ They were authorized to make by-laws and ordinances and given power to make leases not exceeding 2 I years and these were to be made upon reasonably improved rents instead of fines. The master's salary was fixed at $£ 40$ and the allowances granted him in the Huntingdon statutes were revoked. Provision was also made for the development of the hospital in the form of increases in the number of the poor. The Act thus overturned the Huntingdon settlement which had invested in the mastership the whole profit of the hospital's possessions, and introduced reforms which, had they been confirmed at the Restoration, would have put the hospital on a sound footing and enabled its objects to be extended.

Despite Lee's resistance to the bill, and criticism of his accounts made during its progress, he was confirmed as master and granted a licence for nonresidence. ${ }^{44}$ During their short period of control the governors succeeded in increasing the hospital revenues although rents still were inadequate to meet higher expenditure. In 1607 receipts had been $f_{1} \mathrm{I} 5$ and payments $f_{1} \mathrm{I3}$, the Huntingdon rentcharge being accounted for separately; by 1650 , receipts had risen to $£_{222}$ and payments to $£_{240}$; in 1659 , receipts totalled $£ 267$, of which $£ 235$ came in rents, and payments $f_{243}$. In 1656 the number of the poor was increased by the addition of one poor woman for whose maintenance John Whatton of Leicester gave a rent-charge of $f_{7} 7$ from a close in All Saints' parish to the mayor and burgesses. 45

At the Restoration the authority of the Huntingdon statutes was re-established. John Meredith, excluded since 1646 , returned as master in June 1660 , and Thomas Pestell the younger replaced Simmes as confrater. One of Meredith's first measures was to increase the allowances of the poor. These had remained at the scale fixed by the founder for more than a century until Clarke had raised the sums to $13 d$. for the men and nursing women, and I $d$. for the other women. Lee had supplemented the allowances from his receipts from the South Field tithes, and they had been raised in 1659 . Increases in $166 \mathrm{r}$ and 1663 brought the respective sums to $2 s$. and $\mathrm{r} s$. Iod. and the total payments to $£_{4} 0$ above the $165^{\circ}$ figure. Improved rents helped to meet this new charge on the revenues, particularly a reserved rent of f6o on the new lease of the Swannington lands, the original 99-year lease having been surrendered soon after the Restoration. ${ }^{46}$ Thus when Meredith died in 1665 , the hospital was at last able to meet its expenses.

The master, whose salary of $£ 35$ was no longer augmented from the South Field tithes, continued,

42 Leic. City Mun. Room, Hall Papers, I655-6, pp. 237 , 238 ; C.F. vii. $456,461,465,466,486,487,490,492,552$. 43 Nichols, Leics. i. $488-90$.

44 Leic. City Mun. Room, I $\mathrm{D}_{50} / \mathrm{VII} / 3 / \mathrm{I}_{4}$. A group of papers relating to the administration of the hosp. in this period were kept among the boro. rec. : see Leic. City Mun. Room, Misc. VI, I-55.

45 G. Cowie, Hist. of Wyggeston's Hosp. 29; see also Leic. Boro. Rec. I603-88, 244-5; 32nd Rep. Com. Char. Pt. 5, 35. This charity is still paid by the Trustees of Leicester General Charities: ex inf. Mr. S. H. Partridge, clerk to trustees.

${ }^{46}$ Cf. Leic. City Mun. Room, I $550 / 1 / 72,73$. 


\section{THE CITY OF LEICESTER}

however, to take the fullest advantage of his right to take the fines for renewal of leases to the hospital's detriment. The result was that, although most of the leases were renewed during the second half of the I 7 th century, there was an improvement of only $£$, IOo between 1660 and 1697 in the rents received, and of this the increase in the rent of Swannington from $£ 35$ to $f 70$ in 1668 together with some $f_{1} 8$ in mining rents from Snibston contributed the greater part. The 99-year lease of Castle Carlton expired in 1665 but the old rent was increased by only $£ 3 .{ }^{47}$ Although increases in the allowances of the poor and other expenditure fully absorbed this new revenue, the hospital's financial condition was at this period healthy.

In September I697 a commission, appointed by the chancellor of the Duchy of Lancaster, reported favourably on the financial state of the hospital and on the discipline of the poor.48 The revenues were stated to be $£ 342$, the buildings in good repair, and a 'considerable addition' noted in the allowances of the poor. The master, Robert Hardwick, did not reside, but the commissioners regarded this as a benefit to the hospital since this meant that his allowances did not have to be paid. The confrater's salary was considered 'too scanty and narrow' and it was recommended that it should be doubled. The advantages of this office did not compare with those of the mastership, yet when combined with the town and Trinity Hospital lectureships and a Leicester benefice the post provided quite a comfortable living.

Unfortunately the prosperity reported by the 1697 commission was both artificial and temporary, for by I730 the hospital was once more in serious debt. In I 700 rents produced $£ 343$ and although payments amounted to $£ 350$ the hospital had capital of $f_{1} 128$; in 1760 the balance of accounts was similar, rents being $£ 357$ and payments $£ 363$ but the hospital owed the master $£_{120}$. Most of the current leases had been made in the late $\mathrm{I} 7$ th century for terms of three lives and the result was that the value of the hospital lands remained stationary when costs continued to rise. A 1729 rental shows two leases dating from $I 620$ and $I 634$, twelve from $I 660-5$, and the rest from between $\mathrm{I} 66_{5}$ and $\mathrm{I} 689$; no leases, were made between 1689 and 1729.49

During the 18 th and early I 9 th centuries the hospital provided in the mastership a comfortable sinecure for a succession of eminent and learned men who personally had little concern for its well-being. John Jackson, a scholar whose Unitarian views aroused widespread controversy and whose conflict with Samuel Carte, Vicar of St. Martin's, caused much local scandal, was followed by William Rawstorn, Folliott Herbert Walker Cornewall, later successively Bishop of Bristol, Hereford, and Worcester, and John Selwyn. Of these, only Jackson resided at the hospital and it was to his credit that despite inadequate revenues repairs to the hospital buildings were carried out and the allowances of the poor raised in $175 \mathrm{I}$ and I $755 .{ }^{\circ 0}$

The affairs of the hospital, which throughout the

47 Ibid. I $\mathrm{D}_{5} \mathrm{O} / \mathrm{VIII} / 52$.

48 Ibid. $\mathrm{ID}_{50} / \mathrm{XI} / 7$.

49 Ibid. $\mathrm{rD}_{5}$ o/IV/24.

50 Nichols, Leics. i. 495.

5I See R. W. Greaves, 'Old Leic. Corporation and the Town Almshouses', T.L.A.S. xxi. I65 seq.

${ }_{52}$ Rep. of Mayor and Corporation of Leic. relating to
I 8 th century engaged little public attention, were during the I 9 th century the subject of continual debate and many schemes for reforming its government were introduced. Once again reforms arose from the investigation of complaints. In I 82 I Selwyn was criticized for the removal and sale of fabric from the hospital chapel, for his non-residence, and for misappropriating the proceeds from sales of wood. Later it appeared that Selwyn had converted the latter into capital to augment the hospital's negligible income. The master's exclusive enjoyment of the fines for leases was, however, the centre of the criticism. A public meeting held in December $\mathbf{I} 822$ petitioned the mayor for official support of a demand for the remedy of abuses, and the town clerk, Thomas Burbidge, was ordered to examine the borough records relating to the hospital.5I In his report Burbidge reviewed the administration in the light of both the Wigston and the Huntingdon statutes and drew particular attention to two clauses in the latter from which the hospital's difficulties stemmed. He vividly contrasted the way in which the masters had interpreted the clause that rents reserved in new leases should be as much as or more than those received during the previous twenty years, keeping the rents almost stationary, with the latitude of interpretation that they had given to the clause permitting their exclusive use of the fines for renewals. ${ }^{52}$

In 1823 a local committee was formed which sought the abolition of leasing for three lives, a fixed salary for the master, and the amendment of the statutes, ${ }^{53}$ and a petition with 5,400 names was sent to the chancellor of the duchy. The chancellor promised to make rules ensuring the gradual increase in reserved rents and obliging the master to account for the fines he received and also to reside for part of the year. Later the same year, the chancellor admitted that the practice of leasing for three lives was improvident but argued that too sudden a change would be harsh and even unjust. William Vansittart $(1823-47)$ on his appointment undertook not to take excessive fines, ${ }^{54}$ from which Selwyn had received some $f_{24}, 400$, and the committee, feeling its main object achieved, ceased further action. In I 826 and I 833 Vansittart further undertook to raise rents on renewals by a gradual scale to an increase of one-third on the third renewal. Moreover, he agreed to account for fines received, to keep the hospital buildings in good repair, and to raise the confrater's salary to £Ioo. Vansittart, who did not reside, augmented his salary of $£ 45$ by the rent of the master's house and, between I 823 and I 834 , by $\{2,588$ in fines. However, despite new rules and safeguards, the hospital lands by $\mathbf{1} 834$ produced only $£ 416$, compared with $£ 357$ in 1760.55

Commissioners appointed under the Charity Act ( 1837 ) examined the hospital in $1837 .{ }^{.6}$ In 1834 the hospital's income was $£ 508$, of which capital invested by Selwyn in annuities produced $£_{71}$; expenditure in the same year was $£, 500$, the poor receiving a weekly allowance of $4 s$. each. In I 844 Vansittart made a temporary addition of four women to the number of the poor and these he maintained at his

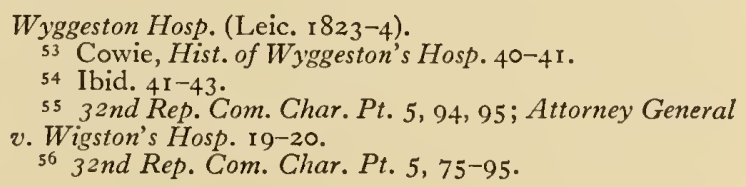




\section{A HISTORY OF LEICESTERSHIRE}

own expense. ${ }^{57}$ Gradually the new rules began to have effect and by 1854 the revenues, excluding mining rents, had risen to $f 840 .{ }^{58}$

Soon after the appointment of Edward Thomas Vaughan (1 847-60) as master, Chancery proceedings were commenced with the objects of reforming the practice of life-leasing and of vesting the administration in the hands of trustees.59 These concluded in I 849 , when the court, declaring that the Huntingdon statutes in so far as they permitted the master to grant leases and retain the fines were neither authorized by the 1572 letters patent nor confirmed by the I 576 Act, ordered that the practice of life-leasing should stop. At the same time the master's salary was commuted to a fixed sum of $f_{2} 200$.

In 1854 proposals that the charity should support the Free Grammar School were widely discussed, and in 1857 a new scheme for reorganizing the hospital was approved in Chancery. ${ }^{\circ}$ This placed the management of the hospital lands in the hands of twenty trustees with power to make leases for terms not exceeding $2 \mathrm{I}$ years. A receiver of rents, a surgeon, and a clerk were also to be appointed. The sum of $f_{0} 2,500$ was settled as the hospital's annual income and the residue of the actual revenues with royalties from mining leases was to be invested as capital. The master's salary was raised to $£ 300$ but his authority was now limited to matters of internal discipline. The confrater, who was now to receive $£ 200$, was charged with reading morning prayers, performing divine service and delivering sermons on Sundays, and administering the Lord's Supper monthly. The poor's allowances were also increased, the keepers or nurses receiving $\mathrm{I} O \mathrm{~s}$. and the remaining poor, both men and women, $8 s$. each. Finally, the trustees were directed to provide new hospital buildings which were in fact built (see below), and given authority to set up schools for 200 boys and 100 girls. ${ }^{61}$

The provisions of the 1857 scheme for the founding of schools were set aside by the Endowed Schools Act of 1869 , and a fresh scheme for the charity was approved 1873 . This divided it into a hospital and a schools branch and appointed a separate body of governors, as distinct from the hospital trustees, to administer the schools. A sum of $f_{1}, 000$, raised to $f_{20}, 000$ in 1875 , was allotted for building the schools, and a yearly sum of $f_{5} 500$ set aside for the boys' school to be increased to $f 2,000$ a year on opening. The powers of the duchy over the schools branch were transferred to the Charity Commissioners, and regulations for the schools, which were to be called the 'Wyggeston Hospital Schools', were established. 'The boys' school near the site of the old buildings was opened in I877 and the girls' school in Clarence Street in the next year.

In 1876 the trustees recommended changes in the administration including a new corporate body to control both the estates and the internal life of the hospital, the appointment of a single chaplain, and a system of outdoor relief. 62

The 1873 scheme almost caused the closing of the

57 Cowie, op. cit. 44 .

${ }_{58}$ The Igth cent. accounts are in the custody of the hospital. 9 Cowie, op. cit. $44-46$.

60 Attorney General v. Wigston's Hosp. 21-44; Cowie, op. cit. 46-5I

61 For the schools see above, pp. 332-3.

62 Cowie, op. cit. 69-7 I.

${ }_{63}$ This had been suspected in 1876 : ibid. 70

64 Cowie, op. cit. $71-72$ hospital, for the charity could not afford the annual payment of $f_{2}, 000$ for the support of the schools. ${ }^{63}$ In 1876 the revenues amounted to only $f 2,800$ from land rents and $f_{\mathrm{I}}, 400$ from mining rents. A temporary arrangement whereby the schools' income was paid from the mining rents, which formerly had been invested to form capital, enabled the hospital to survive. ${ }^{64}$ 'The threat to the hospital's independent existence which lay in the contention of the Charity Commissioners that the schools' income was intended by the 1873 scheme to be the first charge on the revenues was increased when in March 1887 a Chancery order in favour of the schools branch finally settled the relative claims of the two branches of the charity. This time the hospital branch was preserved by a further Chancery order which allowed the mining rents to be diverted to meet its needs.

In May 1892 the Charity Commissioners introduced a new scheme, ${ }^{65}$ which united the trustees and governors of the two branches and gave the new corporate body effective control over the whole charity. Leases were to be for a maximum term of 7 years, both mining rents and receipts from wood sales were to be invested, and the annual payment of $f 2,000$ to the schools was settled as the first charge on the revenues. The trustees were given power to nominate new inmates and to vary their allowances between a minimum of $7 s$. and a maximum of $10 s$. weekly. The scheme included provision for an increase in the number of the poor and the introduction of a system of outdoor relief on which, when the revenues were sufficient, the trustees might spend up to $f, 400$. Another provision for the appointment of one chaplain only was put into effect when, on the resignation of the confrater in 1892 , that office was abolished.

In 1892 the charity received an income of $£ 5,146$ from estates comprising 3,230 acres and in addition had an invested capital of $£_{1}{ }_{5}, 000$. Even at this date almost one-third of the current leases had been made before 1847 , and these produced only $\AA_{1} 85$.

The hospital is at present ( $195^{6}$ ) regulated by a scheme introduced by the Charity Commissioners in March I925. Amendments to the scheme were made in $1932,1937,1947$, and I95 I to enable the amounts of out-pensions and sick-assistance to be raised. ${ }^{66}$ The management is vested in eighteen governors, of whom the lord mayor and the master act ex officio, twelve are appointed by the city and county councils and other bodies, and the remainder are co-opted. The inmates receive each ros. weekly, a yearly sum of $£ 4,000$ is available for outdoor relief, and $£, 500$ is payable in sick-assistance benefits. Recent land transactions, including the sale of the Castle Carlton estates in $1947-8$ and purchases at Norton by Galby in $1928-9$ and $1933-4$ and at Churchover (Warws.) in $1935-7$, have increased the total estates to 4,677 acres. In I950-I the income of the hospital was $f_{20}, 000$ and expenditure some $f 19,000$, while a balance of $£, 5$, ooo was carried over and the hospital possessed stock whose nominal value in March $195^{\mathrm{I}}$ was $f 209,000.67$

65 Ibid. $80-83$; see also Leic. City Ref. Libr., Pamphlets $\mathrm{O}_{3}$, xiv, Rep. of Town Clerk of Draft Scheme for Char. Com. for future administration of Charity.

66 Copies of these schemes are with the clerk to the charity: I 025/878, $\mathrm{C}_{5} 6,087, \mathrm{pt}$. iv; $1932 / \mathrm{r} 829, \mathrm{C}_{107,712 \text {; }}$ I 937/3842, C107,7 12; 1947/1886, C120,765; 1951/2306, CI20,765.

67 The printed accounts of the hosp. are in Leic. City Ref. Libr. from 1907 to date. 


\section{THE CITY OF LEICESTER}

The Wyggeston Grammar Schools are no longer attached to the foundation but the annual payment of $£_{2}, 000$ is continued and is applied in special benefits for pupils of both schools. 68

The buildings in which Wyggeston's Hospital was housed from its foundation until I868 stood in St. Martin's West, facing the west end of the church and the churchyard. The hospital building was a long two-storied building, timber-framed and covered with plaster. There seems, most unusually, to have been a stone parapet and stone buttresses. At the north end was the master's house, originally the same height as the rest of the hospital, but enlarged in 1730 by the addition of one story and a sloping slate roof. ${ }^{69}$ At the south end was the little stone Gothic chapel, abutting on Peacock Lane. This was also restored in 1730.70 The twelve rooms for the male hospitallers were on the ground floor, and there were nine similar rooms for the women on the upper floor, together with the nurses' rooms. A further range of building at the back contained store-rooms and kitchens and was probably built later than the main block. Behind the hospital was a courtyard and garden, with an entrance from High Cross Street in which stood the confrater's timbered house. ${ }^{71}$

The chapel contained a considerable quantity of painted glass, most of which was removed at the beginning of the I 1 th century to the parish church of Ockbrook (Derb.). Some of the windows were blocked up at the same time. The chapel also contained the tombs and monuments of several of the masters and confraters, including that of the first master, William Fisher. ${ }^{72}$

The old hospital was vacated in April i 868 but the building remained standing until I 875.73 Despite proposals, which were urged by the Leicestershire Archaeological Society, to have the hospital converted for use as the hall of the proposed Wyggeston School, the trustees decided in 1873 that it must be demolished.74 In May 1874 the confrater's house, with several other old houses in High Cross Street, was demolished, and the hospital building and chapel were pulled down in 1875 , when the materials and fittings were sold for $f 92.75$ The tombs and memorial slabs from the chapel were removed to the new chapel; the seats from the chapel were given to the

68 See above, p. 333.

69 Cowie, op. cit. 38,54 .

70 Ibid. 55.

71 The old buildings are described in Cowie, op. cit. 54-58; T.L.A.S. i. I 30-I ; T.L.A.S. iv. 52-53. For illustrations see also Nichols, Leics, i, plate xxxiv. Copies of over $3 \circ$ detailed drawings and plans made by Sir Henry Dryden are in the library of the Leics. Arch. and Hist. Soc. at the Guildhall, Leic.

72 Cowie, op. cit. 55 ; Nichols, Leics. i. 495.

73 Cowie, op. cit. 53, 58; T.L.A.S. v. 12.

74 For the negotiations by the Leics. Arch. Soc. see

T.L.A.S. ii. 200-2, 206, 284-5; iv, I05, I I 2, 229-32, 322-3.

75 T.L.A.S. v. I $1-13$.

76 Ibid. I2; and see below, p. 408 .

77 Spencer, New Guide to Leic. (1 888), 38 ; and see above, p. $38 \mathrm{I}$. For a photograph of the new buildings see above, plate facing p. 393 .

${ }_{78}$ For good impressions see Leic. City Mun. Room, IoD $34 / 997,989$, I000.

79 Nichols, Leics. i. 478

so Illustrated on the cover of Wyggeston Hosp. Rec.; the date has been omitted from the block.

${ }_{81}$ Nichols, Leics, i. 495 and plate xxxiv.

82 See above, p. 398.

83 Fisher's will is dated I 5 Dec. 1534: Leic. Wills, I 49 5-I 649 (Index Libr. xxxvii), 22. 'The master's stipend for the year $1534^{-5}$ is divided equally between Browne and
Trinity Hospital and the porches which had faced the path in St. Martin's West were given to St. Nicholas's Church, together with a niche from the chapel. ${ }^{76}$ The site of the old chapel is marked by a railed square in the yard of Alderman Newton's Boys' School.

The new buildings were built in Westcotes and were occupied in I868. The architect was the Crown Surveyor, T. C. Sorby. 77

Four seals of the hospital are known. The first common seal, which was used until the promulgation of the Huntingdon statutes, was a pointed oval seal, $2 \frac{1}{2}$ in. long and $I_{5}^{3}$ in. across at its widest point, depicting the Virgin and Child with the arms of the founder beneath and the legend, in black letter, SIGILLUM COMMUNIE HOSPITALIS WILLELMI WIGSTON. ${ }^{78}$ The Huntingdon statutes provided for a new seal to be kept in the common chest. ${ }^{79}$ A matrix which still survives seems likely to be that of this seal, though it is not now used. It is a round seal, $\mathrm{I} \frac{3}{5} \mathrm{in}$. in diameter, bearing the arms of the founder flanked by his initials with the legend in Roman capitals SIGILLUM HOSPITALIS GULIELMI WIGSTON at the top, and below DATE ELEEMOSYNAM ET ECCE OMNIA MUNDA SUNT voBIs. The date ' $A^{0}$ I 574 ' appears after the word 'Wigston' in the upper inscription. ${ }^{80}$ In 1673 a new matrix was made with the same designs and legend on a rather larger seal $2 \frac{3}{10}$ in. long and $2 \frac{1}{10}$ in. across at its widest point, on which the legend, in Roman capitals, runs in two lines round the founder's arms. The matrix is dated on the back. A smaller seal, probably made at the same time and formerly used for sealing leases, ${ }^{81}$ bears the founder's arms without inscription. These three matrices are kept by the clerk to the governors.

\section{Masters of Wyggeston's Hospital}

William Fisher

Walter Browne

Nicholas Harwar

I 5 I $3^{82}-$ I 534

Thomas Sampson

I $535^{83-I} 560^{84}$

I $560^{85}-$ I 568

Nathanael Sampson

I $568^{86}$ - I 589

John Herault de Saint Sauveur I $589^{87-\text { I } 6 \text { I I }}$ I 6 I I ${ }^{88}-$ I6 6 I 3

Samuel Clarke

I 6 I $3^{89-I 64 I}$

William Chillingworth

Fisher. The financial year began on All Saints' day: Leic. City Mun. Room, ID $50 / I_{1} / 9$

${ }_{84}$ Browne's will, i 560: Leic. Wills, I 495-I649, 46. An inventory of his goods was made $30 \mathrm{Jan}$. 1560/1: Leic.

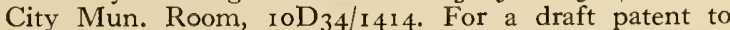
Thomas Lewen, Master of Newarke Hospital, dated I Eliz. I (I 558-9) see D.L. I3/3, I-I I Eliz. I; also P.R.O. Index to Duchy of Lancaster Patents, Henry VIII-I 835 (hereafter cited as D.L. Index to Patents), f. I 21 . 'There is no mention of Lewen in the hosp. rec.

${ }_{85}$ Appointed by Bishop of Lincoln: D.L. 44/r79; cf. accounts: Leic. City Mun. Room, $\mathrm{ID}_{50} / \mathrm{I} / 33,22 \mathrm{D}_{52} / \mathrm{I}$, ID $50 / \mathrm{II} / 33$.

86 Harwar died Aug. 1568: Leic. City Mun. Room, $22 \mathrm{D} 52 / 9$; his administration is in Leic. Wills, I 495-1649, I 59. Sampson's patent, Io Eliz. I: D.L. Index to Patents, f. 124 ; see also D.N.B

${ }_{87}$ Patent, the first granted for life, 3 I Eliz. I : D.L. Index to Patents, f. 124.

88 Herault's first accounts are dated from Sept. I6II: Leic. City Mun. Room, I D $50 / \mathrm{I} / 68$. Clarke's patent gives date of Herault's: ibid. I D5o/XI/I ; see also D.L. Index to Patents, f. I 47v.

${ }_{89}$ Leic. City Mun. Room, ID $50 / X I / I$; D.L. Index to Patents, f. I $49 \mathrm{v}$.

90 D.L. Index to Patents, f. I66. Clarke died April I64I : Leic. City Mun. Room, I D $50 / \mathrm{XI} / 4$. 


\section{A HISTORY OF LEICESTERSHIRE}

John Meredith

Job Grey

Richard Lee

John Meredith (restored)

Richard Clarke

John Pyke

Robert Hardwick

Samuel Clarke

John Jackson

William Rawstorn

Folliott Herbert Walker Cornewall

John Selwyn

William Vansittart

Edward Thomas Vaughan

David James Vaughan

Edward Atkins

Sydney Thorold Winckley

James Sidmouth Cooper

\section{Confraters of Wyggeston's Hospital}

John Thorpe

Richard Walsh

Thomas Thorpe

John Pott

Peter Wood

Geoffrey Johnson

Nathanael Sampson

Thomas Sacheverell

John Angel

William Simmes

Thomas Pestell

John Newton

John Rogers

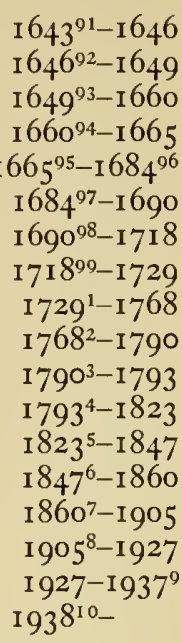

I $5^{1} 3^{11}-1521$

I $52 I^{12}-I 533$

I $533^{13-I} 5_{66}^{14}$

I $566^{15}-$ I $568^{16}$

I $569^{17}-I_{57} I^{18}$

I $572^{19}-1585$

I $585^{20}$ - I 589

I $589^{21}-1626^{22}$

I $626^{23}-1652$

$1652^{24}-1660$

$1660^{25}-\mathrm{I} 667$

I $667^{26}-\mathrm{I} 696$

I $696^{27}-$ I 713

91 D.L. Index to Patents, f. I67; D.N.B. sub Chillingworth; Leic. City Mun. Room, I D5o/VII/3/ra, an acct. of recent events by Norrice Wood, deputy to Richard Lee. ${ }_{92}$ D.L. Index to Patents, f. I67. Leic. City Mun. Room, ID $50 / \mathrm{VII} / 3 / \mathrm{ra}$.

93 Patent dated I649: D.L. Index to Patents, f. I69v. Grey was not certified as being unwilling to take the Engagement until I650: Leic. City Mun. Room, ID50/ $\mathrm{VII} / 3 / \mathrm{ra}, \mathrm{b}, 3$.

${ }^{94}$ Returned to office Oct. I660: ibid. I $\mathrm{D}_{50} / \mathrm{I} / 7 \mathrm{I}$; ID5o/III/7.

95 D.L. Index to Patents, f. I8I.

96 His widow signs account roll for $1683^{-4}$; Leic. City

Mun. Room, ID5o/I/84.

97 D.L. Index to Patents, f. I9o.

98 Ibid. f. 200

99 Ibid. f. 2 I 7 ; see also D.N.B.

D.L. Index to Patents, f. 226 ; see also D.N.B.

2 D.L. Index to Patents, f. 264

3 Ibid.

4 Ibid.

5 Ibid. f. 265.

6 Cowie, Hist. of Wyggeston's Hosp. App. A; Vaughan

Working Men's College, ed. E. Atkins, I2.

Ibid. I 4-I 5 .

8 Leicester's Freemen, 19 (copy in Leic. City Ref. Libr.).

9 Leic. Dioc. Cal. (1938), 92; Leic. Mercury, , о May 1937.

${ }_{10}$ Leic. Dioc. Cal. (1938), 88

II See above, p. 398.

12 Thorpe died Aug. 1521: Leic. City Mun. Room, ID $50 / \mathrm{I} / \mathrm{I}$. For Walsh's succession: ibid. I $550 / \mathrm{I} / 2$.

${ }_{13}$ Walsh and Thorpe shared the confrater's stipend in 1532-3: ibid. I D5o/I/I3.

14 'Thorpe's administration: Leic. Wills, I 495-I649, I 59.

15 Pott's patent, 8 Eliz. I ( $1565-6)$ : D.L. Index to Patents, f. I $23 \mathrm{v}$; see also M. C. Cross, Free Grammar Sch. of Leic. I I, n. 4 , I 2 .

I6 Fled to Louvain, Sept. I 568: see note on account roll I567-8: Leic. City Mun. Room, I D50/I/34.

${ }_{17}$ An unnamed confrater received one quarter's salary in 1568-9 and in $1569-70$ Wood received three quarters' salary, the other quarter being paid to a Mr. Greshop who is otherwise unknown: Leic. City Mun. Room, $\mathrm{I}_{5} \mathrm{O} / \mathrm{I} / 35$,
George Anderson

$1713^{28}-1718$

Robert Anderson

John Jackson

Philip Hacket

William Tiffin

Thomas Ludlam

William Hayton

Jemson Davies

John Wing

Humphrey Davey Millet

Thomas Henry Jones

Thomas Yard

$1718^{29-1719}$

$1719^{30}-1729$

$1729^{31}-1735$

$1735^{32}-1755$

$1755^{33-1} 812$

I 8 I $2^{34-1} 820$

I $820^{35}-1857$

I $857-186 \mathrm{I}$

I $861-1867$

I $867-1875$

I $875-1892^{36}$

\section{TRINITY HOSPITAL}

At the dissolution of the Newarke College in $1547^{37}$ the hospital attached to it continued to exist under royal patronage, providing accommodation for 100 poor men and women and Io nurses. ${ }^{38}$ The annual revenues of the hospital in the period immediately after the dissolution of the college amounted to nearly $f 220$, and were paid through the Duchy of Lancaster. ${ }^{39}$ In I610 the Earl of Huntingdon, who had bought the patent of the former master, William Fowkes, sold it to Leicester Corporation for f26 I3s. $4 d .40$ The hospital was incorporated as the Hospital of the Holy and Undivided Trinity by James I in I6I5.4I The incorporation was preceded by an inquiry into the activities of William Fowkes with regard to the endowments of the hospital, and the corporation was assisted in its application for the charter by Sir William Heyrick. ${ }^{42}$ 'In I6 Io the Com-

36. See also a list of confraters commencing with Wood: ibid. $\mathrm{ID}_{3} \mathrm{I} / 78 / 3$.

I8 Inducted to vicarage of Castle Donnington: Leic. City Mun. Room, ID 4 I/28/I4I.

I9 Mentioned in new statutes, Nov. I573; ibid. IoD $34 /$ I 419; see also Nichols, Leics. i. 477,501 .

${ }_{20}$ Johnson died I 585 : Nichols, Leics. i. 495 ; see also Leic. City Mun. Room, $\mathrm{ID}_{3} \mathrm{I} / 78 / 3$.

2I Sampson became master this year: see above, Sacheverell's patent: D.L. Index to Patents, f. I $32 \mathrm{~V}$.

22 Will in Leic. Wills, I495-1649, 121 .

${ }_{23}$ D.L. Index to Patents, f. I 57 ; for Angel see T.L.A.S. xxxi. 35 sqq.

${ }_{24}$ D.L. Index to Patents, f. I 70. Angel and Simmes each received half the salary for the period Mich. I65 I-Ladyday, I652: Leic. City Mun. Room, I D50/I/70.

${ }_{25}$ D.L. Index to Patents, f. I7Iv.

26 Ibid. f. I8Iv.

27 Ibid. f. $201 \mathrm{~V}$.

29 Ibid. f. 2 I 7.

30 Ibid.

31 Ibid. f. 226

32 Nichols, Leics, i. 503. The account rolls for this period are missing; see also D.N.B.

${ }_{33}$ D.L. Index to Patents, f. 235

34 Ibid. f. 265.

35 Ibid.

${ }^{36}$ Cowie, Hist. of Wyggeston's Hosp. App. A, gives dates for later confraters. Jones's patent, 1867 , is Leic. City Mun. Room, 6D 50.

37 For the Newarke College and its hospital before 1547 see V.C.H. Leics. ii. $48-5 \mathrm{I}$.

${ }_{38} 32 n d$ Rep. Com. Char. Pt. 5 [163], pp. $4 \mathrm{I}-42$, H.C. (I 839), Xv. The only document apparently remaining for this period seems to be a paper sheet of accounts, I 552-3: Leic. City Mun. Room, I D5o/XIII/2-8.

39 32nd Rep. Com. Char. Pt. 5, 4 I.

40 Leic. Boro. Rec. I603-88, 93-94; Nichols, Leics. i. 339.

${ }_{4 i}$ Leic. City Mun. Room, I $\mathrm{D}_{3} \mathrm{I} / \mathrm{I}$; Nichols, op. cit. 340; 32nd Rep. Com. Char. Pt. 5, 42-43.

42 Nichols, op. cit. 340-5; Leic. Boro. Rec. I603-88, I I I-I 2,150, I $56-7$. 
mon Hall decided that the master's yearly salary of £1 $36 s .8 d$. should be paid into the town's chamber, 43 but the salary was granted specifically to the mayor by Charles $I$ in 1625.44

The charter of $161_{5}$ provided that the hospital should be governed by the mayor as master, with four aldermen and the two chamberlains as his assistants. A chaplain was to care for the inmates, who were not to exceed $\mathrm{I} I \mathrm{O}$ in number. The maximum yearly value of land which might be held by the hospital was increased to $£ 35^{\circ}$. In I6 I 9 new statutes for the regulation of the hospital were promulgated under the seal of the Duchy of Lancaster; these have been added to from time to time. 45 The revenues of the hospital consisted of $\$ 229$ in 1643 , all provided by the duchy grant. ${ }^{46}$ In 1647 Parliament stopped this grant and the hospital was supported until I 650 by the corporation, which took great credit for this but in fact regarded the money as a loan.47 In 1650 Parliament granted to trustees certain rents which produced an income of $£ 271$, out of which the hospital, the usher of the Free Grammar School, and the Vicar of St. Mary's were supported. ${ }^{48}$ The duchy's payment of $£ 229$ was resumed at the Restoration. 49

During the late $17^{\text {th }}$ and early 18 th centuries the hospital was almost perpetually in financial difficulties, ${ }^{50}$ which the Duchy of Lancaster was unwilling to relieve. Many donations, however, were made by private persons, ${ }^{5 \mathrm{I}}$ especially members of the corporation, whose connexion with the hospital was maintained unofficially as well as officially from the beginning of the 17 th century. 52

In the later half of the I8th century the corporation's control over the hospital was weakened by the renewed claims of the Duchy of Lancaster. In 1768 the chancellor of the duchy, Lord Strange, asserted his right to nominate to vacant places in the hospital, a right which had previously been exercised by the mayor, although the general surveillance of the duchy was provided for by the charter of $1614 .{ }^{53}$ The chancellor's right to nominate, which he clearly regarded as an important political asset, was affirmed, with the proviso that the mayor should have the nomination if the chancellor failed to act within three months of a place becoming vacant. In 1786 , however, Lord Hawkesbury, then chancellor, stated that for the future he would appoint only at the recommendation of the mayor, and in 1837 the Charity Commissioners found that all appointments were made by the mayor.

Duchy control over the hospital was also renewed in the 18 th century on the question of the rebuilding of the hospital. Repairs had generally been carried out with loans from the corporation, as the repairs fund was too small to permit any piece of work to be

43 Leic. Boro. Rec. $1603-88,94$.

44 J. Throsby, Hist. of Leic. $301 ; 32$ nd Rep. Com. Char. Pt. 5, 44-45; Leic. City Mun. Room, I D 318 .

45 Leic. Boro. Rec. I603-88, 166-7; $32 n d$ Rep. Com. Char. Pt. 5, 43-4.

46 32nd Rep. Com. Char. Pt. 5, 45.

47 Ibid.; T.L.A.S. xxi. I 54.

48 32nd Rep. Com. Char. Pt. 5, 45 ; Nichols, Leics. i. $345^{-6}$; Leic. City Mun. Room, I D $31 / 5$.

4932 d Rep. Com. Char. Pt. 5, 45.

50 Ibid. $45-47$.

5I Ibid. 49-56; Abstract of Accts. of Hosp. of Holy Trinity in the Newarke in Leic. (1953).

52 Throsby, Hist. of Leic. 30 I T.L.A.S. xxi. I $54^{-5}$. carried out without such help. ${ }^{54}$ 'The buildings gradually fell into decay, and suggestions were made by the mayor and his assistants for their improvement. These were carried out, ${ }^{55}$ but the payment was made by the duchy, which also issued new orders for the financial management of the hospital. 56 'The corporation had appealed against the insufficiency of the hospital's funds in 1772, an appeal which was met with accusations from the duchy officials of maladministration on the part of the corporation, said to include the illegal payment of a salary to the mayor and the extensive non-residence of the poor. ${ }^{57} \mathrm{New}$ orders to improve the conditions under which the hospital was maintained were promulgated in $1780 ; 58$ these included the establishments of new benefits to encourage residence, the stopping of the mayor's salary, the increase of the duchy's grant, and the reduction of the number of the poor to sixty. The revised revenues were to be just over $f 488$. 'The resulting improvements in the hospital's financial position enabled a repairs fund to be collected and increased payments to be made to the poor on several occasions up to $182 \mathrm{I} .59$

After effecting these improvements the duchy's control seems to have slackened and that of the corporation strengthened. The hospital was heavily in debt to the corporation by 1835 , when its income was about £, 6 below expenditure. ${ }^{60}$ In I 837 there were ten vacancies and economies were being practised in order to raise extra funds. Each inmate, whether living in the hospital or not, was paid $3 s$. weekly, the keepers receiving $3 s .8 \frac{1}{2} d$. Only 28 of the 70 hospitallers lived in the hospital itself in $1837^{61}$ The annual income then amounted to f 864 i $6 d$. $9 d$., of which $f 485$ came from rents, mainly of property in Leicester itself, but also from lands in Whetstone, Houghton on the Hill, and Enderby. The hospital had received numerous gifts and bequests of lands and rent-charges, some given for specific purposes, such as the provision of clothing or food. 'The Duchy of Lancaster paid a grant of $£ 246.62$

There was still a reduced number of inmates as late as 1846,63 but the hospital supported 90 again in I 877 , when the annual income was $f, 1,35^{\circ}$, the value of the land rents having increased to over $£ 900 .{ }^{64}$ The income in I 953 had risen to about $£ 3,500$, of which $£, 330$ came from rents, many of the gifts of land having been sold and the money invested. The 4 acres of 'charter land', all lying close to the hospital and the only land retained from the I6th century, was still in the possession of the hospital and had a rental of $£ 270$. Rent-charges were paid out of houses in East Bond Street, High Street, Northgate Street, and Frog Island in Leicester, and from land at Donington le Heath, Desford, and Ashby Magna.

53 On this see T.L.A.S. xxi. I $55-7$.

54 Ibid. I57-8; Leic. City Mun. Room, I $\mathrm{D}_{31 / 74}$ building accts. I 736, I 739, I 740 .

55 T.L.A.S. xxi. I 59; for the building, see below.

56 T.L.A.S. xxi. I 59; Leic. City Mun. Room, I D 3 I/ го.

57 T.L.A.S. xxi. I60-1

58 Throsby, Hist. of Leic. 302-5; Leic. City Mun. Room, I D 3 I/I I.

59 T.L.A.S. xxi. I6 $1-2$

60 Ibid. I62; 32 nd Rep. Com. Char. Pt. $5,67$.

6132 d Rep. Com. Char. Pt. 5, 67-68.

62 Ibid. 63

63 White, Dir. Leics. ( I 846), 109.

64 Ibid. (1877), 326. 
The pension of $f^{2} 4^{6}$ from the Duchy of Lancaster was still paid. 65

In 1955 the hospital was regulated by a scheme of the Charity Commissioners of 1907 , revised in $193 \mathrm{I}$ and $1935^{66}$ The Mayor of Leicester was master of the hospital, assisted by four aldermen and two other members of the corporation who retained the name of chamberlains and dealt with the finances. The chaplain was appointed by the Duchy of Lancaster and there was accommodation for 40 inhabitants of the hospital, including the matron and four keepers. There were still some out-pensioners in 1955 , but their number has fluctuated. Appointments to vacancies were made by the chancellor of the duchy, one in every five on the recommendation of the chaplain and the remaining four on the recommendation of the mayor.

The original I 4 th-century building consisted of an aisled hall, probably of seventeen bays, nearly $220 \mathrm{ft}$. long and one of the longest hospital halls in England ${ }^{67}$ The stone arches and piers are still intact for six complete bays at the eastern end of the main nave and the north aisle. The south aisle was demolished in 1776 , when the upper floor was added and the outer walls to a great extent rebuilt to the designs of Joseph Pickford of Derby under the auspices of the Duchy of Lancaster. 68 'The new upper floor cut across the nave and remaining aisle and is lighted by dormer windows. About 100 feet of the west end of the hall was demolished in I902, when a road was cut through the west end of the Newarke to the new bridge. A new hospital building by R. J. and J. Goodacre of Leicester was built along the line of the new road and at an angle to the remains of the old hall. ${ }^{69}$ The inmates of the hospital have their rooms in the new wing; the old hall is occupied by common rooms and passages.

The I 4 th-century chapel stands at the east end of the old hall, the last two bays of which, including part of the south aisle, form an ante-chapel. The chapel retains some of its original windows, and a two-light window from Ashby Folville has been inserted. Some of the woodwork is from the former Wyggeston Hospital chapel. The chapel was restored and refitted in 1876 to the designs and at the cost of Thomas Nevinson, the Leicester architect. ${ }^{70}$

The brass seal of the hospital is an oval, bearing a design of a three-headed arrow, issuing from a cloud. To the left is a scroll, bearing the legend IN ANTITRINITARIOS, and to the right a cinquefoil ermine. The legend reads SIGILLUM HOSPITALIS SANCT\& TRINITATIS IN NOVO OPERE LEIC. An inscription on the back of the seal records that it was the gift of Sir William Heyrick in 1615.71

${ }^{65}$ Abstract of Accts. of Hosp. of Holy Trinity in the Newarke in Leic. (1953); for the 'charter land' see $32 n d$ Rep. Com. Char. Pt. 5, 49 .

66 Copies of these penes the clerk to the governors, Mr. S. H. Partridge, who has given much help as to conditions in 1955.

67 Arch. Inl. cxii. 159-60; W. H. Godfrey, The Eng. Almshouse (1 955), 30.

68 T.L.A.S. xxi. I59 and n.; Throsby, Hist. of Leic. $30 \mathrm{r}$ and n.; Nichols, Leics. i, plate xxix.

69 Arch. $7 n l$. xc, plan facing p. 368; 3oth Ann. Rep. Leic. and Leics. Soc. of Architects (1 902-3), 23.

70 T.L.A.S. v. 54-55.

'Ex dono Gulielmi Heyricke equiti': the seal is kept by the clerk to the governors.

${ }_{72}$ Leic. Boro. Rec. I 509-1603, 250-I.

73 3and Rep. Com. Char. Pt. 5.

\section{ST. JOHN'S AND BENT'S HOSPITALS}

IN I 589 Elizabeth I granted the lands of the dissolved hospital of St. John to the corporation of Leicester. ${ }^{72}$ At an unknown date in the early 17 th century six poor widows were installed by the corporation in the old building in High Cross Street which had been used as a wool hall since the Dissolution.73 The widows seem to have had no other regular income than the annual gift of $55^{5}$. which Trinity Hospital had made since St. John's Hospital had been transferred to it at the end of the $15^{\text {th }}$ century. ${ }^{74}$ Donations were made by all the members of the corporation at the end of the 17 th century and the corporation arranged for the preaching of a sermon for the hospital on St. John's day. ${ }^{75}$ In 1686 lands were purchased for the hospital by the corporation and the number of widows was increased to eight as the result of another gift. ${ }^{76}$ Considerable donations were made to the hospital during the 18 th century. ${ }^{77}$ The income of the hospital was nearly $£ 59$ in 1836.78

In the I7th century St. John's Hospital was refounded in the lower floor of the old hall, but was moved to the first floor in 1682.79 The ground floor of the building was afterwards occupied by Bent's Hospital, founded by John Bent who in I697 left lands at Enderby for the building of four extra rooms at St. John's for the accommodation of four vidows and a nurse. ${ }^{80}$ These were brought into use in $1703 .{ }^{81}$ The hospital's income was nearly always insufficient and it was in debt to the corporation for most of the 18 th and early I 9 th centuries. 82

The old building, especially the Bent's Hospital part, was stated to be in very bad condition at the beginning of the I9th century. ${ }^{83}$ It was rebuilt in I 860. The respective incomes of the hospitals were $£ 70$ and $£ 76$ in $1877^{84}$ by 1936 these had increased to $f_{1} 80$ and $f_{100}$, and they were supporting eleven women between them. ${ }^{85}$ This number has since been gradually reduced, and in 1955 there were no inmates. The trustees intend (I955) to provide new accommodation, as the existing buildings are to be demolished when High Cross Street is widened. The hospitals were controlled in $\mathbf{I} 955$ by the Trustees of the Leicester Church Charities. ${ }^{86}$

\section{SPITAL}

THE origins of this hospital are uncertain, but it seems likely that it was the 'lazarhowse' in St. Margaret's parish mentioned in $155^{0.87} \mathrm{~A}$ leper hos-

74 Ibid.; for St. John's Hosp. before the Dissolution, see V.C.H. Leics. ii. $40-4 \mathrm{I}$.

75 Leic. Boro. Rec. $1603-88,559,589$

76 32nd Rep. Com. Char. Pt. 5, 68-69.

77 Ibid. $69^{-72}$.

78 Ibid. 72

79 Ibid. 68

80 Ibid. $72-73$.

81 Leic. City Mun. Room, Hall Bk. 3 Feb. I 702/3.

82 32nd.Rep. Còm. Char. Pt. 5, 73-74; T.L.A.S. xxi. $162-4$.

83 32nd Rep. Cont. Char. Pt. 5, 74.

84 White, Dir. Leics. (1 877), 328-9.

85 Kelly's Dir. Leics. and Rut. (1936), I 34

${ }^{86} \mathrm{Ex}$ inf. Mr. B. E. Toland, clerk to the trustees.

87 Cal. Pat. 1549-5 I, 122; for the early hist. of this hosp. see V.C.H. Leics, i. 44 
pital 'by Leicester' was supported by the county during the r6th century with a yearly payment of $\AA_{12}$, and was known as the Spital by $1599 .^{88}$ It is marked on Speed's map of 1610 , at the end of Belgrave Gate. ${ }^{89}$ In 1599 the Mayor of Leicester wrote to the Earl of Huntingdon complaining that the county now refused to support the hospital and asking his help in forcing the county to continue its payments. ${ }^{\circ}$ In December he repeated his plea, saying that the inmates of the hospital were starving, and that they could not beg, the nature of their diseases preventing them from going outside. ${ }^{91}$ The borough made one payment to the Spital in $1600^{92}$ and a bequest was made to it in $1628 .{ }^{93}$ 'The borough's efforts were presumably successful. By 1720 the county was again fully supporting the institution, which then usually contained six inmates, probably by then ordinary paupers, each of whom was paid Is. $2 d$. weekly. 94 'These payments were the same in r792, and Throsby, writing at that time, believed that six poor widows lived in the Spital, about which, however, he knew very little. ${ }^{95}$ Nichols equated the Spital with the Cock Muck Hill Houses, but the identification does not seem to be correct. ${ }^{96}$ A house at the end of Belgrave Gate still retained the name of the Spital House at the end of the r 8 th century and is illustrated in Nichols. ${ }^{97}$ It may perhaps be identified with the Pack Horse Inn, which belonged to the county authorities at the beginning of the r $9^{\text {th }}$ century, and was leased for $£ 20$ yearly, which was distributed to five poor persons in the county. The whole of the income, however, was not used in this way, and the Charity Commissioners were of the opinion that the county only held the house as trustees for some unknown charity. ${ }^{8}$ 'This does not seem likely in view of the county's proved connexion with the Spital since the I6th century. The Commissioners suggested that a new arrangement should be made. In 1856 the chairman and treasurer of the county magistrates sought permission from the Charity Commissioners to sell the property and reinvest the proceeds. They urged that nothing was known of the charity except what was in the Commissioners' own report and that it was not certain in whom the legal estate of the property should be vested. The charity had, they said, always been administered by the treasurer of the magistrates who then distributed $f_{1} 46$ s. each year. After some difficulty new trustees were appointed by application to the Charity Commissioners, the property was sold, the purchase money was invested, and arrangements were made for the interest to be distributed to four or five poor persons. Further investments have since been made and although there were complaints in the period I897-I9I3 that the charity should not be administered by the county magistrates since the 'area' of the Spital House was now in the borough,

88 Leic. Boro. Rec. I509-I603, 372.

89 B. L. Gimson and P. Russell, Leics. Maps, plate 3.

90 Leic. Boro. Rec. I 509-I603, 372.

91 Ibid. 387.

92 Ibid. 404.

93 32nd Rep. Com. Char. Pt. 5, 96.

94 Ibid.

95 Throsby, Hist. of Leic. 294 .

96 Nichols, Leics. i. 323 . It may be explained by the fact that St. Margaret's parish was said to appoint to one of the places in the Spital: J. Throsby, Memoirs of Town and Co. of Leic. iv. 160 .

97 Ibid., plate xxiii. it was still so administered in 1955. 'The county magistrates appoint to vacancies on the board of three trustees. ${ }^{99}$

\section{CONSANGUINITARIUM}

The Consanguinitarium was founded in 1795 by John Johnson, the Leicester-born architect, for the benefit of his poorer relatives. ${ }^{1}$ There were to be five occupants and elaborate rules were laid down for their conduct. 'The foundation was endowed with land at Lubbenham. The original building in Southgate Street was a battlemented stone house with Gothic windows, partly screened from the street by a handsome row of four houses also built by Johnson in the classical style on the spot where he was born. ${ }^{2}$ The original endowment was designed to produce an income of $£ 70$ a year and at his death in 1815 Johnson left the four houses to his relatives, charging each with a payment of either $£ 4$ or $£ 6$ for the further endowment of the Consanguinitarium. When the Charity Commissioners reported on the foundation, one of the inmates had a family of children, which 'although not expressly forbidden, appears inconsistent with the objects of the founder', who had laid down that children were on no account to be allowed to play on the lawns. In 1878 the Consanguinitarium was rebuilt in Earl Howe Street, to the designs of Robert Johnson Goodacre, a relative of the founder. ${ }^{3}$ Johnson's original buildings were demolished, but in 1955 his foundation continued.

\section{SARAH BARLOW ALMSHOUSES}

The Sarah Barlow Memorial Cottage Almshouses were built in Knighton Drive in I 887 under the will of Miss Sarah Barlow, who also contributed a large sum to the building of St. John's Church, Clarendon Park Road.4 In I 955 they housed four elderly women. The income from the remainder of the estate was used partly to supplement the almshouse endowment; the residue was dispensed at the discretion of the trustees. 5

\section{MISS LAWTON'S ALMSHOUSES}

Miss Martha Ann Lawton's Almshouses were built in Evington Street to the designs of William Jackson in I864. They housed in 1955 four elderly women, members of the Church of England with small incomes. ${ }^{6}$

98 32nd Rep. Com. Char. Pt. 5, 96.

99 Information about the charity since 1856 has been obtained from the files of the Charity Commissioners. I $32 n d$ Rep. Com. Char. Pt. 5, I00-2; Nichols, Leics. i. 528.

2 Nichols, Leics. i, plate xxxv; Throsby, Hist. of Leic. 3 I 5 .

3 Spencer, New Guide to Leic. (1888), 146.

4 Wright, Dir. Leics. (I 888), 59; and see below, p. 445.

5 Leic. Charity Organisation Society, Social Services in Leic. 43; ex inf. Mr. C. D. B. Ellis.

6 Spencer, New Guide to Leic. (1888), I46; Social Services in Leic. 43. 


\section{THE COUNTESS OF DEVONSHIRE'S HOSPITAL}

IN I 837 the Charity Commissioners reported that although this hospital had disappeared it was still remembered by people then living. ${ }^{7}$ It stood outside the gates of Cavendish House, built on the site of Leicester Abbey, and was founded in the reign of Charles I by Elizabeth, Countess Dowager of Devonshire (d. 1642 ). Throsby, writing in 1777 , stated that it had been decayed but had recently been largely rebuilt by John Manners, son of Lord William Manners. It was originally built to house six poor women and had an income of $f 30$ a year. ${ }^{8}$ The building was demolished about 1796 by Sir William Manners, and the foundation is not mentioned by Nichols. The Charity Commissioners applied to the owner of the land, Lord Huntingtower, who replied that he knew nothing of the hospital but would be willing to support it if his obligation to do so could be proved. Nothing had been done as late as $1877^{\circ}$ and the hospital was never revived.

\section{SIMON'S HOSPITAL}

Matthew Simon by will dated I 72 bequeathed to trustees the hospital which he had founded in Blue Boar Lane for six poor women of St. Nicholas's parish. ${ }^{10}$ The endowments consisted of lands at Scraptoft and Knighton and part of the manor of Hamilton, and by the end of the last century these brought in $f 600$ a year. ${ }^{\text {II }}$ The rents were also subject to various charitable payments. The hospital was rebuilt in 1817 , but was demolished to make way for the building of the Great Central Railway. ${ }^{\mathrm{I2}}$ The endowments were used thereafter for the rest of Simon's charity, which included payments to Trinity and St. John's Hospitals, and bequests for apprenticing eight children. In 1956 the income of the charity was used to provide small pensions to poor women. ${ }^{\mathrm{I3}}$ The charity is vested in private trustees.

\section{MISS MASON'S ALMSHOUSES}

IN I 832 Elizabeth Charlotte Mason built four houses in Vauxhall Street for the reception of four poor women of Leicester. At her death in 1833 she bequeathed the residue of her estate for the endowment of the houses. ${ }^{\mathrm{I}} 4$ The annual dividends amounted to nearly $f, 5^{\circ}$, out of which the inhabitants of the houses received pensions of $4 s$. weekly. The residue of the income was reserved for repairs by the trustees. By I 936 the pensions had been reduced to $2 s$. $6 d$. and the almshouses were demolished in 1937 during clearance in the Vauxhall Street area. ${ }^{15}$ The funds of the charity were formed into a charity for the payment of pensions in $1955 .{ }^{16}$

\section{MUNICIPAL CHARITIES}

Most of the endowed charities established in Leicester between the Reformation and the Municipal Corporations Act of 1835 were vested in the corporation as trustee. The lands bought with the money left by the founders of charities were always regarded as corporation property and the money for the payment of the charities came out of the general funds of the corporation. ${ }^{\text {I }}$ The corporation seems in general to have administered its charities very conscientiously. At the beginning of the r gth century charges of corruption were brought against the unreformed corporation, especially with regard to the large loan charities and the patronage which it exercised in the right of appointments to vacancies in the hospitals for the elderly. ${ }^{2}$ In 1826 Robert Cave denounced in detail the corporation's administration of the White and Newton charities in the House of Commons. ${ }^{3}$ These charges were not unfounded and the singular care which the corporation took of its charity funds was not unconnected with their political potentialities. The very large sums of money

7 32nd Rep. Com. Char. Pt. 5, 96-97.

8 Throsby, Memoirs of Town and Co. of Leic. iv. I 59.

9 White, Dir. Leics. (I877), 329.

1032 d Rep. Com. Char. Pt. 5 [163], pp. 97-100, H.C. ( 1839 ), xv.

II Kelly's Dir. Leics. and Rut. (I888), 567.

12 Cf. ibid. and Kelly's Dir. Leics. and Rut. (1900).

3 Social Services in Leic. 60

4 32nd Rep. Com. Char. Pt. 5 [163], pp. I02-3, H.C. (I 839), xv.

${ }_{15}$ Kelly's Dir. Leics, and Rut. (1936), I 34 ; ibid. (1938), which came from the loan charities made them a formidable weapon of patronage, and the money was said to go to the rich supporters of the corporation rather than to the poor artisans for whom it was intended. 4

Not quite all the corporation's care of its charities can be put down to the desire for political patronage. There was a genuine feeling in 1835 that it was morally indefensible to contemplate placing the control of primarily Anglican charities, like Alderman Newton's charities, in the hands of men whose religious ideas would be at variance with those of the founder. 5 By the Municipal Corporations Act of I835 two bodies of charity trustees were established in Leicester, the Trustees of the Church Charities, to deal with the Anglican charities, and the Trustees of the General Charities, to manage most of the rest. ${ }^{6}$ In 1837 the Charity Commissioners made their report on the charities of the borough and county of Leicester. ${ }^{7}$ The report describes the situation as it was before the passing of the Municipal Corporations

I6 Ex inf. Mr. B. E. Toland.

I 32 d Rep. Com. Char. Pt. 5 [163], p. 2, H.C. (1839),

2 A. T. Patterșon, Radical Leic. I 52; R. W. Greaves, Corp. of Leic. 89.

3 Greaves, op. cit. I I 9.

+ Ibid. 88-89; Patterson, Radical Leic. 96.

5 Greaves, op. cit. I32; for Alderman Newton's Charity, see p. 333.

6 Municipal Corporations Act, $5 \& 6 \mathrm{Wm}$. IV, c. 76, sections $72-76$.

7 32nd Rep. Com. Char. Pt. 5. 
Act, as it was begun in 1836 , only seven months after the dissolution of the old corporation and before the new trustees had taken office. It shows that with one or two exceptions, Leicester's charities were well and fairly administered and that there were in fact no glaring misappropriations of funds or defiance of the intentions of the founders of particular charities.

In 1955 most of the old charities were distributed by the 'Trustees of the Leicester General Charities, who were appointed by the Charity Commissioners, and in whom the legal estate of some charities was vested by the Charitable Trusts Act of I 853 , confirmed by the Municipal Corporations Act of 1882.8 The corporation still paid a considerable proportion of the charity money. The Church Charity Trustees were responsible for 'Tamworth's Gift, Thomas Hayne's Charity, and Hickling's Charity, and for St. John's Hospital.

This article is confined to charities in existence before 1836 which are or were vested in the corporation. The charities of the ancient parishes are dealt with elsewhere. ${ }^{9}$ There are in Leicester charities of various kinds of more recent foundation which are not mentioned here.

\section{CORPORATION CHARITIES}

Before 1628 a Mr. Bennett of London gave $£_{10}$ to the corporation for the use of the poor. In $1635^{-6}$ John Ward of Coventry gave a similar sum. These two donations have been managed together for many years and in 1837 were regarded as part of the Wood and Coal Money. ${ }^{10}$ In $1955 f_{1}$ was paid by the corporation to the Trustees of the Leicester General Charities. II

Alderman Thomas Blunt by will dated 1664 left a rent-charge from three houses and a close in Leicester to be distributed by the corporation in the following way: for shoes for Trinity Hospital, St. John's Hospital, and selected poor persons, $£^{6}$ ros., with Ios. to be spent at their distribution; to the mayor for gloves, $5^{s . ;}$ town clerk and mace-bearer, each $2 s .6 d$.; town crier and beadle, each $6 d$.; four borough servants, each Is.; poor persons in the Spital, 2s. ; Vicar of St. Margaret's, $£_{\mathbf{I}} \mathbf{\text { ; }}$ clerk of St. Margaret's, $5 s$. ; poor of Walton on the Wolds, $18 s$. By 1837 the money for shoes was given solely to Trinity Hospital. ${ }^{12}$ The other payments were still made in 1955 according to the terms of the bequest. The corporation then made no payment to the town crier or beadle, there being no such officers in the

8 Charitable Trusts Act, $16 \&$ I 7 Vic. c. I37; Municipal Corporations Act, $45 \& 46$ c. 50, section I 33 .

9 See above, pp. $343,349-50,360,368-9,380,387$.

so 32 nd Rep. Com. Char. Pt. 5, 24. The Wood and Coal Money was divided among the aldermen for distribution. This amalgamation of several charities is now no longer practised.

Ir Ex inf. Mr. S. H. Partridge, clerk to the Trustees, who has provided information as to the practice in 1955 concerning the charities controlled by the Trustees of the Leicester General Charities; see also City of Leic. General Charities, I 935 (priv. print., no pagination). Information about the payment of the corporation charities in 1955 was provided by Mr. C. D. Wells of the City Treasurer's Office, at the Town Hall.

I2 32 nd Rep. Com. Char. Pt. 5, 36-37.

13 See above, p. 409. The payment is in fact made to town; the four town servants chosen were usually the Town Hall porters. The 2s. for the Spital was paid to St. Margaret's parish for the former Cock Muck Hill Houses. ${ }^{\mathrm{I} 3}$ 'The sum of $£ 4$ was still paid from 38-40 Gallowtree Gate, formerly the Crane Inn, and $f_{2}$ from 79 Belgrave Gate, which belonged to the corporation. 14

The sums forming the charity known as Sir William Courteen's Gift are three separate donations, one by Courteen, one by the 'Gentlemen of the Lottery',15 and the third by a donor named Evington or Elkington. The donations seem to have been made about 1617 , and the money was vested in the corporation for the use of the poor. In 1625 the corporation purchased Freak's Ground and undertook to pay f4 I6s. from it yearly to the poor. In 1837 the charity was distributed in the form of bread. ${ }^{16}$ In I955 the corporation distributed money to the parishes of the old borough in the following proportions: St. Margaret's, St. Martin's, and St. Mary's, each fi Is. 4d.; All Saints', I 8s. 8d., and St. Nicholas's, I 3 s. $4 d .{ }^{17}$

William Cavendish, later Earl of Devonshire, gave

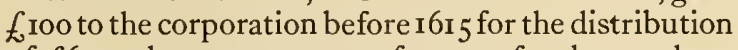
of $f^{6}$ yearly among 20 poor freemen for the purchase of coal. In 1837 this was dispensed as part of the Wood and Coal Money. ${ }^{18}$ In 1955 the corporation was paying $\AA^{6}$ yearly to the 'Trustees of the Leicester General Charities, who distributed it to 20 freemen. ${ }^{19}$

Shortly before 1629 Margaret Hobbie left at her death two tenements in Southgate Street out of which small sums were to be paid by the corporation to the Free Grammar School (I2s.), the poor of Leicester (Is.), Trinity Hospital (2s. 6d.), Wyggeston's Hospital (2s.), St. John's Hospital (6d.), and St. Martin's and St. Mary's parishes ( 4 s. divided between them). ${ }^{20}$ 'The payments to the grammar school, St. John's, and the poor were no longer made in 1955 , but the rest were continued. ${ }^{21}$

William Ive by deed dated $16{ }_{3} 8$ granted lands to the corporation charged with yearly payments of $f_{5}$ I $2 s$. to Trinity Hospital, another $f_{\mathrm{I}}$ (the gift of his wife, Jane Ive) to the same hospital, 8s. to Wyggeston's Hospital, $£ 4$ for the purchase of gowns for eight poor widows, and $£_{4}$ for bread for the poor of Leicester. ${ }^{22}$ 'The payments to Trinity Hospital and Wyggeston's Hospital were made in 1955 by the corporation, which also distributed the $\oint_{4}$ for bread among the parishes of St. Margaret, St. Martin, and St. Mary (£I each), All Saints (I2s.), and St. Nicholas $(8 s.){ }^{23}$ The corporation paid $£ 4$ to the Trustees of the Leicester General Charities. ${ }^{24}$

William Moreton by will dated 1620 gave to the corporation a yearly rent of $£ 3$ for the purchase of

the wrong charity, but the confusion between the Cock Muck Hill Houses and the Spital has existed since Nichols's day: see above, p. 409 .

14 Ex inf. Mr. C. D. Wells.

Is See below, p. 412.

16 32nd Rep. Com. Char. Pt. 5, 28-29; for Freak's Ground see below, p. 449.

i7 Ex inf. Mr. C. D. Wells.

1832 nd Rep. Com. Char. Pt. 5, 24; for the Wood and Coal Money, see above, n. Io.

$19 \mathrm{Ex}$ inf. Mr. C. D. Wells and Mr. S. H. Partridge.

zo 32 nd Rep. Com. Char. Pt. 5, 29.

zI Ex inf. Mr. C. D. Wells.

22 32nd Rep. Com. Char. Pt. 5, 32-33.

23 Ex inf. Mr. C. D. Wells.

${ }_{24}$ Ex inf. Mr. S. H. Partridge. 


\section{A HISTORY OF LEICESTERSHIRE}

fuel for St. John's Hospital and for seven poor freemen of Leicester. In 1837 this was regarded as being part of the Wood and Coal Money.25 In I955 the corporation was paying $\mathrm{I} 8 s$. to the hospital and $f_{2} 22$ s. to the Trustees of the Leicester General Charities, who distributed it to seven freemen. ${ }^{26}$

Elizabeth Ossiter by will dated I 634 gave $£$ I 100 to the corporation for the distribution of $£ 6$ yearly to twenty poor householders of Leicester for coal. In I 837 this charity was regarded as part of the Wood and Coal Money. ${ }^{27}$ In 1955 the corporation was paying $£ 6$ to the Trustees of the Leicester General Charities. ${ }^{28}$

At an unknown date John Stanley granted $£ 80$ to the corporation for the payment of certain sums as charities. In 1837 the corporation paid $f_{\mathbf{I}}$ I OS. to the Vicar of St. Martin's, $f \mathrm{I}$ to the headmaster of the Free Grammar School, I3s. $4 d$. and $6 s .8 d$. to the head and under ushers of the school respectively, and Ios. to ten poor women. ${ }^{29}$ In 1955 the corporation was paying $\oint_{\mathrm{I}}$ I $0 s$. to the Vicar of St. Martin's and Ios. to the Trustees of the Lcicester General Charities. ${ }^{30}$

In 1955 Leicester Corporation also paid $£ 8$ yearly from 'Thomas Ludlam's Charity to the Trustees of the Leicester General Charities. ${ }^{31}$ Andrew's Loan Charity' (will dated I636), Nurse's Charity (c. I644), and the money known as the Benevolence Money (c. I649) were apparently lost very soon after they were first mentioned in the borough records in the I $7^{\text {th }}$ century. The incomes may have been combined with those of other charities. ${ }^{32}$

\section{LEICESTER GENERAL CHARITIES}

Anthony Acham by will proved I64I left a yearly rent-charge of f 9 from the manor of Asterby (Lincs.) to be distributed in the form of bread to the poor of Leicester. In I 837 this sum was paid to a baker for bread for the parishes of St. Martin, St. Margaret, St. Mary, All Saints, and St. Nicholas. ${ }^{33}$ In 1955 the charity was administered by the Trustees, who received the annuity from Wroxham Estates Ltd. Bread was distributed by the Trustees to persons recommended to them. ${ }^{34}$

At an unknown date Hugh Botham left an annuity of $f_{2}$ payable out of a house in Loseby Lane for distribution to the poor of St. Martin's, St. Margaret's, and St. Mary's. In I 837 the payment was still made from a house. ${ }^{35}$ In 1955 the charity was managed by the Trustees, who held stock producing an income of $f 2 .{ }^{36}$

Catherine Brown by will dated I 73I left a house in

2532 nd Rep. Com. Char. Pt. 5, 24; and see above, n. 10. $26 \mathrm{Ex}$ inf. Mr. C. D. Wells and Mr. S. H. Partridge.

2732 nd Rep. Com. Char. Pt. 5, 24; and see above, n. ro.

28 Ex inf. Mr. C. D. Wells and Mr. S. H. Partridge.

2932 d Rep. Com. Char. Pt. $5,38$.

30 Ex inf. Mr. C. D. Wells and Mr. S. H. Partridge.

31 See below, p. 413

32 2nd Rep. Com. Char. Pt. 5, 16, $3^{8-39}$.

33 Ibid. $31-32$.

34 Ex inf. Mr. S. H. Partridge; and see Leic. General Charities, 1935 .

3532 nd Rep. Com. Char. Pt. 5, 35.

$36 \mathrm{Ex}$ inf. Mr. S. H. Partridge; and see Leic. General Charities, 1935 .

37 32nd Rep. Com. Char. Pt. 5, 40-4I.
St. Margaret's parish to provide an income to be distributed to three poor women, relatives of her parents in the first instance. If these failed, the mayor, who was to receive a guinea a year for his trouble, was to choose suitable recipients. In 1837 the house, with two others built in the garden, was being let for $£ 20 .{ }^{37}$ The Trustees held in I 955 stock yielding an income of $£ 49$, which was then being distributed between two relatives of Catherine Brown and a third recipient. ${ }^{38}$

About 1627 Charles I granted 40 acres of land in Leicester Forest, the revenue from which was to be used to buy fuel for the poor of Leicester. In 1837 this was regarded as part of the Wood and Coal Money. ${ }^{39}$ In 1955 it was administered by the Trustees, who held stock in its name and distributed the income to applicants who must be freemen or freemen's widows. 40

The origin of the charity known as the Coal Money is unknown. From the end of the 16 th century the corporation was in the habit of arranging for the distribution of cheap coal to the poor of the borough once a week for about six weeks in the winter. Various small sums and the surplus from other charities were used for this purpose.4I The charity was in $195^{6}$ administered under an order of the Charity Commissioners of 1864.42 In 1955 the Trustees held stock producing an income of EI 2s. 8d. This charity is not technically regarded as one of the General Municipal Charities. 43

In or shortly before 1623 Elizabeth, Countess of Devonshire, gave $£ 50$ for the purchase of land to yield an income of $£ 3$. This was to be distributed in the proportion of one-third to St. Leonard's parish, and two-thirds to the other borough parishes. The property purchased lay in All Saints' parish near the former church of St. Michael. In 1837 the corporation was drawing more than $£ 3$ in rents and distributing only f 3 . The Charity Commissioners advised the selling of the property for building purposes. 44 By 1877 the income had increased to $£ 35{ }^{45}$ In 1955 the Trustees held stock producing an income of nearly $£ 60.46$

The Educational Charity was formed in I 900 from two former charities. Thomas Ludlam by will dated I 742 gave $f_{200}$ to the corporation, the interest from which was to be used to apprentice a freeman's son each year. The sum had not been paid by the corporation for some years in 1837.47 The origin of the other charity, the Lottery Money, is not known, but it first appears in the accounts of the corporation in I 70I, and consisted of a yearly payment of $f_{5}$ for apprenticing a boy. 48 In 1900 these two charities were amalgamated to form the Educational Charity, the income of which was to be used for the payment of the fees of poor boys at the Leicester Colleges of

${ }^{38}$ Ex inf. Mr. S. H. Partridge; and see Leic. General Charities, I 935.

39 32nd Rep. Com. Char. Pt. 5, 23-25.

40 Ex inf. Mr. S. H. Partridge; and see Leic. General Charities, I 935 .

41 32nd Rep. Com. Char. Pt. 5, 39-40.

42 Ex inf. Mr..S. H. Partridge; and see Leic. General Charities, I935.

43 See, e.g., Order of Char. Com. 30 Sept. 1949, 35281 49.

443 and Rep. Com. Char. Pt. 5, 27-28.

45 White, Dir. Leics. (1877), 324.

46 Ex inf. Mr. S. H. Partridge.

47 2nd Rep. Com. Char. Pt. 5, 39.

48 Ibid. $3^{8}$. 
Art and Technology, or in giving prizes there. ${ }^{49}$ The charity was under the management of the Trustees, who in I 949 delegated the application of the income to the committee of the colleges. In 1956 stock was held by the Trustees for the Lottery Money; Ludlam's Gift was paid each year by the corporation. 50

Richard Elkington by will dated r 607 left $f_{\mathrm{s}} \mathrm{oo}$ to the corporation to be lent in sums of $f_{\mathrm{I}} \mathrm{o}$ at 5 per cent. interest to poor workmen in St. Martin's parish, Leicester, and in Lutterworth. The interest from the loans was used to give certain small sums to corporation officials for dispensing the charity and to distribute to the poor in St. Martin's parish and in Lutterworth. This charity was in a chaotic condition in 1837.51 In 1840 it was regulated by an order in Chancery. The Trustees.were in 1955 dealing with that part of the charity which concerned Leicester and held stock to produce an income of f28 6s. 8d. yearly. The interest was to be given to the Vicar and Churchwardens of St. Martin's parish for distribution among the poor of the parish, and the principal was to be available for loans. ${ }^{52}$

Robert Heyrick at his death in 1618 left a rentcharge of $f_{5}$ on his house in Leicester Market Place to be used by the corporation to buy bread for the poor. ${ }^{3}$ The rent was paid in 1955 to the Trustees from 48 Market Place, and was distributed to the vicars and churchwardens of the parishes of St. Margaret, St. Martin, St. Mary, All Saints, St. Nicholas, and St. Leonard in equal portions. ${ }^{54}$ Robert Heyrick also left a sum of $£ 2$ to be paid annually from Grey Friars for distribution to 40 poor widows, 20 from St. Martin's parish and 20 to be chosen at the discretion of the mayor.55 The trustees in 1955 held stock producing an income of $£ 2$ which was distributed at Christmas to the first 40 applicants. 56

John Norrice in 16 I9 granted an annuity of $f_{\mathrm{J}} \mathrm{o}$ from lands at Willoughby Waterless to the corporation. Of this sum $\AA_{5} 5$ was to be given to the Vicar of St. Nicholas's Church, and the other $£ 5$ to be divided between Trinity Hospital and the poor of the borough. In I 837 the charity was not being correctly managed: if distributed at all, it was not usually given in the right proportions, for it was often simply divided between the parishes and Trinity and St. John's hospitals. ${ }^{57}$ In 1877 the income had increased, and $f_{\mathrm{I}}$ o was given to the vicar and the rest divided in the proportion of one to two between Trinity Hospital and the poor. ${ }^{58}$ The income, which is obtained from stock, was in 1955 divisible under an order of the Charity Commissioners of 1929 by the Trustees in the proportion of one-half to the Vicar of St. Nicholas's, one-sixth to the hospital, and one-third by the decision of the Trustees to poor persons of the borough. 59

\footnotetext{
49 Leic. General Charities, I935.

50 Ex inf. Mr. S. H. Partridge and Mr. C. D. Wells.

$5132 n d$ Rep. Com. Char. Pt. 5, I 8-2 I.

52 Leic. General Charities, I935; ex inf. Mr. S. H. Partridge.

53 32nd Rep. Com. Char. Pt. 5, 2 I.

54 Leic. General Charities, I935; ex inf. Mr. S. H. Partridge.

5532 ind Rep. Com. Char. Pt. 5, 2 I-22.

56 Ex inf. Mr. S. H. Partridge; and see Leic. General Charities, 1935 .

57 32nd Rep. Com. Char. Pt. 5, 25-27.

58 White, Dir. Leics. (I 877 ), 323-4.

59 Leic. General Charities, 1935; ex inf. Mr. S. H. Partridge.
}

John Parker by will dated 1639 bequeathed $£_{50}$ to the corporation for interest-free loans to poor knitters, weavers, and lace-makers, or to other artisans. ${ }^{60}$ This has for long been administered with the sum of $£_{3} 6 s .8 d$. bequeathed for loans by Robert Heyrick in I6I8.61 This sum was in 1955 still paid from the Spital House Close in Belgrave Gate. Stock in the name of Parker's Charity was then held by the Trustees, who arranged loans of the interest, half for poor burgesses of Leicester and half for poor artisans. ${ }^{62}$

John Poultney at his death in 1637 left £io yearly charged upon the manor of Cotes-de-val to be distributed by the corporation among the parishes of Leicester. ${ }^{63}$ In 1955 this charity was administered by the Trustees. The rent-charge was paid out of the manor until I944 when it was redeemed for a lump sum, which was invested. ${ }^{64}$

Sir Thomas White's Charity is vested in the corporation of Coventry, but the borough of Leicester is entitled every five years to the net rentals of the properties named in the foundation deed of $155 \mathrm{I} .{ }^{65}$ The practice in 1837 was to lend sums of $f_{1} 100$ to freemen, free of interest, for nine years. The charity was a valuable form of patronage in the hands of the old corporation, and the town clerk, Thomas Burbidge, was held responsible after 1836 for nearly $£, 5,000$ of the charity's money. The Charity Commissioners recommended that the whole charity should be put into Chancery. ${ }^{66}$ In 1850 the Charity Commissioners issued a new scheme under which the charity was still administered in I955, with modifications made at various times. ${ }^{67}$ The Leicester funds of Sir Thomas White's Charity were managed by the Trustees of the Leicester General Charities. The funds of the charity in Leicester were lent free of charge in sums of $£ 5^{\circ}, £_{100}$, or $£_{200}$, free of interest for nine years, to men between the ages of $2 \mathrm{I}$ and 35 upon the production of adequate sureties and reasons for the loan. ${ }^{68}$

\section{LEICESTER CHURCH CHARITIES}

Thomas Hayne of London by will dated I640 left money for the purchase of lands by the corporation for the payment of the following sums: $£^{6}$ to a schoolmaster to teach ten poor children in Thrussington; $f^{6} 6$ to two scholars at Lincoln College, Oxford, founder's kin in the first instance, but in default chosen from the free grammar schools of Leicester or Melton Mowbray; 20s. for the purchase of three Bibles yearly, to be given in Leicester two years, and in Thrussington one year; and $20 s$. for a

60 32nd Rep. Com. Char. Pt. 5, r 5-16.

6! Ibid. 2 r, 22.

62 Ex inf. Mr. S. H. Partridge; and see Leic. General Charities, I935; Sir Thomas White's, Heyrick's and Parker's Charities (priv. print., I95 I), 42.

${ }_{6} 32$ d Rep. Com. Char. Pt. 5, 31 .

64 Ex inf. Mr. S. H. Partridge.

65 Sir Thomas White's, Heyrick's and Parker's Charities, 3-6, for hist. of this charity; the charter is printed ibid. $43-64$.

${ }_{66} 3$ and Rep. Com. Char. Pt. 5, 15-1 8 .

67 Sir Thomas White's... Char. 13. The order of 1850 and its modifications are printed ibid. I6-40.

68 Ex inf. Mr. S. H. Partridge. 


\section{A HISTORY OF LEICESTERSHIRE}

preacher in Leicester to preach a sermon on the Sunday next to Armada Day. The remainder of the charity money to be given to the poor of Leicester at the discretion of the mayor and corporation. In 1837 the charity was well regulated, although there were some surplus funds, partly owing to the fact that the bequest to the Lincoln College scholars had not been claimed for some years. ${ }^{69}$ In 1890 that part of Hayne's bequest which referred to the school was transferred to the new Wyggeston School. ${ }^{70}$ In I 955 the total disposable income of the charity was $f_{5} 8$, which was divided in the proportions of $\frac{6}{24}$ each to Thrussington school and to the Leicester Education Committee; $\frac{1}{24}$ was used for the purchase of Bibles, and $\frac{1}{24}$ was paid to the vicar of a Leicester parish for the sermon. The remaining $\frac{10}{24}$ was distributed to poor persons in three Leicester parishes chosen by the Trustees. ${ }^{7 I}$

69 32nd Rep. Com. Char. Pt. 5, 33-35.

70 M. C. Cross, Free Grammar School of Leic. 47 ; and see above, p. 332 .

71 Information as to the procedure in 1955 with regard to the Church Charities has been kindly provided by Mr. B. E. Toland, Clerk to the Trustees.

72 See above, p. 366.
The Trustees of the Church Charities were also made responsible for the payment of the bequest known as Tamworth's Prayers to the Vicar of St. Martin's Church.72 The Trustees hold stock, the whole income from which is given to the vicar. ${ }^{73}$

The Trustees administer Alderman Gabriel Newton's Charity. ${ }^{74}$ Of the funds which are available for Leicester from the charity, the first $f 80$ are paid to the Alderman Newton Schools for religious education, and the remainder is divided in the proportions of two-thirds to the Education Committee, and onethird for the assistance of scholars at the schools. ${ }^{75}$ Alderman Thomas Read by will dated I 82 I bequeathed $£ 200$ to the corporation, the interest to be paid to any pupil of the Alderman Newton School who had served a satisfactory apprenticeship. ${ }^{76}$ Alderman Read's Charity is now (1955) amalgamated with Alderman Newton's. ${ }^{77}$

73 Ex inf. Mr. B. E. Toland.

74 See above, p. 333 ; and $32 n d$ Rep. Com. Char. Pt. 5 , $7-15$.

32nd Rep. Com. Char. Pt. 5, I 5.

76 Ibid.

77 Ibid.; ex inf. Mr. B. E. Toland. 


\section{PARISHES ADDED TO LEICESTER SINCE 1892}

\section{A YLESTONE}

Aylestone lies $2 \frac{1}{2}$ miles to the south-west of Leicester, on the road from Leicester to Lutterworth, and on the River Soar and the Leicestershire and Northampton Union Canal. The ancient parish lay in Guthlaxton hundred and contained the chapelries of Lubbesthorpe and Glen Parva as well as Aylestone township. Lubbesthorpe and Glen Parva were still in the administrative county in I955 and consequently are not dealt with here. ${ }^{1}$ Aylestone township covered 1,723 acres in $189 \mathrm{I}$. Most of it is now in the county borough and civil parish of Leicester, and since $\mathbf{1} 89 \mathrm{I}$ has been divided ecclesiastically into the two parishes of St. Andrew, Aylestone, and St. James, Aylestone Park. ${ }^{2}$ These had populations of 4,798 and 14,540 respectively in 1931 . The older part of the village is situated on a stretch of river gravel by the Soar. The surface soil of the parish is largely Boulder Clay, with alluvium in the Soar valley.

Aylestone is now an almost completely built up area, but some remains of the old village still survive. Aylestone Hall is a plain, grey-plastered stone building, probably of the Tudor period, standing in its own small grounds, at the corner of Aylestone Road and Hall Lane. It is doubtful if the lords of the manor, either Vernons or Mannerses, ever resided there for any length of time. Dorothy Vernon's son, George Manners, almost certainly lived there for some years, as the baptisms of several of his children are recorded in the parish registers, although it was probably not his principal place of residence and he seems only to have used it until he inherited the Derbyshire property at Haddon on the death of his father. In 1846 part of Aylestone Hall was being used as a ladies' boarding school. ${ }^{3}$ In 1854 it was occupied by a Joseph Knight. 4 When the Duke of Rutland sold the manor in 1869 the hall was in the possession of Nathaniel Stone. ${ }^{5}$ In 1896 it was the residence of Simeon Stretton and was still owned by the Strettons in $193^{8.6}$ It is now (I955) the property of Leicester Corporation.7 The grounds have been made into a small public park, and the house is used as a restaurant.

The stone pack-horse bridge over the Soar is of uncertain date. Judging from architectural evidence

I See V.C.H. Leics. iii. I 8 I.

2 See below, p. 4 I 8 .

3 White, Dir. Leics. ( 1846$), 375$.

4 F. R. Melville, Dir. Leics. (1 854 ), Iо3.

5 P. Dare, Aylestone Manor and Ch. 30.

6 C. N. Wright, Dir Leics. and Rut. (1896), 497; Kelly's Dir. Leic. (1938), p. xix.

7 Leic. Council Minutes, 1949-50, 203-4.

8 V.C.H. Leics. i. 312.

9 Nichols, Leics. iv. 25

10 G. K. Thompson, 'Aylestone', T.L.A.S. xvii. 207. it probably dates from the I 5 th or I6th century. There is one timbered house in the village dating from the 16 th century, but most of the cottages are of the early igth century.

MANOR. Robert, Count of Meulan and probably Earl of Leicester (d. I I I 8 ), held $1 \frac{1}{6}$ hide in $A Y L E$ $S T O N E$ in I086, the village thus forming part of his extensive possessions in Leicestershire. ${ }^{8}$ Aylestone remained in the hands of his successors, the earls of Leicester, until it passed to Margaret, wife of Saer de Quency (later Earl of Winchester) at the division of the estates after the death of Earl Robert FitzParnell in 1204.9 Before his death in 1219 , Saer had settled the manor of Aylestone on his daughter Arabella and her husband, Richard Harecurt. ${ }^{10}$ When Richard died in $\mathbf{1 2 5 8}$, he held the manor of Aylestone, for the service of one knight's fee, from the Earl of Winchester. ${ }^{\text {II }} \mathrm{He}$ was succeeded by his son, William, who forfeited his estates as punishment for his support of Simon de Montfort. ${ }^{12}$ At the instance of his brother-in-law, Alan la Zouche of Ashby, the manors of Aylestone and Tonge (Salop) were redeemed in 1267 for the benefit of William's two daughters, Arabella and Margaret, upon their marriages. ${ }^{13}$ Aylestone passed to Margaret, but she died without issue and the manor was inherited by Arabella's son and heir, Fulk de Pembrugge, in I280, when it was still held for the service of a knight's fee from the heirs of the Earl of Winchester. ${ }^{14}$ The manor was held by Fulk from Richard Harecurt, son of William and half-brother of Arabella and Margaret. Fulk's successors continued to hold from the Harecurt family. ${ }^{\text {Is }}$ Fulk de Pembrugge died in I 296 and was succeeded by his son, Fulk (II), then a minor. ${ }^{16} \mathrm{He}$ died before $\mathbf{1 3 2 6}$, when there was an inquisition post mortem upon his Shropshire estates, although none exists for Aylestone. ${ }^{17}$ Probably he, like his father, held the manor free of service, as it was held to have been settled in free marriage upon his grandmother Alice, wife of William Harecurt. ${ }^{18} \mathrm{He}$ was succeeded by his son Fulk (III), whose widow Alice demanded certain lands in Aylestone as dower in 1345, when she was

Richard and his descendants also held the manor of Braunstone. See below, p. 429 .

II Cal. Inq. p.m. i, p. I I I.

12 Farnham, Leics. Notes, vi. 43; Assoc. Archit. Soc.

Rep. EF Papers, xxxv. 3 I4.

I3 Farnham, op. cit. vi. I6o.

14 Ibid. 44.

15 Ibid. 47; Nichols, Leics. i, p. cx.

16 Farnham, Leics. Notes, vi. 47.

17 T.L.A.S. xvii. 209.

18 Farnham, Leics. Notes, vi. 47. 


\section{A HISTORY OF LEICESTERSHIRE}

already married for the second time, to Richard de Nowers. ${ }^{19}$ The defendant in this action was Robert de Pembrugge, brother and heir to Fulk (III), who was assessed at the aid for knighting the Black Prince in 1346 at $20 s$. for $\frac{1}{2}$ knight's fee in Aylestone. ${ }^{20}$ Robert's son Fulk (IV), who died in I 409 , was the last Pembrugge of the male line, ${ }^{21}$ and the manor was held in dower by his widow Isabel until her death in 1447. Her husband's heir was his sister Juliana, wife of Richard Vernon. ${ }^{22}$ Juliana died before her sister-in-law, and on Isabel's death the next heir was Juliana's grandson, Sir Richard de Vernon. At his death in I45 I the manor was still said to be held of the Harecurts for the service of $\frac{1}{2}$ knight's fee. ${ }^{23}$ 'The manor continued in the possession of the Vernon family, ${ }^{24}$ whose principal seat was at Haddon Hall (Derb.). In I 565 , on the death of Sir George Vernon, ${ }^{25}$ Aylestone passed with Haddon and other Derbyshire manors to Dorothy, his younger daughter and coheir, and her husband John Manners. ${ }^{26}$ Dorothy died in 1584 and John in I6II, when their eldest son George Manners succeeded to their estates. ${ }^{27}$ In 1641 George's son John became Earl of Rutland on the death of his cousin. The manor of Aylestone remained in the possession of the earls and dukes of Rutland until it was sold in $1869,{ }^{28}$ after which the manorial rights seem to have been extinguished.

ECONOMIC HISTORY. In 1086 the holding of the Count of Meulan consisted of $I_{6}^{1}$ hide. The count had 2 ploughs on his demesne, and a further 5 were used by his tenants, who numbered 24 villeins and 5 bordars. A bondwoman also worked on the demesne. 'The count also owned 4 mills, valued at $48 s$, and 55 acres of meadow, and his whole holding was valued at $£ 4$, as against $£ 3$ before the Conquest. Before the Conquest 6 ploughlands had been held by Saxi, from whom they were held by Lewin. ${ }^{29}$ Alveva, widow of $Æ$ lfgar, Earl of Mercia, had held 5 carucates in Aylestone with 12 ploughs before the Conquest. ${ }^{30}$ She was dead by 1086 , and the lands were in the possession of the king, who had 2 ploughs and I serf in demesne; there were also I 8 villeins, a socman and 8 bordars, who had 6 ploughs, and the whole holding formerly possessed by Alveva was worth I Ios. in I 086 . Two further tenants of the Count of Meulan, Turald and Ulnod, held separately described lands, the former the land of 4 villeins and worth 205 ., and the latter 4 carucates worth the same. Ulnod's land had been held before the Conquest by the Saxon Lewin, and these two holdings may perhaps be equated with that of Lewin and Saxi, mentioned above, although they are said to belong to Aylestone and might not have been in the village at all. ${ }^{31}$

19 Farnham, Leics. Notes, 48-49; T.L.A.S. xviii. 102-3. 20 Nichols, Leics. iv. 26.

2 I Farnham, Leics. Notes, vi. 50.

22 Ibid. 50-5 I

23 Ibid. 5 I

24 T.L.A.S. xvii. 2 Io-I I

25 Dare, Aylestone, 25.

26 The legend of Dorothy Vernon's elopement is considered ibid. chap. iv.

27 T.L.A.S. xvii. 2 I I; Complete Peerage, xi. 263.

28 Dare, Aylestone, 30.

29 V.C.H. Leics. i. 312.

30 Ibid. 313.

31 Ibid. 337.

32 Farnham, Leics. Notes, vi. 47; 16 persons had been
The population of Aylestone as enumerated in I 086 was not inconsiderable, and indicates a place of some size. By the I $4^{\text {th }}$ century, so far as the information from the tax returns may be taken as reliable, the riumber of inhabitants, or at least of those wealthy enough to be taxed, seems to have fallen. In 1327 the eight taxpayers in the village paid a total of $32 s$. to the subsidy. By 1332 this was reduced to $24 s$. $6 \mathrm{~d}$. The most heavily taxed was Henry juxta aquam, who paid $5 s$. in 1327 and $6 s$. in 1332.32

At an inquisition taken in 1272 , the condition of tenure of Henry le Forcer was described. His $4 \frac{1}{2}$ carucates were held 'by homage and the service of going into Wales, and staying there at his own proper costs, and of being the pantler and butler of his said lord there'. ${ }^{33}$ 'This land was ordered to be delivered

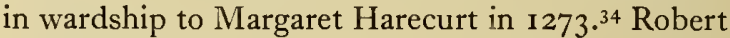
de Aylestone, who was in I339 plaintiff in a suit against Richard de Aylestone for land in the parish, is probably to be identified with the Robert de Aylestone to whom in 1325 a parliamentary petition was referred and who afterwards appears as a baron of the Exchequer. ${ }^{35}$

Only five taxpayers contributed to the subsidy of I $57 \mathrm{I}$, a total of $42 s .8 d .,{ }^{36}$ although in 156340 families were living in the parish. ${ }^{37}$ In 1603 there were $25^{\circ}$ communicants in the village, and this presumably included most of the adult population. ${ }^{38}$ Among the families in Aylestone were some members of the notable Wigston family of Leicester. ${ }^{39}$ In I 645 , before the seige of Leicester, Charles I and Prince Rupert took up their quarters in Aylestone, either at the rectory or the hall. The siege began on Friday, 30 May, and the king is said to have watched the storming of the town from the Raw Dykes on the Aylestone road. $4^{\circ}$

The history of the parish is closely bound up with the Manners family from the middle of the 17 th century. The earls and dukes of Rutland owned the greater part of the land in Aylestone. Nichols stated that there were in 1630 only two freeholders, John Coles and William Palmer,4I although the tenants and copyholders were in some cases quite substantial farmers. The inventory of William Coleman of Aylestone, taken in 1633 , shows that he had a personal estate of $£ 285$, including 120 sheep valued at $£ 60.42$ Richard Neale of Aylestone, baker, had an estate of $\oint_{1} 57,{ }^{43}$ but Thomas Vincent, blacksmith, had only f. 19.44 The inventory of Henry Beale, taken in $\mathbf{1} 685$, gives a little more information, and shows that he had $\mathrm{I} 6$ acres of wheat and barley in the wheat field, I 6 acres of peas and oats in the pease field, and 45 sheep in the fallow field. With a total personal estate of $£_{1} 66$, he may be taken as a typical tenant-farmer. ${ }^{45}$ For the 17 th century, the Hearth Tax returns give some guide to the population. In 1663 tax was paid

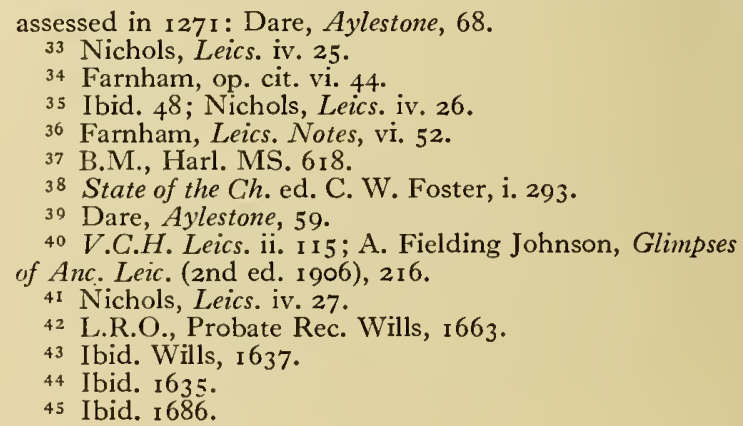


on 83 hearths by 44 occupiers, who included the Earl of Rutland with 9 hearths and the rector with I $0 .{ }^{46}$ In 167084 hearths were paid for and five persons were exempted from paying on account of their poverty. ${ }^{47}$ This seems to indicate a population of about 50 families.

Agriculture on the three-field system was practised in Aylestone. The only medieval field name to survive seems to be North Field, which lay towards the mill, ${ }^{48}$ and is now probably represented by the Aylestone Park neighbourhood. 'There seems to have been a certain amount of ancient inclosure before the passing of the Aylestone Inclosure Act in 1767 . In I 607 it was stated that since I 58 I Sir John Manners had converted 50 acres of arable at Aylestone into pasture, and it seems probable that this land was also inclosed. ${ }^{49}$ Certainly some inclosures had taken place by ${ }^{6} 638$, for closes are mentioned in the glebe terrier for that year, although not many are named.50 The terrier for I 700 refers to eight named closes, although some at least of these, like Hall Close, were probably in the immediate neighbourhood of the village. ${ }^{51}$ 'The inclosed area must have been small, for in $1767 \mathrm{I}, \mathrm{I} 63$ acres remained open out of a total of $1,723.52$ The three open fields were then called South Field, Mill (or North) Field, and Holowell (or Middle) Field and there were several meadows, including the Rye Meadow, Upper Meadow, and the Great North Meadow. The inclosure took place in 1767 after a petition presented by the Marquess of Granby. ${ }^{53}$ There was no opposition at any stage, probably because the only landholders other than the lord of the manor and his son were his kinsman, the rector, and four freeholders, all of whom received very small allotments. The rector received 72 acres in the Middle and Mill Fields in lieu of glebe, and 88 acres of pasture and meadow and 188 of arable in the Middle and Mill Fields in lieu of great and small tithes. Apart from the four other holdings, and just over I acre of land allotted for the repair of the church, the whole of the land went to the Manners family. John, Marquess of Granby, received 735 acres and his father, the duke, 62 acres.

In I764 the inhabitants of Leicester and Lutterworth petitioned Parliament for the repair of the road between the two places, which passed through Aylestone and which was stated to be impassable for carriages in the winter. ${ }^{54}$ In 1785 the trustees of the turnpike asked for their term to be prolonged and their powers increased.55 In spite of the passing of an Act for this purpose, the turnpike seems to have been in poor repair, for in 1786 William Bickerstaffe, the curate of Aylestone, declared that 'in winter it is with difficulty that I can find the way home' to Leicester. ${ }^{56}$ 'The Leicestershire and Northamptonshire Union Canal was cut as a result of petitions to Parliament in 1793 and 1805.57 The canal proceeds

46 Farnham, Leics. Notes, vi. 52.

47 E r 79/240/279, f. r4.

48 Farnham, Leics. Notes, vi. $45^{-} 4^{6}$

49 T.L.A.S. xxiii, 285.

50 Leic. City Mun. Room, $\mathrm{ID}_{4} \mathrm{I} / 3 / 36$.

51 Ibid. $\mathrm{ID}_{4} \mathrm{r} / 2 / 37$.

52 L.R.O., Aylestone Incl. Award, from which all details are taken.

53 C.F. xxxi. 89.

54 Ibid, xxix. 756, 1057.

55 Ibid. xl. 480 .

56 Nichols, Leics. iv. $29 \mathrm{n}$

57 C. . . xlviii. 97 . in the bed of the Soar to the bridge at Aylestone, where the cut begins.

In 1793 there was a population of 378 in the village, 58 and by $180 \mathrm{I}$ this figure had increased to 440 , of whom 78 were employed in agriculture and 87 in trades and manufactures. ${ }^{59}$ 'The Land 'Tax assessments show that most people still continued to be tenants of the Duke of Rutland, although the few small freeholders of Aylestone remained in existence long after the passing of the Inclosure Act. ${ }^{60}$ One of the long-lived families was that of the Brays, many of whose members have been churchwardens and sextons since the first recorded one in 1726 . One of the most recent members of the family to hold office died in 1921.61

In I 860 the Duke of Rutland sold the manor of Aylestone by auction. ${ }^{62}$ 'The hall was bought by the occupant, Nathaniel Stone, a land agent, and the sale of the manor effectively broke the Rutland monopoly of ownership in the village. This can be seen from a comparison of the church-rate books for I 869 , one of which was compiled before the sale and the other after. Clearly, many of the duke's former tenants had been able to buy their cottages and farms. The most important new owners were D. Adderby and the executors of a Mr. Eyre. ${ }^{63}$ The sale of the manor and this division of the land among various small owners created the opportunity for the great growth of Aylestone after I870, which resulted in the complete submergence of the old village. The population figures are striking, when compared with those of the first 70 years of the I 9 th century. By the time of the census of $\mathrm{I} 84 \mathrm{I}$, the population had risen to 526 ; in $\mathrm{I} 87 \mathrm{I}$, a slight drop was recorded, for there were only $45^{\circ}$ inhabitants, perhaps the result of the sale of the Rutland estate. 'The census of I88I, however, presents a very different picture, for the population had multiplied five times in ten years, and was then 2,546 . This remarkable growth is evident in the number of houses which were built in the period, especially in the northern part of the parish in the district known as Aylestone Park, and along the road between the borough and the village. ${ }^{64}$ An event of some importance was the purchase of 16 acres of land in Aylestone by the Leicestershire Cricket Ground Company. Twelve acres of this land were prepared as a running and cycling ground, with a cricket ground in the centre. This ground, now known as Grace Road Ground, was opened in I 878.65 The tram route from Leicester was inaugurated in the same year. ${ }^{66}$ By I $89 \mathrm{I}$, Aylestone was no longer a village but a suburb of Leicester, and as such it was taken into the borough under the Leicester Extension Act of that year. ${ }^{67}$ By I 90 I the population of St. Andrew's ecclesiastical parish was I,009 and that of St. James, which lay between the village and the borough, was 6,366 , a total of $7,426 .{ }^{68}$ During the

58 Nichols, Leics, iv. 27.

59 Census, 1801.

60 L.R.O., Land Tax Assessments, Aylestone.

61 Dare, Aylestone, 75.

62 Ibid. 30.

63 Aylestone par. rec., Ch. Rate Bks. I 869.

64 Many of these houses are dated.

65 E. E. Snow, Hist. of Leics. Cricket, $92 ;$ V.C.H. Leics. iii. 283 .

60 R. G. Waddington, Leic., The Making of a Modern City, 36 .

$6754 \& 55$ Vic. c. 100

68 Wright, Dir. Leic. (rg06), p. xxviii. 


\section{A HISTORY OF LEICESTERSHIRE}

post-war years I 92 I-3I, the population rose sharply, doubling itself in both parishes. ${ }^{69}$ In 1935 the boundaries of the borough were again extended and that part of the old civil parish of Aylestone which had been put into Lubbesthorpe was made part of the borough. ${ }^{70}$ This included the housing estate known as Southfields estate, whose name preserves at least a recollection of the old village community of Aylestone.

MILLS. There were four mills in Aylestone in I $86,{ }^{71}$ but three of these seem to have disappeared before the late $\mathrm{I} 3$ th century, when 'the north field of Aylestone towards the mill' is mentioned in a deed. ${ }^{72}$ This mill probably stood on the site of the present mill building, on the river almost opposite the end of Grace Road. 'There was a corn miller in Aylestone in I 846,73 but there seems to be no mention of the mill before that date. The present building is a ruin, now part of a builder's yard. 'The wheel, which was driven by water, has disappeared, but the trough in which it turned still remains. The buildings are of brick, with heavy wooden beams and probably date from the late 18 th or early igth century. The property was purchased in 1936 by Leicester Corporation. ${ }^{74}$

PARISH ADMINISTRATION. The administration of Aylestone civil parish does not seem to have presented any unusual features. 'The town constable's book for $167 \mathrm{I}-17 \mathrm{I}$, the accounts of the overseers of the poor for I 668-I I I 5 , the churchwardens' accounts for I $700-70$, and the highway overseer's accounts for I $826-48$ are all extant. 75 'The parish possessed its own workhouse by 1803.76 Under the New Poor Law Aylestone was placed in Blaby union, and the parish workhouse ceased to be used. ${ }^{77}$ Aylestone civil parish ceased to exist in 1896 , when it became part of Leicester civil parish. ${ }^{78}$

CHURCHES. There is no record of a church at Aylestone until the beginning of the $13^{\text {th }}$ century, but nothing suggests that it was a recent foundation in I219, when William Harecurt presented Philip de Cuneston to the living..$^{79}$ William was the father of the Richard Harecurt, owner of the manor, who had that year inherited Aylestone on the death of Saer de Quency. In the matriculus of Hugh of Welles it was stated that Richard Harecurt held the advowson, and that the church had two chapelries, Lubbesthorpe and Glen Parva. ${ }^{80}$ The former had a resident chaplain, but the latter was served by the mother church three days in the week. The advowson was held by

\footnotetext{
69 Kelly's Dir. Leic. (1947), p. xxi.

70 V.C.H. Leics. iii. 179 ; County of Leic. Review Order, I935.

V.C.H. Leics, i. 312

72 Farnham, Leics. Notes, vi. $45-46$.

${ }_{73}$ White, Dir. Leics. (1 846 ), 376.

74 Leic. Council Minutes, 1935-6, 261-2.

75 These records are all in the custody of the incumbent.

Abstract of Returns relative to Expense and Maintenance of Poor, H.C. I 75, pp. 260-I (1803-4), xiii.

77 2nd Annual Rep. Poor Law Com. App. D, H.C. 595, p. $530(1836)$, xxix.

${ }_{78}$ V.C.H. Leics. iii. 179, 181 .

${ }^{79}$ Rot. Hugonis de Welles, ed. W. P. W. Phillimore, i. 4I.

80 Ibid. 240.8 8I Cal. Pat. I 292-1301, 491.

82 Ibid. I $301-7,491$. ${ }_{83}$ Ibid. I $307-13,464$

84 Ibid. I $317-24,425,509$. The royal candidate was presented twice, but the king recognized Pembrugge's claim in $132 \mathrm{I}$ : ibid. 555.

85 Linc. Rec. Off., Reg. Beaufort, f. 76; Dare, Ayle-
} stone, 55 . the Harecurts until the manor passed to Fulk de Pembrugge (I), although when the Pembrugge family was first called upon to exercise its patronage in 1293, the rector was presented by the Crown as Fulk was still a minor. ${ }^{81}$ The Crown presented again in $1307,{ }^{82} 1312,83$ and 1320 , but in the last year, Fulk (II) announced that he was of age and won an admission from the king that not only was his presentation in 1320 illegal, but that those in 1307 and I 3 I2 were also wrongful, since Stephen de Segrave had been rector throughout the period from I 293. ${ }^{84}$ The advowson remained with the Pembrugges until the manor descended to the Vernons in 1447 . In $140 \mathrm{I}-2$ the rector had been presented by William Mosse, Robert Saye, and John Walton, clerks acting probably as attorneys for Fulk (IV). ${ }^{85}$ In I 537 William Coffyn presented in right of his wife Margaret, widow of Sir Richard Vernon (d. I 5I7). ${ }^{86}$ Henry, Earl of Rutland presented in $1554^{87}$ and Sir George Vernon in $1560 .{ }^{88}$ Thereafter the advowson was in the hands of the Manners family until it passed to the Bishop of Peterborough, who first presented in $189 \mathrm{I},{ }^{89}$ and from whom it passed to the Bishop of Leicester. 90

The rectory was valued at $£ 336 s$. 8d. in $\mathrm{I} 29 \mathrm{I}$, at $f_{3} I_{8}$ s. I I $d$. in 1535 , and at fioo in $165^{\circ}$, and has always been one of the wealthiest livings in the county. ${ }^{91}$ It was worth $f_{875}$ in 1831.92 There was extensive glebe land, and of this 30 acres remained in I 846.93 The Rectory was built at a cost of $f 3,000$ in I 839 in the Elizabethan style, on the site of an earlier parsonage in which Charles I is said to have stayed before the siege of Leicester. ${ }^{94}$ Little is known of the earlier rectories, but in 1325 and 1336 John de Pyrie was granted two roods of land for the enlargement of his dwelling. ${ }^{95}$ In 1663 there were at least ten rooms with hearths, one more than at the hall. 96

In 1545 the rent of $\mathrm{I} d$. from a rood of land at Aylestone was returned as being for the maintenance of an obit in the church. ${ }^{97}$ Nothing is known of the donor of this gift. In I 549 the land formed part of a large grant of chantry property made to Edward Pease and James Wylson. ${ }^{98}$

In 189 I the ecclesiastical parish of Aylestone was divided, and that of St. James, Aylestone Park, created from the area between the old village and the borough. 99 'The church was built in the same year; the architects were R. J. and J. Goodacre. ${ }^{\text {I }}$ The church of St. Christopher was built in 1929 to serve the new Southfields housing estate. ${ }^{2}$ The livings are both in the gift of the Bishop of Leicester. ${ }^{3}$

The church of $S T$. ANDREW stands at the junc-

${ }^{86}$ Linc. Rec. Off., Reg. Longland, f. 164.

87 Ibid. Reg. xxviii, f. 1 10; Lincs. N. $\mathscr{E}^{\circ} Q$. v. 175.

${ }^{88}$ Linc. Rec. Off., Reg. xix, f. I 10.

89 Dare, Aylestone, 65.

90 Leic. Dioc. Cal. (1 954), 89.

91 Nichols, Leics. iv. 30; Tax Eccl. (Rec. Com.), 63; Valor Eccl. (Rec. Com.), iv. ז86; W. G. Hoskins, Essay's in Leics. Hist. 2.

92 White, Dir. Leics. ( 1846$), 375$

93 Leic. City Mun. Room, I D 41/2/36-37; White, op. cit. 375.

94 White, Dir. Leics. (1877), I 40; Nichols, Leics. iv. 29.

95 Dare, Aylestone, 52.

96 Farnham, Leics. Notes, vi. 52.

97 Assoc. Archit. Soc. Rep. 60 Papers, xxx. 569.

98 Cal. Pat. 1549-5 I, 47.

99 Kelly's Dir. Leics. and Rut. (1936), I 35.

I Leic. City Mun. Room, Minute Bk. Leic. Ch. Extension Soc. 17 Dec. I89o; T.L.A.S. vii. 319.

2 Leic. Dioc. Cal. (1954), 90.

3 Ibid. 89, 9o. 
tion of Middleton Street and Old Church Street, a few hundred yards from the river. The tower is all that survives of the I 3 th-century church, which consisted of nave, chancel, and west tower. In the $14^{\text {th }}$ century the aisles were added, with the south porch, and the tower arch was replaced by one more suited to the style of the new work. The original arch was inserted in the north wall of the tower and a small room built with a lean-to roof, to which this arch gave access and which was probably used as the vestry. Later in the century the chancel was rebuilt with a new vestry on the north side, and on its completion the building on the north side of the tower was demolished. The opening was built up with rubble and provided with a small crude single-light window with a straight-sided pointed arch. ${ }^{4}$ In the I 5 th century a clerestory was added to the nave. The church was restored in $1894^{-190 I^{5}}$ and the roof repaired in $1924 .{ }^{6}$ The south porch was replaced in I 926,7 although the zigzag floor of I7th-century brickwork was retained. In 1935 as a jubilee commemoration a new choir vestry was built on the old site to the north of the tower and a new doorway pierced through the blocked arch. ${ }^{8}$ Most of the window tracery is modern.

When Archdeacon Willcock visited the church in 1517, he found that the chancel was in a ruinous condition and also ordered that the churchyard should be properly enclosed. 9 In I 633 the church was in a deplorable state. The chancel windows wanted mending and 'the wall of the Great Window in the forefront of the chancel' was 'cracked and cloven'. The church wanted whitening and plastering, and the belfry, which was full of rubbish, needed retiling. Of the vestry it was said that the window must be glazed 'as the pigeons come in and defile the room' ${ }^{10}$ In 1779 , beside the regular complaint about the need for whitewashing and replastering, the archdeacon ordered that the chancel roof should be repaired together with its seats and floor, that the rubbish should be removed from the belfry, and that the elder and ivy growing in the walls and foundations of the church should be destroyed. ${ }^{11}$ By 1785 the steeple had been restored and the chancel was repaired three years later, ${ }^{12}$ but like so many repairs carried out at this time they seem to have been poorly done and by 1797 Archdeacon Burnaby had to order that much the same things should be done again. ${ }^{13}$ Repairs to the Rectory and to the church were carried out in the first 40 years of the I 9 th century. ${ }^{14}$

The church now consists of chancel, nave, north and south aisles, west tower with a broach spire, two vestries, and a south porch. It is built of small random rubble in a mixture of local stones with subsequent ashlar patching. All the roofs are slated. The chancel, of four long bays, is lighted by an east window of five trefoil lights and a window in each bay. In the second bay from the east on the south

4 Cf. Dare, Aylestone, 39-40. The complicated explanation offered here seems hardly credible.

5 Kelly's Dir. Leics. and Rut. (1936), 134; the Duke of Rut had restored the west door earlier, and he is probably responsible for the heads of Queen Victoria and her husband, which support the arch: White, Dir. Leics. (1877), I 40.

6 Dare, Aylestone, 75 and facing plate.

7 Inscrip. in porch.

8 Kelly's Dir. Leics. and Rut. (1936), I 34.

9 Assoc. Archit. Soc. Rep. EO Papers, xxiii. 138

to Leic. City Mun. Room, ID 1 I/18/8, f, Io $v$. side the window-sill is raised to accommodate a small doorway, and in the same bay on the north side is the entrance to the vestry, a small building with a lean-to roof. The organ stands in the western bay on the north side in which the window has been blocked to accommodate it. At the east end of the south wall are an ogee-headed piscina with a damaged trefoil basin and a triple sedilia, in which the eastern seat is raised a little above the other two. The nave, of three bays, retains its 15 th-century roof. The pillars of the north arcade are circular; those on the south, octagonal. Both have moulded capitals and bases. The pews are modern, but into them six carved bench ends of the early i6th century have been incorporated, three of them bearing the Vernon arms. The tower arch is pointed, of three orders, with moulded capitals on the innermost. The font stands in the south aisle; it dates from the $13^{\text {th }}$ century, and has a plain circular bowl, supported on a circular stem, with four semi-detached shafts, all with moulded capitals. The south aisle is known as the Vernon or Manners aisle ${ }^{15}$ and was at one time detached from the rest of the church. Just east of the south door, from the wall to the western pillar of the arcade, there is a stone screen covered in plaster and with a battlemented top, and the two eastern bays of the arcade bear evidence of the existence of wooden screens. By the south door is an oak alms box, dated $\mathbf{I}_{6} \mathbf{I}_{3}$. In the north wall of the chancel is a very fine late brass of 1594 to William Heathcote, Rector of Aylestone, erected by his nephew and successor. He is depicted in knee breeches and a long gown with puffed sleeves, worn over his surplice. The Latin inscription is in Gothic characters. In one of the south aisle windows there is a small square of coloured glass said to have come from the church of St. Ouen at Rouen after its destruction in 1789 . There are in the church a piscina in the south aisle, whose basin has been cut

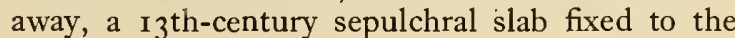
west wall and a I 7 th-century oak chest in the chancel. The organ was erected by public subscription in c. 1875.16

There are 8 bells, 3 by Newcombe of Leicester cast in I 580 (recast I 887), I602 and I609. Another is inscribed Wilielmus filius Johannis Reseyuour fecit me in honore beate Marie, and probably dates from the I $5^{\text {th }}$ century. In I4I2 a William Rekevour was granted land in Aylestone and he may have been the donor of the bell. ${ }^{17}$ The bells were restored and a new tenor by Taylor of Loughborough was added in I 887 to commemorate the jubilee of Queen Victoria. ${ }^{18}$ In 1948 the bells were rehung with new fittings and framework and two new bells by Gillet and Johnstone were added. ${ }^{19}$

The earliest pieces of plate are a silver cup and paten dated 1662 , and a silver dish and flagon of 1717.20 The registers date from 1561 .

In the churchyard there is a curious carved stone

II Ibid. I $\mathrm{D}_{4} \mathrm{I} / \mathrm{I} 8 / 2 \mathrm{I}$

12 Ibid. note added later.

13 Ibid. I 1 I/ $18 / 22$.

34 Ibid. 245 , $50 / 6,8$.

is An oil-painting of the Manners crest, the peacock, hangs in the aisle, probably dating from the late 18 th or early igth cent.

${ }_{16}$ White, Dir. Leics. (1877), I 40.

17 Nichols, Leics. iv. 27.

18 Inscrip. on west wall of south aisle.

19 Dare, Aylestone, 72-74

20 A. Trollope, Ch. Plate of Leics. i. 3 I 0. 


\section{A HISTORY OF LEICESTERSHIRE}

probably of Norman origin, but now surmounted by a modern cross.

ROMAN CATHOLICISM. The church of St. Edward the Confessor, Aylestone Road, was built in I 2 I I-2 as a chapel of ease to be served by Holy Cross Priory. The chapelry has now become a parish and in 1937 the chapel of St. John Bosco was built in Stonesby Avenue to serve the Saffron Lane area.2I

PROTESTANT NONCONFORMITY. At the beginning of the I 8 th century there were in Aylestone five Presbyterians, one Quaker, and three Independants. ${ }^{22}$ Nothing further is known of the nonconformists in the parish until the building of the Baptist chapel in Sanvey Lane in $187_{2.23}$ The Primitive Methodist chapel in Cavendish Road was built in I $883 .{ }^{24} \mathrm{~A}$ second Baptist chapel was built in 1954 in Lutterworth Road, ${ }^{25}$ and there are Methodist chapels in Vernon Road $(1897)^{26}$ and in Southfields Drive (1928). ${ }^{27}$

SCHOOLS. In I 786 William Bickerstaffe, the curate of Aylestone, petitioned the Duke of Rutland as lord of the manor that 'a charity school at Aylestone... is an establishment highly necessary to prevent bar- barism' and solicited the duke's bounty for this purpose, stating that 'there are at this time 30 children here whose parents are unable to give them the least education'. This petition was signed by 58 householders in the parish, but Bickerstaffe only succeeded in establishing a Sunday school. ${ }^{28}$ The National school was built about $\mathrm{I} 846$, on a site given by the then Duke of Rutland, who also made a substantial contribution to the building of the schools. About 40 boys and 50 girls attended in 1846.29 The school was later enlarged, but only about I oo children attended in I877.30 In 1879 the Aylestone School Board was established, and two schools were built, one for the Aylestone Park area in Lansdowne Road in I88I, and one in Granby Road in 1889.31 The Aylestone School Board came under the control of the Leicester education authority after Aylestone was brought into the borough in I891. The National school was enlarged in I88I, and seven years later had an average attendance of 170 boys, the same number of girls and about 300 infants. ${ }^{32}$ The school was closed soon after Aylestone became part of the borough. ${ }^{33}$

CHARITIES. There are no endowed charities in Aylestone.

\section{BELGRAVE}

THE name Belgrave seems to have been a new one under William $I ;$ i the first syllable is probably of Norman origin and the name should therefore be translated as 'fine wood'. ${ }^{2}$ The older name of Merdegrave means 'marten grove'.

Belgrave lies a mile and a half north-east of the centre of Leicester. The ancient parish of Belgrave lay in East Goscote hundred and contained the chapelries of Birstall and South Thurmaston as well as the township of Belgrave itself. Birstall and South Thurmaston became separate civil parishes, apparently in the $\mathrm{I} 9$ th century, and are not dealt with here. Belgrave civil parish itself covered $\mathbf{I}, 38 \mathbf{I}$ acres in I $88 I^{3}$ and became a local board of health district under an Act of 1877.4 This board was dissolved in I 892 , when the greater part of Belgrave was transferred to Leicester. Belgrave ceased to be a civil parish in 1896 and became part of Leicester civil parish. The remaining part of the parish was transferred in 1892 to Beaumont Leys and became part of Leicester in 1935.5

The village of Belgrave stands on a small area of river gravel, below which lies red marl, which forms

${ }_{21}$ A. H. Kimberlin, Return of Catholicism to Leic. I746-I $946,33-34,49-50$.

22 Assoc. Archit. Soc. Rep. छ Papers, xxix. 234.

23 Wright, Dir. Leic. (1882), 284.

24 Spencer, Nerv Guide to Leic. (1 888), I06.

25 See Leic. Mercury, 8 Nov. 1954.

26 Wright, Dir. Leics. and Rut. (1896), 96; Wright, Dir. Leic. (1 898), I о I.

27 Illus. Leic. Chron. I 5 Sept. I928.

28 Nichols, Leics. iv. $29 \mathrm{n}$.

29 White, Dir. Leics. (1846), 375

30 Ibid. (1877), I 40.

31 Wright, Dir. Leic. (1 882), 284; see above, pp. 336-7.

32 Kelly's Dir. Leics. and Rut. (1888), 480.

33 Cf. ibid. and Wright, Dir. Leic. (1894), 362-3.

Dugd. Mon. vi. I 078 the surface soil in the eastern part of the parish. Along the banks of the Soar there are deposits of alluvium. In I93 I the population of the two ecclesiastical parishes of St. Peter and St. Michael and All Angels, which approximate to the area of the old township, was $22,738 .{ }^{6}$ The small part of the township which is still available for agricultural purposes is mainly pasture and Belgrave is largely an urban area of terrace houses, mostly built in the last century. There are a few large factories. The British Railways (Eastern Region) railway line from Leicester to Nottingham runs through the westernmost part of the parish, although Belgrave and Birstall Station lies just outside the area under consideration. The parish is intersected by the main roads from Leicester to Melton and Loughborough.

The area around the parish church (St. Peter's) and along the Thurcaston road retains the atmosphere of earlier days. Here stand the vicarage, a house in the Georgian style built in 1825,7 and the two fine houses known as Belgrave House and Belgrave Hall. Belgrave Hall was built for Edmund and Ann Craddock between 1709 and $1713 ; ;^{8}$ the stable building,

2 W. G. Hoskins, 'Anglian and Scandinavian Settlement of Leics.', T.L.A.S. xviii. I 38 .

3 Census, I $88 \mathrm{I}$.

4 4084 I Vic. c. 242 (local act)

5 V.C.H. Leics, iiii. I79-80.

6 A small part of the former Belgrave township and civil parish lies outside the two ecclesiastical parishes; it is not possible to obtain recent figures for the pop. of the old township.

7 White, Dir. Leics. (1 846), 325 ; Leic. City Mun. Room, 245 '50/9.

8 See dates and initials on lead rain-water heads. For Belgrave Hall see also $A r c h$. $7 n l$. cxii. I 76-7. Inf. also supplied by J. A. Daniell, assistant keeper, Dept. of Antiquities, Leic. Museum. For a photograph see below, plate facing p. 429 . 
which adjoins the house, may be more precisely dated to $1710.9^{9}$ The house is interesting as a small country house of the Queen Anne period, severely plain in style. The only important addition which it has suffered since its erection is the addition, probably between $\mathrm{I} 820$ and I 840 , of a large bay window to the drawing-room. Much of the interior retains its original panelling. About 1740 the house came into the possession of IVilliam Vann, later High Sheriff of Leicestershire. When the Vanns built Belgrave House they retained the Hall and it was inhabited by various members of the family until the death of the last Mrs. Vann in I $844^{\text {I0 }}$ In I 845 John Ellis, Chairman of the Midland Counties Railway, bought the Hall and it was inhabited by his family until the death of his last daughter, Margaret Ellis, in $1923^{\text {II }}$. In r 937 the house was opened as a museum of the I 8 th century, having been acquired by Leicester Corporation from the last owner, Mr. T. A. Morley. ${ }^{12}$

Belgrave House, a Georgian brick building with stone facings, was built by William Vann in 1776 and remained the property of the Vann family until the $19^{\text {th }}$ century. ${ }^{13}$ After passing through various hands it is now (1955) the property of the corporation and is temporarily used as a day nursery.

In Thurcaston Street are the Talbot Inn, the present building dating from the late 18 th century, and Cross Corners, an early 18 th-century house of great charm, now also the property of the corporation and used for the schools service department of Leicester Museum. The old bridge over the Soar probably dates from the $15^{\text {th }}$ century but has been much altered in modern times.

In the present building of the Belgrave Constitutional Club in the Loughborough Road are some remains of the old manor-house of Belgrave, which is said to have belonged to the Hastings family and then to the Byerleys. The window of the Roman Catholic chapel which was established in the manorhouse is still visible on the north side of the house. ${ }^{14}$

MANORS. In I 0867 carucates of land in Belgrave were held by Hugh de Grentemesnil and one other by his wife Adeliz. ${ }^{15}$ At some date before I 29 Belgrave, like many other Grentemesnil lands, was acquired by either Robert de Beaumont or his son Robert le Bossu, Earl of Leicester. Twelve carucates of land formed the younger Roberts' Belgrave holding in $\mathrm{I}^{1} 3^{0.16}$ When the earldom of Leicester was divided in 1204 , Belgrave was divided also, part falling to Saer de Quency and part to Simon de Montfort. ${ }^{17}$ 'This division and the fact that the whole township

9 Date in brickwork.

1o Ex inf. J. A. Daniell.

II I. C. Ellis, Rec. of I 9th Cent. Leic. 54, and table, p. 46. Margaret Ellis and her sisters were well-known and muchloved figures in Belgrave and Leic.

12 Ex inf. J. A. Daniell; Leic. Council Mins. 1935-6, 254-7; Leic. Advertiser, 23 Jan. 1037. For opposition to the scheme see Leic. Mercury, 22 May 1936; Illus. Leic. Chron. 16 May 1936.

${ }_{13}$ Ex inf. J. A. Daniell; cf. Nichols, Leics. iii. I76, who gives $1783-4$

${ }_{14}$ Nichols, loc. cit.; A. H. Kimberlin, Return of Catholicism to Leic. $1746-1946$, 10. On the Hastings family and Belgrave see Rep. of Proc. in connexion with Belgrave Working Men's and Choral Soc. 4I-42 (Leic. City Ref. Libr., Pamphlets $\mathrm{O}_{3}, \mathrm{x}$ ). For the hall see D. Campton, Hist. of Belgrave, 40-43.

15 V.C.H. Leics. i. 31 5, 335.

16 Leics. Survey, ed. C. F. Slade, 16. was not held by one lord in ro86 strongly implies the existence of two manors in the IIth and I 2 th centuries, but definite proof of this cannot be given. The descent of the lands which appear to have constituted Simon de Montfort's fee, and which later became Belgrave's and Davenport's manors, will be traced first.

Simon de Montfort probably never obtained possession of his lands at Belgrave ${ }^{18}$ since his English possessions were seized by King John. ${ }^{19}$ Presumably Belgrave remained in the hands of the custodians of Simon's lands until Henry III restored them to his son, the younger and more famous Simon. After 1265 the overlordship of Belgrave was inherited by the successive earls and dukes of Lancaster and it became parcel of the Duchy of Lancaster in 1399 .

The history of the tenants in demesne of the Lancaster fee is obscure. On two occasions it was stated that members of the Ferrers family held land at Belgrave from the Earl or Duke of Lancaster. ${ }^{20}$ These statements may be due to a confusion of the Lancaster holding at Belgrave with the manor belonging to the honour of Winchester. ${ }^{21}$ Some of the land in question seems to have been held by a family bearing the surname of Belgrave. A William de Belgrave was among the vassals of the earldom of Leicester whose lands were allotted to Simon de Montfort after $1204 .{ }^{22}$ References to lands held by this family throughout the $14^{\text {th }}$ and $15^{\text {th }}$ centuries are numerous and the family seem to have remained vassals of the Duchy of Lancaster throughout the period. There is, however, no evidence that their holding in Belgrave formed a manor in the Middle Ages.

By the I6th century the descent is clearer for a short time. In I 5 I 2 John Belgrave died possessed of a manor in Belgrave ${ }^{23}$ and his family continued to hold it until the beginning of the 17 th century, ${ }^{24}$ when after having been mortgaged several times it was sold, probably between 1635 and $c$. 1645, when William Byerley held it. ${ }^{25}$ After it came into his possession it seems to have become merged in the manor which had belonged to the Davenport family. The manor seems to have been known as the 'manor of Belgrave and Davenports'. ${ }^{26}$ After its acquisition by the Byerley family BELGRAVE'SMANOR, as it was called in the 17 th century, descended with Davenport's manor.

The manor afterwards known as DAVENPORT'S $M A N O R$ was in existence by $152 \mathrm{I}$, when it came into the possession of William and Elizabeth Wigston. ${ }^{27}$ It seems likely that its possessions were enlarged by the addition during the century of various monastic

17 Close R. 123I-4, 19; Pipe R. 1209 (P.R.S. N.S. xxiv), 24 ; Hist. MSS. Com. Hastings, i. 340.

is The names of the manors are taken from a 17 th-cent. survey, the only known document to give them.

19 For descent of lordship see E.H.R. liv. 394; Pipe R. $1209,24$.

20 Cal. Inq. p.m. iii, p. 319; Cal. Close, 1360-4, 206.

2I See below, Pultney's manor, p. 422.

22 Hist. MSS. Com. Hastings, i. $3+0$.

23 Farnham, Leics. Notes, vi. 87.

24 T.L.A.S. xvi. 62-64; G. F. Farnham, Leics. Medieval Pedigrees, I 2 sqq.

25 e.g. Farnham, Leics. Notes, vi. 92, 94. The actual deed is missing. Survey of Wm. Byerley's property, I645: Leic. City Mun. Room, 35'29/57. The Belgraves had been selling property since about I600: Farnham, Leics. Notes, vi. 91, 94; Cal. S.P. Dom. 1629-3 1, 71.

26 e.g. T.L.A.S. xvi. $62,64,69$.

27 Farnham, Leics. Notes, vi. 87 . 


\section{A HISTORY OF LEICESTERSHIRE}

holdings which were among the properties of Roger Wigston, William's kinsman, when he died in I609.28 The religious houses of Leicester Abbey, Drax (Yorks.), Sulby (Northants.), Gracedieu, Kirby Bellars, and Studley (Warws.) had all held land in Belgrave and these properties were acquired by the Wigstons. In I 589 the manor was granted in reversion to Elizabeth Wigston on her marriage with William Davenport of Henbury (Ches.) ${ }^{29}$ and remained with their descendants until I64I, when it was settled upon William Byerley to pay the debts of the last William Davenport. 30 It remained in the possession of the Byerleys and their descendants, the Beaumonts, until about I830.31 John Beaumont then sold a considerable part of his property, some being purchased by Henry Harrison. ${ }^{32}$ In 1831 the manors in Belgrave were owned by T. B. Oliver and Henry Harrison ${ }^{33}$ and it seems likely that although Harrison must have bought considerable quantities of Beaumont's lands, Oliver had acquired the lordship of his manor. ${ }^{34}$ It descended from him to the Tempest family 35 and from them to the Wades, who moved away from Belgrave at the end of the last century. ${ }^{36}$

It is not possible to give a very satisfactory account of the tenants in demesne of the lands at Belgrave which were allotted after I204 to Saer de Quency, Earl of Winchester. After Saer's death his lands at Belgrave passed to his son Roger, who died seised of them in $1264.37 \mathrm{He}$ had no male heirs and his lands were divided among his daughters. The Winchester fee at Belgrave went to Margaret de Ferrers, ${ }^{38}$ although some of the revenues appear in the hands of John Comyn, the son of another daughter. ${ }^{39}$ Lands at Belgrave continued for long to be held by the Ferrers family of Groby 40 and by their heirs the Greys. ${ }^{41}$ Roger de Quency had granted a considerable part of Belgrave to Garendon Abbey before his death, surrendering his right to exact suit of court and foreign services. ${ }^{42}$ Another part of the fee was held in 1264 by Ernald de Bosco, ${ }^{43}$ from whom it descended to his son John, who held it in $1279-80.44$ Richard Burdet held it under John de Bosco and he was probably the tenant in demesne as none of his

28 For the properties see Valor Eccl. (Rec. Com.) under these houses; L. E P. Hen. VIII, xx (2), p. I I8; ibid. xxi (I), p. I 50; ibid. xv, p. I I 5 ; Farnham, Leics. Notes, vi. 9 I.

29 Farnham, Leics. Notes, vi. 91 ; T.L.A.S. xvi. 62.

30 C.F.ii. 164 ; and see Hist. MSS. Com. Cowper, i. 424.

${ }_{31}$ Nichols, Leics. iii. I 75-6; Leic. Fnl. I9 May I 826.

32 L.R.O., Belgrave Land Tax Assessments, I829-31.

3 Curtis, Topog. Hist. Leics. I 4.

34 See below, n. 35 .

5 J. G. Harrod \& Co., Dir. Leics. and Rut. (1870), 38 I ; Ellis, Rec. of I 9 th Cent. Leic. I I 2 , I 16

${ }_{36}$ Ellis, op. cit. I 3 I, I7 I ; W. Scarff, Leics. and Rut. at Opening of 2 oth Cent. 195.

37 Cal.Inq. p.m. i, p. 257

38 Hist. MSS. Com. Hastings, i. 325.

39 Cal. Inq. p.m. iii, p. 228; Complete Peerage, ii. 375

40 Cal. Inq. p.m. viii, p. 3 I 7; Cal. Inq. p.m. (Rec. Com.), iii, p. 94 ; ibid. iv, p. 223; Cal. Close, 1346-9, I84; ibid. I $369-74,274$.

41 Cal. Inq. p.m. (Rec. Com.), iv, p. 279

${ }^{42}$ Cal. Chart. R. 1327-4r, 473, where Roger de Quency's gift is confirmed.

43 Cal. Inq. p.m. i, p. 257

44 Bodl. Libr., MS. Rawl. B 350, f. 22

45 Cal. Fine R. 1273-1307, 270.

46 Ibid. $1307-19,164$.

47 Cal. Inq. p.m. vi, p. 444 ; ibid viii, p. 3 I7. Farnham states that in $1295 \mathrm{Wm}$. de Bosco made an agreement with Millicent de Monte Alto to settle lands in Belgrave with tenants had more than a few virgates. After the deaths of John de Bosco ${ }^{45}$ and his brother William ${ }^{46}$ the property descended to their niece, the wife of William la Zouche of Haringworth, ${ }^{47}$ and was held by the Zouches until after $1457 . .^{8}$ By the I4th century, however, the Ferrers lands at Belgrave had been divided between a number of sub-tenants, 49 including several religious houses, and it seems that by I 468 the Zouche family's possessions in the township consisted only of the right to hold a view of frankpledge. ${ }^{50}$ In the later 15 th century the descent of this manor is lost.

In 1542 it is probably to be seen again in the manor which was granted by the Earl of Rutland to Robert Dalby and Robert Pyne ${ }^{5 \mathrm{I}}$ and which was almost certainly augmented by the lands of Garendon Abbey which had been granted to the earl in the previous year. ${ }^{52}$ Dalby and Pyne held the manor together until I 549, when Dalby died, and it was then held by Pyne alone until I606.53 It seems to have been sold before I6I7 to Sir John Pultney, who died in that year, seised of a manor at Belgrave held of the fee of Winchester.54 In about 1645 it was still known as PULTNEY'S MANOR and the chief rent from it was payable to William Byerley, the owner of the other two manors. 55 It seems very likely that this manor continued to have a separate existence until the Igth century and that it was the one held by Samuel Taylor and Henry Colborne in $1654,{ }^{56}$ by their sons in 1662,57 and by Francis Holbeach of Leicester before his death about $1740 . .^{88}$ In the lawsuit which followed the probate of his will, 59 one of the contestants was a member of the Edwyn family, who must have been successful, for in Nichols's day Archdeacon Burnaby, who was descended from the Edwyns, was the owner of part of this manor jointly with a Mrs. Allanson. ${ }^{60}$ In $\mathrm{I}_{83} \mathrm{I}$ it had passed into the possession of Henry Harrison, ${ }^{61}$ who probably acquired it when it was put up for sale in 1826.62 It remained the property of the Harrison family until at least 1877.63

ECONOMIC HISTORY. Although Belgrave is now included in the city of Leicester, its early history

other property on the marriage of Millicent's son, Wm. la Zouche, and Matilda, de Bosco's niece: T.L.A.S. xii. 204. The inq. taken after Millicent's death includes Belgrave among her possessions, although it is difficult to see how she could have acquired it. See also Warws. Feet of Fines, ii. 40-4I (Dugdale Soc. xv).

${ }^{48}$ Cal. Inq. p.m. (Rec. Com.), iv, p. 279; Nichols, Leics. iii. 174

49 Nichols, Leics, i, p. cv.

50 Cal. Inq. p.m. (Rec. Com.), iv, pp. $15,345$.

51 Farnham, Leics. Notes, vi, 90.

52 L. E P. Hen. VIII, xvi, p. 326. In 1608-9 Sir Geo. Belgrave had a view of frankpledge in Belgrave for the Garendon or Garradon fee: Leic. City Mun. Room I $\mathrm{D}_{50} / \mathrm{XII} / 3 \mathrm{~b}$.

53 Farnham, Leics. Notes, vi. 90.

54 T.L.A.S. xvi. 5 I.

55 Leic. City Mun. Room, 35'20/57.

56 C $33 / 2$ 19, f. $362 b$; Nichols, Leics. iii. 175 .

57 C $33 / 219$, f. $326 b$.

58 L.R.O., Probate Rec. St. Marg. wills, no. 383 , will dated 1737 .

59 Ibid. case papers tied up with will; $42 n d$ Dep. Kpr.'s Rep. $\mathrm{I} 86$.

60 Nichols, Leics. iii. I76.

61 Curtis, Topog. Hist. Leics. I 4.

62 Leic. Fnl. I9 May 1826.

63 White, Dir. Leics. (I877), I5 I ; the Harrisons also owned Newfoundpool: see p. 456 . 
is rural and agricultural rather than urban and industrial. Nothing is known of Belgrave before the Conquest. Like so many other Anglo-Saxon villages in east Leicestershire it was built on a small area of river gravel. ${ }^{64}$ In 1086 there were 3 ploughs with three servi on the demesne of Hugh de Grentemesnil. His tenants, free and unfree, had a further 4 ploughs. The lands held by Hugh's wife were all apparently in the hands of unfree tenants. Hugh and his wife held in all 8 carucates at Belgrave and in addition he had 24 acres of meadow which probably lay along the river. ${ }^{65}$ 'Ten houses in Leicester were attached to the manor and were probably occupied by men whose function it was to make purchases for Hugh's fee at Belgrave. ${ }^{66}$ The woodland is described in the Domesday survey as 5 furlongs in length and 3 in breadth, and probably lay to the west of the village, where the forest still extended as far as the village fields in the I 3 th century. ${ }^{67}$ During the 12 th and 13 th centuries the amount of arable land at Belgrave increased, probably through the clearing of the forest, for in the early 12 th century there were 12 carucates of land ${ }^{68}$ and in 1279 rather more than sixteen.69 The lands adjoining the village fields which Leicester abbey obtained from Simon de Montfort were apparently woodland when acquired, 70 but in 1341 they are described as an assart. ${ }^{2} \mathrm{I}$

Some encroachments were made upon Leicester Abbey's territory, for at an unknown date a certain Lawrence de Belgrave was forced to recognize that he had appropriated some of the abbey's waste where he had apparently inclosed several plots in severalty. ${ }^{72}$ In an attempt to end disputes between the abbey and the village, the abbot and convent granted to the villagers the right to pasture their animals in one of their riverside meadows during the winter months, receiving in return permission to pasture in one of the village's meadows. ${ }^{73} \mathrm{It}$ is interesting to note that this agreement with the abbey was made by the community of the village as a whole (tota communitas de Belgrave). ${ }^{74}$ The dispute with the abbey caused serious disorders in 1357 when the men of Belgrave, led by John Lawrence, who claimed certain rights over the abbey lands, threw down the abbot's gallows, which were in a corner of the field called the 'Stokking', ${ }^{75}$ and obstructed the transit of provisions to the abbey. They were fined for these outrages and John was forced to abandon his claims. ${ }^{76} \mathrm{It}$ is not known whether the agreement with the abbey mentioned above occurred before or after this outbreak.

Much of the land in the parish changed hands after the Dissolution.77 It was not, however, untii more than a century later that a drastic change was made in the agricultural life of the village by the

${ }_{64}$ T.L.A.S. xviii. I $17-18$.

65 V.C.H. Leics. i. 315, $335 . \quad 66$ Ibid. $306,303$.

${ }^{67}$ Cal. Chart. R. 1 226-57, 408; Dugd. Mon. vi. 415.

68 Leics. Survey, ed. Slade, I 6.

${ }^{69}$ Bodl. Libr., MS. Rawl. B. 350, f. 22.

70 In or before 1252: Cal. Chart. R. 1226-57, 405; Dugd. Mon. vi. 456 ; R. H. Hilton, Econ. Development of some Leics. Estates, 6I, n. I.

71 Hilton, loc. cit.

72 Nichols, Leics. iii, App. p. II.

73 They acquired Beaumont Leys from Simon de Montfort: Rot. Hund. (Rec. Com.), i. 238. The number of ecclesiastical holdings in Belgrave was comparatively large: see above, p. 422.

74 Nichols, Leics. iii, App. p. I I.

${ }_{75}$ Probably the same as the present Stocking estate: see p. $45 \mathrm{I}$. inclosure of the open fields. Before the inclosure of I654 a three-year system of rotation seems to have been practised. Thomas Brewerne, for example, had at his death in 15868 acres sown with barley and 8 acres of pease, with no doubt a further 8 acres lying fallow in a third field. ${ }^{78}$ Robert Booth's property, when he died in 1629 , included 7 acres under corn, a further 4 acres of barley and 3 acres of oats, with presumably another 7 acres of fallow land. ${ }^{79}$ In I $_{5}$ I there seem to have been 6 arable fields in the township, Townside Field, Clayland Field, Moor Field, Breach Field, Hadland Field, and Mill Hill Field. ${ }^{80}$ Thomas Brewerne, a member of a family who were yeomen at Belgrave for centuries, may be taken as a typical example of a fairly prosperous yeoman farmer. At his death, besides the 24 acres of land already mentioned, he possessed 4 cows, 9 pigs, and 5 draught animals. His house consisted of a hall, parlour, chamber, and kitchen, with a stable and barn. The total value of his personal estate was fig4 I9s.

The inclosure of Belgrave was made under articles of 1654 , confirmed in Chancery in 1662.81 In 1654 there were 23 persons owning land in the open fields and rights in the commons of Belgrave. ${ }^{82}$ Seven of these, who only owned cottages to which rights of common were attached, received 5 acres each under the inclosure agreement. The extent of the lands obtained by the other landowners is not stated in the agreement but it seems clear that by 1657 many of the smaller landowners had disposed of their property. In John Coffin's map of 1657 the land is grouped under six estates. ${ }^{83}$ It is not stated whether those named as holding the lands were owners or tenants, but some at least were probably tenants, as William Byerley owned about $\mathbf{I}, 200$ acres of land in the parish before it was inclosed, and is shown on the map as only holding 323 acres. ${ }^{84}$ The township is shown divided into fields, mostly between 40 and 80 acres in area, except for a group of smaller closes round the village itself, which probably represent old inclosure. The meadows still lay on either bank of the Soar.

Early in the 18 th century Belgrave gradually began to see changes which were to alter its position as a purely agricultural village. The building of Belgrave Hall in $1709-13$ for Edmund Craddock ${ }^{85}$ marked the beginning of the village's life as a residential suburb for the wealthier of the Leicester tradespeople. The Byerleys, who had come to Belgrave 60 years before, had also originally been inhabitants of the borough. 86 In 1726 the road from Market Harborough to Loughborough which ran through the village was turnpiked. ${ }^{87}$. The turnpike trust undertook the repair of Belgrave Bridge in 1762 , in consideration of $f_{1} 100$ from the parish. ${ }^{88}$ The bridge was altered in $\mathrm{I} 77 \mathrm{I}$

76 Hen. Knighton, Chron. (Rolls Ser.), ii. 96-97.

77 L. छ० P. Hen. VIII, xv, p. I I5; ibid. xvi, p. 326 ; ibid. xx (2), p. I 8 ; ibid. xxi (1), p. 224; Cal. Pat. I 553, 305 ; ibid. I $553^{-4}, 283$; ibid. I $557^{-8}, 49$.

78 L.R.O., Probate Rec., Inv. Thos. Brewerne, I 586.

79 Ibid., Inv. Robert Booth, 1633.

80 Nichols, Leics. iii. I 80.

81 C $33 / 2$ I 9 , ff. $362,363$.

82 Details of incl. from ibid. Part is printed in Nichols, Leics. iii. 175 .

${ }_{83}$ Leic. City Mun. Room, ${ }_{4} \mathrm{D}_{49} / \mathrm{I}$.

84 Ibid. 35 '29/57

85 See above, p. 420.

86 See pedigree in Nichols, Leics. iii. I 78.

87 C. F. xx. 680 . For the earlier hist. of the bridge see V.C.H. Leics. iii. 69 n., 72.

88 V.C.H. Leics. iii. 86. 


\section{A HISTORY OF LEICESTERSHIRE}

and in $1795 .{ }^{89}$ In 1834 the turnpike at Belgrave was straightened. A new bridge was built to the designs of William Parsons, the Leicester architect and surveyor to the turnpike trust, and the new road from Vann's Corner in Belgrave to the foot of Birstall Hill was opened in $1835 .{ }^{90}$

The construction of the Leicester Navigation in I 79I also affected Belgrave, where a canal was dug to the south of the village and another to the north to provide a passage for barges at two points where the Soar was unsuitable for navigation. 91 Such improvements in the communications between Leicester and Belgrave probably accelerated the development of the village as a suburb of Leicester and the home of several prosperous tradesmen from the borough. ${ }^{92}$ By $\mathrm{I} 800$, too, industry and trade were becoming more important than agriculture, with the development of the hosiery industry. In I 80 I more than I 48 persons out of the population of 601 were engaged in trade and industry, while only 55 were employed agriculturally. ${ }^{93}$ Belgrave apparently concentrated on the making of socks. ${ }^{94}$ In 1844 there were 200 frames at work in the village ${ }^{95}$ and in $183 \mathrm{I}$ it was said that most of the population were framework-knitters. ${ }^{96}$ In I 85 I out of a total of 1,398 there were 323 framework-knitters. $97 \mathrm{~A}$ map of the township drawn in I 845 shows only three stockingers' shops, ${ }^{98}$ so that the industry must have been mostly carried on in the operatives' own homes.

In 1845 Belgrave, with a population of about $\mathrm{I}, 200,{ }^{99}$ was still a village distinct from the expanding borough of Leicester. Houses were concentrated around St. Peter's Church and along Bath Street, and there were a few out along the Loughborough Road, while the Melton Road still ran through fields where it passed through Belgrave township. West of the river there were few buildings except for a number of scattered houses along Abbey Lane. ${ }^{1}$ The buildingup of the village into a suburb took place between about 1870 and $1900 .{ }^{2}$ Streets of terrace houses were built and the population reached 12,000 in $1900 .^{3}$ The outlines of the old village vanished and Belgrave became part of the urban mass of Leicester. The village was lighted with gas in $1864^{4}$ and horse trams were established in $1874 . .^{5} \mathrm{By}$ I $89 \mathrm{I}$ lines of houses stretched along both sides of Loughborough Road

89 P. Russell, Leics. Road, I I 8.

90 Ibid. I 39-41; V.C.H. Leics. iii. 83 .

91 C.F. xl. 562 ; L.R.O., Plan for Intended Navigation from Loughborough to Leic. June I791, sect. iii. See also Leic. City Mun. Room, 3 $\mathrm{D}_{42} / 57 / 142$.

92 Nichols, Leics. iii. I72.

93 Census, i $80 \mathrm{I}$.

94 V.C.H. Leics. iii. 5

95 Ibid. 20.

96 Curtis, Topog. Hist, Leics. I 4 .

97 V.C.H. Leics, iii. 20 ; cf. Census, $185 \mathrm{I}$

98 L.R.O., Belgrave tithe map, 1845 .

99 White, Dir. Leics. (I 846), 325.

L.R.O., Belgrave tithe map, I 845 .

e.g. Leic. Inl. 8 Jan. 1863 (sale of the Grange); Leic Chron. and Leics. Mercury, 4 Feb. 1871 ; Leic. City Mun. Room, $3 \mathrm{D}_{42} / 42 / 30_{3}, 3 \mathrm{D}_{42} / 57 / 139-40$. Many of the terrace houses are dated.

3 C. N. Wright, Dir. Leics. and Rut. (I900), p. xxx.

4 Campton, Hist. of Belgrave, 48.

Ibid. 49. On life in Igth-cent. Belgrave see Ellis,

Rec. of Igth Cent. Leic. I 12 sqq., 129 sqq., and passim.

6 L.R.O., Boro. of Leic. Extension map, I 89 I

7 V.C.H. Leics, i. 315.

8 Dugd. Mon. vi. 464 ; Cal. Chart. R. $1300-26,380$.

Nichols, Leics. iii, App. p. I I.

to Rot. Hund. (Rec. Com.), i. 238. See below, p. 453 . nearly linking Belgrave and Leicester ${ }^{6}$ and the formal recognition of their connexion followed in 1892 when most of Belgrave was absorbed in the borough.

MILLS. At the time of the Domesday survey there was only one mill in Belgrave, belonging to Hugh de Grentemesnil and rendering I2s. yearly.7 Not later than I 62 the mill was granted by Hugh's successor, Robert le Bossu, Earl of Leicester, to Leicester Abbey. ${ }^{8}$ Later references to the mill pool show that the abbey's mill was a water-mill on the Soar. ${ }^{9}$ 'The new mill between Leicester and Belgrave' mentioned in 1274 was probably the abbey mill.10 There were other mills in Belgrave during the Middle Ages. In I333 Laurence de Belgrave obtained a mill there by fine from Adam de la Wolde and Thomas Davy. ${ }^{11}$ Laurence's son John held the mill at his death in I 398 or $1399 .{ }^{12}$ In the 16 th century another mill in Belgrave was held by Grace Dieu Priory. ${ }^{13}$

The subsequent fate of these mills is obscure. Roger Wigston died possessed of a mill in 1609 , which was probably the one formerly belonging to Leicester Abbey, and probably also the one which descended with Davenport's manor to the Tempest and Wade family. ${ }^{14}$ Four mills are mentioned in the I 7 th century as belonging to this manor. ${ }^{15}$ In ${ }^{16} 67$ only one was shown on the map of Belgrave, ${ }^{16}$ and it seems likely that from that time it remained the sole water-mill in the village. At the end of the I8th century it was leased to a Henry Swain but in 1828 the corn miller was Robert Spence, and in 1835 John Biggs. ${ }^{18}$ By I 846 John Tempest, the mill-owner, had taken over. ${ }^{19}$ Before I 863 William Evans leased the mill from the Tempests $^{20}$ and until about 1870 worked it as part of his corn-milling business. ${ }^{21}$ It was purchased by the corporation in 1872 from John Tempest's executors, for use in connexion with flood prevention works, ${ }^{22}$ although it seems to have continued to be leased to a miller. ${ }^{23}$ It last appears in the corporation's accounts in $1895^{24}$ and was probably demolished very shortly afterwards. This mill stood on the river near the point at which it is now crossed by a foot-bridge at the west end of Holden Street. 25

The Grace Dieu mill was granted in I 545 to William Sheldon and John Draper with other pieces of monastic property, ${ }^{26}$ and may have been one of

II Farnham, Leics. Notes, vi. 76.

12 Ibid. vi. 8o; Cal. Inq. p.m. (Rec. Com.), iii, p. 227.

I3 L. छळ P. Hen. VIII, xx (2), p. I 18.

14 Farnham, Leics. Notes, vi. 91. The Belgrave mill was probably in the possession of Roger Wigston before I 589 when his manor was settled upon the Davenports: see above, p. 422 .

is Leic. City Mun. Room, 35'29/57.

16 Ibid. ${ }_{4} \mathrm{D}_{49} / \mathrm{I}$.

17 L.R.O., Belgrave Land Tax Assessments, 1773. For the mill at the beginning of the 19 th cent. see Nichols, Leics. iii. 176 , and plate $\mathrm{xxxi}$.

is Pigot, Dir. Leics. (1835), I 33 ; ibid. (1828), 487.

19 White, Dir. Leics. (1846), 326.

20 Ellis, Rec. of I9th Cent. Leic. I I2. The Evans family came to Leic. about I850: Memoir of Wm. Evans, 1830$I 92 I$, I (copy in Leic. City Ref. Libr.).

21 See ibid. and Ellis, op. cit. I 27. For description of the mill see Ellis, op. cit. I $12-27$ and passim.

22 Leic. Chron. and Leics. Mercury, 2 I June I871; J. Storey, Hist. Sketch of Boro. of Leic. 76.

23 Boro. of Leic. Abstract of Accts. I 899-90, 205

24 Ibid. $1894-5,220$; cf. Ellis, Rec. of Igth Cent. Leic. 127

25 L.R.O., Belgrave tithe map, 1845 ; Boro. of Leic. Extension map, I 89I.

${ }_{26} L$. छ $P$. Hen. VIII, xx (2), p. I 18. 
the other water-mills which were attached to Davenport's manor in the I 7 th century but which do not appear after that. ${ }^{27}$ This manor also had a windmill at the same date. ${ }^{28}$ In $155^{8}$ George Belgrave had eight windmills in Belgrave and elsewhere, ${ }^{29}$ and in I 568 his son Ambrose acquired a horse-mill in the village. ${ }^{30}$ Nothing more is known of these.

PARISH ADMINISTRATION. Belgrave was governed by the usual parish officers until the igth century, when the growth of the village necessitated the establishment of a local board of health and later a burial board. Belgrave certainly had a workhouse before 1776 , although the first known mention of one is in that year. ${ }^{31}$ The parish expended a considerable amount of money on poor relief in the late I 8 th and early I9th centuries. ${ }^{32}$ Lack of records makes it impossible to give details of parish administration in the Igth century. ${ }^{33}$ The workhouse was converted into private houses about I $880 .^{34}$

In 1878 , when the turnpike trust was wound up, the local board received $f_{53}$ I2s. $2 d$. of its surplus revenues and was thereafter charged with the care of I $\frac{5}{8}$ miles of the former turnpike road. 35 The last toll gate, at the end of the tram terminus in the Loughborough road, was abolished in 1878.36

Belgrave Local Board petitioned unsuccessfully against the bill to include the township in the borough of Leicester in I 890, though the burial and school boards and the ratepayers were all in favour of the scheme. 37 The school board, the board of health, and the burial board were dissolved by the Act. ${ }^{38}$

Birstall and South Thurmaston appear to have been administered along with Belgrave until after I 86 I, but by I 88I they were separate civil parishes. ${ }^{39}$

CHURCHES. The church of Belgrave with its tithes and eleven virgates was granted to the Norman abbey of St. Evroul (Orne), by Hugh de Grentemesnil at some date before Io8I.40 About I220 it was stated that the patron of the church was the Abbot of St. Evroul, and that the two chapels of Birstall and South Thurmaston, which Hugh had also given to the abbey, were still attached to the church. ${ }^{4 I}$ During the I 3 th century the rights of patronage remained the property of the abbey, but presentations were made by the Prior of Ware (Herts.), a cell of the French abbey. ${ }^{42} \mathrm{~A}$ pension of 10 marks was being paid in I 220 by the Rector of Belgrave to the Abbot of St. Evroul. ${ }^{43}$ Owing to the seizure by the Crown of the

27 See above and Leic. City Mun. Room, 35'29/57.

28 Leic. City Mun. Room, 35'29/58.

29 Farnham, Leics. Notes, vi. 88.

30 Ibid. 89.

3 Campton, Hist. of Belgrave, 34, 36.

32 Answers and Returns relative to Expense and Maintainance of Poor, H.C. I 75, pp. 256-7 (1803-4), xiii.

33 The rec. of the local board cannot be traced.

34 Campton, Hist. of Belgrave, 49.

35 Russell, Leics. Rd. I 59.

36 Campton, Hist. of Belgrave, 49.

37 Storey, Boro. of Leic. I $50,155$.

38 Leic. Extension Act, $54 \& 55$ Vic. c. 100

39 Census, I861, I881.

40 Round, Cal. Doc. France, 229; Reg. Regum AngloNormannorum, ed. H. W. C. Davis, no. I40. The peasant tithe-collectors who were also given are discussed in E.H.R. lxix, 580 sqq.

${ }^{41}$ Rot. Hugonis de Welles, ed. W. P. W. Phillimore, i. 256

42 Ibid. ii. 303, 319 ; Rot. Robert Grosseteste, ed. F. N. Davis, 405, 410, 411, 414; Rot. Ricardi Gravesend, ed. Davis, 1 42. For Ware see V.C.H. Herts. iv. 455 .

43 Rot. Hugonis de Welles, i. 256. possessions of alien monasteries the patronage of Belgrave came repeatedly into the king's hands under Edward II and Edward III.44 The king continued to act as patron until in I4I4 Henry $\mathrm{V}$ granted the advowson to the new Carthusian priory of Sheen (Surr.), ${ }^{45}$ which retained possession until the Dissolution; in $\mathbf{I} 535$ a pension of 5 marks was being paid by the incumbent to the Prior of Sheen. ${ }^{46} \mathrm{At}$ the Dissolution the advowson came into the king's hands, and he presented when a vacancy occurred in I 54I.47 In 1547 the advowson of the rectory was granted to the Bishop of Coventry and Lichfield, and it was provided that the rectory should be appropriated to the bishop when it next fell vacant. The bishop was to pay the Crown $f 9 \mathrm{I}_{4} s .3 \frac{3}{4} d$. a year in satisfaction of first fruits and tenths, and to appoint a vicar, paying him a stipend of $£_{1} 3_{3} 6 s .8 d .4^{8}$ The rectory was duly appropriated, but in $\mathrm{I}^{6} 6 \mathrm{o}_{3}$ it was stated that Belgrave was not endowed with a vicarage but was served by a curate with a stipend of $f_{1} 120.49$ The rectory was evidently leased in 1633 when Laud made his metropolitical visitation, and the previously satisfactory state of affairs had ended. An unknown Lady Morrison held the rectory and provided only $£ 50$ a year for the upkeep of the services and for the payment of the various unlicensed preachers who served Belgrave church and its two chapels. ${ }^{\circ 0}$ In I6 $5 \mathbf{I}$, however, Belgrave was again being served by a vicar. ${ }^{5 I}$

Belgrave was one of the wealthier livings in Leicestershire in the Middle Ages. In 1217 it was valued at 16 marks, at 30 in 1254 and at 60 in $1291 .{ }^{52}$ In 1535 it was valued at $f_{043} \mathrm{I} 6 \mathrm{~s}$. $3 \frac{1}{2} d .53$ In $165 \mathrm{I}$ the incumbent's stipend was increased. ${ }^{54}$ Between 1790 and I 825 the living was augmented by $f_{1} \mathbf{1}, 200$, contributed from Parliament and Queen Anne's Bounty, and by a gift of $f_{1} 100$ and a yearly payment of $f 8$ from the patron. In $183 \mathrm{I}$ the stipend was valued at $£_{154}$, and it was increased to $£ 300$ by the gift of the commuted tithes in 1847.55

In 1227 Stephen de Lucy and Robert and Gilbert de Birstall were parties in a dispute whether certain lands in Belgrave were free alms of the church of Belgrave. ${ }^{56}$ At the inclosure in 165444 acres of the parish were allotted as glebe, although the agreement was made when episcopacy had been abolished in England, and the patron was not a party to the settlement. 57 In 1846 there were 50 acres of glebe, of which only 20 remained in $1955.5^{8}$

44 Cal. Pat. $1324-7,134$ is the earliest example. See also, e.g., ibid. I $358-61,98 ; 1367-70,298$; I $391-6,550,608$, 6I 4; I399-I 40I, 503; I 40I-5, 237.

45 Farnham, Leics. Notes, vi. 85 ; Dugd. Mon. vi. 3 I.

46 Valor Eccl. (Rec. Com.), iv. I66. It is also stated that a pension of $\frac{1}{2}$ mark was payable to the abbot of 'Exam'. This monastery has not been identified.

47 L. छ. P. Hen. VIII, xvi. 33 I.

48 Cal. Pat. $1547-8,179$, I 80. In 1554 the presentation was made by Geo. Incestre for one turn, by grant from Sheen: Linc. N. छ Q. v. 209.

49 State of the Ch. ed. C. W. Foster, i. 296.

50 V.C.H. Leics. i. 379.

51 Nichols, Leics. iii. I 8 I

52 Val. of Norw., ed. W. E. Lunt, 532.

53 Valor Eccl. (Rec. Com.), iv. I66.

54 V.C.H. Leics, i. 384 n.; Campton, Hist. of Belgrave,

56.

55 White, Dir. Leics. (1846), 325; (1877), I 5

${ }^{5}$ Pat. R. $1228-32,159$.

$57 \mathrm{C} 33 / 219$, f. $362 b$.

58 White, Dir. Leics. (1846), 325; Kelly's Dir. Leic. (1954), p. xxi. 


\section{A HISTORY OF LEICESTERSHIRE}

At the confirmation of the inclosure agreement in I662 it was agreed that in commutation of tithes an annual rent of $f_{\mathrm{f}} \mathrm{roo}$ should be paid to the bishop or his representatives. Each acre of inclosed ground was to contribute $20 d$. a year, except for the Poor's Plot which was only to pay $16 d$. an acre. ${ }^{59}$ In 1845 a new arrangement was made whereby the tithes were again commuted for a rent charge of $f_{4} 45^{6} 7_{s}{ }^{60}$ The Bishop of Coventry and Lichfield continued to present to the church of Belgrave until the advowson was transferred to the Bishop of Peterborough, probably in 1855 when the rectory was handed over to the Ecclesiastical Commissioners. ${ }^{61}$ They sold the whole of the rectorial lands in I 860 to Sir Cornwallis Ricketts, Bart., who was already leasing the rectory from the Bishop of Lichfield in 1846.62 The tithe charges had been made over to the vicars of Belgrave and Thurmaston in 1847 in augmentation of their stipends. 'The rectorial lands were sold by Sir Cornwallis Ricketts to Isaac Harrison and 'Thomas Allen. ${ }^{63}$ After the establishment of the see of Leicester in I 926 the advowson was transferred to the bishop of the new diocese. 64

The chapelry of South 'Thurmaston was separated from Belgrave in $\mathrm{I} 84 \mathrm{I}$, and made in to a new ecclesiastical parish. ${ }^{65}$ The chapelry of Birstall was separated from Belgrave in 1928 , when it became an independent district chapelry. ${ }^{66}$

In 1887 part of Belgrave parish was transferred to the new parish of West Humberstone, and in the following year the parish of St. Michael and All Angels was formed out of the eastern part of Belgrave parish. ${ }^{67}$ The new church had been erected in I 887 on a site given by Isaac Harrison of Newfoundpool. It replaced an iron church erected in I 878. ${ }^{2}$ 'The architect of the new church was George Vialls of Ealing. ${ }^{69}$ Part of St. Michael's parish was detached to form the new parish of St. Alban in I906.70 In 1933 the conventional district of $\mathrm{St}$. Gabriel was formed and was created a statutory district in I953; the church in Edgehill Road was built in 1898.71 The mission church of the Good Shepherd is now also attached to St. Peter's. ${ }^{72}$

The church of ST. PETER ${ }^{73}$ consists of nave and chancel, north and south aisles, and porches, west tower, and vestry. It is built of rubble, in some places roughly coursed, of a mixture of local stone and waterworn boulders. The main part of the present church dates from the 13 th century, although some features from the 12 th-century church have been preserved, including the south doorway and the two lower stages of the tower. The nave and aisles and the present tower arch and lancet date from the $\mathrm{i} 3$ th century. The chancel was entirely rebuilt in the $4_{4}$ th century,

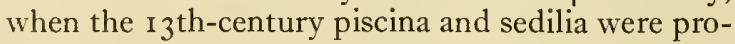

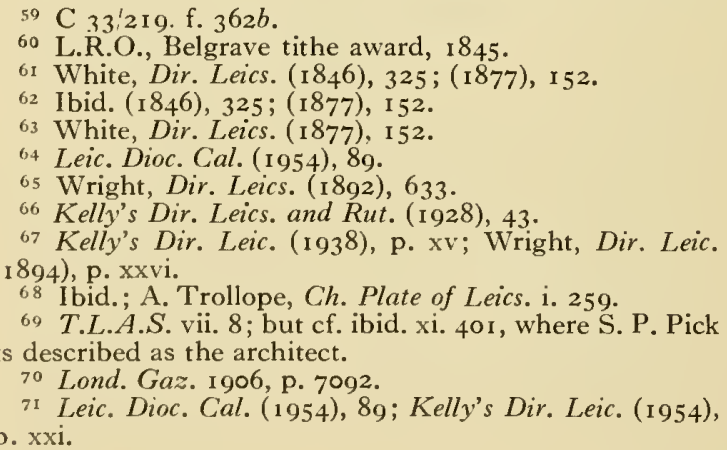

bably moved to their present position in the south aisle to make way for the more elaborate 14 th-century ones at present in the chancel. The clerestory and the upper stage of the tower date from the 16 th century.

In 15 I 8 , when Belgrave was visited by the Bishop of Lincoln, it was found that the windows of 'St. Mary's chapel', about which nothing else is known, needed repair. ${ }^{74}$ In ${ }_{1} 55^{6}$ the chancel was much dilapidated, 75 but had evidently been repaired by I 636, when no serious structural defects were noted. ${ }^{76}$ Belgrave church seems to have been reasonably well cared for throughout the rest of the 17 th and for most of the 18 th century, 77 although in common with many other Leicestershire churches it was criticized by Archdeacon Burnaby in 1793 as needing considerable minor repairs. ${ }^{78}$ In 1826 the south porch, which hides the old 12 th-century doorway, was built by William Bradley in a style different from that of the rest of the building. ${ }^{79}$ In 1832 and 1837 the chancel, which should have been maintained by the lessee of the tithes, was in need of repair. At this time the church had a lead roof throughout and the tower had a low leaden spire. ${ }^{80}$ New pews were fitted in $1857^{81}$ and the church was extensively repaired in I 862. 82 The choir vestry was built in 1877 , when the organ and organ chamber were installed, 83 and enlarged in 1908 when the clergy vestry was built. ${ }^{84}$ The north porch was added in $\mathbf{I} 9 \mathbf{I} 2$ and the church was again reseated in 1938.85

The tower is in three stages, the two lower ones dating from the isth, the upper from the 16 th century. Each stage is diminished by weathered offsets, and the tower is finished with a battlemented parapet, now much restored. On the west side is a modern doorway, with a $\mathbf{I} 3$ th-century lancet window above. There is no interior staircase.

The nave is of four bays with a good early-I6thcentury timber roof. The arcades are of pointed arches, which are supported on pillars with moulded capitals and bases except for the central pillar on the south side which has a floriated capital. The tower and chancel arches are in a similar style, but the capital on the north side of the tower is carved with three heads with ivy leaves issuing from their mouths, and that on the south is decorated with vine stems and leaves. The pulpit dates from I 882 and the lectern from $186_{3}$. The $3_{3}$ th-century font stands in the west end of the nave. It has a circular bowl, supported in six engaged columns separated by dog-tooth ornament.

The south aisle contains a I 3 th-century trefoil piscina and triple sedilia with graduated seats. Both aisles have similar roofs to that in the nave. The rear arches of the east and west windows in the south

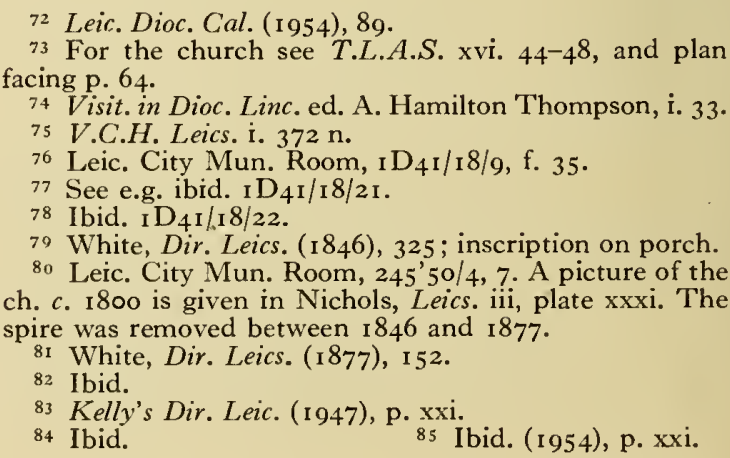


aisle have round heads and are probably retained from the I 2 th-century church, as is the west window in the north aisle. The parish chest stands in the south aisle. It has a small division at one end with a separate lid slotted for alms. The south doorway is from the 12 th-century church. The inner order of carving is a plain modern replacement but the outer one is decorated with interlaced ribbed strapwork and the middle one with interlaced ribbed semicircles. The same decoration appears on the capitals.

The chancel is lighted by an east window of five cinquefoil lights. There are three windows on the south side and a small doorway in the centre. The vestry on the north side has been built using one of the north windows and the doorway, leaving a window on each side. In the south wall is a piscina with a trefoiled ogee head, crocketed hood and floriated finial. The triple sedilia which adjoin it have cinquefoil ogee heads to the seats and the decoration in general resembles that of the piscina. The priest's stall is of late-1 5 th-century work, and evidently comes from a row of stalls.

The plate consists of a chalice of $c .1680$, a silver paten presented $c .185^{\circ}$, a silver flagon given by the parishioners in 1782 , and a pewter plate, probably obtained between 1761 and 1763.86

There are six bells, dated $1630,1631,1871$, and the remaining three 1888.87 The registers date from I 653.88

ROMAN CATHOLICISM. Belgrave may be regarded as the cradle of the Roman Catholic revival in Leicester. From at least the last quarter of the i th century until the early years of the 18 th, the Byerley family at Belgrave Hall had a Franciscan chaplain, and the Franciscans were probably succeeded by Jesuits. The Dominican mission to Leicester was revived at Belgrave in 1746 and moved into the town in 1777.89 There were said to be five Roman Catholics at Belgrave in 1676 , and 18 Catholic families out of a total of 60 in 1709 , but no figures are available for the later 18 th century and there were apparently no Roman Catholics in 1829 , although it is possible that they might have been included in the figure then given for Leicester. ${ }^{90}$ The Roman Catholic chapel at Belgrave Hall was still in existence about 1800 although unused.91

After the establishment of the Causeway Lane mission in Leicester in $1777^{92}$ there was no permanent Roman Catholic chapel at Belgrave until I920 when the chapel of Our Lady between Moira Street and Canon Street was begun. The building was completed in 1922, and was a chapel of ease to St. Patrick's, Royal East Street. When St. Patrick's

86 Trollope, Ch. Plate of Leics. i. 257-8.

87 Kelly's Dir. Leic. (I 954), p. xxi; see also T. North, Ch. Bells of Leic. I $43-4$.

88 Transcripts for several years before 1653 are in Leic.

City Mun. Room and Linc. Dioc. Registry.

89 V.C.H. Leics. ii. 61 -62 .

90 Ibid. 69 ; Nichols. Leics. iii. 18 I ; L.R.O., ret. of places of worship, 1829 .

91 Nichols, Leics. iii. I 76.

92 See above, p. 380 .

93 Kimberlin, Ret. of Catholicism, 53.

94 Assoc. Archit. Soc. Rep. छ Papers, xxix. I46.

95 Nichols, Leics. iii. I 8 I.

96 L.R.O., dissenters' meeting-houses, orig. applications, Belgrave.

97 Ibid., ret. of places of worship, 1829

98 White, Dir. Leics. (1846), $3^{2} 5$; Wright, Dir. Leic. (1882), 7 . was closed in 1940 the church centre was moved to Our Lady's, which is now the parish church of Our Lady and St. Patrick. The Roman Catholic school in Harrison Road was opened in 1937 when the Royal East Street School was closed.93

PROTESTANT NONCONFORMITY. There has always been a considerable body of dissenters in Belgrave since at least 1676 , when it was reported that there were six 'schismatical recusants'. ${ }^{94}$ In 1709 out of 60 families in the township, 7 were Anabaptist. 95 In 1807 William Agar's house was used as a meeting-place for Protestant dissenters ${ }^{96}$ and in 1829 it was estimated that there were 20 Methodists and 6o Primitive Methodists, with two chapels. ${ }^{97}$ A Wesleyan Methodist chapel was built in Bath Street in 1834 but about I 880 seems to have become only a church room and lecture hall. 98 The small Primitive Methodist chapel erected in Claremont Street in 1838 was rebuilt in 1880.99 The Baptist chapel in Loughborough Road was built in $1842 .{ }^{\text {I }}$ To serve the new residential district in the eastern part of the parish a United Methodist chapel was built in Harrison Road in $1905 .{ }^{2}$ Belgrave Hall, the chapel of the Wesleyan Methodists in Belgrave Road, was built in I901.3 To the west, Beaumont Hall, in Beaumanor Road, was built by the Primitive Methodists as a mission hall about $1894 .^{4}$

SCHOOLS. In 1832 there were two Anglican Sunday schools at Belgrave. One, which had been opened in 1787 , was maintained by Mrs. Vann and was attended by 30 boys and 30 girls. The other was attended by 92 pupils. 5 The Wesleyan and Baptist chapels also had Sunday schools in 1846.6 The National school was built at the bottom of Mill Hill in 1836,7 and was enlarged about 1848 by the addition of an infants' school which was largely supported by the Ellis family of Belgrave Hall. The infants' school existed until after $1871 .{ }^{8}$ In I 86 I this National school was replaced by a new building in Loughborough Road. ${ }^{9}$ In 1877 it was attended by about $35^{\circ}$ pupils. It was still in existence in $1956 .{ }^{10}$ The first of the Belgrave board schools was that in Mellor Street, built in 1879. ${ }^{11}$ Belper Street Board School was built in $1888 . .^{12}$ The Belgrave board schools were taken over by the Leicester School Board in 1891 .

CHARITIES. Under the inclosure agreement of I654, I acre for each yardland in the township except 2 was set aside to form a pasture for cottagers whose houses had no rights of common. The pasture was known as the Poor's Land ${ }^{13}$ and in 1787 amounted to 53 acres. ${ }^{14}$ In 1837 any of the poor could use it for 4 s. a year. Those who did not exercise their rights

99 Spencer, New Guide to Leic. (1888), 106; inscription on chapel.

I White, Dir. Leics. (1846), 325 .

2 Handbk. of Methodist Conference at Leic. $1934,48$.

3 Wright's Dir. Leic. (1 900), 12; ibid. (1 902), I3.

4 Wright, Dir. Leic. (1 894), 8; Kelly's Dir. Leics. (1 895), 128.

Leic. City Mun. Room, 245'5o/4; Campton, Hist. of Belgrave, 36 .

6 White, Dir. Leics. (1 846), 325.

7 Campton, Hist. of Belgrave, 45-46.

8 See Hagar \& Co., Dir. Leics. (1849), I 19; H. Hartopp,

R. of Mayors of Leic. 254.

9 White, Dir. Leics. (1877), I 52.

Io Ibid. (1 877 ), I 52 .

II See above, p. 337 .

12 Ibid. I3 C $33 / 2$ I9, f. $362 b$.

I4 Campton, Hist. of Belgrave, 35 . 


\section{A HISTORY OF LEICESTERSHIRE}

were paid I 2s. a year. A road had been made over the land and the sides of it were used as gardens by the

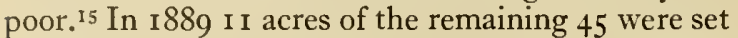
aside as a recreation ground; the rest is now used as allotments. ${ }^{16}$

Before the inclosure there existed three cottages, called the Town Houses. At the inclosure ${ }^{17}$ I I acres were added to the cottages in compensation for the loss of common rights attached to them. In 1837 they comprised 21 acres and the rent was set aside for church purposes, with the rent from the Talbot Inn and a cottage. The Church Lands, just over 2 acres allotted to Belgrave at the inclosures of St. Margaret's, Leicester, and Humberstone, were also let and the rent was used for church purposes. ${ }^{18}$ The land belonging to the three charities comprised 40 acres in 1947. It has since been reduced by sale to $20 \frac{1}{2}$ acres, which with the exception of the recreation ground are let partly as grassland, partly as allotments. ${ }^{19}$

There are three smaller charities. ${ }^{20}$ William Vann bequeathed stock which would produce $£ 5$ yearly to be spent on bread for the poor. James Vann by will proved I8 i 2 left stock producing Io guineas a year for coals for the poor. William Bradley by will dated I 830 left $£, 500$, of which only $£ 250$ could be paid, in trust for the provision of bread, coals, and blankets. No distribution had been made by I 837 .

\section{BRAUNSTONE}

BRAUnSTONE, formerly a chapelry of Glenfield, is about $2 \frac{1}{4}$ miles south-west of the centre of Leicester. In 189 I the civil parish and former chapelry of Braunstone, which is the area whose history is described here, consisted of 1,743 acres. ${ }^{1}$ The north boundary ran westwards from the Soar, north of Rowley Fields, to the Narborough road, along Fulhurst Avenue, Gooding Avenue, and the north-east side of Braunstone Park, and then crossed the Hinckley road to take in the area to the south-east of the Braunstone Frith estate. In $\mathbf{I} 892254$ acres in the north-east part of the chapelry were incorporated in the borough and included in St. Mary's parish. ${ }^{2}$ Leicester Corporation's purchase of land for a housing estate in I 925 made it inevitable that Braunstone should become part of the borough sooner or later. In 1935 the part of the chapelry to the north of Braunstone Lane was incorporated in the borough. The southern part of Braunstone remained a separate civil parish in the rural district of Blaby, and in $193^{6}$ this parish was enlarged by the addition of a small part of the parish of Lubbesthorpe. ${ }^{3}$ In $\mathbf{I} 93 \mathbf{r}$ the population of the civil parish as then constituted was 6,997 , and in I95 $18,986.4$ The surface soil of the area is mostly Boulder Clay, with small areas of gravel in the east. Beneath the Boulder Clay is a stratum of triassic marl, which appears on the surface in some places. The valley of the Dove Brook contains some alluvium. The country is undulating, rising westwards from the Soar to a height of about $300 \mathrm{ft}$. The original village was founded on a patch of glacial sands and gravels rather less than a mile from the Fosse Way, which crosses the eastern side of the area.

The northern part of the old chapelry is now mostly occupied by a large housing estate, built since 1925

15 32nd Rep. Com. Char. Pt. 5 [163], pp. 473-4, H.C. ( 1839 ), Xv.

16 Leic. City Mun. Room, 5D33/214/19.

17 Ibid.; 32 d Rep. Com. Char. Pt. 5, 473-4; C. 33/219, f. $363 a$.

${ }_{18} 3$ 2nd Rep. Com. Char. Pt. 5, 474; Leic. City Mun. Room, 5D33/214/19.

I 9 Kelly's Dir. Leic. (I 947), p. xxi ; (1954), xxi.

${ }^{20} 32 n d$ Rep. Com. Char. Pt. 5, 474-5.

I Census, I89I, which gives the acreage of the parish as changed by the Leicester Extension Act of I 89 I. It should be noted, however, that before the Act the borough surveyor calculated the area to be about $1,610 \mathrm{a}$. by Leicester Corporation. ${ }^{5}$ Braunstone Park has been retained as an open space, and it is now used as a public park. Within it on the crest of a rise stands Braunstone Hall, a plain red-brick house of three stories in the late Georgian style. It was built about I775 for Clement Winstanley, whose descendants for long possessed it. The architect was probably William Oldham of Leicester. ${ }^{6}$ In 1925 it was sold to Leicester Corporation, and is now (I955) a school. Some houses of the old village still stand along Braunstone Lane. At Hall Farm, at the south-east end of the village, the brick surrounding wall and some of the farm buildings, including a barn with a dovecote in the gable, are survivals from the old manor-house, which was probably built by Henry Hastings in $c$. $1600 .{ }^{7}$ Farther west, along Braunstone Lane, stands a timber-framed farm-house in dark red brick, with the front of the upper story projecting slightly, which dates from the I 7 th century. The village also contains two timber-framed cottages, one of them still retaining its thatch, which probably date from the 16 th century, and a very small timberframed building, perhaps of the 17 th century, now a shop.

MANOR. In I 086 Hugh de Grentemesnil was the tenant in chief of BRAUNSTONE, which was held from him by the son of Robert Burdet. ${ }^{8}$ In the 1 2 th and $I 3^{\text {th }}$ centuries Braunstone was probably held from the king first by the earls of Leicester, who acquired Hugh's Leicestershire lands, ${ }^{9}$ and then by the earls of Winchester, who after 1204 inherited half of the lands belonging to the earls of Leicester. There is no evidence about the tenants in chief of the manor until 1264, when Roger de Quency, Earl of Winchester, died in possession of Braunstone. ${ }^{10}$

2 Leicester Extension Act, I 89 I, 54 \& 55 Vic. c. Ioo; J. Storey, Hist. Sketch of Boro. of Leic. I 66.

3 Census, I $93 \mathrm{I}$.

4 V.C.H. Leics. iii. I 84.

5 See plate opposite.

6 Nichols, Leics. iv. 620; H. M. Colvin, Biog. Dict. of Eng. Architects, 423. Two views of the house in $c .1810$ are given by Nichols, Leics. iv, plate ci.

7 L. Fox and P. Russell, Leic. Forest, 90.

8 V.C.H. Leics. i. 316.

9 E.H.R. liv. 386

o Cal. Inq. p.m. i, p. 257. 


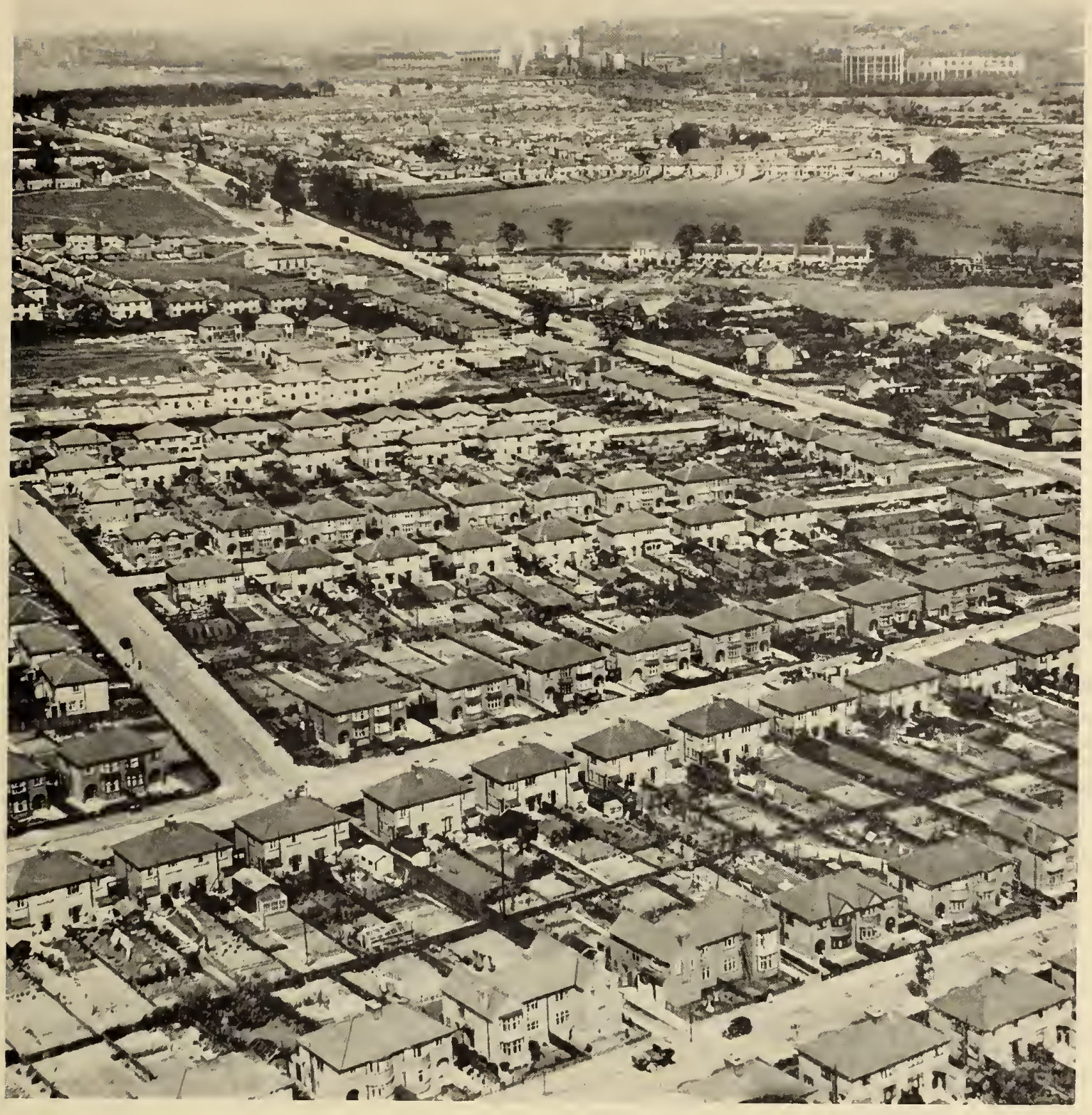

Braunstone Housing Estate from the air

The view is roughly east, across the Narborough road. The river runs in front of the gas-works and furnaces in the background 


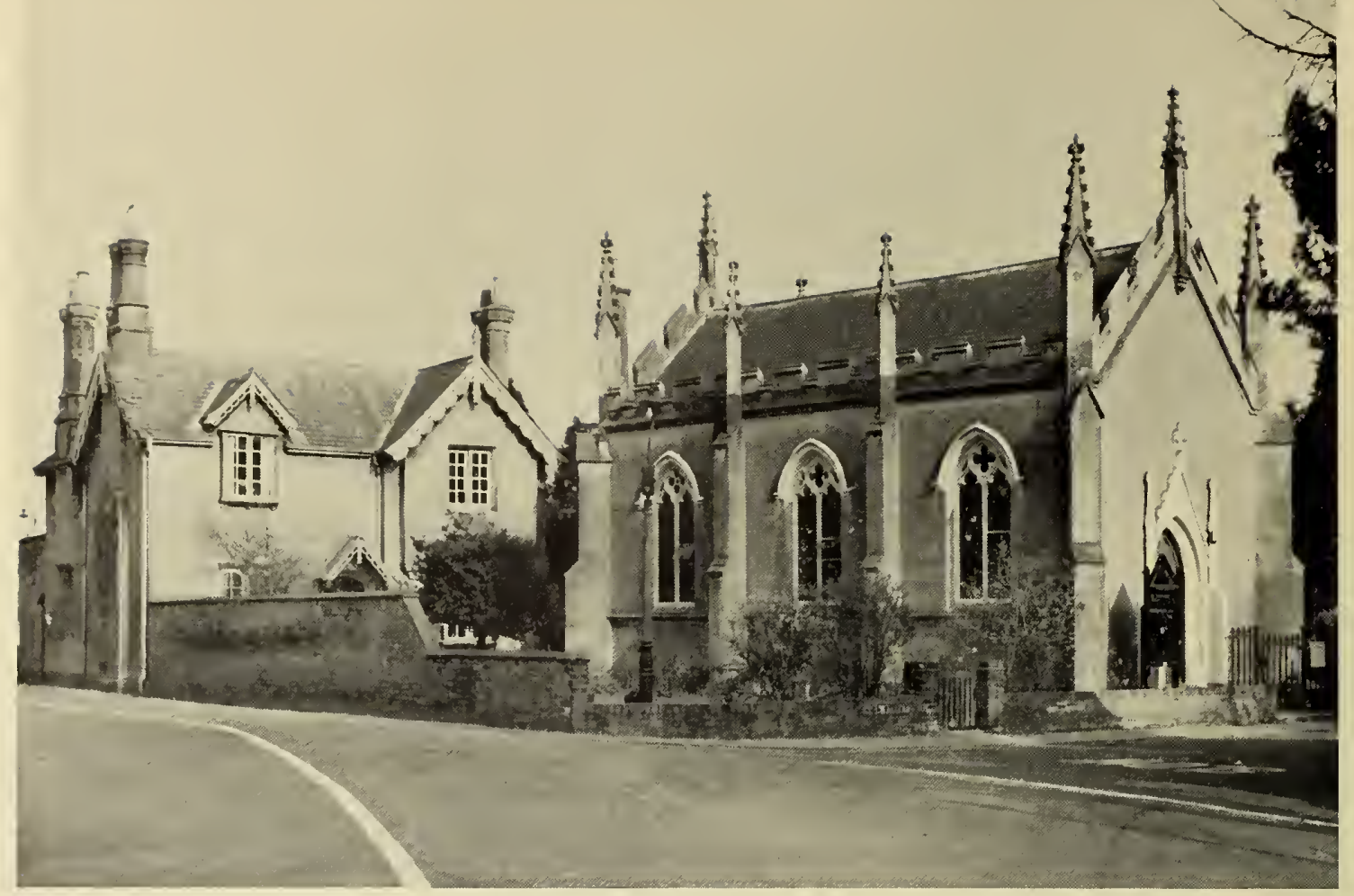

Evington Chapel and Manse

originally belonging to the Countess of Huntingdon's Connexion and later to the Strict Baptists

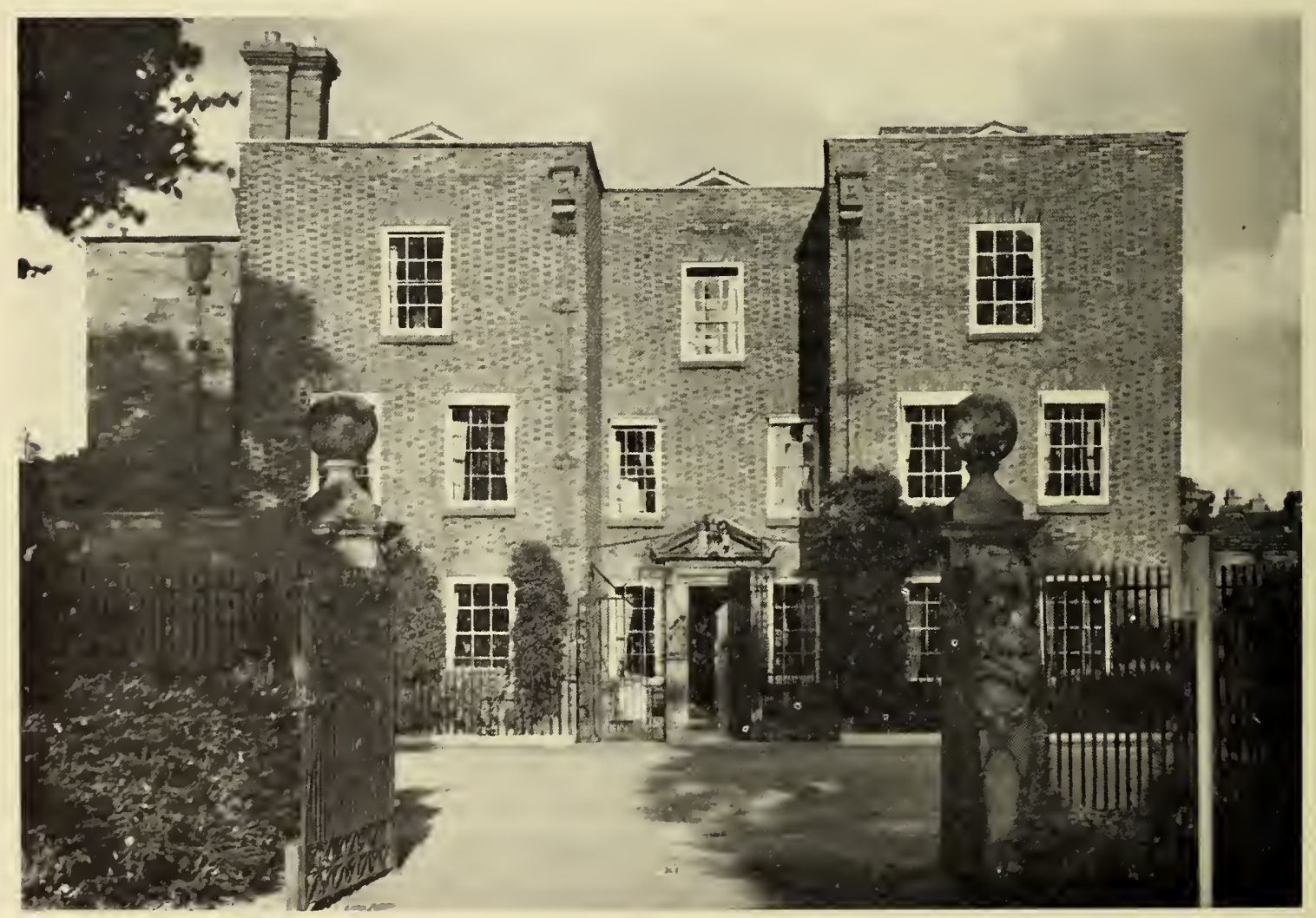

Belgrave Hall

built $c$. 1710 
After Roger's death Braunstone was assigned in dower to his widow, II and eventually it was inherited by his daughter, Margaret de Ferrers, ${ }^{12}$ whose descendants, the family of Ferrers of Groby, long retained it. ${ }^{13}$ After the death of William, Lord Ferrers, in I445, Braunstone fell to his granddaughter Elizabeth and her husband, Edward Grey. ${ }^{14}$ In I 505 Thomas Grey, Marquess of Dorset, was holding the manor ${ }^{15}$ and it probably remained in the hands of the Grey family until the attainder in I 554 of Henry Grey, Duke of Suffolk, and the forfeiture of his possessions. The history of the sub-tenants at Braunstone during the Middle Ages is less simple than that of the tenants in chief. In 1086 the son of Robert Burdet was apparently the tenant in demesne. ${ }^{16}$ His descendants continued to hold the manor from the tenants in chief until about $1450,{ }^{17}$ but by the early i $3^{\text {th }}$ century, at the latest, they had subinfeudated it. In 1207 William Harecurt was in possession of the manor, ${ }^{18}$ and the Harecurt family retained it as vassals of the Burdets ${ }^{19}$ until the sisters of Sir William Harecurt sold it in 1510.20 In 1279 Braunstone was held from Richard Harecurt by Philip le Polers, who was the tenant in demesne. ${ }^{2 I}$ In 1293 the manor was held from Richard Harecurt by Thomas de Camville, ${ }^{22}$ but Thomas was probably not then the tenant in demesne, since in 1299 the manor was held from him by Hugh of Braunstone. ${ }^{23}$ Members of Hugh's family had been holding land in the parish earlier; Hugh's brother, Master Henry of Braunstone, was holding land at Braunstone in $1297,{ }^{24}$ and Adam son of Ivo, who was holding land in the township in $\mathbf{2 2} 5$, $^{25}$ was probably Master Henry's father. ${ }^{26}$ At the end of the 13 th century there were thus three lords between the tenant in demesne and the tenant in chief. Hugh of Braunstone was succeeded by his son Henry, who in 1312 granted his lands at Braunstone to William de Herle for life. ${ }^{27}$ William's son, Robert de Herle, held considerable property at Braunstone, which was inherited by his nephew Ralph de Hastings, ${ }^{28}$ who held the manor in I $388-9,{ }^{29}$ but though his descendants held land in Braunstone they do not appear to have held the

II Close $R$. I 26I-4, 407.

12 Nichols, Leics. i, pp. cxv, cxvi; Hist. MSS. Com. Hastings, i. 323.

${ }^{13}$ Cal. Inq. p.m. viii, p. 317 ; Cal. Inq. p.m. (Rec. Com.), iii, p. 94 ; iv, p. 223 .

14 Ibid. iv, p. 297; Complete Peerage, vi. 358.

I5 Farnham, Leics. Notes, i. I 82.

16 V.C.H. Leics. i. 3 I 6.

17 Close R. I 261-4, 407; Cal. Inq. p.m. i, pp. I I I, 257 ; viii, p. 3 I 7 ; Cal. Inq. p.m. (Rec. Com.), iv, pp. 223, 279; Hist. MSS. Com. Hastings, i. 323; Nichols, Leics. i, p. cxvi.

${ }_{18}$ Rot. Litt. Claus. (Rec. Com.), i. 7 I6. William's son and heir, Richard, acquired the adjacent manor of Aylestone, before I 2 I 9 . See above, p. 4 I 5.

19 Cal. Inq. p.m. i, p. I I I ; Nichols, Leics. i, p. cxvi; Cat.

Anc. Deeds, i. A. I 407.

20 Farnham, Leics. Notes, i. I 82-3.

21 Nichols, Leics. i, pp. cxv, cxvi.

22 Cal. Inq. p.m. iii, p. 76.

23 Ibid. iii, p. 400.

24 Nichols, Leics. i, p. cxvi; Hist. MSS. Com. Hastings, i. $57-58$.

25 Farnham, Leics. Notes, i. I 74.

26 Hist. MSS. Com. Hastings, i. 61 .

27 Ibid. 65.

28 Cal. Inq. p.m. xi, p. 450; Hist. MSS. Com. Hastings,

i. $21,22$.

29 Cal. Close, 1 396-9, 95-96.

30 Cal. Inq. p.m. (Rec. Com.), iv, p. I79; Cal. Fine $R$. I 430-7, 3 II; Farnham, Leics. Notes, i. I81. manor, ${ }^{30}$ nor do those of Henry of Braunstone. By 1364 the manor was in the hands of Thomas de Erdyngton, ${ }^{31}$ who was probably the tenant in demesne. Erdyngton had married Margaret, daughter of Thomas Corbet, who had inherited the manor from William, son of Thomas de Camvile. ${ }^{32}$ Thomas de Erdyngton's descendants continued to hold the manor from the Harecurts ${ }^{33}$ until the last Thomas de Erdyngton, who died without issue in $1467,{ }^{34}$ gave up his rights in the manor to William Harecurt. ${ }^{35}$ The Harecurts were then presumably the tenants in demesne.

Before $\mathrm{I}_{48} 8_{3}$, the overlordship of the manor was acquired by the well-known Yorkist, William Hastings, ${ }^{36}$ who probably received it as a grant from Edward IV, although the means by which he acquired Braunstone cannot be ascertained. 37 In I 484 Richard III granted the manor to Marmaduke Constable, on the grounds that it had been forfeited by the rebellion of William Norreys. 38 Braunstone was held in dower by the relict of William Harecurt, Anne, who had married Norreys as her second husband, 39 so that Norreys in any case can only have had an interest in the manor during his wife's lifetime. Although Constable obtained a commission ordering the bailiffs of the manor to accept him as lord, 40 the grant to him seems to have had no permanent effect, probably because of the overthrow of Richard III in $\mathbf{I}_{48} 8$.

In I509, Simon Harecurt sold the manor to Edward Bury and others, ${ }^{41}$ who disposed of it in I 5 I I to Richard Sacheverell and others. ${ }^{42}$ The descendants of William Hastings remained overlords of the manor. ${ }^{43}$ Richard Sacheverell (d. I 534) bequeathed the manor to John Slory, who was the tenant in demesne in I 537.44 John Slory seems to have been succeeded by his son Richard, who was disposing of property at Braunstone in $I 553,45$ but by $I 589$ the manor seems to have been held in demesne by the Earl of Huntingdon, who then transferred it to Walter Hastings. ${ }^{46}$ The manor remained in the hands of the Hastings family until $\mathbf{1}_{5} 5^{\circ}$, when it was sold to Benjamin Kinge by the heirs of Sir Henry

31 Cal. Inq. p.m. xi, p. 450.

32 Farnham, Leics. Notes, i. I79, I80. It was later stated (ibid. i. 180; Cal. Close, 1392-6, 433) that Thomas and his wife had been given the manor by Thomas's father Giles, but there seems no other way by which the manor could have passed to the Erdyngton family than through the marriage of Thomas with Margaret Corbet.

${ }_{33}$ Cal. Close, 1392-6, 433; Cal. Inq. p.m. (Rec. Com.) iv, p. I 53; Farnham, Leics. Notes, i. I 80, I 8 I ; G. F. Farnham, Leics. Medieval Pedigrees, I I.

34 Farnham, Leics. Medieval Pedigrees, I I.

35 Farnham, Leics. Notes, i. 182.

36 Hist. MSS. Com. Hastings, i. 297.

37 The position of the Hastings family in relation to the Greys is unknown. The terms of a doc. of 1505 suggest that Thomas Grey and Edward Hastings were then joint overlords of the manor: Farnham, Leics. Notes, i. 182.

38 Cal. Pat. 1476-85, 47 I.

39 Farnham, Leics. Notes, i. 183 ; Hist. MSS. Com. Hastings, i. 26, 27.

40 B.M. Harl. MS. 433 , f. $169 b$.

41 Farnham, Leics. Notes, i. 183.

42 Ibid.

43 Ibid. 184; Hist. MSS. Com. Hastings, i. 309, 3 I 3 , 314.

44 Farnham, Leics. Medieval Pedigrees, 66; Hist. MSS. Com. Hastings, i. 26; Nichols, Leics. iii. 508.

45 Farnham, Leics. Notes, i. I 84.

46 Ibid. Walter Hastings's activities in inclosing the manor show that he was the tenant in demesne: T.L.A.S. xxiii. 269-7I. 


\section{A HISTORY OF LEICESTERSHIRE}

Hastings. ${ }^{+7}$ Not long afterwards it was acquired by James Winstanley, ${ }^{48}$ whose family retained it until the Igth century. James IVinstanley (d. I862) devised Braunstone to his sister, the wife of Ralph Pochin. 49 The manor continued to be held by the descendants of Ralph Pochin, who assumed the name of Winstanley, until 1925, when most of Braunstone was bought by Leicester Corporation for use as a housing estate. ${ }^{50}$

LESSER ESTATE. In 1279 Master Henry of Braunstone was holding 3 virgates of the Peverel fee at Braunstone from Millicent de Cantilupe, who held them from Roger de Montalt, the tenant in chief. ${ }^{5 I}$ Millicent had married, as her first husband, John de Montalt, whose relationship to Roger is uncertain. ${ }^{52}$ In 1299 a carucate at Braunstone was being held from Roger la Zouche by Henry's brother, Hugh. ${ }^{53}$ Millicent had married as her second husband Ivo la Zouche. When she died in 1298 her heir was her son IVilliam la Zouche, but she had given the manor of Lubbesthorpe to Roger in 1267-68, and had probably given him her lands at Braunstone as well.54 In I 346 Roger la Zouche and Robert Herle were assessed jointly for $\frac{1}{6}$ fee belonging to the honour of Peverel in Braunstone and Lubbesthorpe, and Roger Curley was assessed for $\frac{1}{6}$ fee in Braunstone, belonging to the honours of Peverel and Winchester. 55 The lands of which Robert Herle died seized in 1364 included $£_{4}$ rent at Braunstone, held of William la Zouche. ${ }^{56}$ The descent of this holding cannot be traced further, but probably it was absorbed into the lands held by Herle's successors, the Hastings family, at Braunstone.

ECONOMIC HISTORY. According to the Domesday survey ${ }^{57}$ there were at Braunstone 5 carucates and 3 bovates of land. In demesne were 4 serfs with I plough, and there also 2 sokemen, 4 villeins and a bordar with a further 2 ploughs. There were 5 acres of meadow, and woodland 5 furlongs in length and 3 furlongs in breadth. The estimated value of Braunstone had trebled in the period before the survey, perhaps indicating that the village had been ravaged after the Conquest. ${ }^{58}$ The woodland of Braunstone probably formed part of the great chase known as Leicester Forest, which bordered the village on the west. ${ }^{59}$ Although Leicester Forest was held by a series of great lords, ${ }^{60}$ to whom the timber

47 Farnham, Leics. Notes, i. 185.

48 By 1653 , according to Nichols, Leics. iv. 6I9. No authority is quoted for this statement, but it appears to be based on documentary evidence and may well be cor rect. White, Leics. Dir. ( 1846$)$, 546, says that Hastings sold the manor to Winstanley for $£ 6,000$ in 1650 . It is possible that Kinge was simply the agent for Winstanley. The Winstanleys were important Parliamentarians: V.C.H. Leics. ii. II 0.

49 W. G. D. Fletcher, Leics. Pedigrees and Royal Descents, 40.

50 City of Leic. Abstract of Accts. I025-6, 556.

5 I Nichols, Leics. i, pp. cxv, cxvi.

52 Complete Peerage, ix. I3; W. Farrer, Honors and Knights' Fees, ii. I I 3.

53 Cal. Inq. p.m. iii, p. 400.

54 Ibid. iii, p. 4 I I ; iv, p. I I 2.

55 Nichols, Leics. iv. 616.

56 Farnham, Leics. Notes, i. I 78 .

7 V.C.H. Leics, i. 316

Ibid. 284 .

59 For the approximate boundaries of the forest as they existed at the time when it was deforested, see Fox and and hunting rights belonged, the woodland was during the Middle Ages of considerable economic importance to the inhabitants of Braunstone. Both the lord of the manor and his tenants had the right to pasture their livestock in the forest, ${ }^{61}$ from which wood for repair of buildings and hedges could be obtained. ${ }^{62}$ The burgesses of Leicester, at least from the I2th century onwards, had the right to collect wood in the forest. ${ }^{63}$ Until the late 16 th century Braunstone was inhabited by free and customary tenants. In 1279 Philip le Polers held at Braunstone 7 virgates in demesne together with I I virgates held by I I villeins. A further $5 \frac{3}{4}$ virgates were held by 4 free tenants. ${ }^{64}$ Hugh of Braunstone, lord of the manor, at his death in $\mathbf{1 2 9 9}$, held $25 \mathbf{I}$ acres of arable land and 22 acres of meadow in demesne, with a separate pasture. His 8 free tenants, none of whom held more than a virgate, rendered money payments only for their holdings and his 6 villeins had evidently commuted most of their labour services for money rents. By 1299 two of them, holding a full virgate each, were performing no works for the lord, but paid in money only, while the remaining four, who each held a messuage and half a virgate, did only one day's work with one man at haytime, and one day's mowing, and each paid an annual rent of $9 s .{ }^{65}$ In I38I 22 inhabitants of Braunstone were described as husbandmen, ${ }^{66}$ and were therefore probably either freeholders or customary tenants.

There seems no reason to doubt that until the late I6th century Braunstone was a village with openfield cultivation of the normal type. Four fields belonging to the village are mentioned in a document of 1477,67 which may indicate that a two-yearly system of rotation was then being employed. The manor-house, which is first mentioned in $1299,{ }^{68}$ is said to have stood between the chapel and Braunstone Lane. ${ }^{69}$ Attached to it were a dovecote and a fruit garden.70 This house was leased to a farmer in I $415,^{71}$ and about 1600 it was replaced by a new house which occupied the site of the present Hall Farm. ${ }^{72}$

In the late 16 th century the old agricultural routine of the village was broken up by the widespread inclosure of arable for conversion to pasture, followed in the early 17 th century by the inclosure of Leicester Forest. The inclosure of the village fields was mostly the work of Walter Hastings, the lord of the manor, and his son Henry, though three of their

Russell, Leic. Forest, r 20 ; and see V.C.H. Leics, ii. 266-7. 60 On the lords of the forest, see ibid. passim, and below, p. 447

61 Farnham, Leics. Notes, i. I 75 ; Nichols, Leics. iv. 789.

62 Farnham, Leics. Notes, i. 174. The lordship of the manor's woodland, from which timber was obtained, formed part of Leic. Forest: ibid. i. 175.

${ }_{63}$ Leic. Boro. Rec. I $103-1327,6$.

64 Nichols, Leics. i, pp. cxv, cxvi.

65 Farnham, Leics. Notes, i. I75-6. There is some discrepancy between the inf. concerning Braunstone given in I 279 and I 299. This may be partly due to changes having taken place between the two dates, but the inf. for 1299 , which is derived from a detailed extent, is probably more accurate than that for 1279 , which comes from the general inq. taken at that time.

66 Farnham, op. cit. i. I79, I80.

67 Nichols, Leics. iv. 616.

68 Farnham, Leics. Notes, i. 175.

69 Fox and Russell, Leic. Forest, 90.

70 Farnham, Leics. Notes, i. I 75,178

7 Ibid. I 8 I.

72 Fox and Russell, Leic. Forest, 90. 
tenants also carried out inclosure on a small scale. At an inquiry held at Leicester in $1607^{73}$ it was stated that 468 acres of arable in Braunstone had been converted into pasture. Of this, 150 acres had been so converted since I $579 .{ }^{74}$ Walter and Henry Hastings since 1596 had inclosed and converted to pasture 290 acres of arable, while George Bennett and John Connywaie, who were probably tenants of Walter Hastings, had each converted I4 acres to pasture during the same period. Bennett must have been a fairly wealthy freeholder, for in 1589 he acquired property at Braunstone described as Ioo acres of land, 20 acres of meadow, and 20 acres of pasture, with two barns and common rights. 75 The report of the 1607 inquiry does not state how many people were displaced through the conversion of arable to pasture, but it notes that three houses were uninhabited, and in 1608 , when Walter and Henry Hastings were charged in the Star Chamber with depopulating Braunstone, it was stated that at least 40 people had left the village. ${ }^{76}$ This must have represented a substantial proportion of the population, for in $15^{6} 3$ there were 28 families in Braunstone. 77 The parish registers show that the population declined sharply during the period when the village fields were being inclosed; in the five years between I 566 and I 570 the average number of baptisms a year was $8 \cdot 2$, against an average of 4.4 for the years 1630 to $1634 .^{78}$ From the answer made by Walter and Henry Hastings to the charges brought against them in the Star Chamber ${ }^{79}$ it appears that they had absorbed three farms into the manorial demesne, demolishing one of the farm-houses. Henry Hastings had leased a fourth holding from one Hackett for $£ 5^{\circ}$, and purchased a fifth from John Iliffe, who had previously converted it into pasture. According to the version of events given by Walter and Henry Hastings, the remaining tenants, who held their lands for terms of ten or twelve years only, then agreed that all their lands should be inclosed, after which some of the land was to be allotted to the tenants, while the remainder reverted to the Hastingses. It seems that Hackett, Bennett, Iliffe, and possibly Connywaie, were freeholders, and were either bought out or had inclosed lands themselves. The freeholders seem to have offered no opposition to the inclosure. The remaining tenants, being mainly leaseholders, were unable to do so. After three of them had been evicted and their holdings taken over by the Hastingses, they consented to the inclosure on conditions which must have been disadvantageous to them. By the early I th century there were apparently no customary tenants left at Braunstone. No mention was made in 1607 of any inclosure of waste or pasture land. It is possible that some may have been inclosed at an earlier date, ${ }^{80}$ since by I4I 5 Richard Hastings was leasing his lands

73 T.L.A.S. xxiii. $269-7$ I.

74 The name of the person concerned is illegible: ibid. 270.

75 Farnham, Leics. Notes, i. 184.

76 L. A. Parker, Enclosure in Leics. $1485-1607$ (Lond. Univ. Ph.D. thesis, 1948), I 23

77 B.M. Harl. MS. 618.

${ }^{78}$ Braunstone par, reg. $1561-1655$ (in custody of vicar).

79 Parker, Encl. in Leics. 123-4.

80 A separate pasture is mentioned in 1299: Farnham, Leics. Notes, i. 175

81 Ibid. $180-1$

82 See map in Fox and Russell, Leic. Forest, 120. at Braunstone, ${ }^{8 \mathrm{I}}$ and a farmer leasing land at a presumably competitive rent might well have been tempted to inclose. For pasture, however, the village probably relied mainly on lands within Leicester Forest, which occupied the western part of the township. ${ }^{82}$ John Wellinger, for example, a substantial farmer of Braunstone who died in $\mathrm{I} 603$ leaving personal estate worth $£_{\mathrm{I}} 23$, was then pasturing in the forest thirteen cows with four calves. ${ }^{83}$ Not content with having converted much arable land at Braunstone into pasture, Henry Hastings kept large flocks of sheep in the forest, although it was contrary to the rules of Leicester Forest to do so. ${ }^{84}$ In I 605 it was stated that he was pasturing 160 sheep there, and that he had cut down trees covering 500 acres, so that in a short time there was likely to be no cover left for the deer of the forest. ${ }^{85}$ The maintenance of large numbers of sheep in the forest may have caused a shortage of grazing for the tenants' livestock and thus have assisted Hastings in his efforts to inclose the village arable. ${ }^{86}$ The disafforestation of Leicester Forest in I 628 enabled Henry Hastings to inclose the parts of Braunstone township which had lain within the forest boundaries. The Exchequer decree providing for the inclosure of the forest ${ }^{87}$ laid down that the land in Leicester Forest belonging to the manor of Braunstone was to be divided between Sir Henry Hastings, who was to receive two-thirds, and the king, as Duke of Lancaster, who was to obtain onethird in compensation for the loss of his forest rights. Out of his share Sir Henry was to set aside 64 acres to compensate his tenants at Braunstone for the loss of pasture in the forest. The tenants, who despite depopulation still numbered $I 7$, were to receive 6 acres for every yardland they held, and 2 acres for every cottage. Hastings's share was about 270 acres, but he also purchased the 135 acres at Braunstone which had been allotted to the king. ${ }^{88}$ An annual fee farm rent of $\mathbf{I} s$. an acre was levied from all the lands purchased from the Crown. ${ }^{89}$ An area of about 120 acres, lying between Braunstone Frith and the Hinckley road and known as the King's Wood, ${ }^{90}$ was partly allotted to some freeholders at Glenfield and others, and partly to the corporation of Leicester in compensation for the loss of pasture rights belonging to the Newarke Grange. ${ }^{91}$ All land which had formed part of the forest was ordered to be inclosed with hedges and ditches by May 1628.92 The lands of Leicester Forest to the west of Braunstone were thus brought under regular cultivation. After the disafforestation of $\mathrm{I} 628$ there can have been little uninclosed land left at Braunstone. The whole area of the chapelry was $I, 489$ acres in $\mathrm{I} 89 \mathrm{I} .{ }^{93}$ The inclosures reported in 1607 , together with those made in 1628 , totalled about 990 acres, and allowance has to be made for a number of small closes already existing in the $15^{\text {th }}$ century, ${ }^{94}$ besides land occupied by houses,

83 L.R.O., Probate Rec. Inv. 1603.

84 Fox and Russell, Leic. Forest, 94.

85 Ibid. 96.

86 In I628, Henry Hastings claimed to be entitled to pasture livestock in the forest 'without stint': Nichols, Leics. iv. 787.

87 Printed ibid. iv. $785-9$

88 Fox and Russell, Leic. Forest, I I 5, I 36, I 37.

89 Nichols, Leics. iv. 782 .

90 Fox and Russell, op. cit. 7 I, 82.

91 Ibid. I I ; Nichols, Leics. iv. 782 .

92 Nichols, op. cit. iv. 795 .

93 Census, $\mathrm{I} 80 \mathrm{I}$.

94 Farnham, Leics. Notes, i. 18 I. 


\section{A HISTORY OF LEICESTERSHIRE}

gardens, and roads. The hearth tax returns furnish some evidence about the size of the village in the I 7 th century. In I 666 I 8 houses in the village paid tax, including 2 which were empty. ${ }^{95}$ In 1670,17 houses paid tax, but a further i I were listed as exempt. There would appear to have been 28 households at Braunstone in 1670 , the same number as in ${ }_{15} 6_{3}$, so that some recovery had taken place since the early 17 th century. ${ }^{96}$ The clearing of Leicester Forest, and the inclosure of the village fields, must have caused great changes. Not only the fields but the roads of the township were altered, for a road leading from Braunstone to Leicester was blocked up by Walter and Henry Hastings, and another road to Leicester was closed by Walter Ruding, lord of the adjacent manor of Westcotes. ${ }^{97}$ The old body of small-holders was largely destroyed, and the village lands came increasingly into the ownership of the lord of the manor.

Sir Henry Hastings supported Charles I in the Civil War, and was in consequence ruined. ${ }^{98}$ Under the Winstanley family Braunstone remained a small agricultural village during the 18 th and 19 th centuries. By 1773 about two-thirds of the land in the township was in the hands of Clement Winstanley, the only other owner of importance being the Duke of Rutland. ${ }^{99}$ There were nine other proprietors. In I 809 by the Glenfield Inclosure Act lands at Glenfield were set apart for the Rector of Glenfield in commutation of tithes due from the lands at Braunstone belonging to Clement Winstanley, ${ }^{\mathrm{I}}$ who was by far the most important landowner there. ${ }^{2}$ In 1829 , the only landowners at Brauustone were Clement and George Winstanley and the Duke of Rutland. ${ }^{3}$ In 1846 the duke's rental in Braunstone was $£ 472$ as against Winstanley's of $f^{2}, 564$ Ios. ${ }^{4}$

Braunstone was for long little affected by the growth of the adjacent industrial centre of Leicester. The village remained almost entirely agricultural, and the size of the population showed little change. Some framework-knitting was done in the late I8th century. ${ }^{5}$ In 1801 the population was 202 , of whom I6 5 were chiefly employed in agriculture, compared with 22 employed in trade and manufactures. ${ }^{6}$ It was not until Leicester Corporation purchased a large part of Braunstone in 1925 that any change took place. In I 921 the population was only 238 ; in I93 I it was nearly 7,000.7 Though Braunstone Hall and its surrounding park were preserved, a large housing estate was built, covering most of the township to the north of Braunstone Lane. During the financial year $1926-7, £ 87,000$ was spent on the building of houses alone, while further large sums were expended on roads and drains. ${ }^{8}$ In the next year the expenditure on houses was $£ 292,000.9$ Further building took place to the south of Braunstone Lane, and though some agricultural land still remains in

95 Farnham, Leics. Notes, i. 185.

$96 \mathrm{E}$ I79/240/279, m. 7 .

97 T.L.A.S. xxiii, $270-1$.

98 Cal. Cttee. for Money, ii. 832; Cal. Cttee. for Compounding, 1760 .

99 L.R.O., Land Tax Assessments, Braunstone, 1773. 'The duke's land at Braunstone was in the hands of his tenant at Aylestone: Leic. City Mun. Room, I D 52/1/19. I 49 Geo. III, c. 55.

L.R.O., Land Tax Assessments, Braunstone, 1809.

Ibid. I 829.

Leic. City Mun. Room, I D52/1/19.

V.C.H. Leics. iii. 20.

6 Census, I80 I. the south and the north-west of the township, Braunstone has largely become a suburb of Leicester.

PARISH ADMINISTRATION. Braunstone was governed by the usual parish officers until its amalgamation with the borough of Leicester. It had no separate workhouse although maintaining its poor separately from Glenfield, 10 and from i 836 was in Blaby union for poor relief purposes.

CHURCH. In the $\mathbf{I} 2$ th century Braunstone church was a chapel dependent on the parish church of Glenfield. The chapel is first mentioned in a document which is not later than I I68. II About I220 the chapel was being served by a resident chaplain, ${ }^{12}$ but apart from this there is no evidence of how the chapel was served during the Middle Ages, or of what the relations were between the clergy serving it and the Rector of Glenfield. In 1650 there was a minister serving Braunstone, ${ }^{13}$ but the circumstances at that time may have been exceptional. During the I 9 th century and until 1937 , the chapel was served by the Rector of Glenfield, or his curates, but in I937 Braunstone became a separate ecclesiastical parish, with the Bishop of Leicester as patron of the living. ${ }^{14}$ In 1948 two Anglican mission rooms, those of St. Boniface and St. Crispin, were opened to serve the new housing estate. ${ }^{15}$

In 1585 the stipend of the curate who was in charge of Braunstone was $£^{8}$ a year. ${ }^{16}$ In 1650 the minister at Braunstone had a net income of $£ 30$ I 7 s. a year. In December of that year his stipend was raised to $f_{5} 5^{\circ}$ by a grant from the rectorial tithes arising from the chapelry, but the increase was withdrawn immediately afterwards. ${ }^{17}$

The greater part of the church of ST. PETER, as it existed in 1956 , was built in the 14 th century. The I 4 th-century church consisted of chancel, nave, and west tower. It is built of random rubble, the roofs are slated, and all the windows except those of the tower are pointed. The chancel has a plinth of one splay, string-course at sill level, diagonal buttresses at the angles and modern central ones on the north and south. It is lighted on the east by one window of three lights, on the north and south by two of two lights. Between the windows on the south there is a narrow pointed door of one splay with a hood without terminals. The south wall of the nave is similar, with buttresses at the angles, and lighted by three two-light windows. The south door has an 18 thcentury porch built of red brick with a round-headed arch, moulded brick cornice, and pediment, the cornice being continued as an eaves course to a steeply pitched slate roof. Internally, it has a four-centred vaulted ceiling and is plastered. The door has a moulded pointed head, the mouldings continued down the jambs without capitals. The tower is of two

7 V.C.H. Leics. iii. 184

8 City of Leic. Abstract of Accts. 1926-7, 304.

9 Ibid. I $927-8,298$.

to Nichols, Leics. iv. 620. Some par. rec. are in Leic. City Mun. Room, I D $52 / \mathrm{I}$,

II Dugd. Mon. vi. Io70.

12 Rot. Hugonis de Welles, ed. W. P. W. Phillimore, i. 245 .

3 Cal. Cttee. for Compounding, 176 1

14 White, Dir. Leics. (1846), 546; ibid. (1877), 172; and ex inf. Revd. W. H. Gibb.

is Leic. Dioc. Cal. (1954), 8I.

16 State of the Ch. ed. C. W. Foster, i. IoI.

17 Cal. Cttee. for Compounding, 1761 . 
stages; a third stage has been taken down to a little above the sills of the original belfry windows, leaving low rectangular openings on each face below the eaves of a slated roof. It has diagonal buttresses in four weathered stages; one buttress has two inscriptions, one stating that the steeple was repaired in 1704 and another stating that it was restored in 1938 . A late I 5 th-century window with a four-centred head of two hollow splays has been inserted in the west wall of the lower stage. Internally the tower walls are plastered and the floors laid with modern tiles.

The chancel has segmental pointed rear arches to the door and windows. At the eastern end of the south wall is a moulded trefoil-headed piscina with the remains of a pointed hood. The altar rails, dating from the $I$ th century, are of oak with moulded rails and turned balusters, partly restored. The chancel has a modern steep-pitched open collar-beam roof with curved brackets resting on floriated stone corbels. The space above the collar is fitted with opentracery panels. The nave has a modern tiled and boarded floor and an open trussed-rafter roof of uncertain date. The chancel and tower arches are pointed, of two splayed orders, the responds repeating the inner orders with moulded capitals and bases.

In 1637 the church was found to be in very poor condition, ${ }^{18}$ but in general it seems to have been well maintained. The red brick porch was added in the I 8 th century. Repairs were carried out in 1838 , when the building was said to be very damp, ${ }^{19}$ and again in I 867 and in $1875^{\circ} .^{\circ}$ In 1885 the floor was raised and relaid, part of the gallery, which had been inserted at an unknown date, was removed, and heating apparatus was installed. ${ }^{21}$

Extensive alterations and additions to the fabric were begun in 1937. A large part of the north wall of the I 4 th-century nave was cut away, and a squareheaded concrete arch was inserted. Running northwards from the opening so created, and at right angles to the original nave, a new nave was constructed. This extension was originally intended to consist of a nave, with east and west aisles, and a vestry, but shortly after the outbreak of war in 1939 building came to an end. In 1956 the new nave remained incomplete. ${ }^{22}$

The chancel has a late $5^{\text {th-century carved oak }}$ screen with open-traceried panels, a central opening with traceried panels in the head, crocketed finial and moulded pendant, and is finished with a modern cornice; it has been slightly restored. The font, now in the west aisle of the extension, is built up with an inverted basin of a plain circular 13 th-century font supporting a basin made from a I $4^{\text {th-century }}$ octagonal moulded capital of an arcade pillar. The windows in the extension are copied from the old

${ }_{18}$ Leic. City Mun. Room, ID4I/I 8/9.

19 Ibid. 245'50/6.

20 White, Dir. Leics. (1 877 ), 172.

${ }_{21}$ C. N. Wright, Dir. Leics. and Rut. (1896), 512.

22 Leic. Mercury, 7 Oct. I954. For a view of the completed design see ibid. 7 April 1933

${ }^{23}$ Nichols, Leics. iv. 62 I stated that this tomb was that of a Hastings and his wife.

24 Inf. from the vicar.

25 Ibid.

${ }_{25}$ T. North, Ch. Bells of Leics. 152.

27 A. H. Kimberlin, Return of Catholicism to Leic. $1746-$ 1946,50 . For recusancy in Braunstone in earlier times see church and two, taken from the demolished north wall of the nave, have been reused and contain fragments of early stained glass. The pulpit, a modern octagonal one of oak, has also been moved to the extension and is placed on the west side of the new chancel arch. In the old nave is a I 7 th-century oak chest, with a panelled lid, bound with iron straps. In the floor, near the chancel, is a I5th-century memorial slab, much worn, showing traces of two incised figures and a marginal inscription. ${ }^{23}$ 'There are two hatchments, one above the tower arch and the other on the north wall.

Beneath the altar of the Lady chapel, formerly the high altar, is a vault belonging to the Winstanley family. A wooden reredos, believed to have been Elizabethan or Jacobean, was removed and broken up in $c$. I900; some fragments have been used to make a processional cross, which is now in the church. ${ }^{24}$ 'The church plate consists of a silver paten with a foot, dated I 72 I, and a silver gilt cup, paten, and flagon, all dated 1858 and given by the wife of George Winstanley, Rector of Glenfield. There is also a gilt dish of base metal. The church formerly possessed a very beautiful silver gilt standing cup,

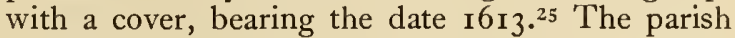
registers begin in $\mathbf{I}_{5} 6 \mathrm{I}$, and are in the vicar's custody. There are three bells, inscribed 'Robert 'Taylor St. Neots fecit, I $812{ }^{\prime} \cdot{ }^{26}$

ROMAN CATHOLICISM. In 1938 the temporary church of the Fathers of the Blessed Sacrament was established at Braunstone. ${ }^{27}$ In 1954 work began on the permanent church. ${ }^{28}$

PRO'TESTANT NONCONFORMI'TY. 'There is no record of any dissenting chapel in Braunstone until the establishment of the Trinity Methodist Church in 1929 , at first in a temporary chapel, and later in a permanent one built in 1934, and of Christ Church ${ }^{29}$ Congregational chapel in Barbara Road in I930, both to designs by Albert Herbert. ${ }^{30} \mathrm{~A}$ small Baptist chapel was built in Braunstone Avenue in I950 after many years of missionary work from Friar Lane chapel. ${ }^{31}$ In I939 a site was purchased in Braunstone for the building of a Congregational chapel to replace that in Bond Street, whose congregation had largely been moved to the Braunstone estate. This project has not so far been carried out. ${ }^{32}$

SCHOOLS. Braunstone possessed a Sunday school before 1846 , which was supported by the lord of the manor. ${ }^{33}$ In 1868 a small National school was built by Captain R. G. Pochin. ${ }^{34}$ Many new schools were built to provide for the children on the housing estates, and Braunstone Hall has been in use as an infants' school since $1932 .{ }^{35}$ 'The National school was closed in 1930.36

V.C.H. Leics. ii. 58, 69 .

28 Leic. Mercury, 8 Nov, 1954

29 Ibid., 23 Jan. 1934. A temporary chapel had been made in a barn in 1929: Pictorial Leic. 1929.

30 Leic. Mail, 23 Oct. 1929, 20 Mar. 1930.

31 D. Ashby, Friar Lane, 23.

32 E. M. Drew, Those Taking Part, 26-27.

33 White, Dir. Leics. (1 846$), 546$.

34 Wright, Dir. Leic. (I88o), 268.

35 See p. 336. The schools include those in Folville Rise, Hallam Crescent, Ellesmere Road and Benbow Rise, and in Ravenhurst Road outside the city boundary.

${ }^{36}$ Leics. Council Mins. 12 Nov. 1930. 
THE nucleus of the ancient parish of Evington lies some $2 \frac{1}{2}$ miles south-east of the centre of Leicester. The area of the ancient parish, formerly in Gartree hundred, was about I,950 acres. The total population of the Spinney Hill ward and the old village, which covered most of the ancient parish, was $30,08 \mathrm{I}$ in I931. 'The boundaries of the ancient parish ran along Mere Road, the Willow Brook, Uppingham Road, Spencefield Lane, Stoughton Road, ${ }^{2}$ Evington Brook, and part of Evington Lane. To the east of Spencefield Lane, however, the boundary included a considerable area beyond that road, adjoining Thurnby. The surface soil is largely Boulder Clay, except in the valley of the Evington Brook, where there is Lower Lias Clay and limestone. The village of Evington itself was built on a patch of sand and gravel, close to the south-eastern boundary of the parish and not far from the Roman Gartree road which forms part of its southern boundary. A prehistoric trackway from Tilton passed through the northern part of the parish to the ridge known as Crown Hills. ${ }^{3}$ About onethird of the parish, lying in the north next to the borough boundary, was transferred to Leicester County Borough in 1892 as North Evington civil parish. It was absorbed in Leicester civil parish in I 896 . The new boundary between Evington and the borough ran across the fields from Uppingham road to a point near the present Highway Road. Evington civil parish, which had remained outside the borough, was dissolved in 1936 . The greater part was transferred to Leicester and the two remaining pieces became parts of Stoughton civil parish and Oadby urban district respectively. 4

The character of the village has greatly changed in recent years from that of a village with primarily agricultural interests to that of an industrial and residential suburb of Leicester. In the old village the oldest surviving buildings are probably two thatched cottages dating from the mid-I8th century. The hall, built in the I 830 's for Henry Coleman, is a stucco house and is now a convent school. 5 Evington House was built in $1836^{6}$ and is a brick house, with some later additions. It retains some of its original glass and a pleasant mahogany staircase. It stands in what is now a public park and is used as a corporation restaurant. The village green still survives as a recreation ground for children. The Cedars Hotel, formerly the home of the novelist, E. Phillips Oppenheim, was opened as a public house in 1937.7

MANOR. In Io86 Io $\frac{1}{2}$ carucates of land in EVINGTON were held by Hugh de Grentemesnil and under him by his sub-tenant, Ivo, who was also probably the holder of Cadeby and Ashby de la Zouche. ${ }^{8}$ There was also I carucate held from the king by Robert de

I White, Dir. Leics. (1846), 497; Census, I 93 I.

2 This part of the boundary is described in 1515 :

E $150 / 1122 / 9$.

${ }^{4}$ Ibid. 187.
5 See below, p. $43^{8}$; White, Leics. Dir. (1 846$), 497$.

White, op. cit.

Leic. Mercury, 12 April 1937

V.C.H. Leics. i. $317,292,323$.

9 Leics. Survey, ed. C. F. Slade, 23.

10 E.H.R. liv. 385-99, 401 .

11 Farnham, Leics. Notes, ii. 221.

12 Ibid. 222; Cal. Inq. Misc. i, p. 234.
Buci, which had passed to Richard Basset by c. I I 30. After the death of Hugh de Grentemesnil his property descended to the earls of Leicester and became part of their honour. ${ }^{9}$ 'The overlordship of Evington remained in the hands of the earls of Leicester until r 265 when it was granted after the forfeiture of Simon de Montfort to Henry III's son Edmund of Lancaster. Edmund's successors, the earls and dukes of Lancaster, remained overlords of the manor of Evington until the Duchy of Lancaster was merged with the Crown in $1399 .{ }^{10}$

Before 1239 the manor had been subinfeudated to Richard de Grey, who received a grant of free warren in Evington in that year. ${ }^{11} \mathrm{He}$ was a member of the Derbyshire family of Grey of Codnor, and he and his descendants held Evington as sub-tenants until the end of the $15^{\text {th }}$ century. In 1265 the then Sir Richard de Grey, constable of Dover Castle, who had fought for his lord, Simon de Montfort, at Evesham, forfeited his lands to the king. ${ }^{12}$ Evington was restored to his son John at some date before his death in $127 \mathrm{I}$, when he was holding the manor of the honour of Leicester for the service of $3 \frac{1}{2}$ knight's fees. ${ }^{13}$ By 1299 the service had been reduced to that of $I_{2} \frac{1}{2}$ fee ${ }^{14}$ and by 1346 to only $\frac{1}{2}$ fee. ${ }^{15}$ During the 15 th century the manor was held in trust for the Greys at least from I434, when Henry, Lord Grey, conveyed it to three trustees. ${ }^{16}$ When he died ten years later his heir was a minor, and the service by which he held the manor was unknown. ${ }^{17}$ In or just after I 491 it was acquired by Sir William Stanley, who held it for the service of I knight's fee and a yearly rent of $4{ }^{s .}{ }^{18} \mathrm{In}$ I 494 Stanley was attainted for his support of the pretender Perkin Warbeck and his property was seized by the king. ${ }^{19}$ The king leased the manor to Robert Orton, bailiff of Leicester, in I 500 for 40 years at a yearly rent of $£ 5^{\circ}$. At an unknown date Orton assigned his lease to the Leicester merchant, Roger Wigston. ${ }^{20}$ In I 5 Io Henry VIII granted the overlordship of the manor to Anne, one of the daughters of Edward IV and wife of Thomas Howard, Earl of Surrey, as part compensation for lands claimed in right of her great-grandmother. Provision was made in this grant that the earl was to have no rights in the property and was merely a tenant by courtesy. In I 520 he duly returned the letters patent which had given the land to his wife, who was then dead, and at the same time he released to the king, to the cofferer of the royal household, and to the tenant, Robert Orton, all the actions which he might thereafter bring against the manor. ${ }^{21}$ In I 527 Roger Wigston, as the assignee of Orton, surrendered his lease to the king, ${ }^{22}$ possibly as a result of the grant of the manor again in 1526 to George Hastings, who was created Earl of Huntingdon in $1529 .{ }^{23}$ The Hastings family

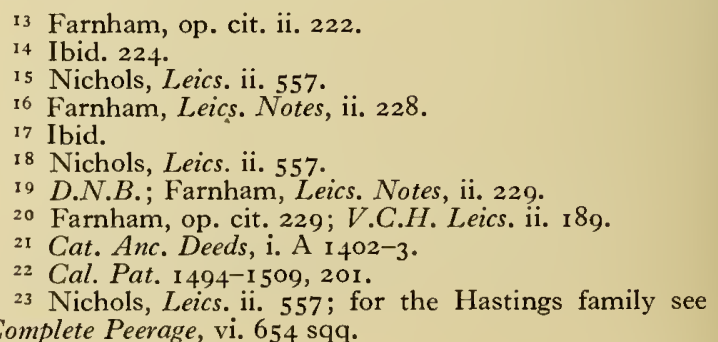


retained the manor until 1616 , when it was sold to William Cavendish, Earl of Devonshire, whose family held it for the next hundred years. ${ }^{24}$

In or about 1734 it was purchased by Dr. James Sherrard of Eltham. ${ }^{25}$ Under the provisions of his will, dated 1737 , the manor was to be divided at his death among his five nieces. When this division was affirmed by Act of Parliament in I76I, the ownership of the manor passed into the hands of five families. ${ }^{26}$ The new owners were Mary and John Edwyn of Baggrave, Christian and Richard Sharpe of Wing (Rut.), Ann and Henry Coleman of Market Harborough, Elizabeth and Samuel Taylor of the same place, and Susanna and the Revd. Samuel Statham of Loughborough. These shares descended to the three families who held Evington in the rgth century: the Kecks, who held the Statham portion, the Burnabys, descended from the Edwyns, and the Colemans. There was in the last century no longer any lord in a position of authority in the village, although the lordship of the manor was divided in I 846 between the three owners, and had passed to the Keck branch by 1877.27 In r91 6 most of the property in the village belonged to Thomas PowysKeck, ${ }^{28}$ who sold his estate very shortly after the end of the First World War. The chief purchaser was the Co-operative Wholesale Society, which in 1955 still owned a great deal of property in the district. ${ }^{29}$

ECONOMIC HISTORY. In Io86 Evington was assessed at I I $\frac{1}{2}$ carucates, of which Ivo, the principal tenant, held $10 \frac{1}{2}$. On this land he had 3 ploughs and 6 serfs in demesne; there were also 25 villeins and 2 bordars with $5^{\frac{1}{2}}$ ploughs. There was a mill and 20 acres of meadow, and the value of the manor had increased from 40 s. in the time of Edward the Confessor to Ioos. at the date of the survey. ${ }^{30}$ The remaining carucate was held by Robert de Buci, who had land for half a plough on his demesne, while his four villeins held land for one plough. His holding was worth $5^{5.31}$

The village was small and the inhabitants few, and the extent of land under cultivation remained unchanged until at least I279, when there were still only I 2 ploughlands. Four ploughlands and I virgate were held in demesne by the lord of the manor, and a further 4 carucates were held in villeinage. Three free tenants held I virgate each and another had a whole ploughland. ${ }^{32}$ In 1265 the manor was worth $£ 30.33$ In 1298 John Dyve of Baldeston (Notts.) died seised of 4 virgates in Evington, held of William de Bosco;34 the land was inherited by his sister, from whom descended the Bussy family, who held land in Evington throughout the I4th century. ${ }^{35}$

24 Farnham, Leics. Notes, ii. $23 \mathrm{I}$.

25 Nichols, Leics, ii. 558. Sherrard was a famous botanist and apothecary: see D.N.B.

26 The lands were allotted by the drawing of tickets. The estate was divided into 5 equal portions. The original award is in L.R.O. and has been mistaken for an inclosure award, e.g. in $V . C . H$. Leics. ii. 261. The provisions of the will and of the Act of Parl. are recited in it.

27 White, Dir. Leics. (1846), 497; ibid. (1877), 2 I 2.

28 Kelly's Dir. Leics. and Rut. (1916), 79.

29 Ibid. (1922), 8o.

30 V.C.H. Leics. i. 317.

31 Ibid. 323.

32 Nichols, Leics. ii. 556.

33 Cal. Inq. Misc. i, p. 234.
In the inquisition made in 1308 after the death of Henry de Grey, the extent of the manor reveals an interesting change. There were then only 12 bovates in demesne (about $2 \frac{1}{2}$ ploughlands), with the manor house, a dovehouse, 2 ponds and wind- and watermills. There were no less than ig free tenants, of whom only 4 paid any sort of rent in kind, and 36 customary tenants who paid a money rent and did only 6 days' service yearly of harrowing and reaping. Twelve cottars paid money rents for their cottages. ${ }^{36}$ The inquisition into the property of Richard de Grey made 20 years later in 1335 shows that the lord of the manor had successfully doubled the money rents of his free tenants and increased the labour services of the customary tenants. Twenty villeins then performed 220 days' work between them during the year, and the cottars no longer existed. All the sources of income in the manor had been made to show a greater profit. ${ }^{37}$

The lord of the manor had a park at Evington, where deer were preserved for hunting. On two occasions in the $14^{\text {th }}$ century the park was broken into and deer removed. ${ }^{38}$ The earliest manor-house very probably stood on the moated site still visible to the west of the church, where there is also a well. ${ }^{39}$ In I 4I2-I 3 payments were made to a carpenter for rebuilding a house outside the gate of the manorhouse, which had been blown down ventu et tempestate. ${ }^{40}$

The names of the medieval fields of Evington are not known, nor are their exact boundaries. At the end of the I $3^{\text {th }}$ century there was a very considerable increase in the amount of pasture in proportion to the amount of arable and the impression given in the few surviving bailiffs' accounts of the I 5 th century is that a great deal of this meadow and pasture had been retained in the demesne, or was separately leased for a money rent.4I

By the nature of its position, away from the main roads or road junctions, Evington remained virtually undisturbed until it was inclosed in the I 7 th century. The population seems to have remained fairly stable from the end of the I 4 th century. The poll tax return of $\mathrm{I}_{3} 8 \mathrm{I}$, which is not altogether reliable, lists 53 adults who lived in the village and paid $\operatorname{tax}_{0}{ }^{42}$ In $\mathrm{I} 563$ there were still only 3 I families. ${ }^{43}$ In 166632 persons paid tax on a total of $6 \mathrm{I}$ hearths ; 44 in 167028 persons paid on 56 hearths, and a further I9 were excused on account of their poverty, giving a total of 47 inhabited houses. 45 In 1608 as many as 48 persons defaulted in some way at a sitting of the court. Of these, 6 were free tenants, 24 leaseholders, ro tenants in demesne and 6 cottagers. This, although not a complete list of tenants of the manor, suggests that the number of free tenants, as opposed to lease-

34 Farnham, Leics. Notes, ii. 224.

35 Leic. City Mun. Room, Farnham MS.

36 Farnham, op. cit. ii. 224-5; V.C.H. Leics. ii. 162-3.

37 Ibid. 226 .

38 Ibid. $225,227$.

39 See V.C.H. Leics. i. 265 . The moat is still very deep and the original depth was presumably greater.

40 Nottingham Univ. Libr., Middleton MS. 6/1 7o/74.

$41 V . C . H$. Leics. ii. I62-3; the bailiffs' accts. for I $412-$ I $3, I 435^{-6}, I 43^{8}-9,1450-1$ and I 455-6 are among the Middleton MSS. in Nottingham Univ. Libr.

42 Farmham, Leics. Notes, ii. 227.

43 B.M. Harl. MS. $6{ }_{1} 8$

44 Farnham, op. cit. ii. 232.

45 E I $79 / 240 / 279$, f. I8. 


\section{A HISTORY OF LEICESTERSHIRE}

holders, was small; most of the land was apparently orrned by the lord of the manor. ${ }^{46}$

This concentration of the land in the lord's possession facilitated the process of inclosure, which began early in the $17^{\text {th }}$ century. In a survey of inclosed land in Leicestershire made in 1607 there is no mention of Evington, ${ }^{47}$ but from a map of the manorial estate of the Earl of Devonshire which was made in 1627 it is clear that almost the whole of the parish was inclosed by that time, and it seems likely that the inclosure took place after the Cavendish family acquired the manor in $\mathrm{x} 6 \mathrm{I} 6.48 \mathrm{~T}$ The Devonshire estate is shown in this map as consisting entirely of closes, some of over 100 acres, the whole totalling more than 1,600 acres, only 350 acres less than the total extent of the parish. The lord had clearly been able to inclose at will, and no legal record of the inclosure exists. Strip farming on the old system was carried on in a small area to the north and east of the church and is clearly differentiated on the map. A few of the inclosed fields in the south of the parish were held by several tenants and jointly farmed, but most of the land was held by the 35 tenants whose holdings are separately marked. 49

In $1761,1,800$ acres were divided between the nieces of James Sherrard, some 200 acres more than the Earl of Devonshire had possessed in $1627.5^{\circ}$ This increase was apparently due to the fact that some of the small freeholders had been bought out, for the number of freeholders who polled from the parish was reduced from 7 in 1722 to one in $1775 .{ }^{51}$ After the division of the manor in 1761 , most of the land seems to have been given over to grazing, and by the middle of the roth century there were several substantial graziers in the parish. ${ }^{\mathbf{2}}$

Early in the 18 th century a few of the inhabitants found an occupation in the hosiery industry, and the first reference to a stockinger in the village occurs as early as 1704.53 The numbers of those engaged in the trade increased slightly during the $\mathrm{I} 8$ th century and some framework-knitting was done in the parish, although Evington never became a centre of the industry. ${ }^{4}$ The parish remained predominantly agricultural until well into the $\mathrm{g}$ th century, and farmers and labourers outnumbered those in other occupations. ${ }^{5}$ The descendants of the landowners who came into possession in $176 \mathrm{I}$ became increasingly prosperous. Prominent among these families were the Colemans and the Burnabys; Henry Coleman built Evington Hall about 1830 and the Misses Burnaby endowed the village school in $\mathrm{I} 84 \mathrm{I} .{ }^{56}$

As late as $188 \mathrm{I}$ the population numbered only $45^{\circ}, 57$ but in the next decade there was a sudden increase as the result of the development of the north

${ }_{46}$ Leic. City Mun. Room, I 2 $443 / 53 / 5 b$.

47 T.L.A.S. xvii.

48 Leic. City Mun. Room, 8D 33/6, copy of map made in I 9 th cent.; no source is given.

49 In 1678 there were at least 24 uninclosed yardlands. In 1698 there were 30 , divided into 'old' and 'new' demesne: Leic. City Mun. Room, I $D_{41 / 2 / 219,222 .}$

50 L.R.O., Evington and Stoughton award, $176 \mathrm{r}$; the estate included some land in Stoughton: Leic. City Mun. Room, $12 \mathrm{D}_{43} / 56 / 24 . \quad{ }_{51}$ Nichols, Leics. ii. $55^{8}$.

52 White, Dir. Leics. (1846), 497

53 Evington par. reg. 54 V.C.H. Leics. iii. 2 I.

55 White, Dir. Leics. (1877), 212 ; C. N. Wright, Dir. Leic. (1 882), 289. In the latter year the parish clerk owned a threshing machine. See also Census Reports.

56 White, Dir. Leics. (1846), $497 . \quad 57$ Census, I 881.

58 On Wakerley's work in North Evington see A. part of the parish, with a simultaneous change in the type of employment available as new factories were built. The number of farm workers declined rapidly and artisans took their place. The development of North Evington was primarily the work of Arthur Wakerley, a Leicester architect, who devoted the greater part of his working life to the task. His first purchase of land in North Evington was made in r 885 and from then onwards he concentrated on building new roads, houses, and factories, and providing public buildings. In 1892 the market square was laid out and the market hall built. ${ }^{8}$ The new suburb was separated from the old village by a considerable stretch of open country, and this separation was further marked by the detachment of North Evington from the parish in 1892 , when it became part of the borough of Leicester. ${ }^{59}$ In 1905 the Leicester Poor Law Institution was built in North Evington near Crown Hills; it was taken over by the City Health Committee in 1930 and is now the General Hospital. ${ }^{\circ 0}$ About the same time an engineering factory and a clothing factory, the first of several, were built in East Park Road.61

Meanwhile, the old village was being gradually developed. Some new houses were built and in ror 2 the village hall was erected, ${ }^{62}$ but it was not until the I930's that intensive building began. Since that time a residential district has grown up linking the village with North Evington, although there is still a good deal of open ground around the village, and the Leicester Golf Course lies between Evington Lane and Stoughton Road, partly in Oadby Urban District. It was during this period of expansion that the civil parish of Evington was dissolved and the greater part transferred to Leicester. Development of a commercial kind continued along Evington Valley Road, where chemical and engineering works were built. The Evington House Estate has developed to the north of the village.

Of the two corporation parks in the parish, Spinney Hill Park was purchased from the Burnaby family in $1885^{63}$ and Evington Park in 1947.64 There are two farms belonging to the Co-operative Wholesale Society in the northern part of the parish, and Evington still remains the most rural of any of the Leicester parishes.

CHURCHES. The parish of Evington was formerly a peculiar, at least from $5_{564}$ when the vicar had an exempt jurisdiction, attached to the manor. ${ }^{65}$ As most of the earlier records have not survived, ${ }^{66}$ little is known of either peculiar or church. Sir John Lambe doubted the validity of the claim to peculiar jurisdiction in 1633.67 The peculiar had ceased to

Wakerley, North Evington, Leic. (1913), copy in Leic. City Mun. Room; W. Scarf, Leic. and Rut. at Opening of $20 t h$ Cent. 157; Leic. City Ref. Libr., Cable Coll. xxxiv. 44-45.

5954 and 55 Vic. c. Ioo.

60 Kelly's Dir. Leics. and Rut. (1908), 157; Kelly's Dir. Leic. (1947), p. xx.

61 Wright's Dir. Leic. (1 902), 94-05; Kelly's Dir. Leics. and Rut. (I916), 248-9.

62 Kelly, op. cit. 79 .

63 J. Storey, Hist. Sketch of Boro. of Leic. 129.

64 Leic. Council Mins. 1946-7, 248; ibid. 1947-9, 50, $346-7$.

65 Nichols, Leics. ii. 559.

66 Leic. Museums and Art Gallery, Handlist of Rec. of Leic. Archdeaconry, 42.

67 Assoc. Archit. Soc. Rep. छ' Papers, xxix. 514. The peculiar was then still said to be manorial. 
perform any real function by the early igth century. Appointments of commissaries (nearly always the lord of the manor), registrars (the vicars), and apparitors (the parish clerks) survive to 1846 , and the court was sitting yearly as late as $1857,,^{68}$ but there seems to be only one surviving document showing that cases were ever dealt with. ${ }^{69} \mathrm{By}$ the I 840 's all the fees of the court came from marriage licences and visitations of the church. ${ }^{70}$ The peculiar seems to have disappeared about 1880.71

In the I2th century the rectory and advowson of Evington were granted by Ernald de Bosco and John Humet to Leicester Abbey, ${ }^{72}$ and their grant was confirmed between I I 68 and I I 90 by Robert, Earl of Leicester. ${ }^{73}$ The church was appropriated between 1209 and 1219.74 The abbey held the advowson until the Dissolution, ${ }^{75}$ after which it passed to the king, and was granted by Edward VI to the Bishop of Lincoln in $1547 .^{76}$ It was probably at this time that the peculiar was created, when the lord of the manor seems to have usurped the jurisdiction. ${ }^{77}$ The bishops of Lincoln presented to the living until Leicester became part of the see of Peterborough, when the advowson was granted to the new bishop. ${ }^{78} \mathrm{It}$ is now in the hands of the Bishop of Leicester. ${ }^{79}$

The vicarage was endowed by Leicester Abbey with 6 marks yearly, consisting of various dues, the altarage, small tithes, and corn tithes from a carucate of land in the parish. ${ }^{80}$ In 1217 the living was valued at I I marks yearly; in I254, I 2 marks; and in I29I, 20 marks. ${ }^{81}$ In 1535 it was worth $£^{8.82}$ In 183 I it was worth only $£ 47$, but received a grant from Queen Anne's Bounty in $1840 .{ }^{83}$ The great tithes were the property of Leicester Abbey and were granted with the advowson to the Bishop of Lincoln, who held them until $\mathrm{I} 840$, when they were purchased by the landowners. ${ }^{84}$ The small tithes were the property of the vicar. In 1678 they included corn from five yardlands, and wool, lambs, eggs, apples, pigs, and other offerings from the 24 yardlands which remained uninclosed. ${ }^{85}$ These seem to have been commuted for money payments by 1698 , when the land which was old demesne paid 5 s. $6 d$. a yardland, new demesne paid $32 s .6 d$. a yardland, and vacant yardlands $2 s .6 d .86$ These tithes were exchanged at the division of the manor in I 76I for an annual payment of $£ 45^{87}$ One acre of land was set aside during the Middle Ages for the repair of the church. ${ }^{88}$ It had apparently been lost by 1837 as it is not mentioned in the Charity Commissioners' Report.

The church of St. Stephen in East Park Road was built to the design of J. Stockdale Harrison in $1897^{89}$ In 1904 the parish was created from those of Eving-

68 Leic. City Mun. Room, I D $4 \mathrm{I} / 48 / \mathrm{I}-2$.

69 Ibid. I D $4 \mathrm{I} / 48 / 2-14$ : a caveat against the proving of a will.

70 e.g. ibid. $\mathrm{ID}_{4 \mathrm{I} / 45 / 4-28}$

71 White, Dir. Leics. (1877), 212 ; C. N. Wright, Dir. Leic. ( 1882 ), 289.

72 A. Hamilton Thompson, Leic. Abbey, 136.

73 Dugd. Mon. iv. 464 .

74 Rot. Hugonis de Welles, ed. W. P. W. Phillimore, i. I $36-7,264$.

75 For a list of vicars appointed by the abbey see Hamilton Thompson, op. cit. I 36-9.

${ }_{76}$ Cal. Pat. I 547-8, I 53-4.

77 Handlist of Rec. of Leic. Archdeaconry, 42.

78 White, Dir. Leics. (1 846), 497.

79 Leic. Dioc. Cal. ( 1954$), 89$.

80 Rot. Hugonis de Welles, i. I 36-7.

81 Val. of Norw. ed. W. E. Lunt, 533. ton and St. Barnabas, New Humberstone. The Bishop of Leicester is patron. ${ }^{90}$ St. Philip's Church in Evington Road was built in 1913 at the cost of I. L. Berridge. ${ }^{91}$ The architects were the Leicester firm of Pick, Everard.92 The patronage is vested in trustees. ${ }^{92}$ The district church of St. Chad, Coleman Road, was built in 1922 , from the materials of an iron and brick chapel which was used as a base chapel in France during the First World War. ${ }^{94}$ It serves the Coleman Road estate.

The church of ST. DENYS consists of chancel, nave, north and south aisles, north porch, and west tower and spire. It is mostly built of random rubble in a mixture of local stones. The lower stages of the tower are of roughly squared and coursed stone, and the clerestory in the north aisle is of ironstone. The earliest surviving part of the church dates from the I $3^{\text {th }}$ century, when it consisted of a chancel, nave and west tower. The aisles date from the I 4 th century and the clerestory was added to the nave in the 15 th century. The porches, which had also been added, were removed in 1840 , the south doorway blocked and the whole church extensively restored. 95 In I 867 the chancel was rebuilt in a debased Gothic style. ${ }^{96}$ A further restoration took place under the direction of Joseph Goddard of Leicester in $1884 .{ }^{97}$ The north porch was rebuilt as a war memorial for the First World War. The roofs, which were renewed during the 16 th century, were repaired in 1840 and some of the original timbers and carved bosses were used again.

The modern chancel is of three bays, indicated on the outside of the building by buttresses on the south side; there is a blocked doorway in the central bay on this side. The roof of the chancel is elaborate, with arched trusses filled in with open tracery, and traceried panels between the rafter feet. The trusses rest on carved stone corbels and short shafts. The floor is paved with encaustic tiles. The unfortunate effect of the chancel is relieved by its monuments, which were replaced after the original chancel was rebuilt. The most interesting is to James Sherrard (d. 1737), a fine marble wall monument erected by his wife, and only spoilt by the cramped insertion of the date of her death at the foot of the inscription.

The nave is of four bays, with arcades of pointed arches. Those on the north side rest on roughly squared blocks of riasonry, part of the old nave wall. The lines of an earlier roof may be seen above the tower arch and the blocked door which once gave access to the rood loft in the north wall of the nave. The south aisle is very little later in date, probably of the very early years of the I $4^{\text {th }}$ century or the last

82 Valor Eccl. (Rec. Com.), iv. I 59.

83 White, Dir. Leics. (1 846), 497.

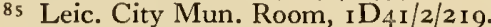

86 Ibid. $\mathrm{ID}_{4 \mathrm{I} / 2 / 222 \text {. }}$

87 L.R.O., Evington and Stoughton award.

88 Nichols, Leics. ii. 559.

89 T.L.A.S. viii. 356 ; Leic. City Mun. Room, Min. Bk Leic. Ch. Extension Soc. 7 Mar. 1895.

90 Kelly's Dir. Leics. and Rut. (1936), I 36 ; Leic. Dioc.

Cal. (1954), 9 I.

91 Kelly, op. cit. I 36.

92 T.L.A.S. x. 225

93 Leic. Dioc. Cal. (1954), 9I.

94 Kelly's Dir. Leics. and Rut. (1936), I 3 I.

95 White, Dir. Leics. (1 846$), 497$.

96 Ibid. (1877), 212.

97 Kelly's Dir. Leics, and Rut. (1036), I35; 28th Ann. Rep. Leic. and Leics. Soc. Architects (1900-1). 


\section{A HISTORY OF LEICESTERSHIRE}

decade of the 13 th. The doorway in the second bay from the west has been blocked. In the south wall is a piscina with a mutilated basin. The tracery in the windows is of the plainest, and contrasts sharply with that in the windows of the north aisle, which was probably built about $\mathrm{I} 350$, perhaps by a member of the Grey family, whose arms appear in the windows. In the centre of the plain parapet to the east gable of this aisle there is a broken crocketed pinnacle, with a niche below containing a figure of St. Denis, and a grotesque gargoyle at the angle. At the west end there are traces of trefoiled panels in the parapet. The windows at the east and west ends are contemporary with the aisle, and their tracery is of considerable interest. The west window is pointed, of four trefoiled lights with flowing tracery, its hollows richly studded with dogtooth, masks, and ballflower ornaments. Inside the arch is supported on slender columns with foliated capitals. The hollow mouldings of the tracery are studded with ornament as on the outside, but on the mullions, which have been restored, this has not been reproduced. The east window is also pointed, of four cinquefoil lights, its roll moulding forming shafts with foliated capitals and moulded bases to the arches of the four lights. The tracery of this and of the second window from the east in this aisle is filled with fragments of early glass. That in the east window is mainly heraldic, and includes the arms of the Clare, Warenne, Geneville, Giffard, and Grey families. That in the side window, which is less muddled, is clearly in its original position. The quatrefoil panels of the tracery contain figures of angels.

The doorway in this aisle seems to have been completely renewed when the porch was built after the First World War.

The tower rises in three stages, diminished at each by weathered offsets. The lower stages are built of roughly squared and coursed stone, and there are ashlar buttresses on the north and south corners. Two buttresses were added against the west wall, probably when the aisles were built. There is a lancet window on the west wall, but all but one of the smaller windows which lighted the belfry have been blocked. From behind the battlemented parapet rises the graceful octagonal spire, surmounted by a floriated finial and a weathercock. There are eight windows set around the spire alternately at the foot of each face and half-way up.

The font stands in the south aisle. It dates from the $13^{\text {th }}$ century and has a heavy round bowl, supported upon a thick round column surrounded by four detached shafts with moulded capitals and bases, the capitals distorted to fit under the bowl. The church chest probably dates from the early 16 th

98 A. Trollope, Ch. Plate of Leics. i. 205.

99 'T. North, Ch. Bells of Leics. 174 ; Kelly's Dir. Leics. and Rut. (1936), I 35.

I See below, p. 442 .

A. H. Kimberlin, Return of Catholicism to Leic. I7461946,57 .

L.R.O., return of places of worship, $x 829$. tions.

Ibid., dissenters' meeting-houses, orig. applica5 Ibid. century and is 7 feet in length. The registers begin in 1601 . Some of the earlier entries are almost illegible and there is a gap between 1648 and 1652 (inclusive). The earliest pieces of plate still in use are a silver cup and paten dated 1632.98 There are four bells, dated I605, I637, I797 (cast by Edward Arnold of Leicester), and 1906.99

ROMAN CATHOLICISM. There is no Roman Catholic church in Evington, which is in the parish of St. Joseph's Church at Humberstone. I The Catholic school at Evington Hall was opened in I939. ${ }^{2}$

PROTESTANT NONCONFORMITY. In $\mathrm{x} 829$ it was estimated that there were in Evington 50 Independents and 20 Primitive Methodists, ${ }^{3}$ and it was presumably one of these sects which applied in $181 \mathrm{I}$ for a licence for its meeting-place there. ${ }^{4} \mathrm{~A}$ further application was made in 1838,5 probably for the chapel of the Countess of Huntingdon's Connexion, which was built in the same year at the expense of Samuel Davenport of Leicester. ${ }^{6}$ The chapel stands on the green, with the minister's house next door, and is a delicate building in the Gothic style, with slender crocketed pinnacles. The west end, which faces the road, has a crenellated parapet above the door. The chapel is now (1955) that of the Strict Baptists. The Primitive Methodist chapel in Leicester Street was built in 1895 for the North Evington district.?

MILLS. There was a mill in Evington in 1086 , held by the lord of the manor and rendering $2 s$. yearly. ${ }^{8}$ This was probably on the same (unknown) site as the water-mill which was valued at $20 s$. in 1308 , by which time there was also a windmill, valued at $105 .{ }^{9}$ The value of the windmill had increased to 20 . by I 335 , but the water-mill is not mentioned in the extent of the manor which was made in that year. ${ }^{10}$ There was a water-mill in the early $\mathbf{I} 5$ th century but no evidence of its existence after $\mathrm{I}_{4} \mathrm{I}_{3}$ is to be traced. ${ }^{\mathrm{II}}$ The stream which forms the present boundary with Oadby was probably never large enough to drive a large mill. Perhaps the most obvious site for the mill would be at the junction between this stream and the now very small one which runs to the west of the moated site near the church.

SCHOOL. The National school was built in $\mathrm{I} 84 \mathrm{I}$ by the Burnaby family. I2 It was transferred to the Leicester Education Committee in $1935 .{ }^{13}$

CHARITIES. There are no endowed charities in Evington.

6 White, Dir. Leics. (I 846), 497; see above, plate facing p. 429 .

7 C. N. Wright, Dir. Leic. (1894); Kelly's Dir. Leics. and Rut. (1895), I56.

${ }^{8}$ V.C.H. Leics. i. 317

9 Farnham, Leics. Notes, ii. 224

Io Ibid. 226.

II Nottingham Univ. Libr., Middleton MS. 6/170/74.

I2 White, Dir. Leics. (1846), 497.

13 See above, p. 336 . 


\section{HUMBERSTONE}

Humberstone lies $2 \frac{1}{2}$ miles north-east from Leicester and was formerly an ancient and civil parish in East Goscote hundred and Billesdon union. In I 892445 acres of the parish were taken into the borough of Leicester as West Humberstone civil parish. This new civil parish was dissolved in 1896 and absorbed in Leicester civil parish. The remainder of Humberstone (I I 74 a.) was transferred to Leicester in $1935^{1}$ The old village stands on an island of glacial sands and gravels in the Boulder Clay to the north-east of Leicester. ${ }^{2}$ The British Railways (Midland) line runs to the west and the line from Leicester to Melton Mowbray runs through New Humberstone to the south. There is a station on this line at New Humberstone.

Little of the old village remains. Of the two manorhouses only Humberstone Manor at the west end of the village survives. It dates mainly from the $I 7^{\text {th }}$ century, although parts of the building may be older. This house now forms part of the Towers Hospital, as does the early-I 7 th-century barn, reputed locally to be a tithe barn. ${ }^{3}$ The barn is built of brick and is a fine building of ten bays with a slate roof. It was restored in 1954.4 The other manor-house is probably represented by the homestead site in what used to be known as Swan's Orchard, a little to the east of the church in Sterns Lane. Excavation of this site was carried out in 1955 for the Ministry of Works and

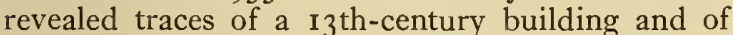
Tudor cottages.

Of the other houses in the village, Humberstone Lodge, on the north side of Main Street, is a lateI 8th-century house of three stories. The Grange, on the south side of the street, is a smaller house of the same date and style, although substantially altered. No. Io6 Main Street is the single cottage of any interest; it is of brick with a timber and thatched porch and thatched roof.

The name of the parish is possibly derived from 'Hunbeorht's stone'. A stone called the 'Humber' stone stands near Thurmaston Lane in the parish and is the object of a certain amount of legend and tradition as a supposed sacred site. ${ }^{5}$

MANORS. In Io86 Hugh de Grentemesnil held 9 carucates of land and $\mathrm{I} 2$ acres of meadow in $H U M$ $B E R S T O N E$ as socland of his manor of Earl Shilton. ${ }^{6}$ Although the Earl of Leicester is not returned as the owner of Humberstone in the Leicestershire Survey of $c$. I I 30 , it seems very probable that the manor did descend from Hugh to the earls of Leicester since between IIgO and I204 the Earl of

I V.C.H. Leics. iii. 189-9o; for areas, see Census, I 89I, I93I.

For the site, see T.L.A.S. xviii. 125-6.

3 G. E. Kendall, Humberstone, 33-35.

4 T.L.A.S. xxx. 123.

5 Ibid. xvii. I 82 ; ibid. xxvi. 86; Kendall, Humberstone, 60-62; Leic. Mercury, 28 June I934, 20 Jan. 1937; Memorials of Old Leics. ed. A. Dryden, I 95 sqq.

V.C.H. Leics. i. 3 I 5 .

7 Cal. Doc. France, ed. Round, 229-3o; see below, p. 44 I.

8 For the descent of the honour of Leic., see E.H.R. liv. $385-402$.

9 Leics. Survey, ed. C. F. Slade, I6; for Martival, see below.

10 Nichols, Leics, iii. 269-7o.

I For the Grey family see Complete Peerage, vi. I 23 sqq.
Leicester confirmed a grant of property at Humberstone made by Hugh to St. Evroul Abbey. ${ }^{7}$ Humberstone belonged to Edmund, Earl of Lancaster, at his death in 1296 and passed to the Crown with the rest of the Duchy of Lancaster in $1399 .^{8}$

In $c$. II 30 three men were returned as holding land in Humberstone, Roger de Ramis, who held 8 carucates, Walter de Musters, who held I, and Ralph de Martival, who held $3 .{ }^{9}$ It seems likely that they were the Earl of Leicester's tenants in demesne. The holdings of Walter and Roger cannot be traced subsequently. Later in the $\mathrm{I} 2$ th century land in Humberstone was held by John Humet, who made grants to Croxton Abbey and Leicester Abbey. ${ }^{10}$ John Humet's yrant to Croxton was confirmed by Richard de Grey, ${ }^{\mathbf{I}}$ the owner of Evington manor, who had married Humet's daughter, Lucy, and a small quantity of land in Humberstone continued to be held as part of the manor of Evington.12 Farnham suggested that the Grey family were the mesne lords of the manor called Hotoft's manor, and although there is no direct evidence of this, in 1376 John de Grey claimed the marriage and wardship of one of the Hotoft heirs. ${ }^{13}$

Two manors held in demesne from the Duchy of Lancaster existed in Humberstone from at least the beginning of the I 4 th century, although the date of their separation is not clear. The first, called HOTOFT'S MANOR, was returned as the property of Robert Hotoft in I3 16. ${ }^{14}$ An earlier Robert Hotoft had held land in the parish some time before $\mathbf{I} 288.15$ This manor descended in the same family until it was sold between I 475 and I 485 to Thomas Keble. ${ }^{16}$ He was a wealthy sergeant-at-law, descended through his mother from Richard (d. I45I), the last male Hotoft, and he had already purchased a considerable estate for himself in the county before his purchase of Humberstone. His brother John (d. I485) also held land in the parish ${ }^{17}$ and his son Walter acquired Hesilrige's manor from Thomas Hesilrige in I 5 19. ${ }^{18}$

The holding later known as HESILRIGE'S $M A N O R$ was the property in I3I6 of Roger de Martival, the descendant of the Ralph de Martival of the Leicestershire Survey. ${ }^{19}$ From the Martivals the manor descended to Robert de Saddington, who was Chancellor I $343-5$, through his marriage with the Martival heiress, Joyce, probably the daughter of Anketil de Martival.20 Saddington's great-granddaughter, Isabel Heron, married Thomas Hesilrige of Fawdon (Northumb.), and Noseley and the manor of Humberstone thus passed into the hands of the family from whom it came to be named. ${ }^{21}$ In $15^{\text {I } 9}$ Thomas Hesilrige sold it to Walter Keble and from

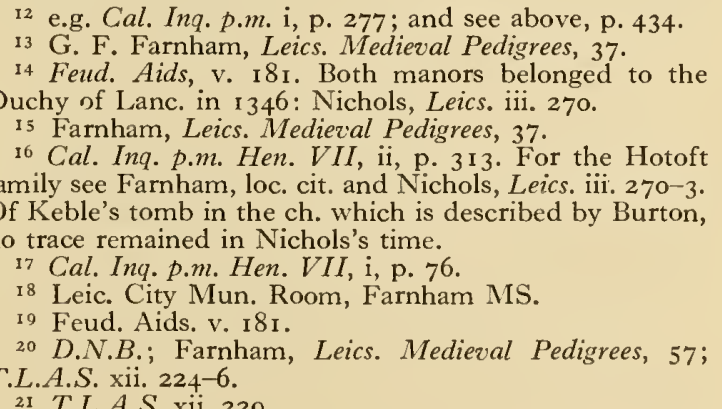$$
2 \mathrm{I} T \text { T A S xii } 229
$$ 


\section{A HISTORY OF LEICESTERSHIRE}

that time both manors descend together. They were confiscated for a time because of the recusancy of Henry Keble's wife Jane, and were sold to Sir Henry Hastings in $\mathrm{I}^{6} \mathrm{I}_{4}$ by Margaret Bowes, the daughter and heir of Henry Keble. 22 The Hastings family retained the manors until $\mathrm{I} 687$, in spite of the heavy fines imposed upon them for their support of Charles I. ${ }^{23}$ Shortly before his death in $\mathrm{I} 697$, Henry Hastings sold the Humberstone manors to Thomas Sutton, a Londoner ${ }^{24}$ who was connected with an old Humberstone family, the Bales, which had formerly held land there. ${ }^{25}$ In 1755 Thomas Sutton's son, another Thomas, sold the manors, which still bore their old names, to William Pochin, M.P., of Barkby Hall, ${ }^{26}$ whose descendants are still the principal landowners.

The house known as the Manor House was sold by Mr. V. R. Pochin in 1933 to the tenant, Mr. Stafford Fox, together with a plot of 2 acres of grass-land, known as the Cunnery, which marks the site of the former fishponds and which is mentioned in the inclosure award as an ancient close. ${ }^{27}$ This estate was sold to the Leicester Corporation in the same year ${ }^{28}$ and since I 948 has formed part of the land attached to the Towers Hospital. It is not clear to which of the manors this house was attached.

ECONOMIC HISTORY. There were four open fields in Humberstone, South, Middle, North, and Mill fields. ${ }^{29}$ The glebe terrier of I60 I names Stayne and North meadows, but by 1788 the names of these meadows were Marston and South meadows; there were also in $\mathbf{I} 788$ two cow pastures. ${ }^{30}$ Little early inclosure took place. In 1607 it was reported that the house of a husbandman was in decay and the vicar, Thomas Wilson, was said to have seized the land belonging to another. ${ }^{31}$ In 1788 only eight existing closes are mentioned. The designations of occupations given in the parish registers indicate a community of small farmers, husbandmen, yeomen, and labourers.

The parish was inclosed in 1788 and in addition to the lord of the manor, the impropriator, and the vicar, I 7 freeholders received allotments under the award. Of these $I 7,8$ received less than 5 acres and one other less than Io acres. A schedule of tithe payments on house sites and gardens is appended to the parish copy of the award. ${ }^{32}$ This list contains the names of I I owner-occupiers, I9 occupiers who did not own their houses, and 7 owners who did not occupy their houses: none of these names, except that of the vicar, appears in the award. Some families appear constantly in the parish register from the middle of the 16 th century to the I 9 th, but of the proprietors of I 788 , only nine belonged to families of long standing in the village. Of these, the name Hawes first appears in the register for the year $\mathrm{I} 55^{8}$. Several members of

22 Nichols, Leics. iii. $273 ;$ V.C.H. Leics. ii. $58-50$

${ }^{23}$ Kendall, Humberstone, 54; Nichols, Leics. iii. 278.

24 Kendall, op. cit. 55 .

25 For the Bales, see Nichols, Leics. iii. 273

26 MS. penes Mr. V. R. Pochin, J.P., of Barkby Hall.

27 Ibid.; V.C.H. Leics. i. 273 ; L.R.O., Humberstone Incl. Award.

28 Leic. Council Minutes, 1932-3, I 40-4.

29 Leic. City Mun. Room, I D 4 I/2/330.

3o L.R.O., Humberstone Incl. Award, from which all details are taken.

${ }_{31}$ T.L.A.S. xxiii. 263.

32 In parish chest.

33 Leic. City Mun. Room, I $\mathrm{D}_{41 / 2 / 330 .}$ the family held the office of churchwarden in the early I 7 th century and the family holding is referred to in the glebe terrier of $1601 .{ }^{33}$ Entries relating to the Bright family occur in the registers from ${ }_{5} 62$ onwards. Two members of the family paid subsidy in $1628^{34}$ and Thomas Bright paid tax on one hearth in 1670.35 The Bright allotment in 1788 was seven acres. The first mention of the name Norman in the register is in 1659 : the alternative name for Thurnby Road in the inclosure award is Norman's Lane. Two members of the family received small allotments (8a., 2a.) in 1788 . The family of Hartopp, represented in the award by E. Hartopp Wigley, the impropriator, had lived in the village since the end of the $17^{\text {th }}$ century.

About five-sevenths of the land allotted in 1788 went to half the landowners, the bulk to Marmaduke Tomline, William Pochin, E. Hartopp Wigley, Thomas Allsopp, William Tailby, and John Dudley, in that order. More than a third was allotted to nonresidents, Pochin, Allsopp, and Tomline. The rest was divided into the small allotments of the husbandmen. No great changes in land ownership followed the inclosure. One small owner had disappeared by I 792 and another by $1797 .{ }^{36}$ By 1805 the greatest single landowner, Tomline, had disposed of his property to William Haseldine, but in I82I fourteen owners named in the award still appear, and ten were still there in 1832 . From 1816 Thomas Paget, the Leicester banker, began to buy land in the parish, where he already lived and where his son John had been born in I 8 I I . ${ }^{37}$ By I 829 he was a very considerable landowner. In 1922 the three principal owners were still called Pochin, Paget, and Hartopp. ${ }^{38}$

Humberstone seems always to have been a fairsized village. Twenty-five persons paid hearth tax in I 670 and a further 23 were excused as poor. ${ }^{39}$ Fortyeight paid tithe at the time of the inclosure. 40 Thereafter the number of inhabitants increased sharply as Humberstone became a centre for framework-knitting and gradually a suburb of Leicester. Framework-knitters and hosiers are not mentioned in the parish registers until $\mathbf{I} 782$, except for the baptism of a hosier's child in $\mathrm{I} 703$, but we know from other sources that they were there from the early years of the 18 th century. ${ }^{4}$ Between 1812 and 183322 different names of framework-knitters appear and in three of these families a second generation was living in the parish and carrying on the same occupation; some of the second generation, on the other hand, had moved into Leicester and some were beginning to be termed 'operatives' or 'hosiery hands'.

In $182 \mathrm{I}$ the population was $4 \mathrm{I} 5$. This figure more than doubled during the next 40 years. ${ }^{42}$ The borough lunatic asylum, now known as the Towers Hospital, was opened in $1869 .{ }^{43} \mathrm{New}$ Humberstone, first men-

34 Leic. City Mun. Room, Farnham MS.

35 E I $79 / 240 / 279$.

36 L.R.O., Land Tax Assessments, Humberstone; details of ownership in subsequent years from same source.

37 D.N.B.; Leic. Daily Post, I 7 Oct. I 892.

38 Kelly's Dir. Leics. and Rut. (1922), 105.

39 E I 79/240/279.

40 List of tithe-payers attached to incl. award in parish chest.

$4 \mathrm{I}$ V.C.H. Leics. iii. $2 \mathrm{I}$.

42 Ibid. 180

43 J. Storey, Hist. Sketch of Boro. of Leic. 48. The architect of the original building was Edward Loney Stephens, the boro. surveyor. 
tioned in the parish registers in 1880 , comprised that part of the parish which bordered on the borough. Leicester tradespeople and manufacturers were building their houses there, especially along Overton Road and Victoria Road. When the parish was divided in 1892 the depleted village outside the borough, with a population of only 365 , still retained the marks of a true rural community. 'Though there ceased to be a miller in Humberstone between 1855 and $1863^{44}$ and though the last mention of the village cabinet-maker is in 1849,45 the Humberstone of 1895 still had its own carpenter, blacksmith, bootmaker, and maltster. ${ }^{46}$ The building up of the village of Humberstone was completed in the I930's, though there is still some agricultural land to the north of the old village.

PARISH ADMINISTRATION. The organization of the parish of Humberstone presents no singular features. The village had its own workhouse by I 776.47 No parish records dealing with civil affairs survive from the days before Humberstone was placed in the Billesdon union under the new Poor Law. ${ }^{48}$

CHURCHES. No church is mentioned in Humberstone until the early i 3 th century, when the advowson was held by Leicester Abbey, to whom it had been granted by Ernald de Bosco and Jordan Humet, ${ }^{49}$ either of whom may have been responsible for its foundation. In 1217 the living was worth $£ 5.5^{\circ} \mathrm{In}$ I329 the abbey received a licence to appropriate the church although this was not done until about $\mathrm{I} 35 \mathrm{I} .{ }^{.5 \mathrm{I}}$ Before the appropriation the rector gave half a mark yearly to the abbey, and the monks of St. Evroul in France had two-thirds of the tithes of corn from two halls and one virgate under a grant of Hugh de Grentemesnil.52 The abbey continued to present to the vicarage until the Dissolution, when the rectory and advowson passed to the Crown. In 1254 the vicarage was valued at $f_{1} 5$ and at $£_{24} 6 s$. 8d. in I 29I, but in ${ }_{1535}$ it was valued at $£ 8$ net.53 In 1582 Sir Christopher Hatton sold the advowson and rectory, which had been granted to him in the same year by the queen, to John Chippendale, D.C.L., of Humberstone. ${ }^{54}$ 'The descent of the rectory is obscure after this date, but the rectorial tithes were still attached to the vicarage in 1696 , when they were granted to William Noble. 55 In 1788 the lay impropriator was Edward Hartopp Wigley, who received two yearly sums of $£ 284$ IOs. and $8 s .5 \frac{1}{2} d$. in lieu of tithes at the inclosure. ${ }^{56}$ John Chippendale's granddaughter passed on the advowson to her husband, Valentine 60 .

44 P.O. Dir. Leics. (1 855), 5I ; White, Dir. Leics. (1 863),

${ }_{45}$ Hagar's Dir. Leics. (1 849), I 27.

46 Kelly's Dir. Leics. and Rut. (1895), 92.

47 Nichols, Leics. iii. 274.

48 2nd Arn. Rep. Poor Law Com. App. D, H.C. 595, p. $533^{\circ}$ (1 836 ), xxix.

49 A. Hamilton Thompson, Leic. Abbey, 5-6. For a list of vicars presented by the abbey, see ibid. I 47-50.

$50 \mathrm{Val}$. of Norw. ed. W. E. Lunt, 532.

51 Cal. Pat. 1 327-30, 376.

52 Nichols, Leics. iii. 275; Cal. Doc. France, ed. Round,

230. This had passed into the charge of the Prior of

Ware (Herts.) by 1 428 : Feud. Aids, iii. I I 4 .

53 Val. of Norw. ed. Lunt, 532 ; Valor Eccl. (Rec. Com.), iv. $\mathbf{I} 66$.

54 Nichols, Leics. iii. 275; for the Chippendale pedigree see ibid. 278.

55 C.P. 25 (2)/846/Trin. $8 \mathrm{Wm}$. III. For suggestions as
Bale, on their marriage in 1628 and it remained in the Bale family's possession for the next fifty years. After passing through various hands it came into the possession of Isaac Dudley, who presented in $176 \mathrm{I}$ his brother John in succession to their father, Paul Dudley, who had been vicar since I 7 I 5.57 John was succeeded by his son, another John, a miscellaneous writer of some note, who inherited the advowson and held the living until his death in $1856.5^{8} \mathrm{He}$ sold the advowson before 1846 to Halford Adcock, whose son was the curate in charge of the parish. ${ }^{59}$ After passing through the hands of various clerical owners, the advowson came into the possession of the Leicester Diocesan Board of Patronage. ${ }^{60}$

The living was augmented in 1787 by two grants of $£ 200$ each from Queen Anne's Bounty and from Isaac Dudley and a William Stevens. ${ }^{61}$ By the inclosure award 120 acres of glebe were allotted to the vicar, who also received a yearly sum of $\oint_{\mathrm{I}}$ I 10 I 5 s. in lieu of the small tithes and a further $8 s .5 \frac{1}{2} d$. in lieu of tithes from a separate 2 acres, probably old inclosure. ${ }^{62}$

A new church, $S T$. BARNABAS, New Humberstone, was completed in 1886 , from the plans of Joseph Goddard, of the Leicester firm of Goddard and Paget. ${ }^{63}$ 'The parish was formed in 1887 out of those of Humberstone, Evington, and Belgrave and includes the Towers Hospital. The presentation was originally in the hands of the Bishop of Peterborough, but has since passed to the Bishop of Leicester. ${ }^{64}$

Two chapels, Swan's chapel and Keble's chapel, are mentioned in 1637.65 In 1535 the chaplain of Keble's chapel received a salary of $£_{5} 6 s$. 8d. from money left by Thomas Keble. ${ }^{66}$ Nothing further is known of the foundation or subsequent history of either.

The parish church of $S T$. MARY consists of nave, chancel, north and south aisles, south porch, vestry, and west tower. Of the original 13 th-century church, little remains but the tower and parts of the outer walls, more especially in the chancel. In I $_{5} 18$ the visitation of the Bishop of Lincoln revealed that the image of the patron saint was putrifacta et senex, that there was no bell, that the chancel and the gate of the churchyard were in bad repair, that the rain leaked through the church roof upon the pyx, and that various pieces of church furniture were scattered about the village in private houses. ${ }^{67}$ In 1637 the roof leaked in many places and the east window was broken. The chapels, Keble's chapel and Swan's chapel, needed paving, and it was also complained that 'the Clarke doth not goe' ${ }^{68}$ Repairs had evidently been carried out before the end of the 17 th century: in

to the subsequent hist. of the tithes see Kendall, Humberstone, 20.

56 L.R.O., Humberstone Incl. Award.

57 P.R.O., Inst. Bk.

${ }_{5} D . N . B$. Contemporary portraits of the two John

Dudleys hang in the ch. vestry.

59 White, Dir. Leics. (1 846$), 43^{8}$.

60 Leic. Diac. Cal. (1954), 89.

61 White, Dir. Leics. (I 877), 245.

62 L.R.O., Humberstone Incl. Award. Part of the glebe was sold in I930: sale doc. in par. rec.

63 Leic. City Mun. Room, Mins. of Leic. Ch. Extension

Soc. 7 July I 884; Kelly's Dir. Leics. and Rut. (1922), I 28.

64 Leic. Dioc. Cal. (1954), 9o.

65 Leic. City Mun. Room, I D $_{41 / 18 / 9}$

66 Valor Eccl. (Rec. Com.), iv. I 66.

67 Visit. in Dioc. Linc. I517-31, ed. A. Hamilton Thompson, i. 31-32.

68 Leic. City Mur. Room, I D41/18/9. 


\section{A HISTORY OF LEICESTERSHIRE}

I692 the church was reported to be in good condition. ${ }^{69}$ In 1779 the chancel needed repair again and a considerable number of minor matters were brought to the notice of the archdeacon. ${ }^{70}$ Twelve years later it was stated that the church was damp and decayed, with bricks and rubbish inside it and weeds and moss growing out of the walls. ${ }^{71}$ Before 1836 the parapets had all been replaced and the chancel had been reroofed..$^{72}$ In $1857-8$ the nave, aisles, and porch were all rebuilt in the style of 13 th-century Gothic and the interior of the chancel was refaced with alabaster. ${ }^{73}$ The tower was restored in $1869^{74}$ and a complete redecoration took place in $\mathrm{I} 950$.

The rebuilt portions of the church are of ashlar while the chancel is of rubble with worked stone dressings and plain stone parapets to low-pitched, lead-covered roofs. There is a clerestory, lighted on each side by five windows. The tower rises in four stages, diminished at each by weathered offsets and crowned by a broach spire. The tower parapet was originally decorated with quatrefoil panels, of which only the lower parts remain. Below its base moulding there is on the south side a carved frieze with two effigies; on the east side are quatrefoil panels, two decorated with a star and crescent; on the north are grotesque animals, separated by panels each containing a cock; and on the west there is foliated scroll-work. The tower doorway and the windows to the ringing- and bell-chambers are original.

The roofs were rebuilt during the restoration of I $857-8$ but a few pieces of I 5 th-century timber were used. The roof bosses and carvings were gilded in I 950 . The font dates from the last century and stands at the west end. The Early English font was destroyed in $1857-8$ but was pieced together and, after standing for a short time in a Humberstone garden, was taken in I9I I to Little Dalby Hall. ${ }^{75}$ The six bells were rehung in 1948 . The earliest is dated 1620 ; the rest date from $I 628, \mathbf{1 6 7 3}$, and $I 743$ (the last by $T$. Eayre). One is undated but was cast by Eayre probably about I740. 'The sixth was cast by 'Taylor of Loughborough and was the gift of 'T. T. Paget about I $870 . .^{76}$

In the north aisle is a table tomb with an alabaster top, bearing the figure of a man in armour. The marginal inscription is to Richard Hotoft (d. I 547). The tomb was restored in 1852 . There are several I 8 th-century stone slabs in the floor, and one wallmonument.77

The main series of registers dates from I 557 , but there are isolated entries from 1552 . There is no ancient plate.

${ }^{69}$ Leic. City Mun. Room, I $D_{41 / 18 / 19}$.

70 Ibid. I 4 I $/ 18 / 2$ r.

$7 \mathrm{I}$ Ibid. I D4I/18/22.

${ }^{72}$ Ibid. 245 '50/7.

of St. Mary, Humberstone.

75 Kendall, Humberstone, I2; inf. from Mr. C. Bramley. Although Little Dalby Hall was demolished in I95I it proved impossible to restore the font to Humberstone, and it was still in the grounds of Little Dalby Hall in 1955 : T.L.A.S. xxxi. 65.

${ }_{76}$ Davis, Par. Ch. of St. Mary.

77 On the other monuments in the ch. see Nichols, Leics. iii. 276-7, and Kendall, Humberstone, 24-27.

78 See above, pp. 439-40.

79 V.C.H. Leics. ii. 58-59, where Jane Keble is named as Jane Bowes, and the property is (wrongly) said to have been sold by John Bowes.

80 A. H. Kimberlin, Return of Catholicism to Leic. I $746-1946,56-57$.

$8 \mathrm{r}$ Ibid. 57 ; and see above, p. 438 .
ROMAN CA'THOLICISM. Members of the Keble and Bowes family, in which Humberstone manor descended, ${ }^{78}$ were convicted as recusants in the late I 6 th century and early I 7 th. 79 They may have maintained a private chapel. After the departure of the Bowes family in I6I4, there was no Roman Catholic chapel until the chapel of St. Joseph, Goodwood Road, was established on the site of a disused farm in 1938 , and the buildings were converted to a chapel by voluntary labour. The parish of St. Joseph was created from part of that of Sacred Heart in $1942 .{ }^{80}$ The convent school at Evington Hall, run by a community of the Sisters of the Nativity of the Blessed Virgin Mary, is in this parish. It was opened in I939, when the school was moved from St. Peter's parish, where it had been established since I9I $8 .^{81}$

PRO'TESTANT NONCONFORMITY. Anabaptists are mentioned occasionally in the parish registers from the beginning of the 18 th century, and in 17 I 2 a Quaker living in the parish was buried in Leicester. ${ }^{82}$ About the same time it was reported that a Quaker and two Anabaptists were living in the parish, and a few years later there were one Presbyterian and one Anabaptist, and Quaker and Presbyterian ministers. ${ }^{83}$ By I 829 a congregation of 20 Wesleyan Methodists had a meeting-house; $; 4$ their chapel was built in I $841 .{ }^{85}$ A second Wesleyan chapel was built in Overton Road in 1882.86 'There is a Baptist chapel in the same road (built in $\mathrm{I} 88 \mathrm{I}$ ). ${ }^{87}$ 'There are Methodist chapels in Uppingham Road (1925) (88 $^{8}$ and Edgehill Road (I90I), ${ }^{89}$ and a Congregational chapel in Abbots Road (I85I). ${ }^{90}$

SCHOOLS. The National school was built in 1857 by Halford Adcock. Twenty years later it was attended by about 70 pupils. ${ }^{91}$ In 1935 it was transferred to the Leicester Education Committee and is still (1955) an infant and junior school. There was a school board at West Humberstone which built the Bridge Road Board School (I889) and the Overton Road Board School (I88I). ${ }^{92}$

CHARITIES. The inclosure award allotted just under an acre of land to the church and the poor in respect of the Town or Church Land. It was leased in 1837 for $£ 3$, but nothing further is known of it. The rent of $£, 3$ and a further $£ 7$ from $I_{2} \frac{1}{2}$ acres called the Orchard were divided in 1837 between the upkeep of the church and the poor rates. ${ }^{93}$ The Orchard was sold in I93I. The income from the proceeds, now amounting to $£ 5^{2}$, is divided between the poor

82 Humberstone par. reg.

83 Assoc. Archit. Soc. Rep. Eீ Papers, xxii. 207

$8+$ L.R.O., ret. of places of worship, 1829 .

85 Inscr. on chapel.

86 This was closed in 1925 when the Uppingham Rd. chapel was built: C. Howes, Leic., Its Industrial, Institutional and Social Life, 226.

87 C. N. Wright, Dir. Leic. (1880), 59; ibid. (1882), 62.

88 See n. 86.

89 Wright's Dir. Leic. (1902), 40, where Edgehill Rd. appears for the first time.

9o Kelly's Dir. Leics. and Rut. (1928), I I 2.

91 White, Dir. Leics. (1877), 245.

92 See above, pp. 336-7.

93 32nd Rep. Com. Char. Pt. 5 [163], p. 48 I, H.C. ( 830$), \mathrm{xv}$. This land was believed in the I 8 th cent. to have been left to the parish by Hugh Botham: Nichols, Leics. iii. 274 , n. 5. There seems to be a confusion with the Botham Charity mentioned below. 
and the church. The land, a triangular patch bounde by Humberstone Drive, Thurmaston Lane and Gips v Lane, was lately known as the Crow Orchard. ${ }^{94}$
Two furth:r charities, one of $£ 35$ from an unknown donor and one of $£ 20$ from Hugh Botham, had been lost for over 40 years before 1837.95

\section{KNIGHTON}

KNIGHTON is now part of the city of Leicester and is largely a built-up area two miles south-east of the town centre. It was formerly a chapelry of the ancient parish of St. Margaret, but, unlike the rest of the parish, Knighton lay outside the borough and formed part of Guthlaxton hundred. It raised its own rate and was a separate civil parish until I 896 , when part of it (567 acres), which had been transferred to Leicester borough in 1892 , was absorbed in Leicester civil parish. I In 1892 the remainder of the parish had been left out of the borough after a petition against its inclusion alleged that it was largely agricultural. The eastern portion, which included Manor Road, was attached to Oadby parish, while the southern part, lying between Washpit Brook and Wigston Urban District, was attached to Lubbesthorpe but was united with Leicester in $1935 .^{2}$

Knighton lies on Boulder Clay in the north, and in the south extends to the band of mixed clay and limestone which runs east from the Welford road to the east side of the village of Oadby. The British Railways (Midland) line from Leicester to Market Harborough runs through the west of the parish. To the north lies the area known as Stoneygate, and to the north-west, Clarendon Park. The main roads which run through the parish are those from Leicester to Wigston and to Market Harborough.

Little of the old village of Knighton remains, although there are some small timber-framed cottages and the 'Craddock Arms', part of which probably dates from the early 17 th century. Knighton Hall, formerly the manor-house, also dates from the $17^{\text {th }}$ century. The oldest parts of the house are built on a timber-frame structure, covered with roughcast, and rising to three gables. The front of the house was added at various dates in the I8th century and is of red brick with cement-covered moulded brick sills, window-frames and string courses. There is a projecting semi-circular porch with two Tuscan columns. The I8th-century extensions are probably to be attributed to John Johnson, the Leicester architect. ${ }^{3}$ In 1846 the lord of the manor was using the house as a hunting box.4 It is now the property of University College, Leicester, and is the official residence of the principal.

MANOR. In 1086 the Bishop of Lincoln held

94 Inf. from the vicar.

95 32nd Rep. Com. Char. Pt. 5, 48 I.

I Leic. Extension Act, 54 \& 55 Vic. c. roo; V.C.H. Leics. iii. I $79 \mathrm{n}$.

${ }^{2}$ Co. of Leic. Review Order, 1935.

3 J. Simmons, City of Leic. 52.

4 White, Dir. Leics. (1 846 ), 399.

5 V.C.H. Leics. i. 309.

6 The transactions are summarized and all relevant docs. printed in Reg. Antiquissimum, ed. C. W. Foster, iii. 21 3-27.

7 Cal. Pat. 1547-8, 153. Nichols's assertion that John Grey of Codnor died seised of the manor in 1392 is erroneous: Leics. iv. 237.

8 G. F. Farnham, Quorndon Rec. 272; see also ibid. 20-22 for a discussion of the Farnham family at this date.
KNIGHTON, then consisting of under a hide of land.5 In I 43 Bishop Alexander granted out land worth f, ro to Robert le Bossu, Earl of Leicester, who held it for the service of one knight's fee. After a complicated series of transactions involving Robert and his successors, the bishops of Lincoln, and Leicester Abbey, to which Robert had granted the property, it was eventually returned to the see of Lincoln in $1218 .^{6}$ Knighton remained the property of the bishops of Lincoln until in 1547 the bishop granted the manor to Edward VI.7 In 1577 it was granted to Matthew Farnham of Quorndon and Sir George Turpin of Knaptoft by Elizabeth I. Farnham's brothers, Thomas (d. I 562) and Robert, had been successively stewards of a number of Crown manors including Knighton. In his will, Matthew Farnham valued his right and title in Knighton at $f_{2} 2$ yearly and left it to his son Humphrey. ${ }^{8}$ After this until the end of the 18 th century the descent of the manor is completely obscured. ${ }^{9}$ No lord of the manor is mentioned in the inclosure award of $1756,{ }^{10}$ although the chief landowners were the family of Craddock, from whom Sir Edmund Craddock Hartopp, lord of the manor in I 8oo, was descended. II He was the son of Joseph Bunney and Mary Craddock, and took the additional names of Craddock and Hartopp upon succeeding to various properties in Knighton under the will of his maternal uncle, Joseph Craddock, and upon his marriage to Anne Hurlock, granddaughter of Sir John Hartopp of Freeby. ${ }^{12}$

By the I 8 th century the Craddock family had long been settled in Leicester, and were notable citizens and merchants there. ${ }^{13}$ The first member of the family to buy land in Knighton was Edmund Craddock of Leicester, woollen-draper, who did so in I 720. ${ }^{\text {I }}$ It would seem as though the manorial rights had been forgotten or extinguished during the 18 th century, which would explain the omission of any mention of a lord of the manor in 1756 . In 1846 Sir Edmund Craddock Hartopp was described as lord of the manor, ${ }^{15}$ and his descendant, also Sir Edmund, Principal of Brasenose College, Oxford, was lord in I 878. ${ }^{16}$ The manor-house, Knighton Hall, was sold by their descendant Colonel Edmund Craddock in 1931. ${ }^{17}$ Much of the Craddock property at Knighton was sold as building lots in 1854 , though some had been disposed of earlier. ${ }^{18}$

9 Farnham quotes the inq. p.m. of an Alexander Cotes (d. 1630 ), who was said to hold land in Knighton: Leic. City Mun. Room, Farnham MS.

Io I.R.O., Knighton Incl. Award.

II Nichols, Leics. iv. 419 , where it is suggested that Hartopp derived his title to the manor from the Farnhams. 12 W. D. Fletcher, Leics. Pedigrees and Roy'al Descents, $9 \mathrm{I}-92$.

${ }_{13}$ The family is frequently mentioned in H. Hartopp, Reg. Freenen of Leic. passim, and in Leic. Boro. Rec. I 5091603 , and ibid. $I 603-88$, passim.

I4 Leic. City Mun. Room, I D 32/295.

15 White, Dir. Leics. (1846), 399.

16 Ibid. (1877), 259.

17 Burke, Land. Gent. (1937), 501.

18 Leic. City Mun. Room, 3D42/2/327; and see below. 


\section{A HISTORY OF LEICESTERSHIRE}

ECONOMIC HISTORY. Knighton's $\frac{2}{3}$ hide was stated to be sufficient to support 6 ploughs at the time of the Domesday survey. There were 30 acres of meadow and the enumerated population amounted to 20 villeins and 4 socmen. ${ }^{19}$ About 1230 there were 7 substantial free tenants and 16 others who, though free and performing no services, had very small holdings and small rents. There were in addition 24 villeins, whose services were on a considerably higher scale than those of the free tenants. ${ }^{20}$ In 1327 23 persons were named in the tax list, the highest contribution being $3 s .9 d$, , and 200 years later 24 persons were assessed for tax. ${ }^{21}$

Knighton was inclosed in 1756 , when 17 proprietors from 14 families received allotments from the $I, 520$ acres which remained for distribution when the land for roads, houses, and gardens had been subtracted. Of these I7, the three members of the Craddock family received about 7oo acres, or nearly half the total available land. Several ancient closes were put into the award and reallotted. There were four fields, called Stockwell, Saftorn, Goldhill, and the Breach Field, ${ }^{22}$ and about Ioo acres of meadow and pasture called the Cow Pasture. Of the members of yeoman families of long standing, Edward Inge received 260 acres and two members of the Foster family received just over 132 acres. Of other names, that of Edmund Johnson, dyer, who received just over I 27 acres, seems prophetic of Knighton's future in the coming century as a place of residence for business men from Leicester. ${ }^{23}$ By 1832 only four of the families who had owned land in 1756 still held any. The Craddocks sold a great deal of their land before 1832 , and part at least of it was purchased by the Kecks of Stoughton Grange. ${ }^{24}$

Framework-knitters are mentioned at Knighton during the 18 th century, though they had disappeared by $1844 \cdot{ }^{25}$ The sole indication of any form of industrial activity to be found in the parish registers, however, is a solitary reference to a stocking-weaver in I 712. A carpenter and a cordwainer are mentioned in the inclosure award. For the most part the village of Knighton itself remained quietly agricultural until the last quarter of the igth century, and was somewhat overshadowed by the development of its suburban neighbours, Stoneygate and Charendon Park. In 1846 and 1877 agricultural land still formed the greater part of the parish and in 1877 there were still three large farms. ${ }^{26}$

The growth of the area known as Stoneygate ${ }^{27}$ to form the chief residential suburb of 19 th-century Leicester seems to have begun in the last years of

19 V.C.H. Leics, i, 309.

20 MS. Queen's Coll. Oxf. 366, f. in

${ }^{21}$ Leic. City Mun. Room, Farnham MS.

22 'La Breche' ( 1332$)$ is the only medieval field- or place-name identifiable in the incl. award: Leic. City Mun. Room, Farnham MS.

${ }_{23}$ L.R.O., Knighton Incl. Award.

24 L.R.O., Land 'Tax Assessments, Knighton.

25 V.C.H. Leics. iii. 21.

${ }^{26}$ White, Dir Leics. (1 846 ), 398; ibid. (1 877 ), 259

27 The suburb takes its name from the Leicester-Medbourne road, the so-called Gartree road. This is known to have been called Stongate in I 5 I $5:$ E I $50 /$ I $_{2} 2 / 9$. That the name was in use in the 18 th century is indicated by the name of Stoneygate House. An early use of the name to denote the area occurs in 1800 : Leic. Fnl. 25 April, 9 May 1800 .

${ }^{28}$ H. Hartopp, R. of Mayors of Leic. 158; P. Russell, Leics. Road, 78 .

29 It is marked on John Prior's map of 1779 and on the I8th century. The first house in Stoneygate is said to have been built on the Harborough-Loughborough turnpike about 1760 by Samuel Oliver, Mayor of Leicester in $1762 .{ }^{28}$ The evidence for this is not known and it is not clear to which house the statement refers, but it seems likely that it means Stoneygate House, in the present Toller Road, which was built before I779, but cannot have been built long before. ${ }^{29} \mathrm{It}$ is a large stucco house with a steeply pitched slate roof and was enlarged in the early i 9 th century. In 1846 it was the home of a grocer, Thomas Nunneley, ${ }^{30}$ but was later purchased by Richard Toller, who gave his name to the road which was built on part of his estate after his death in $1896.3 \mathrm{r}$

Stoneygate House was not, however, the first house to exist on the Harborough road. Parts of The Stoney Gate, 227 London Road, date probably from the late $17^{\text {th }}$ century and seem to have formed part of a farmhouse. 32 The kitchens and the whole front of the house are probably 17 th-century work as are some of the outbuildings. About 1780 the whole house and at least part of the farm buildings were recased in soft red brick, the gables were heightened artificially, and a wing was built at the rear. The new style of the house was Gothic of an early, delicate variety; the library, which preserves some of its Gothic mouldings, is certainly of this date, though the drawing-room may be a little later. Thus converted from a farm into a gentleman's residence, The Stoney Gate remained in 1955 much as it did in 1800 , though considerable alterations to the interior took place in $1949-51$. The house was for many years the home of Major W. J. Freer, Clerk of the Peace for Leicestershire. ${ }^{33}$

In a directory of 1846 , 10 houses are listed in Stoneygate, all belonging to prosperous Leicester tradesmen and professional men. ${ }^{34}$ Among them were C. B. Robinson, whose house, The Shrubbery, had ornamental gardens by Paxton ${ }^{35}$ and who was the lessee of the Leicester gas works; John Biggs, whose house stood where Knighton Park Road now runs ; ${ }^{36}$ and Richard Toller. Springfield House (now 2 Springfield Road) and Brookfield are other named houses which still stood in 1955. In 1848 Samuel Stone built his new house, Elmfield. ${ }^{37}$ Development was accelerated by the sale of part of the D'Oyly estate, adjoining Elmfield in $185^{8} .{ }^{8}$ One of the houses built on this land was G. B. Franklin's school, built in $1859 .{ }^{39} \mathrm{In} \mathrm{I} 863$ there were 32 houses. $40 \mathrm{Up}$ to this time the development of the area had been the work of independent persons building large houses in spacious grounds for their own use; these were for

stylistic grounds must belong to the I77o's: B. L. Gimson and P. Russell, Leics. Maps, 18.

30 White, Dir. Leics. (1 846), 399.

${ }^{31}$ Reminiscences of Eliza Spurrett, 5 ; E. M. Drew, Those Taking Part, 20.

32 The outbuildings, round a cobbled courtyard, included a bakery and blacksmith's shop: ex inf. Mrs. T. M. J. d'Offay.

$33 \mathrm{Wm}$. Fesse Freer, ed. H. Hartopp, 25, and photographs facing pp. 16, 20

34 White, Dir. Leics. (1846), 399.

35 Illus. Leic. Chron. 25 April I93 I, article on Stoneygate by $\mathrm{R}$. G. Waddington.

${ }^{36}$ Ibid. For a picture of the house see Leic. Mercury, 7 Nov. I930.

37 Reminiscences of E. Spurrett, 19.

38 Leic. City Mun. Room, I2D 43/93/38.

39 E. S. Drake, Dir. Leic. (1861), 276 ; T.L.A.S. xviii. 30.

40 White, Dir. Leics. (1863), 75 I. 
the most part on the London road. About 1865 the side roads appeared, and the area began to interest speculative builders and land societies. Knighton Park Road was laid out in I 867 , across the grounds which had belonged to John Biggs's house, and before I 870 several houses had been built along it.41 Avenue Road appeared at about the same time and was the scene of early activity on the part of the Freehold Land Society; it was long used as allotment ground ${ }^{42}$ and the absence of houses along its north side is probably to be explained by this. Stoneygate Road was proposed in or just before 1867 and the area bounded by it, London Road, and Stoughton Road was sold in building lots in 1867.43 Alexandra Road and Sandown Road (formerly Lansdowne Road) were completed between $\mathrm{I} 877$ and I $88 \mathrm{I}^{44}$ and Thornleigh, one of the houses facing London Road, was built in 1871.45

Between I 875 and I 885 the Clarendon Park estate was broken up 46 and before I 888 most of the streets had been laid out and the houses built, 47 mostly in terraces of red brick. Some of the area was owned and developed by Samuel Francis Stone, whose own house, The Woodlands, gave its name to Woodland Avenue, also laid out from land belonging to Stoneygate House. On the other side of London Road, Francis Smith developed an area of terrace houses in Francis Street. ${ }^{48}$

To the south, beyond Knighton Road, building along the London road took place from an early date, and the suburb known as New or South Knighton began to grow up about I880. Large houses continued to be built along London Road, and the roads to the east of it were the result of building development towards the end of the century. A further part of the D'Oyly estate, facing Stoughton Road and London Road, was sold in I 868.49

The social position of those who developed Stoneygate had great effect upon its character. The houses were at first large and set in their own grounds, and the tree-lined London Road of today is the result of this. The early houses were Italianate in style, like the two which flank the eastern end of Knighton Park Road. About I 860 came the Gothic houses, like Stoneygate School, of a much heavier style than the graceful Gothic of The Stoney Gate. Finally, about I 875 the timbered house began to appear, and by far the greater part of the large houses built in the latter part of the century are in this style, which was perfected in Leicester by architects such as Isaac Barradale, many of whose houses are easily recognizable today. ${ }^{50}$

4 I Russell, Leics. $R d$. I46; Leic. Trade Protection Soc. Dir. Leics. (1870), 56.

42 Illus. Leic. Chron. 25 April I03 I.

43 Leic. City Mun. Room, I $2 \mathrm{D}_{43} / 93 / 6_{5}-6$.

44 White, Dir. Leics. (1 877 ), 260; C. N. Wright, Dir. Leic. ( 1882 ), 74

45 W. Scarff, Leic. and Rut. at Opening of 20 th Cent. 71.

46 Illus. Leic. Chron. 25 April 193 I.

47 Kelly's Dir. Leics, and Rut. (1888), 548-9.

48 Illus Leic Chron loc cit.

49 Leic. City Mun. Room, I2D43/93/68-72.

50 Designs for houses in Stoneygate by Barradale in Building News, 7 Nov. I 879,20 Aug., and 24 Sept. I 880. The Hawthorns in Knighton Park Rd. was built by Barradale for Wilmot Pilsbury, late Principal of Leic. Sch. of Art, who himself designed the plaster decoration between the timbers of the upper story: see ibid. I7 Nov, I882. Barradale also seems to have bought up land for development, e.g. in Knighton Park Rd.: map of 1875 penes Mrs.
By I 880 Stoneygate was virtually a part of Leicester. 'The population of the parish of Knighton rose from 383 in 183 i to nearly three times that number 40 years later, and increased by nearly 1,000 between I $87 \mathrm{I}$ and I $88 \mathrm{I} .51$ The tramway from Leicester to Stoneygate was opened in $1875 .^{52}$ Building continued to the south of the old village between the wars and practically the whole of the parish is now a built-up area.

CHURCH. Ecclesiastically, Knighton was separated from the parish of St. Margaret, Leicester in I 878,53 to which it had apparently been attached since before I 086.54 The parish of St. John the Baptist, Clarendon Park Road, was formed from Knighton in $1917,{ }^{55}$ the church having been built as a chapel of ease in I885. The architects were Goddard and Paget of L.eicester and the church was built largely from a gift of $£ 6,000$ from Miss Sarah Barlow. ${ }^{56}$ The church of St. Michael and All Angels was built near Knighton Fields Road in 1898 and the parish was formed in $1930 .{ }^{57}$ The architect was S. Perkins Pick. ${ }^{58} \mathrm{~A}$ chapel of ease, St. Guthlac's, was attached to Knighton in I9I2. The building is only partially completed and was one of the last works of the architect J. Stockdale Harrison. ${ }^{59}$

Knighton, as a chapelry of St. Margaret's, was served from that church until I $878 .{ }^{60}$ The advowsons of the three parish churches in Knighton were in r 956 vested in the Bishop of Leicester. ${ }^{61}$

In 1646 the committee of sequestrators ordered that $£_{25}$ from the revenues of St. Margaret's and a similar sum from the estates of Sir John Beaumont should be paid yearly for the upkeep of a minister at Knighton, whose curate then received only $f_{5} 5$ yearly. Similar orders were made in 1649 and $165^{\circ}$ but in I 7 I 6 the chapelry was worth only $£ 6.62$ In I 649 the Council of State ordered an inquiry into a 'very foul riot' and 'great insolency and violence' shown towards Dr. Harding who had been appointed to preach a probation sermon in the chapel, with a view to being appointed permanent chaplain. ${ }^{63}$ Shortly after the creation of the parish of Knighton the living was worth $f_{2} 240$ yearly. ${ }^{64}$ The prebendary of St. Margaret's received the tithes from Knighton. 'The great tithes were commuted for a yearly payment of $f_{12}$, and the small tithes for $£_{6} 6$, by the inclosure award. There were $7 \frac{1}{2}$ acres of glebe in 1756 .

The present church of ST. MARY MAG$D A L E N E$ contains no fabric earlier than the $3^{\text {th }}$ century when it probably consisted simply of chancel and nave. About the middle of the $14^{\text {th }}$ century a

T. M. J. d'Offay.

51 V.C.H. Leics. iii. 191, 197.

52 White, Dir. Leics. (1877), 260.

${ }_{3} 3$ Kelly's Dir. Leics. and Rut. (1936), 131 ; Lond. Gaz. I878, p. 4810.

54 See above, p. 357 .

55 Kelly's Dir. Leics. and Rut. (1936), I 3 I.

56 Spencer, New Guide to Leic. (1888), 93; see also $\mathrm{W}^{7} \mathrm{~m}$. Fesse Freer, ed. Hartopp, I 6.

${ }_{57}$ Kelly's Dir. Leics. and Rut. (1936), I3 I.

58 T.L.A.S. xi. $40 \mathrm{O}$

59 E. Morris and L. Cox, Ch. of St. Mary Magdalene, Knighton, 24; T.L.A.S. xi. 62.

60 See above.

${ }^{61}$ Leic. Dioc. Cal. (1954), 89.

${ }_{62}$ Nichols, Leics. iv. 238.

63 Cal.S.P. Dom. I649-50, I 80; Leic. Boro. Rec. I60388,393 .

${ }_{64}$ Kelly's Dir. Leics. and Rut. (1 888), 543. 


\section{A HISTORY OF LEICESTERSHIRE}

new nave of four bays with chancel and west tower was built against the north side of the old church, the former nave thus becoming the south aisle. The tower was raised by an additional stage, making a total of four, and early in the $15^{\text {th }}$ century it was crowned by a slender octagonal spire. The interior of the church was restored in about 1860.65 The roof had probably been restored during the 18 th century. An organ recess has been constructed in the south wall of the chancel, and on the same side of the church there is a small vestry. The north porch is also modern. The church is built of rubble with sandstone dressings, but the original fabric has become overlaid by extensive restorations. The east window has three trefoil lights. The tower is of sandstone ashlar and has traces of ball-flower decoration at the top of its third stage. The fourth stage has a battlemented parapet with crocketed pinnacles and grotesque gargoyles at each angle. The spire is lit by small windows set alternately in the faces.

In the chancel are sedilia with three seats and a decorated hood. The pulpit is modern, ${ }^{66}$ but the font, although badly damaged, probably dates from the $13^{\text {th }}$ century and is decorated with narrow beading at top and bottom. There are four bells: (I) 1796 by Edward Arnold of Leicester; (2) I 770 by Joseph Eayre of St. Neots; (3) I 769 by Joseph Eayre; (4) I627.67 The registers date from I6 64 , but no other parish records survive independently of St. Margaret's parish. The plate includes a silver cup of $\mathbf{I} 732$, made by William Draker and engraved with the names of the then churchwardens, including that of Edmund Craddock. There is also a silver plate, perhaps dating from 1684 , presented by Sir Edmund Craddock Hartopp in $1839 .{ }^{68}$

ROMAN CATHOLICISM. The mission of St. Thomas More was established in 1947 and the church, at the corner of Knighton Road and Southernhay Road, was built in 1951.69 The St. Francis Hospital in London Road is run by a community of Franciscan Minoresses and was opened in 1941.70 The convent and school of Our Lady of the Angels (the Poor Clares) was opened in Ratcliffe Road in $\mathbf{1 9 5 5 .}$

65 White, Dir. Leics. (1 877), 259.

66 The former pulpit was said to come from St. Margaret's Ch., Leic.

67 T. North, Ch. Bells of Leics. I 98.

68 A. Trollope, Ch. Plate of Leics. i. $108-9$.

69 Cath. Dir. (1952), 271.

70 A. H. Kimberlin, Return of Catholicism to Leic. I7 46-I946, 59 .

7 T.L.A.S. xxv. I 24; and see above, p. 390.

72 Assoc. Archit. Soc. Rep. E๐ Papers, xxii. 297

73 L.R.O., roll of dissenters' meeting-houses, m. I.

74 Ibid.

75 L.R.O., ret. of places of worship I 829 .

76 White, Dir. Leics. (1877), 260. 68.

77 By G. Lawton Brown and P. C. Jones: T.L.A.S. xi.
PROTESTANT NONCONFORMI'TY. Three dissenting meeting-houses are mentioned as being in Knighton in $\mathrm{r} 669$, but as they are the same as those given elsewhere as being in St. Margaret's parish, it is impossible to tell whether the houses were in Knighton or another part of the mother parish.71 The latter is perhaps more likely. There were three Anabaptists in Knighton at the beginning of the 18 th century ${ }^{72}$ and occasional references to members of that sect occur throughout the century in the parish registers. In 1768 a meeting-house was built, but it is not clear to which sect it belonged. ${ }^{73}$ In 1802 the house of Peter Manning was licensed as a meeting-house. ${ }^{74}$ The Wesleyan chapel was built in 1816 and sixteen members of this church were reported in $1829.7^{75}$ This chapel was rebuilt on a larger scale in $1871 .{ }^{76}$ The development of Stoneygate and Clarendon Park was marked by the erection of six chapels of various denominations. Stoneygate Baptist church (1914) ${ }^{77}$ and Clarendon Park Congregational chapel (1886) ${ }^{78}$ are both in London Road. The Wesleyan Methodist chapel (IgOI) ${ }^{79}$ in Clarendon Park Road replaced a mission chapel farther west in the same road. ${ }^{80}$ Clarendon Hall, the Baptist chapel in Clarendon Park Road, was built in I $894 .{ }^{81}$ The former Primitive Methodist chapel in Queen's Road was built in I 887 and taken over by the Salvation Army in I90r ${ }^{82}$ The Congregational chapel in Queen's Road was built in r $905.83 \mathrm{~A}$ Quaker meeting-house was built in 1955 in Queen's Road, opposite Victoria Park.

SCHOOLS. The National school was built by Sir Edmund Craddock Hartopp in I 840 and an infants' school was added in 1874.84 Church schools were built for St. John's, Clarendon Park Road, in $\mathbf{I} 890 .{ }^{85}$ After the southern part of Knighton parish had been brought into the borough of Leicester in 1892 the need of school accommodation was met by the Leicester School Board. ${ }^{85}$

CHARITIES. James Willey by will dated $\mathrm{r} 803$ left $£ 5^{\circ}$ in trust for bread to be distributed monthly to such of the poor of the parish as attended church regularly. ${ }^{86}$

${ }^{78}$ By James Tait: Spencer, New Guide to Leic. (I888), 105.

79 By A. E. Sawday: Scarff, Leics. and Rut. 152 ; Wright, Dir. Leics. and Rut. (1900), 27 ; ibid. (1902), 29.

80 Wright, Dir. Leics. (I 892), 25.

81 C. Howes, Leic., Its Industrial, Institutional and Social Life, 225.

82 Wright, Dir. Leic. (1 886), 28; Wright, Dir. Leics. (1 888), 28; ibid. (1 900), 90; Wright, Dir. Leic. (I902), 98. It is now a plastics factory.

${ }_{83}$ Wright, Dir. Leic. ( 1904), ro8; ibid. (1906), 105.

84 White, Dir. Leics. (1 877), 260.

85 See above, pp. 336-7.

${ }^{86}$ 32nd Rep. Com. Char. Pt. 5 [163], p. 317, H.C. (1839), xv. 


\section{NORTH-WEST LEICESTER}

IN 1956 the boundaries of Leicester included in the north-western section of the city a number of areas which were formerly extra-parochial. ${ }^{\text {T The existence }}$ of several small areas outside the usual parochial organization was due to the inclusion of the district in Leicester Forest ${ }^{2}$ during the early Middle Ages. An entry in Domesday Book states that the woodland of the whole sheriffdom, ${ }^{3}$ called 'Hereswode', 4 was four leagues in length and one league in breadth, 5 and this may refer either to Leicester Forest or to Charnwood Forest. Domesday Book does not state who held the forest, but in the late I Ith century Leicester Forest may have been in the hands of Hugh de Grentemesnil. ${ }^{6}$ At an inquest taken in 1253 it was stated that Robert de Beaumont, Count of Meulan and Earl of Leicester (d. I I I8), who had acquired the rest of the Grentemesnil lands in Leicestershire, ${ }^{7}$ had regulated the rights of the men of Leicester to collect wood in the forest $; 8$ certainly from before II 68 it was in the possession of the earls of Leicester, from whom it descended to the earls and dukes of Lancaster, and in I 399 it passed to the Crown as part of the Duchy of Lancaster. ${ }^{9}$

The districts which form the north-west of the city of Leicester were mostly in origin part of Leicester Forest, but were divided from it at different times. Until separation occurred, each district shared the history of the whole forest, and very little is known of the history of individual places before separation took place. The account given here of each extraparochial place will therefore in general begin with its separation from the rest of the forest.

\section{BEAUMONT LEYS}

Beaumont Leys, formerly an extra-parochial place, acquired the status of a civil parish under the Act of I $857 .^{\text {I0 }}$ It then had an area of 1,2 Io acres. In 1892 parts of the parishes of Belgrave and Leicester Abbey were transferred to Beaumont Leys. "I In 1935 almost all Beaumont Leys was brought within the city of Leicester, the remainder being added to the parishes

1 Areas which were formerly extra-parochial have been treated as separate topographical units for the purposes of this work.

2 On the hist. of Leic. Forest see V.C.H. Leics. ii. 266-7.

3 i.e. of the co. of Leic.

4 A name probably meaning 'the wood of the army', i.e. the Danish army of Leic.

5 V.C.H. Leics. i. 306.

6 Cal. Doc. France, ed. Round, 229; Dugd. Mon. vi. 1079, where grants of the forest's tithes to St. Evroul are printed. It is not certain that these grants were made by

Hugh, but in view of his close connexion with St. Evroul it is highly probable.

7 L.Fox, 'Honor and Earldom of Leic.', E.H.R. liv. 386.

8 L. Fox and P. Russell, Leic. Forest, 23; Leic. Boro.

Rec. IIO3-I327, 43 .

9 V.C.H. Leics. ii. 266.

Io Census, I 83 I, I 85 I, I 87 I ; Extra-Parochial Places Act, 20 Vic. c. I9. The description of Beaumont Leys as a parish in Census, I801, is evidently an error: cf. Nichols, Leics. iv. 492; White, Dir. Leics. (I 846), 324.

II Leic. Extension Act, I 89 I, 54 \& 55 Vic. c. Ioo.

12 Co. of Leic. Review Order, 1935.

13 Nichols, Leics. i, p. xc; Rot. Hund. (Rec. Com.), i. 238.

${ }_{14}$ W. Burton, Description of Leics. 36 ; Nichols, Leics. iv. 492 .

is Census, i 8 or and later.

16 Rot. Hund. (Rec. Com.), i. 238. of Anstey and Thurcaston. ${ }^{12}$ Beaumont Leys lay on the boundary between the hundreds of West Goscote and Sparkenhoe, and there seems little doubt that it was originally in Goscote hundred. ${ }^{13}$ During the $I 7$ th and 18 th centuries it seems at times to have been considered as being in Sparkenhoe. ${ }^{14}$ Beaumont Leys contains Leicester's main sewage works, which occupy much of the area, but agriculture is still carried on. The soil is mostly Boulder Clay, with some sand and gravel in the small valley near Beaumont Leys Farm and on the slope leading to the-Soar valley in the east of the area.

Beaumont Leys was grantea by Simon de Montfort to the Hospitallers, ${ }^{16}$ probably in 1240 , when Simon is known to have sold some forest land near Leicester. ${ }^{17}$ In 1 274-5 $^{-5}$ the Hospitallers possessed 8 carucates of land at Beaumont, attached to their preceptory at Dalby on the Wolds. ${ }^{18}$ In the 13 th century a small part of Beaumont Leys was transferred to Leicester Abbey, ${ }^{\mathrm{I} 9}$ and was apparently absorbed into the abbey's lands adjoining it to the south. ${ }^{20}$ The Hospitallers' lands at Beaumont were administered by a separate bailiff in the 14 th century, and seem to have consisted largely of meadow and pasture. ${ }^{21}$

In 1482 Beaumont Leys was acquired in exchange for the rectory of St. Botolph's, Boston, from the Hospitallers by the Duchy of Lancaster, ${ }^{22}$ which already possessed Leicester Forest. Shortly afterwards Edward IV imparked Beaumont Leys, and it remained a royal deer park until Henry VIII removed the deer and disparked it in 1526.23 In the same year much of Leicester Forest was inclosed, and the inhabitants of Leicester were given limited rights to pasture livestock in Beaumont Leys, in compensation for pasture rights lost through the inclosure. ${ }^{24}$ This gave rise to a dispute between the town and John Corbet, who had leased Beaumont Leys from the duchy, and in $155 \mathrm{I}$ Corbet was forced to agree that the town could pasture cattle and horses in the Leys. ${ }^{25}$ More litigation followed, ${ }^{26}$ and a further agreement about pasture rights was made in $15^{6}{ }_{1.27}$

17 Matt. Paris, Chron. Majora (Rolls Ser.), iv. 7.

18 Rot. Hund. (Rec. Com.), i. 238.

I9 Nichols, Leics. iv. $49^{2}$. The transfer is said to have been made when the Hospitallers were under Robert de Manneby, who was prior in I 25 I : Dugd. Mon. vi. 799.

20 See below, p. 45 I

21 Knights Hospitallers in Eng. ed. L. B. Larking, (Camden Soc. Ist ser. lxv), 63, 65. Beaumont Leys was apparently still mostly meadow when it passed out of the Hospitallers' hands: T.L.A.S. xii. 7o, 72.

${ }_{22}$ Rot. Parl. vi. 2ro. The negotiations seem to have begun in I 478: Cal. Close, I 476-85, 2 I 5-16, 2 I 9. Beaumont Leys was said to be inclosed by a pale in 1482 . In May 1525 the area was granted to the Marquis of Dorset in fee, but the grant does not seem to have taken effect: L. Eீ P. Hen. VIII, vi (r), p. 6 ro.

23 Leland, Itin. ed. Toulmin Smith, i. 20; D.L. $3 / 57$, ff. 7o, 71 ; D.L. $3 / 16$, f. Io; L. E P. Hen. $V I I I$, iv (r), p. 56 .

24 D.L. $3 / 57$, f. 71 ; D.L. $3 / 16$, f. Io. Before 1526 the livestock of Leic. had been pastured in Beaumont Leys, but apparently only at the pleasure of the keeper. The Leys contained much timber up to I 526 : Fox and Russell, Leic. Forest, 80.

25 Leic. Boro. Rec. I509-I603, 6I-66, 79; Nichols, Leics. i. 394 ; D.L. $3 / 16$, f. 10.

${ }_{26}$ Leic. Boro. Rec. I 509-I603, 79; Duchy of Lanc. pt. iv, Cal. Pleadings, i. 278.

27 Leic. Boro. Rec. I509-I603, pp. xxxvi. Ioo. 


\section{A HISTORY OF LEICESTERSHIRE}

How long these rights continued to be exercised is not known. They may have ceased when Elizabeth I granted Beaumont Leys to Sir Henry Skipwith, whose son and grandson sold it to Sir Edward Moseley, a Lancashire baronet, before $1639 .{ }^{28}$ Moseley devised it to his nephew, another Edward Moseley, who in 1656 sold it to German Pole. ${ }^{29}$ After being in the hands of William Rawlinson, who was in possession in 1686 , Beaumont Leys was acquired early in the $\mathbf{1} 8$ th century by William Aislabie, M.P., whose descendants continued to hold it until after $1832 .{ }^{30}$ Aislabie's great-granddaughter, a Miss Lawrence, devised it to Admiral Sir Cornwallis Ricketts, Bt., who was the owner in I $846.31 \mathrm{On}$ Admiral Ricketts's death, in I885, the property passed to Sir Robert Tempest. ${ }^{32}$ In the same year Sir Robert agreed to sell ioo acres at Beaumont Leys, and to lease for 30 years about $\mathrm{I}, 260$ acres (comprising practically the whole of Beaumont Leys and some land outside it) to Leicester Corporation, which required the land for sewage works. ${ }^{33}$ From 1887 onwards very extensive works were carried out by the corporation, though the pumping of sewage did not begin until $1890 .{ }^{34}$ The greater part of Beaumont Leys remained in the ownership of the Tempest family until it was bought by Leicester Corporation in 1901.35 In 1956 the corporation were still the owners.

Beaumont Leys has always been agricultural, with a small population. In the late 18 th century the land, though all owned by one person, was usually divided between five or six occupiers, but there seem to have been only two farm-houses. ${ }^{36}$ In 180 I there were 20 persons living in Beaumont Leys, all engaged in agriculture; there were only 2 houses. ${ }^{37}$ In 183 I the population was just under 30 , and it remained at about that level until in I89I the boundaries of Beaumont Leys were enlarged. ${ }^{3} 8$

For ecclesiastical purposes Beaumont Leys seems always to have been an extra-parochial area, and in 1956 it still remained one. ${ }^{39}$ Like all other lands which had formed part of Leicester Forest in the 12:th century, Beaumont Leys was liable to pay tithe to the Norman Abbey of St. Evroul.40 In 1338 the Hospitallers were paying $26 s$. $8 d$. yearly in lieu of tithes to the Prior of Ware (Herts.), an English cell of St. Evroul.4I At one time the tithes seem to have been farmed from Ware by Leicester Abbey. ${ }^{42}$ In I $_{4} \mathrm{I}_{5}$ the possessions of Ware were granted to the Carthusian Priory of Sheen (Surr.), and sub-

28 Nichols, Leics. iv. 492; Farnham, Leics. Notes, ii. 317-1 8; T.L.A.S. xvii. $57,58,60$.

29 Farnham, op. cit. 318.

30 Nichols, Leics. iv. 492 ; L.R.O., Land Tax Assessments, Beaumont Leys, I773-I832; Leic. City Mun. Room, $3 \mathrm{D}_{42} / \mathrm{M} .12$

3 I White, Dir. Leics. (1 846$), 325$.

32 Kelly's Handbook to the Titled, Landed and Official Classes (1897), p. I067; J. Storey, Hist. Sketch of Boro. of Leic. 20.

33 Storey, op. cit. 20, 2 I

4 Ibid. 27-30; and see above, p. 279.

Boro. of Leic. Abstract of Accts. (I901), I93; ibid. ( I 902), I 89-9.

6 L.R.O., Land Tax Assessments, Beaumont Leys, I773, I780, I781, I782, I783. A map of I686 (Leic. City Mun. Room, 3 $\mathrm{D}_{42} / \mathrm{M}$. I 2) shows Beaumont Leys divided into 50 closes, partly wooded. 5 houses, apparently farms, are shown.

37 Census, I80 I.

38 Ibid. I 83 I ; fordetails of pop. see V.C.H. Leics, iii. I82. sequently Sheen seems to have received the tithes of Beaumont Leys. ${ }^{43}$ There is no record of any tithes having been paid after the Dissolution, when Sheen's rights of tithe fell to the Crown, which was clready the owner of the property.

Beaumont Leys has at times been described as a manor, ${ }^{44}$ but there is no evidence that a manor court was ever held. In the north-west of the area there is a rectangular earthwork, known as Castle Hill, about 200 yards long and about I 30 yards wide. It consists of a ditch and low bank, the distance between the bottom of the ditch and the top of the bank varying from 3 to 8 feet. The origin and purpose of this work are unknown. 45

\section{BRAUNSTONE FRITH}

Braunstone Frith is a small district on the western fringe of Leicester. The district was formerly an extra-parochial place in Sparkenhoe hundred, but under an Act of 1857 it became a separate civil parish. ${ }^{46}$ Its area was 232 acres.47 In I 935 the area was absorbed into the city of Leicester. The soil is nearly all Boulder Clay; in 1956 most of the district was occupied by a housing estate belonging to Leicester Corporation.

Braunstone Frith was first separated from Leicester Forest in 1526 , when the large district in the forest known as the Frith was inclosed and divided into a number of separate pastures. ${ }^{48}$ After the inclosure the Dean and Canons of the College of St. Mary in the Newarke at Leicester, a foundation closely connected with the Duchy of Lancaster which owned the forest, claimed compensation for the loss of certain common rights that they had previously enjoyed in the uninclosed Frith, and in consequence Henry VIII allotted to the college certain rights in Braunstone Frith. ${ }^{49}$ As early as the reign of Elizabeth I it was uncertain exactly what rights Henry VIII had granted to the college. ${ }^{50}$ After the inclosure of I 526 Braunstone Frith was leased out by the Duchy of Lancaster. ${ }^{51}$ Towards the end of Elizabeth I's reign the corporation of Leicester, which was leasing from the Crown the grange in the South Fields formerly owned by the dissolved College of St. Mary, ${ }^{52}$ claimed on the basis of Henry VIII's grant to have the right to lease certain closes, containing about 60 acres, as part of the grange. 53 The corporation succeeded for a time in making good its claim to

39 Leic. Dioc. Cal. (1 952), 84, I26; Nichols, Leics. iv. 492; White, Dir. Leics. (I 846$), 324$

40 See above, p. 379; Cal. Doc. France, ed. Round, 229; Dugd. Mon. vi. Io79.

${ }^{41}$ Knights Hospitallers in Eng. ed. Larking, 65.

42 B.M., Cott. MS. Otho B. I 4, f. I07.

43 Ibid. f. Iogv; Cal. Chart. R. I34I-I4I 7, 479.

${ }^{4}$ B.M., Cott. MS. Otho B. I4, f. I07; Kelly's Dir. of Leics. and Rut. (1908), 36; Cal. Close, 1346-9, 495.

45 See description and plan in Leics. and Rut. $N$. $๒ O$. i. 9-13, and a plan of the earthwork, drawn in 1913 , in B.M., Add. MS. 3884 I , f. 9 .

${ }^{46}$ Extra-Parochial Places Act, 20 Vic. c. I9; Census, I 87 I ; White, Dir. Leics. (1877), I 73 ; Nichols, Leics. iv. 620.

47 Kelly's Dir. Leics. and Rut. (I 925), $5 \mathrm{I}$.

${ }_{48}$ L. Fox and P. Russell, Leic. Forest, 82.

49 Ibid. 86-87; Leic. Boro. Rec. I 509-1603, 270.

50 Leic. Boro. Rec. I 509-I603, 219.

${ }_{51}$ D.L. $42 / 35$, f. 216

52 Dissolved in $1548:$ V.G.H. Leics. ii. $5 \mathrm{I}$.

53 Leic. Boro. Rec. I 509-I603, 2 18, 307, 345. 
lease the closes, ${ }^{54}$ but its possession of them as part of the college grange was repeatedly challenged. In I 598 the corporation protested against the possibility of the closes being leased to Robert Worship. ${ }^{55}$ In 1600 , after some litigation, the corporation decided that it was necessary to place its claim to the closes on a secure basis, ${ }^{5}$ but that was not achieved, and further litigation took place over the closes in $1609-$ 14.57 Finally in $1613^{-1} 4$ the corporation, though it succeeded in buying the whole grange, gave up its claims in the closes in -Braunstone Frith to John Sherman, who then acquired the disputed property..$^{58}$

Meanwhile the Duchy of Lancaster presumably remained the owner of the rest of Braunstone Frith. It is not known when the duchy disposed of this remaining part, but by 1705 the whole of Braunstone Frith was being held in fee farm by William Inge. ${ }^{59}$ The property remained in the hands of his descendants, the Inges of Thorpe Constantine (Staffs.), until $1795 .{ }^{60}$ Braunstone Frith was then acquired by John Kirk, who remained the owner for only three years. ${ }^{61}$ From 1799 to 1804 the owner was William Hook, who had previously occupied the land as Kirk's tenant. ${ }^{62}$ The property then came into the hands of Clement Winstanley, a large landowner in the adjacent parishes of Braunstone and Kirby Muxloe. ${ }^{63}$ Braunstone Frith remained in the hands of Winstanley's descendants until it was bought by Leicester City Corporation in $1925 .{ }^{64}$ The corporation was still the owner in 1956 .

After its inclosure in 1526 Braunstone Frith was used as pasture. ${ }^{65}$ From the late 18 th century until after the purchase of the land by Leicester corporation in 1925 the parish formed a single farm.66 In I930 the corporation decided to use Braunstone Frith as the site for an airfield, which was opened in I935. ${ }^{67}$ In 1950 it was decided to appropriate 125 acres at the Frith, including a large part of the airfield, for a municipal golf course. Most of the remainder of the parish was laid out shortly afterwards as a housing estate. ${ }^{68}$ Since 1945 much of the eastern part of the parish has become a housing estate owned by Leicester corporation.

For ecclesiastical purposes Braunstone Frith has always been, and in I954 still remained, extraparochial. ${ }^{69}$

s4 Ibid. 2 I $8,307,345$.

55 Ibid. 345 .

55 Ibid. 345.
57 Ibid. $1609-88$, I 08, I 09, I 49, I 86
58 Ibid. I 49,2 I 6 .

59 Nichols, Leics, i, p. cxlvi.

60 L.R.O., Land Tax Assessments, Braunstone Frith, I $773-95$.

61 Ibid. I796, I 797, I 798.

62 Ibid. I 799-1804.

63 Ibid. I 804; Nichols, Leics. iv. 620, 624.

64 Fox and Russell, Leic. Forest, 87 ; Leic. Council Mins. I 923-4, 32I-3; ibid. I924-5, 370, 372

65 D.L. $42 / 35$, f. 216 ; Leic. Boro. Rec. I509-I603, 270-I.

66 L.R.O., Land Tax Assessments, Braunstone Frith, I 773-1830; Census, I80 I ; Census, I 871 ; Kelly's Dir. Leics. and Rut. (1925), 5 I.

67 Leic. Council Mins. I 928-9, I 79-80, I 82-3; ibid. I 929-30, 90-95; ibid. I934-5, 73-74.

68 Ibid. I 949-50, $32 \mathrm{I}-2$; ibid. I 95I-2, I6I, I 70-I.

69 Leic. Dioc. Handbook (1 954), 172.

$70 \mathrm{~T}$. and G. Ellis, Plan of Leic. $(1828)$

71 Census, I $84 \mathrm{I} ;$ V.C.H. Leics. iii. $187 \mathrm{n}$.

72 Census, I85I; Census, I 861.

73 Census, I87 I; Census, I88I.

\section{FREAK'S GROUND}

Freak's Ground was until I 89 I a separate civil parish, immediately to the west of the borough of Leicester. The status of Freak's Ground as an administrative unit is for a long period obscure. A small and almost uninhabited area, it seems to have remained in an indeterminate position until the late I 9 th century. A map of 1828 marks Freak's Ground as an extra-parochial liberty. ${ }^{70}$ In the census of I $84 \mathrm{I}$ it was returned as part of the Augustine Friars liberty, in the borough of Leicester. ${ }^{71}$ In $185^{1}$ and 186I Freak's Ground was listed as an extraparochial place outside the borough,72 and in $187 \mathbf{1}$ and I88I as a separate civil parish. ${ }^{73}$ It seems certain that Freak's Ground was not included in the borough until I 891 , though as late as 1877 it was by some oversight not assessed for the county rate at all. ${ }^{74}$ Under an Act of 1891 the whole of Freak's Ground was brought within the borough of Leicester, and included in Leicester Abbey parish.75 The area of the former civil parish was 49 acres. ${ }^{76}$

The southern part of the former parish is occupied by several streets of 2oth-century houses, but the northern part is covered by allotments. The soil is mostly Keuper Marl. Freak's Ground forms a rough rectangle of 48 acres on the western slope of the Soar valley and the land rises to some $230 \mathrm{ft}$. above sea-level at the western boundary. The line of the Leicester and Swannington Railway, built in 1830-2,77 runs through Freak's Ground; the line was in 1956 controlled by British Railways Eastern Region, but was little used. The northern boundary of the parish is formed by the road from Leicester to Ashby de la Zouch. This road was placed under the care of a turnpike trust in $1753,{ }^{78}$ and in 1810 some land which formed part of Freak's Ground was sold to the trustees for road improvement. ${ }^{79}$ The eastern boundary is formed by the medieval track known as the Fosse Road. ${ }^{80}$

It is not known when Freak's Ground was first separated from Leicester Forest, but it seems to have been inclosed before 1526 , when further large inclosures took place in the northern part of the forest. ${ }^{81}$ By I 577 Freak's Ground was owned by Henry, Earl of Huntingdon, who in 1589 sold it to Philip Freake, a prominent Leicester butcher. ${ }^{82}$ Freake devised the

${ }_{74}$ White, Dir. Leics. (1877), 305; Rep. Com. on Proposed Division of Cos. and Boundaries of Boros. ii (I), H.C. I 4I, p. 87 ( 183 I-2), xxxix; Rep. Com. on Boundaries and Wards of Certain Boros. pt. ii, H.C. 238 (1837), xxvii; Rep. Boundary Com. for Eng. and Wales: Eng. Boros. [3972], p. I 83 , H.C. ( $1867-8$ ), xx.

55 Leic. Extension Act, I89 I, 54 \& 55 Vic. c. Ioo.

${ }^{76}$ Leic. Extension Act, I89I:Rep. Parl. Sub-Cttee. and Town Clerk (Leic. City Ref. Libr., Pamphlets $\mathrm{O}_{3}$, vol. xxiv), 13

77 T.L.A.S. xxx. $64-68$.

78 V.C.H. Leics. iii. $9 \mathrm{I}$

79 Leic. City Mun. Room, Hall Bk. Io Mar. I8 Io.

80 On the history of this track, see V.C.H. Leics. iii. 72.

L. Fox and P. Russell, Leic. Forest, 68.

82 Leic. City Mun. Room, 20D52/25/552; W. G. Hoskins, Essays in Leics. Hist. I I 3 . In or before 577 the earl granted to Wyggeston's Hosp. several rent charges, including one of fIo from land occupied by Philip Freake: Leic.

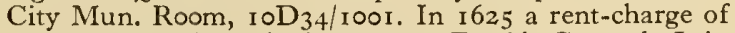
fio was payable to the hosp. from Freak's Ground: Leic. Boro. Rec. $1603-88,226$. It is therefore almost certain that the land which the earl charged with a rent of $f_{1} \mathrm{O} \circ$ in 1577 was that later known as Freak's Ground. 


\section{A HISTORY OF LEICESTERSHIRE}

property to his son John, ${ }^{8}$ who in 1625 sold it to Leicester corporation. ${ }^{84}$ In $195^{6}$ the corporation was still the owner of almost the entire parish.

Philip Freake presumably used his land for grazing stock for his large butchering business, ${ }^{85}$ though when he acquired the property from the Earl of Huntingdon it included some arable. ${ }^{86}$ The parish remained agricultural until well into the Igth century. ${ }^{87}$ In 1871 a small fever hospital was built in Freak's Ground by Leicester corporation. The buildings were of corrugated iron and covered 2 acres. ${ }^{88}$ The hospital was enlarged in 1893 , but some years later it was replaced by a new hospital at Gilroes, opened in 1900.89 Most of the remaining land was by the end of the I corporation in garden plots, 90 which in 1956 still occupied much of the parish. In the 1870 's the corporation made use of Freak's Ground for loading the borough's night soil upon the railway. This practice led in 1878 to the prosecution of the corporation by Blaby sanitary authority, and the county magistrates ordered the corporation to abate the nuisance that had been caused.91 In 1933 the corporation decided to build several streets of houses in the southern half of Freak's Ground, to provide accommodation for people displaced by street improvements and by the clearance of unhealthy districts in other parts of the city, mainly in St. Margaret's parish. ${ }^{92}$

A windmill in Freak's Ground is marked on maps of 1828,93 I 832,94 and 1868.95 The mill had disappeared by $\mathrm{I} 89 \mathrm{I} .{ }^{96}$

Freak's Ground was extra-parochial for ecclesiastical purposes until I904, when it became part of the newly established parish of St. Augustine, Newfoundpool. ${ }^{97}$ It still remained in that parish in 1956 .

\section{GILROES $^{98}$}

Gilroes, successively an extra-parochial place ${ }^{99}$ and a civil parish, lies to the north-west of Leicester. The area became a civil parish under the Extra-Parochial Places Act of 1857 , and the civil parish was dissolved in 1935 when Gilroes was transferred to Leicester county borough. ${ }^{1}$ Its area in 1885 was 185 acres. $^{2}$ The soil is Boulder Clay, overlying gravel and red marl.

83 Hoskins, op. cit. I 13.

84 Leic. Boro. Rec. I603-88, 213.

85 On his commercial activities, see Hoskins, op. cit. 108 sqq.

86 Leic. City Mun. Room, 2oD 52/25/552.

87 Nichols, Leics. i. 44I, 444; Census, I 86 I; Census, I 871 ; Ellis, Plan of Leic. (1828); O.S. Map, I" sheet LXIII ( 189 I).

88 White, Dir. Leics. (1877), 320-1; J. Storey, Hist. Sketch of Boro. of Leic. 59.

89 Storey, op. cit. 62 ; and see below, p. $45 \mathrm{I}$.

90 C. N. Wright, Dir. Leic. (I900), p. xxvi.

91 Leic. Fnl. 2 Aug. 1878; Leic. Chron. and Leics. Mercury, 29 June; Leic. Council Mins. I932-3, I79-8o.

92 City of Leic. Abstract of Accts. (1934-5), 553; ibid. (1935-6), 5 I6.

93 Ellis, Plan of Leic. (1828).

94 Rep. Com. on Proposed Division of Cos. and Boundaries of Boros. ii. (I), 87 .

95 Rep. Boundary Com. for Eng. and Wales: Eng. Boros. ii. $\mathbf{r} 82$. Libr.

6 Mawbey's map of Leic. (1891), in Leic. City Ref.

97 Kelly's Dir. Leics. and Rut. (1922), 128

98 The name appears as Gilwro (1322), Joly Roo (I 6th cent.), Jelilowe (i 6 th cent.), Jellyrowes (1705). Its deriva-
Gilroes is first mentioned in 1322 , when it was in Leicester Forest. ${ }^{3}$ The pasture between the roads from Leicester to Groby and to Anstey, given to Leicester Abbey by Robert FitzParnell, Earl of Leicester, and recovered from the abbey by his successor, Simon de Montfort, ${ }^{4}$ may have included Gilroes. It is uncertain whether in 1322 the area was fully inclosed, though it was then at least partly hedged.5 Gilroes appears then to have been partly woodland, as timber from the coppice of Gilwro is mentioned. ${ }^{6}$ In 1354 Henry, Earl of Lancaster, the Lord of Leicester Forest, allowed Henry Dowel to inclose Gilroes, in return for a yearly rent of $f .4 .^{7}$ It was probably as a result of this grant that the area was finally cleared of timber and became permanent pasture. In $15^{8} 5^{-6}$ Gilroes was being leased out by the Duchy of Lancaster. ${ }^{8}$ It is not known when the duchy disposed of the property, but by 1639 it had come into the possession of Sir Edward Moseley, ${ }^{9}$ who possibly acquired Gilroes in 1628 , when rnuch land in Leicester Forest was sold by the duchy. ${ }^{10}$ Moseley, at his death in 1639 , devised Gilroes to his nephew, also called Edward Moseley, who in 1656 sold a great deal of property, including some, and probably all, of Gilroes, to German Pole. ${ }^{11}$ By I 705 Gilroes was owned by Sir Nathaniel Curzon, Bt., ${ }^{12}$ and it remained in the hands of the Curzon family until after 1795.13 Subsequently Gilroes was sold, and by I 8I I it was in the hands of three owners, of whom Henry Harrison, of Leicester, was much the most important. ${ }^{14}$ The Harrison family remained in possession of most of Gilroes until I 896, when nearly all of Gilroes was purchased by Leicester corporation, ${ }^{15}$ which in 1956 was still the principal owner.

Gilroes was for long a purely rural area, despite its nearness to Leicester. It seems unlikely that any of the Curzon family lived there, and during the late I 8 th century the property was in occupation of one or two tenants of theirs. ${ }^{16}$ The Harrison family, too, though they seem to have farmed the land themselves, and not let it to tenants, ${ }^{17}$ did not live at Gilroes, but left the land to be occupied by their labourers..$^{18}$ In I 8 I I the population was 4 . In I85I there were 8 inhabitants, and in 1871 10.19 Leicester corporation began to lay out a cemetery in the western part of Gilroes immediately after their purchase

tion has never been satisfactorily explained.

99 Census, I 811 , I 85 I ; L.R.O. Land Tax Assessments, Gilroes, $1781,1818$.

I V.C.H. Leics. iii. 188.

2 J. Gordon, Rep. on Proposed Enlargement of the Boro. (I 885 ), 28 (Leic. City Ref. Libr., Pamphlets $\mathrm{O} 3$, vol. xvii).

3 L. Fox, 'Mins. Accts. of the Honor of Leic.' T.L.A.S. xix. 224.

4 Nichols, Leics. i, App. 55, 56.

5 T.L.A.S. xix. 224

6 Ibid. 225 .

7 L. Fox and P. Russell, Leic. Forest, 30-31.

8 Duchy of Lanc. pt. 4, Cal. Pleadings, iii. 192.

9 Farnham, Leics. Notes, ii. 3 I 7-1 8.

so Nichols, Leics. iv. 782 ; Fox and Russell, Leic. Forest, $136-7$.

II Farnham, Leics. Notes, ii. 318.

12 Nichols, Leics. i, p. cxlvi.

13 L.R.O. Land Tax Assessments, Gilroes, 1795

14 Ibid. I 8 I I.

15 Leic. Council Mins. I 895-6, 63, 64

I6 L.R.O. Land Tax Assessments, Gilroes, I 773-96.

I7 Ibid. I81 I-30; White, Dir. Leics. (1846), 342; ibid. (1877), 219.

18 White, Dir. Leics. (1 846), 342 .

19 V.C.H. Leics. iii. 188. 
of it in $1897,{ }^{20}$ and in 1956 much of the area was occupied by this municipal cemetery. A hospital for infectious diseases was opened by the corporation at Gilroes in $1900,{ }^{21}$ and subsequently very extensive hospital buildings have been erected. Originally the property of Leicester corporation, the hospitals were transferred to the Ministry of Health under the National Health Act of 1946.

For ecclesiastical purposes Gilroes remained extraparochial in 1954.22

\section{LEICESTER ABBEY PARISH}

Leicester Abbey, an extra parochial place which acquired the status of a civil parish under the ExtraParochial Places Act of I 857, lies on the west bank of the Soar, to the north-west of the ancient borough of Leicester. In 1892 a small part of the parish was transferred to Beaumont Leys, and the rest was incorporated in Leicester county borough. ${ }^{23}$ In 1896 the civil parish of Leicester Abbey was merged in the civil parish of Leicester. ${ }^{24}$ The area of the parish was 838 acres. ${ }^{25}$ The site of the abbey itself, with some adjacent land, is now a public park, but the rest of the former parish had in 1956 nearly all been built over. The district is largely residential, and includes in the north Leicester corporation's Stocking Farm housing estate which was begun after 1948 and where large-scale building was still continuing in I955. In the eastern part of the former parish, however, there are a number of factories, many of them concerned in the preparation of foodstuffs. The only buildings of historic interest in the parish are those on the site of Leicester Abbey. ${ }^{26}$ Of the abbey buildings virtually nothing survives, owing to their destruction shortly after the surrender of the abbey to the crown in 1538.27 In 1923 and 1928 the site of the abbey was partially excavated, and some foundations were discovered. Subsequently a reconstruction of the foundations of the chief abbey buildings has been laid out. To some extent this reconstruction is based on the extant remains, but for the rest it is conjectural. ${ }^{28}$ A survey of the buildings, apparently drawn up shortly after the Dissolution, has survived, but it is difficult to reconcile the statements made in it with the existing remains. ${ }^{29}$ The medieval wall,

20 Boro. of Leic. Abstract of Accts. (1 898), 126. The cemetery was opened in 1902 ; Leic. Council Mins. I90I-2, I 88.

21 Boro. of Leic. Alstract of Accts. (1 898), I 44-5; Rep. Medical Officer of Health (1900), 30, 44 .

22 Leic. Dioc. Cal. (1954), 86.

23 Leic. Extension Act, I89 I, 54 \& 55 Vic. c. 100.

24 V.C.H. Leics. iii. I 79 n.

25 J. Gordon, Rep. on Proposed Enlargement of the Boro. ( 1885 ), 28 (Leic. City Ref. Libr., Pamphlets $\mathrm{O}_{3}$, vol. xvii).

${ }^{26}$ For what follows see in general L. Fox, Leic. Abbey: Hist. and Description, I $3-17$.

27 Fox, op. cit. I $3 ;$ V.C.H. Leics. ii. I 6.

28 For an air photograph of the reconstruction, see Fox, op. cit. frontispiece; and see Leic. Mercury, I 2 Apr., I 4 Apr., I 7 Apr., I 8 Apr., 2 I Apr., I5 May I923.

${ }_{29}$ 'The surv. is printed Fox, op. cit. $14^{-1} 5$, and T.L.A.S. iv. $33-34$.

30 V.C.H. Leics. ii. I 9; Leland, Itin. ed. Toulmin Smith, i. I7

3I Nichols, Leics. i. 287 , states that the house was built by the earl, but gives no evidence. The full facts about the building are unknown. A mansion seems to have been in existence on the abbey site by 1605 : Leic. Boro. Rec. I603-88, 45 . partly brick and partly stone, around the abbey precincts, still survives. The brick portion is known to have been built by John Penny, abbot I496-I 500.30

Within the grounds of the abbey are the remains of a large mansion, said to have been built by Henry, Earl of Huntingdon (d. I 595), and usually called Cavendish House. ${ }^{31}$ In 1645 it was destroyed by the royalists, shortly after Charles I's capture of Leicester.32 Fairly extensive remains of the mansion still exist, ${ }^{33}$ and from them it is evident that the house was partly constructed with stone from the abbey buildings. 34

In a close to the north-west of the abbey precincts there formerly stood a stone, once about $7 \mathrm{ft}$. high, known as St. John's stone. For a long time previously to the Igth century it was customary on St. John's Day to pay visits to the stone, which was vaguely supposed to have magical properties. Presumably the beliefs connected with the stone were survivals from the midsummer rites of pagan antiquity. In the I9th century the stone was destroyed by the occupier of the close. ${ }^{35}$

Leicester Abbey was founded in I I 43 by Robert le Bossu, Earl of Leicester, who presumably gave to the new monastery its site and the immediately adjacent land. ${ }^{36}$ In the $13^{\text {th }}$ century, probably in 1 $240,{ }^{37}$ Simon de Montfort, Earl of Leicester, granted to the canons of Leicester 320 acres of land near the abbey. ${ }^{38}$ 'The land thus granted was the estate later known as Stocking Farm, which formed the northern part of Leicester Abbey parish, ${ }^{39}$ and after this addition to its possessions the abbey held most, if not all, of the land in the area of the later civil parish. In 1484 the abbot was granted the right to hold a weekly market, and a yearly fair for five days, at the abbey. 40

In I 538 Leicester Abbey was surrendered to the king, ${ }^{\mathrm{I}}$ who in $\mathbf{I} 539$ leased it to Francis Cave for $2 \mathrm{I}$ years.42 In 1550 the site of the abbey, with other nearby property which apparently included Stocking Farm, and which probably included most if not all of the area of the civil parish, was granted by the Crown to William Parr, Marquess of Northampton. ${ }^{43}$ In I 553 the abbey property came into the Crown's hands again through Northampton's attainder, 44 and most of it was granted in the same year to Sir Edward Hastings, later Lord Hastings of Loughborough.45 The change of ownership from Northampton to

33 See ibid. for a description of the remains as they were c. I 800 , with several plates.

34 Fox, Leic. Abbey, I3.

35 S. H. Skillington, Hist. of Leic. I 7-18. The earliest known ref. to St. John's stone seems to be in 1381 : B.M., Cott. MS. Galba E. 3, f. I ogv.

36 V.C.H. Leics. ii. I 3. A charter of Hen. II confirming the abbey's possessions mentioned the site as being the gift of the founder: Nichols, Leics. i, App. 57.

37 Matt. Paris, Chron. Majora (Rolls Ser.), iv. 7

38 The grant was made before 1252: Nichols, Leics. i. 259, 26I ; Cal. Chart. R. I 226-57, 408.

39 Nichols, Leics. i. App. 68; L. Fox and P. Russell, Leic. Forest, 25. A field called le Stokking is mentioned in I 357 : Hen. Knighton, Chron. (Rolls Ser.), ii. 96.

40 Cal. Pat. 1 476-85, 471 .

4 I L. छे P. Hen. VIII, xiii (2), p. 80.

42 Ibid. xiv (I), p. 6ro; Assoc. Archit. Soc. Rep. छळ Papers, xxiii. 24I.

43 Assoc. Archit. Soc. Rep. E๐ Papers, xxiii. 24I ; Cal. Pat. I 549-5 I, 370 .

44 Complete Peerage, ix. 67I.

45 Cal. Pat. $1553-4,283$. This grant was in fee tail. Later the property was granted to Hastings in fee simple: ibid. $1557-8,49,254$. 


\section{A HISTORY OF LEICESTERSHIRE}

Hastings reflected the political circumstances of the age, for Northampton had been influential under Edward VI, while Hastings was Queen Mary's Master of the Horse and one of her Privy Council.46 In 1558 Hastings obtained from the Crown two woods, which had not been granted to him in I553, though they had been included in Northampton's grant of $155^{0.47}$ One at least of the two, Stockinge Wood, was probably within the area of the civil parish, for it was presumably adjacent to Stocking Farm. ${ }^{48}$ In I 56 I Hastings of Loughborough was imprisoned, and the site of Leicester Abbey, with the adjacent lands, is said to have been granted in 1562 to his kinsman, Henry Hastings, 3rd Earl of Huntingdon, who in turn sold it back to Hastings of Loughborough. ${ }^{49}$ Early in 1572 Hastings of Loughborough returned the abbey lands to the queen, who granted them to Sir Christopher Hatton; before the end of the year he in turn granted them to the Earl of Huntingdon. ${ }^{50}$ The motives for this complex series of transactions are not clear. The abbey property remained in the hands of the earl and of other members of the Hastings family until $\mathrm{I}^{6} \mathrm{I}_{3}$, when it was sold to William Cavendish, Earl of Devon.5I The Cavendish family owned the land until the $3^{\text {rd }}$ Duke of Devonshire sold it to Lord William Manners in 1733.52 From Lord William the land descended to his illegitimate son John Manners, who married Louisa, later Countess of Dysart in her own right. ${ }^{53}$ John Manners was succeeded by his son, Sir William Manners, Bt., and after Sir William's death in 1833 the ownership passed to his descendants, the earls of Dysart. 54 In 18 I 5 Sir William Manners's property at Leicester Abbey was said to amount to I, 500 acres. 55 This must have included practically the whole parish, and it is probable that the property had descended undivided to Sir William from the Hastings and Cavendish families. The property remained in the hands of the earls of Dysart until after I91 $8.5^{6}$ About I920 the last Earl of Dysart ${ }^{57}$ sold much of his property in the parish to William Parker. ${ }^{88}$ In 19 I9 the earl offered to give 32 acres in the parish, including the site of Leicester Abbey, to the city corporation. This offer was

46 Complete Peerage, vi. 384 ; ix. $67 \mathrm{I}$.

47 Cal. Pat. I $557^{-8,} 254$.

${ }_{48}$ The other wood, Doveland Coppes, was in Bromkinsthorpe: Leics. and Rut. N. छ Q. ii. 201 .

49 Complete Peerage, vi. 384 ; Nichols, Leics. i. 287.

50 Nichols, Leics. i. 287 ; C.P. 25 (2) $/ 2600$, Trin. I4 Eliz.; C.P. 25 (2)/5999, Hil. I4 Eliz.; C.P. 40/1305, m. I 248

51 C.P. 25 (2) $/ 3$ I , Trin. II Jas. I; C.P. 25 (2)/314,

Mich. II Jas. I; Nichols, Leics. i. 288.

52 Nichols, Leics. i. 293.

53 Ibid.; Complete Peerage, iv. 565-6.

54 Nichols, Leics. i. 293; Complete Peerage, iv. 566; White, Dir. Leics. (1 846 ), 82-83.

55 Nichols, Leics. i. 293.

56 White, Dir. Leics. (1877), 294; Kelly's Dir. Leics, and Rut. (I 88 I), 552; ibid. (I 888), 558; ibid. (I 900), I I 9; ibid. (1908), I27; ibid. (1922), I 28; Wright, Dir. Leics, and Rut. ( $\mathrm{r} 900)$, p. xxx.

57 Died 1936.

58 Leic. Council Mins. I919-20, 132-3

59 Ibid. 65-66; ibid. I $927-8$, IOI, 35 I, 363-5. The transfer of this property was not completed until i 927 : ibid. $1927-8,60$.

60 Ibid. 1947-8, 264-6.

61 Nichols, Leics. i. 259 , App. 56.

62 Hen. Knighton, Chron. (Rolls Ser.), ii. 74; A. Hamilton Thompson, Leic. Abbey, 33. This was probably the park of 180 acres which existed at the abbey at the accepted, and the abbey precincts became a public park. ${ }^{59}$ In 1948 much land at Stocking Farm was acquired by the corporation for housing purposes. 60

It is not clear whether the abbey's site, when originally granted by the Earl of Leicester, was wooded, or whether it was meadow land, as is perhaps more probable from its proximity to the Soar. The name of St. Mary in the Meadows which the abbey acquired shows that at a later date the land around it must have been meadow. The 320 acres given to the abbey by Simon de Montfort were partly woodland. ${ }^{61}$ In $135^{2}$ the canons of Leicester imparked a wood near their monastery, ${ }^{62}$ but it is not certain exactly where this new park was situated. Until the Dissolution much land close to the abbey was retained in demesne by the canons, and used to produce food for the monastery's needs. ${ }^{63}$ At the Dissolution, the demesne around the abbey included $5^{6}$ acres of arable, Io closes of pasture totalling $157 \frac{1}{2}$ acres, I 33 acres of meadow, and a park totalling I 80 acres. ${ }^{64}$ Of this property the 56 acres of arable was in two fields which lay outside the area of the later civil parish, ${ }^{65}$ while the park, which at the Dissolution was being used as pasture and was stocked with deer, ${ }^{66}$ was no doubt that adjacent to the abbey buildings. ${ }^{67}$ Of the closes, one covering 3 acres lay within the great wall surrounding the conventual buildings, 68 and two others, Ashe Close and Pinders Close, with Ashe Meadow, lay within the later parish, in its south-east portion near the river Soar. ${ }^{69}$ The location of the other closes and meadow is unknown; some at least of them may have been outside the parish area. It seems, however, that by the 16 th century much land in the parish consisted of closes used as pasture, and it is likely that the whole area was enclosed by the Dissolution. ${ }^{70}$

Until well into the I 9 th century Leicester Abbey remained free from urban development. For many years from the I8th to the early 2oth centuries the former abbey precincts were used as a nursery garden. ${ }^{71}$ As late as $189 \mathrm{I}$ the parish was almost entirely agricultural land, and the population was only $76 ; 72$ a pumping station had been built near the Soar under the Leicester Sewerage Act of $1851 .{ }^{73}$ By 1920, how-

Dissolution: R. H. Hilton, Econ. Development of some Leics. Estates, 55.

63 Hilton, op. cit. 39, 55, 64; Nichols, Leics. i, App. 89; Bodl. Libr., MS. Laud 625.

64 Hilton, op. cit. 55. The closes, with their acreages, are listed in Cal. Pat. $1553-4,283$.

65 Cal. Pat. I 549-5 I, 370.

66 Ibid.; ibid. I 553-4, 282-3; Assoc. Archit. Soc. Rep. छे Papers, xxiii. $241-2$.

67 The park is mentioned in I 528: Hamilton Thompson, Leic. Abbey, 79; Visitations in Dioc. Linc. I5I7-3I, ed. A. Hamilton Thompson, i. I93.

68 Cal. Pat. 1553-4, 282; Assoc. Archit. Soc. Rep. छळ Papers, xxiii. $24 \mathrm{I}$.

69 On the location of the closes, see Fox and Russell, Leic. Forest, 68. In I 576 the Earl of Huntingdon endowed Wyggeston's Hosp. with rent charges from the two closes and the attached meadow: Nichols, Leics. i. 484-5.

${ }_{70}$ It has been suggested that the parish was inclosed in the I8th cent.: W. Camden, Brit. (I806, ed. R. Gough), ii. 307 . There is no evidence for this view.

${ }_{71}$ W. Gardiner, Music and Friends, iii. 52; White, Dir. Leics. (1846), 83; ibid. (1877), 294, 494; Wright, Dir. Leic. ( 1882), I; Ellis, Plan of Leic. (1828); Kelly's Dir. Leics. and Rut. (1888), 558; ibid. (1 922), 1 28 .

72 Census, 1891 ; Mawbey's map of Leic. (1891), in Leic. City Ref. Libr.

${ }_{73}$ J. Storey, Hist. Sketch of Boro. of Leic. 13; I4 \& I5 Vic. c. 2 (priv. act). 
ever, the south-eastern part of the parish had largely become a residential area, and new streets were being built along both sides of Abbey Lane which runs from north to south through the parish. ${ }^{74}$ Further building followed, and by 1938 only the north and north-west parts of the parish remained open ground.75 Since 1948 Leicester Corporation have constructed a large housing estate in the northern part of the parish.

Leicester Abbey Mill was almost certainly the new mill between Leicester and Belgrave mentioned in $1274 .{ }^{76}$ There is no earlier record of the mill, which was presumably only built shortly before I274. The abbey mill was a watermill standing on the west bank of the Soar, a little to the north of the abbey buildings. ${ }^{77}$ The mill was owned by Leicester Abbey until the Dissolution, after which it was granted away with the abbey site. ${ }^{78}$ So far as is known, the mill was in the possession of the owners of the abbey site for the rest of its existence. In 1690 part of the mill was in use for fulling and scouring cloth. ${ }^{79}$ It is not known when the abbey mill fell into disuse; it is not marked on the detailed and precise map of Leicester published in $1828,,^{80}$ and it had definitely ceased to exist by $1852.8 \mathrm{I}$

As an extra-parochial area with a small population the administrative needs of Leicester Abbey were insignificant. During the 18 th and early I 9 th centuries the expenditure on poor relief seems to have been negligible. 82

Before the Dissolution the site of the abbey and the other lands which later formed the civil parish were not included in any parish, and after the Dissolution the precincts and the lands attached to them formed an extra-parochial liberty. ${ }^{83}$ In I904 a small part of Leicester Abbey was placed in the newly created parish of St. Augustine, Newfoundpool, ${ }^{84}$ but in 1954 the remainder was still extraparochial for ecclesiastical purposes $;^{85}$ the Church of England then possessed on the Stocking Farm estate a site, purchased from Leicester Corporation, for the building of a church.

A Methodist chapel was erected in Fosse Road North, in the southern part of Leicester Abbey civil parish, in $1903 .{ }^{86}$ The Baptist Archdeacon Lane Memorial church in Buckminster Road was built in I 936, in place of the older chapel in Archdeacon Lane. ${ }^{87}$ In 1954 Leicester Corporation decided to sell a site on the Stocking Farm estate for the building of a Baptist chapel.

${ }_{74}$ Wright, Dir. Leic. (1920), I, I 2, I 9, 29, 44, I 43 and passim.

75 Kelly's Dir. Leic. (1938), passim, and street plan attached.

76 Rot. Hund. (Rec. Com.), i. 238

77 J. S. Crossley and G. Foxton, Rep. on Condition of River Soar (1 852), frontispiece plan (Leic. City Ref. Libr.

Pamphlets O 3, vol. iv); Leic. Boro. Rec. I 509-I 503, map facing p. xvii.

79 Leic. City Mun. Room, 5D $33 / 339 / 21$.

80 Ellis, Plan of Leic. ( 1828 )

8I Crossley and Foxton, Rep. Cond. River Soar, 9. A worsted-spinning mill at the corner of the present Abbey

Park Road and Ross Walk became known as the Abbey

Mill during the I 9 th cent.

${ }_{82}$ Abstract of Returns Relative to the Expence and Maintainance of the Poor, H.C. I 75, p. 258 ( $1803-4)$, xiii; Rep. of H.C. (Ist Ser.), ix, p. 383 .

83 Census, I 801 ; White, Dir. Leics. (1 846), 82; Kelly's Dir. Leic. (1 947), p. xxii.

${ }_{4}$ Kelly's Dir. Leics. and Rut. (I922), I 28.

85 Leic. Dioc. Cal. (1954), 91.

\section{LEICESTER FRITH}

The former extra-parochial place known as Leicester Frith was not co-extensive with the larger area in Leicester Forest known by the same name up to the I6th century. ${ }^{88}$ The extra-parochial place was known as Sherman's Lodge or Sherman's Grounds in the $I 7$ th and 18 th centuries after the principal landowning family. It was also known as Markham's Close. ${ }^{89}$ For many years it lay in West Goscote hundred, having apparently been considered as extraparochial ever since it was separated from Leicester Forest. ${ }^{90}$ Under the Act of 1857 it acquired the status of a civil parish. In 1935 nearly all of Leicester Frith was absorbed into the city of Leicester, and the small remaining part was placed in Glenfield parish. ${ }^{91}$ For ecclesiastical purposes Leicester Frith seems to have been extra-parochial until it was placed in Glenfield ecclesiastical parish in 1887.92 The area of the parish as it existed in 1935 was 256 acres. 93 The north-west boundary of the parish is formed by the ancient road between Leicester and Anstey known as Anstey Gorse, which still remained in I955 a broad track with wide unenclosed verges. The southern boundary of the parish is formed by the road from Leicester to Groby, which from 1753 onwards was part of the turnpike between Leicester and Ashby de la Zouch. ${ }^{94}$ This road was, until the I 9 th century, a broad open ride, similar to Anstey Gorse. 95 Both these boundary roads were mentioned about $\mathbf{I} 200.96$ The soil is chiefly Boulder Clay with small patches of sand and gravel. Leicester Frith House is a brick mansion, built for Thomas Taylor in $1873 .{ }^{97} \mathrm{It}$ is now (1956) part of the premises of Glenfrith Hospital.

An enclosure called 'le Marclose', which is mentioned in 1322 , may perhaps have been the area which later became Leicester Frith parish, ${ }^{98}$ but this is very uncertain. The first definite reference to the later parish as a distinct unit occurs in I6ro, when it was an inclosure under lease from the Duchy of Lancaster to John Sherman. ${ }^{99}$ The property was held by members of the Sherman family at fee farm from the 17 th century until the 19 th. ${ }^{I}$ In I 812 Leicester Frith was held by Mrs. Elizabeth Sherman, but in I 812 or $18 I_{3}$ it was acquired by William Oldham, the Leicester architect and builder, ${ }^{2}$ whose family retained it until it was sold in I86 I to Isaac Harrison. ${ }^{3}$ By 1870 much of the property had been acquired by Thomas Swift Taylor, a Leicester cotton

86 Inscr. on building.

87 Inscr. on building.

88 L. Fox and P. Russell, Leic. Forest, 2 I, 3 I.

89 Ibid. 64; Nichols, Leics. i, p. cxlvi.

90 Nichols, Leics. iv. $92 \mathrm{I}$; Census, I $8 \mathrm{I}$ I ; Census, $185 \mathrm{I}$; White, Dir. Leics. (1 846$), 347$.

9 I Co. of Leic. Review Order, I 935, Schedule I.

92 Lond. Gazette, I887, 676.

93 J. Gordon, Rep. on Proposed Enlargement of the Boro. ( 1885 ), 28 (Leic. City Ref. Libr. Pamphlets O 3, vol. xvii) 94 V.C.H. Leics. iii. $9 \mathrm{I}$.

96 Nichols, Leics. i, App. 55, 56.

97 White, Dir. Leics. (I877), 495. It occupies the site of an earlier house, built in 1816 ; White, Dir. Leics. ( 1846$), 347$

98 T'.L.A.S. xx. 89; Fox and Russell, Leic. Forest, 64.

99 Fox and Russell, op. cit. 88.

I Nichols, Leics. i, p. cxlvi; ibid. iv. I055; Fox and Russell, op. cit. I 39 ; L.R.O., Land Tax Assessments, Leic. Frith (Sherman's Lodge), I 804-I2.

2 L.R.O., Land Tax Assessments, Leic. Frith, I 8 I 2, I 8 I 3. For Oldham, see H. Hartopp, $R$. of Mayors of Leic. I 69-70. 3 White, Dir. Leics. (1846), 347; Leic. City Mun. Room, I $2 \mathrm{D}_{43} / \mathrm{I} 95 / 26$. 


\section{A HISTORY OF LEICESTERSHIRE}

manufacturer. 4 A large part of the parish remained in the hands first of Taylor, and then after his death of h is trustees, for some 4 oyears. ${ }^{5}$ Taylor's trustees were still in possession in 1909 , when 93 acres of Leicester Frith were bought by Leicester Corporation. ${ }^{6}$ Ten years later the corporation bought a further I 8 acres. ${ }^{7}$ In 1956 the corporation was still the principal owner, although that part of Leicester Frith which was used for hospital purposes was vested in the Ministry of Health.

Until after its acquisition by Leicester Corporation the area was purely agricultural. In I 8 I I it contained one house and seven inhabitants. ${ }^{8}$ During the I 9 th century the population slowly increased: there were 33 inhabitants in $185 \mathrm{I}, 47$ in $187 \mathrm{I}$, and $\mathrm{I} 19$ in I 921.9

During the First World War Leicester Frith House was enlarged and converted into a hospital for servicemen suffering from neurasthenia. It continued to be used for that purpose unitil in 1924 it was handed back to Leicester corporation. The corporation used it for a short time as a convalescent home attached to Leicester Royal Infirmary, and then as a hospital for the mentally deficient. ${ }^{10}$ It was still being used for that purpose in 1956 , when it was known as Glenfrith Hospital. Under the National Health Act of I 946 it was transferred from the corporation to the Ministry of Health, being administered by the Sheffield Regional Hospital Board. In $195^{6}$ the hospital and its grounds occupied a large area in the southern part of Leicester Frith.

\section{NEW PARKS ${ }^{\text {II }}$}

New Parks originally formed part of the large section of Leicester Forest known as the Frith, in which the population of Leicester had certain rights of common. In the I 4 th century the area contained a forester's lodge, known as Bird's Nest Lodge, which was rebuilt in $1377^{-8.12}$ In $15^{2} 5^{-6}$ the lodge was again extensively repaired; it was then a moated building with a drawbridge. ${ }^{13}$ By I 790 the house had altogether disappeared; ; 14 was still in existence in I $560,{ }^{15}$ but it was apparently allowed to decay after New Parks had been inclosed in I 526. The moat which surrounded the lodge survived until the area was built over about I950.

For civil purposes New Parks was for many years after its creation an extra-parochial place. ${ }^{16}$ From

4 White, Dir. Leics. (1877), 495; F. G. Harrod E Co.'s Dir. Leics. and Rut. (1870), 525 .

5 Wright, Dir. Leic. (1 880), 275; ibid. (1 906), p. xxviii.

6 Boro. of Leic. Abstract of Accts. (1910), 7; Leic. Council Mins. 1907-8, 290-2; ibid. 1908-9, 69 .

7 Ibid. I918-19, 64, 66

8 Census, I8I I. Leic. Frith is not in Census, I801.

9 V.C.H. Leics. iii, 192, 209.

1o Ibid. 209; F. P. Armitage, Leic. I9I4-18, 286-8; Leic. Council Mins. 1916-17, 179; ibid. 1920-1, 192; ibid. I 922-3, 97-99.

11 So called first when newly inclosed in 1526 .

12 L. Fox and P. Russell, Leic. Forest, 32-33.

13 Ibid. $8 \mathrm{I}$.

14 J. Throsby, Leics. Viezws, ii. 7 I.

15 Fox and Russell, Leic. Forest, 124.

16 Nichols, Leics. i. 105; ibid. iv. 784; Census, 1801; Hagar $6^{\circ}$ Co.'s Dir. Leics. (1849), 290.

17 Census, 1871 .

18 Co. of Leic. Review Order, 1935.

19 Rep. Boundary Com. Eng. and Wales [Cd. 8756], vol. iii, Leicester.
I 87 I New Parks was referred to as a civil parish. ${ }^{17}$ In I 935 nearly all of New Parks was absorbed into the city of Leicester, and the remainder was placed in the parish of Glenfields. ${ }^{18}$ The area of the original civil parish was 812 acres. ${ }^{19}$

New Parks was in 1956 almost entirely covered by a large modern housing estate owned by Leicester corporation. The estate consists predominantly of two-storied houses, including some of the prefabricated type, but some large blocks of flats have been built. In $195^{6}$ almost the whole parish had been built over. Near the northern boundary of the parish stands New Parks House, an undistinguished brick mansion built by a Leicester hosiery manufacturer in $1845^{-6},{ }^{20}$ but now possessed by Leicester Corporation and used as part of a school. In the south-west of the parish there is a large public park.

New Parks stands on the plateau of Boulder Clay that borders the Soar valley on the west. The eastern boundary of the parish coincides very approximately with the edge of the plateau. The surface soil is mostly Boulder Clay, overlying gravel and limestone. The area of New Parks, when it existed as a separate civil parish, was 789 acres. $^{2 \mathrm{I}}$

In 1526 the Frith was inclosed, and New Parks was then first separated from the rest of the forest, and surrounded by a pale. ${ }^{22}$ It was reported in 1526 that New Parks would bring in a yearly rental of $£ 707$ s. $6 d^{23}$ and presumably the intention was to rent or lease out the estate, and to retain it as part of the lands of the Duchy of Lancaster, to which with the rest of Leicester Forest it then belonged. In I $55^{\circ}$ New Parks was granted to William Parr, Marquess of Northampton, ${ }^{24}$ who obtained other grants of land in the same district from the Crown. ${ }^{25}$ Northampton was attainted in $1553,{ }^{26}$ and all his property was forfeited to the Crown, which presumably then regained New Parks. Bird's Nest Lodge itself was certainly in the Crown's hands in 1560 , when it was surveyed by a commission set up by the Duchy of Lancaster. ${ }^{27}$ By I 57 I New Parks was in the hands of William, Lord Cobham, ${ }^{28}$ and it remained in the ownership of his family until it was forfeited to the king through the attainder of Henry, Lord Cobham, in $1603 .{ }^{29}$ In May 1604 New Parks was granted to Sir William Woodhouse, ${ }^{30}$ but in the following June the same property was granted to Sir Thomas Knyvet and to Edward, George, and Nathaniel Bacon, ${ }^{31}$ to whom Woodhouse may possibly have transferred his rights. Neither of these grants can

20 White, Dir. Leics. (1 846), 596.

2 J. Gordon, Rep. on Proposed Enlargement of the Boro. (I885), 28 (Leic. City Ref. Libr., Pamphlets $\mathrm{O}$ 3, vol. xvii).

${ }_{22}$ Fox and Russell, Leic. Forest, 79, 82, 84; Leland, Itin. ed. Toulmin Smith, i. 20.

23 Fox and Russell, Leic. Forest, I 34

24 Cal. Pat. I 549-5 I, 370; Assoc. Archit. Soc. Rep. छ० Papers, xxiii. 240-2.

25 See above, p. 45 I.

26 Complete Peerage, ix. 671.

27 Assoc. Archit. Soc. Rep. छ Papers, xxiv. 268-9; Fox and Russell, Leic. Forest, 124; the lodge was then estimated to be worth $f_{25} \mathrm{I}_{3} s .4 d$. In $1553 \mathrm{Sir}$ John Harrington was keeper of the lodge: Nichols, Leics. iv. 781.

28 Nichols, loc, cit.

29 Ibid. 784; Cal. S.P. Dom. 1603-10, 106; Complete Peerage, iii. 349 .

30 Cal. S.P. Dom. 1603-10, 106. New Parks was regranted shortly afterwards to Woodhouse on slightly different terms: ibid. I 12.

31 Cal. S.P. Dom. 1603-10, 123. 
have taken immediate effect, as in 1603 James I granted a large part of the forfeited Cobham estates to the wife of the attainted Lord Cobham, and she was in possession of New Parks, for life, in $1606 .{ }^{32}$ For more than a century after 1606 the descent of the property is obscure. ${ }^{33}$ William Mitchell is said to have died possessed of New Parks in $1745 .{ }^{34}$ The descent of the property becomes clear again in $178 \mathrm{I}$, when it was in the hands of a Mr. Clarke. ${ }^{35}$ The Clarke family remained the owners of New Parks until $1843,{ }^{36}$ but subsequently it was divided between various owners. In 1843 a good deal of land in the northern part of New Parks was acquired by Thomas Stokes, a Leicester hosiery manufacturer, and most of the remaining land went to another hosier, J. O. Harris; 37 in I 863, though Stokes was an important landowner, the largest single landlord in the parish was John Mellor. ${ }^{38}$ For many years the greater part of New Parks continued to be owned by Mellor and Stokes, and later by their trustees, though there were a number of minor owners. ${ }^{39}$ Nearly all of New Parks was eventually acquired by Leicester corporation. In 1897 the corporation purchased 183 acres in the south-west of the parish for use as a public park, ${ }^{40}$ and in $1933-7$ it bought most of the remainder. ${ }^{4 I}$ In $195^{6}$ the corporation was still the owner of almost all the land.

Presumably New Parks was until its inclosure in I 526 largely woodland. ${ }^{42}$ After the inclosure the area was evidently cleared, for a survey of 1606 reports New Parks as consisting of rather less than 702 acres of pasture, and just over II 2 acres of meadow. There was a small quarry of freestone, but it was considered valueless. The stock then on the property consisted of I, ooo sheep, and 40 milch cows, besides some store cattle and horses. The annual value of New Parks as a whole was estimated at over $f_{4} 400$, though it was then being rented for only $£ 260$ a year. ${ }^{43}$ New Parks remained purely agricultural until the late I 9 th century. In I80 I the population was only three, and there were only two houses. ${ }^{44}$ In I 87 I there was a population of 69 , with I I houses. 45 In 1898 Leicester corporation bought a large area in the south-west of New Parks to form a public park. ${ }^{46}$ In 1.906 a home for incurable patients was established by the Dominican Order near the border of the parish. 47 By 1938 the city of Leicester had begun

32 See the survey of 1606 , printed Nichols, Leics. iv. 784; Complete Peerage, iii. 349-50.

${ }_{33}$ Nichols, Leics. iv. 784 , states that in 1620 Lord Cobham settled Bird's Nest Lodge on his eldest son George; but there was no Lord Cobham between 1603 and 1645 ; Complete Peerage, iii. $349^{-50}$.

34 Nichols, Leics. iv. 784 .

35 L.R.O., Land Tax Assessments, New Parks, I 78 I.

36 Ibid. I 78I-I 830; Curtis, Topog. Hist. Leics. I $32 ;$ A. T. Patterson, Radical Leic. 375. Nichols, writing about I 8 Io, states that Clement Winstanley was then the owner of New Parks. The land tax assessments show this to be an error, probably due to confusion with the adjacent area of Braunstone Frith, which was owned by Winstanley: Nichols, Leics, iv. 784 ; cf. above, p. 449 .

37 Patterson, op. cit. 375; White, Dir. Leics. (1 846), 45; Hagar and Co.'s Dir. Leics. (1849), 290. Stokes was the builder of New Parks House: see above, p. 454 .

38 Later Sir John Mellor: White, Dir. Leics. (I 863), 683.

39 Kelly's Dir. Leics. and Rut. (I895), 303 ; ibid. (1908), 540 ; ibid. (1922), I 28 ; ibid. (1932), I 37 ; Wright, Dir. Leics. and Rut. (1895-6), 664.

40 Kelly's Dir. Leics. and Rut. (1922), I27; Boro. of Leic. Abstract of Accts. (1898), I 44-5 ; Leic. Council Mins. I896$7,277-8$.

41 Leic. Council Mins. I 932-3, 330-I, 336; ibid. I934- to spread into New Parks, and the south-east of the parish had become a residential area. 48 Since 1945 most of the remainder has become a housing estate owned by Leicester corporation.

For ecclesiastical purposes New Parks remained extra-parochial until I 904 , when it was included in the newly created parish of St. Augustine, Newfoundpool.49 In 1947 New Parks, with a small part of Glenfields and part of the parish of St. Anne, Letchworth Road, was formed into a new ecclesiastical district, St. Aidan's. ${ }^{50}$ The church and parish hall were begun in 1954 on a site in New Parks.

\section{NEWFOUNDPOOL}

The origins of the extra-parochial place of Newfoundpoolsi are unknown, and the area does not appear in any records until the I 9 th century. It first appears on a map of 1828,52 where it is marked as an area of open land measuring about 650 yards from east to west, and about 400 yards from north to south, situated between Fosse Road North and the borough boundary as it then existed. In the census report of I84I Newfoundpool was listed as part of the Augustine Friars liberty in Leicester borough, ${ }^{53}$ and in early census returns its population may have been included under Augustine Friars. In the reports of I85I and I86I Newfoundpool was listed as a separate extra-parochial place, ${ }^{54}$ and in 1871 and I 88I as a civil parish. ${ }^{55}$ Under the Leicester Extension Act of I89 I Newfoundpool became part of Leicester county borough, and in 1896 with the creation of a new civil parish which included the whole borough Newfoundpool ceased to exist as a separate unit. ${ }^{56}$ Although Newfoundpool was part of the administrative county of Leicester until it was brought within the borough, as late as I 877 county rates were not being levied in the area. ${ }^{57}$

By about I 830 Newfoundpool belonged to Isaac Harrison, a member of a Leicester firm of market gardeners, ${ }^{58}$ who discovered and decided to exploit a spring of medicinal water on the land. $59 \mathrm{He}$ built a large house as a hydropathic institution, with houses for the doctor and his attendants, and for a time the institution seems to have flourished. ${ }^{60} \mathrm{It}$

5, I60-I, I64, 3I7, 384; ibid. 1935-6, 64, 66, 204; ibid. I $936-7,390,436,438$.

${ }_{42}$ For the wooded character of the Frith, see V.C.H. Leics. ii. 267.

43 Nichols, Leics. iv. 784

44 Census, 1801.

45 Census, $187 \mathrm{I}$.

46 Boro. of Leic. Abstract of Accts. (1898), I 44-5; Kelly's Dir. Leics, and Rut. (1922), 127.

47 Kelly's Dir. Leics. and Rut. (1908), 540.

${ }^{48}$ Kelly's Dir. Leic. (1938), frontispiece street map.

49 Wright, Dir. Leic. (I920), p. xxv.

${ }^{50}$ Leic. Dioc. Cal. (1952), 94.

${ }^{51}$ The name is apparently derived from the hydropathic institution mentioned below.

${ }_{52} \mathrm{~T}$. and G. Ellis, Plan of Leic. (1828).

53 V.C.H. Leics. iii. I 79 n.

54 Census, I $85 \mathrm{I}$; Census, I $86 \mathrm{I}$

55 Census, $187 \mathrm{I}$; Census, 1881 .

56 V.C.H. Leics. iii. I 79 n.

57 White, Dir. Leics. (1877), 305.

$5^{8}$ For the Harrison family see Reg. Freemen of Leic. $1770-1830$, ed. H. Hartopp, $85,256$.

59 Harrison's projects are described in an article by R. G. Waddington, in Leic. Illustrated Chronicle, 28 Mar. I93 I.

60 Ibid. There are 2 large plates showing the house and baths in Leic. City Ref. Libr., Cable Coll. ix. 25-27. 


\section{A HISTORY OF LEICESTERSHIRE}

failed, however, probably before $1835,{ }^{61}$ and in 1836 Harrison began to look for coal measures under the site. He converted the house into one for himself, and may have sold or leased some of the land to his brother Henry, who seems to have owned it in 1845 , when some of it was surveyed by the Midland Railway with a view to the construction of a line. ${ }^{62}$ After the death of both the brothers the property descended to their nephew, Isaac Harrison, and then to his daughter Beatrice, who about I 885 sold the land to Orson Wright, a Leicester builder. ${ }^{63} \mathrm{He}$ laid out the area in streets, building some small houses himself and selling some of the land in building plots. ${ }^{64}$ The initials of the streets which join Pool Road and Beatrice Road form an acrostic on the name 'Isaac Harrison'. By i 89 I the development of

6I It does not appear in Pigot, Dir. Leics. (1835).

62 Leic. City Mun. Room, Stretton Coll. I903/2.

${ }_{63}$ Kelly's Dir. Leics. and Rut. (1888), 558.

64 Leic. City Mun. Room, I2D $43 / 158 / 1$. Most of the houses in Newfoundpool bear dates between 1885 and I 895 . the area was almost complete, and the population had risen from 56 in 188 I to $2,160.65$

In 1894 the ecclesiastical parish of St. Augustine, Newfoundpool, was created. A temporary mission church had been built in $1888.66 \mathrm{~A}$ red brick church was begun in I90I and completed in I9I2. The architect was W. M. Cowdell. ${ }^{67}$ The ecclesiastical parish originally included Newfoundpool itself, Freak's Ground, New Parks, and part of Leicester Abbey parish. In 1947 a conventional district was formed for New Parks. ${ }^{6} 8$

Newfoundpool had a separate school board, which was responsible for the construction of the Ingle Street board school in 1891 . This came under the Leicester school board when Newfoundpool was included in the borough. ${ }^{69}$

I I 96. I 99. 136.

T.L.A.S. viii. I3I; Kelly's Dir. Leics. and Rut. (1900),

See above, p. 455 .

69 Leic. Fnl. 2 Jan. I891, p. 5. 


\section{THE SEALS, INSIGNIA, AND CORPORATE OFFICES OF LEICESTER}

IN 1258 the guild merchant bought a 'new' seal, which suggests that they had had one previously. I It is not clear whether this is the same as the seal of the community of Leicester, first mentioned in $1277^{2}$ The earliest surviving impression of that seal is attached to a document of 1343 . It is circular, $2_{4}^{3}$ in. in diameter, and bears a cinquefoil, surrounded by the legend, in lombardic lettering, SIGILLUM COMMUNITATIS LEYRCESTRIE. ${ }^{3}$ In some impressions it can be seen that the cinquefoil is covered with small rough marks, probably intended to indicate that the cinquefoil is ermine. ${ }^{4}$ The matrix, which was said in I 5 I I to be of gilt copper, ${ }^{5}$ remained in use until Charles I captured Leicester in 1645 , when it was carried off by the Royalists. ${ }^{6}$ In August I645 a new common seal, similar to the old one, was ordered to be made. ${ }^{7}$ It was of brass. ${ }^{8}$ No impression is known. A new one was made in $1647-8$. It closely resembled that lost in 1645 , being circular, about $2 \frac{1}{2}$ in. in diameter, and bearing a cinquefoil, with a single conventional mark indicating ermine on each leaf of the cinquefoil. The legend, in humanistic lettering, reads SIGILLUM COMMUNITATIS BURGI LEICESTRIE. ${ }^{9}$ By I 706 borough documents were being sealed with a wafer. ${ }^{10}$ The seal in use in 1956 was that made for the reformed corporation in 1836 . It is circular, about $2 \frac{1}{4}$ in. in diameter, and bears a pierced ermine cinquefoil, with the legend in humanistic lettering, SEAL OF THE MAYOR ALDERMEN AND BURGESSES OF LEICESTER I 836 .

A detached impression of a mayor's seal was exhibited to the Leicestershire Archaeological Society in I 873. It was circular, and bore, within a canopy, a seated figure of the Virgin holding the Child, in base a shield charged with a cinquefoil. This device was surrounded by the legend SIGILL' MEIORATUS VILLE LEYCESTRIE. It was judged at the time of exhibition, perhaps wrongly, to be of Edward III's reign. ${ }^{11}$ The first documentary reference to a mayor's seal occurs in $1420 . .^{12}$ In I 5 I the mayor's seal was of silver. ${ }^{13}$ Like the common seal, it was carried off by the Royalists in $1645{ }^{\mathrm{I} 4} \mathrm{~A}$ new mayor's seal of silver was

I Leic. Boro. Rec. IIO3-I327, 82.

2 Ibid. 166.

3 Leic. Boro. Rec. $1327-1509,55-57$. The seal is illustrated ibid., p. lxxviii. This impression is counter-sealed with the seal of Will. de Fulutun, a person not otherwise known.

${ }_{4}^{4}$ Leic. City Mun. Room I8/152; I 5/194.

5 Leic. Boro. Rec. I 509-I603, 3 .

6 Leic. Boro. Rec. I603-88, 334, where the date is given as 1644 in error. 'The date on the original is 1645 .

7 Ibid. $33 \mathrm{I}$.

8 Ibid. 342 .

Ibid. $365,366,377$; Leic. City Mun. Room, 67/12754, 11423 .

${ }_{10}$ Leic. City Mun. Room, 88/1581.

II T.L.A.S. iv. 225 . ordered to be made in August $1645 .{ }^{\text {I5 }}$ It is probably the matrix of this seal that is now preserved in the Leicester City Museum. The seal is circular, with a diameter of $\mathrm{I} \frac{3}{8}$ in., and shows the Virgin crowned, holding the Child in one hand, and a sceptre in the other. The legend, in humanistic lettering, reads SIGILLUM STAT'MAIO' BURGI LEICESTRI. This seal was in existence about $\mathrm{I} 8 \mathrm{I} 5$, when it was said to be in use for sealing statutes. ${ }^{16}$ In 1873 it was said to have been long disused. ${ }^{17} \mathrm{~A}$ circular seal, $\frac{5}{8}$ in. in diameter, bearing a cinquefoil and surrounded by the legend BURGUS LEYCESTRIAE was being used on documents of I620-30 as a counter-seal to the common seal. ${ }^{18}$ It was presumably the same as the seal described by Nichols about I8I5 which was then being used for sealing capiases and letters, and was kept by the mayor for the time being. ${ }^{19}$

Besides the seals already described there were about $\mathrm{I}_{8} \mathrm{I}_{5}$ two further seals belonging to the mayor and corporation, but it is not possible to give full descriptions of either of them. One bore a cinquefoil, and the legend SIGILLUM STATUT' BURGI LEICESTRIE. It was then used for sealing statutes, and was kept by the clerk of the statutes. The other is said to have borne a cinquefoil surmounted by a casque and a dragon. It is probable that the device in this case was a cinquefoil surmounted by a casque bearing as a crest a wyvern, the crest of the borough. ${ }^{20}$

In $1378-9$ a mace was purchased by the chamberlains of Leicester. ${ }^{2 I}$ It is possible that this was the first mace that the borough possessed. ${ }^{22}$ By I 53 I-2 there were also four lesser maces, of silver. ${ }^{23} \mathrm{~A}$ 'night mace' is mentioned at the same date, ${ }^{24}$ but nothing further is known about it, though it may be the same as the brazen mace mentioned in $1517-18.25 \mathrm{An}$ inventory of the town plate drawn up in $155^{\mathrm{I}}$ lists only the great mace and the four lesser ones. ${ }^{26}$ In 1585 it was decided that a new great mace should be bought, and that the old one should be retained. ${ }^{27}$ The old mace was repaired in $\mathrm{I} 60 \mathrm{I},{ }^{28}$ but nothing further is known of it.

12 Leic. Boro. Rec. I327-I 509, p. Ixviii.

13 Leic. Boro. Rec. I 509-I603, 3 .

14 Leic. Boro. Rec. I6o3-88, 334.

15 Ibid. 342 .

16 Nichols, Leics. i. 354.

17 T.L.A.S. iv. 226.

I 8 Leic. City Mun. Room 56/II30;56/II34;59/I I75; $56 /$ I I 5 I .

I9 Nichols, Leics. i. 354.

20 Ibid.

21 Leic. Boro. Rec. I327-I 509, 160

22 Ibid. $I 327-I 509$, p. Ixviii

23 Ibid. I 509-I603, 32 .

24 Ibid. 32.

25 Ibid. 9. 26 Ibid. 66.

28 W. Kelly, Great Mace of Leic. I6. 


\section{A HISTORY OF LEICESTERSHIRE}

At the sack of Leicester in May I645 the great mace was carried off by the king's forces, and later in the year a new one was purchased. ${ }^{29}$ In 1649 the Common Hall decided that the great mace should be altered to conform with the pattern laid down by the House of Commons, ${ }^{30}$ but in 1650 a new and considerably larger mace was bought, and the old one was apparently sold. ${ }^{3 I}$ At the Restoration the great mace and the four small silver maces were altered, probably by having the royal arms affixed. ${ }^{32}$

In $18{ }_{3} 6$ the great mace and the four lesser maces were sold by order of the reformed corporation. ${ }^{33}$ The great mace was repurchased in 1856 , and in I 956 was still in the possession of Leicester Corporation. ${ }^{34}$ Two of the small maces have been regained by the corporation. ${ }^{35}$

In 1867 the corporation purchased a gold and

29 Leic. Boro. Rec. $1603-88,331,342$. On the date see n. 5 above.

30 Ibid. 38 3-4.

31 Ibid. $394,398$.

33 See above, p. 255.

${ }^{34}$ Kelly, Great Mace of Leic. 45. enamelled chain, with a medallion bearing the town's arms, for the mayor's use. ${ }^{36}$

A list of aldermen who acted as chief magistrates of Leicester during the first half of the $13^{\text {th }}$ century, of the mayors from 1250 to 1928 , and of lord mayors from I 928 to I935, is printed in the Roll of the Mayors of the Borough and the Lord Mayors of the City of Leicester, by Henry Hartopp. No complete list of town clerks has been published, but the names of such town clerks as are known for the period before I 688 are listed in the printed volumes of the Leicester Borough Records. ${ }^{37} \mathrm{~A}$ list of town clerks up to 1807 is printed by Nichols. ${ }^{38}$ This list is complete from I 577 onwards, but not for the period before that date. A list of town clerks for the years $1836-94$ has been printed by Storey. ${ }^{39}$

35 Ex inf. Leic. City Mus.

${ }^{36}$ Kelly, Great Mace of Leic. $45-46$.

37 Leic. Boro. Rec. IIO3-1327, 403-4; ibid. $1327-$ 1509,451 ; ibid. $1509-1603,459$; ibid. $1603-88,597$.

${ }^{38}$ Nichols, Leics. i. 454

39 J. Storey, Hist. Sketch of Boro. of Leic. 260.

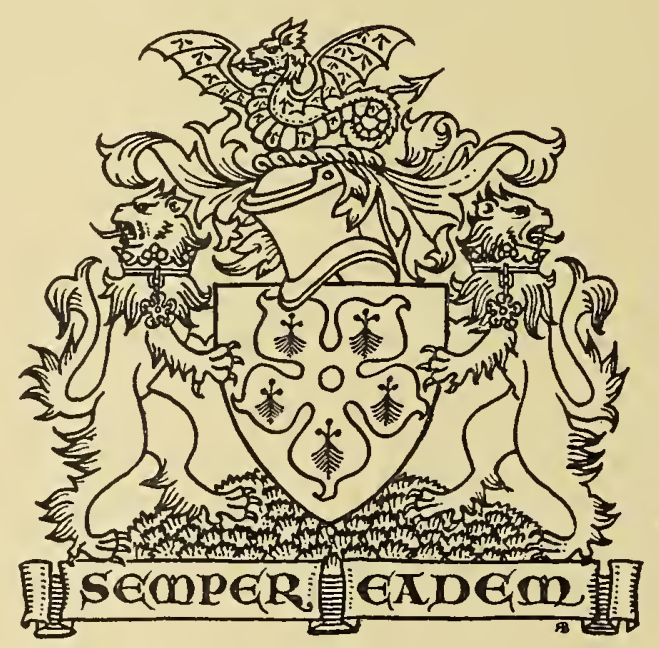

Leicester City and County Borough. Arms: Gules, a cinquefoil ermine, pierced at the centre. Crest: On a wreath argent and gules, a silver legless wyvern strewn with red wounds. Supporters: Two lions reguardant gules, each with a gold ducal coronet about its neck, and hanging therefrom by a gold chain a pierced cinquefoil ermine.

[Arms and crest recorded by the heralds, I619; supporters granted 1926$]$ 


\section{GENERAL INDEX}

THERE are two indexes in this volume, a General Index and a Leicester Index. The first consists of all entries other than those in the Leicester Index, the second consists of entries which would otherwise begin with the word 'Leicester'. Cross-references to entries in the Leicester Index from entries in both the General Index and the Leicester Index are prefixed with the letter 'L.' Places named in the text merely as residences are indexed only as a means of cross-reference to the residents. Lists of subject-entries are given in the Leicester Index at the end of the entries for 'city and borough' and 'trade and industry'.

The following abbreviations have been used, sometimes with the addition of the letter $s$ to form the plural: Abp., Archbishop; admin., administration; Alex., Alexander; And., Andrew; Ant., Anthony; Art., Arthur; Assoc., Association; Ave., Avenue; Bart., Bartholomew; bd., board; Ben., Benjamin; Bp., Bishop; bounds., boundaries; cast., castle; Cath., Catherine; ch., church; char., charity; Chas., Charles; Chris., Christopher; Ctss., Countess; d., died; Dan., Daniel; econ. hist., economic history; Edm., Edmund; Edw., Edward; Eliz., Elizabeth; fam., family; Fran., Francis; Fred., Frederick; Geo., George; Geoff., Geoffrey; Gil., Gilbert; Hen., Henry; Herb., Herbert; hosp., hospital; Humph., Humphrey; hund., hundred; incl., inclosure; ind., industry; Jas., James; Jos., Joseph; Laur., Laurence ; Lawr., Lawrence; Ld., Lord; lib., liberty; m., married; man., manor; Marg., Margaret; Mat., Matthew; Nat., Nathaniel; Nic., Nicholas; non-conf., non-conformity; par., parish; Pet., Peter; pop., population; R.C., Roman Catholic; R. Cath., Roman Catholicism; Rd., Road; Ric., Richard; riv., river; rly., railway; Rob., Robert; Rog., Roger; s., son; Sam., Samuel; sch., school; Sim., Simon; Soc., Society; St., Street; Steph., Stephen; stn., station; Thos., Thomas; Val., Valentine; w., wife; Wal., Walter; Wm., William.

Abbatt, John, IoI $n$.

Abell (Aboll), Alice (Johnson), $88 n$, Ioo $n$; Isaac, 396 ; Val., I $05 n$; fam., 396.

Aberdeen, Earl of, see Gordon, Geo. Hamilton.

Abney, Dannet, 95, I02, I03 $n$; Sir Edw., I2I ; Phil., I87 $n$; Thos., $124 n$; Sir Thos., 121 ; - , chamberlain, I I 5 .

Aboll, see Abell.

Abyssinia, 247.

Acham, Ant., 412.

Adam s. of Ivo, 429 .

Adcock, Halford, 44I, 442.

Adderby, D., 417.

Agar, Wm., 427.

Aires, see Ayres.

Aislabie, Wm., 448

Albert, Prince Consort, 4 I $9 n$.

Alexander, Bp. of Lincoln, I6, 353, 443.

Alexander, Dr. Edw., 382.

Allanson, Mrs., 422.

Allen, John, 82 ; R. Wilberforce, 243$4,245,246 n$; Thos., 426.

Allington (Lincs.), 398,400

Allsop, Allsopp, see Alsop.

Almond, Wm., 74 .

Alnwick, Wm., Bp. of Lincoln, $35^{8}$.

Alsop (Allsopp, Allsop, Halsope), Nic., $90 n$, 91 $n, \mathbf{1 6 8 ,}$ I $69 n$, I70, I78; Thos., hosier, I $68 n$; Thos. (f. c. I 788), 440; Wm. (d. I 546), 85; Wm. (f. c. I670), $157 n$.

Alton, Ric., $88 n$.

Alveva, w. of Ælfgar, Earl of Mercia, 416.

Amalgamated Soc. of Boot and Shoe Makers (formerly, of Cordwainers), $32 \mathrm{I}-2$.

America, United States of, 204, 206, $218,312,313,327 n$; footwear ind., 315,318 ; see also New York, Virginia.

Amice, Ctss. of Leicester, m. Sim. de

Montfort (d. c. I I 88), 3

Anderson, Geo., 406; Rob., 406.

Andrew (Andrewe), Dorothy, $88 n$; Jas. (d. 1636 ), $80,81 n$; Jas. (d. I638), 368 .

Andrewes, Gerrard, 332.

Andrews, footwear manufacturers,

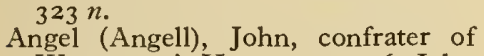
Wyggeston's Hosp., 40I, 406; John (d. I665), , $06 n ;-59$.
Anstey par., 300, 447; road from Leicester to, 450, see also L., Anstey Gorse.

Anti-Corn Law League, 249.

Antwerp (Belgium), 78 .

Appleby (Westmld.), M.P., see Curtis, Pet.

Arch, Jos., $228 n$.

Archer, Fran., 371 ; Ric., 371.

Armeson, Thos., 97.

Armeston, John, I68 $n$.

Arnold, Edw., 368, 438, 446; Dr. Thos., 137.

Asfordby, 353 .

Ash, - , I 70 .

Ashby, Shuckburgh, 135-6.

Ashby de la Zouche, 434 ; cast., 67 ; road from Leicester to, 449,453 glovers, 86 ; see also Hastings fam., Zouche fam.

Ashby Folville, 408 .

Ashby Magna, 407.

Ashley-Cooper, Ant., Ld. Shaftesbury, I I 4 .

Ashop, Riv. (Derb.), 285.

Ashton, Pet., 380 .

Asquith, Herb. Hen., Ist Earl of Oxford and Asquith, 244, 245.

Astell, see Astill.

Asterby (Lincs.), man., 4I2.

Astill (Astell), Edw., I $57 n$; Thos., 397; Wm., 397.

Asty, Wm., 42.

Atcheson, Nat., I4I.

Atherstone, Jonathan, 139.

Atkins, Canon Edw., 386, 406.

Atton, Ric., $92 n$; Rob., I60; Rog., $92 n$.

Atwater, Wm., Bp. of Lincoln, 426,

$44 \mathrm{I}$.
Auceter, Rob. and his w. Eliz., 360.

Auger, Wm., $97 n$.

Australia, 312; see also New South Wales.

Avery, Wm., $105 n$.

Aylesbury (Bucks.), 233, 234.

Aylestone, Ric. de, 416 ; Rob. de, 416.

Aylestone par., 278, 287, 332, 397, $400,415-20,432 n$; admin., 418 ; bridge, 4I5; chapelries, see Glen Parva, Lubbesthorpe; chs., 4I82I, chants., 4I8; curate, see Bickerstaffe, Wm. (fl. c. I786); econ. hist., 4I6-I8; man., 4I5-I6, $429 n$; mills, 417,418 ; non-conf., 420 ; priest, see Cuneston; rector, 4I7, see also Heathcote, Wm.,
Pyrie, Seagrave; rectory, 416, 4I8; R. Cath., 420; schs., 336, 337, 420; sch. bd., $336 n, 337 n, 420$.

Aylestone Hall, 415, 416; Aylestone Park, 417; Cavendish Rd. chap., 420; Grace Rd. cricket ground, 4I7; Granby St. sch., 336, 420; Great North Meadow, 4I7; Hall Close, 4I7; Hall Lane, 4I 5; Holowell (Middle) Field, 417 ; Lansdowne Rd. sch., 337, 420; Lutterworth Rd. chap., 420; Middleton St., 4I9; North (Mill) Field, 4I7, 4I8; Old Ch. St., 4I9; Rye Meadow, 4I7; St. Christopher's ch., 418; St. Edward the Confessor R.C. ch., 420; St. James, Aylestone Park, ch., 418; St. John de Bosco R.C. chap., 420; South Field, 417 ; Southfields Drive chap., 420 , sch., 337 ; Southfields housing estate, 418; Upper Meadow, 4I7; Vernon Rd. chap., 420; see also L., Aylestone ward.

Ayre (Eyre), Kath., 90; -, I66, 417; see also Eayre.

Ayres (Aires), Thos. (d. 1697), $90 n$, $168 n$; Thos. (fl. $c$. I 705), 122.

Ayshehill, Ric., 87.

Babington, Mat., I42 $n$, I48; Thos. (M.P. I685-9), II7, I I9, $12 \mathrm{I}$; Thos. (M.P. I800-I 8), I 37 , I 38 , I 39, I 40, I 45; see also Mansfield \& Babbington.

Bacon, Edw., 454; Geo., 454; John, R.A., 368; Nat., 454.

Baggrave, see Edwyn.

Bagley, E. A., 240.

Bagworth, Pet. of, 42 .

Bailey (Bayley, Baylie), Nic., I02, I03 $n$; Thos., $96 n$; Wm. (d. I602), I05 $n$; Wm. (d. I66I), 9 I, $98 n$; -, I 39 ; see also Johnson \& Bailey.

Baines, Wm., 207, 21 1, 256, 365 .

Baker (Bocher), Chas., 386; Ingram le, 43 ; see also Shenton \& Baker.

Bakewell, Rob., I 3 I-3, I 35 .

Bakewell (Derb.), see Waterhouse.

Baldeston (Notts.), see Dyve.

Bale, John, I I I; Valentine, 44I; fam., 440, $44 \mathrm{I}$.

Ball, John, $83 n$; Wm., $88 n, 97 n$.

Bambrigge, Eliz., $106 n$.

Banbury (Oxon.), 42. 


\section{A HISTORY OF LEICESTERSHIRE}

Bannerman, (Sir) H. Campbell, 235.

Banton, Geo., 233, 234, 235, 24I, 243 , $244,245,246$

Baptist Missionary Soc, $39 \mathrm{I}$.

Barber (Barbor), Harvey, I 42 n; Wm., and his w. Agnes, 359.

Bardsley, Dr. Cyril, Bp. of Leicester, 366.

Barkby Hall, see Pochin, Wm.

Barkestone, 399.

Barlow, Sarah, 409, 445 ; Wm., Bp. of Lincoln, 349.

Barnes, Ric., 77, 79, 82 .

Barradale, Isaac, 445 .

Barron \& Son of Derby, builders, 354.

Barrow upon Soar, 319.

Barton, John, 349 .

Barton in the Beans, chap., 391.

Barwell, I 8 .

Basford (Notts.), 42.

Bass, John, 35 I $n, 360$.

Basset, Ric., 434.

Bassford, John, I 82

Bates, Wm. Hen., 397

Bates, W. \& A., elastic-web manufacturers, 327.

Baxton, Rob., i о I $n$.

Bayley, Baylie, see Bailey.

Beaconsfield, Ld., see Disraeli, Ben.

Beale, Hen., 4I6; Ric., I3 1 .

Beaufort, Hen. de, Duke of Somerset, 7 .

Beaumanor, see Heyrick fam. ; builder, see Herrick, W. Perry.

Beaumont, Sir Geo., I2I-3, I24, I3I ; Hen., 346, 347; Sir Hen., I I 3 , I I 7 , I I 8, I I9, I2I; John (f. c. I550), 7 I ; John (fl. c. I 548-52), 346, 396 ; John (f. c. 1830), 422; Sir John, 445 ; Rob. de, see Rob.; Thos., I $84 n$; Sir Thos., 346; fam., of Belgrave, 422 ; fam., of Grace Dieu, 346 ; fam., of Stoughton Grange, 127.

Beaumont Leys, see L., Beaumont Leys.

Beazley, Sam., 363 .

Beckett (Becket, Beckit), Eliz., 90; Wm., 94.

Bedells, Caleb, 326, 327.

Bedford, 5, 3 I.

Beeby, Wm. of (A. c. 1 297), 39; Wm., mercer, $39 n$; fam., 39.

Beeston, Ric., 79.

Belgrave, Ambrose, 425; Geo. (fl. c. I 558), 425; Geo. (fl. c. I60I), 60 ; Sir Geo., $422 n$; John de (d. I3989), 424; John (d. I 512 ), 42 I ; Lawr. de (fl. c. I333), 423, 424; Lawr. de (fl. c. 1398), $43 n$; Rog. de, 47; Wm. de, 42I; fam., $42 \mathrm{I}$.

Belgrave (Merdegrave) par., I8I, $229 n, 286,287,292,355,420-8$, $44 \mathrm{I}, 447$, 453; admin., 425; bd. of health, 420,425 ; bridge, 421 , $423-4$; burial bd., 425 ; chapelries, see Birstall, Thurmaston, South; chars., 427-8; chs., 420, 424, 425-7; econ. hist., I09, 422-5; elastic web ind., 327 ; mans., $42 \mathrm{I}-2$; mills, 43, 45, 424-5; non-conf. 427 ; pop., 420; R. Cath., 427; rector, 425 ; rlys., 420 ; road from Leicester to, I 54, 26I, see also L., Belgrave Rd.; schs., 336, 337, 427; sch. bd., $336 n, 337 n, 425,427$; vicar, 425, 426; vicarage, 420 ; woods, 423 ; workhouse, 425 .

Abbey Lane, 424; Bath St., 424, chap., 427; Beaumont Hall chap. 427; Belgrave Hall, 420-I, 423, see also Belgrave's man., man. house; Belgrave House, 420, 42I; Belper St. sch., 336, 427; Breach Field, 423 ; Canon St., 427 ; Church Lands,
428; Claremont St. chap., 427; Clayland Field, 423; Constitutional Club, 42I; Cross Corners, $42 \mathrm{I}$; Good Shepherd ch., 426; Hadland Field, 423; Harrison Rd. chap., 427, sch., 336 , R.C. sch., 336, 427; Holden St. bridge, 424; Loughborough Rd., 424, 425, chap. 427 , sch., 336, 427; Mellor St. sch., 337 427; Mill Hill Field, 423; Mill Hil sch., 332, 427; Moira St., 427; Moor Field, 423; Our Lady \& St. Patrick R.C. par., 390, ch., 390, 427, schs., 336, 337, 427; Poors' Land, 427; Poors' Plot, 426; St. Alban's par., 360, 426; St. Gabriel's ch., 426; St. Michael \& All Angels' par., $360,420,426$, ch., 426 Talbot Inn, 42I, 428; Thurcaston Rd., 420; Town Houses, 428; Townside Field, 423; Vann's Corner, 424 ; seealso Beaumont fam. Belgrave's man., Davenport's man., Pultney's man., Stanton, Zacharias, Thompson, John (d. I645).

Belgrave Rubber Co., $323 n$.

Belgrave's man., in Belgrave, $42 \mathrm{I}$ man. house, $42 \mathrm{I}$, chap., $389,42 \mathrm{I}$, 427

Bell, (Sir) Jas., 289; John (d. I62I), $88 n$; John (d. I63 I), $99 n$, I05 $n$; Thos., 303.

Bellamy \& Harding, architects, 360. Bellowe, John, 387.

Belvoir, 399.

Bengal, I34.

Bennett (Bennet), Eliz., $87 n$; Geo., 43 I ; Rob., r oo $n$; Thos., $79 n$, 8o; - 4 I I

Bennion, see Pearson \& Bennion.

Bent, Geo. (d. I709), I57 $n$, I $87 n$; Geo. (d. 1736), 369; John, mayor of Leicester (d. I700), I I 4, I I6, I I7, 120, 408; John, slater (d. I 70o), I $87 n$.

Bentley, Wm. (fl. c. I684-0), I I4, I I 7 , I I 9,120 ; Wm. (fl. c. I 769), 382 .

Benton, John, 392.

Berowe, Wm., $98 n$

Berridge, I. L., 437; Wm., I05 $n$.

Berry, Chas., I 48, I 50, 273.

Beverley, Ric. of, $48 n$.

Beverley (Yorks.), 49

Bewdley, 一, $73 n$.

Bickerstaffe, Wm. (fl. c. I738), I26; Wm. (fl. c. I786), 417, 420 .

Bickersteth, Rob., 230.

Biddle, Hen., I03 $n$.

Biddolph, Edw., $96 n$

Biggs, John, 206, 214-I5, 2 I8， 2 I 9 220, 22I, 223, 249, 250, 252, 265-6 291, 424, 444; Jos., 303; Thos., 76, 90; Wm., 204, $206 n$, 2 II, 212 , 2I4-I5, 220, 252, 265-6, 303, 306, $307,308,309,310 n$.

Biggs, John, \& Sons, footwear and hosiery manufacturers, $207 n, 306$, 317

Billers, Edw. (d. I664), 8I ; Edw. (f. c. I665), I I2; Julius, $380 ; \mathrm{Wm}$. (d. I642), I03 $n$; Wm. (fl. c. I672), 393

Billesdon, Poor Law Union, 439, 441

Birkhead, John, $95 n$.

Birmingham, John, 349

Birmingham, 206, 2 I I, 2 I 3, 22 I, 224 , 225,226 ; corp., 289; town clerk 288

Birstall (Burstall), Gil. de, 425; Ric. I oo $n$; Rob. de, 425 ; Thos., $98 n$; Wm., I05 $n$.

Birstall Hill, 424

Birstall par. (chapelry), 300, 39 I $n$, 420, 425, 426; chap., 425; see also Paget, Hen.

Bishop, Jas., 391 .
Blaby, Ric. de (fl. c. 1234-42), I4 $n$; Ric. de (f. c. I 273), $24 n$.

Blaby, 450; Poor Law Union, 418, 432 ; Rural District, 428.

Blackshawe, John, $77,85 n ., 88$.

Blanche, w. of John of Gaunt, Duke of Lancaster, 5,6

Blanchesmains, Rob., see Rob. Blanchesmains.

Blane, T. A., 243, 244.

Blankley, John, I 30.

Blisse, Wm., $99 n$.

Blois, Wm. of, Bp. of Lincoln, 382 .

Blomfield, A. W., 359 .

Blount, see Blunt.

Blundeville, Ranulf de, see Ranulf de Blundeville.

Blunt (Blount), Thos. (d. I66o), IoI $n$; Thos. (d. I663), 77; Thos. (d. I664), 4II.

Bocher, see Baker.

Bodley, G. F., 358, 367, 377

Bohun, Mary de, Ctss. of Hereford, m. Hen. Bolingbroke (Henry IV), 6,7 .

Boithe fam., 78 .

Bolingbroke, Hen., see Hen. IV.

Bolivant, John, $96 n$.

Bonnett (Bonett), John, $87 n, 99 n$; Mary, I o6 $n$.

Bonney, Thos. Kaye, Archdeacon of Leicester, 379.

Boot \& Shoe Union, 248; secretary, see Inskip, Wm.

Booth, Sir Geo., 56; Rob., 423.

Boothby, Thos., 126

Boroughbridge (Yorks.), battle, 4.

Bosco, Ernald de (fl. I th cent.), 437 , 44I ; Ernald de (fl. c. 1264), 422; John de, 422; Wm. de, 422, 435.

Bossu, Rob. le, see Rob. le Bossu.

Boston (Lincs.), $40 n, 45 n$; fair, 48 ; rectory, 447 .

Bosworth Field, battle, $7,8,384$.

Bosworth, Market, 79; see also Hutton, Jonathan.

Botham, Hugh, 412, $442 n, 443$.

Bottesford, 399; see also Easthorpe.

Bottomley, Jas., 390.

Bowden, H. W., $248 n, 249 n$.

Bowden, Great, 398.

Bowes, Jane, $442 n$; John, $442 n$; Marg., see Keble; fam., 442.

Bown, Geo., 137, 190, 254.

Bowyer, Wm., $83 n$.

Boxall, John, 77, 96 .

Brace, Ric., $88 n$.

Bracina, Wm. de, 45.

Bradford (Yorks.), see Hartley.

Bradgate (Broadgate), I I 5, I20; see also Grey of Groby fam.

Bradlaugh, Chas., $228 n$.

Bradley, Wm., 426, 428.

Bradshawe, Rob., $99 n$.

Braham, Rob., 7o.

Brand, Thos., I 38 ; Wal., 353, 392.

Brandon, John, 392 ; John Raphael, 367.

Brassey, Thos., Earl, $324 n$.

Braunstone, Hen. of (f.. c. 1297), 429, 430; Hen. of (fl. c. I 312 ), 429, 430; Hugh of (fl. c. 1299), 429; Hugh of (f. c. I $32 \mathrm{I}$ ), $4 \mathrm{I}$; fam., 429; see also Adam s. of Ivo.

Braunstone par., 287, 300, 360, $394 n, 428-33,449$; admin., 432; bounds., 428; ch., 430, 432-3; econ. hist., 430-2; man., 4I5 $n$, 428-30, house, see Braunstone, Hall Farm; non-conf., 433; pop., 428, 431, 432; R. Cath., 433; road from Leicester to, 432 ; schs., 433 .

Braunstone Hall, 428, 432, 433 sch., 336; Braunstone housing estate, 297, 300, 432; Braunstone Lane, 428, 430, 432, chap., 433; 
GENERAL INDEX

Braunstone Meadows (Holmes), Ioo; Braunstone Park, 428, sch., 336; Christ Ch. chap., 433; Dove Brook, 428; Ellesmere Rd. sch. $336,433 n$; Fathers of the Blessed Sacrament ch., 433; Folville Rise sch., 336, $433 n$; Fulhurst Ave. 428; Gooding Ave., 428; Hall Farm (man. house), 428, 430; Hallam Crescent sch., $433 n$; King's Wood, 43 I ; Ravenhurst Rd. sch., $433 n$; Rowley Fields, 428; St. Boniface Mission, 432; St. Crispin mission, 432; Trinity ch., 433; see also Winstanley fam.

Braunstone Frith, see L., Braunstone Frith.

Bray fam., 4I7.

Breedon, 400 .

Brewerne, Thos., 423; fam., 423.

Brewin, Hugh, $92 n$; Rob. (fl. $c$. I 8oo), I 38 ; Rob. (fl. c. I800-52), I38, I 48, I $50,208 n, 2$ I 9.

Brewin \& Whetstone, $207 n$.

Breyfield, Wm., 399.

Briggs, John, 327.

Bright, John, radical, 2 I 5, 220, 221 , 239; Thos., 440; fam., 440.

Brisbone, Ric., 86, 87.

Bristol, 265, 316 ; Univ., 241 .

Bristol, Bp. of, see Cornewall.

Bristowe, Ric., 79.

British Electricity Authority, $302 n$.

British Rlys., 388.

British United Shoe Machinery Co. Ltd., 320.

British Workers' League (National Democratic Labour party), 242, 243.

Brixworth (Northants.), ch., 386 .

Broadgate, see Bradgate.

Broadhurst, Hen., 232, 233, 234, 235, $236,237,238,239,249$.

Brokesby, see Brooksby.

Bromkinsthorpe, Rob. s. of Wm. s. of Aufred of, $382 n$.

Bromkinsthorpe, see L., Bromkinsthorpe.

Bromley, Ric. of, I6; Geo., 40 I.

Broneman, see Brunman.

Brook (Brooke), Chas., 226; Frances, see Howard; Hen., Ld. Cobham, 454, 455; Wm., Ld. Cobham, 454.

Brookes, John, 8I $n$.

Brookesbie, see Brooksby.

Brookhouse, Jos., 172.

Brooksby (Brokesby, Brookesbie, Brooksbye), Nat., 8o, 8I $n$; Rog., $89 n$; Thos., $97 n$; 一, I I 4, I I 7, 120.

Brooksby, I Io; see also Villiers, Sir Wm., Wright, Geo.

Broughton, Edw., I 82

Brown (Browne, Browen), Anne, 90; Cath., 412; Edw., 79; Eliz., 90, I $68 n$; John, I 88 ; Rob., $83 n$; Sam., 394; Thos., $87 n$, I о0 $n$; W., $249 n$; Wal. (A. c. 1265), 33; Wal. (d. I 560), 399, 400, 405; Wm. (d. I 594), $89 n$; Wm. (H. c. I 700), I69; -, town solicitor, I 15 .

Brownsover (Warws.), see Leigh, J. Boughton.

Broxholme, John, 387.

Bruarns, Vasper, I oo $n$.

Bruce, Ric., $93 n$.

Bruges (Belgium), 78.

Brunel, Sir Marc Isambard, 308.

Brunman (Broneman), Wal., I $4 n$.

Bruntingthorpe, $38 \mathrm{I} n$.

Brushfield, Wm., $124-5$.

Bryan, Ric., $96 n$

Buci, see Bussy.

Buckby, Geo., 2 I6, 2 I7, 2 I 8.

Buckingham, Archdeacon of, see Geary; Duke of, see Stafford, Hen., Villiers, Geo.
Budde, Ric., 382 .

Budworth, Alborne, $97 n$.

Bullingham, Nic., Bp. of Lincoln,

$405 n$.
Bunney, Jos., 443; Mary, see Craddock.

Bunyan, John, preacher, 390, 39 I $n$.

Burbage, I 26; hosier, I 75.

Burbidge (Burbage), John, 92; Jos., 257, 258; Thos., I 28, I44, I 45, I 46, I 47, I 48, I 49, I 5O, I 5 I, I 52, 253 , $254,257,403,4 I 3$.

Burch, John, $90 n, 96 n$.

Burdet, Ric., 422; Rob., 428, 429; fam., 429 .

Burgaland, John, Io3 $n$.

Burgess, Edw., 327, 333, 352, 353, 362,363 ; John, 393 ; Jos., 234, 235 , 237, 242 ; Thos., $105 n$.

Burleton, Wm., I 30 .

Burnaby, And., Archdeacon of Leicester, 419, 422, 426; F. G., 360; Rob., I3o; fam., $362,435,436,438$.

Burrows, R. A., $249 n$.

Burstall, see Birstall.

Burton, Fran., I05 n; Ric., 85; Rob., 8 I $n$.

Burton on Trent (Staffs.), 398; rly. from Leicester to, 260.

Bury, Edw., 429.

Bury St. Edmunds (Suff.), abbey, 27.

Bushby, I09; char., 126.

Bussy (Buci), Rob. de, 434, 435; fam., 435 .

Buxton (Buxston), 一, I I 4, I I 7.

Byerlèy, Wm., 42I, 422, 423; fam. $389,421,422,423,427$.

Byllyng, Ric., 77, 81-82.

Byrd, John, I05 $n$; Thos., I $24 n$.

Cade, Jack, rebellion, 7 .

Caestryck, Fr. Benedict, 389 .

Cagg, Ric., $49 n$.

Calais (France), staple at, 40, 78, 398; staplers, see Wigston, Rog. (d. I 507 ), Wm. (d. c. I 469), Wm. (d. I 536).

Caleys, see Callis.

Calfof, Pet. de, 37.

Callis (Caleys), John, $43 n, 398$; Wm., $157 n$.

Cambridge, 31 ; Univ., 231, 246, 334; Emmanuel Coll., 332.

Camville, Thos, de, 429 ; Wm. de, 429.

Canada, $3 \mathbf{1 2}$

Canning, Geo., I 45.

Canterbury, Abp. of, see Courtney, Laud, Reynolds, Wal.; convocation of, 5 .

Cantilupe, Millicent de, m. I John de Montalt, 2 Ivo la Zouche, $422 n$, 430.

Carey, Wm. 384, 39 I .

Carlos, Don, 205

Carlton, see Palmer, Hen. (fl. c. I608)

Carlton Curlieu, see Palmer, Hen. (fl. c. 1828 )

Carlton, Castle, (Lincs.), man., 398, $400,401,403,404$.

Carnegie, Sir And., 295, 353.

Caroe, W. D., 359.

Carr, John, I i 8, I I 9 ; Rob., 84; Thos. $89 n$.

Carte, Sam., I 23, I 25, I9 I, 403.

Carter, Edw. (d. I 557), $98 n$; Edw. (d. I 562), $93 n$; Isabel, IOI $n$; Lawr., I I 9, I 2 I, I 22, I 23, I 24, 395 Thos. (d. I 748), 395; Thos. (fl. c. I 865), 39 I ; - , I I 4 .

Cartwright \& Warner of Loughborough, hosiery manufacturers, 308 ; see also Warners of Loughborough.
Cadeby, 333, 434

Carteret, John, Ld., I 24
Cater, Gabriel, $89 n$

Catherine (of Valois), queen of

Henry V, 6, 23

Catlyn, Rob., 358,367 .

Cauldwell, Rob., $97 n$.

Cave, Fran., 45 I ; Rob. Otway, I 44-7, 4I0; Sir Thos., I 26.

Cavendish, Chas., 353; Christian Ctss. of Devonshire, 58, 353; Eliz., Ctss, of Devonshire, 4IO, 4I2; Wm., Ist Earl of Devonshire, 4I I, 435,452 ; Wm., 2nd Earl of Devonshire, 353,436 ; Wm., 3rd Duke of Devonshire, 452 ; fam., 65,435 , 436 , 452; see also Devonshire, Earls of.

Cecil, Sir Rob., 68.

Cetteling, Edw., I05n.

Chadwell, 398.

Chadwick, Edwin, 265, 266, 267

Chamberlain (Chamberlin), Jos., Lib. Unionist, 225, 227, 229, 230, $23 \mathrm{I}$, $236,238,250$; Wm., 77, $79 n$, 80 .

Chambers, John, $99 n$; Jos., I 33, I 34.

Champeden, Ric. de, I $4 n$.

Chaplin, - 243.

Chapman, Mary, Io6 $n$; Thos., 357 , 359; Wm., $96 n$.

Chapman Fraser \& Co., hosiery manufacturers, 3 I $n$.

Chappell, Fr. Francis Xavier, 389 .

Charles I, 56, 64, 66, I08, 412, 416, $4 \mathrm{I} 8,43 \mathrm{I}, 432,440,45 \mathrm{I}, 457$; jeweller, see Heyrick, Sir Wm.

Charles II, 75, I I0, I I 4, I I 5, I I 7, I 59.

Charlesworth, see Preston \& Charlesworth.

Charlton fam., $38 \mathrm{I}$.

Charnwood Forest, 284; see also Hereswode

Charyte, Wm., 384-5.

Cheshire, John, $379 n$

Chesney, Edw., I 45.

Chester, 32, 34 .

Chester, Earl of, see Edm. Crouchback, Ranulf de Blundeville.

Chettell, Ralph, I $06 n$.

Chettleton, Kath., $97 n$; Thos., $97 n$, I $00 n$.

Children's Fresh-Air Mission, 233

Chillingworth, Wm., 402, 405.

Chippendale, Dr. John, 44I ; fam., 44 I $n$.

Chippingdale, Dr. John, 63, 64, $99 n, 395$.

Christian, Ewan, 359, 377; Wm., 390.

Churchill, Ld. Randolph, 229, 230 ; (Sir) Winston, 240, 245, 248.

Churchman, Fran., $83 n$, $106 n$.

Churchover (Warws.), 404.

Cinque Ports, 49.

Clare fam., arms, 438

Clarke (Clark, Clerk), Eliz., 387 ; Ric., 406; Rob., I05 $n$; Sam. (fl. $c$. I6 $13-$ 4I), 40I, 402, 405; Sam. (fl. $c$. I 7 I 8-29), 406; Thos. (A. c. I43 I), 45; Thos. (fl. c. I 586), I O2; Thos. (f. c. I 598), 61; Wm. (fl. c. I43I) 45 ; Wm. (d. I6 13), 82; 一, 455; fam., 455 .

Clarkson, Thos., $90 n$, I05 $n$.

Claver, Wm., $97 n$.

Claxton, Thos., 105

Clay, John, Io6 $n$.

Clerk, see Clarke.

Cleveland, T. B., 273.

Clynes, J. H., 234.

Coats, John, 398

Cobbett, Wm., radical, I45, I99, 304 , 374.

Cobham, Geo., $455 n$.

Cobham, Ld., see Brooke, Hen., Wm.

Cockburn, 一, I 48.

Cockshaw, - printer, $\mathbf{I}_{3} 8, \mathbf{I}_{4} 8, \mathrm{I}_{5}$.

Cockspur, Albert, 273. 


\section{A HISTORY OF LEICESTERSHIRE}

Coffyn, Marg., see Vernon; Wm., 4I8. Coke, Sir John, 60; Thos., 60; see also Cooke.

Colborne, Hen., 422

Coleman, Hen. (f. c. I 76I), and his w. Ann, 435; Hen. (fl. c. I 830), 434, 436 ; Jas. I 73 ; Ric., 390 ; Wm., 416 ; fam., 435,436 .

Coleorton, 127.

Coles, John, 416.

Colinson, Wm., $\mathrm{IO}_{2}, \mathrm{IO}_{3} n$.

Collin, Dorcas, I06 $n$.

Collins, Thos., 306, 308, 312.

Coltman (Coultman), John, I 37, I $_{3} 8$, I 40, I 42, I 45, I 48, I 50, I 72, I 78 $392 n$.; Ric., $87 n$.

Combe, Thos., $273-4$.

Comyn, John, 422.

Congrave, Conyers, $39 \mathrm{I}$.

Connywaie, John, 43 I.

Constable, Marmaduke, 429.

Constance (of Castile), m. John of Gaunt, Duke of Lancaster, 6.

Cooke (Coke, Cook), Amice, 48 Hen., 48; John, $85 n$; Jonathan, I09; Thos., 352; Wm., $106 n$; builder, 305 ; see also Coke.

Cooper (Cowper), Godfrey, 82 ; Jas. $83 n$; Jas. Sidmouth, $83 n$; Phil. 8 I $n$; Rob. (d. 1544), $99 n$; Rob. (d. I645), 106 $n$; Thos., 209, 2 10 $n$, 2II-I 4, 249

Coote, Col. Eyre, I34.

Corah, J., 247; see also L., Corah's St. Margaret's works.

Corbet, John, 447; Marg., m. Thos. de Erdington, 429; Thos., 429.

Cordell, - , engineer, 308.

Cornewall, Folliott Herb. Walker, Bp. of Bristol (later, of Hereford, Worcester), 403, 406 .

Cort, Ben., I $42 n$; Jas., $142 n$

Cosby, ch., $384-5$.

Cotes, Alex. (d. I630), $443 n$; Alex. (d. I66o), 8 I $n, 88 n$; Wm., $88 n$, 92-93.

Cotes-de-val, man., 413.

Cotesbach, 108.

Cotton, Thos., 8 I $n$, $106 n$; Wm., 308.

Coulson, Wm., $98 n$.

Coultman, see Coltman.

Courteen, Sir Wm., $4 \mathrm{II}$; see also L., charities, Courteen's Gift.

Courtis, see Curtis.

Courtney, Wm., Abp. of Canterbury, 359.

Cousens, Rob., 92.

Coventry, Thos., 36, 48 .

Coventry (Warws.), 40, 67, I 16, I98, 276, 398; mayor, 58; char., 75, II3 see also, L., charities, White char. see also Bewdley, Ward, John.

Coventry and Lichfield, Bp. of, 425 . 426; see also Lichfield.

Cowdell, W. M., 456 .

Cowley, Ralph, 376.

Cowling, Sam., 3 I 5

Cowper, see Cooper.

Cox (Coxe), Chas., 305; Wm. (d. I 664), I05 $n$; Wm. (f. c. I 870), 295

Craddock (Cradock), Ann w. of Edm. (fl. c. I 709-32), 420; Edm., (d. I667), I06 $n$; Edm. (fl. c. I 70932), 420, 423, 443, 446; Col. Edm. 443; Jane, see Hastings; Jos. (f. $c$. I 684-8), I I 5, I I 7, I I 9, I $58 n$; Jos. (f. c. I 800 ), 443 ; Jos. (f. c. I8 I 5), 387; Mary, m. Jos. Bunney, 443; fam., 443, 444; see also Hartopp.

Crawford, Maj. E., 248.

Creswell, 一, I I 8.

Crick, Thos., 315, 316, 3 I 7; Throne,

$3 \mathrm{I5.}$
Crick, ' $\Gamma$. \& Co., footwear manufacturers, 3 I $5 n, 320$.
Crofton, Rob., I 00 .

Crompton, Art., $105 n$.

Cromwell, Oliver, 56, 228; Ric., 56, 58 .

Cropston, reservoir, 284 .

Crosby, Margery, $85 n$.

Croston, Rob., $88 n$.

Crouchback, Edm., see Edm. Crouchback.

Crown Hills, 434, 436

Croxton, abbey, 439 .

Culloden, battle, 126.

Cuneston, Phil. de, 4 I 8

Curlevache (Curlevach'), Sim., 4, I $4 n, 4$ I.

Curley, Rog., 430.

Curtis (Courtis, Curteis), Ant., $97 n$; Hen., 48; John, 305; Pet., 27, 28.

Curzon, Geo. Nat., Ld. Curzon of Kedleston, 240; Sir Nat., 450; fam., 450 .

Cuthwine, Bp. of Leicester, 384 .

Dalby, Rob., 422; Wm., $40 n$; inventor, I 70 .

Dalby, Great, 106.

Dalby, Little, Hall, 442.

Dalby on the Wolds, preceptory, 447 .

Dalton fam., $40 n$.

Dampard, Alice, $96 n$.

Dan, Ric., 92.

Dand, Ric., $90 n$, 9I $n$.

Danet, Amaury, 38I, 397; Gerard, $382 n$; John, Io9; Phil., 388 ; Ric. $45,381,397$; fam., 9, I 7, 62, $379 n$, $381,382,397$.

Danvers, Augustus Butler, $\mathrm{I}_{3} 8$; Jos., I $24 n, 125 n$.

Dare, Jos., 270, 271, 330.

Darker, John (d. I $\left.55^{8}\right), 8_{3} n$; John (d. I 784 ), I 3 I-3, I 34, I 35 .

Davenport, Eliz., see Wigston; Sam. 438; Thos., 78 ; Wm. (f. c. I 589), 422 ; Wm. (d. I64I), 422 ; fam., 421 , $422,424 n$.

Davenport's man., in Belgrave, $42 \mathrm{I}-2$, 424,425 .

Daventry (Northants.), 3 I 5, 3 I 6 .

Davie, see Davy.

Davies, Jemson, 406; Ric., 329, 332, 334

Davis, Edw., $364 ;-$, I 30 .

Davy (Davie, Davye), John (f. $c$ I 586), 79; John (d. I642), I05 $n$; John (fl. c. I677-I 700), I68 $n$; Thos. (f. c. I 333), 424; 'Thos. (d. I632), $85 n$; Thos. (fl. $c$. I 709), 39 I ; Wm., $96 n$.

Dawes, Wm., rog.

Dawson, Wm., I70.

Deacon, John, 39 I.

Deakins, -, I I 8 .

Deane, Wm., tailor, I $57 n$; Wm., woollen draper, I05.

Delft (Netherlands), 78

Denbigh, Ld., see Fielding.

Denman, -, I 45 .

Dent, Edw., 354

Denton (Lincs.), 400.

Derby, 6I, I I 8 , I $26,276,284-5$, 307 ; rly. from Leicester to, 260 architect, see Moneypenny, Pickford; builder, see Barron \& Son; framework-knitters, I75; merchants, 2 I $4 n$.

Derby, Earl of, see Hen.; honor of, 4 . Derbyshire, Thos., I69.

Derbyshire, framework-knitters, I69, I75.

Derwent, Riv. (Derb.), 284-5; reservoirs, 285 .

Desford, 407; industrial sch., 330.

Desgrand, J. V., $326 n$.

Despenser, Hugh, the elder, 4, 5; Hugh, the younger, 4,5 .
Dethick, Wm., 389

Devet (Dovet, Duyet), Rog., 40;

fam., $40 n$.

Devonshire, Thos., $97 n$.

Devonshire, Earls of, 353 ; see also Cavendish.

Dewes, Wm., 145.

Dicks, W., 3 I 7 .

Dilkes, J., 3 I 5 .

Disraeli, Ben., Ld. Beaconsfield, 22 I, 224, 227, 228.

Dix, Fr. Fabian, 390

Dixley Mill, see Hogsonn.

Dixon, Rob., 74.

Donaldson, F. L., 238.

Donington, Castle, vicar, see Wood, Pet.

Donington le Heath, 407.

Donington Park, see Hastings fam.

Donovan, T., $248 n, 249 n$.

Dorset County Asylum, superintendent, see Wallett.

Dorset, Marquis of, see Grey of Groby, Hen., Thos.

Dover (Kent) cast., constable, see Grey of Codnor, Sir Ric. de.

Dovet, see Devet.

Dowell (Dowel), Hen., 450; Wm., 79

Downinge, Edm., 380 .

Draker, Wm., 446.

Draper, John, 424.

Drax (Yorks.), abbey, 422.

Duce, John, $83 n$.

Duckworth, Sam., 204, 208, 2 I0, 2 I 6.

Dudley, Ambrose, Earl of Warwick, 67; Isaac, 44I; John (f., c. I76I$88), 440,44 \mathrm{I}$; John (d. I 856), 44I ; Paul, 44I; -, I I 4 , I I 7.

Duffy,,- 213.

Dugdale, John, 247.

Dunlop, Messrs., rubber manufacturers, $327,397$.

Dunstable (Beds.), I3I.

Durham Cathedral, prebendary, see Sampson, Thos.

Duyet, see Devet.

Dysart, Earls of, 353,452 ; see also

Manners, Wm. John; Tollemache,

Lionel Wm. John; Ctss. of, see Tollemache, Louisa.

Dyve, John, 435.

Ealing (Middx.), architect, see Vialls.

East India Co., I 34.

Easthope, John, 204, 208, 2I2, 2 I 5 , 2 I 6.

Easthorpe, in Bottesford, 399.

Eaton, Hen., $99 n$.

Eayre, Jos., 446; Thos., 359, 442; see also Ayre.

Edmund Crouchback, Earl of Lancaster, Leicester, and Chester, 4, I I, I 2, I 4, I9, 24, 46, 345, 434, 439. Edward the Confessor, 8.

Edward I, 4.

Edward II, 4, 4I8, 425.

Edward III, 5, 6, 425 .

Edward IV, 6 n, 7, 8, 26, 47, 429, 447 .

Edward VI, 56, 70, 437, 443, 452, Prince of Wales, 55 .

Edward VII, as Prince of Wales, 354.

Edwyn, John, and his w. Mary, 435; fam., 422, 435 .

Edyngton, John de, $357 n$.

Elizabeth I, I6 $n, 55,56,6 \mathrm{I}, 74$, . $79 n, 332,346,353,376,388,396$, $398,400,408,441,443,448,452$.

Elkington, Ric., $41_{3}$; see also Evington, -

Ellis, E. S., 226, 227; John, 2 I 5,217 , 218, 226, 42I ; Marg., 42I ; Wynn, I $47,149,202,203,210,212,215$; fam., 421,427 .

Ellistown, in Ibstock, colliery, 284 . 


\section{GENERAL INDEX}

Eltham (Kent), see Sherrard.

Ely, Bp. of, see Hothum.

Emery, Thos., 273.

Emmanuel Coll., Cambridge, see Cambridge.

Enderby, I I $, 187 n, 368,369,407$ 408; see also Smith, Chas. Loraine; Hall, see Brook, Chas.

English, Wm., 48 .

'Equity' (Productive Soc., Eagle), $323^{-4}, 325$

Erdington, Giles de, $429 n$; Marg., see Corbet; Thos. de (fl. c. I 364 ), 429; Thos. de (d. I 467), 429; fam., 429.

Erieck, Rob., 8 I $n, 88 n$.

Eton Coll., 240.

Evans, De Lacey, I 45; Capt. H. A., 244; P. W. Emrys, 246, $247 n$; Wm. (fl. c. I 825-35), I 44, I 45, I 46, 147, $149 n, 202,203$; Wm. (f. $c$. I 863), 424; Mrs. Wm., 33 I.

Everard, John Breedon, 352, 384 .

Everard \& Pick, architects, 363,437 , \& Keay, 363,377

Evesham (Worcs.), battle, 4, 434.

Evington (Elkington), - , 4I I .

Evington par., $187 n, 229 n, 287,300$ 434-8, 44I; bounds, 434; chs. $436-8$; econ. hist., 435; golfcourse, 436; man., 434-5, 439; man. house, 435 ; mills, 438 ; nonconf., 438 ; pop. 434,435 ; R Cath., 438 ; schs., $336,436,438$; vicar, 436,437 .

Cedars Hotel, 434; Coleman Rd. housing estate, 297,437 , sch., 336 ; East Park Rd., 436; Evington Brook, 434; Evington Hall, 434, 436, R.C. sch., 438, 442; Evington House, 434 ; Evington housing estate, 436; Evington Lane, 356, 434, 436; Evington Park, 436; Evington Valley estate, 294; Evington Valley Rd., 436, sch., 336; Highway Rd., 434; Leicester St. chap., 438; Mayflower sch., 336 ; St. Chad's ch., 437; St. Philip's ch., 437 ; St. Stephen's par., 437, ch., 437; Spencefield Lane, 434 Spinney Hill Park, 294, 436; Stoughton Rd., 434, 436; Uppingham Rd., 434; see also L., Evington, North, Spinney Hill ward.

'Exam', abbot of, $425 n$.

Exeter (Dev.), 37, I 59 .

Eyre, see Ayre.

Facken, Noye, $83 n$

Faire, (Sir) Sam., 229, 23I, 238; 229.

Faire Bros., elastic web manufacturers, 327.

Fairfax, Sir Thos., 68.

Fallows, Wm., ro5.

Farmer, John, I22; Wm., 359; - of Kilby, 390 .

Farnham, Humphrey, 443; Mat., 443, Rob., 443; Thos., 443; fam., $443 n$.

Faunt, Geo., I I I

Fawcett (Fawsitt), Gil., 76, 85, Io6 $n$ R., 3 I 6.

Fawdon (Northumb.), see Hazlerigg, Thos. (f. I5th cent.).

Fawkner, Ralph, $83 n$.

Fawsitt, see Fawcett.

Federated Assoc. of Boot \& Shoe Manufacturers of G. Britain, 322; president, see Ward, J. Griffin.

Felkin, Wm., 303, 305, 306, 307, 308, 309, 3 10.

Fenning, A. R. G., 394.

Fenstanton (Hunts.), conventicle, $39 \mathrm{I}$.
Fenwick, Miss, 357.

Ferrers, Eleanor de, m. Rog. de Quency, 429; Marg. de, see Quency.

Ferrers of Chartley, Ld., see Shirley.

Ferrers of Groby, Wm., Ld., 429; fam., $421,422,429$.

Fielding, Basil, Ld. Denbigh, I33, I34.

Fields, see Rawson \& Fields.

Finch, Dan., Earl of Nottingham and Winchilsea, I I $3 n$, I I $7 n$; Heneage, Earl of Nottingham, I 13 .

Firmadge, Wm., I 5 I, $290 n, 33^{8}, 358$, 372.

Fisher, John, I30, I 33, I34 n; Wm., $398,405$.

Flanders, 37,78 .

Fleckney, see Devet fam.

Fleetwood, Sir Miles, 64.

Fleming (Flemyng), Thos., I oo, IOI $n$; Wm., $352,353,356$.

Flint \& Wickes, architects, 377

Flower, Jane, 395 ; fam., 395.

Forcer, Hen. le, 4 I 6 .

Forrester fam., 343.

Fortrey, Wm., 359

Fosbrooke, T. H., 362 .

Fosse Way, 3 I, I93, 381, $383 n, 428$; see also L., Narborough Rd.

Foston, I24.

Foston (Lincs.), 398

Fotheringay (Northants.), cast., 55 .

Fowke, Sir Fred., I4I.

Fowker, John, $88 \mathrm{n}$.

Fowkes, Wm., 406.

Fowler (Fowlzer), John, $97 n$; Wyatt, 395 .

Fownes, Lucy, 380.

Fox, Chas. Jas., I35, I37; Geo., 390, 394; Jas., 80, 8г $n$, I09; Stafford, 440.

Foxon, Jas., 84

Framework Knitters' Co., I69, I70 $n$, I 7 I, $175^{-6}$

France, 5, 220, 327, 437; see also Calais, Paris, Rouen, Rhé, Isle de, St. Evroul.

Franciscan Minoresses, 446.

Franke, Wm., I $57 n$.

Franklin, G. B., 335, 444

Fraser, Foster, 240.

Freake, John (d. 1 595), 77, ror $n$; John (f. c. I625), 450; Phil. (d. I 588), 92, IOI ; Phil. (fl. c. I 589), 449-50.

Freak's Ground, see L., Freak's Ground.

Free Church Council, 248.

Freeby, see Hartopp, Sir John.

Freeman, And., I I $4 n$, I I $5 n, 157 n$; Ralph, I02, I03 $n$; Rob., $83 n$.

Freeman, Hardy \& Willis, footwear manufacturers, 3 I 9 .

Freer, Thos., 382 ; Maj. W. J., 444.

Frewen, C. H., 210; Thos., 377; fam., 377.

Friendly Socs. Council, 24I.

Frisby on the Wreake, 45.

Fruett, Bart., $96 n$.

Fulutun, Wm. de, $457 n$.

Fyllyppe, see Philip.

Gaddesby, man., I 36

Gainsborough (Lincs.), 97; man., lord of, 107.

Galer, Eliot, 362

Galloway, M. G., $248 n$

Gardner, Ric., 215, $216,218,219$, 220.

Garendon, abbey, 422.

Garland, Ben., 369.

Garle, Ric., I69, I 70.

Garnate, Edw., $85 n$.
Furnys, Geo., $89 n$.
Garner, D., $315 n$.

Garrett, Ralph, $79 n$, $90 n$.

Gartree hund., I6; see also Evington, L., Bishop's Fec; constable, see Nedham, Fran.

Gartree Rd. (Stongate), 35 I, 354, 370, $434,444 n$.

Gas Council, $302 n$

Gascoigne, Royce, \& Co., footwear manufacturers, 3 I0.

Gaunt, John of, see John of Gaunt.

Gaveston, Piers, 4.

Gayhurst (Gotehurst) (Bucks.), see Wright, Geo.

Gayton (Northants.), I 3 I.

Geary, Dr. John, Archdeacon of Stowe (later, of Buckingham), I I4I 8.

Gee, H. Simpson, 229, 23I, 3 I 6.

Geneville fam., arms, $43^{8}$.

George I, I 23, I 24

George II, as Prince of Wales, I24.

George III, I35, I4I.

George IV, as Prince Regent, I39 $n$.

George, D. Lloyd, 243, 244, 245, 246

Germany, 220, 248; hosiery ind., 313.

Gerothwohl, M. A., 245, $246 n$.

Gies, Wm., 346.

Giffard fam., arms, 438 .

Gilbert, Alice, 76, I06 $n$; Ant., I09 Faustin, 9I, 96.

Gillet \& Johnstone, bellfounders, 419

Gillot, Nic., I $06 n$; Wm., 79-8o, $88 n$ Io6 $n$.

Gilroes, see L., Gilroes.

Gimson, S., 245

Gimson Shoe Machinery Co., 320; see also L., Vulcan Works.

Gissing, Alan of, 39.

Gladstone, Thos., 149, 203, 205 ; Wm. Ewart, 223, 226, 227, 228, 229, 231

Glen, Great, I 8 I.

Glen Parva, $187 n$; chapelry, 4I5 4 I 8 .

Glenfield, par., 43I, 453; chapelry, see Braunstone; rector, 432 ; see also Winstanley, Geo.

Glenfields, 455 .

Glossop, Edw., 76, 105 $n$.

Gloucester, 45; bellfounder, see Rudhall.

Goddard, Hen., 342; Hen. Langton, 360 ; Jos., 35I, 352, 353, 392, 437 , 441 .

Goddard \& Paget, architects, 334 $342,360,363,44 \mathrm{I}, 445$.

Good, Thos., I0 4 .

Goodacre, J., 408, 4I8; Rob. Johnson, 408, 409, 4I 8 .

Goodyear, Fred., 255

Gordon, Gen. Chas. Geo., 229; Geo. Hamilton, Earl of Aberdeen, 2 I9; Jos., 279

Goscelin, Hen., 37 I $n$.

Goscote, East, hund., see Belgrave, Humberstonc.

Goscote, West, hund., see L., Abbey Gate, Beaumont Leys, Leicester Frith.

Gotehurst (Bucks.), see Wright, Geo.

Goulburn, Edw., I49-50, 203, 205 ; Hen., 205.

Gould, F., 248.

Gracedieu (Gracedue), Bart., 76-77, 96; Wm., 108

Gracedieu, see Beaumont, John, fam.; priory, 422, 424.

Granby, Marquis of, see Manners, John.

Great Central Rly., 290 n, 344, 383, 384,410

Great Northern Rly., 356.

Greathead, Bertie, I36.

Greaves, Jas. Liptrott, I 45, I 47. 


\section{A HISTORY OF LEICESTERSHIRE}

Green (Greene, Grene), G., 3 I6; Geo., I67; J. Baker, 226; J. F., 242, 243,244 ; Thos., 83 ; Wm., $85 n$.

Gregory, John, the elder, I90; John, the younger, I90; Mansfield, I 45; Thos., I 69; Wm., $98 \mathrm{n}$.

Grendon, Peter of, 42,342 .

Grene, see Green.

Grentemesnil, Adeliz w. of Hugh de, 42I, 423; Hugh de, I-2, 3I, 376 $379,38 \mathrm{I}, 42 \mathrm{I}, 423,424,425,428$, 434 , 44I, 447; Ivo de, 2 ; fam., $2 n$, 370.

Greshop, - $406 n$.

Grey, John, I I O, I I 2, I I 3; Job, 402, 406.

Grey of Codnor, Hen. de (d. I 308 ) 435; Hen., Ld., 434; John de (d. I 27 I), 434; John de (d. I 392), 439 $443 n$; Lucy, see Humet; Ric. de (fl. c. I 239), 434; Sir Ric. de (fl. c. I 265), 434, 439; Ric. de (d. I 335 ) 435 ; fam., $434,438,439$, arms, 438 .

Grey of Groby, Booth, I 34, I 35, I 36 ; Edw., 429; Eliz. w. of Edw., 429; Harry, Earl of Stamford, I 34 Hen., Marquis of Dorset, Duke of Suffolk, 55, 343, 354, 429; Hen., Ld., Earl of Stamford, 56, 395; Hen., Ld., 66, 67; Sir John, 59; Thos., Marquis of Dorset, 429, $447 n$; Thos., Ld., Earl of Stamford, 60 , I $19^{-20}$, I 21 ; fam., 55,56 , $422,429$.

Grimsby (Lincs.), 45

Groby, road from Leicester to, 450 , 453; see also Ferrers of Groby fam., Grey of Groby fam.

Grosseteste, Rob., Archdeacon of Leicester, prebendary of Lincoln Cath., $357 n$, Bp.of Lincoln, 4, 357. Gumley, 393; see also Craddock, Jos. (fl. c. I8I 5 ).

Guthlaxton hund., see Aylestone, Knighton, L., Castle, Newarke, The

Gutteridge, Wm. (d. I662), $95 n$; Wm. (d. I675), $95 n$.

Guy's Cliffe (Warws.), see Greathead.

Hacket (Hackett), Phil., 406; -, 43 I.

Hackle, John, I I 2 , I 17.

Haddon Hall (Derb.), 4I 5, 4I 6.

Haimes, see Hames.

Halford, Hen., I 16 ; Sir Hen., $205 n$, 216.

Hall, Amos, 352; John (d. I 584), 86, $87 n$; John (fi. c. I645-50), 84; John (fl. c. I66o), I 84 ; Rob., I 76 , 39 I ; Thos., I3 I, I32.

Hallam, Ric., 3 I 6.

Hallaton, I 26 .

Hallhead, Nat. Brassey, I 36.

Halpennye, Hen., $98 n$.

Halsope, see Alsop.

Halstead, man., $57 n$.

Hames (Haimes), F. J., 363 ; Rob., I I 3

Hamilton, man., 4Io.

Hammont, Sam., I $68 n$.

Hand Framework Knitters' Fed., 3 Io.

Hanover, King of, 205.

Hansom, Jos., 335, 392.

Harbert, see Herbert.

Harborough, Market, I 72, 316; road from Leicester to, I 54; rly. from Leicester to, 260, 443; turnpike from, to Loughborough, I6I-2, $264,265,352,423,424,443,444$ surveyor, see Parsons, Wm.; see also Coleman, Hen. (fl. c. I 76I), and his w. Ann, Taylor, Sam. (fl. c. I 761 ), and his w. Eliz.

Harcourt (Harecurt), Alice w. of Wm. (fl. I $4^{\text {th }}$ cent.), 4I 5 ; Anne w. of Wm. (f. c. I 467), m. 2 Wm. Norris, 429; Arabella, see Quency; Arabella (d. I 280), 4I 5; Marg., 4I 5, 4I6; Ric. (fl. c. I2I0), $429 n$; Ric. (d. I 258), 4I5, 4I8; Ric. (fl. $c$. I 293), 4I5, 429; Sim., 429; Wm. (fl. $c$. I2I9), $4 \mathrm{I} 8 ; \mathrm{Wm}$. (fl. I 4 th cent.), 4I5; Wm. (fl. c. I 467), 429; Sir Wm., 429; fam., 4I 5, 4I6, 4I8, 429.

Hardie, Keir, 234; see also Hardy.

Harding, Rob., I I I $n$, I I 3 ; Dr. 445 ; see also Bellamy \& Harding.

Hardwick, Rob., 403, 406.

Hardy, J. Stockdale, I 4I; John, 328; see also Freeman, Hardy \& Willis, Hardie.

Harecurt, see Harcourt.

Hargreave, Hen., 328.

Haringworth (Northants.), see Zouche fam.

Harlaxton (Lincs.) 398

Harrington, Sir Hen., 57, 353; Sir John, $454 n$.

Harris, J. O., 455; John, 220, 22 I, $222,223,224,226,227$; Jos. (fl. $c$. I 846 ), 382 ; Jos. (fl. c. I 890 ), 377 ; Ric., I78, 206, $207 n, 217,218$, 220; - I I 4, I I 7, I 20.

Harrison (Heryson), Beatrice, $m$. Orson Wright, 456; Geo., I 46 ; Hen., 422, 45o, 456; Isaac, 426, 453, 455-6; J. Stockdale, 384, 437, 445 ; Joshua, 362 ; Rob., $97 n$; Wm., $338-41,372$; - 392 ; fam., architects, $34 \mathrm{I} n$; fam., market gardeners, $422,450,455$

Hart, Sir Israel, $236-7,238$

Hartewell, see Hartwell.

Hartley, E. R., 24 I.

Hartopp, Anne, see Hurlock; Sir Edm. Craddock (fl. c. I846), 443, 446; Sir Edm. Craddock (fl. c. I 878$), 443$; Sir John, I I 3, 443; Sir Wm., I I 2, I I 3 ; fam., 440; see also Craddock.

Hartshorn (Hartshorne), C. W., 246 $247 n$; Thos. (d. I66I), I05 $n$; Thos. (fl. c. I 705), I 86.

Hartwell (Hartewell), Thos., I82; Wm., I $86 n$.

Harvey, Steph., 396.

Harwar, Nic., 400, 405.

Haseldine, Wm., 440.

Haslocke, John, $85 n$.

Hassell, Hugh, I о I $n$.

Hastewell, Wm., $99 n$.

Hastings, Sir Chas. Abney, I 44, I 45, I 46; Edw., Ld. (d. I 506), 8, $429 n$; Sir Edw., Ld. Loughborough (d. I 558), 45I-2; Sir Edw. (d. I603) 57, 6I, 94, 395, 396; Fran., 64, 396, 40I ; Geo., Ist Earl of Huntingdon, 8, 78, 434; Geo., 4th Earl of Huntingdon, 56; Hen., 3rd Ear of Huntingdon, $64,66,74,86,332$, $36 \mathrm{I}, 395,400,40 \mathrm{I}, 429,449,450$, $45 \mathrm{I}, 452$; Hen., 5 th Earl of Huntingdon, $57,58,60,6 \mathrm{I}, 62,64,70$ 7 I $n$, I $08,365,406$; Sir Hen. (d. I 629), 397, 440; Sir Hen. (d. c . I650), 67, 428, 429-30; Sir Hen (d. I697), 440; Jane, m. John Craddock, I I 5 ; Ralph de, 429 Ric., 43I; Theophilus, 7th Earl of Huntingdon, I I I, I I 3, I I 4-I I24, his chaplain, see Geary; Wal. 429, 430, 431, 432; Wm., Ld., 8, 429 ; fam., $8,65,66,42$ I, 429, 430 , $434-5,440,452$; see also Huntingdon, Earls of.

Hathern, 400; see also Zouch bridge.

Hatton, Sir Chris., 44I, 452.

Hawes (Hawys), John, 45 ; fam., 440. Hawford, Hamiel, $85 n$.

Hawkes, Wm., 97.
Hawkesbury, Ld., see Jenkinson.

Hawys, see Hawes.

Hayne, Thos. (d. I640), 4I3; Thos

(fl. c. I 645), 365 .

Hayton, Wm., 406.

Hazell, W., 233, 234, 235, 236.

Hazlerigg (Hesilrige), Sir Art. (fl. c. I 654-60), 56, 60, 66, 67, I 10; $\mathrm{Sir}$ Art. (fl. c. I 754), I 27 ; Isabel, see Heron; Thos. (fl. I 5 th cent.), $439^{\circ}$

Thos. (fl. c. I 5 I9), 439; fam., 439.

Heath, J. Wedgewood, 3 I 9.

Heathcote, John, 308; Wm., 419.

Hedleyhope (Dur.), see Sanderson.

Heighton, Geo., I 88-0.

Henbury (Ches.), see Davenport, Wm. (fl. c. I 589 ).

Henderson, Art., 238; Wm., $372 n$.

Henry II, 345 .

Henry III, $3 n, 4$, I $n$, I I, I 9, 32,47 ,

Henry IV, 6, 22, Duke of Lancaster, 6-7.

Henry V, 6, 7, 425 .

Henry VI, 7 .

Henry VII, $6 n, 7-8,27,43,54,434$.

Henry VIII, $54,284,343,387,425$, $434,437,447,448,45$ I

Henry the young king, s. of Henry II, 3

Henry, Earl of Derby and Lincoln,

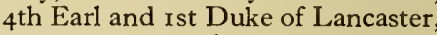
5,2 I $, 33,47,346,397,450$.

Henry of Lancaster, 3 rd Earl of Lancaster, 5, 20, 22, 346, 37 I, 395. 396.

Henry juxta aquam, 416.

Henry le Forcer, see Forcer.

Henshaw, John, $98 n$.

Herault de Saint Sauveur, John, 40I, 405.

Herbert (Harbert), Alb., 433; Ric. $89 n$.

Hereford, Bp. of, see Cornewall; Ctss. of, see Bohun.

Hereswode, 32, 447

Herle, Rob. de, 429, 430; Wm. de, 429.

Heron, Isabel, m. Thos. Hazlerigg (fl. I 5 th cent.), 439 .

Herrick, Jas., 59; Rob. (fl. c. I 59I), 86; Rob. (fl. c. I666), 80; Thos., I $06 n$; W. Perry, $359 ;$ Wm., I32 $n$; fam., 362,367 .

Hertfordshire, East, M.P., see Rolleston.

Heryson, see Harrison.

Hesilrige, see Hazlerigg.

Hesilrige's man., in Humberstone, 439-40.

Hewart (Heward), (Sir) Gordon, 24I, 242, 243; Hen., $99 n$.

Hewin, Rog., I о I $n$.

Hewitt, Fran., 294-5; Wm., I24 n, I $25 n$.

Hewitt, F., \& Son Ltd., newspaper proprietors, 295

Heygate, W. V., $22 \mathrm{I}-2,223$.

Heyrick, John (d. I633), $92 n$, I06 $n$; John (f. c. I 765), I 30, I $31,132-3$ Rob., $57 n, 387,413$; Thos. (d. I625), 8I $n$; Thos. (d. I63 I), $89 n$; Sir Wm., 66, 406, 408; fam., 65, 66, I 28, I 32 .

Heyting, W. J., $249 n$.

Heyward, Rob., $99 n$.

Hill (Hyll, Hull), Alf., 244; John (d. I 584), 79; John (fl. c. I 833), I $42 n$; Randall, $89 n$; Ric., I68 $n$; Thos., $96 n$.

Hilton (Hylton), Jas., 93; Ric., 80; T., 3 6 ; Wm., 93.

Hinckley, 68, 79, 97, 126, 389 ; market $4 \mathrm{I}$; road from Leicester to, 38I, see also L., Hinckley Rd.; hosiery ind., 307 .

Hinman, Geoff., I $68 n$. 
Hitchcock (Hitchcocke), Wm. (d. 1632), 90, $99 n$; Wm. (d. 167I) $99 n$; fam., 397.

Hitchin (Herts.), 260

Hobart, Sir Hen., Chief Justice of Common Pleas, 74.

Hobby (Hobbie), Marg., 4II ; Wm., $97,102$.

Hodges \& Turner, elastic web manufacturers, 327 .

Hogsonn, Geo., 9 I $n$.

Holbeach, Fran., 422

Holme, Thos., $99 n$.

Holmes, Cath., 36o; John Kirk, 398 Wm. (fl. c. I649), 94; Wm. (d. 1770 ), 130

Holyoake, G. J., $228 n$.

Hood, Wal., I I 9.

Hook, Wm., 449.

Hopkins, Wm., $83 n$.

Hopps, Page, 226.

Horne, John, 95.

Horninglow (Staffs.), 398.

Hothum, John de, Bp. of Ely, 4.

Hotoft, Ric. (d. I45I), 439; Ric. (d I 547), 442 ; Rob. (fl. c. I 288), 439 Rob. (fl. c. I 3 I6), 439; -, bailiff, 23; fam., 439.

Hotoft's man., in Humberstone, 439.

Houghton on the Hill, 126, 407.

Houhil, Hen., 39 .

How, see Howe.

Howard, Anne w. of Thos., Earl of Surrey, 434; Frances, m. 2 Hen Brooke, Ld. Cobham, 455; John, prison reformer, 163,388 ; T. B., 316; Thos., Earl of Surrey, 434.

Howe (How), Emanuel Scrope, Viscount Howe, $124 n$; Ric. Wm. Curzon, Earl Howe, 360 ; Thos., $105 n$.

Howell, Rob., 48.

Howgham, John, Ioo $n$.

Hubbarde, Eliz., $100 n$.

Huddyleston, Ric., $99 n$.

Hugh le Mercer, see Leicester, Hugh de.

Hull, see Hill.

Humberstone par., 126, 26I, 279, $287,300,332,439-43$; admin., 44I; chs., $439,44 I-2$; chars., $442-3$; econ. hist., 428, 440-1 ; mans., 43940 ; man. house, 439, 440; nonconf., 442; pop., 440, 44I ; R. Cath., 442 ; rector, 441 ; schs., 336 442 ; vicar, 440, see also Dudley, John, Paul, Wilson, Thos.; vicarage, 44I ; workhouse, $44 \mathrm{I}$.

Abbots Rd. chap., 442; Bridge Rd. sch., 336, 442; Cunnery, The, 440 ; Edgehill Rd. chap., 442 Gipsy Lane, 443; Grange, The, 439; Humberstone Drive, 443 ; Humberstone Lodge, 439; Main St., 439; Marston (Stayne) Meadow, 440; Middle Field, 440; Mill Field, 440; Mundella (Tailby Estate) sch., 337; North Field, 440; North Meadow, 440; Orchard, The (Crow Orchard), 442-3; Overton Rd., 360, 44I, chap., 442, sch. 337, 442; Sacred Heart R.C. par., 442; St. Barnabas par., 437, 44I, ch., $44 \mathrm{I}$; St. Joseph's R.C. par., 438, 442 , chap., 442; South Field, 440 ; Stein's Lane, 439; Swan's Orchard, 439; Tailby Estate, 297; Thurmaston Lane, 439, 443; Thurnby Rd. (Norman's Lane), 440; Towers Hosp. (lunatic asylum!, 279, 439, 440, 44I ; Town (Church) Land, 442; Uppingham Rd. chap., 442; Victoria Rd., 44I; see also Hesilrige's man., Hotoft's man., Humberstone, New, L., Humberstone, West.
Humberstone, New, 439, 440-I ; rly. stn., 439.

Hume, Jos., $21 \mathrm{I}$.

Humet, John, 437, 439; Jordan, 44I ; Lucy, $m$. Sir Ric. de Grey of Codnor (fl. c. 1 265), 439 .

Humphries, John, 9I.

Hungary, 220

Hungerford, J. P., I 32, I 33

Hunt, Bart., $96 n$; Geo., $89 n$; Hen., I 45 ; John, 79.

Huntingdon, Earls of, 8, 6o, 66; see also Hastings, St. Liz; house, see L., Lord's Place.

Huntingtower, Ld., see Tollemache, Lionel Wm. John.

Hurlock, Anne, m. Sir Edm. Craddock Hartopp (fl. $c$. 1846), 443.

Huskisson, Wm., I 45 .

Hutton, Jonathan, 91 $n$; Rob., $105 n$. Huxley, Sam., $88 n$, I05 $n$.

Hyll, see Hill.

Hylton, see Hilton.

Ibstock, 42 ; see also Ellistown.

Ichind, Thos., $97 \mathrm{n}$.

Iliffe, John, $43 \mathrm{I}$

Illston on the Hill, I8I, I87 $n$.

Incestre, Geo., $425 n$.

Independent Labour Party, 232-3.

Inge (Ynge), Edw., 444; John, $96 n$;

Ric., 78 ; Wm., 449; fam., 444; fam., of Thorpe Constantine (Staffs.), 449.

Ingham, Thos., I05 $n$

Ingram le Bocher, see Baker, Ingram le.

Ingulward, Ric., 98.

Inman, Chas., I5 I $n$.

Inninges, Geo., 88.

Inskip, Wm., 232, 233, 234.

Instone, Alf, 244-5

Ipswich (Suff.), 33 .

Ireland, Geo., 143 ; Jos., 389

Ireland, 108, 205, 229.

Isabel (of France), queen of Edw. II, 4,5 .

Italy, Soc. of Friends of, 222.

Ive, Jane w. of Wm., 4II; Wm., 4II.

Ives, Wm., 82.

Ivo, 434,435 .

Ivo, Adam s. of, see Adam s. of Ivo.

Jackson, John, I25, 403, 406; Wm. 353,409 .

James I, 55, 57, 61 , 62, 66, 455

James II, I I 3 , I I 7 , I I 9 .

James, Hen., Ld. James of Hereford, 322

Janner, B., $248 n, 249 n$.

Japan, 247

Jarvis (Jerves), John, I05; Ric. (d. 1670), $96 n$; Ric. (d. 1675 ), $96 n$.

Jeffery (Jefferey), John, $96 n ;$ Wm. $83 n$.

Jenkinson, Chas., Ld. Hawkesbury, 407.

Jerman, Wm., $88 n, 99$

Jerusalem, Knights of the hospital of, 447; prior, see Manby, Rob. de. Jerves, see Jarvis.

Jessons, Thos., $99 n$.

John, King, 3, 10, I I, I9 $n, 32,42 \mathrm{I}$.

John XXII, Pope, 4.

John of Gaunt, Duke of Lancaster, $6,22,33,47,49$.

John, mason, 42 .

Johnson, Edm. (fl. c. I684), II $15-16$ I 77 : Edm. (fl. c. I 724), $397 ; \mathrm{Edm}$. (fl. c. I 756), 444; Fielding, 229 Geoff., 406; Hen., 397; Jas., 58 ; John(d.c. 1786), and his W. Frances,
368; John (d. I815), I63, 338, 362, $363,368,409,443$; Ralph, $83 n$; Ric. 77,79 ; Rob. (d. 1538 ), $83 n$; Rob. (d. 1627), 82; T. Fielding, 333, 374 Thos., 77; Wm., 87-88; fam., 409; see also Abell, Wilkes Bros. \& Johnson.

Johnson \& Bailey, footwear manufacturers, $323 n$.

Johnstone, John, 105; see also Gillet \& Johnstone.

Jones, Luke, $8_{3} n$; Thos. Hen., 406 .

Jordan, Rob., 94

Joseph, Thos., $88 n$, $105 n$.

Judge, Wm., 390.

Judith, Ctss., I, 32, 395.

Keay, Wm., 367; see also Everard \& Pick.

Keble, Hen., 440; Jane w. of Hen., 440, $442 n$; John, 439; Marg., m. - Bowes, 440; Thos., 439, 44I ; Wal., 439 ; fam., 442.

Keck, Ant. Jas., I 3 I, I 33, I34; fam., 435, 444; see also Powys-Keck.

Keckwick, Thos., 77, 103 $n$.

Keene, Wm., I 55 .

Kellam, Mary, $88 n$

Kelly, 一, 387

Kempson, W., 31 7 ; see also Walker \& Kempson.

Kemsley Press, 295.

Kent, 193.

Kershaw, Eliz., 382 .

Kestyn (Kestian), Eliz., m. Edm. Spencer, 393; Nic., 393

Kettering (Northants.), 273, 316; rly. from Leicester to, 260 .

Kettleby, Eye, 131.

Ketton, Rog. of, 38

Kibworth, I 12.

Kilby, see Farmer, -

Kimcote, 398.

King (Kinge), Ben., 429, $430 n$; Gregory, 79; Jas. (d. I625), IOI $n$; Jas. (d. 1660), $97 n$.

Kingsthorpe (Northants.), $40 \mathrm{r}$

Kingston, Sir Wm., $65 n$.

Kingston-upon-Hull (Yorks.), 40.

Kirby, J. A., $248 n$; Sam., 253-4.

Kirby Bellars, priory, 422.

Kirby Muxloe par., 300, 449

Kirk, John (fl. c. I 696), I 82 ; John (fl. c. I795), 449; Joshua, I82; Wm. (d. I660), $92 n, 93$; Wm. (fl. $c$. I 8 I 8 ), 372 .

Knaptoft, see Turpin.

Knight, Eliz., $90 n$; Jos., 415; Randall, $99 n$.

Knighton, Hen. of, $53 n$.

Knighton par. (formerly chapelry) I6, I 97, 260, 287, 350, 35 I, 354, $370,381,410,443-6$; chars., 446 ; chs., $357,445-6$; econ. hist., 4445; man., 16, 107, 353, 354, 443; non-conf., 446 ; pop., 444,445 ; $\mathrm{R}$. Cath., 446 ; schs., $337,444,446$.

Alexandra $\mathrm{Rd}$. 445. Avenue

Rd., 445; Breach Field (la Breche), 444; Brookfield, 444; Clarendon Hall chap., 446; Clarendon Park, 29I, 443, 444-5, 446, chap., 446; Clarendon Park Rd. chap., 446, sch., 336, 446; Cow Pasture, 444; Craddock Arms, 443; D'Oyly estate, 444, 445; Elmfield, 444; Francis St., 445; Goldhill Field, 444; Hawthorns, $445 n$; Knighton Fields factory, 324; Knighton Fields Rd., 445; Knighton Fields Rd. West sch., 337; Knighton Hall, 443; Knighton Park Rd., 444, 445; Knighton Rd., 445, 446; London Rd., 445; Manor Rd., 443; New (South) Knighton, 445; Our 


\section{A HISTORY OF LEICESTERSHIRE}

Knighton (cont.)

Lady of the Angels convent, 446; Queen's Rd. chaps., 446; Safforn Field, 444; St. Francis, hosp., 446; St. Guthlac's chap., 445; St. John the Baptist par., 445; St. Margaret's ch., $446 n$; St. Michael 8 All Angels par., 445, ch., 445 ; St. Thomas More R.C. ch., 446 Sandown (Lansdown) Rd., 445; Shrubbery, 444; Sir John North sch., 337; Southernhay Rd., 446; Springfield House, 444; Stockwell Field, 444; Stoneleigh sch., 331 ; Stoney Gate, The, 444, 445: Stoneygate, 23 I, 242, 260, 29 I, 443, $444,445,446$; Stoneygate chap. 446; Stoneygate House, 444, 445; Stoneygate Rd., 445; Stoneygate sch., 33 I , 335, 445, proprietor, see Franklin; Stoughton Rd., 445 ; Thornleigh, 445; Toller Rd., 444; Washpit Brook, 443; Welford Rd. 443; Woodland Ave., 445; Woodlands, 445 ; see alsc L., Abbey Park, Knighton St. Martin's ward, St. Margaret's Pasture.

Knott, Jas., 3 5 ; Thos., 3 I 5.

Knyvet, Sir Thos., 454.

Kyrkeham, Wm., roo $n$.

Labour Representation League, 224; secretary, see Broadhurst.

Lacy (Lacey, Laicy), Anne, 376,380 John, and his w. Anne, 380; Thos., I05 $n$.

Ladysmith (Natal), 235, 236.

Laicy, see Lacy.

Lambe, Sir John, 436.

Lambert, John, I05 $n$.

Lancashire, I93.

Lancaster, Duchy of, I, 6, 8, 22, 26 $33,49,6$ I-65, I07, I I 3, I $30, I_{4}$ I $179 n, 198,332,363,395,397,398$ $400,408,421,434,439,447,448$ $449,450,453,454$; council, 401 court of Duchy Chamber, $61,63,94$ 402 , officers, 66 ; attorney-general 86, see also Bromley, Geo.; chancellor, 6o, 6r, 70, 400, 403, 408, see also Grey of Groby, Thos., Ld. Earl of Stamford, Jenkinson, May, Sadler, Stanley, Jas.; steward, see Pares, Thos. (fl. c. I 768); auditor forLeicester, 63 ; receiver, for Leicester, 47,63 ; seal, $6,61,407$.

Lancaster, honor, earldom, 4, 6 earls of, $I, 56,344,345,346,38 \mathrm{I}$ $395,421,434,447$, see also Edm. Crouchback, Hen., Hen. of Lancaster, Thos.; dukes of, I, 35, 50 56, I $53,344,345,38 \mathrm{I}, 395,42 \mathrm{I}$ $43 \mathrm{I}, 434,447$ see also Hen. IV, Hen., John of Gaunt ; duke's (earl's) steward, 4I, 344, see also Belgrave Rog. de; palace, see L., Castle.

Langford, John, 82, $87 n$.

Langham, J., \& Sons, footwear manufacturers, 317

Langham, Thos., $99 n$

Langton, Rob., 79.

Laud, Wm., Abp. of Canterbury, 390, 425

Launder, Anne, 77, 97; John, 77, 97.

Laurence le Seler, see Seler, Laur. le.

Lauretta, Ctss. of Leicester, 43

Lawrence, John, 423; Pethick, 245 , $246 n, 247 n ;-, 448$.

Lawson, F., $246,247 n, 248$.

Laxton, Geo., I 68 ; Thos., I68 $n$

Layton, Wm., I05 $n$

League of Nations, 247, 248; Union, 248.

Leamington, John, 40; Ralph, 40.
Lee, Edw., 89; Ric., 402, 406; Wm., 307 ; see also Leigh.

Leeds (Yorks.), 31 5, 316.

Legitt, Ric., $95 n$.

Leicester, Ellen, 338; Hugh de, le Mercer, 40; Kettell of, 55; Pet. of, I8.

Leicester, Archdeacon of, see L., archdeacon.

Leicester, Bishop of, see L., bishop.

Leicester, Earls of, see L., earls.

Leicester, see of, see L., see.

Leicester Abbey par., see L., Leicester Abbey.

Leicester Frith, see L., Leicester Frith.

Leicestershire, 2, 56, 192, 302; third penny, $2 n, 3$; taxation, 6o; pop. I9I; assizes, see $\mathbf{L}$., courts and the administration of justice.

Officers, 66-68, III; (high) sheriff, I $8,56,66,67,68$, I 53, see also Grentemesnil, Hugh de, Ivo de, Simons, Mat., Skipwith, Sir Hen. (fl. c. 1636), Vann, Wm.; lord lieut., 66, 67, see also Grey of Groby, Thos., Earl of Stamford, Hastings, Hen., 3rd Earl of Huntingdon, Theophilus, 7 th Earl of Huntingdon, Manners, John, ist Duke of Rutland; maj.-gen., see Whalley, Col. Edw.

J.P.s, 25, 26, 57, 66, 1 25-6, I 48 , $345,362,409$, see also Burnaby, Rob., Mundy, Winstanley, Clement (f. c. I773-I8Io), L., courts and the administration of justice, J.P.s, jurisdiction; clerk of the peace, see Freer, Thos., W. J

Survevor, see Parsons, Wm.; M.P. see Halford, Sir Hen., Paget, Thos.; carters, 40; footwear ind., $317 n, 326$; hosiery ind., 167,175 , 192

Leicestershire County Council, 287, 279.

Leicestershire and Northamptonshire Union Canal, see L., Grand Union Canal.

Leicestershire and Rutland Sunday Sch. Union, 328.

Leicestershire, Royal, Regt., 346, 368. Leicestershire, West, Coalfield, I 99.

Leigh, Sir Egerton, I 37; J. Boughton, I47, 202; see also Lee.

Lennard, Sam., 3 I6.

Leveric. Wm. s. of, see Wm. s. of Leveric.

Leverich, Ric., 28.

Lewin, 4 I 6.

Lewin (Lewen), John, I68; Rog., I 57; Thos., $405 n$.

Lewis, Hugh, 369 ; S. K., $249 n$; Wm., I78, 392.

Leydebeater, Ric., 79, 86.

Leyden (Netherlands), 78.

Lichfield, Bp. of, 426; see also Coventry and Lichfield.

Liddington (Rut.), 350.

Liège, Jakemin of, 39,46 .

Lincoln, Ric. of, $47 n$.

Lincoln, 22, 49; lawmen, $12 n$; cast., 2 ; Cathedral, prebend, see L., St. Margaret's ch., prebendary, see Edyngton, Grosseteste, Lound, Walcote, Dr. John; architects, see Bellamy \& Harding.

Lincoln, Bps. of, 2, I6, 43, 65, 350, $395,437,443$, see also Alexander. Alnwick, Atwater, Barlow, Wm. Blois, Bullingham, Grosseteste, Longland, Remigius, Wells, Hugh of, Williams, John; officers, 65 ; commissary, 328 , see also Chippingdale; registrar, 328 ; registrar's clerk, see Palmer,Hen. (fl. I 7 th cent.).
Lincoln, Earl of, see Hen.

Lindsey, Marg., go $n$.

Liverpool (Lancs.), 225, 265; see also Roscoe, Walmsley.

Local Government Board, 278-9, 28I $287,288$.

Lockwood, Geo., I42 $n$, I 5 I $n$.

Loddington, I I 3 ; man., I I $3 n$; see also Pretyman.

Loder, Capt. J. V., 245, 246, $247 n$.

Loleby, Wm., $9 \mathbf{I}$.

London, Ralph, 390.

London, city of, 22, 49; ld. mayor see Abney, Sir Thos., Whitehead, Sir Jas.; St. Bartholomew's Hosp., treasurer, see Darker, John (d. I784); St. Paul's Cath., prebendary, see Sampson, Thos.; currier, see Foxon; hosiers, I69; merchant, see McArthur, Whitehead, Sir Jas.

London and Westminster, 7, 19, 49, $65,71,80,81,82,91,92,98,99$,

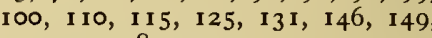
I 50, 170, 189, 190, 193, 213, 323; road from Leicester to, 55, I 54, 299, 370; rly. from Leicester to, 260, 344 .

British Museum, 220; Gerard St., I I 5; Gray's Inn, see Tamworth; Grub St., I06; Lincoln's Inn, see Simons, Nic.; National Gallery, 220; Savoy palace, 6; Tottenhall man., I06; architects, see Reed, Allan D., Smith, W. Basset, Tarring, Young; bellfounder, see Mears; see also Atcheson, Bennett, - , Hayne, Thos. (d. I640); Sutton, Thos. (f. c. I697).

London Emancipation Soc., treasurer, see Taylor, P. A.

London Fournal, 272.

Long, Geo., 393.

Longland, John, Bp. of Lincoln, 399.

Lorimer, see Pool \& Lorimer.

Loseby, Hen. of, 362 .

Loughborough, 97, $214,276,294$, 295; bellfounder, see Taylor of Loughborough; ch., 40; glovers, 86; hosiery ind., I76, see also Cartwright \& Warner, Pagets, Warners; canal from Leicester to, see L., Grand Union Canal; road from Leicester to, I54, see also Harborough, Market, turnpike; see also Leamington, Ralph, Quenby Hall, Quorn Hall, Statham.

Loughborough, Ld., see Hastings, Sir Edw.

Lound, John, 351 .

Louvain, Geoff. of, 39 .

Louvain (Belgium), $406 n$.

Low, Hugh, $99 n$.

Lowdham (Ludham), Caleb, 128, I30; John, $98 n$.

Lowestoft (Suff.), 45.

Lubbenham, Nic., 400; Ric. of, 41 .

Lubbenham, 409.

Lubbesthorpe par. (formerly chapelry), 415, 4I8, 428, 443; man., 430 .

Lucy, Steph. de, 425.

Ludham, see Lowdham.

Ludlam, John (d. I602), $98 n$; John (d. I669), 77, 91 ; Ric., I $03 n$; Thos. (d. I697), I I 5, I I6, I I 9; Thos. (d. I724), 412; Thos. (fl. $c$. I755-1812), 406; Wm. (d. 1603), I06 $n$; Wm. (d. I628), 77, 103 $n$, I06 $n$.

Lush, Wm., 96.

Lutenham, Thos., $89 n$.

Lutterel, Sir And., $370 n$.

Lutterworth, $40,80,81,417$; char., 413; road from Leicester to, 371 , 4I5, 4I7; see also Dowell, Wm., Paner. 
Lymington (Hants), M.P., see Hallhead.

Lynn, King's, (Norf.), 37, 40, 45; fair, 48.

Lyons, A. M., 247, 248.

Mabbs (Mabbes), Mary, $106 n$; Thos. I03 $n ;-, \quad 102$.

Macauley, C. C., I $47 n$; 'T., $203 n$, $205 n$.

MacDonald (Macdonald), A. F. 224, 226; J. Ramsey, 235, 236, 237 $238,239,240,241,242,243,247$, 249, 250.

Macnamara, John, I36, 139 .

Maddock, H. L., 248.

Mafeking (Bechuanaland), 236.

Maior, see Major.

Maisnil, Gerard de, 37

Major (Maior), Gabriel, 393; John, $71 ;$ Wm., I 6 , I $8 n$.

Malton (Yorks.), $8 \mathrm{I}$.

Manby (Manbie, Manneby), Rob. de, $447 n$; Wm., 80 .

Manchester (Lancs.), 8I, 206, 2I 4 265 ; see also Gardner.

Manchester, Sheffield \& Lincolnshire Rly., 375 .

Mann, Tom, 234

Manneby, see Manby.

Manners, Chas., 4th Duke of Rutland, 136, 420; Chas. Cecil John, 6th Duke of Rutland, 415, 417, 419 $n$ Dorothy, see Vernon; Geo., 415, 416; Hen., 2nd Earl of Rutland, 418; Sir John (fl. c. I58I), 4I7 John (d. 16I1), 416; John, 8th Ear of Rutland, 66, I I 2, 41 6, 4I7; John Ist Duke of Rutland, I I 3, I I 4-16, I $19-20$; John, Marquis of Granby 417; John (fl. c. 1777), 353, 410 452; John, 3 rd Duke of Rutland I 23-4, I34, 417, 432; John (fl. $c$. I 80o), 138 , I 39; John Hen., 5th Duke of Rutland, I43, 176,330 $364,417,420,432$; Ld. John (fl. $c$. I867), 226; Louisa, see Tollemache; Thos., Ist Earl of Rutland, 422; Wm. (fl. c. I 722), I $24 n$; Wm. (fl. c. I 764), 355; Ld. Wm. (fl. c. I 764), 353, 410, 452; Sir Wm. (d. I833), I 38, I 4I, 452; Wm. John, Earl of Dysart, 452 ; fam., 66, 4I 5 , $4 \mathrm{I} 6,4 \mathrm{I} 7,4 \mathrm{I} 8$, crest, $4 \mathrm{I} 9 n$; see also Dysart, Earls of, Rutland, Earls, Dukes of.

Manning, Pet., 446; Randall, 6r.

Mansfield, John (d. I798), I36; John (d. I839), I 40-I, I 43, I 44 .

Mansfield \& Babbington, bankers, 254; see also Babington.

Mapwell, Wm., I8I.

March, Earl of, see Mortimer.

Margaret (of Anjou), queen of Hen. VI, 6.

Margaret, maid, ro5.

Markby (Markbie), Ric., 79; Thos. $88 n$, 10o.

Markham, John, 209-10, 211, 213, $217,218,220$.

Marlow, E. A., 243-4.

Marrow, Thos., 397.

Marshall, Joshua, 368 ; Sam., 8 r, $87 n$, $90 n, 109$.

Marston, see Boothby.

Martin, Thos., $49 n$.

Martival, Anketil de, 439; Joyce de,

m. Rob. de Saddington, 439; Ralph de, 439; Rog. de, 439.

Mary I, 55, 56, 59, 396, 452 .

Mary II, I 2 I.

Mary, Queen of Scots, 55, 67 .

Mason, Eliz. Charlotte, 410.

Massey, Edw., $85 n$.
Masters, E., $249 n$.

Matthews, C. L., Archdeacon of Leicester, 342.

Maudit, Sim., 22.

Mawdely, Ric., Archdeacon of Leicester, 399.

May, Sir Humph., 60.

Mayes, Pet., $99 n$.

Mazzini, Guiseppi, 222

McAll, R. W., $394 n$.

McArthur, Alex., 227, 228, 229, 230, 232.

M'Carthy, Felix, I $38, \times 39$.

Meade, John, I05.

Mears, T., 379

Mease, Rob., $96 n$

Measures, Wm., to5 $n$.

Mechlin (Belgium), 78 .

Medbourne, road from Leicester to, see Gartree Rd.; see also Watts, Dr. Wm.

Medland, Jas., 352.

Mellor, (Sir) John, 455.

Melton Mowbray, 79, 8o, 81, 295; man., I3I; sch., 4I3; road from Leicester to, 420 ; rly. from Leicester to, 439; hosiery ind., $172 n$.

Mercer, Hugh le, see Leicester, Hugh de.

Merdegrave, see Belgrave.

Meredith, John, 402, 406

Merrick, Dan., 224, 227, 232.

Merry, Thos., I I I.

Messina (Sicily), 3

Metropolitan Towns Improvement Co., 266.

Meulan, Count of, see Rob. de Beaumont.

Mexico, 327.

Meyer, F. B., 392

Miall, Edw., 207-8, 21 3, 227.

Midland (formerly, Midland Counties) Rly., 21 5, 26o, 355-6, 374, 456; chairman, see Ellis, John.

Miguel, Don, 205.

Miles, Ralph, I68 $n$; Sam., I $42 n$; Wm., I 5 I $n$.

Mill, J. S., 222

Miller, Jas., 333; Rob., 8o, 8r $n$, $90 n$; Wm., I05 $n$.

Millet, Humph. Davey, 406.

Millican, Wm., 229, 23I, 352, 363, 364 .

Millington, Ric., 94

Mitchell, Wm., 455.

Mitford, Rob., 127.

Moira, Earl of, see Rawdon-Hastings.

Molde, Rob., $87 n$.

Mole, Ric., $83 n$.

Monck, Gen. Geo., 56, I 09, I 10

Moneypenny, Geo., 338.

Montague, Jas., I $24 n$, I $25 n$.

Montalt (Monte alto), John de, 430; Millicent de, see Cantilupe; Rog. de, 430 .

Montfort, Amaury de, Count of Montfort, 3; Amice de, see Amice; Sim. de (d. 1 1 88) 3; Sim. de (d. 12 I 8), 3, 32, 42 I; Sim. de (d. I 264) Earl of Leicester, 3-4, I0 $n$, I $9 n$, 32, 4I, 35I, 370 $n, 37 \mathrm{I}, 38 \mathrm{I}, 4 \mathrm{I} 5$, $42 \mathrm{I}, 423,434,447,450,45 \mathrm{I}, 452$; fam., 3 .

Montolieu, Louis, I 36

Moore (More), Chris., $86 n$; John, 328; Ric., $83 n$; Temple, 367,368 ; Thos. (d. I 556 ), $59 n$; Thos. (d. I 657), 97 ; Wm., 88; -, 109.

Moreton, see Morton.

Morfine, see Murfyn.

Morgan, J., 248.

Morley, T. A., 421.

Morning Chronicle, 204; proprictor, see Easthope.

Moroney, M. J., $249 n$.

Morris, John, $85 n$; Ric., $97 n$.
Morris, Messrs. J. J., footwear manufacturers, $323 n$.

Morrison, Sir Ric., 353; - , Lady, 425

Mortimer of Wigmore, Rog. de, Earl of March, 5.

Mortin, - 386

Morton (Moreton), Fran., $106 n$ Wm. (d. I620), I06 $n$, 4II; Wm. (f. c. 1806), 314; 一, 102.

Moseby, Ric., $179 n$.

Moseley (Mosiey), Sir Edw. (d. I639), 448, 450; Edw. (f.c. I656), 448,450 ; Hen., 76, $87 n$.

Mosse, Wm., 4I8.

Mottley, Fran., $97 n$.

Mounteney, Geo., $88 n$, 103 $n$.

Mountsorrel, Wm., 48 .

Mountsorrel, 86, 212; market, 86; glovers, 86 .

Mug (Mugg), Hen., 87 , 9I ; John, 390.

Muggeridge, R. M., 303, 304, 305, $306,307,308$.

Mundella, A. J., 250 n, 3 I0.

Mundy, C. J., I 44

Murfyn (Morfine), Dan., 89, I $06 n$.

Mursell, J. P., 207, 208, 209, 2 10, 2 I 2, $213,215,220$.

Musters, Wal. de, 439

Muston, Jas., 334 .

Napoleon, Louis, 218.

Narborough, I Io; asylum, 374; road from Leicester to, $38 \mathrm{I}$.

National Co-operative Boot \& Shoe Manufacturing Co. Ltd., 323.

National Education League, 226.

National Educational Union, 226

National Federation of Boot \& Shoe Manufacturers, president, see Lennard.

National Hosiery Federation, 3 r 3.

National Liberal Federation, 225.

National Society, 320.

National Union of Boot \& Shoe Operatives (formerly, National Soc. of Boot \& Shoe Riveters \& Finishers), $32 \mathrm{I}-5$.

National Union of Bootclickers, 323.

National Union of Conservative Associations, 225.

Neale, Ric., $4 \mathrm{I} 6$.

Neath (Staffs.), 3 I 9

Nedham (Needham), Chris., $97 n$; Fran., 130; Mary, 355, 357; fam., 367.

Netherseal (Derb.), 400.

Nevinson, Thos., 408 .

New Parks, see L., New Parks.

New South Wales (Australia), 227.

New York (U.S.A.), I 35, 307.

Newbold, Hen., 396, 397.

Newcastle, Duke of, see PelhamHolles.

Newcastle upon Tyne (Northumb.) 3 I 4.

Newcombe, Edw., 343; Rob., 97-98, 343; Thos., $87 n, 98,359$.

Newcombe of Leicester, bellfounders, 419

Newfoundpool, see L., Newfoundpool.

Newmarket (Suff.), i 14.

Newport, C. A., $249 n$.

Newport (I. of W.), M.P., see Biggs, Wm.

Newsham, Ric, 164

Newton, Gabriel, 333, 343, 351, 367, see also L., charities, L., Newton, Alderman, schs.; Geo., 367; John, I I 4, I20, 406; Thos., $80 n$; Wm., 82 .

Nichols (Nicolls), Sir Augustine, 7 I ; John, 360,369 . 


\section{A HISTORY OF LEICESTERSHIRE}

Nickolds, Fr. Thos., 390.

Nicoll, John, 367.

Nicolls, see Nichols.

Nicolson, Sir Chas., 367, 368; (Sir) Harold, 247, 248; N., $249 n$; Sydney, 368 .

Noble, Fran., I I 5, I $57 n$; Dr. Jos., $221-2,382$; Thos., 123 ; Wm., 441; fam., 362,379 .

Nonconformist, The, 208; editor, see Miall

Noone, Edw., I68; Thos., 90.

Norbury (Staffs.), see Skrymsher.

Norman, Ralph, 34; fam., 440.

Normandy, Duke of, see Rob. Courthose.

Norris (Norreys, Norrice), Anne, see Harcourt; Jas., I $68 n$; John (fl. $c$ I 492), 42; John (fl. c. I 546), 85 John (fl. c. r6r9), 413; John (d. 1670), 87 , I о I $n$; Thos., $99 n$; Wm. (f. c. I484), 429; Wm. (fl. c. I6I2), 343.

North, Fred., Ld., r35; (Sir) Jonathan, 243, 296, 331 ; Thos., 268.

Northampton, 4, 29, 49, 276; fair, 48 ; corp.; $32 \mathrm{I}$; sch., 333 ; road from Leicester to, I54; footwear ind. 3 I 5,3 I $6,319,32 \mathrm{I}, 323,326$; footwear manufacturer, see Marlow.

Northampton, Earl of, see St. Liz; Marquis of, see Parr, Wm.

Northamptonshire, 2, 55; footwear ind., 326.

Norton, Rob., I 25, I 40; Thos., I0 $n$.

Norton, King's, 389 , 401, 404; bellfounder, see Fortrey.

Norwich (Norf.), St. George's guild, 50.

Noseley, see Hazlerigg, Thos. (fl. I 5 th cent.)

Nottingham, Hugh of, I 8.

Nottingham, I 44, I 45, I 98, 2 I 2,276 , $284^{-5}, 302,352$; cast., 2 ; mayor, 61 ; poor law guardians, 259; rly. from Leicester to, 260,420 ; Dr. of, 304; hosiery ind., I7I, I75, I76, 303, 310 ; lacemakers, I 44 ; see also Smith, Abel.

Nottingham, Earl of, see Finch, Dan., Heneage; R.C. Bp. of, 390.

Nottinghamshire, hosiery ind., 169.

Nowers, Alice de, see Pembridge; Ric. de, 416.

Nunneley, Thos., 444.

Nurse, John, 380; fam., 397

Nutt, Jas. (d. I 663), $88 n, 97 n, 103 n$; Jas. (d. I668), $88 n$.

Oadby par., 29I, 398, 443; urban district, $434,436,438$; race-course, 294 .

Oakham (Rut.), canal, 182.

Oates (Otes), Sam., 390; Titus, $390 n$.

Ockbrook (Derb.), ch., 405.

O'Connell, Dan., 2 I I, 2 12.

October Club, 121 .

Odams (Odames), Sam., 3ro; W., 3 I 5 .

Ogden, Cecil, 352 ; Rob., $98 n$.

Okes, John, $6 \mathrm{r}$; Wm., $6 \mathrm{r}$.

Oldham, John, $87 n, 88 n$, Ior $n$; Wm., $34 \mathrm{I}, 428,453$.

Olive, Wm., ro5 $n$.

Oliver, Chas., 3 I9; Geo., 3 I9; Sam., I 66, 444; T. B., 422.

Oneby, John, i 18 .

Oppenheim, E. Phillips, 434.

Orange, Wm., Prince of, see Wm. III.

Ordish, F. W., $349,363 n, 364,377$, 386,392 .

Ordriz, Wm., 20; farn., 35.
Orton, John, I22; Ric., I I I Rob., 434; Wm., I 12.

Ossiter, Eliz. (d. I634), 412; Eliz. (fl. c. I653), 368 ; John, $96 n$.

Otes, see Oates.

Overinge, Thos., I $57 n$; see also L., Overinge's ward.

Overseal (Derb.), 400.

Overton, Cold, see Frewen, Thos.

Oxford, 60; Univ., 231, 240, 334; Brasenose Coll., Principal, see Hartopp, Sir Edm. Craddock (f. c. 1878); Christ Ch., Dean, see Sampson, Thos.; Lincoln Coll., 4I3, 4r4; Ridley Hall, Principal, 377.

Oxford and Asquith, Earl of, see Asquith.

Paget (Pagett), Hen., 217 ; John, 220, 440; T. T., 226, 254, 442; Thos., I $39,140,142,143,144,147,148$, I 5O, I 52, $208 n, 2$ I I , 2 I 9, 220, 226, $252,254,256,440$; see also Goddard \& Paget.

Pagets of Loughborough, hosiery manufacturers, 308 .

Paine, Tom, 137, r 90.

Palmer, Archdale, I2I; Edw. (fl. c. I 645-62), 56, 7 I, I I I, I I 2 ; Edw. (f). c. I 766-8), I 3 I, I 34; Fran., 387;

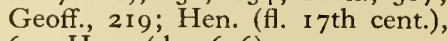
65 ; Hen. (d. I626), I02, $103 n$; Hen. (fl. c. I698), I2 I $n$; Hen. (f. c. I 828), I 46, I 48; John (d. I 627), 77, 93; John (fl. c. I6771700), I $68 n$; Ric., I $58 n$; Thos. (d. I670), $87 n$; Thos. (d. 1717), I 8 , I 19, 1 22; Wm. (fl. c. 1626), $396 ; \mathrm{Wm}$. (fl. c. I630), 4 I6.

Palmerston, Viscount, see Temple, Hen. John.

Paner, Rob., 36

Pare, - I 8 .

Pares, John (d. I 7 I 5), I $58 n$, 186; John (fl. c. I 790), 1 36, I 38 ; Thos. (f. c. 1768 ), 1 30, I 34 ; Thos. (fl. c. 1800-35), I38, 1 40-1, I 44, 362, $365,380,393$; 一, 127; fam., 362 .

Paris (France), I 53; Hôtel de Ville, 363.

Parker, Jas., 2I 6, 2 I 7 ; John (d. I 564), I OI $n$; John (d. I639), 4r3; Jos., I68; Thos., ro6 $n$; Wm. (fi. $c$. I 856 ), 206; Wm. (fl. c. r920), 452 .

Parkyns, Thos. Boothby, Ld. Rancliffe, I 36, r 37 .

Parnell, Rob. s. of, see Rob. FitzParnell.

Parnell, Chas. S., 229.

Parr, Geo., 94; John, $79 n$; Wm., Marquis of Northampton, 353, $354,45 \mathrm{I}-2,454$.

Parsons, John, 94; Wm., 345, 359, $363,374,424$

Pate, Hen., I $57 n$, I $86 n$

Paxton, Sir Jos., 444

Peace Soc., treasurer, see Hazell.

Peache Trustees, 377 .

Peale, see Peel.

Pearson, J. L., 367 ; John, 397.

Pearson \& Bennion, footwear machinery manufacturers, 320

Pease (Pese), Edw., 358, 367, 4r8.

Peatling Magna, 37 $n$.

Peatling Parva, 371 i .

Peckleton, see Tooley Park.

Peel (Peale), Hen. (d. I639), 77, 97, I03 $n$; Hen. (d. I664), $97 n$; (Sir) Rob., I 41, I 45, I 46, I 50, 202, 203.

Pegg, Jerman, 157.

Peke, John, 397.

Pelham-Holles, Thos., Duke of Newcastle, 125 .
Pelton, Wm., $99 n$.

Pembridge (Pembrugge), Alice w. of Fulk de (d. c. 1 345), m. 2 Ric. de Nowers, 41 5-16; Fulk de (d. 1296), 4I 5, 4I8; Fulk de (d. c. I326), 4I 5, 4I8; Fulk de (d. c. I 345), 4r5. Fulk de (d. I 409), 4I6, 4I8; Isabel w. of Fulk de (d. I 409), 4I6; Juliana de, m. Ric. Vernon, 4r6; Rob. de, 4I6; fam., 4I8.

Penny, John (d. c. I 496), 42 ; John (d. I 520), 358-9, 45 r.

Persia, 240.

Pese, see Pease.

Pestell, Thos., 402, 406.

Pestrell, Thos., 94.

Peter s. of Rog., I $4 n$.

Peterborough (Northants.), rly. from Leicester to, 260.

Peterborough, Bp. of, $342,349,357$, $366,376,377,385,418,426,437$, $44 \mathrm{I}$

Petersfield (Hants), M.P., see Atcheson.

Peverel, honor of, 430 .

Philip, King of Spain, 396

Philip (Fyllyppe), Rob., $8_{3} n$.

Philippa (of Hainault), queen of Edward III, 5 .

Philips (Phillips), Jos., I 45, I 5 I $n$; Ric., 137, I90.

Phipps, C. J., 362 ; Thos., 131,132 , $133,166$.

Pick, S. Perkins, $346,362,426 n, 445$; see also Everard \& Pick.

Pickering, E. H., 247.

Pickford, Jos., 408.

Picton, J. A., 228, 229, 230, 232, 233.

Piddocke, Leonard, 124-5.

Pighte, Thos., $105 n$.

Pike, Jas., 39I.

Pilkington, John, I $06 n$.

Pilsbury, Wilmot, $445 n$.

Pippin, Thos., $85 n$, roo, ror $n$.

Pitefrid, Seward, 382 .

Pitt, Wm., the younger, I35, 1 36, 137.

Plungar, 399.

Pochin, Capt. R. G., 433; V. R., 440; Wm., 440; see also Winstanley, Ralph.

Pocklington, John, I33, I 34.

Pole, German, 448, 450; Wm., and his w. Thomasina, 398 .

Polers, Phil. le, 429, 430 .

Police News, The, 272.

Pollard, Edw., $90 n, 96 n$; John; I o I $n$; -, 120.

Pontefract (Yorks.), 4.

Pool \& Lorimer, hosiery manufacturers, 317, \& Tabberer, 3 I I.

Pope, see John XXII.

Porter (Portarius), Ranulf, 382 .

Portugal, 205.

Pott, John, 400, 406.

Potter, Jos., 232.

Potteries (Staffs.), 2 I 3,2 I 4.

Pougher, Abstinence, I 68 n, I 70,178 ; Dan., I68; Eliz., 90-91, 96; Sampson, 77, 91, 96; fam., $168 n, 178$.

Poultney, see Pulteney.

Powell, John, $87 n ;-, 3^{82}$.

Power, Frances, 369 .

Powys-Keck, Thos., 435.

Pratt, T. A., $248 n, 249 n$.

Preston, J., \& Co., hosiery and footwear manufacturers, 315,317 .

Preston \& Charlesworth, footwear manufacturers, 3 I 5 .

Pretyman (Prittiman), Sir John, I $12-13$.

Price, John, I41, 190; -, 59; fam., I90.

Priestley, Dr. Jos., I 37

Primrose, Archibald Philip, Earl of Rosebery, 238 .

Prince, see Symington \& Prince. 
GENERAL INDEX

Prince Regent, see George IV.

Prittiman, see Pretyman.

Productive Soc., see 'Equity'.

Proudlove, Wm., 63.

Pulteney (Poultney, Pultney), Sir John (d. I617), 422; John (d. I637), Io6 $n, 4 \mathrm{I} 3$.

Pultney's man., in Belgrave, 422.

Purchase, H. G., 246, $247 n$.

Purss, Frances, I05 $n$.

Pyke, John, 406.

Pyne, Rob., 422.

Pyrie, John de, 4 I 8

Pywell, Jos., 395.

Quenby Hall, in Loughborough, see Ashby.

Quency (Quincy), Arabella de, $m$. Ric. Harcourt, 4I 5 ; Eleanor de, see Ferrers; Marg. w. of Saer de, 3 353, 4I 5 ; Marg. de, m. Wm. de Ferrers, Earl of Derby, 422, 429; Rog. de, Earl of Winchester, 32, $415,422,428$; Saer de, Earl of Winchester, 418, 421, 422 .

Queniborough, man., I3I.

Quorn Hall, in Loughborough, see

Warner, J. H. B.

Quorndon, see Farnham, Mat.

Raby, Ric., 389 .

Racy, Adam, 42

Ramis, Rog. de, 439.

Ramsdale, Thos., and his w. Ellen, $87 n$.

Rancliffe, Ld., see Parkyns.

Randall, Wm., $89 n$.

Ranulf de Blundeville, Earl of Chester, 3

Ranulf Portarius, see Porter, Ranulf.

Ratby, soke, 3 I, 38 I.

Raven, John, $87 n$.

Rawdon-Hastings, Fran., Earl of Moira, $139 n$.

Rawlinson, Wm., 448.

Rawlyns, Ambrose, $106 n$.

Raworth, Onesiphorus, I42 $n$.

Rawson, Jas., I 5 I; John, 397.

Rawson \& Fields, hosiery manufacturers, 306.

Rawstorn, Wm., 403, 406.

Read, see Reed.

Reasoner, The, 272.

Redmill, 399.

Redwey, Dominic, $88 n$, I05 $n$.

Reed (Reid, Read, Reyd), Allan D., 390; John, $36 n$; Thos., 387,4 I4 Wm., $99 n$.

Reinagle, R. R., 363 .

Rekevour, see Reseyuour.

Remigius of Fécamp, Bp. of Lincoln, I, I6, 353, 357, 443 .

Rennell, - , widow, 9o

Reseyuour '(Rekevour), Wm. s. of John, 4I9.

Retford (Notts.), M.P., see Evans, Wm. (f. c. $1825-35$ ).

Reve, Thos., 382.

Reyd, see Reed.

Reynold, John, 40; Ric., 27.

Reynolds, W. G. Waterhouse, 244 245 ; Wal., Abp. of Canterbury, Rhé, Isle de (Charente-Inférieure, France), 58.

Ricard, Thos., $96 n$.

Richard II, 6.

Richard III, 7, 8, 27, 382, 384, 429.

Richard, Duke of York, 7 .

Ricketts, Admiral Sir Cornwallis, 426,448

Riley, F. F., 243.
Roads (Rodes), John, 106 $n$; Rob., $83 n$. Roberdes, see Roberts.

Robert Blanchesmains, Earl of Leicester, 3, I0, 53, 437 .

Robert Courthose, Duke of Normandy, 3 .

Robert de Beaumont, Count of Meulan, ?Earl of Leicester, 2, 9, I 5 , $32,33,344,370,375,38 \pm n, 388$, 4I 5, 4I 6, 42 I, 447 .

Robert FitzParnell, Earl of Leicester, 3, 3I , 32, 37I, 376, 379, 382, 4I5, 439,450 .

Robert le Bossu, Earl of Leicester, 23 , I2, I6, I9, 344, 348, 353, 382 $n$ $42 \mathrm{I}, 424,439,443,45 \mathrm{I}, 452$.

Robert, vassal of the Count of Meulan, 38 I $n$.

Roberts (Robertes, Roberdes), John, 28; Jos., II9; Rob. (fl. c. 1586), I02; Rob. (d. I614), $85 n$; Rob. (d. I627), $85 n$.

Robinson, C. B., 444; Chas., 77, $88 n$, $99 n$; Fred. John, I45; J. B., I45; John, I36; Nic., $98 n$; Thos., 329 ; Wm., $99 n$.

Rodes, see Roads

Rodington, see Ruddington.

Roger, Pet. s. of, see Pet. s. of Rog.

Rogers, John, 406; Thos. (fl. c. I 598) 6I; 'Thos. (fl. c. I669), 39 I.

Rolleston, (Sir) John L. F., 234, 235, $236,238,239,240,250$.

Roos, Ld., see Villiers, Geo.

Roscoe, Wm., I 39 .

Rosebery, Earl of, see Primrose.

Rossendale (Lancs.), 326.

Rossi, J. C. F., R.A., 362, 363

Rotherby, I I0, II 2 .

Rothley, IIo; see also Babington, Thos. (M.P. I685-9); soke, see Gaddesby.

Rothley Temple, see Babington, Thos. (M.P. I 800-I 8), Parker, Jas.

Rouen (Seine-Maritime, France), St. Ouen ch., 4I9.

Ruddington (Rodington), Hen. of, I 3 , I 5,$22 ; \mathrm{Wm}$. of, I9.

Ruddyarde, see Rudyard.

Rudhall, Abraham, 359 .

Rudiard, see Rudyard.

Ruding, John (fl. c. 1536), 382; John (fl. c. I 558 ), 382; Rogers, I24, I25; Wal., the elder (fl. c. 1652), 380 ;

Wal., the younger (fl. $c$. I652-7o), 380,432 ; Wal. (fl. c. I 722 ), I25 $n$; Wal. (fl. c. I 790-6), I36, 397 ; Wal. (fl. c. I8I3-2I), I 39, 382 ; Wm., I $25 n$, 380; fam., 344,375 , $380,382,397$.

Rudyard (Rudiard, Ruddyarde) Thos., 56; Wm. (d. I626), $99 n$; Wm. (fl. c. I646), 349 .

Rugby (Warws.), rly. from Leicester to, 260 .

Rupert, Prince, 67, 416.

Russell, Dorothy, 249 $n$; John, I08; Ld. John, 219; Thos., I05 $n$.

Russia, 220, 246.

Rutland, Earls of, 416; Dukes of, 416; see also Manners.

Rypley, Rob., $88 n$, $105 n$.

Sacheverell (Sacheverill), Hen., I2I, I22; Ric., 357, 429; Thos. (d. I626), 401, 406; Thos. (d. I628), I06 $n$.

Saddington, Joyce de, see Martival; Rob. de, 439 .

Sadler, Ralph, 4 o I

St. Evroul (Orne, France), abbey, $376,379,425,439,44 \mathrm{I}, 447 n$ 448; abbot, 425; cell, see Ware (Herts.).
St. Ives (Hunts.) fair, 4I, 48, court, 36,48 .

St. Liz, Sim. of, Earl of Huntingdon and Northampton, 2

St. Lo, Wm. de, I 4 .

St. Neots (Hunts.), bellfounder, see Eayre, Jos, 'Thos., Taylor, Rob.

Salt, -, 243

Sampson, Nat., 376, 40 I, 406; Thos. $400-I, 405$

Sanderson, John, 65

Saunders, Ambrose, 357 ; John, 343 Rob., $179 n$.

Savage, John, I86 $n$

Sawday, A. E., 392.

Saxi, 4I 6 .

Saye, Rob., 418

Scampton, John, I68.

Scarborough (Yorks.), 45 .

Scotland, 4, 5, 26, 55 .

Scott, Sir Geo, Gilbert, 358, 360, $363 n, 377,379$; Wm., $105 n$.

Scottum, Rob. de, I 4 .

Scraptoft, 110, 126, 187n, 302, 410;

Hall, see Wigley, Jas.

Seagrave (Segrave), Steph. de, 418.

Seagrave, 353

Seal, John, 209, 212.

Searson, G. R., 295.

Seawell, Thos., Io8.

Seburgh, Thos., 4I.

Sedgewick, Geo., 232.

Sedley, John, 353.

Segrave, see Seagrave.

Seler, Laur. le, $4 \mathrm{I}$.

Self Help Emigration Soc., 233.

Selwyn, John, 403, 406.

Severn, Riv., 45.

Shackerstone, rector of, see Hall, Thos.

Shaftesbury, Ld., see Ashley-Cooper.

Sharman, see Sherman.

Sharnfold, John de, $24 n$.

Sharp (Sharpe), Ric., and his w. Christian, 435 ; 一, 90 .

Shaw, Jas., 306.

Shawell, John, I05 $n$.

Shearman, see Sherman.

Sheen (Surr.), priory, 379, 425, 448 prior, 425 .

Sheffield (Yorks.), 227, 284-5; architect, see Whiteman, -

Sheldon, Wm., 424

Shenton \& Baker, architects, $394 n$.

Shepie, John, 88, $90 n$.

Sherford, John of, 39 .

Sherman (Shearman, Shirman, Sharman), Eliz., 453; John (fl. c. I6IOI4), 449, 453; John (d. I627), $87 n$; John (d. I663), Iо I $n$; John (d. 1675), IоI; Luke, 33; Wm. (d. I663), 77 ; Wm. (fl. c. $1677-8$ ), 380 ; fam., 453 .

Sherrard, Dr. Jas., 435, 436, 437

Shilcock,,- 89 .

Shilton, Earl, man., 439

Shilton, Ric. of, 39 .

Shipton, Ric., IO3 $n$.

Shirley, Rob., Ld. Ferrers of Chartley, I I4, I 6.

Shirman, see Sherman.

Shrewsbury (Salop), corp., II 7 .

Shropshire, North, M.P., see Bickersteth.

Shuter, Wm., 85

Sikes, - 145 .

Simmes, Wm., 402, 406

Simon, Mat., 4 Io

Simons, Mat., 343 ; Nic., 349

Simons, Messrs., footwear manufacturers, 325 .

Simpson, Nic., $85 n$; Rob., 102 Sam., I31; Thos., $89 n$; Wm. $99 n$; see also Stead \& Simpson.

Simpson, A. H., footwear manufacturers, $323 n$ 


\section{A HISTORY OF LEICESTERSHIRE}

Sismey, Jas., 133, 134.

Skeffington, Sir Wm., 368.

Skipwith, Sir Hen. (fi. I6th cent.), 448; Sir Hen. (fl. c. I 636), 59 .

Skrymsher, Thos. Boothby, I 24

Slater, Hen., 76, 95; John, 143.

Slatters, John, $80 n$.

Slory, John, 429; Ric., 429

Smart, - 350 .

Smeeton Westerby, I 8I; sokemen, $38 \mathrm{r}$.

Smirke, Sid., 377.

Smith (Smyth), Abel, I36; Chas Loraine, 1 $28 n, 136$, 137; Dan. I $57 n$; Fran., 445; Jos., 394; Mary, 90; Sam., I36-7, I38-9 I 40; Thos., 399; W. Basset, 342 ; Wm. (f. c. 1382 ), $359 ; \mathrm{Wm}$. (d. I 557), I о0 $n$; Wm. (d. I66I), $89 n$.

Snetzler, - organ builder, 368 .

Snibston, 401, 403; collieries, 215 ; colliers, 2 I 3.

Socialist party, 239.

Somerset, Duke of, see Beaufort.

Sorby, T. C., 405.

South Africa, 238, 239, 246, 327; see also Ladysmith.

Southwell, Wm., I $57 n$.

Spain, 205, 327.

Sparkenhoe hund., 447; see also L. Braunstone Frith.

Spence, Ant., 85; Rob., 424.

Spencer, Edm., 393; Eliz., see Kestyn; Herbert, $228 n$; Rob., Ld. 371 ; Rob., Earl of Sunderland, I 18 ; Wm. , 398

Spero, G. E., 244

Springthorpe, Ric., 77, 79, 85-86 $88 n$, I00, I OI $n$; Wm., 350

Stacy, Wm., $83 n$.

Stafford, Hen., Duke of Buckingham, 7; John de (fl. c. 1340), I8-19; John de (fl. I $4^{\text {th }}$ cent.), 343; John (d. I 676), $89 n$.

Stafford, infirmary, 372; footwear ind., 315,322 .

Staines, Law., $206 n$; fam., footwear manufacturers, 3 I 5

Stamford (Lincs.), 79; fair, 48 lawmen, I $2 n$.

Stamford, Earl of, see Grey of Groby.

Standard, 240.

Standard Engineering Co., 320.

Standbridge, Thos., 288-0.

Stanford Hall, see Cave, Sir Thos.

Stanforde, Hen., $8_{5} n$; John, $8_{3} n$; Wm. $106 n$.

Stanley, Jas., Ld. Strange, 134, 407; John, 366, 412 ; Sir Wm. (fl.c. 1491), 434; Wm. (fl. c. I 596), 8o; Wm (fl. c. I 656), 402; Wm. (d. I665) 8 I $n, 106 n$.

Stanton, Thos. of, 34; Zacharias, 391 .

Stanyon, -, 3 I 7.

Staples, Wm., $80 n$.

Statham, Sam., and his w. Susanna, 435 .

Staunton, Hen. of, 34

Stead \& Simpson, footwear manufacturers, $316,317,319,322$.

Stephens, Edw. Loney, 279, $440 n$.

Stephenson, Rob., 267.

Stevens, Wm., 44I.

Stewart, J. Henderson, 245.

Stoke Golding, 126.

Stokes, Thos., 252, 455

Stokes, Thos., \& Nephew, footwear manufacturers, $207 n, 317$

Stone, Nat., 4I5, 4I7; Sam., 253 288, 289, 291, 330, 353, 444; Sam. Fran., 445; -, I 48, I 50 .

Stongate, see Gartree Rd.

Storey, John, 280.

Stoughton, I I0, I I 3, I 3 I , 434, $436 n$; Grange, see Beaumont, Sir Geo. fam., Keck, Ant. Jas.
Stowe (Hunts.), fair, 48.

Stowe, Archdeacon of, see Geary.

Strange, Ld., see Stanley, Jas.

Street, Geo. E., 358, 360, 367; Thelma, $249 n$.

Stretton, Clement, I 33; John, I05 $n$; Mary, I oo $n$; Ric., $88 n, 96 n$; Simeon, 4I5; Zachary, IO5 $n$; fam., 4I 5 .

Stringer, John, 8I.

Strutt, Jedediah, I $73 n$.

Stuart, Chas. Jas., Young Pretender, 126; Jas., Prince of Wales, Old Pretender, 117.

Studley (Warws.), priory, 422.

Sturdy, John, 45.

Sturge, Jos., 213.

Sturges, Thos., 80 n, 8 I $n$.

Sudan, 229.

Suffolk, Harry, $83 n$.

Suffolk, Duke of, see Grey of Groby, Hen.

Sulby (Northants.), abbey, 422.

Sunderland, Earl of, see Spencer, Rob.

Surrey, Earl of, see Howard, Thos.

Sutton, Chris., I07; Edm., I 8 I, I $87 n$; Thos. (fl. c. I697), 440; Thos. (fl. c. I 755 ), 440.

Sutton Coldfield (Warws.), 387; see also Wilson, Sir Wm.

Swan (Swanne, Swain, Swane), Hen., 424; John (fl. c. 1622), 95; John (f. c. I 838), 209-10; Ric. (d. I 588), ror $n$; Ric. (d. I595), 77, $99 n$; Thos., 76, $88 n, 94$, 1 02, $103 n$, 396.

Swannington, 42 ; man., 398, 400, 401 , 402, 403; see also L., Leicester \& Swannington $\mathrm{Rly}$.

Swepstone, I I4, I3I; rector, see Geary.

Swift, Jonathan, 123.

Swithland in Charnwood, 42 ; reservoir, 284; Hall, see Danvers, Augustus Butler.

Swynderby, Wm., 359.

Symington \& Prince, architects, 333.

Tabberer, Osmond, 311; see also Pool \& Lorimer.

Tailby, Wm., 440.

Tait, Jas., $329 n, 354$.

Tamworth, Chris., 57, 6I-62, 63, 366.

Taplife, Geo., I $05 n$.

Tariff Reform League, $238,240$.

Tarring, - , architect, $392 n$.

Task, Thos., $370 n$.

Tatam, Geo., 396; John, $85 n$, $88 n$.

Taverner, Ric., 348 ; Rob., 348 ; Rog., 348.

Taylor, Dan., 352; E., $249 n$ : Edw., $88 n, 94$; H. A., $249 n$; John, 343 ; P. A., 222, 223-4, 226, 227, 228-9, 249; Rob., 433; Sam. (fl. c. I654), 422; Sam. (fl. c. 1761 ), and his w. Eliz., 435; Thos. (d. I 570), I о I $n$; Thos. (fi. c. I 873), 453; Thos. Swift, 453-4; Wm. (d. I 557), $97 n$; Wm. (d. I 575), $98 n$.

Taylor of Loughborough, bellfounders, $343,368,419,442$.

Tempest, John, 424; Sir Rob., 448; fam., 422, 424, 448 .

Temple, Hen. John, Viscount Palmerston, 220, 223; Peter, 60; Rob., 387, 396; Thos., 396.

Teulon, S. S., 377 .

Thomas, Earl of Lancaster, 4-5, I I, I 2, 38, 47, 49 .

Thomas, David, $106 n$; W. F., 3 I 5 ; Wm., 332.

Thomasson, Franklin, 239, 240.
Thompson (Tompson), Geo., 215 ; Howard H., 360; Jas., 219,223 , 273, 294; John (d. I 57 I), IOI $n$, IO2: John (d. I645), 1 00 , $103 n$; Perronet, 2 I0; Thos. (d. I638), 76,

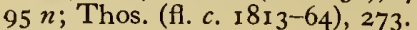

Thornton, J., $3 \mathrm{I} 6$

Thornton, reservoir at, 268, 284; see also Herrick, Jas.

Thorpe, Hen., $106 n$; John, 398, 406; Thos., 399, 400, 406.

Thorpe Constantine (Staffs.), see Inge fam.

Throsby, John, 368

Thrussington, sch., 413, 414.

Thurcaston par., 447.

Thurmaston par., 300, 353; vicar, 426; sewage farm, 279.

Thurmaston, South, par. (formerly chapelry), 420, 425, 426; chap., 425.

Thurnby, I I 3, 302, 434; char., 126.

Tiffin, Wm., 406.

Tilbury (Ess.), 67.

Tillys, Thos., I05

Tilton, road from Leicester to, 434 rly. from Leicester to, 356 .

Times, The, ${ }_{3} 8$.

Timson (Tympson), Rob., I03 $n$; Thos., 186.

Tod, Eliz., 90.

Tollemache, Lionel Wm. John, Ld. Huntingtower, Earl of Dysart, 354, 410; Louisa, Ctss. of Dysart, m. John Manners, 353, 452 .

Toller, Geo., 253, 288, 289; Ric., 444.

Tomline, Marmaduke, 440.

Tomlinson, F. A., $249 n$.

Tompkinson, Rog., $86 n$.

Tompson, see Thompson.

Tong (Salop), man., 4 I 5.

Tooley Park, in Peckleton, 124.

Toone, Thos., 304

Topp (Top), Thos., г 68, 368; fam., 126.

Torksey (Lincs.), fair, 45.

Tottenhall man., see London and Westminster.

Townsend(Townshend), Edm., I $57 n$, 180-I, I87 $n$; Isaac, 316; Mat., 308.

Towton (Yorks.), battle, 7.

Trades Union Congress, 232.

Travel, John, $96 n$.

Traylen, J. C., 377 .

Tribune, 239.

Trickton (Trickten), Eliz., 77, $99 n$; Wm., $99 n$.

Trigg, Rog., 42.

Tring Park (Herts.), see Yates, Edm.

Trowell, John, 105.

Truro, Ld., see Wilde, Thos.

Truville, John, I $86 n$.

Turald, 416.

Turner, see Hodges \& Turner.

Turner, Messrs. Archibald, elastic web manufacturers, 327 .

Turner, Messrs. Luke, elastic web manufacturers, 327

Turpin, Sir. Geo., 443.

Turville, John, $97 n, 395$.

Tutbury (Staffs.), 5.

Tyler, H. P., 3 I 9.

Tympson, see Timson.

Ulnod, 4I 6.

Underwood, John, $99 n$.

Ungoed-Thomas, Sir A. L., $249 n$.

United Framework Knitters' Soc. 3 IO.

United Shoe Machinery Co. of America, 320.

United States of America, see America, United States of. 
Unwin, Sam., 382.

Uppingham (Rut.), 79; road from

Leicester to, 35 I-2

Usher, H. B., 246, $247 n$.

Vann, Jas., 428; Wm., 42I, 428; 一, $42 \mathrm{I}, 427$; fam., $42 \mathrm{I}$.

Vanni, -, sculptor, 368

Vansittart, Wm., 403-4, 406.

Vaughan, David Jas., 406; Canon Edw. Thos., I 45, 229-30, 367 404, 406; Geo. Hartley, I 37

Vernon, Dorothy, m. John Manners, 4I5, 4I6; Sir Geo., 4I6, 4I8; Juliana, see Pembridge; Marg. w. of Sir Ric., m. 2 Wm. Coffyn, 4I8; Ric. de, 4I6; Sir Ric. de, 4I6; fam., 4I 5, 4I6, 4 I 8 .

Vialls, Geo., 426.

Victoria, Queen, 23I $n$, 4I9 $n$.

Vincent, Thos., $4 \mathrm{I} 6$.

Villiers(Vyllers), Geo., Duke of Buckingham, 64; Geo., Ld. Roos, I I 3 ; Sir Wm., I I 8 , I 2 I $;-78$

Virgin Mary, Sisters of the Nativity of the Blessed, 442.

Virginia (U.S.A.), 192 .

Vyllers, see Villiers.

Wade fam., 422, 424

Wakerley, Art., 436 .

Walcote (Walcot), Dr. John, 357; Ric. of, 28.

Walcote, 126.

Wales, Prince of, see Edw. VI, Geo. II, Stuart, Jas.

Waleys, see Walsh.

Walker, Edw., $95 n$; Ric., I $04 n$. Thos. (d. I606), $86 n$; Thos. (d. 1648), $88 n$; W. H., 306, 317,322 ; Wm., I 57.

Walker \& Kempson, footwear manufacturers, 316,317

Wall (Whall), Chris., 367 ; E., $249 n$; Josiah, 398 .

Wallet,,- 374

Wallin, Jos., I $81-2 ;$ 一, I I $4,117$.

Walmsley, Sir Joshua, 215, 216-17, 2I 8, 2I 9, 220, 22 I , 222.

Walpole, Sir Rob., I 24.

Walsh (Waleys), Ric., 406; Wm. le, $24 n, 38 \mathrm{I}$; fam., $38 \mathrm{I}$.

Walter, Thos., $99 n$.

Walton, John, 418; Thos., $96 n$.

Walton, 398.

Walton on the Wolds, $4 \mathrm{I} \mathrm{I}$.

Wanley, Jonathan, 8 I $n$; Sam., 70.

Wanlip, I I0; sewage works, 279; hosier, see Alsop, Nic.; see also Palmer, Archdale.

Warbeck, Perkin, 434.

Warburton (Warberton), Fran., $186 n ; \mathrm{Wm}$., I I 2 .

Ward, Fran., I I 9; J. Griffin, 322; John, 44I ; Sarah, 36o; Thos. $93 n$; Wm. (d. 1558), 80; Wm. (d. I670), $89 n ;-, 360$.

Ware (Herts.), priory, prior, 425 $44 \mathrm{I} n, 448$

Warenne fam., arms, 438 .

Warner, J. H. B., 227, 228; Rog., 77 I05 $n$.

Warners of Loughborough, hosiery manufacturers, 308 ; see also Cartwright \& Warner.

Warwick, 32 ; cast., 2.

Warwick, Earl of, see Dudley, Ambrose.

Warwickshire, 67

Wastell, Nic., $89 n$.

Waterhouse, Capt. Chas., 245, 246, $247,248,249 n$
Waterworth, Ric., I $05 n$.

Wathowe, John, $89 n$.

Watson, Wm., $85 n$.

Watts, Fran., $98 n$; Hugh, 359 ; John, 381 ; Dr. Wm., 372 ; -380 ; fam., $38 \mathrm{I}-2$.

Waverton (Ches.), 42.

Wawarke, Edw., I оo $n$.

Waytestathe, Ric., 359.

Webster, Ant., $83 n$; Thos., $83 n$, $88 n$.

Weeford (Staffs.), architect, see Wyatt, Ben.

Weightman, see Whiteman.

Weldon, Thos., 56.

Welford (Northants.), road from Leicester to, I54, 370, 37I, 372; see also L., Welford Rd.

Welham, ro8.

Wellingborough, footwear manufacturer, see Lawson.

Welles, see Wells.

Wellinger, John, 43I.

Wells (Welles), Hugh of, Bp. of Lincoln, 366; Isabel, 9o; John, 353 ; Wm., 390 .

Went, Jas., 333.

Wesley, John, 392.

Westacote, F., 249 n.

Westcotes, see L., Westcotes man.

Westley, John, 364 .

Westminster, see London and Westminster.

Weston, Ric., I 8 r.

Whall, see Wall.

Whalley, Col. Edw., 68, 402; Wm., I I I.

Wharton, Geoff., 9r.

Whatton, John, 368, 402; Wm., I05 $n$.

Wheeler \& Co., elastic web manufacturers, 326.

Whetstone, Jos., I $38,172,215,219$, 23 I $n, 252,253,256,265,266,267$, 268, 273; see also Brewin \& Whetstone.

Whetstone, man., 20, 75, 106, 407; market, 75 .

Whipps, Thos., $97 n$.

Whitby, John, I oo $n$.

Whitcombe, - 148

White, Edw., I82; Sir Thos., 35I, see also L., charities, White char.

Whitehead (Whiteheade), Sir Jas., 230, 233; John, $87 n$; Pet., $99 n$.

Whiteman (Weightman, Wightman) John, I05 $n ;-, 371,382,394,397$.

Whitwick, collieries, 215; colliers, 2 I 3 .

Wickes, C., 364; see also Flint \& Wickes.

Wicksteed, Thos., 267-8, 272, 276, 278.

Wigg, Sam., 39I.

Wiggington, John, I $05 n$.

Wightman, see Whiteman

Wigley, Edw. Hartopp, 440, 44I ; Jas., I 24, I25, I 26, I 27, I 3 I.

Wigmore (Heref.), see Mortimer.

Wigston, Agnes w. of Wm. (d. I 536), $332,399,400$; Eliz. w. of Wm. (f). c. I $52 \mathrm{I}$ ), $42 \mathrm{I}$; Eliz., m. Wm Davenport (fl. $c$. I 589 ), 422; John, 27, 28, 40; Rog. (d. I 507), 27, 40, 34I $n$, 434; Rog. (d. I609), 422 , 424; Thos. (H. c. I 470), 40; Thos. (d. I536), 332, 399, 400; Wm. (d. c. 1469 ), 27 ; Wm. (fl. $c$. I $52 \mathrm{I}$ ), $42 \mathrm{I}$ Wm. (d. 1534), 40; Wm. (d. 1536), $27,40-4 \mathrm{I}, 78,332,346,35 \mathrm{I}, 39^{8-9}$, 400 , arms, 399 ; fam., $27,40,78$, $416,422$.

Wigston, road from Leicester to 443 ; rly. from Leicester to, $374 n$; urban district, 443; see also Astill, Thos. Wm.
Wigston Magna, 131, 364, 399.

Wigston, South, rly, stn 26 I.

Wilcocks, Ric., 400 .

Wildboare, Kath., , $06 n$.

Wilde, Jas., 2 I9; Thos., Ld. Truro, 2 I 9.

Wilkes Bros. \& Johnson, footwear manufacturers, $323 n$

Wilkins, John, I $58 n$.

Wilkinson, H. J., I9I.

Willcock, Hen., Archdeacon of Leicester, $4 \mathrm{I} 0$.

Willenhall (Staffs.), 3 I 9.

Willesley Hall, see Abney, Sir Edw. Hastings, Sir Chas. Abney.

Willey, Jas., 446.

William I, I, 2, 4 I 6 .

William II, 2.

William III, I2I, I23, Prince of

Orange, I 17,1 I 9.

William IV, I 49, 204

William s. of Leveric, I 5.

Williams, E. Crawshay, 240, 24I ; John, Bp. of Lincoln, 65.

Willis, see Freeman, Hardy \& Willis.

Willoughby Waterless, 4I3.

Willowes, Rob., I86 $n$.

Willson, see Wilson.

Wilne, John, 62

Wilshere, A. Myddleton, 24I.

Wilson (Willson, Wylson), Jas., 358 4I8; John, 89 $n$; Thos., 440; Sir Wm., 387 .

Winchester (Hants.), 32, 49; fair 48.

Winchester, Earls of, 428, see also Quency, Rog. de, Saer de.

Winchester (Winton), honor of, 3 , $42 \mathrm{I}, 422,43^{\circ}$

Winchilsea, Earl of, see Finch, Dan

Windley, Thos., 295.

Wing, John, 406.

Wing (Rut.), see Sharpe, Ric., and his w. Christian.

Wingfield, Rob., $79 n$.

Winks, J. F., $2 \mathrm{O}_{3} n, 2 \mathrm{I}_{3}$.

Winstanley, Clem. (fl. c. I 773-I81o) I 30, I $36,428,432,449,455 n$ Clem. (fl. c. I 849), 380 ; Geo., 432, 433; Jas. (fl. c. I 662), I I I, 430 ; Jas. (d. I7I8), I 2 I-2; Jas. (d. I862), 430; Ralph (Pochin) 430 ; fam., $428,430,432,433$, 449.

Winterscall, Wm., $89 n$.

Winterton, Wm, 228.

Winton, see Winchester.

Wisbech (Cambs.), Holy Trinity guild, 50.

Wise, E. F., 246, $247 n$.

Wodland, see Woodland.

Wolde, Adam de la, 424

Wolsey, Cardinal Thos., 65.

Wolverhampton (Staffs.), 3 I 9

Wood, (Sir) Edw., 23 I $n, 238$; John (d. I635), $92 n$; John (fl. $c$. I 785) 329 ; Jos., 294 ; Norrice, $406 n$; Pet. 406; Tim., 393; Thos., I 45; Wm., I05 $n$.

Woodhouse, Sir Wm., 454.

Woodland (Wodland), Thos. (d. I 59I), $88 n, 98 n$; Thos. (d. I67 I), $98 n, \mathrm{I} 84 n$.

Woodward, Ric., $96 n$.

Woolaston, I., I $25 n$.

Woolrich, Humph, 390.

Wootton, Wm., I05 $n$.

Worcester, 49

Worcester, Bp. of, see Cornewall.

Workman's Times, editor, see Burgess, Jos.

Worship, Rob., 449; Wm., 396.

Worth, Rob., I $68 n$.

Worthington, John, $99 n$.

Wrangle (Lincs.), man., 2 I. 


\section{A HISTORY OF LEICESTERSHIRE}

Wright (Wrighte, Wryghte), Beatrice, see Harrison; Dan., 82, 88; Geo. I 24, I25, I26, I 27, I 3 I ; John, $99 n$; Jos., 343; Nathan, I 16, II7 I24; Orson, 456; Rob., 62; Thos. (A. c. I6r I), 94; Thos. (d. I646) I05 $n$; (Sir) Thos., 230, 231, 238, 322 ; Wm., 346.

Wroxham Estates Ltd., 412.

Wryghte, see Wright.

Wyatt, Ben., 372 ; Jas., 372.

Wycomb, 398.

Wykes, Wm., 9 I $n$.
Wylard, I $4 n$.

Wylson, see Wilson.

Wynckley, Sydney Thorold, 406.

Wynlove, Wm., 367.

Wyvill, Chris., 135 .

Yard, Thos., 406.

Yarmouth, Great, (Norf.), 45, 49.

Yates (Yeatts), Edm., I4I ; John, $97 n$; Sam., $97 n$.

Yaxley, Capt. - , , Io9, I 12.
Yeatts, see Yates.

Ynge, see Inge.

York, 5, 49.

York, Duke of, see Richard.

Yorke, Chas., 129-30.

Young, Art., 390.

Zouch bridge, in Hathern, 4.

Zouche, Alan la, 4 I5; Ivo la, 430 ; Millicent la, see Cantilupe; Rog. la, 430 ; Wm. la, 422, 430; fam., 422. 


\section{LEICESTER INDEX}

THere are two indexes in this volume, a General Index and a Leicester Index. The first consists of all entries other than those in the Leicester Index, the second consists of entries which would otherwise begin with the word 'Leicester' Cross-references to entries in the Leicester Index from entries in both the General Index and the Leicester Index are prefixed with the letter 'L.' Places named in the text merely as residences are indexed only as a means of cross-reference to the residents. Lists of subject-entries are given in the Leicester Index at the end of the entries for 'city and borough' and 'trade and industry'.

The following abbreviations have been used, sometimes with the addition of the letter $s$ to form the plural: Abp., Archbishop; admin., administration; Alex., Alexander; And., Andrew; Ant., Anthony; Art., Arthur; Assoc., Association; Ave., Avenue; Bart., Bartholomew; bd., board; Ben., Benjamin; Bp., Bishop; bounds., boundaries; cast., castle; Cath., Catherine; ch., church; char., charity; Chas, Charles; Chris, Christopher; Ctss., Countess; d., died; Dan., Daniel; econ. hist., economic history; Edm., Edmund; Edw., Edward; Eliz., Elizabeth; fam., family; Fran., Francis; Fred., Frederick; Geo., George; Geoff., Geoffrey; Gil., Gilbert; Hen., Henry; Herb., Herbert; hosp., hospital; Humph., Humphrey; hund., hundred; incl., inclosure; ind., industry; Jas., James; Jos., Joseph; Laur., Laurence; Lawr., Lawrence; Ld., Lord; lib., liberty; m., married; man., manor; Marg., Margaret; Mat., Matthew; Nat., Nathaniel; Nic., Nicholas; non-conf., non-conformity; par., parish; Pet., Peter; pop., population; R.C., Roman Catholic; R. Cath., Roman Catholicism; Rd., Road; Ric., Richard; riv., river; rly., railway; Rob., Robert; Rog., Roger; s., son; Sam., Samuel; sch., school; Sim., Simon; Soc., Society; St., Street; Steph., Stephen; stn., station; Thos., Thomas; Val., Valentine; w., wife; Wal., Walter; Wm., William.

Abbey Gate, 8o, 263, 348, 349; ward, 368 ; chap., 350,39 I-2; sch., see L. St. Leonard's par., sch.

Abbey Lane, 453 .

Abbey Meadow, Meadows, see L., Abbey Park.

Abbey Mill, Mills, 94, 453; another, $326,453 n$.

Abbey Park (Meadow, Meadows, Lammas Ground), 32, 197, 294 , 35 r $355,358,375 n, 45$ I, 452 .

Abbey Park Rd., 355, $453 n$.

Abbey St., 360.

Abbey ward, $242 n$.

agriculture and husbandry, 76, 99ro 4, ro9, r 58, I 86-7; common fields and pastures, $3 \mathrm{I}-32,53,99-$ I oo, I 65-6, 447-8, 454, see also $\mathrm{L}$. East Field, St. Margaret's Pasture, South Field, West Field.

Cornmongers, 79, see also Johnson, Ric.; dairymen, roo, see also Abell, Alice, Brown, Thos., Chettleton, Thos., Markby, Thos., Palmer, John (d. 1627); farmers, 78 , I 02-4, I 06-7, 284, 372, see also Abney, Dannet, Freake, John (d. I 595), Keckwick, Mosely, Hen., Mountenay, Nutt, Jas. (d. I 663), Peel, Hen. (d. r639), Slater, Hen., Swan, Thos. Thompson, John (d. I 645); gardeners, 99, see also Hitchcock, Wm. (d. I632), market, see Harrison fam.; graziers, 77,78 , 100-2, I $80 n$, see also Blunt, Thos. (d. I 66o), Freake, John (d. r 595), Halpennye, Norris, John (d. I67o), Oldham, John, Pippin, Springthorpe, Ric., Swan, Ric. (d. I 595); hay merchants, 96 ; ploughwrights, 97; shepherds, I 04.

Albion St., sch., see L., St. John the Divine par., sch.

Alexander St., chap., 392.

Alfred St., chap., see L., Trinity chap.

All Saints' Open, sch., $33^{\circ}$.

All Saints' par., 42, 53, 69, I 55, I 87 I 88 , I 89, I $92,256,33^{8-43}, 350 n$, $388,390,392,402,412$; bounds., 338 ; ch., 50, I 55, 338, 342-3, 388 393; chars., 343, 4II, 4I2, 4I3; guilds, 342 ; non-conf., 392 ; pop., 342 ; schs., $328 n$; vestry, I 43,256 ; vicar, 342,349 , see also Matthews; workhouse, I 88 .

All Saints' sch., in Charlotte St., 336.

All Saints' sch., in Vine St., 337.
All Souls' par., 377 ; ch., 377.

Allied Assurance building, 363 .

Allsop, Mr., ward, I 56, I 57, I 59, 365 .

Alma St., 292.

alta strata, see L., High Cross St.

Amphitheatre, $212 n, 272,286$.

Angel Gateway, 364 .

Angel Inn, 56, 63, 364 .

Anstey Gorse, 453 .

Anstey Lane, sch., see L., Hallam, Alderman R., sch.

Anti-Truck Soc., 3०3; secretary, see Bell, Thos.

Applegate St. (Applegate, Shambles Lane, St.), 43,44 , I $56 n, 383$.

Apple Lane, 39.

archdeacon, $342,357,379,442$, see also Bonney, Burnaby, And., Grosseteste, Matthews, Mawdely, Willcock.

Archdeacon Lane, 263, 35x, 356; chap., 391, 392; sch., 33 I, 335 .

Archdeacon Lane Memorial ch., 392, 453 .

Arnold; Dr., asylum, $34 \mathrm{I}$.

Art Secondary sch., 334; principal, see Pilsbury.

Ashe Close, 452.

Ashe Meadow, 452 .

Ashwell St., ch., see L., St. John the Divine.

Assembly Rooms, I 94, 35 I.

Athenaeum, 274.

Augustinian friars lib., see L., White Friars.

Avenue Rd., ch., 394; sch., 336.

Aylestone Rd., 260, 286, 370, 373, 374, 41 5; ch., see L., All Souls'; chap., 392; electricity works, 285 , 374 ; gasworks, 285,374 ; sch., 336 .

Aylestone ward, $242 n$; see also Aylestone.

\section{Back Lane, 343.}

Back Side, see L., Cornwall.

Bakehouse (Fosbrooke Bakehouse, Kepeoven, Kephoven) Lane, 43, I $56 n, 369$.

Baker, Mr., ward, r 56, r 57, r 59, 365 .

Balfour St., sch., 336.

Barkby Lane, see L., Bedford St.

Barlow, Sarah, Almshouses, 409.

Barrell Cross, i Io.

Bath Lane, 343,384 ; baths, 294,384 .
Beatrice Rd., 456.

Beaumont Leys par., 300, 349, 420, $423 n, 447-8,45 \mathrm{I}$; pop., 448 ; sewage farm, $279,299,447,448$.

Bedehouse Meadow, Meadows, 370 , $373 n, 375$.

Bedford St. (Barkby Lane), 35 I, 355

Belgrave Gate, I6, 50, 52, 53, 54, I 54 I 55 , I $56 n$, I 6 I, I 62, I 80 , I 95 , I 96 , r $97,262,263,273,291,298,299$, $30 \mathrm{I}, 350,35 \mathrm{r}, 354,355,356,359$, 360, 380, 393, 41 I ; ch., see L., St. Mark's; chap., 393, see also L., St. John the Baptist chap., Tabernacle, The ; gasworks, I $96,285,353$ 354; sch., see L., St. Mark's par., sch.; R.C. sch., 390; see also Coleman, Jas., L., Black Lion Inn, Spital, Spital House Close.

Belgrave Rd., 263, 354, 355; rly. stn., 356 ; sch., 336 ; see also Belgrave, road from Leicester to.

Belgrave ward, $242 n$; see also Belgrave.

Belvoir St., 352, 353; chap., 391, 392, see also L., Harvey Lane chap.

Benbow Rise, sch., 336.

Bent's Hosp., 369, 408.

Berehill (Round Hill, Roundel, Coal Hill), 39, I 29, I $56 n$, I 80, 35 r, 360 .

Berkley St., 338 .

Bird's Nest Lodge, 454, $455 n$.

bishop, 342, 349, 357, 359, 360, 376, $377,385,418,426,432,437,441$, 445, see also Bardsley, Cuthwine, L., see.

Bishop St. (Bishopsgate), 352, 353; chap., 392; library, 295; see also L., Liberal Club.

Bishop's Fee lib., 2, $8 n, 9,16,20$, $24,3 \mathrm{I}-32,36,46,47,49 n, 54,57$, 58 , 1 29, I 30 , I $56,1_{57},{ }_{5} 8 \mathrm{n}, \mathrm{r} 59$, $350,35 \mathrm{I}, 353-4$; constable, I 29; man., 57, 107, 353-4; victualler, 68 ; see also Timson, Thos.

Bishopsgate, see L., Bishop St.

Black Friars lib., I $56 n$, I88, 257 $262,264,290,343-4,387 n, 388$. bounds., 343 ; friary, 1 $54,343,370 n$; chap., 50; see also L., religious orders and houses, Dominican friars.

Black Lion Inn, 360 .

Blackfriars Hall, 390.

Blackpool, 45 .

Blind, Institute for the, 352 .

Blue Boar Inn, $3^{84}$. 


\section{A HISTORY OF LEICESTERSHIRE}

Blue Boar (Guildhall, Mayor's Hall) Lane, 35, 70, 369, 383, 384, 410; see also L., Mayor's Hall.

Bluecoat sch., see L., St. Martin's par., char. sch.

Bond St., 301, 361 ; chap., 394, 433, minister, see Miall.

Bond St., Fast, (Elbow Lane), I 80 , 334, 34I, 407; sch., see L., Great Meeting, schs.

Bond St., New, (Parchment Lane, St. Parcheminergate, vicus parcamenorum, Swinesmarket), I 50, I $56 n$, I 70, I 80, 34I $n, 36$ I, 364 .

Bond St., West, 388.

Bonners Lane, 346; see also L., Rupert's Tower.

Bow (Richard III's) Bridge, I 53, 38 I $n, 382,388$; mills, 383

Bow St., ch., see L., Christ Ch.; sch., see L., Christ Ch. par., sch.

Bowling Green St., 352,363 .

Braunstone Frith par., 300, 43 I 448-9, $455 n$; airfield, 449; golf course, 449; housing estate, 428 , 449 ; sch., see L., New Parks sch.

Braunstone Gate, 277; bridge, 277 , $382-3$.

Bread St., Salvation Army Hall, 394.

Bridge St., 387.

Bridge St., New, 372.

bridges, 23, 5I, 277-8, 347, see also L., Bow Bridge, Braunstone Gate, bridge, Mill Lane, bridge, Walnut St., bridge, West Bridge.

Bromkinsthorpe lib., in St. Mary de Castro par., 9, I6, I 7, 31, 1 08, 369, $375,380-3,398$; chs., see L., Holy Apostles, Martyrs, ch. of the, St. Paul's; econ. hist., 382-3; mans., $38 \mathrm{I}-2$, 397; mill, $38 \mathrm{I}$; see also L., Danet's Hall man., Doveland Coppes, Westcotes man.

Brunswick Square, I 28, I 98.

Brunswick St., sch., see L., St. Matthew's sch.

Buckminster Rd., ch., see L., Archdeacon Lane Memorial ch.

building and building trades, 42,76 , $78,98-99$, 107, I 58, 182-5, 1 94-5, $197,260-3,269,276,290-1,297^{-}$ 8 , $301-2$; architect, see Barradale, Everard \& Pick, Flint \& Wickes, Goddard, Jos., Goodacre, J., R. J., Harrison, Joshua, fam., Jackson, Wm., Johnson, John (d. I 8 I 5), Keay, Millican, Nevinson, Oldham, Wm., Pick, Shenton \& Baker, Tait, Traylen, Wakerley, Westley; bricklaying, I82-3; brickmaking, I 82 ; brickyards, 270 ; builders, 37 42, 52, 297-8, 301, see also Cook, $\longrightarrow$ Hartshorn, C. W., Wright, Orson; clay working, 255; glaziers, 98 , 184 ; layers, 98-99, see also Jerman; masons, 42, 98-99, I 83 , see also Firmadge; painter-stainers, 99 pargeters, 98-09; plasterers, 98 99, I 58, I 84-5, see also Woodland, Thos. (d. I 59I); plumbers, 98, I 84 ; slaters, 98-99, I 58, I 79, I 845, see also Bent, John (d. I 70o), slaters', plasterers', and tallowchandlers' co., 98 , I 05, I $66 n$, I 84 ; tiler, 42 ; see also L., woodworking crafts.

Burgess Meadow, Meadows, 372, 373 .

Burgess St., chap., 392.

Burley's Lane, 356 ; baths, 269.

Butt Close, 63, 392; chap., see L., Great Meeting.

Caldecote Rd., sch., 336. calidus vicus, see L., St. Nicholas St.
Callis, Mr., ward, I 56, I 57, I 59.

Cank, The, 362 .

Cank St., 46, $52 n$, I $56 n, 362$, 364.

Canning Place, sch., see L., St. Margaret's sch.

Carey Hall, 392.

Carey museum, 384, 391 .

Carley St., chap., 391.

Caroline Place, sch., see L., St. Mark's sch.

Cart's Lane, $3^{62}$.

Castle (Duke of Lancaster's palace, Guildhall), 1, 2, 3, 4, 5, 6, 7, 9, 32, $42,43,45 n, 49,53,56,61,63,65$, 70 , I 48, I 53, I 54, I 55, I 56, I 59 , I82, 344-5, 346, $364 n, 395,397$; castellan, 5, see also Grentemesnil, Hugh de, Ivo de; demesne, 5, 32, 53; (earls') court, I O-I I, I2, I3, I 4, 26, 32; gaol, I I, I 3, 345; house, 345; porter, I I, I 2, I4, 22, 32,45 .

Castle Hill, 448

Castle Mill, Mills, 43, 45, 63, 94, I $64,345,395-6,397,398$; shop, 395; see also L., Newarke Mill.

Castle St. (Soar, St. Mary's Church Lane), 369; sch., see L., St. Mary de Castro par., char. sch.; see also L., Southgate St.

Castle View lib. (Castleward), I7, 32, I 30,147, I $88,257,329,344-5$, 347,377 ; pop., 345 .

Castle ward, $242 n$.

Castleward, see L., Castle View.

Cathedral, see L., St. Martin's par., Cathedral.

Catherine St., chap., 393, see also L., Carey Hall; sch., 336.

Causeway (Gaol, St. John's) Lane, 78 , I $56 n$, I 63, I $94 n, 338,34$ I, 389 ; chap., see L., St. Michael's; R.C. chap., 389,427

Cavalry St., see L., Lancaster Rd.

Cavendish House, 4 Io, $45 \mathrm{I}$.

Central rly. stn., 343,36 I.

Chandos St., chap., 393.

Chantry House, 346 .

Chapel Close, $372,377$.

Chapel Yard, 394.

charities, 75 , I 49, I 50 , I $55,410-14$ church, 4IO-II, 4I 4; corporation, 4II-I2; general, 253, 343, 380, 412-13, trustees, $350,36 \mathrm{I}, 369$, $387,402 n, 408,4$ I O-I I , 4I2, 4I3; benevolence money, 4I2; lottery money, 412-13; wood and coal money, 4II, 4I2.

Acham, 4I2; Andrew's Loan, 412; Blunt, 36I , 41 I ; Botham, 412 ; Browne, 4I2; Cavendish, 4II; Courteen's Gift, $343,36 \mathrm{I}, 369,380$, $387,4 \mathrm{II}$; Devonshire, 350, 4I 2; Elkington, 360, 4I3; Fownes (Clarke), 380; Hayne, 4I I , 4I 3-I 4; Heyrick, 343, 350, 36I, 369, 380, 387, 4I 3 ; Hickling, 4I I ; Hobbie, $369,380,41$ I ; Ive, $343,36 \mathrm{I}, 369$, 380 , 4 I I; Ludlam's Gift, 4I2-I 3 ; Lutterworth, 4I3; Moreton, 4I II 2; Newton, I 28, I 49, I 50, I $58 n$, 4I0, 4I4; Norrice, 387 , 413 ; Nurse, 412; Ossiter, 4I2; Parker, 4I3; Poultney, 4I3; Read, 4I 4; Simon, 410; Smart, 387; Stanley, 4I2; Tamworth's Gift, 4II, Prayers, 366, 4I 4; White, 75, I 4I-2, I 46, I 5 I, I $67 n$, 4I0, 4I 3; Wright, 380 .

Hospitals and almshouses, 3984 Io, see also L., Bent's Hosp., Cock Muck Hill Houses, Devonshire, Ctss. of, Hosp., Lewis Almshouses, St. John the Baptist and St. John the Evangelist Hosp., St. Leonard's Hosp., St. Mary Magdalen and
St. Margaret Hosp., Spital, Trinity Hosp., Wyggeston's Hosp.

Charles St., 299, 300, 301, 355, 356; chap., 392 ; sch., 393 .

Charles St., Upper, chap., 392.

Charlotte St., 327; sch., see L., All Saints' par., schs.

Charnor Rd., sch., see L., Forest Lodge sch.

Charnwood ward, $242 n$.

Charnwood St., sch., $33^{6}$.

Cheapside, $301,364$.

Chester St., ch., see L., St. Matthew's; sch., see L., St. Matthew's sch.

Christ Church par., 359, 360; ch., 359 ; sch., 336 .

Christ the King sch., 336.

Christian chap., 392.

Christow St., sch., 336.

Church Congress hall, 360 .

Churchgate, 54, I29, I 39, I 55, I $56 n$, $263,301,329,338,341,35 \mathrm{I}, 358$, 36 I, 393; sch., see L., St. Margaret's sch.; see also Brookhouse, L., St. Margaret and St. Katherine guild, guildhall.

city and borough, area, $31,52,76$, I 53-4, I 55, I 94-9, 26 I-2, 26 5, 287-8, 29I-2, 300, 302; bounds., 8, I 47, 275,287 , see also L., courts, \&c. incorporation, $19-23,56-57$, I I II 9 , county borough, 288, city, 206.

Burgage tenure and borough franchise, $3,9,12,13$, I $9 n, 29-$ 30,36 , I 22, I 50-1, 251 ; Common Hall, 29, 36, 69, I 12 , see also below companies; by-laws, $23-24,73$; council, I $5 \mathrm{I}, 25 \mathrm{I}-2,287$; wards, \&c., 28,73, I 5 I, I 56-7, 25 I, 287, see also L., Abbey, Allsop, Aylestone, Baker, Belgrave, Callis, Castle, Charnwood, Clay, Deacon, De Montfort, East Gate, High St., Humberstone, West, Knighton St. Martin's, Latimer, Newton, Noble, North Gate, Overinge, public services, watch and ward, St. Margaret's, St. Margaret's, East, St. Martin's, South Gate, Southwell, Spinney Hill, Swinesmarket, West Gate, Westcotes, Wycliffe, Wyggeston.

Committees, 128, 160; commis sioners for town lands, 69, estates cttee., I 60, 254, 260; finance cttee., I 49, I 60, 253, 254, 289; improvement cttee., 265 ; investment cttee. I 46 ; pavements cttee., 60 ; sewerage and highways cttee., 267; South Fields cttee., 1 28, I60, 1 98, see also L., education, education cttee., fairs and markets, cttee., Newton, Alderman, Grammar sch., cttee., poor relief, public assistance cttee., public health, health, asylums, sanitary cttees., public utilities, fire, gas cttees.

Financial hist., 70, 253-6; common purse, I 4, 33, 37; earl's rents, $32-33,34-35,37 n, 45-46$; feefarm rents, $56,63-64,65,198,395$ 398; firma burgi, 22, 33, 49, 57 , farmers of, 2, $13 n, 22$, leases of, 22, 47 , see also L., fairs and markets, tolls, \&c.; mint, 2, 8, 348; rates, 68 , I 29, I $30-1,142,143,146,162,165$, $254,266,287-8,302$, improvement, 266, see also L., education, education, lib., rates, gaols, gaol rate, poor relief, rates, public health, general district rate, public works, highway rates, religious life, church rates; rateable area and value, 255 . 277, 288; taxation, medieval, I I, 1 4, 15, 16, 1 7-18, 21, 23, 27, 34, 


\section{LEICESTER INDEX}

$36,37,42,49,5 \mathrm{I}, 59,66,73$, excise, 60 , ship money, 59-60.

Officers, elected; aldermen, 28 , $68-69,73,160,287,458$, see also Alsop, Wm. (f. c. I670), Blunt, Thos. (d. I664), Callis, Wm., Chambers, Jos., Craddock, Jos. (fl. c 1684-8), Curlevache, Firmadge, Gregory, Mansfield, Hood, Ireland, Geo., Ludlam, Thos. (d. I 697), Mansfield, John (d. I798), Newton Gabriel, Noble, Fran., North, Sir Jonathan, Overinge, Palmer, Ric. Peter s. of Roger, Phipps, Thos. Rawson, Jas., Reed, Thos., St. Lo, Simpson, Sam., Sismey, Slater, Hen., Southwell, Toller, Geo. Townsend, Edm., Ward, Fran., Wright, Sir Thos.; auditors, 23, 28 , 72 ; (high) bailiffs (prepositi), I I, I 2 , I $4,23,57,62,72$, I I6, I I 8 , I 5 I, I 60 , see also Blaby, Ric. de (fl. c. I23442), Brunman, Champeden, Curtis, Pet., Hardy, John, Hotoft, -, Major, Wm., Oneby, Orton, Rob., Palmer, Thos. (d. I7 I 7), Piddocke, Scottum, Wilne, Wright, Rob. Wylard, L., earldom, earl's bailiff; chamberlains, $23,24,27,35,51,63$, 70-7 I, I I6, I 19, I 60, I6 I, I67, see also Abney, -, Murfyn, Norris, John (fl. c. 1492), Roberts, Jos., Turville; companies, 24 jurats (jurati), I 2, I 3-1 4, 24-25, 29-30, 37, $68-69,70$, I I 5 , I I6, I I 8 , I I 9, I 52 , I $60,385,48$ (later 36 ) councilmen, 29-30, 68-69, I I 5, I I6, I I 8, I I 9 I 52 , I 60 ; J.P.s, see L., courts, \&c.; (lord) mayor, I 3, I 5, 23, 26-27, 34, $37,58,6 \mathrm{I}, 68,69,70,75, \mathrm{I} 33,25 \mathrm{I}$, $296,344,45^{8}$, see also Alsop, Wm. (fl. c. I670), Astill, Edw., Asty, Ayres, Thos. (fl. c. r 705), Bent, Geo. (d. I 709), John (d. I 700), Bentley, Wm. (f. c. I684-9), Brushfield, Callis, Wm., Carr, John, Chambers, Jos., Clarke, Thos. (f. c. I 586), Craddock, Jos. (fl. c. I6848), Curtis, Pet., Dare, Deane, Wm., tailor, Fisher, John, Franke, Freeman, And., Gillot, Wm. Green, G., Hartshorn, Thos. (f. c. I 705), Heath, Heyrick, Rob., Holmes, Wm. (d. I 770), Hood, Lennard, Ludlam, Thos. (d. I697) Mansfield, John (d. I 839), Noble, Fran., Dr. Jos., Norris, John (f. c. I 492), North, Sir Jonathan, Oliver, Sam., Overinge, Paget, Thos., Pares, John (d. I 7 I 5), Pate, Penny, John (d. c. I 496), Proudlove, Racy, Reynold, John, Roberts, John, Ruddington, Hen. of, Rıdyard, Thos., Seburgh, Seler, Smith, Dan., Southwell, Sutton, Edm., Toller, Geo., Topp fam., Townsend, Edm., Trigg, Wanley, Sam., Ward, Fran., Weston,. Wigston, John, Rog. (d. I 507), Wm. (d. $c$. I 469), Wm. (d. I 536), Winterton, Wright, Sir Thos., deputy, 70.

Officers, appointed; accountant 253, 289, see also Bown; armourer, 67; beadle, 72, I 62, 254, 4II ; beadle, par., $72 n$; bellman, I62, 254; clerk (mayor's, common clerk, steward, clerk of the peace), 27 , $57,61,71,128,160,253,288-9$, 4 II, 458, see also Bell, Sir Jas., Burbidge, Thos., Creswell, Dethick, Hackle, Heyrick, John (fl. c. I765), Palmer, Edw. (fl. c. I645-62), Reynold, Ric., Standbridge, Stone, Sam., Storey, Toller, Geo.; coroners, see L., courts, \&c.; crier, $254,41 \mathrm{I}$; en- gineer, see Everard; land steward, I 28, 254; librarian, 72 ; macebearer, 72, 73, I 5 I, I 60, 254, 4 I I, see also Weldon; mayor's sergeant, 27 ; medical officer, see L., public health; mole-catcher, 254 ; preacher, $66,74,400,403$, see also Angel, John, confrater, Sacheverell, Thos. (d. I 626); recorder, see L., courts, \&c.; scavenger, 73,162 ; sergeants-atmace, 57,72 , I 5 I, I 60,254 ; solicitor, 71, I60, 289, see also Brown, -, Lowdham, Caleb, Major, John; steward, 8, 57, 6I-62, I6o, see also Halford, Hen., Hastings fam., Tamworth, Chris., above, clerk, L., earldom and honour, steward; steward of the fair, see L., fairs and markets; surveyor, 289 , see also Gordon, Jos., Stephens; superintendent of the markets, see L., fairs and markets; treasurer, 253 , 289 , see also Kirby, Sam., Paget, Thos., T.T.; waits, 55, 72, 254 .

Regalia, 68, 255; maces, 72, I $30,255,344,395 n, 457-8$; arms, $45^{8}$, motto, 249 ; seal, 20,68 , I I 5 , 457 , mayor's, 27, 457.

See also L bridges, charities, courts and the administration of justice, education, fairs and markets, gaols, guild merchant, parks and recreation grounds, Parliament and politics, poor relief, population, public health, public utilities and services, public works, recreations and amusements, religious life, religious orders and houses, trade and industry, transport and communications. City Boys' sch., 334.

City Lending Library (New Hall), $272,295,352-3$.

Clarence St., 333; sch., see L., Wyggeston's Hosp. Girls' sch.

Clarke, Mitchell, Philips \& Smith's Bank, $2 \mathrm{O}_{3} n$.

Clay, Mr., ward, I 56, I 57, I 59.

Clock Tower, I 80 o $, 283,35$ I.

Close Meadow, 370, 371, 372 .

Coal Hill, see L., Berehill.

Cock Muck Hill, see L., Spital Hill; Houses, 409, 4 I I.

College of Art \& 'Technology, 3 I 3 $346,347,4 \mathrm{I}_{2}-\mathrm{I} 3$; see also L., Art Secondary sch.

College St., 334; ch., see L., Wycliffe ch.

Collegiate sch., $332,334,335,394$; for Girls, 334 .

Coltmans', 343

Colton St., sch., see L., St. George's par., sch.

Conduit, The, 364 .

Conduit Field, Ioo, 354.

Conduit St., 355; mill, see L., Tower Mill; see also Preston \& Charlesworth.

Conduit St., Upper, 356; sch., see L., St. Peter's sch.

Consanguinitarium, 409

Constitutional Club, $23 \mathrm{I}$

Co-operative Wholesale Soc., 248 , $324,393,435,436$.

Corah's St. Margaret's Works, 3 I I, 353.

Cordwainers Row, 4I. I 79, I 94, 266, 364, 395; keeper, $254 n$.

Cornwall (Corn Wall, Back Side), 79 364.

Corpus Christi guild, 20, 29-30, 35 50-5I, 63, 70, 366-7, 368; chaplains, 366 ; guildhall, $53,68,70$, $7 \mathrm{I} n, 74,133,254,255,352,36$ I
Clyde St., sch., 336 .

Corn Exchange, I 35, I 42, I 62, I 7 I,
2, 365, 366, library (Town Hall library), $65,273 n, 362,365$.

Cort Crescent, sch., 336.

Cossington St., baths, 294; recreation ground, 355 .

Cotton St., 355.

countess of, see Amice, Lauretta.

County Offices, 363 .

County Rooms, 362 .

County sch., 330,336

courts and the administration of justice, $6,8,9-18,62-63,68,270$; of record, 62, 72; profits, I4, 33, $44,61,65$; site, I 79, 290, 364 .

Assizes, $35,68,84,123-4$, I 53 , 342,345 ; justices in eyre, I 7, 21 ; justices of oyer and terminer, 55 ; justices of trailbaston, 18.

Court leet, 62, 73, I I 5 ; frankpledge, view of, I0, I I, 32, 62 ; licensing sessions (cannemol courts), 46, 74, 27I; portmanmoot (portmoot), 9-IO, I I, I 2-I4, 22, $24,25-26,33,37,48,57$, officers, I 3, I 4, jurisdiction, IO, I 3, I6-I 7, $62-63$; sessions, mayor's, 25-26, 36 , quarter, $62,71,72,75,153$.

Coroners, I8, 26, 68, 72, see also

Turville; J.P.s, 26, 27, 28, 29, 68, 72, 75, I 23-4, I 48, I 5 I, I 64, I 87, I 89, see also Sedgewick, associate, I I 5-I6, 124 , clerk, see Stone, Sam., jurisdiction, 57-58, 68, I07, I I I-I 2, I 29-3I, I 42, I 43, I 47, I 64-5, 255; liberties, see Knighton, L., Bishop's Fee, Bromkinsthorpe, Castle View, Newarke, St. Leonard's par.; recorder, 26, 57, 62, 68, 7I, I 60, see also Bakewell, Beaumont, John (ff. c. I 550), Braham, Burleton, Carter, Lawr., Chapman, Thos., Goulburn, Edw., Harding, Rob., Nichols, Sir Augustine, Winstanley, Jas. (fl. c. I 662).

See also L., Castle; (earls') court, fairs and markets, courts, guild merchant, morningspeech.

Cow Lane, 46, 364 .

Cowhay Pasture, 9, 20, 21, 32, 100, $370,371-2$.

Crane Inn, 4II.

Craven St., 338.

Crescent, The, I 98, 361, 374 .

Crescent Cottages, 374 .

Crown Hills sch., 336 .

Crown St., chap., 393.

Cumberland Row, 356.

Cumberland St., 34 I.

Curzon St., chap., 393; sch., see L., St. Matthew's sch.

Dale sch., 337 .

Dane Hills Home for Incurables, 390 , 455.

Danet's (Walsh's) Hall man., in Bromkinsthorpe, 9, I7, 31, 53, I07, 29I, 38I-2; man. house, 383; see also Danet fam., Noble fam., Watts, Dr. Wm.

Dannett St., sch., see L., St. Paul's par., sch.

Deacon, Mr., ward, I 56, I 57, I 59 365 .

Deacon St., sch., see L., St. Andrew's sch.

Dead Lane, see L., Free School Lane. Deadman's Lane, see L., Great Central St.

De Montfort Square, 223.

De Montfort St., 352, 394.

De Montfort ward, $242 n$.

Denman St., chap., 393.

Dent's Meadow, 354, 355 .

Devonshire, Ctss. of, Hosp., 350, 4 Io. 


\section{A HISTORY OF LEICESTERSHIRE}

Dogkennel Lane, see L., Rutland St.

Doveland Coppes, in Bromkinsthorpe, $452 n$.

Dover St., ch., 394; chap., 39 I.

Drapery, The (Le Draperie), 47, 63, 363.

Drill Hall, 346 .

Dudley Ave., sch., see L., Thurnby Lodge sch.

Duns Lane, 387.

Duxbury Rd., sch., 33 I.

Earl Howe St., see L., Consanguinitarium.

earldom and honour, I-3, 6, 7, 9, 2I, $32,56,57,60,65,421,434,439 n$; bailiff (earl's, king's, queen's), 10, I I, I4, 22, 23, 46, 62, see also L., city and borough, bailiffs; receiver, I I, 62, queen's, 64; steward, I I, I2, 13, I5, 61-62, 70, see also Hastings, Hen., 3 rd Earl of Huntingdon.

earls of, I, 49,344, 345, 346, 350, 370, $37 \mathrm{I}, 376 \mathrm{n}, 379,38 \mathrm{I}, 4 \mathrm{I} 5,428,434$ 439 , 447, see also Edm. Crouchback, Montfort, Sim. de (d. I 264), Rob. Blanchesmains, Rob. de Beaumont, Rob. FitzParnell, Rob. le Bossu.

East (Great) Field (Pasture), 9, 31 $32,53,99,100,272,350,354-5$, 381 ; bounds., 354 ; incl., I 65 , I 97 , 355,357 ; see also L., Conduit, Middle, Nether, fields, St. Margaret's Pasture.

East Gate, 20, 32, 36, 39, 42, 43, 46, I 49, I 54, I 55, I 56, I 70, I 80, I 94 $200,283,30 \mathrm{I}, 350,35 \mathrm{I}, 352,353$ $354,360 n, 36 \mathrm{x}$; township, I $n$.

Eastcourt Rd., sch., see L., Overdale sch.

Ebenezer chap., 392.

Edgehill Rd., chap., 393.

education, 74, 225, 270, 286, 294, 302, 309-38; adult, 392; elementary, 328-3I; secondary, 33I-5; tech-

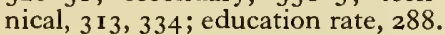

Sch. bd., 224, 225-6, 231,232 , 27 I, 286, 288, 290, 328, 330-I, 333, $335-7,427,446,456$, see also Aylestone, sch. bd., Belgrave, sch. bd., L., Humberstone, West, sch. bd., Newfoundpool, sch. bd.; education cttee., 286, 329, $33 \mathbf{I}, 333,334,335-7,394,4$ I 4,438 , 442 ; education dept., 300.

Schs., $270,332-7,388$; non-conformist, 328; R.C., 330, 331 ; private, 335 , see also Knighton, Stoneygate sch.; boarding, 4I5; day nursery, see Belgrave, Belgrave House; disabled, 33I ; industrial, see Desford; see also L., Art Secondary sch., College of Art \& Technology, Free Grammar sch., Newton, Alderman, sch., Proprietary sch., Wyggeston's Hosp. Boys' sch., Girls' sch.

Libraries, 273-4, see also L., Bishop St., City Lending library, Corpus Christi guild, guildhall, library, St. Mary in the Meadows, library; library rate, 295.

Museums, 267, 274, 335, 362, 392, see also Belgrave, Belgrave Hall, L., Carey museum, Newarke Houses, museum, Skeffington House.

Learned socs., 274; Architectural and Archaeological Soc., 274, 405, library, 362; Literary and Philosophical Soc., 265, 274, 353, 356.
See also L., General News Room, Mechanics' Institute, Shakesperean Assoc., University, Working Men's Assoc.

Elbow Lane, 334, 341 in 343; sch., see L., High Cross sch.; see also L., Bond St., East.

Ellis Ave., sch., 336.

Erskine St., chap., 392.

Essoldo Cinema (Temperance Hall), 272,352 .

Evington Footpath, 352, $370 n, 398$

Evington, North, par., $290 n, 29 \mathrm{I}-2$, 297, 434, 436; see also Evington.

Evington Rd., 398.

Evington St., see L., Lawton, Martha Ann, Almshouses.

Faire Bros. works, 353 .

Fairfax St., 334, 335

fairs and markets, 7, 8, 21, 46-40 56,92 , I I 5, I 79-80, 283-4, 289, $352 n$, earl's, 34,47 ; courts, I I , 33 47,62 ; cttee., I6o; officers, $27-28$, $72,254 n$; regulation, see L., trade and ind., regulation; steward of the fair, 28, 47, 72, see also Coleman Ric., Norris, John (fl. c. I 492); superintendent of the markets, I $5 \mathrm{I}$ tolls and fines, I I-I 2, 2 I-22, 3 I, 33 $34,44,47,49,5$ I $, 6 \mathbf{I}, 63 n$.

Market hall, 266, see also L.

Drapery, The, Gainsborough, The Friday market, 46; Saturday market, 46,86, I 80,364 , see also L. Market Place; Wednesday market, $46,52,179-80,283,338,36$ I

Bean market, 46 ; bread market, 44 ; cattle market, $46,266,362,363$ 364 , fair, $36_{3}$; corn market, 46 , see also L., Corn Exchange; fish mar ket, see L., Fish Market; grain market, 46; hay market, 283 , see also L., Haymarket; horse market, I I I fair, 52,363 ; livestock market, I 80 $265,283-4,290,375$; meat market, 363 ; pig market, $361,362,364$ see also L., Bond St., New, High St.; (St. Nicholas') shambles, 44, $46-47,53,63,179,333,334,383$ 384 , see also L., Applegate St.; sheep market (pens), 46, 63, 364, fair, 362 ; vegetable market, 353 ; wool market, 57.

Fieldingford, 45

Fish Market, 363,364

Fleece Inn, see L., Old Robin Hood Inn.

Forest Lodge sch., 336.

Fosbrooke Bakehouse Lane, see L. Bakehouse Lane.

Fosse Rd., 38 I $n$, 449; ch., see L. Holy Apostles; sch., 336.

Fosse Rd. Central, 38 I $n$.

Fosse Rd. North, 455; chap., 393 453 ; see also L., St. Theresa's convent.

Fosse Rd. South, 335 .

Fosse sch., $336 n, 337$.

Foundry Lane, Salvation Army Hall, 394.

Franciscan (Grey) Friary, I 54-5, 194 $362,363,370$; chap., 50 .

Freak's Ground, 278, 279, 287, 350, 4 I I, 449-50, 456; bounds., 449 ; fever hosp., 279, 282, 331, 450; mill, $45^{\circ}$.

Free Christian ch., 394; minister, see Macdonald, A. F.

Free Grammar sch., 66, 74, I4I, 328, $332-3,334,338,404,4$ I I, 4I 3 ; cttee., I4I ; (head)master, 4I2, see also Andrewes, Davies, Ric., Thomas, Wm., Went; trustees,
332; usher, 407; see also L., Wyggeston's Hosp. Boys' sch.

Free School Lane (Dead Lane, mortua venella), 332, 338, 341, 36I 383 ; sch., see L., Free Grammar sch

Freehold Land Soc., 382, 445 .

Freemen's Common (Meadow), 260, $373 n$.

Friar Lane, 290, 329, 361, 362, 363 , 370 ; chap., see L., General Baptist chap.; sch., see L., St. Martin's par., char. sch.; see also Coltman, John.

Friar Lane (another), $370 n$.

Friars Causeway, $33^{8}, 3^{8} 3$

Friends' Adult sch., 331 .

Frith, The, see L., Leicester Frith.

Frog Island, I 96, 338, 341, 348, 396, 407 ; see also L., North Mill

Fuller's Lane, see L., Soar Lane.

Gainsborough, The, (Town Hall), I I O, I 53, I 79, I 94, 364.

Gallowtree Field, Fields, I oo, 370.

Gallowtree (Galtre) Gate, 52, I 29, I 54, I $56 n$, I 6 I , I 62, I 80, I 90, 290 $298,30 \mathrm{I}, 35 \mathrm{I}, 352,36 \mathrm{I}, 364,4 \mathrm{II}$; chap., 394 ; sch., 330 , see also L. Osborn St., sch.; see also Wilkinson, L., Granby St.

Gallowtree Hill, 6 .

Gaol Lane, see L., Causeway Lane.

gaols, borough, I $3,1_{42}, 143,146,163$, 165, 197, 286-7, 338; officers, 62, $254 n$; county, $163,287,33^{8}-4 \mathrm{I}$, 370 , 374; gaol rate, I 42 , 163 ; see also L., Castle, Gainsborough, The.

Garden St., 360.

Gas Office, 363 .

gates, 9, 3 I, 5 I, 74, I 28, I 53, 1 94, see also L., Eàst Gate, North Gate, South Gate, West Gate; gatekeepers, 5 I.

Gateway schs., 334, 335.

General Baptist chap., I 78, 390, 391, 433; minister, see Bishop, Deacon, Pike, Wigg; sch., 328.

General Baptist Coll., 352.

General Hosp. (Poor Law Union Institution), 33 I, 436.

General News Room, 273-4, 290, 352.

George St., chap., 393.

Gervas Rd., sch., see L., Thurnby Lodge sch.

Gillman Rd., sch., see L., New Parks House sch.

Gilroes (Gilwro, Joly Roo, Jelilorve, Jellyrowes) par., 300, 349, 350, 450-I; isolation hosp., $279,45 \mathrm{I}$; pop., $45^{\circ}$.

Gipsy Lane, sch., see L., Northfield House sch.

Gladstone St., chap., 393; sch., 336, see also L., St. Luke's par., sch.

Glenfield St., sch., see L., Christ the King sch.

Glenfrith Hosp. (Leicester Frith House), 453, 454 .

'Gloversrowe', 47.

Gopsall St., sch., see L., St. Peter's sch.

Gosewellgate, see L., Haymarket.

Gosling Croft (Close), I87 $n, 37$, 372.

Goswell Gate, see L., Haymarket.

Granby St. (Gallowtree Gate), 26o, $274,290,324 n, 352,353,363$, $384 n$; chap., 393,394 ; see also L., Essoldo Cinema, General News Room, Grand Hotel, Blind, Institute for the, Midland Bank, National Provincial Bank.

Grand Hotel, $35^{2}$. 


\section{LEICESTER INDEX}

Grand Union Canal (Leicester Navigation, Leicestershire and Northamptonshire Union Canal), I 95-7, $262,263,264,278,293,338,341$, $353,355,415,417$; Leicester Navigation Co., 354

Grange Lane, $38 \%$.

Granville Rd., ch., 394.

Great Central St. (Deadmans Lane, Sycamore St.), 338, 383, 384; see also L., Vaughan Coll.

Great Field, see L., East Field.

Great Meeting, I 52, I 78, I 82, 252-3, 393-4; burial ground, I 26, 393; domestic mission, 270, 27I, 273; minister, see Berry; schs., 328, 329, $332,334,393$.

Green Lane, sch., 336

Greencoat sch., see L., Newton, Alderman, sch.

Grey Friars, 362, 363, 413.

Grey Friars (house), 362 .

Grove Rd., sch., see L., St. Saviour's par., sch.

Guest House, The, $347 n$.

guild merchant (merchant, chapman guild), I 2, I 4-16, I 9, 33-37, 38, 48, 5 I, I05; guildhall, see L., Mayor's Hall; morningspeech, 15, 20, 24, 25,35 , jurisdiction, 10 , I 5 , see also L., trade and ind., regulation; purse, 15,48 ; seal, I6, 20, 457

Officers, I 5 ; aldermen, I 5, 24, 27, see also Ruddington, Hen. of ; chamberlains, 15, 22, 27, see also L., city and borough, chamberlains; jurats (jurati, council), I 5, 24-25, 35 , see also L., city and borough, companies, 24 jurats; sergeant, 15.

Guildhall, see L., Castle, Corpus Christi guild, guildhall, Mayor's Hall.

Guildhall Lane (Holy Rood, Holyrood Lane, Kirkgate, Kirk Lane, St. St. Martin's Ch. Lane, Town Hall Lane), 43, I $56 n, 36 \mathrm{r}$; see also L., Blue Boar Lane.

Gwendoline Rd., sch., see L., Crown Hills sch.

Haddenham Rd, schs, see L., Manor House sch., St. Mary's Fields sch.

Halford St., 353; Salvation Army Hall, 394.

Hall, Rob., Memorial chap., 392; sch., 337.

Hallam, Alderman R., sch., 335.

Hamelin Rd., sch., see L., Wycliffe sch.

Hangman Lane, 372 ; chap., $393 n$.

Harvey Lane, 361,383 ; chap., I 78 , 391, minister, see Mursell; Memorial Hall, 391.

Hastings St., $374 n$.

Hattern Ave., sch., see L., Woodstock sch.

Hawthorne St., 292.

Haymarket (Goswell Gate, Gosewvellgate), I $56 n, 35$ I.

Hazel St., sch., 336.

Headland Rd., sch., see L., Linden sch.

Hermitage, 'The, 377.

Hermitage Field, 100

High (Market) Cross, 4I, 42, 46, 5253 , I I O, I 23,128 , I 53,154 , I 55 , I $56 n$, I 62, 36I, 395 .

High Cross (Elbow Lane) sch., 331, $334,336$.

High Cross St. (High St., magnus vicus, alta strata), I55, I63, I 79, $180,283,333,334,338-41,342$, $361,369,370,384,393,405,408$; see also L., Bent's Hosp., St. John, \&c., Hosp., Shire Hall.
High St. (Swinesmarket), 40, 4I, 43, $46,52,95,155,180,262,283,290$, $301,338,351,361,362,364,365$, $369,383,395,398,407$; ward, 54 ; see also L., High Cross St., Southgate $\mathrm{St}$.

Highfield St., 360 ; see also L., Whetstone's Mill.

Highfields, 260; chap., 393.

Hill St., 333 ; sch., 336.

Hill St., Lower, chap., 393.

Hillcrest Hosp. (workhouse), $257 n$, 356.

Hinckley Rd., $3^{8} 3 n, 428,43 x$; chap., 393; see also Hinckley, road from Leicester to.

Holme's Mill, 398.

Holy Apostles ch., 377.

Holy Bones, $384,385 n$; sch., see L., County sch.

Holy Cross priory, 389-90, 420; schs., $337,390$.

Holy Rood Lane, see L., Guildhall Lane.

Holy Trinity guild, 5 I

Holy Trinity par., 377 ; ch., 377 ; sch. 337.

Holyrood Lane, see L., Guildhall Lane.

Horse Fair Lane, see L., Millstone Lane.

Horsefair (Horse Fair) Gardens, I 95, I 98,363 .

Horsefair Leys, I 95.

Horsefair St., I $80,283,290,35$ I, 352, $361,363,364$; theatre, see $\mathrm{L}$. Theatre Royal; see also L., Allied Assurance building, National Provincial Bank, Royal Hotel.

Horsepool, I 62.

Hotegate, le, see I., St. Nicholas St.

Hotel St., 362, 364; theatre, 272; see also L., County Rooms.

Hotgate, see L., St. Nicholas St.

Humberstone Gate, I 6, 48, I 29, I 54, I 80 , I 90, I 95, I 97, $200 n, 26$ I , 283, 29 I, 30I, 333, 334, 35 I, 355, 356 400; theatre, see L., Amphitheatre; see also I., St. Mary de Castro par. workhouse, Spa Place.

Humberstone Rd., 261, 263, 272, 286, 201, 354; chs., see L., St. Luke's, Union; chap., 392, 393.

Humberstone, West, par. (ward), $242 n, 291,297,426,439$; rly. stn. 291 ; sch. bd., $336 n, 337 n, 442$; see also Humberstone.

Imperial Ave., sch., 336

Infants' Sch. Soc., 330

Infirmary Rd., 372.

Infirmary Square, 393 .

Ingle St., sch., 336,456

Ironmongerowe (Iremongerowe), 47

Ivanhoe St., 292.

Janus's 'Temple, see L., Jewry Wall Jarron St., ch., see L., St. Andrew's. Jelilowe, Jellyrowes, see L., Gilroes.

Jester House, 384 .

Jewry Wall (Janus's Temple, Jury Wall), I 53, 384, 385, 386 .

Jewry Wall St., 384,387 .

Joly Roo, see L., Gilroes.

Jury Wall, see L., Jewry Wall.

Kent St., Upper, 356.

Kephovenlane, see L., Bakehouse Lane.

Kildare St., Salvation Army Hall, 394.

King, John and Rob., schs., 328.
King St., $374 n$; see also L., Crescent, The, Crescent Cottages.

King Richard sch., 337.

King Richard's Rd. (Watts Causeway), $327,38 \mathrm{r} n, 383 n, 390$; chap., 392 ; sch., 337 .

Kirk Lane, St., Kirkgate, see L., Guildhall Lane.

Knighton Drive, see L., Barlow, Sarah, Almshouses.

Knighton Hill, 397; see also L., Leicestershire \& Rutland Asylum.

Knighton St., 372.

Knighton St. Martin's ward, $242 n$; see also Knighton.

Lachepol, see L., Lethpol.

Lammas Ground, see L., Abbey Park.

Lancaster Rd. (Cavalry St.), $374 n$.

Lancaster sch., 337.

Latimer ward, $242 n$

Lawton, Martha Ann, Almshouses, 409 .

Laxton St., sch., see L., St. Andrew's sch.

Leamington St., $383 n, 390$.

leather crafts and industry, $37,4 x-42$, $54,76,78,83-86$, I 58 ; cobblers, 47 , 84 , see also Bailey, -, Brown, Edw.; cordwainers, $37 n$, 158 , cordwainers' and shoemakers' co., $83-84$, I66; curriers, $77,84-85$.

Footwear ind., I04, I 95, I 99 , $242,259,260,262,269,270,276$, $293,294,296,297,300,301,302$, $314-26,327$; Manufacturers' Assoc., $315 n, 322,325,326$; bd. of arbitration, $321,323,324,325$; Boot and Shoe Union, 244, see also Amalgamated Soc of Boot and Shoe Makers, National Union of Boot \& Shoe Operatives; manufacturers, see Biggs, John \& Sons, Pool \& Lorimer, L., Co-operative Wholesale Soc. ; machinery makers, 320 .

Glovers, 79, 86, I67, I79, see also Bassford, Brisbone, Gracedieu, Bart., Hall, John (d. I 584), Lincoln, Penny, John (d. c. I 496), Racy, Trigg, see also L., 'Gloversrowe', glovers' and fellmongers' co., I $66 n$, I $8 \mathrm{I}$; leather dresser, see Hilton, T.; leather seller, see Bassford; parchment makers, 364 , see also Abell fam., Robinson, Chas., L., Bond St., New; saddlers, 45, 85, see also Fawcett, Gil., Grendon, Seburgh, Seler.

Shoemakers, 37, 41, 47, 83-84, 3 I4, 318, see also Churchman, Webster, Thos., journeymen shoemakers' co., 83 ; skinners, $4 \mathrm{I}$, see also Asty; tanners (barkers), 4I, 84-85, 86,3 I 5, 34I, see also Blackshawe, Brewin, Rob. (fl. c. I 8oo), Norris, John (fl. c. I +92), Pippin, tanners co., IOO; whittawers, 85-86, see also Springthorpe, Ric. ; see also L., Leather Hall.

Leather Hall, 84

Lee St., car park, 356.

Leicester Abbey par., 287, 349, 447, $449,45 x-3,456$; non-conf., 453 ; pop., $452-3$.

Leicester Abbey park, see L., Abbey Park.

Leicester \& Swannington Rly., I99, $293,387-8,449$.

Leicester forest, $9,12,58,64-65,100$, $348,412,430,447$; bounds., $430 n$; incl., $108-9,382,431,447$; see also Braunstone par., King's Wood, Hereswode, L., Beaumont Leys, 


\section{A HISTORY OF LEICESTERSHIRE}

Leicester forest (cont.)

Braunstone Frith, Freak's Ground, Gilroes, Leicester Frith, New Parks.

Leicester Frith (Sherman's Lodge, Grounds, Markham's Close), 74, $300,350,453-4$; bounds., 453; inc., 74 .

Leicester Frith House, see L., Glenfrith hosp.

Leicester Navigation, see L., Grand Union Canal.

Leicestershire \& Rutland Asylum, 1 49, 279, 374, 375 .

Leicestershire Club, 353 .

Leroes, 354.

Lethpol (Lachepol), 357.

Lewis Almshouses, 369 .

Liberal Club, 352 .

Linden sch., 336.

Linwood sch., 337

Littleton St., 349 .

London Rd., I 54, 194, 1 95, 198, 260, $261,286,291,352,355,356,392$, 398; ch., see L., St. James the Greater; chap., 394, minister, see McAll, see also L., St. Paul's chap.; rly. stn., $393,394,398$; see also London and Westminster, road from Leicester to.

Lord's Place, 56, 290, 36r.

Loseby Lane, 46, I56 $n$, 180, 362, $363,364,412$; see also Dilkes, Jackson, Wm.

Magazine Gate, 346.

magnus vicus, see L., High Cross St.

Manor House sch., 33 I.

Mantle Rd., sch., see L., Fosse sch.

Marclose, The, 453.

Market Cross, see L., High Cross.

Market (Saturday market) Place, $37 n$, $44,46-47,52,81,153,154$, I $56 n$, 162, I64, I 79, 1 80, 1 94, 207, 2 I 3 $222,264,265,283,290,354,362$, 363-4, 380, 395, 396, 413; see also Bown, L., Angel Gateway, Conduit, The.

Markham's Close, see L., Leicester Frith.

Marriott Rd., sch., 337

Marston's Mill, 398

Martyrs, ch. of the, 377 .

Marymeadow, see L., Oxhay.

Mason, Miss, Almshouses, 4 Io.

Mayor's Hall (Guildhall, Old Shop), I6, 20, 29, 35, 70, 384 .

Mayor's Hall Lane, see L., Blue Boar Lane.

Meadow Gardens, sch., see L., Linwood sch.

Mechanics' Institute, 274, 353 .

Medway St., sch., 337.

Melbourne Hall ch., 392; minister, see Meyer; schs., 392.

Melbourne Rd., ch., see L., St. Hilda's; chap., see L., Highfields, St. Paul's; sch., see L., Dale sch.

Melton St, chap., 392.

Memorial Hall Baptist chap., 391.

Mere Rd., 35I, 434; ch., see L. Sacred Heart R.C. ch.; chap., see L., Wesley Hall; sch., see L., Sacred Heart R.C. sch.; see also L., St. Joseph of Peace convent.

metal working crafts and industry, 37 , $76,78,97-98,99$, г 04, г 58, 1 85-6, 302 ; arms makers, 76,78 ; bellfounders, 87, 97-98, see also Arnold, Edw., Newcombe, Edw. Rob., Thos.; braziers, 97, I86; clockmaker, see Wilkins; coppersmiths, 97; cutlers, 97, 99, see also Ball, Wm.
Engineering industry, I86, г99, $243,259,260,293,296,297,300$, 301, 302 ; framesmiths, I 86, 306; furbishers, 99; goldsmiths, 45, 97, 186, see also Turville; gunsmiths, 97, 99, I86; iron founding, 259; ironmongers, $37 n, 47,8 \mathrm{I}-82$, 90 , 97, 1 6 , see also Byllyng, Heyrick, Rob., Overinge; ironworkers, I $57 n$.

Locksmiths, 97; needle-makers, I 86; pewterers, 97, I 86, see also Launder, Anne, John, Savage; ploughwright, see L., agriculture, \&c.; sinker-makers, I 86; smiths, 97 , I $57 n$, I 58 , I 86 , see also Chettleton, Thos., Nutt, Jas. (d. 1663), Peel, Hen. (d. I639), Timson, Thos., Vincent, Warner, Rog., smiths' and cutlers' co., I $66 n$, I 86 ; tinplate workers, I 86 ; watchmaker, see Green, Geo.

Metcalfe St., chap., 392 ; sch., 337, 392.

Middle Field, I oo, 354, 370.

Midland Bank, 352, 353

Midland Counties Fire Office, fire brigade, 255 .

Mill Hill Lane, 398.

Mill Lane, 346, $374 n$, 396 ; bridge, 277. mills, $63,94 n, 395^{-8}$; bark, 84 ; fulling, 38,87 ; horse, $43,395,398$; water, 32, 43; wind, 32, 43, 395, 397-8; see also L., Abbey Mill, Bromkinsthorpe, mill, Freak's Ground, mill, Newarke Mill, North Mill, St. Margaret's par., windmill, St. Mary's Mill, South Fields, windmills; millers, see L., victualling trades.

Millstone (Horse Fair) Lane, I 87 , $351,361,363,370 n, 371,372,393$; chap., I78, 392; see also L., Gas Office, Lewis Almshouses.

Milton St., sch., 331, 337

miscellaneous trades and professions; apothecaries, 99, I57, see also Callis; barbers, 99; (barber) surgeons, 99, see also Pollard, -; bookbinder, see Cooper, Godfrey; booksellers, 82, see also Combe, Emery, Hartshorn, Thos. (f. $c$. I 705), Philips, Ric.; chandlers, 92, 98, r 5 ; chapmen, 82 , 95, see also Wright, Dan., L., guild merchant; coal merchant, see Ellis, John; coalmongers, 96; doctor, see Spero; fletchers, 99; furnishing, 76,78 ; lawyers, 99, 260; leech (medicus), 34; physicians, 99; printer, see Cockspur; printer and engraver, see Cockshaw, Typographical Soc., 234 : regraters, $33,44,49$; scriveners, 99 ; retail trades, 76,78 ; solicitor, see Burbidge, Thos., Harris, Jos. (A. c. I 846), Stone, Sam., Toller, Geo.; spitelmen, 34 ; stationers, 82 ; surveyor, see Rolleston; tallowchandlers, $98-99$, I 58, I $79 n$, I 84 , see also Woodland, Thos. (2), guild, 36 , co., see L., building, \&c., slaters; tobacco curing, 95; upholsterers, 99, see also Trickton, Eliz.; watermen (lochelmen, burnmen), 52, 96, guild, 35 ; wholesale trade, 76,78 .

Moat Rd., sch., 337.

Monsell, Eyres, sch., 337

Montrose sch., 337.

Morehead, 395 .

mortua venella, see L., Free School Lane.

Mount Pleasant Mill, 398.

Mowmacre Hill, 214.

Narborough Rd., 381 $n, 383,398$, 428 ; ch., see L., Martyrs, ch. of the; chap., 394 ; sch., see L., Hall, Rob., sch., St. Mary's Fields sch.; see also Fosse Way.

National Provincial Bank, 352, 363 .

Navigation St., chap., 392.

Nether Field, Ioo, 354; see also L., Cossington St., recreation ground. New Hall, see L., City Lending Library.

New Parks, 30o, 454-5, 456; housing estate, $297,298,454$, sch., 33 I $n$; park, 455 ; pop., 455 .

New Parks (Braunstone Frith) sch., 337.

New Parks House sch., 337, 454.

New St., 155, 1 94, $254 n, 260,362$, 363,365 .

New Walk, r94-5, 197, 1 98, 200, 260, $262,335,35 \mathrm{x}, 370 \mathrm{n}, 372,373-4$, $377,389,394$; baths, 269; chaps. see L., Memorial Hall, Sunday sch. Memorial Hall; sch., see L., Holy Cross schs., Proprietary sch.

Newarke, The, lib., I7, 57, 59, 68, 78 $107,130,153,156,159,182,188$ I $91,257,262,272,277,293,329$, $344,345,346-7,376,377,390$ $392 n$; asylum, 347 ; bounds., 346 chars., 347 ; magazine, 67 , see also L., Magazine Gate; museum, see L. Newarke Houses, museum; overseers of poor, I89; St. Mary's vicarage, 333 ; see also Carter, Lawr., Hawes, John, Sutton, Edm.

Newarke, Coll. and Hosp. of St. Mary of the, $5,6,16,17,50,57,63$, $64,346-7,370 n, 371,372,395$, $396,400,406$; canons, $17,45,346$, $347,397,399,448$, see also Wigston, Thos. (d. I 536); chap., 50 ; chant., 398 ; dean, I 7, $45,74,346$, $347,397,399,448$; master, see Fowkes; receiver, 63 ; see also $\mathrm{L}$. Guest House, Newarke Houses, museum, Trinity Hosp.

Newarke Girls' sch., 334-5.

Newarke Grange, 56, 63-64, 74, 1067 , 108, 165, 197, 37 1, 396, 431, 4489; see also L., Close Meadow, Gosling Croft, Oxhay.

Newarke Houses, 346 ; museum, $347 n$, $36 \mathrm{I}$.

Newarke (Swan's) Mill, 63, 64, 94, $395,396,397$; shop, 396

Newarke sch., see L., City Boys' sch.

Newarke St., $300,335,351, \cdot 372 n$; chap., 392, see also L., Christian chap.; sch., 330.

Newby St., 394 .

Newfoundpool, 287, 290 $n, 292,422 n$, 455-6; bounds., 455; hydropathic institute, $455^{-6}$; pop., $45^{6}$; sch. bd., $336 n, 456$.

Newport St., 292.

Newry sch., 337.

newspapers, I89-91, 243-4, 272-3, 294-5, 315; Advertiser, 273, 295, proprietor, see Cox, Wm. (fl. $c$. 1870); Anti-Gallican, I90; Daily Mercury, 294; Illustrated Leicester Chronicle, 295; Leicester Chronicle, I 44, I 48, I 49, I 89, I 90, 202, 205, 208,2 II, 2 I 5,2 I6, 218,2 I9, 220, $221,223,273$, proprietor, see Thompson, Jas., Thos. (f. $c$. I $813-$ 64); Leicester Daily Post, 243, 294, editor, see Wood, Jos.; Leicester Evening Mail, 295; Leicester Evening Mercury, 295; Leicester Evening Nezus, 295, editor, see Searson; Leicester Guardian, 273, 295, proprietor, see Cox, Wm. (A. c. I870); Leicester Herald and General Advertiser, 144, 147, 189, 190, 273; Leicester (and Nottingham) Fournal, I28, I34, I 39, I 40, I4 I, I44, I 47, 


\section{LEICESTER INDEX}

149, I 5 I, I 89-90, $217,273,295$, $328,329,372$, editor, see Gregory, John (2), Price, John; Leicester Pioneer, 237; Leicester Sporting News, 295; Leicester Times, 295 Leicestershire Chronicle and Leicester Mercury, 273, 295, proprietor, see Hewitt, F., \& Son, Thompson Jas.; Leicestershire Herald and General Advertiser, 190-I; Leicestershire Mercury, 208, 209, 21 $8 n$, 223, 273, proprietor, see Cockspur Midland Free Press, 205, proprietor, see Windley; Saturday Herald, 295; South Midland Free Press, 273, editor, see Emery.

Newton, Alderman Gabriel's, (Greencoat) schs., I 49, I 50, 333-4, 362, 405, 414; cttee., 333; headmaster see Muston.

Newton ward, $242 n$.

Noble, Mr., ward, I 56, I 57, I $58 n$, I 59.

Noble St., R.C. mission, 390.

Norfolk St., 38 I $n$.

North, Sir J., sch., 337.

North Bridge, 41, 42, $154,156 n$, 195 , I 96, 341, 348, 349, 396 .

North Gate, 38, 4I, 42, 43, 53, I 54 , I 55, I $56 n, 162,293,341,348,369$; township, Io $n$.

North Mill, Mills, 43, 45, 63, I 55 , 35 I, 396-7.

Northampton St., 355,356 .

Northfield House sch., 336.

Northgate St., I $56 n$, I 59, I 72, I 95 $262,338,341,348,351,360,407$ chap., 392; factory, 341 ; see also Brewin, Rob. (fl. c. $1800-52$ ) Whetstone, Jos.

Nurse's mill, 397.

Oban St., 292

Occupation Rd., see L., St. Peter's Rd., Sparkenhoe St.

Old Robin Hood (Fleece) Inn, 350.

Old Shop, see L., Mayor's Hall.

Opera House, 272, 362

Osborn St., sch., 330.

Overdale sch., 336.

Overinge, Mr., ward, $1_{56}, 1_{57},{ }_{5} 8$, I 59,365 .

Oxford St. (Peatling Gate, Way, South Gate), 346, 351 , $370 n, 371$, 372 , $374 n$; chap., 394 ; sch., 337 , see also L., Paradise Place, sch.; see also Welford, road from Leicester to.

Oxhay (Marymeadow), 32, 370, $37 \mathrm{I}$, 397.

Pack Horse Inn, 409

Palmer, Mr., ward, I 56, I 57, I $58 n$, I 50.

Paradise Place, sch., 337

Parchment St., Lane, Parcheminergate, see L., Bond St., New.

parks and recreation grounds, 266, $27 \mathrm{I}-2,293,294,354$, see also Braunstone, Braunstone Park, Evington, Evington Park, Spinney Hill Park, L., Abbey, Cossington St., New Parks, recreations and amusements, South Fields, Victoria, Welford Rd. Western

Parliament and politics, $6 n$, I 8 -I 9 , $28,49,60,67,69$, г 10-52, 201-50, 393; franchise and electorate, 2930, I I6-I 7, I I 8, I 47, 20 I, 208, 22 I $224,242-3,246,25 \mathrm{I}$, see also $\mathrm{L}$. city and borough, burgage tenure, \&c. ; outvoters, I 27, I34, I 39, I 4 I,
I 43-6, I 48, I 49, 20I ; parliamentary borough bounds., $229 n, 242$; Corporation Act Commissioners, IIO-II ; Reform Act Commissioners, I 42, I 48-50, I 98-9, 202, 203.

M.P.s, 71, I76, see also Abney, Sir Edw., Ashby, Babington, Thos. (2), Beaumont, Sir Geo., Sir Hen. Belgrave, Geo. (f. c. I 6o I), Biggs, John, Broadhurst, Carter, Lawr., Cave, Rob. Otway, Coke, Thos., Coote, Curtis, Pet., Darker, John (d. I 784), Easthope, Ellis, John, Wynn, Evans, Wm., Gardner, Gladstone, Thos., Goulburn, Edw.,Grey, John, Grey of Groby, Booth, Sir John, Harris, John, Ric., Hartopp, Sir John, Sir Wm., Hastings, Sir Chas. Abney, Hazell, Hazlerigg, Sir Art. (fl. c. 1654-6o), Hewart, Gordon, Keck, Leverich, MacDonald, J. Ramsay, Macnamara, Mansfield, John (d. I 839), May, Noble, Thos., Palmer, Archdale, Pares, Thos. (f. c. I 80o-35), Picton, Pretyman, Roberts, John, Ruddington, Wm. of, Rolleston, Skrymsher, Smith Chas. Loraine, Sam., Taylor, P. A., Temple, Pet., Thomasson, Villiers, Sir Wm., Walcote, Walmsley, Whitehead, Sir Jas., Wigley, Jas. Winstanley, Jas. (d. I 7 18), Wright, Geo.

Constituencies, 242, 240; East, 242 , M.P., see Banton, Donovan, Evans, Capt. H. A., Hewart, Gordon, Loder, Lyons, Wise; NorthEast, 249, M.P., see Donovan, Ungoed-Thomas; North-West; 249 , M.P., see Janner; South, $242 n$, M.P., see Allen, R. Wilberforce, Blane, Bowden, Reynolds, W. G. Waterhouse, Waterhouse; SouthEast, 249, M.P., see Waterhouse; South-West, 249, M.P., see Bowden; West, 242 n, M.P., see Green, J. F., Hill, Alf., Janner, Lawrence, Pethick, Nicolson, Sir Harold, Pickering.

Political assocs., I 37, 201-2, 209, $224^{-5}, 23 I_{-5}$; ward assocs., 204 206, 224-5; Adelphi Club, I 37 ; Anarchist Soc., 232; Anti-Corn Law Assocs., 206, 207; Anti-Corn Law League, 213, 2 I 4 ; Anti-Poor Law Assoc., 2 I I ; Citizens' League, 237; Complete Suffrage Assoc., 208, 213, 214, 215, Union, 208; Conservative Assoc., 225. Clubs, I 49, 225, Operatives' Socs., 202, 205, Registration Soc., 202, 225 , Socs., I 47, 202, 206, 222, 225 , Working Men's Assoc., 225, 226-7, 228; Constitutional Soc., I 37 ; Fabian Soc., 231, 232; Fascist Union, 248; Friends to peace, 138 ; Hampden Club, 137; Labour Assoc., 232, Club, 232, 234, Party (Representation Cttee.), 234-6, 238 , 239, 241, 242, 244-5, Party, Independent, 235 -7, 248; Liberal Assoc., 225, 229, 231, Club, 224-5, Free, 243, Registration Socs., 222, 224-5, Unionist Assoc., 23o, Young Liberals, 243; Liberation Soc. (British Anti-State Ch. Assoc.), 208, 226, 237, 249; Municipal Registration Soc., 206; Parliamentary Reform Assoc., 223; Primrose League, 225; Reform Soc. (Political Union), I 47, 202, 204, 206, 220 ; Republican (Democratic) Assoc., 224; Revolution Club, I37, Soc., I 37 ; Social Democratic Federation, $232,238,242$; Socialist party, 24I,
Christian Socialists, 232, 238 ; Working Men's Anti-Corn Law Assoc., 2 I I, 213.

Parochial Union sch., 330.

Peacock, The, 362 .

Peacock (St. Francis) Lane, 338, 362, 405, see also Crick, Thos.

Peas Field, I oo.

Peatling Gate, Way, see L., Oxford St

Peel St., chap., 393

Phoenix Fire Office, 164

Pindar Rd., sch., see L., New Parks

House sch.

Pinders Close, $45^{2}$.

Pingle, The, 262, 34I

Pingle St., $338,34 \mathrm{I}$

Plowman Lane, $35 \mathrm{I}$.

Pocklington's Walk, $36_{3}$.

Pool Road, 456.

Poor Law Union Institution, see L., General Hosp.

poor relief, $64,73,74-75,88$, I $28-9$, $164,174-5,177,187-9,209-10$ 2 I I , 2 I 3, 2 I 7 , 256-9, 269, 288, 32 I; rates, I $88,257,288,394$; unions, I 65, I $87,256-7,344,347,387 n$.

Board of guardians, 226,232 , $256-9,28 \mathrm{I}, 286,288,300,357$ auditor, 258, clerk, see Burbidge, Jos.; overseers of poor, 73, I 74 , I 87, I 88, 257; public assistance cttee., 300 ; relieving officers, 258 .

Poor law office, 243; poor law in stitution, see L., General Hosp.; bridewell or house of correction, $74-75,143,163 n, 338,341$; poor sch., I28; workhouses, 129, I75, I $87,257,258,356$, see also L., Hillcrest Hosp.

See also L., charities.

population, 76 , I 55 , I $56-8$, I 9 I-4 $224 n, 259-60,269,270,271,275-$ $6,287,292,296,297 n, 298 n, 300$ : migrants, 192-3, 263, 276.

Prebend St., 355 ; chap., 394.

Princess St., $374 n$.

Provost's House, 366.

Proprietary sch., 267, 335

public health, $99,256,267,279-83$

200, 294; infectious diseases, I 9 I, $239, \quad 279-83$, Anti-Vaccination League, 28o, Leicester method,

282 ; general district rate, 267,288 .

Board of health, 253, 267, 268, $269,344,357$, clerk, see Stone, Sam.; health cttee., 436; asylum cttee., 374; medical officer of health, $267,279,280,289$; vaccination officer, $28 \mathrm{I}$.

Hospitals, 302, see also L., Freak's Ground, fever hosp. General Hosp., Gilroes, isolation Hosp., Glenfrith Hosp., Hillcrest Hosp., Newarke, The, Asylum, Royal Infirmary, St. Margaret's par. lazar-house, St. Mary in the Meadows, infirmary, St. Nicholas' par. pest-house; lunatic asylum, 372, see also Humberstone, Towers Hosp. L., Leicestershire \&Rutland Asylum.

Sanitation and scavenging, 5 $\mathrm{I}-$ $52,73, \quad 128, \quad 142, \quad 162,256,263$ $264,265-7,267-8,269,272,273$, $276,278-9,282,299,344,383$ sanitary cttee., 267 ; baths, 266,260 see also L., Bath Lane, baths: sewage works, $268,278,279$, see also L., Beaumont Leys, sewage farm; refuse destructor, 354,396 , dump, 345 ; inspector of nuisances, 267 ; sanitary inspectors, $289-90$.

See also L., Blind, Institute for the, Newfoundpool.

public utilities and services, 5I-52, 128-9, 284-6; cemeteries, 266-7, $375,397,450^{-1}$; electricity stns., 


\section{A HISTORY OF LEICESTERSHIRE}

Public utilities and services (cont.) 260, 354, see also L., Aylestone Rd. ; fire cttee., I64, prevention, 73-74, 95 , I $63-4,286$, brigades, 255,286 , 290 , stn., 375 ; gas cttee., 285 , works, see L., Aylestone Rd., Belgrave Gate, gas and electricity $\cos$., 142 , I $62,285,302$; post office, 266 .

Watch and ward, 73, I42, I 62-3; constables, 163 ; police, 210,255 , 270,294 , H.Q., 300, 362, volunteer, $205,213,217$; thirdboroughs, 73 , I60; ward constables, 27, 28, 73 I60, I62-3; watchmen, 73, I63.

Water supply, 52, 73, 107, 128, I 53, I 64, I 65, 264, 266, 267, 268 , 284-5, 395, see also L., Conduit, The; pumping stn., 452; reservoir 268 , see also Thornton; water and sewerage co, , 266; waterworks, I I $9 n$, I 64 ; waterworks co., 268,284

Weights and measures, 74, 129

public works; flood prevention and drainage, $155,263-4,265,277,278 n$, $375,382,395,397$.

Housing, 297-8, 30I-2, 36I, 450, estates, see Braunstone, Braunstone housing estate, Evington, Coleman Rd. Estate, L., Braunstone Frith, New Parks, Stocking Farm housing estates; slum clearance, 298, 301 356 , 4IO, 450 ; building controls, I $98,260,291$.

Street repairs and improvements, $28,5 \mathrm{I}, 73, \mathrm{I} 42-3, \mathbf{1} 60-2, \mathbf{1} 64, \mathbf{1} 65$, $255^{-6}, 264-5,267,269,283,285$, $298-9,301,332 n, 352,361,387$, 408, 424; surveyors, overseers, 73 , 267 ; highway rates, $264,267,344$. I 54

Walls and ditches, repairs, 23,51 ,

Queen St., 355, 356

Queen's Head p. h., $39 \mathrm{I}$.

Rawdykes (Raw Dykes, Raw Dyke Field), I $00,370,397,4$ I 6 .

recreations and amusements, $27 \mathbf{I}-2$; bowling green, 194, 195, 1 98, 272, see also L., Vauxhall, New; cricket ground, see Aylestone, Grace Rd. L., Wharf St.; golf course, see Oadby, L., Braunstone Frith; horse-racing, 255, 35 I , 354, see also L., Victoria Park; theatres, 272 see also L., Amphitheatre, Hotel St., Opera House, Theatre Royal; working men's club, $27 \mathrm{I}$; see also L., Horsefair Gardens, parks and recreation grounds, Vauxhall Gardens.

Red Lion Inn, 153.

Redcross St., I $56 n, 36 \mathbf{r}, 362,369$.

Regent Rd., $374 n$; sch., see L., Holy Trinity par., sch.

Regent St., I98, 333 .

religious life, $49-5 \mathrm{I}, 59,74,270-\mathrm{I}$, $389-94$; chs., $2,49-50,270-1,274$ chaps., 270-I; church rates, 202 , $207-8,2$ I I , 2I 3, 21 $4,256,365$ 394: guilds, 50-5 I, see also $\mathrm{L}$. Corpus Christi guild, St. George's guild, St. Margaret and St. Katherine guild, St. Michael's guild, Virgin, guild of the Assumption of Lollardy, 359; Puritanism, 75, 108, I IO-I I.

Non-conformity, I I 2, I 37-8, I47, I 49, I 5 1, I 59-60, I 78, I9 I, 201 204, 205, 210, 2I 3, 2I I, 220, 22 I 225-6, 23I , 237, 239, 240, 248, 25 I 266-7, 270-I, 390-4, see also above, church rates; Anabaptists, 390,
427; Baptists, 207, 39I-2 ; Christian Scientists, 394; Congregationalists, 207, 390, 393, 394; Methodists, $392-3,427$, Primitive, 391 ; Independents, 39I ; Presbyterians (Unitarians), 207, 393-4; Presbyterian Ch. of England, 394; Quakers, I I 8, 390, 392, 394; Rechabites, 39I; Salvation Army, 394; Voluntary Ch. Soc., 207-8.

Roman Catholicism, 59, I43-5, I 46, 227, 270, 389-90.

religious orders and houses, 56, I 54 ; Augustinian friars, 387 , see also L., White Friars; Dominican friars, $372 n, 389,427$, see also L., Black Friars, Dane Hills Home; Dominican nuns, 390; Franciscan Friars, see L., Franciscan Friary.

Colls., 63, see also L., St. Mary de Castro par., ch.; hosps., $50 n$, see also L., St. John the Baptist and St. John the Evangelist Hosp., St. Mary Magdalen and St. Margaret Hosp.; see also L., Holy Cross priory, Newarke Coll., St. Joseph of Peace convent, St. Mary in the Meadows abbey, St. Theresa's convent.

Richard III's bridge, see L., Bow Bridge.

Rolleston St., chap., 393.

Ross Walk, $453 n$.

Round Hill, Roundel, see L., Berehill. Rowan St., 292.

Royal Hotel, 363

Royal Infirmary, I 28, I 5 I, I 94, 255 , 33 I, 37 I $n, 372-3,377,454$.

\section{Ruby St., 202.}

Rupert's Tower, 346

Rushey Mead sch., 336.

Rutland St. (Dogkennel Lane), 327, 355; fire stn., 290; see also L., Faire Bros. works.

Sacred Heart R.C. ch., 390; sch., 337, 390.

Saffron Lane, 273, 374; estate, 297; sch., see L., Newry sch.

St. Aidan's ch., in New Parks, 455.

St. Alban's ch., 360.

St. Andrew's par., 377 ; ch., 377

St. Andrew's sch., in Deacon St., 336.

St. Andrew's sch., in Laxton St., 337.

St. Anne's par., 377, 455 ; ch., 377.

St. Augustine's ch., see L., St. Nicholas ch.

St. Augustine's par., in Newfoundpool, $453,455,456$; ch., 456 .

St. Barnabas sch., 337

St. Clement's Lane, 388 .

St. Clement's par., 388-9; ch., 50, 343 ; vicar, 388 .

St. Columba's chap., 384-5.

St. Cross ch., see L., St. Martin's par., Cathedral.

St. Cross guild, 5 I

St. Francis Lane, see L., Peacock Lane.

St. George's guild, 51, 367, 368; guildhall, 367 .

St. George's par., 359, 360; ch., 355, 357,359 , organist, 149 ; sch., 336 .

St. Hilda's ch., 360 .

St. James' chap., see L., St. Sepulchre's chap.

St. James the Greater par., 360; ch., 360.

St. John the Baptist chap., 50, 342, 359.

St. John the Baptist and St. John the Evangelist Hosp., 42, 5 I, 63, I 52, $338,34 \mathrm{I}, 343,35 \mathrm{I}, 357,359,408$, 4IO, 4II, 4I2, 4I3; chap., 50; chaplain, 25 ; guild, 5 I , 342, $359^{\circ}$ master, 342 .
St. John the Divine par., 359-6o; ch., 359-6o, 409; sch., 335 .

St. John's Lane, see L., Causeway Lane.

St. John's stone, 45 I.

St. Joseph of Peace convent, 390 .

St. Leonard's Hosp., 63, 350, 388

St. Leonard's Mill, 396.

St. Leonard's par., lib., $8 n$, I6, I7, 32 , $35,54,57,58$, I 87 , I 88 , I 9 I, 256 , $348-50,354,391$; ch., 50, 75, 3489 ; ch. yard, 349,350 ; chars., $349^{-}$ 50, 4I2, 4I3; non-conf., 39I-2; pop., 348 ; sch., 335 , 349 ; vicar, 348-9, see also Barton, Birmingham; workhouse, I 88.

St. Luke's par., 360; ch., 360; sch., 336.

St. Margaret and St. Katherine guild, 5I, 63, 358; chaplain, $35^{8}$; guildhall, $35^{8}$.

St. Margaret's par., 8, I 7, 54, $57 n$, I $29,143,161,162,165,175,186$, I 87, I 89 , I 9 I $n$, I 92, I 94, I 97, 200, $256,261-2,263,264,272,280,294$ $298,301,329,350-61,365,374$, $38 \mathrm{I}, 390,392,409 n, 4 \mathrm{I} 2,445,450$ admin., 356-7; bounds., $35 \mathrm{I}$; ch., I $6,50,5$ I, I 55, I $56 n$, I 59,350 , $35 \mathrm{I}, 355,357-9,392$; ch. wardens, 355 ; ch. vard, 52; chapelry, see Knighton; chars., $355,357,360-1$ 4II, 4I 2, 4I 3; char. sch., 328, 329 355; curate (clerk), 4I I, see also Davies, Ric. ; econ. hist., 354-6 428 ; guild, see L., St. Margaret and St. Katherine guild; lazarhouse, 408; man., see L., Bishop's Fee; non-conf., 390, 392; officers, I6I; overseers, $189,355,357$, see also Davis, -; pop., 355 , 356; surveyor of highways, 264; (select) vestry, I 29, I 47, I 89, 256, 272, 273, $355,357,360$; vestry hall, 356,360 ; vicar, $349,357,360,4 \mathrm{I} \mathrm{I}, 445$, see also Lound; windmill, 398 ; workhouse, $187-8,356,357$.

St. Margaret's Par. Piece, 355, 361 see also L., Cossington St., recreation ground.

St. Margaret's Pasture (Field, Fields), I 6, I $64, \mathrm{I} 97,35 \mathrm{I}, 354,355$.

St. Margaret's sch., in Canning Place, 336.

St. Margaret's sch., in Churchgate, $331,336$.

St. Margaret's ward, $242 n$; East, I 5 I St. Mark's par., 360; ch., 359; sch., 336 ; vicar, see Donaldson.

St. Mark's sch., in Caroline Place, 336.

St. Martin's, 334, 362, 365; see also L., Trustee Savings Bank.

St. Martin's Church Lane, see L., Guildhall Lane.

St. Martin's East, see L., Provost's House.

St. Martin's par., 73, I 43, I62, I87, I $88-9$, I $92,207,2$ I $8,256,361-9$, $383,390,39 \mathrm{I}, 393,394,398,399$; admin., 365 ; bounds., $36 \mathrm{I}$; Cathedral (formerly ch., St. Cross ch.), $50,51,52,53,65,73$, I 53 , I 55, I 59$60,328,342,365-6,401,405$, architect, see Moore, Temple, Nicolson, Sir Chas., see also L., Corpus Christi guild, guildhall, library; ch. wardens, 367, 413; ch. yard, 369,405 ; chars., 368-9, 4II, 4I2, 4I3, 4I 4; char. (Bluecoat) sch., 329,336 ; curate, 385 ; econ. hist., 364-5; girls' sch., 328 ; guilds, 366-7; non-conf., $39 \mathrm{I}$ 394 ; overseers, I 89 ; pop., 364-5; vestry, I 29, I 43, I 89, 256; vicar and provost, $349,365,366,385$, 


\section{LEICESTER INDEX}

$390,399,400,412,413$, see also Carte, Lubbenham, Nic., Newton, John, Vaughan, Canon E. T.; workhouse, I87-8, master, see Heighton.

St. Martin's sch., in Union St., 337.

St. Martin's ward, 330 .

St. Martin's well, $52 \mathrm{n}$.

St. Martin's West, 361, 362, 405; see also L., Wyggeston's Hosp.

St. Mary de Castro par., 8, I 7, 54, 57, $58, \mathrm{I} 04, \mathrm{I} 30, \mathrm{I} 43, \mathrm{I} 56 \mathrm{n}, \mathrm{I} 6 \mathrm{I}, \mathrm{I} 62$, I $81,187,188,192,199,256,262$, $347,365,369-80,383,388 n, 392$, 428 ; admin., 375 ; ch. (coll.), 7, 50, $5 \mathrm{I}, 63,342,343,344,345,346,366$, $375-80,385,388,389,396$; ch. wardens, 182 ; ch. yard, 379 ; chap. see L., St. Sepulchre's chap. ; chars., 376,380 , 4 I I, 4I 2, 4 I 3 ; char. sch., $328,329,336,376$, master, see Wood, John (fl. $c$. I 785 ), trustees, 329; dean, see Cowley; non-conf., 392 ; (close) vestry, I 43, 256, 375; vicar, $73,376,407$, see also Cowley, Robinson, Thos.; vicarage, 376 ; workhouse, 188,380 ; see also L., Bromkinsthorpe.

St. Mary in the Meadows (de Pratis) abbey, 3, 5, 6, 9, 16, 17, 31, 40, 45, 50,65 , 1 00, $342,348,349,353,354$, $359,366,367,376,379,382,388$, $389,396,399,422,423,424,437$, $439,44 \mathrm{I}, 443,447,448,450,45 \mathrm{I}-\mathbf{2}$; abbot, 6, $17,376,379,385,399$, 423 , 45 I, see also Penny, John (d. I 520); canons, $376,379,423,452$, see also Porter; chap., 50; infirmary, 50; library, 50; prior, see Charyte; sch., 50, 332; see also L. Abbey Mills, Abbey Park, Cavendish House, Leicester Abbey par.

St. Mary Magdalen and St. Margaret Hosp., 359; chap., 50

St. Mary's chap., 5o.

St. Mary's Church Lane, see L., Castle St.

St. Mary's Field, see L., South Field.

St. Mary's Fields (Haddenham Rd.), sch., 33 I, 337 .

St. Mary's Lodge (Home), 334.

St. Mary's Mill, Mills, 43, 327, 397.

St. Mary's ward, East, 330 .

St. Matthew's par., 359, 360; ch., 356,360 .

St. Matthew's sch., in Brunswick St., 336.

St. Matthew's sch., in Chester St. 336.

St. Matthew's sch., in Curzon St., 336.

St. Michael's guild, 5 I, 380 .

St. Michael's par., $3,52,53$, I 55,388 , 389 ; ch., 50, $51,53,389,412 ; \mathrm{ch}$. yard, 380 ; vicar, 380 .

St. Michael's R.C. chap., 380 .

St. Nicholas's par., 44, I56 $n, 187$, I $92,290 n, 344,383-7,388$; ch. (St. Augustine's), 50, I 55, I $79 n$, $330,379 n, 384-7,40_{5}$; ch. yard, $35,385,387$; char., $387,411,412$, 4I3, see also L., Simon's Hosp.; overseers, I89; pest-house, 385 ; pop., 384 ; sch., 384 ; vestry, I 43 , 256 ; vicar, 387 , 41 3 ; workhouse 387 .

St. Nicholas Shambles, see L., fairs and markets.

St. Nicholas St. (Hotgate, le Hotegate, calidus vicus), $43,36 \mathrm{I}, 383$, 384,391 i chap., 393.

St. Paul's chap., 393 .

St. Paul's par., 377 ; ch., 377 ; sch., 336.

St. Peter's (Womans) Lane, 34 I, 388; chap., see L., Ebenezer chap.
St. Peter's par., 69, I 55, $342 n, 360$, 388,389 ; ch., 50 , 53 , I $56 n$, 332 34 I, 342,388 ; ch. yard, 388 ; chap see L., St. Hilda's ch.; pop., 388 vicar, 388 ; vicarage, 80 .

St. Peter's R.C. par., 390, 442 ; ch. 300.

St. Peter's (Occupation) Rd., 355.

St. Peter's sch., in Gopsall St., 336

St. Peter's sch., in Upper Conduit St., 337.

St. Saviour's par., 360 ; ch., 360 ; sch., 336.

St. Sepulchre's (St. James') chap., 50, 52, 371, 376-7.

St. Stephen's Presbyterian ch., 394.

St. Theresa's convent, 390.

St. 'Thomas' guild, 5I.

Sand Pit Lane, see L., Willow Bridge St.

Sanvey Gate (Senvey Gate, Skeyth) I 55, I $56 n$, I 59, I 94, I 95, 262, 263, $338,351,356,380$.

Sanvey Lane, chap., 420

Saracen's Head, I 28.

Saturday market place, see L., Market Place.

Savings Bank, see L., Trustee Savings Bank.

Saxby St., chap., 392; sch., 392; see also L., Marston's Mill.

Secularist Institute, $228 n$

see, $349,366,367,376,377,384,426$ Diocesan Board of Patronage, 44I Diocesan Trustees, 377; see also L., bishop.

Senvey Gate, see L., Sanvey Gate.

Shaftesbury Rd., 3.37 .

Shakesperean Assoc., 212.

Shambles Lane, St., see L., Applegate St.

Sheepmarket, see L., Silver St.

Shepsterrowe, 47

Sherman's Lodge, Grounds, see L. Leicester Frith.

Shire Hall, 338.

Short St., sch., 33 I.

Silver St. (Sheepmarket), 46, I56 $n$ $254 n, 301,361,362,364$; see also L., Opera House.

Simmins Crescent, sch., see L., Monsell, Eyres, sch.

Simon's Hosp., 4 Io.

Skeffington House, 334, 34 I n, 346 .

Skeyth, see L., Sanvey Gate.

Slater St., 338 ; sch., 337

Soar Lane (Fullers, Walkers Lane, vicus fullonum), 38,42, I $56 n, 338$ 341, 343, 369; chap., 392, 394; see also L., Castle St.

Soar, Riv., 9, I 7, 20, 3 I, 38, 4 I, 43, 52, $53,100,154,155,262,263,264$, $267-8,272,278,286,299,343,346$, $347,348,35 \mathrm{I}, 354,369,370,373$ $374,375,380,381,382,383,384$ $387,388,397,415,420,423,424$ $428,449,45 \mathrm{I}, 452,453,454$ canalization, $195,277,344,396$, 4 I 7 ; fisheries (stews), $43 n, 45,395$.

South (St. Mary's, Town) Field Fields, 9, 32, 99, 100, 1 02, 127, 1 28, I 30 , I 34, I 60, I65-6, I 86 , I 94 I 95, I 97, 254, 260,262, 263, 29 I, $369,370-5,377,380,381,397,399$, $401-2$; incl., 127, 128, 195, 197-9. $372,373,380$; park, 293, 375; racecourse, 270, 293, 375; recreation ground, 27I-2, 293, 375; windmills, 43, 63 , see also L., Nurse's mill; see also L., Cowhay Pasture Gallowtree Field, Middle Field, Rawdykes.

South Gate, 32, 42, 43, 50, 52, I 54 I $56 n, 363,369,370,371,372,376$ township, Io $n$; see also L., Oxford St.
Southampton St., 355

Southgate (Castle, High) St., I6I, $262,326,36 \mathrm{I}, 369,370,392,4 \mathrm{II}$. see also L., Consanguinitarium.

Southwell, Mr., ward, I 56, I 57, I 59.

Spa Place, $200 n, 352$.

Sparkenhoe St. (Occupation Rd.), $355,356,360$; sch., see L., Parochial Union sch.; see also L., Hillcrest Hosp., St. Margaret's par., vestry hall.

Spinney Hill ward, $242 n$, 434; see also Evington.

Spital, The, $359 n, 360 n, 408-9,4$ II. Spital (Cock Muck) Hill, 35I, 360; see also L., Cock Muck Hill Houses.

Spital House, 409.

Spital House Close, 4 I 3

Stephenson's char. sch., 328.

Stocking (le Stokking, Stoking) Farm

(Field), 423, 45I, 452; housing estate, $423 n, 45$ I, 453, chap., 392.

Stocking (Stockinge) wood, 452 .

Sun Fire Office, fire brigade, 286 .

Sunday School Memorial Hall, 329.

Sutorstowe, $47 n$.

Swan's Mill, see L., Newarke Mill

Swinesmarket, see L., Bond St., New, High St.

Swinesmarket ward, 54

Sycamore Street, see L., Great Central Street.

Sylvan St., 292.

Syston St., sch., 337.

Tabernacle, The, 392 .

Talbot, The, 384

Talbot Inn, 384 .

Talbot Lane, 384 ; see also L., Jester House.

Taskholm, 32, 370 .

Taylor St., sch., 337

Temperance Hall, see L., Essoldo Cinema.

Temperance Soc., 352

textile and clothing trades and industry, 76,78, г 58 , г 69 , г $78-9$, I 8 I-2; clothiers, $47,75 n$, I 53; clothworkers, $87 ;$ collarmakers, I $58 n$; cotton spinning, $34 \mathrm{I}$, see also Taylor, Thos. Swift; drapers, 37 , $39,48,79-80$, see also Chamberlain, Wm., Smith, Thos., linen, 80 , occupation, 99 , woollen, 80,87 , 88 , I 57 , I 58 , I 59, see also Craddock, Edm. (fl. $c$. I709-32), Deane, Wm. Gillot, Wm., Noble, Fran.; dyers, $39,87-88$, I $58 n, 34 \mathrm{I}$, see also Atherstone, Johnson, Edm. (f. $c$. I684).

Elastic web manufacture, 259 , 260, 269, 3I5, 326-7, Elastic Weavers Trade \&c. Soc., 327; haberdashers, $8 \mathrm{I}$, I $58 n$, see also Byllyng, co., 77 , of hats, 80,8 I, I $58 n$. Hosiery and knitted goods, 88 , $90-92,98$, I 04, I 07, I67 $n$, I 68-78, I 88, I 94, I 95, I 99, $205 n, 206,209$, 2 I I, 2 I6, 2 I 9,23 I , 252, 257,258 , $259-60,262,265,269,270,271$, $276,293-4,296,300,301,302,303-$ I $4,321,329,387,4$ I $3,424,432$, $436,440,444$; hosiers, 90-92, 9596, I 47, I 58, I 67, I $78,206,2$ I 6 , 25I, 260, 293, see also Coltman, John, Garrett, Harris, Ric., Lewis, Wm., Pougher, Abstinence, Rawson, John, Topp, 'Thos., Assoc. I 73 ; manufacturers, see Biggs, John, Wm., John \& Sons, Corah, Harris, J. O., Pool \& Lorimer, Preston, J., \& Co., Preston \& Charlesworth, Walker, W. H., Walker \& Kempson, Assoc., 3 I $3 n$, Midland Counties 


\section{A HISTORY OF LEICESTERSHIRE}

Textile and clothing trades (cont.)

Manufacturers Assoc., 313; bd. of arbitration, 3 IO, 3 II, 3I3, 322 allotment soc., 307; Leicester and Leicestershire Amalgamated Hosiery Union, 312, 3I 3, 314 framework-knitter, see Buckby, unions, 175, 176-7; glovers' union 303.

Lace-making, $88, \quad 178-9,4 \mathrm{I} 3$ linen clothiers, 88 , see also Blackshawe; linen spinners, 88 , see also Erieck, Markby, Thos., Mounteney, Nutt, Jas. (d. I663), Rypley, Springthorpe, Ric., Swan, Thos. Taylor, Edw., Webster, Thos.; mercers, $37,39,79,87,90,99$, 106 I 58, I 59, see also Alsop, Nic. Cotes, Wm., Cotton, Thos., Erieck, Fox, Jas., Franke, Marshall, Sam. Miller, Rob., Morton, - Noone, Edw., co., 80-8I, I 8I

Ropers, 88; shirtmaking, 174 ; silk weaving, I $58 n$, 179 , see also Burbidge, John, Saunders, Rob. tailors, 88-9o, i 58, see also Deane, Wm., Murfyn, Wallin, Jos., co (craft) $\quad 35,80-90$, I $66 n$, I $8 \mathrm{I}$ tammy weavers, I 79

Wool trades, $37-41,54,77-79$ 86-88; staple, 57,78 ; staplers, $40-41,54,77-78$, I04, see also Wigston fam.; staple hall, 78 wool hall, 408; badgers, 79 botchers, 8o-0o; fellmongers, 48 79,92 , I 57, I 58, I68, see also Johnson, Ric., Robinson, Chas., Southwell; fullers (tuckers, walkers), 33 $38-39,87,34 \mathrm{I}, 397$, guild, 35,38 ; jersey combers, 90-9 I, I $58 n$, see also Pougher, Sampson; jersey knitting, 90-92; jersey spinning, 86,90 ; shearmen, $39,87,92$, I $58 n$, 179 , see also Loleby, Willowes; wool combers, I68, 172, see also Coltman, John, union, I75; woolmongers, 48, see also Inge, Ric. Wigston fam.; wool spinners, 86 $87,88,99$, 105, 170, 188, 259, see also Abell, Alice, Ball, Wm., Cotes, Wm., Huxley, Jerman, Joseph, Oldham, John, Redwey, Robinson, Chas., Tatam, John, Whetstone, Jos. Woodland, Thos. (d. I 59I); wool wrappers, 40

Worsted combers, I 53; worsted knitting, I72-3; worsted makers' soc., 172 , see aiso Whetstone, Jos. worsted spinning, 86-87, I 72, 259

Thames St., 353.

Theatre Royal, 272, 363 .

Thornton Lane, $36 \mathrm{I}, 38_{3}$; see also L., Carey Museum.

Thorpe St., chap., 392.

Thurnby Lodge sch., in Dudley Ave., 336.

Thurnby Lodge sch., in Gervas Rd., 336

Torchmere, $34 \mathrm{I}$

Tower Mill, 398.

Town Field, see L., South Field.

Town Hall, I8o, 290, 299-300, 363, proposed, I95, 265, 266; keeper, $254 n$; library, see L., Corpus Christi guild, guildhall; porters, 4 II; see also L., Corpus Christi guild, guildhall, Gainsborough, The

Town Hall Lane, see L., Guildhall Lane.

Town Hall Square, 363,364 .

Townsend, Mr., ward, I 56, I 57 , r 59 trade and industry, $37-49,76-109$, I66-87, 293-4, 295-7, 300-1, 302, 303-27; regulation, $15,21,23,26$, $39-40,45,48,58,73,74,79,83-$ $84, \mathbf{1 6 6 - 7 ,}$ г 69, I 76
Guilds, $35-36, \quad 48-49$, I 66-7; trades unions, $175,202,209,224$ $227,234,237,239,307,3$ I0, 3 I 3 $317,319,321$; Chamber of Commerce, 3 I 3 ; Trades Council, $23 \mathrm{I}-6$, 242.

See also L., agriculture and husbandry, building and building trades, fairs and markets, guild merchant, leather crafts and industry, metal working crafts and industry, mills, miscellaneous trades and professions, newspapers textile and clothing trades and industry, victualling trades, woodworking crafts.

transport and communications, 99, I 54, I6 I, I 93, 195-6, I 99, 260, 370 airfield, see L., Braunstone Frith; canal, see L., Grand Union Canal; motor buses, 30I, stn., 298, 347 rlys., 260, see also British Rlys. Midland Rly., L., Leicester \& Swannington Rly.; tramways, 285-6, 29I, 293, 30I, 424, 445, co., 285-6.

Trinity chap., 392.

Trinity (Newarke) Hosp., 65, 71, 75, I 34, I $53,346,347,398,405,406-8$ 4 IO, 4II, 4I 3 ; chaplain, 407, 408; lecturer, 403; master, 407, 408; trustees, 355 ; seal, 408 .

Trinity Lane, sch., 332,337

Trustee Savings Bank, 331, 362, 380 .

Union ch., 394

Union St., sch., see L., St. Martin's ch.

United Baptist chap., 392.

University (University Coll.), 374, 443; arms, 374.

University Rd., 374 n, 392.

Vaughan Coll., 384.

Vauxhall Gardens, 34 I, 389 .

Vauxhall Lane, 389.

Vauxhall, New, bowling green, 34I.

Vauxhall St., 34I ; see also L., Mason, Miss, Almshouses.

Vestry St., baths, 294

Victoria Baptist ch., 391, 392; minister, see Meyer.

Victoria Parade, see Odams, W.

Victoria Park (race-course), 272, 29I, 294, 333, 352, 398, 446

Victoria Park Rd., 352, $370 n$; sch. see L., Lancaster sch.

victualling trades, $37,43-46,49,76$, 78,96 , I 58 , 180; bakers, $43-44,93-$ $94,157,1_{58}, 179,412$, see also Bent, Geo. (d. I709), Freeman, And. Neale, Palmer, John (d. I627), Truville, co., I66 $n$, I $8 \mathrm{I}$; brewers, $45-46,52,72,74,95,96$, г 04,106 $107,157,227$, see also Boxall, $\mathrm{Pal}$ mer, John (d. I627), Townsend, Edm., co., 96; butchers, 12, $37 n$, $4 \mathrm{I}, 44,47,74,92-93$, 100-2, I 58 383 , see also Cotes, Wm., Heyrick John (d. I633), Lewin, Rog., Ludlam, Wm. (d. I628), L., agriculture and husbandry, graziers, co., 4, I00, I $66 n$, I 8 I

Cheesemonger, see Hunt, John; cooks, 44, 96; distilling, 96, see also Boxall; fishmongers, 45 , see also Keckwick, occupation, 77 ; grocers, see Fox, Jas., Manby, Wm., Stanley, Wm. (fl. c. I 595) Ward, Wm. (d. I 558), occupation, 8 o.

Inns, alehouses, \&c., 44, 53, 57, $58 n, 73,95, \mathrm{x} 54, \mathrm{I} 55,27 \mathrm{I}$, see also L., Angel, Black Lion, Blue Boar,
Crane, Old Robin Hood, Pack Horse, Queen's Head, Red Lion, Saracen's Head, Talbot, Wellington, Marquis, White Hart, White Lion; innkeepers, \&c., 37, 43, 45, $74,95,96$, 1 58, 1 800 , 18 1, 216 , see also Clarke, Thos. (fl. c. 1 586), Craddock, Jos. (fl. c. 1684-8), Newton, Gabriel, Pares, John (d. 1715 ), Pate, Pollard, Edw., Staines, Lawr. Mal tsters, 77, 79, 95-96, 104, 106, I07, see also Abney, Dannet, Launder, John, Pougher, Eliz., Slater, Hen., Sutton, Edm., Thompson, Thos. (d. 1638); millers, 87,94 398; see also Carter, Lawr., Swan, Thos., Taylor, Edw.; pepperers' occupation, 8o; salters, 96 , see also Burch; spicer, 45; sugarers' occupation, 80 ; victuallers, 96 , see also Beckett, Wm., Mapwell, Roberts, Rob. (fl. c. 1586); vintners, 37,43 45,82 , Io6, see also Barnes, Ives, Newton, Wm., Palmer, Ric., Pares, John (d. 17 1 5).

vicus, calidus, see L., St. Nicholas St. vicus fullonum, see L., Soar Lane.

vicus parcamenorum, see L., Bond St., New.

Vine St., chap., 392, 393; sch., see L., All Saints' sch.

Virgin, guild of the Assumption of, $5 \mathrm{I}, 342$.

Vulcan works, 353 .

Walkers Lane, see L., Soar Lane.

Walnut St., $374 n$; bridge, 277.

Walsh's Hall man., see L., Danet's Hall man.

Watling St., 37 I $n$; Salvation Army hall, 394 .

Watts Causeway, see L., King Richard's Rd.

Welford Place, $353,370 n$; see also L., Leicestershire Club.

Welford Rd., I 62, I 94, $213,260,262$, 266, 27I , 284, 34I, 373, 375 n, 397; ch., 394; cattle market, 364 ; recreation ground, 272 ; see also Welford, road from Leicester to, L., gaols, county.

Wellington, Marquis, p. h., 352.

Wellington St., 198, 35 I, 352, 389; ch., see L., Free Christian ch.; sch., see L., Holy Cross priory, schs.; see also L., City Lending library.

Wesley Hall chap., 392.

West Bridge, 4I, 42, 50, I 54, I55, $163,197,262,265,277,278,34 \mathrm{I}$, $364 n, 369,382,3^{8} 3,384,387,395$, 396 ; chap., see L., St. Mary's chap.

West Field, 9, 31, 99-100, 102, 165.

West Gate, 3I, 4I, 42, 382, 389 ; township, Io $n$.

Westcotes man., in Bromkinsthorpe, 9, 17, 31, 53, 290, 291, 380, 382; man. house, 383 ; see also Ruding fam.

Westcotes sch., 337.

Westcotes ward, $242 n$

Western Park, 294; sch., 33I, see also L., King Richard sch.

Westminster Bank, 362

Wharf St., 355, 356; cricket ground, 272.

Whetstone's Mill, 398.

White (Augustinian) Friars lib., 154 , $257,382,387-8,449,455$; bounds., 387 ; friary, $154,343 n, 387$, chap., 50 ; see also L., religious orders and houses, Augustinian friars.

White Hart Inn, 123. 


\section{LEICESTER INDEX}

White Lion Inn, 105, 147.

Whitehall Ave., sch., 337

Wigston Lane, 334; sch., see L., Montrose sch.

Willow Bridge St. (Sand Pit Lane),

Willow Brook, 263, 264, 277, 354, 434.

Willow Mead sch., 331, 337 .

Willow St., chap., 394; sch., see L., Willow Mead sch.

Womans Lane, see L., St. Peter's Lane. Wood Gate (Woodgate), 348; see also L., Old Robin Hood Inn.

Woodstock sch., 336 .

woodworking crafts, $76,78,96-97$; carpenters, 42, 94, 96, 97, 98, 1 79, $183_{-4}$, see also Harrison, Joshua, Nicoll, co., $166 n$, union, 184; coopers, 97, see also Johnson, Thos. Walker, Wm. ; joiners, 96-97, 98, see also Pegg; sawyer, 42; timber merchant, see Winterton; turners, 97, turners' and joiners' co., 97, 166; wheelwrights, 97, see also Hobby, Wm.; woodmongers, 96; see also L., agriculture and husbandry, ploughwrights.

Working Men's Assoc., 209, 2 I I.

Wycliffe ch., 334, 394 .

Wycliffe sch., 336 .

Wycliffe ward, $242 n$.

Wyggeston ward, $242 n$.

Wyggeston's Hosp., 4I, 66, 333, 34I $n$, $362,365,381,398-406,4 \mathrm{I} \mathrm{I}, 449 n$, $452 n$; chap., I41, $362 n, 386 n$ 405,408 ; confrater, $399,401,403$,
404, 406, see also Jackson, John; governors, 404; master, I4I, 332 , $399,401,402,403,404,405-6$; seals, 405; trustees, $380,402,404$, 405 , of lands, 398 .

Wyggeston's Hosp. Boys' sch., 3 I 3 , $333,334,400,401,404,405,414$; master, see Pott.

Wyggeston's Hosp. Girls' sch., 334 404, 405; headmistress, see Leicester, Ellen.

Wyvern Ave., sch., 337.

Wyvern Hotel, 394.

Yeoman St., $290 n$.

York St., chap., 393. 


\section{CORRIGENDA TO VOLUMES I, II, AND III}

Vol. I, page $306 a$, line 5 from end, for 2 read 3

" , $306 b$, line 5 , for 2 waste read 3 waste

Vol. II, page $\mathrm{I}_{3} b$, line 4 from end, for Cudworth read Curdworth

" $\quad \mathrm{I} 7 b$, line 2 from end, for Cudworth read Curdworth

" " $\quad 37 b$, lines $\mathbf{I}-2$, for Mountgrace Priory read St. Mary Graces by the Tower of London

" , 92, line 18, for Northgate Street read High Cross Street

" " $\quad$ I 23 , line 29, for succeeded his father as Earl Ferrers read died in 1714

" " $\quad \mathrm{r} 35$, line 26, for J. E. Ellis read James Ellis

" $\quad$ " 136 , line 19 , for J. E. Ellis read James Ellis

" "254, 'Appleby', delete whole line

Vol. III, page 40a, line 19 , for Walmersley read Walmsley

" $\quad$ " 45 a line $\mathrm{r} 9$, delete Ltd.

" $\quad$ " $5^{\mathrm{1} b}$, line $\mathrm{1} 6$, for Babbington read Babington

" $\quad$ " 54a, line 22, for Craddock read Cradock

" $\quad$ " 127 , note 93, for Oct. I872 read Oct. I862

2I7, line 25, for Market Harborough R.D.

" $\quad$ " 248, note 16 , delete Wyggeston

" $\quad " \quad 301 b$, line 46 , for Cudworth read Curdworth

" $\quad " \quad 334 a$, line Ir, for Walmersley, Sir Joshua, of Liverpool, ii, 40 read Walmsley, Sir Joshua, of Liverpool, iii, 40 


DA

670

$\mathrm{L} / 4 \mathrm{~V} 6$

$\mathrm{v} \cdot 4$
The Victoric history of the county of Leicester

\section{PLEASE DO NOT REMOVE \\ CARDS OR SLIPS FROM THIS POCKET}

UNIVERSITY OF TORONTO LIBRARY 
- 